


\title{
A cidade de São José do Rio Pardo e as moradias do Centro Histórico (1865-1940)
}

\author{
The city of São José do Rio Pardo and the dwellings of the Historic Center (1865-1940)
}

\section{Versão Corrigida}

Dissertação de mestrado apresentada ao Programa de Pós-Graduação em Arquitetura e Urbanismo do Instituto de Arquitetura e Urbanismo da Universidade de São Paulo, como parte dos requisitos para a obtenção do título de Mestre em Ciências.

Área de Concentração: Teoria e História da Arquitetura e Urbanismo

Orientadora: Prof. Dra. Maria Angela Pereira de Castro e Silva Bortolucci

Apoio: Conselho Nacional de Desenvolvimento Científico e Tecnológico (CNPq) 


\section{AUTORIZO A REPRODUCAO TOTAL OU PARCIAL DESTE TRABALHO, POR QUALQUER MEIO CONVENCIONAL OU ELETRONICO, PARA FINS DE ESTUDO E PESQUISA, DESDE QUE CITADA A FONTE}

Ficha catalográfica elaborada pela Biblioteca do Instituto de Arquitetura e Urbanismo com os dados fornecidos pelo(a) autor(a)

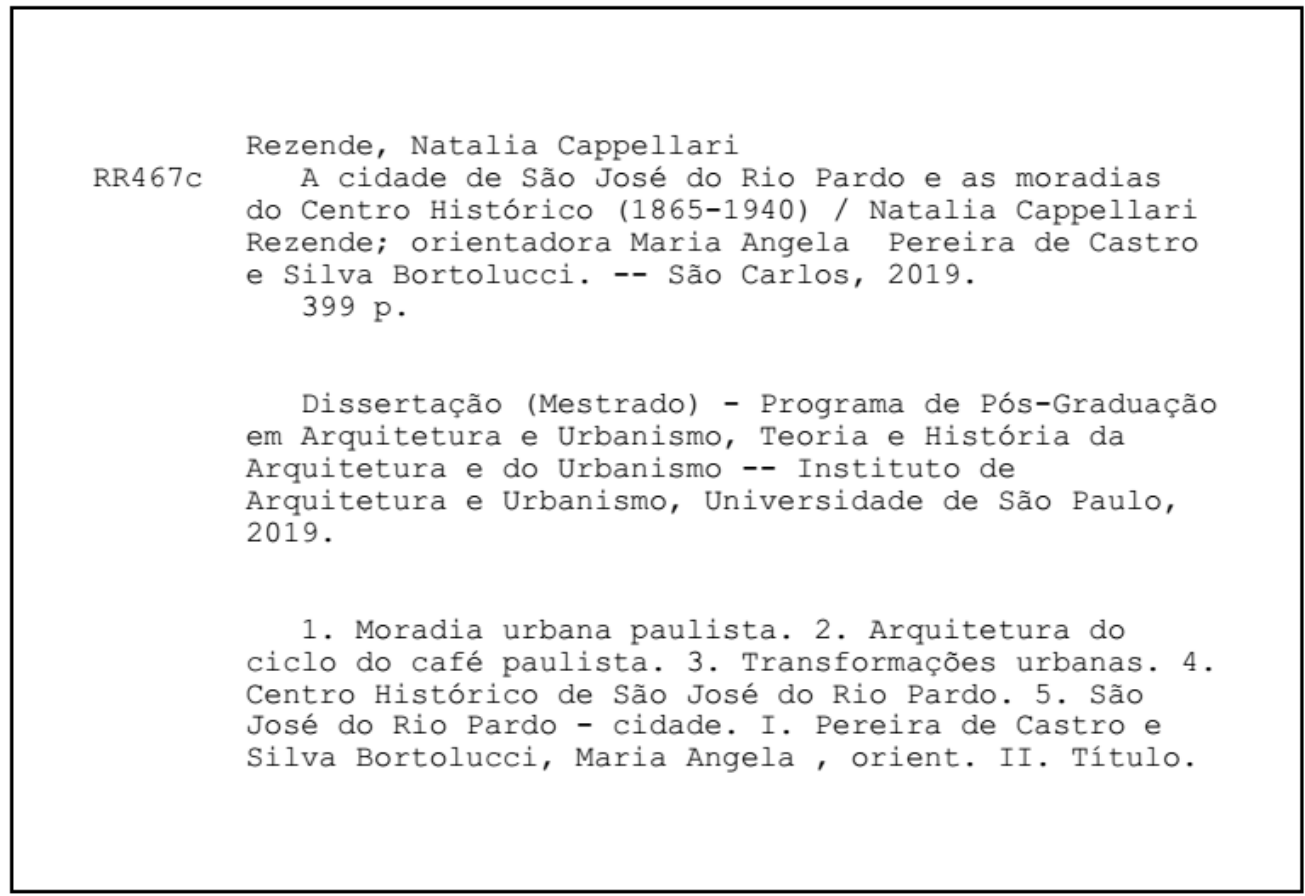

Bibliotecária responsável pela estrutura de catalogação da publicação de acordo com a AACR2: Brianda de Oliveira Ordonho Sígolo - CRB - 8/8229 


\section{FOLHA DE JULGAMENTO}

Candidato(a): Natalia Cappellari de Rezende

Título da dissertação: "A cidade de São José do Rio Pardo e as moradias do Centro Histórico (1865-1940)"

Data da defesa: 18/02/2019

Orientador: Profa. Dra. Maria Angela de Castro e Silva Bortolucci

\section{Comissão Julgadora:}

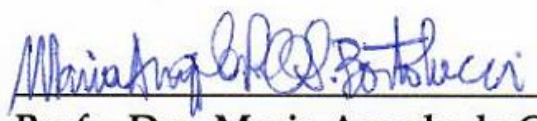

Profa. Dra. Maria Angela de Castro e Silva Bortolucci (IAU/USP)

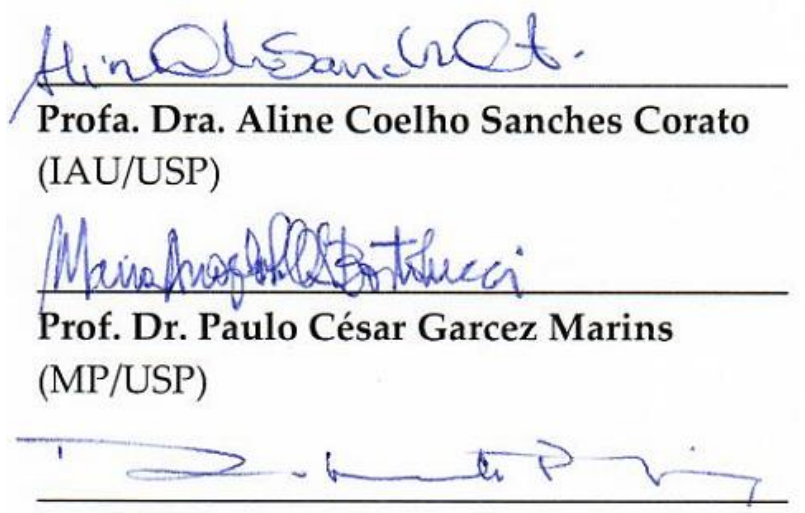

Prof. Dr. Roberto Pastana Teixeira Lima

(Universidade São Francisco)
Resultado:

Não votante

APROVAOA

APROVADA

XPROOSDA.

Coordenador e Presidente da Comissão de Pós-Graduação do Programa de PósGraduação em Arquitetura e Urbanismo: Prof. Dr. Tomás Antonio Moreira. 
DEDICATORIA

Para aquela que foi minha fonte de informação e maior inspiração com suas infinitas histórias ... 
São José, com ou sem feriadão

E só silêncio, tranquilidade Para quem gosta é lugar de sossego

De descanso, de reflexão

De curtir saudade, de cultivar amizade.

Em muito se diferencia das grandes cidades

Que nos dizeres de Euclides da Cunha Era um "meio deplorável, com as suas avenidas,

os seus automóveis, os seus smarts, as suas fantasmagorias de civilização pesteada".

Como percebemos

São José relembra Euclides

Que descansa às margens do Rio Pardo

Lugar tranquilo e acalmado

Por ele exaltado a distância

Quando saudades ele experimentava

E do grande centro reclamava

Simples como o escritor preferia

Porque esnobismo o aborrecia.

Há também uma cabana de zinco e sarrafos

Que conserva sua humilde estrutura

Que testemunhou uma grande proeza

Foi cúmplice de Euclides da Cunha

Em duas obras de grande beleza:

Uma ponte, hoje já restaurada

Imponente, é orgulho de nossa gente

E o livro “Os Sertões"que alça o nome

De nossa cidade pequena e singela

Aos mais distantes rincões da Terra.

São José -muito ainda se poderia dizer

Mas prefiro com Euclides comparar

Pela doce lembrança que ele pode causar.

(CIDINHA GRANADO, 2015) 
(...) Uma cidade não é feita por um homem, nem pelas idéias de um homem. Ė um objeto orgânico, o produto dos esforços, objetivos e desejos de muitos homens. Nasce da forma de trabalho de sua época, e da imaginação de seus construtores. Sua arquitetura é determinada por condições naturais, pelas necessidades, reais ou supostas, pelas tradições, pelas restrições, pela cultura daqueles para os quais é construída e daqueles que a constroem"

(PURDOM, 1913, p. 64) 


\section{AGRADECIMENTOS}

Talvez as palavras não sejam suficientes para expressar tamanha gratidão as inúmeras pessoas que generosamente colaboraram ao longo desse processo que se encerra. Um caminho árduo e trabalhoso de ser percorrido por todas as suas indefinições, angústias, dúvidas, limitações e frustações, mas a cada conquista, a cada descoberta e a cada informação o sentimento de alegria, de satisfação, de recompensa e principalmente da certeza de ter feito a escolha correta quando decidi, lá em 2016, iniciar este trabalho. Possívelmente algumas pessoas que citarei, ou ao menos tentarei citar, porque foram muitas mãos e ombros generosos, jamais compreenderão o tamanho dos seus gestos, essenciais aos resultados que aqui se chega. Em especial, destaco:

A professora Dra. Maria Angela Bortolucci, pela acolhida e confiança depositada em mim e neste trabalho, pela presença constante, dedicação e disposição ímpar, paciência, carinho e o otimismo de sempre. Muito obrigada pelas infinitas orientações e por entender minhas angústias nem sempre relacionadas à pesquisa. Palavras nunca serão o bastante para expressar toda a minha gratidão.

Os amigos que direta ou indiretamente o IAU me deu, em especial a Amanda Moreira e Ana Gléria pelo apoio, companhia (mesmo que a distância) e por dividirem diariamente as angustias, incertezas, conquistas e alegrias dessa vida acadêmica e das outras que temos. A Joana D'Arq de Oliveira pela amizade, disposição e prontidão em ajudar. A Marina Lages e Lorena Couto pela companhia e por serem meus apoios em São Carlos. E o Marcus Vinícius, a Amanda Mitre e a Tatiana Gaspar por compartilharem desse mundo acadêmico. Não poderia deixar de agradecer também os integrantes do maravilhoso grupo de pesquisa Patrimônio, Cidades e Territórios pela acolhida: Vladimir Benincasa, Mônica Ferreira, Rodrigo Jabur, Mateus Rosada, Luciana Mascaro e Camila Santanna. É tamanha a minha admiração por vocês.

A Larissa Cardillo Dias e a Júlia Farah pela ajuda dada quando decidi prestar o processo seletivo de Mestrado e o Timóteo Andrade pelo apoio constante.

As professoras Rosana Parisi, Glacir Fricke, Adriane Matthes e Antônio Carlos Lorette que durante a graduação me incentivaram e apoiaram a seguir adiante com as minhas inquietações. Nesse sentido, destaco também a equipe da Secretaria Municipal de Planejamento, Desenvolvimento Urbano e Meio Ambiente onde aprendi a respeitar e valorizar o patrimônio cultural, de modo especial Carol Nassif, Isa Gambarotto, Bruna Hilário, Thaís Sanches, João Neves, Letícia Loyola e Tati Alves.

A professora Simone Vizioli que abriu as portas de suas disciplinas para realização do estágio PAE, e o professor Paulo Yassuhide Fujioka pelo convite para colaborar em suas disciplinas ministradas na graduação.

Todos os funcionários do IAU, em especial a Mara Lino e a Flávia Macambyra pela dedicação, paciência e atenção. E também a Cleverci Malaman pela gentileza em me ajudar a lembrar dos prazos de devolução dos livros da biblioteca. 
Fundamentais, também foram os funcionários de cada repartição pública, biblioteca e arquivo visitado, em especial: Marlon Callegari e Gabriela Lourenço da Hemeroteca Jornalista Paschoal Artese; Maria Dulce Travassos da Biblioteca Municipal Monteiro Lobato; Renata Roque do Centro da Memória Rio-Pardense Rodolpho José Del Guerra; Idomar Araujo e João Batista Pegorin do Arquivo Público da Secretaria de Obras; Carolina Mokarzel e Ivan Barbosa do Cartório de Registro de Imóveis; e a Eliana do Arquivo Público de Casa Branca.

Cada um dos proprietários que permitiram o acesso às suas propriedades e/ou me cederam informações e todos os entrevistados que compartilharam comigo suas memórias, histórias e conhecimento: Phelomena Stivalle Cappellari, Francisco Trevisan, Carmém Maschietto, Alcides Tiezzi, Clara Garcia, Maria Paula Ribeiro Nogueira, Guilherminda Cappellari de Vitta, Hélio e Doroti Travassos, José Hibrain Curi, leda Ribeiro, Marcio José Lauria, Ernani Vasconcellos, Doraci e Dorival Cappellari, Luis Fernandes, Myrian Rugani, Maria Helena Luz, Leo Lucas Rugani, Marilia Rugani, Leonardo Paiva e Rômulo Galegari.

A minha irmã Stephania que tanto me ajudou com os textos, e os meus pais Sônia e Vitor pelo apoio e amor incontestável e por estarem sempre dispostos a seguir esse caminho de percalços e alegrias comigo. Muito obrigada pelas inúmeras vezes que me acompanharam nos levantamentos, pelos contatos estabelecidos e principalmente por investirem na minha educação.

O meu amigo e companheiro Gabriel Demartini por ser a minha segurança em momentos de instabilidade, pelo carinho, sensibilidade, confiança e compreensão de minha ausência em nome da pesquisa, e por todo compartilhamento, revisões de textos, procura de documentos e realização de levantamentos. Obrigada meu amor.

Os meus primos Paulo Afonso Nasso, Aline Cappellari e Jessyca Ferrari, e também o Carmo e a Natalia Demartini pela ajuda na reta final. E os meus tios Dore, Tata, Neneca e Ivone por tanto companheirismo.

Os professores Dr. Paulo César Garcez Marins e Dra. Aline Coelho Sanches Corato, pelas importantes contribuições no exame de qualificação, decisivas para o encaminhamento do trabalho. Acrescento ainda a colaboração dos mesmos e também dos professores Dr. Roberto Pastana Teixeira Lima e Dra. Mônica Cristina Brunini Frandi Ferreira que fizeram ótimas sugestões na banca de defesa.

O CNPq pelo apoio financeiro que viabilizou a realização desta pesquisa. 


\section{RESUMO}

REZENDE, Natalia Cappellari. A cidade de São José do Rio Pardo e as moradias do Centro Histórico (1865-1940). Dissertação (Mestrado em Teoria e História da Arquitetura e Urbanismo) - Instituto de Arquitetura e Urbanismo, Universidade de São Paulo, São Carlos, 2019.

Trata da moradia urbana paulista do ciclo do café, considerando como recorte o Centro Histórico da cidade de São José do Rio Pardo entre os anos de 1865 e 1940, período que compreende desde a fundação até o início da redefinição econômica com o desenvolvimento do setor comercial e industrial e da própria expansão urbana com o surgimento de novos bairros. Identifica, compreende e analisa a moradia urbana a partir das características arquitetônicas, formais e compositivas, verificando usos e arranjos internos, partidos adotados e técnicas construtivas empregadas. Analisa ainda como que essa moradia se transformou coadunada com as mudanças no espaço urbano após a implantação de infraestrutura, a construção de diferentes tipologias de edifícios e a disponibilidade de material e mão de obra. Constata a atuação de 106 profissionais, práticos licenciados e artífices na construção civil local, destacando, através das moradias, as diferenças entre as diversas gerações de profissionais. O estudo se vale de documentação consultada em arquivos, públicos e privados, bibliotecas e cartórios, que inclui materiais iconográficos, jornais, almanaques, relatórios de governo, mapas e projetos constantes nos processos de aprovação de construção; pesquisa de campo através de mapeamento, registro fotográfico e levantamento métrico das moradias; realização de entrevistas com pessoas engajadas com a história e os movimentos culturais da cidade, e também com antigos moradores do Centro Histórico; e leitura de estudos correlatos. Busca sustentação teórica em importantes autores nas áreas de interesse da pesquisa, dentre eles Carlos Lemos, Nestor G. Reis Filho, Murilo Marx, Emma Debenedetti e Anita Salmoni e Sandra J. Pesavento, além de bibliografia de teóricos, memorialistas e historiadores locais, com destaque para Rodolpho José Del Guerra e Amélia Franzolin Trevisan. Contribui para ampliar o conhecimento da diversidade da produção da moradia urbana brasileira na medida em que qualifica e quantifica o processo de transformações do espaço urbano de São José do Rio Pardo; ao revelar que sua arquitetura, especialmente suas moradias, que ao mesmo tempo em que podem ser tidas como recorrentes e comuns quando comparadas a outras cidades do ciclo do café paulista, também são carregadas de singularidades e nuances próprias; e ainda ao revelar a existência de redes e relações estabelecidas que ultrapassam fronteiras na circulação de saberes, novidades, materiais e tecnologias, dos artífices, práticos licenciados e profissionais, e dos clientes envolvidos nessa produção.

Palavras-chave: Moradia urbana paulista. Arquitetura do ciclo do café paulista. Transformações urbanas. Centro Histórico de São José do Rio Pardo. São José do Rio Pardo - cidade. 


\section{ABSTRACT}

REZENDE, Natalia Cappellari. The city of São José do Rio Pardo and the dwellings of the Historic Center (1865-1940). Dissertation (Master in Theory and History of Architecture and Urbanism) Instituto de Arquitetura e Urbanismo, Universidade de São Paulo, São Carlos, 2019.

It deals with the urban dwelling of the coffee cycle in São Paulo, considering as recort the Historic Center of the city of São José do Rio Pardo between 1865 and 1940, period that consist since the foundation to the beginning of the economic redefinition with the development of the commercial and industrial and of own urban expansion with the emergence of new neighborhoods. Identifies, understands and analyzes the urban dwelling from the architectural, formal and compositional characteristics, verifying uses and internal arrangements, adopted parties and constructive techniques employed. It also analyzes how these dwelling became compatible with changes in urban space after the implementation of infrastructure, the construction of different typologies of buildings and the availability of material and labor. It verifies the work of 106 professionals, licensed practitioners and craftsmen in the local civil construction, highlighting, through the dwellings, the differences between the different generations of professionals. The study is based in documentation consulted in archives, publics and privates, libraries and registry offices, that inclues iconographic materials, newspapers, almanacs, government reports, maps and projects in construction approval processes; field research through mapping, photographic record and metric survey of dwellings; conducting interviews with people engaged in the history and cultural movements of the city, and also with former residents of the Historic Center; and reading related studies. This paper seeks theoretical support from important authors in areas of interest to the research, among them Carlos Lemos, Nestor G. Reis Filho, Murilo Marx, Emma Debenedetti and Anita Salmoni and Sandra J. Pesavento, as well as bibliographies of theoreticians, memorialists and local historians, with highlighted by Rodolpho José Del Guerra and Amélia Franzolin Trevisan. It contributes to increase the knowledge of the diversity of Brazilian urban dwelling production insofar as it qualifies and quantifies the process of transformation of the urban space of São José do Rio Pardo; revealing that its architecture, especially its dwellings, which at the same time can be considered as recurrent and common when compared to other cities of the São Paulo coffee cycle, are also loaded with singularities and nuances of their own; and it also by revealing the existence of established networks and relationships that cross borders in the circulation of knowledges, novelties, materials and technologies, of craftsmen, licensed practitioners and professionals, and of the clients involved in this production.

Keywords: Urban paulista dwelling. Architecture of the paulista coffee cycle. Urban transformations. Historic Center of São José do Rio Pardo. São José do Rio Pardo - city. 


\section{LISTA DE FIGURAS}

Figura 1: Moradias construídas entre o fim do século XIX e início do século XX no Centro Histórico de SJRP.__ 27

Figura 2: Mapa de São José do Rio Pardo indicando o recorte espacial da pesquisa. ___ 29

Figura 3: Mapa do Centro Histórico de São José do Rio Pardo e as edificações identificadas na pesquisa. ___ 35

Figura 4: Fotografias de Innocencio Vilhegas, início do século XX. ___ 36

Figura 5: Fotografias de Celestin Detinne, início do século XX.___ 36

Figura 6: Fotografia panorâmica de Valério Vieira, início do século XX. ___ 37

Figura 7: Fotografias aéreas do núcleo inicial rio-pardense realizadas por Innocencio Vilhegas.___ 37

Figura 8: Parte do trajeto que ganhou foros de Estrada ou Caminho de Goiás em 1725.

Figura 9: Capela de São José do Rio Pardo do ano de 1865 em aquarela de Menechino. ___ 50

Figura 10: Igreja do Rosário em Casa Branca, 1854. ___ 50

Figura 11: Capela Nossa Senhora dos Remédios de Caxambu indicada pela seta, 1868.

Figura 12: Núcleo urbano inicial de São José do Rio Pardo em 1870. 51

Figura 13: Detalhe da antiga Casa de Câmara e Cadeia retratada por Araújo Guerra em 1889. ___ 52

Figura 14: Bandeira da fachada frontal da antiga Casa de Câmara e Cadeia. ___ 53

Figura 15: Bossagens em argamassa falseando um trabalho de cantaria. ___ 53

Figura 16: Forro de tábuas de madeira superpostas. ___ 53

Figura 17: Interior da Casa de Câmara (atual Museu Rio-pardense Arsênio Frigo). ___ 53

Figura 18: Estação ferroviária e Largo da Estação no núcleo urbano rio-pardense, agosto de 1887._____ 58

Figura 19: Primeiro edifício da Estação Central da Companhia Ramal Férreo do Rio Pardo no final do século XIX. 58

Figura 20: Região servida pelas linhas da Companhia Mogyana de Estradas de Ferro. __ 60

Figura 21: Estações localizadas no município de São José do Rio Pardo. ___ 63

Figura 22: Formação do núcleo urbano em 1887 após a implantação da linha férrea. ___ 67

Figura 23: O Cemitério Municipal construído ao norte do núcleo urbano rio-pardense em 1896.

Figura 24: Fachada do Cemitério Municipal de São José do Rio Pardo. ___ 72

Figura 25: Desabamento da ponte metálica (janeiro de 1898). ___ 76

Figura 26: Euclides da Cunha supervisionando a reconstrução da ponte metálica (1898-1901).___ 76

Figura 27: Ponte metálica (1901), década de 1910.

Figura 28: Fachada frontal da primeira Igreja Matriz (1898).

Figura 29: Fachada lateral esquerda da primeira Igreja Matriz (1898), década de 1910.

Figura 30: Fachada lateral direita da Igreja Matriz com as naves laterais aumentadas (década de 1930). ___ 78

Figura 31: Fachada lateral esquerda da Igreja Matriz com as naves laterais aumentadas (década de 1930). _ 78

Figura 32: Altar e retábulo da igreja Matriz de São José do Rio Pardo (1898). ___ 78

Figura 33: Anúncios que mostram a diversificação de colégios públicos e particulares.

Figura 34: Localização das praças Prudente de Moraes e Barão do Rio Branco onde seria realizado o comércio. 81

Figura 35: Casa de Câmara e Cadeia antes da construção do Palácio do Tribunal da Justiça. ___ 81

Figura 36: Prédio do "Palácio do Tribunal da Justiça" de São José do Rio Pardo (1902), início do século XX. __ 82

Figura 37: Planta baixa do "Palácio do Tribunal da Justiça" de São José do Rio Pardo. ___ 83

Figura 38: Cadeia de Piracaia.____ 83

Figura 39: Cadeia de Ribeirão Preto (1912). _____ 83

Figura 40: Jardim Público da Praça XV de Novembro e a Igreja Matriz nos primeiros anos do século XX. ___ 84

Figura 41: Sócios da Società di Mutuo Soccorso 20 Settembre em frente a construção da primeira sede. ___ 85

Figura 42: Prédio da primeira sede da Società di Mutuo Soccorso 20 Settembre (1886) na década de 1910.

Figura 43: Sede do clube maçônico Loja “União Universal” (1897). ___ _ _ 85

Figura 44: Hotel Brasil (1887) retratado por Araújo Guerra na primeira folha do jornal A Platea em 1889.

Figura 45: Hotel Paulista (1903) na década de 1910.

Figura 46: Anúncios em que se nota a diversificação de comércio, atividades liberais e fabris após 1887.

Figura 47: Lotes aforados até o ano de 1889 em São José do Rio Pardo. ___ 98

Figura 48: A abertura da Avenida Euclides da Cunha, década de 1910. 102

Figura 49: Mapa de SJRP mostrando a formação de bairros adjacentes ao núcleo urbano, 1899. ___ 103

Figura 50: Planta cadastral (1901)___ 106

Figura 51: Francisco Escobar. ___ 107 
Figura 52: Vista parcial do paiol da Fazenda Santa Maria da Fartura, Sítio Novo.

Figura 53: Pharmacia Peixoto no núcleo urbano rio-pardense.

Figura 54: Casa sede da fazenda Tubaca.

Figura 55: Em primeiro plano criança não identificada e ao fundo parte do casario construído de taipa.

Figura 56: Edificações construídas entre o final do século XIX e início do século XX no Largo do Mercado.

Figura 57: Vista externa de uma moradia na Rua Paraíso.

Figura 58: Vista parcial das edificações da Rua Marechal Deodoro, década de 1910.

Figura 59: Desenho da fachada da moradia de Honório Luiz Dias (década de 1880).

Figura 60: Desenho da fachada da moradia de José Dias Machado (década de 1880).

Figura 61: Desenho da fachada da moradia de Leonardo Define (1888)

Figura 62: Desenho da fachada da moradia de Saint' Clair Andrade Junqueira (1888-1890).

Figura 63: Localização dos exemplares analisados neste capítulo.

Figura 64: Desenho da implantação da moradia de Honório Luiz Dias.

Figura 65: Desenho da implantação da moradia de José Dias Machado.

Figura 66: Desenho da implantação da moradia de Leonardo Define.

Figura 67: Desenho da implantação da moradia do Saint' Clair Andrade Junqueira.

Figura 68: Desenho da planta da moradia de Saint' Clair Andrade Junqueira.

Figura 69: Projeto de residência construída na Rua do Arouche, no 05, de 1896, São Paulo.

Figura 70: Desenho da planta da sede da fazenda Tubaca.

Figura 71: Reconstituição da planta da edificação de Leonardo Define.

Figura 72: Interior da edificação na Praça Prudente de Moraes. Antiga moradia de Leonardo Define.

Figura 73: Sobrado de Honório Luiz Dias (década de 1880)

Figura 74: Sobrado do capitão Basiliano da Costa Fontes em Jaboticabal -SP.

Figura 75: Antiga residência do Conde do Pinhal em São Carlos -SP.

Figura 76: Sobrado construído na cidade de Casa Branca, moradia ao historiador Lafayette de Toledo.

Figura 77: Eixo de simetria na fachada frontal da moradia de Honório Luiz Dias.

Figura 78: Eixo de simetria na fachada frontal da moradia de Saint' Clair Andrade Junqueira.

Figura 79: Moradia de Saint' Clair Andrade Junqueira (1888-1890) na Praça XV de Novembro.

Figura 80: Bandeira em ferro fundido da porta principal da moradia de Saint' Clair Andrade Junqueira.

Figura 81: Antiga residência do Conde Ribeiro do Valle construída na cidade de Guaxupé (1901).___ 130

Figura 82: Fachada frontal da moradia de José Dias Machado, década de 1910.

Figura 83: Fachada lateral da moradia de José Dias Machado na década de 1910.

Figura 84: Moradia construída na Rua João Alkmin na cidade de Guaxupé.

Figura 85: Moradia (1889) construída na Rua Valdemar Panico 1889 na cidade de Casa Branca.

Figura 86: Desenho da esquadria da moradia do major José Dias Machado.

Figura 87: Moradia de Leonardo Define (1888) na Praça Prudente de Moraes, década de 1910.___ 132

Figura 88: Casa de Câmara na década de 1910.

Figura 89: Artigo sobre a valorização do café publicado no jornal O Rio Pardo, em 30 de janeiro de 1910.

Figura 90: Mapa de São José do Rio Pardo mostrando a malha urbana em 1907.

Figura 91: Santa Casa de Misericórdia, 1913.

Figura 92: Pilaretes do portão e gradil que circunda o terreno da Santa Casa de Misericórdia.

Figura 93: Asilo Padre Euclides Carneiro na década de 1920

Figura 94: Coreto inaugurado em 15 de novembro de 1905 na Praça XV de Novembro. ___ 146

Figura 95: Praça XV de Novembro ajardinada na década de 1910.___ 146

Figura 96: Praça Marechal Deodoro na cidade de Mococa antes da construção do coreto em 1906.

Figura 97: Jardim Artístico sendo construído na década de 1910. __ 147

Figura 98: Jardim Artístico na década de 1930. ___ 147

Figura 99: Jardim Artístico na década de 1950, poucos anos antes de ser demolido. ___ 148

Figura 100: Desenho da fachada do Theatro São José construído em 1905.

Figura 101: Desenho da fachada do Cine Pavilhão XV de Novembro construído por Paschoal Artese em 1910._149

Figura 102: Grupo Escolar Cândido Rodrigues (1908) no início do século XX. ___ 151

Figura 103: Grupos Escolares construídos pela Diretoria de Obras Públicas do Estado de São Paulo. ___ 152

Figura 104: Automóvel adquirido pelo coronel Francisco Soares de Camargo em 1908.

Figura 105: Carros recém chegados em São José do Rio Pardo através do trem.___ 153

Figura 106: Membros da família Flamínio em um automóvel. ___ 153 
Figura 107: Expansão urbana no sentido sul do núcleo no final da primeira década do século XX.

Figura 108: Anúncios de diversos profissionais que atuavam em São José do Rio Pardo na década de 1910.

Figura 109: Prédio do Banco Francês e Italiano para a América do Sul (1913) em São José do Rio Pardo.

Figura 110: Garagem construída na lateral direita do edifícios do Banco Francês e Italiano.

Figura 111: Ponte pênsil construída em 1913 para dar acesso à Ilha de São Pedro.

Figura 112: Matadouro de São José do Rio Pardo (1917) na década de 1910.____ 158

Figura 113: Expansão urbana de SJRP em 1916. ___ 159

Figura 114: Farmácia Itália-Brasil (1908) no final da década de 1910. ___ 160

Figura 115: Rua Francisquinho Dias na década de 1910. ___ 160

Figura 116: Rua Marechal Deodoro na década de 1910. ___ 160

Figura 117: Anúncio sobre a falta de pedreiros para finalização do serviço de esgoto. ___ 167

Figura 118: Anúncio da Marcenaria e Carpintaria Paulista de Miguel Cerávolo. ___ 169

Figura 119: Anúncio da Marcenaria Artística de Salvador Artese. ___ 169

Figura 120: Anúncio de contrato firmado entre Domingos Innechi e Filhos e Salvador Artese.___ 169

Figura 121: Anúncio do escritório de engenharia de João Timotheo P. da Rosa. ___ 170

Figura 122: Anúncio do escritório de engenharia de João Timotheo P. da Rosa e Francisco Constantino. ___ 170

Figura 123: Anúncio do empreiteiro e construtor Pietro Emídio Carrado. __ 171

Figura 124: Capela construída no Cemitério Municipal em 1905.

Figura 125: Residência de Cândido Souza Dias (1893) na Praça Marechal Deodoro, 167, Mococa.___ 172

Figura 126: Residência do Capitão João Ferraz de Siqueira (1896) na Praça Ademar de Barros, 131, Mococa. _172

Figura 127: Residência do Major João Bento Vieira da Silva (1898) na Rua Antonio Cristovam, 314, Mococa. __172

Figura 128: Residência do Sr. Antônio Caetano de Lima. ___ 172

Figura 129: Residência na Rua Marechal Deodoro esquina com a Rua Francisquinho Dias. __ 172

Figura 130: Anúncio da Marcenaria Vibonese de Paschoal Artese. ___ 174

Figura 131: Anúncio da Olaria Fartura e Depósito de materiais para construção de Paschoal Artese. ___ 175

Figura 132: Anúncio da Escola de desenho de Paschoal Artese.__ 175

Figura 133: Anúncio da Escola de desenho de Salvador Artese. ___ 175

Figura 134: Alunos da escola de desenho de Paschoal Artese, início do século XX. ___ 177

Figura 135: Artese anuncia no jornal a necessidade de mão de obra para atuar na construção civil. ___ 178

Figura 136: Anúncio dos serviços oferecidos por Artese. ___ 179

Figura 137: Edificações semelhantes construídas em diferentes cidades do Estado de São Paulo. __ 180

Figura 138: Portão de acesso e detalhes ornamentais do Jardim Artístico, década de 1940 . ___ 182

Figura 139: Casarão do Artese (década de 1910) na Praça Barão do Rio Branco, 156.

Figura 140: Moradia de Dante Artese (década de 1910) na Praça Barão do Rio Branco, 142. ___ 182

Figura 141: Moradia (década de 1910) na Praça Barão do Rio Branco, 182.

Figura 142: Edifício de uso misto (década de 1910) da família Landini na Rua Treze de Maio. ___ 182

Figura 143: Moradia (1917-1918) de Beatriz Cristina Granado do Prado na Avenida Independência, $05 . \ldots 183$

Figura 144: Moradia ( década de 1910) da família Bingoletto na Praça XV de Novembro, 42.__ 183

Figura 145: Moradia (década de 1910) na Rua Francisco Glicério, 546. ___ 183

Figura 146: Rua Treze de Maio, década de 1910.

Figura 147: Implantação da moradia de Dante Arte ___ 184

Figura 148: Vários tipos de implantação de edificações construídas por Artese no início do século XX. ___ 185

Figura 149: Ornamentos do repertório floreal utilizado por Paschoal Artese no Casarão do Artese. ___ 186

Figura 150: Gradis do Casarão do Artese. __ 187

Figura 151: Fechamento da sacada do Casarão do Artese com elementos delgados em concreto. ___ 188

Figura 152: Casarão do Artese reformado e ampliado, 1922.____ 188

Figura 153: Operários e crianças no quintal do Casarão do Artese, no final da obra, na década de 1920. ___ 189

Figura 154: Uso do tijolo no Casarão do Artese. ___ 189

Figura 155: Pintura interna do Casarão do Artese. ___ 189

Figura 156: Diferentes pisos utilizados no Casarão do Artese. __ 189

Figura 157: Estrutura do telhado do Casarão do Artese. ___ 189

Figura 158: Diferentes desenhos de forro no Casarão do Artese. __ 190

Figura 159: Detalhe da fachada da moradia de Dante Artese. ___ 190

Figura 160: Fachada atual do edifício de uso misto da família Landini na Rua Treze de Maio, 152. 
Figura 161: Detalhe dos ornamentos da fachada da moradia localizada na Praça Barão do Rio Branco, 182. 191

Figura 162: Residência na Rua Canuto do Val, Bairro de Santa Cecília, São Paulo.

Figura 163: Residências na Praça XV de Novembro, 42, São José do Rio Pardo.

Figura 164: Residência na Praça Barão do Rio Branco, 182, São José do Rio Pardo.

Figura 165: Reprodução do projeto arquitetônico da moradia de Beatriz Cristina Granado do Prado. ___ 192

Figura 166: Pináculo da residência de Beatriz Cristina Granado do Prado.____ 192

Figura 167: Ático da fachada da residência de Beatriz Cristina Granado do Prado onde se lê a data 1918.

Figura 168: Detalhe ornamental na platibanda da residência localizada na Rua Francisco Glicério, 546. ___ 193

Figura 169: Gradis e portas de ferro encontradas nas edificações construídas por Artese. ___ 193

Figura 170: Anúncio da Serralheria Riopardense. ___ 194

Figura 171: Cidade de São José do Rio Pardo na segunda década do século XX. ___ 199

Figura 172: Vista parcial da Rua Francisco Glicério, início do século XX._______ 199

Figura 173: Vista parcial da Rua Treze de Maio, 1910. ___ 199

Figura 174: Desenho da fachada da moradia da família Ribeiro Nogueira (1911).____ 200

Figura 175: Desenho da fachada da moradia na Rua Francisco Glicério esquina com a Praça Barão do Rio Branco,

831 (década de 1910). _ 200

Figura 176: Desenho da fachada da moradia da família Penna (década de 1900).____ 200

Figura 177: Desenho da fachada da moradia de Dante Artese (década de 1910). ___ 200

Figura 178: Localização dos exemplares de moradias analisados neste item do capítulo.___ 201

Figura 179: Requerimento de licença para construir de 1916. ___ 202

Figura 180: Vários tipos de implantação da moradia urbana rio-pardense no início do século XX. ___ 204

Figura 181: Desenho da implantação da moradia do Sr. Oliveiros Fernandes Pinheiro.___ 205

Figura 183: Desenho da planta da moradia do Sr. Luis Martini. ___ 207

Figura 182: Detalhe do alpendre da moradia de João Gabriel Ribeiro e da casa da Rua Francisco Glicério, 546.207

Figura 184: Vista parcial da moradia do Nhô Ribeiro e detalhe do jardim na década de 1920 .____ 209

Figura 185: Chalé de Oliveiros Fernandes Pinheiro na Rua Francisquinho Dias, década de $1910 . \ldots 209$

Figura 186: Desenho da planta da moradia da família Ribeiro Nogueira.___ 210

Figura 187: Desenho da planta da moradia localizada na Rua Francisco Glicério esquina com a Praça Barão do Rio

Branco, 831. _ _ 211

Figura 188: Desenho da planta da moradia da família Penna na Rua João Gabriel Ribeiro, 382 .____ 213

Figura 189: Desenho da planta da moradia de Dante Artese na Praça Barão do Rio Branco, 142.___ 213

Figura 190: Embasamento de pedra da moradia de Dante Artese. ___ 214

Figura 191: Paredes de tijolos no porão.___ 214

Figura 192: Telhado da moradia da família Penna. ___ 215

Figura 193: Moradia da família Ribeiro Nogueira na Praça Barão do Rio Branco, 22.__ 215

Figura 194: Moradia do Nhô Ribeiro na esquina da Praça XV de Novembro com a Rua Marechal Floriano, 17. _215

Figura 195: Moradia na Rua Francisco Glicério esquina com a Praça Barão do Rio Branco, 831.___ 215

Figura 196: Moradia da família Penna Rua João Gabriel Ribeiro, 382. ___ 215

Figura 197: Vista parcial da Rua Treze de Maio na década de 1910 mostrando edificação com platibanda e outras

ainda com beiral. A seta preta aponta o cano embutido no passeio para conduzir a água para fora da guia. __ 216

Figura 198: Desenho da cobertura da edificação na Rua Francisco Glicério esquina com a Praça Barão do Rio

Branco, 831. _ 216

Figura 199: Desenho da cobertura do Casarão do Artese na Praça Barão do Rio Branco, 156. ___ 216

Figura 200: Formas variadas de platibandas em edificações localizadas na área central, início do século XX.__ 217

Figura 201: Formas variadas de platibandas em edificações localizadas na área suburbana, início do século XX. 218

Figura 202: Moradia de Saint' Clair Andrade Junqueira, década de 1910.

Figura 203: Desenho das moradias de Vicente Darvença e de Sr. Lourenço Tempesta.___ 219

Figura 204: Eixo de simetria nas fachadas das moradias da família Ribeiro Nogueira e Penna. __ 220

Figura 205: Fachada de moradia na Rua Francisco Glicério com a Praça Barão do Rio Branco, 831. ___ 220

Figura 206: Moradia do Capitão João Ferraz de Siqueira Praça Ademar de Barros, 131, na cidade de Mococa._222

Figura 207: Moradia do Coronel José Pereira de Lima de 1916 na cidade de Mococa. ___ 222

Figura 208: Moradia na Rua Valdemar Panico, 102, na cidade de Casa Branca.___ 222

Figura 209: Moradia na Rua Dr. Menezes, 317, na cidade de Casa Branca. ___ 222

Figura 210: Moradia na Praça Antônio Barreto, 93, na cidade de Casa Branca. ___ 222

Figura 211: Ladrilhos hidráulicos. __ 223 
Figura 212: Assoalho da casa na esquina da Rua Francisco Glicério com a Praça Barão do Rio Branco, 831.

Figura 213: Diferentes tipos de forro.

Figura 214: Forros de madeira para ventilação natural da residência na Praça Marechal Deodoro, 17, Mococa. 224

Figura 215: Diferentes esquadrias com uma folha de vidro por fora. ___ 225

Figura 216: Janelas venezianas externas. ___ 225

Figura 217: Mobília da casa do senhor Francisco Trevisan. ___ 226

Figura 218: Anúncios de mobília, objetos e acessórios. ___ 227

Figura 219: Divisão do município de São José do Rio Pardo em zonas conforme Código de Posturas de 1918. _233

Figura 220: Vista aérea da Praça Prudente de Moraes. __ 237

Figura 221: Vista frontal da Praça Prudente de Moraes, 1922.___ 237

Figura 222: Herma Euclides da Cunha, primeira metade do século XX. ___ 237

Figura 223: Inauguração da Gruta Nossa Senhora de Lourdes em 18 de maio de 1918.

Figura 224: Vista parcial do Parque Independência em construção na década de 1910.

Figura 225: Construção da caixa d'água no Parque Independência, década de 1920.

Figura 226: Localização das instalações construídas na gestão do prefeito Mário Rodrigues (1915-1919). __ 238

Figura 227: Mercado municipal de São José do Rio Pardo, final da década de 1920.

Figura 228: Estrutura metálica que sustenta o letreiro indicando a função do edifício: Mercado Municipal. __ 240

Figura 229: Vista parcial da Estação Central construída em 1927.

Figura 230: Vista parcial da Estação Central e do armazém construídos em 1927.

Figura 231: Localização do Hospital São Vicente. ___ 242

Figura 232: Hospital São Vicente, início da década de 1930.

Figura 233: Desenho rebatido das fachadas do Banco F. Barreto. ___ 244

Figura 234: Vista parcial do Banco F. Barreto (1928) em São José do Rio Pardo. ___ 244

Figura 235: Prédio do antigo Banco F. Barreto em Mococa. ___ 244

Figura 236: Escritório de zinco protegido por uma redoma nas margens do rio Pardo.___ 245

Figura 237: Sede da Società di Mutuo Soccorso 20 Settembre (1929), década de 1940.___ 245

Figura 238: Expansão urbana e localização das edificações na década de 1920.

Figura 239: Vista parcial da cidade de São José do Rio Pardo em 1921.____ 247

Figura 240: Vista parcial da ocupação urbana à oeste da área central de São José do Rio Pardo em 1921.

Figura 241: Anúncios de barbeiro, salão de cabeleireiro e oficina de armeiro. ___ 249

Figura 242: Anúncios de hotéis em São José do Rio Pardo. ___ 249

Figura 243: Anúncios de casas e lotes à venda. ___ 250

Figura 244: Anúncio da agência Chevrolet em São José do Rio Pardo. ___ 255

Figura 245: Anúncio da agência Ford em São José do Rio Pardo. ___ 255

Figura 246: Agência Vicente Nasser \& Irmãos, década de 1920. __ 256

Figura 247: Agência de Lincoln Fordson, década de 1920.

Figura 249: Cine Theatro Colombo (1935) na Rua Marechal Floriano, 110.

Figura 250: Ginásio do Estado (1936) fotografado em 1937. ___ 259

Figura 251: Escola Normal Primária (1932) de Casa Branca.___ 259

Figura 252: Ao fundo a Escola Normal Oficial (1939) de Mococa. __ 259

Figura 253: Grupo escolar Tarqüínio Cobra Olyntho (1941). ___ 260

Figura 254: Grupo de operários durante a execução do calçamento. ___ 261

Figura 255: Mapa de São José do Rio Pardo em 1940. __ 262

Figura 256: Anúncio de Labienio Baptista Machado. __ 265

Figura 257: Anúncio de Danielo Clementi. __ 265

Figura 258: Anúncio de Ladeira Rosa e Affonso Sammartino.___ 265

Figura 259: Projeto submetido à aprovação na Prefeitura Municipal de São José do Rio Pardo, 1926. ___ 267

Figura 260: Projeto submetido à aprovação na Prefeitura Municipal de São José do Rio Pardo, 1930.___ 267

Figura 261: Mapa da malha urbana com a divisão de bairros de São José do Rio Pardo em 1940. ___ 269

Figura 262: Vista parcial do Centro de São José do Rio Pardo, 1936. Fotografia tirada do alto da Vila Formosa. 270

Figura 263: Desenho da fachada de uma oficina projetada por Ernesto Giovani Rugani. ___ 272

Figura 264: Desenho da fachada da moradia de Ernesto Giovani Rugani na Rua Francisco Glicério.___ 272

Figura 265: Desenho da fachada de uma moradia projetada por Ernesto Giovani Rugani. ___ 272

Figura 266: Desenho da fachada de uma moradia projetada por Ernesto Giovani Rugani. ___ 273 
Figura 267: Desenho da fachada de uma moradia projetada por Ernesto Giovani Rugani.

Figura 268: Desenho da fachada de uma moradia projetada por Ernesto Giovani Rugani.

Figura 269: Vista do Hotel Brasil, mostrando a parte antiga, e a ampliação projetada por Rugani. ___ 274

Figura 270: Desenho do projeto de Heroino Machado, Rua Benjamin Constant, 15.

Figura 271: Desenho do projeto da moradia de Honório Dias Siqueira, Rua Benjamin Constant, 189. ___ 275

Figura 272: Desenho do projeto de Francisco Barreto na Praça Tiradentes, 63.

Figura 273: Desenho do projeto de Gabriel Gervásio na Praça Barão do Rio Branco, 110.

Figura 274: Desenho da implantação das obras de José Lourenço. ___ 278

Figura 275: Reportagem do jornal exaltando Américo Braghetta. ___ 279

Figura 276: Desenho do projeto de José Luzio na Rua Marechal Floriano, 1.___ 280

Figura 277: Desenho do projeto de Francisco Consolo na Rua Benjamin Constant.___ 280

Figura 278: Desenho do projeto de Pedro Nogueira na Rua Marechal Floriano. ___ 281

Figura 279: Desenho da implantação das obras de Américo Braghetta.____ 282

Figura 280: Projeto arquitetônico da capela de Nossa Senhora das Angústias. ___ 282

Figura 281: Frente do Cartão de Imigração de João Bergamasco. ___ 283

Figura 282: Projeto de José Lourenço aprovado pela Prefeitura Municipal de São José do Rio Pardo. ___ 285

Figura 283: Projeto de João Bergamasco aprovado pela Prefeitura Municipal de São José do Rio Pardo.___ 285

Figura 284: Anúncio de João Bergamasco. ___ 285

Figura 285: Projeto de João Bergamasco aprovado pela Prefeitura Municipal de São José do Rio Pardo.___ 286

Figura 286: Arquibancadas da Associação Atlética Riopardense em construção (1933). ___ 287

Figura 287: Sede social da Associação Atlética Riopardense concluída em 1946.

Figura 288: Cine Theatro Colombo em construção em 1934.___ 287

Figura 289: Ginásio do Estado em construção em 1934.

Figura 290: Igreja de São Roque em construção, década de 1930.___ 288

Figura 291: Fábrica de massas Perocco em construção em 1929.

Figura 292: Padaria e Confeitaria Raddi em construção, 1934.

Figura 293: Ponte pênsil em 1939. ___ 288

Figura 294: Vista parcial do Bairro Bonsucesso com a igreja do São Roque ao fundo, década de 1930. ___ 289

Figura 295: Projeto da Igreja de São Roque elaborado por João Bergamasco.___ 289

Figura 296: Igreja de São Roque, 2018.___ 289

Figura 297: Detalhe do acabamento da cobertura do altar da Igreja de São Roque, 2018.

Figura 298: Detalhe do acabamento da cobertura da torre do sino da Igreja de São Roque, 2018.

Figura 299: Projeto da Igreja Nossa Senhora Aparecida. ___ 290

Figura 300: Igreja Nossa Senhora Aparecida, 2018. ___ 290

Figura 301: Detalhe do acabamento da cobertura da ala lateral da Igreja Nossa Senhora Aparecida, 2018.

Figura 302: Desenho do projeto da fábrica de massas Perocco.___ 291

Figura 303: Antiga Fábrica de Massas Perocco. ___ 291

Figura 304: Hotel Lutti no início do século XX. _ـ 292

Figura 305: Desenho do projeto de um edifício de uso misto de Antonio Raddi.___ 292

Figura 306: Desenho da implantação do edifício de Antonio Raddi e Domingos Perocco.___ 293

Figura 307: Edifício de Antonio Raddi (1935), década de 1940. __ 293

Figura 308: Ponte pênsil da Ilha de São Pedro, década de 1940. __ 294

Figura 309: Desenho da fachada do edifício de Antonio Flora, Rua Marechal Deodoro. ___ 295

Figura 310: Desenho da fachada do edifício de Manoel Ferreira Pinto Júnior, Rua Marechal Floriano.___ 295

Figura 311: Desenho da fachada do edifício de Vicente Nasser e Irmãos, Rua Marechal Deodoro.___ 295

Figura 312: Desenho da fachada do edifício de Vicenza Cogato, Rua Treze de Maio. ___ 295

Figura 313: Desenho da fachada do edifício de Pedro Darcie, Rua Ruy Barbosa. ___ 296

Figura 314: Desenho da fachada do edifício de Francisco Martinez. ___ 296

Figura 315: Desenho do projeto da moradia de Maria Eugênia.___ 297

Figura 316: Desenho do projeto da moradia de Victorio Lavratte, Avenida Independência, 129 . ___ 297

Figura 317: Desenho do projeto da moradia de Francisco Sberce, Rua Ruy Barbosa, 577.

Figura 318: Desenho do projeto da moradia de Paschoal Cerávolo, Rua Francisquinho Dias, 783.

Figura 319: Desenho do projeto da moradia de Paulo Ferreira da Silva, Rua Benjamin Constant (demolido). _ 298

Figura 320: Desenho do projeto da moradia de João Bergamasco, Rua Ruy Barbosa (demolido).___ 298

Figura 321: Desenho da implantação de moradias urbanas projetadas por João Bergamasco. ___ 299 
Figura 322: Elementos decorativos utilizados por Bergamasco na sua produção edificativa.

Figura 323: Espacialização dos projetos/obras de acordo como o responsável pelo projeto e construção.

Figura 324: Vista parcial da Rua Costa Machado com a Rua Treze de Maio, década de 1940

Figura 325: Requerimento de licença para construir.

Figura 326: Projeto da moradia de Horacio Ferreira Pedroso na Vila Pereira, São José do Rio Pardo.

Figura 327: Perímetro urbano e suburbano de São José do Rio Pardo conforme Código de Posturas de 1918. _308

Figura 328: Desenho da fachada da moradia de João Gabriel Ribeiro, Rua João Gabriel Ribeiro, 196 (1924).__ 309

Figura 329: Desenho da fachada das casa de Willian Simonsen, Rua Benjamin Constant, 354 (1925). ___ 309

Figura 330: Desenho da fachada da moradia de Ciro Ferraz, Rua Benjamin Constant, 18A (1926).___ 309

Figura 331: Desenho da fachada da moradia de Messias Candido Ribeiro, Praça XV de Novembro, 152 (1929). 309

Figura 332: Desenho da fachada da moradia de Maria da Conceição Damasio, Rua Benjamin Constant (1934). 309

Figura 333: Desenho da fachada da moradia de Benedicto Amaral, Rua Ruy Barbosa, 381 (1936). ___ 309

Figura 334: Localização dos exemplares de moradias construídas em SJRP entre 1918 e 1940.

Figura 335: Exemplos de edificações implantadas afastadas dos limites do lote. ___ 311

Figura 336: Exemplos de edificações implantadas no limite do lote. ___ 311

Figura 337: Moradia da Rua Benjamin Constant com a Rua Júlio Mesquita, 576 (1918).___ 312

Figura 338: Moradia da Rua Silva Jardim com a também Rua Júlio Mesquita, 506 (1923). ___ 312

Figura 339: Moradia da Rua Costa Machado com a Rua Francisco Glicério, 592 (década de 1910). ___ 313

Figura 340: Moradia da Rua Benjamin Constant com a Marechal Floriano, 189 (1929). ___ 313

Figura 341: Moradia da Rua Dr. Pedro de Toledo com a Rua Floriano Peixoto, 343, Caconde. ___ 313

Figura 342: Moradia da Rua Benjamin Constant com a Rua Vinte e Quatro de Dezembro, 98, Caconde. ___ 313

Figura 343: Moradia da Rua Coronel Antônio Costa com a Rua Francisco Ribeiro do Valle, 05, Guaxupé. ___ 313

Figura 344: Moradia da Rua Capitão Eugênio com a Rua Norberto Ribeiro do Valle, 130, Guaxupé.____ 313

Figura 345: Moradia da Rua Coronel Marçal, 260 (1945). ___ 314

Figura 346: Moradia da Rua Treze de Maio com a Rua João Gabriel Ribeiro, 285 (década de 1930). ___ 314

Figura 347: Moradia da Rua Benjamin Constant, 344 (1925).___ 314

Figura 348: Moradia da Rua Marechal Floriano, 314 (década de 1940). ___ 314

Figura 349: Construção de garagem aproveitando o desnível do terreno na moradia da Rua Silva Jardim, 337.314

Figura 350: Passagem lateral destinada a veículo na moradia da Rua Benjamin Constant, 344-354 (1925).__ 315

Figura 351: Garagem coberta na moradia da Praça dos Três Poderes, 24.___ 315

Figura 352: Abrigo destinado especialmente para automóvel na moradia da Rua Ruy Barbosa, 381 (1936). _ 316 Figura 353: Edícula destinada a garagem, oficina e apartamento para o motorista e criadagem na moradia da Rua João Gabriel Ribeiro, 196 (1924). ___ 316

Figura 354: Desenho da planta da moradia de Ciro Ferraz na Rua Benjamin Constant, 18A (1926). ___ 316

Figura 355: Desenho da planta da moradia de Maria da Conceição Damasio na Rua Benjamin Constant (1934). 317

Figura 356: Desenho da planta da moradia de Messias Candido Ribeiro na Praça XV de Novembro, 152 (1929). 319

Figura 357: Desenho da planta da moradia de João Gabriel Ribeiro na Rua de mesmo nome, 196 (1924).

Figura 358: Jardim, pérgula coberta com vegetação e frutíferas e os canteiros de flores da moradia de João Gabriel Ribeiro (1924), 2017.

Figura 359: Desenho da planta da edificação de Benedicto Amaral na Rua Ruy Barbosa, 381 (1932 e 1936). _321

Figura 360: Edícula da moradia de João Gabriel Ribeiro (1933), 2017.

Figura 361: Desenho da planta da edificação de Willian Simonsen na Rua Benjamin Constant, 344-354 (1925). 324

Figura 362: Corte apresentado no projeto da residência de Ciro Ferraz, na Rua Benjamin Constant, 18A. __ 325

Figura 363: Corte apresentado no projeto da residência da Rua Silva Jardim, 29 (1934). ___ 325

Figura 364: Corte apresentado no projeto da edícula da casa de João Gabriel Ribeiro (1933). ___ 325

Figura 365: Piso em madeira da casa de João Gabriel Ribeiro. ___ 326

Figura 366: Piso em ladrilho hidráulico da casa da Rua Treze de Maio, 338. ___ 326

Figura 367: Piso em ladrilho hidráulico da casa de Messias Candido Ribeiro. __ 326

Figura 368: Piso granilite da casa de João Gabriel Ribeiro. ___ 326

Figura 369: Forro de estuque da sala de visita da moradia de João Gabriel Ribeiro. ___ 327

Figura 370: Forro em madeira trabalhado da sala de visita da casa da Rua Treze de Maio, 338.___ 327

Figura 371: Fachada reformada da moradia de Maria da Conceição Damasio (1934), 2014.

Figura 372: Moradias de Willian Simonsen (1925), 2016.

Figura 373: Moradia na Avenida Deputado Eduardo Vicente Nasser, 813, 2016. 
Figura 374: Desenho da planta da edificação na Avenida Deputado Eduardo Vicente Nasser, 813. 330

Figura 375: Fachada de moradia de João Gabriel Ribeiro (1924), 2016.

Figura 376: Desenho da fachada da moradia de Benedicto Amaral de 1932 e fotografia atual.

Figura 377: Desenho da planta da moradia localizada na Rua Coronel Marçal, 260 (1945).

Figura 378: Postos de combustível com características da arquitetura art-déco.

Figura 379: Edificações de uso misto com características da arquitetura art-déco (1941).

Figura 380: Residências no estilo art-déco.

Figura 381: Habitações destinadas a venda em São José do Rio Pardo.

\section{INDICE DE TABELAS}

Tabela 1: Valores em sacas de café despachado por estação nos anos de 1900 e 1901.

Tabela 2: Produção agrícola de São José do Rio Pardo em 1901.

Tabela 3: Produção pecuária de São José do Rio Pardo no ano de 1901.

Tabela 4: Número populacional do Recenseamento de São José do Rio Pardo em 1890 e 1920.

Tabela 5: Artífices e profissionais atuantes na construção civil de SJRP no final do século XIX e início do XX.__ 173

Tabela 6: Valores correspondentes à produção agrícola rio-pardense no início dos anos 1920.

Tabela 7: Valores correspondentes a pecuária rio-pardense no início dos anos 1920. ___ 251

Tabela 8: Valores correspondentes ao café produzido em São José do Rio Pardo entre os anos 1911 e 1921.

Tabela 9: Produção cafeeira e quadro populacional de São José do Rio Pardo entre os anos de 1854 e 1935.

Tabela 10: Lista parcial dos processos de aprovação de construção pertencentes ao Arquivo Público da Secretaria de Obra de São José do Rio Pardo. 384

\section{INDICE DE GRÁFICOS}

Gráfico 01: Cidade dos acionistas da Companhia Ramal Férreo do Rio Pardo.

Gráfico 02: Número e porcentagem de projetos aprovados entre os anos de 1925 a 1940 .__ 268

Gráfico 03: Ocorrência de projetos aprovados por bairro entre os anos de 1925 a 1940.1268

Gráfico 04: Tipo de obra solicitada para aprovação entre os anos de 1925 a 1940.

Gráfico 05: Ocorrência de projetos aprovados de acordo com o uso por João Bergamasco entre 1925 e 1940.296 


\section{SUMÁRIO}

44 1. São José do Rio Pardo e as moradias urbanas nas primeiras décadas de sua formação: 1865-1902

451.1 Ocupação e povoamento do nordeste paulista

48 Da fundação à autonomia política

54 Café e Ferrovia

661.2 Estruturação e desenvolvimento do espaço urbano

901.3 Do desenho à consolidação e expansão urbana

1091.4 As moradias urbanas anteriores ao Código de 1903

135 2. Ordem e controle na cidade e nas moradias de São José: 1903-1917

1362.1 A cidade no início do século XX

161 A manutenção do poder e a hegemonia econômica

1652.2 Agentes da construção civil rio-pardense: apagamentos e esquecimentos

174 Paschoal Artese

1992.3 As moradias urbanas construídas entre os anos de 1903 e 1917

231 3. São José do Rio Pardo e as moradias urbanas entre guerras: 1918-1940

$2323.1 \mathrm{~A}$ cidade e uma nova perspectiva

265 3.2 Diplomados e práticos licenciados (1918-1940)

271 Ernesto Giovani Rugani

274 José Lourenço

279 Américo Braghetta

282 João Bergamasco

301 Movimento de migrações

303 3.3 As moradias urbanas construídas entre 1918 e 1940

\section{Considerações Finais}

\section{Referências}

364 Anexo 01

365 Anexo 02

368 Anexo 03

369 Anexo 04

370 Anexo 05

374 Apêndice 01

382 Apêndice 02

384 Apêndice 03

393 Apêndice 04

400 Apêndice 05 
"É velho vezo meu amar sensualmente as linhas das casas, agradar-me de umas; antipatisar-me com outras, namorar algumas, desejar duas ou três como se fossem vivíssimas personagens"

(MARIO DE ANDRADE) 


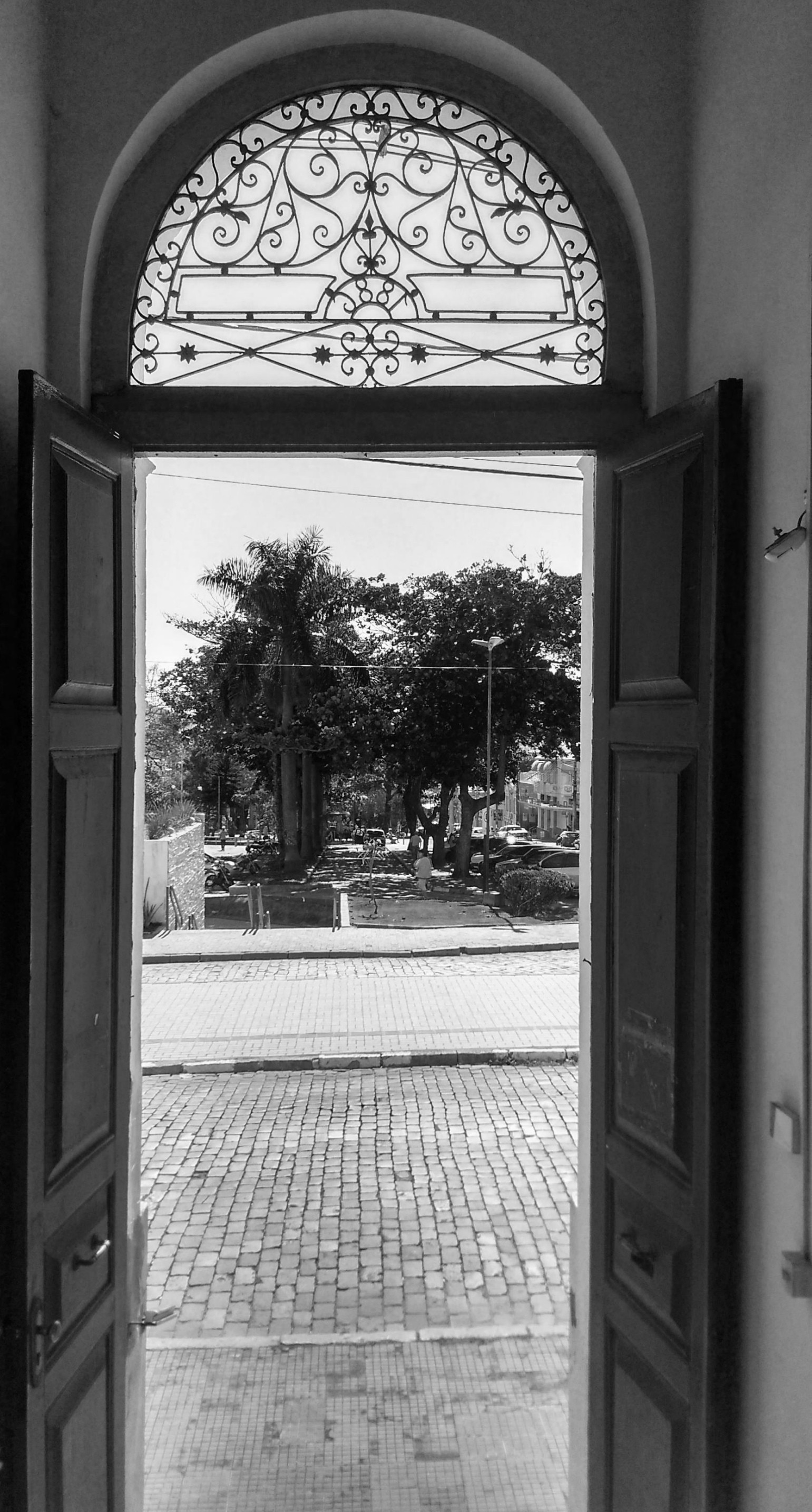


1. INTRODUÇĀO

Não está no portão

a memória da casa,

nem está no porão,

onde tudo se guarda.

Se talvez no jardim

mora alguma lembrança,

erram doces ausências:

borboletas, crianças.

A memória da casa

jaz além da estrutura,

das paredes caiadas

assoalho, nervuras

Vejo outrora na alcova

afogada em cortinas

o rubor de uma rosa

e uma linda menina.

Onde foi essa alcova,

em que tempo se deu,

como entrou nessa história,

em que vão se perdeu?

Essa casa são muitas,

uma só todas elas;

o morar é a casa

com varandas, janelas.

As memórias são tantas,

tantos são os lugares

onde pousam lembranças

nesse lar, nesses lares...

(Memória da Casa)

(FERNANDO DE OLIVEIRA E WALMIR PALMA) 
Buscar explicações sobre o meu interesse pelo tema desta dissertação é como abrir na memória uma flor de mil e uma pétalas onde cada uma guarda a formosura de uma história. Estas, remetem às minhas lembranças de infância quando meus pais levavam eu e minha irmã gêmea para andarmos de trenzinho na Praça XV de Novembro de São José do Rio Pardo. Alí, naquele espaço, circulávamos ao redor do jardim admirando as elegantes residências enquanto meu pensamento viajava pelo seus interiores para buscar cada detalhe e imaginar como que a vida acontecia entre aquelas altas janelas e grossas paredes. Lembrome do fascínio que sentia a cada visita que fazíamos a algum morador da área central e a cada ida ao Museu Rio-pardense onde inúmeros objetos do cotidiano ficavam expostos impelindo minha curiosidade, a qual aumentava ao longo das trajetórias diárias que fazia a pé atravessando o Centro Histórico ${ }^{1}$ até a escola...

Já na universidade, no curso de arquitetura e urbanismo, meu interesse por história e preservação me levou a realizar um estágio na Secretaria Municipal de Planejamento, Desenvolvimento Urbano e Meio Ambiente, dentro da Diretoria de Patrimônio Construído e Tombamento do município de Poços de Caldas - Minas Gerais. Foi durante esse estágio que tive a oportunidade de realizar uma pesquisa com o objetivo de compreender a produção arquitetônica atrelada às transformações urbanas com vistas à produção de um plano de inventário para fundamentar processos de tombamento e laudos de bens tombados, seguindo as diretrizes do Instituto Estadual do Patrimônio Histórico e Artístico de Minas Gerais (IEPHA). Esta experiência foi marcante em minha vida, assim como outro estágio que realizei na Secretaria de Planejamento, Obras e Serviços de São José do Rio Pardo que me permitiu aproximar do arquivo de projetos devido à necessidade de regularização de obras construídas na primeira metade do século XX. O encanto pelos projetos foi imediato, sobretudo por eles terem me possibilitado conhecer o interior de inúmeras edificações que eu ainda não havia entrado. Essa oportunidade, aliada aquele desejo que se iniciou lá na infância de conhecer e compreender as construções antigas de São José do Rio Pardo, me encorajou a desenvolver um trabalho sobre a produção arquitetônica local como parte de uma Iniciação Científica ${ }^{2}$ e do Trabalho Final de Graduação $^{3}$. Estes trabalhos foram fundamentais, mas eu ainda não me sentia satisfeita com os resultados alcançados, isso porque viver junto às raízes, ouvir as memórias dos mais velhos, a melancolia de tudo que foi um dia, rever a paisagem através das falas e fotografias e perceber a sua rápida transformação me impulsionava a querer saber mais sobre a arquitetura, as moradias e a própria cidade, e contribuir de algum modo no (re)conhecimento, preservação e difusão do que foi e o que ainda resta dos casarões do Centro Histórico de São José do Rio Pardo.

Isso tudo foi despertando em mim a vontade de, um dia, poder pesquisar a moradia de uma paisagem urbana ainda repleta de marcos arquitetônicos de um tempo que nos parece tão distante, e onde essa

\footnotetext{
${ }^{1}$ O Centro Histórico de São José do Rio Pardo é reconhecido pelo governo local através da Lei Municipal n. 2920 , de 15 de janeiro de 2007, que "dispõe sobre o Plano Diretor Participativo do Município de São José do Rio Pardo, estabelecendo as diretrizes gerais da política municipal de desenvolvimento territorial, e dá outras providências" (2007, p. 01).

"Esta pesquisa teve como título "A construção urbana através da memória social coletiva: entre o rio Pardo e São José" e foi desenvolvida sob a orientação da professora doutora Rosana Soares Bertocco Parisi, com auxílio financeiro da Fundação de Amparo à Pesquisa de Minas Gerais (FAPEMIG).

3 A proposta final deste trabalho intitulado "Construindo a história através da memória: reabilitação do patrimônio urbano e arquitetônico de São José do Rio Pardo" incluiu a reabilitação dos edifícios pertencentes a um trecho da Rua Treze de Maio, mais especificamente entre a Rua Rui Barbosa e a Rua Marechal Floriano, terminando na Praça XV de Novembro.
} 
tipologia datada do final do século XIX e início do XX constitui em maior número. Todos esses fatores me instigaram a procurar as respostas para minhas inquietações sobre o urbano e a arquitetura, notadamente dessas moradias, determinando assim a escolha do objeto de pesquisa desta dissertação de mestrado.

Destaco que essa oportunidade de desenvolver um estudo mais especificamente voltado à produção da moradia urbana, incluindo os agentes da construção civil, tem também a intenção de contribuir para apontar e superar os limites que não foram ultrapassados pela historiografia brasileira que privilegiou a arquitetura institucional notadamente a religiosa e assinada por um profissional diplomado. Sendo assim, alinhei este trabalho àqueles que nas últimas décadas estão se voltando para o estudo, não somente da arquitetura e da moradia, mas também da cidade e dos agentes da construção civil responsáveis pela sua construção. Tudo isso contribuiu para que a arquitetura de São José do Rio Pardo e de muitas outras cidades do interior se mantivesse excluída da narrativa historiográfica.

Pretendemos, desse modo, ir além dos aspectos formais mais elementares dessa produção, contribuindo com uma leitura abrangente do espaço urbano, seus agentes disseminadores e seus usuários. Com isso, buscamos superar através do reconhecimento, registro e análise dessas moradias os limites que apresentam a historiografia da arquitetura paulista e também brasileira. Vale, nesse sentido, enfatizar as novas possibilidades de pesquisas que tenham como objetivo este assunto que não se esgota aqui, além de oferecer como desdobramento uma efetiva contribuição à preservação do patrimônio da área central de São José do Rio Pardo. Logo, nada mais agradável que dar continuidade aos estudos empreendidos durante a graduação, porém dessa vez com maior profundidade.

Foi assim que decidi contar uma versão da história dessa cidade, mas sem restringir nossas análises nas moradias propriamente ditas e sim nos servir delas, que também são memória, são identidade e pertencimento.

\section{OS OBJETOS}

\section{Urbano, arquitetura e moradia}

São José do Rio Pardo é uma cidade do interior paulista cuja ocupação ocorreu somente em meados do século XIX quando colonizadores mineiros chegaram à região em busca de terras férteis para cultivo de cana-de-açúcar, de café e criação de gado fomentando alternativas econômicas e de sobrevivência. Foi na década de 1870 que a cafeicultura se estabeleceu como cultura agrícola ascendente e grande fonte de riqueza que, acertadamente, associada à instalação da ferrovia em 1887, provocaram as condições favoráveis ao crescimento urbano, alterando a sua estrutura. No bojo das transformações as moradias se destacaram e nos proporcionaram elementos fundamentais de análise, em vista de sua superioridade numérica em relação aos demais edifícios da área central de São José do Rio Pardo, além da significativa 
importância conferida a elas em razão da assimilação das variações tecnológicas, dos materiais empregados, dos modos de morar e também da manutenção das tradições culturais locais, como bem destacou Carlos Lemos (1989b) ao tratar da história da casa brasileira. As observações das fachadas dessas moradias nos mostram a diversidade de manifestações estilísticas, resultado de uma combinação entre particularidades locais e estrangeiras trazidas por pessoas de fora da cidade e do país, fruto da condição socioeconômica e também política local. Foi o ecletismo classicizante sem grandes ostentações que predominou, além do neocolonial, art nouveau, art-déco e do bangalô, como podemos observar na Figura $1^{4}$. Mas como eram essas casas? Quais eram os programas de uso? Que padrões arquitetônicos seguiam? Como seus interiores e exteriores revelavam a sociedade e os gostos da época? Qual a relação entre a edificação, o lote e a rua? Quais as técnicas construtivas empregadas? Quem foram as pessoas responsáveis pelos projetos e obras? Eram titulados? Imigrantes? Em que medida as normativas urbanísticas, edilícias e sanitárias emanadas do poder público ditou regras para a moradia urbana? E como elas foram adotadas? Essas foram algumas das questões primárias que serviram como impulso e nortearam nossas análises.

Figura 1: Moradias construídas entre o fim do século XIX e início do século XX no Centro Histórico de São José do Rio Pardo.
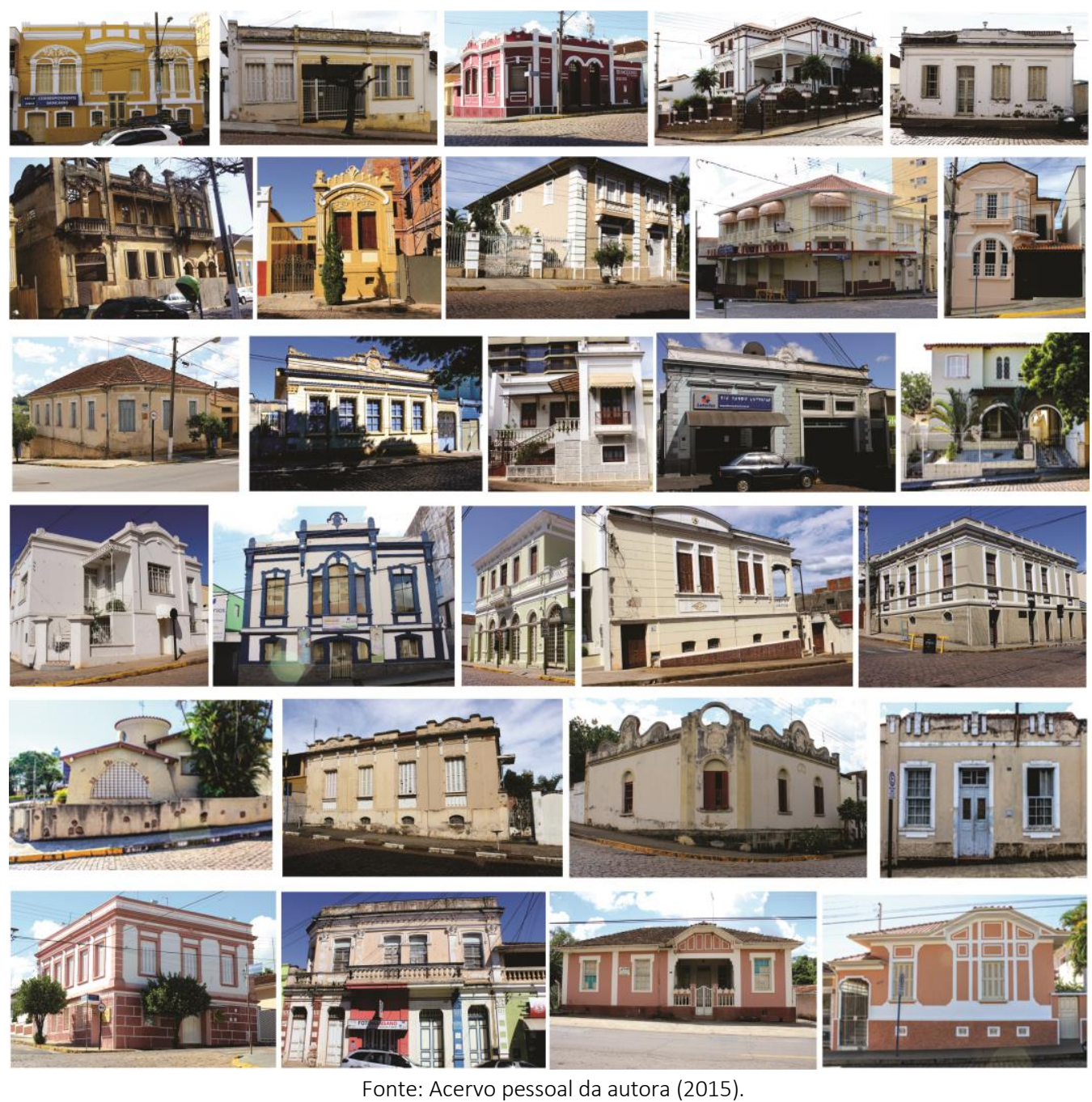

\footnotetext{
${ }^{4}$ Essa seleção de imagens mostra algumas das moradias identificadas no ano de 2015 durante o processo de aproximação do objeto.
} 
Como recorte espacial definimos o Centro Histórico rio-pardense por concordar com o posicionamento de Freire (1997) que atesta em seus estudos a importância do núcleo inicial de uma cidade, por ser este o local constituído pelas primeiras edificações e, por consequência, é a área de ocupação mais antiga, que ao longo do tempo e de forma progressiva foi sendo expandida. Esta autora (FREIRE, 1997, p. 221) diz ainda que o centro é "local mítico da origem, é local de partida ou de chegada dos forasteiros, guarda uma lenda do começo de tudo, quase um mito de origem das cidades". É, portanto, constituído por edificações que exibem valores culturais, estéticos e arquitetônicos de toda uma época e são testemunhas da história. Isto reforçou a nossa defesa: a necessidade de compreender este Centro Histórico, com possibilidade de expansão especialmente nos seus vetores de acesso (Avenida Independência, ao sul; Rua Siqueira Campos, ao leste; Avenida Euclides da Cunha, Rua Dom Pedro II, e Rua dos Paulistas ao oeste; e Rua Francisquinho Dias, ao norte, como pode ser observado na Figura 2) para poder identificar a sua produção residencial e analisar seus programas, soluções arquitetônicas e linguagens estilísticas, assim como os agentes disseminadores envolvidos. Cabe ressaltar que esses vetores de acesso ao Centro Histórico são consequência dos antigos caminhos de ligação do núcleo urbano rio-pardense a outras cidades, como Caconde a leste, Casa Branca e São Paulo ao sul, Mococa e Franca ao oeste, e ao norte a fazenda Tubaca, e acabaram se transformando em vias urbanas importantes do município. O início do recorte temporal corresponde à data de fundação da cidade em 1865, ponto de partida das ações que impulsionaram a formação e transformações urbanas. O fim do recorte temporal é 1940, data que assinala o declínio da economia cafeeira que era a base local, decorrente de um processo complexo que envolvia excesso de produção, concorrência estrangeira, quebra da bolsa de Nova lorque, dificuldades financeiras em razão da incapacidade de absorção dos mercados compradores, o que acarretou em redefinição de atividades agrícolas com a diversificação de produtos e o surgimento de outras para dar suporte à nova dinâmica que se definiu com o setor comercial e as industrias de bens de consumo, sobretudo alimentício e de veículos, e a expansão da cidade com a criação de novos bairros, abertos a partir da venda de glebas de antigas fazendas, sítios e chácaras que circundavam a ocupação urbana, com reflexo direto na construção de moradia. Com isso, o final da década de 1930 foi marcada pela atuação de uma companhia privada que dominou o mercado da construção civil local, sobretudo com a produção de casas para venda, contribuindo com a expansão e ocupação de novas áreas. 


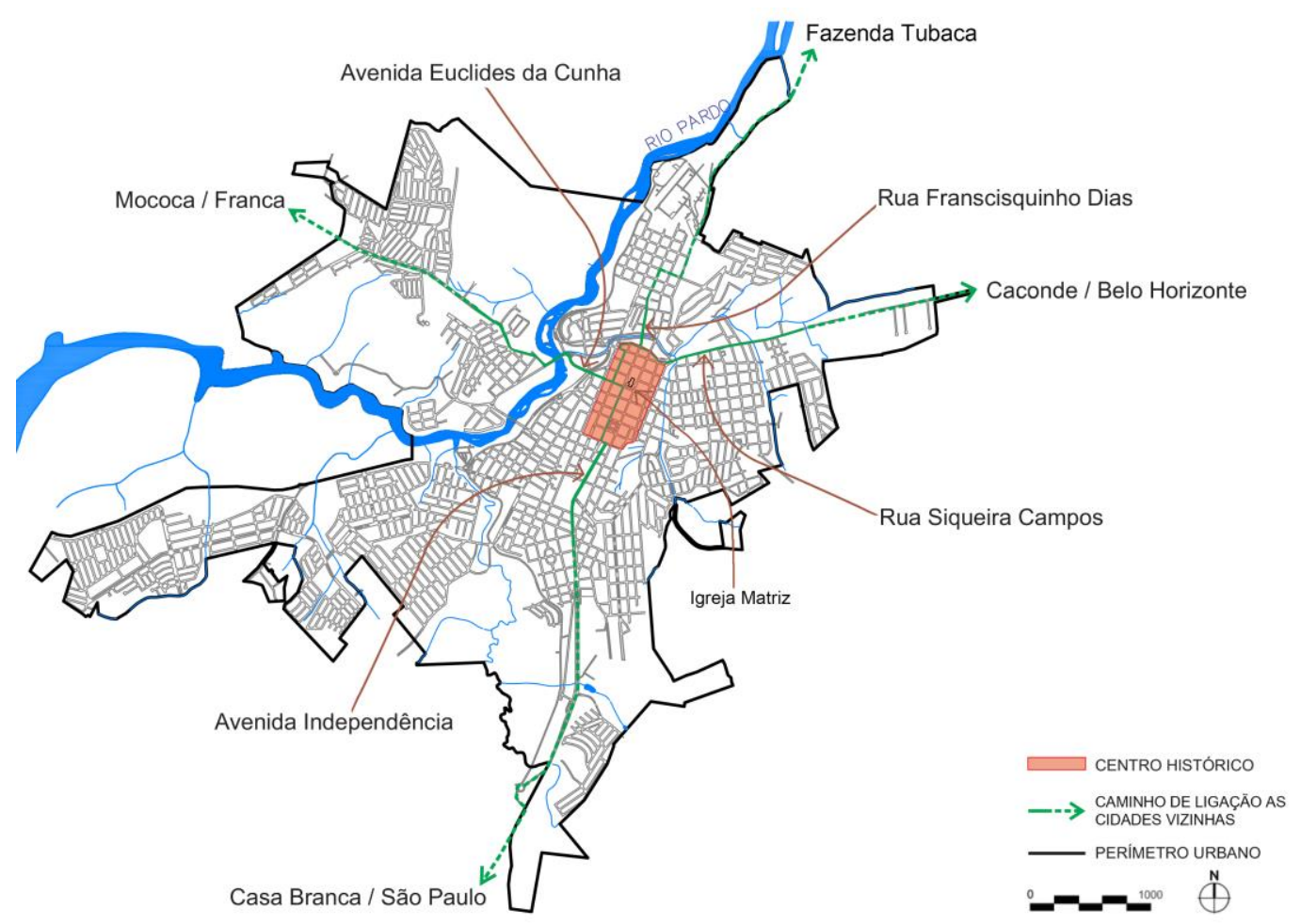

Fonte: Produzido por N. C. Rezende com base em mapa da Prefeitura Municipal de São José do Rio Pardo, 2016.

É necessário salientarmos a imprescindibilidade do estudo, registro e análise dessa produção residencial que em grande parte pode se caracterizar como uma arquitetura "sem arquiteto", projetada e construída majoritariamente por empreiteiros, construtores e mestres de obras. Foram esses agentes, mantidos no anonimato e desconhecidos da historiografia, os responsáveis por difundir padrões técnicos e estéticos a partir de referenciais trazidos de fora, de experiências anteriores e particularidades locais, contribuindo assim na consolidação de certa identidade arquitetônica rio-pardense. Todavia, a ausência de ações mais efetivas das instituições de preservação, especialmente no âmbito municipal, e mesmo da própria população contribuiu para que parte desta produção se perdesse em decorrência de demolições e reformas, em sua maioria realizadas para atender a interesses comerciais. Mas, afora as transformações, muitas das edificações residenciais construídas no recorte que estabelecemos para as análises se mantêm até os dias atuais, como é possível constatar através da leitura dessa dissertação.

A falta de documentação e a perda de muitos dos indícios esclarecedores dificultaram as análises, caso exemplar foi a perda e/ou fim dos projetos de antigos prédios já demolidos, como a moradia de Antônio Ribeiro Nogueira (hoje é o sobrado do Nosso Bar e Poggio); a casa comercial "Ao Ponto" (hoje Santander); o bangalô de Eduardo Porto, depois de Paulo Cobra (hoje é um estabelecimento comercial); o chalé de Oliveiros Fernandes Pinheiro (hoje sede do Rio Pardo Futebol Clube); o bangalô de José Perri (hoje Banco 
Mercantil do Brasil); o palacete ${ }^{5}$ de Dr. Heitor da Gama Corrêa (atualmente sem o andar superior, pertence a Casa Paroquial); o sobrado de José Pereira Martins de Andrade (hoje Banco da Caixa Econômica Federal); e a primeira Casa Paroquial, moradia de Dr. Bacci e Nenê Landini (hoje Casas Pernambucanas) (DEL GUERRA, 2008). Segundo o relato do engenheiro Dr. Walter de Sá Pinto a Del Guerra (2008), na ausência de espaço suficiente e seguro na Prefeitura para acondicionar os projetos datados ainda do século XIX, os mesmos foram guardados no escritório do topógrafo Roque Machado de Paiva. Após a morte do guardião, a sua família autorizou o Dr. Walter, que era o engenheiro da prefeitura na época, a levar todo o acervo para a nova sede do poder local (Praça dos Três Poderes), onde foram colocados nos porões para logo desaparecerem devido à umidade, queima, empréstimos e rasgaduras. Este é mais um caso de destruição e descaso com a documentação em fontes primárias que, nesse caso, contribuiu para agravar a falta de conhecimento sobre a produção arquitetônica rio-pardense, mas ao mesmo tempo nos impulsionou a registrar o que ainda se mantêm.

Acreditamos firmemente que, proporcionando maior entendimento do lugar e de sua arquitetura, este trabalho poderá também contribuir para ampliar os subsídios necessários para a sua preservação. Nesse sentido, concordamos com Calvino (1998) em "As Cidades e a Memória"

[...] a cidade não conta o seu passado, ela o contém como as linhas da mão, nos ângulos das ruas, nas grades das janelas, nos corrimãos das escadas, nas antenas dos pára-raios, nos mastros das bandeiras, cada segmento riscado por arranhões, serradelas, entalhes, esfoladuras. (CALVINO, 1998, p. 14-15).

Consideramos ainda a importância dessa pesquisa na tentativa de preencher lacunas e apontar os limites existentes na historiografia da arquitetura brasileira ${ }^{6}$ que se concentrou em construir uma interpretação nacionalista, privilegiando as criações modernas, o que ajudou a ampliar a desinformação a respeito da arquitetura produzida em torno da segunda metade do século XIX e início do século XX, sobretudo em cidades interioranas. A desinformação é ainda maior quando se trata da arquitetura das residências, como já destacado por autores como Reis Filho (2011) e Lemos, C. (1989a), especialmente quando essa produção é eclética. Isso porque, conforme apontado por Puppi (1998) o ecletismo foi

\begin{abstract}
desqualificado de antemão, desde o princípio, como uma arquitetura de origem estrangeira e 'de fundo acadêmico' para usar uma expressão de Lúcio Costa

$[\ldots]$

conjunto de regras - um receituário - muito estreito e absolutamente desatualizado, passadista e retrógrado. Em outras palavras, retratam o ecletismo como uma forma de projetar (e construir) inadequada ao progresso e à modernidade material, ao qual fatalmente e com razão deveria opor-se uma nova arquitetura, esta sim alinhada aos novos tempos e capaz de expressá-lo culturalmente (PUPPI, 1998, p. 09-10).
\end{abstract}

É esta forma de escrita que já vem sendo revista, e como ressaltado por Bortolucci (1991, p. 02), “não há mais razão para preconceitos infundados, nem com o ecletismo, nem com qualquer outro estilo, e muito

\footnotetext{
${ }^{5}$ Segundo as definições de Homem (1996, p.14) o palacete "constituiu um tipo de casa unifamiliar, de um ou mais andares, com po rão, ostentando apuro estilístico, afastada das divisas do lote, de preferência nos quatro lados, situada em meio a jardins, possuindo área de serviços e edículas nos fundos. Internamente, sua distribuição era feita a partir de um vestíbulo ou de um hall com escada social, resultando na divisão da casa em três grandes zonas: estar, serviços e repouso", conforme constatado na casa do Dr. Heitor.

${ }^{6}$ Autores como Yves Bruand (1981) e Mário Barata (1983) já alertavam sobre essa questão na década de 1980. 
menos com a chamada arquitetura 'sem arquiteto'". Além disso, é imprescindível o reconhecimento das tendências específicas que ocorreram em cada território em razão das questões sociais, econômicas e culturais peculiares, o que contribuiu para a produção de múltiplas expressões artísticas (BORTOLUCCI, 1991).

Deste modo, com base em documentação inédita, procuramos contribuir na ampliação do conhecimento sobre a temática da moradia urbana, dos agentes e da própria arquitetura como história social, como feito por Carlos Alberto Cerqueira Lemos em São Paulo (1989a), Maria Angela Pereira de Castro e Silva Bortolucci em São Carlos (1991) e Amanda Cavalcante Moreira em Teresina (2016), além de

\section{OS OBJETIVOS}

Foram definidos os seguintes objetivos nesta pesquisa:

\section{Geral}

- Identificar, caracterizar e analisar a moradia urbana do Centro Histórico de São José do Rio Pardo entre os anos de 1865 e 1940, a partir da compreensão de sua relação com o contexto local.

\section{$\underline{\text { Específicos }}$}

- Compreender as transformações urbanas ocorridas entre 1865 e 1940, período definido como o recorte temporal da pesquisa.

- Entender o contexto histórico que propiciou a produção arquitetônica do Centro Histórico.

- Identificar os principais agentes que contribuíram para a materialização da moradia urbana do Centro Histórico.

- Analisar as mudanças na produção da moradia urbana rio-pardense ao longo do período determinado, de modo a compreender como se deu sua transformação e quais os fatores responsáveis por estas.

- Selecionar e documentar as moradias do Centro Histórico, através de: coleta de dados históricos, técnicos e construtivos; levantamento fotográfico externo e interno, quando possível; e, no caso de exemplares mais relevantes, realizar levantamento métrico.

\section{EIXOS DE ANÁLISE}

Optamos por estabelecer eixos de análise para nortear o desenvolvimento dessa pesquisa, impulsionar o processo de reflexão e alcançar as respostas às nossas inquietações, são eles: 
I. Café e ferrovia como estimuladores da ocupação e desenvolvimento urbano do interior paulista;

II. O contexto que influenciou a produção da moradia urbana rio-pardense que se propagou entre o final do século XIX e as primeiras décadas do século XX;

III. Os agentes promotores e difusores dessa arquitetura no cenário local.

\section{MÉTODO DE TRABALHO}

Toda a pesquisa foi respaldada por metodologias já conhecidas e que têm sido utilizadas nas investigações concebidas no Grupo de Pesquisa Patrimônio, Cidades e Territórios coordenado pela professora Dra. Maria Angela P. C. S. Bortolucci, de modo que o trabalho prosseguiu de forma segura. A sustentação teórica e o direcionamento da pesquisa tiveram base em diversos autores, especialmente em Pesavento (2004), Waisman (2013) e Lepetit (2001). Desse modo, para o desenvolvimento da pesquisa e o cumprimento dos objetivos, julgamos fundamental a articulação de espaço e tempo considerando a dinâmica da cidade que encontramos em Lepetit (2001) e a cronologia dos fatos, de modo a compreender a diversidade arquitetônica do período como resultado de vários fatores condicionados pelas circunstâncias sociopolíticoeconômicas, e evitando uma ênfase em análises de cunho exclusivamente estilístico conforme aponta Waisman (2013). Vale lembrar que atrelada à elaboração desta dissertação há uma série de carências informativas que buscamos suprimi-las através de um contato e análise de fontes documentais e materiais. Para isso, consideramos que seguir as inicações de Pesavento (2004, p. 29) é o mais acertado, ou seja, o cruzamento de várias fontes de informação, conforme apresentamos a seguir.

O embasamento teórico deu ensejo aos temas abordados, em específico aos que se referem à formação e desenvolvimento das cidades do interior paulista; à dinamização proporcionada pelas linhas férreas; à produção cafeeira; à produção arquitetônica brasileira e paulista do fim do século XIX e primeiras décadas do século XX; e à moradia urbana do fim do século XIX e primeira metade do século XX. Toda a revisão bibliográfica foi realizada em livros, periódicos, artigos, dissertações, teses e bases eletrônicas de dados com o propósito de formar um ferramental teórico de base à pesquisa. Por exemplo, no que diz respeito a oficialização e configuração de núcleo urbanos no Brasil, buscamos contribuições nos trabalhos desenvolvidos por Reis (2000), Delson (1997) e Derntl (2010), o que permitiu embasar nossas análises sobre a constituição do patrimônio religioso rio-pardense e a adoção do traçado notadamente geometrizado com vias ortogonais. Marx (1991) foi outro autor que nos trouxe importantes aportes para o entendimento da formação urbana, uma vez que discute o processo entrelaçado entre Igreja e Estado que marcou o tempo da colonização portuguesa, alcançou o Império e repercutiu até os tempos da República. As análises de Ghirardello (2010) sobre a formação e expansão urbana das cidades do interior paulista que surgiram sob os ditames da relação Igreja-Estado também se mostrou importantíssima, porque foi esse o caso de São 
José do Rio Pardo. Além disso, Ghirardello (2010) analisa a influência da produção cafeeira e da chegada da ferrovia impactando diretamente a organização e concepção da cidade e como as câmaras municipais passaram a controlar o território urbano, o que muito interessa aos objetivos de nossa pesquisa. Já em Monbeig (1998) encontramos um abrangente estudo sobre os espaços e suas condições naturais e históricas, os movimentações populacionais e de capitais pelo interior paulista em busca de novas terras com potencial agrícola, impulsionadas pelo desenvolvimento do complexo cafeeiro, a partir das últimas décadas do século XIX. Monbeig (1998) também investiga as relações sistêmicas entre as zonas de povoamento, a expansão do café como cultura agrícola e a implantação das estradas de ferro, apontando o surgimento de cidades e o dinamismo desses núcleos como mudanças fundamentais no cenário econômico e social do Estado. Em Missura (2003) encontramos análises sobre a constituição da sociedade do café, do desenvolvimento da malha urbana ferroviária e da entrada de imigrante no nordeste paulista, especialmente na região de São José do Rio Pardo, o que muito contribuiu para o entendimento do domínio dessa cultura agrícola na economia local. Sobre a produção arquitetônica, em especial a moradia, buscamos contribuições relevantes em Reis Filho (2011) e Lemos, C. (1987, 1989a, 1989b, 1999), especialmente as análises sobre as transformações do lote; a assimilação de técnicas e materiais construtivos; a ingerência da legislação republicana brasileira e sua interferência na casa; a busca constante por acompanhar as mudanças dos costumes e preceitos higiênicos, salubres de conforto e privacidade, como analisado também por Correia (2004). Buscamos ainda embasamento em autores como Homem (1996) que analisa a moradia urbana paulistana, em especial da classe dominante, explorando suas origens, caraterísticas materiais e espaciais, e suas alterações na segunda metade do século XIX e início do século XX; e Alambert (2003) que estuda a arquitetura residencial da classe média produzida também em São Paulo entre as Grandes Guerras, enfocando suas análises nas inovações técnico-construtivas, nos programas de uso e no repertório formal e estilístico. Bortolucci (1991) é outra autora que nos efereceu sustentação teórica uma vez que analisa a moradia urbana construída em São Carlos no período cafeeiro através de um abrangente estudo que perpassa os estilos e programas, materiais e técnicas construtivas, os profissionais da construção civil e a influência da legislação. Em relação aos agentes, buscamos fundamentar nossas análises em Debenedetti e Salmoni (1981) que abordam de forma sistemática a participação de italianos na produção da arquitetura paulistana a partir da segunda metade do século XIX; e também em Pareto Júnior (2011, 2016) e Francisco (2013) que apresentam estudos sobre a atuação de construtores sem diploma na cidade de São Paulo e de Campinas entre o final do século XIX e início do século XX. Esses foram alguns dos autores e trabalhos utilizados que fazem parte dos principais acervos pesquisados, que inclui: bibliotecas da USP, com especial atenção para a Biblioteca da Escola de Engenharia de São Carlos (USP) e Biblioteca do Instituto de Arquitetura e Urbanismo (USP), bibliotecas da UNICAMP, UNESP e PUC-Campinas; Arquivo Nacional, Biblioteca Nacional e Arquivo do Estado de São Paulo, Biblioteca Monteiro Lobato de São José do Rio Pardo, assim como as bases de dados eletrônicas nacionais e internacionais.

Paralelamente, foi realizado o levantamento documental em arquivos públicos e privados, incluindo materiais iconográficos, jornais, revistas, almanaques, livros, notícias, crônicas, monografias, notas de 
viagem, mapas, planos urbanos, fotografias antigas, etc.. É interessante ressaltar a existência de registros históricos primários em maior quantidade somente a partir de 1900, o que dificultou a construção de uma narrativa sem tantas lacunas sobre a São José do Rio Pardo da segunda metade do século XIX. No entanto, o alimento principal da pesquisa foi a fonte primária, que reunida soma mais de 12 mil arquivos digitais de documentos da época, o que inclui jornais, crônicas, mensagens de governo, atas da câmara, memórias e depoimentos, almanaques, cartas de aforamento, leis, decretos, códigos, transcrições, fotografias, mapas, projetos arquitetônicos e urbanos, solicitações de licença para construção e de ligação das redes de água e esgoto. De todos os arquivos pesquisados, quatro deles foram especiais dado o volume e qualidade do material encontrado. Sendo assim, destacamos o Arquivo da Hemeroteca Paschoal Artese onde registramos o maior volume de informações, com documentos que datam desde 1865, como a ata de fundação de São José do Rio Pardo (Anexo 01) ; além dos jornais publicados sistematicamente no município desde 1899, os quais deram ensejo à compreensão local dos acontecimentos noticiados na época; as leis, Códigos de Posturas de 1887, 1903, e 1918 e os Relatórios de Governo, tendo em vista que para uma melhor compreensão do quadro rio-pardense foi necessário um minucioso exame da legislação promulgada no período. Outro arquivo de suma importância foi o Centro da Memória Rio-pardense que possui cerca de 15 mil fotografias que retratam a cidade, a arquitetura e as manifestações culturais dos fins do século XIX e todo o século XX, além de parte das publicações sobre São José do Rio Pardo. O Arquivo da Câmara Municipal, por possuir as atas desde a sua primeira sessão em 1886 e que em razão do pouco tempo estabelecido para consulta, e dada a quantidade de material a ser lido, optamos por fotografá-lo até 1940, o que nos possibilitou saber, por exemplo, a mudança dos nomes das ruas, a data de aprovação para abertura de novos bairros e a aprovação de obras públicas. E por último, mas não menos importante, o Arquivo Público da Secretaria de Obras que, apesar da perda do acervo do final do século XIX e início do século XX, conta com projetos aprovados desde 1925, o que nos permitiu conhecer os usos e a espacialização das edificações, compensando as dificuldades de acesso a maior parte delas. Foi também nessa Secretaria que conseguimos a cartografia da cidade e, a partir da confrontação de dados históricos, elaboramos os vários mapas que utilizamos para representar o desenvolvimento urbano e a localização de edifícios e espaços analisados ao longo do trabalho. Foi através destes três importantes arquivos que tivemos a oportunidade de conhecer os artífices, práticos licenciados ${ }^{8}$ e diplomados ${ }^{9}$ responsáveis pela difusão da arquitetura e da construção da cidade vivida. Dado o insucesso na procura pelos livros de registros de licenças profissionais, recorremos às assinaturas dos projetos pesquisados no Arquivo Público da Secretaria de Obras, nos anúncios de jornal, livros de impostos e em fotografias que possuíam a identificação das pessoas fotografadas.

\footnotetext{
${ }^{7}$ É possível observar a primeira folha da ata de fundação de São José do Rio Pardo no anexo 01.

${ }^{8} \mathrm{Na}$ definição de Pareto Júnior (2011, p. 18), os práticos licenciados eram "construtores sem ensino superior habilitados pelo poder público, e reconhecidos como competentes para a prática da arquitetura". Segundo esse autor (PARETO JÚNIOR, 2011, p. 23-24), os termos "prático" e "prático licenciado" possuíam uma carga pejorativa porque eram "resultado direto da consagração de um discurso que elege a lógica do diploma como estruturante na formação do campo profissional".

${ }^{9}$ Os sujeitos que atuaram na construção civil rio-pardense aparecerão citados e analisados ao longo da narrativa.
} 
Estes documentos aprofundaram e fundamentaram o processo investigativo, integrando um cabedal de informações que se somou à pesquisa de campo. Esta por sua vez exigiu, em um primeiro momento, a identificação das edificações residenciais que compreendem o recorte espacial e temporal. Desse modo, e com base em fotografias antigas, foi percorrido todo o Centro Histórico utilizando um mapa cartográfico impresso da referida região, câmera fotográfica digital e caderno de anotações, tendo como objetivo apreender as transformações urbanas e identificar as moradias construídas entre 1865 e 1940 que ainda apresentam características perceptíveis, assim como seus estilos e tipologias. O resultado pode ser observado no mapa a seguir (Figura 3) ${ }^{10}$. Também foram realizadas entrevistas semiestruturadas ${ }^{11}$ com personalidades engajadas com a história e os movimentos culturais da cidade, como os historiadores Carmém Cecília Trovatto Maschietto e Márcio José Lauria que escreveram inúmeros livros e artigos; e mesmo cidadãos comuns como o Francisco Trevisan (90 anos) que nasceu e mora até hoje no centro, e diversas outras pessoas que de alguma forma contribuíram e se preocuparam com a história local. Todas as entrevistas $^{12}$ foram gravadas em áudio e vídeo, e transcritas digitalmente no software Microsoft Word. O objetivo foi colher informações sobre a formação e transformações urbanas e arquitetônicas, especialmente do Centro Histórico.

Figura 3: Mapa que mostra o Centro Histórico de São José do Rio Pardo e as edificações identificadas na pesquisa.

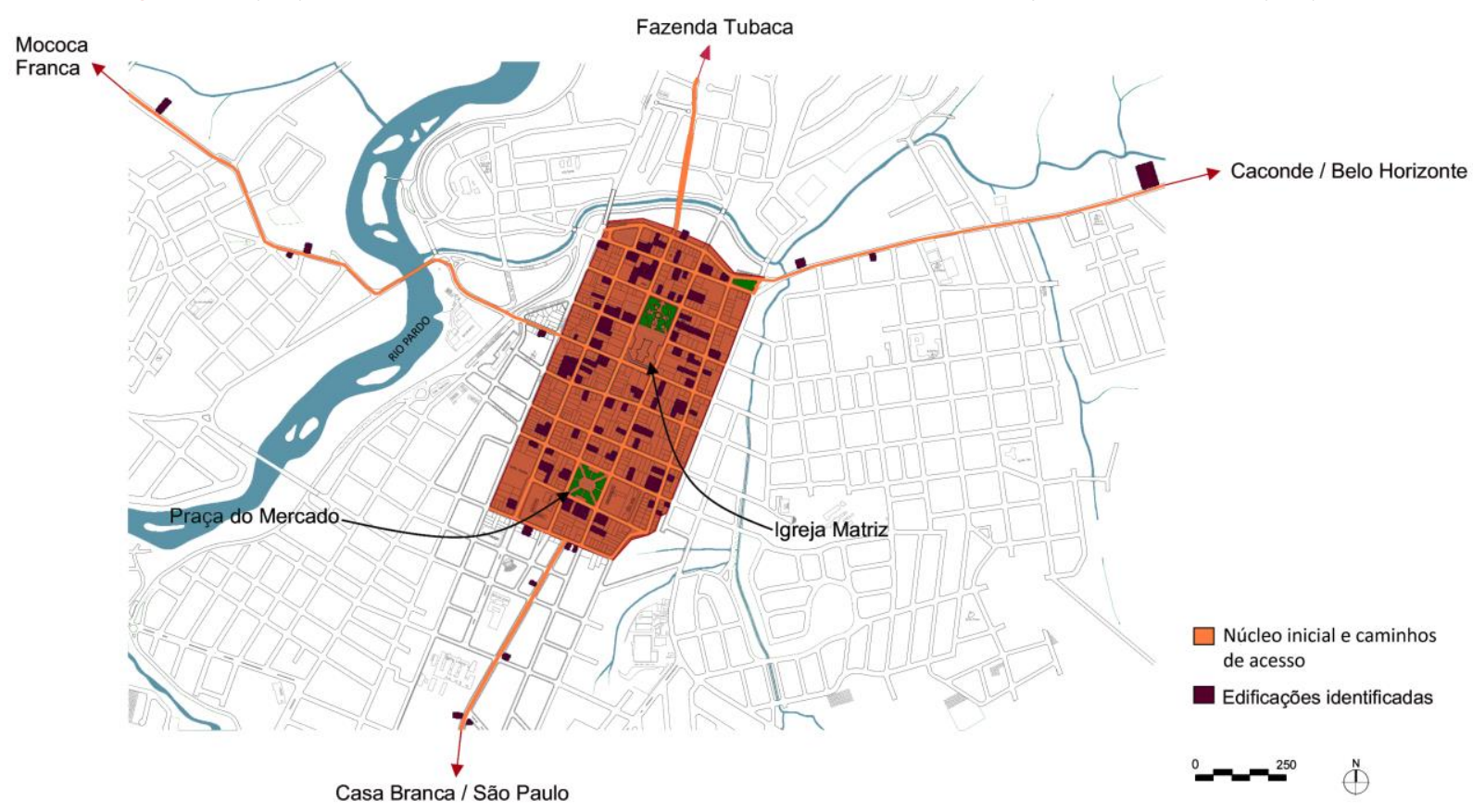

Desenho: Natalia Cappellari de Rezende (2016) com base em mapa da Prefeitura Municipal de São José do Rio Pardo, 2016.

\footnotetext{
${ }^{10}$ No apêndice 01 é possível observar as edificações identificadas e selecionadas para análise na pesquisa.

${ }^{11}$ Segundo Lüdke e André (2012), a entrevista semiestruturada é aquela que não é fechada em um questionário rígido (combina perguntas abertas e fechadas) marcado pela hierarquia entre entrevistador e entrevistado. De acordo com (Boni e Quaresma, 2005, p. 75) “o pesquisador deve seguir um conjunto de questões previamente definidas, mas ele o faz em um contexto muito semelhante ao de uma conversa informal [...] Esse tipo de entrevista é muito utilizado quando se deseja delimitar o volume das informações, obtendo assim um direcionamento maior para o tema, intervindo a fim de que os objetivos sejam alcançados".

12 A estrutura da entrevista previamente definida pode ser encontrada no Apêndice 02. É possível ainda encontrar as cópias das entrevistas na Hemeroteca Jornalista Paschoal Artese.
} 
A realização do levantamento e a coleta de informações nas entrevistas possibilitou as análises, por exemplo, através do método comparativo com as fotografias atuais e de períodos anteriores e identificar as transformações urbanas e arquitetônicas como em um palimpsesto que acumula marcas deixadas no tempo (PESAVENTO, 2004) facilitando bastante o processo de identificação e seleção das edificações que foram analisadas no decorrer deste trabalho. Nesse processo, destacamos a valiosa contribuição das séries de fotografias antigas que consultamos realizadas pelos fotógrafos Innocencio Vilhegas (Figura 4) e Celestin Detinne (Figura 5), as panorâmicas de Valério Vieira (Figura 6) e as aéreas também de Innocencio Vilhegas (Figura 7) que integram o Arquivo do Centro da Memória Rio-pardense.

Figura 4: Fotografias de Innocencio Vilhegas, início do século XX.

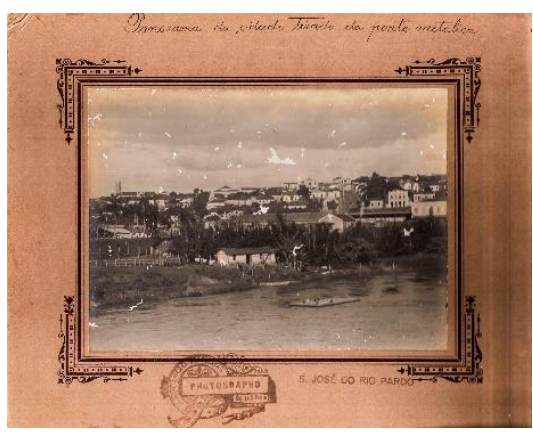

Vista da cidade tirada da ponte metálica

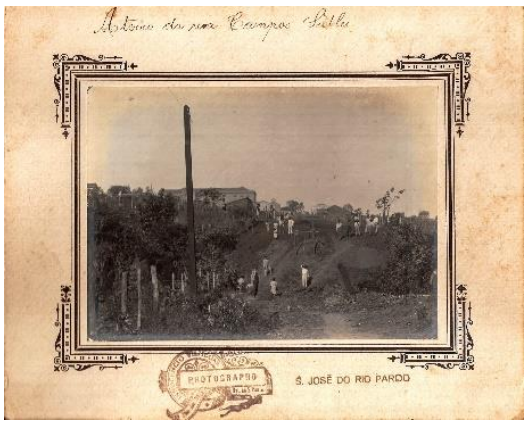

Aterro da Rua Campos Salles

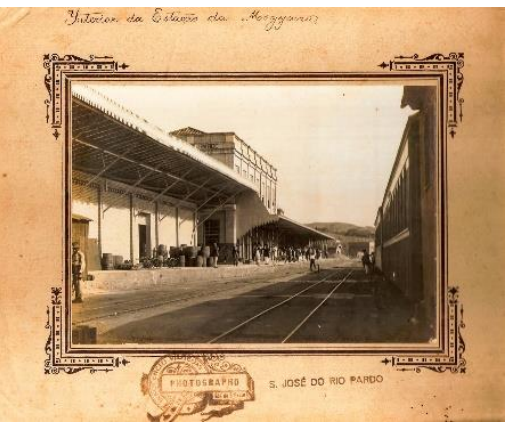

Interior da Estação Central

Fonte: Arquivo do Centro da Memória Rio-Pardense Rodolpho José Del Guerra.

Figura 5: Fotografias de Celestin Detinne, início do século XX.

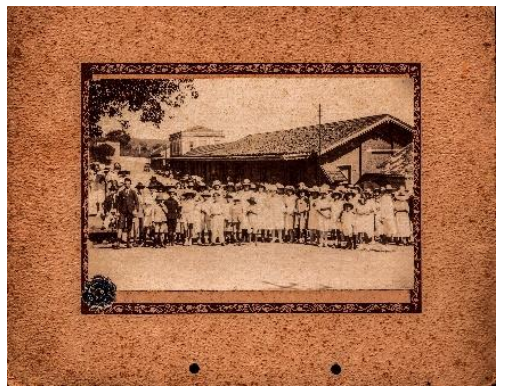

Grupo de pessoas na Estação Central

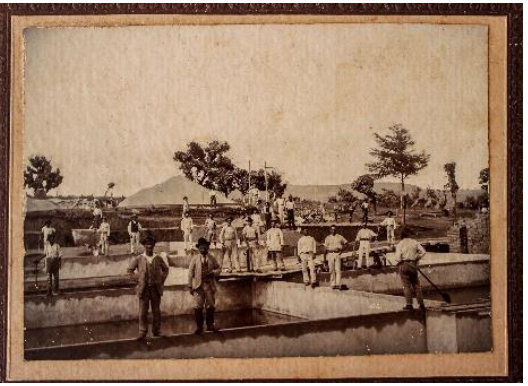

Construção da caixa d'água no Parque Independência ${ }^{13}$

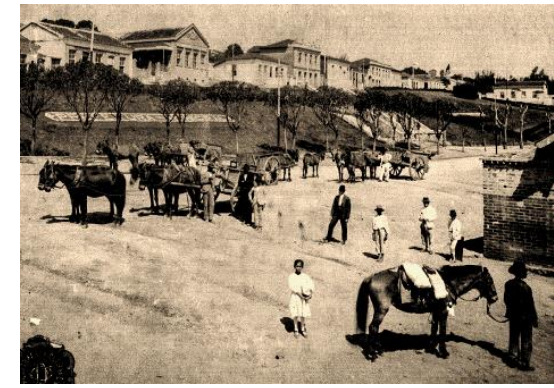

Praça Tiradentes, pátio da Estação Central

Fonte: Arquivo do Centro da Memória Rio-Pardense Rodolpho José Del Guerra.

${ }^{13}$ Por vezes encontramos esse Parque denominado também de Centenário. 


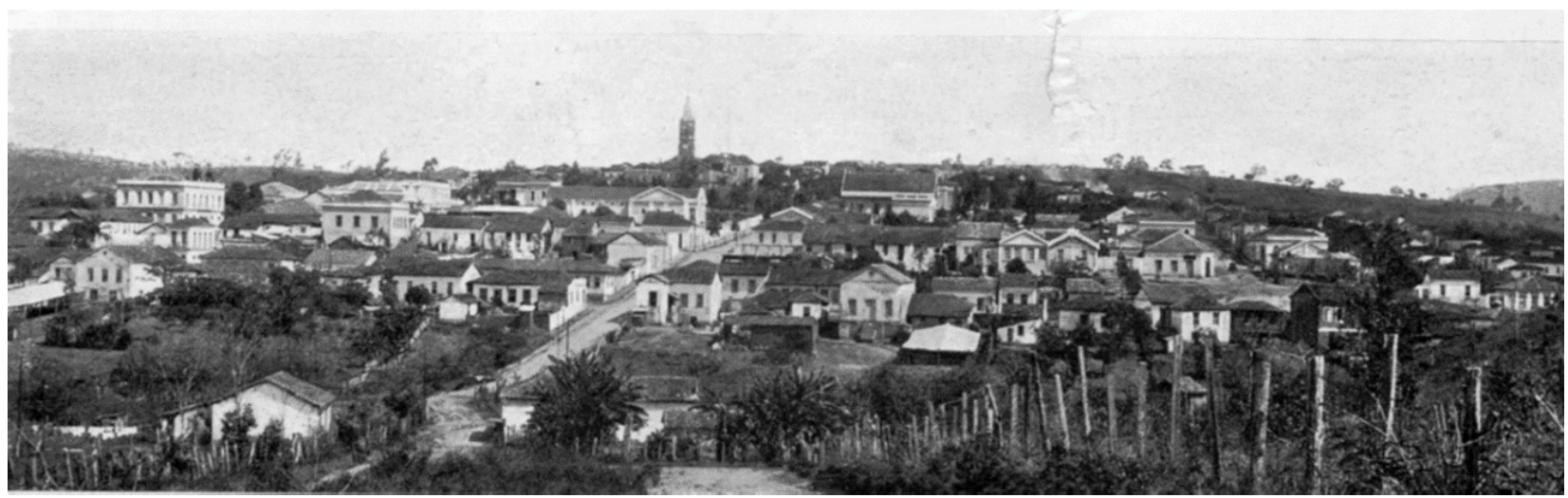

Vista panorâmica do núcleo inicial, tirada da zona norte.

Fonte: Arquivo do Centro da Memória Rio-Pardense Rodolpho José Del Guerra.

Figura 7: Fotografias aéreas do núcleo inicial rio-pardense realizadas por Innocencio Vilhegas, início do século XX.

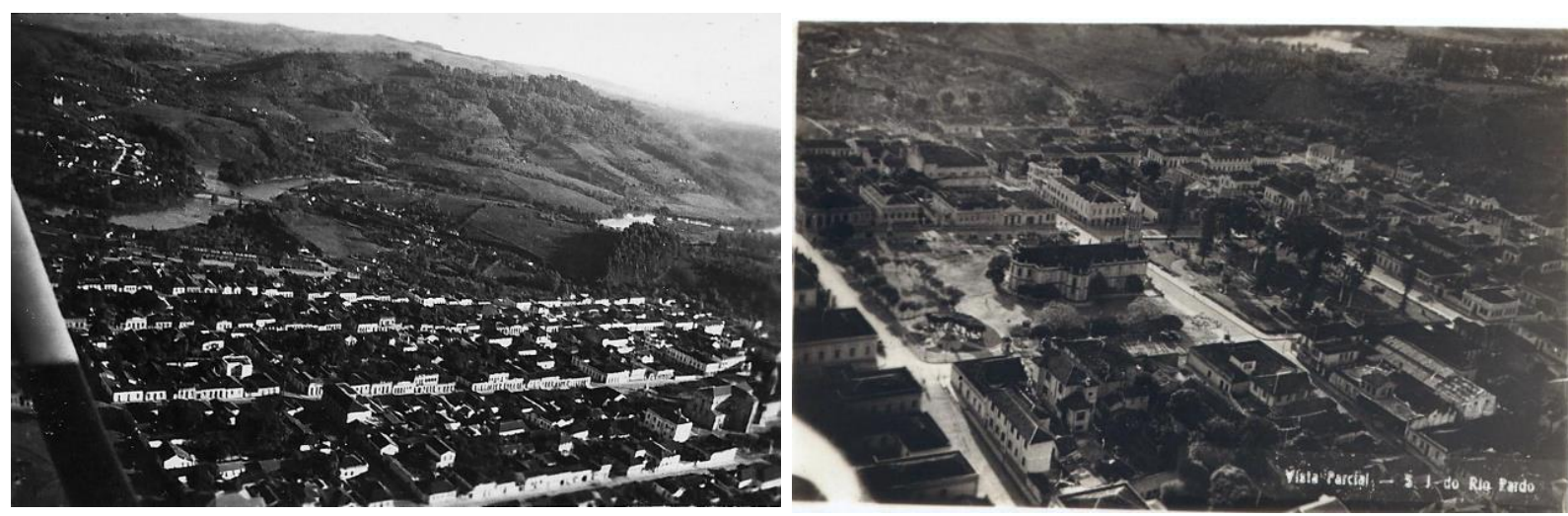

Fonte: Arquivo do Centro da Memória Rio-Pardense Rodolpho José Del Guerra.

As imagens nos permitiram perceber além da arquitetura, os espaços e a dinâmica da cidade, o que nos possibilitou contrapor em vários momentos com as descrições textuais. Desse modo, corroboramos com Kossoy (2001) ao afirmar que a fotografia é uma fonte iconográfica de fundamental importância para melhor compreensão da constituição dos fatos do passado, como testemunha da criação de um tempo e um suporte histórico, e por isso ela foi explorada como ferramenta de pesquisa e fonte de investigação. A fotografia, assim como outros documentos de caráter verbal e não-verbal, compuseram uma forma de suporte histórico integrada à formulação de nossa dissertação.

É fundamental destacar que em virtude da dificuldade de acesso às moradias para fazermos os registros necessários para a sua análise, buscamos alternativas para conseguir, ao menos, os desenhos de plantas e fachadas dessas edificações; fotografias antigas e atuais; descrição falada de antigos moradores; e por meio dos projetos arquivados na Secretaria de Obras ${ }^{14}$, sendo que quando possível as informações foram

\footnotetext{
${ }^{14}$ Devido às inúmeras mudanças de endereço e precariedade da estrutura do Arquivo Público da Secretaria de Obras muita documentação se perdeu, ou foi sumariamente descartada, restando poucos projetos. Apesar da disponibilidade de consulta, este Acervo foi acomodado no mesmo espaço físico do arquivo contemporâneo, e organizado por ano, não havendo uma separação entre os processos de projeto
} 
conferidas in loco. Cabe frisar que nessa instituição consultamos 339 processos entre projetos públicos e privados datados entre os anos de 1925 e 1940. São pranchas de desenhos que se encontram em frágil estado de preservação, e por esse motivo definimos a sua digitalização através do uso de equipamentos fotográficos ${ }^{15}$. Através da digitalização desse acervo, procedemos à sistematização de todo o material que foi organizado em pastas por ano e renomeado de acordo com o número do processo, a tipologia, o endereço (quando identificado) e o número da imagem respectivamente, por exemplo 1929 P26 Residência, Rua Ruy Barbosa (1). Além disso, para facilitar as análises, sistematizamos esse material através de uma base de dados no software Excel, com as seguintes informações: ano, número do processo, assinatura, proprietário, endereço, natureza da solicitação e uso ${ }^{16}$. Através dessa organização cruzamos as informações através da ferramenta "tabela dinâmica" do Excel, de maneira muito mais rápida, fácil e eficiente. Desse modo, esclarecemos importantes informações que puderam ser verificadas, como a introdução de novos elementos no programa das moradias, tais como porão e copa; a adoção de platibandas; a evolução dos materiais, técnicas e sistemas construtivos, por exemplo a gradativa introdução do cimento armado; o aperfeiçoamento das normativas edilícias com as posturas, códigos e leis; e a representação do desenho arquitetônico contendo planta, corte e elevação, escala e etc.. Mas, é válido salientarmos que nem todos os processos apresentam informações completas, como o nome do proprietário, localização da edificação, responsável pelo projeto e obra, e na maioria a representação não atendeu às exigências legais, sendo neste caso analisado apenas 138 (dos 339) que possuem planta com as denominações, corte e elevação. Todavia, ainda assim é um arquivo de suma importância para o (re)conhecimento da história da arquitetura sob todos os aspectos, formais, funcionais e da própria produção da área urbanizada.

Sendo assim, o critério que determinou a relevância dada a uma edificação em relação às demais foi a facilidade de acesso ao seu interior e a disponibilidade de algum tipo de documentação como projeto e informações sobre a data de construção, quem foi o seu projetista, construtor e seus moradores, e também a ausência de reformas que a alteraram de forma significativa. A partir desses critérios, selecionamos as edificações construídas no “Centro Histórico" de São José do Rio Pardo no período de 1865 a 1940.

Procedendo desse modo, analisamos as edificações selecionadas tendo como base a metodologia adotada por Carlos Lemos (1999) ao esquadrinhar a moradia da república, apresentada em seu livro "A república ensina a morar (melhor)", amparada em outros teóricos como Waisman (2013), Lepetit (2001) e Pesavento (2004).

público e privado, o que dificultou o trabalho. Além de não haver espaço adequado (com mesas, cadeiras e iluminação), inexiste uma catalogação que forneça informações como assinatura (responsável pelo projeto e obra), tipo de solicitação (reforma, ampliação e construção), e uso (residencial, institucional, serviço, comércio).

${ }^{15}$ A digitalização desse acervo não foi planejada inicialmente e também não constitui um dos objetivos deste trabalho, todavia consideramos mais prudente a realização dessa ação devido ao estado em que se encontram os desenhos e a falta de organização do arquivo. A reprodução digital foi realizada com o auxílio de uma câmera fotográfica digital Canon (modelo T3i) que gerou imagens de alta resolução que poderão integrar acervos públicos da cidade, servindo de consulta para trabalhos futuros sobre o assunto. Há planos de disponibilizar todas as imagens feitas desse acervo para a Hemeroteca Jornalística Paschoal Artese.

${ }^{16}$ Os dados sobre o ano, número do processo, assinatura, proprietário, endereço e natureza da solicitação fazem parte dos processos e foram descritos como os encontramos, já o uso é uma informação que acrescentamos para auxiliar no processo de análise. Ver Apêndice 03 
Todas as plantas e fachadas que apresentamos nesta dissertação foram desenhadas digitalmente visando manter um padrão gráfico e demos preferência para a representação mais próxima do original. Ademais, respeitamos todas as informações contidas nos desenhos originais, sobretudo as textuais em relação aos usos dos cômodos. Desse modo, estabelecemos os usos originais no redesenho somente quando havia certeza, obtida através da sua denominação constante nos projetos, das menções obtidas nas entrevistas, e da manutenção de sua função nos casos de constatação in loco. Com isso, a escrita para ambientes com o mesmo uso aparece com nomes variados, como o dormitório, quarto ou alcova, ainda que possua aberturas para o exterior. No que se refere ao processo de redesenho, é necessário situá-lo como parte da metodologia de pesquisa que exige, e ao mesmo tempo nos possibilita perceber particularidades sobre as intenções e convicções do projetista, seus desejos e limitações, além das informações sobre o próprio projeto e a obra. Assim, e como enfatizado por Ramos (2016), o redesenho nos oportuniza a interpretação e a crítica apoiada em estudo histórico sobre o personagem, a obra redesenhada e o momento histórico da ação.

Com isso, a comparação, complementação e a confrontação entre diferentes ferramentas de pesquisa e fontes de investigação nos serviram de subsídio à compreensão das características que foram sobrepostas ao longo do tempo, além de nos oferecer uma imensa possibilidade de diferentes leituras e interpretações. Estabelecemos, desse modo, um permanente diálogo com (e entre) os diferentes documentos consultados. Nesse sentido, a colocação de Pesavento (2004) muito serve para esclarecer o método do nosso trabalho

\footnotetext{
Mas se formas foram substituídas e desapareceram, como resgatar velhos espaços? Só através do cruzamento de diferentes fragmentos, como em um puzzle, onde peças de variadas épocas - planos, fotos, pinturas, desenhos, mapas - em composição, permitam juntar partes de forma a compor uma cena. É preciso ousar combinações e correspondências, fazendo viajar, no tempo e no espaço, imagens e textos que possam revelar as cidades ocultas sob a cidade do presente. (PESAVENTO, 2004, p. 29).
}

\section{ESTRUTURA DA DISSERTAÇĀO}

Visando atender o objetivo de identificar e analisar a moradia do Centro Histórico de São José do Rio Pardo a partir da compreensão de sua relação com a cidade, o contexto histórico, social, político e econômico local, apresentamos a estrutura da dissertação. O texto se dividiu em três capítulos limitados por espaços temporais em que fatos relevantes incidiram e ocasionaram alterações na produção residencial e no modo de morar. Sendo assim, no primeiro capítulo compreendemos os processos de produção do espaço urbano da cidade de São José do Rio Pardo a partir de 1865, data de sua fundação, até o ano de 1902, porque já no início de 1903 foi publicado o segundo Código de Posturas, compelindo e intensificando as ações intervencionistas que visavam à higiene e o embelezamento, e que contribuíram para alterar a arquitetura produzida e o modo de vida. Apresentamos o contexto deste período por meio dos primeiros prédios 
públicos e das moradias, e a ingerência da legislação na arquitetura rio-pardense. Para isso, complementamos a análise com autores como Del Guerra e Trevisan ${ }^{17}$ que escreveram sobre São José do Rio Pardo, e em documentos primários como os códigos de posturas, mapas, projetos, livros de registros de impostos, cartas de aforamento, editoriais de jornais, entre outros. Autores como Monbeig (1998), Matos (1990) e Missura (2003) dão o embasamento teórico para discutir os fatores que propiciaram as condições favoráveis para expansão e dominação do cultivo cafeeiro e a construção da ferrovia no Estado de São Paulo, o que contribuiu para impulsionar a ocupação do território, como aconteceu em São José do Rio Pardo. No item 02 desse capítulo, exploramos o contexto e as perspectivas de busca de modernização, da higiene e do embelezamento através de uma série de melhoramentos ${ }^{18}$ que tinha na produção do café o suporte econômico com poder de viabilização para transformar o espaço citadino. No item 03, buscamos esclarecer como a cidade e São José do Rio Pardo assimilou e articulou o processo de ocupação e desenvolvimento, como configurou seu traçado e espaços. Nesse sentido, contribuições importantes são trazidas de Ghirardello (2010), Delson (1997), Derntl (2010), Marx (1991) e Reis (2000). A apreensão desse contexto nos permitiu, no item 04, conhecer as condições que propiciaram e, em alguns casos, até determinaram a constituição da arquitetura residencial produzida no Centro Histórico rio-pardense. Desse modo, tendo como base os autores Lemos (1989a), Reis Filho (2011), Correia (2004) e Perrot (1991), são analisadas algumas moradias construídas neste período que, ora resistiram ao tempo e às descaracterizações, ora se destacaram na representação das mudanças pelas quais a cidade e a sociedade estavam passando naquele momento. No segundo capítulo abarcamos o período de 1903 a 1917 quando a atuação pública incidiu mais fortemente através de regulamentações legais com destaque para o novo Código de Posturas anteriormente mencionado. Nesse período, São José do Rio Pardo foi marcada pela efetivação de uma série de melhorias em infraestrutura, a começar pela implantação do novo sistema de abastecimento de água e coleta de esgoto que redefiniu espaços e usos do ambiente da casa, alterou os modos de morar com a aproximação de atividades antes realizadas externamente, e incutiu novas noções de conforto e novos modos de se relacionar com o urbano. As ações tinham como objetivo dotar a cidade de melhoramentos associados à ideia de modernidade ${ }^{19}$ e à absorção de símbolos tradutores de desenvolvimento e civilidade que permeou a prática da primeira República, financiada principalmente pela riqueza proporcionada pelo cultivo cafeeiro. Desse modo, e tendo como objetivo caracterizar a produção residencial atrelada ao contexto local apresentamos no item 01 o panorama geral da cidade em seus aspectos físicos, sociais, econômicos e políticos de modo a extrapolar uma análise simplista e descritiva e evidenciar os fatores e ações que incidiram diretamente nesse espaço, seja através da materialização, da tomada de decisões ou da promulgação de legislação. Enfatizamos esse contexto por meio da configuração

\footnotetext{
17 Amélia Franzolin Trevisan era mestre pela Universidade de São Paulo, pesquisadora no campo da historiografia e arquivologia. Fo funcionária do Instituto de Previdência do Estado e do Arquivo do Estado de São Paulo onde pode desenvolver suas pesquisas com temas sobre a historia da cidade.

${ }^{18}$ Dentro da análise, adotamos o conceito que Bresciani (2001) estabeleceu para o termo "melhoramentos" a partir da sua ocorrência no contexto das intervenções realizadas em São Paulo no período de 1850 a 1950. Para a autora, por ser um termo fácil de ser com preendido como ação positiva, associa-se a representação ou ideal de progresso como algo concreto, material, que se busca sucessivamente porque é imóvel, e por este motivo provoca um fenômeno que nunca é saturado, sempre há algo novo para completá-lo. O que se busca é a falta que se vincula a ideia de modernização, desenvolvimento e progresso.

${ }^{19}$ Inserido no contexto republicano, associado a apropriação burguesa e ao capital ensejados pela produção cafeeira, a modernidade é entendida dentro do léxico do discurso de poder que tem na cidade a materialização desejada (LAPA, 1996 e GARCIA, 2008 ).
} 
dos espaços, da construção de prédios públicos e privados e da introdução de tecnologias. Para as análises, destacamos o uso da fotografia de época como fonte de caráter oficial que nos permitiu de forma clara, apreender as principais características do conjunto urbano. Além disso, utilizamos todo e qualquer documento primário como mapas, projetos, código de posturas, correspondências, relatórios de governo e reportagens de jornal. No item 02 , investigamos quais foram os embates e quem foram as pessoas envolvidas no processo de construção das edificações urbanas, sejam elas construtores, práticos licenciados e profissionais titulados. Para isso, contribuições relevantes foram trazidas de trabalhos realizados por Debenedetti e Salmoni (1981), Pareto Júnior (2011, 2016), Lody (2015) e Francisco (2013). Objetivamos detectar e melhor compreender quais foram as dificuldades técnicas que incluíam acessibilidade e formação de mão de obra e disponibilização de material, e como o poder público, através da legislação edilícia controlou e interveio na produção do espaço urbano e da arquitetura. No item 03, identificamos e analisamos a produção residencial através de levantamento métrico e fotográfico, aspectos construtivos e tecnológicos empregados. Salientando a base teórica das discussões em Lemos (1978, 1987, 1989a, 1989b, 1999), Reis Filho (2011), Patetta (1987), Fabris (1987), Bortolucci (1991), Homem (1996) e Lima, R. (2001), destacamos o predomínio de edificações caracterizadas pela incorporação de elementos mais fortemente ligados à linguagem eclética, de modo a apontar a introdução das inovações, as mudanças e permanências no que diz respeito à estética e também às maneiras de morar. No terceiro capítulo compreendemos a cidade e a arquitetura rio-pardense entre 1918 e 1940, período que se iniciou com uma nova legislação que deu ainda mais ênfase no embasamento higienista como determinante para o funcionamento e crescimento da cidade, e tem fim após alguns anos de crise da economia cafeeira e o desenvolvimento de uma nova fase com o setor industrial, comercial e de serviço, influenciando diretamente a produção de moradia urbana. Constatamos nesse intervalo de tempo um maior interesse na conclusão de várias obras de infraestrutura, na construção de equipamentos públicos e de estabelecimentos de consumo primários realizados especialmente dentro do perímetro urbano, além da expansão de um mercado de terrenos principalmente nas áreas leste e oeste da cidade. E, paralelamente a essas mudanças, houve também a alteração dos usos e o estabelecimento de um novo cotidiano e relação da casa com a rua - novas configurações entre público e privado -, além de notabilizar a problemática da reestruturação urbana vinculada às necessidades de um ambiente salubre, sadio e moralizado. Desse modo, analisamos no item 01 a cidade e a nova perspectiva que se apresentou à luz dos anos de 1920 e 1930, seus espaços e construções, e qual foi o diálogo estabelecido entre o urbano, a arquitetura e os usuários. A busca pela apreensão deste contexto passou pela análise das principais ações que ocorreram nesse período, para isso recorremos às publicações de editoriais e à legislação promulgada, além de projetos e mapas. No item 02 exteriorizamos os vários agentes envolvidos na difusão da arquitetura produzida, sobretudo ligada à estética do neocolonial, do art-déco e do bangalô, com destaque para a atuação de diplomados e práticos licenciados, em especial a trajetória e as obras de José Lourenço, João Bergamasco e Américo Braghetta. Já no item 03, apresentamos, analisamos e discutimos as mudanças e as permanências das características das residências construídas, tendo como base questões referentes à implantação da casa no lote, programa, 
organização da planta arquitetônica e utilização dos materiais e técnicas construtivas. Nesse sentido, enfatizamos as transformações que visavam à adequação da edificação aos preceitos presentes na legislação edilícia municipal e estadual, e a alteração da feição externa das moradias, acompanhando uma tendência nacional de incorporação e combinação de elementos formais. Para embasar as análises e discussões, valemos de trabalhos realizados por Amaral (1994), Pinheiro (2011), Kessel (2008), Alambert (2003), Atique (2007), Mascaro (2008), Campos, V. (2003) e Segawa (1997). 


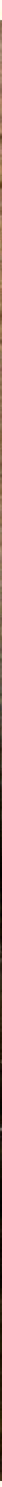




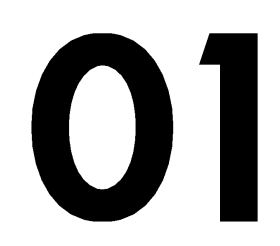

\title{
São José do Rio Pardo e as moradias urbanas nas primeiras décadas de sua formação: 1865-1902
}

\author{
" 0 ambiente construído que nos circunda é [...] o modo de \\ ser físico da sua história, o modo no qual se acumula, \\ segundo diferentes níveis e significados, para formar a \\ especificidade do sitio não só pelo que o ambiente parece \\ ser, mas por aquilo que ele é estruturalmente. 0 lugar é \\ feito pelos traços de sua própria história"
}

(VITTORIO GREGOTTI) 


\subsection{Ocupação e povoamento do nordeste paulista}

Se o lugar é feito pelos traços de sua própria história, conforme nos disse Vittorio Gregotti, é necessário que o analisemos desde a sua ocupação, e que no caso específico da terra que veio a constituir o município de São José do Rio Pardo, na região do "Sertão do Rio Pardo"20, mais propriamente nas "Cabeceiras do Rio Pardo" ${ }^{21}$, ocorreu muito tardiamente se comparado a outras regiões do país, somente em meados do século XIX. Malgrado a escassez de trabalhos desenvolvidos que ofereçam um aporte historiográfico mais consistente, Celeste (2010) ao estudar a ocupação dessa região aponta duas pesquisas que se mostram importantes na compreensão da multiplicidade desse Sertão em termos funcionais, e também no entendimento das suas particularidades: a primeira foi desenvolvida por José Chiachiri (1986) e a segunda foi a obra organizada por Bacellar e Brioschi $(1999)^{22}$. Corroborando com esses autores, Celeste (2010) chama a atenção para a necessidade de compreender a formação dessa região a partir da análise do que representava a Estrada de Goiás, uma vez que segundo Del Guerra (2010), citando os relatos feitos pelo capitão Inácio da Silva Costa em 1765, ela era habitada por índios caiapós e catuás que deixaram o terreno entrecortado por trilhas posteriormente utilizadas pelos bandeirantes como referência juntamente com os rios em direção ao sul de Minas Gerais e a Vila Boas de Goiás. Para Celeste (2010), ao longo desse percurso em que circulavam tropeiros, negociantes, aventureiros e autoridades, pequenos arraias e sítios com criação de gado e lavoura foram se formando, e disseminando pousos para pernoite e comercialização do excedente agrícola. Brioschi (1999), que se deteve nos locais e atuais municípios cortados pela Estrada do Anhanguera ou Caminho dos Goiáses, ou ainda Guaiases, descreveu o seu trajeto que

saía de São Paulo em direção a Jundiaí, dirigindo-se em seguida para Mojimirim, Mojiguaçu e Casa Branca. Depois desse percurso feito no sentido sul-norte, o caminho tomava a direção Noroeste, atingindo os atuais municípios de Cajuru, Batatais, Franca e Ituverava. (BRIOSCHI, 1999, p. 46).

Segundo Celeste (2010, p. 27), todos os locais citados "têm em comum o fato de serem cortados pela estrada", o que demonstra que ela foi um eixo de ocupação, e, sem dúvida, de suma importância, mas não explica tudo (BACELLAR E BRIOSCHI, 1999). Outros fatores também contribuíram para a ocupação dessa porção do Estado, como a "agricultura de subsistência; a economia agropastoril para o mercado interno; as

\footnotetext{
${ }^{20}$ Geograficamente contido entre o Rio Pardo, ao sul, e o Rio Grande ao norte, era assim denominado por ser "desconhecido, selvagem e mítico da colônia", ou "considerado como um dado preexistente à colonização, ou ainda como o negativo do processo de povoamento e urbanização" (FONSECA, 2011, p. 51). Ao pesquisar a apropriação do solo no Nordeste Paulista a partir da formação do Sertão do Rio Pardo e do desenvolvimento de patrimônios religiosos e laicos entre 1800 e 1930, Piccinato Junior (2012) apontou que o termo "Sertão do Rio Pardo" sofreu constantes alterações de acordo com percurso histórico, o interesse, a notoriedade e representatividade dessa região, a exemplo da denominação posteriormente recebida quando foi cortada pela ferrovia da Companhia Mogiana, ficando conhecida como Zona da Mojiana.

${ }^{21}$ Segundo Chiachiri Filho (1986) e Brioschi (1999, p. 50), por volta de 1765 foi descoberto ouro nas Cabeceiras do Rio Pardo, e "dessa descoberta resultou a instalação da primeira freguesia paulista, ao norte do rio Pardo, desmembrada de Mojiguaçu, designada como Nossa Senhora da Conceição das Cabeceiras do Rio Pardo (Caconde)". Ao tratar dessa região, Celeste (2010, p. 97) ressalta a dificuldade em "delimitar seus limites ou quais eram as divisas da antiga Freguesia de N. S. da C. das Cabeceiras do Rio Pardo". Todavia, destacou os atuais municípios de Mococa, São José do Rio Pardo, Tapiratiba, Divinolândia, São Sebastião da Grama e Caconde como constituintes dessa região.

${ }^{22}$ Ambas as pesquisas se deteram no nordeste paulista, mais especificamente na "área que se estende a Oeste, desde a linha formada pelos rios Mojiguaçu e Pardo, depois de sua confluência, até as divisas com o Estado de Minas Gerais ao Norte e a Leste" (BACELLAR E BRIOSCHI, 1999, p.17)
} 
questões das divisas; as políticas de ocupação e as formas de migração" (CELESTE, 2010, p. 28). Foi após Luís Antonio de Sousa Botelho Mourão, o Morgado de Mateus, assumir o governo de São Paulo em 1765, que as questões mais latentes se alicerçaram na necessidade de conhecer e ocupar o interior, aumentar e fixar a população, definir e manter a posse do território e estimular a produção agrícola visando diversificar a arrecadação. Após a descoberta das minas de aluvião nas Cabeceiras do Rio Pardo, as andanças de sertanistas mineiros e paulistas aumentaram nessa área, preocupando a administração paulista que temia o desvio do ouro ao mesmo tempo a posse dessa área pela capitania de Minas Gerais. O crescimento populacional que se originou da atividade mineradora acabou resultando na criação de uma freguesia desmembrada de Moji-guaçu - ao norte dessa região, dando origem ao atual município de Caconde, atraindo gente por estas terras que faz divisa com Minas Gerais (BRIOSCHI, 1999). Apesar dessa atividade nesse local ter sido de curta duração, e até o final do século XVIII ter entrado em decadência assim como o ciclo do ouro de Minas, provocou um aumento populacional e o surgimento de outras atividades como a pecuária e a agricultura, formando uma rede de abastecimento, juntamente com a ação militar e burocrática (CELESTE, 2010). Essas ações levaram Trevisan (1982) a considerar a existência de pouso e ocupação rural que mais tarde deu origem a São José do Rio Pardo ainda no século XVIII.

As novas perspectivas de enriquecimento com o comércio e a busca por terras férteis e boas pastagens devido à expansão agropecuária e ao desenvolvimento da lavoura mista resultaram em um aumento no número de moradores, assinalando a segunda corrente populacional que se dirigiu para as Cabeceiras (CELESTE, 2010). Vindos da região do sul de Minas Gerais, os migrantes fomentando novas alternativas econômicas e de sobrevivência chegaram por volta de 1815, com destaque para o sesmeiro português capitão Alexandre Luis de Mello ${ }^{23}$, que segundo Del Guerra (2010) se estabeleceu juntamente com o seu clã nas terras consideradas férteis e cortadas por água em abundância do rio Pardo, parecendo ser promissora para a lavoura. Através das concessões de sesmarias, esta família se tornou proprietária de uma vasta área, cerca de 12 léguas, cultivando inicialmente cana-de-açúcar nas terras que mais tarde constituiria o município de São José do Rio Pardo.

Celeste (2010, p. 94) destaca a forma de ocupação exercida pelas "famílias, aventureiros e solitários que se dirigiram para a região" em 1817, que dos cerca de 50 fazendeiros "apenas dez se deram por compra ou por requerimento; o restante era formado por posseiros". Foi desse modo, segundo esse autor (CELESTE, 2010), que surgiu o Bairro do Rio Pardo, atual município de São José do Rio Pardo-SP. Situação semelhante ocorreu em Ribeirão Preto onde predominaram grandes extensões de terra sob o domínio de poucas sesmarias que somada a baixa densidade demográfica e a ausência de titulação facilitou a apropriação das terras pelos posseiros que voltaram suas propriedades para o mercado interno de abastecimento (DEMINICE, 2015).

\footnotetext{
${ }^{23}$ Segundo a genealogista Isoldi (1995), o Capitão Alexandre Luiz de Mello era natural da freguesia de Lagares, Arcebispado de Braga em Portugal. Nasceu em 1760, filho de Antônio Luiz de Mello e Liberata Maria. Por volta de 1770 veio para o Brasil, casou-se com Ana Maria de Jesus Pinheiro em São João Del Rei em 1784. Tiveram 13 filhos: Francisca Luiza, Alexandre, Carlos Luiz, Antônio Joaquim, Sebastião, Manoel Joaquim, Joaquim Luiz, Ana Maria de Jesus, José Luiz, Francisco Alexandre, Maria Luíza, João e Cândido Luiz (ISOLDI, 1995, p. 269271).
} 
A partir da década de 1820 migraram para essa região famílias com maiores recursos como os Jun queira ${ }^{24}$ (BACELLAR E BRIOSCHI, 1999). Corroborando com essas pesquisas, Missura (2003, p. 20) em seus estudos sobre a constituição da sociedade do café em Rio Pardo aponta que após a chegada do capitão Mello, vieram outros, cerca de trinta e duas famílias entre os anos de 1822 a 1829, também de Minas Gerais, buscar nessa região terras para seus anseios de enriquecimento através da cana-de-açúcar ou da pecuária, "movimento que continuou até 1877" e permitiu o acúmulo de capital investido no estabelecimento da cultura cafeeira que garantiu 0 desenvolvimento dessa região. Como afirmam os autores Bacellar e Brioschi (1999, p. 17), esse movimento acabou por influenciar os traços culturais, "tais como a arquitetura e o modo de falar tipicamente mineiros". Essas informações nos auxiliam na compreensão do contexto regional em que São José do Rio Pardo foi inserida: entre a Freguesia de Nossa Senhora das Dores de Casa Branca (atual Casa Branca) que se estendeu ao longo do Caminho dos Goiáses e a Freguesia de Nossa Senhora da Conceição do Bom Sucesso das Cabeceiras do Rio Pardo (atual Caconde) ${ }^{25}$ (Figura 8).
Figura 8: Parte do trajeto que ganhou foros de Estrada ou Caminho de Goiás em 1725.

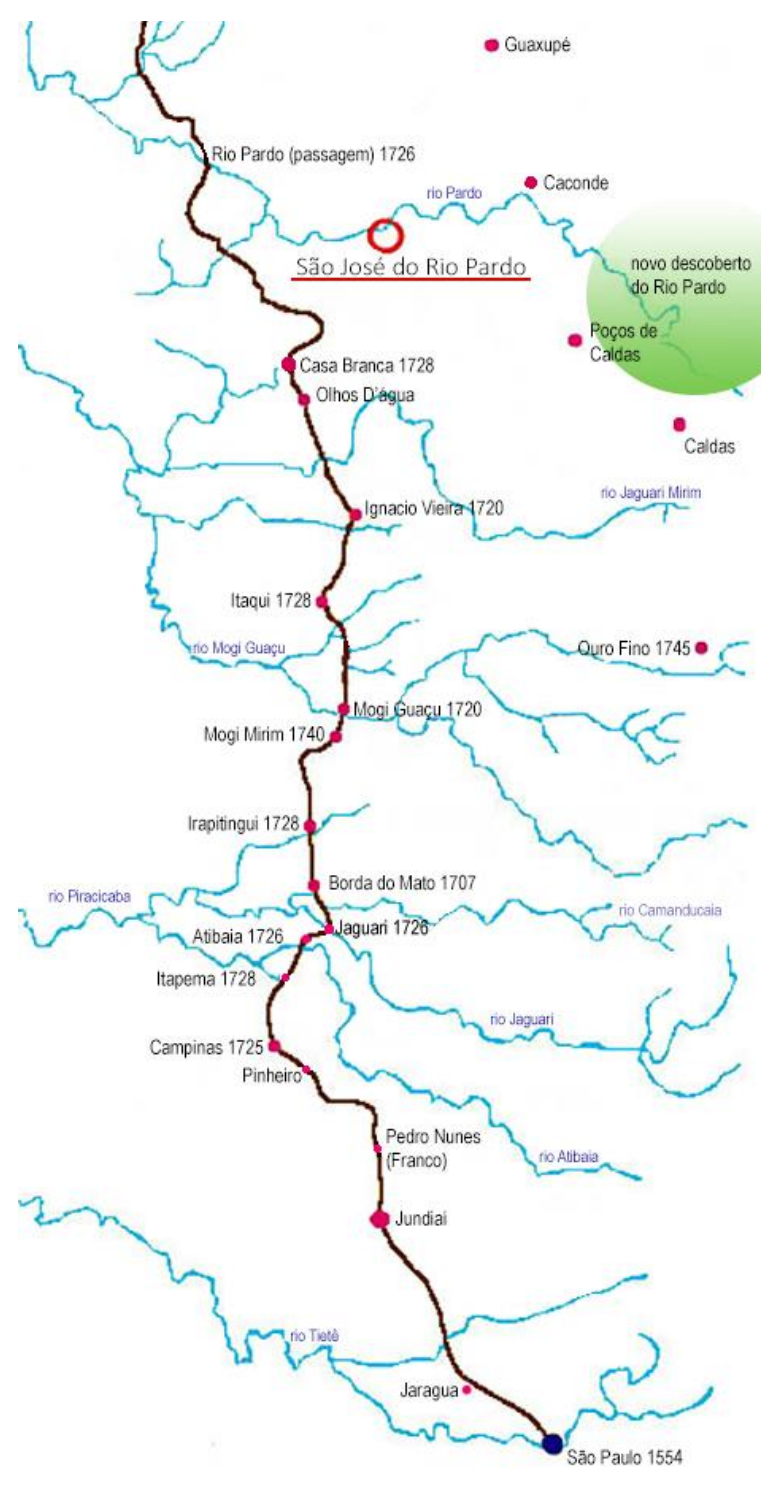

Fonte: BRIOSCHI, 1999: RIHGSP, Vol. XXIV, 1926, organização: R. Vasconcellos Martins. Redesenho: Natalia Cappellari de Rezende (2017).

Nos parece certo que a proximidade do rio Pardo foi fundante para a fixação humana e para o desenvolvimento das atividades agrícolas. E conforme nos esclareceu Celeste (2010), é a oeste desse rio que estão as divisas entre São Paulo e Minas Gerais e as formações geológicas da Serra da Mantiqueira (região de Caconde e São João da Boa Vista) e das Cuestas (Franca e Altinópolis). No leste o planalto chega às escarpas de Botucatu. Ao norte seus limites findam com o Rio Grande. Ao sul o limite é dado pelo atual município de Mogi Mirim-SP, local importante para delimitar o Sertão do Rio Pardo. É a oeste do Rio Pardo que estão as maiores altitudes da região: os cumes da Mantiqueira e das Cuestas. (CELESTE, 2010, p. 19).

\footnotetext{
${ }^{24}$ Importante família que será vista mais adiante através de Saint' Clair Andrade Junqueira.

25 Para saber mais sobre a constituição do município de Casa Branca, ver JOSÉ (1972) e PANTOJA (1942), e sobre Caconde, ver CAMPANHOLE (1979).
} 
Segundo a descrição feita por esse autor (CELESTE, 2010) com base nas análises de Rossini e Oliveira (1999), essa região é predominantemente de planalto o que revela a importância que o relevo exerceu no processo de ocupação dessas terras, juntamente a abundância de água do rio Pardo. A relevância desse último se explica ainda principalmente por alguns fatores: foi o principal guia dos desbravadores; contribuiu na comunicação entre vilas e comunidades; e no escoamento da produção, tornando-se uma referência para os moradores e entrantes. Portanto, as águas desse rio foram essenciais na viabilização da ocupação e no desenvolvimento do povoado. Embora essencial, a presença do rio Pardo trazia perigo para quem morava em suas proximidades, como o risco de alagamento, enchentes e doenças provocadas por insetos, o que justifica a importância da altitude (varia entre $680 \mathrm{~m}$ a $1160 \mathrm{~m}$ ), dos morros e montanhas (formados pela imposição de fatores tectônicos) ${ }^{26}$ na escolha dos locais que foram ocupados e onde se desenvolveram os povoados, como é o caso de São José do Rio Pardo.

Outro fator de relevância e que foi determinante no incremento da atividade agrícola é a qualidade do solo, caracterizado pela predominância do argissolo vermelho-amarelo ${ }^{27}$, associado ao clima tropical com inverno seco, especialmente de junho a agosto quando o regime de chuvas é mais baixo, e com verão quente e chuvoso marcando os meses de dezembro e janeiro quando ocorrem volumes pluviométricos consideráveis (FOLHARINI, 2011). Certamente, esses fatores reunidos propiciaram o desenvolvimento da atividade agrícola que culminou na segunda metade do século XIX com a atração e o estabelecimento do complexo cafeeiro (MISSURA, 2003) que deu ensejo à consolidação da ocupação urbana, conforme abordada nos próximos subitens.

\section{Da fundação à autonomia política}

De acordo com os estudos realizados por Monbeig (1998), a expansão e dominação do cultivo cafeeiro em boa parte do território paulista foi propiciado por algumas condições favoráveis, como a disponibilidade de recursos em especial terreno livre; condições de solo e clima; existência de mão de obra ociosa após a proibição da escravidão e o estímulo à vinda de trabalhadores europeus; implantação do trabalho livre; desenvolvimento de maquinário para o beneficiamento; crescimento do comércio internacional; aumento da demanda de café; descentralização política com a República; e a efetivação do sistema ferroviário.

Como a maioria dos municípios do Nordeste paulista (BACELLAR E BRIOSCHI, 1999), o desenvolvimento de São José do Rio Pardo foi condicionado pela economia cafeeira. Tudo leva a crer que o café tenha sido introduzido neste município na segunda metade do século XIX, visto ser essa a época que o produto começou a ser cultivado em grande escala em Casa Branca e, segundo Rodrigues, M. (2010), citando Furlani (2003), as suas áreas produtoras justapunham-se às terras de São José do Rio Pardo. Foi no contexto de

\footnotetext{
${ }^{26}$ Para informações adicionais consultar Folharini (2011) e Oliveira, R. (2011).

${ }^{27}$ A caracterização das propriedades do solo pode ser encontrada no relatório n. $^{\circ} 40.670$ elaborado pelo Instituto de Pesquisas Tecnológicas (IPT).
} 
expansão dessa produção que um grupo de migrantes decidiu estabelecer sua própria paróquia na Vila de Caconde, território de Casa Branca, conforme ata registrada em 04 de abril de 1865. Era do interesse dos moradores, proprietários de terras, a constituição do patrimônio oferecido à igreja e dedicado à São José, resultando na doação de terras ${ }^{28}$ e materiais de construção para a ereção da capela ${ }^{29}$ que ficou sob o encargo do mineiro João Batista Blandim ${ }^{30}$. Essa ação marcou o nascimento de São José do Rio Pardo.

Os abitantes q. ${ }^{e}$ sircundão esta fuctura Freg. ${ }^{a}$ concorrerão $p .{ }^{a}$ se dar principio a esta nova obra de D. ${ }^{s}$, com uma quantia que chegue para a compra de 2 Sinos, todos os pertences $p .{ }^{a}$ Missa, todo Material p. ${ }^{a}$ fazer-se huma Capella Mór [...] (ATA..., 1865, p. 01).

A formação do patrimônio religioso ${ }^{31}$ foi determinante na organização da vida social, na gênese da constituição do povoado e consequentemente condicionou a forma do tecido urbano desta cidade. Assim como em tantas outras localidades (GHIRARDELLO, 2010), o patrimônio religioso caracterizou o tipo de sítio que deveria ser erigida a ermida e a ocupação ao seu redor, "desenhando por sobre os campos uma série de parcelas, objeto de alguma melhoria que era exigida, e, correspondentemente, uma série de caminhos comuns e vias" (MARX, 1991, p. 41). Foi em um terreno alto, circundado abaixo por córregos e ribeirões que o núcleo se organizou em torno do largo e da capela.

Malgrado a inexistência de registros iconográficos da época, a ata de fundação (1865, p. 01) traz uma descrição sucinta da capela que possuía modestas dimensões, continha "cinqüenta palmos de comprido e vinte e seis de largo, com sacristia de ambos os lados, e com um alpendre em forma de rancho em lugar onde há de ser o corpo da Igreja". Não obstante, a dificuldade em angariar donativos e a fragilidade econômica acarretaram na ausência de alpendre e sacristias (TREVISAN, 1986) e foi a partir desses dados que Menechino (1986) concebeu um registro em aquarela ${ }^{32}$, como pode ser observado na Figura 9. É ainda Trevisan (1986) que nos informa que as sacristias laterais foram executadas em meados da década de 1880.

A influência da mão de obra mineira certamente foi determinante na construção dessa capela que se assemelhou a outras construídas nos núcleos urbanos vizinhos. Podemos citar como exemplos, capelas e matrizes de cidades como Casa Branca (Figura 10), e no sul de Minas Gerais, Caxambu (Figura 11) que apresentavam características semelhantes: nave única com sacristias laterais.

\footnotetext{
28 Doadores: Antônio Marçal Nogueira de Barros, José Theodoro Nogueira de Noronha, Cândido de Faria Moraes, Cândido de Miranda Noronha, João José de Souza. Colaboradores: Ananias Joaquim Machado, Ana Teodora de Assis Nogueira, Antônio Babilo Junqueira, Antônio Cândido, Antônio Carlos Nogueira, Antônio Correa de Sousa, Antônio Joaquim Ferreira, Antônio Joaquim Fonseca, Antônio Teresiano Nogueira, Cândido da Silva Machado, Carlos Ferreira de Aguiar, Custódio de Assis Nogueira, Estébio Ribeiro da Silva, Felix José de Noronha Nogueira, Francisco de Assis Nogueira, Francisco Barbosa Sandoval, Francisco Bernardes de Oliveira, Francisco das Chagas Negrão, Gabriel José de Assis Nogueira, Inácio Fernandes Garcia, Inocência Blandina de Jesus, João Baptista Junqueira, João Cândido de Faria, João Cristovam de Lima, João Damasceno Negrão, João de Deus de Araújo Lasbino, João Honório de Araújo, João Teodoro Nogueira, Joaquim Feliciano Lasbino, Joaquim Gonçalves dos Santos, José Alves Pereira Musa, José Ezequiel de Souza, José Ferreira Pinto, José Maximiano Gama, José Silvestre da Fonseca, Luciano Ribeiro da Silva, Luís Antônio Nogueira de Noronha, Luís José de Andrade, Maria Clementina Nogueira, Miguel José Nogueira de Noronha, Raimundo Estelino Ribeiro da Silva, Reginaldo Gomes da Fonseca, Venerando Ribeiro da Silva (TREVISAN, 1986, p. 14-15).

${ }^{29}$ De acordo com os registros da Ata (1865), foi doada uma quantia de $1325 \$ 00$ e 182 carros de pedras para a feitura da capela.

${ }^{30}$ Conforme Del Guerra (2001), Blandim era natural de São João Del Rei e chegou em São José do Rio Pardo em 1866.

${ }^{31}$ A criação de povoado a partir da doação de terras particulares para a Igreja Católica foi comumente denominado de patrimônio religioso. Sobre o assunto e suas implicações urbanas, ver Marx (2003, 1991), Reis Filho (2000 e 2011) e Ghirardello (2010).

32 O arquiteto Luís Antônio Parreiras Menechino concebeu a aquarela da Capela de São José do Rio Pardo com base no Livro de Atas das Reuniões dos Fundadores 1865/1874 (TREVISAN, 1986) e com orientações de Amélia Franzolin Trevisan (1986).
} 
Apesar das proporções tímidas da edificação inaugurada em 1872, um depoimento dado por João Batista Blandim nos mostra outra percepção ao comparar com o contexto local. Segundo ele, citado por Del Guerra (2001), em 1866 quando chegou às terras rio-pardenses encontrou uma paisagem marcada por casas esparsas com cobertura de sapé o que conferia destaque a capela, mesmo que edificada à meia encosta e de escala humilde, era o referencial maior do lugar ${ }^{33}$. Contudo, essa paisagem será objeto de transformações radicais após a implantação do transporte ferroviário e a ascensão da produção cafeeira.

Figura 9: Capela de São José do Rio Pardo do ano de 1865 em aquarela de Menechino.

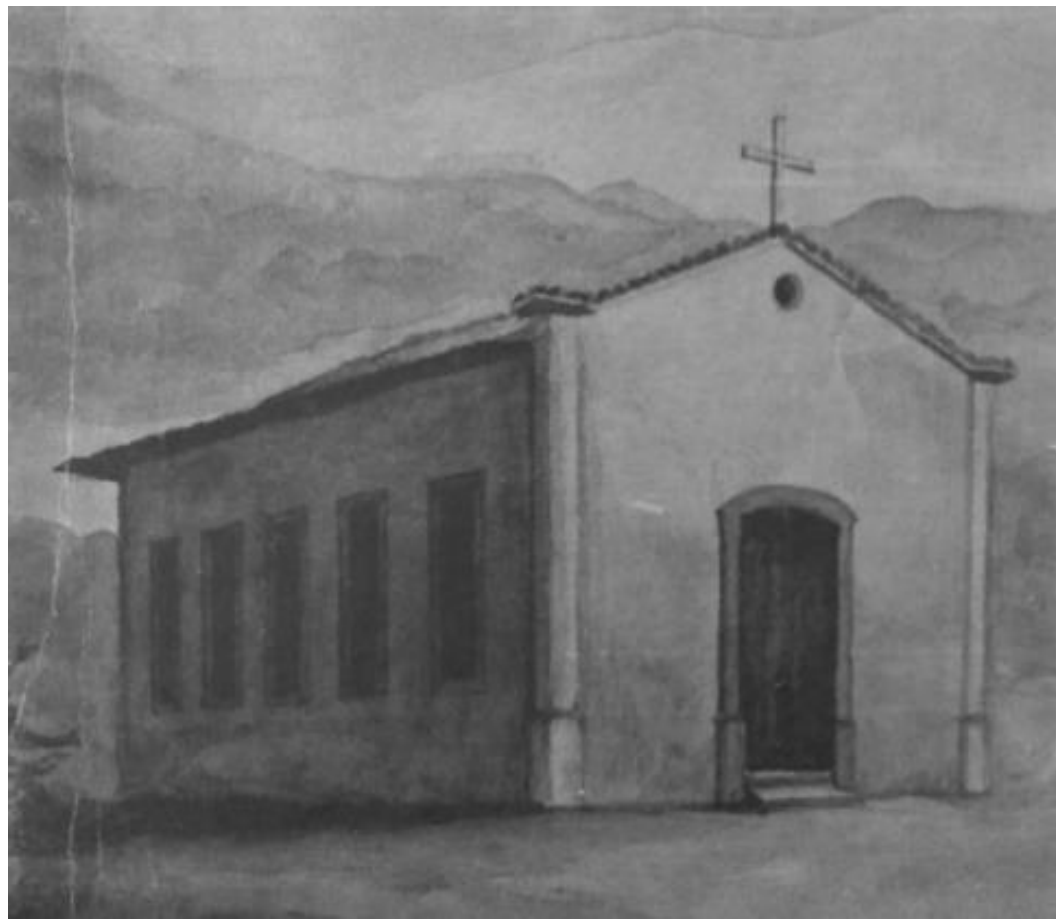

Fonte: Trevisan (1986).
Figura 10: Igreja do Rosário em Casa Branca, 1854

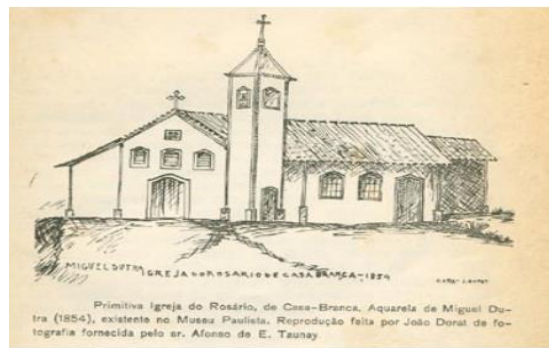

Fonte: Rodrigues, M. (2006).

Figura 11: Capela Nossa Senhora dos Remédios de Caxambu indicada pela seta, 1868.

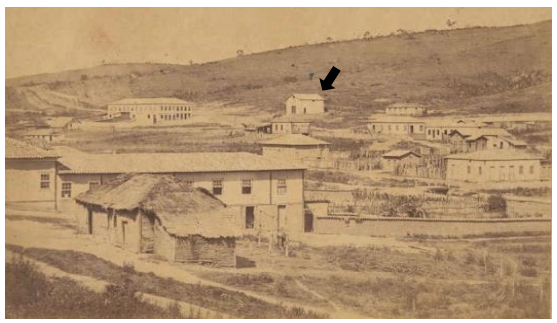

Fonte: Monat (1894).

Foi em 1878 que Antônio Marçal Nogueira de Barros $^{34}$, vereador no município de Caconde, propôs a nomeação de um arruador $^{35}$ para a nova povoação, que seguindo as normas impostas pelo Código de Posturas de Caconde (1866), executou o traçado urbano expressamente geométrico, abrindo ruas de sessenta palmos de largura e as quadras e largos configurados regularmente (Figura 12), modo semelhante ocorreu em Casa Branca e Caconde, por exemplo. A concepção cartesiana de ordenação urbanística foi o padrão da quadra e das subdivisões dos lotes, contudo, é plausível a inexistência de um projeto inicial com

\footnotetext{
${ }^{33}$ A constituição de patrimônios e ereção de capelas atendia às exigências estabelecidas pelas "Constituiçõens primeyras do arce bispado da Bahia" que determinava que as igrejas deveriam "fundar, e edificar em lugares decentes e acommodados, pelo que mandamos, que havendo-se de edificar de novo alguma Igreja parochial em nosso Arcebispado, se edifique em sitio alto, e lugar decente, livre de humidade, e desviado, quando for possível, de lugares immundos, e sordidos (...)" (MARX, 1991, p. 22)

${ }^{34}$ Antônio Marçal Nogueira de Barros, mineiro de Baependi, se mudou para a futura São José do Rio Pardo em 1863 juntamente com sua família e pessoas escravizadas. Foi um dos fundadores desta cidade com a doação de três alqueires de terra para a constituição do patrimônio. Atuante na vida política cacondense, ele foi vereador nos anos de 1865, 1873, 1878 e suplente em 1869.

35 João de Deus Araújo Lasbinio foi o indicado, contudo e segundo Del Guerra (2001) foi João Batista Blandim quem assumiu a função de arruador e traçou as ruas do núcleo urbano inicial rio-pardense.
} 
o traçado urbano que se conformou de acordo com as imposições do Código ${ }^{36}$. Foi através do sistema de aforamento que ocorreu a concessão de pequenas porções de terras, o lote, tendo a praça e a igreja em posição de destaque, e ao sul do núcleo urbano o primeiro cemitério bento em 1868. De acordo com os documentos encontrados no Arquivo da Hemeroteca Jornalista Paschoal Artese e no Arquivo Público de Casa Branca, as datas teriam 13,20 m de frente ${ }^{37}$ e a extensão corresponderia à metade do quarteirão, sob a obrigação do beneficiário realizar um pagamento fixo anual, o foro.

Figura 12: Núcleo urbano inicial de São José do Rio Pardo em 1870.

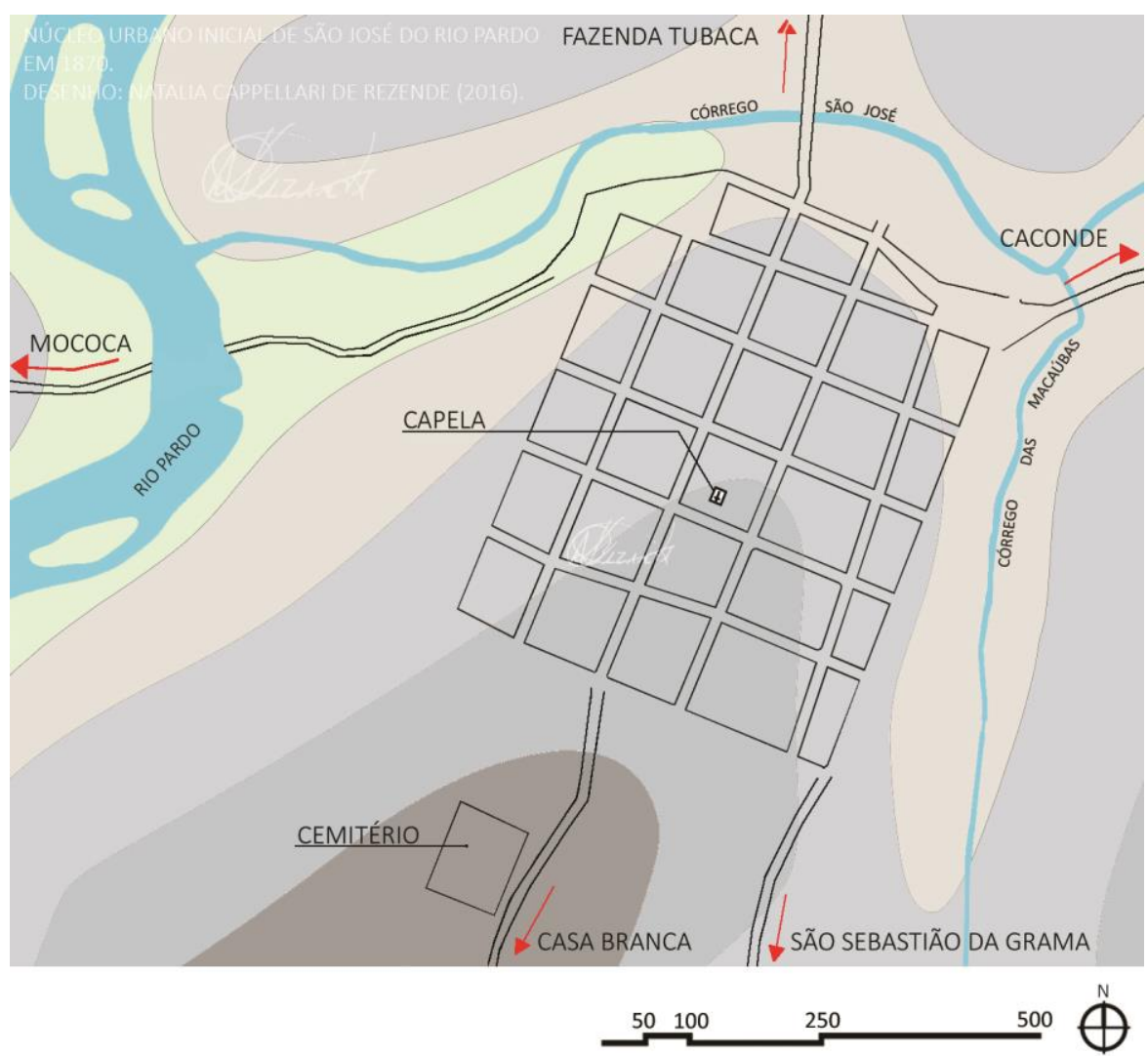

Desenho: Natalia Cappellari de Rezende (2016) com base em dados históricos e cartografia disponibilizada pela Secretaria de Obras de São José do Rio Pardo.

Em 1875, a capela passou a ter um cura o que denota que o povoado já possuía um número significativo de edificações capazes de prover todos os gastos. Cinco anos depois, o povoado foi elevado à categoria de freguesia conforme a lei n. ${ }^{\circ} 70$, desanexando-se da Vila de Caconde e passando a se subordinar à Casa Branca.

\footnotetext{
${ }^{36}$ A existência de um projeto urbano estava condicionada a estudos de estimativa de crescimento populacional e urbano, setorização, projetos arquitetônicos e paisagísticos, entre outros, resultando em um trabalho muito mais sofisticado, o que justifica a sua ausência (GHIRARDELLO, 2010).

${ }^{37}$ Apesar da maioria das cartas de aforamento apontar a medida de 13,20 m de frente, foi encontrada uma variação considerável en tre $3,90 \mathrm{~m}$ e 52,80 m de medidas. Detalharemos no item 1.3 deste capítulo a configuração do traçado, medidas de quadras, ruas e lotes, e o processo de concessão de datas.
} 
Certamente havia um crescimento populacional considerável, ordem econômica e organização social para que, em 1885, através da lei n. 49 de 20 de março, a Freguesia fosse elevada à categoria de Vila. Mas a sua autonomia política e administrativa dependia da instalação de uma Casa de Câmara e Cadeia com recursos advindos da própria localidade. Depois de tomadas as devidas providências, levantou-se a quantia necessária para a construção do prédio de um pavimento que abrigaria Câmara e Cadeia, inaugurado em 8 de maio de 1886, como é possível observar na Figura 13. Contemporâneo ao mais antigo edifício público (1884) construído na cidade de São Carlos (BORTOLUCCI, 1991, p. 76), e a exemplo deste, o prédio da Câmara e Cadeia rio-pardense foi executado sob a influência direta da arquitetura tradicional. Mas, diferente do prédio são-carlense que foi demolido em 1926, o rio-pardense conseguiu se conservar e atualmente é o Museu Rio-Pardense Arsênio Frigo.

Figura 13: Detalhe da antiga Casa de Câmara e Cadeia retratada por Araújo Guerra na primeira folha do jornal A Platea em 1889.

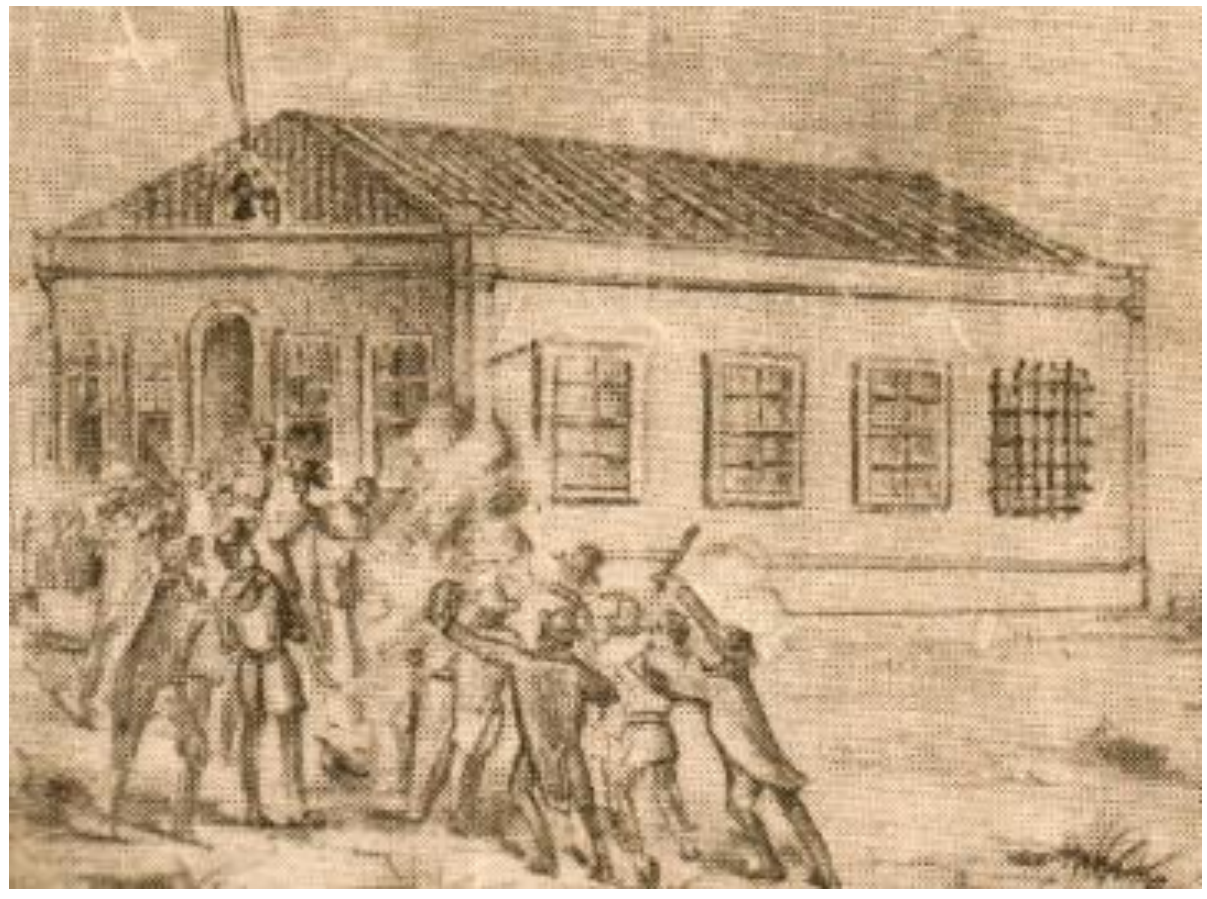

Fonte: Jornal A Platea, ano $2^{\circ}$, n. $^{\circ} 61,1889$.

Sua fachada principal é composta de pilastras, janelas de vergas retas com alvenaria decorada, e porta arrematada por arco pleno com bandeira fixa em ferro forjado (Figura 14). O revestimento externo do edifício, na altura do porão, é marcado com bossagens em argamassa, assim como os cunhais, falseando um trabalho de cantaria (Figura 15). O sistema construtivo empregado foi a alvenaria de tijolos com alicerce de pedras, o telhado em estrutura de madeira serrada coberta por telha capa e canal e forro de tábuas de madeira superpostas (Figura 16). O piso atual é de cimento queimado nos degraus de entrada, enquanto se conservam o ladrilho hidráulico e o assoalho de madeira nos demais cômodos (Figura 17). Um edifício arrojado para os padrões edificados no núcleo urbano rio-pardense naquele momento. 
Figura 14: Bandeira da fachada frontal da antiga Casa de Câmara e Cadeia.

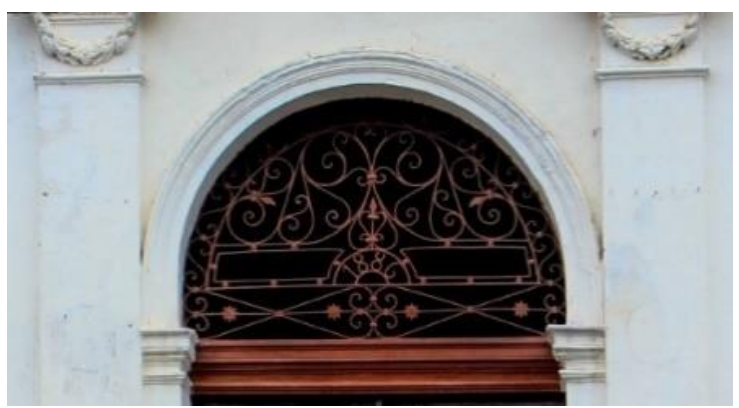

Fonte: Acervo pessoal da autora (2014).
Figura 15: Bossagens em argamassa falseando um trabalho de cantaria.

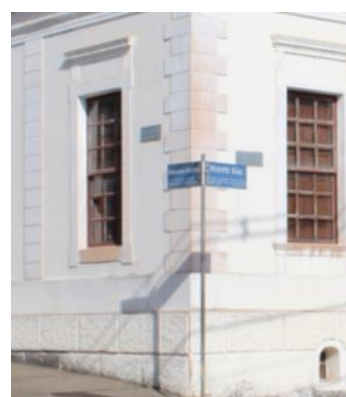

Fonte: Acervo pessoal da autora (2014)
Figura 16: Forro de tábuas de madeira superpostas.

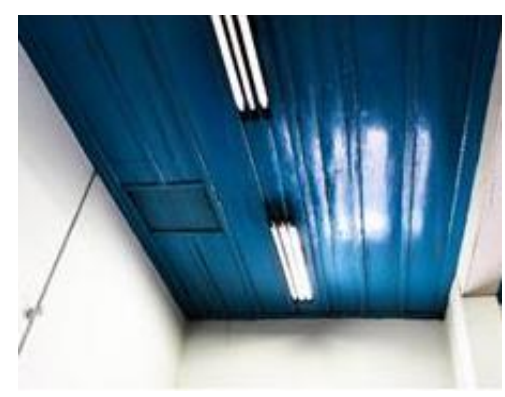

Fonte: Acervo pessoal da autora (2014).

Figura 17: Interior da Casa de Câmara (atual Museu Rio-pardense Arsênio Frigo).

A. Degraus em cimento queimado que dá acesso ao vestíbulo da edificação. B. Assoalho de madeira da sala da Câmara. C. Ladrilho hidráulico da sala do Corpo de Guarda. D. Ladrilho hidráulico do vestíbulo da entrada.
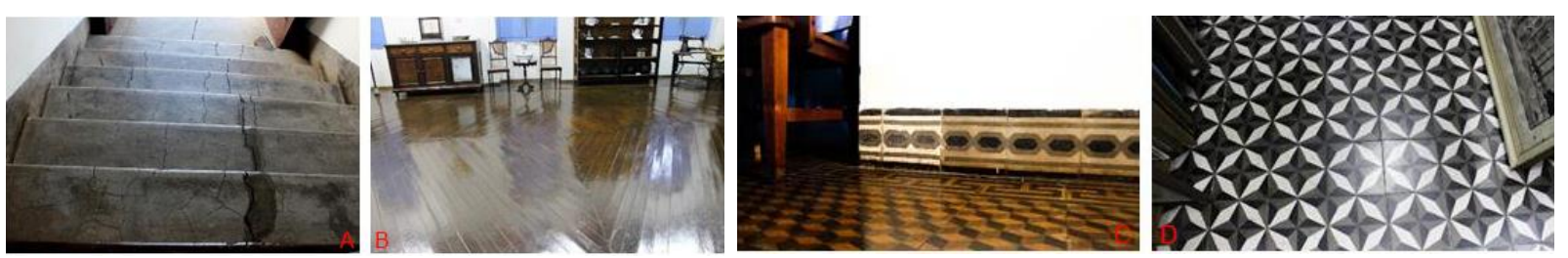

Fonte: Acervo pessoal da autora (2016).

A conquista da autonomia política e administrativa com a eleição dos sete vereadores ${ }^{38}$, dentre eles doadores e colaboradores da constituição do patrimônio, tornou oficial o poder da elite local, que se apoderou também de cargos públicos de prestígio e comando. O controle era mantido pelos principais proprietários de terras e por pessoas que pertenciam a este círculo de amizade, capazes de conservar sob seus interesses a regulação do patrimônio público, utilizando para isso diversas leis, entre as quais estão as Posturas Municipais. Uma matéria jornalística publicada em 1900 pelo jornal O Rio Pardo, da qual foi retirada a citação seguinte, reforça nossas constatações:

quer dominasse o grupo A, quer estivesse o grupo B no poder, os interesses do município eram descurados, procurava-se antes representantes para as varias famílias, alias distinctas era o governo do compadresco, da oligarquia em pequena escala. Cada família contentava-se em ter um seu representante na municipalidade, e tanto bastava, no seu entender, para que tudo corresse as mil maravilhas (S. JOSÉ..., 29/03/1900, p. 01).

E assim seguiu a elevação à categoria de Cidade em 1891 através do Decreto n. ${ }^{\circ} 179$.

\footnotetext{
${ }^{38}$ Todos os sete vereadores eleitos estavam envolvidos diretamente com o principal produto da economia rio-pardense, o café, e além disso, galgavam patentes militares, como o Antônio Marçal Nogueira de Barros (coronel e fazendeiro), Vicente Alves de Araújo Dias (capitão e fazendeiro), Luiz Carlos de Mello (fazendeiro), Joaquim Gonçalves dos Santos (alferes e fazendeiro), José Ezequiel de Souza (coronel e fazendeiro), Antônio Correa de Souza (capitão e fazendeiro), Saturnino Frauzino Barbosa (negociante).
} 


\section{Café e Ferrovia}

As condições que ensejaram a consolidação do núcleo urbano tiveram como prelúdio as transformações da década de 1870 quando o café se firmou como produto ascendente na região, ultrapassando o cultivo da cana-de-açúcar como principal atividade agrícola. Numa referência direta aos motivos que levaram os fazendeiros a optar pelo plantio de café, o coronel Antônio Marçal Nogueira de Barros em correspondência datada de 19 de novembro de 1875 ao Presidente da Província, informou que

[...] poderá criar o engenho em sua fazenda da Becerábia, onde os terrenos são ótimos para o plantio da cana; os lavradores plantam cana em pequena escala por falta de engenhos; os trabalhadores são locais, os quais acham melhores que os estrangeiros, mas pretende experimentá-los; a lavoura mais adotada é o café a qual está bastante desenvolvida (MENECHINO, 1986, p. 12).

Este relato deixa transparecer que a falta de um engenho minimizava a produção de cana-de-açúcar que a partir daquele momento era suplantada pelo café que dominaria quase todo o município. As condições existentes de mercado, meios de transporte e rede de caminhos, mesmo que precários em um primeiro momento, foram recursos disponíveis que atraíram fazendeiros para a região, a exemplo de Felix José Monteiro de Noronha ${ }^{39}$, major Joaquim Gonçalves dos Santos ${ }^{40}$, Vicente Alves de Araújo ${ }^{41}$, e José da Costa Machado e Souza ${ }^{42}$. Todos eles investiram na plantação de café que se tornou a principal fonte de riqueza, e Noronha ${ }^{43}$, major Joaquim Gonçalves dos Santos ${ }^{44}$, Vicente Alves de Araújo ${ }^{45}$ e José da Costa Machado e Souza ${ }^{46}$. Todos eles investiram na plantação de café que se tornou a principal fonte de riqueza, e

\footnotetext{
${ }^{39}$ Felix José Monteiro de Noronha, mineiro de Ouro Preto, chegou às terras rio-pardenses com a mulher, pessoas escravizadas, armas e o filho atraído pelo primo Alexandre Luis de Mello que possuía terras nessa localidade. Seu filho José Theodoro Nogueira de Noronha, conhecido como Juca Gordo, nasceu em Baependi-MG, foi um dos primeiros plantadores de café de São José do Rio Pardo (DEL GUERRA, 2001).

${ }^{40}$ Major Joaquim Gonçalves dos Santos, natural de Casa Branca, se mudou para as terras que dariam origem a cidade de São José do Rio Pardo em 1851, e assim como José Theodoro Nogueira de Noronha, iniciou o cultivo da cafeicultura. Além de ser proprietário de extensas porções de terras que integravam as fazendas Sertão Grande do Rio Pardo, São Vicente, Buenos Aires, Pocinha, Sítio Novo e Santa Maria, foi um dos colaboradores da fundação da capela e da construção da Casa de Câmara e Cadeia, e participou ativamente da política como vereador na legislatura de 1886 e do conselho de intendência entre os anos de 1890 e 1892 (DEL GUERRA, 2001).

${ }^{41}$ Vicente veio de Cabo Verde-MG na década de 1870 quando adquiriu partes de terra que pertencia a Fazenda Pião do Rio Pardo formando uma das mais prósperas fazendas em produção cafeeira de São José do Rio Pardo, a Tubaca. Foi proprietário das fazendas Becerábia, Graminha, Pau d'Alho, Santa Justa entre outras, e participou da política como vereador na legislat ura de 1886 (DEL GUERRA, 2001).

${ }^{42}$ José da Costa Machado e Souza, natural de Baependi-MG, era formado em ciências jurídicas e sociais pela Academia de Direito do Largo de São Francisco em 1853. Costa Machado foi nomeado presidente da província de Minas Gerais por Dom Pedro II, se mantendo no cargo entre os anos 1867 e 1868 quando se demitiu por se declarar republicano. Mudou-se com a família para a região de São José do Rio Pardo em 1877 se fixando nas terras do sogro - Fazenda Água Fria. Após desbravamentos de terras, adquiriu a fazenda Vila Costina que, segundo Missura (2002), era constituída de aproximadamente 507 alqueires dos quais 300 eram utilizados no plantio do café. Na política, participou da fundação do Diretório do Partido Republicano em 1884 voltando a atuar por Minas Gerais em outras três legislaturas como deputado. Além de ser um dos responsáveis pela organização da Companhia do Ramal Férreo do Rio Pardo, trabalhou como seu diretor e advogado (Del Guerra, 2001). Para saber mais sobre José da Costa Machado e Souza, ver Missura (2003).

${ }^{43}$ Felix José Monteiro de Noronha, mineiro de Ouro Preto, chegou às terras rio-pardenses com a mulher, pessoas escravizadas, armas e o filho atraído pelo primo Alexandre Luis de Mello que possuía terras nessa localidade. Seu filho José Theodoro Nogueira de Noronha conhecido como Juca Gordo, nasceu em Baependi-MG, foi um dos primeiros plantadores de café de São José do Rio Pardo (DEL GUERRA, 2001).

${ }^{44}$ Major Joaquim Gonçalves dos Santos, natural de Casa Branca, se mudou para as terras que dariam origem a cidade de São José do Rio Pardo em 1851, e assim como José Theodoro Nogueira de Noronha, iniciou o cultivo da cafeicultura. Além de ser proprietário de extensas porções de terras que integravam as fazendas Sertão Grande do Rio Pardo, São Vicente, Buenos Aires, Pocinha, Sítio Novo e Santa Maria, foi um dos colaboradores da fundação da capela e da construção da Casa de Câmara e Cadeia, e participou ativamente da polític a como vereador na legislatura de 1886 e do conselho de intendência entre os anos de 1890 e 1892 (DEL GUERRA, 2001).

${ }^{45}$ Vicente veio de Cabo Verde-MG na década de 1870 quando adquiriu partes de terra que pertencia a Fazenda Pião do Rio Pardo formando uma das mais prósperas fazendas em produção cafeeira de São José do Rio Pardo, a Tubaca. Foi proprietário das fazendas Becerábia, Graminha, Pau d'Alho, Santa Justa entre outras, e participou da política como vereador na legislatura de 1886 (DEL GUERRA, 2001).

${ }^{46}$ José da Costa Machado e Souza, natural de Baependi-MG, era formado em ciências jurídicas e sociais pela Academia de Direito do Largo de São Francisco em 1853. Costa Machado foi nomeado presidente da província de Minas Gerais por Dom Pedro II, se mantendo no cargo 
acertadamente favoreceu o desenvolvimento dessa porção do nordeste paulista. Segundo Taunay (1939, p. 366-367), em contraposição ao declínio dos municípios de velhas lavouras como Jacareí, Guaratinguetá, Pindamonhangaba, e em outros onde a cultura cafeeira estava prestes a acabar como Bananal, Areias e São José do Barreiro, havia os municípios que ressurgiam através das lavouras novas como foi o caso de São José do Rio Pardo que no ano de 1886 produziu 3.000.000 quilos de café ou 50.000 sacas de 60 quilos. Complementando as afirmações de Taunay, Matos (1990, p. 43) creditou a inerência desta produção à fisionomia paulista, dado que durante a sua "marcha" causou a morte de cidades e povoou outras regiões, abriu zonas pioneiras, plantou cidades que durante muito tempo tiveram o café como base econômica.

Conforme a produção de café se expandia e se distanciava do porto de Santos, maiores eram as dificuldades no escoamento da produção. A solução encontrada foi o desenvolvimento das vias férreas que, sem seguir "um plano sistemático, antes foi conduzido pelos interesses dos administradores, dos produtores e dos comerciantes de café" (MONBEIG, 1998, p. 175).

A necessidade de dinamizar o transporte, diminuir os seus custos de produção, aumentar a produtividade e reduzir as perdas em decorrência das longas e demoradas viagens feitas por mulas e carros de boi foram algumas das razões pelo empenho dos fazendeiros na expansão das ferrovias. Nesse sentido, Saes (1981, p. 82) nos esclarece que "o desenvolvimento do café era auto-alimentado pela própria construção de ferrovias, pois o declínio no custo de transporte criava margem adicional de resistência à queda de preço". E Matos (1990) destaca ainda o interesse dos plantadores de café em ampliar o seu raio de ação que viabilizaria a acumulação através da apropriação e valorização das terras cortadas pela ferrovia, daí serem eles os maiores defensores em ter esse acesso. Complementando, Ghirardello (2010) afirma que havia também o interesse no desenvolvimento do comércio e serviços que a proximidade dos trilhos propiciava, o que contribuía sobremaneira para a integração da cidade em uma rede de negócios. Sobre isso, Saes (1981) nos confirma a relação que se estabeleceu entre café, população e ferrovia no tempo e no espaço, anteriormente atestada por Monbeig (1998), e afirma que a expansão do café e das ferrovias foi antes de mais nada o negócio dos fazendeiros. Enquanto Ghirardello (2010) nos eclarece inda que

Os patrimônios, quando estabelecidos, tinham um principiar urbano bastante precário e penoso, e, para o desenvolvimento destes, a ferrovia era fundamental. Sem ela, essas pequenas vilas corriam sério risco de desaparecer, o que ocorreu com muitas. E mais, sem os trilhos, os investimentos urbanos não seriam realizados [...]. Capitais excedentes vindos das lavouras de café aportavam sob diversas formas no solo urbano. A paisagem da vila se transformava, os ânimos, certamente, também (GHIRARDELLO, 2010, p. 22).

Em 1872, um grupo composto basicamente de fazendeiros produtores de café da região de Campinas fundar a Companhia Mogyana de Estradas de Ferro $^{47}$ com objetivo de ligar Campinas a Mogi Mirim e

entre os anos 1867 e 1868 quando se demitiu por se declarar republicano. Mudou-se com a família para a região de São José do Rio Pardo em 1877 se fixando nas terras do sogro - Fazenda Água Fria. Após desbravamentos de terras, adquiriu a fazenda Vila Costina que, segundo Missura (2002), era constituída de aproximadamente 507 alqueires dos quais 300 eram utilizados no plantio do café. Na política, participou da fundação do Diretório do Partido Republicano em 1884 voltando a atuar por Minas Gerais em outras três legislaturas como deputado. Além de ser um dos responsáveis pela organização da Companhia do Ramal Férreo do Rio Pardo, trabalhou como seu diretor e advogado (Del Guerra, 2001). Para saber mais sobre José da Costa Machado e Souza, ver Missura (2003).

${ }^{47}$ Esta denominação foi alterada para Companhia Mogyana de Estradas de Ferro e Navegação em 1888 quando foram incorporados serviços de navegação no Rio Grande. Após a desativação dos serviços em 1923 voltou à denominação de origem. 
Amparo, e posteriormente estender seus trilhos até a divisa entre os estados de São Paulo e Minas Gerais, passando por Casa Branca e Franca (PINTO, A., 1903; MATOS, 1990 e SAES, 1981). Sobre isso Kühl (1998) destaca que

\begin{abstract}
a Companhia de Estradas de Ferro Mogiana, criada em 1872, foi, como nos casos anteriores ${ }^{48}$, organizada por fazendeiros de café e com as garantias e privilégios habituais, com o intuito de executar uma linha, com bitola de 1,0 metro, entre Campinas e Mogi-Mirim e um ramal para a Cidade de Amparo. Tornou-se uma das mais importantes do Brasil, servindo uma das regiões mais ricas da Província. A construção foi iniciada em agosto de 1873, sendo aberta ao tráfego até Mogi-Mirim dois anos depois, e até Amparo, em novembro de 1875. Seguiram-se os trechos até Casa Branca, concluído em janeiro de 1878, e dessa cidade até São Simão e Ribeirão Preto, terminando em novembro de 1883. [...] Seguiram-se ainda os ramais para São José do Rio Pardo, que atingiu Canoas em abril de 1891, e o ramal para Serra Negra, terminado em março de 1892 (KÜHL, 1998, p. 132).
\end{abstract}

Após a Companhia Mogyana declarar que não havia interesse em estender seus trilhos até São José do Rio Pardo foi concedido ao Dr. Martiniano Reis Brandão, Samuel Severiano de Aguiar e Fernando Scheleicher o privilégio para a construção, uso e gozo de um ramal de estrada de ferro que partindo da divisa de Casa Branca se estendesse até as divisas da província de Minas, passando por São José do Rio Pardo (LEI N.87/1880). Mas em 1884, a Lei n. 24 retirou os privilégios de Samuel Severiano de Aguiar e Fernando Scheleicher, deixando ao Martiniano Reis Brandão a permissão de transmitir essa concessão somente à empresa Ramal Férreo do Rio Pardo, criada após este último declarar que não havia capital econômico suficiente.

Nesse sentido, ressaltamos o esforço desenvolvimentista proporcionado pelo dinheiro do café que possibilitou a um grupo, tendo à frente o republicano José da Costa Machado e Souza, fundar a Companhia Ramal Férreo do Rio Pardo em $1884^{49}$. Composta por 144 acionistas (Anexo 02 ) ${ }^{50}$, sendo estes de São Paulo, Campinas, Santos, São José do Rio Pardo, Casa Branca, Mococa, Guaxupé - MG, Muzambinho - MG, Monte Santo - MG, Caconde, Santa Bárbara e Campanha - MG, como pode ser observado no Gráfico 01 . Estes acionistas conseguiram levantar um capital de 751 contos para a construção do ramal. Para Missura (2003), é plausível a inexistência de capital estrangeiro e financiamentos bancários empregados nessa obra, da mesma forma como ocorreu em outras empresas ferroviárias do Estado de São Paulo, inclusive a Companhia Paulista de Estradas de Ferro que teve seu desenvolvimento "realizado exclusivamente com capitais levantados na província, por meio de ações" (MATOS, 1990, p. 85), mas que não seria de estranhar o emprego de capital externo como ocorreu na São Paulo Railway Company (SPR). Todavia, Missura (2003) ao compartilhar do posicionamento de Matos (1990), ressaltou que a falta de registros que evidenciem tal fato não o exclui por completo uma vez que "essas ferrovias eram organizadas e financiadas pelos fazendeiros paulistas do café e seus aliados no comércio e governos locais, mas a tecnologia, os trilhos e os vagões eram britânicos" (MISSURA, 2003, p. 67).

\footnotetext{
${ }^{48}$ A autora se refere a São Paulo Railway Company (1864); Companhia Paulista de Estradas de Ferro (1868); Companhia Ituana (1870); e Companhia Sorocabana (1870).

${ }^{49}$ Segundo Matos (1990, p. 101-109), a Companhia Ramal Férreo do Rio Pardo não se tratava de um ramal e sim de pequena estrada independente, constituindo "verdadeiras estradas "cata-café" que iam, no seu imediatismo, servir aos interesses das fazendas de uma região que, na época, já se encontrava na vanguarda da produção cafeeira de São Paulo".

${ }^{50}$ Segue anexo (02) a relação nominal dos acionistas do Ramal Férreo do Rio Pardo.

56
} 


\section{Número}

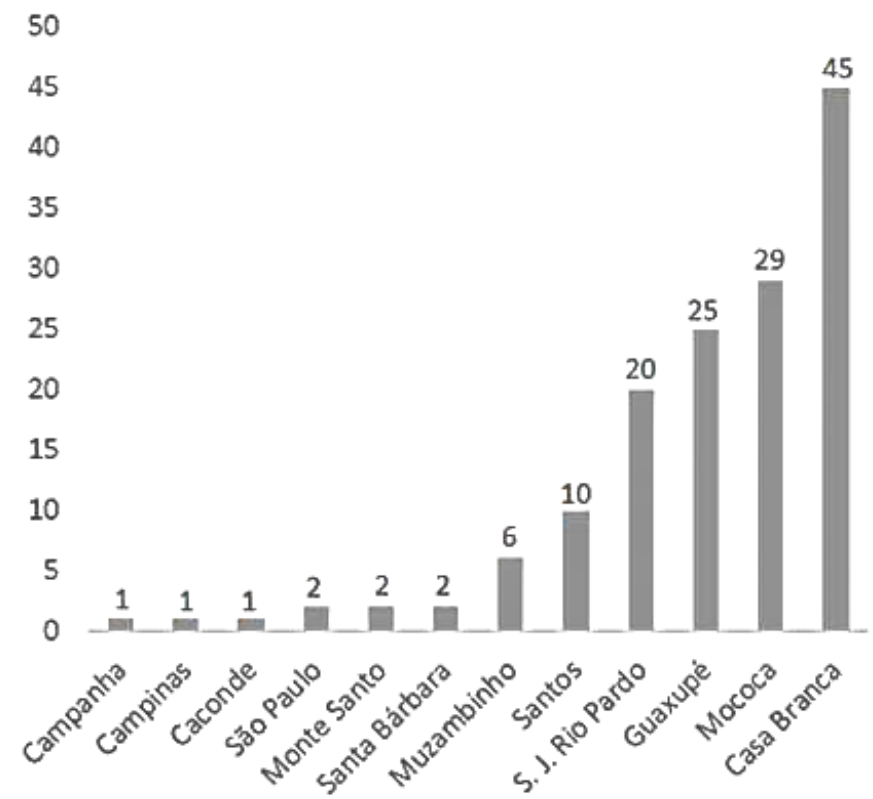

Fonte dos dados: Missura (2003).

Foram muitos os embates entre acionistas para decidir o traçado da linha férrea ${ }^{51}$, aspirando cada um a seu modo, a proximidade dos trilhos às suas terras, e principalmente com a Companhia Mogyana que não concordava com o entroncamento que o Ramal realizaria em sua linha. Caso semelhante aconteceu em São Carlos como relatado por Saes (1981, p. 67) e com mais um agravante, o conflito entre conservadores e liberais "em torno dos méritos no desenvolvimento da viação férrea em São Paulo". O que demonstra que a efetivação da ferrovia não se deu através de um processo tranquilo, e no caso rio-pardense não foi diferente. Os embates ocasionados foram responsáveis por atrasar os serviços, algumas vezes inclusive resultando em embargo da obra, o que enfraqueceu as alianças estabelecidas e consequentemente reduziu o capital econômico do Ramal. Apaziguados os conflitos, prosseguiu a construção da ferrovia no fundo do vale do rio Pardo, e em 27 de agosto de 1887 chegou o primeiro trem a São José do Rio Pardo, enquanto o edifício da Estação só seria inaugurado no dia 7 de setembro de 1887, na área que passou a ser denominada de "Largo da Estação" (hoje Praça Tiradentes) (Figura 18).

${ }^{51}$ Para saber mais, ver Missura (2003). 
Figura 18: Estação ferroviária e Largo da Estação (hoje Praça Tiradentes) no núcleo urbano rio-pardense, agosto de 1887.

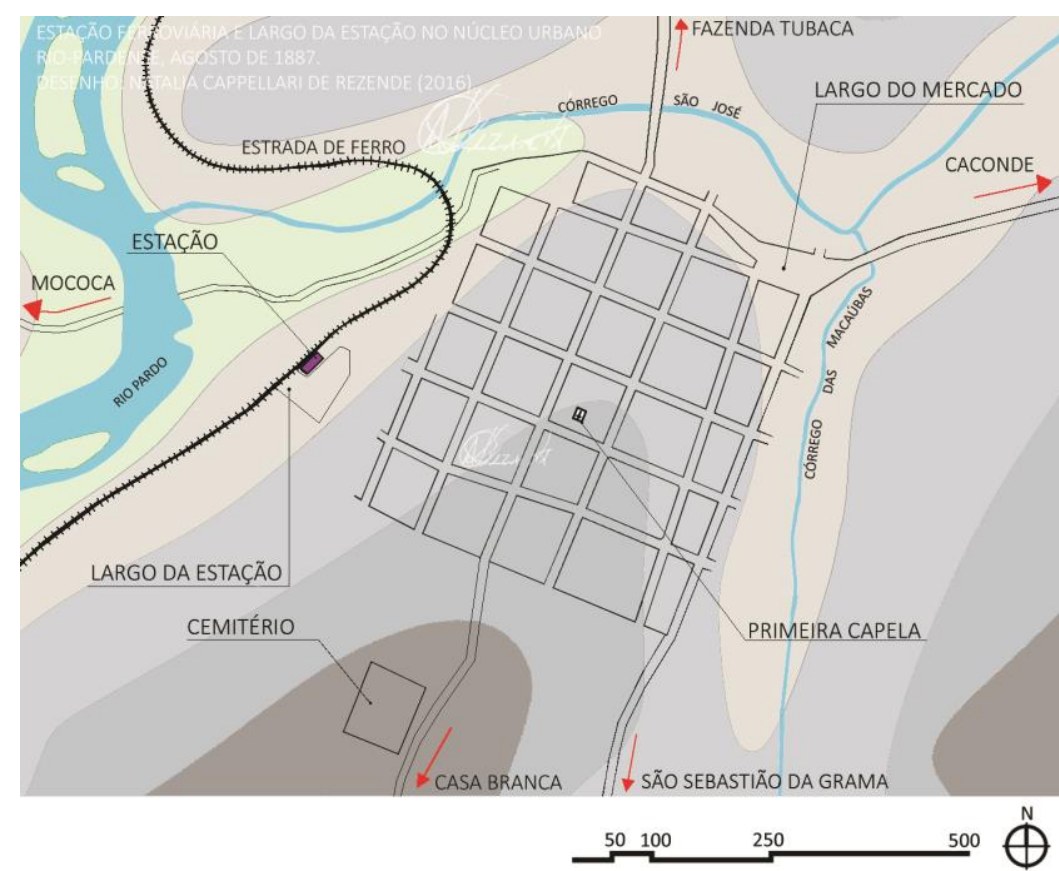

Com planta retangular e dois pavimentos $^{52}$, a Estação

Central de São José do Rio Pardo $^{53}$ foi implantada paralelamente aos trilhos do trem, e seguiu a tipologia e tecnologia construtiva empregada na arquitetura ferroviária da região especialmente no uso do tijolinho à vista, como pode ser observado na Figura 19.

Desenho: Natalia Cappellari de Rezende (2016) com base em dados históricos e cartografia disponibilizada pela Secretaria de Obras de São José do Rio Pardo.

Figura 19: Primeiro edifício da Estação Central da Companhia Ramal Férreo do Rio Pardo no final do século XIX.

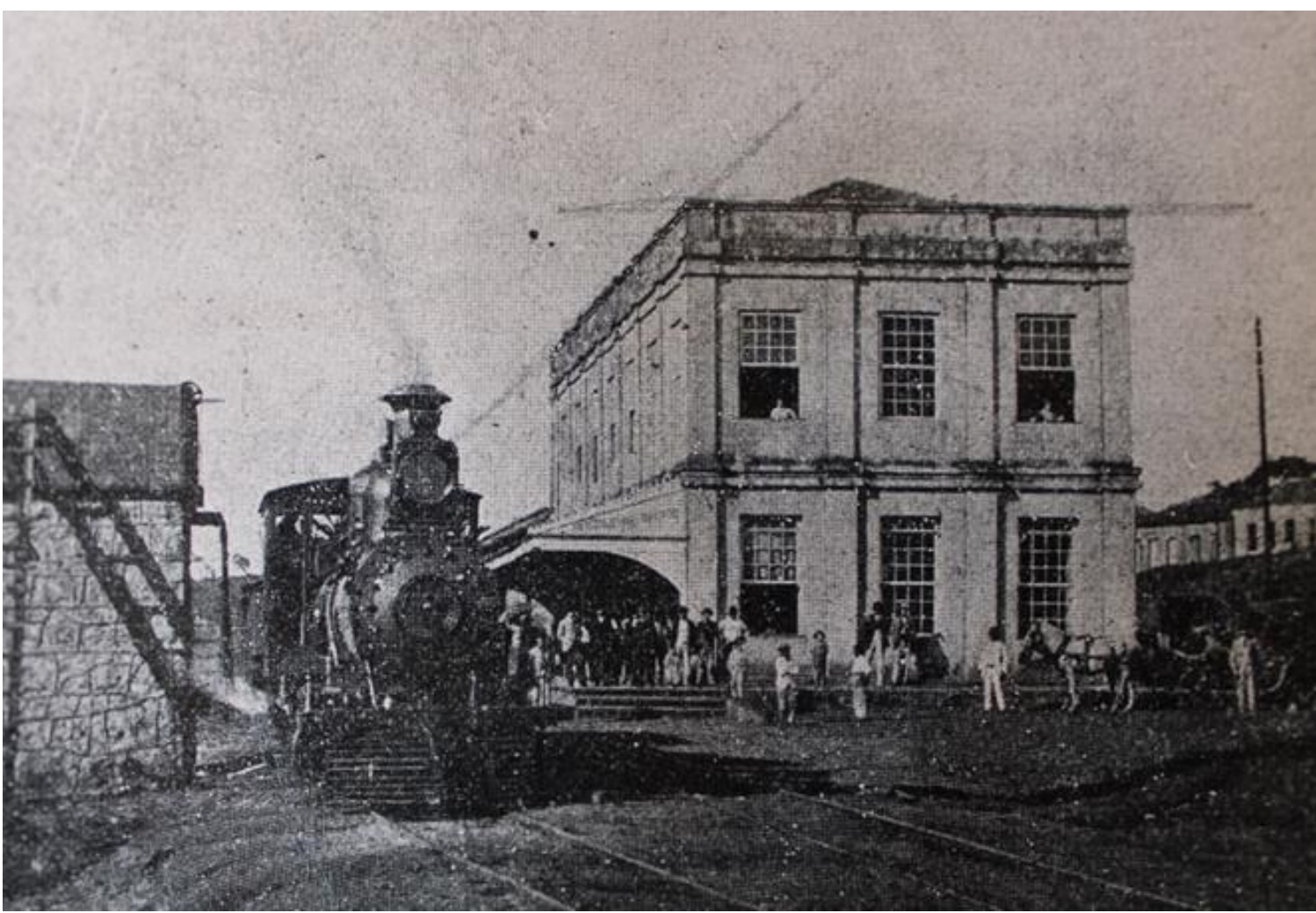

Fonte: Arquivo do Centro da Memória Rio-Pardense Rodolpho José Del Guerra.

\footnotetext{
52 De acordo com Kühl (1998, p. 140), "o edifício para passageiros podia apresentar, basicamente, a forma de um retângulo, de um U ou de um L. Se retangular e disposto paralelamente ao trilho, a estação é chamada lateral e foi a forma, por excelência, das estações de passagem ao redor do mundo".

${ }^{53}$ A Estação Central de São José do Rio Pardo possuía uma composição arquitetônica semelhante à estação da São Paulo Railway construída em 1867 (KÜHL, 1998). Ambos os prédios possuíam linhas classicizantes, mas o que os diferia é que na estação rio-pardense ocorria a inexistência de um corpo central reentrante, presente na São Paulo Railway.
} 
Para Saes (1981), a ferrovia desenvolveu um duplo papel no processo de expansão da lavoura cafeeira e no estímulo ao desenvolvimento de inúmeras atividades modificando a dinâmica urbana. Direta ou indiretamente, a implantação dos trilhos exerceu considerável influência econômica, urbana, social e cultural. Isso pode ser respondido porque a ferrovia contribuiu diretamente na

\begin{abstract}
integração de grande parte do território paulista ao surto de desenvolvimento econômico, que tornou o Estado o principal centro produtor e exportador de café. Anteriormente, muitas cidades estavam isoladas da dinâmica da economia, devido ao excessivo custo do transporte de mercadorias por muares. (KÜHL, 1998, p. 135).
\end{abstract}

Importante notarmos que a ligação do interior paulista com as outras regiões do país criou as condições necessárias para a divulgação e valorização do positivismo calcado no pensamento científico que era enaltecido pela República, esta por sua vez pregava as reformas modernizadoras a serem empreendidas tendo a cultura europeia como referência material e social (SEVCENKO, 1998). Nessa conjuntura, a ferrovia era vista como o fator tecnológico de dinamização e aceleração da urbanização, do desenvolvimento e da civilização. Mas, segundo Lanna (2002), apesar da generalização associativa feita entre a ferrovia, a mobilidade, o progresso e a civilização, não é possível afirmar o quão capaz ela foi de atender a essas expectativas que dependiam de outros agentes envolvidos, do tempo e também do espaço onde os trilhos foram instalados.

No contexto de boa parte dessas cidades do interior paulista, como é o caso de São José do Rio Pardo, a ferrovia significou uma transformação drástica ao consolidar a inserção na rota do café. E mais do que isso, a linha férrea significou um marco de intencionalidade a partir de seu vínculo com a construção da modernidade através dos programas de melhoramentos. Junto à estrada de ferro, novos ritmos, costumes, urbanidade e tipos arquitetônicos originaram obras de porte, como o complexo da estação que incluía

\footnotetext{
armazéns, depósitos e oficinas de locomotivas, etc... Essas edificações deviam responder a programas e exigências até então desconhecidos, reunidos em um conjunto de edifícios funções bastante diversas entre si, além de ter que resolver todas as questões referentes à circulação de passageiros e mercadorias. (KÜHL, 1998, p. 58).
}

Obras que necessitaram de numerosa força de trabalho com qualificação diversificada, o que por si só contribuiu para movimentar o incipiente núcleo urbano. Dificuldades financeiras e desentendimentos entre os acionistas fizeram com que o Ramal fosse fundido à Companhia Mogyana em 1888, dando prosseguimento à construção dos trilhos até Mococa e Guaxupé (Figura 20), como era interesse dos cafeicultores e financiadores dessas cidades, evidenciando as disputas e poder. 


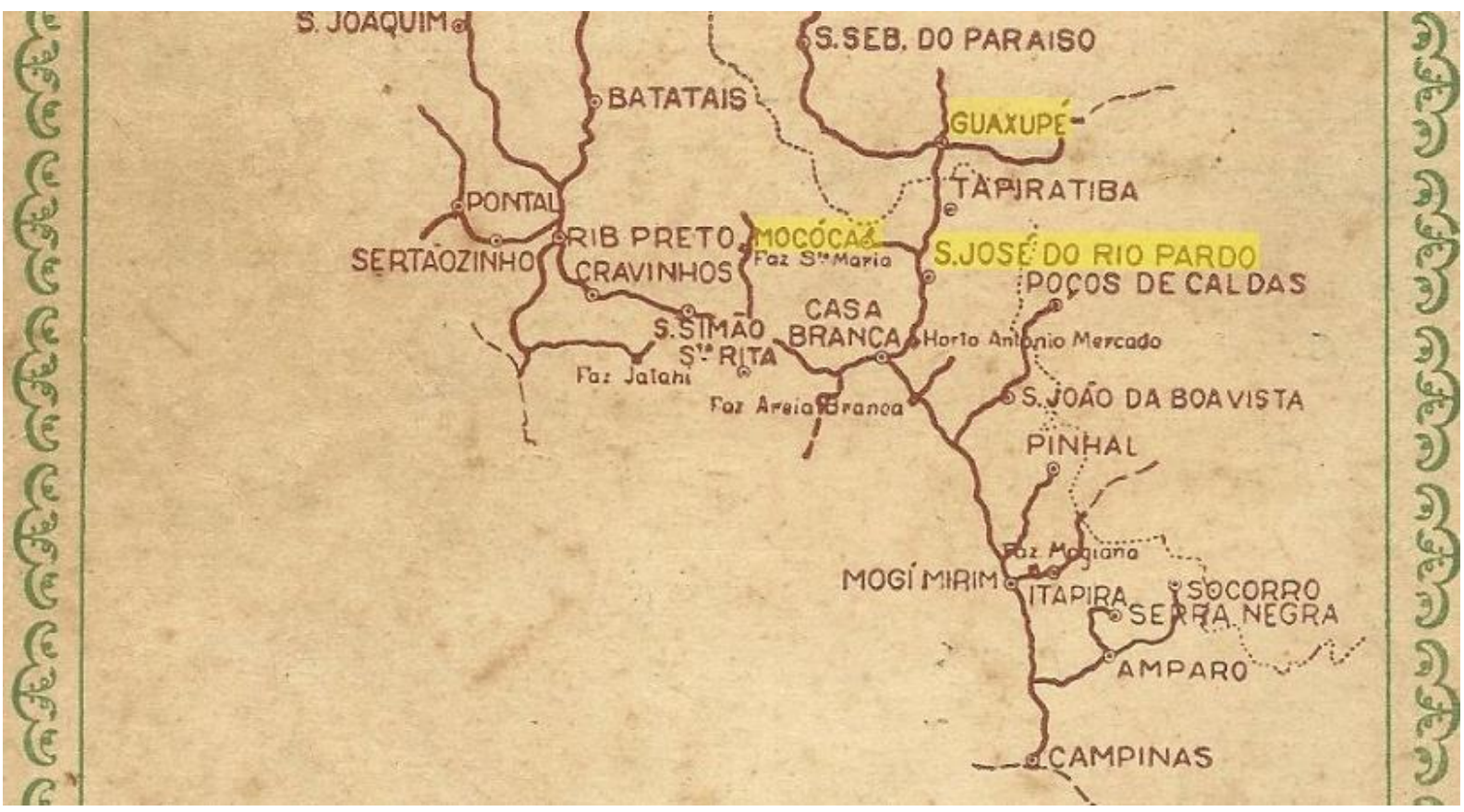

Fonte: Companhia Mogiana de Estradas e Ferro (1945).

O crescimento econômico possibilitado pelo transporte ferroviário mediante a facilidade de escoamento da produção cafeeira contribuiu também para propagação de informações e pessoas ${ }^{54}$. Na medida em que os vagões do trem saíam carregados de café com destino ao porto de Santos, atraíam imigrantes ${ }^{55}$ para trabalhar na lavoura cafeeira, contribuindo para o aumento populacional, econômico, e também de prestação de serviços decorrentes da necessidade de atender novas demandas. Além disso, para Matos (1990), a entrada de imigrantes e o trabalho livre foram preponderantes para a integração brasileira ao capitalismo internacional na medida em que dinamizou a economia de mercado e ensejou a

[...] formação de um início de classe média entre nós, nas zonas semi-urbanas ou já urbanizadas do interior, onde as cidades do café, mais que as do vale do Paraíba se multiplicariam, com tipos de população os mais diversificados (MATOS, 1990, p. 51).

O que levou Menechino (1986, p. 13) a afirmar que "apesar de o café encontrar em São José um núcleo já estabelecido, o ouro verde foi o seu fator de desenvolvimento [...]". Embora haja registros de imigrantes estrangeiros nesta cidade desde o início da década de 1880, foi a partir de 1887 que fazendeiros ${ }^{56}$ trouxeram italianos ${ }^{57}$ de maneira contumaz para trabalhar em sua fazenda, e segundo Del Guerra $(2000)^{58}$

\footnotetext{
${ }^{54}$ Para Martins, J. (2004, p. 12), "a ferrovia anunciava e realizava o novo, ao mesmo te mpo em que nele inseria o velho e tradicional. Era como se descosturasse a trama das velhas relações sem destruí-las inteiramente, recosturando-as no sistema de significados e funções do primado do capital e de sua reprodução ampliada. Não atuava apenas no âmbito da economia, mas também no do reajustamento e refuncionalização das relações sociais, dos valores, das concepções".

${ }^{55}$ A estratégia de favorecimento da imigração branca está relacionada com os discursos da mestiçagem no Brasil, legitimada pelas principais correntes científicas europeias, como o darwinismo social, o eugenismo e o determinismo biológico. A crença na necessidade de branqueamento da população era justificada, entre outras coisas, pela suposta capacidade intelectual do branco e sua relação com o modelo de civilização, comportamento e produtividade. Sobre esta discussão, ver Lira (1999), Santos, C. (2008) e Vianna (1933).

${ }^{56}$ O jornal O Mosquito do dia 25 de novembro de 1887 anunciou que "chegaram no dia 23 do corrente, com destino a fazenda do nosso amigo tenente coronel Antonio Marçal Nogueira de Barros, 28 imigrantes italianos" (IMIGRANTES, 1887, p. 03).

57 Sobre à imigração e os fatores de atração, destino e atividades desenvolvidas pelos italianos no Brasil podem ser encontrados em Trento (1988).
} 
havia também em menor número, espanhóis, austríacos, suecos e dinamarqueses, contribuindo decisivamente para o aumento da população e, consequentemente, no processo de formação cultural e social local.

Como na maioria dos municípios contemplados pelos trens, houve em São José do Rio Pardo uma significativa transformação na relação urbano-rural que impactou diretamente a organização e a concepção da cidade, conforme podemos acompanhar através de Ghirardello (2010) que descreveu o impacto que a ferrovia causava nas cidades do interior paulista:

a ferrovia trazia à cidade um novo ritmo de vida, mais moderno, menos modorrento, controlado pontualmente pelo relógio da estação e inteirado das coisas do mundo pelo telégrafo [...]. Os trilhos além de trazerem melhorias urbanas, atraíam compradores de terras e cafeicultores para a região [...]. A economia do município, certamente, daria um salto demonstrado pelo aumento da arrecadação do imposto ligado à produção do café e, a reboque deste, das próprias atividades urbanas, numa espécie de bola de neve de crescimento (GHIRARDELLO, 2010, p. 158-159).

Esse processo foi possível porque café e ferrovia estabeleceram uma relação de dependência, enquanto o primeiro proporcionava a riqueza através da produção, o segundo a efetivava através do escoamento, importação de equipamentos, materiais e mão de obra. Foi assim que Saes (1981) atribuiu ao binômio caféferrovia o fato de assegurar o processo descrito por Ghirardello (2010). E como destacou Missura (2003), no contexto rio-pardense

a ferrovia representou um grande avanço, pois se percorrermos os primórdios da existência da cidade veremos que desde a sua fundação em 1865 até 1887 data da chegada da ferrovia, o vilarejo não representou nenhum desenvolvimento significativo. Esse cenário muda com a chegada da ferrovia (MISSURA, 2003, p. 64-65).

O Almanaque de 1887, ao destacar o desenvolvimento nas atividades econômicas no ano da inauguração da linha férrea, descreve com especial atenção os 65 proprietários de fazendas que tinham como atividade principal o café e que viam na ferrovia a expectativa de melhora dos rendimentos econômicos, tendo em vista a exportação mais rápida do produto, aliado ainda ao fato do Brasil ter se integrado ao comércio internacional. Já o Almanach da Província de São Paulo (1888) afirma que São José do Rio Pardo foi

[...] assentada à margem esquerda do Rio Pardo e cercada por terrenos ubérrimos de café, promettendo a sua colheita, que orça por 200.000 arrobas, centuplicar em breve praso, attenta a grande quantidade de cafézaes novos e recentes plantações (ALMANACH..., 1888, p. 657).

Era nessa sagacidade que os jornais da época publicavam matérias exaltando a pujança econômica alcançada, e o que poderiam almejar.

Após 1899, o jornal O Rio Pardo, passou a publicar listagens de Imposto sobre o café, o que nos permitiu conhecer os cafeicultores, suas fazendas e suas produções. Referente ao ano de 1898 (IMPOSTO..., 1899, p. 03), a listagem contou com 103 cafeicultores, 38 a mais se comparado com o ano de 1887, o que pode

\footnotetext{
${ }^{58}$ Visando identificar a origem dos imigrantes estrangeiros que residiam em São José do Rio Pardo, Del Guerra (2000) realizou estudos em anúncios de jornais, registros da delegacia de polícia, certidões de nascimento, casamento e óbito da Igreja Matriz desta cidade.
} 
indicar o avanço da produção cafeeira. Os dados publicados pelos Relatórios da Companhia Mogyana de Estradas de Ferro e Navegação $(1901,1902)$ e a sistematização feita por Pinto, A. (1903, p. 248-249) sobre a quantidade de sacas de café despachadas por estação do Ramal rio-pardense nos anos de 1900 e 1901 nos permitiram a elaboração da Tabela 1.

Tabela 1: Valores em sacas de café despachado por estação nos anos de 1900 e 1901.

\begin{tabular}{l|c|c}
\hline \multicolumn{3}{c}{ CAFÉ DESPACHADO POR ESTAÇÃo } \\
\hline \multicolumn{2}{c}{ Companhia Mogyana de Estradas de Ferro } \\
\hline Villa Costina & 1900 & 1901 \\
\hline S. José do Rio Pardo (Central) & 32.683 & 50.481 \\
\hline Engenheiro Gomide & 122.506 & 187.700 \\
\hline Ribeirão Preto & 33.319 & 42.283 \\
\hline Cravinho & 268.241 & 389.321 \\
\hline Espírito Santo do Pinhal & 193.380 & 207.062 \\
\hline Mococa & 82.835 & 126.220 \\
\hline Itoby & 15.839 & 112.996 \\
\hline
\end{tabular}

Fonte dos dados: Relatórios da Companhia Mogyana de Estradas de Ferro e Navegação $(1901,1902)$ e Pinto, A. (1903).

Levando em consideração os números apresentados, e somando os totais das estações de Villa Costina (1889), Engenheiro Gomide (1889) e Central (1887), constatamos no ano de 1901 a quantidade de 280.464 sacas de café, o que demonstra a posição de destaque desta cidade no cenário da produção cafeeira do interior paulista. Seguramente, o crescimento da produção, a oportunidade de valorizar as terras e aumentar o poder dos cafeicultores foram as causas da instalação de outras estações ao longo do ramal. Desse modo, a partir do complexo formado pela Central (1887), foram erguidos outros edifícios: Vila Costina (1889); Engenheiro Gomide (1889); Ribeiro do Valle (1890); Dr. José Eugênio (1906); Venerando (1909) e Paula Lima (1914) (Figura 21). 
Figura 21: Estações localizadas no município de São José do Rio Pardo.
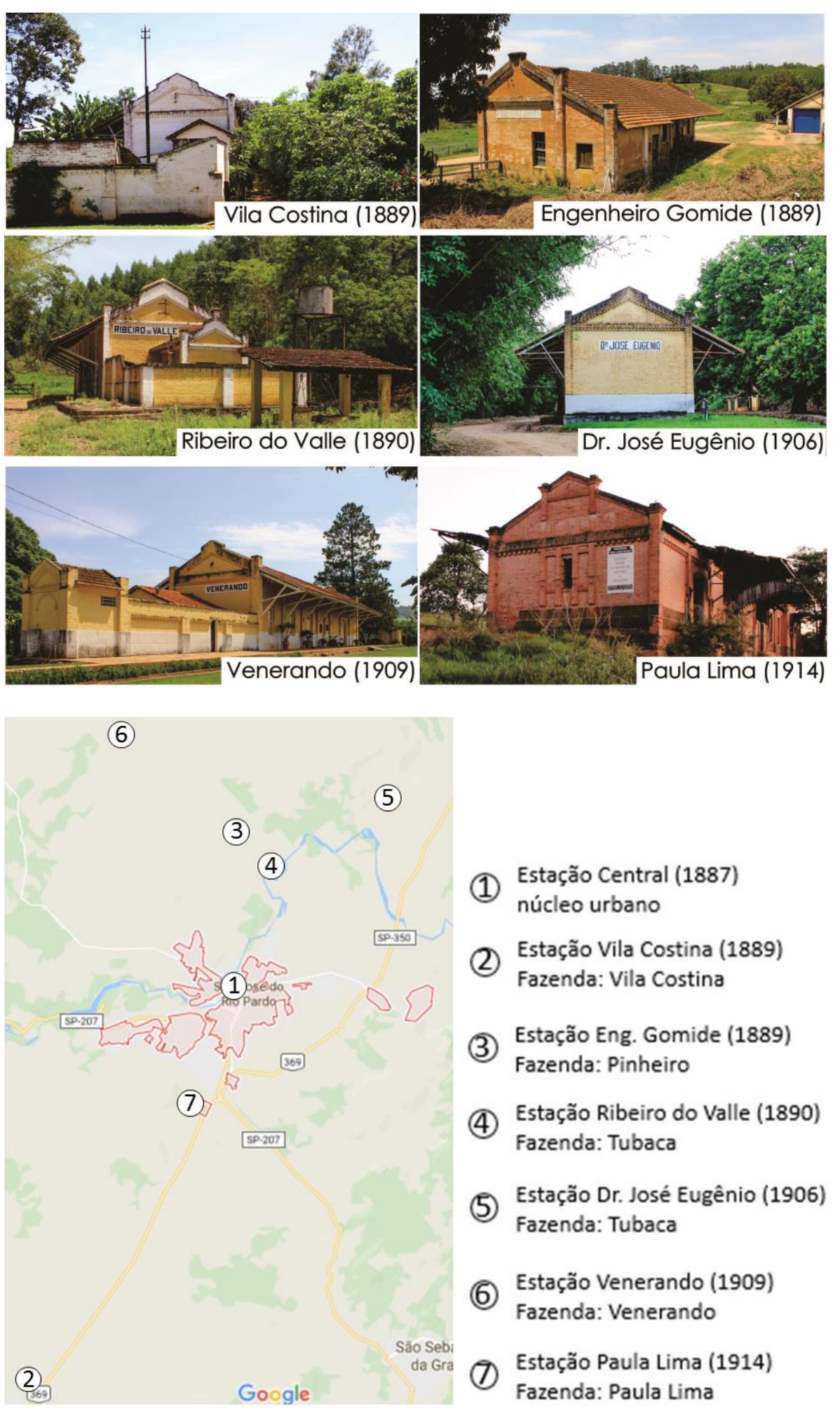

Fonte: Acervo pessoal de autora (2015) e Google Maps (2017).

Ainda assim, a partir da Estatística Geral do Município de São José do Rio Pardo para o ano de 1901, Cassossola sistematizou dados importantes a respeito da produção agrícola que apresentamos na Tabela 2. 
. Segundo Cassassola (2009, p. 56), apesar da diversificação de gêneros, o inspetor agrícola do 3o Distrito agronômico, Júlio Brandão Sobrinho, relatou que "esta produção estava muito aquém do que se podia esperar de um importante município como São José do Rio Pardo, a qual não satisfazia sequer as necessidades da população local".

Tabela 2: Produção agrícola de São José do Rio Pardo em 1901.

\begin{tabular}{c|c|c}
\hline \multicolumn{2}{c}{ PRODUÇÃO AGRÍCOLA DE SÃO JOSÉ DO RIO PARDO EM 1901} \\
\hline Gêneros & \multicolumn{2}{c}{ Quantidade } \\
\hline milho & 5.978 & carros \\
\hline feijão & 15.750 & alqueires \\
\hline arroz & 8.620 & alqueires \\
\hline batata & 1.478 & alqueires \\
\hline batata inglesa & 620 & alqueires \\
\hline cará & 10 & alqueires \\
\hline mandioca & 924 & alqueires \\
\hline fumo & 07 & arrobas \\
\hline amendoim & 50 & alqueires \\
\hline grão-de-bico & 25 & alqueires \\
\hline soja & 20 & alqueires \\
\hline
\end{tabular}

Fonte dos dados: Cassassola (2009, p. 56).

O quadro apresentado pela produção pecuária em 1901 (Tabela 3) era tão modesto quanto a produção agrícola, também considerada pelo inspetor deficiente em quantidade e qualidade, classificando-a como atrasada.

Tabela 3: Produção pecuária de São José do Rio Pardo no ano de 1901.

\begin{tabular}{c|c}
\hline \multicolumn{2}{c}{ PECUÁRIA EM SÃO JOSÉ DO RIO PARDO EM 1901} \\
\hline Rebanho & № de cabeças \\
\hline equinos & 775 \\
\hline asininos e muares & 950 \\
\hline bovinos & 1.252 \\
\hline suínos & 5.108 \\
\hline caprinos & 375 \\
\hline Total & $\mathbf{8 . 4 6 0}$ \\
\hline
\end{tabular}

Fonte dos dados: Cassassola (2009, p. 56). 
Podemos inferir, através das considerações do inspetor agrícola, que a produção agrícola e pecuária riopardense eram insignificantes em termos econômicos frente à preponderância da cafeicultura.

É fato que essa situação não é exclusiva de São José do Rio Pardo, onde a ferrovia além de promover o escoamento da produção de café, facilitou a aquisição de materiais e equipamentos importados, dinamizando a vida urbana, transformando hábitos e costumes, e lançando "as bases para o aparecimento de um 'fazer arquitetônico' (...) com a adoção de uma nova linguagem arquitetônica e mais que isto, na verdade, um novo modo de construir, mercê de novas técnicas e novos programas" (BORTOLUCCI, 1991, p. 01). Como bem sintetizou Reis Filho (2011), as mudanças que ocorreram no espaço urbano precedidas, sobretudo pelas alterações socioeconômicas e tecnológicas alavancadas pela efetivação dos trilhos, alterou os modos de habitar e construir, isso porque as ferrovias traziam

\begin{abstract}
sobre os seus trilhos, novos recursos de construção, mas sobretudo uma nova maneira de construir. De fato, os edifícios das estações de estrada de ferro, fossem importados ou construídos no local, correspondiam sempre a novos modelos e apresentavam um acabamento mais perfeito, que dependia do emprego de oficiais mecânicos com preparo sistemático. Novas soluções arquitetônicas e construtivas eram assim difundidas pelo interior, influindo sob vários aspectos na arquitetura. (REIS FILHO, 2011, p. 156).
\end{abstract}

Há ainda outras questões que levantamos que é a importância da ferrovia como transporte eficiente e rápido, mas também como instrumento de poder. De modo objetivo, Garcia (2008), ao tratar de Jaboticabal, esclareceu que a ferrovia foi produto e instrumento que alimentou os "discursos ansiosos pelo poder" na medida em que articulou relações e se assentou no universo material, para então se cristalizar no espaço, e "em seguida dinamizar novamente o processo de luta pelo poder" (GARCIA, 2008, p. 84). Assim como em Jaboticabal, os trilhos do trem adentraram em São José do Rio Pardo trazendo os principais elementos do discurso republicano - progresso, ordem e modernidade.

Sem deixar de lado a crítica historicista, analisamos os fatos carregados dos ideais acima citados que ocasionaram e definiram, em um determinado momento, o espaço construído, ou melhor, a cidade e sua arquitetura.

Nessa conjuntura, questionamentos nos vêm à tona:

Como ocorreu a estruturação e desenvolvimento do espaço urbano?

Como a cidade processou e articulou a produção do espaço em um momento marcado pela busca da modernização através de intervenções que não se restringiram apenas ao espaço público, mas também ao privado?

Com alguns parâmetros metodológicos estabelecidos, como quais os tipos de serviço e infraestrutura implantados; qual a arquitetura produzida; e quais os melhoramentos em construções e equipamentos urbanos, vamos procurar responder essas perguntas nos próximos itens. 


\subsection{Estruturação e desenvolvimento do espaço urbano}

Ainda que marcada por uma incipiente formação citadina, as transformações espaciais e sociais representaram uma ruptura, onde o núcleo urbano inicial - correspondente ao Centro Histórico - foi o ponto focal dessa transição que assegurou a configuração e a estruturação até os dias de hoje, como veremos ao longo desta dissertação. É importante ressaltar que a São José do Rio Pardo de 1887 era formada por quatro largos: da Matriz (atual Praça XV de Novembro), do Rosário (Praça Barão do Rio Branco), Mercado (Praça Prudente de Moraes), e da Estação (Praça Tiradentes); as ruas eram 12: Direita (posteriormente denominada de Avenida Rangel Pestana e atual Rua José Andreoli), das Flores (Avenida Silva Jardim e depois Rua Silva Jardim), da Floresta (Avenida Campos Salles e atual Rua Campos Salles), da Conceição (Avenida Francisco Glicério e atual Rua Francisco Glicério), do Carmo (antiga Rua dos Calabreses, depois Avenida Américo de Campos, Rua João Pessoa e atual Rua Francisquinho Dias), da Esperança (Rua Beneficência Italiana e atual Rua Treze de Maio), da Boa Vista (Avenida Marechal Deodoro e atual Rua Marechal Deodoro), do Comércio (Avenida Benjamin Constant e atual Rua Benjamin Constant), do Ipiranga (Rua Ananias Barbosa), da Imperatriz (Rua Marechal Floriano), da Cadeia (Avenida Saldanha Marinho e atual Rua João Gabriel Ribeiro) e a da Estação (Avenida Ruy Barbosa, hoje Rua Ruy Barbosa) (Figura 22); e o comércio e os serviços eram constituídos basicamente por duas farmácias; 32 armazéns de secos e molhados; 11 lojas de armarinhos, ferragens e louças; três restaurantes; um hotel; uma padaria; uma fábrica de cerveja; nove olarias ${ }^{59}$; uma oficina de carroças e troles; dois jornais de circulação local; quatro marceneiros; três sapateiros; um alfaiate; três ferreiros; um seleiro; dois barbeiros; um mestre de obras; cinco pedreiros; dois pintores; três médicos e dois dentistas (ALMANAQUE..., $1897^{60}$ e IMPOSTOS, 1887).

As negociações do café ganharam espaço no meio urbano. Entre 1886 e 1890 a população ${ }^{61}$ mais que dobrou, saltando de 4.255 (BASSANEZI, 1999) para 9.207 habitantes (SYNOPSE DO RECENSEAMENTO, 1898, p. 128), concorrendo para que, ao longo dos últimos anos do século XIX e os primeiros do século XX, fossem implementadas uma série de melhoramentos urbanos em obras de infraestrutura, serviços e construções necessários para um funcionamento satisfatório da cidade.

A partir desse momento, o núcleo urbano representaria o desenvolvimento material através de símbolos que distinguiria os grupos sociais, principalmente a elite cafeeira que também elegeu a cidade para aplicar e investir o seu capital econômico. Como bem observou Martins, A. (1994, p. 185), o espaço urbano apareceu como "solução dupla: instrumento de aplicação do capital [através de obras de infraestrutura] de uma oligarquia enriquecida com o café e local de exercício da civilidade [e ação política] que tal grupo pretendia".

\footnotetext{
${ }^{59}$ Conforme averiguado nos registros de cobrança e pagamento de impostos de 1887, os proprietários de olarias eram Francisco Ignácio de Arruda, Celestino Carneiro, José Constancio, José Manoel Espanhol, Luis Rici, José Tranquilini, Germano Italiano, Joaquim Feliciano Lasbino e José Cândido. Este levantamento contribui para complementar o estudo realizado anteriormente por Trevisan (1987) que anotou apenas cinco olarias, entre as quais estão a de Domingos Vicente e Agostine Rich que não constam no livro de registro de cobrança e pagamento de impostos de 1887

${ }^{60}$ Almanaque republicado por Amélia Franzolin Trevisan no jornal Gazeta do Rio Pardo em 25 de dezembro de 1987.

${ }^{61}$ Segundo a sistematização dos dados demográficos de São José do Rio Pardo realizado por BASSANEZI (1999), dos 9207 habitantes, 7.422 eram brasileiros e 1785 eram estrangeiros, desses 1026 eram homens e 759 mulheres.
} 
Figura 22: Formação do núcleo urbano em 1887 após a implantação da linha férrea.

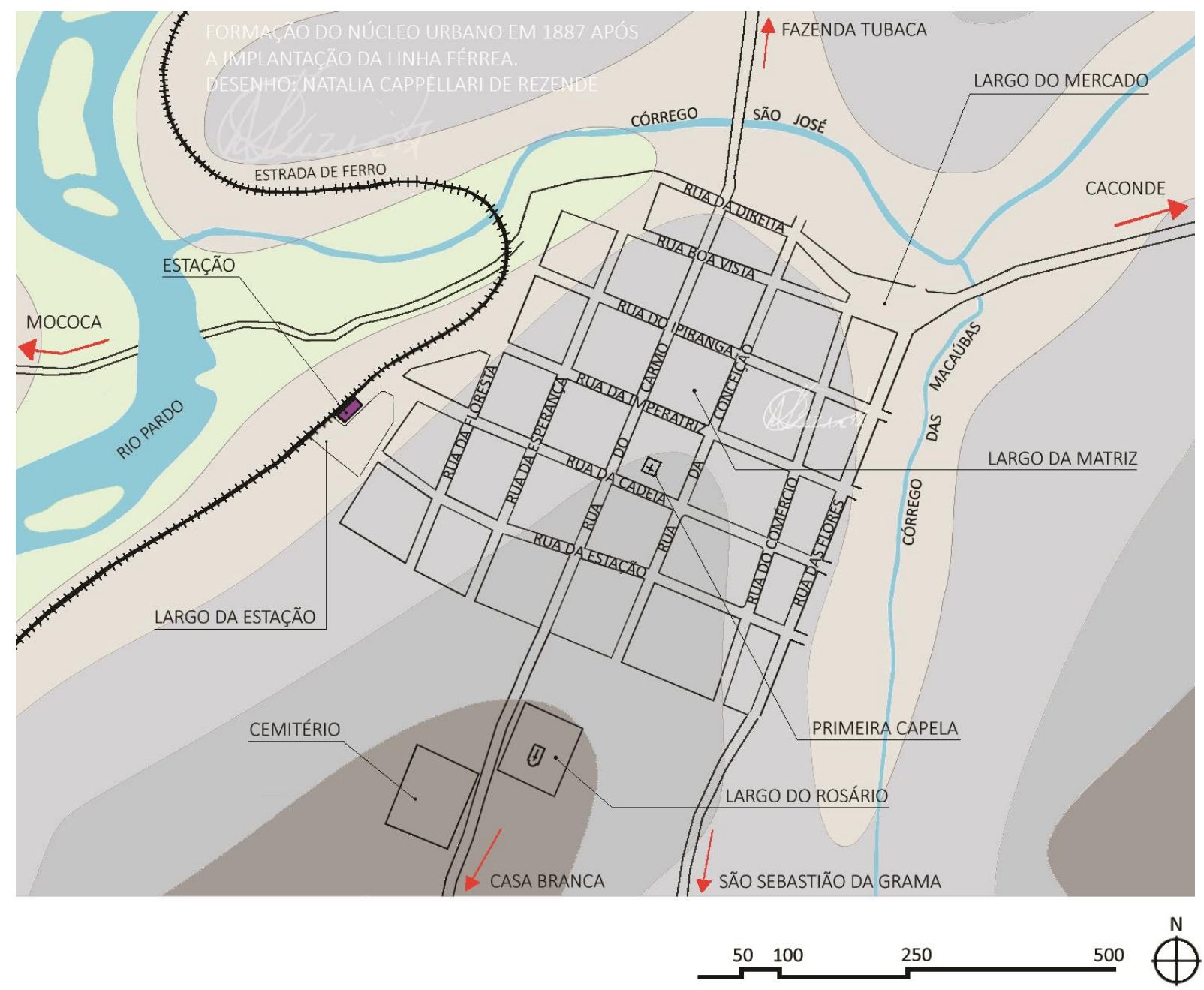

Desenho: Natalia Cappellari de Rezende (2016) com base em dados históricos e cartografia disponibilizada pela Secretaria de Obras de São José do Rio Pardo.

Outra questão importante há de ser considerada no processo de estruturação urbana: o adensamento populacional que aproximou a elite da classe miserável, recorrentemente associada à potencialidade de doenças, vícios, ociosidade e criminalidade. Chalhoub (1996) em seu livro "Cidade Febril" clarificou a associação feita entre a classe pobre e a probabilidade de contágio. Os miseráveis tornaram-se um perigo social que "aparecia no imaginário político brasileiro de fins do século XIX através da metáfora da doença contagiosa" (CHALHOUB, 1996, p. 29). Nesse contexto, havia a existência do temor pelas epidemias que grassavam as cidades causando mortes e afugentando as pessoas o que abalava o desenvolvimento urbano. Em 1893, um dos primeiros inquéritos elaborados na cidade de São Paulo apontou que as classes pobres, a casa e a habitação operária eram "consideradas o 'ponto vulnerável do sistema de defesa da higiene urbana'", "além de terrenos férteis para a propagação de vícios de todos os tipos" (CHALHOUB, 1996, p. 29). Segundo Ribeiro, M. (1993, p. 132), a posição defendida era a de que "nada valia a melhoria do abastecimento de água, do serviço de esgoto, da drenagem do solo, da retificação de rios, da limpeza das 
ruas e quintais, se a unidade urbana - a habitação, não fosse reformada” ${ }^{62}$. Ou seja, havia uma coalisão de constatações que integralizou uma série de iniciativas que foram consideradas representativas do processo de ampliação das condições de salubridade, o que incluía o afastamento da massa populacional pobre, a reforma e suas residências e também de modernização e apelo ao conforto e à imagem da prosperidade, dada a nova racionalidade burguesa ${ }^{63}$.

No que tange a saúde pública, as atas da Câmara apontaram, por inúmeras vezes, preocupações em conter possíveis focos epidêmicos que inevitavelmente atingiriam a cidade como foi o caso da epidemia de varíola que chegou a São José do Rio Pardo em 1889. Conforme nos mostra Ribeiro, M. (1993) ao tratar da saúde pública paulista da primeira república, a mudança de atitude em relação à condição de vida da população veio com o avanço das epidemias na direção das cidades do Oeste paulista. O governo temendo a ameaça à "continuidade da expansão cafeeira e da própria política de imigração em massa", tratou de formular uma política de saúde pública com a organização do Serviço Sanitário como forma também de reafirmar seu compromisso com a transição do regime de trabalho (RIBEIRO, M., 1993, p. 26). Desse modo e contra o quadro epidêmico que assolava outras cidades como Campinas ${ }^{64}$, as autoridades rio-pardenses promoveram ações incisivas que tiveram impacto direto no ordenamento urbano e social entre o fim do século XIX e início do XX, período que coroou um novo regime político ${ }^{65}$ com a instauração do republicanismo ${ }^{66}(1889)$.

O discurso progressista de legitimação de poder que foi adotado pelos republicanos reverberou na cidade através da ideia de progresso como desenvolvimento material e social, melhoramentos urbanos em obras de infraestrutura e embelezamento. E todo esse processo permeou outro, a Abolição (1888), que trouxe a liberdade, mas não garantiu o acesso à cidadania dada a ausência de ações do Estado que garantisse e legitimasse a inserção do negro ${ }^{67}$ na sociedade, em compensação a vultosa entrada de imigrantes estrangeiros "alterando os quadros hierárquicos e de valores da sociedade, na medida mesma em que se consolidavam as práticas do trabalho assalariado e da constituição de um mercado interno e dinâmico"

\footnotetext{
62 Relatório da Commissão de Exame e Inspecção das Habitações Operárias e Cortiços no Distrito de Santa Ephigenia, 1893.

${ }^{63}$ Valemo-nos do que Lapa (1996, p. 19) compreende como racionalidade burguesa, sendo aquela "que se entende pelo econômico, pelo social, pelo político e pelo cultural, atingindo as mentalidades, os costumes e a criação estética", através da normatização do uso do espaço, da vida urbana, das "normas de higiene, moral, mobilidade, desodorização, sonoridade, atividade profissional, comércio, lazer, etc." que atingiu a todos passando a fazer parte do processo de modernização da cidade (LAPA, 1996, p. 27).

${ }^{64}$ A febre amarela abateu Campinas, cidade distante a $170 \mathrm{~km}$ de São José do Rio Pardo, em 1889, desorganizando a vida urbana e rural pelo alto índice de mortalidade, pelo êxodo da população e decréscimo do fluxo migratório, comprometendo a atividade cafee ira que era a base econômica da cidade. Sobre a salubridade urbana, práticas sanitaristas e epidemias em Campinas, ver Lapa (1996), Ferre ira (2017), Salgado (1998) e Ribeiro, M. (1993).

65 Segundo Sevcenko (1998), a fundação do Partido Republicano entrou em cena, formado por uma "nova elite de jovens intelectuais, artistas, políticos e militares, a chamada 'geração 70', comprometida com uma plataforma de modernização e atualização das es truturas "ossidificadas" do Império baseando-se nas diretrizes científicas e técnicas emanadas da Europa e dos Estados Unidos. As bases de inspiração dessas novas elites eram as correntes cientificistas, o darwinismo social do inglês Spencer, o monismo alemão e o positivismo francês de Augusto Comte" (SEVCENKO, 1998, p. 14).

${ }^{66}$ No dia 11 de agosto de 1889, antecipando em três meses o restante do Brasil, os rio-pardenses romperam os laços com a Monarquia e proclamaram a República. Conforme consta em um artigo da Revista do Instituto Histórico e Geográfico de São Paulo (1946, n. ${ }^{\circ}$ XLVI), os jornais: Oéste de São Paulo (1889), Casa Branca (1889), e Tiradentes (1889) de São José do Rio Pardo relataram que o conflito se acirrou durante o assentamento da pedra fundamental da Società di Mutuo Soccorso 20 Settembre (24 de junho de 1889), quando os imigrantes italianos desfilaram pelas principais ruas da Vila cantando a proibida Marselhesa, com o apoio de parcela dos fazendeiros. No dia 11 de agosto de 1889, após alguns confrontos entre monarquistas e republicanos, proclamou-se a República na Vila de São José do Rio Pardo. Para mais informações sobre como este movimento se deflagrou e qual era a base econômica, política e social que deu sustentação ao conflito, ver Pinto, L. (2014).

${ }^{67}$ Há uma extensa bibliografia sobre como ocorreu os processos de exclusão, os percalços, as lutas e as estratégias de sobrevivência no pós-abolição, mas particularmente no contexto de São Carlos-SP entre os anos de 1880 a 1910, ver o trabalho realizado por Joana D’Arc de Oliveira (2018).
} 
(SEVCENKO, 1998, p. 16). No caso rio-pardense, entre os anos de 1850 e 1855, havia 629 pessoas escravizadas dos quais 376 eram homens e 253 mulheres, o que representava 30,90\% do total da população (SENHORES..., 1988, p. 07). Certamente esse número aumentou com o crescimento da produção cafeeira que tinha no trabalho escravo a base da sua mão de obra. Infelizmente não restaram documentos oficiais de referência sobre o tema ${ }^{68}$, mas é certo que após a abolição um número significativo desse contingente tenha encontrado na cidade o seu lugar de moradia, provavelmente em condições precárias e sem recursos de infraestruturas, como ocorreu em outras cidades, a exemplo de São Carlos, constatado por Oliveira, J. (2018) e Costa, N. (2015), e em São Paulo por Santos, C. (2008). Nestes casos, os autores evidenciaram a desqualificação do preto pobre no espaço urbano, considerado pelas autoridades um perigo à ordem pública, à segurança e a moralidade ${ }^{69}$.

Como produto e consequência de todo esse contexto, a saúde se tornou um dos pontos centrais das discussões e ações intervencionistas do Estado "através da utilização da engenharia sanitária e da polícia sanitária como instrumentos privilegiados para as intervenções sobre a cidade" (TELAROLLI JUNIOR, 1996, p. 93). Para Chalhoub (1996) essa política intervencionista resultou na configuração dos pressupostos da Higiene como ideologia, como um conjunto de princípios que se destinava

[...] a conduzir o país ao "verdadeiro", à "civilização" [...] Esses princípios gerais se traduzem em técnicas específicas, e somente a submissão da política à técnica poderia colocar o Brasil no "caminho da civilização". Em suma, tornava-se possível imaginar que haveria uma forma "científica" - isto é, "neutra", supostamente acima dos interesses particulares e dos conflitos sociais em geral [...] (CHALHOUB, 1996, p. 35).

Como afirma Salgado (2003), a higiene foi o ponto central de uma ideologia de transformações urbanas que coloou em prática procedimentos que foram resultantes da influência de teorias médico-sanitaristas utilizadas na Europa, e de tratados elaborados e divulgados no Brasil. Neste caso, a autora destacou o de Vicq $d^{\prime}$ Azir $^{70}$ que abordava os princípios da teoria miasmática ${ }^{71}$ que induziu o movimento higienista brasileiro. Também conhecida como infecciosa, esta teoria creditava às más condições sanitárias as causas das epidemias sendo necessário proceder a desodorização, melhoria no saneamento e desinfecções dos espaços públicos e privados. Condenava a sujeira, o acúmulo de lixo, as águas servidas e estagnadas, a putrefação da matéria orgânica, a falta de circulação do ar, os ambientes quentes e úmidos, e também as

\footnotetext{
${ }^{68}$ Em Memórias do cativeiro: família, trabalho e cidadania no pós-abolição as autoras Ana Rios e Hebe Mattos (2005) mostraram que a oralidade constitui uma das principais fontes de transmissão da cultura e história dos pretos.

${ }^{69}$ No contexto histórico brasileiro a associação entre pobreza e periculosidade social colocou os pretos como elementos de suspeição generalizada. A alforria do cativeiro não significou a sua emancipação quando a maior preocupação do governo era a repressão da ociosidade, a organização do trabalho e a manutenção da ordem pública, daí a necessidade de buscar na repressão a coerção antes realizada pelo senhor de escravo. Para saber mais sobre esse assunto, ver Chalhoub (1996), Lira (1999), Santos, C. (2008) e Oliveira, J. (2018).

70 Segundo Vicq d’Azir, na teoria miasmática "a fermentação era um movimento próprio às substâncias vegetais e animais, nas quais a experiência havia demonstrado que estas degenerariam cedo através da putrefação se uma força orgânica, cuja natureza era desconhecida, não interrompesse os efeitos dela. À medida que a fermentação avançava, o ar elementar se espalharia, sua livre comunicação com o ar da atmosfera lhe transmitiria todas as suas propriedades (...). O ar assim carregado de emanações pútridas, se tornaria necessariamente mortal (...). Se o ar infectado ficasse parado e não se renovasse jamais e, principalmente, se ele fosse respirado por muito tempo, conseqüências danosas poderiam ser esperadas. (...) Estaria aqui a fundamentação para uma intervenção radical na cidade" (D`AZIR apud SALGADO, 2000, p. 02). Ver mais sobre o assunto em Corbin (1987), Beguin (1991), Rosen (1994), Correia (2004) e Ferreira (2017).

71 "Para a teoria miasmática - que dominava o pensamento médico de então - o ar e a água eram os principais veículos transmissores de doenças, por transportarem emanações fétidas e pútridas. Apontava-se a origem das febres epidêmicas na matéria animal e vegetal em putrefação e nas águas estagnadas". (CORREIA, 2004, p. 20).
} 
precárias habitações, os porões úmidos, os cômodos pequenos onde as pessoas viviam amontoadas junto aos alimentos e excrementos propiciando a criação de mau cheiro, fonte dos miasmas que poderiam destruir uma cidade (CORREIA, 2004).

Havia também a crença na teoria contagiosa ${ }^{72}$ que muito marcou o debate neste país. Segundo os seus princípios, a epidemia se propagava através do contágio, e como medida para evitar a proliferação recomendava a quarentena e o isolamento, quando possível distante das áreas urbanas (TELAROLLI JUNIOR, 1996). Além dessas teorias, Beguin (1991) nos mostrou que os estudos desenvolvidos na Inglaterra em meados do século XIX atestaram estatisticamente a associação entre as enfermidades como um fenômeno social $^{73}$ ligado ao caráter vicioso de ambientes físicos insalubres podendo ser resolvidos através da técnica e da engenharia.

Como na administração estadual (TELAROLLI JUNIOR, 1996), a rio-pardense compartilhou de ambas as teorias, empregando para isso medidas tanto contra o contágio quanto para prevenir a transmissão. O controle do "fazer urbano" no tocante às edificações, ao alinhamento, nivelamento e calçamento de ruas e praças, salubridade, higiene e segurança pública se deu através das normas dos Códigos de Posturas ${ }^{74}$ vigentes na época. Este representava, antes de tudo, um modelo de conduta e controle do poder central da Província e da Câmara Municipal, que tinha como responsabilidade a constituição, guarda e fiscalização do patrimônio público em um momento de intensas transformações.

O primeiro Código de Posturas da Villa de São José do Rio Pardo foi publicado pela Assembleia Legislativa Provincial sob a Resolução n. ${ }^{\circ} 122$ em maio de 1887, um ano após a conquista da autonomia política (maio de 1886), e poucos meses antes da chegada do trem (agosto de 1887). Com seis títulos e 21 capítulos, o código de Posturas, seguindo os demais códigos publicados nessa época, atendia às questões acima colocadas, e que mais tarde foram, segundo Lemos, C. (1999), revistas e ratificadas pelo Código Sanitário do Estado em 1894, e visava regras a bem da higiene pública e do desenvolvimento econômico e social almejado pela República. Aliado ao discurso e ao projeto de modernização, este último Código legitimou a intervenção do Estado na resolução das diretrizes edilícias almejadas por ele próprio. Diante disso, a cidade, seus espaços e moradores tornaram-se objetos de esquadrinhamento. A atuação pública se intensificou

\footnotetext{
72 Segundo esta teoria a epidemia se propagava através do contágio, e como medida para evitar a proliferação, recomendava a quarenta e o isolamento, quando possível distante das áreas urbanas. Para saber mais sobre o assunto, ver Corbin (1987) e Rosen (1994).

73 O título da manchete "Hygiene Social" publicada no jornal O Rio Pardo (1907) já presume o assunto tratado. O embasamento é a crítica sobre o ar viciado das habitações urbanas "onde existe a verdadeira vida collectiva (...) um dos principaes objectivos a que mais devem mirar os poderes públicos é justamente o saneamento das populações urbanas, muito principalmente daquellas que já tem sido victimadas por moléstias epidêmicas. Naquellas em que esse saneamento não é feito de accordo com os principios e regras da hy giene, o germen embryonario dessas moléstias sempre fica á espera de uma opportunidade para o seu desenvolvimento evolutivo e propagação" (HYGIENE..., 1907, p. 01). Esta crítica mostra que as pequenas cidades do interior também estavam atentas aos debates realiza dos em grandes centros sobre a salubridade, a higiene e a importância do papel do médico. De acordo com Beguin (1991), que teve a cidade de Londres como objeto de análise, esta preocupação estava fundamentada em um argumento maior, o custo econômico e social do desconforto. Como todo custo tem um preço, segundo o autor (BEGUIN, 1991), o "preço do desconforto" traduzidas em termos econômicos seria a perda do tempo de trabalho e despesas dispendidas para tratar a doença. E em termos sociais, seria a ilegalidade, o desenvolvimento de hábitos e tendências antissociais, a imoralidade, a busca dos prazeres biológicos do corpo fora da casa, em jogos, bares e casas de prostituição o que resultaria na desagregação das famílias. As causas, além da sujeira, era a casa do pobre, pequena desconfortável que propicia a deterioração da saúde e do estado físico de toda a população, e "que, por isso mesmo, elas agem como obstáculo à educação e ao desenvolvimento moral; (...) interrompem o crescimento das capacidades produtivas e diminuem o capital social e moral da comunidade" (BEGUIN, 1991, p. 40). Logo, a base era o pensamento intervencionista de prática preventiva.

${ }^{74}$ Segundo Andrade, F. (1966) e Bortolucci (1991), o Código de Posturas era um conjunto sistemático de leis que se tornou fundam ental ao guiar a formação e manutenção das cidades através de questões variadas e abrangentes que geralmente seguiam esta ordem: 1. quadro físico urbano; 2 domínio edificado; 3 . higiene e salubridade preventivas; 4 . serviços urbanos; 5 . o quadro administrat ivo; e 6 . as finanças municipais.
} 
com medidas efetivas e profiláticas para o saneamento do meio através da execução de infraestrutura urbana, e por meio do controle do espaço público e privado com o propósito de alterar as condições sanitárias e também sociais, conforme algumas restrições do Código:

Art. 48 - É proibido ter-se nos quintaes, áreas, pateos e jardins das casas da villa, depósito de lixos, águas estagnadas ou materias corruptas ou de fácil corrupção, capazes de prejudicar a salubridade pública. $\mathrm{O}$ infractor será multado em $10 \$$ além de se fazer a limpeza à sua custa.

Art. 55 - Todo animal que morrer de peste dentro da villa será por seu dono removido para fora ou enterrado em cóva funda de maneira que não seja fácil a exalação pútrida. Os infractores serão multados em 10 e o serviço feito à sua custa pelo fiscal.

Art. 59 - Todas as pessoas que possuírem terrenos onde passem águas correntes da servidão pública serão obrigados a conservar o leito das águas sempre limpo e livre de estorvos dentro dos limites de seus terrenos. O infractor sera multado em $5 \$$ todas as vezes que deixar de cumprir com o disposto n'este artigo.

Art. 62 - Toda a pessoa, seja qual fôr sua condição, que tiver a seu cargo a educação de outra pessoa de qualquer côr ou condição, será obrigada a mandá-la à casa da pessoa encarregada da vaccina, sob pena de multa de $20 \$$, por pessoa que não for vaccinada, e o dobro na reincidência. (CÓDIGO DE POSTURAS, 1887, p. 11-12-13).

A título de exemplo, na ata de 29 de setembro de 1891, a moradora D. Maria Vitória de Sillos Negrão requereu a Câmara a "relevação de multa que lhe foi imposta por ter seu filho tirado a bandeira preta que foi colocada na porta de sua casa como sinal indicativo da existência da varíola" (ATA..., 29/09/1891, p. 145). Era a disciplina da higiene esquadrinhando a doença, e mais do que isso, as pessoas e as moradias.

E, apesar das teorias microbianas compartilhadas pelo saber médico da época ${ }^{75}$, o temor dos gases pútridos liberados pelos cadáveres e pela matéria em decomposição ${ }^{76}$ colocou o primeiro cemitério, bento em 1868 , localizado ao sul do núcleo urbano em um debate na Câmara Municipal rio-pardense. No dia 09 de março de 1895, foram aprovadas a Resolução n. 8 criando o cargo de médico de higiene, e a Resolução n. 10 que autorizou o Intendente "a proceder a construção de um novo cemitério, municipal, em local que julgar de maior conveniência à salubridade pública" e para esse fim o Intendente deveria nomear uma "comissão de 3 ou 4 médicos para dar parecer sobre as condições hygienicas do local escolhido" (ATA..., 09/03/1895, p. 92). Em acordo com o Código Sanitário de 1894, a área escolhida pelos médicos para a implantação do novo cemitério era afastada do núcleo urbano e em terreno mais elevado e seguro de inundações na "face sudoeste da colina que fica ao norte da cidade na estrada da Tubaca" (ATA..., 03/02/1896), como é possível observar na Figura 23.

Com projeto do "arquiteto Achiles, as obras foram encarregadas ao construtor italiano Felício Maria Calvite" que deveria proceder à execução utilizando areia e cal para o assentamento dos tijolos (ATA..., 06/07/1896). Munido de elementos como frontão de inspiração renascentista, pináculo, arco pleno, pilastra com modenatura e capitel com feição coríntia, o edifício de entrada do Cemitério Municipal demonstra a

\footnotetext{
${ }^{75}$ Referimos às descobertas da ação microbiana por Louis Pasteur no final do século XIX que cientificamente comprovava a ação de microorganismos vivos envolvidos na transmissão de doenças, e dessa forma eliminava o perigo do contágio pelo mau cheiro exalado dos corpos em decomposição (ROSEN, 1994).

76 O jornal O Rio Pardo do dia 26 de maio de 1907, trazia o seguinte: "Está absolutamente reconhecido que o lixo em estado de putrefacção é justamente o que mais produz a insalubridade e viciação do ar. Só a viciação do ar já é bastante para produzir muito gênero de moléstia em uma população" (HYGIENE..., 1907, p. 01).
} 
influência que o classicismo exercia sobre a tradição construtiva possibilitada pelos materiais disponíveis, mão de obra e o saber fazer. Em seu aspecto geral, este edifício (Figura 24) estava ajustado ao ecletismo que estava sendo incorporado aos poucos e se acentuará no início do século XX - período esse que houve uma forte influência do que ocorria na capital que se transformava em uma nova cidade, reconstruída em tijolos e em novo estilo, o ecletismo ${ }^{77}$ (LEMOS, C., 1987; HOMEM, 1996).

Figura 23: O Cemitério Municipal construído ao norte do núcleo urbano rio-pardense em 1896.

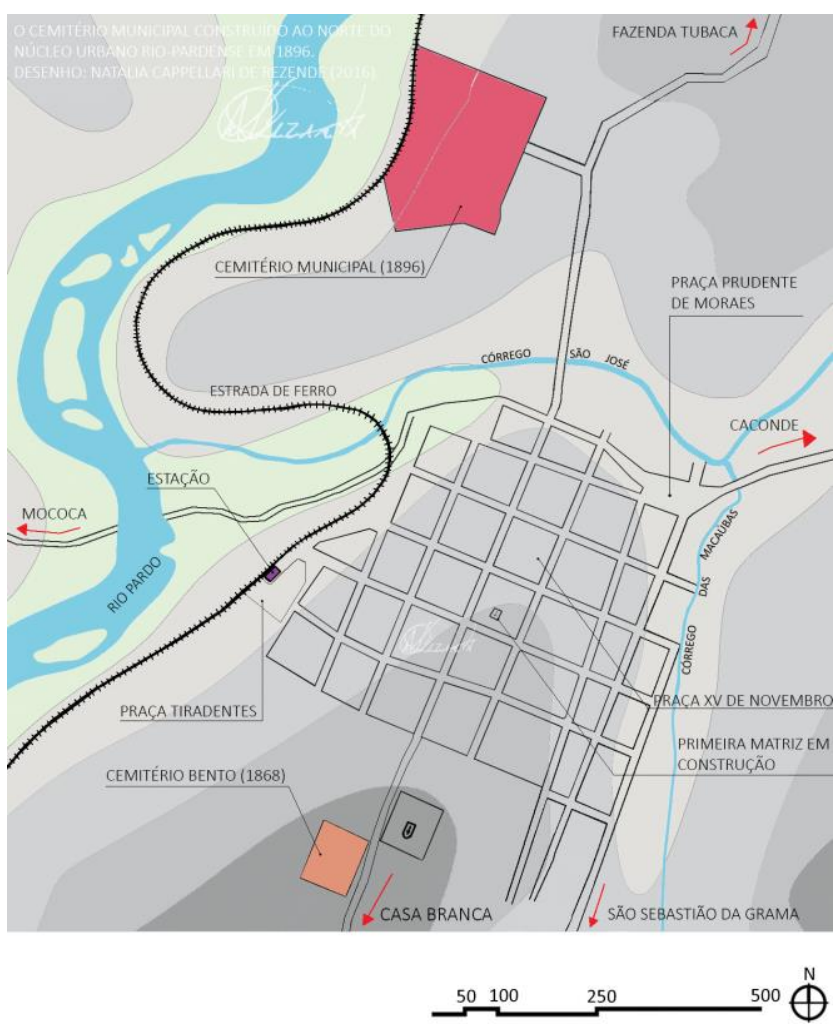

Desenho: Natalia Cappellari de Rezende (2016) com base em dados históricos e cartografia disponibilizada pela Secretaria de Obras de São José do Rio Pardo.
Figura 24: Fachada do Cemitério Municipal de São José do Rio Pardo.

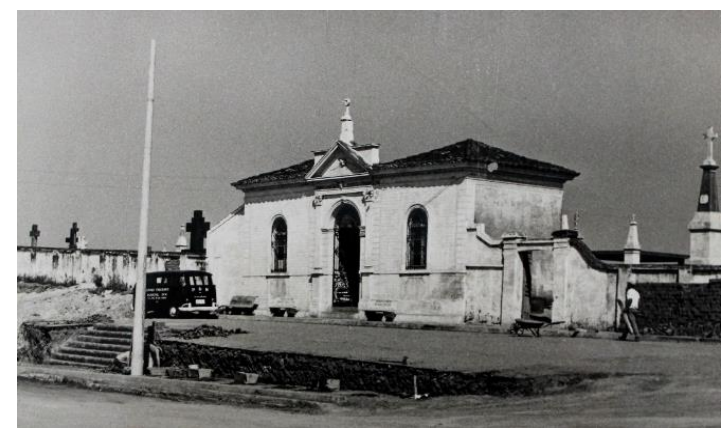

Fonte: Arquivo do Centro da Memória Rio-Pardense Rodolpho José Del Guerra.

Com a conclusão do novo Cemitério Municipal, o próximo passo foi a extinção do antigo com a remoção das ossadas que levou anos, retardando o projeto de Paschoal Artese de transformar aquele lugar em um

\footnotetext{
77 De acordo com Lemos, C. (1987), o ecletismo representava o contexto de prosperidades econômica e cultural proporcionado pela cultura do café. Enquanto na Europa a burguesia identificou no ecletismo sua associação às práticas que "dava primazia ao conforto, amava o progresso (especialmente quando melhorava suas condições de vida), amava as novidades" (PATETTA, 1987, p. 13), no Bra sil este estilo foi adotado no final do primeiro quartel do século XIX como a linguagem da liberdade, da combinação de formas, da tolerância à somatória de diversos elementos de estilos definidos e trazidos através de manuais e pelos imigrantes (LEMOS, C., 1987). Influenciado pelos meios de difusão, pelos padrões de consumo regrados pelos ritmos da moda, novos materiais e novos programas, o ecletismo foi a representação de "[...] uma nova organização social e cultural, que põe fim a toda e qualquer idéia de unidade para apontar para o múltiplo, o diversificado, para privilegiar o instável e o relativo em detrimento do absoluto e do eterno. Sua metodologia fundamental consiste na decupagem, na concepção da arquitetura como linguagem dotada de valores simbólicos e emotivos que deveriam ser transmitidos a todas as camadas da sociedade. (FABRIS, 1993, p. 134)". No entanto, as expressões arquitetônicas não foram compreendidas e praticadas uniformemente nas diversas regiões do Brasil, e por esta razão houve o florescimento de novas e variadas manifestações artísticas (BORTOLUCCI, 1991). Como destacou Fabris (1993), "ao lado do profissional especializado destaca-se a presença de um grupo crescente de autodidatas, que transpõem o debate e a prática da arquitetura para fora do círculo restrito da academia. E também essa ampliação do quadro profissional que explica a multiplicidade de modelos e referências utilizados pelo ecletismo. (FABRIS, 1993, p. 134-135)". Nesse contexto, a região paulista conheceu as manifestações ecléticas a partir de meados do século XIX, quando começou a experimentar o período de riqueza proveniente do café e da mão de obra assalariada. Nessa perspectiva, a implantação da estrada de ferro facilitou o intercâmbio de informações, e as mudanças que ocorreram na capital, não demoraram a chegar ao interior. Por onde os trilhos seguiam, uma série de alterações dava novas feições às cidades, como pode ser observado nas construções realizadas nesse período em São José do Rio Pardo.
} 
jardim, mas não impossibilitou a abertura da Rua Júlio de Mesquita, traçada em 1899, marcando a expansão urbana nesta direção.

A vigilância exercida pelas autoridades municipais também se voltava para o abastecimento de água da Vila. Registros de Estudos e Planos Orçamentários (1887) e um Relatório descritivo dos trabalhos projetados para o abastecimento de água (1888) dão conta da discussão feita na época. Nestes trabalhos realizado pelo exengenheiro da Companhia Ramal Férreo do Rio Pardo, Antonio Candido Rodrigues ${ }^{78}$, chamou a atenção a preocupação dada à quantidade da água fornecida:

Com effeito, o manancial produsindo em 24 horas 345.600 litros e suppondo a população actual da villa de 2.000 habitantes, cada um poderá ser fornecido com a enorme quantidade de 172,80 litros, ou suppondo que os 2.000 habitantes se acomodem em 400 casas, cada uma 864 litros ou 43,2 barris de litros (RODRIGUES, A., 1887, p. 02).

O engenheiro ressaltou a conveniência de realizar exames na sua qualidade por ser esse "um assunto importante de salubridade pública que deve ser cuidadosamente examinado", e assegura que o estudo feito é "suficiente para garantir a potabilidade da água" (RODRIGUES, A., 1887, p. 04). Contudo, a municipalidade não possuía os recursos necessários para a realização deste "importante melhoramento (...) que depois de organizar um plano mais completo de abastecimento" teve que ser refeito para reduzir as despesas (RODRIGUES, A., 1888, p. 02). O novo plano tratou de descrever os materiais utilizados no encanamento, conexões e nos reservatórios, destacando a ênfase dada aos "elegantes chafarizes de ferro fundido e mais duas torneiras colocados nos largos da Matriz [Praça XV de Novembro], Mercado [Praça Prudente de Moraes] e Estação [Praça Tiradentes]". Era dentro desse contexto de melhorias em infraestrutura urbana como medida profilática, que associavam as obras ao embelezamento, à promoção e modernização da cidade. Foi um momento de intensas transformações urbanas, socioculturais, econômicas e políticas que tornavam as ações efetuadas incompatíveis em questão de alguns anos.

Em 16 de abriu de 1899, dez anos após o início da canalização da água, o jornal O Rio Pardo publicou, sob a assinatura de um munícipe com codinome Justus, uma carta exigindo melhoramentos nos serviços de água e esgoto. Ele criticou a omissão do Estado no desenvolvimento desta cidade, que já estava "habituada a progredir sem auxílios do Governo". Deu graças ao "grande número de capitalistas perfeitamente nos casos de organizar uma empresa com o capital necessário para tal fim", desde que fossem garantidos pelo município os juros ao capital investido. Ressaltou que a canalização da água realizada há dez anos não era suficiente para atender o crescimento populacional, sendo necessário e urgente dotar a cidade do abastecimento de água potável e, "como medida complementar, a instalação de uma rede geral de esgotos" (ÁGUA, 1899, p. 01).

\footnotetext{
${ }^{78}$ Além da carreira de engenheiro, Antonio Candido Rodrigues teve uma vida política bastante agitada. No período de 1884 a 1926 foi deputado, senador, secretário e ministro dos governos de São Paulo e da União, e vice-presidente do Estado. Segundo o jornal Gazeta do Rio Pardo (25/12/1965), a construção do Grupo Escolar Cândido Rodrigues deveu aos seus esforços que na época era Secretário da Agricultura e integrante do diretório republicano perante o governo do Estado. Além de possuir laços familiares em São José do Rio Pardo, já que uma das suas filhas se casou com um munícipe (Vicente Dias Júnior). Antonio Candido Rodrigues era proprietário da fazenda Santa Martha, e inclusive chegou a residir por algum tempo nela.
} 
Cedendo às pressões populares, no dia 28 de fevereiro de 1899, a Câmara Municipal autorizou o intende a realizar as despesas necessárias para efetuar os serviços requeridos. Depois de feito os projetos (1900), o engenheiro civil João Timótheo Pereira da Rosa, apontou que somente quatrocentas casas teriam condições de serem abastecidas pelas redes, outras duzentas moradias de proletários não comportavam as despesas do projeto e para isso teriam que fazer uso dos chafarizes públicos. Após várias interrupções na execução da obra por falta de material, recursos econômicos e mão de obra, a nova rede de esgoto e água foi finalizada somente em 1903, como veremos no próximo capítulo, contribuindo acertadamente na alteração das condições sanitárias da cidade e seus edifícios, e o modo de morar e usar o espaço público.

Até a finalização deste serviço e a publicação do novo Código de Posturas de 1903, as reclamações mais recorrentes por parte do poder público e de alguns munícipes incluíam a limpeza e o fechamento de terrenos, demolição das casas e muros em ruína e caiação dos outros, sarjeteamento, abaulamento, capina e limpeza das ruas e calçamento dos passeios. Estes eram os melhoramentos colocados com mais urgência por serem considerados os responsáveis por configurar um quadro de insalubridade propício ao aparecimento de enfermidades. Além disso, havia a recorrente associação da insalubridade e da falta de higiene à feiura, saúde e ordem pública e moral. A limpeza era colocada como "condição necessária a vida do indivíduo, muito mais o é da vida de uma população", que "quer se encare pelo lado do embellesamento da cidade, quer pelo lado hygienico, e é por isso que devemos prestar toda a nossa attenção para esse melhoramento de que tanto carecemos" (MELHORAMENTOS..., 1899, p. 01).

Era o discurso que justificava as intervenções apoiadas em três preceitos: circular, sanear e embelezar. A omissão do poder público frente à situação era alvo constante de críticas que o intimidava a punir de forma mais efetiva, justificando como meio para romper os costumes estabelecidos em prol de todos.

\footnotetext{
É que aqui existe um costume já inveterado, permittido pela camara, ou por negligencia ou por má disposição do seu codigo de posturas, que faculta aos habitantes depositarem na rua, em frente de suas moradias, o lixo das suas casas e até de seus quintaes. Ora, haverá cousa mais feia, mais nojenta, do que deparar o transeunte com um montão de lixo na rua, exhalando um cheiro desagradável? [...] É preciso, pois, é de urgente necessidade, que a câmara tome providencias no sentido de prohibir esse abuso, abolindo esse costume tão contrário ao asseio, aos preceitos hygienicos. (MELHORAMENTOS..., 1899, p. 01).
}

A iluminação pública à base de querosene também era uma das reivindicações dos munícipes que estavam descontentes com o serviço fornecido desde 1889. Uma discussão travada há anos sobre o provimento de energia elétrica veio à tona quando o engenheiro Arthur Pio Deschamps de Montmorency ${ }^{79}$, vencedor da concorrência para a construção de uma ponte metálica ${ }^{80}$ sobre o rio Pardo, iniciou um movimento local visando atrair acionistas para à construção de uma usina hidrelétrica.

O crescimento econômico proporcionado pela produção cafeeira no final do século XIX tornou possível a acumulação e investimento do capital excedente em setores urbanos e na industrialização como foi o caso

\footnotetext{
79 O francês Arthur Pio Deschamps de Montmorency era formado em engenharia civil (1879) pela Universidade de Gand (Bélgica) (KÜHL, 1998).

${ }^{80}$ Ver nota 82 
da iluminação pública que nesse momento passaria por reformulações. O "Syndicato da Luz Electrica de São José do Rio Pardo" foi formado com o apoio de 22 acionistas (Anexo 03) ${ }^{81}$, entre eles cafeicultores, fazendeiros, médicos, políticos, comerciantes e três imigrantes italianos. Com um montante que totalizava 50:000\$000 contos, a iluminação elétrica foi inaugurada em 19 de dezembro de $1897^{82}$, oportunizando para as noites novas formas de lazer. Ao tratar desse tema, Maschietto $(1979$, p. 27) destacou que a "totalidade dos capitais investidos no empreendimento era proveniente do café, direta ou indiretamente. Para todos os investidores a empresa representava uma alternativa de aplicação lucrativa desses capitais".

Assim como a iluminação elétrica, a ponte metálica ${ }^{83}$ inaugurada no mesmo dia também foi um melhoramento tornado possível pelo surto cafeeiro, considerada pelos produtores da margem direita do rio Pardo uma conquista por facultar maior rapidez de escoamento. No entanto, no dia 23 de janeiro um dos seus pilares ruiu cedendo à correnteza do rio (Figura 25). Diante do fato, Euclides da Cunha ${ }^{84}$, então engenheiro fiscal da Superintendência de Obras Públicas do Estado de São Paulo, assumiu a responsabilidade de reconstrução da ponte (Figura 26), reinaugurando-a em maio de 1901 (Figura 27).

Segundo Silva (2004), a nomeação de Euclides para a Superintendência ocorreu em um período em que a cultura cafeeira agiu efetivamente sobre o espaço urbano através de ações pontuais como em São José do Rio Pardo, ou de forma ampliada como na então capital Rio de Janeiro que passou por reformulações significativas conhecidas como Regeneração cujo objetivo era

alinhar o país ao que havia de mais moderno na Europa. Tais mudanças compreendiam desde transformações urbanísticas, a higienização da cidade e a mudança de comportamentos e costumes tidos como retrógrados. (SILVA, 2004, p. 06).

Nesse mesmo período e seguindo pretensões semelhantes, Campinas foi redefinida através da criação do seu sistema de saneamento realizado por Saturnino de Brito que corrigiu "tanto a drenagem urbana quanto a melhoria da captação de água", e ainda criou "avenidas arborizadas dotando esses caminhos de áreas verdes" (DEMINICE, 2016, p. 28-81). Como analisado por Deminice (2016, p. 81), "as reformas efetuadas pelo engenheiro [Saturnino de Brito] também serviriam ao objetivo burguês de transformar o antigo cenário da cidade", imprimindo a ela características da nova forma de poder.

\footnotetext{
${ }^{81}$ Para saber quem foram os associados e os valores que cada um contribuiu, ver anexo 03.

${ }^{82}$ A título de conhecimento e comparação ao ineditismo rio-pardense, "a primeira cidade brasileira a possuir energia elétrica no Brasil foi a cidade de Campos, no Estado do Rio, que instalou uma pequena usina térmica em 1883. A primeira usina hidrelétrica da Améric a do Sul foi construída em 1889, por Bernardo Mascarenhas, no Rio Paraibuna, a qual fornecia energia à sua fábrica de tecidos e à cidade de Juiz de Fora. A energia elétrica só foi explorada, sistematicamente, em São Paulo, a partir de 1899, quando foi organizada em Toronto, a The São Paulo Railway, Light \& Power. [...] Em nossa região, o contrato para iluminação elétrica de São João da Boa Vista é de 1900; em 1905, a Câmara Municipal de Caconde entrou em entendimento com o Cel. Vicente Dias Júnior para dotar aquela cidade de iluminação elétrica; Casa Branca contou com a energia elétrica em 1912; em Mococa os serviços de energia elétrica foram concluídos pelo Capitão Antonio José Dias Lima, por volta de 1905, com a organização da Cia Luz e Força de Mococa. Em São Sebastião da Grama e Espírito Santo do Rio do Peixe (atual Divinolândia) a iluminação elétrica só foi inaugurada em 1913". (MASCHIETTO, 1979, p. 27).

${ }^{83}$ Após o decreto da Superintendência de Obras Públicas autorizando a construção de uma ponte, o engenheiro Heitor Georgotich apresentou o projeto que foi aprovado, e a obra ficou sob a responsabilidade de Arthur Pio Deschamps de Montmorency. A ponte de estrutura metálica importada da Alemanha foi aberta ao trânsito no dia 3 de dezembro de 1897, e em 23 de janeiro de 1898 ela desabou após escavações em um dos pilares.

${ }^{84}$ Euclides Rodrigues Pimenta da Cunha (1866-1909) nasceu em Cantagalo no Rio de Janeiro. Formado pela Escola Superior de Guerra em Engenharia Militar e Ciências Naturais, Euclides se desligou da carreira militar por divergências políticas e passou a atuar como superintendente de obras do Estado de São Paulo e escritor e jornalista do jornal "O Estado de São Paulo". Como jornalista, ele foi enviado como correspondente para cobrir a Guerra de Canudos, e ao regressar foi para a cidade de São José do Rio Pardo-SP administrar a reconstrução de uma ponte metálica sobre o rio Pardo. Foi durante os momentos livres de supervisão desta ponte que Euclides escreveu o livro Os Sertões. Nessa obra, ele retratou o que foi a Guerra de Canudos e a realidade regionalista do nordeste brasileiro. Informações sobre o período em que Euclides da Cunha residiu em São José do Rio Pardo, assim como os trabalhos que foram desenvolvidos por ele podem ser encontradas em Del Guerra (1998), Trevisan (1980) e Maschietto (2002).
} 
Desse modo percebemos que, alinhada ao discurso ordenador e modernizador, a execução da ponte metálica estava imbuída da ideia de desenvolvimento material e organização do espaço como parte do projeto de construção da nação intrínseco aos princípios republicanos defendidos por Euclides da Cunha que considerava as vias materiais o caminho assertivo a ser seguido (SILVA, 2004).

Figura 25: Desabamento da ponte metálica (janeiro de 1898).

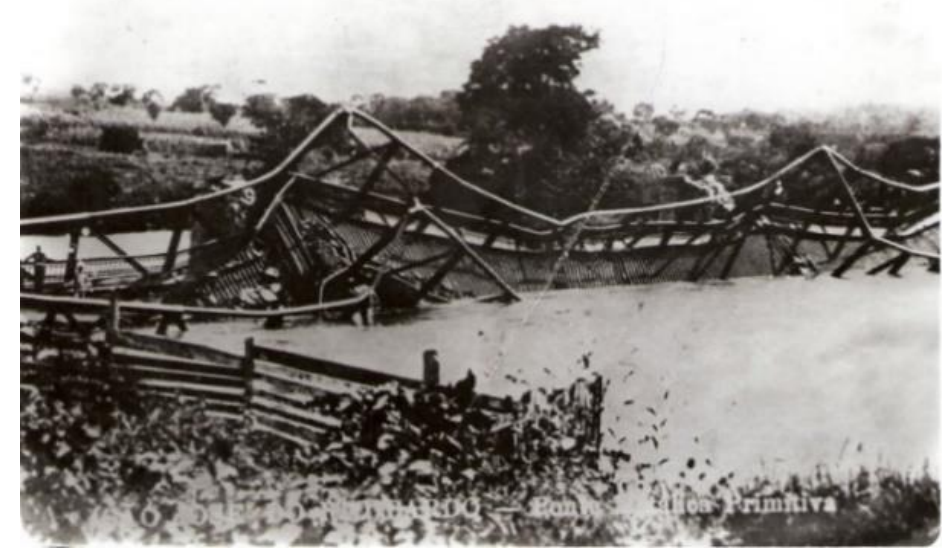

Fonte: Arquivo do Centro da Memória Rio-Pardense Rodolpho José Del Guerra.
Figura 26: Euclides da Cunha supervisionando a reconstrução da ponte metálica (1898-1901).

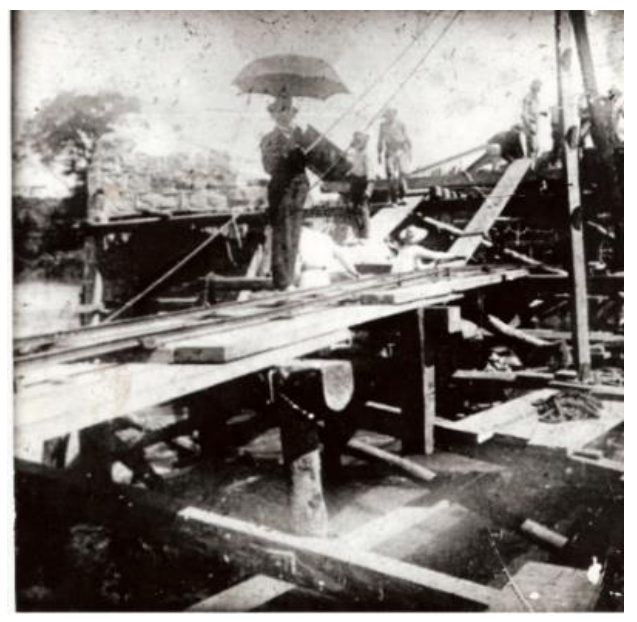

Fonte: Arquivo do Centro da Memória RioPardense Rodolpho José Del Guerra.

Figura 27: Ponte metálica (1901), década de 1910.

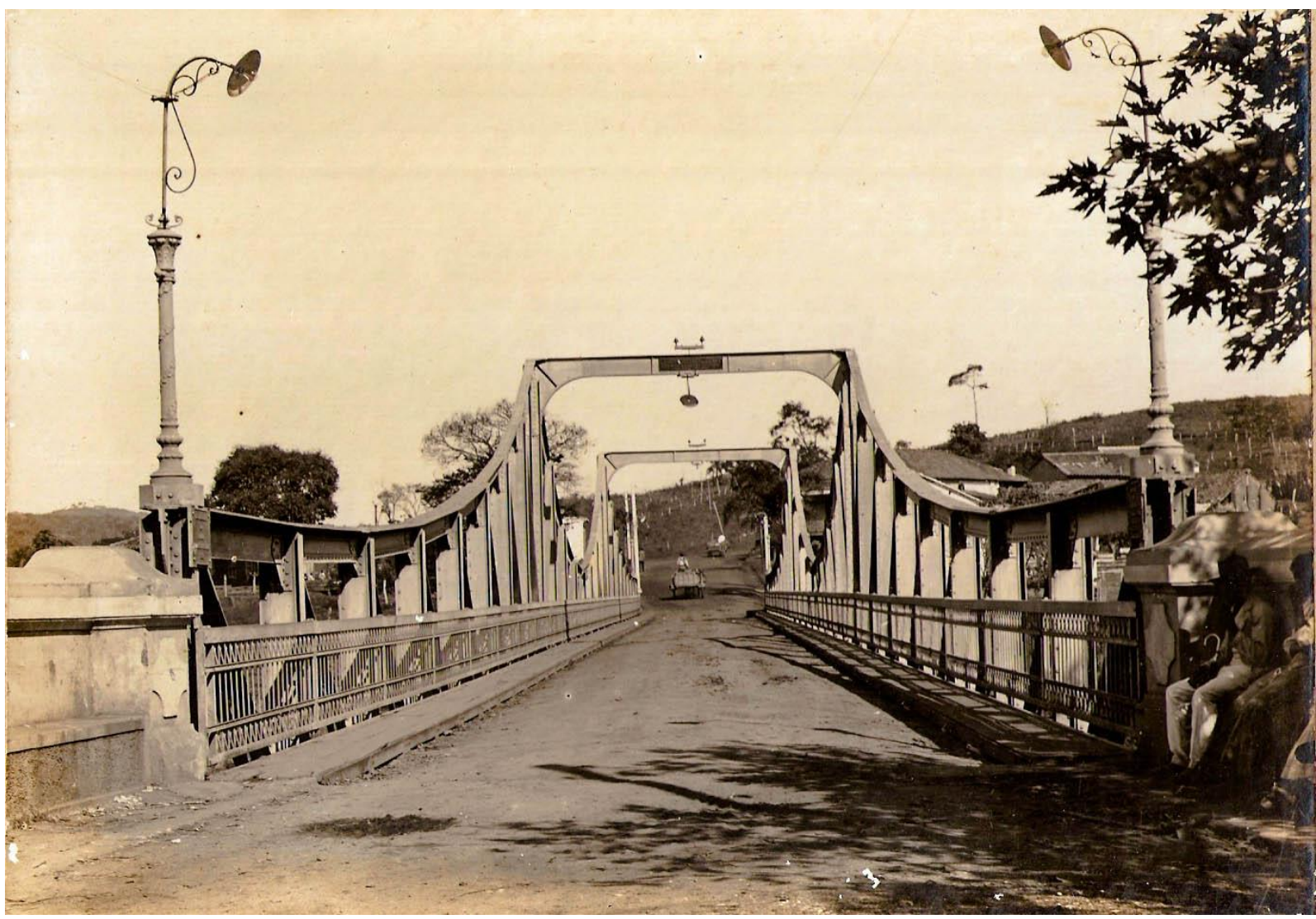

Fonte: Arquivo do Centro da Memória Rio-Pardense Rodolpho José Del Guerra. Fotografia de Innocencio Vilhegas. 
Os ecos destas ações atingiram também a vaidade da igreja católica, a qual haveria de se incluir no processo de construção e reformulação enlaçado pela dinâmica do poder. Foi quando o vigário Joaquim Thomáz Ancassuerd propôs às elites rio-pardenses, formadas por fazendeiros, negociantes, médicos, políticos e representantes de outras classes, a construção de uma nova igreja. Com o apoio da população e da Câmara Municipal, a construção sob a direção do construtor Felício Maria Calvite e projeto do escritório de Ramos de Azevedo foi finalizada em 1898. No lugar da taipa de mão, a igreja acabou por incorporar materiais construtivos industrializados como a alvenaria de tijolo, o que, segundo Reis Filho (2011, p. 159), "implicava em um significativo aumento de precisão" reduzindo os erros de medida para centímetros. O destaque estava nas suas características neogóticas (Figura 28 e Figura 29) com todas as aberturas em arco ogival, tríglifos em goteira, quadrilóbulos e pináculos confirmando a destinação do edifício à definição da tipologia estilística mais recorrente, inclusive internamente, com arcadas ogivais e possibilitando decorações nos pontos de encontro das nervuras. Após as naves laterais serem aumentadas em reforma posterior (Figura 30 e Figura 31), o telhado passou a ser escondido por platibanda com arcadas cegas arrematadas por pináculos que partiam de pilastras. Além de Ramos de Azevedo e Felício Calvite, outros profissionais deram suas contribuições, como Marino de Favero que esculpiu o altar (Figura 32); o púlpito, confessionário, balaústres e colunas foram entalhados por Salvador Artese; os afrescos foram feitos pelos artistas Bruno Scarcelli, Domingos De Rocco, Giacomo Mommo, e Eduardo Giudice; e o coro foi obra de Paschoal e Salvador Artese (DEL GUERRA, 2001). Refletindo o desenvolvimento material empregado e as características estilísticas, a construção da nova igreja representava a adesão ao movimento local de transformação da paisagem e de esforço de modernização.

Figura 28: Fachada frontal da primeira Igreja Matriz (1898).

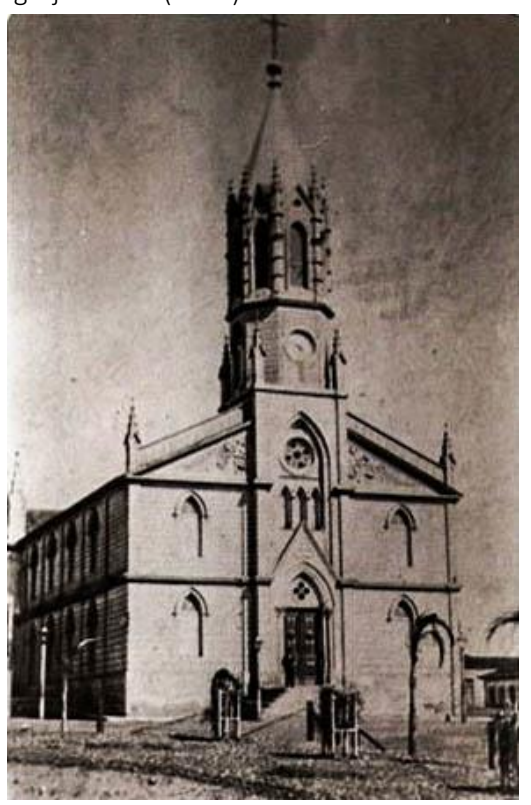

Fonte: Arquivo do Centro da Memória RioPardense Rodolpho José Del Guerra.
Figura 29: Fachada lateral esquerda da primeira Igreja Matriz (1898), década de 1910.

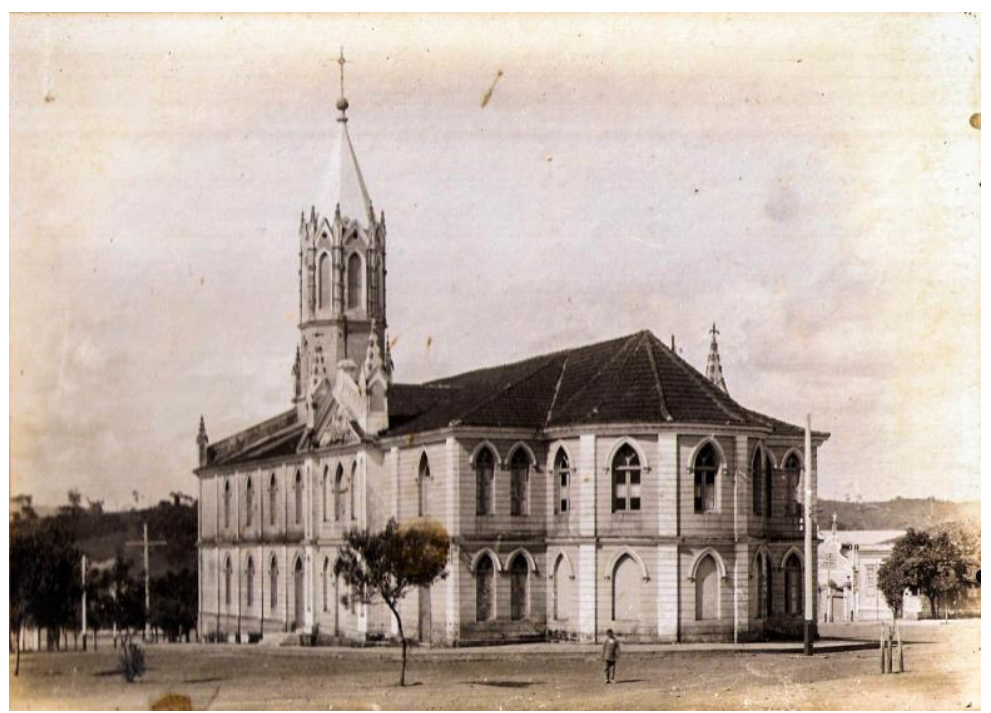

Fonte: Arquivo do Centro da Memória Rio-Pardense Rodolpho José Del Guerra. Fotografia de Innocencio Vilhegas. 
Figura 30: Fachada lateral direita da Igreja Matriz com as naves laterais aumentadas (década de 1930).

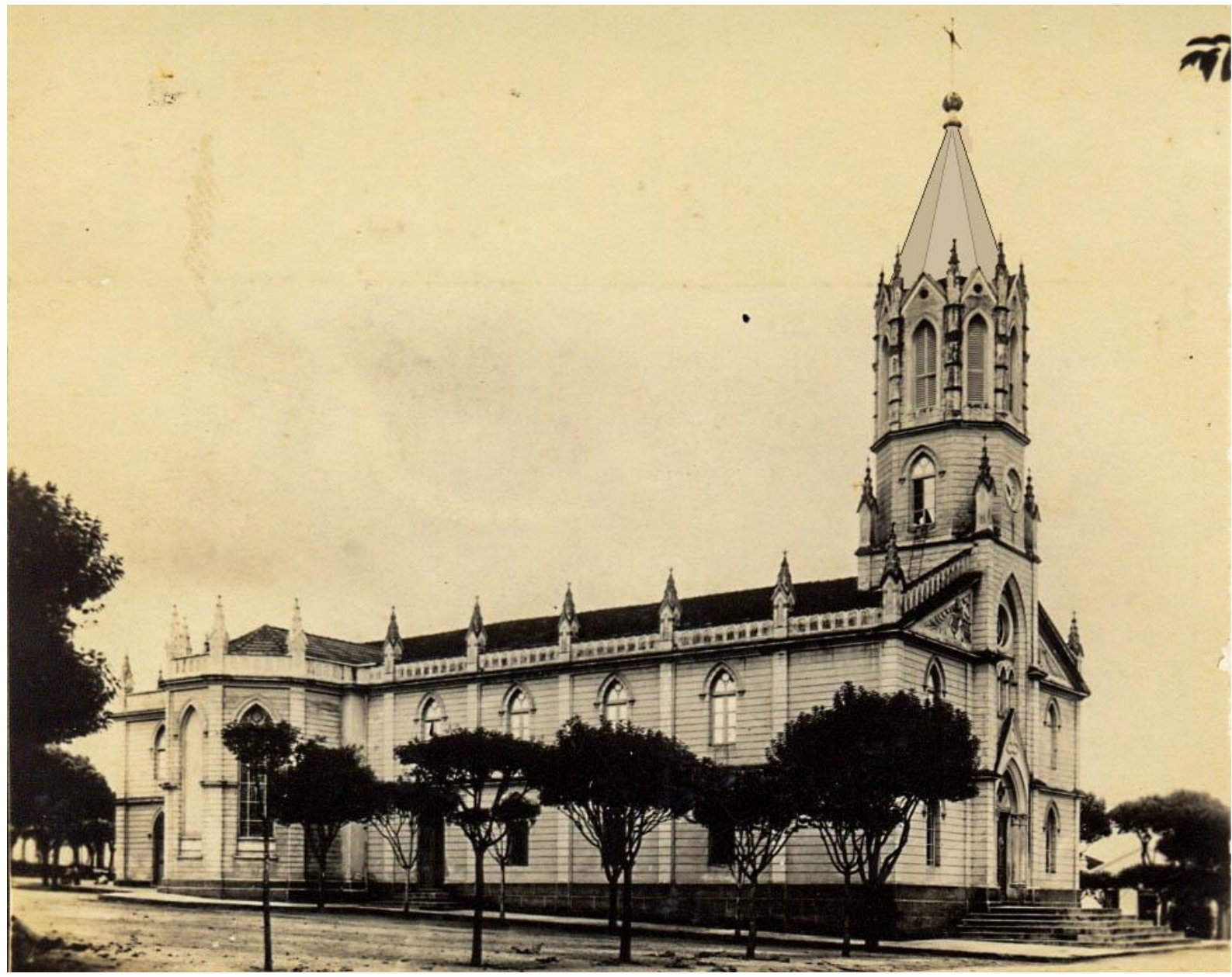

Fonte: Arquivo do Centro da Memória Rio-Pardense Rodolpho José Del Guerra.

Figura 31: Fachada lateral esquerda da Igreja Matriz com as naves laterais aumentadas (década de 1930).

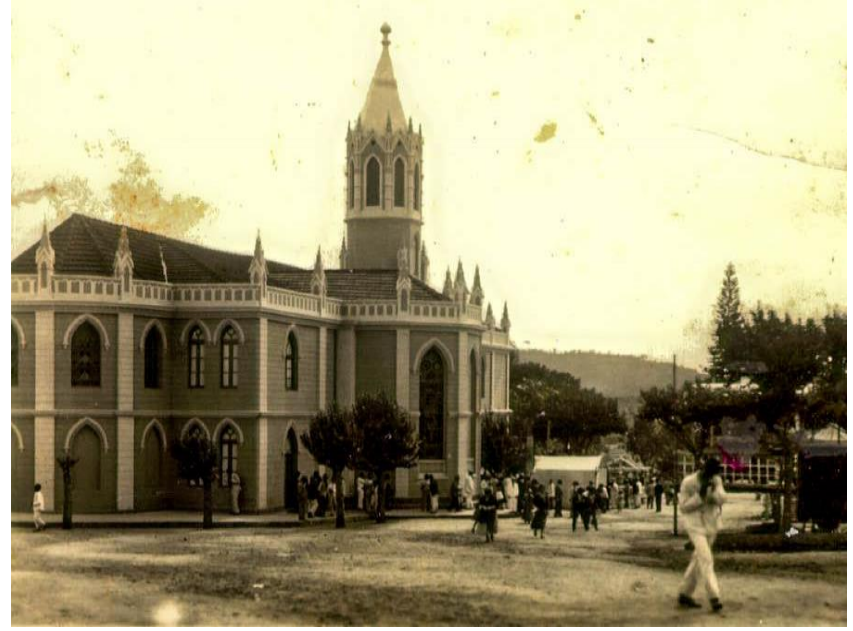

Fonte: Arquivo do Centro da Memória Rio-Pardense Rodolpho José Del Guerra.
Figura 32: Altar e retábulo da igreja Matriz de São José do Rio Pardo (1898).

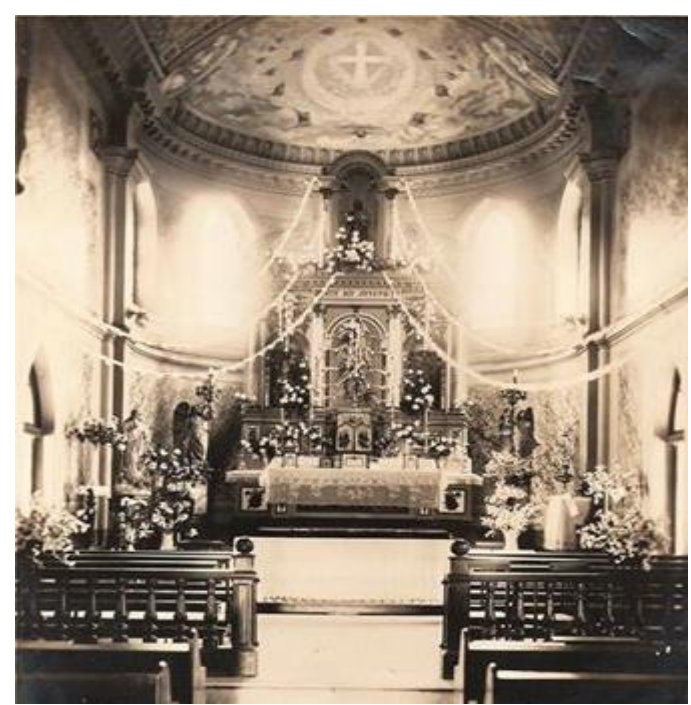

Fonte: Arquivo do Centro da Memória Rio-Pardense Rodolpho José Del Guerra. 
Em um processo de ruptura, nascia uma nova paisagem urbana, mas que abrigava contrastes, ainda que incipiente núcleo urbano, e nesse sentido as colocações feitas por Martins, A., (1994) ao tratar das cidades medias paulistas da segunda metade do século XIX vai ao encontro do que ocorria em São José do Rio Pardo no final da década de 1890 e início dos anos 1900, ou seja a cidade passou a ser o "locus privilegiado do exercício de uma transição, inaugurando outros pontos de convívio além da Igreja, edificando monumentos laicos", e onde "estavam presentes, em constante oposição, mas interagindo numa dialética de complementariedade, o rural e o urbano, o arcaico e o moderno, o campo e a cidade, em movimento de ajuste e engaste, certamente mediados pelos trilhos da ferrovia" (MARTINS, A., 1994, p. 184-185). Como parte do movimento de laicização, a instrução foi valorizada. Trabalhos realizados por Del Guerra e Trevisan com base em reportagens publicadas nos jornais e relatórios da Intendência e da Câmara nos ajudam a tecer um quadro da educação rio-pardense ${ }^{85}$. De acordo com o primeiro autor (DEL GUERRA, 2001), em 1881 foi instalada uma classe para meninas de 13 anos. Em 1883, havia notícias de aulas particulares para meninos. Em 1886 foi criado o "Gabinete de Leitura Riopardense", e em 1887 o Conselho Municipal de Instrução propôs a criação de duas escolas públicas: "uma fixa no Bairro de Santo Antônio e outra ambulante para o Bairro de Bonsucesso e estação de Vila Costina" (DEL GUERRA, 2001, p. 221). Ainda nesse mesmo ano se instalaram em São José do Rio Pardo outras duas escolas de instrução particular primária e secundária, um era o Colégio Constantino para meninos, e o outro era o Colégio Conceição para meninas. Mas foi a partir de 1889 que ações mais efetivas no âmbito escolar foram tomadas, a começar pela criação do Gymnasio Riopardense seguido do Colégio Regina Margherita, Colégio Nogueira, Licções Particulares, Colégio Leonor, Colégio Santana, Internato e externato S. José, Escola M. Intyr, e o Ensino Particular preparatório para os exames do Mackenzie College. A maioria dos anúncios chegava a descrever as matérias oferecidas, alguns destacavam o preço cobrado e a preocupação em oferecer as aulas no período noturno, e em outros como o anúncio do Colégio Leonor ressaltava inclusive que o prédio onde funcionava a escola era magnífico e possuía todas as condições hygienicas como sinônimo de qualidade e distinção (Figura 33).

Figura 33: Anúncios que mostram a diversificação de colégios públicos e particulares.
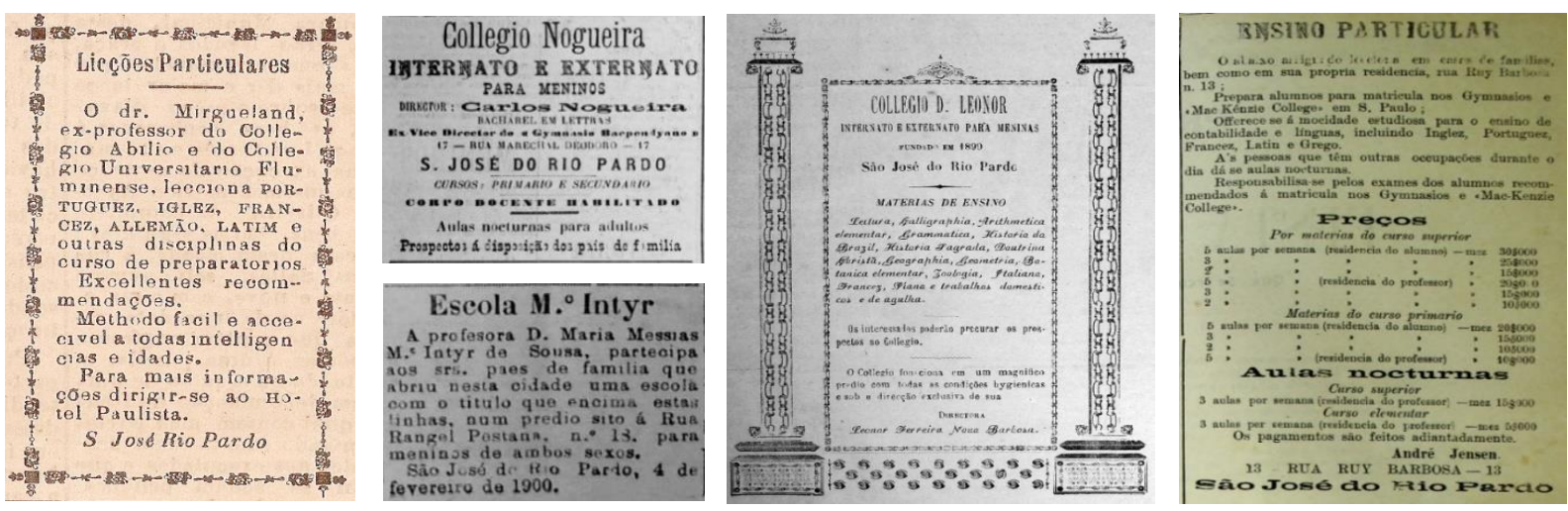

Fonte: Jornal O Rio Pardo, 1899.

${ }^{85}$ Os autores se basearam em documentos que hoje não estão acessiveis ao público. 
Em 1893 a Câmara Municipal autorizou o intendente a firmar acordos com o Governo do Estado para a construção de um grupo escolar. Em 1902, a Câmara municipal visando "promover o progresso", adquiriu da igreja um terreno para esse fim, considerado "mais um melhoramento que trará grande proveito a instrucção publica, além de concorrem para o embellezamento local” (GRUPO..., 1902, p. 02). No entanto, até o início do ano de 1903, recorte final desse capítulo, nada foi noticiado a respeito da construção deste grupo, continuando as escolas a funcionarem de forma dispersa no núcleo urbano.

Outra questão importante a ressaltar nesse período eram as feiras públicas realizadas na Praça Prudente de Moraes (Largo do Mercado, popularmente conhecido como Várzea ${ }^{86}$ ), motivo de denúncia das autoridades, médicos e técnicos que as consideravam uma verdadeira confusão, onde diferentes produtos eram comercializados no mesmo espaço, somando-se ao ajuntamento de pessoas e animais. O tráfego de carroças e carros de boi transportando sacos de café agitavam o entra e sai da cidade em direção à estação. A preocupação com a imagem de uma cidade sadia, limpa, bela, equilibrada, organizada, racional, eficiente, e ordenada - peculiaridades consideradas sinônimo de civilidade, progresso e felicidade - era a constante implícita no discurso das autoridades (ATA... 11/07/1896). Além do mais, havia a intolerância desenvolvida aos cheiros, aos fedores exalados dos lixos produzidos durante a feira, e à aglomeração de pessoas em contraposição ao desejo de oxigenação, de espaço perfumado e organizado ${ }^{87}$. Em 11 de julho de 1896, o intendente foi "autorizado a chamar concorrentes para a construção de um mercado, mediante uma concessão de privilégio por vinte anos" (ATA... 11/07/1896). Esse debate foi feito por uma junta médica que indicou o a Praça Barão do Rio Branco (antigo Largo do Rosário) situado a quatro quarteirões da Matriz (Figura 34) como o local ideal para a construção desse edifício que não se concretizou. Certamente, além do Código de Posturas, outros mecanismos coercitivos atuaram no sentido de determinar o comportamento disciplinar da população que atuava na área da Praça Prudente de Moraes, a exemplo da Lei n. ${ }^{\circ} 13$ a seguir:

Art. $1^{\circ}$ - Enquanto não houver edificio proprio, o Intendente Municipal designará um logar mais conveniente da cidade para o mercado de generos alimentícios onde deverão estacionar os mascates.

Art $2^{\circ}$ - Aos domingos e até as quatro horas da tarde aquelles generos não poderão ser vendidos e os mascates não poderão estacionar, senão no logar designado pelo intendente, sob pena de multa de 30\$000 e cinco dias de prisão. (LEI N.13/1899).

É necessário considerar ainda que além das questões estéticas e higiênicas, as regulamentações sobre as atividades do mercado partilhavam o momento econômico que necessitava centralizar o comércio em determinados estabelecimentos de modo a facilitar o controle sobre as trocas de mercadorias e a cobrança dos impostos, como noticiado pelo jornal O Rio Pardo do dia 13 de abril de 1899: "Um mascate circumscripto em um ponto determinado não poderá fazer concorrência com os grandes estabelecimentos de fazendas o armarinhos" (MERCADO, 1899, p. 01).

\footnotetext{
${ }^{86}$ Termo apropriado para uma baixada cercada por veios de água.

${ }^{87}$ Segundo Margareth Rago (1985), a ascensão da burguesia e a imposição de sua hegemonia, acentuada desde o final do século XVIII na Europa, supôs a "instituição de um novo imaginário social, de novas formas de percepção cultural e de uma nova sensibilidade". (RAG O, 1985 , p. 169). A partir de então, segundo Rago (1985, p. 169), a cidade passou a ser lida com base nas "novas concessões médicas e biológicas do determinismo físico e moral".
} 
O desenvolvimento da cidade e a crescente complexidade das relações exigiram ainda melhores instalações da Casa de Câmara e Cadeia, para atender o seguinte programa: câmara, intendência, fórum, coletoria, corpo de guardas e duas celas para presos, como podemos observar na Figura 35.
Figura 34: Localização das praças Prudente de Moraes e Barão do Rio Branco onde seria realizado o comércio.

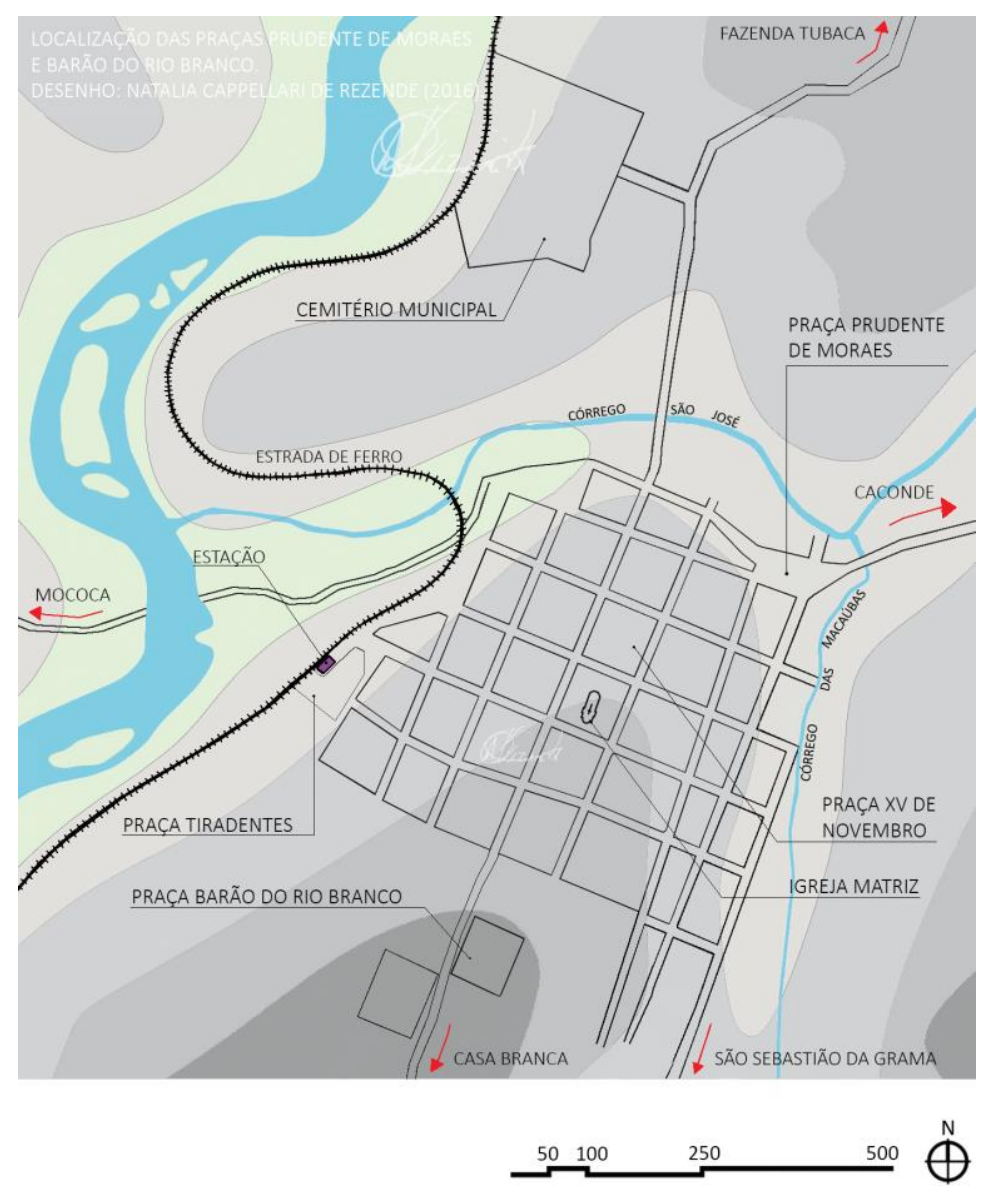

Desenho: Natalia Cappellari de Rezende (2016) com base em dados históricos e cartografia disponibilizada pela Secretaria de Obras de São José do Rio Pardo.

Figura 35: Casa de Câmara e Cadeia antes da construção do Palácio do Tribunal da Justiça.

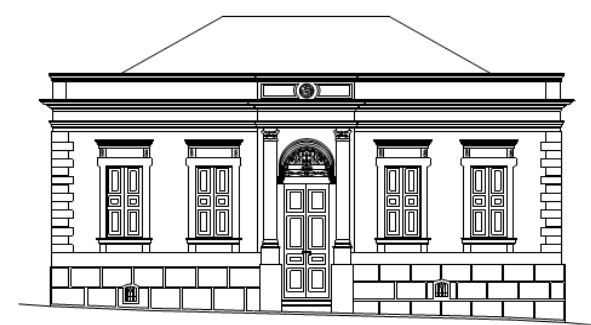

Fachada

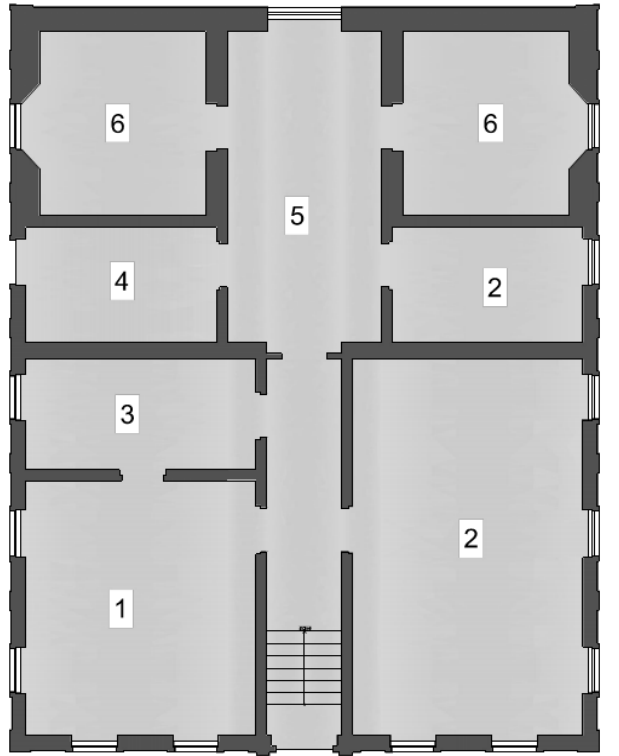

1 Intendência

2 Câmara

3 Coletoria

4 Corpo de guarda

5 Atrio

6 Cela
Planta

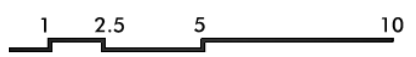


Conforme Menechino (1986), um projeto de ampliação foi elaborado e o edifício térreo se transformaria em sobrado. Porém, após parecer realizado pelo engenheiro Euclides da Cunha, foi decidido pela construção de um novo prédio coerente com as necessidades de fórum e cadeia exigidas naquele momento. O projeto do novo edifício foi elaborado pelo corpo técnico da Secretaria da Viação e Obras Públicas com data de 1899 e assinado por V. Hueth Bacellar, Ricardo Medina, J. W. Cochrane e José Van Humbeeck, todavia as características neogóticas do edifício são próprias da produção de Victor Dubugras ${ }^{88}$. Segundo Menechino (1986), a construção "teve a concorrência para execução vencida pelo engenheiro Carlos Ekman ${ }^{89}$, entre outras dez propostas, inclusive uma da própria Câmara" (MENECHINO, 1986, p. 26). O novo prédio denominado de "Palácio do Tribunal da Justiça" foi inaugurado em 1902.

Construído isoladamente no lote e com funções distribuídas em dois pavimentos, este edifício adotou a linguagem eclética com aberturas apresentando moldura em arco ogival e pleno e também verga reta, pilastras com feições dóricas, frontão triangular, régulas e cunhais com bossagens imitando pedras aparelhadas. Apresentava recursos técnicos construtivos mais apurados se comparado com o que era produzido nessa época em São José do Rio Pardo, como é possível observar na Figura 36. Internamente, a planta era simétrica e a circulação se desenvolvia a partir do saguão. O acesso ao pavimento superior era realizado por uma escada de dois lances, como pode ser observado na Figura 37. Em várias publicações locais foram enaltecidas as qualidades do novo edifício, como recorrentemente era feito em anúncios de jornais e almanaques, a exemplo do jornal O Rio Pardo que publicou no dia 05 de abril de 1902 uma descrição do novo prédio destacando a especificidade dos usos:

É edificio notavel pela solidez, elegância e comodidades. No pavimento inferior estão collocadas as prisões, espaçosas e hygienicas, corpo da guarda e sala da policia. No superior, um bello salão de jury, sala do conselho secreto, salas do juiz, dos officiaes de justiça, dos advogados e das testemunhas. (CADEIA..., 1902, p. 01).

Figura 36: Prédio do "Palácio do Tribunal da Justiça" de São José do Rio Pardo (1902), início do século XX.

Fonte: Arquivo do Centro da Memória RioPardense Rodolpho José Del Guerra.

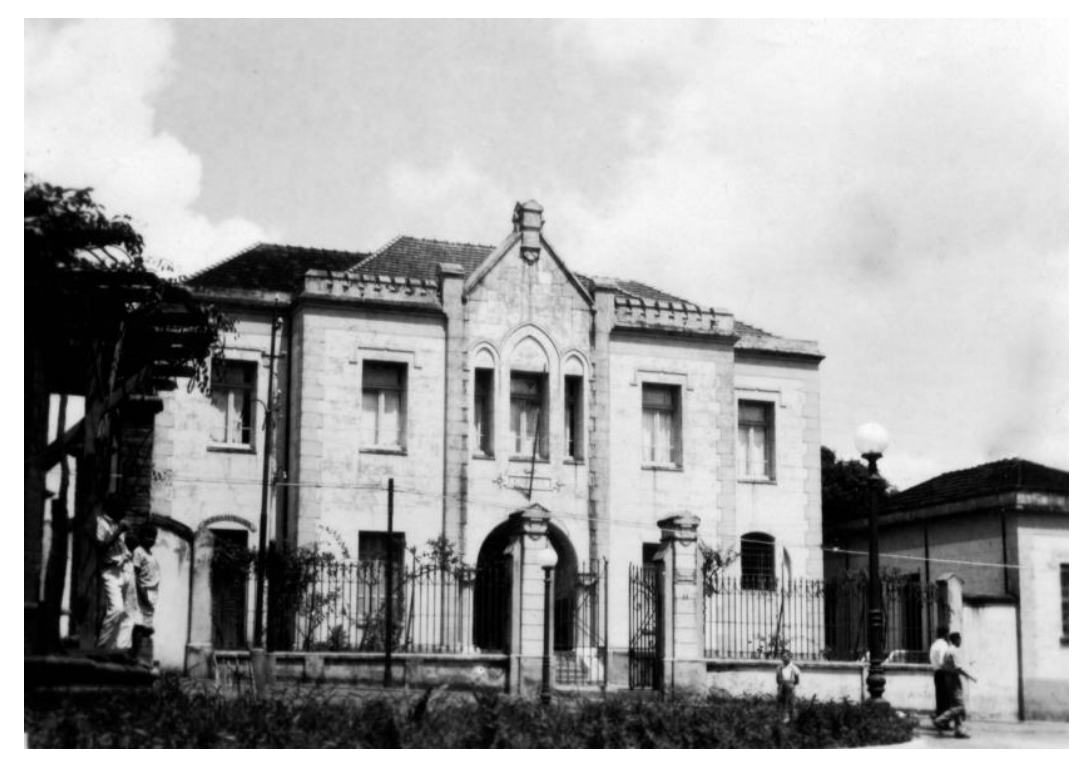

\footnotetext{
${ }^{88}$ Para saber mais sobre a produção de Victor Dubugras, ver o livro Racionalismo e proto-modernismo na obra de Victor Dubugras de Reis Filho (1997).

${ }^{89}$ Carlos Ekman era arquiteto de origem sueca que se estabeleceu em São Paulo em 1895 (TOLEDO, 1993).
} 
Figura 37: Planta baixa do "Palácio do Tribunal da Justiça" de São José do Rio Pardo.

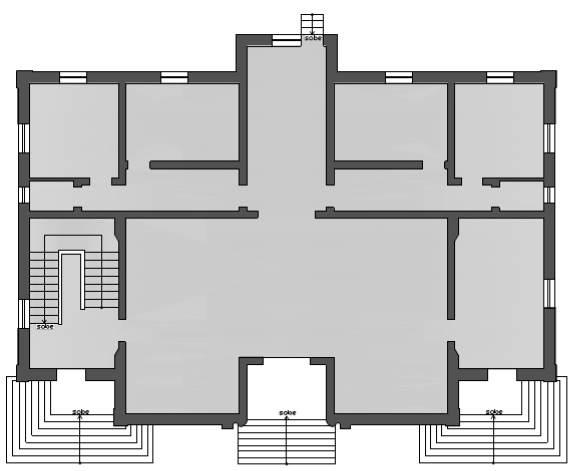

Térreo

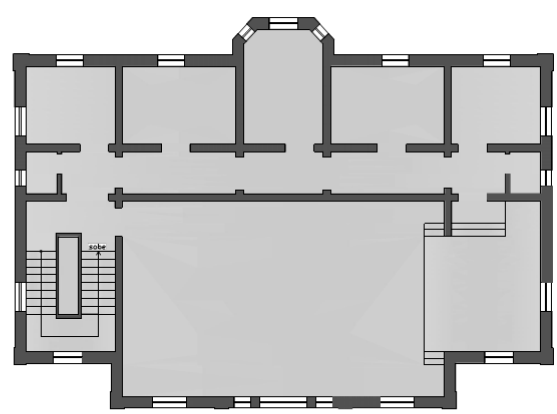

Primeiro Pavimento
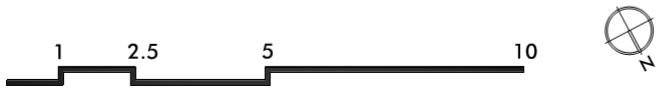

Desenho: Natalia Cappellari de Rezende (2016) com base em Menechino (1986).

Outros edifícios semelhantes a este foram identificados no Estado de São Paulo, entre eles o prédio da Cadeia de Piracaia (Figura 38) e de Ribeirão Preto, este último construído em 1912 (Figura 39).

Figura 38: Cadeia de Piracaia.

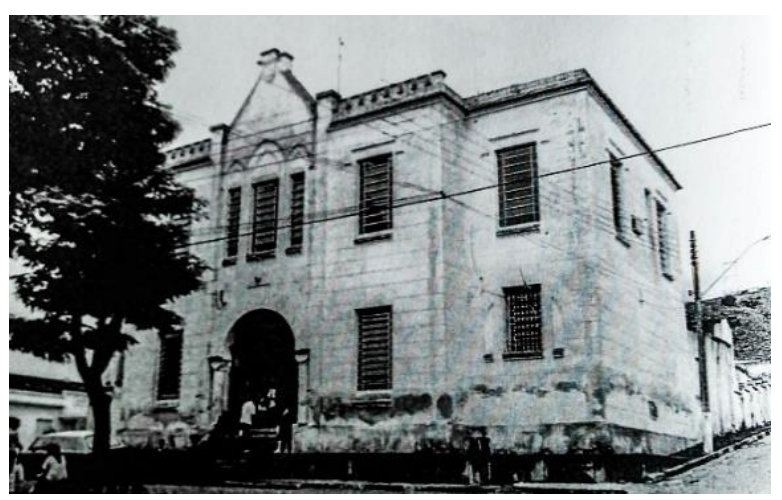

Fonte: Lima, R. (2001).
Figura 39: Cadeia de Ribeirão Preto (1912).

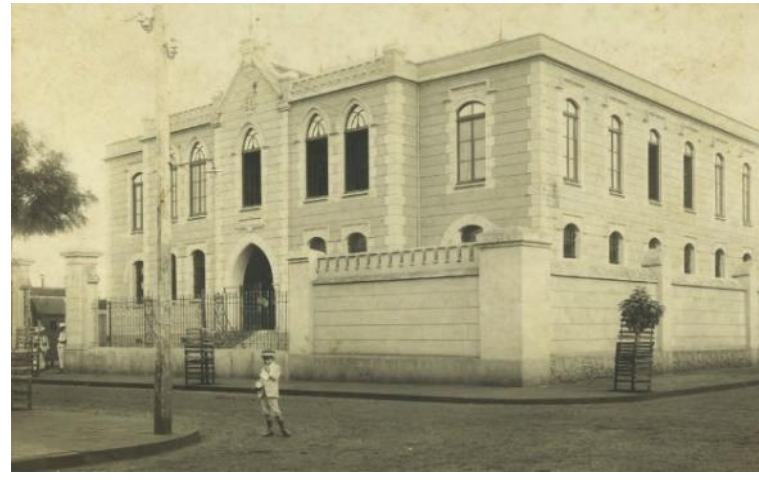

Fonte: Mercadante Júnior (1988).

Os serviços de embelezamento e melhorias incluíram ainda a construção dos jardins na Praça XV de Novembro. A transformação deste local (Figura 40) em um espaço ajardinado, arborizado e assepsiado, ensejava novos hábitos. Ao tratar especificamente das praças e das oscilações de forças no campo de confronto pelo poder dos espaços da cidade na primeira república, Garcia (2008, p. 30-34) fundamentou a transição do significado do local sagrado, "ponto de encontro para ritos e cerimônias", para um "ato deliberado de escolha" inserido principalmente no modo de vida burguês que o transformou em um espaço "de circulação e visibilidade" , e ainda chamou a atenção para a conjuntura brasileira que resultou na publicação do Código Sanitário de 1894, atribuindo a mudança de postura humanista que abarcava o "florescimento moral do espírito humano" para a "ordem prática do desenvolvimento material". Foi nesse 
ambiente que o Estado se viu "obrigado a zelar pela manutenção da propriedade, seja esta pública ou privada", assumindo "também a tarefa de organizar esses espaços" (GARCIA, 2008, p. 35-36). Assim, o Código Sanitário de 1894 incluiu em seus artigos um conjunto de normas ordenadoras para as praças e jardins,

Figura 40: Jardim Público da Praça XV de Novembro e a Igreja Matriz nos primeiros anos do século XX.

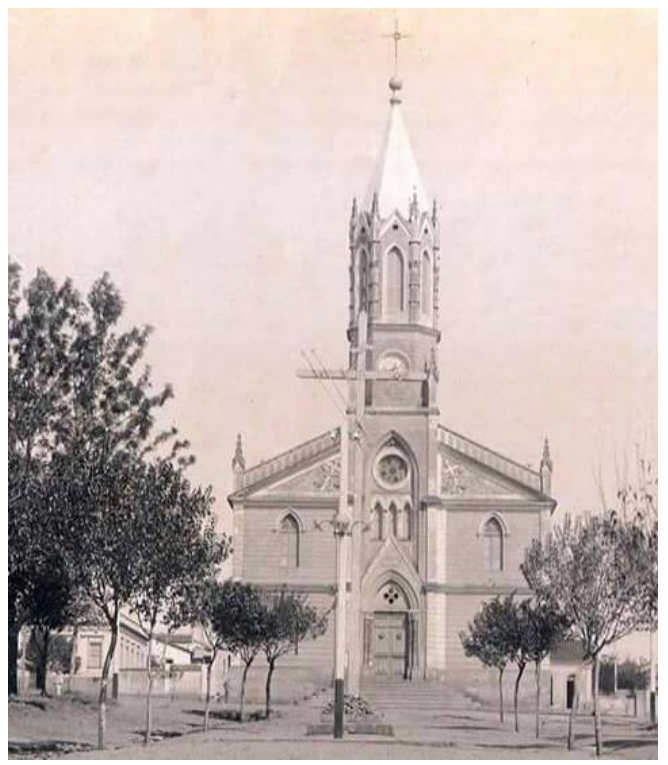

Fonte: Arquivo do Centro da Memória Rio-Pardense Rodolpho José Del Guerra.
Artigo 10. As praças publicas deverão ser calçadas ou ajardinadas.

Artigo 12. Os jardins e arborização das ruas e praças publicas deverão ser estabelecidos e cuidadosamente conservados.

Artigo 13. Na escolha do arvoredo deve haver todo o cuidado; as arvores escolhidas deverão ter folhagem exuberante, persistente, e raizes verticaes. (CÓDIGO SANITÁRIO, 1894, p. 01).

Atestando as análises acima, o Jardim da Praça XV de Novembro se tornou um lugar de contemplação, como reporta o jornal O Rio Pardo:

permanecerá aberto aos domingos, dias santos e feriados, das 3 as 6 horas e meia da tarde [...] a guarda do jardim está confiada a boa educação do povo, e a Intendência municipal espera que cada visitante do jardim seja um dos zeladores e conservadores das plantas. (JARDIM..., 1903, p. 02).

Era o signo do ordenamento, limpeza, aburguesamento e modernização da cidade que deseja a mudança, o novo. Era também a ótica do embelezamento reordenando a relação entre o espaço vazio e construído, a arquitetura e o urbanismo, conforme a publicação do jornal O Rio Pardo publicou em 1900:

Quem a conheceu como nós sem escolas, sem collegios particulares para a educação das creanças, e que a vê hoje além de varias escolas publicas, estabelecimentos de ensino particular para ambos ao sexos, dirigidos por provectos professores. Quem a conheceu naquela epoca com as suas ruas esburacadas, sem sarjetas, levantando, no tempo da secca, verdadeiras nuvens de pó, e que nas aguas se transformavam em tremendos atoleiros e que hoje as vê sargettadas, abauladas, arborizadas. Quem a conheceu com os seus casebres sem passeio e hoje com os seus palacetes modernos que a tornam uma cidade elegante. Quem a viu com as suas praças cheias de altos e baixos transformadas em pastagens de animaes e à noite, em completa escuridão, notava aqui e ali, pequenos pontos frouxa e palidamente iluminados e movediços indicando alguns noctívagos que premuniam-se desse systema rudimentar de iluminação afim de, evitando os buracos e mundéos, não andassem aos trancos e barrancos com os annimaes que, em grande numero, deitados ao longo de suas ruas, placidamente remuiam, e hoje, a vê com ellas niveladas e a sua praça principal ajardinada, com novas ruas para maior facilidade e comunidade dos seus transeuntes nota com rea satisfação que nesta cidade trabalha-se para o bem estar de todos, e que S. José do Rio Pardo, em relação as outras suas irmãs, representa um verdadeiro seio de Abrahão. (S. JOSÉ..., 1900 p. 01). 
Havia também as sociedades organizadas, como a Società di Mutuo Soccorso 20 Settembre criada em 1886 por italianos. A sede dessa Sociedade, inaugurada no final do século XIX, foi projeta por Luigi Prezzia após vencer a concorrência dos italianos Giovanni Delucca e Giuseppe Quercia. A direção das obras ficou a cargo de Nicola Delucca (DEL GUERRA, 1999). Com volumetria pouco movimentada, o edifício foi construído afastado das divisas laterais e frontalmente em relação à rua. Sua fachada era marcada pela presença de cimalha, platibanda e pilastras arrematadas por um arco abaulado decorado com elementos em relevo; porta em madeira e arco pleno com bandeira fixa em ferro fundido; janelas emolduradas com verga reta e sob elas almofadas (Figura 41 e Figura 42).

Figura 41: Sócios da Società di Mutuo Soccorso 20 Settembre em frente a construção da primeira sede, última década do século XIX.

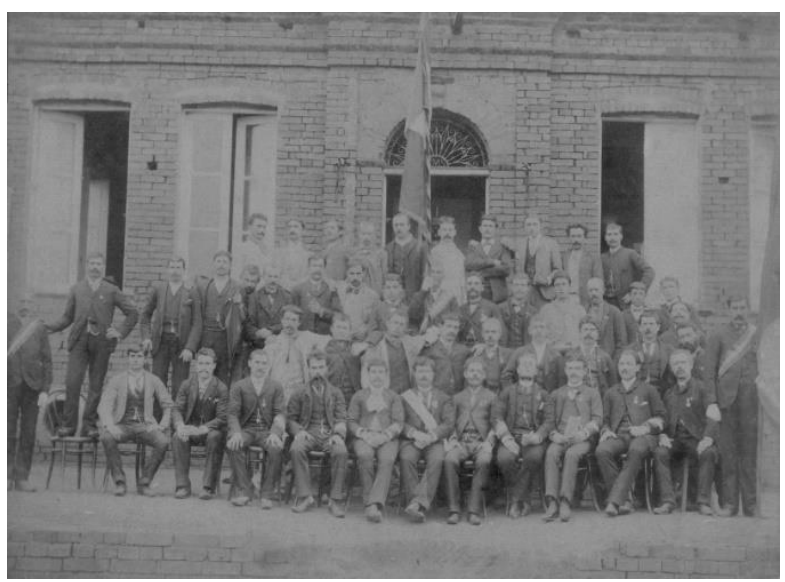

Fonte: Arquivo do Centro da Memória Rio-Pardense Rodolpho José Del Guerra.
Figura 42: Prédio da primeira sede da Società di Mutuo Soccorso 20 Settembre (1886) na década de 1910.

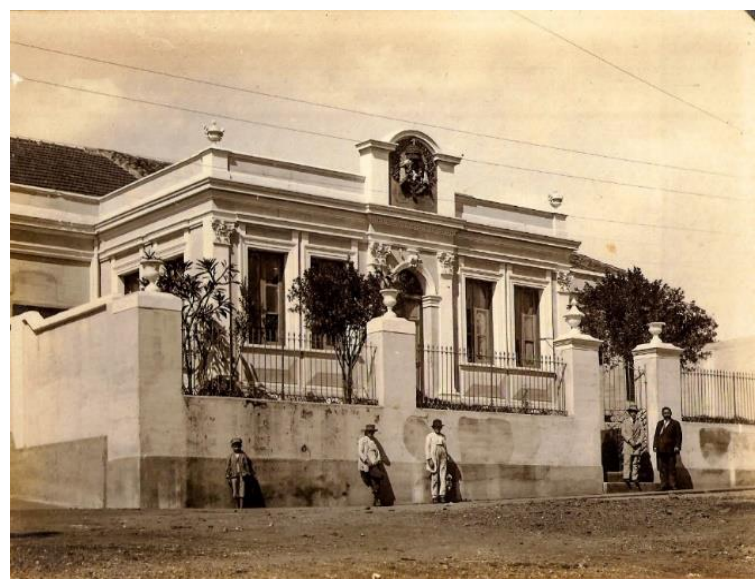

Fonte: Arquivo do Centro da Memória Rio-Pardense Rodolpho José Del Guerra. Fotografia de Innocencio Vilhegas.

Outra sociedade que também marcou presença na área urbana foi o clube maçônico com a Loja "União Universal" no 463, fundado em 1894 pelo baiano formado em medicina Dr. Pedro Agapio de Aquino. O prédio foi inaugurado no final de 1897, na atual Rua Francisquinho Dias (anteriormente denominada de Rua dos Calabreses, depois Rua do Carmo, mais tarde Avenida Américo de Campos e Rua João Pessoa), entre os n. 273 e 291, e se destacava pela imponência, verticalidade e monumentalidade (Figura 43). A entrada

Figura 43: Sede do clube maçônico Loja "União Universal" (1897).

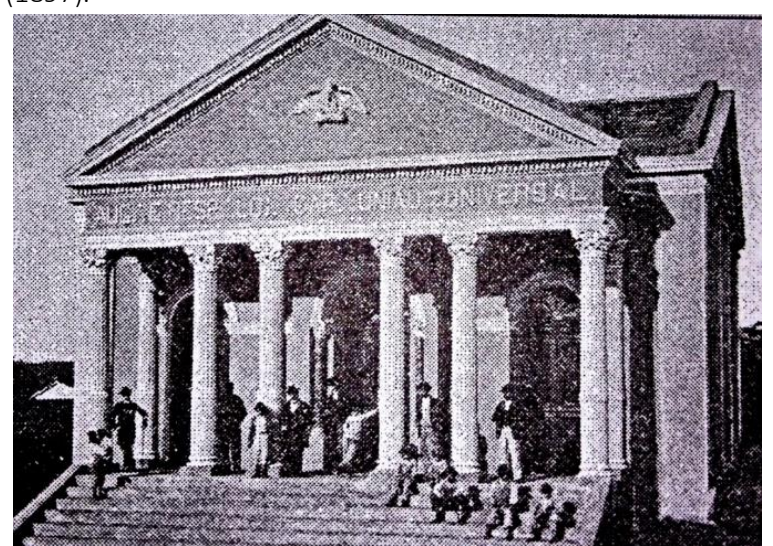

Fonte: Arquivo do Centro da Memória Rio-Pardense Rodolpho José Del Guerra. 
do edifício acontecia por um pórtico sustentado por oito colunas da ordem coríntia constituindo um átrio de transição onde havia três portas em arco pleno com bandeira fixa. O entablamento era coroado por um amplo frontão tendo ao centro uma pomba, símbolo maçônico por excelência.

Apesar de até o início dos anos 1900 São José do Rio Pardo não ter sala de cinema, conheceu o cinematógrafo a partir de ambulantes que usavam o salão da Sociedade Italiana para transmitir os filmes. Del Guerra (2003) destacou que foi o ambulante alemão Kahurt quem trouxe pela primeira vez esse aparelho em 29 de setembro de 1899. Também não havia teatros, mas uma reportagem do jornal O Rio Pardo de 15 de fevereiro de 1900 apontou a existência de um projeto elaborado pelo arquiteto italiano Carlo Sada, mas por dificuldades financeiras a obra orçada em aproximadamente 300 contos de reis foi inviabilizada.

Aparentemente, pelas reportagens dos jornais a vida social movimentava a cidade, principalmente a elite rio-pardense que tinha nos salões dos palacetes seus lugares reservados, como segue no trecho de uma publicação:

Naquele dia, após a procissão e os fogos de artifício, queimados logo ao cahir da tarde, por causa de impertinente chuva, abriram-se os elegantes salões do palacete do Exmo. Snr. Coronel Francisco Soares a receber numerosos convidados dentre o que há de selecto em nossa sociedade. Dançou-se animadamente ao som da orchestra Rio-Pardense e pela alta madrugada retiraram os convidados [...] (FESTA..., 1900, p. 02).

Em um momento de ampliação das sofisticações dilatadas pelas ferrovias que alcançou as mais longínquas áreas da Mogiana - como foi o caso de São José do Rio Pardo -, favorecendo a chegada, "ao longo do século XIX, dos novos hábitos de consumo, já que os vagões cargueiros transportavam com muito maior rapidez, e segurança contra danos, todo tipo de mobiliário, além de serviços de porcelana e cristal" (MARINS, 2004, p. 146).

Nessa época a cidade contava com dois hotéis de maior expressão: um era o Hotel Brasil, inaugurado no final de novembro de 1887 de propriedade de Ananias Barbosa, e o outro era o Hotel Paulista adquirido em 1903 pelos Srs. Mascaro \& Moffa (HOTEL..., 1903).

Era no Hotel Brasil que aconteciam exposições de enfeites, mobiliários, porcelanas e cristais vindos da Casa Cypriano do Rio de janeiro. As novidades eram sempre muito festejadas pela sociedade da época que se empenhava em acompanhar os inúmeros anúncios feitos nos jornais locais, aproveitando para enaltecer as qualidades do hotel e o seu protagonismo no movimento republicano rio-pardense. Construído na esquina da Rua Treze de Maio esquina com a Rua Ananias Barbosa (anteriormente denominadas de Rua Esperança e Rua Ipiranga), era um prédio compacto, térreo, com porão para vencer o declive do terreno, trazia em sua fachada principal uma porta e seis janelas, todas de verga reta com o dístico anunciando a função do lugar "Hotel Brasil" (Figura 44).

Também de proporções modestas o Hotel Paulista foi construído na Praça XV de Novembro (Largo da Matriz), na esquina das Ruas Francisco Glicério (antiga Rua Conceição) e João Gabriel Ribeiro (antiga Rua da 
Cadeia e depois Saldanha Marinho). Apresentava todas as aberturas com verga reta e emolduradas; a altura do porão era marcada por argamassa em relevo assim como os cunhais imitando pedra, e para arrematar o telhado de telha capa e canal, havia uma cimalha ( Figura 45).

Figura 44: Hotel Brasil (1887) retratado por Araújo Guerra na primeira folha do jornal A Platea em 1889.

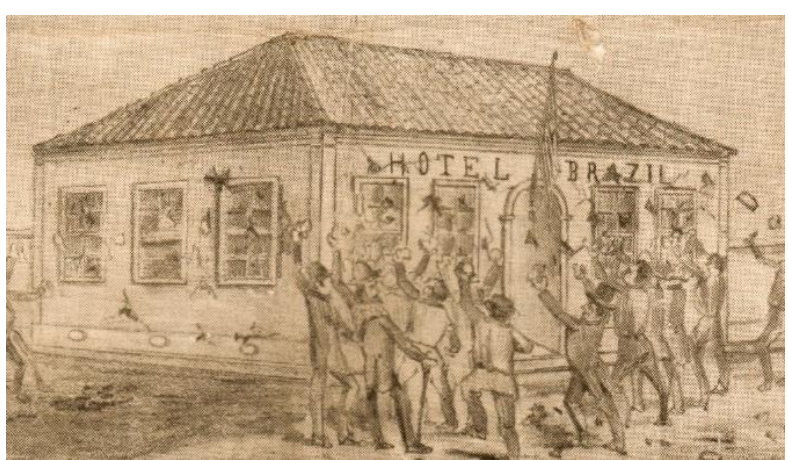

Fonte: Jornal A Platea, ano $2^{\circ}$, n. $^{\circ} 61,1889$
Figura 45: Hotel Paulista (1903) na década de 1910.

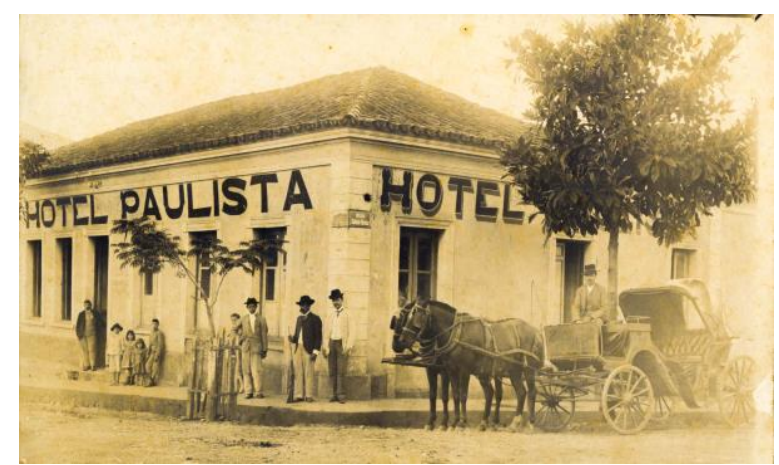

Fonte: Arquivo do Centro da Memória Rio-Pardense Rodolpho José Del Guerra.

O desenvolvimento da cidade possibilitou a abertura de casas bancárias, como a Casa de Câmbio e Descontos fundada em 1894 pelos irmãos Angerami, e outras atividades comerciais e industriais se diversificaram impulsionadas, principalmente pelos imigrantes atraídos para o exercício de atividades (pedreiro, carroceiro, ferreiro, marceneiro, sapateiro, alfaiate, seleiro, barbeiro, mestre de obra, pintor, fotógrafo, camareira, cozinheiro etc...). Neste sentido, é oportuno destacar alguns dos anúncios encontrados no jornal O Rio Pardo que mostram a diversificação do comércio com gêneros produzidos artesanalmente e também com os importados que chegavam pela a ferrovia. Pequenas fábricas de ladrilho, serrarias, móveis, marmorarias, olarias, corda e barbante, trole, pólvora e fogos de artifício, bebidas e laticínios surgiram, e muitas dessas fabriquetas foram implantadas na área urbana, mas outras como as olarias localizavam-se afastadas. Mesmo sendo pequenas produções, assinalavam os novos padrões de consumo acompanhados de divulgações, principalmente através dos anúncios dos jornais, possibilitando compreender a notória diversificação da incipiente atividade industrial, de serviços e comercial exemplificado pela Marmoraria Amparense que anuncia a variedade de mármores importados da Itália e a Casa de Câmbio e Desconto dos Irmãos Angerami que informa a possibilidade de encaminhar qualquer valor em dinheiro para Portugal, Espanha e Itália, além de oferecer passagens de ida e volta para o último país, ou ainda o Trivellato Irmão e Companhia que comunica a exclusividade dos seus produtos; ao mesmo tempo de profissionais liberais com clínicas médicas, escritórios de advocacia, e ateliês de fotografia e arte como o do Celestin Detinne e Paschoal Artese, ambos demonstram um esforço em atender as demandas locais (Figura 46). 


\section{OPFICINA ME HAVICA DE CLLDERELIRO \\ FORTUNATTI ANGELO RUA AMERICO DECAMPÓs}

Fabrica-se alambiques com verificador e simples serpentinha de qualquer tamanho

Faç tanques de cobres, e qualquer con. certo concernente a esta arte dando garantia de seu trabalho e perfeiçào.

24--RUA AMERICO DE CAMPOS--24 S. JOSE' DO RIO PARDO

\section{Marmoraria Amparense}

Esta acreditada marmoraria, participa ao povo desta eidade que acaba de receber um grande sortimento de marmores de todas as qualidades, euja acquisição fez na Jtalia.

Tem á disposicão um rieo album de desenhos modernos, nara construcēão de tumulos e tudo quanto eoncerne á sua industria.

IRMÃOS ANGERAMI tes om S. Tos bin Rio Pand.

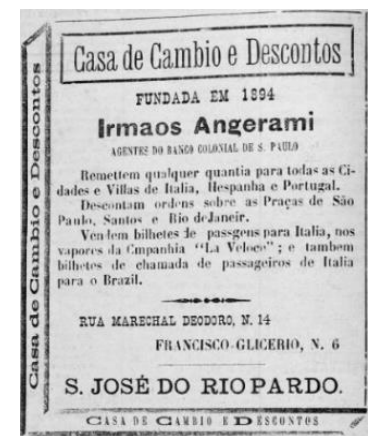

\section{AGENGIA DABAVARIA \\ Em São José do Rio Pardo Trivellato Irmão \& Comp.}

Communicam ao commereio desta cidade e visinhas, que desta data em diante sa. os unicos agentes da cerveja Bavaria, tendo já um bom sortimento de Pilsen e München ja um bom sortimento de Pilsen e München,
caixas com 49 garrafas. Cerveja Clara e escura, e Culmbach-preta caixas com 24 1/2 garrafas, com $481_{1} 2$ e com $721_{1} 2$.

Vende-se pelo mesmo preco da fabrica acerescentando-se sómente o frete e carreto de $\mathrm{S}$. Paulo aqui.

S. José do Rio Pardo, 22--2--1 _ 30

Trivellato Irmão \& Comp.

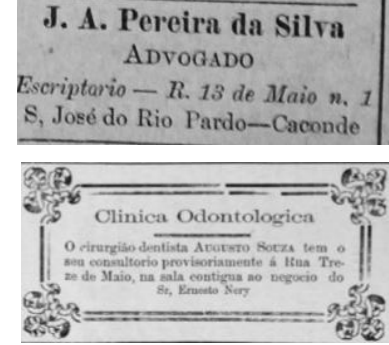

(1) Dr Guilb̨rme Tell Medico e operador

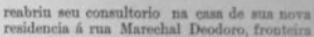
SAO JOSÉ DO RIO PARDO 然

\section{Photographia Detienne}

0 proprietario deste conbecido estabelacimentu tem a honra de convidar o illustradı publico Rio Pardense para visitar o seu Atalier, que so acha caprichosamente montado. de modo a pocier fazer qualquer s rvisço de sua profição. como seja :-Retratos de todos os tamanhos, e com a maior perfeição, desde cartão de visita até o-tamanho nataral.

Acceita chamad is para fora. para qualquer servisço como seja : vistas de fazend +s, etc : -Garante a p feição de seu trabalho.

N.: 11 A Rua 13 de Maín N: 11. Sล̃o Jos Celestin Detinne (Photographo)

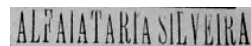

0 proprietario des. te conhecido e antigo estabelecimento, regressanilo da Capital acaba de trazer um explendido sortimento de cazemiras, sarjas, diagonaes, córtes de calcas, colletes de fustão branceo, tudo escolhido com muito gosto e o que ha de maior novidade em tecidos e padrões.

ua 13 Rule Maio, n’ 20 S. José do Rio Pardo

\section{Retratista}

'aschoal Artec, recentemente chegado á exta cidade, communiea. an respeitavel publico que promptifica-se a reproduzir qual. quer retrato pequeno em ponto natural, a cracan por preços baratissimos.

Póte ser procurado á rua Americo de Campos, n. 27=Marcunaria Rin-Pardense, do Pasihoal Leravolo.

Fonte: Jornal O Rio Pardo, 1899-1902.

Os estabelecimentos funcionavam principalmente nas Ruas Treze de Maio, Marechal Deodoro (antiga Rua Boa Vista), Francisquinho Dias e João Gabriel Ribeiro. Como bem enfatizou Martins, A. (1994, p. 187) ao tratar da transformação que ocorreu em muitas cidades no início da República, em um momento laicizado, apareceriam os "artefatos representativos das transformações do capital, dos novos grupos sociais", que

ao lado da velha Matriz e da tosca Câmara e Cadeia, evocativas de um tempo religioso pretérito, vicejavam confirmando o tempo secular e a dessacralização do espaço, inúmeras casas de comércio, hotéis de viajantes, agências bancárias, escolas públicas, templos protestantes, incipientes unidades fabris, identificando-se posteriormente, as indústrias pioneiras e os consequentes bairros operários. (MARTINS, A., 1994, p. 187). 
A implantação de equipamentos, obras de infraestrutura, prédios públicos e a assimilação de novas técnicas construtivas e novos materiais, permitiu reconhecer que a alteração socioeconômica ocorrida no fim do século XIX foi acompanhada de medidas que modificaram as condições urbanas, muito em função do dinheiro que circulava e tendo o café como catalisador desse processo. Tornaram-se autênticas manifestações das necessidades e da complexidade das relações urbanas após a construção da estrada de ferro.

Ainda que não fosse uma estratégia planejada houve certo empenho em atingir determinados objetivos, sob determinadas condições e ideias. Desse modo e, conforme veremos no próximo item deste capítulo, nesse período São José do Rio Pardo não contou com um plano macro de reforma urbana, mas uma série de ações ocorreram, ora financiados pelo poder público ora pela elite local, contribuindo na alteração da feição da cidade e corroborando com a dinamização econômica e da própria vida urbana. 


\subsection{Do desenho à consolidação e expansão urbana}

Para melhor compreendermos a morfologia e a complexidade urbana alcançada por São José do Rio Pardo até o início do século XX precisamos resgatar a ocupação inicial desse povoado. Para isso, estabelecemos critérios de análise a partir de estudos realizados por Murillo Marx, Nestor Goulart Reis, Roberta Delson, e eventualmente outros autores que abordaram esse assunto ao discutir questões distintas como Pierre Monbeig. Questões como as peculiaridades do desenho urbano e as relações que puderam ser estabelecidas a partir da urbanização de outros núcleos vizinhos a São José do Rio Pardo; as características morfológicas do terreno e da arquitetura produzida; o retalhamento das glebas e a relação que se estabeleceu entre o lote e a quadra e entre o lote e a edificação. Esses questionamentos, aqui creditados como critérios de análise, serviram de orientação para compreender o espaço dessa cidade e inserí-la no quadro da urbanização do interior paulista, mais especificamente do nordeste de São Paulo. Ressaltamos que ainda há uma carência de estudos realizados sobre o urbanismo desenvolvido no Brasil do século XIX, o que dificulta uma discussão mais embasada sobre esse assunto.

Diferentemente das cidades de Casa Branca e Caconde onde a ocupação foi incentivada pelo governo por serem considerados pontos estratégicos para a dominação do território, São José do Rio Pardo cresceu a partir da formação de um patrimônio religioso em meio às frações de terras doadas pelos fazendeiros. Mas o que determinou a escolha do terreno doado para constituir o patrimônio? Sabemos que o fator determinante na formação de uma vila era a proximidade a cursos d'água ${ }^{90}$, e é isso que explica o início do povoado rio-pardense entre os córregos São José, Macaúbas e o rio Pardo, em um sítio caracterizado por uma declividade acentuada. Nesse processo a população procurou oficializar a ocupação com a presença da Igreja que assumiria as responsabilidades administrativas. Todavia, como destacou Marx (1991), para a capela ser oficializada, o local não poderia ser ermo e despovoado, deveria haver um assentamento que provesse os rendimentos necessários para a sua manutenção. Para atingir esse fim, o terreno foi dividido em parcelas concedidas mediante o pagamento do foro aos interessados em habitar ou utilizar o lote como meio de subsistência nas proximidades do templo. Foi nesse processo que a paisagem se transformou e alterou o meio social.

O patrimônio religioso rio-pardense, assim como outros núcleos de povoamento que surgiram do decurso da urbanização do interior do Estado de São Paulo em meados do século XIX, têm um traçado notadamente geometrizado com vias ortogonais. Muitos são os caminhos para tentar compreender a sua adoção. Dentre as análises e pesquisas realizadas sobre a oficialização de núcleos urbanos no Brasil, Roberta Marx Delson (1997) procurou demonstrar como ocorreu a aplicação de um urbanismo de matriz portuguesa. Segundo essa autora (1997), a aplicação de planos regulares, concebidos a partir de traçados geométricos ocorreu ainda no século XVIIII, e sua representação não estava ligada apenas a um "requinte artístico, mas sim uma

\footnotetext{
${ }^{90}$ Até serem implantadas redes de abastecimento de água, os rios e córregos cumpriam papel fundamental na formação dos núcleos de povoamento. Segundo Marx (1991), quando o patrimônio fosse instalado em um vale, o parcelamento da terra ocorria em tiras paralelas ortogonalmente aos cursos d'água facilitando o escoamento das águas pluviais, servidas e a utilização domiciliar.
} 
clara representação da imagem "civilizada" e "europeizada" que Portugal esperava projetar no interior da colônia", e mais do que isso, "a regularidade equivalia a beleza, sofisticação, civilização e progresso" (DELSON, 1997, p. 04). Nesse sentido, Reis (2000) aponta que em 1720 já era possível afirmar a efetiva geometrização dos tratados com características de regularidade e racionalidade. Com posicionamento semelhante, Maria Fernanda Derntl (2010) apontou que a adoção de padrões de traçado geométrico foi parte dos esforços da política urbanizadora que visava agilizar o trabalho de implantação e difundir determinada disciplina, organização e controle espacial. Todavia, a Coroa exerceu uma ação mais efetiva em locais onde havia o interesse em garantir a posse do território e onde os jesuítas - que seriam expulsos tinham constituído suas missões (RODRIGUES, M., 2010), o que não corresponde ao caso específico de São José do Rio Pardo que surgiu e se desenvolveu como patrimônio oficializado pela presença de um membro religioso.

Mas é interessante atentar para o processo de criação e desenvolvimento dos núcleos urbanos vizinhos à São José do Rio Pardo que certamente influenciaram essa cidade, como Caconde e Casa Branca. Segundo Rodrigues, M. (2006, 2010) que se empenhou em estudar a evolução urbana e o patrimônio rural de Casa Branca entre os anos de 1830 e 1900, esse município surgiu de um pouso que era conhecido como "Boca do Sertão", importante entroncamento de caminhos que seguiam em direção a Minas e Goiás. Em 1814 o povoado foi elevado a Freguesia através de um Alvará Régio e em 1872 se tornou Cidade. Ao analisarmos as características do traçado urbano casa-branquense, constatamos a sua regularidade e suas quadrículas ortogonais, além da organização ter acontecido em torno de uma praça que contém a igreja. Segundo Rodrigues, M. (2006) é plausível que o Regimento de $1747^{91}$ tenha definido o programa, o ordenamento e o traçado urbano para ali instalar açorianos, como aconteceu. Após a Independência do Brasil em 1822, foi promulgada a Lei de Organização Municipal (1828) que compôs um quadro de instruções que visavam padronizar o crescimento, a organização e configuração dos núcleos urbanos a partir da ação regulamentadora das prefeituras que na maioria das vezes compunham as posturas municipais (DELSON, 1997). Este pode ser considerado uma das questões que influenciou a prevalência das malhas urbanas ortogonais, e no caso de Casa Branca se somou as instruções do Regimento de 1747.

Já Caconde foi criada em 1775 como estratégia do governo de São Paulo para assegurar a posse do território dos novos descobertos auríferos e definir as fronteiras paulistas frente à atuação do governo de Minas Gerais na região ${ }^{92}$. Em 1864, Caconde foi elevada à Vila e na ausência de legislações mais consistentes, acabou por adotar o Código de Posturas de Casa Branca até o seu ser elaborado (CAMPANHOLE, 1979). Certamente, e sob a influência da urbanização de Casa Branca, prevaleceu uma clara intenção de ordenamento do traçado com desenho e quadrículas regulares.

\footnotetext{
${ }^{91}$ Segundo Delson (1997), as instruções do Regimento de 1747 "definiam o programa para cada nova comunidade criada para famílias açorianas, insistiam num traçado ordenado das ruas e elementos arquitetônicos. As instruções sobre o projeto das cidades eram detalhadas com maior precisão nessa legislação do que em qualquer lei de planificação de vilas". Era antes de tudo "um modelo de uniformidade e ordem" (DELSON, 1997, p. 45).

${ }^{92}$ Sobre o assunto ver Celeste (2010).
} 
Analisando o desenho urbano das atuais cidades circunscritas à região de Caconde no século XVIII e XIX e que surgiram do processo de urbanização do interior do Estado de São Paulo em meados do século XIX, como Mococa, São José do Rio Pardo, Tapiratiba, Divinolândia e São Sebastião da Grama, todas elas apresentam um traçado notadamente geometrizado que pode ter se resultado pela reprodução sistemática das instruções do Código de Posturas de Casa Branca e Caconde.

Mas apesar das questões levantadas, outras devem ser consideradas nesse processo. Nesse sentido, nos valemos do entendimento de Murillo Marx (1991) sobre a mudança na ordem legal que ocorreu em meados dos oitocentos que fez com que a terra passasse a ter um valor nítido de troca, o que exigiu um preciso parcelamento, marcação e medição dos limites exatos de frações e seus contornos. O autor (MARX, 1991) se referia à Lei de Terras de 1850, que apesar de início ter sido pouco respeitada, sobretudo no que diz respeito às formas de gerenciamento e atuação sobre a terra urbana, ela deu condições jurídicas para que a terra se tornasse uma mercadoria em negociação (ROLNIK, 2007). Outra questão que não podemos deixar de mencionar foi a publicação da Lei 1.237, de 24 de setembro de 1864, com regulamento n. 3453 , de 26 de abril de 1865, que tratava da reforma da legislação hipotecária e o estabelecimento das bases das sociedades de crédito real com a criação do Registro Geral de Imóveis. Segundo Garcia (2013, p. 219), a regulamentação dessa lei ampliou a perspectiva tradicional da expansão da frente pioneira para o oeste paulista na medida em que forneceu meios que garantia o título de propriedade, desdobrando-se na viabilização da obtenção de créditos para a lavoura cafeeira. No cerne dessa dinâmica estava a ampliação das formas de crédito, a expansão da economia cafeeira, a valorização da propriedade fundiária e a sua importância como variável econômica capitalista. Logo, a delimitação precisa do terreno se tornou fundamental na medida em que a ele foram atribuídos um preço e um registro privado (ROLNIK, 2007).

A acelerada ocupação conduzida pela produção cafeeira resultou na fundação de inúmeras cidades, como destaca Pierre Monbeig (1998), incluindo São José do Rio Pardo, o que exigiu, segundo Ghirardello (2010, p. 21), um "padrão de arruamento urbano fácil e rápido de ser executado". O resultado foi a implementação de soluções urbanísticas estereotipadas através da reprodução da quadrícula, que se tornou modelo para implantação e expansão dos patrimônios na capitania de São Paulo durante o Império (GHIRARDELLO, 2010). Mas havia ainda outros fatores que influíram no ordenamento geométrico de ruas retilíneas, como apontou Ghirardello (2010): a largura, a insolação e a ventilação, decorrências do "atendimento a questões de ordem sanitária, presentes nas discussões sobre a cidade naquele momento" (GHIRARDELLO, 2010, p. 119).

Certamente, todos esses fatores contribuíram na tomada de decisão do retalhamento urbano rio-pardense. Como enfatizado, São José do Rio Pardo foi fundada em 1865 quando já estava em vigor a Lei de Terras, mas foi através do patrimônio religioso que "nasceu" o povoado. O tenente Antônio Marçal Nogueira de Barros, liderando um grupo de fazendeiros, juntos procederam à doação de terras e se organizaram para pleitear a formação de um grupo solidário à construção da ermida, célula mater do núcleo populacional (TREVISAN, 1986), definindo-se significativamente e materialmente como espaço simbólico do nascente 
cenário urbano. Com isso uma centralidade estabeleceu a hierarquização física e social da ocupação ao redor da ermida. Portanto, a capela desde a sua concepção esteve circunscrita nas relações de poder e essa ação foi registrada na ata da Câmara Municipal de Caconde de 7 de novembro de 1868:

Foi proposto pelo Vereador Marçal que tendo ele, e outros, seus vizinhos, dado para um patrimônio a São José uma sorte de terras, aconteceu que para esse lugar tem afluído algumas pessoas para morar, e para que aquele lugar que naturalmente deve se tornar uma povoação não fique arruado com grande defeito como aconteceu em muitos lugares, entende ser de suma necessidade esta Câmara criar para ali um fiscal não só para a direção daquela povoação como para manter a ordem pública, e pondo o presidente em votação, então deliberou a favor da proposição acima. O mesmo Vereador Marçal indicou que estava no caso de servir naquele lugar o cargo de fiscal o cidadão João de Deus Araújo Lasbinio, o qual deverá servir cumulativamente o cargo de arruador, por se achar habilitado para um e outro cargo. E sendo aprovada pela Câmara o senhor presidente ordenou que se oficiasse para vir tomar posse. O mesmo vereador indicou que fosse demarcado para o novo fiscal da Capela de São José os seguintes limites: "Começando na estrada que vai desta Vila para a morada do Capitão Tomás, no lugar aonde faz limite com esta Vila, por esta estrada até a ponte do Rio do Peixe, e desta ao espigão mais alto entre a morada do cap. Tomás com o finado cap. Gomes, por este acima até a serra, e por esta a embicar no rio Fartura pelas divisas da Fazenda de Luís de Melo, daqui às divisas de Casa Branca". Sendo aprovada o senhor Presidente determinou que fosse levada esta medida ao fiscal da Freguesia do Espírito Santo do Rio do Peixe, bem como se dessa cópia dessa ao fiscal nomeado. Joaquim Alves Moreira, presidente, João Pereira da Silva, Antônio Marçal Nogueira de Barros, Antônio Bernardes de Oliveira, Joaquim Pereira da Silva. (ATA ..., 1868).

Nessa conjuntura, para o estabelecimento do procedimento de retalhamento urbano entrou em ação o trabalho do arruador João de Deus Araújo Lasbinio, nomeado pela câmara de Caconde ${ }^{93}$, que segundo Reis (2000, p. 120), representava "um esforço das municipalidades para controlar as mudanças que ocorressem em sua organização espacial". Isso porque, de acordo com esse autor (REIS, 2000, p. 120), as câmaras atuavam como órgão de administração de todas as "tarefas de controle dos mecanismos do crescimento urbano". Era através das posturas, principal lei a guiar a formação e manutenção das cidades e que exercia influência prática e amparo legal que a câmara manifestava a sua autoridade (REIS, 2000). Este foi o caso de São José do Rio Pardo, em que o Código de Posturas da Câmara Municipal da Vila de Caconde de 1866 ditou as diretrizes relativas ao traçado, largura e formato das ruas e largos, resultando na implantação da quadrícula como modelo de organização urbana, fácil de ser implantada e expandida. Apresentada nas disposições do primeiro capítulo,

Art. $1 .^{\circ}$ - Os arruadores desta villa e das povoações do município serão nomeados, juramentados e demittidos pela Câmara, terão a seu cargo o esquadro e alinhamento de todas as ruas e travessas das povoações, e serão obrigados a demolir e reedificar a porção do edifício que, por sua causa, ficar fora das regras estabelecidas.

Art. $2 .^{\circ}$ - Todas as ruas que forem abertas dentro da villa, e nas povoações de seu município terão a largura de sessenta palmos; e os largos que existirem serão quadrados, quando para isso houver possibilidade. (CÓDIGO DE POSTURAS, 1866, p. 248) (4. $^{9}$.

\footnotetext{
${ }^{93}$ A Câmara Municipal de Caconde indicou João de Deus Araújo Lasbinio, mas quem assumiu o trabalho de arruar e traçar as ruas fo i João Batista Blandim (DEL GUERRA, 2001).

94 Apesar de se tratar do Código de Posturas da Vila de Caconde, muitos dos seus artigos foram baseados e copiados do Código de Posturas paulistano de 1875 (Resolução n. ${ }^{\circ}$ 62). Observem a similitude dos artigos do código, a exemplo: "Art. 1. ${ }^{\circ}-$ Todas as ruas ou travessas que se abrirem nesta Cidade, e em outras povoações do Municipio, terão a largura de 13 metros e 22 centimetros, sal vo quando por algum obstaculo incencivel não fôr possivel dar-lhes esta largura. As praças e largos serão quadrados, tanto quanto o terreno o permitir". (CÓDIGO DE POSTURAS, 1975, p. 01).
} 
Logo as primeiras ruas foram abertas. O local de referência era a popularmente conhecida Várzea, caracterizada por um braço de terra localizado entre o córrego São José e o ponto de deságue do córrego das Macaúbas. Era nesse local que ocorria a paragem e eram realizadas trocas comerciais dos que seguiam rumo a Caconde e ao sul de Minas, e onde os animais da tropa descansavam sob a sombra e bebiam água. Um espaço singular de permanência da ocupação do espaço, que se ligou a uma região que ficava mais ao alto, menos íngreme e longe das áreas alagadiças e lamacentas que eram focos de moléstias. Foi na encosta, considerado local ideal por possibilitar maior salubridade em razão da boa ventilação e escoamento das águas pluviais que a capela foi construída, e o núcleo inicial traçado. É necessário considerar também que havia restrições da própria Igreja Católica relativa a instalação das capelas e igrejas, que conforme nos esclarece Marx (1991, p. 22), citando as Contituições Primeiras do Arcebispado da Bahia $^{95}$, determinava a construção em "sitio alto, lugar decente, livre de humidade, e desviado, quando possível, de lugares immundos, e sórdidos". Logo, a igreja, inicialmente estabelecida sob a subscrição dos moradores em uma eminência de terra, formou o Largo - constituíram local de central importância dos patrimônios religiosos - e atraiu moradores para as suas proximidades.

Em meados da segunda metade do século XIX, dizia João Batista Blandim que a Vila era um despovoado, com casas esparsas construídas precariamente, assinalando um principiar urbano bastante limitado, formado por apenas cinco quadras (DEL GUERRA, 2001) que foi paulatinamente ocupado, persistindo o mecanismo físico de concessão das terras do patrimônio religioso através do aforamento.

Toda a área ao redor da igreja pertencia à Irmandade que distribuía mediante a administração da Câmara a terra aos requerentes sob a condição do pagamento do foro anual. O aforamento se caracterizava por ser uma medida de cunho urbanístico tendo em vista que definia o tamanho do lote, e que, inclusive, detinha a prerrogativa de não conceder área excessivamente grande a uma só pessoa, a menos que o tamanho da edificação justificasse um terreno maior. As quadras foram traçadas de maneira uniforme aproximando-se da forma quadrada, mas não apresentavam as mesmas medidas. Analisando as cartas de aforamento, foi possível identificar uma tentativa de organização do espaço urbano a partir do estabelecimento das dimensões dos lotes, predominando a medida de 13,20 m de frente pela metade do comprimento da quadra. Essa dimensão correspondia à determinação do Código de Posturas (Resolução n. ${ }^{\circ} 04$, de 15 de março de 1882) de Casa Branca, a qual São José do Rio Pardo se subordinou após a sua elevação a Freguesia em 1875.

$\S 60$. Todos os proprietários de prédios no terreno do patrimônio de Nossa Senhora pagarão do aforamento annualmente um mil réis de cada data, assim como os que forem requerendo e obtendo as referidas datas, não podendo cada data exceder de 13,20. (CÓDIGO DE POSTURAS, 1882).

\footnotetext{
${ }^{95}$ Segundo Marx (1991), as Contituições Primeiras do Arcebispado da Bahia foram redigidas em 1707 e publicadas em 1719. "Normas que, conquanto atingidas em pontos cruciais - também para a configuração de nossas cidades - pela constituição política do império do Brasil, atravessaram todo o período monárquico e cujos últimos reflexos vieram morrer neste século, em plena república, pelo caráter laico que assumiu o novo Estado, pela evolução internacional e das práticas canônicas em toda parte". Para saber mais sobre isso, ver Rosada (2016). 
Um tipo de lote, demarcado de forma retilínea, com características bastante definidas, guardando na implantação das edificações uma relação com o urbanismo colonial, que segundo Reis Filho (2011, p. 32) tem sua origem no "urbanismo medieval-renascentista de Portugal", e que foi determinante no esquema arquitetônico adotado que avançava sobre o alinhamento frontal e os limites laterais, como veremos no item 1.4 deste capítulo. Notar também que apesar da despretenciosidade, foi reservada uma quadra para a capela e outra à sua frente para o Largo, estabelecendo a importância central de ambas na configuração e ordenação do espaço.

Com a elevação da Freguesia a Vila (1885-1886), o Estado, através da Câmara, pôde controlar a ocupação e o desenvolvimento do núcleo urbano, e de forma efetiva sem as prerrogativas eclesiásticas após a instauração do republicanismo, em 1889. Nesse meio tempo, outras providências foram tomadas, a mais importante delas foi a regulamentação do Código de Posturas da Villa de São José do Rio Pardo em 1887, que passou a reger a vida urbana rio-pardense. Dentre as normativas constavam os meios - e as obrigações - de acesso a essa terra:

Art. 120 - Ninguém poderá edificar nos terrenos municipais denominados de S. José, sem que tenha obtido da câmara título de venda ou aforamento. O infractor será multado em $30 \$$ e a obra demolida a sua custa.

Art. 121 - Os títulos de venda ou aforamento, serão passados pelo secretário da câmara, mencionando-se nelles o lugar aforado ou vendido, o número de metros e o preço do aforamento ou venda.

Art. 122 - O secretario terá um livro especial competentemente numerado e rubricado, em que averbará os títulos de fôro ou venda.

Art. 123 - O fiscal logo que forem apresentados esses títulos, irá com o arruador demarcar o lugar, notando no mesmo título a demarcação.

Art. 124 - Nenhum título de venda ou aforamento poderá conter mais que 13m,20 de frente com a fundura de metade da extensão do quarteirão ou conforme determinar a câmara, salvo se a edificação o fizer depender de maior terreno.

Art. 125 - O preço da transferência do terreno, nunca será menos de $4 \$$ por cada metro de frente, quando vendido, e na razão de 160 réis por anno de cada metro de frente, quando aforado.

Art. 127 - O producto das vendas e aforamento dos terrenos municipais serão cobrados nos fins de cada anno pela câmara e pela mesma applicado nas obras da egreja matriz.

Art. 128 - Todo o proprietário de prédio no patrimônio desta villa é obrigado a apresentar os respectivos títulos de compra ou aforamento ao empregado designado pela câmara para os devidos lançamentos e cobranças dos aforamentos, sob pena de multa de $10 \$$ por cada vez. (CÓDIGO DE POSTURAS, 1887, p. 24-25).

Além disso, o Código abordava o quadro físico urbano de maneira mais incisiva ao estabelecer as condições e obrigações que a atividade edilícia responderia, e também o tempo para construir após a aquisição do lote.

Art. 126 - Os que adquirirem ou possuírem terrenos municipais, a título de aforamento, deverão começar marcar o terreno, com dois esteios na frente, no prazo de três mezes, começar a edificação no prazo de seis, e concluir o edifício exteriormente ao menos na frente, no prazo de um anno, tudo a contar da data do título em diante, sob pena de reverter o mesmo terreno sem indenização alguma para o domínio municipal, embora já se ache numerado e com começo de edificação. (CÓDIGO DE POSTURAS, 1887, p. 25). 
Certamente essa medida provocou maior rapidez na construção, ordenamento e desenvolvimento da Vila. Principiou a ocupação ao longo das vias de maior fluxo e importância do núcleo ao redor do tempo religioso e do Largo do Mercado, onde aconteciam as trocas comerciais, e das estradas de ligação da Vila a outros centros urbanos, como Caconde a leste, Casa Branca a sul, e Mococa a oeste.

De maneira conjunta, todas as questões levantadas de certa forma influenciaram e contribuíram para sanar as peculiaridades locais e alcançar os ensejos pela constituição de um núcleo urbano independente, conformando a São José do Rio Pardo.

Passados anos da fundação, o núcleo inicial se estabeleceu consolidado com a construção da Casa de Câmara e Cadeia (atual Museu Rio-pardense Arsênio Frigo) no Largo da Matriz em 1886. Em 1887 com a construção da Estação e da estrada de ferro, o crescimento urbano rompeu os seus limites se estendendo colina abaixo, nas proximidades ao chamado Largo da Estação (hoje Praça Tiradentes).

O interesse e a atuação, particularmente da elite agrária, foram determinantes para o desenvolvimento de São José do Rio Pardo, evidenciando que suas ações não se restringiram apenas à agricultura posto que essa gente procurou expandir seus negócios através dos serviços urbanos, como visto no tópico 1.3. Ademais, os limites entre poder público e privado eram tênues uma vez que eram eles próprios que comandavam a Câmara Municipal, os trabalhos de administração, coleta de dinheiros, construções e demais serviços necessários para dotar a Vila de infraestrutura necessária que pudesse prover um quadro urbano favorável ao comércio e serviços ${ }^{96}$. E foi após a implantação da ferrovia, em 1887, que a cidade adquiriu dimensões mais respeitáveis e incorporou novos padrões de sociabilidade, como pode ser percebido através minuciosa da descrição realizada em 1887 por Aprígio Cesarino, repórter do "Diário Popular" de São Paulo:

Esta florescente e nova localidade dista de Casa Branca 35 quilômetros e 9 da Estação de Engenheiro Gomide, presentemente ponto terminal do ramal que começa naquella cidade e termina no rio das Canoas, passando por Mococa.

A villa está situada em logar elevado e bastante accidentado, à margem esquerda do rio Pardo, onde este rio descreve uma curva.

Os horizontes não são vastos; limitamos logo montanhas que se elevam de todos os lados; em compensação, porém, o rio, que não é pequeno, e muitas bonitas edificações dão um aspecto agradável à villa.

A villa conta 4 alfaiatarias, 2 padarias, 2 selarias, 2 funilarias, 1 casa de bilhares, 2 barbearias, 3 sapatarias, 2 marcenarias, 5 ferrarias, 2 hotéis, 2 pharmacias, 1 atelier de photographo, 1 dito de retratista a óleo, 3 restaurants, 2 fábricas de cerveja, 12 negócios de fazendas, muitos de seccos e molhados cujo número não pude precisar, 2 cocheiras, 2 açougues, 1 relojoeiro, mais de 9 olarias, sendo uma a vapor.

Em todo o município há 123 casas de negócio que pagam imposto; os da população são em número de 72.

Existem 11 ruas, 4 praças e 1 bom edifício térreo que serve de cadeia e onde funciona a Câmara Municipal, sendo também digna de menção a estação do Ramal do Rio Pardo. (CESARINO apud SÃO JOSÉ..., 2015, p. 02).

\footnotetext{
${ }^{96}$ Sobre a formação do patronato político brasileiro e as suas formas de manutenção, ver Leal (1976) e Faoro (2012).
} 
Salvo os enaltecimentos corriqueiros neste tipo de circunstâncias, Cesarino forneceu informações sobr o ritmo e também o aspecto das construções que eram

[...] em geral de tijolos e há muitas bem elegantes, sobresahindo o palacete de Honório Dias, um lindíssimo sobrado que poderia ser destacado mesmo em uma grande cidade. Há seguramente de 40 a 50 prédios em obras, o que quer dizer que a villa cresce com extraordinária rapidez. (CESARINO apud SÃO JOSÉ..., 2015, p. 02).

Porém o repórter enfatizou seu desapontamento no que concerne ao porte e aparência da igreja, descrevendo-a como um "pequenino pardieiro, que está cahindo em pedaços", mas ressalta a expectativa dos munícipes na construção de uma igreja "decente" após ser lançada, em fevereiro (1887), a primeira pedra no lugar onde a mesma iria ser construída. Sua descrição ainda segue com minucioso destaque para as condições das ruas, instruções públicas, assistência médica, e produção cafeeira:

Os lampiões da illuminação pública já foram collocados nos devidos logares, mas até agora anda-se pelas ruas, algumas bem esburacadas, às apalpadellas nas noites escuras, por falta absoluta de luz, pois ainda nenhum lampeão foi aceso.

Fornece-se a instrucção primária em 2 escolas do sexo masculino, uma pública e outra particular; e não há nenhuma para meninas, pois a que existia fechou-se com a retirada da professora e não foi de novo provida a cadeira.

Os médicos são em número de 4 e advogados formados de 2; existe também 1 dentista. A lavoura de café está em escala ascendente e calcula-se a colheita do precioso grão em 200.000 arrobas. Tratando-se de uma lavoura nova, já é uma safra auspiciosa. (CESARINO apud SÃO JOSÉ..., 2015, p. 02).

Por fim, Aprígio Cesarino manifestou sua expectativa quanto ao engrandecimento e desenvolvimento de São José do Rio pardo, que com "todo o espírito observador" deveria ser, em breve

uma lindíssima cidade, de bastante movimento commercial, pois dispõe de elementos sufficientes para futuramente colocar-se a par dos bons centros de actividade de nossa província.

Tenho percorrido muitos municípios paulistas e adquirido certo espírito de observação, eis porque não receio emittir juízo acerca do grau de adiantamento ou atrazo deste ou daquelle.

Na minha opinião, a S. José do Rio Pardo está reservado um bonito futuro e não se pode esperar menos de um município cujas terras são ubérrimas e cujos habitantes, na sua maioria, progressistas, laboriosos e intelligentes, trabalham incansavelmente não só em prol do seu bem-estar como da collectividade, procurando abrir novos horizontes, afim de que dentro em pouco entremos no goso de maior somma de liberdades públicas que só a República nos pode dar. (CESARINO apud SÃO JOSÉ..., 2015, p. 02).

Malgrado a ausência de dados mais consistentes como mapas, plantas cadastrais, fotografias, projetos arquitetônicos, e dados estatísticos (população, economia e educação) sobre esse período do desenvolvimento urbano rio-pardense, foi encontrado significativa quantidade de registros e cartas de aforamento que foram compilados (Anexo 04 e Apêndice 04$)^{97}$. A sistematização deste material se oferece para complementar a descrição acima, possibilitando compreender aspectos muito importantes da constituição do núcleo inicial de ocupação, como pode ser visto na Figura 47, restringindo-se até o ano de 1889.

\footnotetext{
${ }^{97}$ Uma das cartas, a título de ilustração do tipo de documento, pode ser conferida no Anexo 04 . E no Apêndice 04 é possível ver listagem com informações sobre aforeiros, a localização e a dimensão da testada do lote, quem ou quais eram as confrontações e a exist ência de prédio edificado.
} 


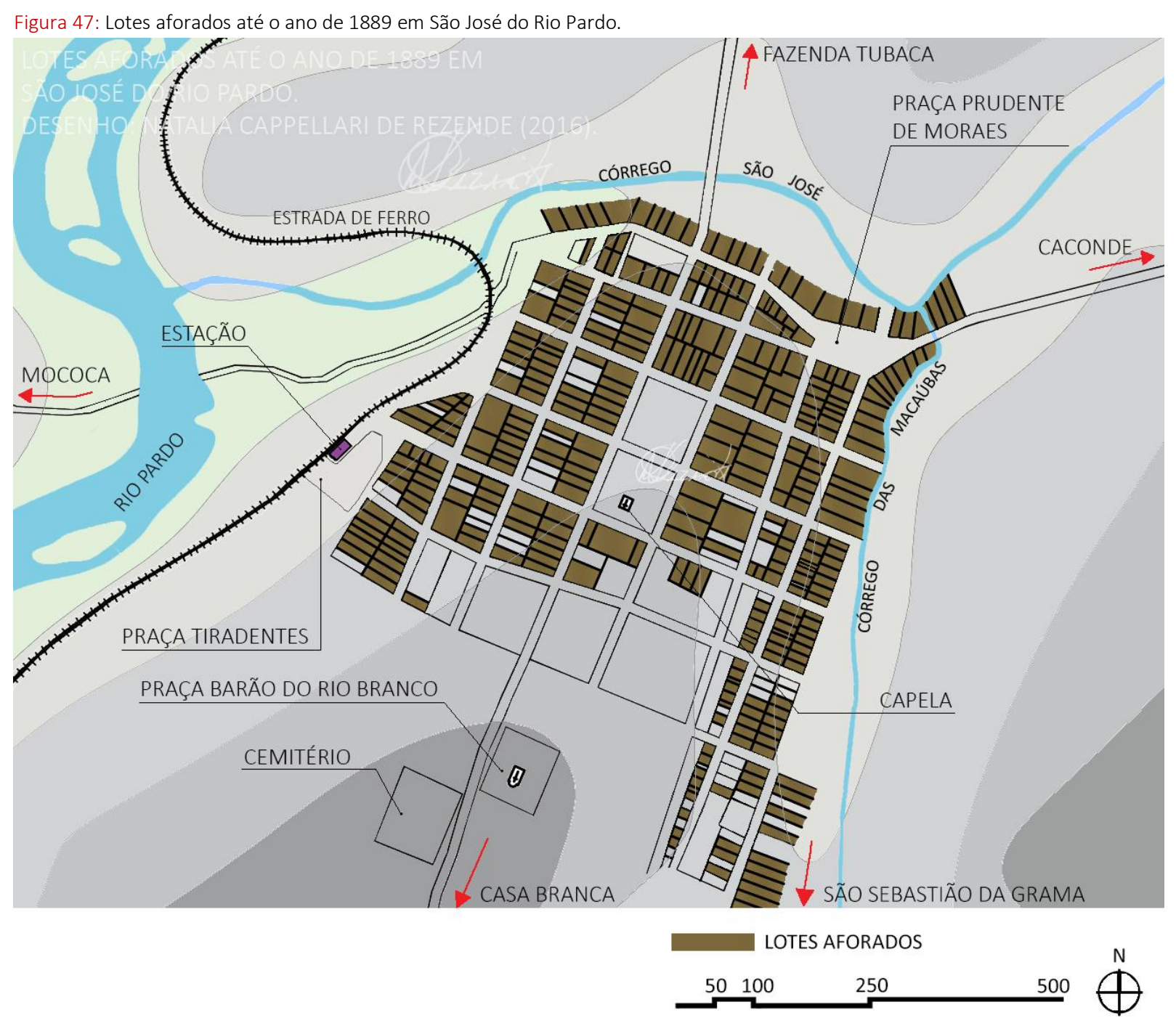

Desenho: Natalia Cappellari de Rezende (2016) com base em dados históricos e cartografia disponibilizada pela Secretaria de Obras de São José do Rio Pardo.

Esse aspecto urbano alcançou os primeiros anos do século XX com significativo adensamento populacional fruto da nova conjuntura social - abolição escravocrata e chegada de imigrantes -, econômica - produção cafeeira e início da industrialização -, e política - República. Este fato evidenciou, sobretudo a carência de moradias e o inchamento da cidade, provocando a expansão das suas dimensões físicas. Pela sua formação, os arruamentos definidos estavam completos (ver Figura 34 na página 81) e novas ruas foram abertas e outras tiveram seus nomes alterados por personagens e símbolos republicanos, como é possível observar no Apêndice 05. Um processo compreendido como um momento político importante que teve o espaço urbano como ancoradouro das mudanças, às vezes sutis, mas que refletiram as pretensões do período.

Simbólico ou não, dentro do léxico republicano o espaço citadino foi imerso em elementos metafóricos que atestavam a centralização do poder. A aspiração a uma modernidade se translada também para os espaços e suas denominações, a construção de monumentos e a alteração do significado do largo enquanto espaço 
de domínio eclesiástico para praça e jardim como um símbolo cívico. Na base dessa compreensão, analisamos o processo de construção urbana de São José do Rio Pardo a partir das suas ruas e praças.

No sentido leste oeste do núcleo:

a Rua da Direita que teve sua denominação alterada para Avenida Rangel Pestana (atual Rua José Andreoli) seguiu o prolongamento da estrada de ligação do núcleo urbano com o sul de Minas e a cidade de Caconde. Esta rua configurava o limite do núcleo urbano de ocupação no sentido norte, cerceado pelo córrego São José, transposto unicamente pela Avenida Américo de Campos (antiga Rua do Carmo e atual Rua Francisquinho Dias) que seguia em direção ao Cemitério Municipal com uma bifurcação que direcionava para a fazenda Tubaca;

a Rua Boa Vista cognominada de Avenida Marechal Deodoro (atual Rua Marechal Deodoro) teve a sua extensão até o córrego São José autorizada em 05 de fevereiro de 1895. O limite em um corpo d'água evidencia a esquiva em termos econômicos e técnicos da administração local em sua transposição. Ao mesmo tempo, demonstra a importância da água como fator determinante para a manutenção do núcleo urbano, dada a ausência de redes de abastecimento de água;

Essas duas ruas tornaram-se, após a construção da linha férrea e da estação, as mais movimentadas do núcleo urbano. Era através delas que o tráfego de carroças e carros de boi, carregados de sacos de café e outras mercadorias, chegavam e saiam da Estação em direção à Caconde e ao sul de Minas. Não por acaso, a Rua José Andreoli foi caracterizada pela construção de armazéns;

a Rua do Ipiranga teve seu nome alterado para Rua Ananias Barbosa ${ }^{98}$, e foi prolongada no sentido leste até o córrego das Macaúbas, e no sentido oposto, o limite foi a Rua da Floresta, denominação modificada para Avenida Campos Salles (hoje Rua Campos Salles), que margeava na sua extremidade norte a estrada de ferro;

a Rua da Imperatriz cognominada de Rua Marechal Floriano, seguiu o mesmo destino da Rua Ananias Barbosa, ambas foram estendidas até o corpo d'água que se configurou como barreira e limite de crescimento do núcleo urbano naquele momento;

a Rua da Cadeia então denominada de Rua Saldanha Marinho (atual Rua João Gabriel Ribeiro), teve sua ocupação consolidada com a construção da Casa de Câmara e Cadeia, e mais tarde com o retalhamento do Curral do Conselho. Viu sua extensão ser prolongada com a construção da Estação no Largo da Estação (denominada atualmente de Praça Tiradentes) a oeste do núcleo. Foi constantemente criticada pela declividade de $9 \%$ o que muito dificultava o tráfego, e por inúmeras vezes necessitava de concertos para evitar os sulcos que os carroções abriam nos constantes vai e vem do transporte de mercadorias que abasteciam a Vila. A movimentação nessa rua contribuiu para que ao longo dela inúmeros estabelecimentos comerciais e de serviços fossem criados, como hotéis, bares, e lojas de ramos diversos;

\footnotetext{
${ }^{98}$ Ananias José Ferreira Barbosa, natural de Barra Mansa (RJ), se mudou para São José do Rio Pardo no final do século XIX, inaug urando em 1887 o Hotel Brasil, palco do movimento republicano rio-pardense.
} 
a Rua da Estação nomeada de Avenida Ruy Barbosa (hoje Rua Ruy Barbosa), diferenciava das demais pela leve distorção na sua trajetória retilínea o que evidencia a falta de rigor no alinhamento executado pelo arruador. A extensão leste dessa rua esbarrou no talude criado para a construção da Estação e do Largo do Estação, onde anos mais tarde foi construída uma escadaria de acesso à Avenida Belmonte (denominada atualmente de Rua Nove de Julho);

a rua autorizada a abrir em 2 de dezembro de 1899 para ligar o Largo da Estação com a Avenida Campos Salles, foi prolongada e denominada de Coronel Marçal. Foi inicialmente ocupada em consequência da proximidade com a estação, todavia, o temor pela iminência com o antigo cemitério fez com que poucas edificações fossem construídas nessa rua até a primeira década do século XX.

No sentido norte-sul do núcleo:

as ruas do Carmo e Conceição que tiveram suas denominações alteradas para Avenida Américo de Campos (hoje Rua Francisquinho Dias) e Avenida Francisco Glicério (atual Rua Francisco Glicério) constituíram os arruamentos principais, e foram primeiramente ocupadas garantindo a função do patrimônio religioso. Ambas foram caracterizadas pela ocupação e construção de moradias das personalidades de maior poder econômico e político local, salvas exceções;

a Rua do Comércio nomeada de Avenida Benjamin Constant (atual Rua Benjamin Constant), diferentemente das demais, apresentava um relevo mais suave, de pouco aclive. Iniciada a partir do Largo do Mercado (hoje Praça Prudente de Moraes), de onde proveio sua denominação e característica comercial, foi prolongada na direção sul do núcleo;

a Rua das Flores intitulada de Avenida Silva Jardim surgiu como prolongamento do Largo do Mercado, e por esse motivo, o início da sua ocupação foi caracterizado pela construção de edificações de uso misto, comércio nos cômodos dianteiros e moradia nos fundos. A importância dessa rua residia ainda na sua proximidade com as águas do córrego das Macaúbas, essencial para a viabilização das atividades domésticas, fator que contribuiu para o seu delineamento e ocupação. Essa questão pode ser evidenciada através do traçado dos lotes das duas primeiras quadras, caracterizados pela ampla extensão que se findava somente no encontro com o córrego. Embora a proximidade com as águas fosse real, inexistia o perigo de alagamento dada a declividade do terreno;

a Rua Nova, então Rua José Theodoro, surgiu no sudeste do núcleo, abaixo da Avenida Silva Jardim. Inicialmente ocupada esparsamente com casas de sapé foi prolongada até a viela do Buracão que seguia o aclive do terreno e ligava-se à Avenida Benjamin Constant, a partir dessa junção, o traçado acompanhava a estrada na direção de São Sebastião da Grama; 
a Rua da Esperança nomeada de Rua Beneficência Italiana (hoje Rua Treze de Maio), totalmente delineada foi prolongada até as proximidades do cemitério. Foi caracterizada pela construção de edificações de uso misto, ocupadas principalmente por turcos que investiram na atividade comercial ${ }^{99}$;

a Rua da Floresta teve sua denominação alterada para Avenida Campos Salles. Por ser rota de travessia dos carroceiros que vinham de Caconde, esta rua se caracterizou pela construção de armazéns.

Nessa época, o centro urbano contava com quatro largos que tiveram suas denominações alteradas, eram eles:

o Largo do Mercado denominado de Praça Prudente de Moraes era um braço de terra localizado entre o córrego São José e o ponto de deságue do córrego das Macaúbas. Popularmente conhecida como Várzea, era o local de paragem dos que seguiam rumo ao sul de Minas e Caconde. Foi neste espaço que os "produtores rurais comercializavam o que produziam, com grande barulho e movimentação [...]" (DEL GUERRA, 2001, p. 344). A importância desse local é evidenciada pela sua integração à malha urbana e na permanência de sua ocupação.

o Largo da Estação por sua vez foi nomeado de Praça Tiradentes foi totalmente delimitado pelos edifícios da Estação e do armazém, e se conformou como um descampado, livre de vegetação, com um bebedouro de água para animais e espaço para estacionamento dos carros da Estação e demais meios de locomoção de mercadorias e pessoas. De pronto, tornou-se um local de referência na malha urbana, atraindo para as suas proximidades estabelecimentos comerciais e de serviços.

o Largo da Matriz então denominado de Praça XV de Novembro era de início um espaço ermo, mas de atração para a formação do núcleo habitacional. Após a República se transformou rapidamente em um jardim cívico, arborizado e assepsiado, símbolo da organização e do embelezamento que se desejava.

o Largo do Rosário marcado a princípio pela construção de uma capela de sagração aos mortos, foi posteriormente denominado de Praça Barão do Rio Branco, conformando-se a algumas quadras do Largo da Matriz e nas proximidades do cemitério, o que conferia a essa praça desprezo e distanciamento da população;

Conforme descrito acima, as ruas e ladeiras foram surgindo de forma análoga, acompanhando o traçado viário estabelecido e o relevo local. O núcleo urbano se expandiu principalmente na direção sul onde a topografia, sem tantos declives e aclives, favorecia a implantação de edificações; e na direção leste se limitando ao córrego Macaúbas onde sua transposição conferia um obstáculo, mas ao mesmo tempo, a proximidade das edificações ao curso d'água era satisfatório e eficiente em um momento de inexistência de instalações sanitárias e hidráulicas. A oeste do núcleo urbano estava a Estação e o Matadouro que foi removido a pedido do engenheiro Euclides da Cunha para abrir caminho para a construção do pátio de obras da notória ponte metálica (DEL GUERRA, 2010).

\footnotetext{
${ }^{99}$ Segundo Clara Alves Z. Garcia e Phelomena Stivalle Capellari os principais comércios da Rua Treze de Maio eram de turcos, os quais se mantiveram pelo menos até a década de 1960.
} 
Salientamos ainda que as causas da transferência do Matadouro não se deram apenas por uma exigência desse espaço físico, certamente estava atrelada à noção simbólica de feiura e insalubridade pouco desejosa de estar associada às proximidades da Estação, que por vezes assumiu o papel de porta da cidade, e justamente por este motivo deveria se apresentar ao visitante como um espaço agradável, perfumado e embelezado. Essas características, somadas à movimentação de pessoas, foram responsáveis por atrair para as proximidades hotéis e restaurantes delineando a abertura da Avenida Belmonte prolongada ao encontro de uma estrada rural até a Fazenda Monte Bello.

A ponte construída a poucos metros da Estação proporcionou a ligação do núcleo urbano com as terras à margem direita do rio Pardo através da Avenida Euclides da Cunha (Figura 48). Por conseguinte, a expansão da malha seguiu nessa direção fazendo surgir o Bairro Santo Antônio - onde havia a fazenda Açudinho caracterizado pela ocupação operária e de imigrantes com rendimentos moderados ${ }^{100}$. As poucas ruas e quarteirões abertos seguiram o traçado da estrada que rumava para a cidade de Mococa.

Figura 48: A abertura da Avenida Euclides da Cunha, década de 1910.

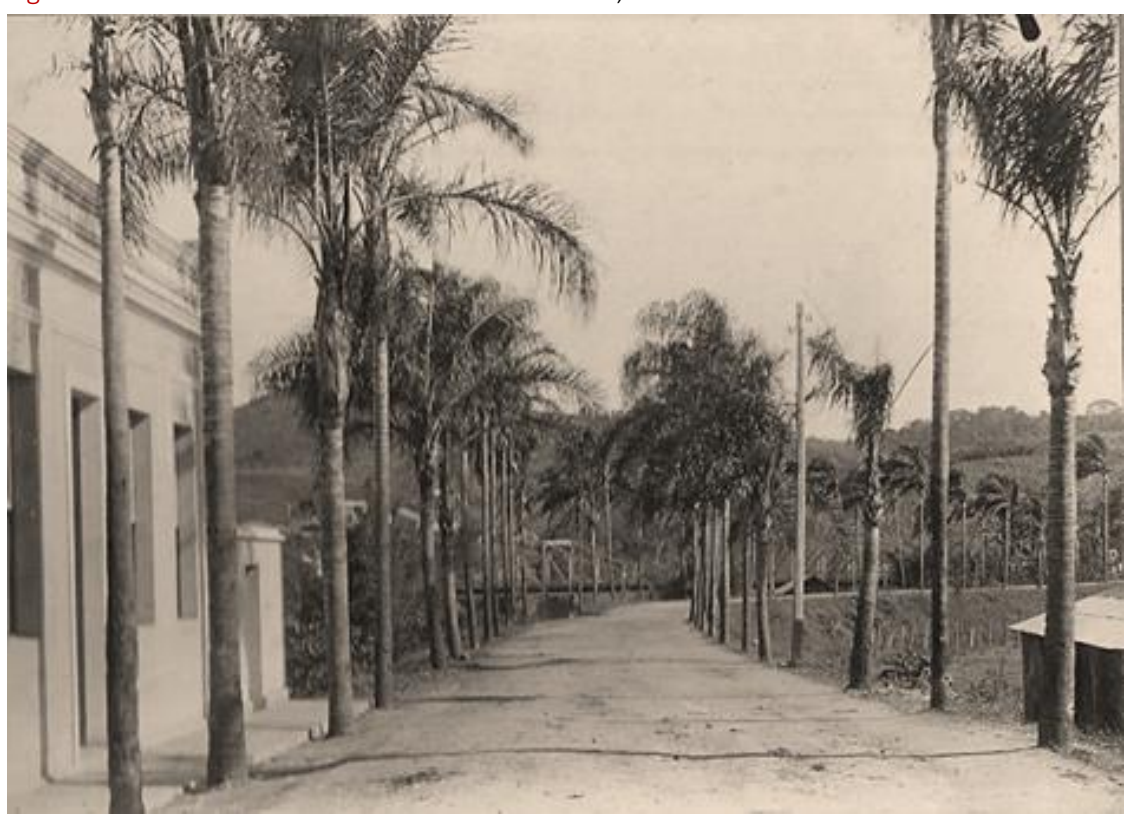

Fonte: Arquivo da Hemeroteca Jornalista Paschoal Artese. Fotografia de Innocencio Vilhegas.

Formando um eixo de expansão no sentido leste-oeste, a ocupação insipiente ao longo do caminho que ligava São José do Rio Pardo ao entorno rural e com Caconde, se intensificou e surgiu o Bairro Bonsucesso. No dia 03 de julho de 1899, foi registrada na Ata da Câmara a denominação dessa rua que comunicava o núcleo urbano a este bairro, de Rua Coronel Estevam Marcolino (hoje Rua Siqueira Campos).

\footnotetext{
${ }^{100}$ Alcides Tiezi nos informou que o bairro Santo Antônio era considerado periferia em função da distância da área central da cidade e também pela condição econômica miserável dos moradores. 
Iniciou-se assim a formação dos bairros adjacentes (Figura 49) caracterizados pela ocupação de operários com baixos rendimentos que não encontravam espaço e condição para se estabelecer nas vertentes mais valorizadas e próximas ao patrimônio religioso.

Figura 49: Mapa de São José do Rio Pardo mostrando a formação de bairros adjacentes ao núcleo urbano e o nome das ruas, 1899.

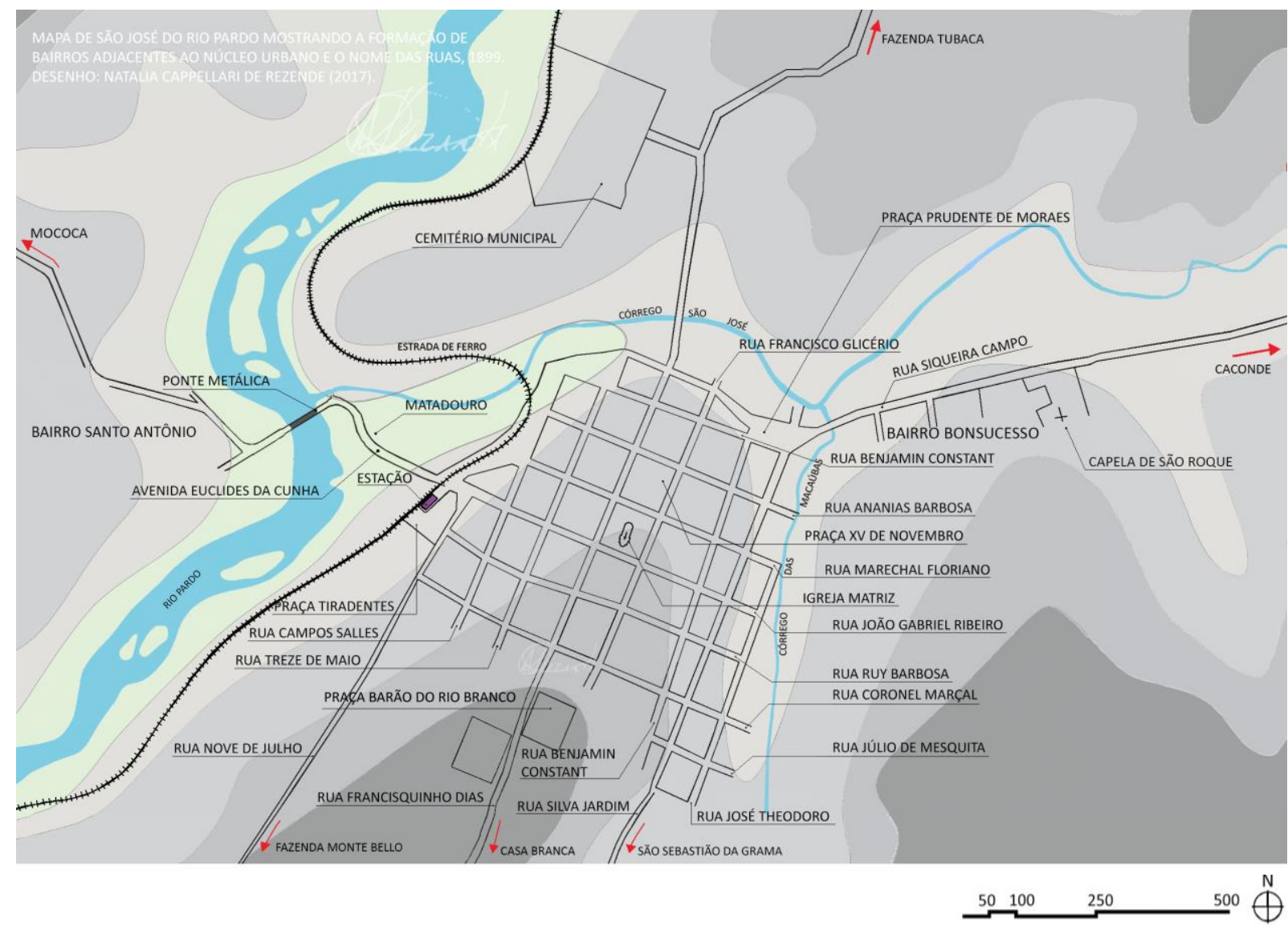

Desenho: Natalia Cappellari de Rezende (2017) com base em dados históricos e cartografia disponibilizada pela Secretaria de Obras de São José do Rio Pardo.

O crescimento das atividades comerciais, industriais e de serviços realizadas na zona urbana ensejou a fixação das pessoas nessa área. Contudo, acreditamos que inicialmente a ocupação não ocorreu de forma regular e organizada, e muitas vezes as construções interrompiam o traçado linear das ruas. Encontramos nas cartas de aforamento diversas situações que mencionavam as edificações fora do alinhamento, o que se explica pela ausência de um projeto urbano, configurado aos poucos de acordo com os códigos de Posturas. Ademais, o controle e fiscalização exercido ora por Caconde, ora por Casa Branca e ora pela Câmara Municipal local pode ter contribuído com essa questão.

Segundo as análises realizadas por Bortolucci (1991, p. 30) na cidade de São Carlos e que muito serve para compreender o que ocorria em São José do Rio Pardo, a fixação da população na cidade se explica tanto pelo desejo de "usufruir dos serviços e benefícios, como aqueles que exerciam estas atividades, originando, 
consequentemente, a ampliação e a diversificação das relações urbanas". Esta autora (BORTOLUCCI, 1991) considerou ainda "o fato de que, nas cidades, as 'barreiras eram mais facilmente transponíveis' para os imigrantes atingirem suas aspirações de sucesso do que na lavoura" (BORTOLUCCI, 1991, p. 30). Certamente este foi o caso de São José do Rio Pardo que em 1899 (Anexo 05) , $^{101}$ "das $536^{102}$ casas relacionadas, até mesmo as do "subúrbio", das "chácaras", e do "arrabalde"103, 251 eram ocupadas por moradores com sobrenomes italianos ${ }^{104 ”}$ (DEL GUERRA, 2004a, p. 23). Segundo este autor (DEL GUERRA, 2004무),

haviam ruas, praças e arrabalde com nenhuma, ou pouquíssimas famílias de imigrantes, como o Bom Sucesso, com 19 casas, sem nenhum italiano; a Praça Tiradentes, com 23 casas e apenas com 4 moradores italianos; das 51 casas da Campos Sales, apenas 12 eram alugadas ou pertenciam a estrangeiros... Em compensação, em outras ruas predominavam os italianos: das 40 casas da Francisco Glicério, 33 eram de moradores italianos, bem como predominavam nas ruas Benjamin Constant, Rua Nova [hoje Rua José Theodoro], Marechal Deodoro, Silva Jardim, Coronel Marçal, Buracão [hoje Rua Paraíso), Rui Barbosa... No centro da cidade, Praça XV de Novembro, moravam 3 famílias estrangeiras entre 14 nacionais. Eram eles: Laura Braghetta, que em 1889 adquiriu um fundo de negócios e a casa no 7 de uma família síria; Luiz Ayello, casa no 2: Hotel Paulista; e Lourenço Fornari, casa 25. Os outros moradores da Praça eram: Maria C. Ribeiro, Dr. José Rodolpho Nunes, José Gonçalves S. Queiroz, Luiz Thomaz de Andrade, Saint-Clair Andrade Junqueira, João Octaviano Ribeiro, Antonio S. Souza Nogueira, Joaquim Custódio Dias, José Jorge Nogueira, Francisco Soares de Camargo, João Baptista Junqueira, José Theodoro Nogueira de Noronha, Órphãos Lima e Raphael Raphael. Em 1900, mais uma casa é acrescentada à relação: a do padre Joaquim Ancassuerd. (DEL GUERRAa, 2004, p. 23).

Indubitavelmente, ter casas de aluguel foi um negócio rentável visto que dos 565 edifícios, 312 eram alugados, o que significa $55,22 \%$ do total.

Nesta configuração urbana, muito próximos das casas da elite rio-pardense, estavam as pessoas que possuíam baixas condições econômicas, as casas comerciais, as escolas, os hotéis, as pequenas fábricas e os bordéis. Era uma mistura de grupos sociais, usos, odores, sons, estéticas e interesses distintos que muito incomodava a elite local. Fundado na preeminência atribuída à ordem sanitária em seus aspectos físicos e simbólicos, o núcleo urbano rio-pardense tinha que ser saneado e embelezado em todos os aspectos. A sujeira física e a higiene da cidade foram aos poucos extrapolando a ordem material, as condições das ruas, praças, passeios (calçadas) e edifícios para a ordem social, da mistura dos diferentes estratos sociais, e do perigo que essa situação poderia ocasionar na ordem pública. O jornal O Rio Pardo publicou uma série de editoriais condenando a existência de "conventículos" (prostíbulos e bordéis) próximos à igreja Matriz. Os

\footnotetext{
${ }^{101}$ No primeiro ano de circulação do jornal O Rio Pardo foi publicado o lançamento do imposto predial da cidade de São José do Rio Pardo. A listagem trazia o nome do devedor com o respectivo endereço (rua e número), valor locativo mensal, imposto anual, e se a edificação era própria ou alugada. Felizmente, dos 5 números publicados, 4 foram encontrados em bom estado de leitura. As listas se encontram no anexo 05.

${ }^{102}$ Esta contagem foi feita através do nome do responsável do pagamento do imposto predial e não por edificação, que no caso soma 565.

${ }^{103}$ Apesar de a listagem trazer as denominações de "subúrbio", "chácara" e "arrabalde", inexistia essa definição enquanto espaço físico delimitado em São José do Rio Pardo, logo inviabiliza análise mais acertada de suas localizações.

${ }^{104}$ Del Guerra se empenhou em pesquisar quem eram as famílias de imigrantes que se estabeleceram em São José do Rio Pardo, para isso ele recorreu além dos registros de nascimento, casamento e óbito da Igreja Matriz, os arquivos dos principais clubes italianos como a Società di Mutuo Soccorso 20 Settembre, o clube maçônico Loja "União Universal", "Clube Socialista dos Operários" e o "Clube Democrático Internacional Filhos do Trabalho".
} 
trechos $^{105}$ a seguir exemplificam a suposta preocupação com a "decadência" e "imoralidade" de São José do Rio Pardo e dos rio-pardenses por aceitarem a proximidade destes lugares.

Em um ponto central da cidade, na rua Benjamin Constant, fomos informados por pessoa fidedigna, de que existe um conventículo abominável pela devassidão de seus habitantes [...]. É uma escola repelente para ainda descuidadas crianças que constantemente ali se encontram brincando e ouvindo frases indecorosas e palavras de baixo calão. (MORALIDADE...1899 apud DEL GUERRA, 2004b, p. 120).

[...] o conventículo, que ofendendo o pudor público e respirando a máxima devassidão, achase aberto em uma das ruas centrais desta cidade - a Benjamin Constant. Protestamos pelas providências necessárias [...]. É assim que no coração da cidade, bem no largo da Matriz, muito próximo à cadeia pública, vivem airadamente mulheres sem a mínima noção de decoro e com grandissíssimo despejo, exibindo-se, seminuas, não raro, pelas portas entreabertas, e muitas vezes palrando, assentadas nos passeios, com homens de moralidade mais que relaxada! É o cúmulo da imoralidade! E isto revolta a boa educação, deprime o bom conceito em que nossa cidade é tida no Estado, degrada a nossa civilização. Protestamos mais uma vez por providências [...] não só para essa desafronta como também para livrarmo-nos do trabalho de exibir, pela imprensa, as imundícies da rua Silva Jardim, ironicamente chamada - das Flores, onde os mais vergonhosos vícios, o jogo, a depravação, o desbragamento, a bebedeira pompeiam libérrimos em bordéis infectos! (MORALIDADE...1899 apud DEL GUERRA, 2004b, p. 120-121).

Chamamos a atenção da polícia para uma casa de mulheres alegres, à rua Rui Barbosa, onde costumam alguns moços reunir-se, perturbando não só o sossego público como ainda trazendo as famílias vizinhas em constantes sobressaltos com tiros que partem da referida casa. (MORALIDADE...1899 apud DEL GUERRA, 2004b, p. 122).

Mas, sem sombra de dúvidas, o Palácio de Naná, o mais rico prostíbulo construído distante aproximadamente 500 metros da igreja Matriz - para os lados do velho cemitério - a mando dos ricos coronéis do café era pouco denunciado. Ao lado do conservadorismo dos velhos padrões e moral puritana estava a satisfação pela inauguração do local que movimentaria e mudaria a rotina de reuniões e encontros dos coronéis. Segundo descrição publicada por Del Guerra (2005a, p. 119), tudo no sobrado, apelidado de Palácio $^{106}$, do final do século XIX "era estrangeiro, de muito bom gosto: piano, móveis, tapetes, cortinas, lustres, pinturas a óleo e aquarelas, esculturas, louças e cristais, roupas de linho e bordados...". O Palácio de Naná funcionou até 1903 quando as "meninas dos coronéis" decidiram fugir da epidemia de febre amarela.

Tanto quanto as denúncias acima, existiam outras descrições com teor crítico e intolerante à mistura de usos considerados incompatíveis com a salubridade e embelezamento. Recorrentemente essa situação era associada aos territórios de pobreza e promiscuidade que ameaçavam não apenas a saúde pública, mas também a ordem econômica. A solução era a coerção e a expulsão para as margens do núcleo como aconteceu com o cemitério, lazareto, matadouro e prostíbulo, e que logo não tardou a chegar às habitações dos pobres a exemplo do que ocorria na capital do estado (RIBEIRO, M., 1993). Era necessário expandir a malha urbana, evitar o adensamento e a proximidade dos diferentes, controlar as atividades consideradas insalubres e organizar o espaço de modo a garantir uma favorável circulação física e produtiva. A cidade

\footnotetext{
${ }^{105}$ Devido à perda de vários editoriais do ano de 1899, tomamos a decisão de colocar alguns trechos transcritos por Del Guerra.

${ }^{106}$ A denominação Palácio evidência o refinamento que algumas construções rio-pardenses possuíam, e o que nos chama a atenção pela sua significância é atribuir esse termo para um bordel.
} 
começava a se encaixar na dinâmica da nova ordem e se apresentar como uma entidade imóvel. Novas ruas foram abertas como a Júlio de Mesquita em 1899, e outras vielas deram lugares a avenidas "bonitas e elegantes", como a rua denominada Buracão (hoje Rua Paraíso), na saída para a povoação de São Sebastião da Grama (MELHORAMENTOS..., 1899, p. 01).

$\mathrm{Na}$ ausência de mapas urbanos da época, o projeto cadastral desenvolvido pelo Departamento de Água e Esgoto da Capital e assinado por Theodoro Sampaio ${ }^{107}$ em 1901 para a construção das redes de abastecimento de água e coleta de esgoto, talvez seja, segundo Menechino (1986), o primeiro registro urbanístico de São José do Rio Pardo, como pode ser observado na Figura 50.

Figura 50: Planta cadastral (1901) elaborada para compor o projeto de abastecimento de água e coleta de esgoto.

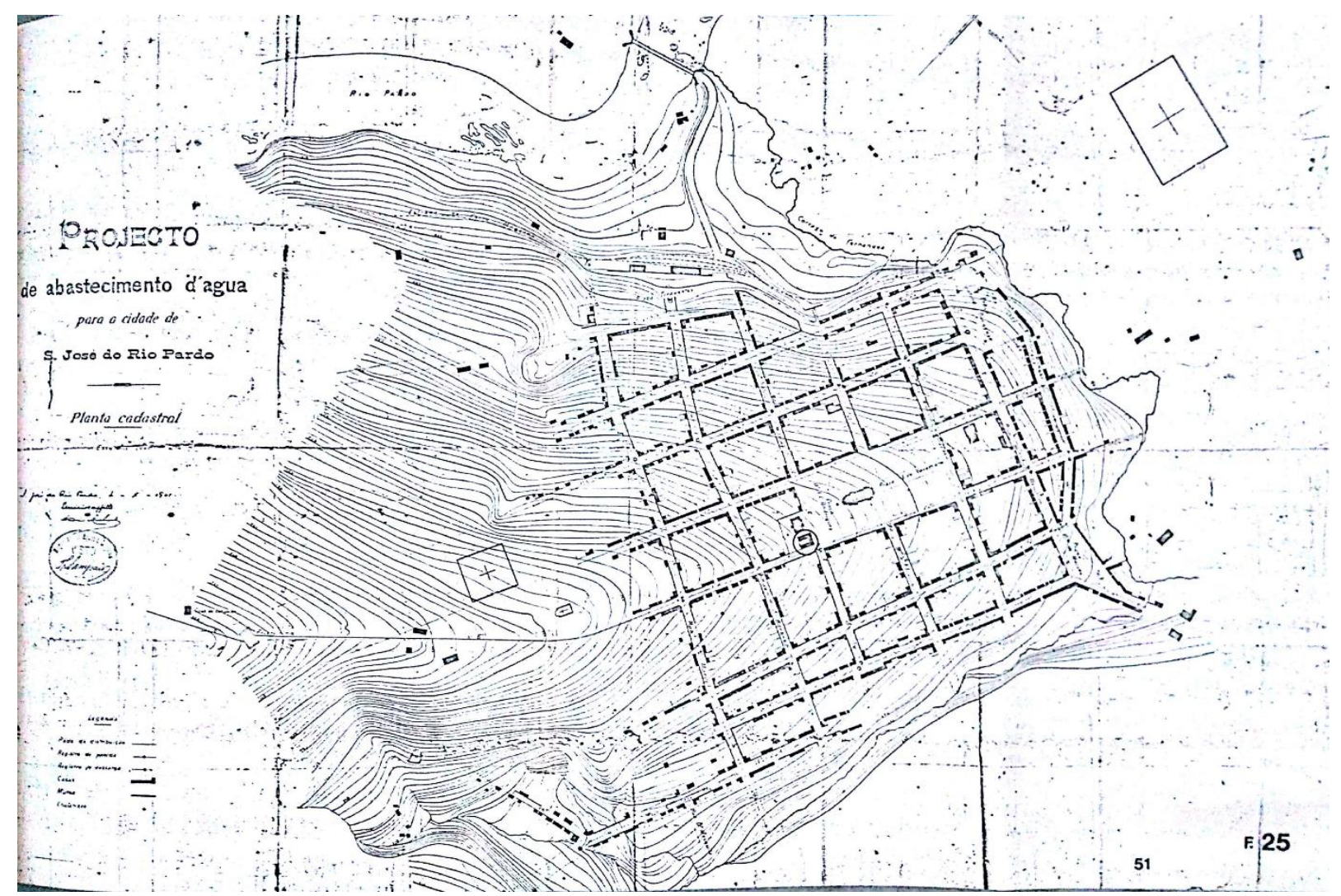

Fonte: Departamento de Água e Esgoto da Capital e assinado por Teodoro Sampaio em 1901. Arquivo da Hemeroteca Jornalista Paschoal Artese. Encontrado em Menechino (1986).

Foi, sobretudo a construção do sistema de abastecimento de água e coleta de esgoto em 1903, sob a coordenação do engenheiro civil Timotheo Pereira da Rosa, que ocasionou maiores transformações no quadro de melhorias da cidade. Acompanhado da drenagem e retificação de córregos, a construção das

\footnotetext{
${ }^{107}$ Segundo Borin (2016), Theodoro Sampaio nasceu em 1855 na Bahia. Formou-se engenheiro em 1877, tendo atuado no serviço público paulista entre os anos de 1886 e 1903 quando exerceu diferentes cargos: engenheiro da Comissão Geográfica e Geológica de São Paulo, engenheiro da Superintendência de Obras Públicas, chefe dos serviços de água e esgoto da capital, e posteriormente chefe da Repartição de Águas e Esgotos do Estado (1898-1903). Para saber mais como ocorreu a atuação profissional de Theodoro Sampaio e também as principais políticas de infra-estruturação territorial e urbana do estado de São Paulo praticada pela Secretaria de Agricultura, Comércio e Obras Públicas do governo estadual paulista no período compreendido entre 1892 e 1926, ver Bernardini (2007).
} 
redes favoreceu a redução das doenças crônicas através da fluidez dos líquidos, e acabou por intervir na disposição interna da casa, aproximando banheiro e cozinha do seu interior. Contudo, o projeto foi desenvolvido para atender a área central da cidade, excluindo os bairros localizados à margem do núcleo e as ruas que estavam sendo abertas. Era exatamente nas direções leste e oeste que a canalização de água e esgoto não chegou e que por isso, certamente não foi contemplado na representação do projeto. Ademais, a existência do mesmo fornece um panorama de ocupação e expansão do núcleo inicial, além de trazer a representação gráfica das frentes dos quarteirões construídos, murados e em aberto - apesar de não corresponder exatamente a projeção dos edifícios - o que muito contribuiu para a numeração dos imóveis, fiscalização das observâncias das posturas municipais e cobrança de impostos.

\section{Francisco Escobar}

Parte dos melhoramentos apresentados foram realizados sob a intendência de Francisco Escobar (Figura 51), mineiro de Jaguari (atualmente Camanducaia), chegou a São José do Rio Pardo em 1890 após convite realizado pelo seu amigo republicano José da Costa Machado e Souza. Nesse mesmo ano foi nomeado Intendente e vice-presidente do Conselho, e no ano seguinte presidente, mas foi por pouco tempo até a sua renuncia ao cargo. Após a Constituinte de 1891 e a determinação do governo do Estado, o poder municipal passou a ser exercido por uma Câmara composta de vereadores que elegiam um presidente e vicepresidente, e um intendente. A eleição para a primeira Câmara republicana aconteceu em 30 de agosto de 1892, sendo Francisco Escobar eleito suplente, permanecendo nessa condição até 1895 quando foi eleito vereador. Em 1896, Escobar foi eleito presidente da Câmara, e depois intendente até o ano de 1899.

\section{Figura 51: Francisco Escobar.}

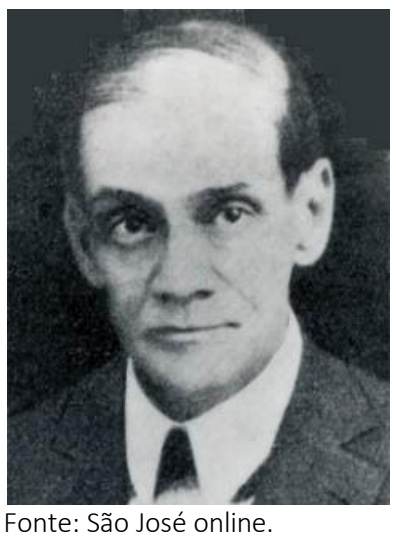

Logo, foi na década de 1890 que se intensificou a realização de uma série de obras no espaço urbano, contribuindo para torná-lo cada vez mais um lugar de representação e expressão simbólico e material. Cenário análogo a outros centros urbanos como Ribeirão Preto ${ }^{108}$ e Campinas ${ }^{109}$ onde intervenções em infraestrutura marcaram um novo padrão de urbanização concorrente para enfrentar as novas demandas e caracterizar a atuação do poder republicano.

\footnotetext{
108 Para informações adicionais consultar o trabalho desenvolvido por Faria (2010) que trata da construção de Ribeirão Preto a luz dos discursos de higiene, beleza e disciplina entre os anos de 1895 e 1930; e também o trabalho de Deminice (2015) que analisa a cidade de Ribeirão Preto a partir da atuação e polarização política e dos divergentes interesses urbanísticos e financeiros.

${ }^{109}$ Sobre Campinas ver o trabalho de Krohg (2012) que analisa a reconfiguração urbana dessa cidade no contexto das epidemias de febre amarela no final do século XIX. Outra contribuição é o trabalho de Lapa (1996) que aborda a transfiguração que Campinas sofreu no final do século XIX.
} 
Desse modo, diversas obras foram empenhadas em São José do Rio Pardo como: drenagem das águas subterrâneas e canalização das águas pluviais que alagavam a Praça Tiradentes; construção de caixa d'água para captação de águas drenadas até o matadouro municipal; construção de sanitários para servir aos funcionários da Cadeia Pública; inauguração do Cemitério Municipal; marcação das divisas litigiosas entre São José do Rio Pardo e o município de Mococa; diversos melhoramentos em estradas com destaque para a que fazia a ligação com a cidade de Caconde como foi ressaltado pela publicação abaixo:

\footnotetext{
Este melhoramento, que de há muito se fazia sentir, vem trazer incalculáveis vantagens e grandes benefícios para o comercio e a lavoura dos dois municípios. Toda importação do município exporta, todo commercio em fim para aquella localidade se faz por essa estrada, que, com os melhoramentos que vae adquirir, será uma bela via de communicação dos dois municípios vizinhos. O nosso município também muito lucrará, porquanto a exportação de uma bôa parte do nosso café se faz pela dita estrada. Melhorada convenientemente esta via de communicação, os tropeiros e carroceiros, forçosamente baixarão os actuaes preços de carreto, trazendo assim economia para a importação e exportação. (ESTRADA..., 1899, p. 01).
}

Além da abertura de outras estradas, como um trecho que seguia para Espírito Santo do Rio do Peixe (Divinolândia); compra de terreno para instalar a usina hidrelétrica responsável pelo serviço de luz elétrica mediante a concessão de privilégios de exploração conseguida pelo "Syndicato da Luz Electrica de São José do Rio Pardo"; autorização de verba para estudos, orçamentos e levantamento de plantas para o serviço de água e esgoto; ajardinamento da Praça XV de Novembro; após convite de Francisco Escobar, instalou em São José do Rio Pardo o jornal Oeste de São Paulo em 1897, vendido anos depois ao Partido Republicano que fundou o jornal O Rio Pardo; construção da ponte metálica sob a coordenação de Arthur Pio Deschamps de Montmorency, e o início dos trabalhos de reconstrução pelo engenheiro Euclides da Cunha; construção de uma ponte sobre o rio Fartura; e reforma e construção de pontes. Foram realizados também o sargeteamento e abaulamento de ruas; construção de muros de arrimo para conter às enchentes do córrego São José; prolongamento de ruas; aterro, taludamento e construção de uma escadaria na Praça Tiradentes; reparos no edifício da Câmara Municipal; desaterro do contorno da Igreja Matriz; extinção de formigueiros; e anexação dos Distritos de Paz de Grama (São Sebastião da Grama) e Espírito Santo do Rio do Peixe (Divinolândia).

Foi com o espírito de renovação que a burguesia local, representada pelo Francisco Escobar, ao mesmo tempo aspirava e propiciava as condições necessárias para a transformação das condições de vida nessa cidade. E assim como ocorreu em São Carlos (BORTOLUCCI, 1991), Ribeirão Preto (GARCIA, 2013; DEMINICE, 2015), Casa Branca (RODRIGUES, M., 2006), Mococa (RIBEIRO, S., 2011), Guaxupé (CYRINO FILHO, 2008) e, sobretudo na capital (LEMOS, C., 1989), a São José do Rio Pardo também buscou o desenvolvimento material, o conforto e as novidades tecnológicas em um processo em que as ligações entre o passado antiquado e o moderno eram bastante tênues. Mas, essas buscas também ocorreram no espaço privado, na moradia? E de que modo? Para responder essas questões, analisaremos no próximo item algumas moradias construídas entre o final do século XIX e início do século XX. 


\subsection{As moradias urbanas anteriores ao Código de 1903}

Evidentemente, como vimos, atrelado ao desenvolvimento urbano estava ocorrendo a produção das moradias urbanas, mas, apesar da estreita relação, poucos foram os fragmentos desse período encontrados em nossa pesquisa de campo e levantamento bibliográfico. Sabemos que de início os materiais disponíveis em abundância na região eram terra e madeira, logo, a opção simles e inevitável da maioria da população antes da chegada da ferrovia foi erguer pardes de taipa de mão cobertas de palha. Ratificamos a afirmação nas menções feitas em cartas de aforamento e termos de alinhamento que citavam esta técnica, como no documento em que João Honório de Araujo se referia ao "linhamento da frente da casa do Sr. Angelo Tardelli na rua que sai do Largo da Estação [Praça Tiradentes] devendo o mesmo observar o que dispunha o vigente Código de Posturas sobre a altura da mesma taipa" (TERMO..., 03/07/1887). E baseado no depoimento de Blandim sobre as condições das edificações e as menções de uma carta de aforamento pedindo uma data de terreno localizada na "rua Nova [atua Rua José Theodoro], abaixo da rua das Flores [atual Rua Silva Jardim], existindo uma pequena casa coberta de palha e fora do alinhamento" (CARTA..., 07/06/1887), complementa as características e técnicas que predominaram nas construções desta cidade na segunda metade do século XIX.

Influenciadas pela arquitetura mineira, as características construtivas dessas edificações são perceptíveis e vão ao encontro do que foi destacado por Carlos Lemos em seu livro Alvenaria Burguesa (1989). Diferente dos pequenos aglomerados urbanos formados com a inevitável taipa de pilão trazida pelos bandeirantes, a "bacia do rio Grande, formada, principalmente no lado paulista, pelos rios Mogji-Guaçu, Pardo e seus afluentes", como foi o caso de São José do Rio Pardo, "já apresentava outro tipo de confrontação cultural porque, na época do desenvolvimento do café ali, a zona já estava pontualmente ocupada por mineiros que refluíram sobre nossas divisas devido ao esgotamento das lavras (...)" (LEMOS, C., 1989a, p. 32). A introdução de atributos da arquitetura mineira de pau-a-pique ${ }^{110}$ apoiada em embasamentos de pedra foi o sistema construtivo empregado.

A assertiva é confirmada por Benincasa (2007) em sua análise da arquitetura rural paulista durante o ciclo cafeeiro entre as décadas de 1880 e 1940. Todavia, este autor (BENINCASA, 2007) identificou um limiar bastante tênue e difícil de estabelecer entre a prevalência da tradição paulista da taipa de pilão, e a influência dita "mineira" da taipa de mão, popularmente conhecida na região paulista como pau-a-pique. Esta análise se vale também das descrições de viajantes que seguiam o caminho de Goiás no início do século XIX, entre eles: Aires de Casal e Luiz D’Alincourt. Ambos teceram informações sobre as técnicas construtivas observadas nas edificações dos povoados por onde passaram, das quais Benincasa (2007) destacou que

\footnotetext{
110 Taipa, como está na carta de aforamento e termo de alinhamento, ou taipa de pau-a-pique, no dizer de Lemos, são apenas denominações diferentes para a taipa de mão, entre outras que existem no Brasil afora, que às vezes exigem maior cuidado na interpretação das fontes como no caso dos textos de viajantes analisados por Benincasa (2007).
} 
até Moji-Mirim, são sempre mencionadas as casas de taipa, o que, evidentemente, refere-se ao barro socado a pilão, e, logo a seguir, desaparecem as referências a essa técnica, dando lugar às casas de pau a prumo, também conhecido como pau-a-pique. (BENINCASA, 2007, p. 10).

De fato, em São José do Rio Pardo predominou o emprego do sistema estrutural composto pela base de pedras, "gaiola" isostática ${ }^{111}$ com preenchimento da taipa de mão, como pode ser observada na Figura 52. Essa técnica construtiva pode ser observada também nas fazendas construídas na cidade de Casa Branca (RODRIGUES, M., 2010), Guaxupé (CYRINO FILHO, 2008) e Mococa (RODRIGUES, M., 2006), cidades da região de São José do Rio Pardo.

A exemplo do paiol que fazia parte da Fazenda Santa Maria da Fartura, constatamos, por todas as características, a similaridade das edificações rurais e urbanas como a edificação onde funcionou a Pharmacia Peixoto (Figura 53), que possuía estrutura autônoma e utilizava em sua cobertura a telha capa e canal, tendo as esquadrias e fechamento das aberturas em madeira serrada. Podemos perceber também a substituição do uso do sapé e do capim em contraposição ao uso da telha cerâmica, atendendo ao Código de Posturas em vigor que desejava manter certo distanciamento destes materiais das principais ruas e praças da Vila.
Figura 52: Vista parcial do paiol da Fazenda Santa Maria da Fartura, Sítio Novo.

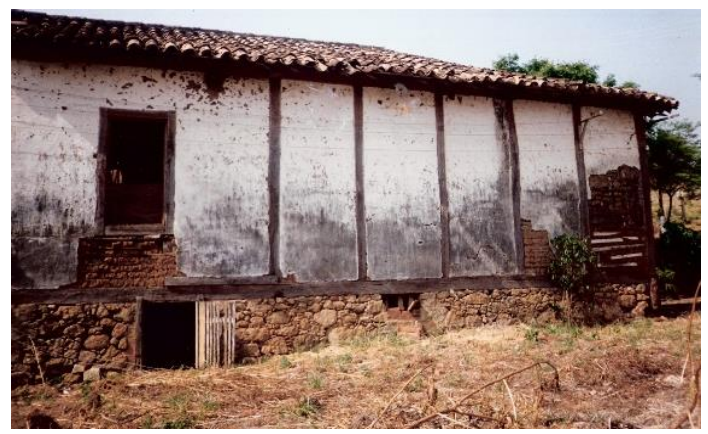

Fonte: Arquivo da Hemeroteca Jornalista Paschoal Artese.
Figura 53: Pharmacia Peixoto no núcleo urbano riopardense.

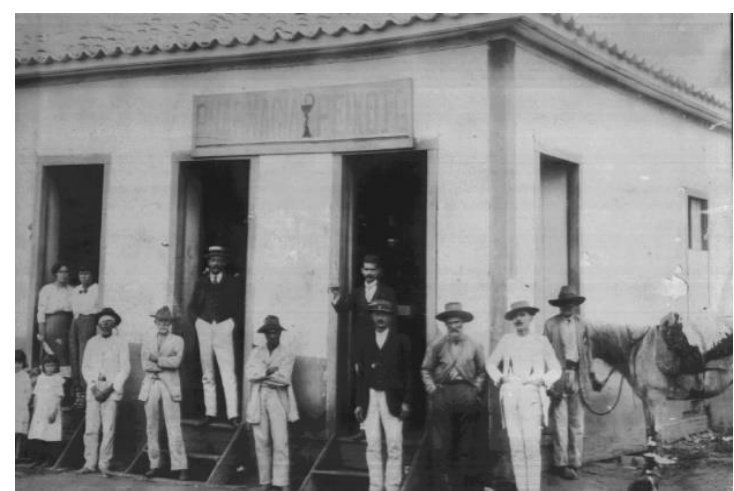

Fonte: Arquivo da Hemeroteca Jornalista Paschoal Artese.

\footnotetext{
${ }^{111}$ Não há um consenso entre os autores que trataram desse sistema nas edificações construídas na região sudeste do Brasil. Como fica claro no posicionamento de Lemos ao ressaltar que ao invés da denominação gaiola, o correto é "pau-a-pique" "justamente por possuir paus roliços verticais cravados ao mesmo tempo nos baldrames e nos frechais, enfiados em furos idênticos e largos possíveis graças aos recentestrados, os sucessores das verrumas de diminuto diâmetro. Essa foi a carpintaria levada para Minas Gerais e para as fazendas de café de São Paulo, não sendo entre nós, no entanto, correta a denominação portuguesa "gaiola" por não ser a armação destinada a enfrentar terremotos". (LEMOS, C., 2012, p. 12). Já Cícero Ferraz Cruz, diz que a técnica construtiva conhecida como "estrutura autônoma de madeira", ou "gaiola de madeira" "em que o esteio vai somente até o baldrame, é uma estrutura que trabalha apenas com vínculos articulados e não com conexões rígidas; trata-se, portanto, de uma estrutura isostática” (CRUZ, 2010, p. 49). Apesar da importância da discussão sobre o assunto, nesta dissertação nos interessa mostrar que a edificação construída na área urbana rio-pardense estava fortemente vinculada ao que era produzido na zona rural.
} 
Influência mineira nas características construtivas também estavam presentes na implantação a meia encosta térreas no fundo e assobradas na frente e com varandas acessíveis por escada -, denominada por Lemos, C. (1989a) de "novo partido". Como exemplo tem-se a fazenda Tubaca cuja sede foi construída em 1870 Figura 54) a mando do seu proprietário Vicente Alves de Araújo Dias.

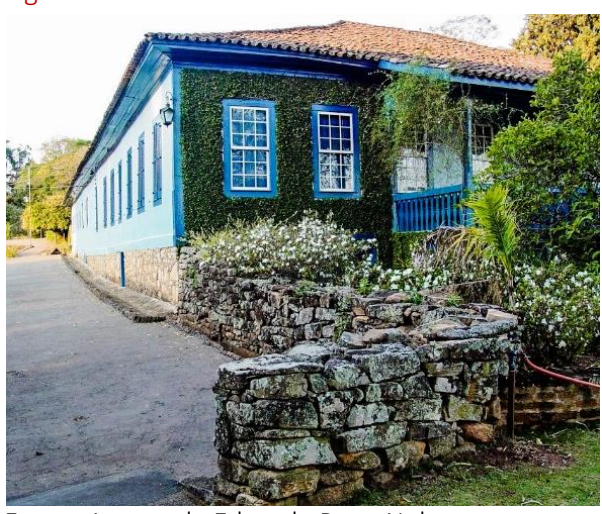

Fonte: Acervo de Eduardo Roxo Nobre.

Em relação às moradias urbanas rio-pardenses desse período, podemos perceber indícios que constatam a feição dessas construções, marcadas nos primeiros anos de sua fundação por um misto de simplicidade e precariedade em decorrência das condições econômicas e sociais, o que explica a quase inexistência de exemplares arquitetônicos remanescentes.

Felizmente, conforme se aproximou dos últimos anos do século XIX, quando a cultura cafeeira já era a base econômica rio-pardense e o sistema ferroviário estava instalado, o contato do interior com os maiores centros urbanos do país e também com a sociedade industrial europeia e os recursos provenientes da política de exportação, fatalmente tudo isso refletiu em avanços técnicos na arquitetura. Para Reis Filho (2011) era parte das transformações em curso no país, e

nessas condições, as novas formas de habitar e construir não devem ser consideradas apenas como consequências das mudanças vividas pelos vários grupos sociais, mas vistas como parcelas importantes dessa renovação (REIS FILHO, 2011, p. 146).

Nesse sentido, o autor acrescenta que localidades afastadas do litoral passaram a receber graças à ferrovia,

novos tipos de mercadorias, como máquinas e materiais de construção mais pesados, cuja condução seria impossível com o transporte em lombo de burro, passariam a chegar, com toda facilidade e pela vigésima parte do preço, a essas regiões (REIS FILHO, 2011, p. 148).

A legislação também fez parte das transformações em curso. Em 1887 foi publicado o primeiro Código de Posturas da Villa de São José do Rio Pardo que estabeleceu normas referentes ao aspecto urbano e à construção de casas. Através da lei, a Câmara Municipal determinou condições que pudessem assegurar padrões mínimos de ordem construtiva, o que certamente contribuiu no arranjo e nas características arquitetônicas das moradias. E assim, como ocorreu com o arruamento em quadrícula, as edificações construídas em diferentes regiões do estado de São Paulo também foram condicionadas por essas normas, resultando em uma produção com características semelhantes, ainda que ajustadas as condições e necessidades locais, como a mão de obra disponível.

Foram as edificações com telhados de duas águas com caimento para a rua e o quintal que predominaram em São José do Rio Pardo no final do século XIX, raras eram as exceções que empregavam o sistema de 
captação e condução das águas pluviais. Perduraram as construções sobre os limites laterais na busca por estabilidade e proteção das empenas. Manteve-se a relação com o lote e a uniformidade dos partidos arquitetônicos, assim como as fachadas simplificadas com pouca ornamentação. A planta com a sala na frente (recorrentemente aproveitada para o comércio), alcovas no centro e as áreas de serviço no fundo definiram uma volumetria sem grandes movimentações e, isolada no quintal, a "casinha". Foi segundo Reis Filho (2011) o período em que

a uniformidade dos terrenos correspondia à uniformidade dos partidos arquitetônicos: as casas eram construídas de modo uniforme [...] as plantas deixadas ao gosto dos proprietários, apresentavam sempre uma surpreendente monotonia. As salas da frente e as lojas aproveitavam as aberturas sobre a rua, ficando as aberturas dos fundos para a iluminação dos cômodos de permanência das mulheres e dos locais de trabalho. Entre estas partes com iluminação natural, situavam-se as alcovas, destinadas à permanência noturna e onde dificilmente penetrava a luz do dia. A circulação realizava-se sobretudo em um corredor longitudinal que, em geral, conduzia da porta da rua aos fundos. Esse corredor apoiava-se a uma das paredes laterais, ou fixava-se no centro da planta, nos exemplos maiores. (REIS FILHO, 2011, p. 24).

O que Lemos, C. (1989a) complementa ao dizer que

a casa antiga, ainda de taipa, dos primórdios do café [...] estava ainda vinculada ao partido colonial: geminada de ambos os lados ou raramente provida de passagem lateral para carros, coberta sempre por telhados de duas águas, sendo a cumeeira necessariamente paralela ao alinhamento e isso devido à possibilidade de os panos de telhas das casas contíguas terem continuidade fácil, o que evitava interseções vulneráveis às águas pluviais, providencia típica de sistemas construtivos destituídos de recursos apropriados aos desvios da chuva. (LEMOS, C., 1989a, p. 94-95)

Conforme já foi dito, é pouca a iconografia que mostra edificações construídas de taipa, mas por sorte, uma fotografia do início dos anos 1900 registrou em segundo plano parte do casario, onde foi possível identificar a edificação vizinha eclética enquanto outra ao lado mantêm a tradição (Figura 55), em flagrante desacordo aos padrões estabelecidos pelo Código de Posturas (1887).

Figura 55: Em primeiro plano criança não identificada e ao fundo parte do casario construído de taipa.

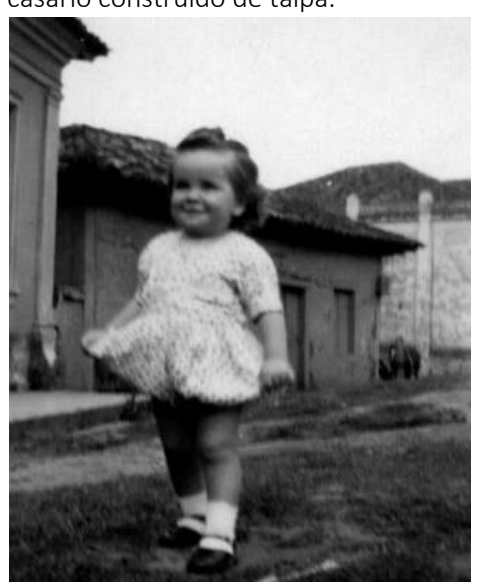

Fonte: Acervo pessoal de Rodolpho José Del Guerra.
Além disso, essa fotografia evidenciou a diferença de classe social convivendo lado a lado. O contraste não se resumiu apenas à composição volumétrica e a feição de suas fachadas, mas também àpresença do passeio nivelado $e$ calçado em observância ao Código, como exposto em seu Título I, artigo $2^{\circ}$ :

Ficam os proprietários obrigados a calçar de pedras ou tijollos as frentes de seus prédios na largura de um metro e vinte centímetros, comprehendidos os muros ou paredes que fizerem frentes para as ruas, travessas, beccos e praças, sob pena de multa de 30\$000. (CÓDIGO DE POSTURAS, 1887, p. 04). 
Através do recurso do zoom, conseguimos identificar em diversas fotografias antigas outras residências em meio à paisagem urbana com predominância da simplicidade formal e estilística, restrita à moldura das aberturas em verga reta e cimalha com frisos no beiral, como na sequência de edificações (Figura 56) na Praça Prudente de Moraes (antigo Largo do Mercado). Há um exemplar que resiste ao tempo na Rua Paraíso (denominada anteriormente de Rua Buracão) (Figura 57) que também evidencia essas características e a predominância da relação da arquitetura tradicional com o lote padronizado.

Figura 56: Edificações construídas entre o final do século XIX e início do século XX no Largo do Mercado (atual Praça Prudente de Moraes).

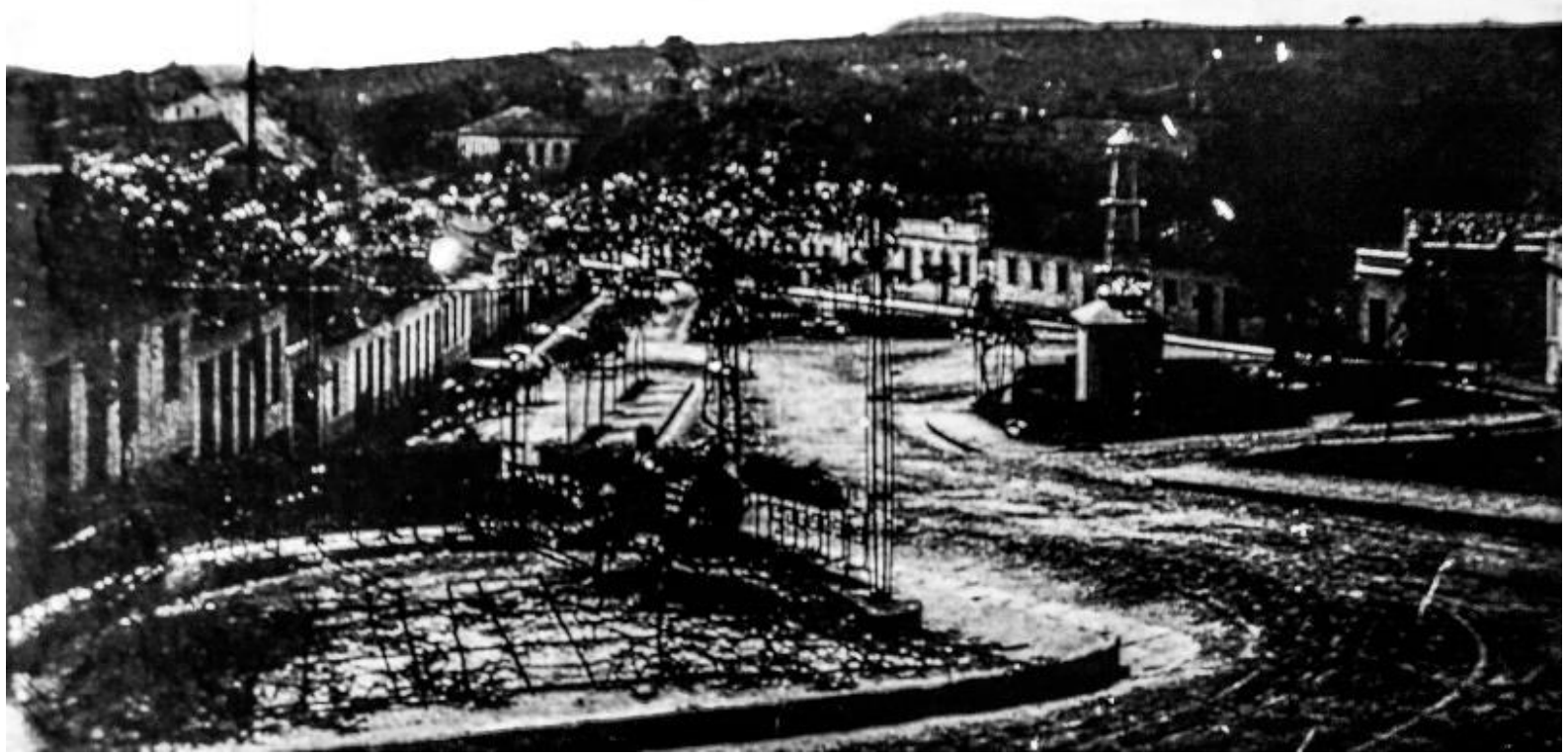

Fonte: Arquivo da Hemeroteca Jornalista Paschoal Artese.

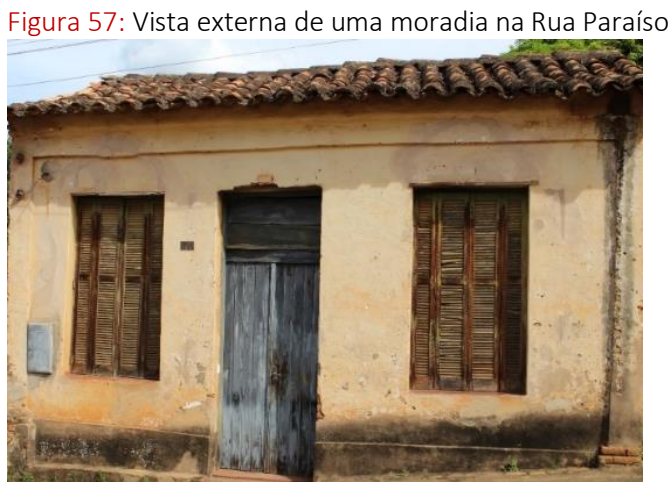

Fonte: Acervo pessoal da autora (2016).

A par de um ou outro edifício, algumas residências se destacaram pelo seu tratamento diferenciado, mesmo que timidamente em pequenos detalhes como a porta da entrada principal maior em arco pleno, 
cimalha mais bem trabalhada, régulas e eventualmente pilastras com inspiração classicista ${ }^{112}$ (Figura 58). Ressaltamos que a ideia que dominou no século XIX foi a de que a arquitetura deveria ser representativa do status do seu ocupante, logo a atenção era dada para a estrutura e a forma exterior, afinal de contas, era ela o elemento constitutivo do cenário urbano, daí a decoração ter se tornado um elemento indispensável (FABRIS, 1993; ANGOTTI-SALGUEIRO, 1987) que também passou a fazer parte do interior das edificações. Conforme a afirmação de Eudes Campos (2005)

\footnotetext{
o gênero que mais se prestava a expressar os sentimentos sociais e morais do homem era a arquitetura doméstica. Assim, as construções residenciais deviam não apenas exprimir um certo ideal de domesticidade, como também servir de meio para que os proprietários manifestassem sua necessidade de afirmação pessoal e de evasão sentimental. (CAMPOS, E., 2005, p. 35).
}

Esses elementos eram suficientes para distinguir uma residência da outra, e também o poder social e econômico do morador, chegando em alguns casos a quebrar a homogeneidade das ruas formadas por linhas contínuas e baixo gabarito.

Figura 58: Vista parcial das edificações da Rua Marechal Deodoro, década de 1910.

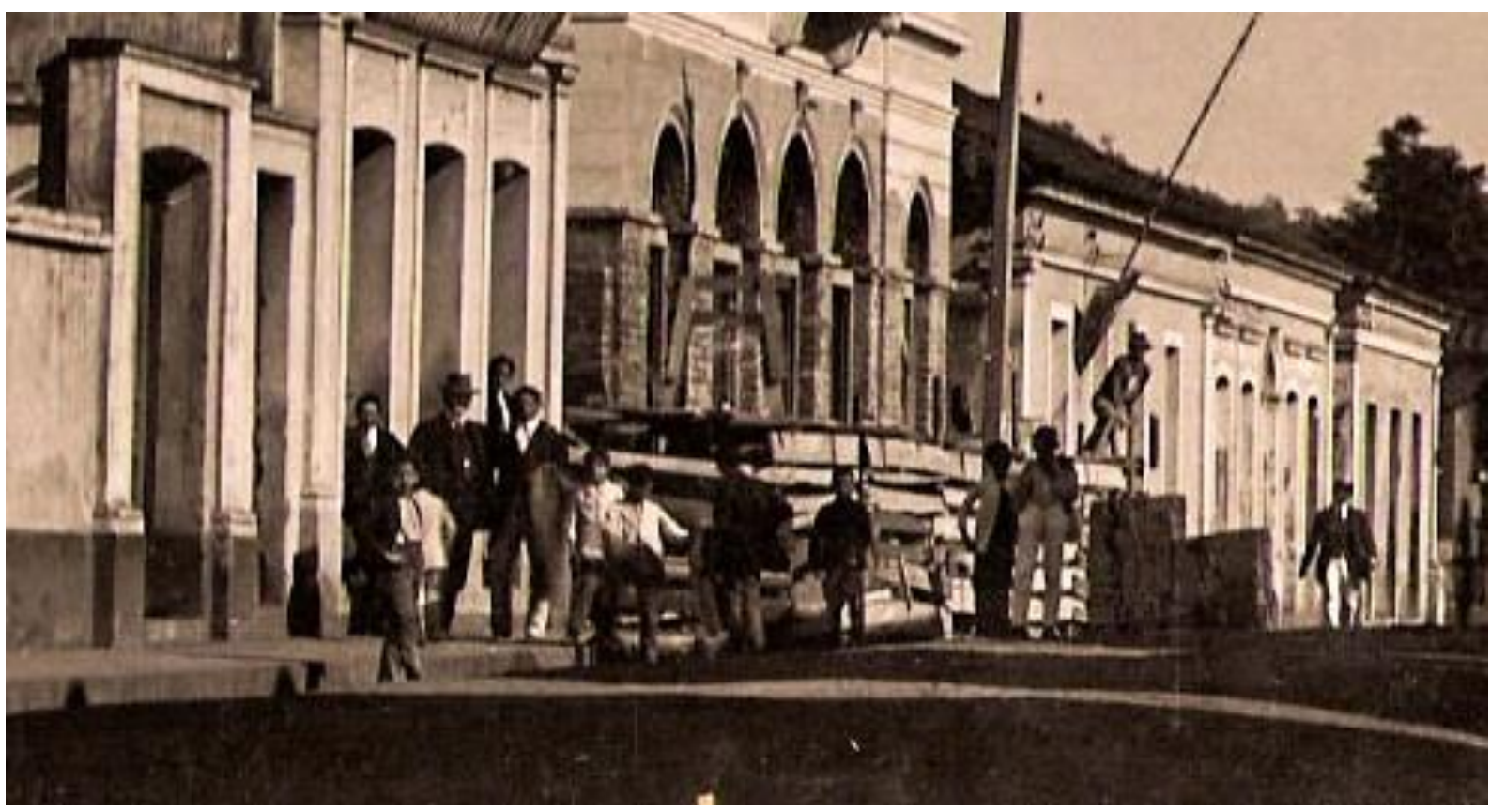

Fonte: Arquivo da Hemeroteca Jornalista Paschoal Artese. Fotografia de Innocencio Vilhegas.

Apesar de muitas dessas moradias terem sido substituídas por outras em meados do século XX, o material iconográfico existente do começo do século que flagra essa arquitetura nos permitiu discutir e analisar nesse e nos próximos capítulos, as moradias, acrescentando a esse material quatro exemplares que guardam as suas características originais do final dos oitocentos e que veremos a seguir: a moradia dos fazendeiros Honório Luiz Dias (Figura 59), José Dias Machado (Figura 60), a do imigrante italiano Leonardo

\footnotetext{
112 O acabamento limitava-se a apenas alguns elementos secundários, conferindo a composição da fachada aspectos de sentido classicista. Essa foi também a composição adotada por muitas moradias paulistanas do Império, conforme analisado por Eudes Campos (1997, 2005).
} 
Define (Figura 61) e de Saint' Clair Andrade Junqueira (Figura 62), todas localizadas entre a Praça Prudente de Morais - principal entrada da cidade e onde ocorriam as trocas comerciais que sustentável o abastecimento local - e a Praça XV de Novembro (Figura 63).

Figura 59: Desenho da fachada da moradia de Honório Luiz Dias (década de 1880).

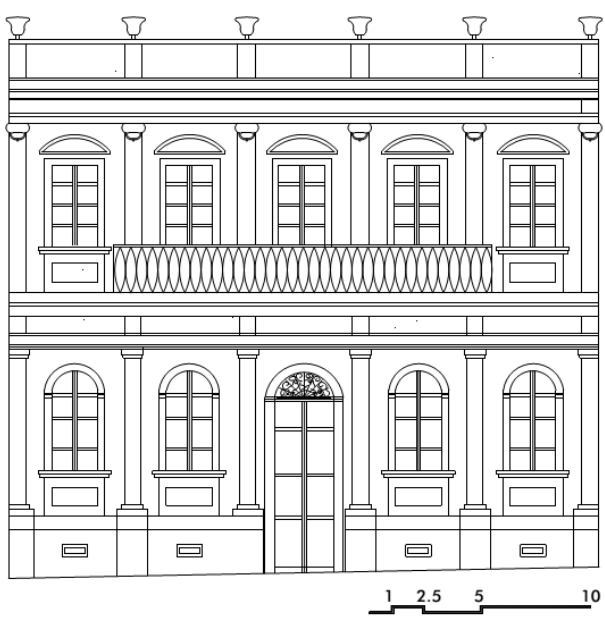

Desenho: Natalia Cappellari de Rezende (2018) a partir de fotografias antigas.

Figura 61: Desenho da fachada da moradia de Leonardo Define (1888).

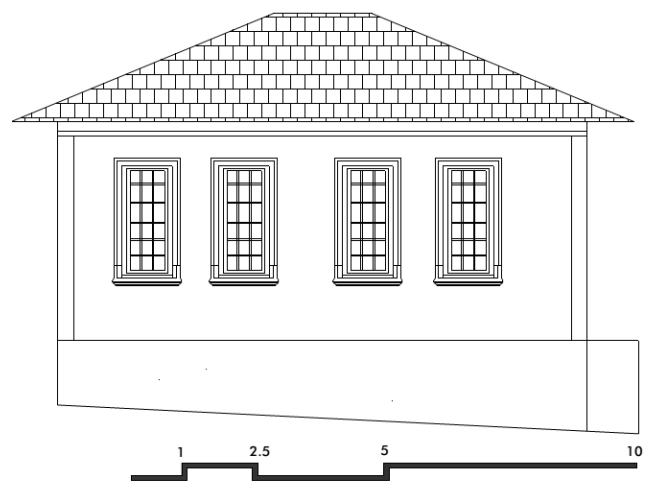

Desenho: Natalia Cappellari de Rezende (2018) a partir de fotografias antigas.
Figura 60: Desenho da fachada da moradia de José Dias Machado (década de 1880).

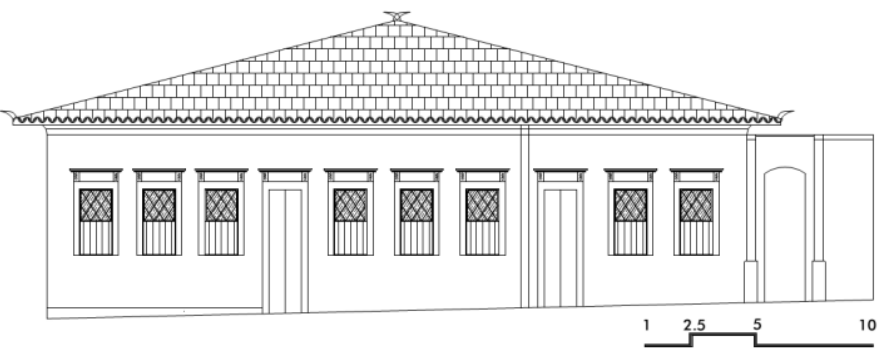

Desenho: Natalia Cappellari de Rezende (2018) a partir de fotografias antigas.

Figura 62: Desenho da fachada da moradia de Saint' Clair Andrade Junqueira (1888-1890)

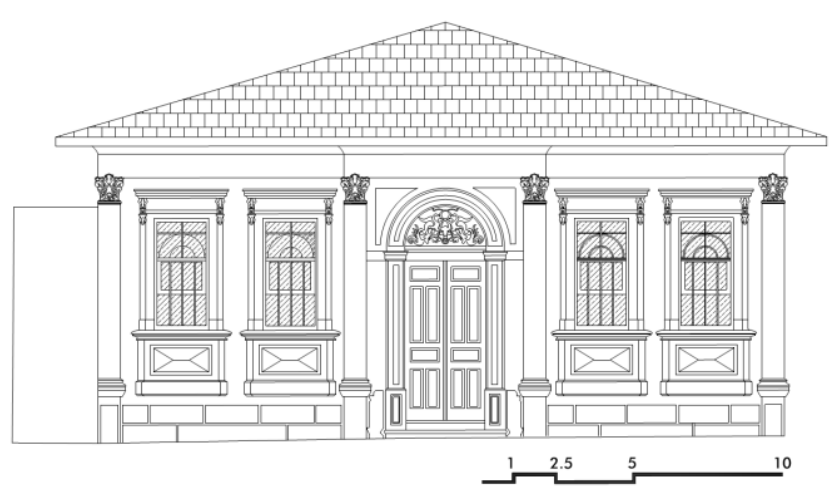

Desenho: Natalia Cappellari de Rezende (2018) a partir de fotografias e levantamento in loco. 
Figura 63: Localização dos exemplares analisados neste capítulo.

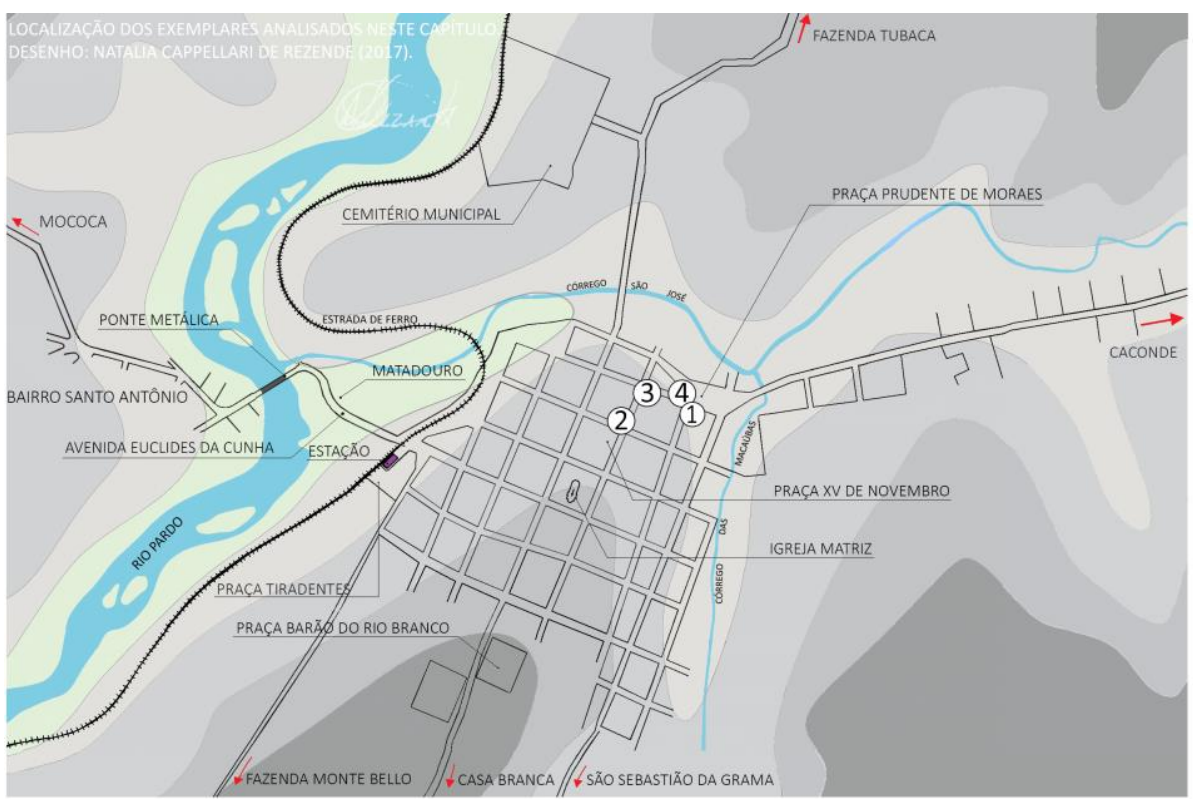

(1) JOSÉ DIAS MACHADO

(2) SAINT' CLAIR ANDRADE JUNQUEIRA (3) HONÓRIO LUIZ DIAS (4) LEONARDO DEFINE

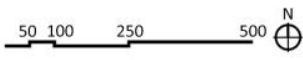

Desenho: Natalia Cappellari de Rezende (2017) com base em dados históricos e cartografia disponibilizada pela Secretaria de Obras de São José do Rio Pardo.

É certo que a cidade construída de taipa e coberta de sapé, casas simples, térreas, alinhadas à rua, ambientes enfileirados e mal iluminados, possuidoras de limitações técnicas e construtivas que dificultavam a inserção de ornamentações e sofisticações foi gradativamente dando espaço para construções mais requintadas ou mesmo reformas modernizadoras que almejavam a arquitetura dos materiais importados, de um outro modo de construir e morar. Sem dúvida, as edificações mais luxuosas pertenciam aos fazendeiros, e assim como destacou Bortolucci (1991, p. 92) ao tratar da cidade de São Carlos, as poucas lembranças da arquitetura tradicional nas moradias dessa camada social foi a ausência de recuos, mantendo-as no alinhamento da rua, "porque de resto tudo era importado da Europa e completamente estranho à sociedade local, os materiais, as técnicas, o gosto e também o programa". Exemplo dessa descrição em São José do Rio Pardo era o palacete ${ }^{113}$ pertencente ao fazendeiro, político e coronel Honório Luiz Dias ${ }^{114}$ construído na década de 1880. Essa moradia foi edificada nos limites de um lote da Rua Marechal Deodoro esquina com a Rua Francisco Glicério em São José do Rio Pardo (Figura 64) e possuía uma volumetria compacta em forma de " $\mathrm{L}$ ".

\footnotetext{
${ }^{113}$ De acordo com a definição de Homem (1996), a denominação de palacete para a moradia de Honório não é adequada uma vez que ele não foi construído afastado das divisas do lote e desconhecemos a existência de edícula nos fundos. Todavia o apuro estilístico, a monumentalidade e a quantidade de cômodos fez com que edificações desse porte e com essas características fossem assim denomi nadas em São José do Rio Pardo e outras cidades do interior paulista, como é o caso da moradia de Honório e da residência do Conde do Pinhal em São Carlos.

${ }^{114}$ Natural de Cabo Verde-MG, Honório era filho de Vicente Alves de Araújo Dias e Lucinda Candida de Jesus que adquiriram terras em São José do Rio Pardo formando a fazenda Tubaca em 1870 (CASSASSOLA, 2009, p. 84). Honório assumiu a administração da fazenda de seu pai aos 17 anos, antes da transferência completa da família para essa cidade (1876), começando ali a formação de suas posses. Honório era proprietário de terra nessa cidade, em Poços de Caldas-MG, São João da Boa Vista-SP e Cascata-MG, e investiu o capital proveniente da sua produção cafeeira em empreendimentos diversificados como a fundação de duas casas comissárias em Santos; exploração de mina de zircônio no atual município de Águas da Prata; e na produção de energia elétrica para o município, como sócio no "Syndicato da Luz Electrica de São José do Rio Pardo". Outros investimentos também ocorreram no comércio local com armazéns de secos e molhados, e lojas de fazenda, armarinhos, ferragens e louças. Honório ainda se envolveu na política como vereador rio-pardense entre os anos de 1887 a 1889 e integrante do Conselho de Intendência de 1890 a 1892, mas neste último caso por um curto período de tempo (CASSASSOLA, 2009). Honório enquanto líder do Movimento Republicano utilizou seu sobrado para aprisionar defensores da monarquia, e afugentar a tropa republicana, fazendo com que sua edificação ficasse conhecida como a "Fortaleza Republicana".
} 
Figura 64: Desenho da implantação da moradia de Honório Luiz Dias.

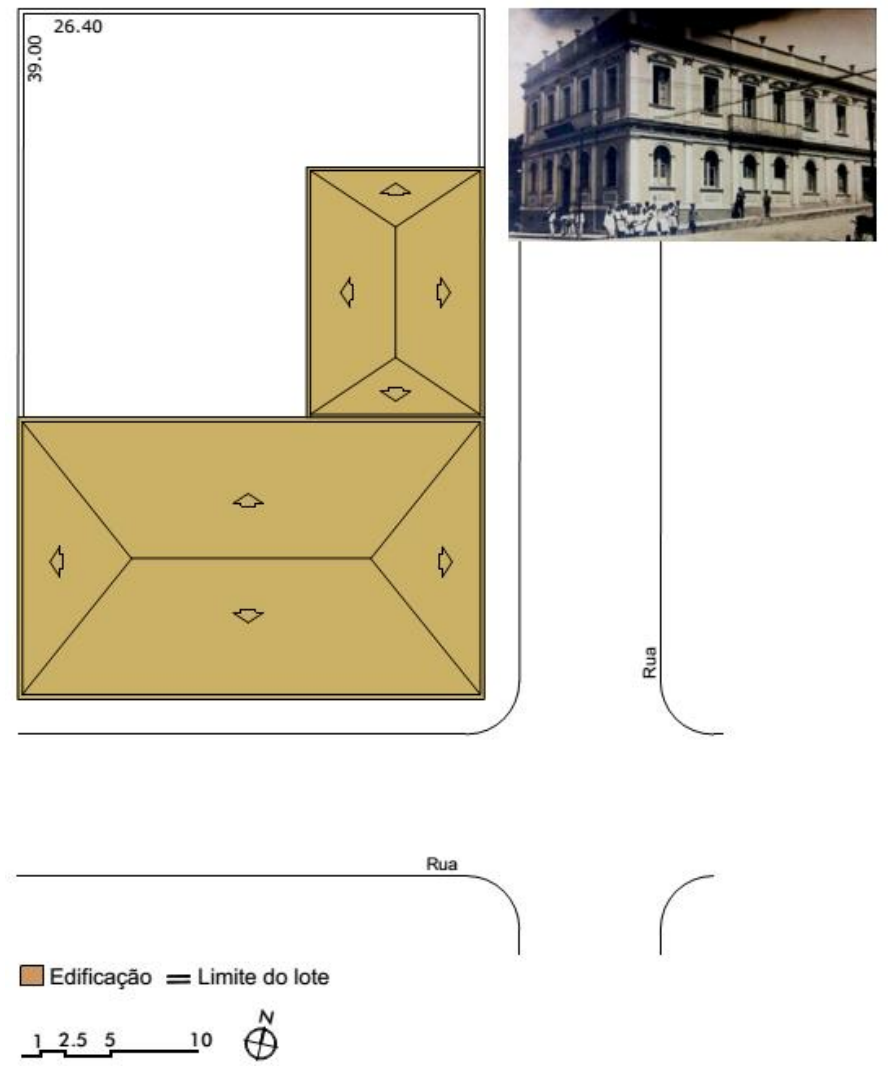

Desenho: Natalia Cappellari de Rezende (2017).

Diferentemente da implantação da moradia do Honório Luiz Dias, a moradia do fazendeiro e major José Dias Machado ${ }^{115}$, edificada na esquina da Praça Prudente de Moraes com a Rua Benjamin Constant, apresentava afastamento do limite da lateral direita do lote em relação ao vizinho. Nesse caso, a propriedade do Machado possuía um tímido esforço de movimentação a partir da sua implantação em forma de " $U$ " (Figura 65). Corroborando com as transformações em curso, essa residência revelava as primeiras modificações nas soluções de implantação através do afastamento lateral, mas ainda mantinha a relação com o alinhamento frontal na via pública. Segundo Reis Filho (2011, p. 44), a nova implantação que rompia com a tradição consistia em um processo geral, "em todas as regiões onde se fazia sentir o declínio da escravidão e a presença do progresso tecnológico, encontravam-se os mesmos mecanismos de adaptação às novas condições". Ainda segundo esse autor (2011, p. 48-49), o "deslocamento" da construção dos limites do lote ocorreu também em consequência do "progresso das condições higiênicas e desprestígio dos velhos hábitos de dormir em alcovas, sem iluminação e insolação direta".

\footnotetext{
${ }^{115}$ Segundo Zveibil (2000), que escreveu sobre a genealogia da família Machado, o major José e sua esposa Francelina Augusta Ribeiro chegaram a São José do Rio Pardo em 1875 atraídos por familiares que já tinham se estabelecido nesta cidade, depois de residir em Paty do Alferes-RJ entre os anos de 1850 e 1861 e Passa Vinte-MG entre 1861 e 1874. Conforme Zveibil (2000) pontuou, a base econômica dele era decorrente do café produzido em suas fazendas e de seus engenhos de açúcar. Para esta autora (ZVEIBIL, 2000), o major veio com dinheiro de Minas, tanto que adquiriu vastas extensões de terra na região de São José do Rio Pardo. Por ser monarquista, depois da República ele se afastou da vida política, mas continuou participando de movimentos públicos dada a sua condição econômica (DEL GUERRA, 2001). De acordo com a pesquisadora (2000, p. 32-33) que publicou o testamento de Francelina Augusta Machado, a moradia da família ocupava o terreno da esquina das ruas Marechal Deodoro e Benjamin Constant, em frente à Praça Prudente de Moraes.
} 
Figura 65: Desenho da implantação da moradia de José Dias Machado.

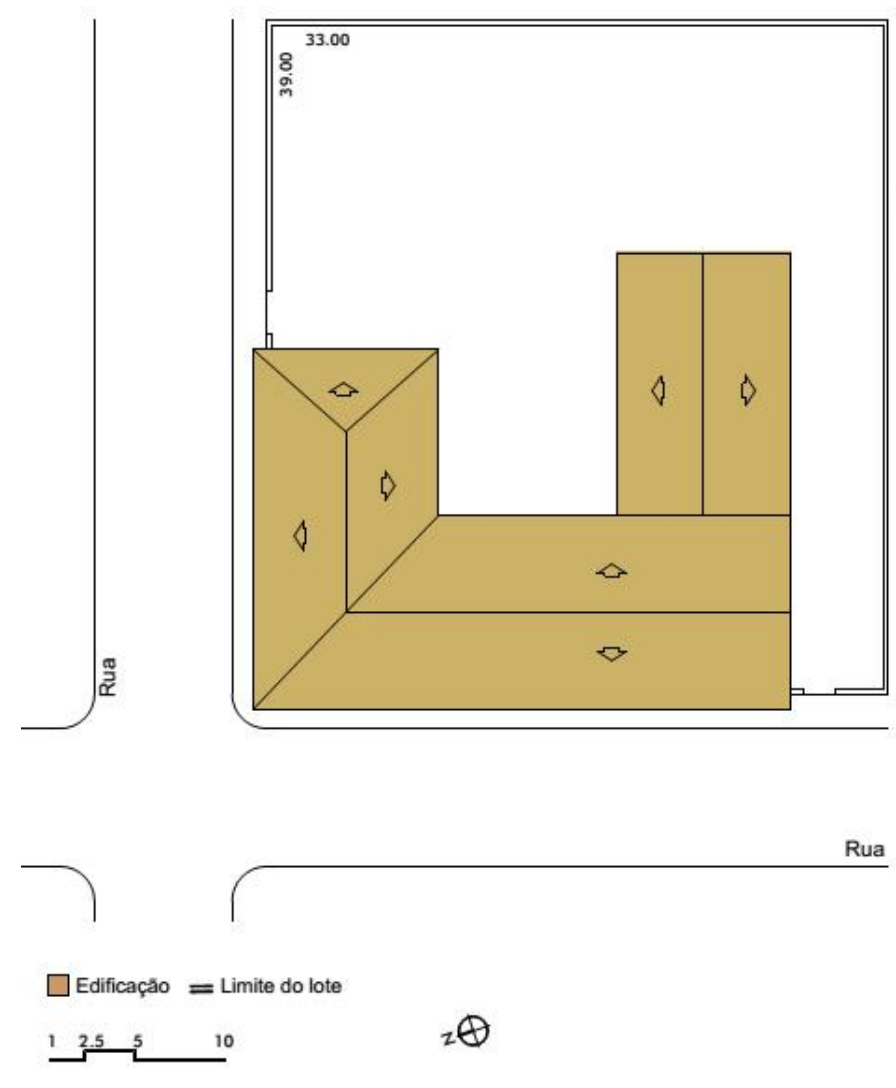

Desenho: Natalia Cappellari de Rezende (2017).

A presença desse corredor, patrocinador de ar e luz naturais, evidencia o atendimento aos conceitos de higiene e conforto ${ }^{116}$, ao mesmo tempo de independência dos compromissos com os telhados vizinhos, rompendo a continuidade de fachadas com cumeeiras paralelas ao alinhamento, apesar de não haver essa exigência na legislação municipal dessa época. Além disso, o afastamento lateral dos limites do lote contribuía para tornar a sujeira visível induzindo à limpeza tão associada com a moral. Segundo Correia (2004), uma casa iluminada e arejada mostrava a preocupação da família com a saúde e com o bem-estar, demonstrando que eles estavam atentos às discussões da época, tão preconizadas também pelas publicações locais. A exemplo do artigo intitulado "Um Fato a Reprimir" publicado no jornal O Rio Pardo (1900) em que estabeleceu evidências entre doença, falta de higiene e pobreza, e entre desconforto e formas diversas de ilegalidade e de imoralidade, como se segue:

A nossa formosa cidade tem também, contrastando-lhe o aspecto ridente, a sua White Chapel lobrega e sinistra onde dezenas de pardieiros arruados delatam no desgracioso das fachadas de tijolo cru todas as tristezas e o deplorável desconforto e a existência suspeita dos que vivem lá dentro entregues à miséria, ao vicio, e porventura ao crime. (UM FACTO..., 1900, p. 01).

\footnotetext{
116 Segundo a noção de conforto, RYBCZYNSKI (2002) nos diz que ele evoluiu no tempo de acordo com a inserção sócio cultural, significando desde satisfação física, privacidade, intimidade, domesticidade, aconchego e eficiência. Para saber mais sobre isso, ver o livro publicado por Witold Rybczynski (2002): Casa: pequena história de uma ideia.
} 
Provavelmente o texto tenha sido endereçado à elite rio-pardense, mas de qualquer modo, evidencia as estratégias de desodorização, descongestionamento e embelezamento, desejados por esta camada da sociedade, e que vai influenciar nos preceitos estéticos e no arranjo espacial da casa, sendo as moradias analisadas neste item exemplares.

Certamente essas também foram questões que permearam a definição da implantação da moradia de Leonardo Define ${ }^{117}$ (Figura 66) construída na Praça Prudente de Moraes esquina com a Rua Marechal Deodoro.

Figura 66: Desenho da implantação da moradia de Leonardo Define.

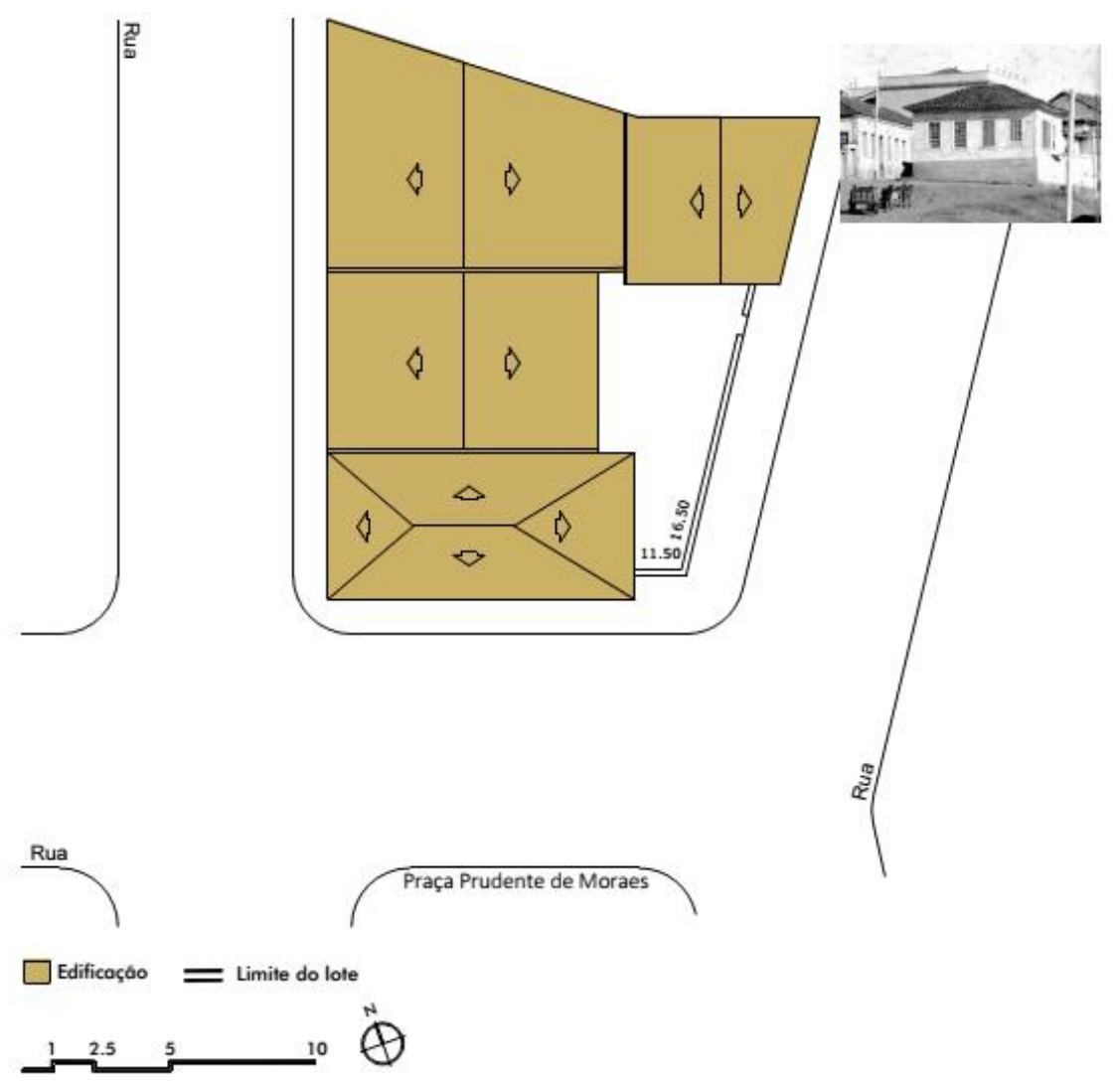

Desenho: Natalia Cappellari de Rezende (2017).

Encontramos ainda em nosso levantamento de campo outra residência construída afastada lateralmente do limite do lote com o vizinho, localizada na Praça XV de Novembro esquina com a Rua Francisco Glicério (Figura 67). Era a propriedade do fazendeiro Saint' Clair Andrade Junqueira ${ }^{118}$. Certamente ela tenha sido

\footnotetext{
${ }^{117}$ De acordo com o registro do livro de batismo da igreja, no dia 8 de outubro de 1881 nasceu o primeiro filho de imigrantes italianos em São José do Rio Pardo, era Giacomo Define, filho de Leonardo e Antônia Damasco (DEL GUERRA, 1999). A partir deste dado, supomos que este italiano muito provavelmente tenha chegado à cidade no final da década de 1870. Leonardo era um ferrenho defensor dos in teresses dos colonos o que o levou a ser presidente da Società di Mutuo Soccorso 20 Settembre. Aspirando ascensão econômica, esse italiano tinha o seu próprio negócio, uma loja de fazenda, armarinhos, ferragens e louças. De acordo com o Lançamento Geral das Datas Aforadas e Vendidas no patrimônio da Villa para cobrança no aforamento (1888), a propriedade de Leonardo Define correspondia a um terreno de esquina com testada de 29,20 metros com uma casa edificada na Rua Boa Vista (atual Marechal Deodoro) entre o Largo do Mercado (atual Praça Prudente de Moraes) e Francisco Isidoro Dias.

118 Saint' Clair Andrade Junqueira pertencia a uma família tradicional e extensa de fazendeiros produtores de café de São José do Rio Pardo. Em 1888, ele figurava entre os principais cafeicultores, se aventurando também na pecuária com a criação de equinos. Assim como
} 
construída entre o final da década de 1880 e o início da seguinte, uma vez que em 1888 esse fazendeiro requisitou um lote de terreno no Largo da Matriz (hoje Praça XV de Novembro). Como sabemos, de acordo com as determinações do Código de Posturas de $1887^{119}$ e confirmadas na carta de aforamento,

todo proprietário que possuir terreno, a título de aforamento começar a marcá-lo fincando dois esteios na frente dentro do prazo de três meses, a começar a edificar dentro do prazo de seis meses e concluir o edifício ao menos exteriormente na frente, dentro do prazo de um anno. (CARTA..., 1888).

Outro recurso que apareceu foi o porão que, além de permitir vencer o desnível do terreno e afastar o piso da umidade do solo, possuía outros méritos como destacou Lemos, C. (1989a, p. 98), evitava que "fossem os cômodos dianteiros devastados por quem passasse pela calçada", conferindo maior privacidade ao interior. Este recurso esteve presente nas quatro moradias analisadas, sendo que o considerável desnível do terreno da residência do Junqueira e do Machado permitiu o uso como extensão da edificação.

Figura 67: Desenho da implantação da moradia do Saint' Clair Andrade Junqueira.
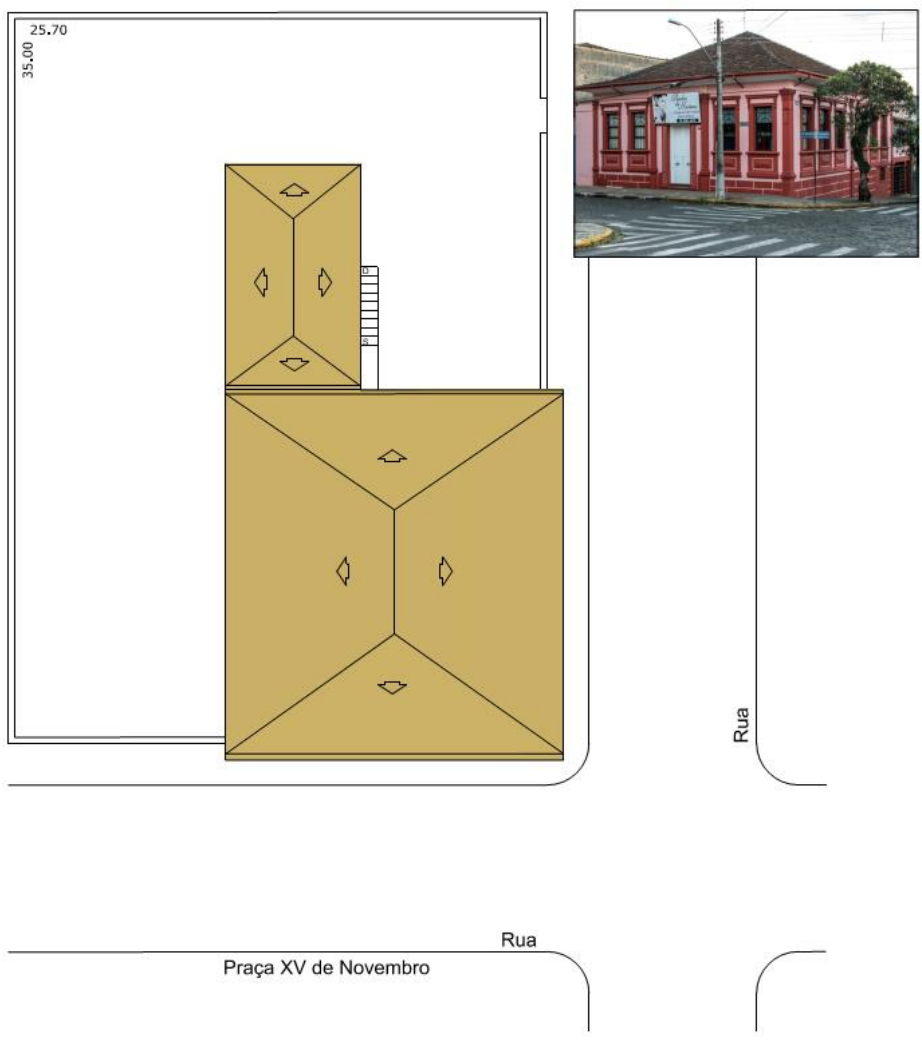

$\square$ Edificação $=$ Limite do lote

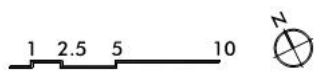

Desenho: Natalia Cappellari de Rezende (2017).

Honório Dias, Saint' Clair participou da política sendo vereador e vice-presidente da Câmara na legislação de 1892 a 1895 , sem terminar seu mandato, renunciando-o. Não há notícia de quando a família Junqueira se estabeleceu nessa cidade, mas em 29 de maio de 1887 quando foi eleita uma comissão destinada a angariar donativos e a dirigir os trabalhos para a construção da primeira igreja Matriz, Saint Clair figurava entre os escolhidos.

${ }^{119}$ As determinações do Código de Postura sobre o aforamento foram apresentadas na página 94. 
O aumento da circulação do capital proveniente, sobretudo da produção cafeeira, a proximidade com o mundo europeu após a implantação das linhas férreas e o afluxo de profissionais tencionou a livre cópia do que aparecia nas revistas e jornais, dos elementos, da fachada, mas também de seus interiores. Diretamente relacionada com estas transformações é a questão da relação entre o público e o privado, que segundo Perrot (1991, p. 286), ao tratar do contexto europeu, pós-Revolução Francesa, foi o centro da discussão que estruturou novos preceitos, entre eles, ela chamou a atenção para a introjeção da importância da família nuclear como base social e "garantia da moralidade natural" (PERROT, 1991, p. 80). Apoiada na constituição biológica de cada $\operatorname{sexo}^{120}$ e reforçada pela religião, essa família deveria ser composta pelo homem - figura paterna e responsável pela vida pública - e pela mulher - responsável pelos cuidados domésticos e educação dos filhos -, tendo o lar como local da sua existência, ponto de encontro e disciplinador social e que por isso ganhou uma atenção especial (PERROT, 1991, p. 285-286). E nesse sentido, a moradia pequena, úmida, suja, mal iluminada, local de imundice e das exalações pestilentas era considerada o ambiente ideal para o desenvolvimento de enfermidades físicas e morais, em contraposição à boa moradia "chave para a paz social" (GUERRAND, 1991, p. 331). Sendo assim, Guerrand (1991) colocou que

\begin{abstract}
a casa, o domicílio, é a única barreira contra o horror do caos, da noite e da origem obscura; encerra em suas paredes tudo que a humanidade pacientemente recolheu ao longo dos séculos; opõe-se à evasão, à perda, à ausência, pois organiza sua origem interna, sua civilidade, sua paixão. Sua liberdade desabrocha no estável, no contido, e não no aberto ou no infinito. Estar em casa é reconhecer a lentidão da vida e o prazer da medição imóvel [...]. A identidade do homem é portanto domiciliar; e eis por que o revolucionário, aquele que não possui eira nem beira, e portanto nem fé nem lei, condensa em si toda a angústia da vagabundagem [...]. (EDELMAN apud PERROT, 1991, p. 285).
\end{abstract}

Pautado em discussões desse teor que, progressivamente, a moradia passou a ter um outro sentido, o de habitação, compreendida como um local privado, afetando a sua organização interna.

No Brasil, Correia (2004) nos mostra as alterações que estavam ocorrendo na casa durante as últimas décadas do século XIX e a primeira metade do século XX. Segundo a autora (2004, p. 01) “a moradia urbana no Brasil passou por ampla reforma, que envolveu mudanças de ordem espacial e alterações de uso e de significados", sendo que

tal reforma se fundamentava em noções de conforto, higiene e economia, que visavam a tornar a casa um ambiente solidário com a saúde, a privacidade, o fortalecimento dos laços familiares, o aumento da produtividade no trabalho e com um reordenamento das atividades e do uso do tempo no âmbito doméstico. (CORREIA, 2004, p. 01).

Os amplos espaços da casa colonial reduziram de tamanho, afinal de contas, não havia mais a farta mão de obra disponível após a Abolição, e nos casos onde os ambientes possuíam múltiplos usos, definiu-se com atividades cada vez mais especializadas. Como afirmado por Correia (2004), e constatado nas moradias aqui analisadas, as mudanças que ocorriam na casa se apoiavam em um projeto que visava

\footnotetext{
${ }^{120}$ Hall (1991, p. 62) destaca que casas construídas para a vida familiar constituía uma nova ideia, "os deveres atribuídos aos homens e mulheres, e de suas relações com o mundo"
} 
converter a moradia em espaço confortável, penetrado por normas de higiene, capaz de garantir certa privacidade a seus moradores e de alterar a vida doméstica por meio de instrumentos de regulação. Na construção desse novo modelo de moradia, o interior da casa foi reorganizado segundo uma racionalidade nova, que modifica seu projeto e seu uso, separando e classificando funções, ordenando, clareando, iluminando e arejando ambientes. (CORREIA, 2004, p. 48).

O mais interessante e que muito explica as alterações do ambiente doméstico que estavam acontecendo em fins do século XIX na moradia rio-pardense, mas que na capital já ocorria desde meados desse século (CAMPOS, E. 1997), foi segundo Lemos, C. (1993, p. 103) o "novo critério de circulação dentro de casa". Conservou, em partes, a tradição da planta de corredor central, mas inovou com a divisão da moradia em zonas distintas (LEMOS, C., 1993). E é desta maneira que a edificação de Saint' Clair Andrade Junqueira se desenvolveu. Com uma volumetria compacta composta por uma planta que se assemelha a forma de um L, essa moradia tem no seu núcleo central as áreas sociais e íntimas, e nas adjacências desses espaços, reservada em uma parte menor em planta, a área de serviços. O vestíbulo - engastado entre a antiga capela e quarto de hóspedes que se tornaram salas - era o elemento de distribuição através do corredor e para o qual as portas dos dormitórios se abriam. Já os acessos e fluxos ocorriam de modo relacionado com a distribuição dos usos, sendo o social realizado pelo vestíbulo e corredor central que conduz aos cômodos destinados ao repouso, enquanto o acesso às áreas de serviços, localizadas na extremidade posterior da planta, acontece pela lateral direita do terreno através do quintal, como pode ser observado na Figura 68.

Para Lemos, C. (1989b, p. 52), essa foi a "novidade programática trazida pelos arquitetos eruditos do ecletismo", a qual Fabris (1993, p. 135) reforçou ao dizer que "a arquitetura

Figura 68: Desenho da planta da moradia de Saint' Clair Andrade Junqueira.

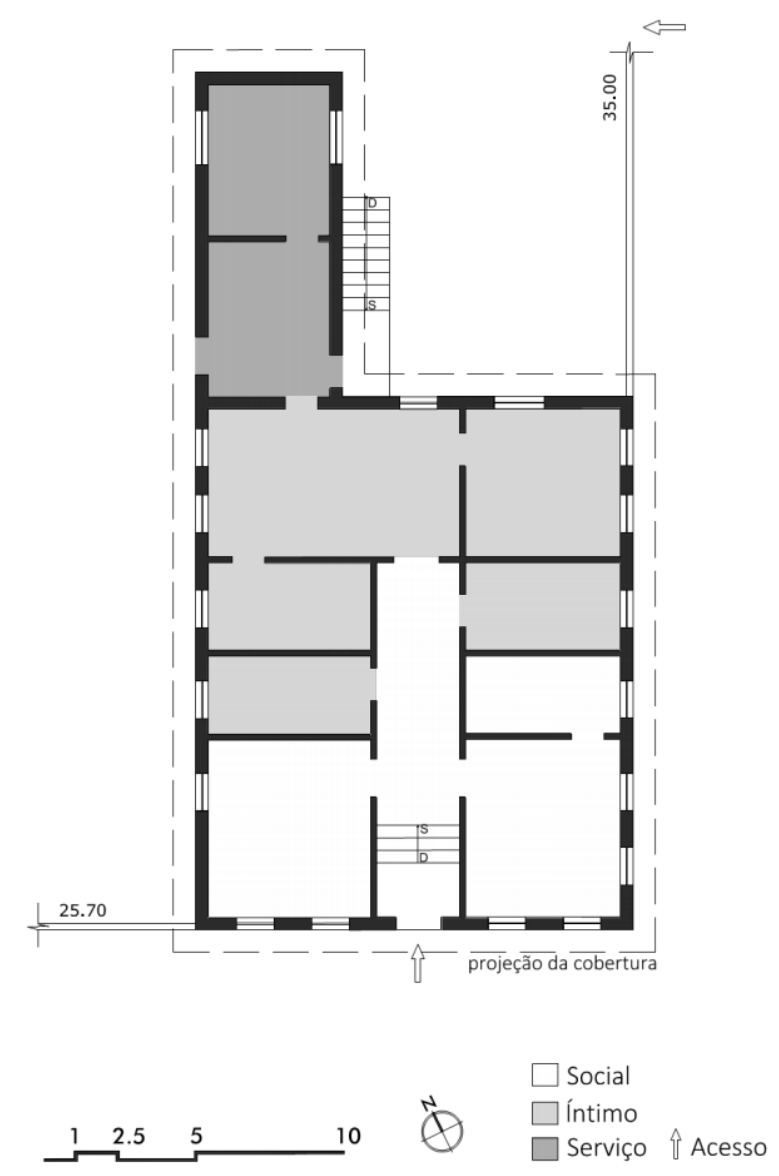

Fonte: PAULINO, 1993. Desenho: Natalia Cappellari de Rezende (2016). eclética não é apenas representativa: está também atenta ao caráter funcional dos ambientes e dos objetos entendidos antes de tudo como um valor que possa coincidir com um conforto estetizante". Logo, podemos afirmar que, apesar da moradia do 
Junqueira estar fortemente vinculada a casa tradicional brasileira ${ }^{121}$, apresenta certa independência entre os ambientes.

Ainda se tratando da arquitetura do café, Lemos, C. (1978) atribuiu à produção paulistana da segunda metade do século XIX a inspiração das alterações maiores, modificando os modos de viver que passaram a ser mais definidos. A exemplo, esse autor (LEMOS, C., 1978) apresentou o projeto de uma residência com data de 1896 (Figura 69), onde persistiu o corredor central, a varanda - então sala de jantar -, como centro de interesse do lar, e o banheiro foi inserido do interior da edificação. Com um esquema de circulação semelhante a moradia de Saint' Clair e guardando similaridade com a planta da sede da fazenda Tubaca ${ }^{122}$ (Figura 70), analisada por Paulino (1993), é implícito a uniformidade da casa urbana. Desse modo, a disposição interna da residência de Saint' Clair denuncia a adoção de uma circulação segregada, de uma privacidade e de uma preocupação com a iluminação e ventilação natural de todos os ambientes - definidos e com atividades especializadas - antes inexistentes, reforçando a importância da sua análise nesta dissertação.

Figura 69: Projeto de residência construída na Rua do Arouche, noํ0, de 1896, São Paulo.

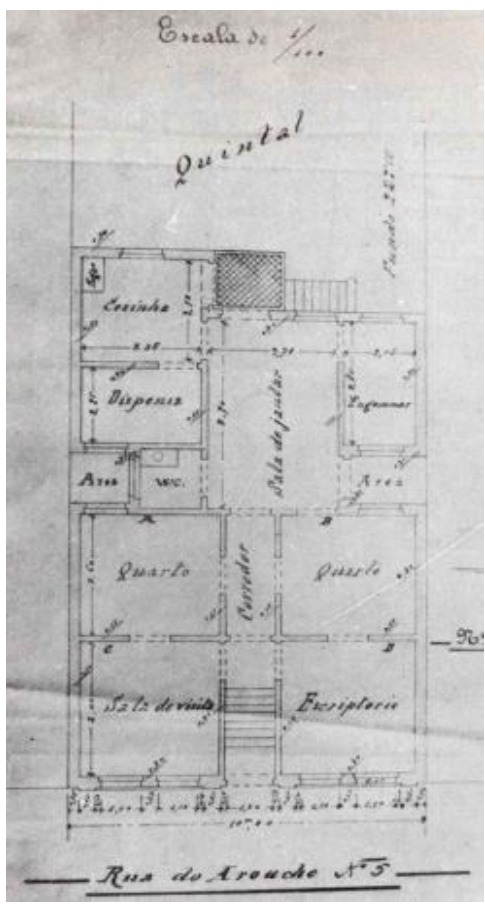

Fonte: Lemos, C. (1978).
Figura 70: Desenho da planta da sede da fazenda Tubaca.
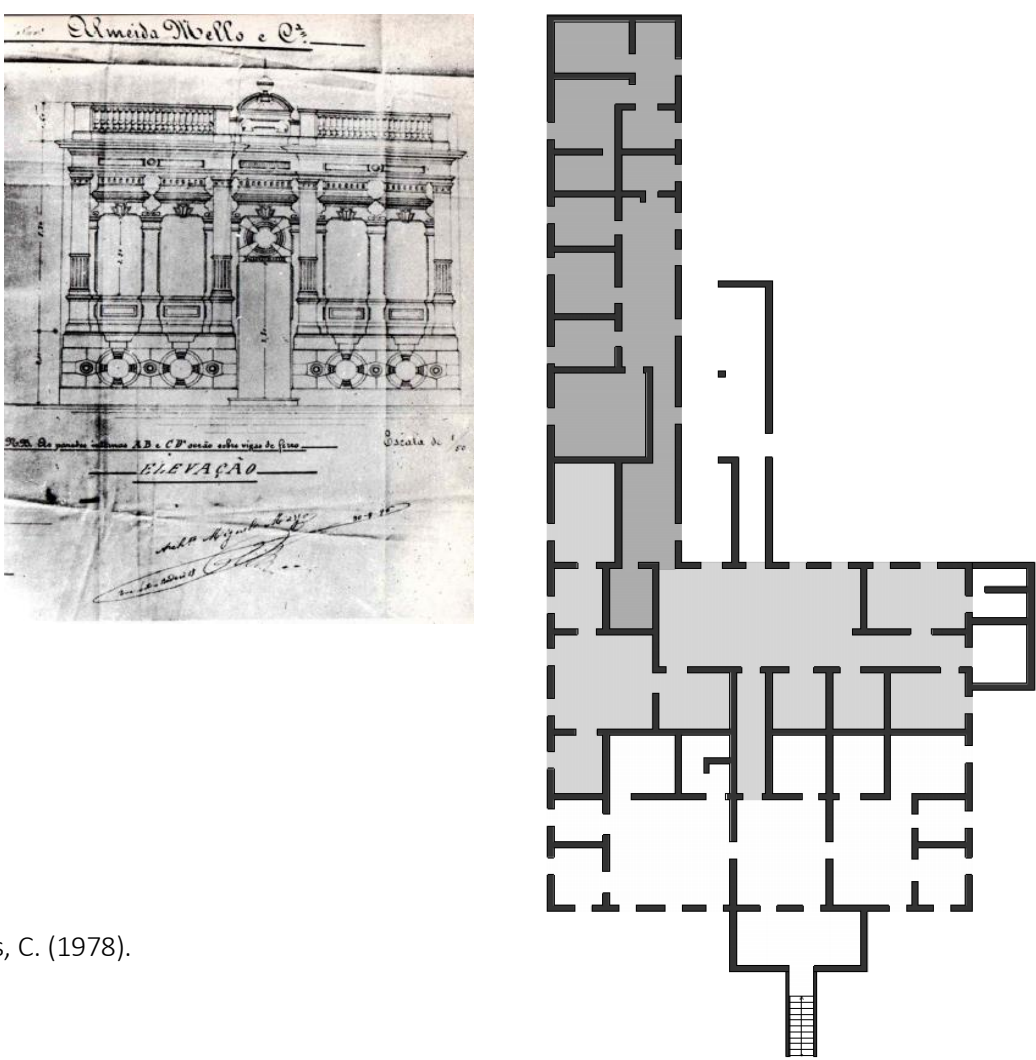

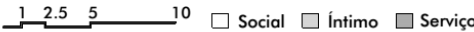

Fonte: Paulino (1993). Desenho: Natalia Cappellari de Rezende (2017).

\footnotetext{
${ }^{121}$ Similaridades entre o agenciamento interno dessa residência e as inúmeras moradias rurais e urbanas construídas ainda nos novecentos podem ser encontradas em Cozinhas, etc. de Carlos Lemos, C. (1978).

122 Nesse sentido, ver outros exemplos de casas urbanas e rurais apresentadas por Lemos, C. (1978), como a Fazenda D. Pedro II construída por descendentes de Antônio Ferraz de Arruda, dono da Fazenda Milhão, em 1900; e uma casa urbana de Raul Fonseca construída em Jundiaí em 1877.
} 
Contudo, no final do século XIX, período em que foi construída a moradia do Junqueira, a precariedade tecnológica, a dificuldade de acesso aos materiais construtivos e a inexistência de rede de esgoto impossibilitavam a presença do banheiro dentro da casa, sendo sua construção nas adjacências do quintal, na popularmente denominada "casinha" (PAULINO, 1993). Em contrapartida, a cozinha apareceu integrada ao corpo principal da moradia se situando na parte posterior da edificação, o que possibilitava a comunicação direta com a sala de jantar e, ao mesmo tempo com o quintal onde havia estrita dependência em consequência das atividades realizadas cotidianamente, como o provimento de frutas e verduras e criação de animais. Esse arranjo permitia ainda que a fumaça e os odores fossem eliminados para fora da moradia, não se espalhando para os demais cômodos. Como descreve Veríssimo e Bittar (1999, p. 24) ao tratar da localização da cozinha e do seu arranjo, exemplificado por essa edificação:

Com os novos materiais [importação de produtos manufaturados e industrializados], a cozinha já não precisa ser tão isolada da casa como em partidos anteriores, onde se procurava afastar o calor e impedir a fumaça no interior das residências [...] a cozinha vai ocupar seu lugar determinado no organograma das novas casas. Ela deve ficar próxima aos quintais, no fundo da casa, porém dentro dela [...]. (VERÍSSIMO e BITTAR, 1999, p. 24).

A planta dessa moradia nos mostra a dinâmica de evolução das áreas de serviço, que dentro da casa assume e força o convívio da família com as pessoas responsáveis pelos afazeres domésticos.

Como o agenciamento interno da moradia do Junqueira, o programa de usos da residência do Leonardo Define se divide nas áreas: social, íntima e serviço. O ambiente de negócios também faz parte do programa, incorporado à casa, e denota o caráter de Define como homem do comércio. São três os acessos da edificação e indicam a estreita relação do programa com a implantação. Observamos ainda que todos estão relacionados com a função do ambiente, sendo o acesso social o principal que nos conduz da Rua Marechal Deodoro ao interior da casa; o acesso de negócios acontece de forma separada e independente, apesar de existir uma comunicação com o interior da moradia de maneira restrita; é desse mesmo modo que se chega aos ambientes de serviços e a área de banho que estão separados do corpo principal da moradia e Figura 71: Reconstituição da planta da edificação de Leonardo Define.

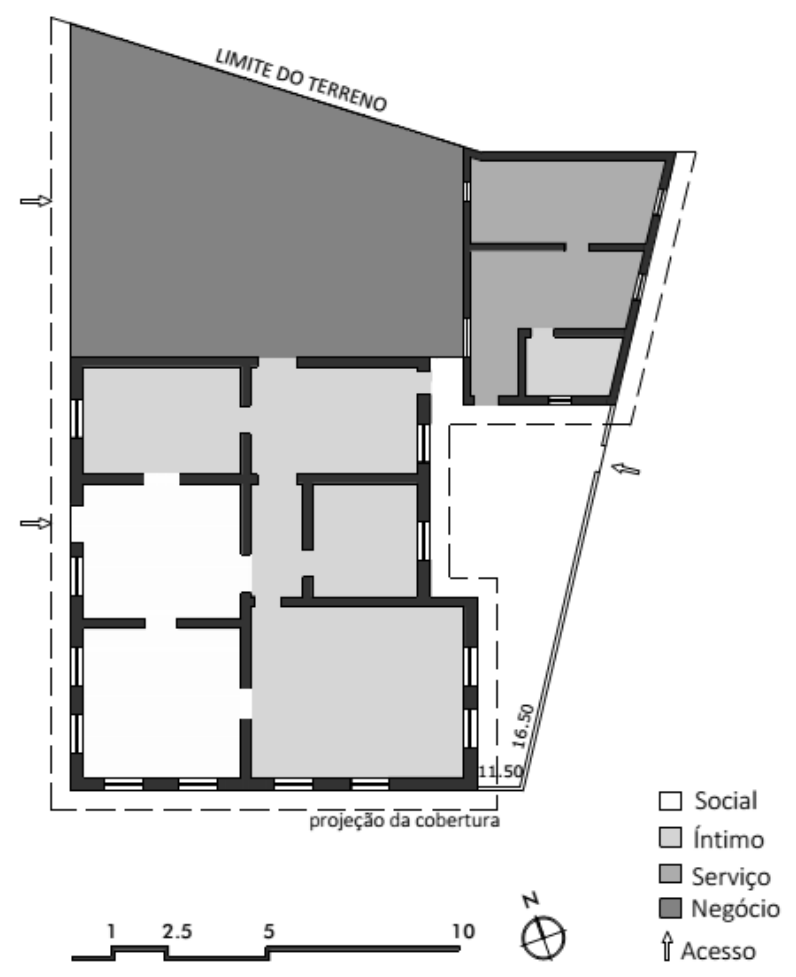

Desenho: Natalia Cappellari de Rezende (2016) com base em fotografias, projeto de reforma arquivado na Secretaria de Obras (1941, P11) e conferido in loco. 
José Andreoli, como pode ser observado na Figura 71. Internamente, manifestou o aparecimento das alterações nas maneiras de morar com a ascensão de novas sensibilidades acerca da privacidade, como um pequeno corredor que conduz da área social aos cômodos da área íntima.

Já a moradia de Honório Luiz Dias não dispõe de documentação como projeto ou fotografias internas, o que dificulta tecer qualquer análise. Mas sabemos através das notícias publicadas nos jornais que havia uma intensa vida social nos salões da residência desse fazendeiro, que promovia festas para a elite rio-pardense, como destaca a publicação do jornal O Rio Pardo de 1900:

A elegante residência do Snr. Coronel Honório Dias foi pequena para conter o elevado número de convidados, a fina flor rio-pardense, que foi assistir ao baile por S. S. oferecido na noite de 6. Num enthusiasmo, sempre latente, numa harmonia, sem discrepância, realizaram-se as danças que se prolongaram até pelo amanhecer, hora em que começou a retirada dos convivas, satisfeitíssimos com as já proverbiais atenções que lhes sabe dispensar o illustre hospede. (SARAU, 1900, p. 02).

Certamente, Honório como sócio do Syndicato da Luz Electrica de São José do Rio Pardo era um dos 62 consumidores particulares que se beneficiou da energia elétrica instalada em $1897^{123}$, a qual, segundo Lemos, C. (1989b, p. 45), contribuiu para mudar "os hábitos caseiros, os horários. Propiciou à chamada tertúlia, quando todos os membros da família permaneciam à volta da mesa, a refeição terminada, conversando, jogando, lendo, costurando, ouvindo música". Consequentemente, o "programa de necessidade alterou-se porque já se manifestava uma certa 'civilidade' moderna que permitia o acesso de estranhos a essas reuniões já não mais intimas". Certamente foi com esse beneficiamento que os jantares sociais se tornaram frequentes na casa de Honório, como constatado em outros artigos de jornais.

Em se tratando da técnica construtiva, constatamos o esforço pelo aperfeiçoamento e incorporação dos benefícios mais recentes da sociedade industrial, fazendo com que a taipa de mão fosse superada pelo uso do tijolo assentado com areia e cal permitindo o ornamento e a maior liberdade no agenciamento dos vãos. Nas duas edificações ainda existentes, a pedra foi o elemento empregado no alicerce, seguida da alvenaria de tijolos argamassada com barro nas paredes - técnica utilizada em conformidade com o material disponível, o barro, e das olarias que facultou a produção e viabilização deste material que também foi utilizado nas telhas cerâmicas. Como podemos constatar nas moradias do Define e do Junqueira, a utilização do tijolo e sua variação no assentamento resultou em diferentes espessuras de paredes, sendo as externas variando de $30 \mathrm{~cm}$ a $40 \mathrm{~cm}$ e as internas de $17 \mathrm{~cm}$ a $25 \mathrm{~cm}$. O sistema da cobertura de ambas as edificações é composta da estrutura em madeira e telhas capa e canal - posteriormente trocadas pelas francesas -, em acordo com as normas do Código de Posturas de 1887 que determinava em seu artigo 14 a proibição

\footnotetext{
${ }^{123}$ Sobre este melhoramento, segundo estudo realizado por Maschietto (1979), em 1900 havia somente 62 consumidores particulares, o que demonstra certa precariedade do serviço e lentidão na incorporação de um novo costume que contribuiria sobremaneira no ar ranjo da planta e no modo de morar. Para mais informações sobre as consequências da iluminação no agenciamento da casa e no modo de morar, ver Homem (1996)
} 
nas ruas e praças desta villa:

$\S 1^{\circ}$ - Edificarem-se casas de meia-água no respectivo alinhamento.

$\S 2^{\circ}$ - Cobrir-se casa com sapé ou capim. O infractor será multado em $30 \$$ além da obrigação da demolição. (CÓDIGO DE POSTURAS, 1887, p. 05-06).

De acordo com o levantamento da moradia de Saint' Clair Andrade Junqueira feito por Paulino (1993), o piso utilizado era o ladrilho hidráulico decorado na cozinha e nos demais ambientes tábuas de ipê, enquanto os forros eram de saia e camisa. Essas também foram as preferências utilizadas na moradia de Leonardo Define, como podemos perceber na Figura 72 que evidencia o piso dos ambientes que, antes da reforma, eram as salas.

Figura 72: Interior da edificação na Praça Prudente de Moraes. Antiga moradia de Leonardo Define.

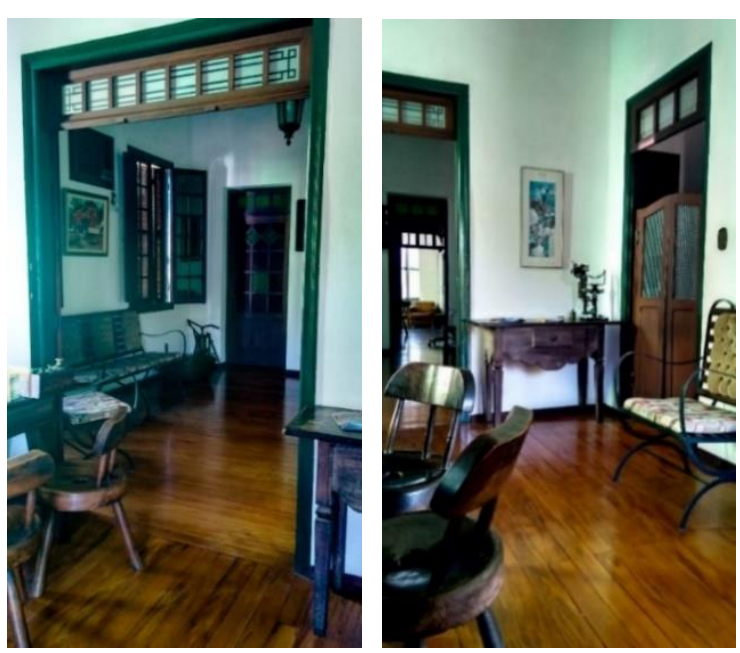

Fonte: Acervo pessoal da autora (2016).

Esse provavelmente tenha sido o momento em que as moradias rio-pardenses estavam se ajustando ao descrito por Reis Filho (2011) sobre as facilidades de importação que estavam ocorrendo na segunda metade do século XX com a instalação de um extenso sistema ferroviário: "novas técnicas e recursos construtivos, como materiais de todos os tipos, desde vigas e colunas de metal, até elementos de acabamento, mobiliário e decoração" passaram a fazer parte das edificações (REIS FILHO, 2011, p. 148). Influenciados pelos meios de difusão que acresceram

enormemente o cabedal de conhecimentos do homem oitocentista. Jornais, revistas, manuais, enciclopédias, livros ilustrados, a divulgação de imagens e repertórios através de gravuras e fotografias, o crescente interesse pelo romance histórico, o papel do melodrama na constituição de um imaginário pitoresco colocam o homem do século XIX no interior de uma rede de relações', que Ihe permite transitar livremente entre passado e presente, sem se preocupar com a adesão a este ou àquele momento da história por estar potencialmente aberto a todos eles. (FABRIS, 1993, p. 137).

Sobre isso cabe destacar os jornais e periódicos que circulavam em São José do Rio Pardo, o que demonstra que a elite rio-pardense estava antenada às novidades europeias, com destaque para o livro ilustrado "L'Europe pittoresque - Pays du nord", publicado no final do século XIX, entre outros doados por fazendeiros locais que indubitavelmente exercerceram influência no estilo arquitetônico adotado por essa elite.

Em relação às intenções plásticas adotadas pelas moradias rio-pardenses desse período, o repórter Aprígio Cesarino citou no "Diário Popular" de São Paulo (1887) o sobrado de Honório Luiz Dias como sendo "um lindíssimo sobrado que poderia ser destacado mesmo em uma grande cidade". Apesar deste edifício lamentavelmente ter sido demolido no início da segunda metade do século XX, podemos apreender as suas 
características externas através de fotografias das fachadas que demonstravam uma adesão a elementos do neoclássico ${ }^{124}$. Nesse sentido, Lemos, C. (1989b, p. 55) ao tratar da moradia construída em São Paulo e no Rio de Janeiro no fim do século XIX, apontou que elas quando "providas de ornamentação classicizante situada de modo especial nas platibandas coroadas por vasos, pinhas ou estátuas de louça, filiam-se verdadeiramente a um neo-renascentismo", logo comprometida a outros estilos, "caracterizando, então, aquilo que se chamou de ecletismo" (LEMOS, C., 1989b, p. 55).

A exemplo do que já ocorria em São Paulo, registrado pelas lentes de Militão e analisado por Eudes Campos (1997) em sua tese de doutorado, a "Fortaleza Republicana" (Figura 73) possuía modenatura ritmada e com proporções rígidas, e coroando o edifício havia a platibanda intercalada de pedestais nas prumadas das pilastras que sustentavam vasos tipo "compoteiras" e escondia o telhado. Dispunha de aberturas em arco pleno e em verga reta, com vãos encimados por frontões em arco abatido, pilastras com feição dórica e jônica.

Figura 73: Sobrado de Honório Luiz Dias (década de 1880).

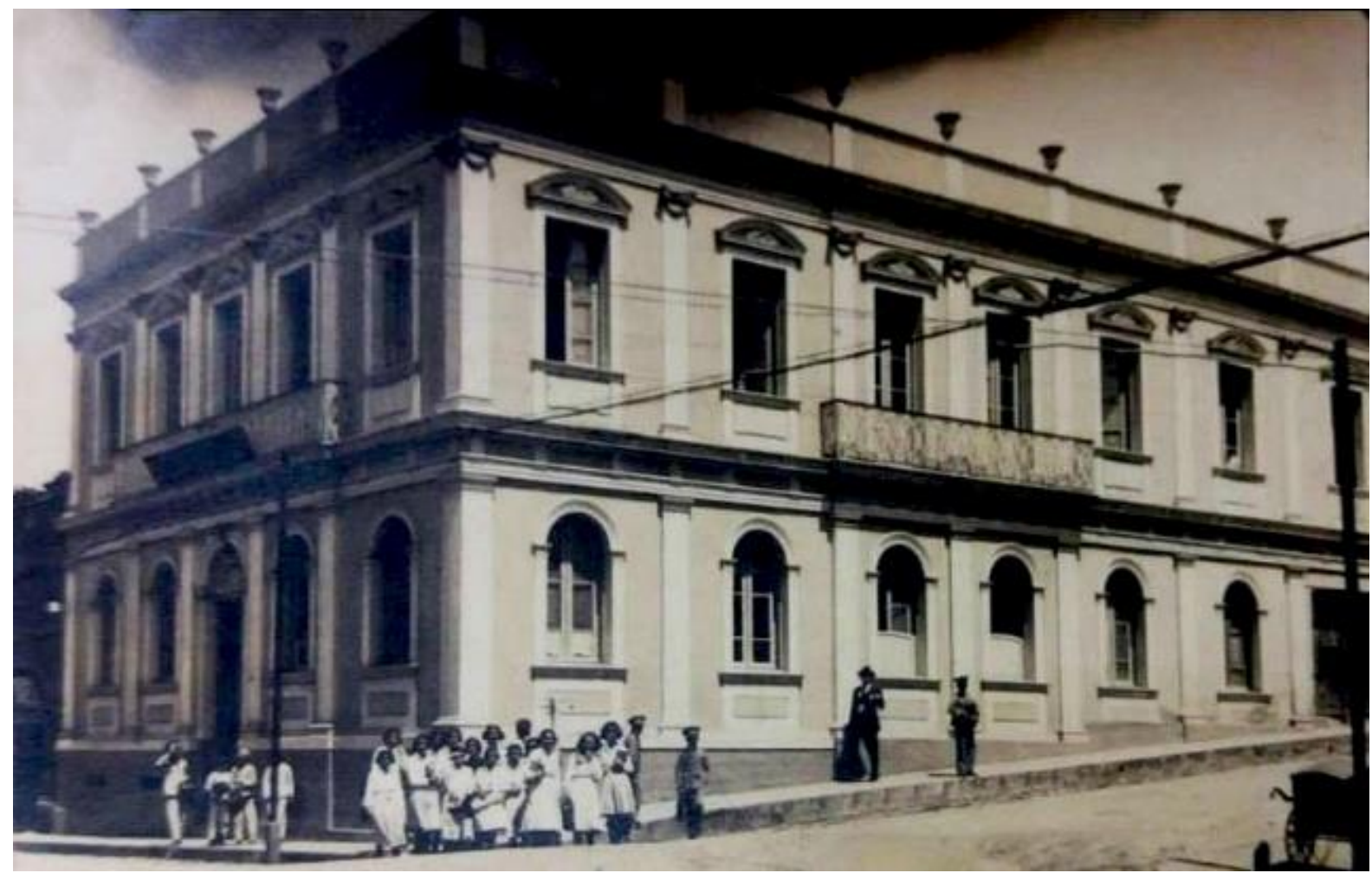

Fonte: Arquivo da Hemeroteca Jornalista Paschoal Artese.

Análoga a essa edificação é o sobrado do capitão Basiliano da Costa Fontes (Figura 74), fundador e administrador da primeira casa bancária de Jaboticabal (GARCIA, 2008). Este, assim como o de Honório,

\footnotetext{
${ }^{124}$ Segundo Souza (1994, p. 21), seria impróprio dizer que no Brasil houve uma arquitetura neoclássica. "O prefixo neo - significa novo, tal designação só seria apropriada se já tivéssemos vivido no Brasil um movimento arquitetônico classicista anterior, o que na verdade não ocorreu". Para saber mais sobre as posições de Souza, consultar seu livro Arquitetura neoclássica brasileira: um reexame. São Paulo: Pini, 1994.
} 
ostentava ornamentos ecléticos e materiais industrializados, mas perpetuava os "valores tradicionais arraigados em seu modo de vida e denunciados pela forma de exercer o poder, de morar e pela organização social” (GARCIA, 2008, p. 99). Solução compacta e adaptada dos palacetes paulistanos (HOMEM, 1996; RAMALHO, 1989), e que muito se assemelha ao Palacete Pinhal, residência do Conde do Pinhal (Figura 75), construído em São Carlos em 1893 (BORTOLUCCI, 1991, p. 227-232), e também a alguns sobrados construídos na região de São José do Rio Pardo, como em Casa Branca (Figura 76).

Figura 74: Sobrado do capitão Basiliano da Costa Fontes em Jaboticabal -SP.

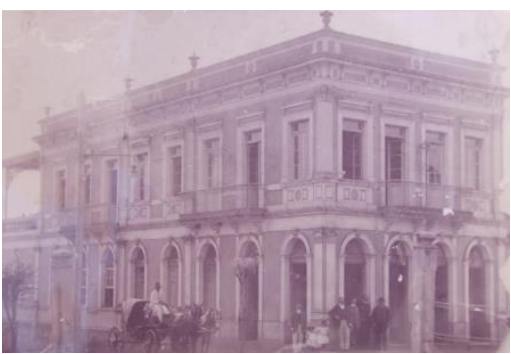

Fonte: Garcia (2008, p. 99).
Figura 75: Antiga residência do Conde do Pinhal em São Carlos -SP.

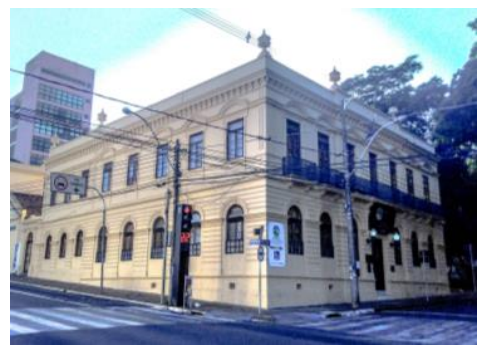

Fonte: Acervo pessoal da autora (2018).
Figura 76: Sobrado construído na cidade de Casa Branca para servir de moradia ao historiador Lafayette de Toledo.

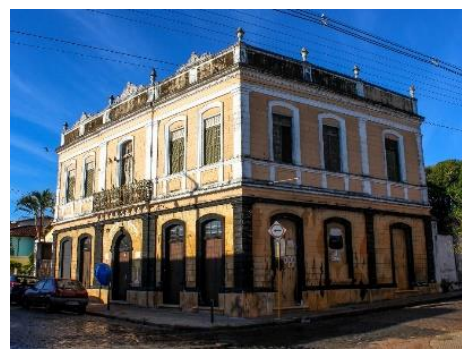

Fonte: Acervo pessoal da autora (2017).

Ao tratar da produção eclética, Bortolucci (1991) diz que ela era recorrentemente "aplicada por uma mão de obra estrangeira e de acordo com uma estética estranha à sociedade local - comoveu não só o paulista da capital, mas também o do interior" (BORTOLUCCI, 1991, p. 87), como foi o caso da moradia de Honório Luiz Dias. Constatamos ainda a busca da simetria (Figura 77) como ideal de beleza e em acordo com as imposições do Código de Posturas, como se segue:

\footnotetext{
Art. $9^{\circ}$ - Nenhum prédio será construído ou reedificado nesta villa sem que tenha pelo menos 3,96 de altura contados da soleira á cimalha; sendo o prédio de sobrado terá 3,96 o primeiro andar e o segundo terá 3,52 de altura. As portas terão pelo menos 1,10 de largura. 0 infractor será multado em $30 \$$.

$\S 1^{\circ}$ - Nenhum prédio será construído nesta villa sem que nelle sejam observadas as symetrias e regularidades necessárias. (CÓDIGO DE POSTURAS, 1887, p. 05).
}

Intenções estas também perseguida na residência do Saint’ Clair Andrade Junqueira (Figura 78), que assim como na moradia de Dias, ostenta uma composição de elementos com adesão ao ecletismo (Figura 79). Sua fachada voltada para a Praça XV de Novembro, 118, apresenta janelas equidistantes com verga reta, porta principal em arco pleno com bandeira fixa ornada em ferro forjado (Figura 78) - garantia de iluminação e ventilação permanente -, aduela antropomórfica, pilastra que remetem à toscana e compósita, modilhões e bossagens na parte inferior das paredes externas, na altura do porão. A exemplo do palacete do Dias, essa edificação representa os anseios de uma sociedade que buscava o desenvolvimento material, o conforto e as novidades no campo estético, construtivo e tecnológico a partir do que se produzia em centros maiores. 
Figura 77: Eixo de simetria na fachada frontal da moradia de Honório Luiz Dias.

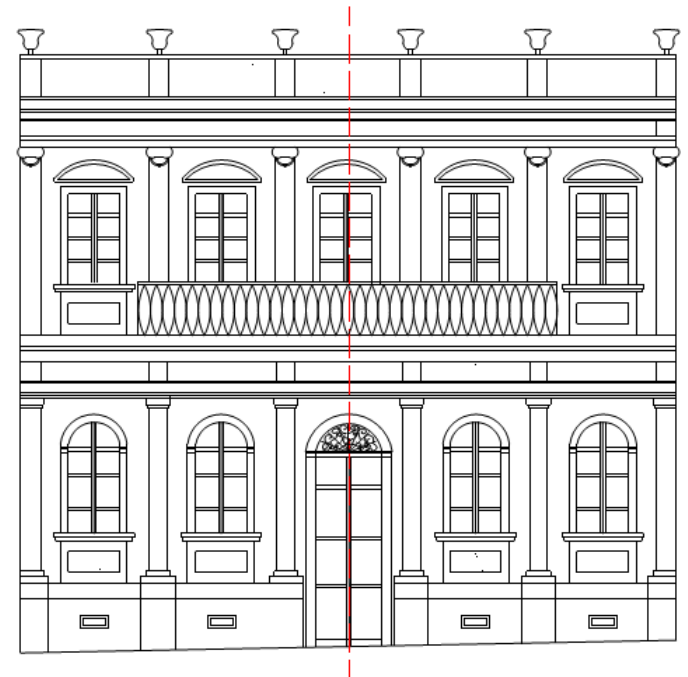

$12.5 \quad 5 \quad 10$

Desenho: Natalia Cappellari de Rezende (2017).
Figura 78: Eixo de simetria na fachada frontal da moradia de Saint' Clair Andrade Junqueira.

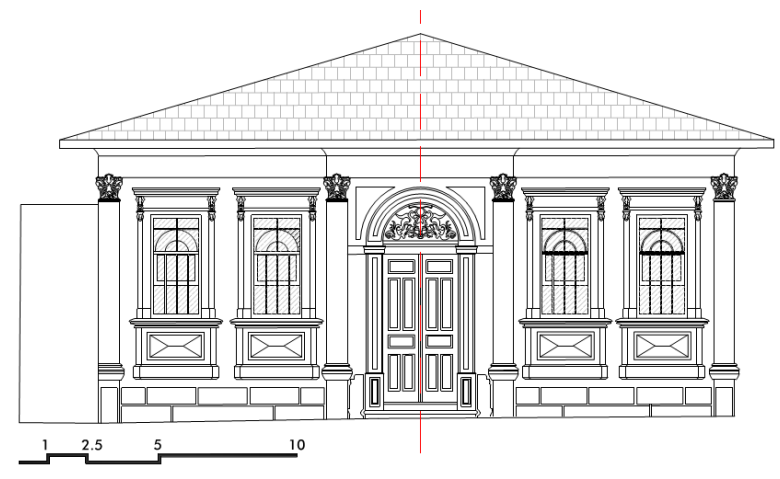

Desenho: Natalia Cappellari de Rezende (2017).

Figura 79: Moradia de Saint’ Clair Andrade Junqueira (1888-1890) na Praça XV de Novembro esquina com a Rua Francisco Glicério.

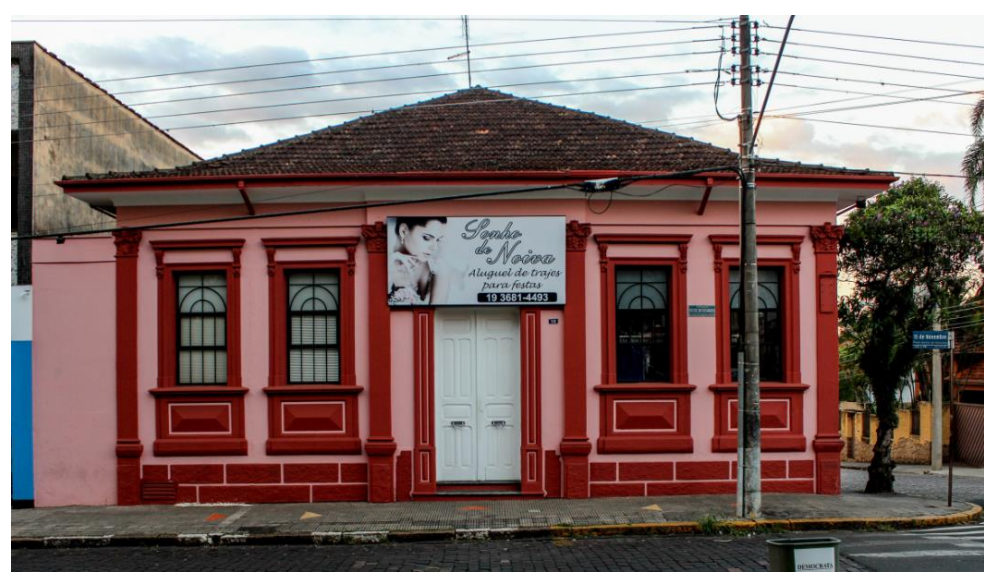

Fachada voltada para a Praça XV de Novembro

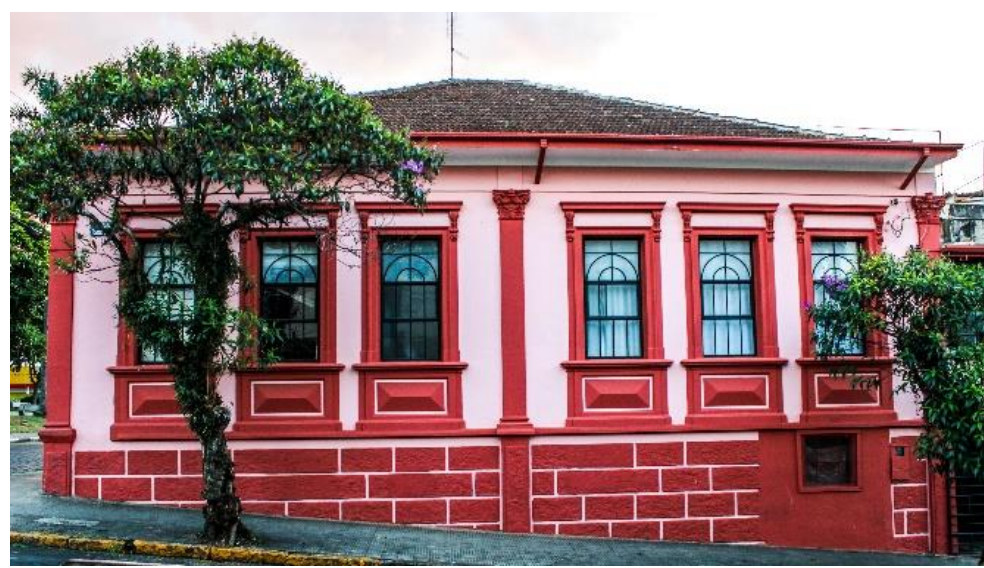

Fachada voltada para a Rua Francisco Glicério

Fonte: Acervo pessoal da autora (2018). 
Figura 80: Bandeira em ferro fundido da porta principal da moradia de Saint' Clair Andrade Junqueira.

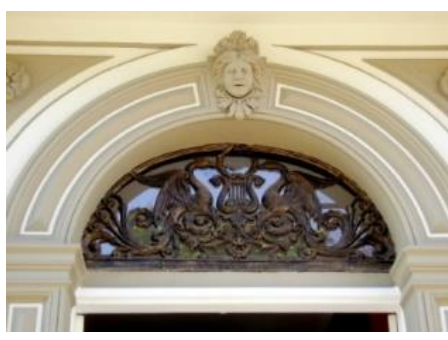

Fonte: Acervo pessoal de Rodolpho José Del Guerra (2006).
Afora a ausência de informações sobre o autor do projeto, sabemos que na cidade de Guaxupé, no ano de 1901, foi construída uma residência para abrigar a família do Conde Joaquim Augusto Ribeiro do Valle. Este por sua vez havia convidado o italiano José Puntel ${ }^{125}$ para residir junto com a sua família em Guaxupé, sendo Puntel o provável autor e construtor da casa. Ambas as moradias, do Ribeiro do Valle em Guaxupé e do Junqueira em São José do Rio Pardo, apresentam características muito semelhantes, principalmente no que diz respeito à composição da fachada, como é possível observar na Figura 81, presumindo assim que a moradia do Junqueira possivelmente tenha sido obra também de Puntel.

Figura 81: Antiga residência do Conde Ribeiro do Valle construída na cidade de Guaxupé (1901).
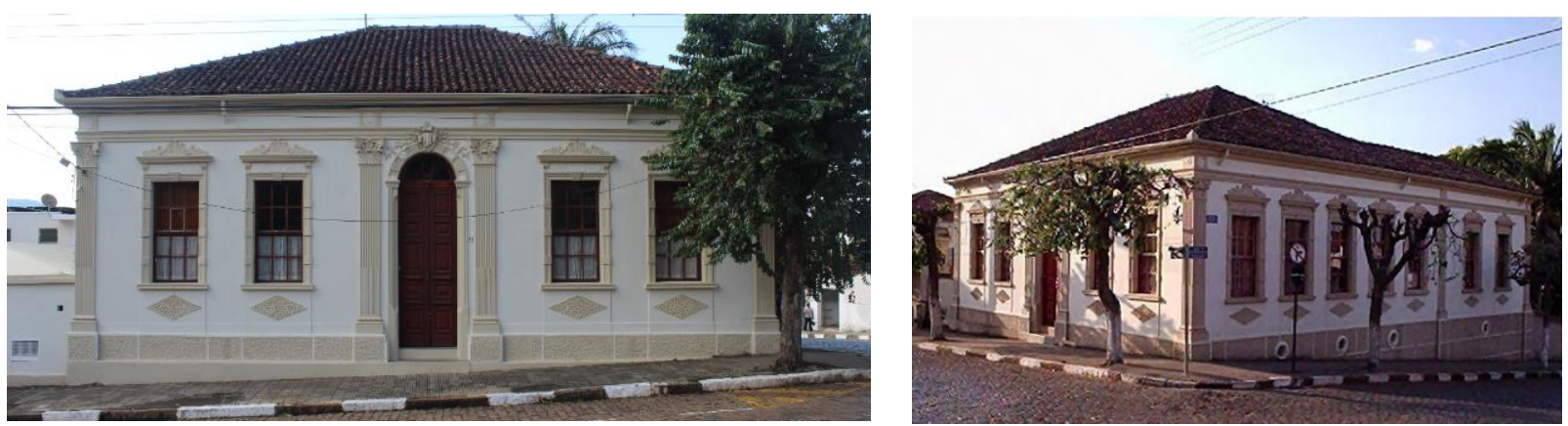

Fonte: Acervo pessoal da autora (2018) e Cyrino Filho (2008).

Constatamos através da análise do material levantado e da pesquisa de campo que a adoção de características disseminadas pelo ecletismo apareceu em São José do Rio Pardo no final do século XIX, mas ainda persistindo as semelhantes com a arquitetura tradicional. O que será alterado no século XX, quando o ecletismo passa a dominar, adotado nos prédios públicos e também nas moradias como símbolo do status de seus ocupantes. E nesse sentido, a moradia de José Dias Machado e Leonardo Define são os exemplos.

Como podemos observar na Figura 82 e Figura 83, as intenções plásticas da residência do Machado se resumem à cimalha, uma sequência rítmica de aberturas em verga reta encimadas por régulas, sendo as janelas de guilhotina fechadas por vidro de motivos geométricos do lado externo. É possível perceber na fotografia de Innocencio Vilhegas da Rua Benjamin Constant que essa moradia, em vista das demais

\footnotetext{
${ }^{125}$ Segundo Cyrino Filho (2008, p. 89), José Puntel foi casado com Úrsula, da região alpina do norte da Itália, próximo da divisa com a Áustria, com os filhos Oswaldo, Celeste, José (Fitti), Basílio, Ursula e Maria, chegando a São Paulo no final do século XIX" trabalhando em construção civil. Incentivado pelo pai, José (Fitti) foi um hábil escultor, sendo responsável por diversas obras na cidade de Guaxupé Basílio e Celeste retornaram a São Paulo para estudar no Liceu de Artes e Ofício, onde depois trabalharam no ramo da construção civil. Já Luiz Puntel, filho mais velho, veio para Guaxupé e associou ao seu pai e irmãos, depois de concluir os estudos em Arquitetura e Desenho em Uberlingen na Alemanha. Para saber mais sobre essa família e as obras que deixaram em Guaxupé, ver Cyrino Filho (2008).
} 
edificações, se caracteriza por ser uma persistência em momento de transformações, as quais serão melhores analisadas no segundo capítulo quando trataremos da cidade e das moradias entre os anos de 1903 e 1917.

Figura 82: Fachada frontal da moradia de José Dias Machado (identificada com a seta preta) na esquina da Rua Benjamin Constant, década de 1910.

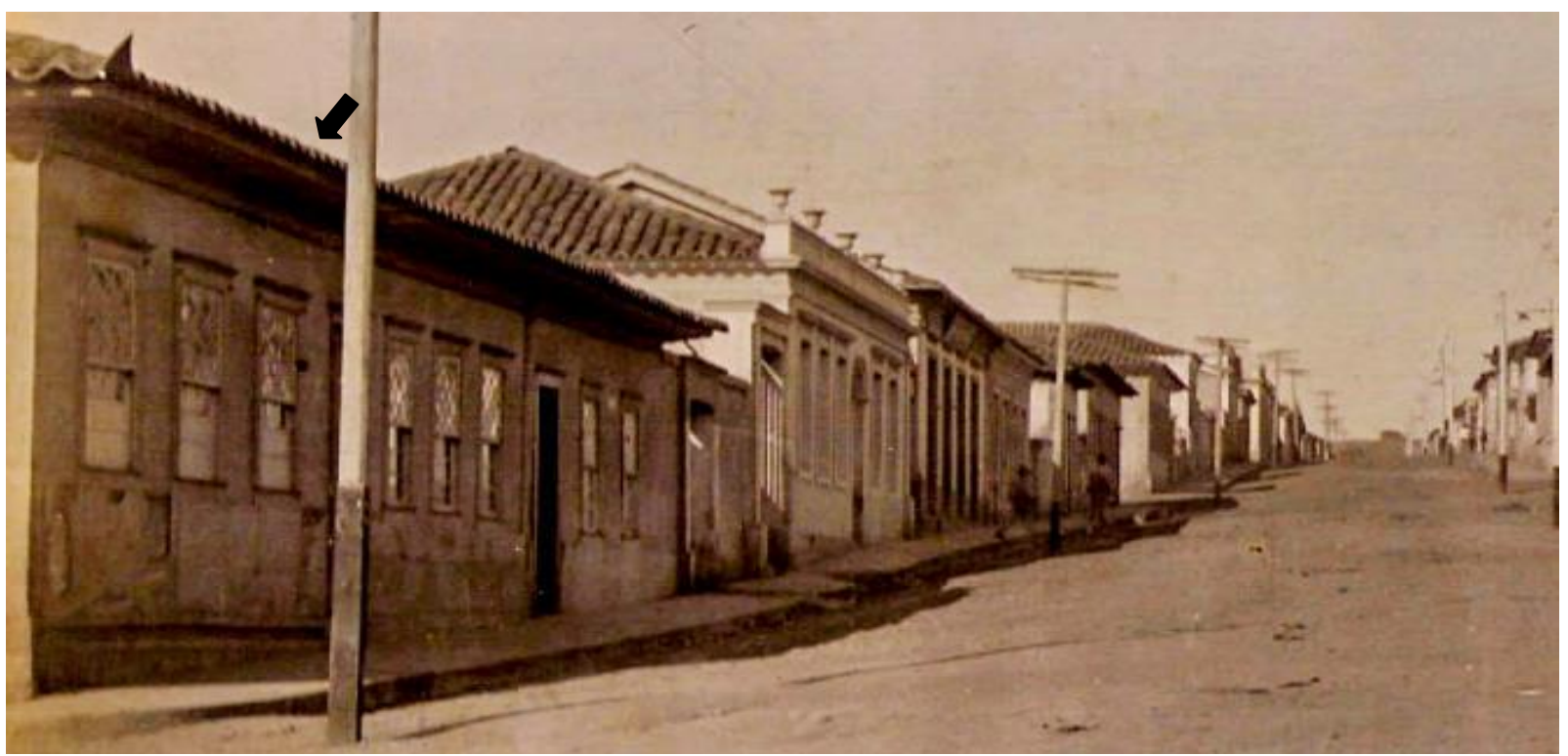

Fonte: Arquivo do Centro da Memória Rio-Pardense Rodolpho José Del Guerra. Fotografia de Innocencio Vilhegas.

Figura 83: Fachada lateral da moradia de José Dias Machado (indicada com a seta preta) voltada para a Praça Prudente de Moraes na década de 1910.

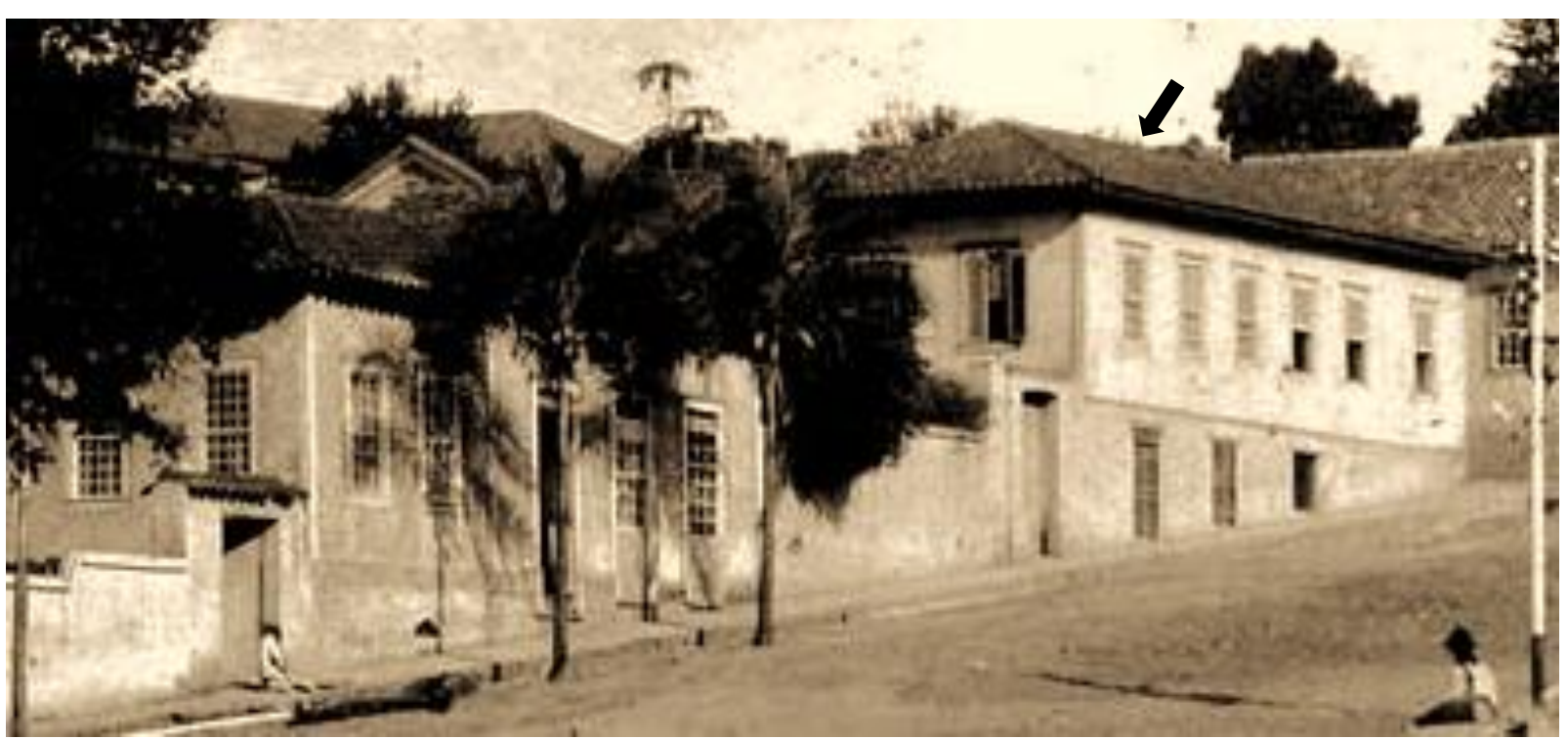

Fonte: Arquivo do Centro da Memória Rio-Pardense Rodolpho José Del Guerra. Fotografia de Innocencio Vilhegas.

Semelhante às moradias construídas no mesmo período na cidade de Guaxupé (Figura 84) e Casa Branca (Figura 85), a edificação de Machado estava ajustada ao que recorrentemente se fazia na época. 
Figura 84: Moradia construída na Rua João Alkmin na cidade de Guaxupé.

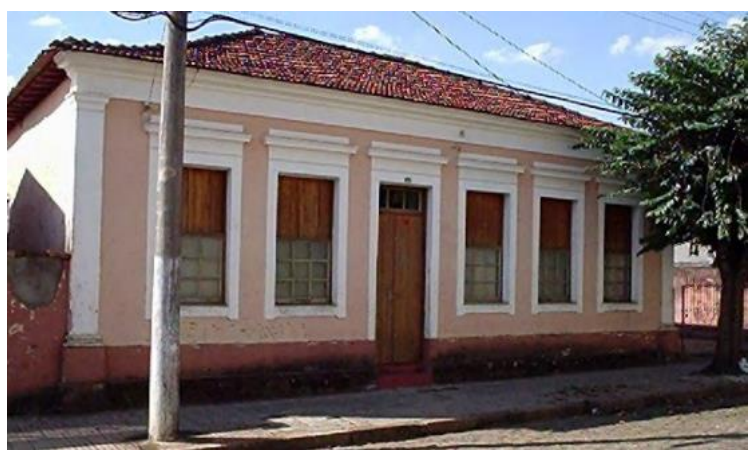

Fonte: Cyrino Filho (2008).
Figura 85: Moradia (1889) construída na Rua Valdemar Panico 1889 na cidade de Casa Branca.

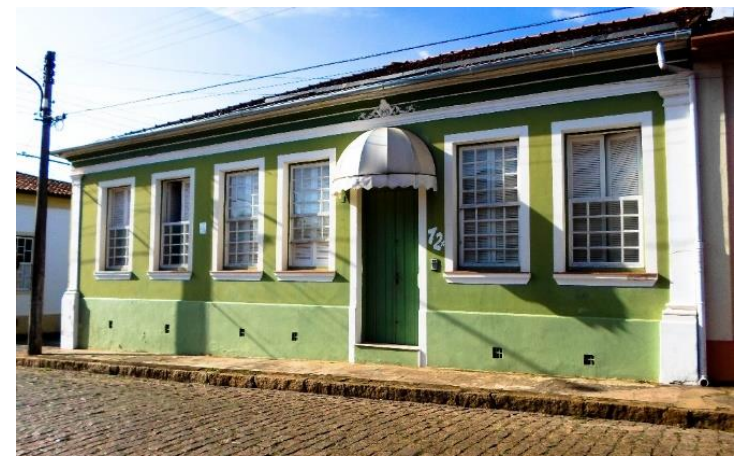

Fonte: Acervo pessoal da autora (2016).

Apesar da simplicidade formal apresentada, podemos observar que o número e o desenho das esquadrias (Figura 86) eram também uma forma de transmitir o cuidado e distinção econômica e social do morador.

Características semelhantes encontramos na moradia do Define (Figura 87) que apresenta janelas em guilhotina com verga reta e régulas superiores e inferiores, bossagem na altura do porão, e cimalha sob o extenso

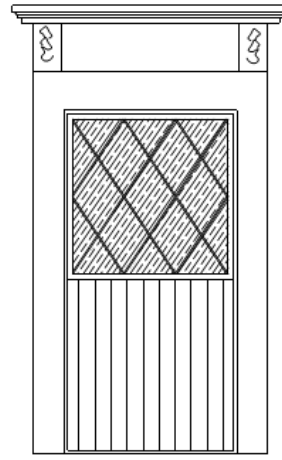

Figura 86: Desenho da esquadria da moradia do major José Dias Machado. Desenho: Natalia Cappellari de Rezende (2017). beiral que compunha o telhado. De maneira evidente, essa habitação sofreu influência do que estava sendo discutido e adotado naquele momento, e é um exemplo de que as classes menos abastatas também estavam preocupadas com a qualificação das fachadas de suas habitações.

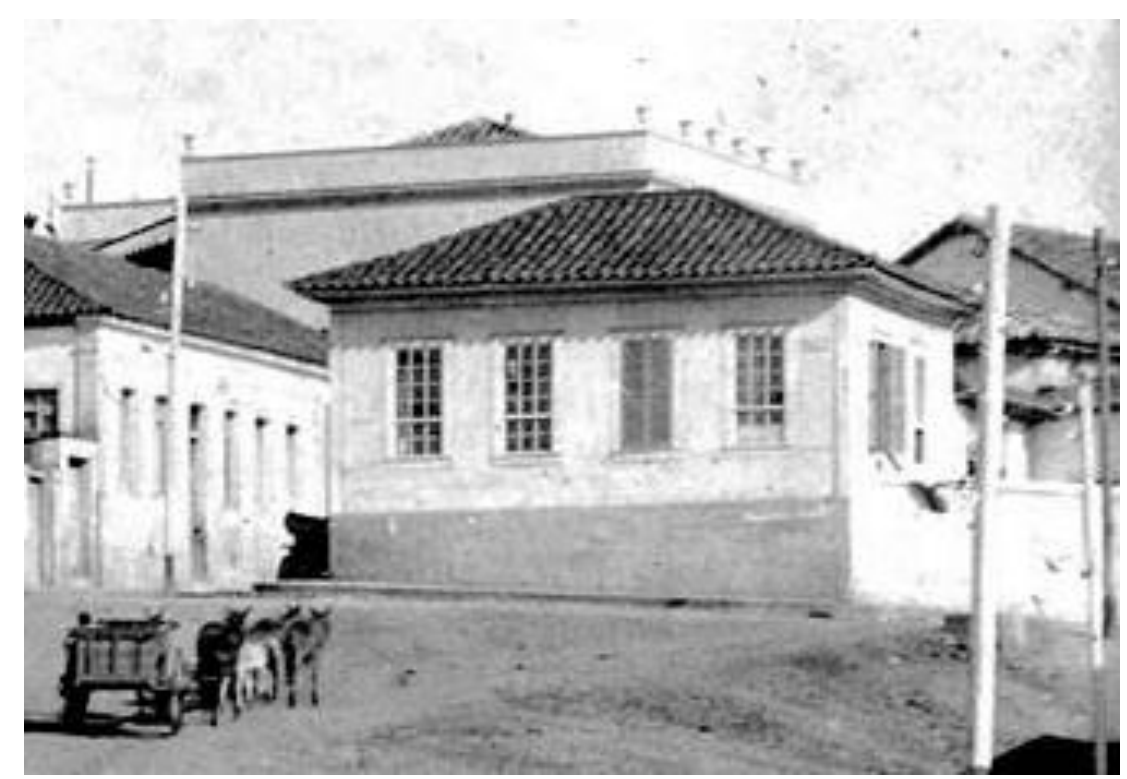

Figura 87: Moradia de Leonardo Define (1888) na Praça Prudente de Moraes esquina com a Rua Marechal Deodoro, década de 1910.

Fonte: Arquivo do Centro da Memória Rio-Pardense Rodolpho José Del Guerra. Fotografia de Innocencio Vilhegas. 
Das análises realizadas, podemos perceber que a construção das moradias rio-pardenses significou uma adequação aos fatores locais, almejando, segundo as condições econômicas do proprietário, representar uma nova forma de construir e morar. De maneira geral, a cidade da taipa foi substituída pela cidade de tijolos que permitiu, juntamente com o desenvolvimento da fundição e ferraria, a inserção de boas soluções técnicas e estéticas. Em um primeiro momento, predominaram as edificações térreas, implantadas nos limites frontal e lateral dos lotes, coladas às edificações vizinhas na expectativa de garantir estabilidade e proteção das empenas sem grandes preocupações com a composição das fachadas e dos elementos decorativos. Posteriormente as edificações se afastaram dos limites do lote, ao menos em um dos lados, refletindo antes de tudo as exigências de conforto e bem-estar em um espaço que se urbanizava. Multiplicaram exemplares melhor acabados e refinados seguindo os preceitos de conforto e ostentando correntes na época. A ferrovia e o ciclo cafeeiro permitiram esse tipo de moradia que assimilou a importação de bens e incentivou a fabricação local de materiais construtivos para serem empregados em edificações mais sólidas.

Com base na discussão feita anteriormente nesse capítulo e corroborando com o exposto por Correia (2004), o final do século XIX foi o momento em que correntes higienistas dominaram os debates sobre a saúde, a cidade, a casa e a família, o qual se somou com a implantação da estrada de ferro e a construção de infraestrutura, afetando tanto a configuração da malha quanto o modo de vida urbano.

O requinte dos interiores, o conforto e o bem-estar possibilitaram a abertura dessas moradias, ampliando o convívio social. E, adaptando ao contexto de São José do Rio Pardo exposto por Lapa (1996, p. 104), a cidade não esperou "a liquidação do escravismo e a mudança do regime político para se transformar na cidade burguesa. Foi atropelada pelo bonde da história, que conduzia a modernidade com seus novos valores urbanos". A difusão do sistema econômico capitalista e a assimilação dos confortos modernos e da febre das novidades contribuiu para alterar a paisagem urbana, quebrando a hegemonia retilínea das edificações implantadas nos limites do lote com a via pública e com o vizinho. Mas é preciso notar que as inovações programáticas e estilísticas surgidas em São José do Rio Pardo neste período, a exemplo do que já ocorria em centros maiores como São Paulo (LEMOS, C., 1989a), São Carlos (BORTOLUCCl, 1991) e Campinas (FRANCISCO, 2013; FERREIRA, 2017), não alterou o modo de morar da classe média e proletária da mesma forma e na mesma proporção. Contudo, esse quadro foi alterado após 1903 quando o sistema de abastecimento de água e coleta de esgoto foi implantado e o segundo Código de Posturas promulgado, provocando transformações mais significativas as quais abordaremos no capítulo seguinte. 


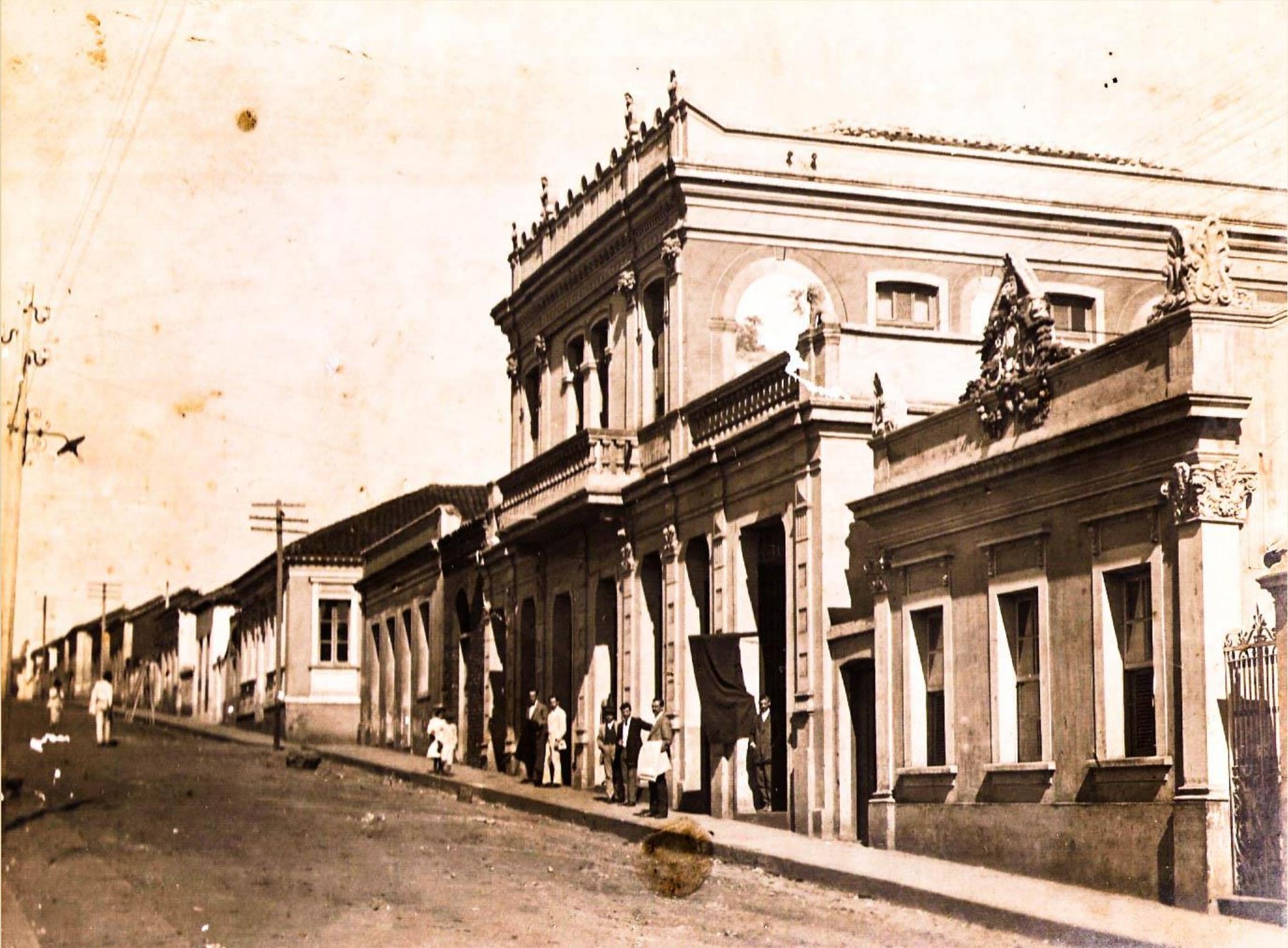




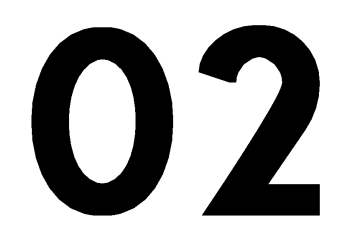

\title{
Ordem e controle na cidade e nas moradias de São José : 1903-1917
}

\author{
"A arquitetura é a prosa do pensamento \\ e sentimento inarticulados, mas belos. \\ As vezes, fala do trivial na vida; \\ subindo mais alto, \\ fala de paz doméstica e felicidade; \\ e, numa dicção ainda mais sublime, \\ realça os mais nobres \\ e os mais amplos objetivos da vida. \\ Relata o passado, registra o presente \\ e propõe ideais para o futuro"
}

(JOHN BELCHER, 1904) 


\subsection{A cidade no início do século XX}

No início dos anos 1900, São José do Rio Pardo esteve sujeita a uma conjugação de esforços por parte do poder público na intenção de assegurar uma cidade limpa, sadia, desodorizada e agradável. Uma nova urbanidade se estruturava mediante complexidades novas que repercutiam na dinâmica da especificação de funções a partir do desenvolvimento da produção e comércio cafeeiro e início da industrialização. Sob a responsabilidade direta da Câmara Municipal, a implantação de leis reguladoras das atividades urbanas e da ordem pública teve ação efetiva contra a doença. A associação entre o saber político e a colaboração dos profissionais da saúde constituiu uma aliança que, segundo Lapa (1996, p. 183), procurava "viabilizar as normas burguesas de bem-viver, assegurando a vida, a saúde, o bem-estar social no espaço urbano". De qualquer maneira, um conjunto de normas pautou o cotidiano, ditado por uma política de saúde pública que buscou acompanhar o desenvolvimento citadino. Assim como ocorreu em São Carlos (BORTOLUCCI, 1991), Campinas (LAPA, 1996; FRANCISCO, 2013; FERREIRA, 2017) e Ribeirão Preto (GARCIA, 2013; DEMINICE, 2015), em São José do Rio Pardo foi proposta a elaboração de um novo código de posturas alinhado com as reformas estruturais que estavam sendo implementadas diante da crise sanitária. Uma série de ações com vistas à diminuição e prevenção das moléstias foram iniciadas, com destaque para aquelas relacionadas à transformação do ambiente urbano como a construção de redes de distribuição de água e de coleta de esgoto.

Como integrante da Comissão de Saneamento do Estado de São Paulo, Saturnino de Brito, envolto na Teoria dos Meios, já havia criticado a ineficiência do sistema de saneamento e a consequente feição mórbida das cidades do interior paulista (ANDRADE, 1992). Embasado nessa teoria, o engenheiro Saturnino propôs Planos Gerais de Saneamento, e como no caso de Campinas que havia sofrido uma sequência de epidemias a partir de 1889 (RIBEIRO, M., 1993), foi necessária uma reestruturação urbana que alterou fortemente sua paisagem. Entre as medidas de controle sanitário se destacaram aquelas relacionadas a drenagem de pântanos, redes de água e esgoto, retificação de córregos e arborização de ruas e avenidas ${ }^{126}$. Francisco (2013, p. 53) destacou que o projeto de Saturnino "estava inserido em um quadro maior, em termos nacionais, que o regime republicano empreendia, alterando as formas urbanas que herdara do Império", em que o objetivo era a reordenação da organização e ocupação do espaço urbano, das vias de circulação, da arquitetura, e até mesmo dos comportamentos sociais. Tratava-se de um contexto de ações modernizadoras da dinâmica urbana, das novas relações de trabalho, da imigração, do crescimento demográfico, das primeiras décadas da República e do aburguesamento social que requeria melhoramentos em infraestrutura e serviços públicos. Desse modo, o projeto campineiro - modelo de intervenção para outras cidades - consorciou a ciência (saneamento e higiene) e a arte (paisagem e beleza) para transformar o antigo cenário da cidade às aspirações burguesas.

${ }^{126}$ Sobre o projeto de Saturnino de Brito para Campinas, ver Andrade, C. (1992). 
Nos anos de 1903 e 1904, Ribeirão Preto sofreu com a epidemia de febre amarela que se abateu principalmente na região baixa da cidade onde havia a pior situação de higiene e aonde a rede de esgoto não chegava. Segundo Ribeiro, M. (1993), o número de mortes em Ribeirão Preto somou a metade de todo o Estado de São Paulo em 1903, não se agravando mais porque foram adotadas medidas de combate ao mosquito e uma Comissão sanitária permanente foi estabelecida. Situação semelhante ocorreu em São José do Rio Pardo entre 1902 e 1903 quando a cidade foi acometida pela febre amarela. A condição sanitária precária da cidade era pauta constante da Câmara Municipal que decidiu pela construção de uma rede de água e coleta de esgoto como uma das medidas preconizadas por Saturnino de Brito na tentativa de amenizar e prevenir crises epidêmicas. No início do relatório de Timotheo Pereira da Rosa, apresentado aos vereadores em 1900, aparece sua preocupação com a condição do saneamento local.

Deficiente e imprestável como é o actual abastecimento de São José do Rio Pardo, nenhum outro melhoramento merecerá mais a attenção dos poderes municipaes que o de dotarem a sede do município com um serviço completo de águas e seu decorrente: o trabalho de esgottos. (ROSA, 1900, p. 01).

O auto custo dessa obra apresentado no relatório do engenheiro excedia a arrecadação municipal, o que exigiu o investimento do Estado e a contração de empréstimos para que ela fosse realizada. Inseridos no processo de racionalização da primeira República, os serviços de higiene foram empenhados e regulamentados a partir da coalização de interesses entre o poder estadual e municipal. Havia, nesse sentido, facilidades em aprovar medidas que denotassem melhorias nas condições sanitárias, mesmo que para isso houvesse o dispêndio com novos materiais, técnicas e mão de obra. Isso porque, segundo Madel Therezinha Luz (1982), a aliança estabelecida entre o Estado e a medicina, a prática e o discurso, era uma estratégia para intervir no espaço e na sociedade, de modo a modificá-la com fins na inserção do país no sistema capitalista internacional.

A resposta à República e ao capitalismo que se impõem no final do século XIX será do ponto de vista médico, uma multiplicidade de propostas de intervenção sobre o espaço urbano com o propósito de saneá-lo. As novas alianças e estratégias de poder tomam forma de controle médico-sanitário e de esquadrinhamento do espaço urbano. (LUZ, 1982, p. 33).

A resposta prática foi alcançada através da construção das redes de água e esgoto, mas que em virtude da onerosa construção e das dificuldades encontradas ao longo da sua execução, tardou a sua conclusão, sem impedir a ocorrência da epidemia de febre amarela. Mas, diferentemente da crença nos miasmas e nos micróbios como ocorreu em casos anteriores, dessa vez a Comissão Sanitária já alertava para o mosquito pernilongo rajado como o principal propagador, e como medida sanitária urgente o Sr. Intendente Municipal ordenou que fossem tomadas algumas medidas, além da conclusão das redes de água e esgoto, como: a desinfecção de casas e roupas, limpeza de quintais e que fossem "entupidas todas as latrinas cavadas no solo" (MEDIDA..., 1903, p. 01).

Constamos que a comissão sanitária [sob a chefia do médico dr. Faria Rocha] vae proceder a rigorosa visita nas habitações, determinando, com vistas ao Regulamento Sanitário em vigor tudo quanto fôr necessario estrictamente ao saneamento local, e impondo multas aos 
refractarios, que serão pagas em 48 horas na collectoria estadoal e na falta disto serão cobradas executivamente. (VISITAS..., 1903, p. 01).

O esquadrinhamento das pessoas e do espaço urbano, como chamado por Foucault (1984), tinha como objetivo a desobstrução da sujeira, das emanações pútridas, da organização e limpeza do meio físico capazes de eliminar e redefinir as práticas impuras, impedindo sua emergência. Era necessário intensificar a promulgação de leis, decretos e intimações, e intervir nos ambientes suscetíveis aos prejuízos econômicos e sociais, o que significava controlar o uso e redefinir o local para que atendessem às condições sanitárias, e também a tipologia mais adequada para cada equipamento. Assim, Foucault (1984) coloca,

\begin{abstract}
Higiene, como regime de saúde das populações implica, por parte da medicina, um determinado número de intervenções autoritárias e de medidas de controle. E, antes de tudo, sobre o espaço urbano em geral: porque ele é, talvez, o meio mais perigoso para a população. [...] ela exigiu, em todo caso, um discurso médico sobre a morbidade urbana e uma vigilância médica de todo um conjunto de disposições, de construções e de instituições. [...] Isolam-se, portanto, no sistema urbano, regiões de medicalização de urgência, que devem se tornar pontos de aplicação para o exercício de um poder médico intensificado. Além disso, os médicos deverão ensinar aos indivíduos as regras fundamentais de higiene que estes devem respeitar em beneficio de sua própria saúde e da saúde dos outros. (FOUCAULT, 1984, 203204).
\end{abstract}

Além da organização do meio físico, era necessário que a sociedade compactuasse com a nova ordem e, para isso, dispositivos ${ }^{127}$ foram criados como força ideológica capaz de impulsionar as transformações (FOUCAULT, 1984).

O momento histórico das disciplinas é o momento em que nasce uma arte do corpo humano, que visa não unicamente o aumento de suas habilidades, nem tampouco aprofundar sua sujeição, mas a formação de uma relação que no mesmo mecanismo o torna tanto mais obediente quanto é mais útil, e inversamente. Forma-se então uma política das coerções que são um trabalho sobre o corpo, uma manipulação calculada de seus elementos, de seus gestos, de seus comportamentos. O corpo humano entra numa maquinaria de poder que o esquadrinha, o desarticula e o recompõe. [...] A disciplina fabrica assim corpos submissos e exercitados, corpos 'dóceis'. (FOUCAULT, 2009, p. 133).

Foi no contexto dessas discussões, particularmente no Brasil, que as orientações de médicos e engenheiros foram transpassadas para o corpo legislativo, mediante os Códigos de Posturas, e no qual as intervenções passaram a ser respaldas.

O novo Código foi publicado no mesmo edital em que anunciou o fim da epidemia de febre amarela e no mesmo ano em que as obras de água e esgoto foram concluídas. Para Lapa (1996), a publicação de um Código consagrava, afirmava e legitimava a legislação anterior, acrescentando a esta novos instrumentos reguladores da vida urbana "produzidos em momentos em que supostamente a mudança e a evolução da sociedade exigiam respostas, alterações, correções e novas normas do viver na cidade" (LAPA, 1996, p. 55). Nesse sentido, a estreita ligação entre a legislação e a dinâmica urbana evidenciada pelas novas normas criadas com o Código de Posturas de 1903 nos interessa, pois dedica uma atenção especial à estética e à

\footnotetext{
127 Segundo Foucault (2009), a institucionalização da violência psicológica - por vezes mais sutil que a física - por meio das ações do Estado tinha como objetivo a disciplinarização e docilização dos corpos. É nesse sentido que Beguin (1991, p. 45) observou que "a reorganização de um serviço permite aqui operar uma reforma sensível nos hábitos domésticos e extra-domésticos (...) a nova polícia investe sempre mais no interior dos dispositivos técnicos, onde o controle e o funcionamento dos serviços necessários à exist ência dos habitantes tendem a tornar-se uma só e mesma coisa". 
higiene, demonstrando o esforço e as estratégias de planejamento da cidade. De maneira incipiente essas preocupações podiam ser encontradas no Código anterior, mas dessa vez ganharam destaque com novos e minuciosos artigos.

O capítulo um desse Código trata das vias da cidade e expõe a intenção de alterar sua aparência através de algumas mudanças como o aumento para $16 \mathrm{~m}$ a largura mínima para a abertura de novas ruas e travessas. O objetivo era privilegiar a circulação racionalizada exigindo que as ruas fossem alinhadas, o que foi amplamente enfatizado pelo poder público local e apontado no relatório de Timotheo Pereira da Rosa ao se referir ao plano cadastral elaborado:

\footnotetext{
Por elle se vê quanto irregularmente foi alinhada uma cidade de constituição topográfica tão interessante, salientando-se no referido plano algumas construcções a demolir-se, já porque interceptam quasi de todo uma rua, como no entremeio da Rua Américo de Campos, já porque em outros quarteirões tem-se continuado a construir um alinhamento só, mas sem deixar espaço a ruas transverssaes, como na rua Benjamin Constant, além da Coronel Marçal. (ROSA, 1900, p. 17-18).
}

Seguindo o objetivo da racionalização dos fluxos, o Código de Posturas de 1903 apontou a obrigatoriedade da execução de passeios na largura de 1,50 m, o que foi copiosamente divulgado na imprensa local através de editais da Intendência Municipal. De modo semelhante ocorreu ao tratar dos espaços, regulamentando aqueles ainda não construídos, devendo os proprietários fechar seus terrenos com muros de tijolo ou pedra, sendo a taipa e o tapume de zinco proibidos. Especificamente em relação às edificações, o Código apontava com riqueza de detalhes as prescrições a serem seguidas de acordo com a higiene, a segurança e o embelezamento. A altura estipulada para as casas térreas em princípio foi de ao menos 4,00 m. Norma semelhante já havia sido apresentada no Código de Posturas de 1887, no qual as medidas eram inferiores, mas indicava de maneira meticulosa em caso de a edificação ser um sobrado, situação inexistente no Código de 1903, o que nos faz inferir duas hipóteses: não havia um processo de verticalização em curso; ou como destacado anteriormente, a elaboração de um Código atendia a uma situação real na qual a atenção se voltou para o atendimento da saúde e higiene.

Muito influenciado pelo Código Sanitário Estadual de 1894, as diretrizes e regulamentações do Código de Posturas de São José do Rio Pardo de 1903 apresentavam parâmetros higienistas e também de polícia sanitária com o seguinte teor:

Art. 159 - A polícia sanitária do município, que será exercida pelo Intendente Municipal, médico da Câmara e fiscais, tem por fim prevenir os abusos que compromettam a salubridade publica e velar pela fiel observância das disposições sobre hygiene, contidas neste Cód., nas leis do Estado e no Cód. Sanitário promulgado pelo decreto 232 de 2 março de 1894. (CÓDIGO DE POSTURAS, 1903, p. 06-43).

Essa medida era utilizada mediante a necessidade do controle sanitário, assim todos os proprietários de prédios e terrenos eram obrigados a abrir seus imóveis para que fossem feitas as visitas de vistoria pela comissão, assim como todas as pessoas sob o risco do contágio. 
Art. 172 - Todo o predio em que tenha sido verificada a existencia de molestia epidemica ou transmissivel será rigorosamente desinfectado pelo processo determinado pela autoridade sanitaria municipal.

Art. 173 - Nenhum medico ou particular poderá, sob qualquer pretexto, oppor-se ás medidas de isolamento e desinfecção ordenadas pelas autoridades sanitarias, sob pena de incorrer na multa de $50 \$ 000$ e prisão por 5 dias. (CÓDIGO DE POSTURAS, 1903, p. 46).

Havia desse modo, um objetivo a ser perseguido: a salubridade urbana que passava pelo controle dos espaços públicos e privados, dos costumes e comportamentos. Apesar de constatarmos a exigência dessas medidas que contribuíram para modificar o modo de viver em São José do Rio Pardo, elas não foram suficientes para assegurar todas as transformações de modo repentino, pois encontramos com frequência nos jornais da época críticas à situação sanitária e ênfase na necessidade de incluir na pauta da política de higiene a construção de novos equipamentos urbanos. Sanear, circular, e embelezar eram alguns dos temas centrais utilizados para justificar as intervenções postas em prática, como publicado no jornal O Rio Pardo em 17 de março de 1907:

De facto, a limpeza não representa somente um papel importante, como medida hygienica, na vida de um povo, como também é um dos caracteristicos de uma civilização. Uma cidade sem limpeza não tem o brilho das cidades civilizadas. Este é um fato que comumente se observa. [...] De que serve uma cidade ostentar com todo o esplendor da arte sumptuosos palacetes, avenidas arborizadas e calçadas, theatro, café, clubs com os seus salões doirados, e não ter nos lugares ocultos, como sejam quintaes, etc., o necessário asseio? Não, uma cidade para que tenha um aspecto deslumbrante e refflicta sobre seus habitantes, é preciso que seja limpa e asseada, observando assim os preceitos da hygiene social. S. José do Rio Pardo, pois está nos casos de ser uma das mais belas cidades do Estado, não só pelos elementos de que dispõe, como tambem pela atividade e iniciativa que muito caracterizam este povo; porém ainda faltam alguns requisitos e aquelle [limpeza] é um delles. (HYGIENE PUBLICA, 1907, p. 01)

Procurando melhorar a feição da cidade, o poder público atuou na busca pelo desenvolvimento mateiral através da execução de melhorias nos prédios públicos a exemplo do edifício da Câmara que teve suas características arquitetônicas, no que se refere às intenções plásticas, modificadas com a elevação da platibanda ${ }^{128}$, mas mantendo a composição simétrica. Pelas características de sua fachada, percebemos o emprego da arquitetura eclética (Figura 88). Internamente foram construídos banheiros em resposta às necessidades de higiene e em cumprimento da Lei (publicada em 26/10/1902) que proibia, na área urbana, a existência de fossa e a consequente obrigação da ligação

Figura 88: Casa de Câmara na década de 1910.

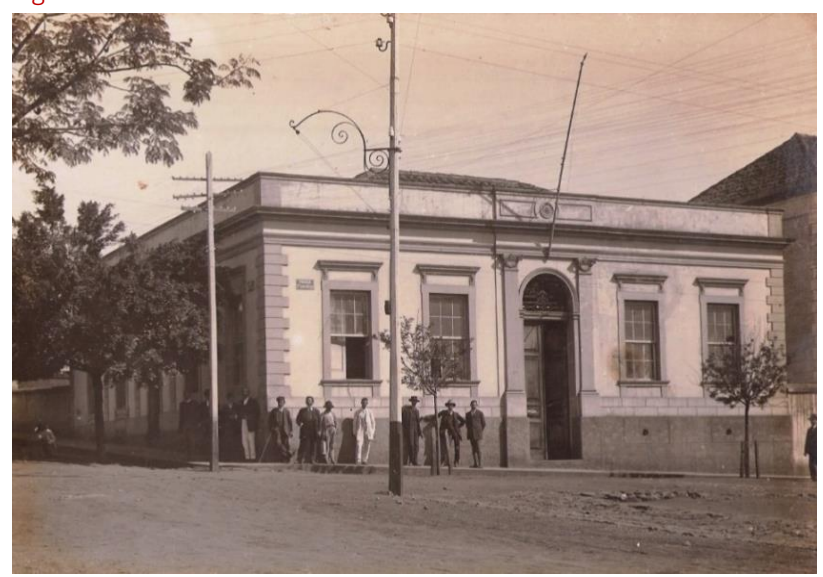

Fonte: Arquivo do Centro da Memória Rio-Pardense Rodolpho José Del Guerra. Fotografia de Innocencio Vilhegas.

\footnotetext{
${ }^{128}$ Em atendimento ao Código de Posturas de 1903 que veremos mais detalhadamente no terceiro item deste capítulo. 
com as redes de água e esgoto quando concluídas (MENECHINO, 1986).

Outra questão de evidência nesse período era o objetivo do governo e agricultores no combate a desvalorização do café, base econômica responsável por proporcionar as condições favoráveis das obras tidas como essenciais para atender os propósitos descritos acima. Devido a sua importância, os periódicos locais tratavam a condição do café com destaque, ora em tom apreensivo, ora com entusiasmo. Os altos e baixos valores deflagrados pelas constantes aumentos da produção na passagem do século XIX para o século XX e a valorização do câmbio, como exposto por Taunay (1945), acompanhou uma política de camuflagem com base na especulação financeira estabelecida pelo governo, conhecida como Encilhamento. O resultado dessa medida foi uma grave crise econômica de desvalorização da moeda e alta inflacionária que afetou fortemente os produtores. A solução encontrada pelo governo na tentativa de minimizar a crise estabelecida ficou conhecida como Convênio de Taubaté, assinado em 1906, e consistia em uma política de "valorização do café" através da intervenção do Estado na compra dos excedentes produzidos para serem estocados e futuramente vendidos (FURTADO, 1984). Segundo Taunay (1945), não se pode negar que tal medida minorou a desorganização financeira do país e evitou baixas significativas no preço, todavia não impediu a expansão da plantação cafeeira, sobretudo para o Oeste paulista. Para Monbeig (1998, p. 118119), o motor da ampliação do excedente pode ser explicado pelo alto potencial de produção dos planaltos ocidentais, que mesmo com o baixo valor do café, a maior produtividade física, a queda do salário dos trabalhadores envolvidos diretamente com a produção e a condição favorável criada pelo governo brasileiro estimulou o investimento em áreas afins como a indústria de beneficiamento, embalagem e manufatura de bens de consumo, a infraestrutura urbana, o sistema de transporte e o sistema bancário tendo como atividade fim o empréstimo de crédito à lavoura. Conforme afirmou Monbeig (1998),

nascido no momento em que se instalava a economia capitalista, o movimento de conquista dos planaltos ocidentais não cessou, pois, de progredir, a despeito das crises inerentes ao sistema e até mesmo por causa dessas crises". (MONBEIG, 1998, p. 118-119).

O respaldo aos plantadores sobre o que estava sendo discutido em âmbito nacional e mundial era feito através da publicação nos periódicos locais, conforme podemos acompanhar através das percepções escritas no jornal Fanfulla e publicado no Jornal O Rio Pardo (Figura 87). Marcado pelo otimismo, os lavradores rio-pardenses comemoravam o desenvolvimento da cultura do café acompanhado pelas culturas em crescimento que contribuíam para o aumento da receita do município:

A cultura principal é o café, cuja producção media é de quinze milhões de kilos por anno; segue-se depois o arroz, cuja cultura aumenta constantemente: a exportação, em 1906, foi de 10.000 saccas, e no anno seguinte attingiu o dobro. As terras são favoraveis, a muitas outras lavouras, tendo já obtido soberbos resultados os ensaios de cultivo do tabaco. [...] Pode-se dizer que o commercio e a industria em geral são prosperos em S. José do Rio Pardo. Mas, quantas cousas ainda estão por explorar-se; quantos lucros por realisarem-se! [...] É preciso confessar que é lisongeiro para um município de formação muito recente; mas que entretanto honra o estado de S. Paulo, pelo curto periodo de seu desenvolvimento e pela solidez de seu bem estar moral e material. (O NOSSO MUNICÍPIO, 1908, p. 01). 


\section{0 mercado do café \\ B a valorisação}

\section{Previsões oplimislas do $\mathrm{Dr}$} F. Ramos

Um collaborador nosso que achava-se em Anvers, no mez passado, com o egregio dr. Ferreira Ramos, Commissario Geral do Governo de S. Paulo, obteve numa amistosa palestra, pedida $\mathrm{em}$ nome do oFanfullas varias e interessantes noticias sobre o mercado de café.

O dr. Ferreira Ramos, relembrando que o nosso jornal sustentou a opportunidade e a conveniencia do eplano da valorisaçao, estendeu-se fallando dos bons resultados do mesmo, chegando a conclusoes optimistas e que infunden esperanças lisongeiras.

Eis as suas declaraçôes, transmittidas pelo nosso collaborador.

-O plano da defesa do café, que no seu inicio fora julgado pessimo, assombra agora os financeiros do velho mun do que começam por com preender que a operaçâo feita pelo Estado de S. Paulo, garantida pelo Governo Fede ral, consolidou as finanças bra. sileiras e salvou a Caixa de Conversâo, chamando ao Brasil aquella avultada quantidade de ouro que em poticos meze: fez elevar de 5 para 10 milhoes esterlinos o proprio deposito.

$\mathrm{O}$ s robres fasendeiros que sempre sofleram os borrore da crise cafeeira e que resignados, sempre continuaram em sua labuta para o esplendor e engrandecimento do paiz, vâo ter em pouco a recom. pensa de seus soffrimentos com a gradual consolidacác do preço do caf́́. Com effeito, com a colheita mundial actual, que se suppunha nuito grande porquanto mal chegue para o consumo que orça en cerca de 18 milhoes e meio de sacsas e com a proxima colheita prevista pelos entendidos abai xo da media, os stocks mundiaes snffrerno diminuiça consideravel e o preço de 50 francos por sacca e talvez mais será considerado como muito natural.
Năo é de muiros annos que considerava-se como sendo exorbitante para o consumo mundial uma protucsáo de 8 para 9 milhoes de saccas, no Estado de S. Pavlo : pouco tempo depois, to milhoes de saccas nao cram mais sufficien. tes e precisaram bem il mi. thoes.

A proxima campanha terá necessidade de 20 milhoes de saccas; e, como os outros Estados: Rio, Minas, Bahia e Espirito Santo, nåo produzem $\mathrm{cm}$ media mais que 4 milhoes, e a mesma quantia, mais or menos, produzem os outros paizes ; é evidente que o Brasil, para poder satisfazer ao consumo, deverá produzir uma media um pouco superior aos 15 milhoes de saccas de café.

Para os que conhecem a lavoura paulista e a dos outros Estados do Brasil, é obvio deduzir que será impos sivel, antes de 10 annos, alcançar uma producçũo media de 15 milhoes rie saccas.

Se o mercado de borracha sustentar seus preços, o Brasil em breve tempo conseguirá uma affluencia de ouro ainda mais importante e o café terá readquirido o lugar que sem. pre teve na riqueza do Paiz. E' evidente pơis que nåo devemos esquecer que uma politica financeira, economica e previdente é sempre necessa. ria para o problema da econo. mia de um paiz, qualquer que seja a sua importancia politica e a sua propria riqueza.

Felizmente para o Brasil, os que regem a sua sorte procu raram, mais ou menos, de nunca se afastarem de faes principios e estou convencido de que para o futuro sempre mais aquelles mesmos princi pios estarâo ligados intima mente.s

(Fxtraldo e traduzido em portuguez do * Fanfullas espe cialmente para esta folha).

Fonte: Jornal O Rio Pardo, 30 de janeiro de 1910. 
Os sinais de valorização do café refletiram na própria condição urbana através de empreendimentos evidenciados pelo jornal O Rio Pardo ao anunciar, no mesmo edital, a regulamentação dos serviços de higiene ligados à rede de água e esgoto e a fundação de uma Irmandade de Misericórdia. Esta tinha como objetivo a criação de um hospital de caridade, uma casa de recolhimento, um asilo para indigentes e uma casa de recuperação. Aos poucos, a antiga Vila do século XIX foi se transformando em uma cidade com infraestrutura e equipamentos urbanos.

Os primeiros passos dados para a construção do hospital Santa Casa de Misericórdia foi, segundo o registro da ata da primeira reunião da diretoria, a doação do terreno ${ }^{129}$ que ficava duas quadras acima do velho cemitério, onde a malha urbana ainda não tinha alcançado, como pode ser observado no mapa da cidade de 1907 (Figura 90) (MISERICÓRDIA, 1907). O passo seguinte foi a elaboração do projeto feito pelo Dr. Horácito Rodrigues, oferecido por intermédio de Tarqüínio Cobra Olyntho ${ }^{130}$, sendo os serviços de execução confiados a Paschoal Artese que o concluiu em 1913 (Del Guerra, 2001).

Figura 90: Mapa de São José do Rio Pardo mostrando a malha urbana em 1907.

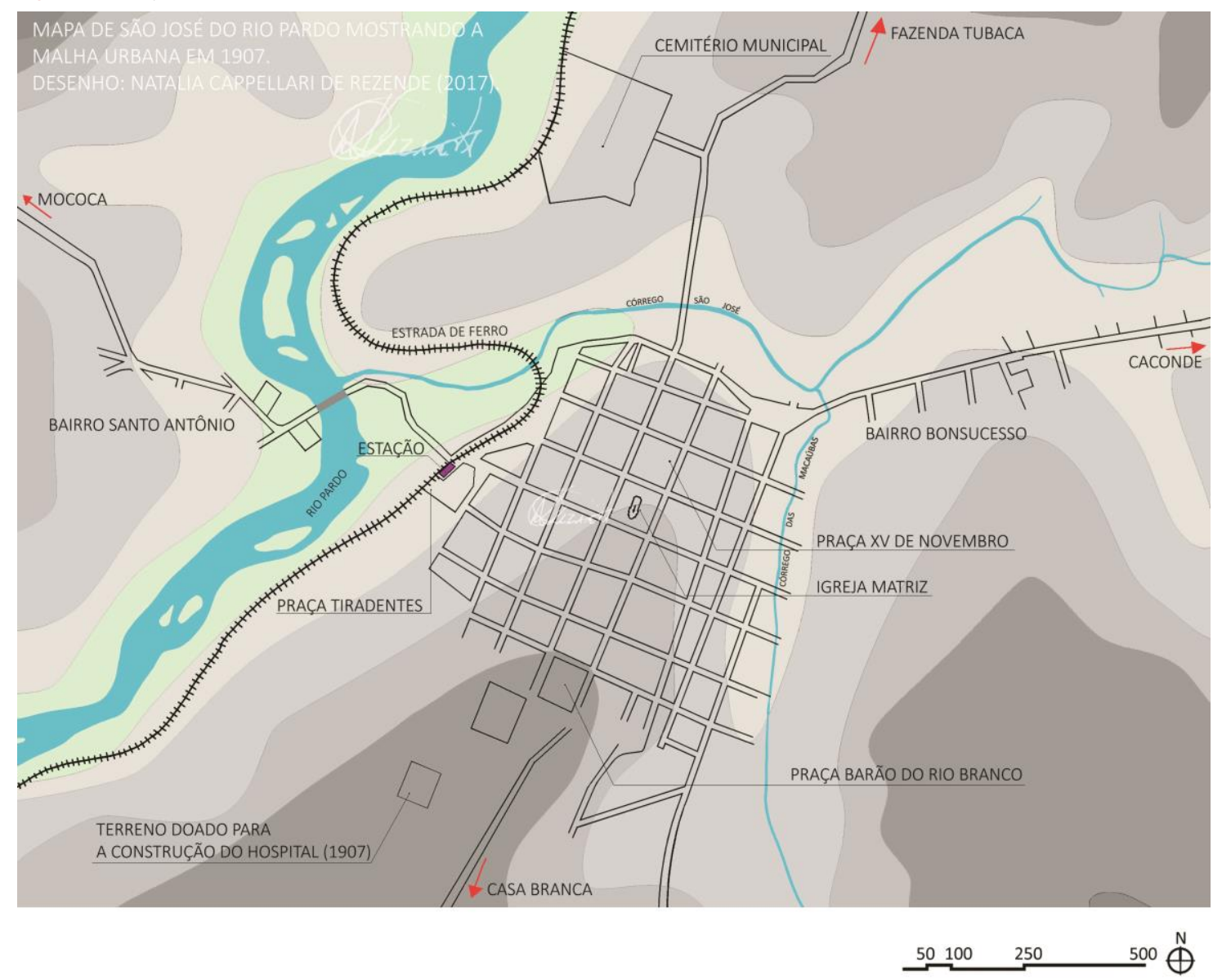

Desenho: Natalia Cappellari de Rezende (2017) com base em dados históricos e cartografia disponibilizada pela Secretaria de Obras de São José do Rio Pardo.

\footnotetext{
129 Honório Luiz Dias foi quem doou o terreno, com escritura lavrada em 02 de agosto de 1907.

130 Tarqüínio nasceu em Pouso Alegre em 1898. Pertencia a uma família rica cujo pai, Adolpho Augusto Olyntho, foi desembargador, ministro e presidente do Supremo Tribunal Federal em 1897. Tarqüínio, seguindo os passos do pai também foi um homem de vida pública. Após cursar farmácia no Rio de Janeiro e se casar com Josephina Prado, mudou-se para São José do Rio Pardo onde foi vereador, secretário da Câmara, juiz de Paz, inspetor escolar, proprietário de uma farmácia, e enquanto secretário do PRP intermediou a criação do segundo Grupo Escolar em 1928, e que mais tarde recebeu seu nome, Escola Estadual Tarqüínio Cobra Olyntho (Del Guerra, 2010).
} 
O edifício (Figura 91) construído isolado no lote possuía em sua fachada frontal uma porta central e duas janelas, ambas encimadas por régulas retas que, com as cimalhas e ático liso da platibanda, reforçavam a horizontalidade do edifício, principalmente na extensão das suas fachadas laterais, evidenciando a aceitação ao "gosto clássico". Já os pilaretes do portão e o gradil eram mais sofisticados e apresentavam elementos do repertório art nouveau, como é possível observar na Figura 92.

Figura 91: Santa Casa de Misericórdia, 1913.

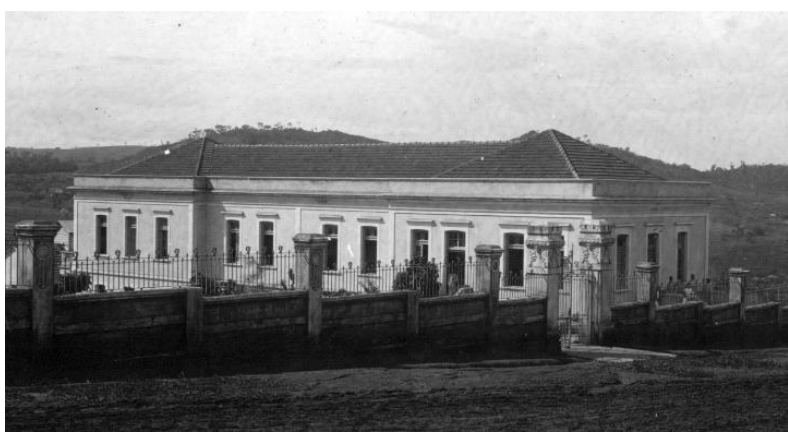

Fonte: Arquivo da Hemeroteca Jornalista Paschoal Artese.
Figura 92: Pilaretes do portão e gradil que circunda o terreno da Santa Casa de Misericórdia.

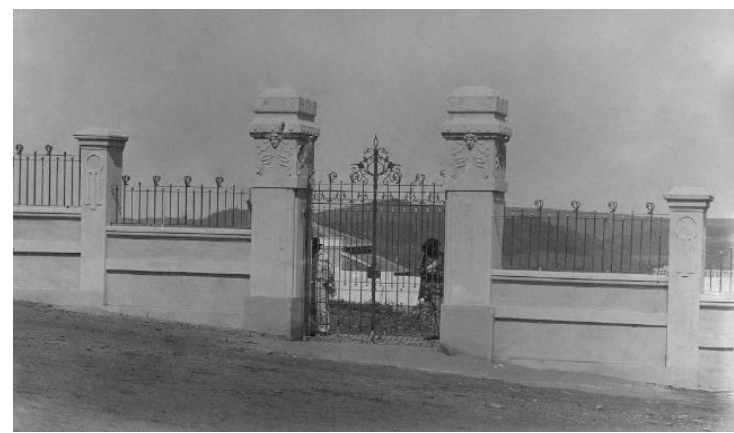

Fonte: Arquivo da Hemeroteca Jornalista Paschoal Artese.

Instituições de caridade trataram também de amparar indigentes, pobres enfermos e inválidos. A decisão do local do asilo se baseou nos mesmos pressupostos que permearam a construção do Lazareto, do cemitério e matadouro, persistindo assim a escolha de um terreno distante da área urbano, nas terras ao leste do núcleo. E como medida profilática foi implantado afastado dos espaços considerados sadios e belos, em áreas onde os ventos predominantes soprassem as "doenças", os "gases" e as "poeiras" no sentido contrário à cidade. Por iniciativa de um padre chamado Euclides Carneiro ${ }^{131} \mathrm{e}$ com apoio da população, o asilo de mendicidade (Figura 91), inaugurado em 1916, "viria ao encontro da pobreza desvalida, dos infelizes que diariamente partilhavam nossas ruas esmolando" (NOTAS ..., 1916, p.

Figura 93: Asilo Padre Euclides Carneiro na década de 1920.

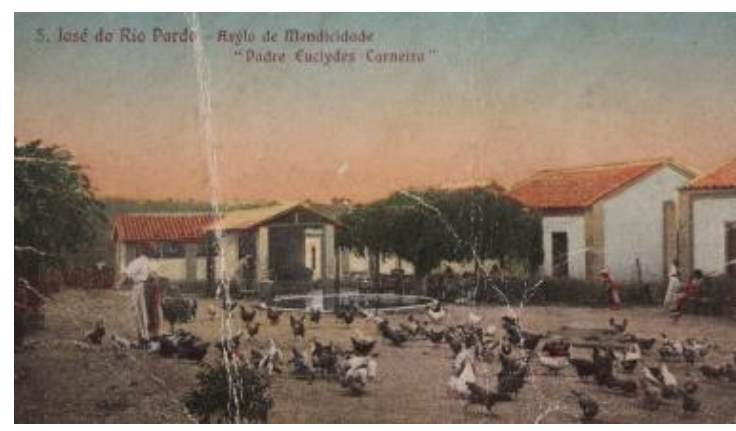

Fonte: Arquivo da Hemeroteca Jornalista Paschoal Artese. 02).

\footnotetext{
${ }^{131}$ De acordo com Del Guerra (2001), Euclides Carneiro chegou em São José do Rio Pardo em meados da década de 1910, vindo de Ribeirão Preto. Em 10 de junho de 1915 tomou posse como vigário da paróquia rio-pardense onde ficou até 1916 quando foi transferido para outra cidade. 
Em meio aos novos serviços destinados à salubridade urbana e social, outros equipamentos fizeram parte da produção do espaço urbano, frequentemente destacados nos jornais da época exaltando a modernização e a construção de uma boa imagem, progressista. Alinhado à essa condição estava o processo de embelezamento na tentativa de tornar o ambiente mais agradável aos anseios pelo menos de uma parte da sociedade rio-pardense. O jornal O Rio Pardo de 12 de junho de 1904 assim expõe a condição do recém-inaugurado jardim da Praça XV de Novembro:

Mas o nosso jardim, cercado á arame, separado em duas partes, desprovido de bancos decentes e apropriados, sem um coreto onde as corporações musicaes possam dar execução aos seus repertórios, não pode atrair as vistas de uma população ávida de novidades. (UMA IDEA, 1904, p. 01).

Indubitavelmente essa praça foi o local de maior representação por fazer parte de um conjunto de elementos simbólicos imateriais e materiais que deram forma à cidade. Como instrumento do progresso, a cidade republicana rearticulou e regimentou a sua organização priorizando a reestruturação dos espaços públicos. No tocante à estética, podemos perceber que o poder público local elegeu o redesenho e ajardinamentos das praças como campo de ação, objeto e objetivo de uma transição de significado e poder, a exemplo do que aconteceu em outras cidades como Jaboticabal (GARCIA, 2008). Logo, o antigo largo tornou-se um espaço recreativo e comercial cerceado pelas classes privilegiadas. Era um local para ver e ser visto, onde as moças desfilavam suas roupas, segregadas dos incômodos dos populares. Afinal de contas, os costumes e uso público desse espaço eram restringidos no Código de Posturas de 1903:

Art. 91 - Ninguem poderá, nas ruas, praças e logares públicos, proferir palavras injuriosas ou obscenas, nem praticar actos offensicos á moral e aos bons constumes. Multa de $20 \$ 000$ e detenção por 24 horas.

Art. 93 - Ninguem poderá estar nas ruas, praças e outros logares públicos senão decentemente vestido. Penas do art. 91. (CÓDIGO DE POSTURAS, 1903, p. 26).

A dimensão material e profana se sobressaiu na produção dos elementos, especialmente na retirada do cruzeiro para alí ser construído um coreto. Ao justificar essa mudança, a publicação enfatizou que em São Paulo a igreja do Rosário foi demolida em nome do aformoseamento, progresso e civilidade, logo a retirada do cruzeiro não traria prejuízos.

Sera offender o esperito religioso de ninguém, pois que somos os primeiros a elevar sua grandesa, achamos pouco util ostentar-se no centro uma praça elegante um grosso cruseiro, como linha divisória de um passeio publico. [...] Promova-se festivamente a mudança do cruseiro para o largo do Rosario e conclúa-se o aformoseamento do jardim, tirando se lhe a feição triste de um cemiterio abandonado, que elle conserva. (UMA IDEA, 1904, p. 01).

Em 1905 o jornal O Rio Pardo noticia a reinauguração do jardim da Praça XV de Novembro composto de um "bonito coreto art nouveau" (FESTA, 1905, p. 02), com rico trabalho em serralheria como pode ser observado na Figura 94. Certamente a expressão de conhecimento de um estilo em florescimento se deva à circulação de catálogos e livros, como L'Europe pittoresque - Pays du nord", comentado anteriormente. 
A preocupação com o desenvolvimento material, a salubridade e conforto dos espaços públicos foi incorporada por parte da população que se organizou para financiar as obras de melhoramentos, e que acabou por intervir no cotidiano dos moradores locais. Nessa esteira, o jardim da Praça XV de Novembro foi totalmente reformulado em 1915 e as características estéticas do novo jardim passaram a ser organizadas a partir de caminhos em cruz sem a rigidez geométrica previsível, mas simétrica, como é possível observar na Figura 95. Marcada por um ponto focal, pelo passeio perimetral, pelo desenho do caminho em cruz que conduz a uma convivência social e à contemplação da natureza, esta praça possui elementos do ecletismo clássico, mesma linguagem adotada na construção do jardim da Praça Marechal Deodoro na cidade de Mococa (Figura 96).

Figura 95: Praça XV de Novembro ajardinada na década de 1910.

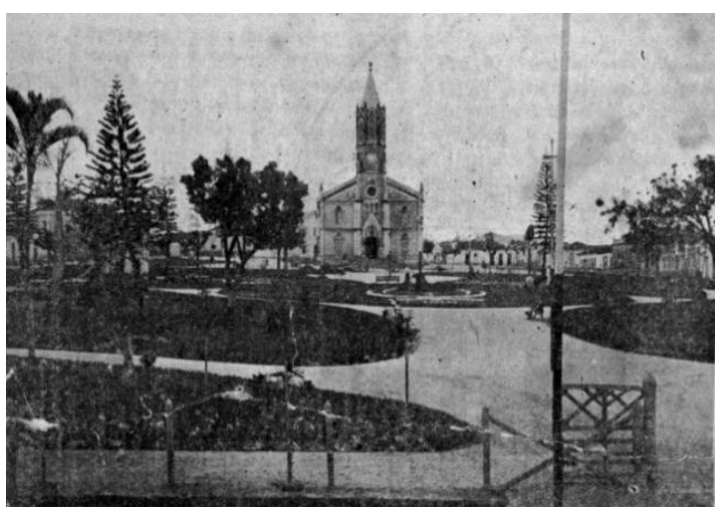

Fonte: Arquivo da Hemeroteca Jornalista Paschoal Artese.
Figura 94: Coreto inaugurado em 15 de novembro de 1905 na Praça XV de Novembro.

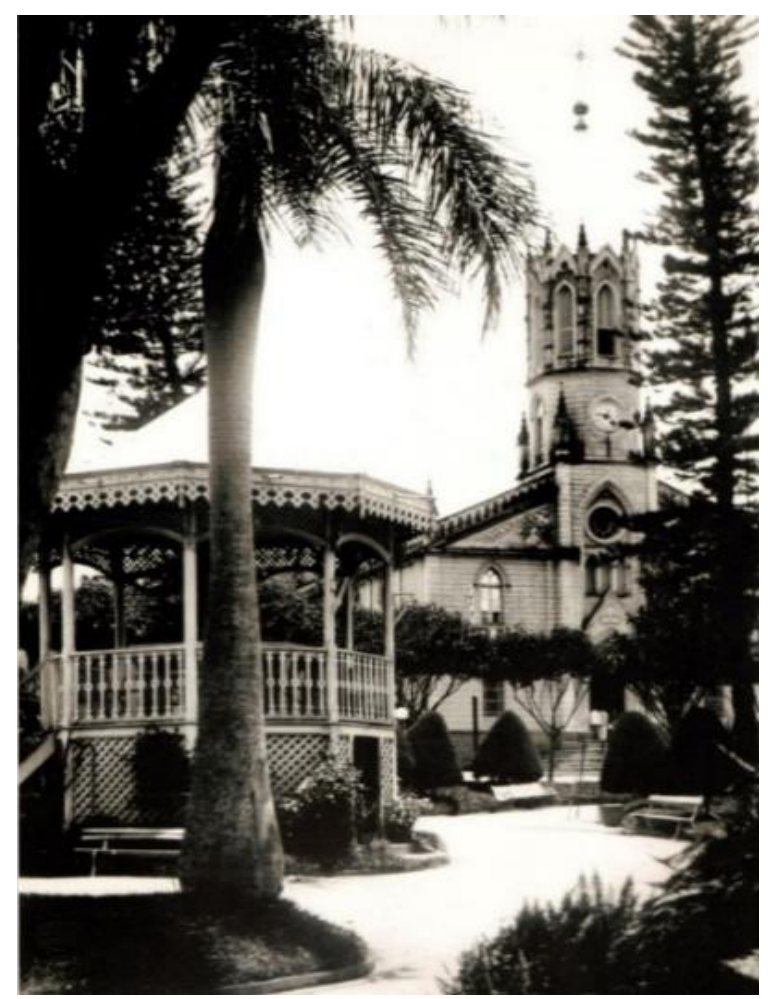

Fonte: Arquivo da Hemeroteca Jornalista Paschoal Artese.
Figura 96: Praça Marechal Deodoro na cidade de Mococa antes da construção do coreto em 1906.

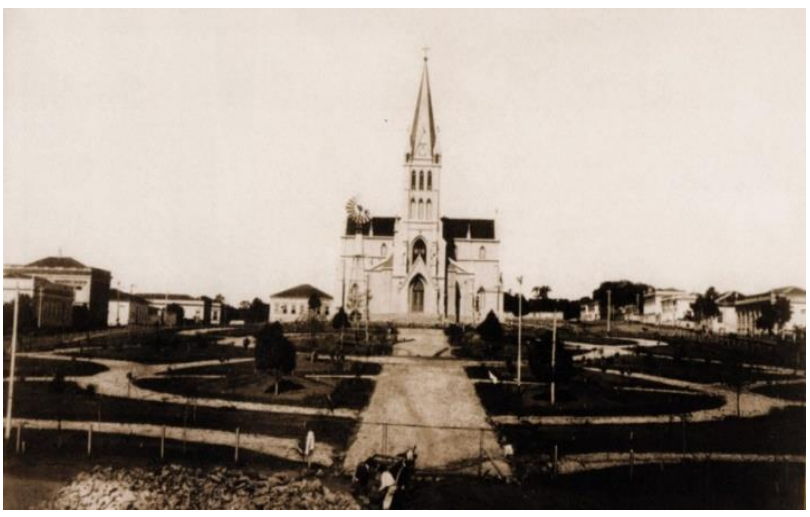

Fonte: Ribeiro, S. (2011).

Como medida estética, o paisagismo foi incorporado ao espaço urbano manifestando a preocupação com o embelezamento, e como medida sanitária, a ideia do jardim como auxílio no combate preventivo contra doenças que eventualmente externava, acometendo a população (DEL GUERRA, 2010). Foi a partir desses 
preceitos que uma comissão foi organizada para subscrição pública de arrecadação de fundos para a construção de um outro jardim, denominado de Jardim Artístico, no local do antigo cemitério. O mentor desse Jardim foi Paschoal Artese que publicou em um exemplar do jornal O Rio Pardo do dia 01 de fevereiro de 1913 a contratação dos serviços prestados por João Dierberger ${ }^{132}$, como segue abaixo:

\begin{abstract}
Sabemos que vai ser contractado para construcçáo do jardim, o snr. João Dierberguer, proprietário da Loja Floricultura da Capital. O encarregado da construcção do tão notável melhoramento appella para o espirito adiantado do povo desta terra afim de que a subscripção popular alcance o maior êxito possível, para o que, dirigiu juntamente com a lista de subscripção [...] Torna-se, por conseguinte, uma necessidade urgente fazer sahir dequelle lugar o velho campo santo, e isso em respeito aos nossos semelhantes e afim de não se continuar a ver tal profanação aos mortos. Em nome da memória dos que ali reposam no ultimo somno, em nome da civilização e do progresso, espera o abaixo assignado que V. S. concorra e faça concorrer os seus amigos e parentes qualquer quantia para fazer face as despesas necessárias. (O VELHO CEMITÉRIO, 1913, p. 02).
\end{abstract}

Desse modo, o Jardim de inspiração pitoresca, vegetação exótica e com chafariz, passeios serpenteados, estátuas de mármore importadas da Itália representando as estações do ano e fechado por gradil de ferro tomou forma progressivamente como apresentado em diferentes ângulos na Figura 97, Figura 98 e Figura 99. Era, nesse sentido, o espaço e a representação da exclusão e da intolerância da ordem republicana, a qual Sevcenko destaca (1985, p. 29) que o significado da prosperidade era alinhar-se aos padrões europeus, logo "a imagem do progresso - versão prática do conceito homólogo de civilização - se transforma na obsessão coletiva da nova burguesia".

Figura 97: Jardim Artístico sendo construído na década de 1910.

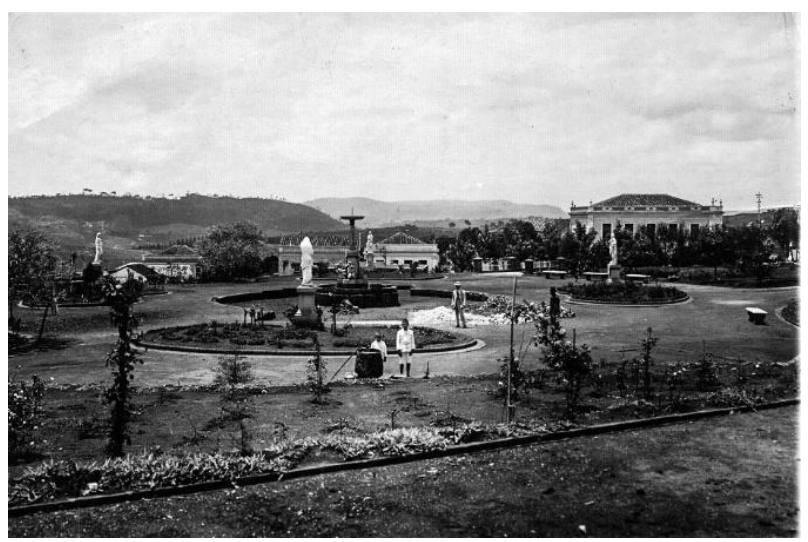

Fonte: Arquivo da Hemeroteca Jornalista Paschoal Artese.
Figura 98: Jardim Artístico na década de 1930.

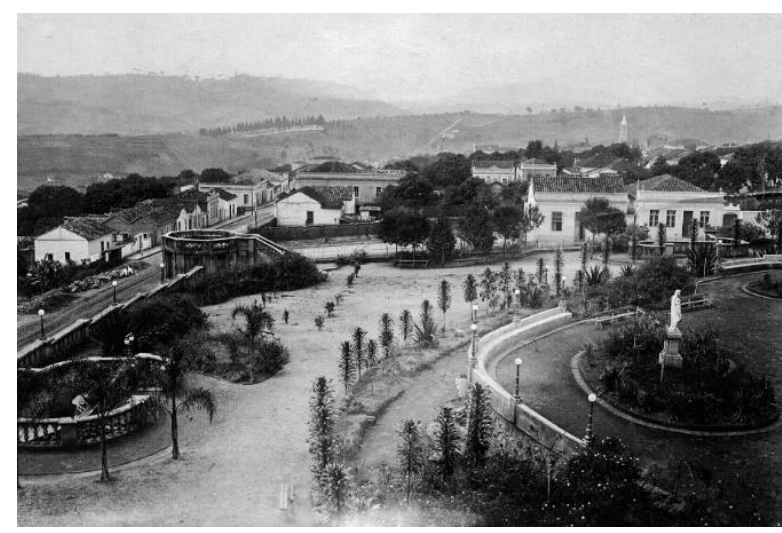

Fonte: Arquivo da Hemeroteca Jornalista Paschoal Artese.

\footnotetext{
132 João Dierberger atuou no ramo paisagístico no Brasil. Fundou sua primeira empresa "voltada à produção e comercialização de pl antas ornamentais, hortícolas e frutíferas, bem como à elaboração e execução de jardins em 1993 na cidade de São Paulo" (ENOKIBARA, 2016, p. 35). A partir de 1919, Reynaldo Dierberger e João Dierberger Jr., filhos do patriarca João Dierberger e Elisa Trebitz, ingressaram na empresa, diversificando a expansão das atividades. O grupo Dierberger foi responsável por projetar e executar jardins de expressão, entre eles o do jardins do Palácio Guanabara - RJ; os Jardins do Museu do Ipiranga - SP; a reforma dos jardins do Palacio dos Campos Elyseos RJ; o parque e jardim da Ilha de Santa Theresa de propriedade da família Guinle - RJ; a Praça da República de Jaboticabal; o Jardim Público de Poços de Caldas; entre muitos outros (ENOKIBARA, 2016).
} 
Figura 99: Jardim Artístico ajardinado e pouco cuidado na década de 1950, poucos anos antes de ser demolido ${ }^{133}$.

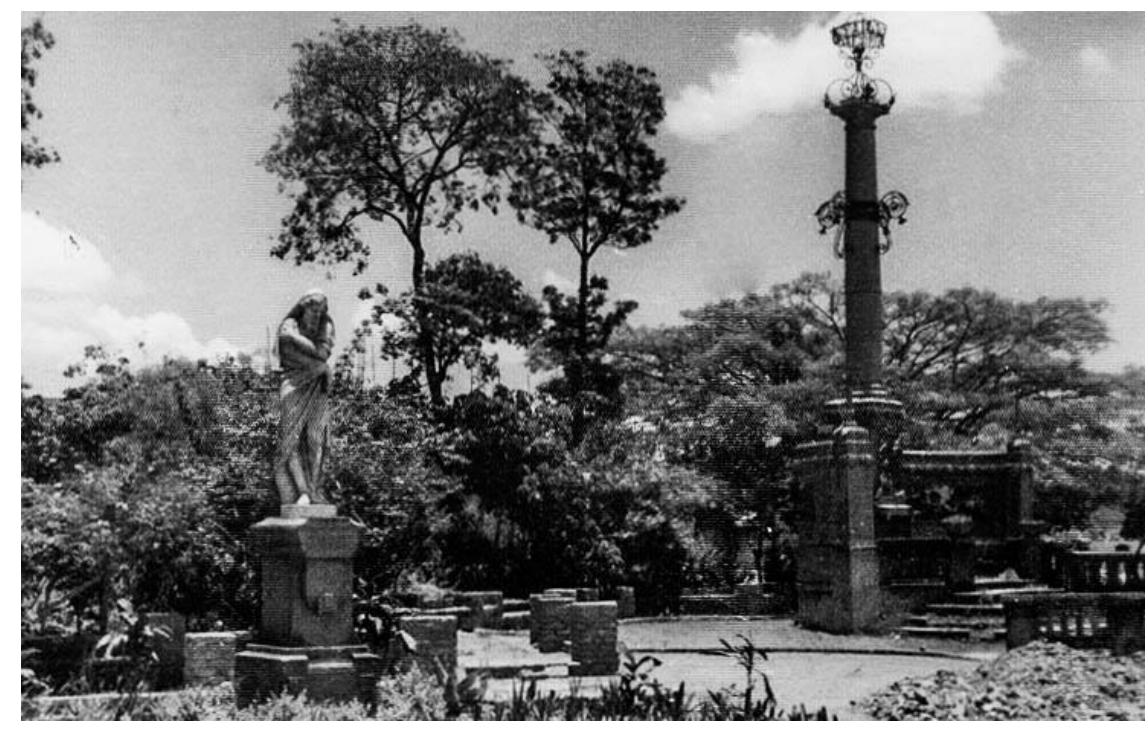

Fonte: Arquivo da Hemeroteca Jornalista Paschoal Artese.

Ambos os jardins eram utilizados pela população, transformando-se em espaços importantes dentro da malha urbana, lugares de ver e ser visto, ensejando um novo comportamento que, segundo Ghirardello (2010), ocorria em consequência de um conjunto de fatores: repressão policial, intimação social e cultural. Desse modo, e como destacado por esse autor (GHIRARDELLO, 2010, p. 206), a assepsia da paisagem se transferia "para aqueles que a usufruíam de acordo com os novos costumes, comportamentos e hábitos 'civilizados', nitidamente expressos com base em uma nova indumentária aos moldes europeus". A Praça e o Jardim estabeleceram-se como espaço pleno de domínio social, onde a natureza era controlada e atividades diversas eram realizadas, marcando o processo de laicização.

Alvo de uma transformação elitizada, a área central, nobre por excelência, necessitava da construção de edifícios destinados ao lazer para compor um cenário coerente com os novos ideais e mais expressivos do esplendor e riqueza rio-pardense. A cargo da abastada classe dominante local, o Theatro São José (Figura 100) foi construído em 1905 e o Cine Pavilhão XV de Novembro (Figura 101) em 1910 pelo empreiteiro e construtor Paschoal Artese. Ambos edifícios representaram importantes símbolos de modernização do tecido urbano, estando diretamente associados a um cenário em transformação, e nessa nova paisagem que se constituía a plástica do ecletismo foi uma aliada.

\footnotetext{
133 Artese foi o responsável por cuidar do Jardim Artístico por mais de 40 anos, provendo-o dos cuidados com jardinagem, limpeza, energia, água e porteiro, custando-Ihe parte dos seus bens em troca das dívidas acumuladas. Em 1957, após um acordo realizado entre a Prefeitura Municipal, o Paschoal Artese e a Igreja - proprietária do terreno -, o Jardim Artístico começou a ser demolido para ali ser construído os prédios dos três poderes: Legislativo, Executivo e Judiciário (DEL GUERRA, 2001). 
Figura 100: Desenho da fachada do Theatro São José construído em 1905.

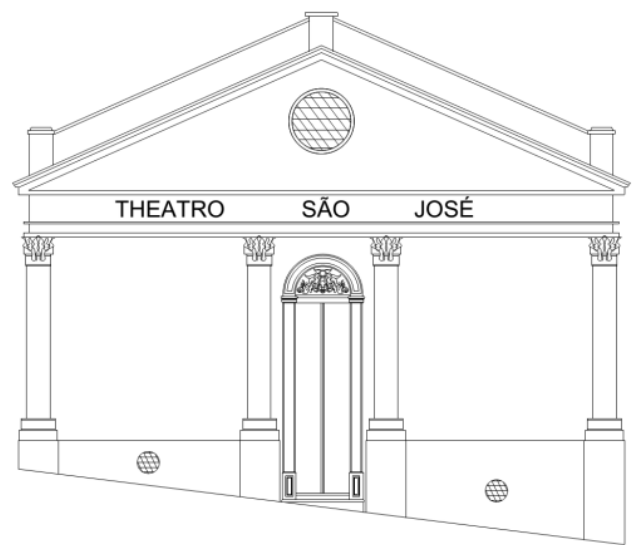

Desenho: Natalia Cappellari de Rezende (2017) com base em fotografias pertencentes ao Arquivo do Centro da Memória Rio-Pardense Rodolpho José Del Guerra.
Figura 101: Desenho da fachada do Cine Pavilhão XV de Novembro construído por Paschoal Artese em 1910.

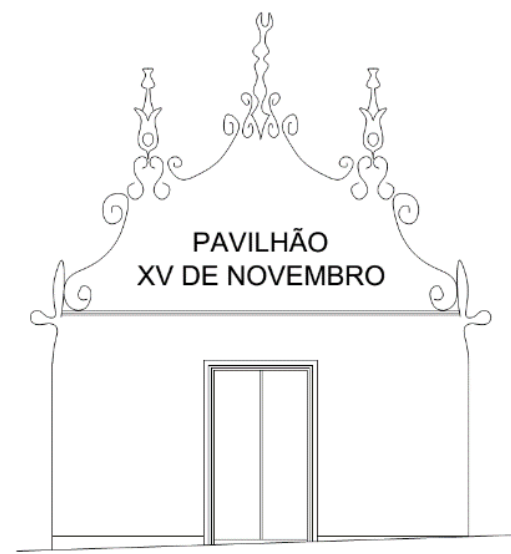

Desenho: Natalia Cappellari de Rezende (2017) com base em fotografias pertencentes ao Arquivo do Centro da Memória Rio-Pardense Rodolpho José Del Guerra.

A experiência de urbanização e a produção arquitetônica, incitadas pela ordem republicana, se cercaram também da necessidade do desenvolvimento cultural e intelectual. O texto publicado no jornal O Rio Pardo sinaliza a preocupação que havia:

De fórma que, sem a instrucção, é simplesmente impossível o homem aperfeiçoar-se em uma boa educação. Ella é por isso mesmo a base de todo o progresso da civilização. O desaparecimento da instrucção é a negação das sociedades civilizadas porque dela, exclusivamente dela é que dependem todos os conhecimentos humanos, na sua evolução progressiva, tanto na ordem physica, como na ordem intelectual e moral. A grandeza de uma nacionalidade está na razão direta do desenvolvimento da instrucção do seu povo, porque à proporção que ele se instrue, tambem educa-se. (INSTRUIR..., 1906, p. 01).

Entre nós, pequeno, quase insignificante é o numero de chefes de família que se preoccupam seriamente com o futuro mental e moral dos filhos. A massa geral contenta-se em formar prole patriarchal, deixar no mundo uma tribo mais compacta que a de Jacob, e considerando que a educação é dispensável, contenta-se em prover os meios de subsistência da filharada, envelhece no trabalho áspero para legar alguma fortuna e prendar os mais intelligentes com o titulo de letrado ou professor de escola do Estado que Ihes garanta collocação condigna e sirva de apresentação para arranjar casamento vantajoso, que absolutamente não o salvará dos desastres, se os moços não levarem no espirito licções de experiência e direcção de vida. (GRUPOS ESCOLARES II, 1908, p. 01).

Como atestado por Homem (1996) e ratificado por Ghirardello (2010), o governo republicano se manifestou ideologicamente com o objetivo de criar escolas visando a disciplina, o controle, e, sobretudo o culto ao trabalho. Transposto para os governos municipais, a preocupação com a educação em diferentes níveis reuniu esforços de alguns rio-pardenses que aproveitando a passagem por Mococa do secretário de ensino, Carlos Botelho, requisitaram um posicionamento do Estado na construção de um grupo escolar em São José do Rio Pardo (DEL GUERRA, 2001) como já manifestava desde 1902.

Falla-se novamente, e agora com alguma insistência, na creação do Grupo escolar desta cidade. Nesse sentido alguma cousa se tem feito, constando-nos que vae dirigida uma 
representação ao patriótico governo do Estado. Não é demais se se insistir para obtenção desse melhoramento bastante necessário, pois ultimamente foram creados alguns Grupos escolares - e esta cidade é uma das que mais precisa, visto o municipio despender grande parte de sua renda com a manutenção de escolas municipaes. (GRUPO ESCOLAR, 1905, p. 01).

Regressaram de São Paulo os senhores dr. Antonio Candido Rodrigues ${ }^{134}$ e tenente coronel Vicente Dias Júnior ${ }^{135}$. O exmo. dr. Antonio Candido está muito interessado em attender o pedido que the fez o partido republicano desta cidade, por intermedio do directorio, da creação do Grupo escolar. Parece que agora será uma realidade a creação do Grupo, muito em breve, devido a intervenção prestigiosa do illustre dr. Antonio Candido e do directorio republicano, perante o governo do Estado. (REGRESSO, 1905a, p. 02).

Após a sinalização de apoio do governo do Estado, o município requisitou a planta do grupo escolar que foi enviada junto com o orçamento da obra, ficando assim ambos os governos autorizados a contratar a sua construção que ocorreu em um terreno que foi assunto de muita discussão entre a classe dirigente local e técnicos, dado a sua localização e condição sanitária. Na Praça Barão do Rio Branco (antigo Largo do Rosário que após a construção da escola ficou conhecido como Largo do Grupo), em um terreno de $9000 \mathrm{~m}^{2}$ que o Grupo Escolar de $750 m^{2}$ com 10 salas para 400 alunos e um pátio interno de $205 m^{2}$ (DEL GUERRA, 2001) foi construído.

A impressa se posicionou defendendo o lugar da construção do edifício, considerado

um prédio importante que vem embellezar a cidade, já porque chamará a attenção da população para aquelle aprazível logar que em breve se desenvolverá com as novas edificações que naturalmente se darão desde que alli seja estabelecido o Grupo. (GRUPO ESCOLAR, 1904, p. 01).

A citação acima nos mostra que havia estímulos para o desenvolvimento dessa região que estava se valorizando com a construção desse prédio e com o Jardim Artístico. Assim sendo, o edifício do Grupo Escolar Candido Rodrigues, representante do ideal republicano contra o analfabetismo, foi inaugurado em abril de 1908. O edifício eclético, seguindo o modelo da cidade de Caçapava (CORRÊA, 1991) de um pavimento, se destacava pela sofisticação e composição simétrica da fachada. Implantado de forma isolado na quadra, a organização espacial interna foi concebida seguindo as questões previstas no Código Sanitário Estadual (1894) para atender os preceitos higiênicos de ventilação e iluminação, tendo as salas de aula distribuídas em duas alas racionalmente setorizadas para meninos e meninas, separadamente. Atenção especial também foi dada ao mobiliário e sua disposição, como segue na publicação abaixo:

A claridade bilateral é a melhor: entretanto, pelas difficuldades de sua realização nossas escolas, tem-se preferido a unilateral, contanto que venha do lado da sala donde parta a claridade não seja exposta aos raios solares directamente afim de evitar-se que modificam o poder clarificante e enfim que seja a salla alta para que a luz possa chegar até os logares mais afastados da salla, sendo a superfície clareante das janellas igual ao terço ou quarto da superfície do soalho. $\mathrm{O}$ excesso de janellas, portanto o excesso de luz tem o inconveniente de tornar a classe muito sensível as variações thermicas exteriores. A mobília escolar deve preencher as condições seguintes; a distancia entre o banco deve ser negativo (meza se inclinando ao banco) ou nulla. A diferença de altura entre o banco e a meza deve ser tal que o cotovello do alunno se apoie naturalmente por sobre a meza. O banco deve ser munido de um

\footnotetext{
${ }^{134}$ Para saber mais sobre ele ver nota 78 na página 73.

${ }^{135}$ Vicente Dias Júnior, irmão de Honório Luiz Dias e filho de Vicente Alves de Araujo Dias, era casado com a filha de Antonio Candido Rodrigues. 
espaldar muito aproximado para servir de apoio durante a escriptura. (HYGIENE ESCOLAR, 1906, p. 01).

Apesar de não encontrarmos documentos que comprovem a autoria do projeto, certamente o mesmo tenha sido obra do arquiteto belga José van Humbeeck que prestou serviços à Superintendência (Diretoria de Obras Públicas; Secretaria da Agricultura, Comércio e Obras Públicas - DOP - SACOP) do Estado de São Paulo. Segundo Silvia Ferreira Santos Wolff (2010) que realizou estudos sobre as escolas públicas paulistas da República, José van Humbeeck foi o responsável por vários projetos, mas apesar disso

\begin{abstract}
é um arquiteto completamente desconhecido sobre o qual não se conserva sequer o prontuário funcional, como de resto de nenhum funcionário antigo da secretaria de Obras. (...) Sua contribuição, no entanto, se faz por seu trabalho como profissional de atuação longeva e dedicada. Humbeeck já estava presente quando Victor Dubugras experimentava no século XIX, ainda estará quando novos profissionais inovarem nos anos 1910. E, ainda, participará muito ativamente da grande produção desse momento. Durante esse período ele se debruçou sobre sua mesa de trabalho e estudou com afinco a arquitetura necessária para as escolas paulistas. Propôs ideias simples e exequíveis para cuja concepção olhou com muita atenção para os passos já realizados por seus colegas. Recriando-os, não raro copiando-os literalmente. (...) é um personagem cuja participação é inquestionável na história da arquitetura escolar paulista. (WOLFF, 2010, p. 214-219).
\end{abstract}

Ainda segundo essa autora (Wolff, 2010), os projetos de José van Humbeeck repetia o mesmo esquema nas plantas e fachadas, como se segue, indo ao encontro das características do Grupo Escolar Cândido Rodrigues, como é possível observar na Figura 102.

\begin{abstract}
Uma fachada sóbria, cuja composição era marcada por elementos que muito simplificadamente lembravam sua inspiração de origem neoclássica. Vãos de arco pleno no térreo e de vergas retas no primeiro, frisos horizontais marcados nos revestimentos, recriando a aparência das construções de pedra do Renascimento, e platibandas singelamente decoradas. Centralizando a composição, um pequeno frontão que apenas coroava a platibanda, sem extravasar seus limites, e onde se inscrevia claramente a função do edifício, um Grupo Escolar. (WOLFF, 2010, p. 219).
\end{abstract}

Reforçando a colocação acima, outras escolas de um só pavimento foram construídas a partir do mesmo projeto que é estritamente semelhante ao edifício do grupo escolar de São José do Rio Pardo, são elas: Caçapava (1905), São Simão (1905), Itatiba (1907), Bragança Paulista (1907), Santa Bárbara (1911) e Cajuru (1911) (Figura 103) (CORRÊA, 1991; GORDINHO, 2013; WOLFF, 2010).

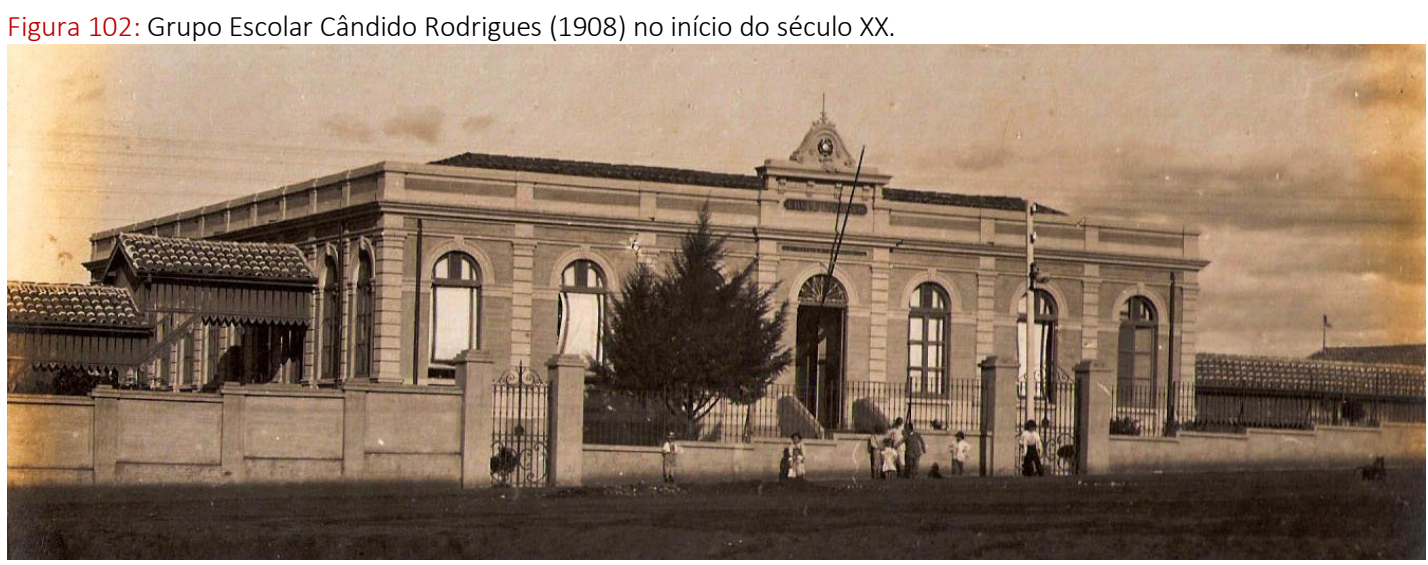

Fonte: Arquivo do Centro da Memória Rio-Pardense Rodolpho José Del Guerra. Fotografia de Innocencio Vilhegas. 
Figura 103: Grupos Escolares construídos pela Diretoria de Obras Públicas do Estado de São Paulo a partir de projeto elaborado por José van Humbeeck no início do século XX.
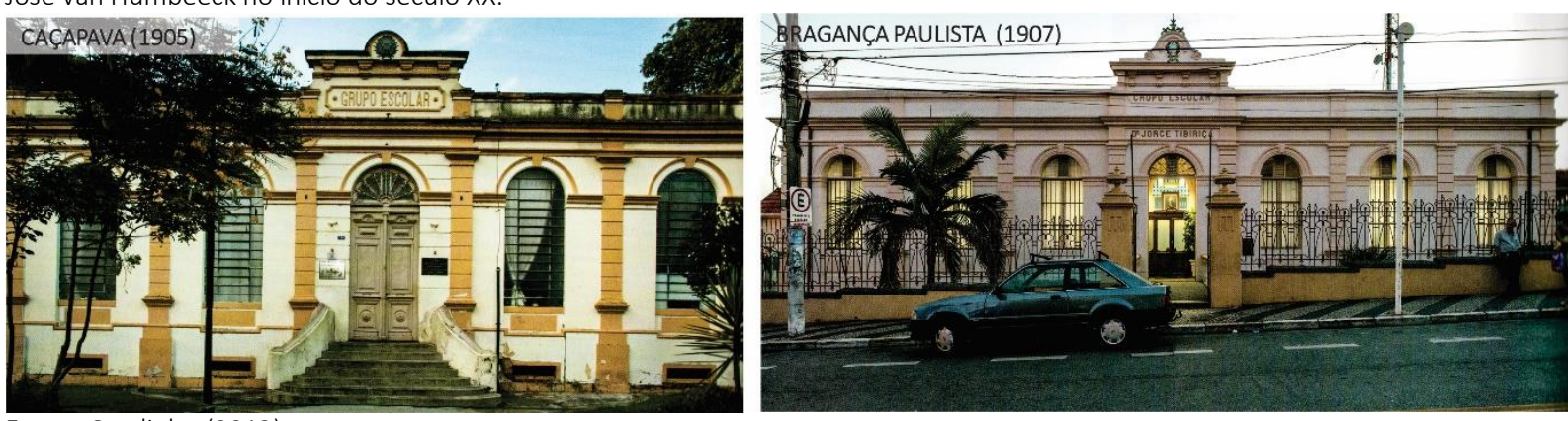

Fonte: Gordinho (2013).

É evidente que a circunscrição desses melhoramentos urbanos foi definida com a discriminação do perímetro das redes de água e esgoto, estando fora aqueles equipamentos associados ao imaginário da morte. Assim sendo, a área central da cidade foi se estruturando com a mesma tendência segregacionista empregada na construção das respectivas redes que passou pelas principais ruas, formando o contorno do seu quadrilátero, tendo os córregos São José e Macaúba como limites (ver Figura 50 na página 106).

Ainda que seja visivelmente ufanista, a citação abaixo clarifica o momento pelo qual a cidade estava passando. As reformas e construções de novos prédios, os reparos e abaulamentos de ruas, e o movimento de passageiros e mercadorias na estação eram considerados sinônimo de desenvolvimento e bem-estar. Em paralelo à nova dinâmica e para que essas transformações ocorressem no ambiente urbano, foi necessária a realocação da posição do homem como agente ativo e responsável por decidir e organizar estratégias direcionadas na composição de um projeto político, econômico e social, como destacado na citação.

\footnotetext{
Uma cousa que de um anno a esta parte tem sido digno de nota, entre nós, é o movimento de progresso que aqui se observa. Podemos dizer que São José do Rio Pardo, bela e elegante cidade, começa a entrar novamente em uma phase de prosperidade. Quem percorrer a cidade, há de forçosamente notar esse movimento de progresso, o que hoje em bem poucas cidades do interior se vê. Rarissimas são as ruas em que não se veja um predio em construcção ou em reconstrucção. Em todos se nota vontade de construir predios. [...] Para se calcular da vida activa desta cidade, é bastante ver o movimento diario da estação. [...] Ninguem contesta que a epidemia causou-lhe um grande mal, paralysando o seu progresso por muito tempo. Mas, como dizíamos, ella começa a entrar novamente nessa phase de progresso. Este afan de construir e reconstruir prédios, reparos e abaulamentos de ruas, são factos que denotam bem estar e animação e que ao mesmo tempo caracterizam a energia, a iniciativa dos seus habitantes. A continuar assim, pois, daqui a poucos anos S. José será uma das mais belas e importantes cidades do nosso grande Estado. (PROGRESSO, 1907, p. 01).
}

A cidade de São José do Rio Pardo se inseriu durante a Primeira República no panorama de relações fortalecida por laços econômicos e políticos mais amplos. A dinâmica produção cafeeira deu ensejo à materialização das relações no espaço urbano e no curso desse processo, segundo Sevcenko (1998), surgiu uma série de novos equipamentos e produtos que entraram e alteraram de maneira profunda o cotidiano, a sociabilidade, as noções de tempo e espaço, como os veículos automotores. Estes chegaram em São José do Rio Pardo em 1908, adquiridos pelo "intelligente e progressista fazendeiro" cel. Francisco Soares de 
Camargo (Figura 104), após o apoio do prefeito cel. João Moreira que tratou de fazer uma estrada nova ligando a cidade à fazenda Santo Antônio, propriedade do coronel (NOTICIÁRIO, 1908, p. 02).

Apesar das condições das estradas inibirem o entusiasmo de fazendeiros e outros moradores abastados, novos automóveis chegaram em São José do Rio Pardo através do trem no início do século XX (Figura 105), servindo mais como distintivos sociais do que como meio de transporte, conforme podemos observar em uma série de fotografias e exemplificado na Figura 106. Foi no início da década de 1910 que São José do Rio Pardo passou a contar com empresas que comercializavam automóveis, como a concessionária da família Flamínio que já possuía uma oficina de fabricação e conserto de trole.

Em 1912, anúncios eram publicados comunicando às pessoas interessadas o serviço de alocação de um carro na Praça XV de Novembro, bem como a inauguração de uma garagem para automóveis de aluguel e transporte de passageiros.

No que tange ao crescimento populacional, quase quadruplicou em relação à década anterior, saltando de 9.207 habitantes em 1890 para 32.000 habitantes em 1912, segundo recenseamento realizado pela Secretaria de estatística do município e publicado no jornal O Rio Pardo do dia 11 de abril de 1912. Já o Recenseamento realizado em 1920 que abrangeu todo o Brasil, Estados e municípios, apontou que a população riopardense era de 32.507 habitantes, corroborando com o número anunciado em 1912 no jornal local (Tabela 4).
Figura 104: Pessoas posicionadas para a foto junto com o automóvel adquirido pelo coronel Francisco Soares de Camargo em 1908.

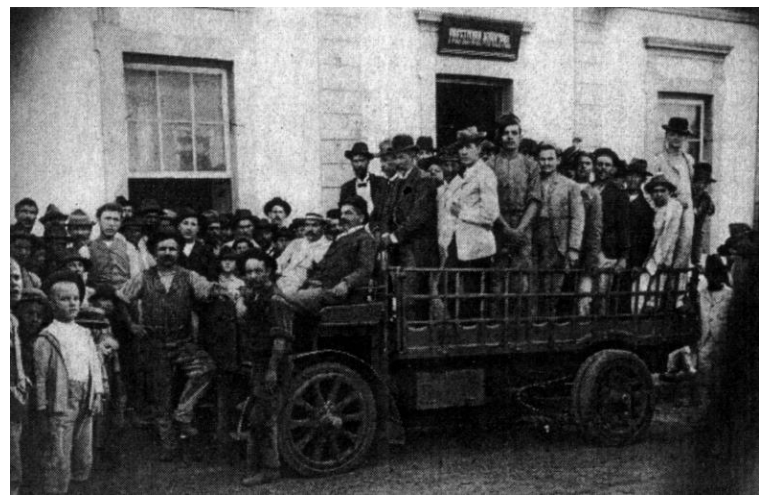

Fonte: Arquivo do Centro da Memória Rio-Pardense Rodolpho José Del Guerra.

Figura 105: Carros recém chegados em São José do Rio Pardo através do trem.

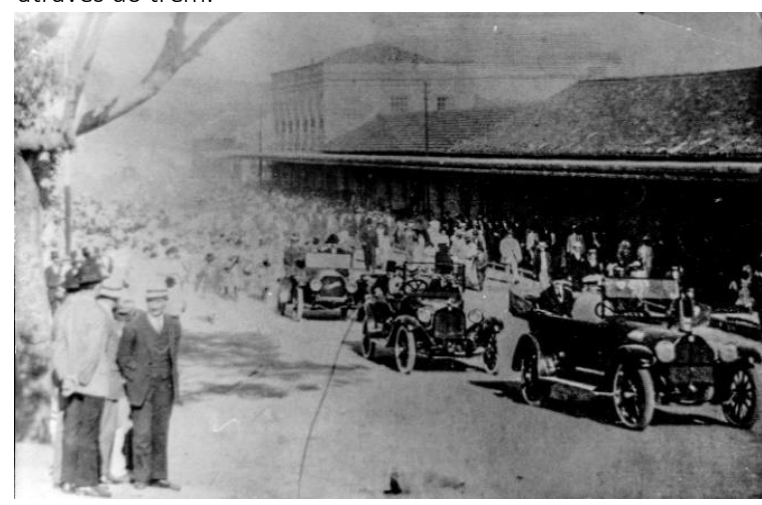

Fonte: Arquivo do Centro da Memória Rio-Pardense Rodolpho José Del Guerra.

Figura 106: Membros da família Flamínio em um automóvel.

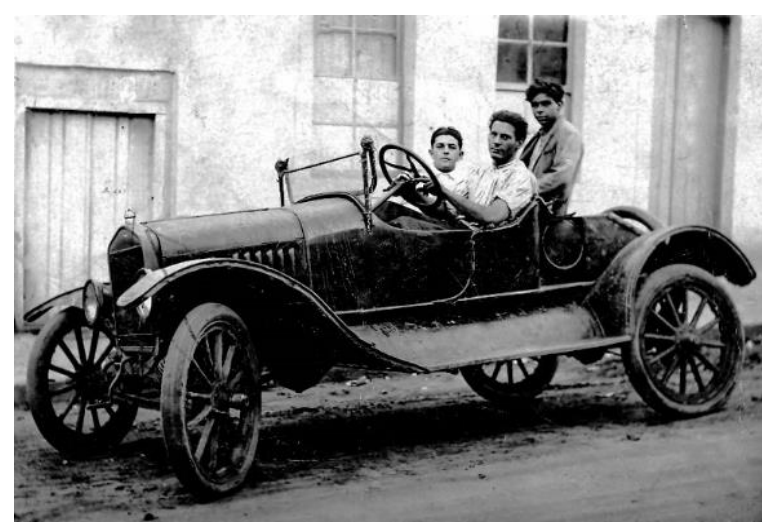

Fonte: Arquivo do Centro da Memória Rio-Pardense Rodolpho José Del Guerra. 
Tabela 4: Informações sistematizadas sobre o número populacional do Recenseamento de São José do Rio Pardo em 1890 e 1920.

POPULAÇÃO DE SÃO JOSÉ DO RIO PARDO EM 1890 E 1920

\begin{tabular}{l|l|c}
\hline \multirow{2}{*}{ Ano } & \multicolumn{2}{|l}{ Nacionalidade } \\
\hline \multirow{2}{*}{1890} & nacional & 7.422 \\
\cline { 2 - 3 } & estrangeira & 1.785 \\
\cline { 2 - 3 } & Total & 9.207 \\
\hline \multirow{2}{*}{1920} & nacional & 24.736 \\
\cline { 2 - 3 } & estrangeira & 3.771 \\
\cline { 2 - 3 } & Total & 32.507 \\
\hline
\end{tabular}

Fonte: IBGE.

Em contraposição aos investimentos na área central e ao aumento populacional, e como denunciado nas páginas do jornal O Rio Pardo, havia em 1912 um déficit habitacional que resultava em prejuízo para o local, afastando os interessados em residir em São José do Rio Pardo, como apontado pela reportagem abaixo:

\footnotetext{
Existem em S. José, mais ou menos 800 casas, para accommodar cerca de 8.000 pessoas. Ora, por este calculo approximativo compreende-se facilmente em que condições permanecem numeráveis famílias, repartindo uma casa para duas e mais, não tanto pela economia mas porque ainda que pretendessem alojar-se em prédio próprio não o encontrariam. (LOCAES, 1912, p. 01).
}

É importante enfatizar que a expansão da cidade estava condicionada à abertura de novas ruas e quadras para serem loteadas. Surgiu nesse momento em São José do Rio Pardo a figura do loteador. Caso exemplar foi o de Honório Luiz Dias que anunciou em 1905 a divisão das suas terras próximas à caixa d'água, ao sul do núcleo urbano, prolongando a Rua Treze de Maio e a Avenida Campos Salles. Desse modo, 120 novos lotes foram postos à venda aos preços de $60 \$ 000$ a $205 \$ 000^{136}$. A consequência foi a construção de novas moradias, provocando efeitos no espaço urbano, sobretudo a manutenção do que já vinha ocorrendo, ou seja, a exclusão dos populares da área central, segregando-os na periferia (área leste e oeste do centro) com suas habitações operárias (Figura 107). Conjuntura explicada pela prevalência de "ações de disciplinamento legal, policiamento e medicalização do espaço urbano e da habitação proletária" alinhadas às abordagens sanitaristas, urbanísticas e de raça que considerava o pobre degenerador de uma cidade asséptica, higienizada e civilizada (LIRA, 1999, p. 49).

\footnotetext{
${ }^{136}$ A variação de preços reflete a dinâmica de ocupação, exclusão, segregação e privilégio da cidade, estando aqueles com menor poder aquisitivo limitados pelas condições impostas pelo mercado, ou seja, conseguiam adquirir lote em áreas onde a infraestrutura urbana era mais precária, ou mesmo inexistente. 
Figura 107: Expansão urbana no sentido sul do núcleo no final da primeira década do século XX.

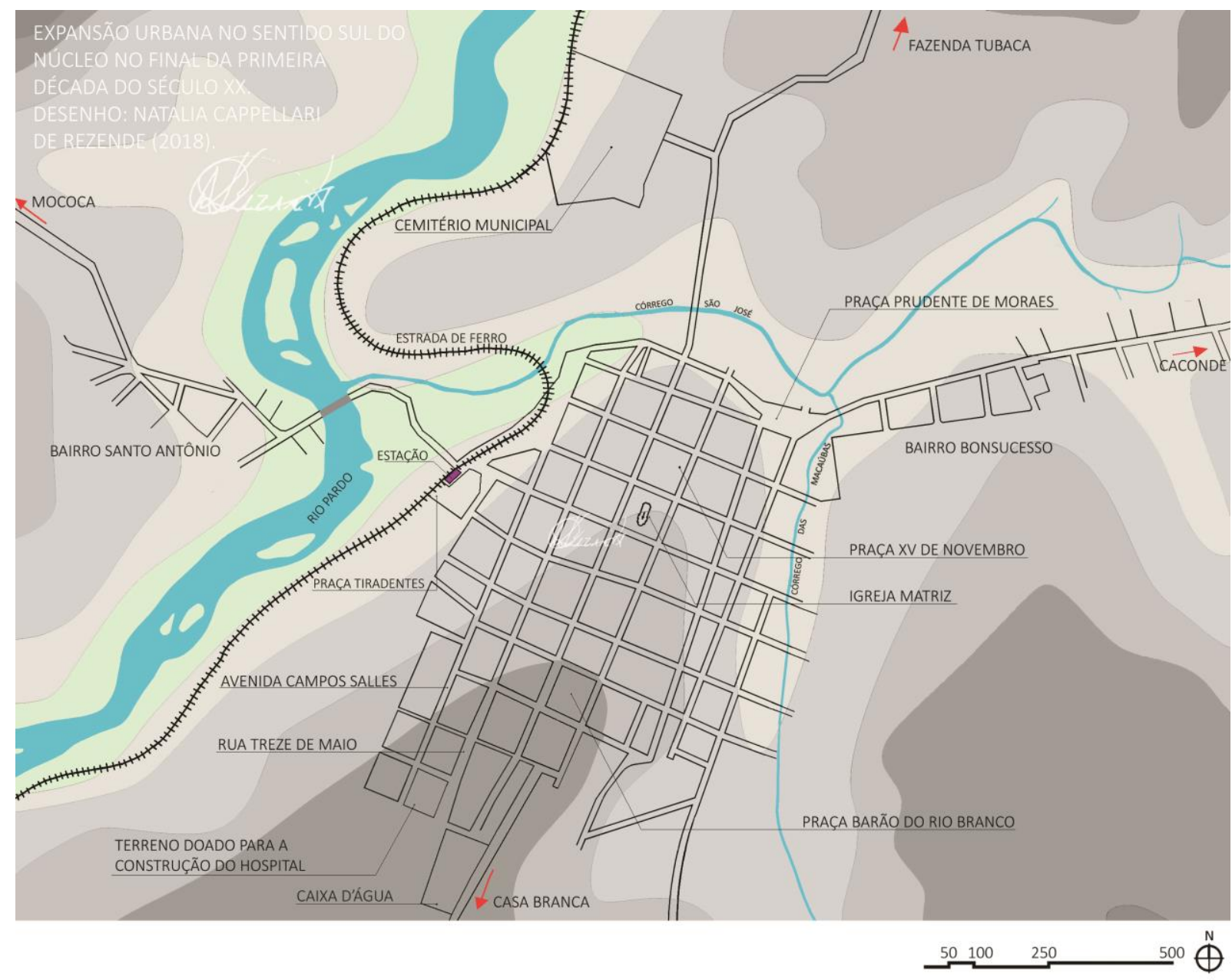

Desenho: Natalia Cappellari de Rezende (2018) com base em dados históricos e cartografia disponibilizada pela Secretaria de Obras de São José do Rio Pardo.

Valorização da área central; discriminação e exclusão da população pobre; separação e definição de usos, funções e locais adequados; novos usos e costumes guiados, sobretudo pelo desejo da produção de uma imagem que se queria moderna em acordo com a demanda da expansão do capital. Obras de infraestrutura; intervenções para o aformoseamento; novos edifícios e equipamentos públicos construídos seguindo a preocupação com a salubridade pública e em acordo com as legislações criadas, arregimentou esforços de um pequeno grupo que constituiu um círculo autônomo de serviços apoiados pelos investimentos realizados pelo Estado, com o objetivo de direcionar as ações de organização urbana para a acumulação do capital. Nova dinâmica, uso e produção, a cidade assenhoreou-se de uma nova paisagem. Esse movimento de transformação urbana, atrelado ao espírito higienizador e embelezador, deu ensejo a novas atividades e investimentos: novas ruas foram abertas (1905) e outras drenadas (1913), pavimentadas (1912) e arborizadas (1913), praças e jardins construídos (1913) e cursos d'água canalizados (1913). Como via para o desenvolvimento econômico, a abertura de atividades comerciais e industriais foi incentivada. Uma série de novas necessidades condicionou a vida na cidade e com isso demandas foram criadas, atraindo profissionais da saúde, da construção civil e do direito (Figura 108). 


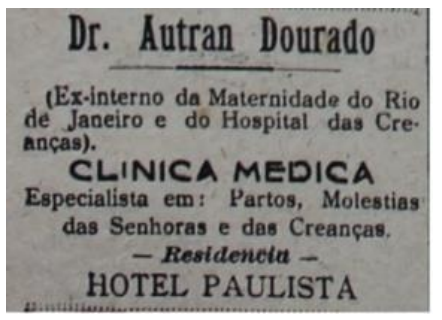

Escriplorio de Engenharia José Barbosa de Oliveira

Incumbe-se de quaisquer servi. cos de engenharia civit, arquitec tura, mecínica e electrici lade. Projectos e orcernentos, cipente armado e construcęoes em ferro. Levantamentos, demarcaçoes o divisoes.

Triefono 60 - Provisoriamente.

RUA JULTO DE MESOUITA Esquina da rua 13 de Maio.
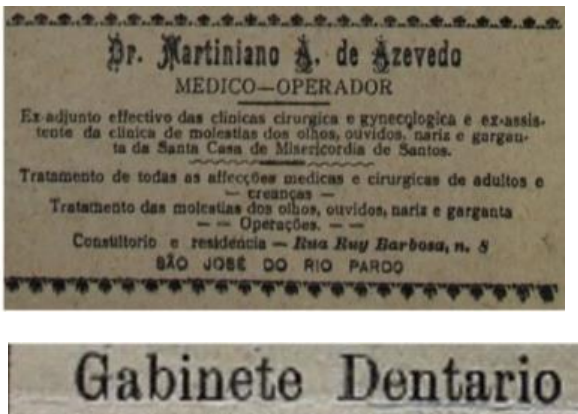

Joầo Cartiejro de Araujo, de volta a esta cidade, previne aos seus amigos, que reabriou seu consultorio dentario a rua 13 de Majo n. 44 , onde fiça a disposiçấo dos mesmos, das - 8 ás 10 e das 11 ás 16 horas, para todo e qualquer trabaibo concernente a gua arte, garantindo perfeiçáo e solider.
Dr. Joaquim de Albuquerque $\rightarrow$ Maranhão $\longleftrightarrow$ ADVOGADO

Encarrega-se de causas civeis, commerciaes e orphanologias. Residencia e escriptorio Rua Ahattias Burbosa, 8 ,

Fonte: Jornal O Rio Pardo e O Progresso, 1903-1918.

Multiplicaram-se fábricas de móveis, sabão, vela, bebidas alcoólicas, refrigerantes e de cigarros; farmácias, restaurantes, barbearias, sapatarias, alfaiatarias, tipografias, hotéis, confeitarias e padarias; lojas especializadas em artigos para escritórios e materiais para a construção civil; garagens para venda, aluguel e conserto de automóveis; representantes de vinhos, remédios e automóveis nacionais e internacionais; e bancos de financiamento como a Caixa Econômica (1917) e o Banco Francês e Italiano para a América do Sul (1913) (Figura 109). Construído em 1913, o edifício do Banco Francês e Italiano para a América do Sul, ainda preservado, se destacava na paisagem pela monumentalidade e sofisticação. Um prédio eclético marcado pela simetria quebrada apenas pela cobertura da garagem que foi construída anos depois, formando um terraço fechado por elementos vazados (Figura 110). Uma das portas laterais (à direita) dá acesso ao primeiro pavimento que foi projetado para servir de morada do gerente do banco. A centralidade do edifício se destaca pelo leve recuo em sua fachada, pela aduela no arremate do arco pleno das portas principais, pelo balcão com balaustrada ornamentado por duas mísulas, e a ornamentação de uma concha sobre a porta do primeiro pavimento. 
Figura 109: Prédio do Banco Francês e Italiano para a América do Sul construído em 1913 em São José do Rio Pardo.

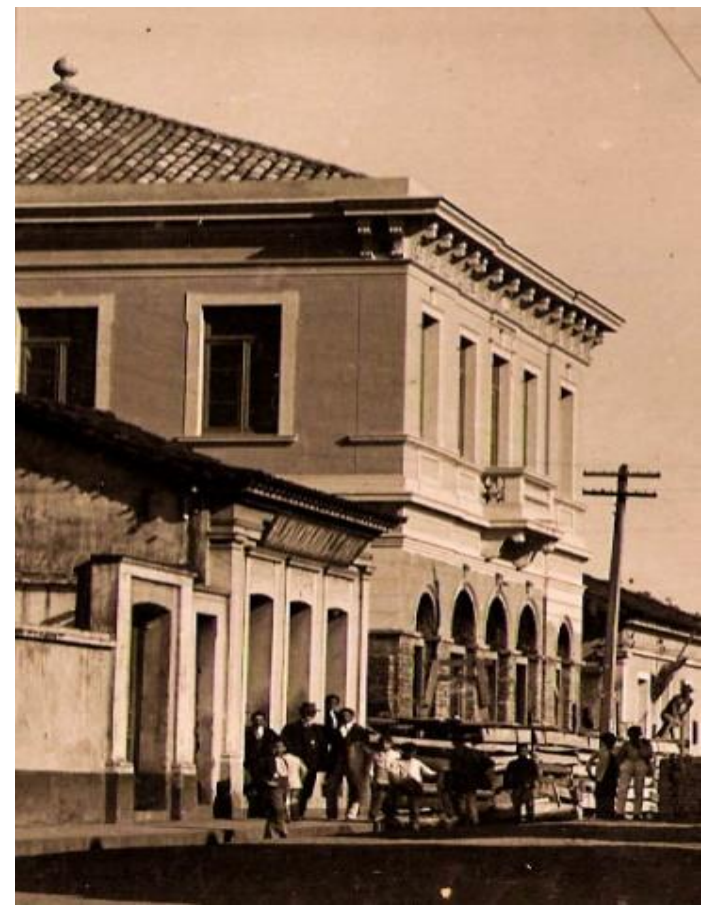

Fonte: Arquivo da Hemeroteca Jornalista Paschoal Artese. Fotografia de Innocencio Vilhegas.
Figura 110: Garagem construída na lateral direita do edifício do Banco Francês e Italiano para a América do Sul.

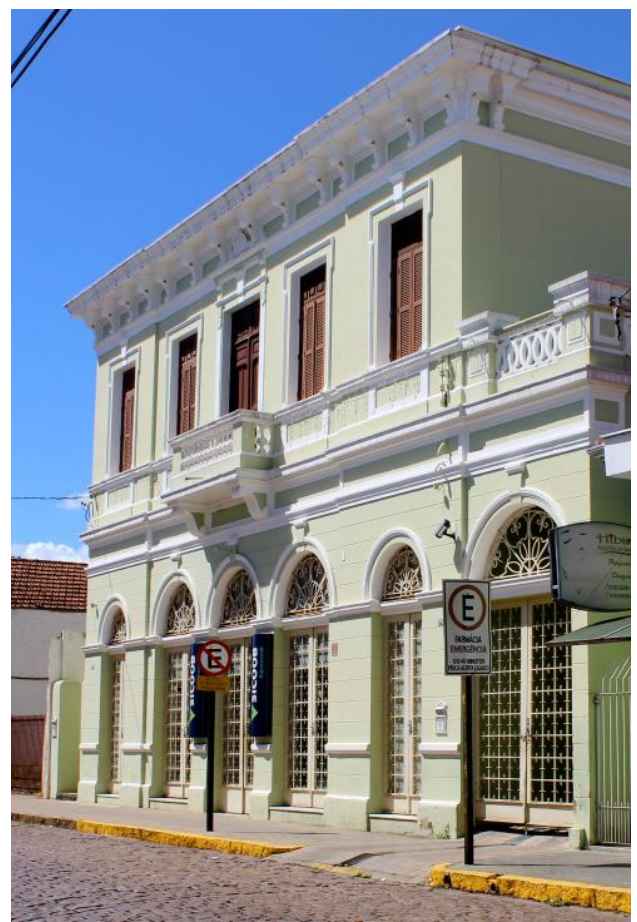

Fonte: Acervo pessoal da autora (2018).

Figura 111: Ponte pênsil construída em 1913 para dar acesso à Ilha de São Pedro.

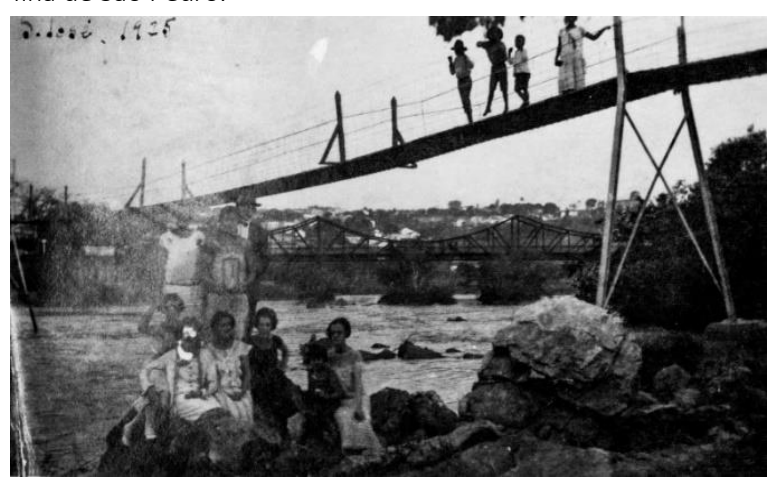

Fonte: Arquivo da Hemeroteca Jornalista Paschoal Artese. construída, em 1913, uma ponte pênsil de 145 $\mathrm{m}$ de comprimento, ligando a ilha à cidade, nas proximidades da ponte metálica e da Estação Central (Figura 111).

O resultado de todo esse processo foram intervenções singulares e isoladas na trama urbana revestidas da roupagem de desenvolvimento. Logo, morar no centro de São José do Rio Pardo significava pagar um valor considerável de taxas de instalação e manutenção de serviços urbanos prestados. Para além da área central pouco se fez em termos de melhoramentos urbanos, uma vez eram nessas regiões que a população mais pobre ocupava. 
Foi o período em que várias obras foram empreendidas pela propalada administração municipal que tinha à frente o republicano Mário Rodrigues ${ }^{137}$ - filho de Antonio Candido Rodrigues - que expôs no relatório de 1915 a dificuldade financeira encoberta - como segue na citação abaixo - ao contratar empresas privadas para empreender obras que propiciassem desenvolvimento material e conforto social, como aconteceu com a eletricidade assumida pela Companhia Paulista de Energia Elétrica ${ }^{138}$; a telefonia pela Empresa Telephonica ${ }^{139}$ que também se encarregou de fazer a troca dos postes de madeira por postes de ferro; a limpeza pública assumida por livre concorrência capitalizada pela Câmara, certamente após a ação da Comissão de Saneamento do Estado de São Paulo; a efetivação de um contrato com uma empresa belga para a construção do novo Matadouro ${ }^{140}$ (Figura 112) próximo dos trilhos da ferrovia e do rio Fartura, facilitando inclusive o escoamento da produção de carne.

As dividas se elevavam a importante soma de Rs. 153:113\$594, em letras, vales e contas diversas [...] somada esta importância com a necessária para o custeio indispensável do serviço Municipal (Rs. 69:280\$000), seria preciso uma arrecadação de Rs. 222:393\$594, para fazer face a despesa total quando é certo que a maior arrecadação até hoje feita (a de 1913), attingio apenas Rs. 186:889\$310! (RELATÓRIO..., 1915, p. 04-05).

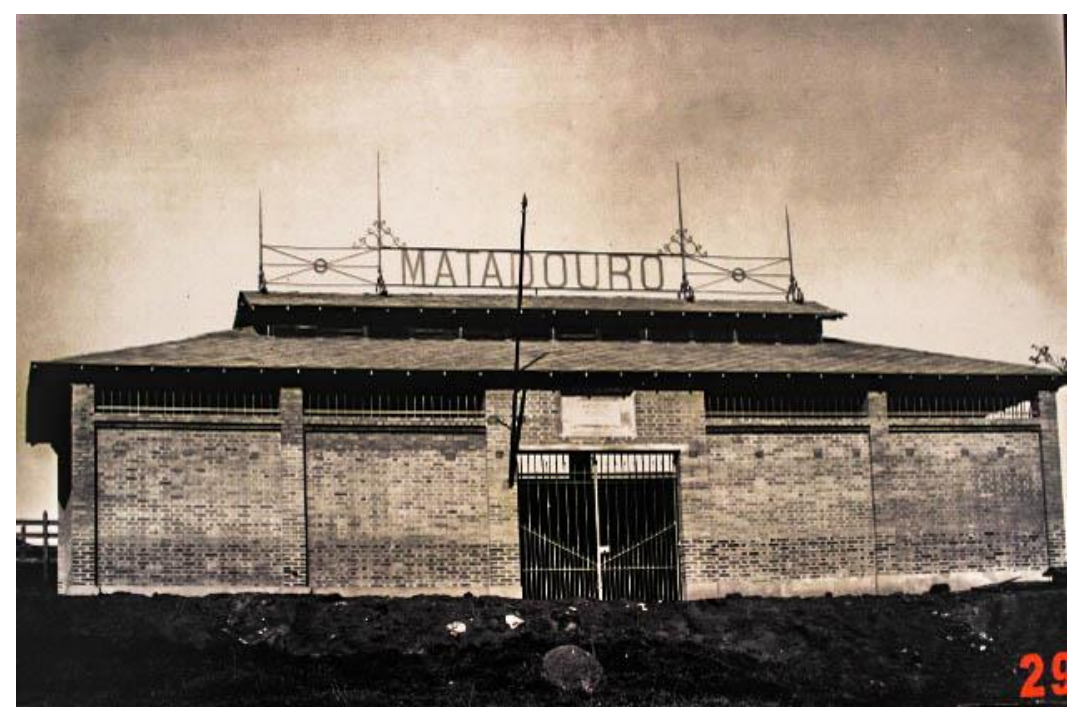

Figura 112: Matadouro de São José do Rio Pardo (1917) na década de 1910. Fonte: Arquivo do Centro da Memória Rio-Pardense Rodolpho José Del Guerra. Fotografia de Innocencio Vilhegas.

Nesse período a cidade se expandiu com o prolongamento e abertura de novas ruas, como é possível observar no mapa da Figura 113 onde também são localizados todos os equipamentos analisados nesse item, os quais conviveram no mesmo espaço em que predominou a ocupação com edificações de uso

\footnotetext{
${ }^{137}$ Mário Rodrigues permaneceu na função de prefeito entre os anos de 1915 a 1919

${ }^{138}$ Após desfeita a sociedade do "Syndicato da Luz Electrica de São José do Rio Pardo", Vicente Dias Júnior assumiu a empresa que passou a se chamar Companhia Paulista de Energia Elétrica. Para saber mais sobre Vicente Dias Júnior ver o subitem $A$ manutenção do poder e a hegemonia econômica na página 161.

139 O primeiro contrato de instalação de telefones assinado pela Prefeitura Municipal foi com a "Empresa Telephonica Riopardense" de propriedade de Vicente Dias Júnior.

${ }^{140}$ A Câmara Municipal aprovou no dia 22 de maio de 1914 o projeto de lei $\mathrm{n}^{\circ} 13$ que condicionava as decisões da construção do matadouro. Já na ata da sessão ordinária do dia 05 de abril de 1915 foi decidido pela aprovação do projeto de lei que terminava a matança dos porcos e as taxas cobradas. 
predominantemente residencial - como veremos no terceiro item deste capítulo -, contribuindo com o desenvolvimento citadino.

Figura 113: Expansão urbana em 1916 com destaque para a localização das principais edificações construídas no período.
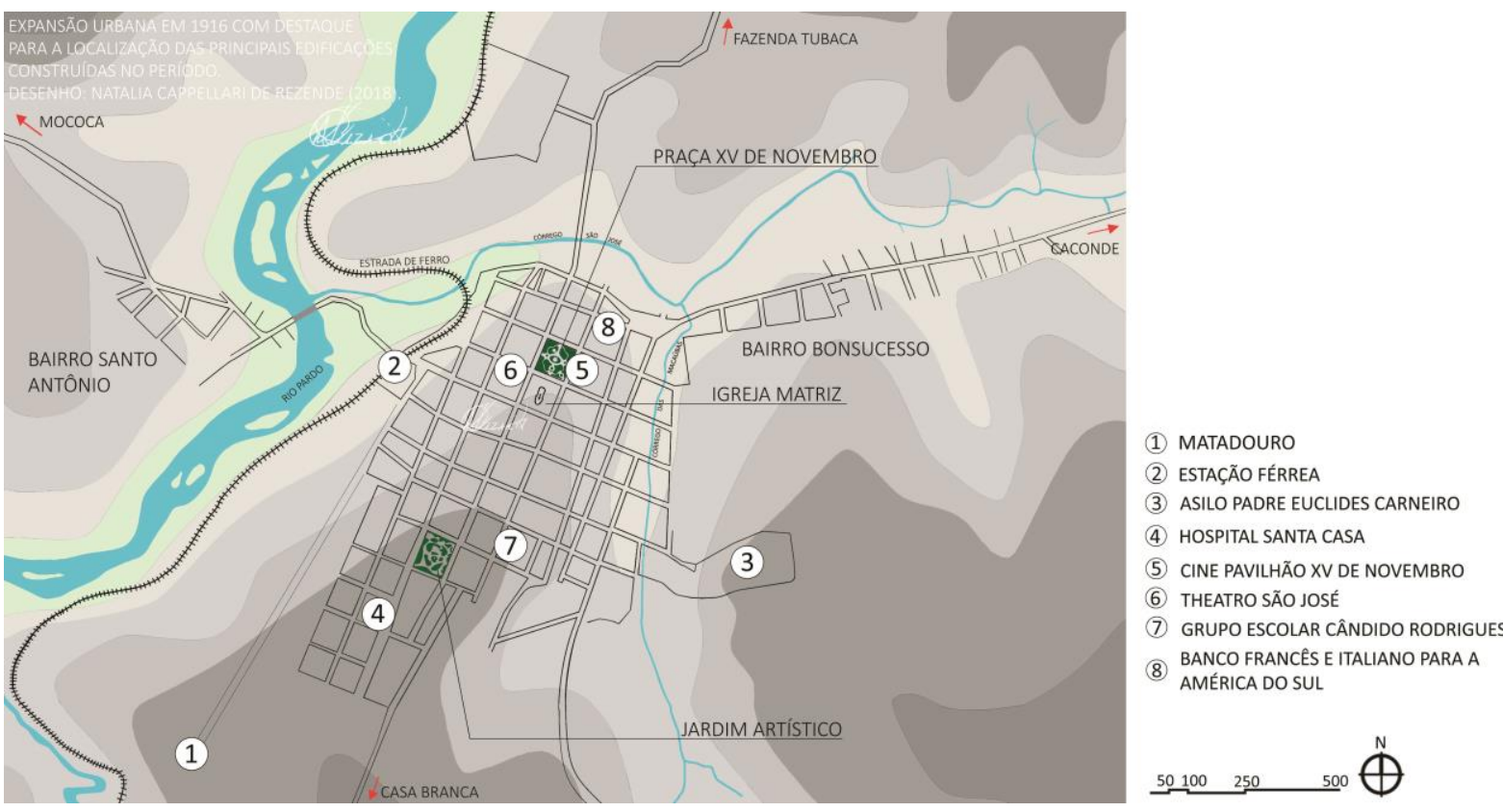

Desenho: Natalia Cappellari de Rezende (2018).

A condição do café, somada à produção de outros gêneros, trouxe prosperidade para os lavradores que investiram seu capital em empreendimentos urbanos, atestando a lucratividade que as obras ligadas a engenharia e infraestrutura proporcionavam. Situação que foi abalada durante os anos da Primeira Guerra Mundial com impactos negativos na economia brasileira. As consequências na construção civil foram sentidas imediatamente, causando quase que uma paralisação repentina, evidenciado por Lemos a partir de um diagrama das construções de São Paulo, elaborado por Arthur Saboya em 1929 (LEMOS, C., 1989a, p. 164). Sem dúvida alguma o mercado da construção civil em São José do Rio Pardo também foi afetado, e sobre isso o prefeito capitão Mário Rodrigues expôs no relatório de 1917 a exígua quantidade de prédios construídos, que não chegavam a 10 nesse ano. A dificuldade de importação de produtos europeus utilizados na construção civil provocou um encarecimento dessa atividade, consequentemente abalando a opção a cidade eclética, de alvenaria de tijolos, impregnada de elementos classicizantes que marcou a arquitetura produzida em São José do Rio Pardo no início do século XX (Figura 114, 115 e 116). 
Figura 114: Farmácia Itália-Brasil (1908) no final da década de 1910.

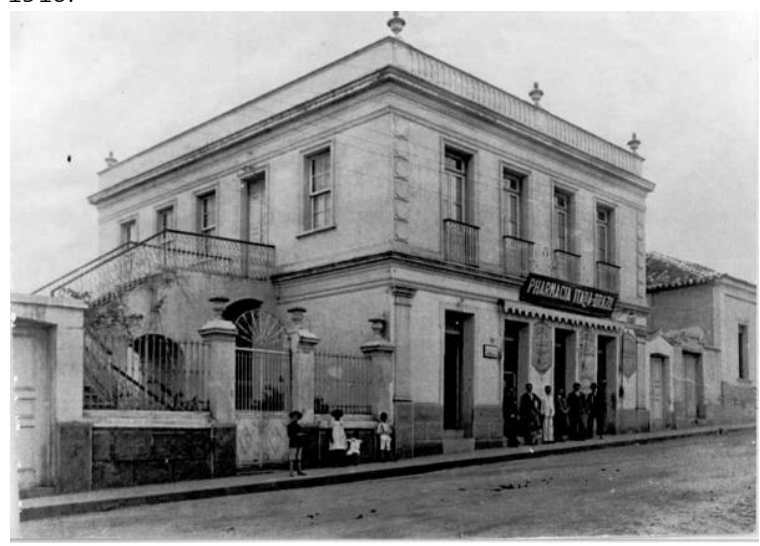

Fonte: Arquivo do Centro da Memória Rio-Pardense Rodolpho José Del Guerra. Fotografia de Innocencio Vilhegas.
Figura 115: Rua Francisquinho Dias na década de 1910.

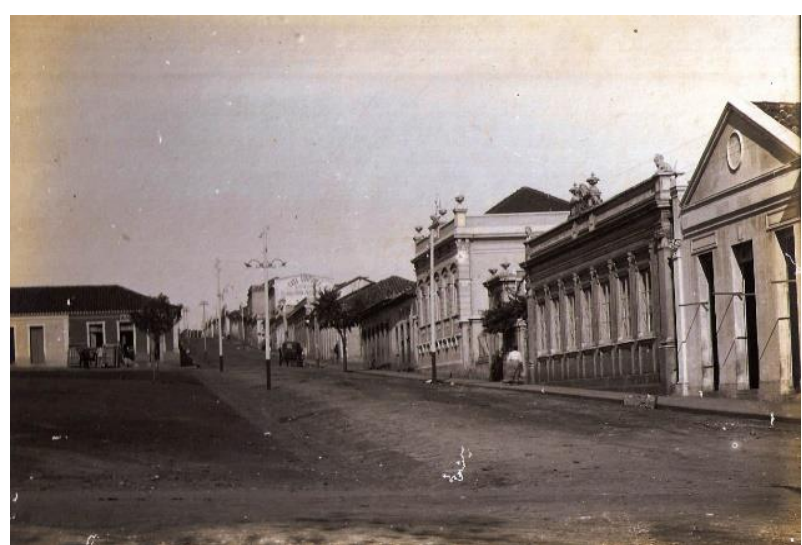

Fonte: Arquivo do Centro da Memória Rio-Pardense Rodolpho José Del Guerra. Fotografia de Innocencio Vilhegas.

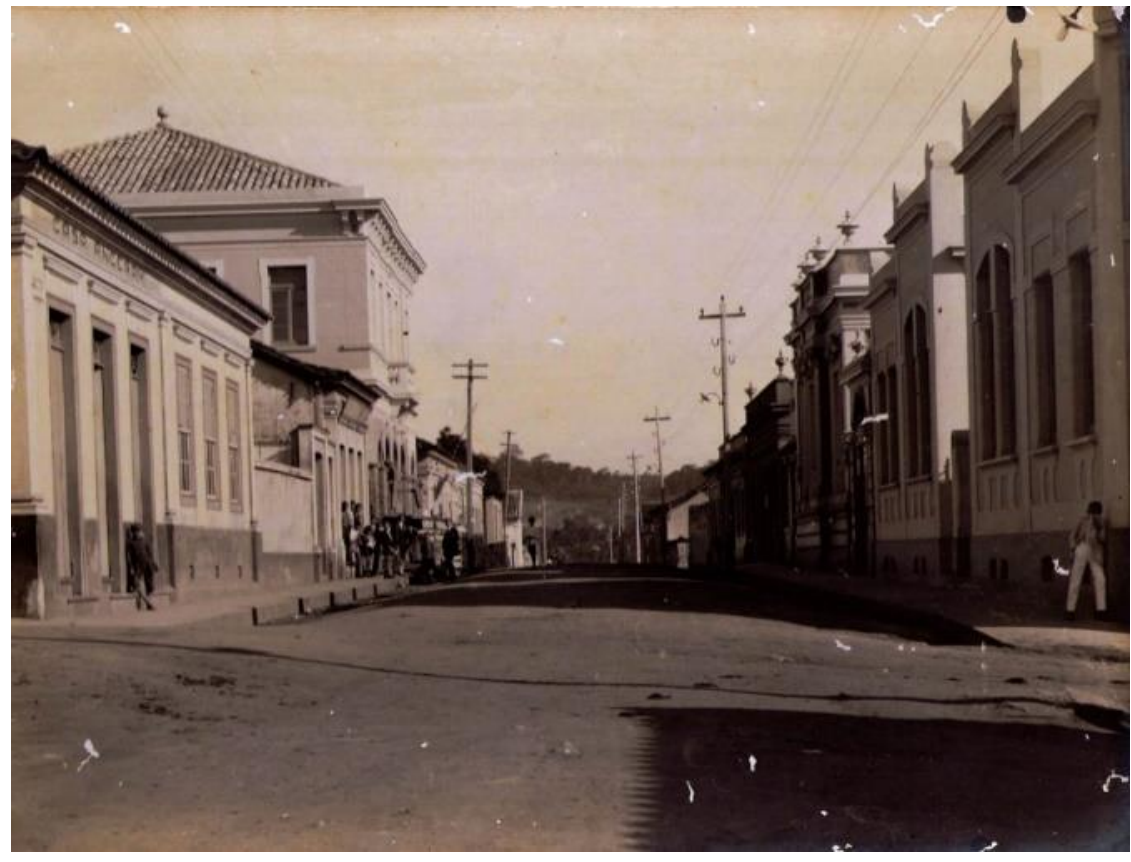

Figura 116: Rua Marechal Deodoro na década de 1910.

Fonte: Arquivo do Centro da Memória Rio-Pardense Rodolpho José Del Guerra. Fotografia de Innocencio Vilhegas.

Todos os aspectos levantados até aqui apresentam o que foi a cidade de São José do Rio Pardo na passagem do século XIX e primeiros anos do século XX. Dentro do recorte temporal desse capítulo, a atuação da família Dias à frente do movimento político e econômico se sobressaiu durante todo o período, causando consequências diretas no desenvolvimento urbano e na produção arquitetônica. Sendo assim, e entendendo a relevância dessa discussão para esta dissertação, destacamos a seguir o contexto de ação desses agentes. 


\section{A manutenção do poder e a hegemonia econômica}

No contexto político, a situação do início do século XX foi francamente dominada pelo partido republicano, tendo à frente membros da família Dias. Conforme dissertou Cassassola (2009), com base na discussão sobre a divisão oligárquica proposta por Frank (2001), os Dias compunham uma família de elite extensa que pode ser classificada como transitória já que se desenvolveram no final do Império e nas primeiras décadas da República, acompanhando o próspero crescimento que a economia exportadora estava apresentando com a cultura cafeeira. Nesse sentido, Levi (1977) ao tratar da flexibilização, como habilidade de algumas famílias tradicionais na tentativa de se adaptarem às condições em curso, visando hegemonia econômica e política, destacou o papel da família Prado em São Paulo. Segundo ele (LEVI, 1977), essa família se arranjou para superar a estrutura vigente, buscando "maior interação à cultura europeia, como também a adoção de valores capitalistas (que salientavam o investimento e a acumulação de capital, o oportunismo e a inovação)" e ainda através de velhos e novos laços familiares, meios que facultaram a modernização do grupo frente às inovações socioeconômicas, políticas e culturais de seu tempo (CASSASSOLA, 2009, p. 71). Em sentido semelhante, a família Dias que possuía origem portuguesa, veio para o Brasil motivada pelo sonho do enriquecimento rápido através da mineração do ouro, se instalando inicialmente na região de Caldas, sul de Minas Gerais. Com o declínio da atividade aurífera, os Dias, já possuidores de vastas extensões de terras, adquiriram uma grande gleba em São José do Rio Pardo, formando a fazenda Tubaca onde passaram a se dedicar quase que exclusivamente à lavoura cafeeira em ascensão.

A hegemonia política dos Dias nessa cidade iniciou com o patriarca Vicente Alves de Araujo Dias na eleição da primeira Câmara Municipal rio-pardense em 1886, preparando o caminho seguido pelos seus filhos Honório, Vicente e Alípio. E como apontou Cassassola (2009), a hegemonia econômica da segunda geração dos Dias em São José do Rio Pardo foi mantida dada a antecipação da transmissão material (herança) ainda em vida que propiciou, além da condição financeira, a manutenção do poder.

A diversificação de empreendimentos da família abarcava propriedades em diferentes regiões de São Paulo e Minas Gerais; casas comissárias ${ }^{141}$; mina de exploração de zircônio em Águas da Prata-SP ${ }^{142}$; investimentos no setor de serviços urbanos, sobretudo com Vicente Dias Júnior ${ }^{143}$ que investiu na eletricidade e telefonia. Vicente Dias Júnior ainda firmou sociedade comercial com a empresa Cássio Muniz \& Co ${ }^{144}$ de São Paulo que tinha como negócio a importação geral e a venda por atacado de materiais para a construção civil.

\footnotetext{
${ }^{141}$ Ver nota 114 na página 116.

${ }^{142}$ A exploração da mina de zircônio pertencia à Honório Luiz Dias, irmão de Vicente Dias Júnior e filho de Vicente Alves de Araujo Dias.

${ }^{143}$ Vicente, filho de Vicente Alves de Araujo Dias, também era proprietário da Companhia Paulista de Energia Elétrica (C.P.E.E.) no âmbito local.

${ }^{144}$ A sociedade era formada por Cássio Muniz de Souza, Vicente Dias Júnior e seus dois cunhados, Horácio Rodrigues e Mário Rodrigues, filhos de Antonio Candido Rodrigues e irmãos de sua esposa Alice.
} 
Mas parte dos investimentos dos Dias ocorreu quando em 1906 o governo do Estado de São Paulo, a partir de um projeto de lei do deputado paulista Antonio Candido Rodrigues ${ }^{145}$, autorizou a criação dos Bancos de Custeio Rural que teria a função de promover e valorizar o café através do crédito agrícola. Em 1907 foi constituída na cidade rio-pardense uma sociedade anônima, com a denominação de "Banco de Custeio Rural de São José do Rio Pardo". Entre os 79 sócios estavam Antonio Candido Rodrigues e outros oito membros da família Dias.

Antenado com os acontecimentos mundiais, Vicente e seus irmãos Honório ${ }^{146}$ e Alípio se empenharam em visitar e participar de exposições e feiras mundiais como pressuposto para avaliar a absorção do mercado aos produtos brasileiros. Foi assim na Feira Mundial de St. Louis, também conhecida como Exposição Universal que ocorreu nos Estados Unidos em 1904. Exaltado pelo Correio Paulistano e republicado no jornal O Rio Pardo de 24 de julho de 1904, a participação dos brasileiros foi reverenciada assim como o sucesso dos produtos expostos. No dia 31 de outubro de 1904 o jornal O Rio Pardo voltou a exaltar a participação dos irmãos Dias e suas conquistas

Entre os expositores que neste certamen obtiveram premios figuram os nossos amigos, lavradores aqui residentes, srs. Honório Luiz Dias e Vicente Dias Júnior, cujos productos expostos foram premiados com medalhas de bronze. Alipio Luiz Dias, premiado com medalha de prata. Também a firma Dias, Irmão \& Comp., de Santos, que é constituída pela mesma família Dias desta cidade, obteve o grande premio, figurando, portanto, entre os melhores expositores. (EXPOSIÇÃO..., 1904, p. 01).

O poder econômico e político exercido em São José do Rio Pardo era tal que seu regresso após a viagem ao estrangeiro era motivo de comemoração, como reportado pelo jornal abaixo:

\footnotetext{
Regressou hontem de sua excursão pelo estrangeiro o estimado cidadão tenente coronel Vicente Dias Júnior, presidente do directório republicano e membro da importante família Dias. Aguardaram sua chegada em Casa Branca alguns de seus dedicados amigos, que desta cidade foram em trem especial acompanhados pela corporação musical Riopardense. Alli foi servido ao illustre conterraneo uma taça de champanha, sendo o mesmo brindado pelo $\mathrm{Dr}$. Jovino de Sylos, em nome dos seus admiradores.

As 2 horas, ao chegar o especial, na estação desta cidade tocou a corporação Giuseppe Garibaldi, vendo-se a gare, que se achava bellamente adornada de folhagens e bandeiras, repleta de povo que saudou o tenente coronel Vicente Dias Júnior.

$[\ldots]$

Em Engenheiro Gomide, até aonde a comissão acompanhou o nosso illustre conterraneo, fo offerecido pelo mesmo uma taça de champanha aos manifestantes.

O sr. José Honorio de Silos dirigiu uma breve saudação ao manifestado, em nome de seus amigos desta cidade. (REGRESSO, 1905b, p. 02)
}

Nesse sentido, ao falarmos de poder a referência fundamental é Michel Foucault (1984). Segundo esse autor (FOUCAULT, 1984), poder não é algo físico, portanto o que se exerce são práticas ou relações de poder que funcionam como uma máquina social que se dissemina por toda uma estrutura. É algo que "se exerce, só existe em ação, como também da afirmação que o poder não é principalmente manutenção e

\footnotetext{
${ }^{145}$ Persuasivo na defesa da valorização do café, Antonio Candido Rodrigues, como delegado do governo paulista, participou da reunião de assinatura do Convênio de Taubaté (TAUNAY, 1941) em 1906, que deu início a uma série de medidas em favor da cafeicultura diante da baixa de preços e estimativa de superçafra. Ver mais sobre esse assunto em Furtado (1984).

${ }^{146}$ Para saber mais sobre Honório, ver nota 114 na página 119

162
} 
reprodução das relações econômicas, mas acima de tudo uma relação de força" (FOUCAULT, 1984, p. 175). Nesse sentido, e como destacou Cassassola (2009, p. 127), Vicente ao partilhar de "antigas práticas como o personalismo, o clientelismo, o empreguismo, entre outros", colocou em prática a relação de poder estabelecida na estrutura vigente, compartilhada pela sua família que desempenhava um corporativismo político, representado pelos seus irmãos, cunhado e sobrinho, constituindo-se uma própria oligarquia. Além de que, os laços de parentesco estabelecido entre Vicente que se casou com a filha do Dr. Antonio Candido Rodrigues facultou a expansão dessa oligarquia a nível estadual.

Como vimos anteriormente, Candido Rodrigues exerceu importantes cargos no governo estadual, federal e também municipal como intendente e chefe do Diretório Republicano rio-pardense. A inter-relação entre Vicente e Candido Rodrigues tinha como base o apoio político e financeiro de um lado e de outro a representação dos interesses. Trechos de cartas trocadas entre Vicente Dias Júnior, Candido Rodrigues, Francisco Glicério, Fernando Prestes, Campos Salles, entre outros, evidenciam a estreita relação entre a oligarquia Dias e a altas esferas de poder. Em um dos trechos Candido Rodrigues escreveu:

Vou hoje pedir sementes de alfafa e aveia para você, Alípio e Honório Dias. O presidente do Estado mostra-se interessado em ver amostra do arroz do Alípio, sobre quem eu conversei com ele. Faça com que ele [Alípio] mande-me um pouco para eu mostrar a ele [presidente do Estado] e ao secretário da Agricultura (RODRIGUES apud CASSASSOLA, 2009, p. 131).

As vantagens conseguidas a favor, sobretudo de Vicente e sua parentela, e as combinações e arranjos informais constituídos dentro do sistema de poder para alcançar os objetivos pretendidos eram parte do compromisso firmado em proveitos das trocas de favores.

\section{Meu Vicentinho}

$[\ldots]$

Recebi hoje as duas cartas juntas que me satisfizeram bastante, porque antevejo nossa vitória no pleito municipal próximo. Como minha presença absolutamente nada adiantará para a escolha dos candidatos a juízes de paz e vereadores, porquanto não conheço o eleitorado; peço-te que promovas juntamente com o Damaso e Pacheco, membros do antigo diretório [...] e outros, uma reunião com o Jovino e outros do diretório hermista para acordarem na chapa que devemos sufragar e que submeteremos à aprovação prévia do eleitorado, que só então convocaremos.

[...]

Não há tempo a perder, mãos a obra meu filho. (RODRIGUES apud CASSASSOLA, 2009, p. 132).

Não há dúvidas de que Vicente era um articulador político junto como seu sogro, cunhado, sobrinho e irmãos que participaram ativamente do governo nacional, estadual e local, e representava os interesses do grupo. Dentre esses, com exceção de Antonio Candido Rodrigues que teve amplo destaque na política nacional e estadual, Alípio foi quem mais ganhou notoriedade no exercício de cargos públicos local, sendo vereador, vice-presidente e presidente da câmara rio-pardense entre os anos de 1896 a 1907.

É fato que na República a elite cafeeira se manteve no poder. E no caso dos Dias de São José do Rio Pardo que além de possuíam interesses semelhantes às pessoas que ocupavam cargos no governo estadual, eram cafeicultores, industriais, comerciantes e políticos, o que contribuía sobremaneira para o fortalecimento de sua base de apoio em âmbito local. Aos representantes das novas relações de poder nos municípios era 
confiado o aliciamento eleitoral da política coronelista dando garantia de votos para a salvaguarda do sistema (FAORO, 2012). De acordo com Faoro (2012, p. 497), o coronelismo se afirmava da troca de vantagens, cujas relações pessoais e regimes de bens era determinado previamente entre o chefe político local e o governo estadual na constituição e manutenção das oligarquias. Este fato é facilmente evidenciado no caso rio-pardense: no período compreendido por este capítulo (1903 a 1917), os principais cargos intendente/prefeito e presidente da Câmara Municipal - foram todos chefiados por coronéis e capitães republicanos tradicionais ou adesistas, apadrinhados por Antonio Candido Rodrigues e a parentela dos Dias. Ainda segundo Faoro (2012), o fenômeno coronelista não era algo novo e sim um elemento em processo de construção:

sua coloração estadualista e sua emancipação no agrarismo republicano, mais liberto das peias e das dependências econômicas do patrimonialismo central do Império. O coronel recebe seu nome da Guarda Nacional, cujo chefe, do regimento municipal, investia-se daquele posto, devendo a nomeação recair sobre pessoa socialmente qualificada, em regra detentora de riqueza, à medida que se acentua o teor de classe da sociedade. Ao lado do coronel legalmente sagrado prosperou o "coronel tradicional”, também chefe político e também senhor dos meios capazes de sustentar o estilo de vida de sua posição. (FAORO, 2012, p. 541 542).

Conforme Leal (1976), a imagem do coronel refletia o estilo social de vida que tinha a incumbência burocrática e política, sobretudo na área urbana.

Homens ricos, ostentando vaidosamente os seus bens de fortuna, gastando os rendimentos em diversões lícitas e ilícitas - foram tais 'coronéis' os que deram ensejo ao significado especial que tão elevado posto militar assumiu, designando demopsicologicamente 'o indivíduo que paga as despesas'. E, assim, penetrou o vocábulo 'coronelismo' na evolução político-social do nosso país, particularmente na atividade partidária dos municípios brasileiros. (LEAL, 1976, p. 21) $)^{147}$.

A teia de reações estabelecida pela família Dias na política e economia assegurou a sua hegemonia em São José do Rio Pardo, e como vimos, as ações tomadas trouxeram consequências para o desenvolvimento urbano. Acreditamos que, tão importante quanto as análises até então realizadas, é compreender quem foram e de que modo atuaram os agentes da construção civil nessa cidade. Desse modo, consideramos indispensável analisar a atuação de carpinteiros, pintores, marceneiros, pedreiros, serventes, mestre de obras, empreiteiros e engenheiros responsáveis por difundir a arquitetura produzida no início do século XX, assunto que será discutido a seguir.

\footnotetext{
147 Segundo o biografia publicada pelo site do Instituto Histórico e Geográfico Brasileiro, Basílio de Magalhães atuou como professor catedrático de História Geral e do Brasil da Escola Normal (depois Instituto de Educação do Rio de Janeiro) e livre-docente da Escola Nacional de Belas Artes. Na política, Magalhães foi senador estadual em Minas Gerais e deputado federal entre os anos de 1922 e 1928. Foi um importante autor de obras que se situam principalmente nas temática da literatura, folclore, política e história. Nas obras que sitamos, Basílio de Magalhães foi citado em Vitor Nunes Leal, op. cit., p. 21 e transcrito em Raymundo Faoro, op.cit., p. 541-542. Para saber mais sobre Magalhães, ver https://ihgb.org.br/perfil/userprofile/bdemagalhaes.html, acesso 04.2019.
} 


\subsection{Agentes da construção civil rio-pardense: apagamentos e esquecimentos}

Em consonância com os estudos realizados por Pareto Júnior sobre os profissionais da construção civil de São Paulo entre 1893 e 1933 (2011), encontramos semelhanças quando o mesmo diz que ao conversar com especialistas ou leigos sobre a construção urbana e arquitetônica da cidade de São Paulo no fim do século XIX e início do XX, prevalece a figura do mestre de obra italiano sem formação acadêmica. Assim como ocorreu em São Paulo, atestado também por autores como Emma Debenedetti e Anita Salmoni no livro “Arquitetura Italiana em São Paulo" (1981) e Yvoty Macambira no livro "Os mestres da fachada" (1985) e no artigo "Os italianos e a arquitetura paulistana" (1995), em São José do Rio Pardo o predomínio na construção civil foi dos italianos e seus descendentes ${ }^{148}$. Constatação que podemos fazer após levantar - em livros de impostos, jornais, almanaques e na produção historiográfica de autores locais - quem foram as pessoas que atuaram em São José do Rio Pardo entre o final do século XIX e primeira década do século XX, as quais foram discriminadas na Tabela 5, página 172. Mas é necessário enfatizar que apesar dessa dominância, havia um hibridismo cultural e do "saber fazer" entre as pessoas que se estabeleciam e o que já existia nessa cidade, constituindo um processo inacabado que em termos materiais vai resultar na alteração da paisagem.

Como dito, não por acaso, os nomes que predominaram são de origem italiana. Certamente isso se deve ao conhecimento e qualidades técnicas e artísticas construtivas, contribuindo, entre outras coisas, na substituição da tradicional taipa pelo uso do tijolo de barro cozido em um momento de crescimento de cidades como São Paulo ${ }^{149}$ (ALAMBERT, 1993; MACAMBIRA, 1995), São Carlos (BORTOLUCCl, 1991) e Campinas (FRANCISCO, 2013). Foi fazendo uso deste material que platibandas foram elevadas para esconder os telhados de duas águas, que peças decorativas foram aplicadas mais facilmente às fachadas e que edifícios foram construídos mais rapidamente para servir às diferentes classes sociais, desde vilas operárias e casas de aluguel até residências para os enriquecidos da Avenida Paulista, mudando o aspecto visual da cidade de São Paulo, e também de tantas outras do interior paulista, dentre elas São José do Rio Pardo.

Mas, apesar da legitimidade da presença italiana na arquitetura, Macambira (1995, p. 57) destaca que invariavelmente o que se reconhece é o "trabalho braçal do imigrante em geral e as habilidades do italiano em particular". Com raras exceções, a falta de aprofundamento por parte da historiografia sobre esse tema pode ser justificada pelo interesse nos estudos da arquitetura oficial e da classe dominante, mesmo que a atividade dos italianos tenha sido comprovadamente atuante também na construção de edifícios de grande porte para os mais abastados. E, há ainda o preconceito infundado acerca das intenções plásticas que foram mais utilizadas justamente no período em que predominou a atuação italiana, sobretudo quando se trata do Ecletismo. Desqualificado de antemão e taxado de não possuir valor estético, arquitetônico e

\footnotetext{
148 Os nomes foram conferidos com as listas de registro de imigrantes italianos que se encontram no Centro Cultural ítalo Brasileiro.

${ }^{149}$ Alambert (1993) afirma que antes da entrada maciça de italianos atuantes na atividade construtiva de São Paulo havia os germânicos, os quais foram os responsáveis pela difusão da alvenaria de tijolos na cidade de São Paulo.
} 
historiográfico, o ecletismo foi rotulado de arquitetura estrangeira, que utilizou de forma indiscriminada todo e qualquer tipo de ornamento oferecido pelo comércio e copiado livremente dos catálogos impressos, das publicações periódicas de arquitetura e decoração e das imagens e ilustrações que chegavam da Europa. Considerado inadequado pela historiografia brasileira esforçada em criar uma "cultura 'autêntica', nacional e moderna" (PUPPI, 1998, p. 176), o ecletismo foi desprestigiado por ser o retrato de uma arquitetura produzida em um momento em que os profissionais reproduziam e criavam de acordo com os interesses dos clientes e utilizando o que estava disponível no mercado.

Esses fatores associados foram preponderantes para que ocorresse o desconhecimento, ou mesmo pelo apagamento intencional da memória e da atuação individual desses profissionais não diplomados, não obstante, relembrados como criação coletiva pela historiografia da arquitetura brasileira. Dessa maneira, e dentro de uma nova atitude de pesquisa sobre São José do Rio Pardo, nos valemos da moradia urbana e de quem foram as pessoas responsáveis por essa produção. Embora não sejam pessoas tão proeminentes, nos interessa saber todos os envolvidos, partilhando similaridades com os estudos realizados por Pareto Júnior (2011, 2016) em São Paulo e por Rita Francisco (2013) em Campinas, ambos evidenciaram a atuação de construtores não diplomados.

É certo destacar que a atuação dos artífices e profissionais da construção civil estava submetida a mecanismos de controle do poder público. No âmbito municipal, a publicação do Código de Posturas de 1887 outorgou toda a responsabilidade construtiva ao proprietário sem exigir quaisquer atribuições do construtor. Somente no início do século XX, a Câmara Municipal desenvolveu mecanismos mais abrangentes através da publicação do Código de 1903 que incluiu alguns artigos em que as obrigações passaram a ser igualmente divididas entre proprietário e construtor, como o que se segue:

\footnotetext{
Art. 25 - Si durante a construção ou reconstrucção de qualquer obra licenciada, verificar-se infracção por parte do proprietário ou constructor, de qualquer das disposições deste Codigo, será a obra imediatamente embargada pelo fiscal ou qualquer agente da Municipalidade, que, com duas testemunhas, intimará o propretario ou constructor a não proseguir na obra.

$1^{\circ}$. Proseguindo o proprietario ou constructor na obra, depois de embargada, o Intendente Municipal requisitará auxilio da autoridade policial afim de tornar effectivo o embargo.

$2^{\circ}$. O embargo uma vez feito só será suspenso mediante requerimento do proprietario ou constructor, dirigido ao Intendente Municipal, e no qual se comprometta a fazer as alterações ou demolições necessárias na obra e proseguil-a conforme preceitúa este Codigo. (CÓDIGO DE POSTURAS, 1903, p. 06-43).
}

Conforme Pareto Júnior (2011), a consolidação de uma burocracia mais ampla ocorreu em paralelo à mudança do regime político que inclinou para um maior controle dos quadros técnicos e dos espaços urbanos. Nesse sentido, o Código rio-pardense de 1903 exigiu em seu artigo 18 que o proprietário obtivesse a permissão de licença para construir ou reformar, mediante requerimento com informações do local e indicação da rua e número, a natureza e o destino da obra, planta do terreno e de localização do edifício com as elevações assinaladas, a disposição dos encanamentos para água e o plano de execução. Todavia, a atribuição de licença era feita apenas ao proprietário ou seu procurador, eximindo o profissional da construção civil de qualquer envolvimento direto nesse acordo. Reforçando a exigência do Código, o 
Intendente Municipal Antônio Martins de Oliveira lançou vários editais chamando a atenção para aplicação e fiscalização das edificações e obras, e em caso de irregularidades o construtor e o proprietário seriam penalizados $^{150}$.

As fotografias de época e as publicações nos jornais, como a que se segue abaixo, nos dão pistas de que as normas estavam sendo aplicadas.

Le costruzioni della città, tra le quali si distinguono molte elegante palazzine, sono di architettura moderna, ed in massima parte molto spaziose ed igieniche. [...] L'aspetto della città è quanto mai simpatico, buona l'illuminazione elettrica, sano il clima, abbondante l'acqua, le vie diritte, larghe, ombreggiato da alberi ben conservato. (IL BRASILE E GLI ITALIANI, 1906, p. 693-697).

Averiguamos a inexistência de impedimentos severos à atuação dos artífices e profissionais da construção civil, e nesse sentido consideramos a possibilidade de que a falta de mão de obra e material construtivo visto nos constantes anúncios (Figura 117) foram fatores fundamentais para esse acontecimento. Situação, inclusive, que levou um grupo de rio-pardenses a cogitar a formação de uma empresa destinada a prestar serviços na área da edificação, empreitada seguida também por alguns italianos como veremos no subitem que trata da atuação e produção de Paschoal Artese.
Figura 117: Anúncio sobre a falta de pedreiros para finalização do serviço de esgoto.

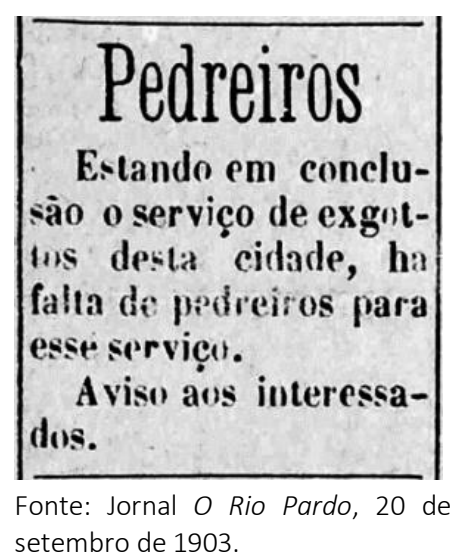

Infelizmente parcas são as informações encontradas na produção acadêmica ou nos historiadores locais sobre os artífices e profissionais que atuaram na construção civil em São José do Rio Pardo no período de 1903 a 1917. E, talvez, se tivéssemos realizado nosso estudo há alguns anos, mais sucesso nesse sentido haveríamos de ter obtido, uma vez que boa parte dos documentos que nos interessariam, pertencentes a arquivos públicos locais, foram recentemente descartados. Mesmo assim, por acreditar que saber mais a respeito dessas pessoas seria fundamental para compreender o panorama da construção civil rio-pardense, buscamos outros meios de investigação para obtenção de dados, fossem eles pedreiros, serventes, marceneiros, carpinteiros, pintores, construtores, empreiteiros, mestre de obras, engenheiros ou arquitetos, todos praticamente mantidos até hoje no anonimato.

O reduzido número de anúncios encontrados e a brevidade das descrições, ainda que dirimindo algumas de nossas dúvidas, são registros parcos e vagos. Apesar disso, acreditamos serem fundamentais para complementar, ou mesmo preencher essa lacuna de informações, e também por acreditarmos que as

\footnotetext{
${ }^{150}$ Nos anos que se seguiram à promulgação do Código de Postura de 1903 foram publicados vários editais reforçando a aplicação dessa lei e chamando a atenção para as penalidades decorrentes do não atendimento, como divulgado no jornal 0 Rio Pardo do dia 22 de janeiro de 1905 ao tratar da necessidade de licença para construir e reformar. Ou ainda o comunicado aos proprietários de edificações da Rua Américo de Campos que teriam um prazo de 60 dias para regularizarem suas propriedades de acordo com a artigo $3^{\circ}$ do Código de Posturas (O RIO PARDO, 20/08/1908).
} 
pessoas que faziam anúncios nos jornais certamente estavam em acordo com as regulamentações municipais para exercer a profissão. De qualquer modo, demos visibilidade a todos os nomes encontrados a partir do ano e da profissão exercida ${ }^{151}$, conforme discriminando na Tabela 5, página 173. Com isso, abrimos outras possibilidades de pesquisas que podem ser investigadas aprofundando mais o aspecto dos agentes envolvidos com a construção civil da cidade.

Devido a inexistência de livros de registro de profissionais e de projetos arquivados na Secretaria de Obras desse período, recorremos a qualquer outro tipo de documentação oficial como os livros de impostos que mencionassem os nomes, com ou sem formação acadêmica. Foi assim que conseguimos saber mais sobre quem foram essas pessoas, como é o caso dos pedreiros João DeLuca, Francisco de Tal, Joaquim Rodrigues Carreira, Victorino da Rocha Carreira, Martiniano de Tal, Joaquim (conhecido por Guita), Benedicto, Nicolas Deluca, Antonio Craceia, José Giglio, Raphael Picelrielo, Francisco Leonardo, José de Souza, José Quercia, José Gomes da Silva, Manoel Rolani. Todos esses nomes foram encontrados nos Livros de Impostos de 1887 a 1896. Já Felício Semeoni e Francisco Riga foram citados por Del Guerra (2007) ao tratar da construção da capela de São Roque. Outras publicações particulares e não oficiais como almanaques, jornais e periódicos foram consultadas, ampliando o quadro de profissionais e artífices que atuaram entre 1903 e 1917, como é o caso de Miguel Precioso que consta no balancete de obra realizada no Cemitério Municipal e publicado no jornal O Rio Pardo do dia 13 de dezembro de 1903. Carlos Piquetti também foi mencionado no jornal O Rio Pardo do dia 19 de fevereiro de 1905 quando relatado a reforma do palacete de Francisco Soares de Camargo. E os italianos Sperandio Foiadelli, Angelo Acquarolí, Giacomo Marzocchi, Abramo Savoldi, Vicente Sistito, Salvador Gulli e Francisco Maida foram os pedreiros que trabalharam na construção do hospital Santa Casa (SANTA CASA ..., 1913). Foi ainda nessa obra que Domingos Fontebasso, Baptista Bassini, Sebastião de Oliveira, Francisco C. Martins, José Eugênio, Eugênio Presentino, Alberto Isberti, José Galdino, Domingos Onorio, Levindo de Mello, Antonio Siverino trabalharam como serventes de pedreiro (JORNAL O RIO PARDO, 24/04/1913). Já José Ortega, Pedro Januário, Luiz Bonet, Jonas Nani e Antônio de Mello auxiliaram a execução das obras da festa de Nossa Senhor da Conceição Aparecida realizada em 1906 em benefício do hospital Santa Casa (JORNAL O RIO PARDO, 23/12/1906).

Pudemos ainda encontrar informações sobre a atuação de marceneiros nos livros de Impostos do final do século XIX, como é o caso dos italianos Luís Rich, Paschoal Cerávolo, Domingos Cerávolo e Miguel Cerávolo. José Vano foi outro marceneiro que atuou em São José do Rio Pardo. Sabemos através de Del Guerra (2007) que ele trabalhou na construção da capela de São Roque em 1899. Como pudemos constatar nos inúmeros anúncios dos jornais, Paschoal, Domingos e Miguel Cerávolo pareciam dominar essa profissão em São José do Rio Pardo na passagem do século XIX para o século XX. Eram proprietários de oficinas, ainda que pequenas fábricas artesanais, e ofereciam a execução de qualquer mobília a partir de mostruários e catálogos que podiam ser reproduzidos de forma indiscriminada, e de acordo com o gosto do cliente

\footnotetext{
${ }^{151}$ É importante ressaltar que todas as pessoas mencionadas foram encontradas nos livros de impostos, nas reportagens e anúncios de jornais ou na produção de historiadores locais, e por vezes um mesmo nome foi escrito com grafia variada. 
(Figura 118). Além de marceneiros, os Cerávolos ofereciam serviços de carpintaria como o Osorio Soares, responsável pela estrutura da cobertura do hospital Santa Casa (O RIO PARDO, 23/12/1906).

Figura 118: Anúncio da Marcenaria e Carpintaria Paulista de Miguel Cerávolo.

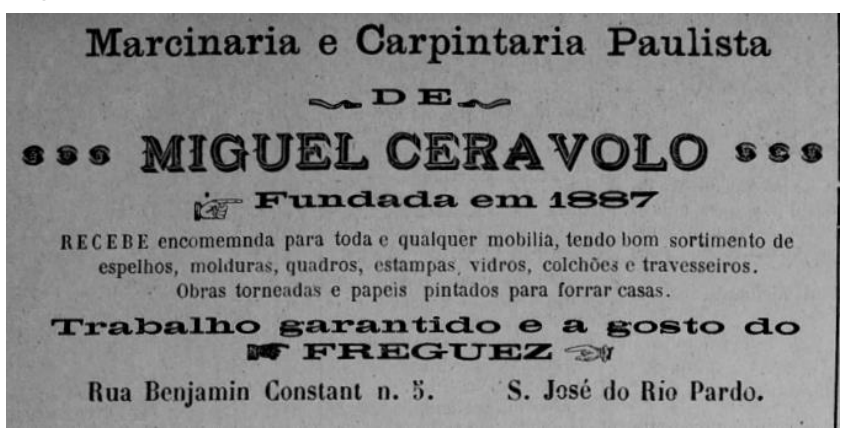

Fonte: Jornal O Rio Pardo, 16 de junho de 1902.

Alfredo Mariani, Antonio Maria da Cunha, Fortunato Paglia, José Lacorazza e Paschoal Artese aparecem na lista de Lançamento do Imposto de Indústrias e Profissões do exercício de 1908 (O RIO PARDO, 26/01/1908). No Lançamento de 1911 outros nomes passaram a constar, além dos mencionados anteriormente, Antonio Cautela e Luiz Có. Entre eles estava também o italiano Salvador Artese que após retornar do Rio de Janeiro reabriu a Marcenaria Artística com exposição permanente de mobílias de fabricação própria e de importação. Os trabalhos oferecidos eram a produção de mobília completa, trabalhos de entalhe, altares, púlpitos, e também serviços de carpintaria com a execução de esquadrias e a construção de casas. Chama atenção ainda para a realização de plantas de edificações. De acordo com os anúncios (Figura 119), a especialidade de Salvador Artese eram os trabalhos em estilo art nouveau também chamado por ele de "Arte Nova", o qual Ihe rendeu um contrato de fornecimento de móveis de luxo para a loja de Domingos Innechi e Filho, de Ribeirão Preto (Figura 120).

Figura 119: Anúncio da Marcenaria Artística de Salvador Artese.

\section{MARGINERIA ARTISTICA}

\section{SALVADOR ARTESE}

Premiado na Exposipaso Artistica da Italue

Nesta officina apromtam se com a maxima perfeiçāo, arte • gosto todos os trabalhos como sejam:

Mobilia completa-Trabalho de entalhe-Altares-Pulpitos

Especialidade em trabalhos ,Art-Noveau, Exposição permanente com deposito de mobilias e Camas de Ferro da fabrica Paulistana * Ribeirāo Preto.

Alguns prefos de mobilias da $7 /$ arcenaria Artistica Lasatorios desde $25 \$ 000$ até $200 \$ 000$. - Cresdo Modo desde $20 \$ 000$ até $50 \$ 000$

Fabrica de Colchões e Travesseiros--Secção de Carpinteria Executa-se qualquer trabalho de esquadro, como encarrega-se de cons truç̧ōes de easas, etc.-Tiram-se plantas para construeçōes

Fonte: Jornal O Rio Pardo, 08 de fevereiro de 1912.
Figura 120: Anúncio de contrato firmado entre Domingos Innechi e Filhos e a Marcenaria Artística de Salvador Artese.

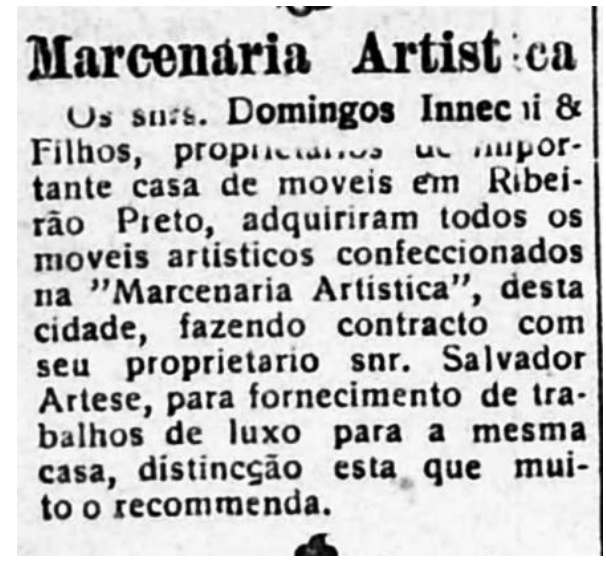

Fonte: Jornal O Rio Pardo, 22 de janeiro de 1911. 
João Batista Blandim, José Francilino, José Barbosa, Herculano de Tal, Francisco Ribeiro, Antonio José dos Santos Junior, Mizael Costa e Silva, Antonio Cardozo dos Santos, Jacintho Jose de Oliveira, Manoel Serafim dos Anjos, Zeferino Gomes de Avelino, Herculano Alves de Moura, Joaquim Antonio da Silva, Manoel Marques e José Candido Lourenço eram os carpinteiros que pagavam imposto no final do século XX. Já Angelo Colli apareceu na lista do Imposto de Indústrias e Profissões do exercício de 1908 (O RIO PARDO, 26/01/1908).

Na pintura, o argentino Eduardo Giudice apareceu como responsável pelo interior de prédios públicos e privados, como a primeira Matriz. Segundo Del Guerra (2001), o motivo do estabelecimento de Giudice em São José do Rio Pardo foi a pintura do teto dessa igreja, após ter realizado trabalho semelhante em Pirapora. Entre os muitos serviços que realizou em São José do Rio Pardo, estão as pinturas do Theatro São José, o Pavilhão XV de Novembro e o prédio da "Sociedade Italiana XX de Setembre" (DEL GUERRA, 2001; O RIO PARDO, 16/07/1905 e 01/11/1908). Além de Giudice, outros nomes como Antônio Joaquim Teixeira e Antonio Zeferino Gonçalves constam como pintores nos Livros de Impostos de 1887 a 1896.

Poucos foram os engenheiros que atuaram em São José do Rio Pardo entre o final do século XIX e início do século XX. Sabemos que o engenheiro civil João Thimóteo Pereira da Rosa foi o autor dos projetos das redes de água e esgoto. E através dos jornais de circulação local, pudemos saber um pouco mais sobre sua formação em engenharia civil pela Escola Polytechnica do Rio de Janeiro (Figura 121), e a parceria feita com Francisco Constantino e os serviços disponibilizados: medições de áreas, levantamentos de plantas e divisões, projeto para construção rural e civil em geral, cálculo de movimento de terra e cubações, traçado de estradas, orçamentos, etc. (Figura 122). Aristides Dias Pinheiro foi outro engenheiro civil formado pela Escola Polytechnica de São Paulo que atuou em São José do Rio Pardo (O RIO PARDO, 05 de julho de 1908), no entanto não encontramos registros de obras projetadas ou executadas por ele.

Figura 121: Anúncio do escritório de engenharia de João Timotheo P. da Rosa.

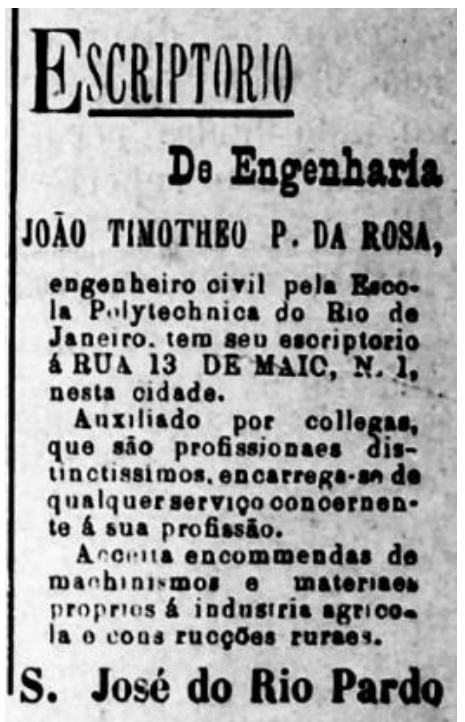

Fonte: Jornal O Rio Pardo, 21 de maio de 1899 e 27 de fevereiro de 1900.
Figura 122: Anúncio do escritório de engenharia de João Timotheo P. da Rosa e Francisco Constantino.

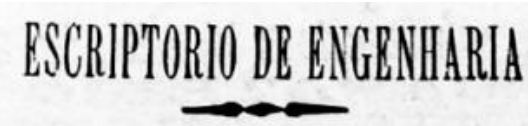

Os engenheiros Timotheo da Roja Francisco Costantino encarregamese de : Serviços lopographicos, como sejam : mediçסes de areas, levantamentos de plan. tas a divisðes, quer amigaveis, quer judisıaeo; projectos para construç̧̄es raraes $\theta$ civis em geral ; calculos de movimentos de terras a cubaçōes em goral, Iraçados do estradas. orçamentos, etc.

Em sea escriptorio, á rua 13 de Maio n. 1. podim ser procurados a qualquer bo:a. Acceitam Irabalhos em toda a zona servida pela linha Mogyaba.

Disporem de pessual apto para qualquer servige profissional.

Fonte: Jornal O Rio Pardo, 21 de maio de 1899 e 27 de fevereiro de 1900 
Os italianos Francisco Rigo, Felício Calvite, Luigi Prezzia, Giovanni Delucca, Giuseppe Quercia, Nicola Delucca foram construtores e empreiteiros que atuaram em São José do Rio Pardo no final do século XIX, segundo o registro nos Livros de Impostos de 1887 a 1896 . Felicio Semione também foi um empreiteiro que trabalhou nessa cidade, sendo responsável pela abertura da rua que liga o Largo da Estação à Rua Campos Salles em 1900 (O RIO PARDO, 15/02/1900). Já o italiano Luigi Prezzia foi responsável pelo projeto da sede da Società di Mutuo Soccorso 20 Settembre. Dr. Jesuíno Felicíssimo e Rogério de Andrade trabalharam na construção das redes de água e esgoto inauguradas em 1903. Outro pedreiro e construtor atuante foi o italiano Pietro Emídio Carrato que destacava em seus anúncios os anos de experiência e prática adquirida sob a orientação de engenheiros e construtores (Figura 123).

Felício Calvite foi outro agente que trabalhou em São José do Rio Pardo e foi registrado em reportagem do jornal O Rio Pardo do dia 26 de junho de 1910 como sendo um construtor de "comprovadas habilitações" pelos vários edifícios públicos e particulares que construiu, entre eles a Igreja Matriz (ver Figura 30 e Figura 31 na página 78), a fachada e a Capela do Cemitério Municipal (ver Figura 24 na página 72 e Figura 124).

Calvite figura ainda entre os principais agentes da construção civil da cidade de Mococa entre os anos de 1894 e 1925. Segundo o pesquisador Paladini (2009), esse italiano atuou principalmente na construção de
Figura 123: Anúncio do empreiteiro e construtor Pietro Emídio Carrado.

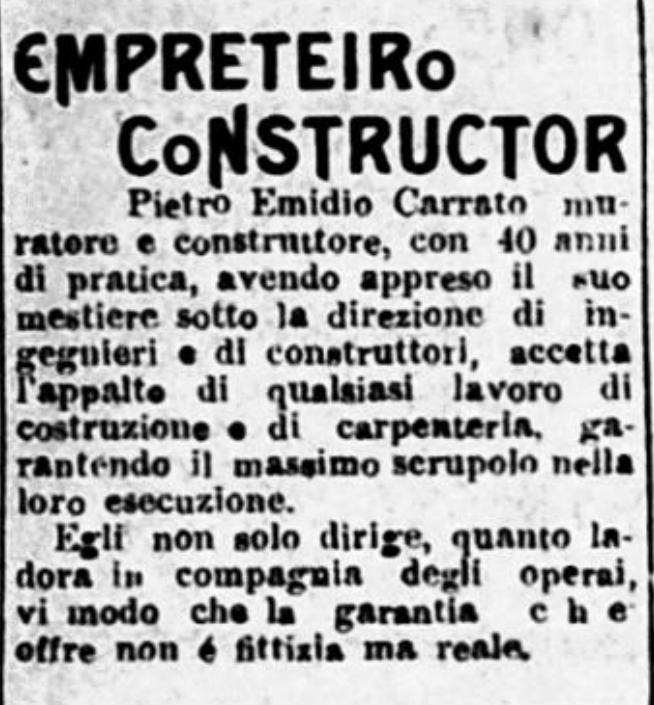

Fonte: Jornal La Nuova Italia, 01 de maio de 1913

Figura 124: Capela construída no Cemitério Municipal em 1905.

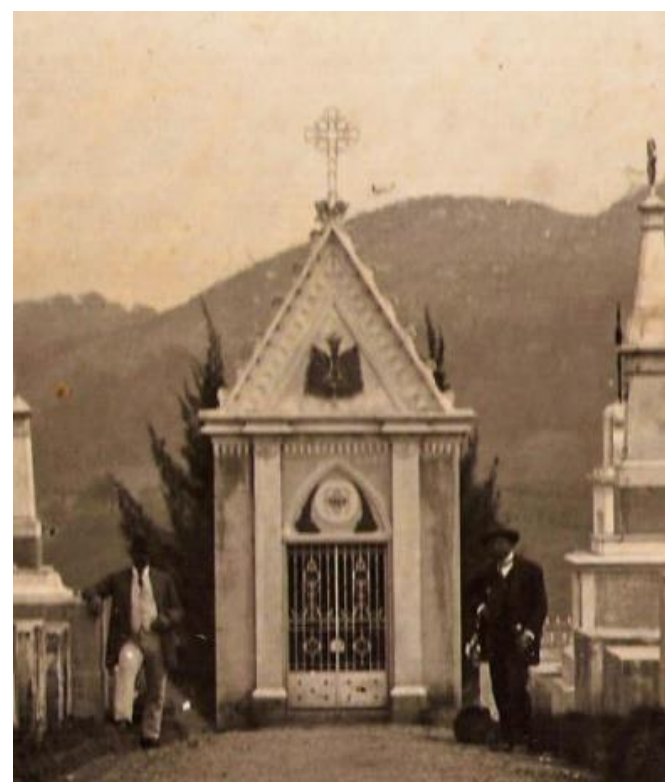

Fonte: Arquivo do Centro da Memória Rio-Pardense Rodolpho José Del Guerra. Fotografia de Innocencio Vilhegas. 
moradias e prédios públicos. Sabemos que ele foi o construtor da residência de Cândido Souza Dias que data de 1893 (Figura 125), do Capitão João Ferraz de Siqueira de 1896 (Figura 126) e do Major João Bento Vieira da Silva de 1898 (Figura 127), todas em Mococa (PALADINI, 2009, RIBEIRO, S., 2011). Ambas possuem similaridades no que diz respeito às intenções plásticas. Apresentam uma riqueza de ornamentação de inspiração renascentista incluindo cornija, modilhões, platibanda de balaustrada intervalada, pináculo, fachadas simétricas e ritmadas, mantendo correspondência entre janelas e aberturas do porão habitável, como é possível observar nas figuras a seguir.

Figura 125: Residência de Cândido Souza Dias (1893) na Praça Marechal Deodoro, 167, Mococa.

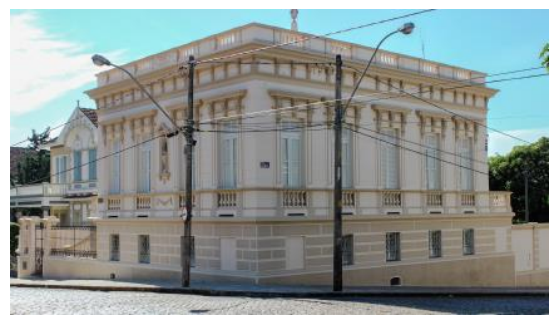

Fonte: Acervo pessoal da autora (2018).
Figura 126: Residência do Capitão João Ferraz de Siqueira (1896) na Praça Ademar de Barros, 131, Mococa.

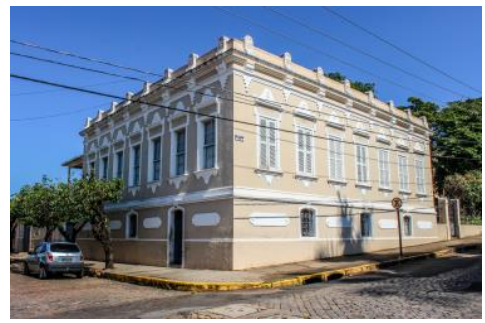

Fonte: Acervo pessoal da autora (2018)
Figura 127: Residência do Major João Bento Vieira da Silva (1898) na Rua Antonio Cristovam, 314, Mococa.

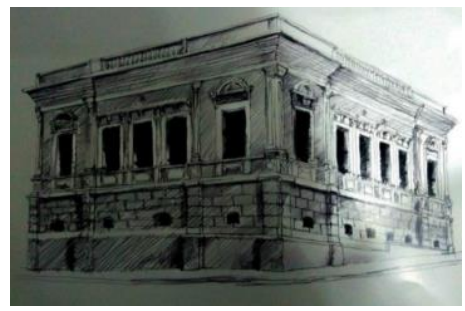

Fonte: Ribeiro, S. (2011).

Essa produção se assemelha com algumas edificações de São José do Rio Pardo, o que nos leva a acreditar que seja ele o construtor responsável. Como exemplo a moradia demolida do Sr. Antônio Caetano de Lima que ficava na Rua João Gabriel Ribeiro esquina com a Rua Francisco Glicério (Figura 128) e a edificação localizada na Rua Marechal Deodoro esquina com a Rua Francisquinho Dias, que apesar das alterações em suas fachadas, mantêm as características iniciais (Figura 129).

Figura 128: Residência do Sr. Antônio Caetano de Lima.

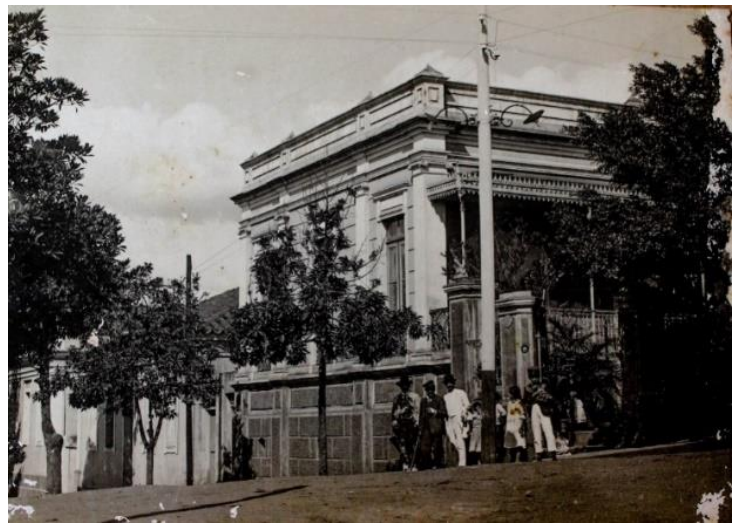

Fonte: Arquivo do Centro da Memória Rio-Pardense Rodolpho José Del Guerra. Fotografia de Innocencio Vilhegas.
Figura 129: Residência na Rua Marechal Deodoro esquina com a Rua Francisquinho Dias em São José do Rio Pardo.

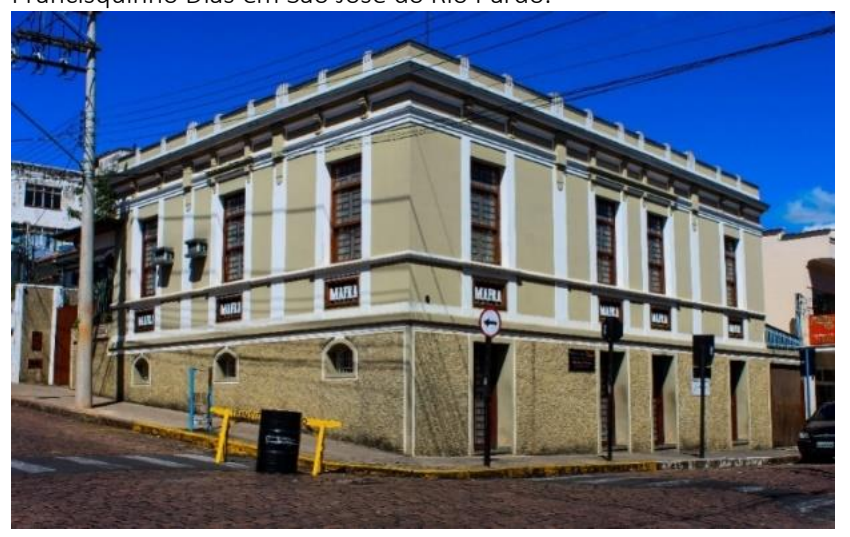

Fonte: Acervo pessoal da autora (2016). 
Tabela 5: Sistematização dos artífices e profissionais atuantes na construção civil de São José do Rio Pardo no final do século XIX e início do XX.

\begin{tabular}{|c|c|c|}
\hline \multicolumn{3}{|c|}{ MÃO DE OBRA ATUANTE EM SÃO JOSÉ DO RIO PARDO EM FIM DO SÉCULO XIX E INÍCIO DO SÉCULO XX } \\
\hline & Final do século XIX & Início do século XX \\
\hline Pedreiros & $\begin{array}{l}\text { João DeLuca, Francisco de Tal, Joaquim Rodrigues Carreira, } \\
\text { Victorino da Rocha Carreira, Martiniano de Tal, Joaquim (conhecido } \\
\text { por Guita), Benedicto, Nicolas Deluca, Antonio Craceia, José Giglio, } \\
\text { Raphael Picelrielo, Francisco Leonardo, José de Souza, José } \\
\text { Quercia, José Gomes da Silva, Manoel Rolani, Felício Semeoni e } \\
\text { Francisco Riga. }\end{array}$ & $\begin{array}{l}\text { Miguel Precioso, Carlos Piquetti, } \\
\text { Sperandio Foiadelli, Angelo } \\
\text { Acquarolí, Giacomo Marzocchi, } \\
\text { Abramo Savoldi, Vicente Sistito, } \\
\text { Salvador Gulli e Francisco Maida. }\end{array}$ \\
\hline Servente & & $\begin{array}{l}\text { Domingos Zamtebasso, Baptista } \\
\text { Bassini, Sebastião de Oliveira, } \\
\text { Francisco C. Martins, José Eugênio, } \\
\text { Eugênio Tresentino, Alberto Isberti, } \\
\text { José Galdino, Domingos Honorio, } \\
\text { Levindo de Mello, Antonio Siverino, } \\
\text { José Ortega, Pedro Januário, } \\
\text { Antônio de Mello, Luiz Bonet e } \\
\text { Jonas Nani. }\end{array}$ \\
\hline Marceneiro & $\begin{array}{l}\text { Paschoal Cerávolo, Domingos Cerávolo, Miguel Cerávolo, Luís Rich, } \\
\text { José Vano e Paschoal Artese. }\end{array}$ & $\begin{array}{l}\text { Osorio Soares, Paschoal Cerávolo, } \\
\text { Domingos Cerávolo, Miguel } \\
\text { Cerávolo, Alfredo Mariani, } \\
\text { Fortunato Paglia, José Lacorazza, } \\
\text { Paschoal Artese e Salvador Artese. }\end{array}$ \\
\hline Carpinteiro & $\begin{array}{l}\text { João Batista Blandim, José Francilino, José Barbosa, Herculano de } \\
\text { Tal, Francisco Ribeiro, Antonio José dos Santos Junior, Mizael Costa } \\
\text { e Silva, Antonio Cardozo dos Santos, Jacintho Jose de Oliveira, } \\
\text { Manoel Serafim dos Anjos, Zeferino Gomes de Avelino, Herculano } \\
\text { Alves de Moura, Joaquim Antonio da Silva, Manoel Marques e José } \\
\text { Candido Lourenço. }\end{array}$ & $\begin{array}{l}\text { Osorio Soares, Angelo Colli e } \\
\text { Salvador Artese. }\end{array}$ \\
\hline Pintor & $\begin{array}{l}\text { Antônio Joaquim Teixeira, Antonio Zeferino Gonçalves e Eduardo } \\
\text { Giudice. }\end{array}$ & $\begin{array}{l}\text { Eduardo Giudice e Rodolpho } \\
\text { Giudice }\end{array}$ \\
\hline $\begin{array}{l}\text { Engenheiro } \\
\text { civil }\end{array}$ & João Thimóteo Pereira da Rosa. & $\begin{array}{l}\text { Dr. Hugo Moschini, João Thimóteo } \\
\text { Pereira da Rosa, Aristides Dias } \\
\text { Pinheiro e José Barbosa de Oliveira. }\end{array}$ \\
\hline $\begin{array}{l}\text { Construtor / } \\
\text { Empreiteiro }\end{array}$ & $\begin{array}{l}\text { Felicio Semione, Francisco Rigo, Felício Calvite, Luigi Prezzia, } \\
\text { Giovanni Delucca, Giuseppe Quercia e Nicola Delucca. }\end{array}$ & $\begin{array}{l}\text { Felicio Semione, Dr. Jesuíno } \\
\text { Felicíssimo, Rogério de Andrade, } \\
\text { Pietro Emídio Carrato, Felício } \\
\text { Calvite e Paschoal Artese. }\end{array}$ \\
\hline
\end{tabular}

Fonte: Jornal O Rio Pardo, listas de Imposto de Indústrias e Profissões e através da produção do historiador Rodolpho José Del Guerra.

Outro agente da construção civil desse período em análise foi o italiano Paschoal Artese que, pela sua atuação e consequente contribuição para a alteração da paisagem urbana, será discutido a seguir, assim como a sua produção e a escolha arquitetônica e estilística de suas obras. 


\section{Paschoal Artese}

Paschoal Artese nasceu em 26 de dezembro de 1881 em Vibo Valentia na região da Calábria e ainda muito jovem veio para o Brasil junto com seus pais, José Artese e Filomena Montesanti Artese, chegando em São José do Rio Pardo no ano de 1897. Casou-se em primeiras núpcias com Adele Ramacciotti com quem teve dois filhos ${ }^{152}$, e em segundas núpcias com Noemia Piovesan com quem teve outros 12 filhos.

Paschoal Artese trouxe na bagagem a experiência de marceneiro e entalhador, profissão que logo lhe rendeu um emprego na marcenaria de Paschoal Cerávolo, ao mesmo tempo em que se dedicava à reprodução de fotografias em desenho. Segundo Trevisan (1977), Artese exerceu ainda os ofícios de professor, construtor e empreiteiro, jornalista, político e escritor, alcançando muito destaque na sociedade rio-pardense, além de tornar-se um dos principais agentes da construção civil e formador de mão de obra no início do século XX. Certamente que tudo isso foi determinante para que obtivéssemos bons registros documentais e nos auxiliasse a descrever a sua trajetória de forma mais aprofundada.

Conforme anúncio de 1902, vemos que pouco tempo desde sua chegada a São José do Rio Pardo, Paschoal já possuía marcenaria própria, a Vibonese, que Figura 130: Anúncio da Marcenaria Vibonese de Paschoal Artese. aceitava "encomendas de obras, mobílias de todos os estilos, obras de entalhe, etc." a partir de modelos escolhidos pelos fregueses nos catálogos (Figura 130). Artese era um homem de múltiplas aptidões, e vislumbrando oportunidades no precário cenário da construção civil riopardense em prevalência à falta de materiais e oficiais investiu na criação de uma olaria, denominada Fartura, para o fornecimento de telhas e tijolos produzidos a preços módicos, e de um depósito onde se comercializava principalmente cal, cimento, manilhas e mosaicos (Figura 131).

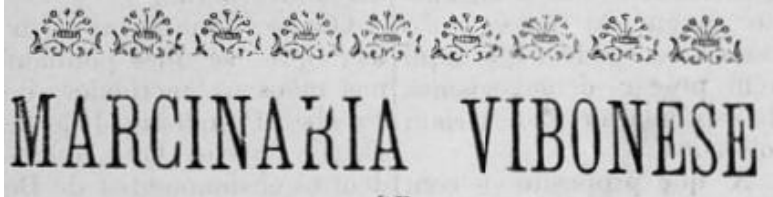

DE

\section{FA}

Acceita-se encommendas de obras, mobilias de todos os estylos, obras de entalho, etc. 0 freguez encantra cathalogos para escolher modelos.

Trabalho arli-tico garantido e solido 0 proprietario, que tem anexo a officína sua escola dè desenho, acceita alumnos para a mesma me diante pequena remuneração

Nesta marcinaria apromta-se caixões para defuntos por preços baratissimos sendo elles feito na moda nacional, argentina e européa conforme o gosto

R. Marechal Deodoro N. 21 5)

Fonte: Jornal O Rio Pardo, 09 de março de 1902.

\footnotetext{
152 Um dos filhos é José Germinal Artese que nasceu em 1903 na cidade de Mococa quando sua família, fugindo da febre amarela em São José do Rio Pardo, se mudou para lá. No início da década de 1920 Germinal seguiu para a capital e depois para o Rio de Janeiro onde cursou as escolas Liceu de Artes e Ofícios e Belas Artes, formando em desenho, pintura e ornato. Entre os seus professores, destacam-se Antonio Rocco, Modesto Broccos, José Barchitta, Campos Ayres, Nicola Rollo, Henrique Vio, Rodolfo Amoedo e Rodolfo Cham belland. Entre seus colegas da escola de Belas Artes, destaca-se Cândido Portinari. No início da década de 1930 retorna para São José do Rio Pardo para lecionar desenho pedagógico no Ginásio Estadual Euclides da Cunha onde permanece até a sua aposentadoria, em 1973, vindo a falecer em 1982 nessa mesma cidade. 

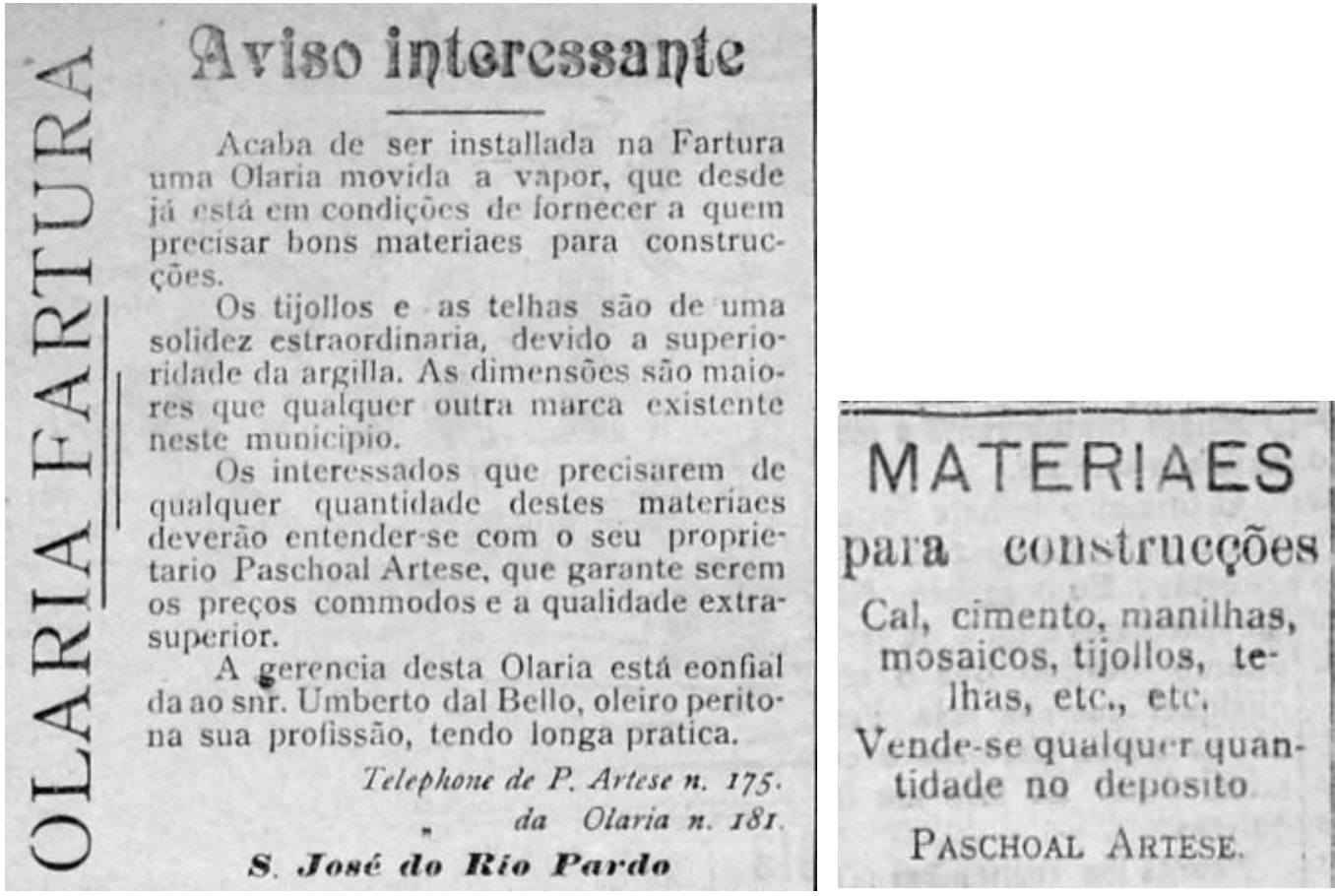

Fonte: Jornal O Rio Pardo, 08 de novembro de 1913.

Diplomado pela Escola de Arte de Monteleone na Calábria e aluno da também Escola de Arte Mestieri em Roma, Artese abriu em 1900 a sua primeira escola de desenho ornamental e geométrico, incluindo a alfabetização do operariado de forma gratuita (Figura 132). O objetivo desse italiano era instruir o pobre e formar mão de obra qualificada que, afinal, ele próprio utilizaria na condição de empreiteiro e construtor, obtendo dessa maneira maior qualidade em suas obras (AULA..., 1900, p. 02). Foi assim também que seu irmão, Salvador Artese, inaugurou sua própria escola voltada ao ensino do desenho aplicado à construção, em 1905 (Figura 133).

Figura 132: Anúncio da Escola de desenho de Paschoal Artese.

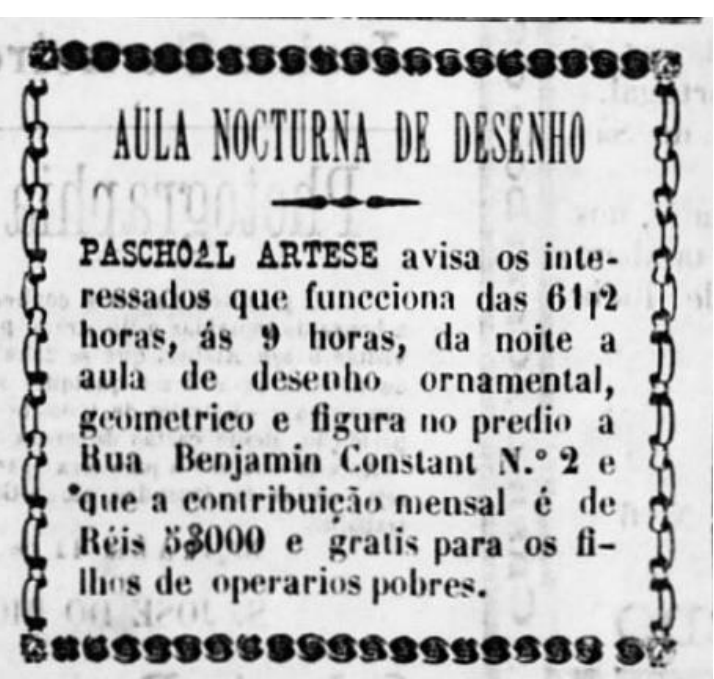

Fonte: Jornal O Rio Pardo, 02 de setembro de 1913.

Figura 133: Anúncio da Escola de desenho de Salvador Artese.

\section{DESENHO}

Aula noctuına de desenbo applicado e construç̧ão, dirigida por Salvador Artese, á rua Francisco Glycerio N. 25.

Pagamento adeantado-Rs. $5 \$ 000$ por mez. Das 7 ás 9 da noite.

Na mesma casa, a senhora Artese Julia acceita por encommenda, qualquer trabalho de bordado, como tambem eusina bordado $\theta$ desenho applicado a esse mister.

A mensalidade para desenho e bordado, é de Rs. $8 \$ 000$, e para bordado só Rs, $6 \$ 000$. Horario: Das 10 ás 3 da tarde. 
A relevância do desenho e da representação nos meios acadêmicos foi abordada por Solange Ferraz de Lima (2008) ao tratar do trânsito de repertórios, enciclopédias, manuais e guias de estilo europeus no Brasil. Segundo ela (LIMA, S., 2008), reforçando o exposto por Lemos, C. (2011), o marco do ensino de desenho e artes nesse país ocorreu com a vinda da Missão Artística Francesa em 1816. Todavia, o projeto pedagógico que se tentou implementar não obteve o sucesso desejado, possivelmente porque dentro do contexto do regime escravocrata, o trabalho artesanal era ostensivamente desprezado. Mas, com a fundação da Academia Imperial de Belas Artes, o ensino das artes liberais foi concretizado, e o ornato ganhou espaço nas diferentes disciplinas, atividades e resenhas manuais, nas aulas de desenho e nos trabalhos produzidos e expostos anualmente. O conteúdo curricular tendia a um favorecimento da educação visual, e a representação do ornato a se desvincular do produto final, tornando-se um modelo, "mudança fundamental, que a produção industrial seriada iria introduzir" (LIMA, S., 2008, p. 162). Tratava-se de um contexto muito mais europeu do que brasileiro de indústria nascente, mas se justificava pela implementação de planos pedagógicos oriundos daqueles países, por exemplo, o programa-tipo de ensino de desenho da Bélgica e da França que priorizavam a observação, o método, a disciplina e a experimentação. Para Belluzzo (1988) e Lima, S. (2008), a valorização estética atribuída ao ornamento e o modelo de ensino adotado que fragmentava os elementos dos diversos estilos acabou por interferir diretamente na produção da arquitetura. Os resultados puderam ser percebidos já em 1906 no Congresso Internacional de Desenho e também na publicação de setembro da Revista de Ensino que acentuaram a "vocação do desenho e dos trabalhos manuais para a preparação não só de artesãos, mas também de operários". Estava apontado aí o caminho que tomaria a produção da arquitetura brasileira, e Lima, S. (2008, p. 164) esclarece ainda que a "visão idealista ambicionava um operário ilustrado, conjugando o trabalho industrial com uma formação humanística". As colocações eram as seguintes:

O estudo de medidas que tornem para o futuro obrigatórios a todos os estudos fundamentaes de geometria, perspectiva e architectura elementares qualquer que seja a indústria á qual se destinem. Preparação previa de grande alcance para os operarios chamados a executar composições decorativas. Na escola de arte decorativa, o desenho, a modelagem, a geometria, a perspectiva, a architectura elementar, o estudo dos estylos, devem ser incluidos como disciplinas essenciaes e obrigatorias; na escola de artes e officios a educação esthetica dos futuros operarios deve ser ministrada a par com a educação profissional. (Cf. CONGRESSO INTERNACIONAL DE DESENHO apud LIMA, S., 2008, p. 164).

Inferimos com isso o avanço do ensino de desenho para o interior do Estado de São Paulo e a sua relevância na formação do operário iniciado por Artese em 1900 na cidade de São José do Rio Pardo, concomitantemente às duas grandes capitais, Rio de Janeiro e São Paulo.

Na chamada do jornal em que Artese anunciou o início das aulas (AULA..., 1900, p. 02), a justificativa utilizada era a importância do desenho e da representação para o operariado, com base no projeto pedagógico francês de artes decorativas. Este projeto privilegiava o movimento art nouveau enquanto discussão estética e política, apoiada pelo governo como parte do projeto de consolidação da República e da "imagem do país como centro mundial do bom gosto e da produção refinada, artesanal, vanguardista" 
(LIMA, S., 2008, p. 161). Possivelmente, o art nouveau e o Arts and Crafts Movement ${ }^{153}$ foram as influências de Pachoal Artese ao favorecer o desenho ornamental, geométrico e de figura como campo propício de criações e combinações, suficientemente caracterizada em sua produção arquitetônica como veremos à frente (Figura 134).

Figura 134: Alunos da escola de desenho de Paschoal Artese, início do século XX.

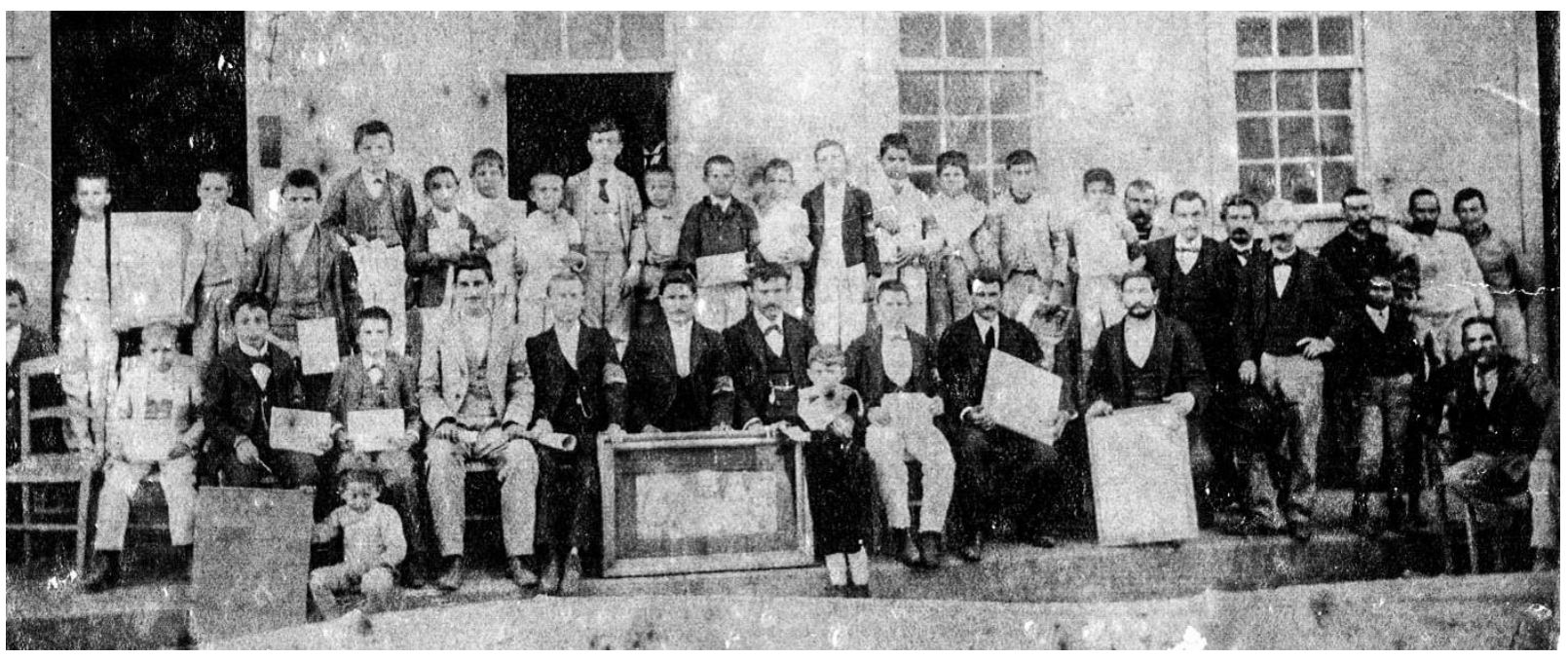

Fonte: Arquivo do Centro da Memória Rio-Pardense Rodolpho José Del Guerra.

$\mathrm{Na}$ atividade de empreiteiro, Paschoal Artese arregimentou esforços na formação de um grupo de artífices, tarefa que certamente não foi fácil. Eram constantes as postagens nos jornais da época anunciando a necessidade de pedreiros, carpinteiros e marceneiros. Todavia, esse italiano destacava o bom ordenado pago e o melhor horário de serviço oferecido, como o que se segue (Figura 135), o que nos leva a crer que havia algum tipo de disputa entre os empreiteiros, de modo que o salário e a quantidade de horas trabalhadas por dia seria um dos atrativos oferecidos por Artese na arregimentação de mão de obra. Essa última questão, inclusive, foi motivo de uma greve sem sucesso nos dois primeiros dias de abril de 1913 (O RIO PARDO, 1913, p. 02) organizada pelos pedreiros e carpinteiros atuantes em São José do Rio Pardo que exigiam oito horas no máximo de serviços diários.

\footnotetext{
${ }^{153}$ Segundo Pinheiro (2011, p. 288), o Arts and Crafts foi um movimento originalmente inglês que buscava uma "ínfima afinidade entre a moradia, seus habitantes e o meio ambiente, privilegiando relações de empatia e de informalidade". Sobre esse movimento, Naylor (1971, p.07) ressalta que ele foi "inspirado por uma crise de consciência. Suas motivações foram sociais e morais, e seus valores estéticos se desenvolveram a partir de uma convicção de que a sociedade produz a arte e a arquitetura que merece". Para Janjulio (2009, p. 42), tendo como base de discussão a teoria formulada por William Richard Lethaby, as repercussões desse movimento na arquitetura não pode ser definido pela forma ou por um estilo, e sim "caracterizada pelo espírito do Gótico, reavivado, em sua ordem, clareza e racionalidade. A simplicidade é almejada e o supérfluo deve ser esquecido. O edifício é um organismo, suas partes estão conectadas entre si e com o todo". É o conceito de unidade de desenho que prevalece, ou seja, a integração desde o menor detalhe, o interior, o exterior e o entorno imediato do edifício.
} 


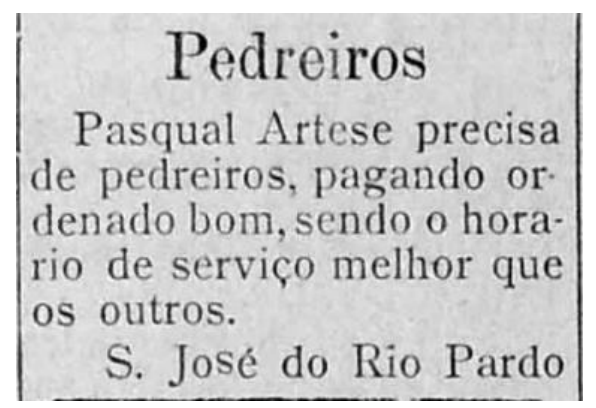

OFFICIAES

Precisam se de officiaes carpinteiros, marcineiros $\theta$ pedreiros.Paga.se bom ordenado. Tratar com o cons. tructor

Pasqual Artese S. José do Rio Pardo
Figura 135: Artese anuncia no jornal a necessidade de mão de obra para atuar na construção civil.

Fonte: Jornal O Rio Pardo, 16 de maio de 1912 e 23 de junho de 1912.

Artese era socialista e defendia a classe operária, sobretudo quando se tratava dos italianos, denunciando através do Clube Democrático Internacional Filhos do Trabalho ${ }^{154}$ e dos jornais de sua propriedade - O Proletário (1900-1902), A Defesa do Povo (1917) e a Resenha (1922-1965) - as mazelas que eles sofriam (DEL GUERRA, 2002). Essa postura assumida conferiu a Artese vários processos e perseguições, principalmente por parte daqueles que detinham o poder econômico e político local.

Nos chama a atenção o modo como Artese descrevia os serviços por ele oferecido (Figura 136), sendo os projetos de reforma e construção planejados e executados em "ordem architectonicas e em estylos modernos", referindo-se à arquitetura clássica e ao que se tinha de mais avançado, possivelmente o art nouveau 155 , ou ainda de acordo com o gosto do cliente. Ao se referir a "pontualidade e garantia pelas empreitadas", Artese se colocava como um profissional que cumpria o cronograma de obras com garantias na qualidade do serviço. E ao informar que "executa e vende qualquer ornamento em cimento ou gesso para frente de prédios, sejam, como capitéis, cimalhas, balaustres, cantoneiras, etc.", quer dizer que ele fabricava tudo o que era utilizado nas suas obras ou ainda o que era encomendado por clientes que dispunham de catálogos e modelos em seu escritório, estabelecido em um local privilegiado, entre o Grupo Escolar Cândido Rodrigues e o Jardim Artístico, no Largo do Grupo Escolar (atual Praça Barão do Rio Branco, 156).

Roberto Lima (2001) ao estudar as semelhanças entre a arquitetura paulista e a portuguesa praticada no período compreendido entre o início do século XIX e primeiros anos do século XX, verificou a impregnação de elementos de tradição clássica nessa produção, o que certamente ocorreu conforme o conhecimento das regras publicadas pelos manuais. E constatou ainda a prevalência desse gosto no interior paulista que se

\footnotetext{
${ }^{154}$ Fundado em 25 de setembro de 1900, o Clube Democrático Internacional Filhos do Trabalho era ideologicamente ligado ao Círculo Socialista "Avanti" de São Paulo, e tinha como principal representante Paschoal Artese como "defensor dos oprimidos e da classe desfavorecida" (DEL GUERRA, 1999). Em 1909 o Clube encerrou suas atividades, extinguindo-se a última agremiação socialista riopardense.

${ }^{155}$ Ramalho (1989) destaca em suas análises que o estilo art nouveau se apresentou bastante restrito no Brasil devido a sua incapacidade de ultrapassar a dimensão meramente ornamental. Nesse sentido, Lemos, C. (1989) após revelar exemplares arquitetônicos projetados por Carlos Ekman e Victor Dubugras, ressaltou que "o estilo art nouveau espalhou-se em versões popularescas que, na verdade, não compreenderam o seu espírito inovador, principalmente quanto às relações espaciais. Ficaram todos na ornamentação simplesmente aposta a arcabouços prismáticos de alvenaria tradicional. [...] A decoração era simplesmente aplicada às paredes, substituindo todo o vocabulário neoclássico corriqueiro e já exaurido. Foram comuns as grandes janelas centrais das salas de visitas, na forma de ferradura e as ferragens dos gradis e portões eram executadas no estilo segundo modelos tirados de revistas francesas, onde a ornamentação do metrô de Paris era o ponto alto do bom gosto. Resumindo, o estilo art nouveau foi absorvido pelo povo e incorporado ao ecletismo sem contemplações, e passamos a presenciar exemplares neoclássicos, neogóticos ou neoqualquercoisa, mostrando também pormenores art nouveau distraidamente aplicados aqui e ali, ora numa vidraça lapidada, ora numa maçaneta, ora numa grade de ventilação de porão, ora numa luminária de vidro colorido, ora num vitral importado". (LEMOS, C., 1989, p.148). Essas observações descrevem muito bem a produção de Paschoal Artese em São José do Rio Pardo.
} 
Figura 136: Anúncio dos serviços oferecidos por Artese.

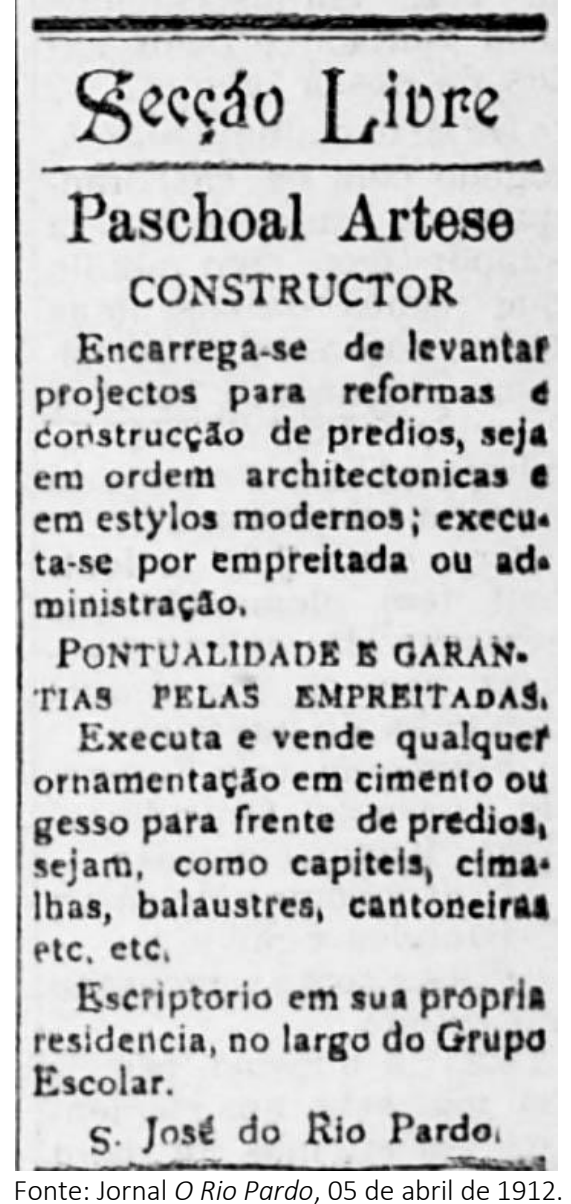

acentuou na segunda metade do século XIX e tendeu a uma estilização com ornamentação mais complexa, muitas vezes contaminada pelo neogótico e art nouveau no início do século $X X$, como é o caso da produção de Artese em São José do Rio Pardo. Para Lemos, C. (1989), corroborando com Debenedetti e Salmoni (1981), os manuais inspirados" 156 nas "Regras das cinco ordens de Arquitetura", de Vignola, circulou no mundo inteiro e foram difundidos no Brasil, permitindo o conhecimento das regras clássicas. Além do gosto vignolesco, Debenedetti e Salmoni (1981, p. 68) apontaram a inclusão do estudo das ordens da arquitetura por Domiziano Rossi ${ }^{157}$ - professor de Desenho Geométrico e Ornato - no programa de ensino do "Liceu de Artes e Ofícios", após ser reformado por Ramos de Azevedo ${ }^{158}$ em 1895 (MACAMBIRA, 1995; FABRIS, 1987; LEMOS, C., 1989a). A partir de então o Liceu se transformou efetivamente em um "centro formador de mão de obra especializada, capaz de atender às necessidades de uma cidade moderna em expansão, à demanda duma elite que necessitava de artesãos que pudessem responder a suas exigências estéticas" (FABRIS, 1987, p. 286).

Segundo Fabris (1987, p. 286) o papel do Liceu na formação de uma mentalidade profissional foi determinante para a propagação do gosto eclético, o qual foi, "em parte, fruto da contribuição dos profissionais italianos, os quais Ramos de Azevedo sublinha enfaticamente". Sendo, pois, o corpo docente do Liceu, em sua fase de organização, formado por italianos, e sucessivamente, os artesãos diplomados por essa escola se tornaram os próprios colaboradores de Ramos (DEBENEDETTI E SALMONI, 1981, p. 76). Logo, a qualidade e influência exercida pelos italianos significou uma via de mão dupla, que associado à liberdade e às diferentes possibilidades de composição e organização das fachadas, produziu uma arquitetura

\footnotetext{
${ }^{156}$ Exemplo é a versão reduzida e simplificada, intitulada "O Vignola dos proprietários", traduzido por José da Fonseca, que teve ampla circulação entre os profissionais da construção civil. Para mais informações sobre como ocorreu a circulação e sua utilização, ver o trabalho desenvolvido por Debenedetti e Salmoni (1981).

157 O italiano Domiziano Rossi, chegou ao Brasil com aproximadamente 30 anos, depois de ter estudado arquitetura em Gênova. Segundo Debenedetti e Salmoni (1981, p. 80), "não foi por pura coincidência que as semelhanças com a arquitetura italiana se tornaram mais frequentes e precisas nas obras dos brasileiros, a partir daquele ano [1895, chegada de Rossi em São Paulo]". Após conhecer Ramos de Azevedo, Rossi foi introduzido na Escola Politécnica ocupando a cátedra de desenho, e no Liceu de Artes e Ofícios onde lecionou Desenho Geométrico e Ornato entre os anos de 1896 e 1920 quando faleceu.

${ }^{158}$ Ramos de Azevedo (1851-1928) cursou engenharia na Universidade de Gand, na Bélgica, onde assistiu também aulas de arquitetura na Academia de Belas Artes. Formado engenheiro-arquiteto retorna a Campinas, cidade onde nasceu, permanecendo ali até 1886 quando se muda para São Paulo para dirigir a Carteira Imobiliária do Banco União e realiza projetos e construções para entidade públicas e particulares. Segundo Monteiro (2009) em 1907 ele instalou o seu Escritório Técnico F. P. Ramos de Azevedo e Cia em parceria com colaboradores, entre eles Domiziano Rossi, Victor Dubugras, Maximiliano Hehl, Alexandre Albuquerque, Anhaia Melo, Ricardo Severo e Arnaldo Dumont Villares, entre outros. Para saber mais sobre Ramos de Azevedo, sua atuação profissional e as atividades de seu escritório, ver o livro de Monteiro (2009).
} 
composta de elementos inspirados no estilo clássico, floreal entre outros. Corrobora nesse sentido, as múltiplas combinações possíveis e verificadas por Lemos, C. (1987) na capital e por Lima, R. (2001) no interior paulista, deixando as fachadas parecidas, sem serem iguais. Segundo Lemos, C. (1987) foi o momento em que

a variedade passou a compor o cenário sem repetições, mas, ao mesmo tempo, homogeneizado pelas mesmas regras de composição, pelos mesmos ritmos das envasaduras que ganhavam predomínio sobre os cheios das alvenarias, as mesmas platibandas, os mesmos gabaritos reguladores. Era o Ecletismo. (LEMOS, C., 1987, p. 74).

O que levou o autor (LEMOS, C., 1987, p. 74) a afirmar a possibilidade de uma classificação das obras ecléticas paulistanas ser "válido para outras localidades brasileiras, em vários grupos digamos estilísticos; alguns de existência concomitantes, outros surgidos em sequência temporal". Contudo, e apesar das edificações apresentarem semelhanças, verificamos certas peculiaridades que as tornam singulares, sendo necessária a análise da produção eclética de cada lugar, como podemos observar na Figura 137 que retrata edifícios de São Paulo, São Carlos, Mococa, Casa Branca, Bocaina e São José do Rio Pardo. É o detalhe do gradil, o desenho das aberturas, a superposição dos elementos, a platibanda, a composição dos ornatos, o modo de implantação e a disposição interna dos ambientes ${ }^{159}$ que faz um edifício ser único, apesar das semelhanças. Para Lima, R. (2001, p. 130), essa singularidade se justifica ainda pelas limitações dos códigos de posturas que direcionou a produção arquitetônica, a mão de obra, o gosto do cliente, as técnicas construtivas e os materiais disponíveis.

Figura 137: Edificações semelhantes construídas em diferentes cidades do Estado de São Paulo.

Rua Costa Machado, 592, São José do Rio Pardo.

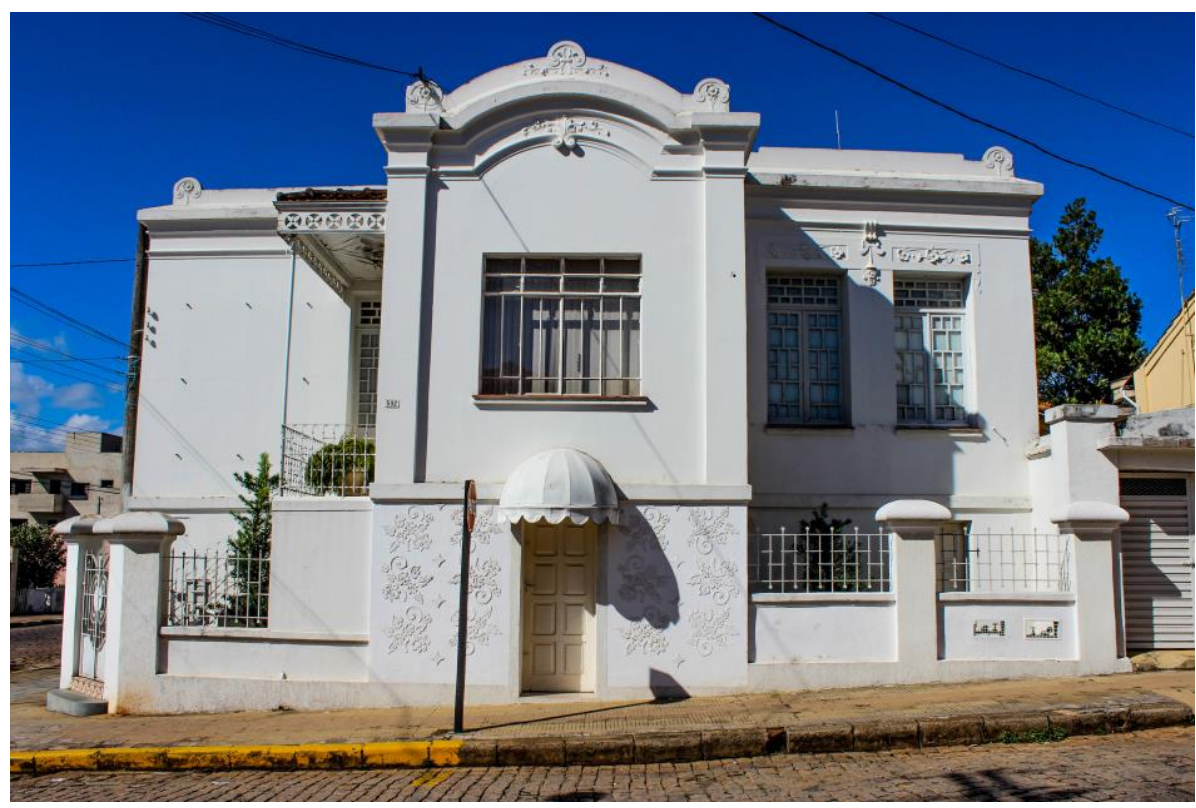

Fotografia da autora (2015).

${ }^{159}$ Devido a impossibilidade de acesso ao interior dos edifícios de Casa Branca e Bocaína, optamos por restringir nossa análise à fachada. 
Residência da Sra. Margherita Marchesini, São Paulo.

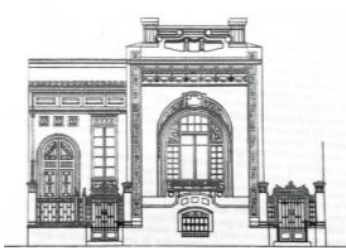

Lemos, C. (1989a).
Avenida São Carlos, 2352, São Carlos.

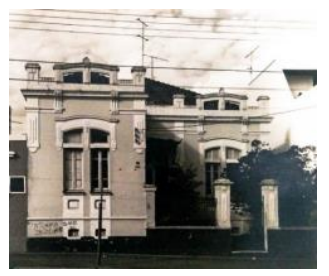

Bortolucci (1991).
Rua Marechal Deodoro, 61, Mococa.

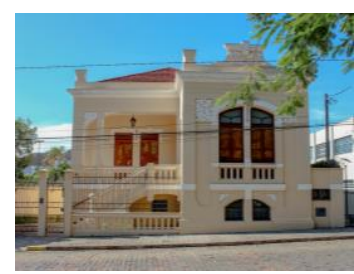

Fotografia da autora (2018).
Rua Sete de Setembro, 384, Bocaina.

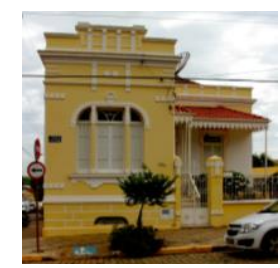

Fotografia da autora (2015).

Sendo assim, consideramos imprescindível a análise da produção de Paschoal Artese, que procurando acompanhar as novidades, dentro das possibilidades técnico-construtivas, condicionou a sua produção. De fato, e como enfatizado anteriormente, não havia uma exigência plástica pré-estabelecida na produção desse profissional, que projetava e executava com base na arquitetura clássica, no art nouveau ou no desejo do cliente, fazendo uso do tijolo de barro, cimento e gesso. Logo, a variedade de motivos, de diversos estilos, associados a liberdade de criação permitiu o desenvolvimento de certa originalidade no ecletismo praticado por Artese, tornando a sua produção singular se comparado, por exemplo, com a arquitetura das cidades vizinhas como Mococa ${ }^{160}$, Casa Branca ${ }^{161}$, Caconde ${ }^{162}$ e Guaxupé ${ }^{163}$. Desse modo, dentre as várias obras de Artese, destacamos a execução do Hospital Santa Casa (1913) (ver Figura 91 na página 144); o Jardim Artístico (1913) (ver Figura 97 na página 147 e Figura 138); o Cine Pavilhão XV de Novembro (1910) (ver Figura 101 na página 149); o Casarão do Artese na Praça Barão do Rio Branco (Figura 139) e também a moradia de Dante Artese, 142 (Figura 140) e a moradia 182 (Figura 141), todas da década de 1910; o edifício de uso misto - comércio e moradia - da família Landini (década de 1910) (Figura 142); a residência de Beatriz Cristina Granado do Prado (1917-1918) (Figura 143), a moradia da família Bingoletto (por volta de 1915) (Figura 144) e a residência na Rua Francisco Glicério, 546 (Figura 145), também da década de 1910. Através das imagens podemos afirmar a importância dessa arquitetura para o estabelecimento do ecletismo em São José do Rio Pardo e de Paschoal Artese como agente difusor dessa produção no cenário local ${ }^{164}$.

\footnotetext{
${ }^{160}$ Para saber mais sobre a produção arquitetônica mocoquense, ver o livro Inventário Arquitetônico de Mococa, desenvolvido por Ribeiro, S. (2011).

${ }^{161}$ No livro Casa branca: levantamento sistemático destinado a inventariar bens culturais do Estado de São Paulo, Rocha Filho (2005) apresenta uma série de edificações construídas até o ano de 1950. Outro livro que apresenta as particularidades da cidade de Casa Branca, incluindo suas moradias é 200 Anos Casa Branca escrito por Meira Molinari (2014).

162 Sobre a produção da arquitetura de Caconde, ver Caconde: levantamento sistemático destinado a inventariar bens culturais do Estado de São Paulo realizado por Rocha Filho (2005).

${ }^{163}$ A produção arquitetônica de Guaxupé pode ser vista em Cyrino Filho (2008).

${ }^{164}$ Dada a impossibilidade de acesso aos edifícios ainda existentes e que não sofreram tantas reformas que alteraram a disposição inte rna dos ambientes, restringimos nossa análise a tipologia arquitetônica e as intenções plásticas.
} 
Figura 138: Portão de acesso e detalhes ornamentais com características art nouveau do Jardim Artístico, década de 1940.
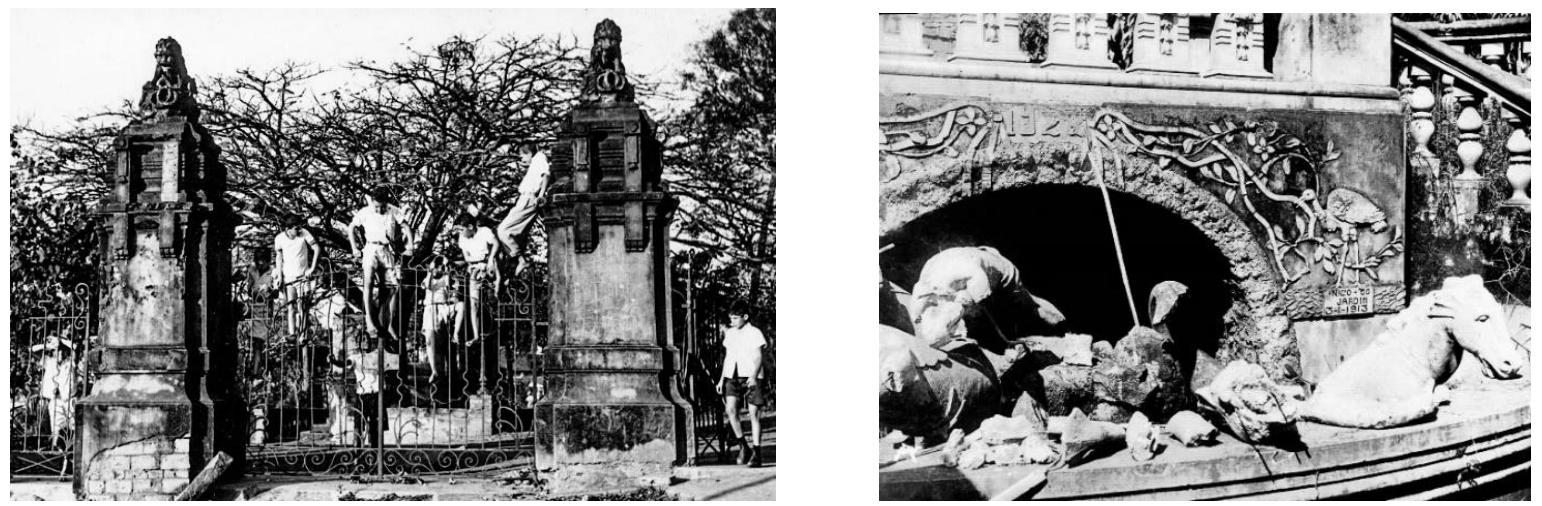

Fonte: Arquivo do Centro da Memória Rio-Pardense Rodolpho José Del Guerra.

Figura 139: Casarão do Artese (década de 1910) na Praça Barão do Rio Branco, 156.

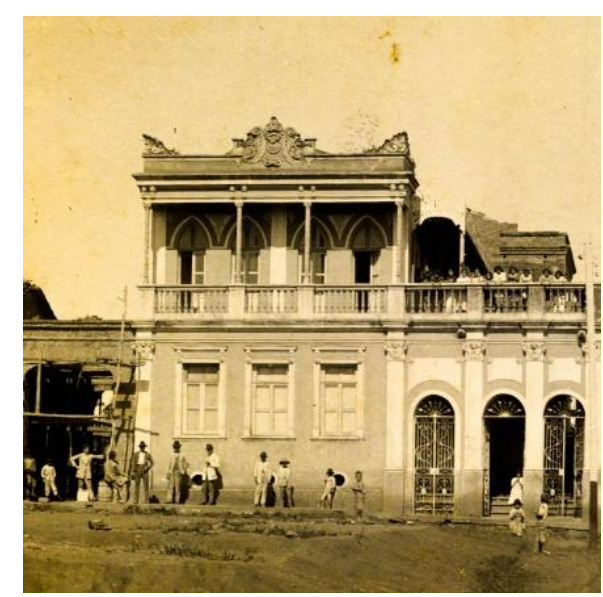

Fonte: Arquivo do Centro da Memória Rio-Pardense Rodolpho José Del Guerra. Fotografia de Innocencio Vilhegas.
Figura 140: Moradia de Dante Artese (década de 1910) na Praça Barão do Rio Branco, 142.

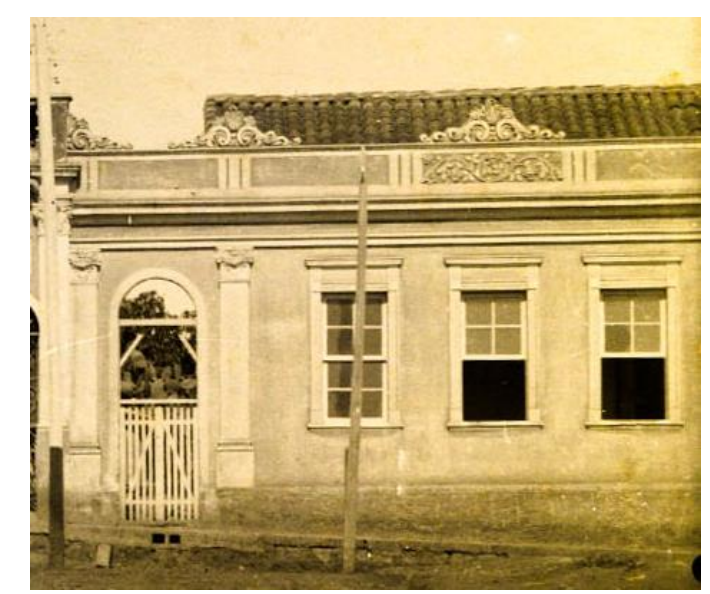

Fonte: Arquivo do Centro da Memória Rio-Pardense Rodolpho José Del Guerra. Fotografia de Innocencio Vilhegas.

Figura 142: Edifício de uso misto (década de 1910) da família Landini na Rua Treze de Maio.

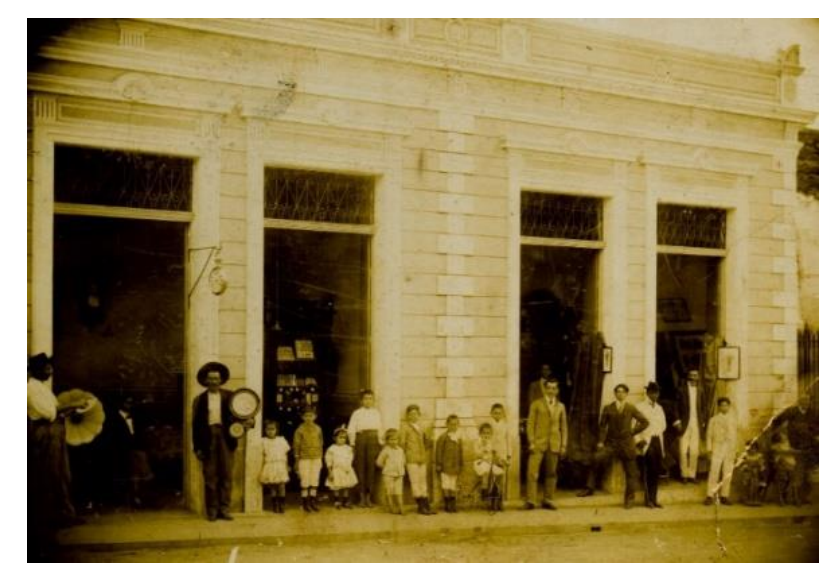

Fonte: Arquivo do Centro da Memória Rio-Pardense Rodolpho José Del Guerra. Fotografia de Innocencio Vilhegas. 
Figura 143: Moradia (1917-1918) de Beatriz Cristina Granado do Prado na Avenida Independência, 05

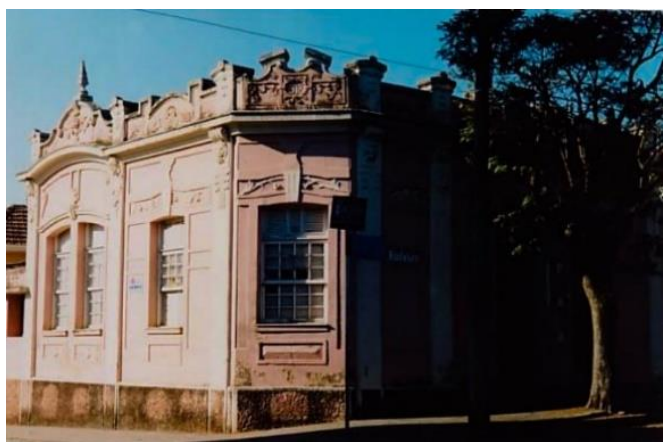

Fonte: Arquivo do Centro da Memória Rio-Pardense Rodolpho José Del Guerra.
Figura 144: Moradia ( década de 1910) da família Bingoletto na Praça XV de Novembro, 42.

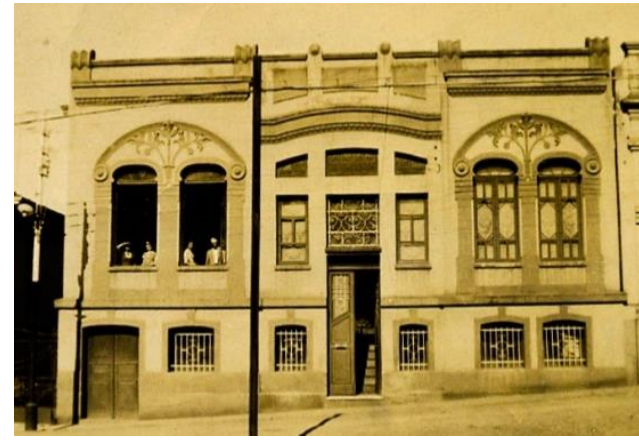

Fonte: Arquivo do Centro da Memória Rio-Pardense Rodolpho José Del Guerra. Fotografia de Innocencio Vilhegas.

Figura 145: Moradia (década de 1910) na Rua Francisco Glicério, 546.

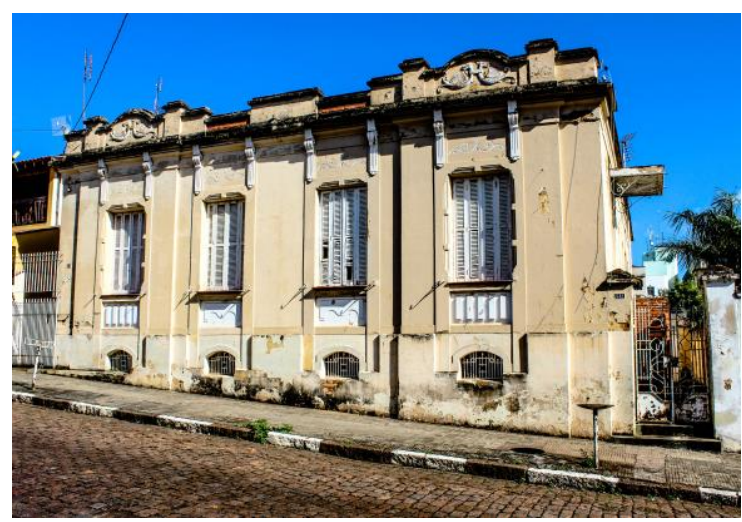

Fonte: Acervo pessoal da autora (2017).

Apesar da singularidade de cada edifício, observamos que todos possuem caracacterísticas semelhantes, por exemplo a implantação alterada com o distanciamento dos limites laterais do lote, mantendo o alinhamento frontal em relação à via pública. Parece ter sido uma mudança adotada por Artese até desvencilhar por completo a edificação dos seus vizinhos como na edificação da família Landini na Rua Treze de Maio, 152. Possivelmente a obrigatoriedade de se construir na "linha do arruamento", exceto dentro dos terrenos desde que ele fosse fechado por muros ou gradis de ferro, direcionou a atividade edificativa em São José do Rio Pardo (CÓDIGO DE POSTURAS, 1903). Como é possível observar na (Figura 146), os telhados já não dependiam dos seus vizinhos para garantir a estabilidade, mas ainda assim as edificações permaneceram no alinhamento da via pública, apresentando um corredor lateral descoberto que veio a se tornar o acesso principal da edificação, como é o caso da moradia de Dante Artese ${ }^{165}$ na Praça Barão do Rio Branco, 142 (Figura 147). Fatores que associados ao próprio formato dos terrenos, predominantemente alongados, condicionou a implantação e os acessos.

\footnotetext{
165 Filho de Paschoal Artese, Dante teve participação ativa na política como presidente do Partido Social Progressista, chegando a se candidatar para prefeito em 1947 e 1959 e a deputado estadual em 1950, perdendo todas.
} 


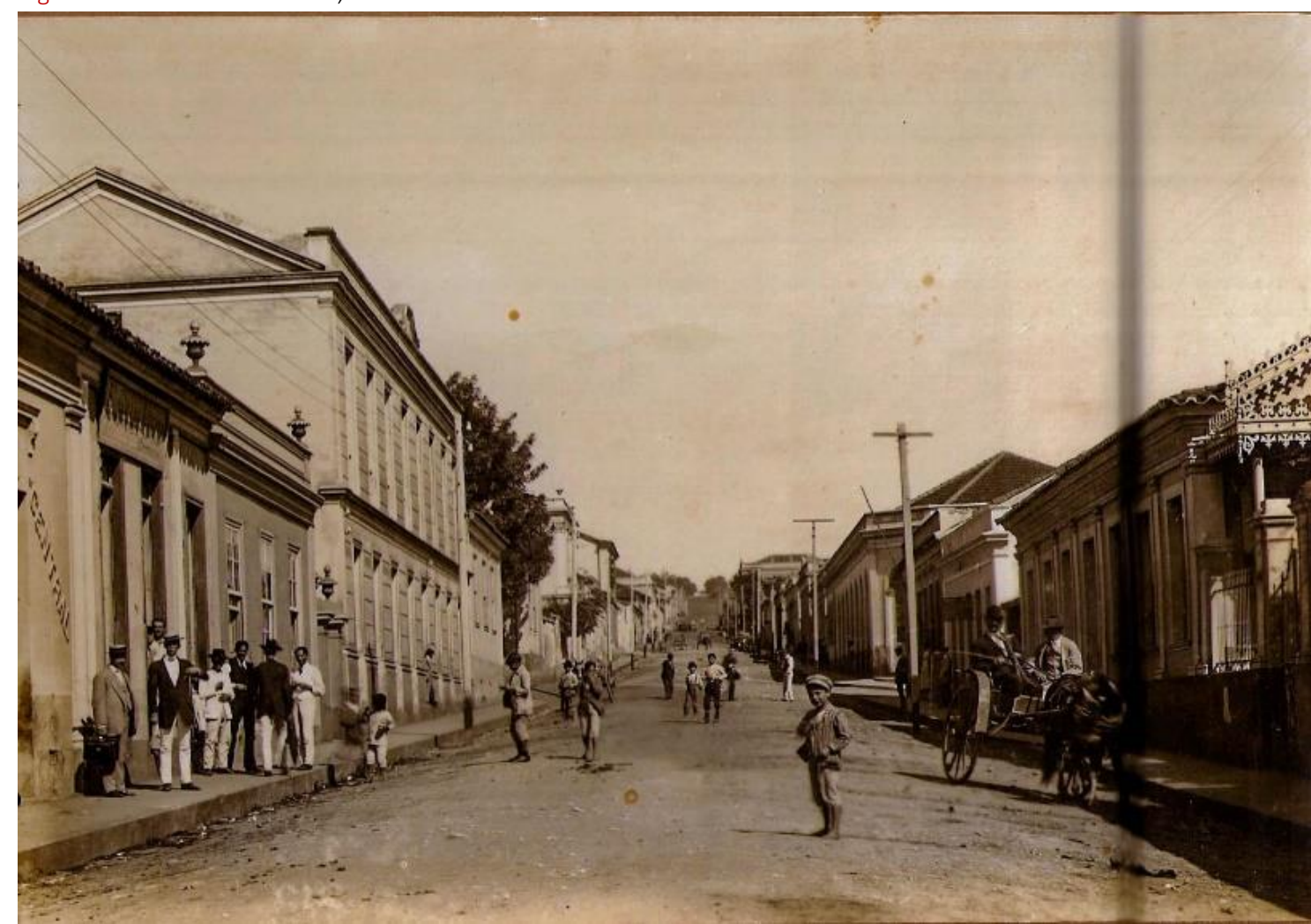

Fonte: Arquivo do Centro da Memória Rio-Pardense Rodolpho José Del Guerra. Fotografia de Innocencio Vilhegas.

Figura 147: Implantação da moradia de Dante Arte

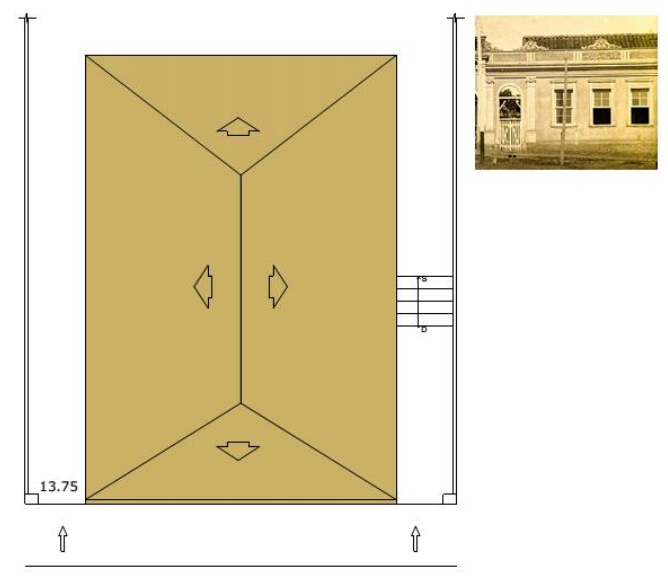

Ruo

Praça Barão do Rio Branco

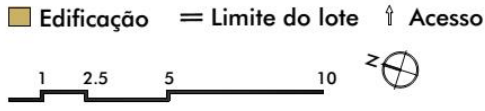

Desenho: Natalia Cappellari de Rezende (2018)
Exceto a moradia da família Bingoletto ${ }^{166}$ que manteve a parte frontal da edificação nos limites do lote com a via pública, todas as outras possuíam afastamentos em ao menos um dos lados do terreno, favorecendo luz e ar natural para dentro das edificações (Figura 148) Certamente, Artese se preocupava com as condições de higiene, conforto e salubridade, e associado à obrigatoriedade da utilização das calhas e rufos no telhado, propiciou os afastamentos em acordo com o Código de Posturas de 1903 que determinou em seu artigo 12 o seguinte em

Dentro do perímetro urbano todo o proprietario de prédios é obrigado a collocar nos telhados calhas de cobre ou de ferro zincado, que recebam as aguas pluviais e as conduzam para fora das guias, por meio de canos embutidos nas paredes e por baixo dos passeios. É egualmente obrigado a concertar, sob as mesmas prescripções deste artigo

\footnotetext{
166 Essa edificação que ficou popularmente conhecida como moradia da família Bingoletto foi construída na década de 1910 (ZVEIBIL, 2000) após encomenda feita à Paschoal Artese pelo fazendeiro Manoel Ribeiro Machado.
} 
Figura 148: Vários tipos de implantação de edificações construídas por Artese no início do século XX.

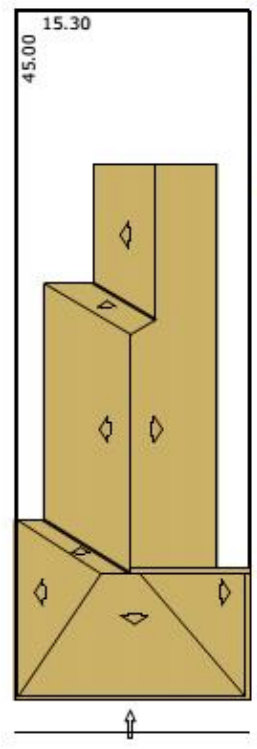

Rua

FAMILIA BINGOLETTO

$z \oplus$
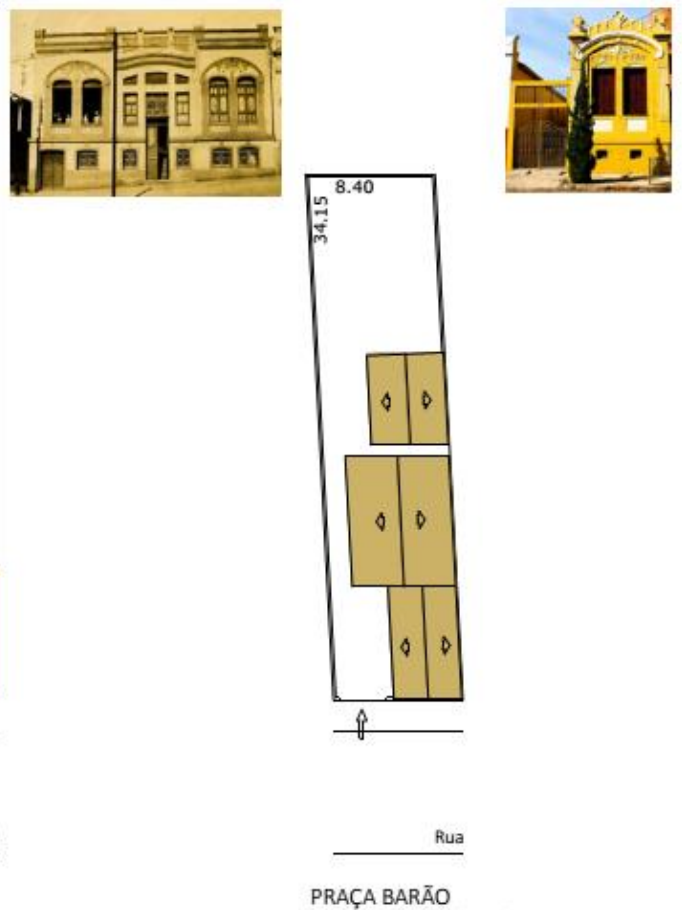
DO RIO BRANCO, 182

Q. $\oplus \mathrm{z}$
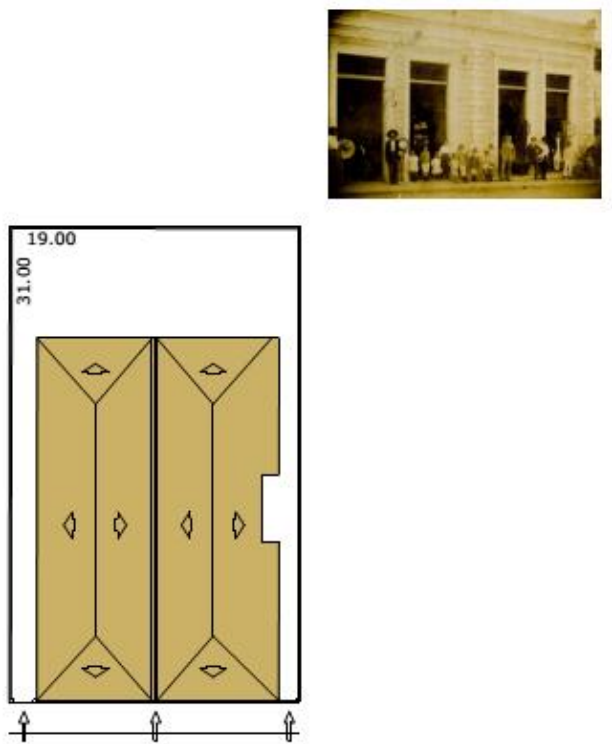

FAMILIA LANDINI

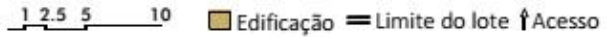

Desenho: Natalia Cappellari de Rezende (2018).

Outra característica que atesta o atendimento às normas e a busca por salubridade foi o afastamento do piso em relação ao terreno, sendo a edificação dos Landini o único exemplar que encontramos no mesmo nível do passeio, uma vez que o desnível do terreno para o fundo exigiu a construção de dois pavimentos, sendo o porão habitável.

As semelhanças não ficaram restritas à implantação, mas também à liberdade de criar novos motivos dentro da linguagem eclética. O que nos mostra que Artese foi suficientemente criativo para estabelecer variadas combinações, como é possível observar nos diferentes ornatos que ele utilizou (Figura 149) ${ }^{167}$.

\footnotetext{
${ }^{167}$ As figuras 146, 147, 148, 151, 152, 153, 154 e 155 fazem parte de uma série de fotografias realizadas em 2006 quando o edifício estava em ruínas. Todas essas fotografias foram cedidas por Antônio Carlos Lorette e Rosana Soares Bertocco Parisi.
} 
Figura 149: Ornamentos do repertório floreal utilizado por Paschoal Artese em sua residência na Praça Barão do Rio Branco, 156.
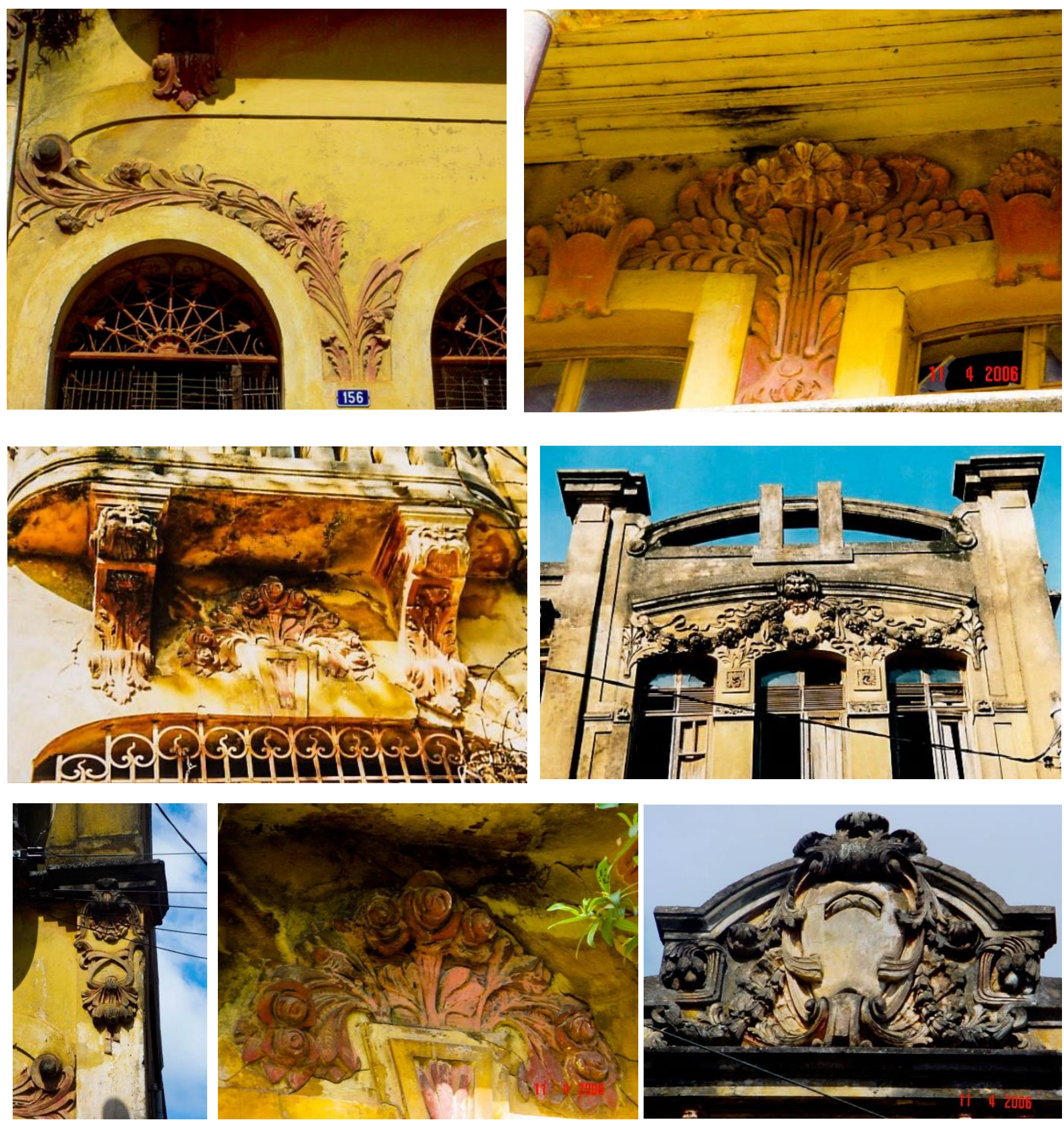

Fonte: Autor desconhecido (2006).

Tais elemententos faziam parte do sobrado de Paschoal Artese que foi construído no início da década de 1910 e ficou popularmente conhecido como Casarão do Artese. Edificação que serviu de moradia, escritório, gráfica e edição de jornal, e depois de anos como residência da família foi utilizado como creche e escola. Esse edifício foi o primeiro de grande dimenção e importância construído por esse profissional em São José do Rio Pardo, e localizava-se nas proximidades do Grupo Escolar Cândido Rodrigues, onde predominavam edificações térreas, conferindo a essa moradia de dois pavimentos destaque na paisagem. Sobre as características do prédio, sobressai a riqueza de detalhes da composição da fachada que era marcada pela disposição ritmada e diferenciada das molduras das aberturas em arco pleno, em verga reta 
encimadas por régulas e em arco ogival. Utilizava ainda pilastras e pilares com feição coríntia e jônica. Todo o peitoril da sacada e da varanda era decorado com balaustrada, enquanto a platibanda era marcada pela composição livre de elementos florais. Já o gradil de fechamento apresentava ferro forjado e fundido com motivos e curvaturas de inspiração na natureza (Figura 150).

Figura 150: Gradis do Casarão do Artese.
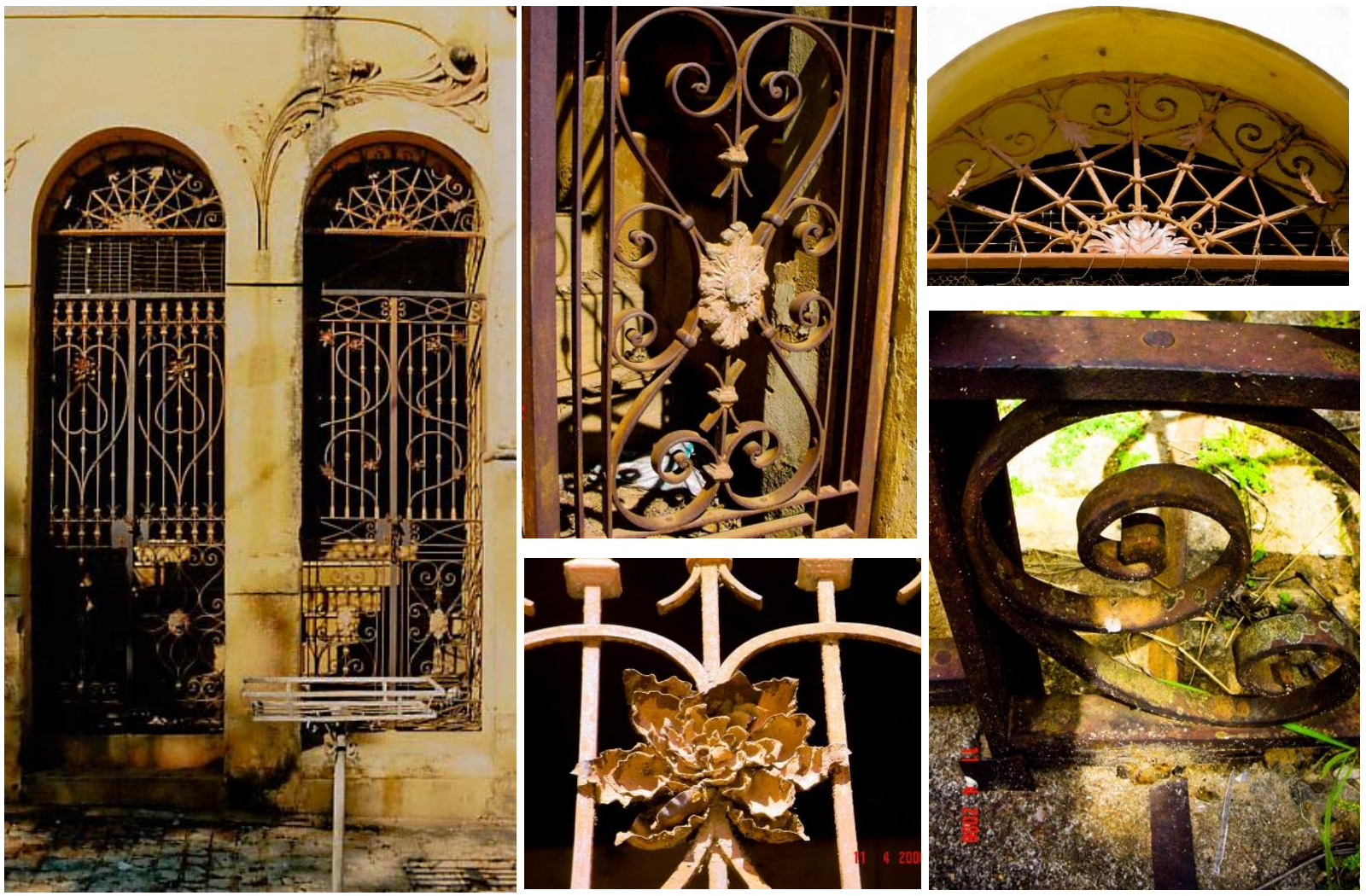

Fonte: Autor desconhecido (2006).

Características estas que foram realçadas e outras alteradas no início da década de 1920 quando o Casarão foi reformado visando a sua ampliação. A partir de então o edifício adotou uma profusão de elementos decorativos com figuras mitológicas e da natureza. A composição apresentou arranjos volumétricos marcados pelo contraste entre cheios e vazios e com aderência de ornatos claramente inspirados no estilo art nouveau. Com efeito, as régulas sobre as aberturas e a rítmica sequência de pilastras foram suprimidas. No detalhe, observamos mudanças no tratamento dos óculos; a balaustrada da varanda foi substituída por elementos delgados em concreto (Figura 151); nas sacadas sustentadas por mísulas o desenho do balaústre foi alterado; as molduras em arcos ogivais deram lugar a arcos abaulados encimados por ornatos floreais; e a platibanda dos volumes laterais adotou um semicírculo seccionado e ladeado por pilares coroados por formas geométricas retangulares, particularidades que podem ser observadas na Figura $152^{168}$.

${ }^{168}$ As alterações podem ser facilmente percebidas comparando a Figura 152 com a Figura 139. 
Figura 151: Fechamento da sacada do Casarão do Artese com elementos delgados em concreto.

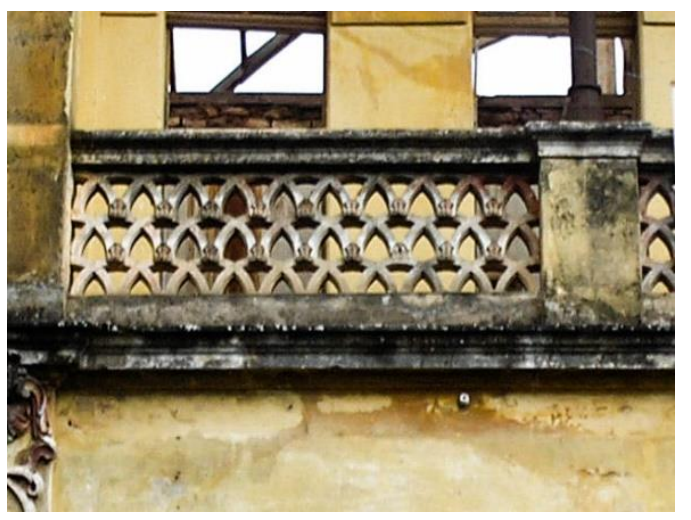

Fonte: Autor desconhecido (2006).

Figura 152: Casarão do Artese reformado e ampliado, 1922.

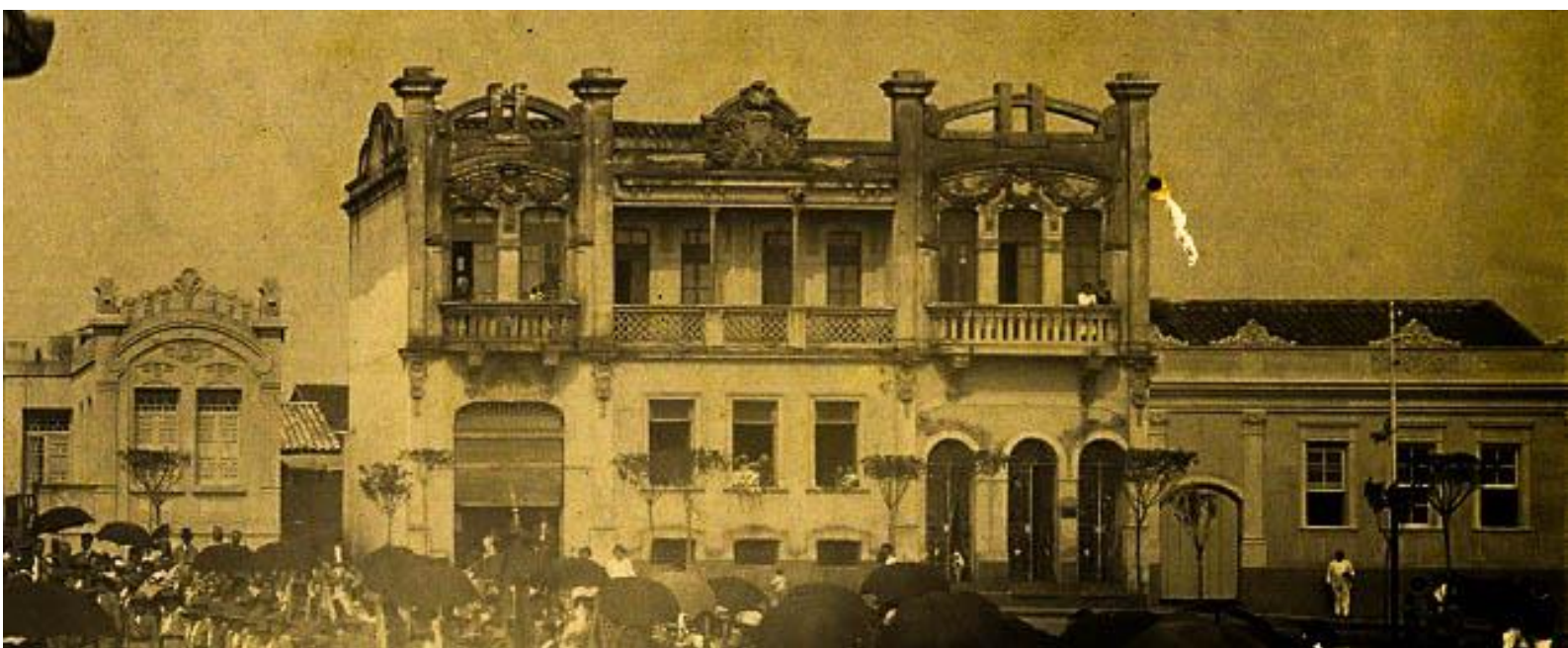

Fonte: Arquivo do Centro da Memória Rio-Pardense Rodolpho José Del Guerra.

Sobre a técnica construtiva, Artese utilizou no Casarão e em todas as outras edificações a alvenaria com tijolos autoportante, provavelmente produzidos na sua olaria (Figura 153 e Figura 154). Todas as paredes foram argamassadas e pintadas, sendo os ambientes da área social e íntima revestidos por pintura com estêncil em motivos geométricos e florais (Figura 155). Predominou o uso de esquadrias de madeira, e aberturas com bandeiras fixas, permitindo a iluminação natural. Os pisos originais da edificação eram o ladrilho hidráulico, o assoalho de madeira e o tijolo cerâmico, como é possível observar na Figura 156. O telhado era composto por tesouras, terças, caibros e ripas de madeira com entelhamento em capa e canal (Figura 157). Como se pode perceber na Figura 158, assim como o piso, o forro cumpria a função de hierarquizar os ambientes, apresentando desenhos de formas variadas nos cômodos sociais e íntimos, enquanto nos demais era tabuado de madeira lisa corrida. As fotos apresentadas abaixo (Figuras 154-158) foram tiradas em 2006 quando o edifício estava em ruínas. Em 2008 o Conselho de Defesa e Estudos do Patrimônio Histórico, Artístico e Cultural de São José do Rio Pardo (CONDEPHAC-SJRP) iniciou um estudo de tombamento, mas o Casarão foi demolido antes da conclusão do processo. Por essa razão, o poder judiciário decidiu pela reconstrução da fachada aos moldes do antigo Casarão, que foi finalizada em 2015. 
Figura 153: Operários e crianças no quintal do Casarão do Artese, no final da obra, na década de 1920

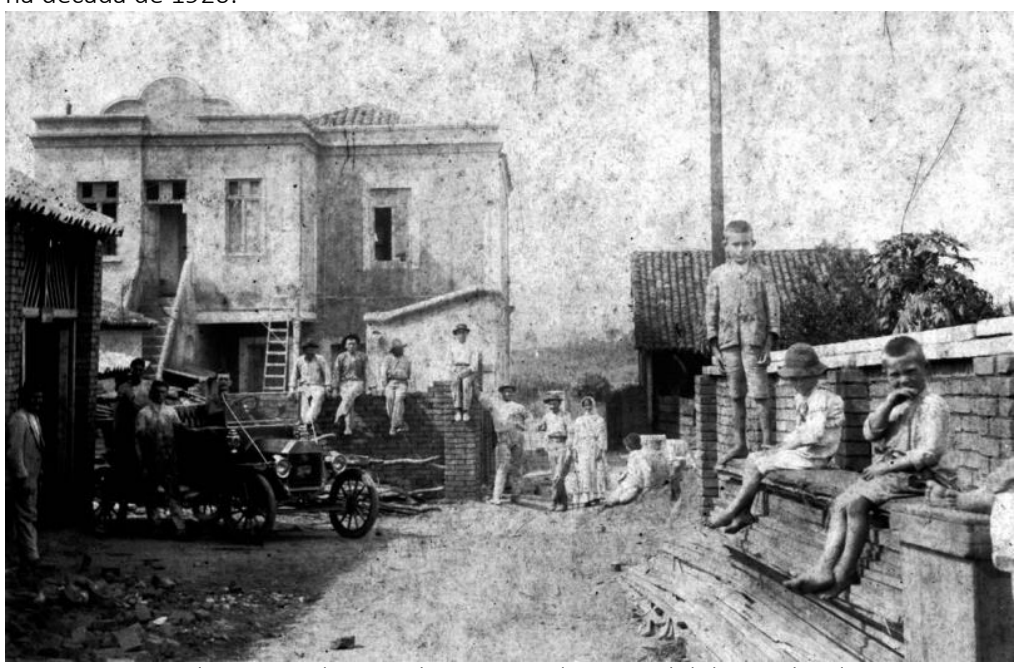

Fonte: Arquivo do Centro da Memória Rio-Pardense Rodolpho José Del Guerra. Fotografia de Celestin Detinne.

Figura 155: Pintura interna do Casarão do Artese.

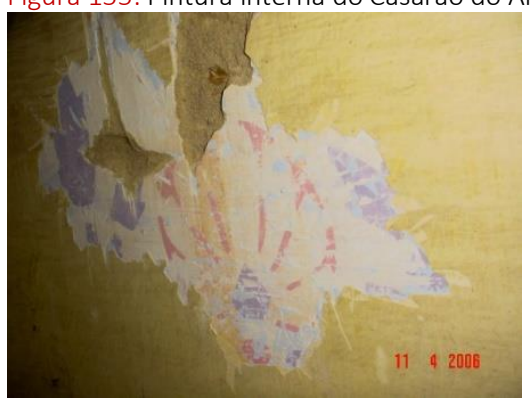

Fonte: Autor desconhecido (2006).

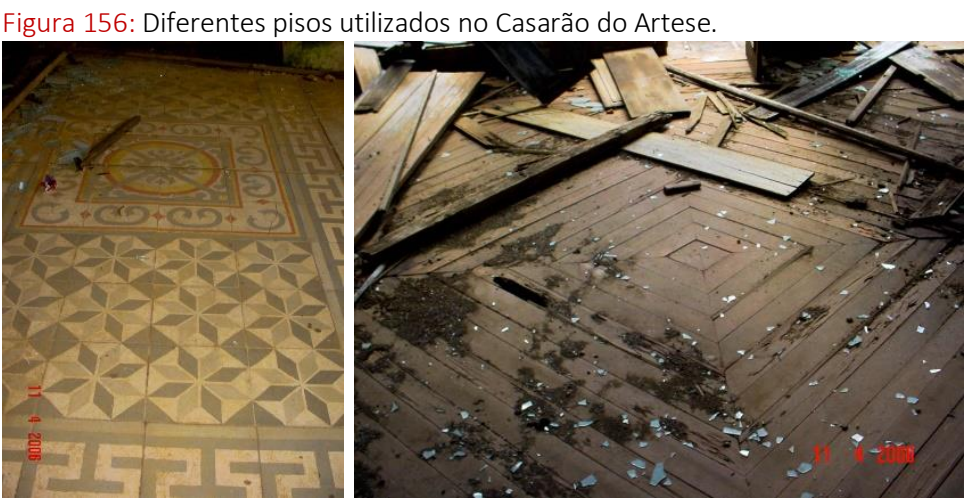

Fonte: Autor desconhecido (2006).
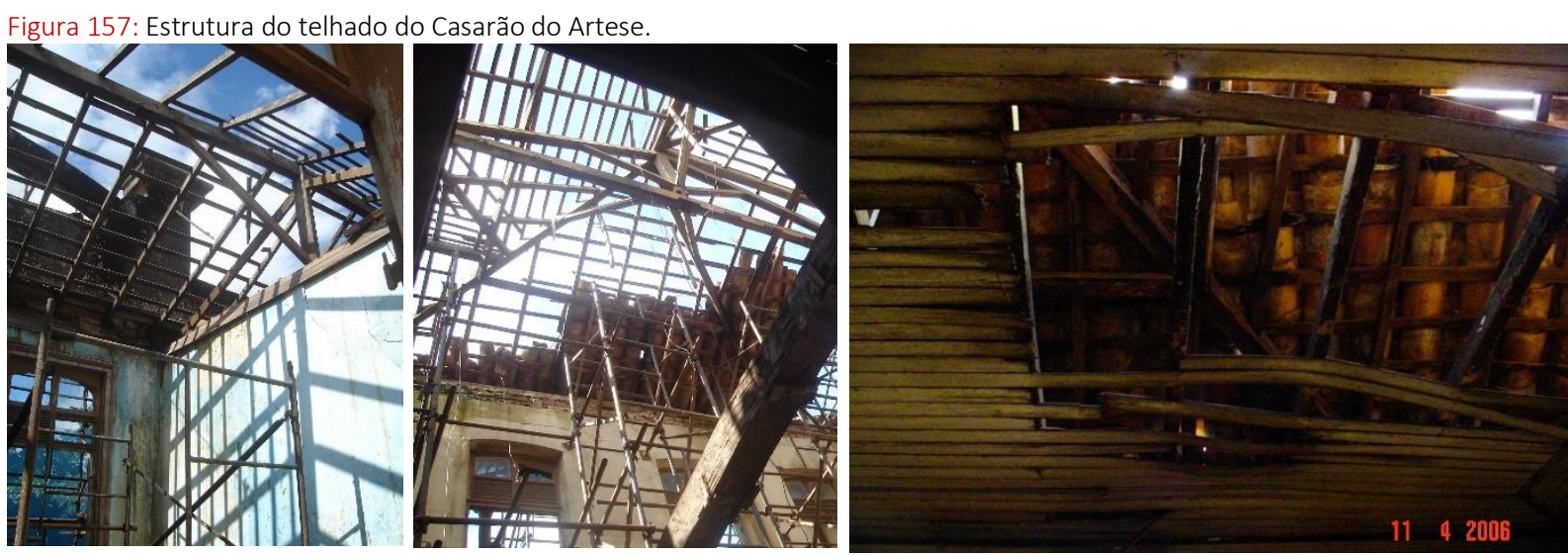

Fonte: Autor desconhecido (2006). 
Figura 158: Diferentes desenhos de forro no Casarão do Artese.
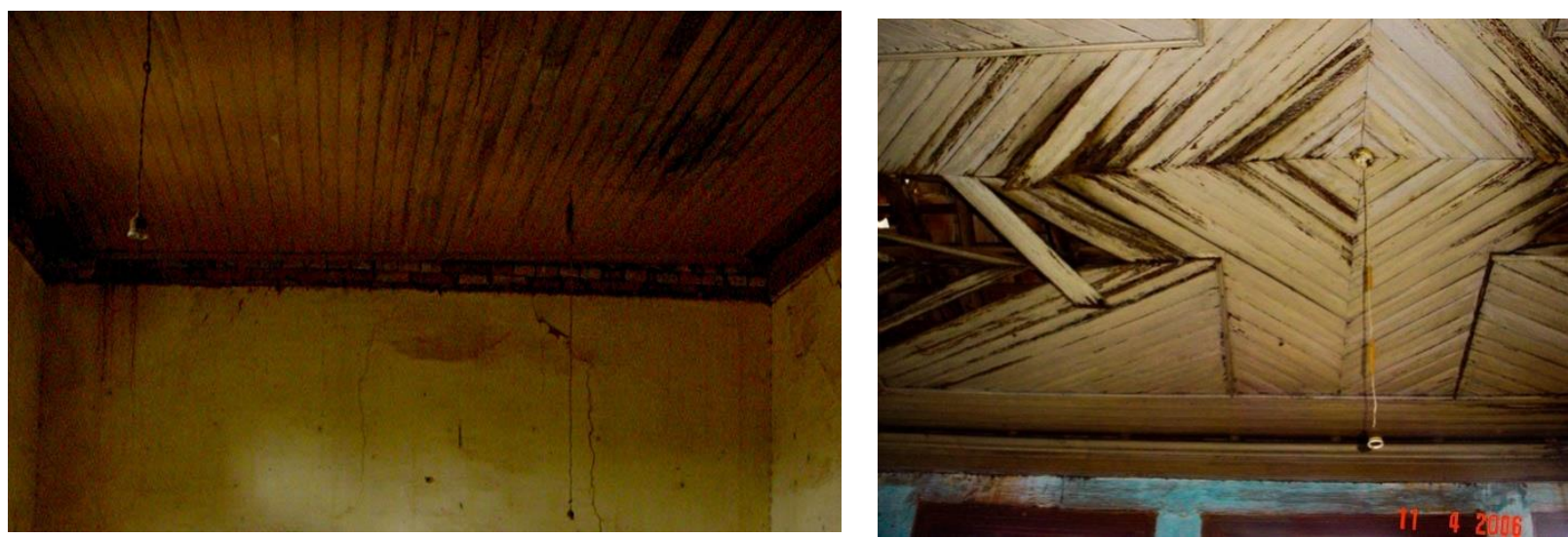

Fonte: Autor desconhecido (2006).

As características apreendidas através da análise da edificação em termos estéticos, decorativos e estruturais nos permitiu perceber o domínio que Artese tinha dos artefatos, demonstrado também nas residências vizinhas (Praça Barão do Rio Branco, 142 e 182) ao Casarão. Apesar de em ambas o ornato aparecer como elemento de caracterização e qualificação do edifício, a residência de Dante Artese apresentava motivos clássicos em maior presença como pilastras, capitéis que remetem à ordem coríntia, cimalha, ático e régulas (Figura 159), estes percebidos também na edificação da família Landini, mas com maior acentuação na decoração em bossagens e uso de linhas retas horizontais e verticais (Figura 160), enquanto na moradia de número 182 Artese introduziu elementos ornamentais do estilo art nouveau e também de inspiração greco-romana (Figura 161).

Figura 159: Detalhe da fachada da moradia de Dante Artese.

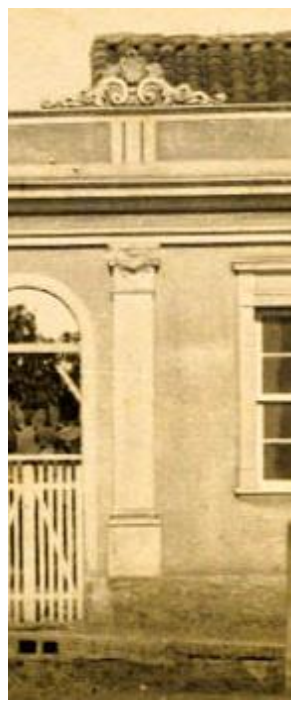

Figura 160: Fachada atual do edifício de uso misto da família Landini na Rua Treze de Maio, 152.

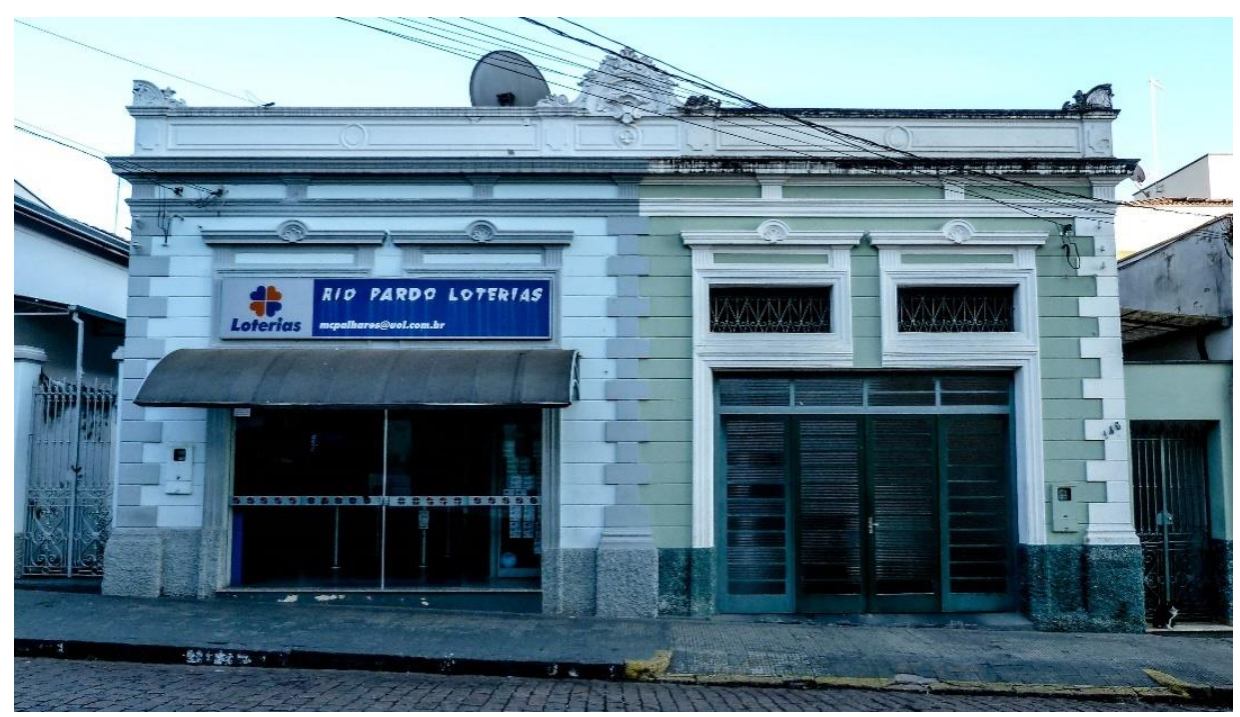

Fonte: Arquivo do Centro da Memória Rio-Pardense Rodolpho José Del Guerra e acervo pessoal da autora (2016). 
Figura 161: Detalhe dos ornamentos da fachada da moradia localizada na Praça Barão do Rio Branco, 182.

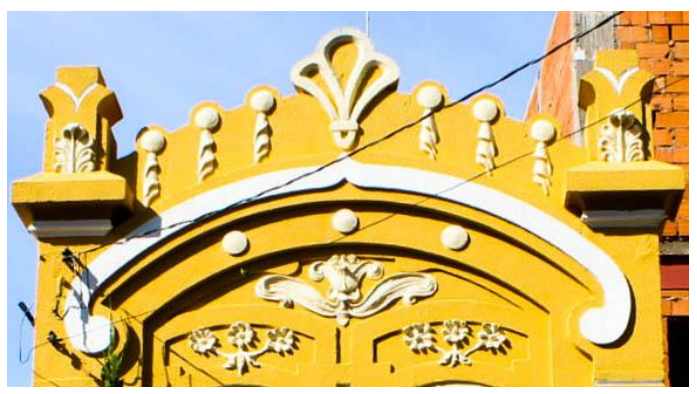

Fonte: Acervo pessoal da autora (2017).

Ao tratar das residências paulistanas, Solange Lima (2008, p. 180) levantou a possibilidade de adequação das preferências decorativas a um padrão de gosto mais conservador do cliente. Dessa maneira, sem descartar as soluções classicizantes, introduziram inovações do estilo art nouveau, por exemplo, como ocorreu com a produção de Artese. A autora (LIMA, S., 2008) afirma ainda a possibilidade de citar inúmeras residências paulistanas, como a moradia localizada na Rua Canuto do Val (Figura 162), no Bairro de Santa Cecília, que muito se assemelha às edificações construídas por Artese. Na Figura 163 e Figura 164 podemos perceber no desenho que compõe as aberturas que ambas remetem àquelas também encontradas nos projetos de Felisberto Ranzini ${ }^{169}$ com elementos inspirados no estilo art nouveau. São janelas aximezas arqueadas superiormente, tendo ao centro a profusão de elementos de inspiração floreal e ladeadas por pilastras.

Detalhes das esquadrias da fachada principal evidenciando os ornamentos.

Figura 162: Residência na Rua Canuto do Val, Bairro de Santa Cecília, São Paulo.

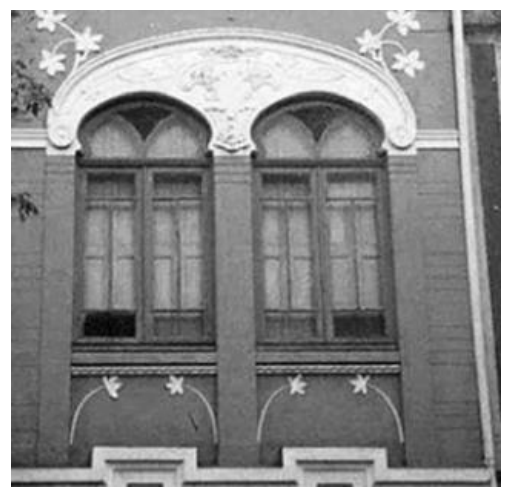

Fonte: LIMA, S., 2008.
Figura 163: Residências na Praça XV de Novembro, 42, São José do Rio Pardo.

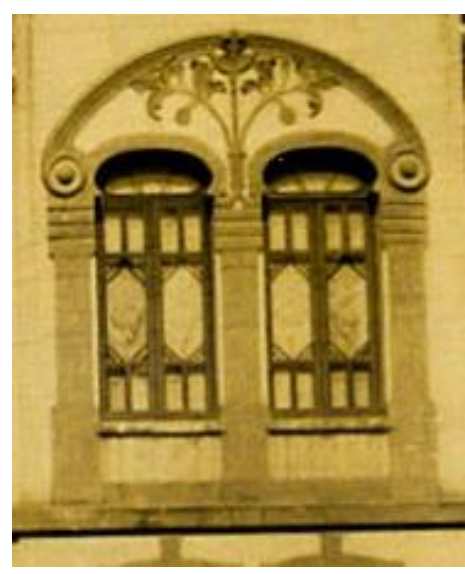

Fonte: Arquivo do Centro da Memória Rio-Pardense Rodolpho José Del Guerra.
Figura 164: Residência na Praça Barão do Rio Branco, 182, São José do Rio Pardo.

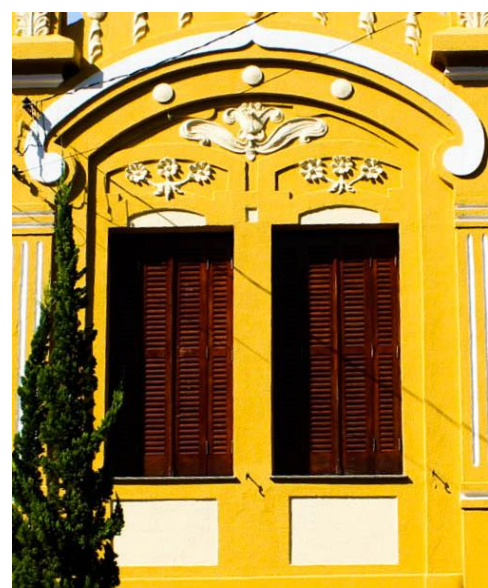

Fonte: Acervo pessoal da autora (2017).

\footnotetext{
169 Felisberto Ranzini foi um italiano que atuou ativamente como arquiteto sem diploma na cidade de São Paulo. O historiador Waldir Salvadore se deteve em descrever e analisar a produção de Ranzini bem como o contexto histórico e estético de sua atuação, procurando abordar as expressivas variantes do ecletismo paulista, sendo o "estilo florentino" o mais incisivo. Para saber mais, ver Italiano e nosso: Felisberto Ranzini e o "estilo florentino" (SALVADORE, 2015).
} 
A exemplo do que foi dito por Lima, S. (2008), duas edificações construídas por Artese conjugam elementos classicizantes com aqueles do estilo art nouveau, evidenciando, assim, uma prática eclética, são elas: a moradia da família Bingoletto (ver Figura 144 na página 183) e a residência de Beatriz Cristina Granado do Prado edificada em 1918 na Avenida Independência esquina com a Rua Costa Machado, e o já analisado Casarão do Artese. Ambos os edifícios apresentam contraste entre as linhas curvas e retas com a profusão decorativa. Contraste que se acentua na platibanda, como é possível observar no projeto arquitetônico ${ }^{170}$ da moradia de Beatriz (Figura 165).
Figura 165: Reprodução do projeto arquitetônico da moradia de Beatriz Cristina Granado do Prado na Avenida Independência, 05.

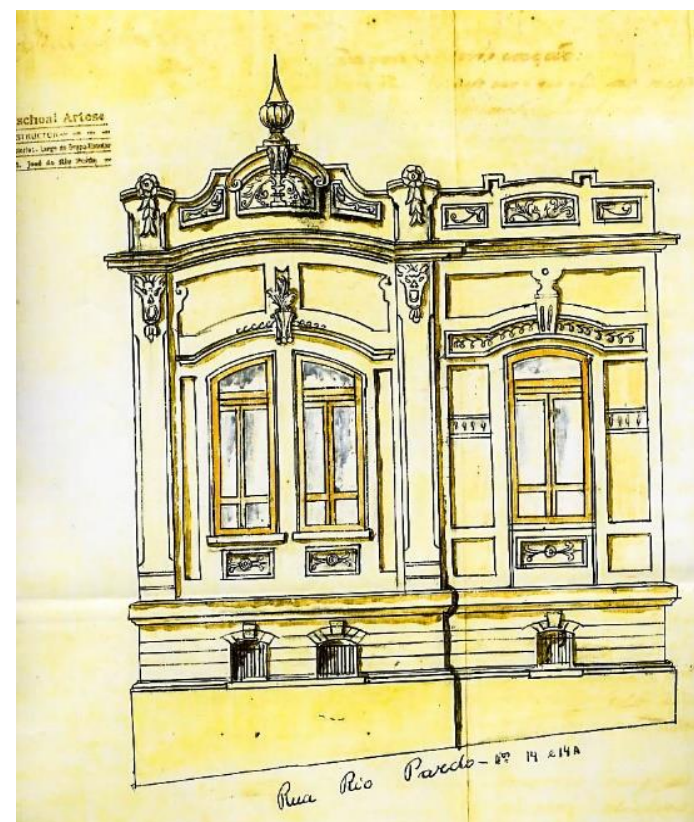

Fonte: Conselho de Defesa e Estudos do Patrimônio Histórico, Artístico e Cultural de São José do Rio Pardo.

Distintamente da composição formal adotada nas outras edificações, nessa residência Artese optou pela secção da fachada marcada por pilastras, dando origem a módulos que se diferenciam pelo requinte, por exemplo, a presença do pináculo (Figura 166) e do ático da parede chanfrada ostentando ao centro uma coroa de folhas com a data da respectiva construção, 1918 (Figura 167).

Figura 166: Pináculo da residência de Beatriz Cristina Granado do Prado.

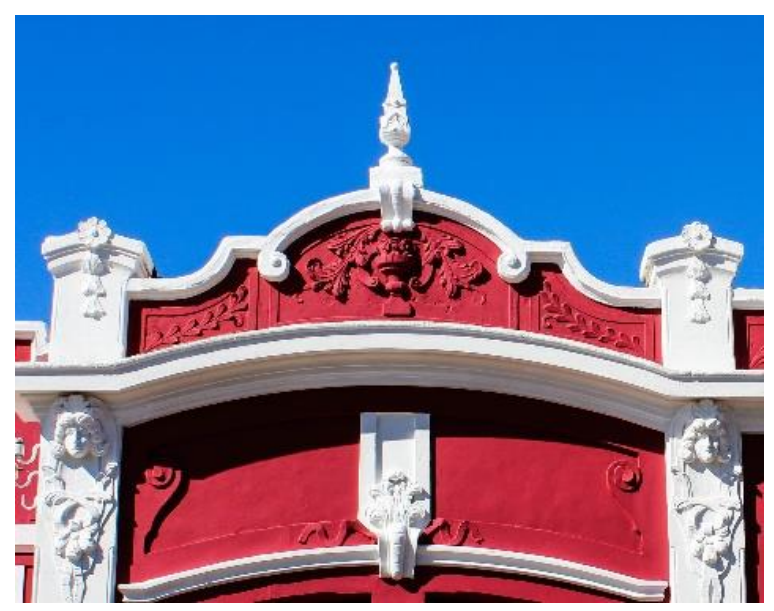

Fonte: Acervo pessoal da autora (2017).
Figura 167: Ático da fachada da residência de Beatriz Cristina Granado do Prado onde se lê a data 1918.

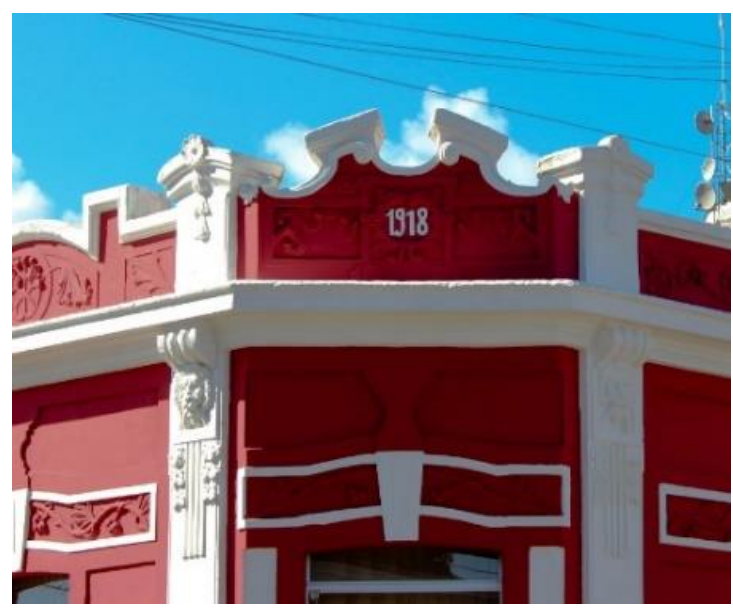

Fonte: Acervo pessoal da autora (2017)

\footnotetext{
${ }^{170}$ A execução do embasamento da edificação não seguiu fielmente o projeto, como podemos observar na página 192.
} 
Já na residência localizada na Rua Francisco Glicério, 546 (ver Figura 145 na página 183), Artese optou por uma fachada mais sóbria com composição marcada por elementos simplificados combinando formas geométricas retilíneas e curvas, mísulas em tríglifo apoiando uma cimalha bastante saliente, uma sequência ritmada de aberturas e elementos decorativos estritamente simétricos, assim como na edificação da Rua Treze de Maio, 152, e na Praça XV de Novembro, 42. Como nos outros edifícios, neste a platibanda também esteve presente, mas nessa o ático em arco abatido apresenta elementos zoomórficos, como é possível perceber na Figura 168.

E, igualmente a ornamentação aplicada nas fachadas com referenciais classicizantes e floreais, os gradis e portões utilizados nas obras de Artese apresentavam curvaturas, sinuosidades, motivos do gênero natureza ou mesmo a combinação destes com a pura geometrização, comprovando a preocupação que este construtor tinha inclusive com a serralheria artística, os quais estão adiante representados (Figura 169) através de desenhos produzidos a partir de fotografias e levantamento métrico. Neles foram utilizados o ferro forjado e fundido, sobretudo nos portões, gradis, óculos dos porões, mãos francesas e esbeltas colunas ornamentadas que experimentaram soluções floreais, mas tenderam nas últimas produções a geometrização e simplificação de elementos.

Figura 169: Gradis e portas de ferro encontradas nas edificações construídas por Artese.
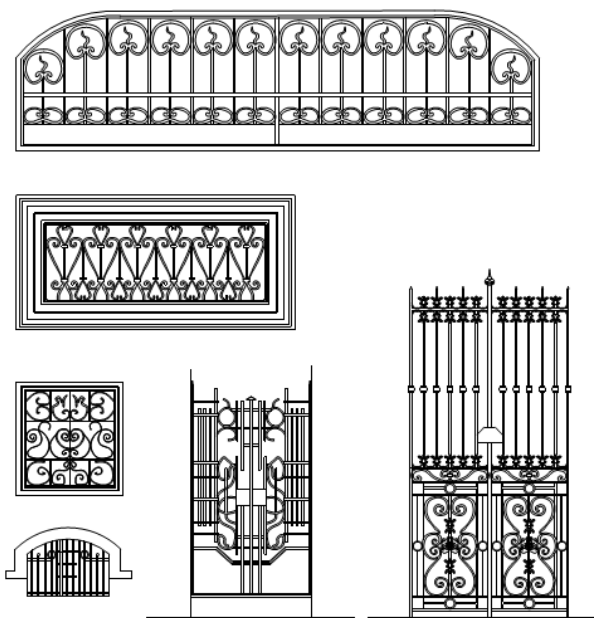

Desenho: Natalia Cappellari de Rezende (2018).
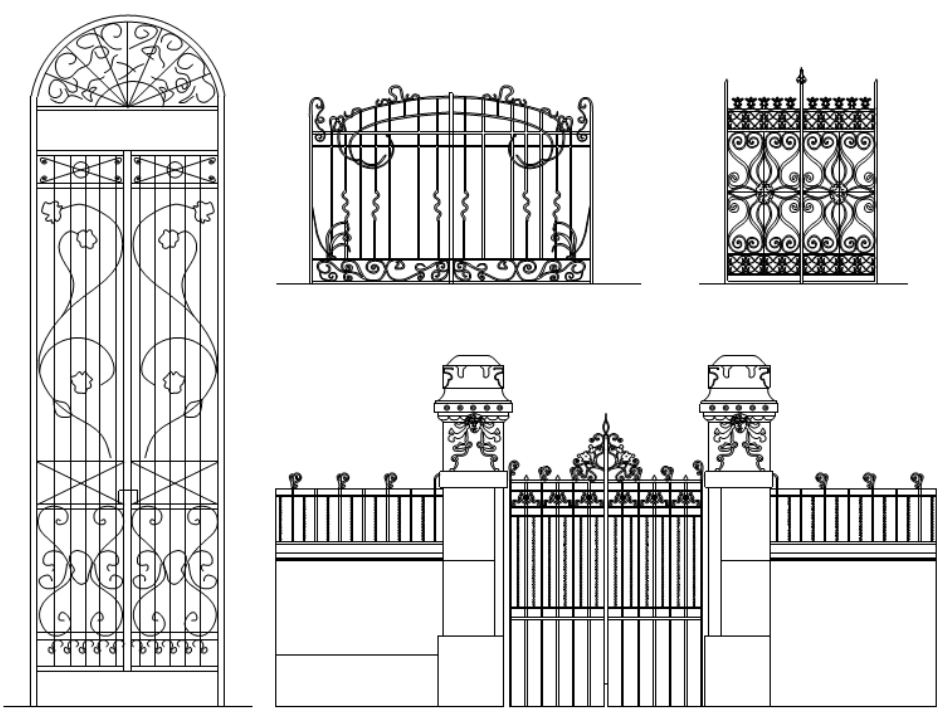
A utilização excessiva do ferro na arquitetura brasileira ocorreu, segundo Costa, C. (2001), em um momento de aspiração ao progresso, à sofisticação e ao enriquecimento, o que levou, sobretudo a classe média na segunda metade do século XIX e início do XX a importar componentes e até estruturas inteiras da Europa. Possivelmente os elementos em ferro utilizados na produção de Artese tenham sido produzidos nas serralherias locais, principalmente os que empregaram ferro forjado, como a "Riopardense" (Figura 170) que executava "todos os serviços concernentes ao officio" e fabricavam qualquer elemento em todos os estilos, como os portões. Certamente as serralherias tinham como inspiração as peças apresentadas nos catálogos da MacFarlane ${ }^{171}$ que, de acordo com Costa, C. (2001), foram largamente divulgados no Brasil.

Figura 170: Anúncio da Serralheria Riopardense.

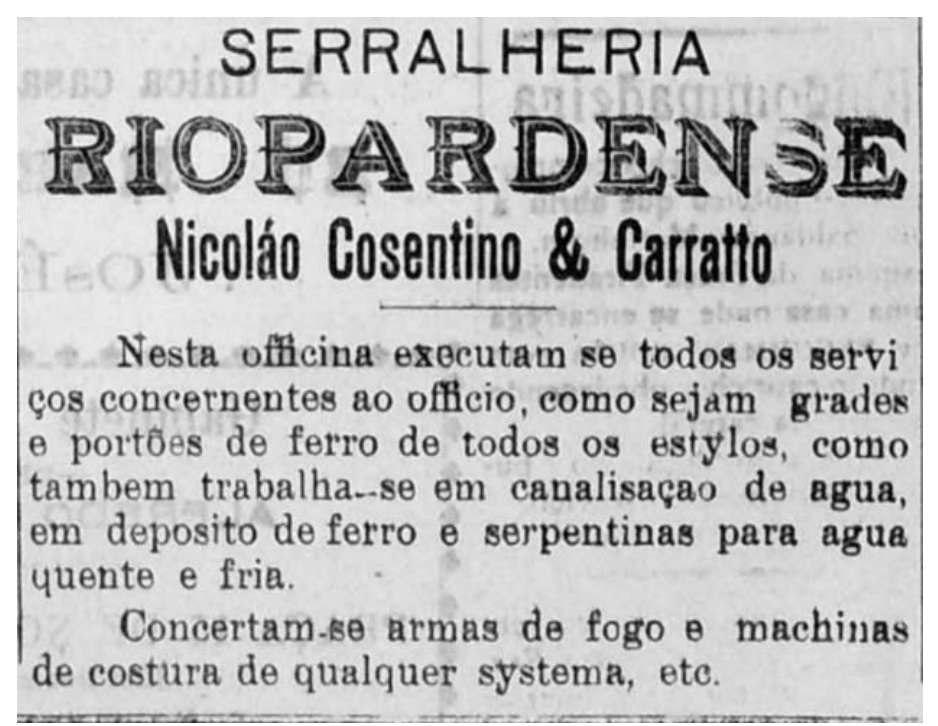

Fonte: Jornal O Rio Pardo, 18 de agosto de 1910

É necessário ainda salientarmos que Paschoal Artese se apropriou e reinterpretou o que estava à disposição no mercado, segundo as suas preferências estilísticas e o gosto do cliente, porque segundo Lemos, C. (1987, p. 70), designa a tolerância, "a licença de criar, de recriar, ou combinar formas, de misturar ornamentações próprias de estilos definidos regionalmente pela Europa afora". Tolerância que deu abertura à participação dos clientes na escolha e criação da composição arquitetônica, significando a inclusão do cidadão comum na cidade que se transformava visualmente. E foi ainda a resposta lógica em um momento de efervescência informativa visual proporcionada pela intensificação e diversificação editorial com manuais, repertórios, enciclopédias, catálogos comerciais e guias de estilos e decorações que promoveram a produção e o consumo, e induziram formas de composição arquitetônica.

É possível afirmar que Paschoal Artese tenha sido um agente representativo desse momento no contexto local, promovendo um saber fazer técnico e formal com novas soluções estéticas, seja em função do seu

\footnotetext{
${ }^{171}$ Segundo Beatriz Kühl (1998, p. 75), a Macfarlane se destacou "pela eficiente e racional produção, em larga escala, tanto de estruturas inteiras, quanto, principalmente, de elementos modulares, que davam origem a inúmeras combinações de edifícios para os mais $v$ ariados fins". Ainda de acordo com essa pesquisadora (KÜHL, 1998), o destaque conquistado pela Macfarlane no Brasil ocorreu em razão do competente sistema de distribuição aliado à versatilidade dos seus produtos. 
vínculo com a Europa, mais precisamente a Itália, da erudição adquirida, das novidades apresentadas pelo mercado ou mesmo em conformidade com o que estava sendo produzido nos grandes centros. A dimensão faustosa, a variedade de arranjos compositivos e as combinações espaciais de sua produção estão estreitamente relacionadas ao estabelecimento de tipologias arquitetônicas e intenções plásticas em consonância com o que acontecia em outras cidades, como São Paulo e toda a região de São José do Rio Pardo. Além disso, sua experiência como empreiteiro, construtor, desenhista, professor e promotor de lutas simbólicas demonstra a versatilidade e erudição de um profissional que, no mínimo, nos incomoda constatar esse apagamento ou esquecimento que já era vislumbrado por ele mesmo. Como o próprio Artese fez questão de destacar em seu discurso proferido na Câmara Municipal no dia 30 de dezembro de 1966, quando Ihe foi outorgado o título de Cidadão Rio-pardense.

Antes de agradecer as homenagens que neste momento nos são prestadas, queremos contarIhes, resumidamente, nossa história decorrida nesta cidade. História bem mais amarga do que doce, como a de todo homem norteado por ideais sadias e inimigas de injustiças.

O tom de decepção caracterizou a sua fala desde o início e Artese seguiu o discurso ressaltando as dificuldades enfrentadas e combatidas ao longo da viagem da Itália ao Brasil e qual a situação que encontraram ao chegar a São José do Rio Pardo, causando-lhe ainda mais decepção.

Tínhamos cerca de 15 anos quando aqui chegamos. Viéramos sozinhos, disposto a lutar e vencer, animado que nos sentíamos por espírito jovem e combativo. Já a bordo, tivemos ocasião de demonstrá-lo: quase fomos presos por revoltarmos contra a péssima comida que várias vezes atiramos ao mar em sinal de protesto.

Nessa terra, encontramos o ambiente dos coronéis mandões, perigosos, temíveis por seu séquito de capangas fiéis, boçais e sanguinários.

De início, causou-nos profunda indignação as injustiças praticadas contra o trabalhador da roça, na sua maior parte, imigrantes italianos enganados.

Com teor inconformista, Artese expôs alguns dos mecanismos que foram desenvolvidos para atacar a sua imagem e reputação, como o livro escrito por José Aleixo Irmão.

Não é preciso que lhes contemos como foi a nossa companha em favor do colono desprotegido - Aleixo Irmão fê-lo por nós num livro ${ }^{172}$ pago pelo Governo, editado e profusamente distribuído pela Casa de Euclides [Casa Euclidiana].

Toda fase de nossos primeiros anos aqui passados, alí está escrita e documentada, não para nos dignificar, mas, pelo contrário, para nos desmoralizar e eliminar uns tons vermelhos que segundo ele, puséramos no retrato do grande escritor. Quiseram-no tão somente "verde e amarelo" e, para consegui-lo, tal como se faz com os criminosos, devassaram nossa vida pregressa a fim de nos apontar como mentirosos.

Aleixo Irmão, porém, conseguiu sua ambiciosa projeção literária à custa de nossa desmoralização e dos dinheiros do Estado, deixando para o Diretor e Editor da Euclidiana Distribuidora também, algumas boas vantagens ...

Mas ainda assim, seguiu o discurso ressaltando o trabalho realizado com ajuda de outros italianos e intelectuais, amigos de Euclides da Cunha, na defesa do trabalhador.

Voltamos a afirmar: foi com o auxílio dos amigos e intelectuais que rodeavam Euclides [Euclides da Cunha], que fundamos aqui, o Clube Filhos do Trabalho, ou "Filhos da Candinha", como foi alcunhado pelos nossos inimigos. Com tal medida procuramos congregar, amparar,

\footnotetext{
${ }^{172}$ Artese se refere ao livro escrito por José Aleixo Irmão, intitulado Euclides da Cunha e o Socialismo de 1960.
} 
defender o trabalhador, pleiteando-lhe as reinvindicações para tirá-lo da condição de escravo em que se achava.

Seu posicionamento político e social, que foi externado também através dos jornais, combatendo políticos e fazendeiros, acabou colocando a vida de Artese e de sua família em risco.

foi nessa ocasião que surgiu o "O Proletário", órgão de ideias avançadas, defensor da classe operária, famoso pela sua missão corajosa. O bem proporcionado neste terreno, não só nos custaram difamações, processos, mas também por várias vezes, colocou nossa vida em perigo Datam dessa época o início das comemorações do $1^{\circ}$ de maio, ousadia que nos pôs na cadeia, naqueles tempos, em que uma alvorada com o Hino ao Trabalho, era coisa proibida, subversiva.

Seguiu o discurso expondo os trabalhos realizados, como o Jardim Artístico construído no local do antigo cemitério que foi aterrado com material retirado da Praça Barão do Rio Branco, diminuindo o desnível que havia entre a Rua Francisquinho Dias e a Rua Treze de Maio, além de fechar uma grota que impedia o prolongamento desta última. As pretenções para o Jardim eram muitas, o que incluiu a importação de estátuas italianas e fontes ornamentais da capital paulista, além da contratação do paisagista João Dierberger. Mas assim como eram muitas as pretenções, eram também os obstáculos impostos às suas realizações.

Arrefecidos os roubos da mocidade, encaminhamos nossos esforços para a senda do progresso e bem estar público.

Passamos a trabalhar incansavelmente para o desenvolvimento da cidade. Promovemos quermesses a fim de concluir obras do interesse público que se achavam paralisadas por falta de verba; incrementados a abertura de novas ruas para as quais chegamos a ceder terreno nosso; ruas que desejávamos ver abundantes, extensas, desimpedidas, em defesa das quais, sempre protestos solenemente, quando algum prefeito tacanho, ou chefe político retrógrado as trancavam, atravessando-lhe grandes prédios no caminho, como que proibindo que o progresso fosse mais adiante ...

Certa ocasião sonhamos dotar a cidade de um lindo jardim [...] já bem dentro do perímetro urbano, havia um velho cemitério cercado de paredões derruídos, tétrico, em completo abandono: pasto para animais que eram tidos como assombrações. [...] Restos humanos foram transladados; melhoramos uma praça desaterrando-a [atual Praça Barão do Rio Branco] e conquistamos outra - a do cemitério - aterrando uma enorme grota que, além de inutilizá-la pela metade, interrompia o curso de uma rua vizinha [atual Rua Treze de Maio]; encomendamos estátuas no estrangeiro, e fontes ornamentais na Capital do Estado; contraímos também muitas dívidas que nos desorganizaram para sempre a vida econômica, somente com vistas à realidade desse sonho.

Durante mais de 30 anos conservamos às nossas expensas esse jardim com suas obras incompletas, hostilizadas pela política, depredadas por crianças e adultos; de sonho que era, nossa infeliz iniciativa converteu-se em atroz pesadelo. Longe de ser encontrado um acordo ou auxílio por parte das administrações que se sucederam, só tivemos delas uma guerra aberta, rancorosa.

Artese destacou ainda como ocorreu a posse do Jardim por parte do poder público local e sua consequente demolição. Fim semelhante teve o Monumento da Independência, destruído antes mesmo de ser finalizada a sua obra. Em contraposição à conquista da construção de um Sanatório para Tuberculosos na cidade vizinha, Divinolândia, e à instalação de escolas de grau médio, após a campanha iniciada através do seu jornal Resenha. Por fim, Artese encerra seu discurso dizendo que 
nada do que pretendemos construir, ficou de pé. Nosso esforço foi rejeitado naquilo que pretendêramos deixar ligado o nosso nome. Nossa obra, além de recusada, foi impiedosamente arrasada [...] Enfim, de tudo quanto aqui nos aconteceu, de uma coisa estamos certos: o chão rio-pardense, nossa próxima morada, em que quase setenta anos caminhamos, agora, com pernas mal-firmes, tateando-o com uma bengaja, nunca se riu, nem gozou de nossos fracassos, porque sabe do amor com que nele norteamos os nossos passos, induzido sempre pela melhor de nossas intenções. E, isto, nos consola!

Inegavelmente Artese foi um profissional que marcou presença na cidade, mas infelizmente os conflitos gerados foram preponderantes a ponto de levar à destruição de parte de suas obras. Todavia, muitos exemplares ainda existentes nos permitiram analisar sua produção e afirmar sua inegável importância para o estabelecimento do ecletismo em São José do Rio Pardo no início do século XX. 


\subsection{As moradias urbanas construídas entre os anos de 1903 e 1917}

Como vem sendo possível perceber desde o item anterior deste capítulo, o crescimento demográfico riopardense entre os anos de 1903 e 1917 contribuiu para estimular o desenvolvimento urbano em vários aspectos e exigiu da administração pública o comprometimento com a ampliação dos instrumentos reguladores da atividade edificativa. A paisagem da área central (Figura 171), ocupada majoritariamente por residências, sofreu mudanças consideráveis decorridas da implementação de infraestrutura, sobretudo no que tange às redes de água e esgoto e energia elétrica. Tais mudanças colaboraram para alterar significativamente o cotidiano urbano e a organização espacial das edificações, que foram sofisticadas, mantendo-se dentro do gosto eclético, mas com implicações diretas no modo de morar que será discutido ao longo desse item. Sobre isso, as Figura 172 e Figura 173 que retratam parcialmente ruas centrais da cidade, exibem também edificações ecléticas, onde podemos perceber a incorporação das novidades e o refinamento da arquitetura, sobretudo na vista parcial da Rua Treze de Maio. Nesse sentido, ao tratar da produção eclética brasileira, Fabris (1987) e Puppi (1998), entre outros autores, nos dizem que o ecletismo é parte de um contexto de formação da sociedade burguesa, fruto da presença do imigrante, das técnicas construtivas, dos ritmos da moda, da liberdade de escolha e do desejo de participar da modernidade contemporânea. Integra um amplo campo de descobertas em materiais e técnicas facultado por um mercado em desenvolvimento e assegurado pelas condições econômicas que abriu possibilidades à utilização de novas tecnologias. Além do mais, é necessário enfatizar que a incorporação das novidades para atender função e uso também era resultado da promulgação de legislações e posturas, como por exemplo, na exigência da utilização de sistema de calhas e condutores pluviais, acabando por contribuir com as transformações produzidas no período em termos estéticos, de programa e escala. 
Figura 171: Cidade de São José do Rio Pardo na segunda década do século XX.

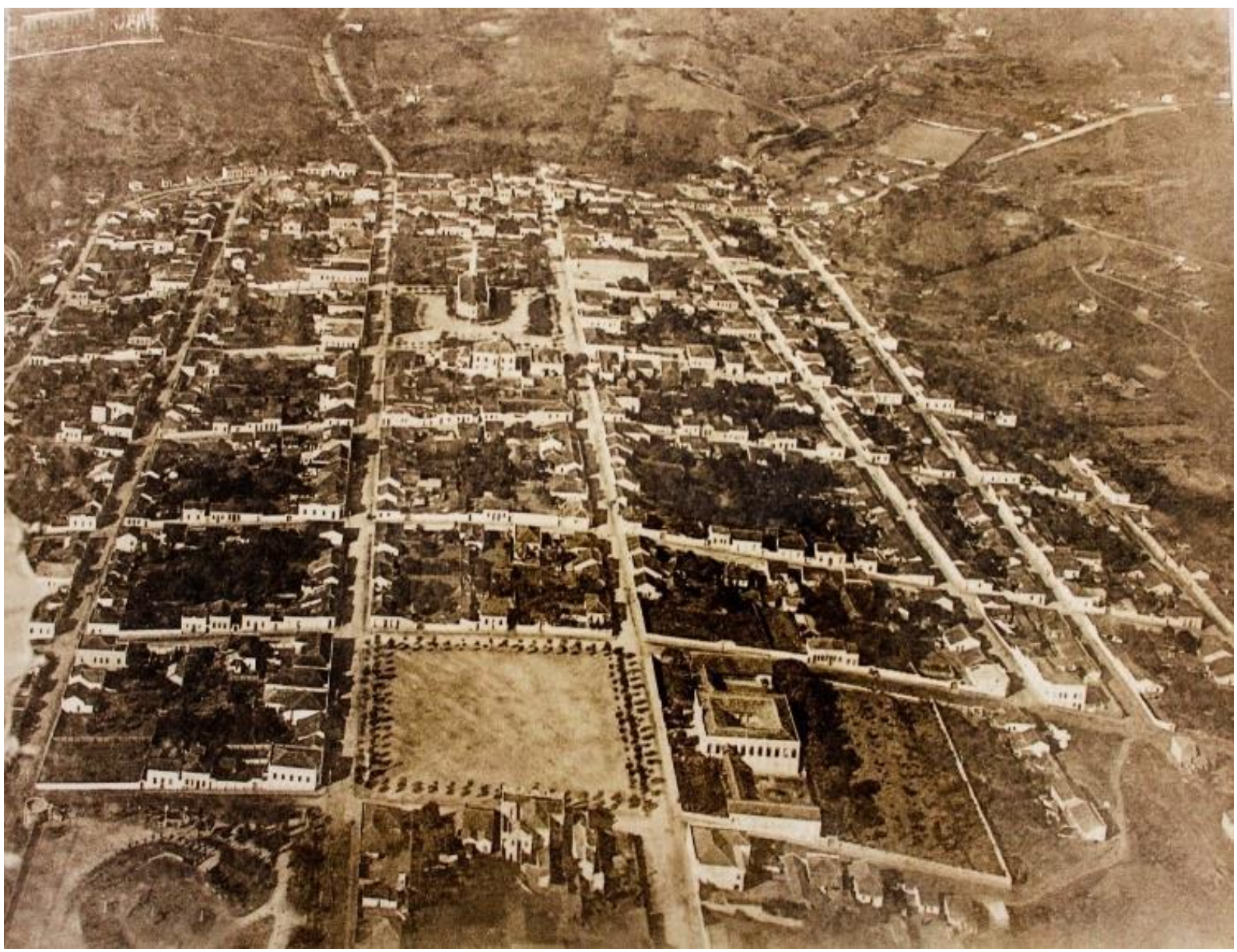

Fonte: Arquivo do Centro da Memória Rio-Pardense Rodolpho José Del Guerra. Fotografia de Innocencio Vilhegas.

Figura 172: Vista parcial da Rua Francisco Glicério, início do século XX.

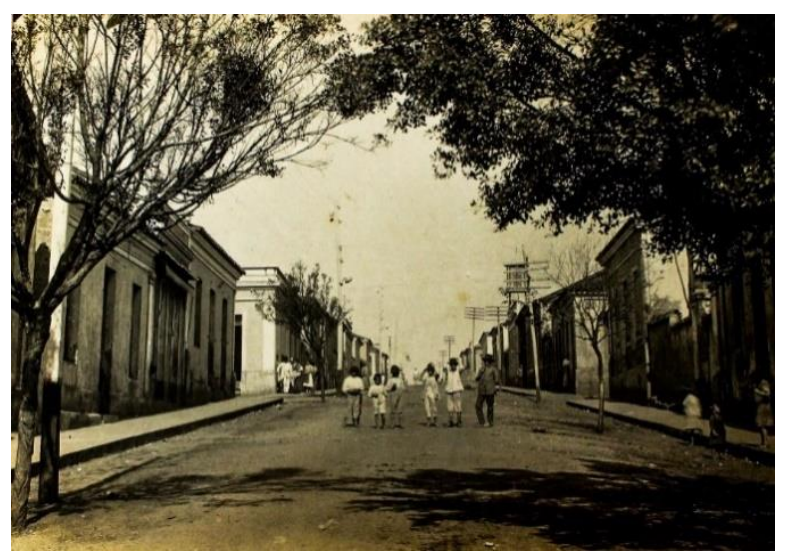

Fonte: Arquivo do Centro da Memória Rio-Pardense Rodolpho José Del Guerra. Fotografia de Celestin Detinne.
Figura 173: Vista parcial da Rua Treze de Maio, 1910.

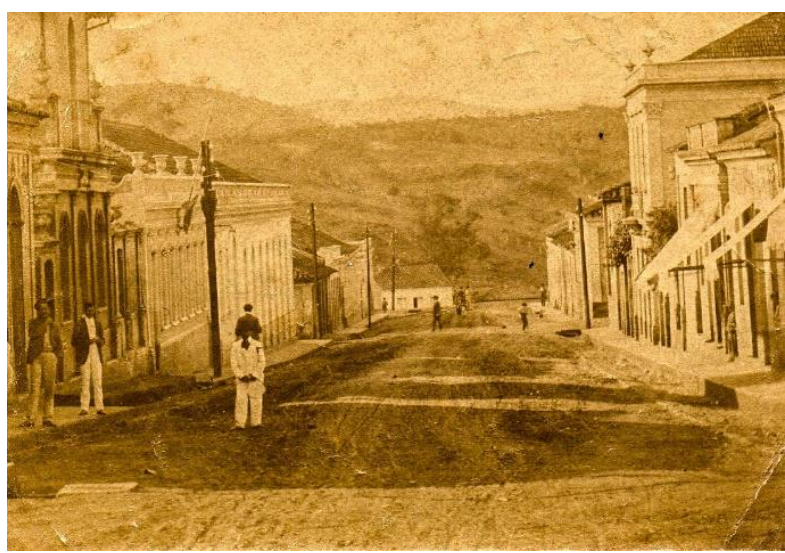

Fonte: Arquivo do Centro da Memória Rio-Pardense Rodolpho José Del Guerra. Fotografia de Celestin Detinne.

Desse modo, e perseguindo o objetivo desta dissertação que é identificar e analisar a produção residencial rio-pardense da passagem do século XIX e início do século XX, discutiremos as características, mudanças e permanências da moradia construída entre os anos de 1903 e 1917 a exemplo da residência da família 
Ribeiro Nogueira na Praça Barão do Rio Branco, 22 (Figura 174); da moradia da Rua Francisco Glicério esquina com a Praça Barão do Rio Branco, 831 (Figura 175); moradia da família Penna na Rua João Gabriel Ribeiro, 382 (Figura 176); e moradia de Dante Artese na Praça Barão do Rio Branco, 142 (Figura 177). Outras moradias também serão analisadas a partir de alguns aspectos, tais como implantação, platibanda, esquadrias e mobiliário, como a residência de Antônio Ribeiro Nogueira (conhecido como Nhô Ribeiro ${ }^{173}$ ) na Praça XV de Novembro esquina com a Rua Marechal Floriano, 17; e o chalé de Oliveiros Fernandes Pinheiro na Rua Francisquinho Dias esquina com a Praça XV de Novembro. A Figura 178 mostra a localização dessas edificações, todas nas proximidades das duas principais praças, na área mais valorizada da cidade ${ }^{174}$, e em terrenos amplos. Por isso enfatizamos que apesar dessa arquitetura ser representativa desse período, ter sido registrada em fotografias, mencionadas em publicações de Rodolpho Del Guerra e ter resistido ao tempo, ela pertenceu a uma parcela minoritária da população.

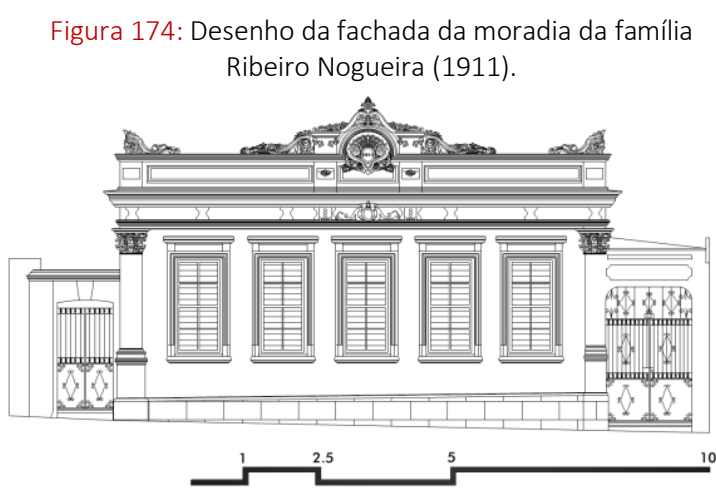

Desenho: Natalia Cappellari de Rezende (2016) a partir de levantamento in loco.
Figura 175: Desenho da fachada da moradia na Rua Francisco Glicério esquina com a Praça Barão do Rio Branco, 831 (década de 1910).

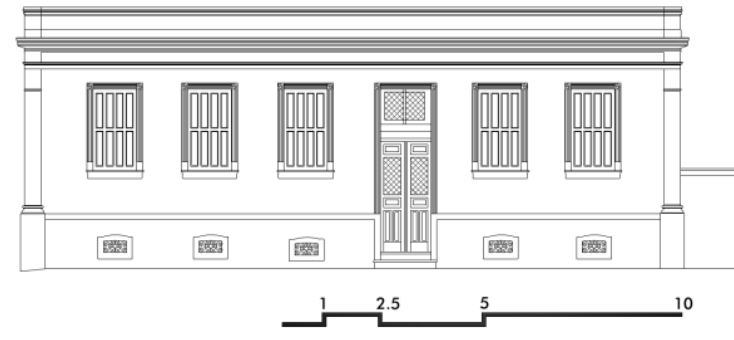

Desenho: Natalia Cappellari de Rezende (2016) a partir de levantamento in loco.
Figura 176: Desenho da fachada da moradia da família Penna (década de 1900).

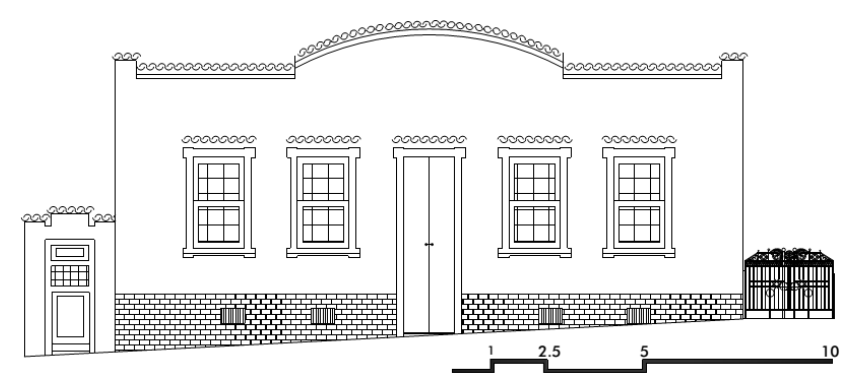

Desenho: Natalia Cappellari de Rezende (2016) a partir de fotografias antigas e levantamento in loco.
Figura 177: Desenho da fachada da moradia de Dante Artese (década de 1910).

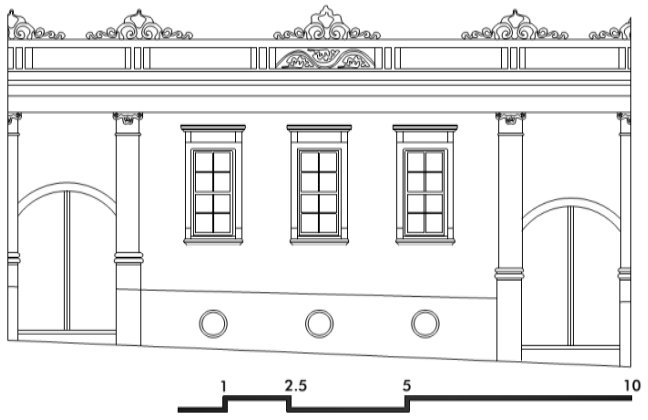

Fonte: Arquivo Público da Secretaria de Obras de São José do Rio Pardo (1948, P70). Desenho: Natalia Cappellari de Rezende (2016) a partir de fotografias antigas e o projeto de reforma (1948).

\footnotetext{
${ }^{173}$ Antônio Ribeiro Nogueira, conhecido como Nhô Ribeiro, veio para São Sebastião da Grama, distrito de São José do Rio Pardo, ainda criança. Segundo Del Guerra (2001), Nhô Ribeiro dedicou-se à lavoura, constituindo fazendas na região. Participou da política como vereador e presidente da Câmara Municipal entre os anos de 1920 e 1925 . Faleceu em 1951 aos 79 anos.

${ }^{174}$ As áreas que compreendem as Praças XV de Novembro e Barão do Rio Branco tornaram-se as mais valorizadas do Centro Histórico desde a construção da igreja Matriz na primeira, e a construção do grupo escolar na segunda.
} 
Figura 178: Localização dos exemplares de moradias analisados neste item do capítulo.

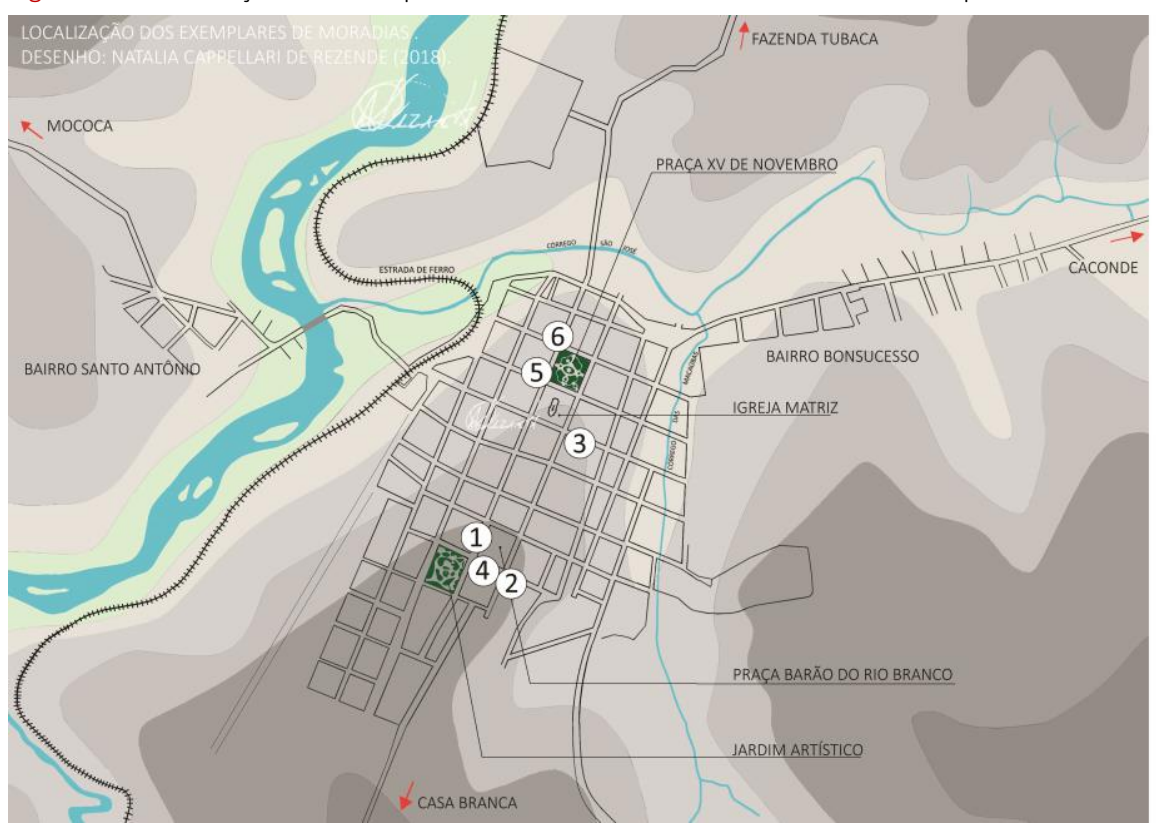

(1) FAMÍLIA RIBEIRO NOGUEIRA

(2) RUA FRANCISCO GLICÉRIO ESQUINA COM A PRAÇA BARÃO DO RIO BRANCO, 831

(3) FAMÍLIA PENNA

(4) DANTE ARTESE

(5) NHÔ RIBEIRO

(6) OLIVEIROS FERNANDES PINHEIRO

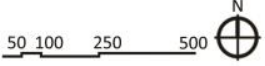

Desenho: Natalia Cappellari de Rezende (2018) com base em dados históricos e cartografia disponibilizada pela Secretaria de Obras de São José do Rio Pardo.

Na passagem do século XIX para o século XX ainda não existia um rigoroso dispositivo de controle da prática edificativa. É fato que desde 1887 quando foi publicado o primeiro Código de Posturas já havia intenção por parte do governo municipal da disciplinarização da construção civil rio-pardense, mas foi com a publicação do Código em 1903 que ficou estabelecido que todo proprietário que quisesse construir dentro do perímetro urbano deveria apresentar um requerimento de licença ao Intendente Municipal, como discutido no item anterior deste capítulo. Além disso, a licença só seria concedida mediante o atendimento das prescrições do Código Sanitário Estadual e 1894:

Art. 16 - A Municipalidade, por seus agentes e em observância a hygiene e segurança das obras e ao embellezamento da cidade, terá fiscalização sobre toda a obra ou edificação que se fizer dentro do perímetro urbano.

Art. 17 - Sem o preenchimento das condições impostas pelo Código Sanitário do Estado, especialmente as do Cap. II, sobre as habitações em geral - e sem a imprescindível licença do Intendente Municipal, nenhuma obra, construção, reconstrução ou concerto far-se-á dentro do perímetro urbano. O infractor será multado em $50 \$ 000$ sendo a execução da obra suspensa immediatamente sob pena de desobediência (art 233) e do emprego da força pública, até ser exhibida a licença. (CÓDIGO DE POSTURAS, 1903, p. 05-06).

Substancialmente, o conteúdo dos requerimentos de licença para construir era a localização do terreno e a função do edifício conforme determinado no artigo 18 e como mostra o exemplar (Figura 179) encontrado no Arquivo da Hemeroteca Jornalista Paschoal Artese. De modo bastante curioso, este requerimento trata da construção de uma "pequena casa" no Bairro Euclides da Cunha ${ }^{175}$ que era considerado área suburbana, e, portanto, estava excluído da necessidade de licenças. A falta de definições legais que determinassem os

\footnotetext{
${ }^{175}$ No dia 08 de maio de 1916 foi aprovada a mudança da denominação do Bairro Santo Antônio para Bairro Euclides da Cunha. Todavia, alguns meses depois a decisão foi revertida e o bairro voltou a ser denominado de Santo Antônio. Apesar da nova decisão foi recorrente encontrarmos projetos arquitetônicos e alvarás de licenças da década de 1920 e 1930 com a denominação equivocada.
} 
perímetros urbano, suburbano e rural de São José do Rio Pardo acarretou em incertezas da própria população que temendo repressões acabou por submeter requerimentos de licenças à prefeitura. Apesar da exigência dessa documentação, a não obrigatoriedade de apresentação de planta e fachada ${ }^{176}$ faz com que esse material acabe por se mostrar insuficiente para questionarmos a organização interna, a ocupação do espaço e a estética dos edifícios.

Figura 179: Requerimento de licença para construir de 1916.

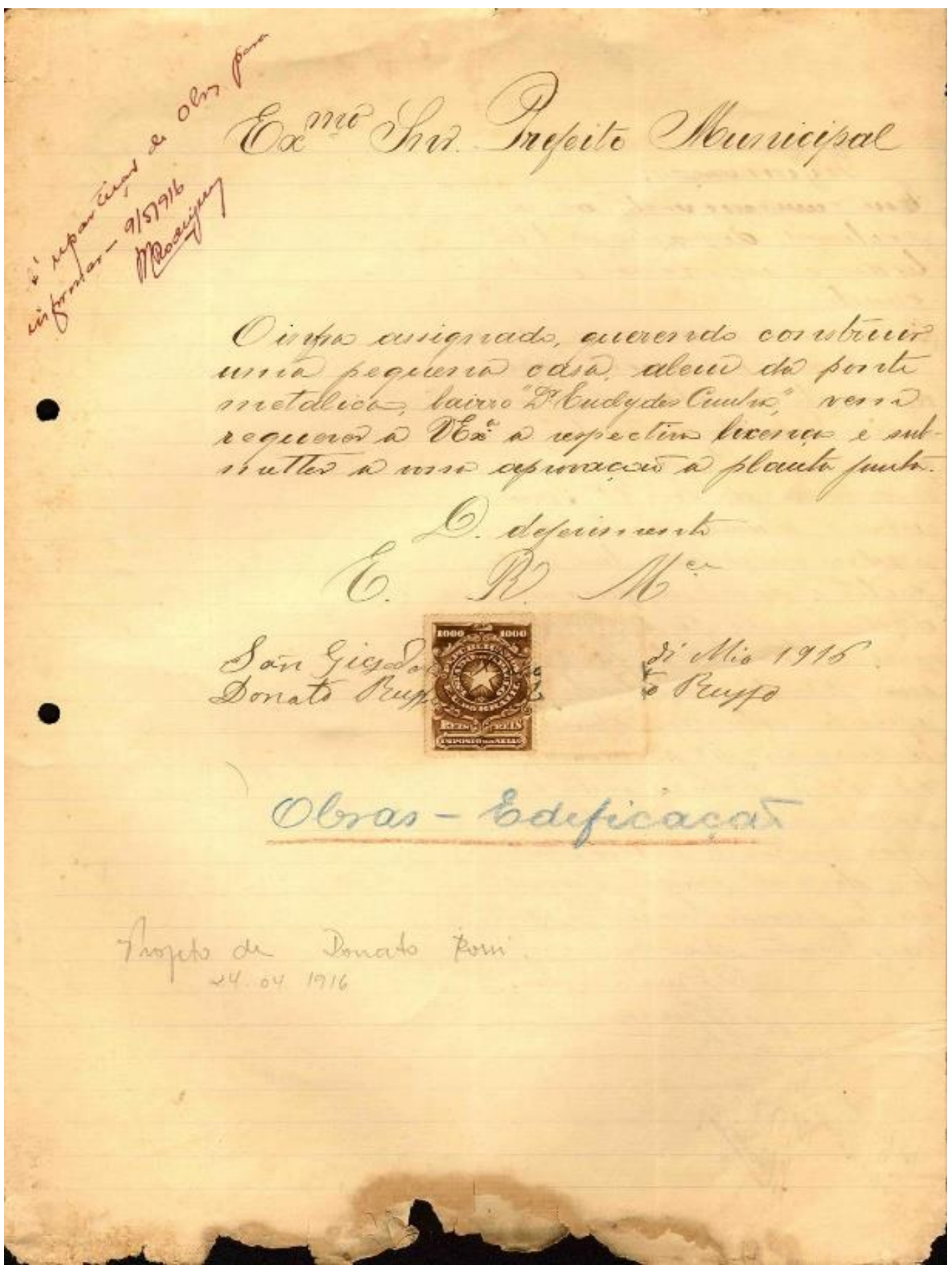

Fonte: Hemeroteca Jornalista Paschoal Artese.

\footnotetext{
${ }^{176}$ A necessidade de aprovação de projeto passou a ser uma exigência somente em 1918 quando o terceiro Código de Posturas entrou em vigor, o qual será melhor analisado no terceiro capítulo desta dissertação.
} 
Dentre os nossos critérios de análise, observamos que a implantação é um dos aspectos que influiu diretamente na busca de higiene e salubridade, predominando nesse período um novo esquema que distanciou a edificação dos limites laterais do lote, criando um corredor descoberto. Todavia, a exigência de afastamentos não era uma determinação das posturas municipais de 1903, o que nos leva a considerar outras virtudes para a recorrência dessa manifestação que não a legislação. Podemos destacar a condição socioeconômica apresentada anteriormente; as facilidades advindas com o transporte ferroviário que barateou e impulsionou o comércio de materiais construtivos e o fluxo de pessoas, e permitiu o contato com outros mercados; os serviços de água e esgoto e também de energia elétrica que proporcionaram a abertura da casa para o exterior; e as discussões e determinações do Código Sanitário Estadual de 1894 sobre as condições mínimas de higiene e salubridade que deliberou a existência de um corredor lateral e descoberto que permitisse a iluminação direta dos cômodos e a troca de ar. Todos esses fatores contribuíram para que a arquitetura residencial rio-pardense se desprendesse dos limites do lote e se tornasse significativa na paisagem urbana do início do século XX, adequando-se mesmo que tardiamente às descrições feitas por autores como Reis Filho (2011) e Lemos, C. (1999) ao tratarem das inovações no esquema de implantação que ocorreu na segunda metade do século XIX. Segundo Reis Filho (2011), a nova implantação que conservava o edifício sobre o alinhamento da via pública, mas o afastava dos limites laterais, rompeu com as tradições e exigiu modificações nos tipos de lotes, como constatado em São José do Rio Pardo e que já acontecia em São Paulo, como verificado por Debenedetti e Salmoni (1981) e Lemos, C. (1989a). Para Reis Filho (2011), tais transformações ocorreram muito em consequência também do desprestígio dos hábitos tradicionais, da valorização de novos costumes e novas sensibilidades acerca da privacidade, higiene e conforto (CORREIA, 2004), e ainda sob forte inspiração do ecletismo e do apoio dos imigrantes. Pautado nessas questões, destacamos na Figura 180 alguns exemplares do novo esquema de implantação das moradias construídas em São José do Rio Pardo no início do século XX que passaram a conviver com aquelas tradicionais, apresentando configurações que se tornaram recorrentes a partir de então: alinhamento da edificação sobre o limite do lote com o passeio público, e liberação da construção em relação a um dos limites laterais, criando um corredor. Como exemplo, o Casarão do Artese onde o acesso lateral é da garagem e serviços, com possibilidades de adentrar a edificação pelos fundos, além da sequência de portas na fachada principal; a residência da Rua Francisco Glicério, 546, isolada lateralmente dos limites do lote, sendo o acesso pela esquerda para automóveis e pela direita a entrada social; e o sobrado de esquina, construído em 1908, em que o acesso social ocorre pela Rua Júlio Mesquita enquanto o de serviços acontece pela Rua Treze de Maio. É importante enfatizar que essas situações foram possíveis também devido a configuração e dimensão do lote, sendo que nas edificações analisadas que usufruíam de recuos laterais, a extensão mínima frontal encontrada foi de 17,10 metros. 

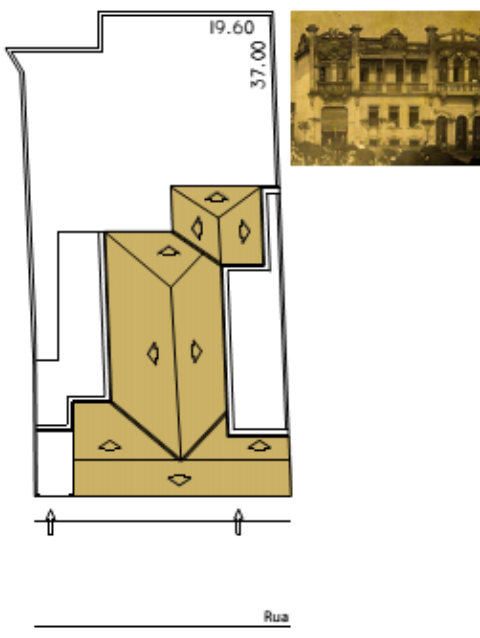

CASARÃO DO ARTESE

$\ddot{\theta}$
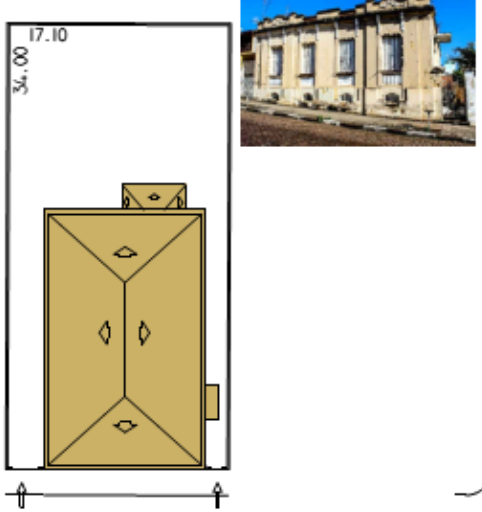

Rua

RESIDÉNCIA RUA FRANCISCO GLICÉRIO, 546

$Q^{2}$

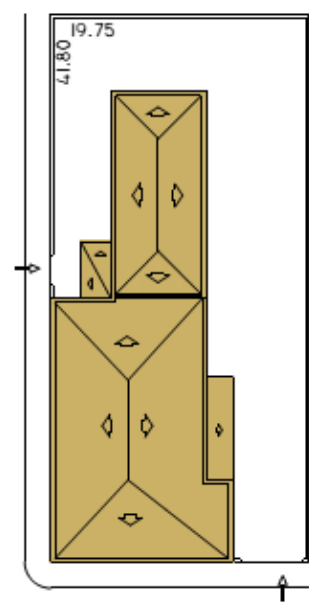

Rua

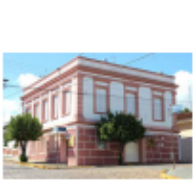

$1 \underbrace{2.55} \quad 1^{0} \square$ Edificaçăo $=$ Limite do lote $\uparrow$ Acesso

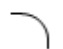

EDIFICAČ̃O NA RUA TREZE DE MAIO COM RUA JÚLO MESQUITA, 603

Desenho: Natalia Cappellari de Rezende (2018).

Em se tratando da tipologia tradicional, verificamos a existência com maior frequência das residências menores em tamanho e com mais simplicidade em termos estéticos construídas nos limites laterais e frontal do lote. Contudo, também percebemos em nosso levantamento edificações mais sofisticadas, como a moradia da família Bingoletto, construída na década de 1910, ainda que apresente apenas a parte frontal da edificação nesses limites (ver Figura 148 na página 188).

Verificamos ainda, mas em menor número, edificações totalmente isoladas dos limites do lote, como o chalé do Sr. Oliveiros Fernandes Pinheiro ${ }^{177}$ (Figura 181), construído na esquina da Rua Francisquinho Dias com a Praça XV de Novembro (demolido em 1957). Sobre esse modo de implantação Homem (1996) explica que a proposta de isolar a casa estava diretamente relacionada à noção de intimidade que se associou à de conforto, logo, os recuos laterais e frontal possibilitavam o isolamento dos moradores ao mesmo tempo que dificultava a audição dos ruídos e a propagação dos odores da rua. Contudo e em contraposição às inúmeras moradias isoladas no lote construídas em São Paulo no final do século XIX e início do século XX ${ }^{178}$, constatamos em nosso levantamento de campo que seu aparecimento em São José do Rio Pardo ocorreu com maior frequência em meados da década de 1920 quando serão incorporados outros beneficiamentos e legislações que irão modificar os arranjos compositivos. Desse modo e atestando o adiantamento do chalé do Sr. Pinheiro, ressaltamos mais uma vez as permanências e mudanças que ocorreram no esquema de

\footnotetext{
177 O coronel Oliveiros Fernandes Pinheiro (1857-1936) era natural de Lavras do Funil - MG quando ainda criança se mudou com a família para Mococa onde possuíam terras. Casou-se com Virgínia Dias, filha de Vicente Alves de Araújo Dias e Lucinda Cândida de Jesus. Era fazendeiro, cafeicultor e junto com Honório e Vicente, irmãos de Virgínia, constituiu a sociedade "Dias, Irmãos, Oliveiros e Companhia" que tinha como ramo de atuação comissões de café e outros gêneros (DEL GUERRA, 2001).

${ }^{178}$ Para saber mais sobre essas edificações, ver Homem (1996).
} 
implantação da moradia urbana rio-pardense no início do século XX. Logo, é possível afirmar a coexistência de uma vasta gama de disposição da edificação no terreno em diálogo com a configuração do lote e da paisagem do núcleo urbano desse período, e em consonância com o que estava acontecendo em outras cidades do país.

Figura 181: Desenho da implantação da moradia do Sr. Oliveiros Fernandes Pinheiro.

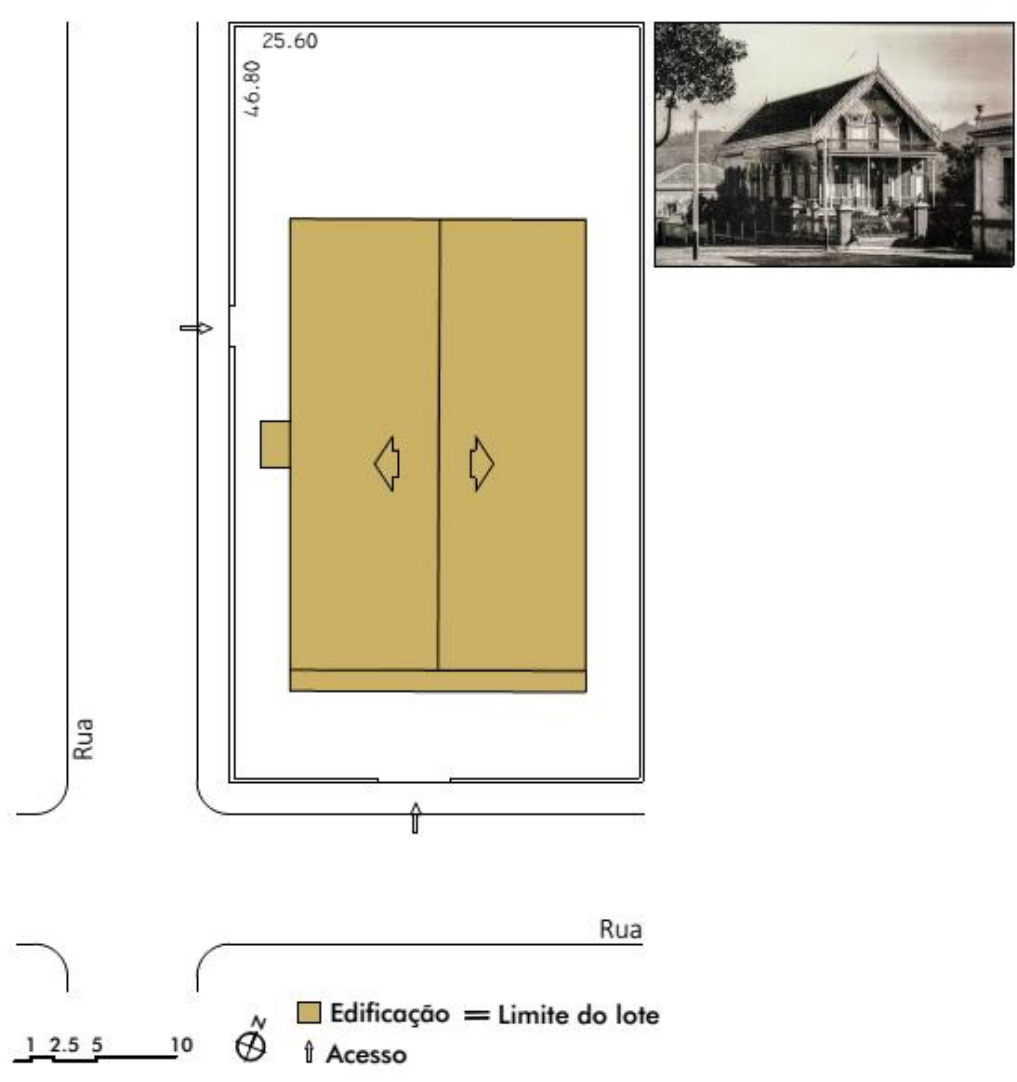

Desenho: Natalia Cappellari de Rezende (2018).

Às alterações introduzidas no esquema de implantação correspondem mudanças na organização espacial interna das edificações. Alguns itens do Código de Posturas de 1903 foram determinantes ao apontar detalhes indispensáveis que contribuíram na definição da arquitetura produzida, como a altura mínima de aberturas que possuíssem folhas que abrissem para fora em edificações construídas no alinhamento e a fixação mínima do pé-direito, como se segue:

Art. 20 - Além das disposições contidas nos arts. 16 e 17, nenhuma casa, no alinhamento das ruas ou praças, poderá ter portas, meias portas, cancellas, ou venezianas, cujas folhas abram para o lado externo; exceptuando-se apenas as venezianas que estiverem collocadas em altura superior a 2,5 metros,

Art. 22 - As casas térreas terão, pelo menos, a altura de 4 metros contados do soalho ao frechal e as portas 2,90 metros de altura, 1,10 de largura, distando symetricamente umas das outras 0,60 metros quando menos. (CÓDIGO DE POSTURAS, 1903, p. 07). 
Embora não estivesse explícito no texto do Código municipal de 1903 o cumprimento da higiene, segurança das obras e embelezamento da cidade, a exigência feita nos artigos 16 e 17 (ver página 201) sobre as determinações do Código Sanitário Estadual de 1894 ocupa essa lacuna, como demonstram a seguir:

Artigo 40. A espessura destas paredes deve ser de 30 centímetros pelo menos.

Artigo 41. As paredes internas deverão ser impermeáveis.

Artigo 43. Os compartimentos do subsolo, ou porões, constituem garantia hygienica para as edificações; mas não deverão servir de habitação.

Artigo 44. O assoalho do andar térreo deve estar separado do solo 50 centímetros, pelo menos.

Artigo 45. Os diferentes andares, até 3, deverão ter a altura mínima de 4 metros; de 3 em deante essa altura será proporcional á largura e altura total do predio e á quantidade de individuos que habitarem cada pavimento, de modo a tocar a cada individuo, em cada andar, o espaço nunca inferior a 14 metros cúbicos livres.

Artigo 46. As alcovas que se destinarem a dormitórios ou permanência constante dos moradores de um predio devem ser prohibidas em absoluto.

Artigo 47. Não devem ser permittidos nas habitações aposentos de dormir tendo menos de 14 metros cubicos livres para cada individuo.

Artigo 48. Todos os compartimentos deverão ter, sempre que fôr possivel, aberturas para o exterior, dando para a rua, jardins ou pateos interiores, de modo a receberem luz directa e diffusa, não devendo ser admissivel luz reflectida sinão excepcionalmente e em aposentos não destinados á permanencia continua dos habitantes ou a dormitorios. (CÓDIGO SANITÁRIO ESTADUAL, 1894, p. 03).

Lemos, C. (1999) diz que apesar da sistematização das exigências do Código Sanitário, a falta de regulamentação deu margens a várias interpretações. Nesse sentido o autor (LEMOS, C., 1999) questionou o controle na aprovação de projeto sobre a condição do artigo 45 que estipula $14 \mathrm{~m}^{3}$ por indivíduo que habitar o pavimento, e analisou a redação dos artigos que tratam da proibição da alcova, os quais dão brechas para a sua existência, desaprovando somente a atividade de dormir e a permanência por tempo prolongado nesse ambiente. O Código Sanitário Estadual continha ainda determinações sobre o agenciamento interno da moradia, como a proibição do acesso direto da latrina ao dormitório (comumente denominado de quarto) e destes para a cozinha, advertência que não foi seguida nem em São Paulo, como apontou Lemos, C. (1999), nem em São José do Rio Pardo como veremos à frente. Apesar dessas questões, Lemos, C. $(1999$, p. 30) ressaltou que o ponto central do Código Sanitário Estadual era "mostrar que as casas deveriam ser secas, ventiladas, iluminadas e fáceis de serem limpas [...]".

As especificações técnicas ligadas direta ou indiretamente às questões pontuadas acima e articuladas com as condições econômicas e socioculturais geraram, ainda que lentamente, modificações nas edificações residenciais construídas no início do século XX, como também na estrutura e costumes locais. Há ainda a produção de manufaturas e a importação de materiais de construção que, aliados a novos conhecimentos técnicos e construtivos passaram a responder aos novos anseios.

De fato, quando aconteceu a liberação da construção em relação aos limites do lote, ao menos um dos lados deu lugar à entrada lateral e descoberta, realizada por meio de escada, portão e gradil de ferro, elemento que passou a ser largamente utilizado, apresentando variedade de soluções que encontramos em 
nosso levantamento e apresentamos na Figura 169, página 193. O ferro apareceu também nas colunas e no guarda-corpo do alpendre, como na moradia de João Gabriel Ribeiro na Rua de mesmo nome, 196, ou ainda de modo mais singelo na moradia da Rua Francisco Glicério, 546, onde a armação, combinado com o gradil do portão, dava sustentação a uma cobertura que protegia a entrada lateral (Figura 183). Ainda sobre o emprego do ferro na arquitetura brasileira, Reis Filho (2011) destacou o simbolismo da sua utilização, sobretudo em elementos junto à rua, o que conferia status, demonstrando a posição social do morador. Certamente, a difusão desse material em São José do Rio Pardo esteja associada à questão colocada por Reis Filho (2011) e também à facilidade de importação através da ferrovia, ou da produção das serralherias locais.

Sob a influência de outros hábitos e costumes, e respaldado na legislação, a tendência foi a abertura dos ambientes para o exterior. Com isso, as velhas casas de corredor central seguido de alcovas, que ainda encontramos em nosso levantamento do início do século XX (Figura 182), foram adaptadas ou substituídas. Correia (2004, p. 29) relaciona ainda a criação das aberturas com a "ideia de luz como fonte de saúde e de efeitos morais". Isso porque a claridade favorecia as "condições de limpeza do ambiente e dos atos nele praticados", indiretamente ligados a ordem e decência. Circunstância fortalecida pela determinação do Código quando do tratamento das dimensões mínimas das aberturas e altura do pé-direito, evidenciando a preocupação com a condição de arejamento, iluminação natural e a moral.

Figura 183: Detalhe do alpendre da moradia de João Gabriel Ribeiro e da casa da Rua Francisco Glicério, 546.
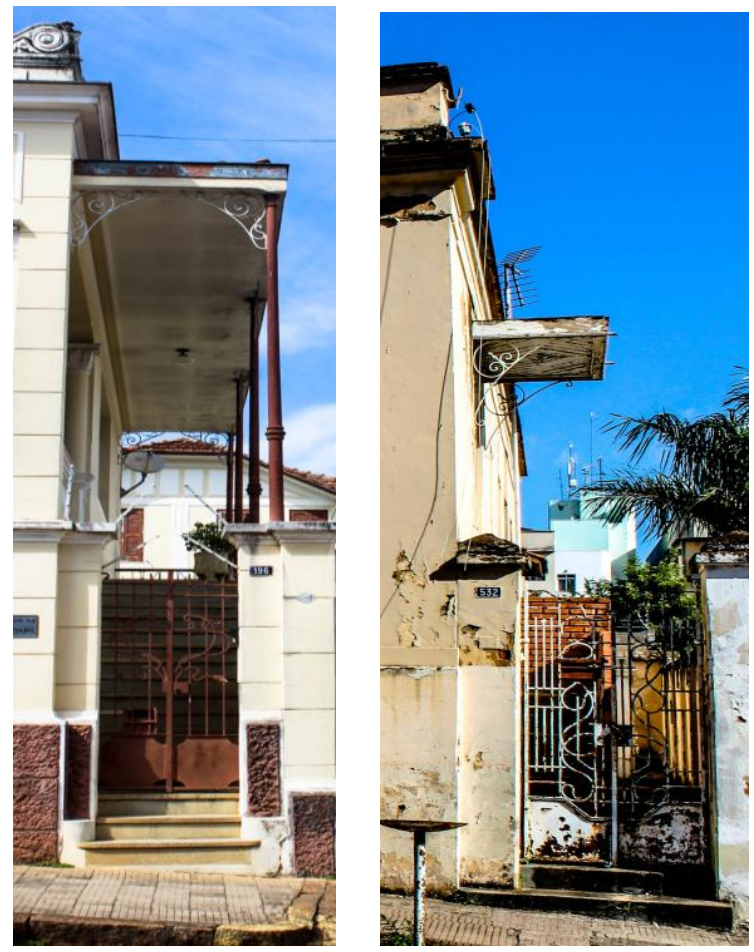

Fonte: Acervo pessoal da autora (2016).
Figura 182: Desenho da planta da moradia do Sr. Luis Martini.

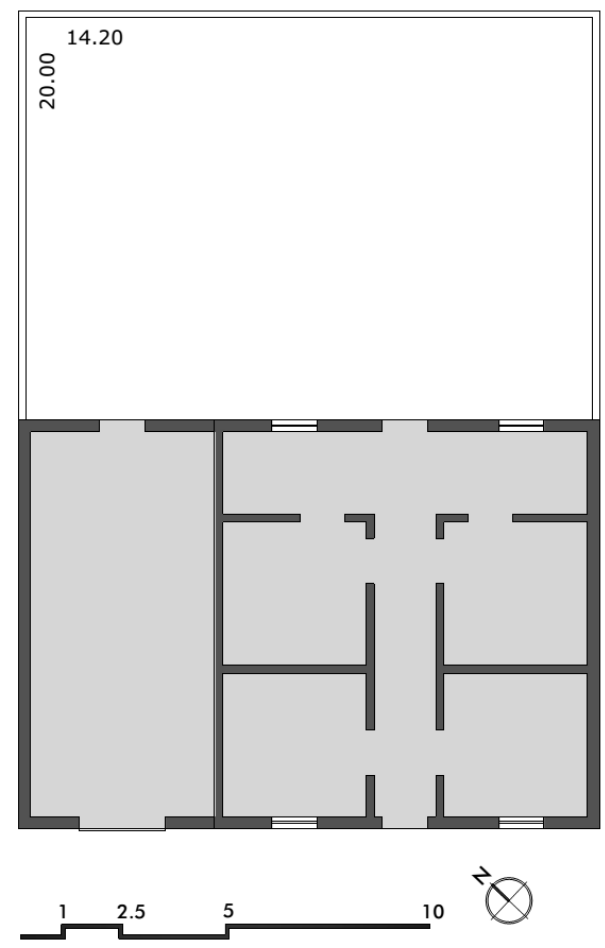

Fonte: Arquivo Público da Secretaria de Obras (1928, P29). Desenho: Natalia Cappellari de Rezende (2018) com base em um projeto de reforma. 
Consequentemente, o agenciamento dos ambientes da casa se alterou, aparecendo uma divisão mais complexa dos cômodos com funções específicas e mais compartimentados, inaugurando uma "nova maneira de morar" (LEMOS, C., 1989b; CORREIA, 2004). A memória de dona Carmém Cecília Trovatto Maschietto sobre a casa onde morou com seus pais na Rua Francisquinho Dias exemplifica o novo programa:

Atrás das vitrines da alfaiataria do meu pai, que escondia a entrada de um corredor, estava instalada a máquina e a mesa de costura da minha mãe, ali ela cortava as peças. Tinha uma ajudante que fazia o trabalho de costura na máquina. Minha mãe fazia toda as roupas da casa. Nada era comprado pronto. (MASCHIETTO, 2016).

A nova conformação da casa reflete em muito a nova configuração social, a importância atribuída à família e à separação de gêneros na sociedade, discutida anteriormente no primeiro capítulo. Sendo o ato de morar uma manifestação de caráter cultural, as transformações sociais em ressonância também com mudança de hábitos, técnicas construtivas, materiais e tecnologias contribuíram para alterar a casa. Desse modo, concordamos com Lemos, C. (1989) ao dizer que

antes de tudo, o ato de morar é uma manifestação de caráter cultural e enquanto as técnicas construtivas e os materiais variam com o progresso, o habitar um espaço, além de manter vínculos com a modernidade também está relacionado com os usos e costumes tradicionais da sociedade. (LEMOS, C., 1989, p. 07).

Ainda sobre a sua moradia, Maschietto nos diz que a entrada acontecia por um

corredor lateral com um portão pequeno porque não tinha carro e era nesse corredor, ao lado de todo o muro, que meu pai plantava muitas margaridas para levar no hospital no dia de finados. Um canteiro enorme de margaridas, depois tinha um tanque [para lavar roupas], depois tinha pitanga, jabuticabeira, goiabeira, pé de manga comum, tinha galinheiro. (MASCHIETTO, 2016).

Apesar da inexistência da obrigatoriedade de jardim no Código de 1903, ele surgiu no distanciamento da edificação com a construção vizinha, exemplificado através da moradia da Sra. Maschietto. E, como descreveu Reis Filho (2011), esse elemento paisagístico se tornou importante para a higiene, pois oferecia possibilidades de purificação do ar, arejamento e iluminação dos ambientes, garantia mais privacidade e conforto aos seus moradores, e enquanto elemento representativo proporcionava beleza, valorizava socialmente a residência e simbolizava a sensibilidade e bom gosto dos ocupantes (CORREIA, 2004). Nas edificações mais luxuosas, o jardim apareceu ocupando uma extensão considerável do grande lote, o que atesta a importância dada a esse elemento paisagístico, como podemos observar na edificação já demolida do Nhô Ribeiro na esquina da Praça XV de Novembro com a Rua Marechal Floriano (Figura 184), e a moradia do Sr. Pinheiro construída isolada no lote, circundada por jardins e gradil de ferro (Figura 185). 

do jardim na década de 1920.
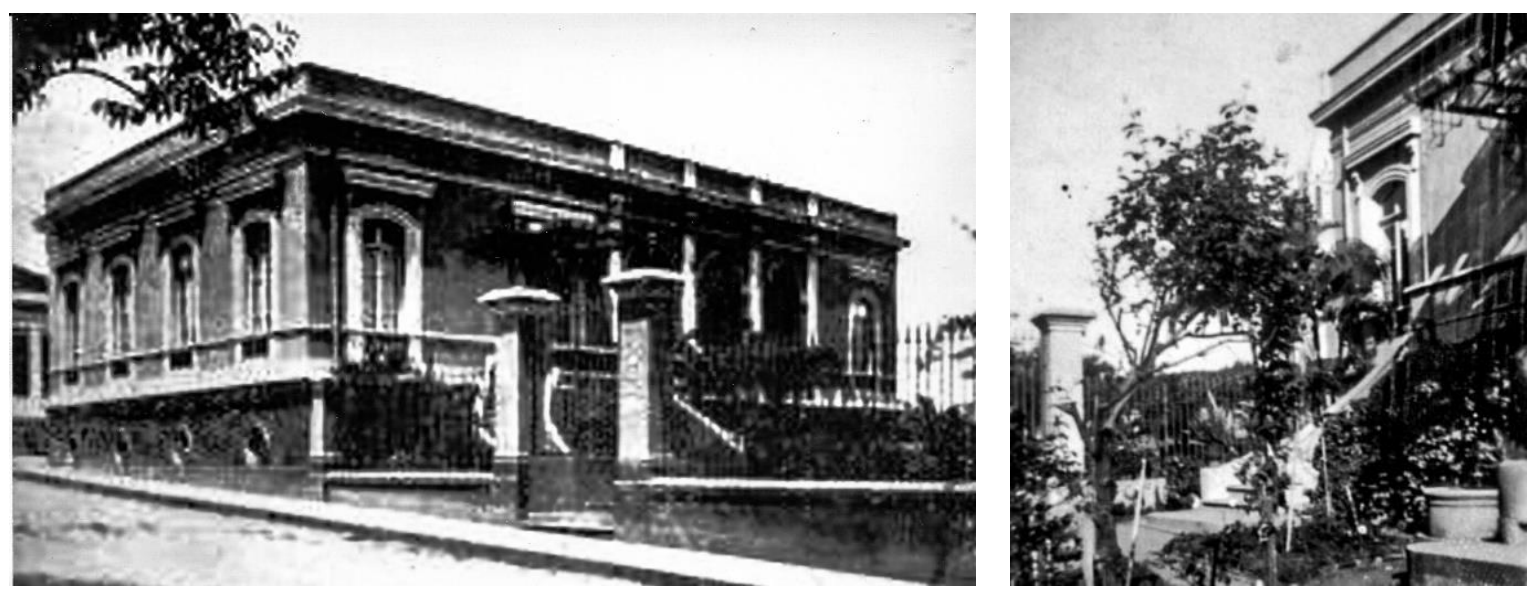

Fonte: Arquivo do Centro da Memória Rio-Pardense Rodolpho José Del Guerra.

Figura 185: Chalé de Oliveiros Fernandes Pinheiro na Rua Francisquinho Dias com a Praça XV de Novembro, década de 1910.

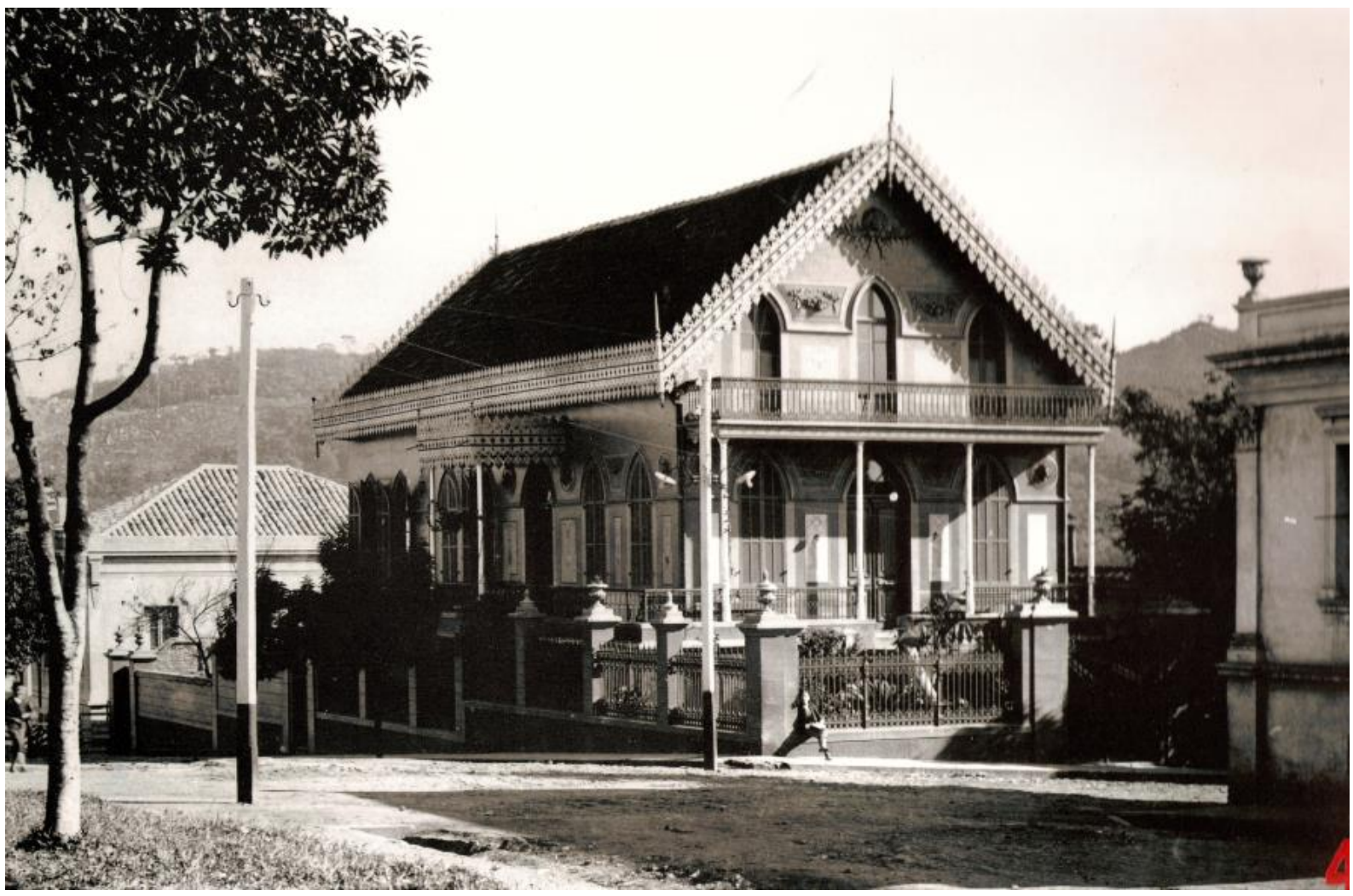

Fonte: Arquivo do Centro da Memória Rio-Pardense Rodolpho José Del Guerra. Fotografia de Innocencio Vilhegas.

Ligado a uma nova sensibilidade e ao desejo de privacidade, a compartimentação das plantas arquitetônicas e a função específica de cada ambiente da casa gerou novos recursos como corredores, escadas e também vestíbulos, como ocorreu na moradia localizada no Largo do Grupo (atual Praça Barão do Rio Branco), 22. O 
proprietário era João Ribeiro Nogueira Sobrinho, conhecido como Zitão ${ }^{179}$. Sua casa, datada de 1911, foi construída no alinhamento do lote com a via pública, mas recuada das construções vizinhas e com porão elevado de 2,25 m para vencer o desnível que existe no terreno para os fundos. Sua entrada principal acontece por um portão que se abre para um pequeno alpendre. Este por sua vez oferece acesso para um corredor lateral externo e descoberto em direção aos fundos da residência e para a sala de visitas. Internamente, um corredor partindo da sala leva aos fundos, permitindo acesso a vários quartos, sala de jantar, cozinha e banheiro, como podemos observar na (Figura 186).

Figura 186: Desenho da planta da moradia da família Ribeiro Nogueira.

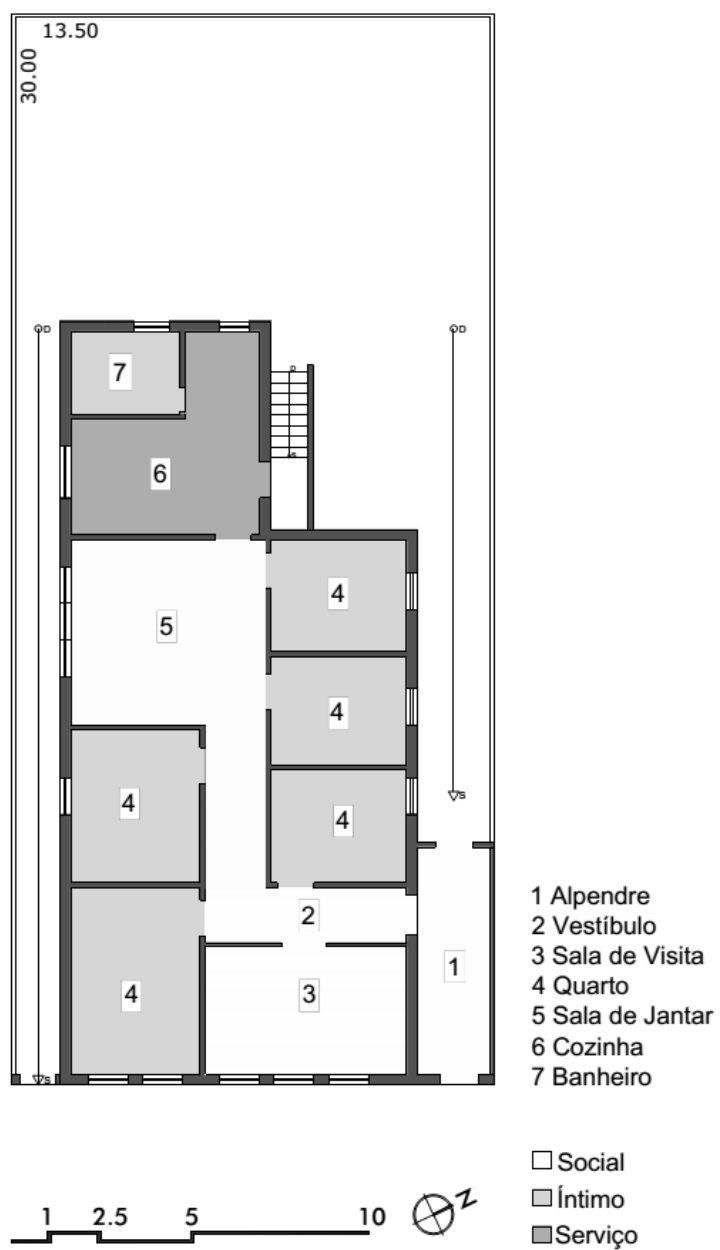

Fonte: Arquivo Público da Secretaria de Obras (1956, P349). Desenho: Natalia Cappellari de Rezende (2018) com base em um projeto de reforma.
É preciso salientar a presença do banheiro no corpo da casa. Diretamente relacionado às transformações ocorridas na arquitetura e no morar, o banheiro pôde ser definitivamente incluído nos programas após as modificações na infraestrutura urbana, sobretudo com as redes de esgoto e abastecimento de água que permitiram o fluxo contínuo e a canalização das águas servidas, ambas construídas em São José do Rio Pardo no ano de 1903. A construção das redes combinada com o aperfeiçoamento técnico e a industrialização de canos galvanizados, materiais impermeáveis, torneiras, sifões e privadas "permitiram que a água corrente passasse da pia da cozinha ao lavabo e ao W.C. e, daí, ao banheiro" (HOMEM, 2010, p. 29), resguardando a casa do mau cheiro e propiciando conforto e privacidade até então inexistente. Foi assim que surgiu o binômio banheiro-cozinha, justificado pela necessidade de economia de tubulação "de ferro galvanizado, sempre cara por ser importada" (LEMOS, C., 1898a, p. 78). Tal como a moradia da família Ribeiro Nogueira, a edificação dos pais da Sra. Clara Alves Zenaro Garcia, na Rua Treze de Maio, pode desfrutar desse avanço, como nos descreveu:

\footnotetext{
179 Graduado em engenharia agrônoma pela Escola Agrícola "Luis de Queiroz" (ESALQ-USP), Zitão se casou com Messias Candido Ribeiro Nogueira, filha de Venerando Ribeiro da Silva Filho e Luzia Delphina Dias, tradicional família rio-pardense que, inclusive, esteve envolvida na fundação do povoado de São Sebastião da Boa Vista (atual Mococa) através da doação de terras e elaboração do plano urbanístico. Com amplos poderes aquisitivos e políticos, a sua principal atividade econômica era a exportação de café (Del Guerra, 2005b; PALADINI, 2008). Na política, os Ribeiro Nogueira figuraram no poder desde o ano de 1896 quando João Ribeiro Nogueira foi eleito vereador e assumiu a intendência. Zitão por sua vez foi vereador e vice-presidente da Câmara na legislatura de 1956-1959.
} 
O banheiro ficava grudado na cozinha, porque antigamente as coisas eram assim, não tinha chuveiro. Como tinha fogão a lenha era serpentina e a água quente saia na torneira do banheiro, e a gente tomava banho de banheira, anti-higiênico. Então cada um que tomava banho tinha que lavar a banheira para não deixar gordura para o outro, dava um trabalhão. Então tinha a banheira, uma pia e a privada (GARCIA, C., 2017).

Dessa maneira tornou-se possível a aproximação entre a cozinha e o banheiro, na medida em que propiciou maior facilidade de obtenção de água quente, conforme diversos autores e ratificado também pelo depoimento da Sra. Clara Alves Zenaro Garcia (2017).

Como visto na moradia da família Ribeiro Nogueira, a presença de um corredor interno favoreceu a intimidade dos ambientes, e a circulação poderia acontecer pela área social sem passar pelo interior dos dormitórios, por exemplo. Havia também situações em que os dormitórios abriam para as salas, como é o caso da moradia localizada na Rua Francisco Glicério esquina com a Praça Barão do Rio Branco, 831 (Figura 187).

Figura 187: Desenho da planta da moradia localizada na Rua Francisco Glicério esquina com a Praça Barão do Rio Branco, 831.

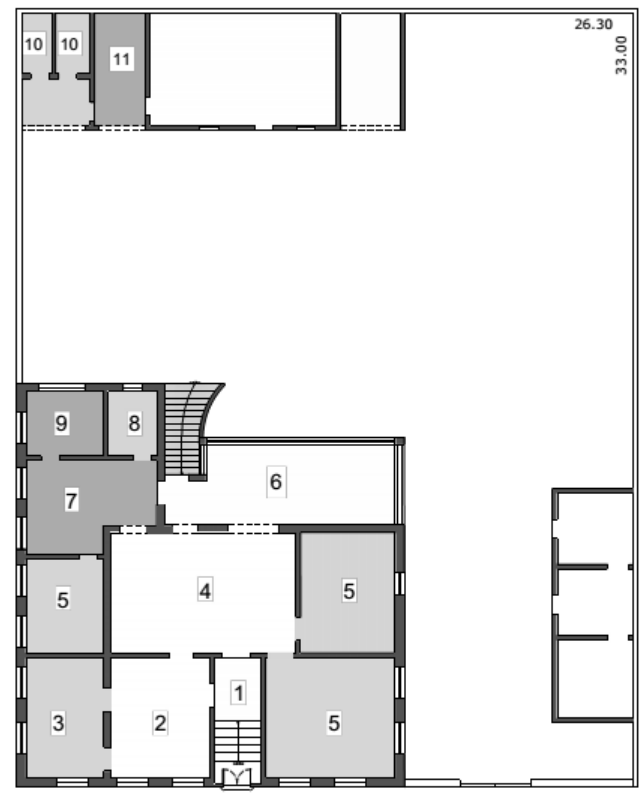

Térreo

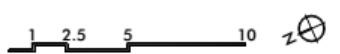

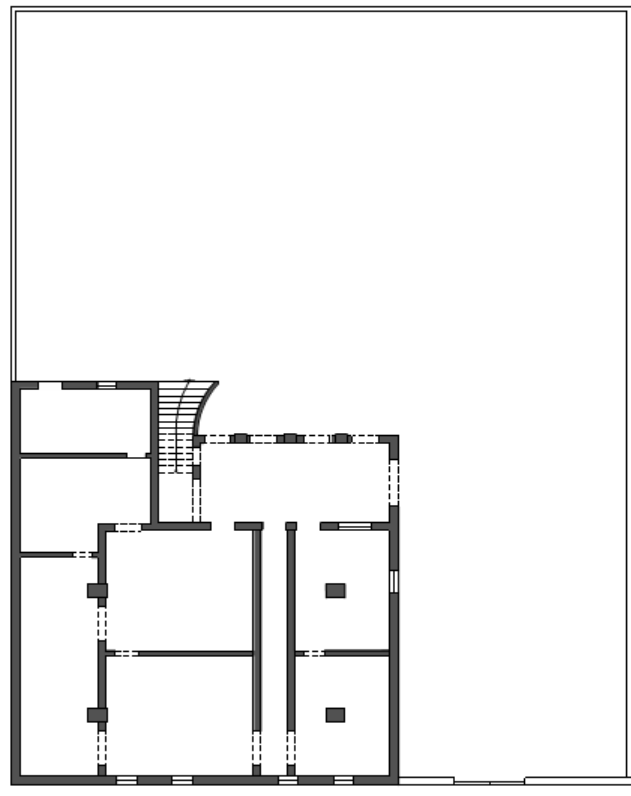

Porão
1 Dormitório

2 Sala de Visita

3 Dormitório visita

4 Sala de Jantar

5 Dormitório

6 Alpendre

7 Copa

8 Banheiro

9 Cozinha

10 Banheiro empregados

11 Tanque

$\square$ Social

$\square$ Serviço

Desenho: Natalia Cappellari de Rezende (2018) a partir de levantamento in loco (2016).

Nesse exemplar construído no alinhamento do lote com a via pública, o acesso ao interior acontece por uma porta que se abre para a rua. A entrada é constituída por um vestíbulo onde um patamar, seis degraus e mais um patamar direcionam a circulação. É nesse vestíbulo que as portas da sala de visitas e de jantar se abrem. O banheiro e a cozinha continuam juntos e no fundo na residência. Digno de destaque é a copa que 
forçou a aproximação entre as salas de jantar e de visita. Certamente nesse caso, a copa ainda não tinha se firmado como centro de convivência da família, que irá acontecer no período seguinte de nossas análises (após 1918), em concordância com o que Lemos, C. (1989b, p. 66) descreveu ao se referir às casas da década de 1920, onde esse cômodo acabou por "converteu a velha varanda, ou sala de jantar, em mero apêndice da sala de visitas e ambas se tornaram área morta de uso esporádico. Ali, mobílias de pouco uso, que mais serviam para dar status à família". Mas, antes disso, a sala de jantar era o espaço por excelência da centralização familiar e distribuidora dos passos por ser passagem obrigatória quando o destino é a cozinha, banheiro e quintal (VERÍSSIMO e BITTAR, 1999).

O agenciamento dos ambientes dessa edificação (Figura 187) se desenvolveu de modo semelhante à moradia do médico José Penna Fernandes ${ }^{180}$ (Figura 188). Construída afastada dos limites laterais do lote em relação aos vizinhos, o acesso principal conduz a um vestíbulo que distribui a circulação para as salas de visita e jantar. Sua organização interna lembra a moradia de Saint' Clair (ver Figura 66 na página 119), mas com novidades, a copa aparece como passagem obrigatória para quem deseja ir até a cozinha que por sua vez está ligada ao banheiro. Nesse caso, certamente a copa se afina à descrição de Lemos, C. (1978, p. 132134) ao tratar das casas paulistanas do final do século XIX:

\begin{abstract}
o termo "copa", até então usado mais para designar o grande armário destinado a guardar os utensílios e guarnecido da mesa - não a cristaleira da sala de jantar ou varanda, não o armário de cozinha, o guarda-panelas, mas o grande armário do corredor, onde se guardava a louça do diário, as latas de biscoitos, os bules de chá, os vidros de remédio e uso, as frutas por amadurecer e mais uma infinidade de coisinhas do trivial, do dia-a-dia sem muitos horizontes. Essa copa que surge aqui e ali nas casas paulistanas do final do século seria derivada da sala que, às vezes, antecedia a cozinha, que era a passagem obrigatória entre a varanda e o resto da zona de serviço. [...] Agora, a copa seria mesmo a saleta de almoço, um local para o preparo de refeições ligeiras à custa de espiriteiras. (LEMOS, C., 1978, p. 132-134).
\end{abstract}

Juntos também aparecem os dois dormitórios com comunicação direta e inevitável. O alpendre comprido ainda está presente. E conforme nos diz Lemos, C. $(1978$, p. 46) a "sala de jantar e varanda passaram a ser expressões sinônimas", mas ainda guardando referência com o ambiente exterior através do alpendre. É uma moradia muito interessante e, sem dúvida alguma, retoma a arquitetura tradicional brasileira. Apesar de apresentar uma ortodoxia parcial no agenciamento interno dos ambientes, os quais estão abertos a luz e ventilação direta, ainda demonstra vínculos com o que se produzia em períodos anteriores, mas comprometida com um outro modo de vida. Ambas edificações estavam estritamente aliadas com o que se produzia nesse período em outras cidades do interior paulista, como São Carlos a exemplo da edificação da Rua Episcopal, 1232 (BORTOLUCCl, 1991, p. 239).

\footnotetext{
${ }^{180}$ Esta moradia foi construída nos primeiros anos do século XX e adquirida pelo Dr. Penna no início da década de 1940. 
Figura 188: Desenho da planta da moradia da família Penna na Rua João Gabriel Ribeiro, 382.

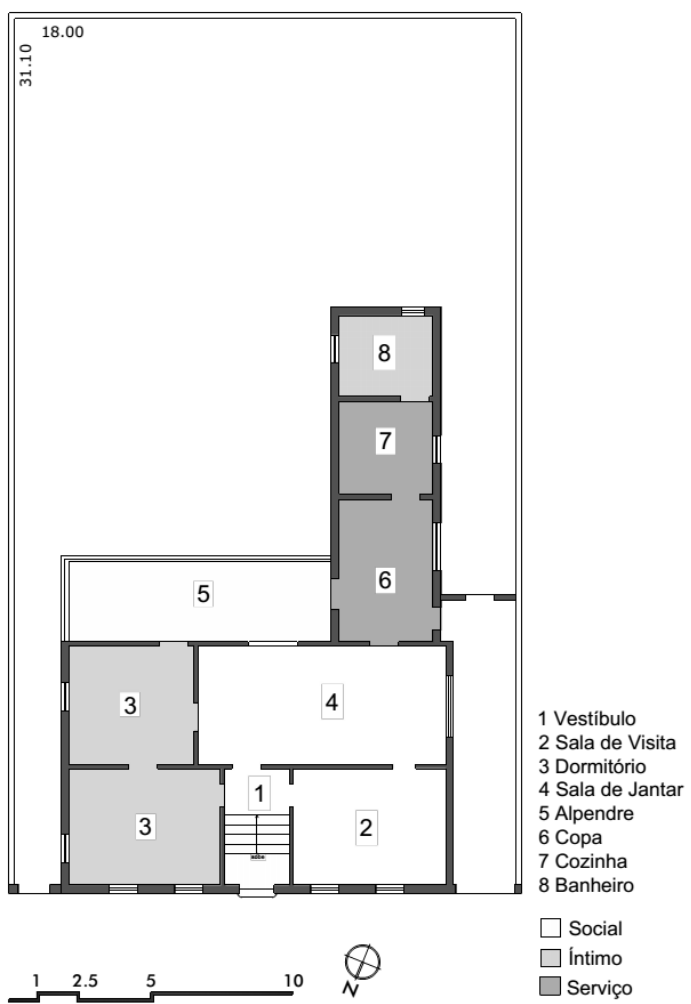

Fonte: Arquivo Público da Secretaria de Obras (1960, P87). Desenho: Natalia Cappellari de Rezende (2018) com base em um projeto de reforma (1960) e fotografia antiga pertencente ao Arquivo do Centro da Memória Rio-Pardense Rodolpho José Del Guerra.

Figura 189: Desenho da planta da moradia de Dante Artese na Praça Barão do Rio Branco, 142.

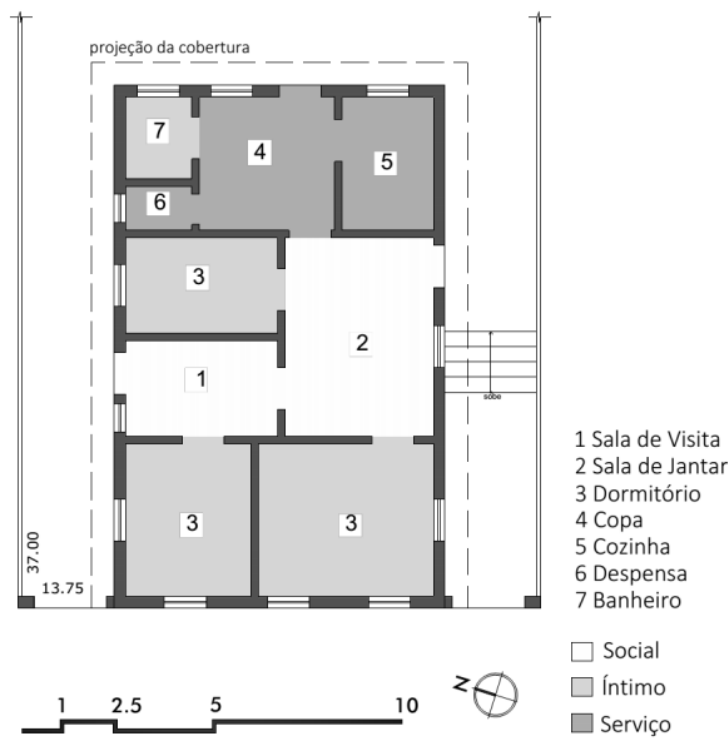

Fonte: Arquivo Público da Secretaria de Obras (1948, P70). Desenho: Natalia Cappellari de Rezende (2018) com base em um projeto de reforma (1960), fotografias antigas pertencentes ao Arquivo do Centro da Memória Rio-Pardense Rodolpho José Del Guerra e levantamento in loco.
Como visto nas três residências analisadas (da família Ribeiro Nogueira; a moradia localizada na Rua Francisco Glicério esquina com a Praça Barão do Rio Branco, 831; e da família Penna), o banheiro e a cozinha aparecem juntos, em uma "convivência forçada" (LEMOS, C., 1989b, p. 57). Mas com distinção, a casa de Dante Artese (Figura 189), construída por Paschoal Artese, apresenta o banheiro e a cozinha separados pela copa. Implantada no alinhamento do lote com a rua e afastada lateralmente dos vizinhos, o acesso principal ocorre por um corredor externo onde se abre a sala de visitas. Diferentemente das outras três moradias onde o vestíbulo é o ambiente que distribui a circulação, nessa residência é passando pela sala de visitas e ainda pela de jantar que as demais repartições são acessadas. A sala de jantar, maior cômodo da casa, certamente desempenhava a função centralizadora das atividades familiares de Dante Artese no início do século XX, além de ser passagem obrigatória quando o destino eram as áreas de serviço e o banheiro.

Dinâmica semelhante ocorreu com a técnica construtiva. Os sérios problemas de salubridade e higiene decorrentes dos ambientes sem ventilação e iluminação diretas, a umidade ascendente nos assoalhos assentados diretamente no solo e a falta de revestimento adequado nos pisos e paredes sofreu alterações, ainda que tenhamos encontrado permanências.

O aperfeiçoamento das técnicas construtivas aliado à mudança de gostos, hábitos, usos e costumes, e a influência da mão de obra são 
também acusadas pela legislação. Nesse caso, é importante enfatizar que nem sequer em muros a legislação estava permitindo o uso da taipa, assumindo uma franca defesa das alvenarias de tijolo e pedra.

Art. 11 - Os proprietários de terrenos dentro do perímetro da cidade e à frente das ruas são obrigados a mura-los de alvenaria de tijolo ou pedra, devendo os de alvenaria de tijolo ter as juntas tomadas com cal branca, quando não sejam rebocados e caiados. Estes muros terão no mínimo 2 metros e no máximo 2,20 metros de altura e a espessura será de 30 centímetros ou de 15 , se tiverem pilares de 30 centímetros de grossura, convenientemente espaçados.

Único - Ficam prohibidos os tapumes de zinco, de pedra ou taipa. O infractor incorrerá na multa de $30 \$ 000$, e será obrigado a cumprir o disposto neste artigo dentro de 30 dias, sob pena de ser elevada a multa a $50 \$ 000$ e repetida de 10 em 10 dias até o cumprimento da obrigação. (CÓDIGO DE POSTURAS, 1903, p. 04).

Medidas adotadas em contraposição ao Código de 1887 que permitia a utilização da taipa. É certo afirmar que em 1886, antes da chegada da ferrovia, São José do Rio Pardo já conhecia o tijolo empregado na construção da Casa de Câmara e Cadeia, todavia, seu uso foi difundido e adotado quando começou a ser produzido localmente, como visto no item anterior deste capítulo. Conforme observamos nos levantamentos realizados, a pedra continuou sendo o material empregado no alicerce (Figura 190), enquanto o tijolo cerâmico foi utilizado nas paredes estruturais (Figura 191).

Figura 190: Embasamento de pedra da moradia de Dante Artese.

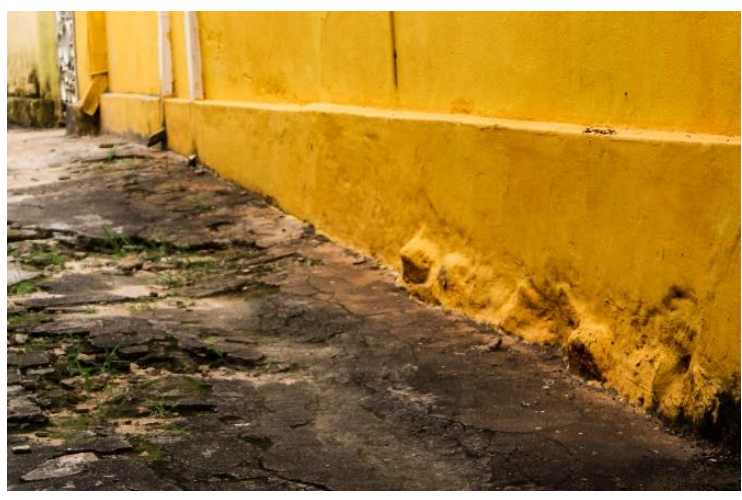

Fonte: Acervo pessoal da autora (2018).
Figura 191: Paredes de tijolos no porão da moradia na Rua Francisco Glicério esquina com a Praça Barão do Rio Branco, 831.

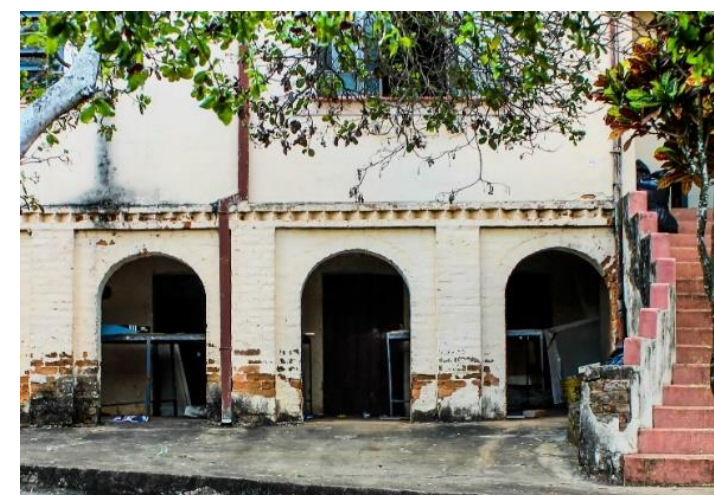

Fonte: Acervo pessoal da autora (2017).

Sobre a cobertura dessas edificações, percebemos em nossos levantamentos que não houve mudanças significativas, mantendo o emprego da tesoura com madeira serrada, mas as telhas capa e canal foram substituídas pela francesa, a exemplo da moradia da família Penna, como é possível observar na Figura 192 apontada pela seta. 
Figura 192: Telhado da moradia da família Penna na Rua João Gabriel Ribeiro, 382, no início do século XX e uma fotografia atual.
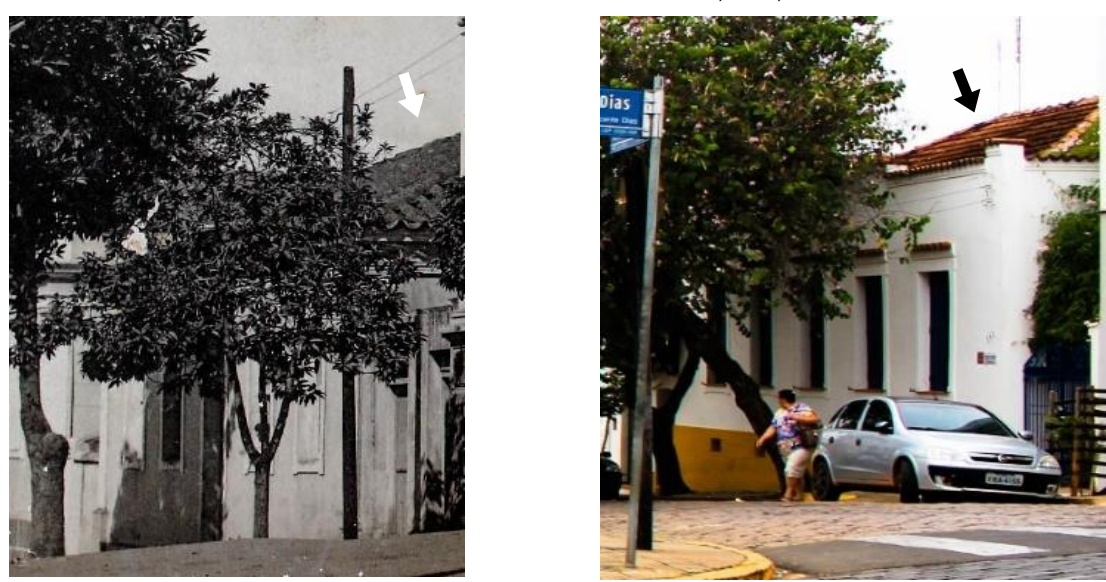

Fonte: Arquivo do Centro da Memória Rio-Pardense Rodolpho José Del Guerra e pessoal da autora.

Outra questão relevante e inovadora refere-se à proibição de construções com beirais para a rua, forrados de tábuas e cimalhas de telhas encalhadas, em contraposição à platibanda. Como podemos observar nas figuras (Figura 193, Figura 194, Figura 195 e Figura 196), em todas as edificações analisadas nesse item, a platibanda apareceu escondendo o telhado e como elemento de composição da fachada.

Figura 193: Moradia da família Ribeiro Nogueira na Praça Barão do Rio Branco, 22.

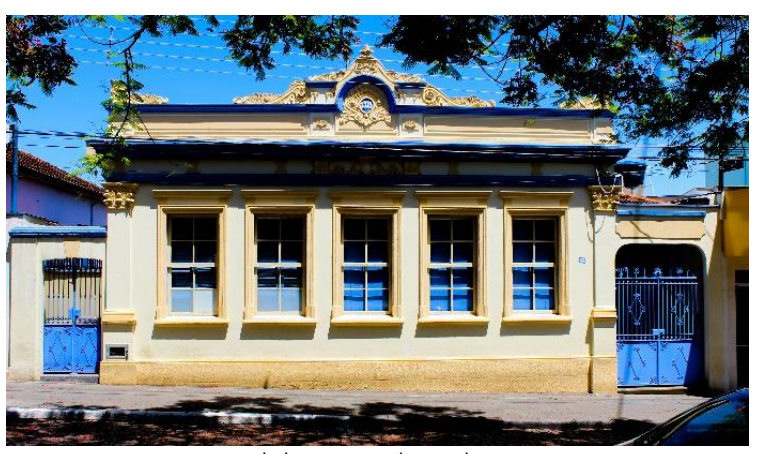

Fonte: Acervo pessoal da autora (2017).
Figura 194: Moradia do Nhô Ribeiro na esquina da Praça XV de Novembro com a Rua Marechal Floriano, 17

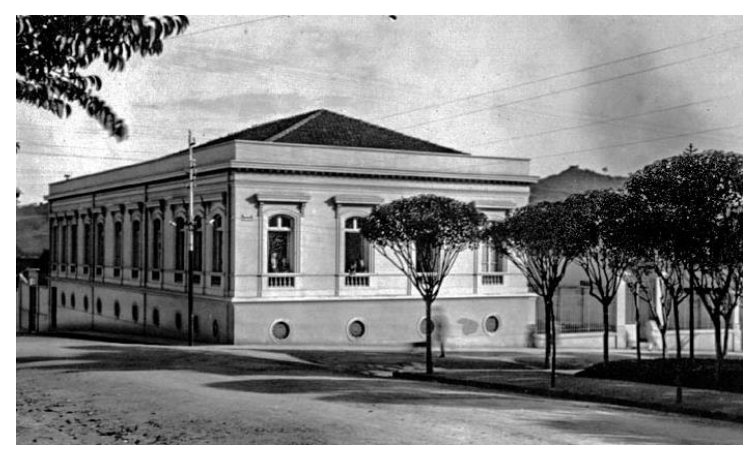

Fonte: Arquivo do Centro da Memória Rio-Pardense Rodolpho José Del Guerra. Fotografia de Innocencio Vilhegas.

Figura 196: Moradia da família Penna Rua João Gabriel Ribeiro, 382.

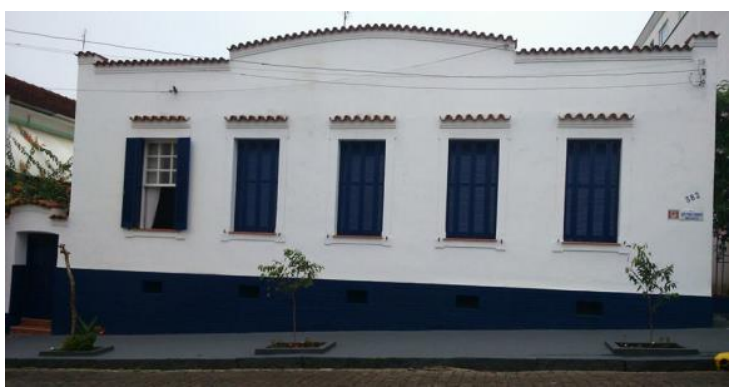

Fonte: Acervo pessoal da autora (2018).
Praça Barão do Rio Branco, 831.

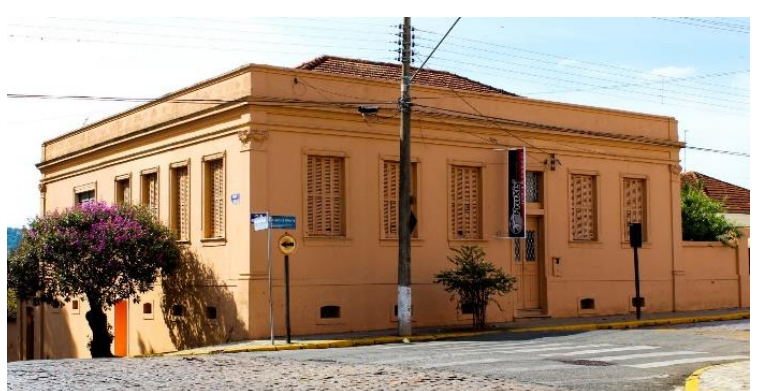

Fonte: Acervo pessoal da autora (2017). 
Figura 197: Vista parcial da Rua Treze de Maio na década de 1910 mostrando edificação com platibanda e outras ainda com beiral. A seta preta aponta o cano embutido no passeio para conduzir a água para fora da guia.

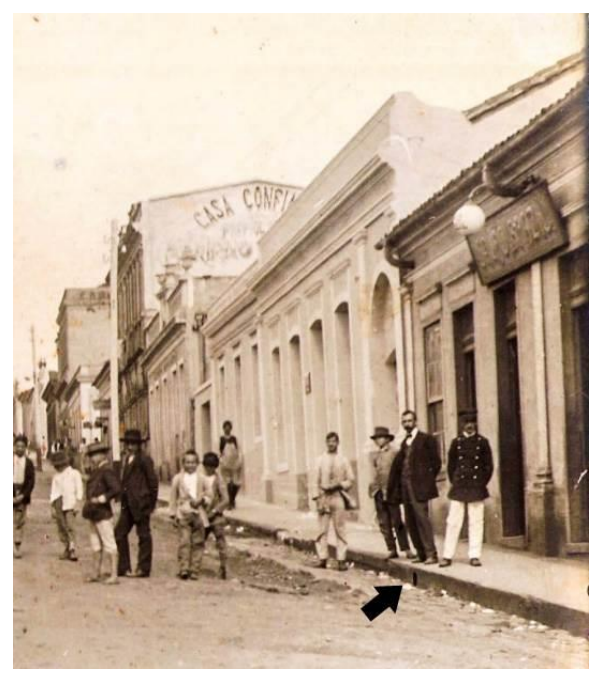

Fonte: Arquivo da Hemeroteca Jornalista Paschoal Artese. Fotografia de Innocencio Vilhegas.
Mas em nosso levantamento documental e de campo encontramos edificações que não adotaram a platibanda, para esses casos o Código de 1903 determinou em seu artigo 21, parágrafo único, que

nas e não guardarem esta disposição, em quanto não forem modificadas de accordo com este artigo serão os proprietários obrigados a collocar nos telhados calhas que recebam as águas pluviaes, conforme a prescripção do art.12. (CÓDIGO DE POSTURAS, 1903, p. 07).

O artigo 12 determinava a obrigatoriedade do emprego de calhas ou qualquer outro sistema de captação e condução das águas pluviais com canos embutidos na parede e por baixo dos passeios para conduzirem a água para fora das guias, como é possível observar na Figura 197.

As técnicas e materiais construtivos utilizados, o uso da calha e do condutor de água pluvial, os afastamentos da edificação em relação aos limites do lote, a busca por luz e ar natural e o arranjo da planta provocou também um cuidado com os telhados que tenderam a se tornar mais complexos, como no exemplo da casa na Rua Francisco Glicério esquina com a Praça Barão do Rio Branco, 831 e o Casarão do Artese (Figura 198 e Figura 199), abandonando o tradicional duas águas que predominou nessa cidade nos períodos anteriores.

Figura 198: Desenho da cobertura da edificação na Rua Francisco Glicério esquina com a Praça Barão do Rio Branco, 831.

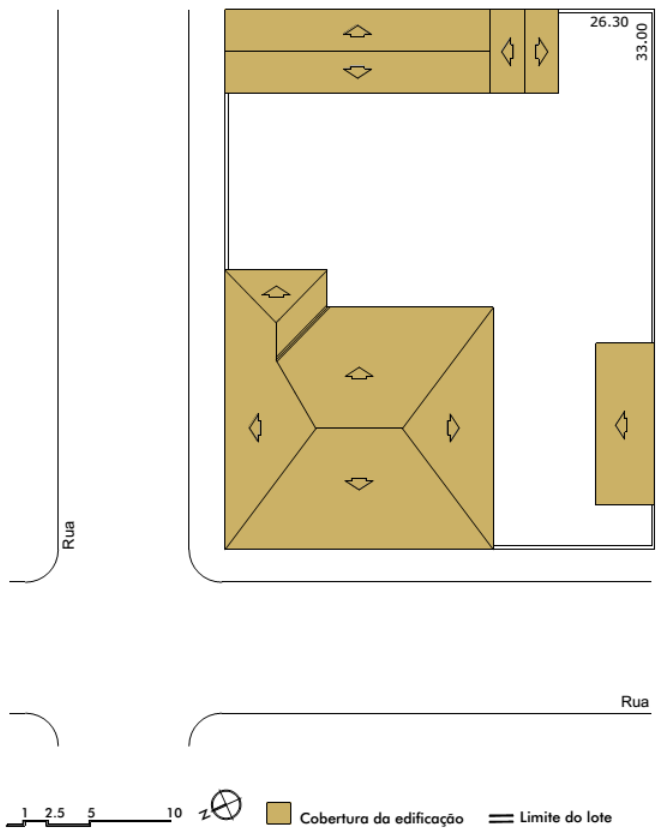

Desenho: Natalia Cappellari de Rezende (2018).
Figura 199: Desenho da cobertura do Casarão do Artese na Praça Barão do Rio Branco, 156.
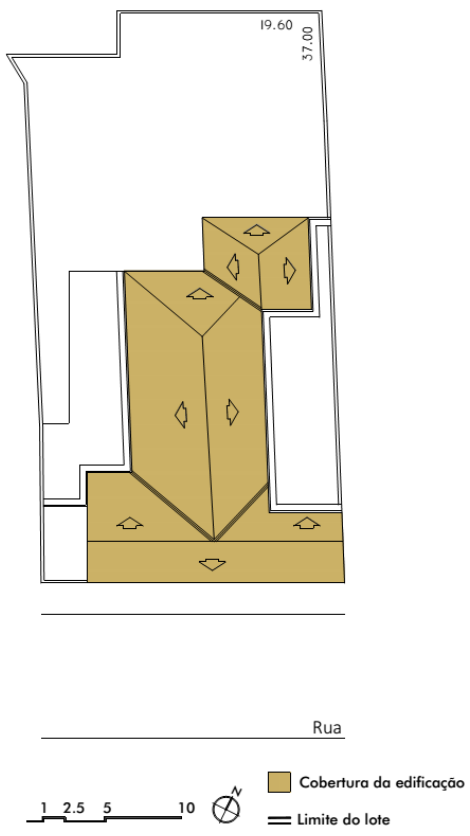

Desenho: Natalia Cappellari de Rezende (2018). 
Todas essas inovações representaram um momento de modernização da arquitetura rio-pardense, que além de exibir alterações formais, buscava ostentar uma liberdade compositiva com elementos de referências várias e de diferentes épocas. Essa liberdade pode ser facilmente identificada nas platibandas que exibiram uma diversidade de formas em contraposição a monotonia dos beirais dos primeiros tempos, contribuindo para alterar a paisagem urbana rio-pardense (Figura 200).

Figura 200: Formas variadas de platibandas em edificações localizadas na área central de São José do Rio Pardo no início do século $X X$.

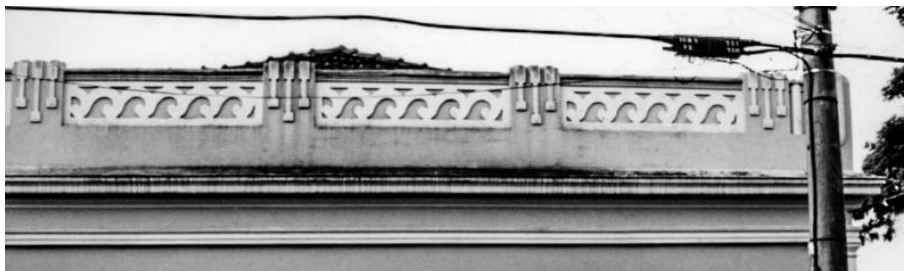

Esquina da Rua João Gabriel Ribeiro com a Rua Benjamin Constant

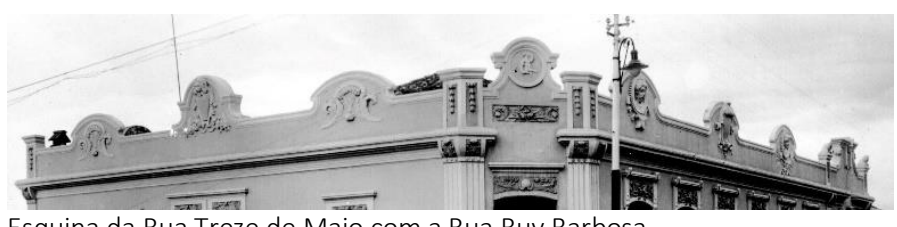

Esquina da Rua Treze de Maio com a Rua Ruy Barbosa

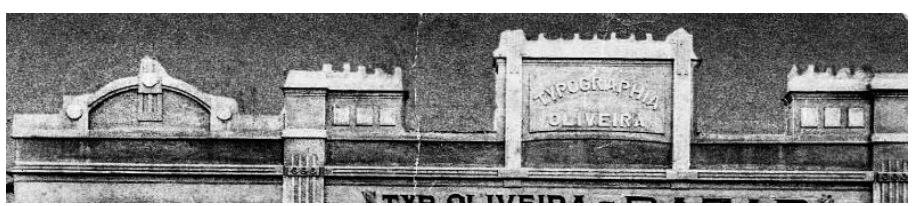

Rua Treze de Maio

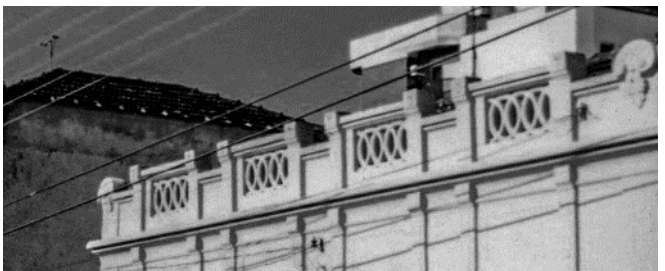

Esquina da Rua Marechal Deodoro com a Rua Francisco Glicério

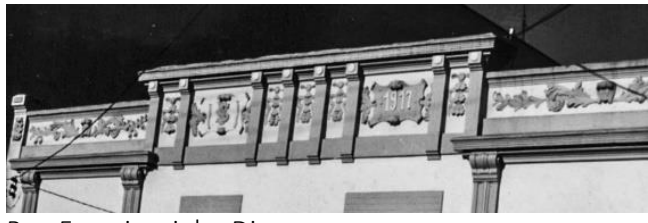

Rua Francisquinho Dias

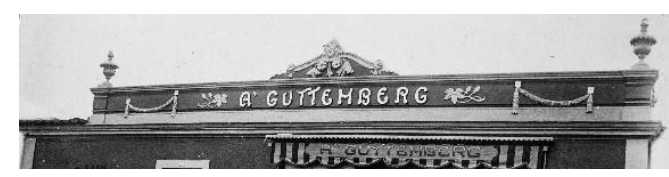

Rua Treze de Maio

Fonte: Arquivo da Hemeroteca Jornalista Paschoal Artese.

Verificamos ainda a adoção desse recurso em edificações construídas em áreas distintas e suburbanas onde as determinações do Código não eram uma imposição, demonstrando uma tendência que se tornou comum em São José do Rio Pardo no início do século XX (Figura 201). 
Figura 201: Formas variadas de platibandas em edificações localizadas na área suburbana de São José do Rio Pardo no início do século XX.

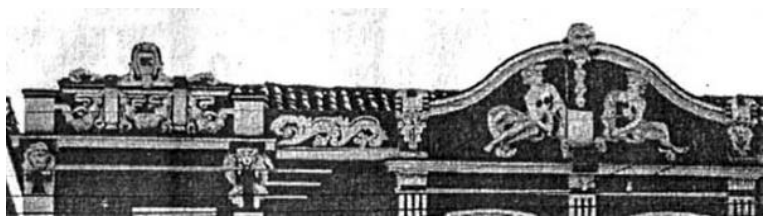

Rua Siqueira Campos, Bairro Bonsucesso

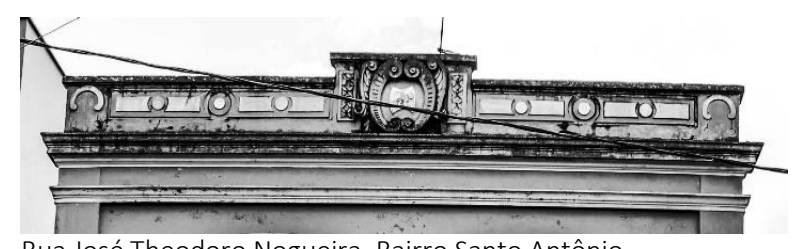

Rua José Theodoro Nogueira, Bairro Santo Antônio

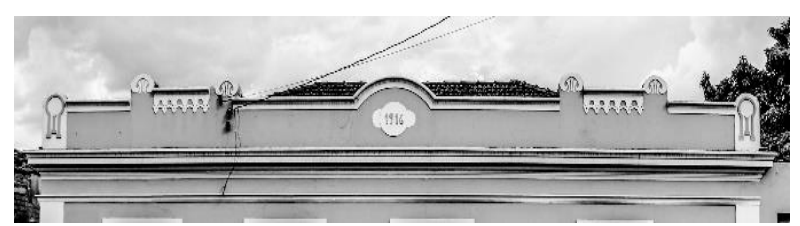

Rua José Theodoro Nogueira, Bairro Santo Antônio

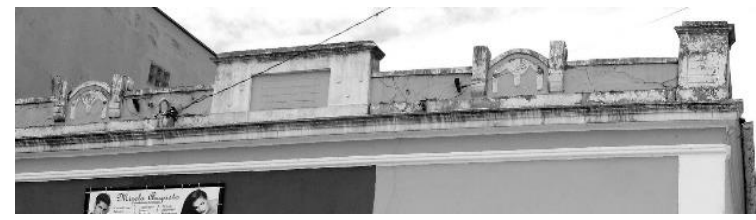

Rua José Theodoro Nogueira, Bairro Santo Antônio

Fonte: Arquivo da Hemeroteca Jornalista Paschoal Artese e pessoal da autora.

Além disso, averiguamos edificações públicas e particulares que atenderam à normativa do Código e substituíram seus beirais pela platibanda, sobretudo aquelas localizadas ao redor das praças, como a moradia de Saint' Clair Andrade Junqueira (ver Figura 79 na página 129), apresentada no primeiro capítulo, que podemos ver na Figura 202 (indicada com um círculo amarelo).

Figura 202: Moradia de Saint' Clair Andrade Junqueira, década de 1910.

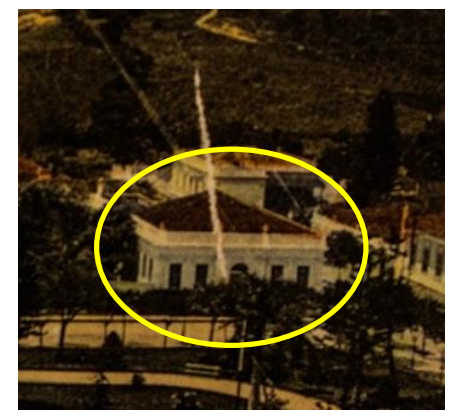

Fonte: Arquivo da Hemeroteca Jornalista Paschoal Artese.

Além de todas as exigências apresentadas, o Código Sanitário estabeleceu em seu artigo 44 a exigência de afastamento do piso em relação ao solo em ao menos 50 centímetros para evitar a umidade vinda do solo, amplamente denunciada por médicos e engenheiros por ser considerada potencializadora de doenças e causadora de muitos prejuízos materiais (CORREIA, 2004). Apesar de já constatarmos o uso do porão em moradias construídas em São José do Rio Pardo nos períodos anteriores, esse recurso passou a ser uma exigência legal e tinha ainda como objetivo a garantia de higiene.

Desse modo, o porão seguiria sendo utilizado até as primeiras décadas do século XX, mas, nesse momento, diante da determinação do Código de Posturas de 1903 ele se difundiu, como pudemos constatar em nosso levantamento. A adesão a esse recurso ocorreu ainda em edificações que não apresentavam recuos em relação aos limites laterais e frontal do lote, e com disposição interna tradicional, como mostram as moradias do Sr. Lourenço Tempesta e Vicente Darvença (Figura 203), construídas na primeira década do 
século XX. O que também justifica adoção do porão foi, segundo Homem (1996), a noção de intimidade, na medida em que a elevação do imóvel desestimulava os olhares indiscretos.

Figura 203: Desenho das moradias de Vicente Darvença e de Sr. Lourenço Tempesta em São José do Rio Pardo.

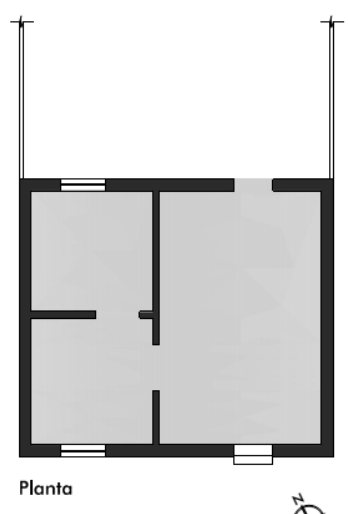

$\ddot{\oplus}$
Fachada

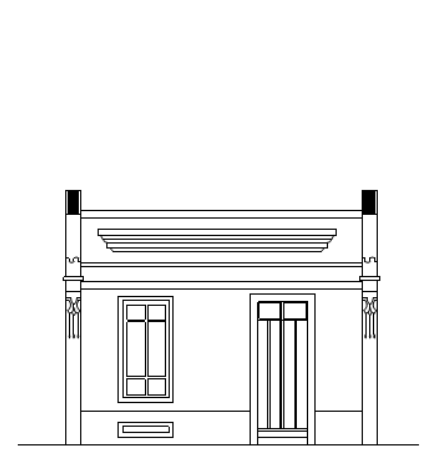

10

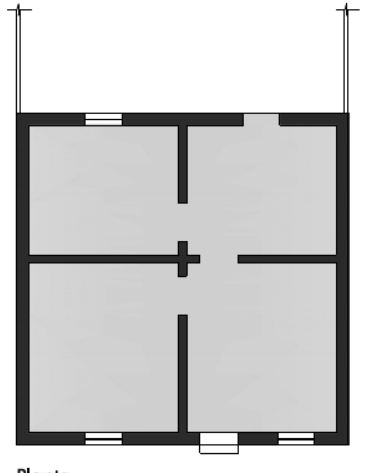

Planta
Fachada

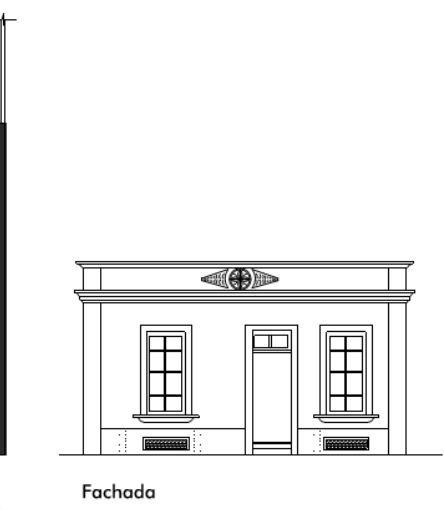

$z \otimes$

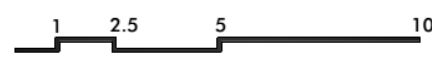

Fonte: Projetos encontrados no Arquivo da Hemeroteca Jornalista Paschoal Artese. Desenho: Natalia Cappellari de Rezende (2018).

É necessário ressaltar que constatamos a existência do porão em todas as edificações analisadas nesse item, sendo em alguns casos alto e habitável, mesmo que proibido pelo Código Sanitário Estadual (1894) que determinava

Artigo 43. - Os compartimentos do sub-solo, ou porões, constituem garantia hygienica para as edificações; mas não deverão servir de habitação.

Artigo 44. - O assoalho do andar terreo deve estar separado do solo 50 centimetros, pelo menos. (CÓDIGO SANITÁRIO, 1894, p. 03).

O Código Sanitário (1894) definia ainda em seu artigo 45 a altura mínima para que o pavimento pudesse ser habitado, sendo nesse caso de quatro metros. Nas casas rio-pardenses o porão aparece, por exemplo, na residência da família Ribeiro Nogueira e na edificação da esquina da Rua Francisco Glicério com a Praça Barão do Rio Branco, 831, onde a altura constatada foi de dois metros e oitenta e cinco centímetros (2,85 m).

Além dos porões recorrentemente revelados pelos mais diversos modelos de óculos, e a variedade de formas de platibanda por vezes carregadas de ornamentos e vasos decorativos, percebemos a preocupação formal nos detalhes da fachada representados por pilastras ou imitações, bossagens - indicando a existência e a altura do porão -, elementos ornamentais com formas geométricas e floreais, e os desenhos das esquadrias.

Todas essas peculiaridades foram constatadas nas moradias analisadas, sendo em algumas mais ressaltadas. Nesse sentido, destacamos a destinação entre a fachada da moradia da família Ribeiro Nogueira e a fachada 
da casa da família Penna ${ }^{181}$ que é caracterizada por um "ar neocolonial", semelhante a edificações construídas em São Carlos, conforme constatado por Bortolucci (1991, p. 252-253). É essa estética tida como nacionalista, a qual Lemos, C. (1989a) atribuiu os reflexos da primeira Grande Guerra, que vai predominar nas edificações das décadas seguintes, e que por isso será mais bem explorada no próximo capítulo.

Apesar das diferenças programáticas e da linguagem estilística, tanto na moradia dos Ribeiro Nogueira quanto de Penna, a simetria como ideal de beleza (Figura 204) foi perseguida, diferentemente do que ocorreu na casa da Rua Francisco Glicério com a Praça Barão do Rio Branco, 831 (Figura 205).

Figura 204: Eixo de simetria nas fachadas das moradias da família Ribeiro Nogueira e Penna.
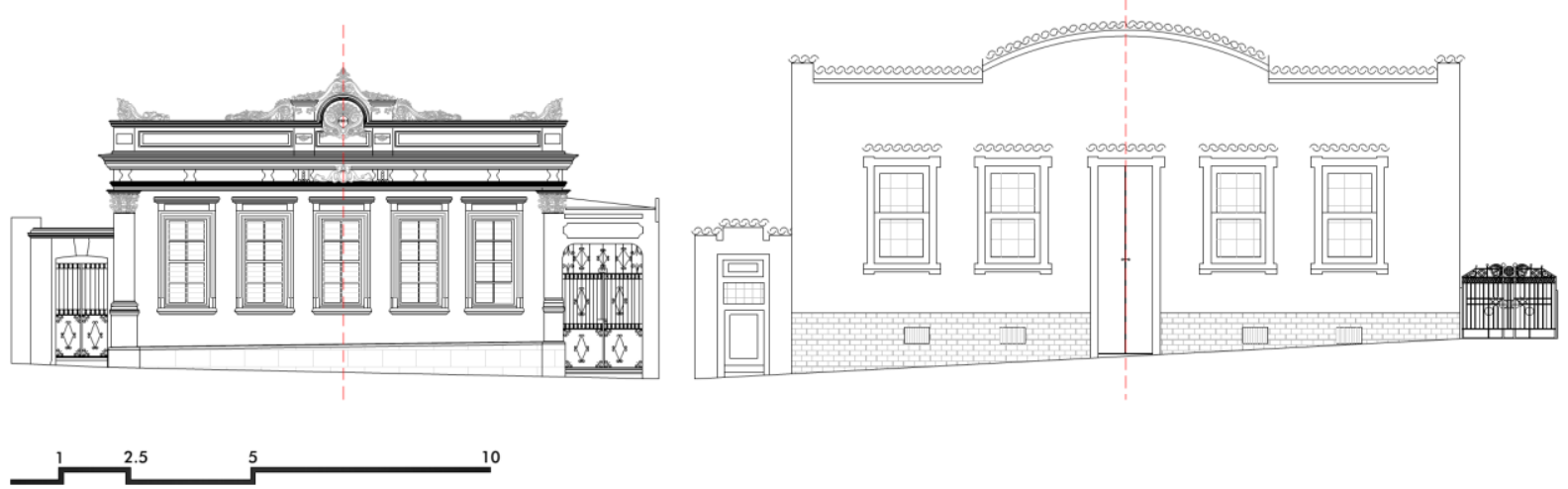

Desenho: Natalia Cappellari de Rezende (2018) a partir de fotografias e projetos do Arquivo Público da Secretaria de Obras .

Figura 205: Fachada de moradia na Rua Francisco Glicério com a Praça Barão do Rio Branco, 831. Desenho: Natalia Cappellari de Rezende (2018).

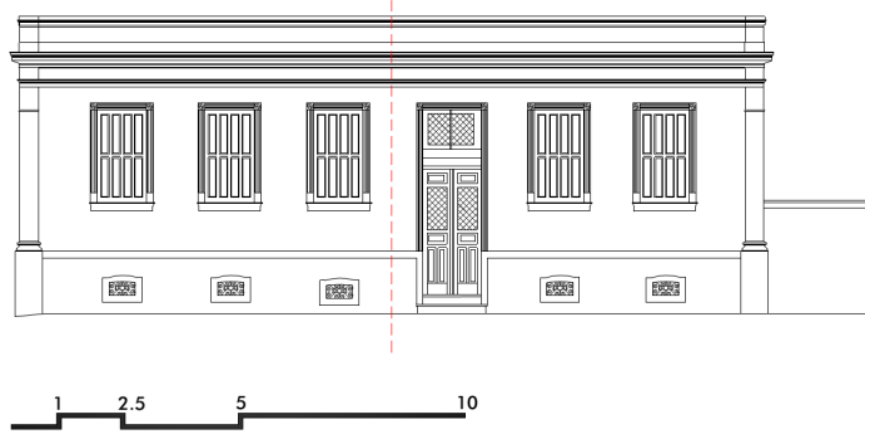

O controle da ordem estética ficou condicionado às determinações do Código de Posturas de 1903 que funcionou mais como uma tentativa de assegurar a higiene e a salubridade nas edificações, usando recursos como, por exemplo: definição das medidas mínimas das aberturas, discriminadas nos artigos 20 e 22 (ver página 205); ou ainda na determinação da caiação interna e externa nos meses de março e a pintura a cada dois anos, conforme o artigo 117.

\footnotetext{
${ }^{181}$ Certamente essa edificação é uma daquelas que sofreu reforma nas primeiras décadas do século XX que alterou sua estética, além de ajustá-la às disposições do Código de Posturas de 1903, quando foi exigido platibanda. 
Art. 58 - Todos os prédios da cidade, arrabaldes ou povoações do município serão caiados durante o mez de março de cada anno e pintado de 2 em 2 annos, tanto interiormente como na frente e oitões, salvo determinação especial imposta por autoridade sanitária. Multa de $30 \$ 000$ e, si dentro de dez dias não cumprir com esta postura, será a multa elevada a $50 \$ 000$ e repetida de 5 em 5 dias, independente de nova intimação até o cumprimento da obrigação.

A diversidade de expressões próprias do ecletismo, técnicas e materiais, mão de obra especializada, novas soluções construtivas e arquitetônicas contribuíram para transformar e diversificar a produção edificativa sob vários aspectos e consequentemente a paisagem urbana. Difundido pelo interior, por exemplo, a tipologia do chalé foi, segundo Reis Filho (2011), uma consequência dessas transformações em que se pretendia adotar características de residências construídas na Europa, especialmente a Suíça. Coerente com as características descritas por Reis Filho (2011), a moradia do Sr. Oliveiros Fernandes Pinheiro é um desses exemplares em São José do Rio Pardo (ver Figura 185 na página 209). Construído isolado no terreno, esse chalé possuía telhado de duas águas com inclinação muito acentuada e em sentido oposto à tradição lusobrasileira ${ }^{182}$; ostentava beiral arrematado por lambrequins e nas extremidades um mastro torneado; todas as aberturas apresentavam moldura em arco ogival e exibia ainda alpendre lateral, gradil de fechamento e jardins que circundavam a edificação.

É importante ressaltar a diversidade arquitetônica da moradia urbana desse período no interior do estado de São Paulo, particularmente a região de São José do Rio Pardo. Por exemplo, a cidade de Mococa que ainda possui inúmeras edificações - em ótimo estado de conservação - construídas no final do século XIX e início do século XX. Grande parte dessas moradias pertenceu a pessoas que possuíam um capital econômico significativo, o que justifica a complexidade dos seus interiores em termos de programa, espacialidade e composição estilística das fachadas. Podemos citar alguns exemplos significativos em Mococa, como a moradia da Praça Ademar de Barros, 131, construída em 1896 para o Capitão João Ferraz de Siqueira (Figura 206) e a moradia do Coronel José Pereira de Lima de 1916 na Praça Marechal Deodoro, 133 (Figura 207). Em sentido semelhante, a cidade de Casa Branca preservou boa parte da sua produção arquitetônica do começo do século XX, como exemplo a casa de 1915 na Rua Valdemar Panico, 102 (Figura 208), outra datada de 1908 na Rua Dr. Menezes, 317 (Figura 209), e na Praça Antônio Barreto, 93 (Figura 210). Todas as moradias citadas, independente da sofisticação apresentada, foram construídas no alinhamento do lote com via pública, afastadas lateralmente dos vizinhos e distantes do solo, assim como verificamos nas casas rio-pardenses.

\footnotetext{
${ }^{182} \mathrm{Na}$ tradição luso-brasileira as empenas são voltadas para os lados de maior dimensão - as laterais - com as águas do telhado caindo para os lados menores, a frente e os fundos da edificação.
} 
Figura 206: Moradia do Capitão João Ferraz de Siqueira Praça Ademar de Barros, 131, na cidade de Mococa.
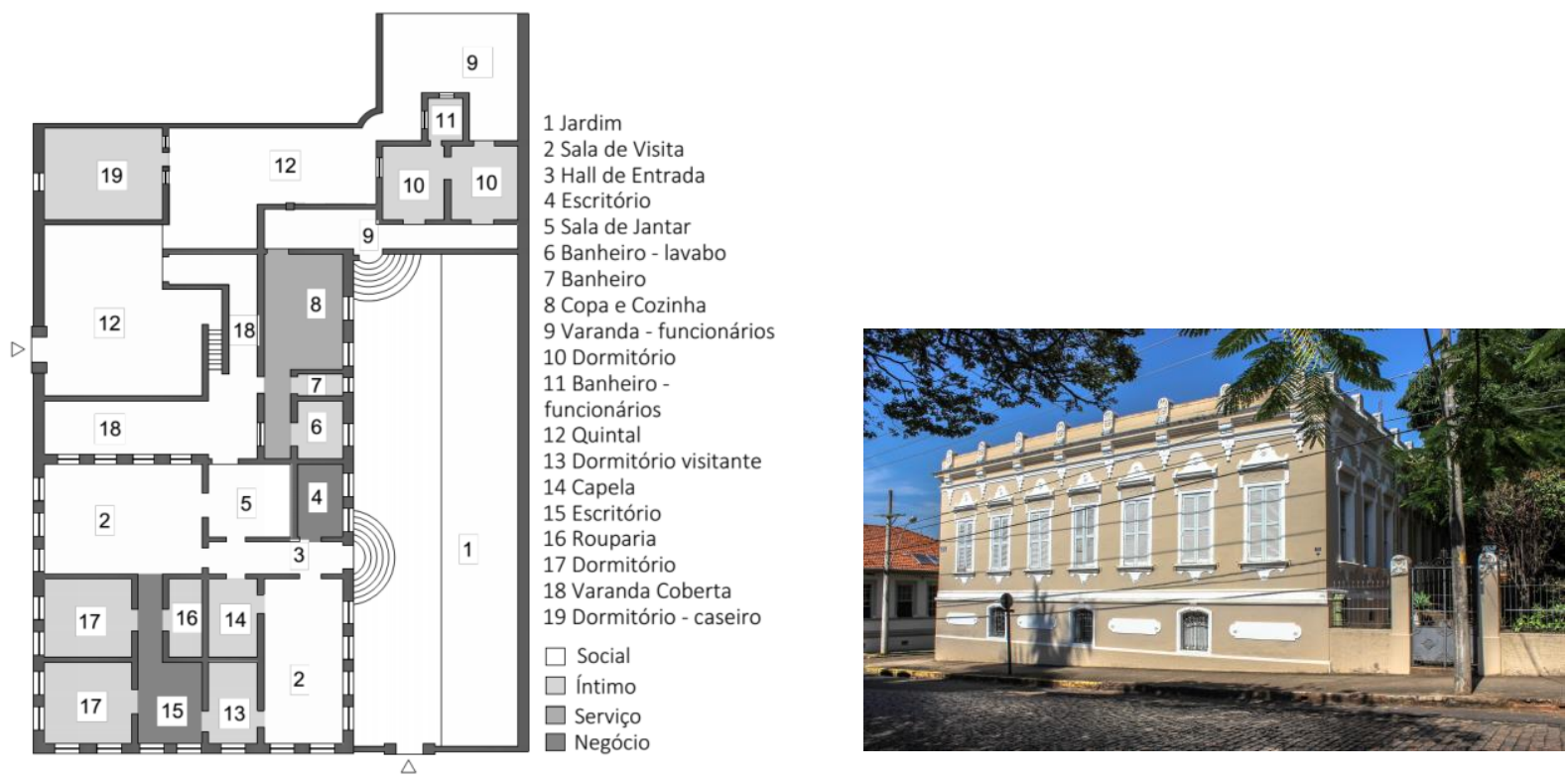

Fonte: Planta publicada por Ribeiro, S. (2011) e fotografia da autora (2018).

Figura 207: Moradia do Coronel José Pereira de Lima de 1916 na Praça Marechal Deodoro, 133, na cidade de Mococa.
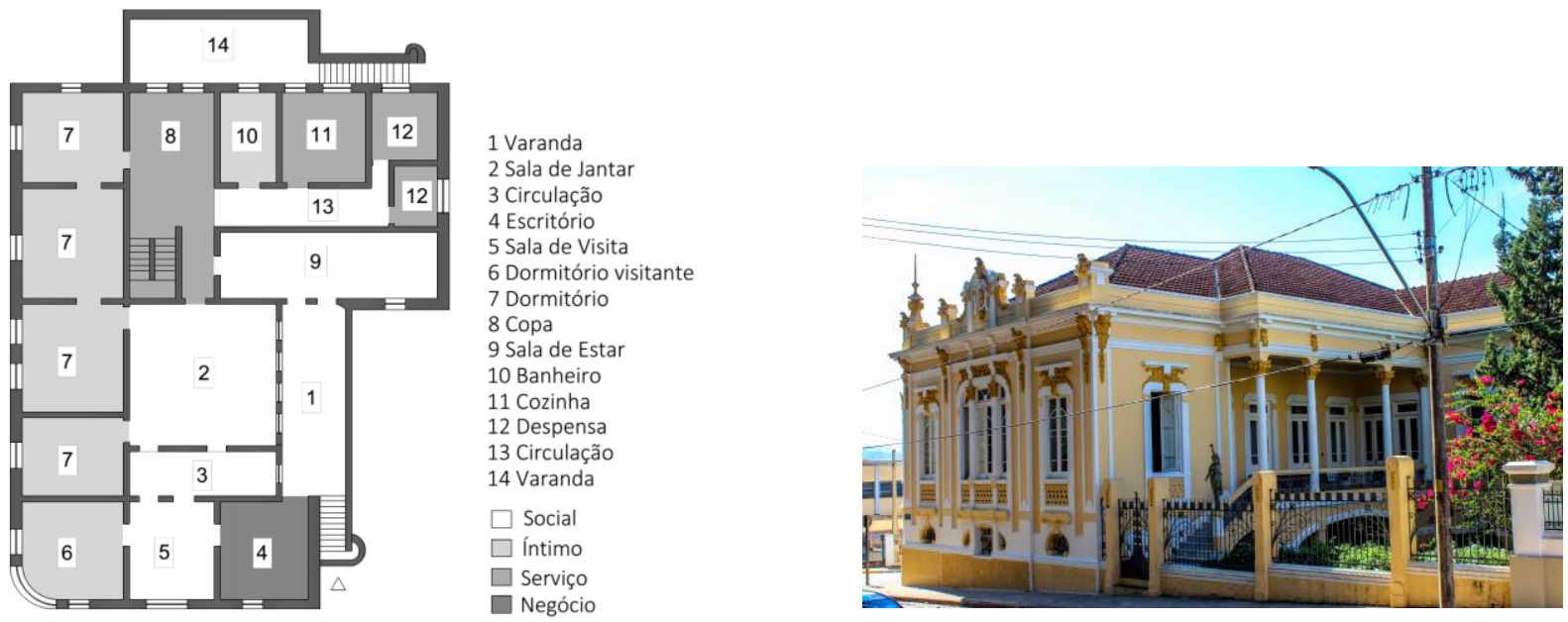

Fonte: Planta publicada por Ribeiro, S. (2011) e fotografia da autora (2018).

Figura 208: Moradia na Rua Valdemar Panico, 102, na cidade de Casa Branca.

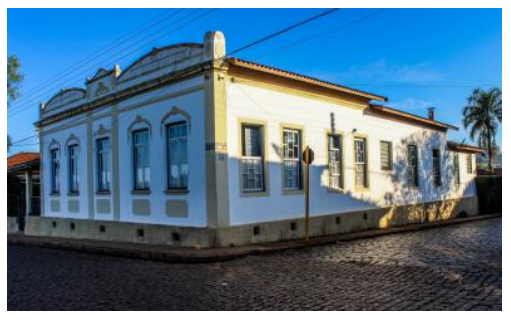

Fonte: Acervo pessoal da autora (2017).
Figura 209: Moradia na Rua Dr Menezes, 317, na cidade de Casa Branca.

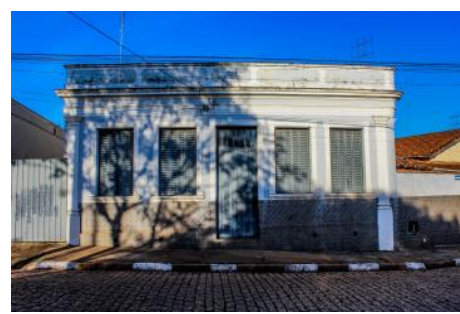

Fonte: Acervo pessoal da autora (2017).
Figura 210: Moradia na Praça Antônio Barreto, 93, na cidade de Casa Branca.

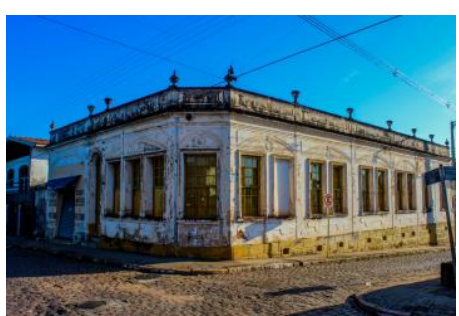

Fonte: Acervo pessoal da autora (2017). 
Nos interiores, os elementos construtivos empregados foram condicionados segundo os limites econômicos do proprietário e dos conhecimentos técnicos da mão de obra utilizada, porque de resto tudo poderia chegar através da ferrovia. Desse modo, foi recorrente o uso da madeira nas áreas sociais e quartos e o ladrilho hidráulico nos vestíbulos e nas áreas molhadas. A diferenciação dos ambientes ainda foi feita pela sofisticação do desenho e variedade de cores dos ladrilhos, a exemplo do vestíbulo e área do tanque de lavar roupas (Figura 211), e de modo semelhante entre o assentamento das tábuas de madeira com formas variadas e espécies distintas no vestíbulo, na sala de visita e jantar, diferentemente dos demais ambientes que possuem o tabuado corrido com o mesmo tipo de madeira, como podemos observar na Figura 212.

Figura 211: Ladrilhos hidráulicos da casa na esquina da Rua Francisco Glicério com a Praça Barão do Rio Branco, 831.

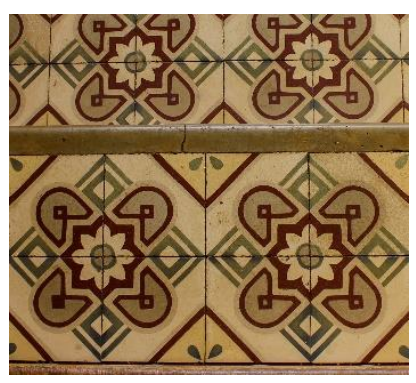

Ladrilho hidráulico policromado do vestíbulo

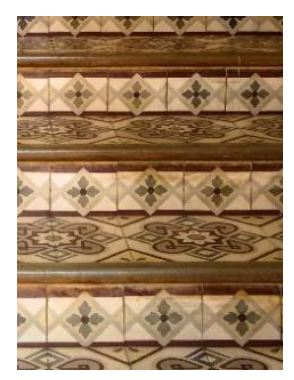

Ladrilho hidráulico policromado do vestíbulo

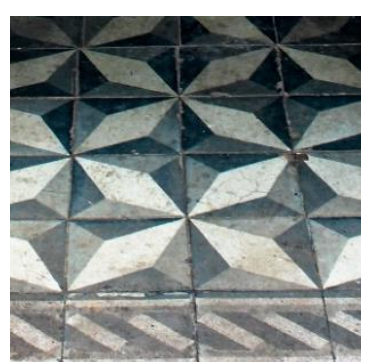

Ladrilho hidráulico em dois tons da área do tanque de lavar roupas

Fonte: Acervo pessoal da autora (2017).

Figura 212: Assoalho da casa na esquina da Rua Francisco Glicério com a Praça Barão do Rio Branco, 831.

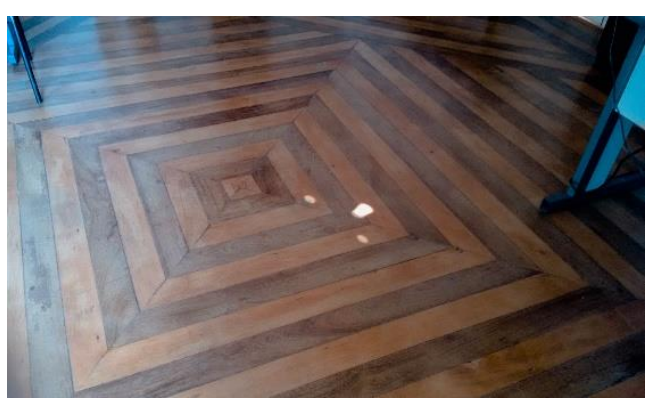

Assoalho policromado da sala de visitas

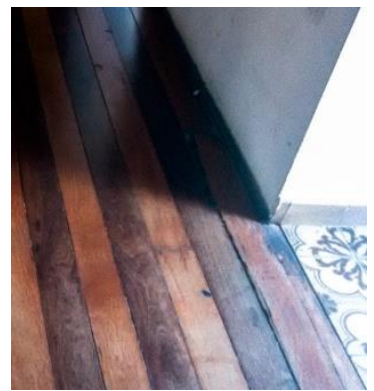

Assoalho policromado da sala de jantar

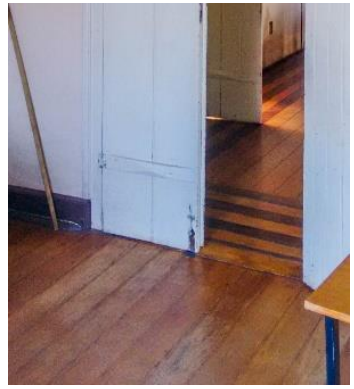

Assoalho de tábuas estreitas do quarto

Fonte: Acervo pessoal da autora (2017).

Interessante notar a correspondência do desenho entre o piso e o forro, contribuindo para refinar ainda mais o ambiente. Nesse sentido, o forro das áreas sociais era ainda mais sofisticado, possuindo pequenos disposições para ventilação natural permanente, de modo a proporcionar a saída do ar quente e melhor arejamento nesses ambientes. Predominaram forros de tábuas com mata-junta na horizontal e na diagonal e ainda com rodateto contornando e decorando o forro Figura 213. A adoção dos discretos orifícios, aliados 
à altura mínima do pé-direito de quatro metros e a exigência de aberturas em todos os ambientes também com dimensões mínimas de 1,10 metros de largura, evidenciam a intenção de adequar a construção às condições climáticas locais. Soluções que não foram exclusivas das edificações rio-pardenses. No caso das cozinhas, Lemos, C. (1978) e Homem (2015) apontam que os hábitos de preparação e conservação dos alimentos exigiram maior preocupação com o arejamento desse ambiente que adotou como solução o forro constituído por fasquias cruzadas (forro treliçado) de forma a permitir aberturas para facilitar a saída de fumaça proveniente dos fogões. Encontramos, por exemplo, residências ecléticas em Mococa que adotaram esse recurso na cozinha, ou ainda o forro paulista com encaixe macho-fêmea e aberturas de ventilação permanente próximo ao rodateto, como podemos ver na Figura 214, revelando com isso a reprodução de um saber fazer e de uma resposta viável às circunstâncias locais.

Figura 213: Diferentes tipos de forro na residência da esquina da Rua Francisco Glicério com a Praça Barão do Rio Branco, 831.

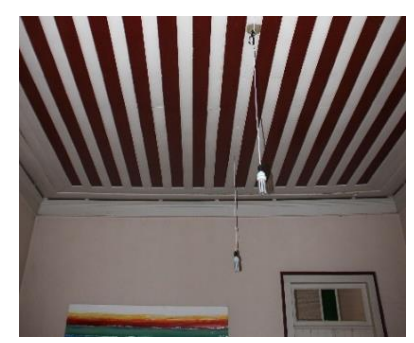

Forro de mata-junta e orifícios de ventilação

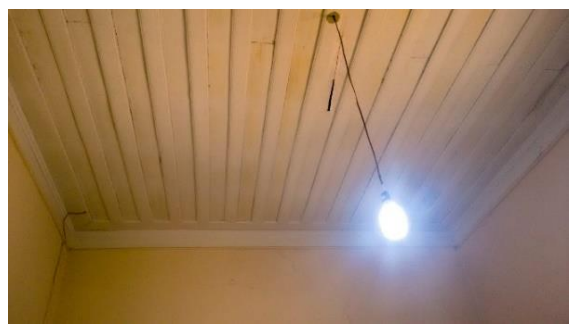

Forro de mata-junta sem ventilação

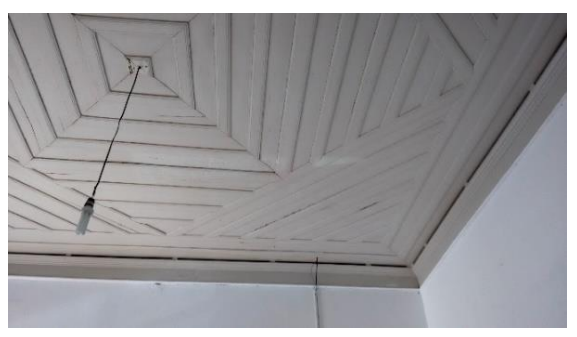

Forro com mata-junta formado por tábuas em diagonal e orifícios de ventilação

Fonte: Acervo pessoal da autora (2017).

Figura 214: Forros de madeira para ventilação natural da residência na Praça Marechal Deodoro, 17, na cidade de Mococa.

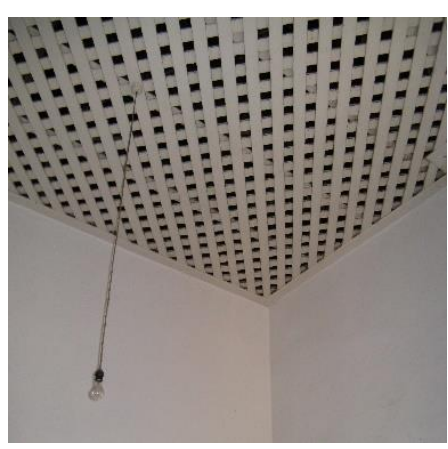

Forro treliçado

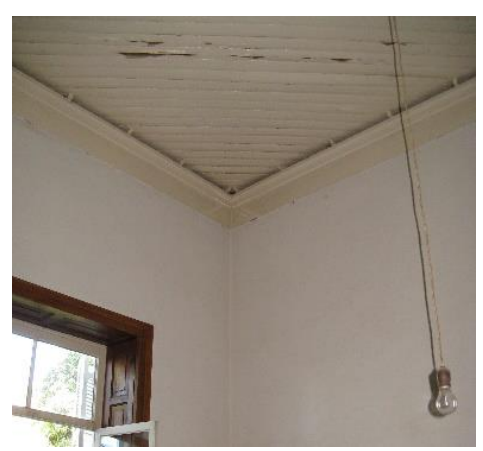

Forro paulista com encaixe macho-fêmea e aberturas de ventilação

Fonte: Acervo pessoal de Bortolucci (2011).

Outro recurso utilizado visando arejar a edificação foi a esquadria do tipo veneziana que permitiu a troca de ar mesmo quando fechada, ainda que minimizando a entrada de luz. Nesse caso, o uso do vidro permitia a iluminação natural, mas comprometia a privacidade que era garantida com o uso de uma folha de 
veneziana. Com exceção da casa do Nhô Ribeiro que possuía folha de vidro e veneziana de abrir, todas as outras faziam uso da guilhotina, como nas residências da família Ribeiro Nogueira, no Casarão do Artese, na moradia da Rua Capitão João Theodoro Nogueira, 141, e na moradia de Dante Artese. Constatamos ainda que na residência de Nhô Ribeiro a bandeira da janela era fechada por vidro, já na casa de Beatriz Cristina Granado do Prado o fechamento foi feito por veneziana, ou como no Casarão do Artese que exibia duplamente o fecho em vidro e veneziana (Figura 215), evidenciando a preocupação com o arejamento. Encontramos também a veneziana por fora e a folha de vidro por dentro, como na residência da família Penna, na moradia da Rua Francisco Glicério com a Praça Barão do Rio Branco, 831, no sobrado da Rua José Theodoro Nogueira, 110, e na moradia de Dante Artese (Figura 216). Cabe evidenciar que o uso do vidro foi tardio e até a chegada da ferrovia, que facilitou o seu uso, era recorrente esquadrias com folhas cegas ou janelas de guilhotina com vidro de pequenas dimensões.

Figura 215: Diferentes esquadrias com uma folha de vidro por fora.
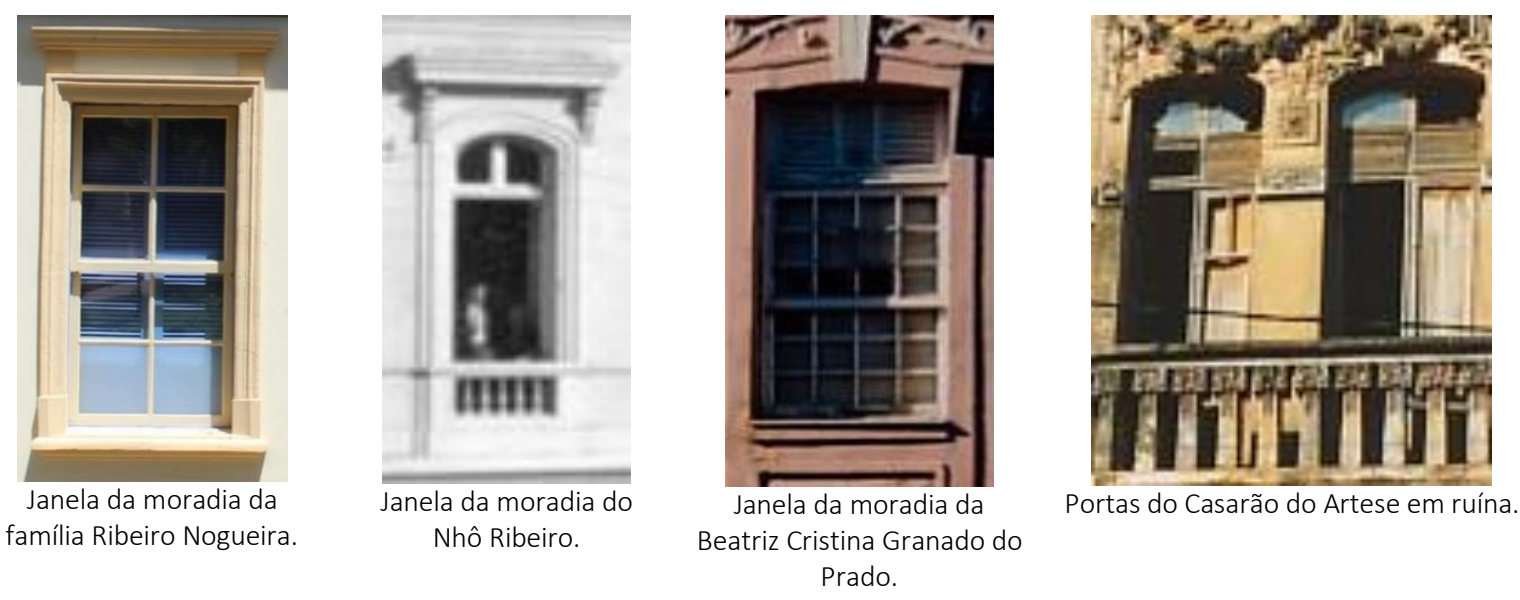

Fonte: Arquivo da Hemeroteca Jornalista Paschoal Artese e pessoal da autora.

Figura 216: Janelas venezianas externas.

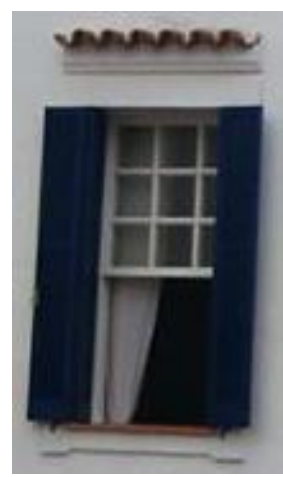

Janela da moradia da família Penna.

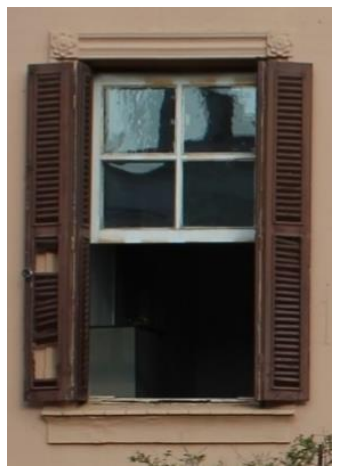

Janela da moradia da esquina da Rua Francisco Glicério com a Praça Barão do Rio Branco, 831.

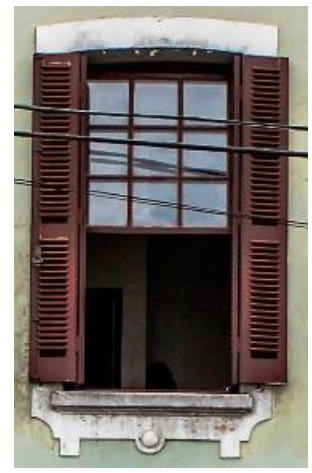

Janela da moradia da Rua José Theodoro Nogueira, Bairro Santo Antônio, 110.

Fonte: Acervo pessoal da autora (2016). 
A compatibilização da sofisticação de acabamento dos ambientes conforme seu uso, quem usa e a função, eram também revelados pelos móveis, objetos e utilitários no interior da casa, testemunhando o gosto, a riqueza, as pretensões e a qualificação social (LEMOS, C., 1989b). Nesse sentido, Correia (2004, p. 62) ao analisar a moradia diz que ela se tornou o "templo da vida privada e o local de expansão e expressão das individualidades" através da acumulação dos produtos que a indústria lançava, a começar pela cadeira de palhinha Thonet ${ }^{183}$ que foi produzida em série e se destacou pela leveza, baixo preço e facilidade de transporte já que era composta por reduzido número de peças (COSTA, L., 1939; CANTI, 1989), cortinas, tapetes, vasos de flores, estatuetas, armários envidraçados, cristais, retratos, pinturas, relógios de parede e bibelôs de várias origens (LEMOS, C., 1989b). A abundância de elementos, nem sempre funcionais, que penetrou no espaço doméstico ganhou um novo sentido, expresso também nas edificações mais simples ocupadas pela população sem tantas posses que desejava alcançar um pouco do desenvolvimento material e do conforto que os enricados proprietários das edificações mais sofisticadas usufruíam. A fala do senhor Francisco Trevisan sobre a mobília que foi da sua mãe (Figura 217), a qual ainda o pertence, denota essa pretensão e também o apreço dedicado a cada objeto:

Tínhamos mobília, não era muita coisa, o suficiente para o nosso conforto. Mobília de qualidade vinha de fora, não era produzido aqui, era madeira, coisa boa que nem cupim pega! Ainda tenho uma penteadeira que era da minha mãe, um armário de cozinha que veio da Itália, uma cama de 1915 que minha mãe usava, um relógio que tem mais de 150 anos, e algumas cadeiras. (TREVISAN, 2016).

Figura 217: Mobília da casa do senhor Francisco Trevisan.

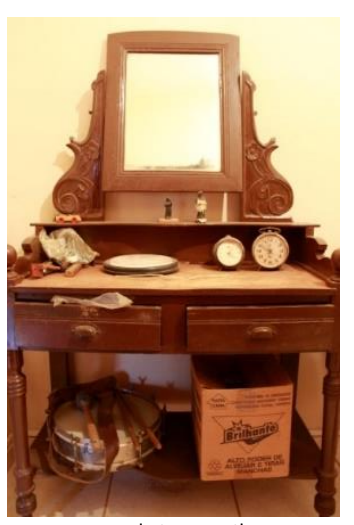

Penteadeira estilo art nouveau

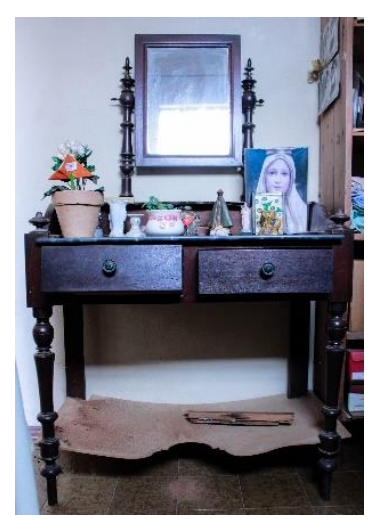

Penteadeira estilo Império

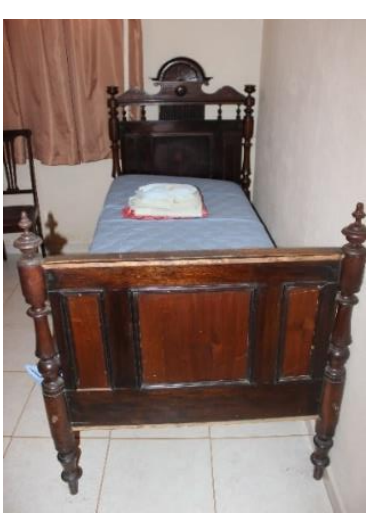

Cama estilo Império

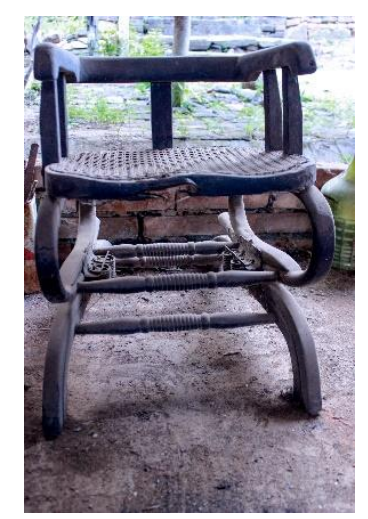

Cadeira estilo Austríaco

Fonte: Acervo pessoal da autora (2016).

Ainda que não tenhamos conseguido comprovar a veracidade sobre a origem da mobília da casa do senhor Francisco Trevisan, verificamos a existência de marcenarias e revendedores de produto semelhantes na cidade, como mostra a Figura 218. No anúncio da Marcenaria Artística está evidente o esforço do

\footnotetext{
${ }^{183}$ A cadeira Thonet, caracterizada pelo encosto arredondado e assento em palha entrelaçada, foi internacionalizada, sendo vendida até os dias de hoje. Marina Kosovski Maluf (2013) em sua dissertação sobre o design e o mobiliário no Brasil destacou que além do preço leveza física e visual, a popularização da cadeira Thonet ocorreu após a instalação da Companhia de Móveis Curvados no Rio de Janeiro que passou a produzi-la em 1890.
} 
proprietário, Salvador Artese, em querer atender à clientela, dispondo-se a produzir qualquer mobília "com a máxima perfeição, arte e gosto" e em diversos estilos, contando com lavatórios, criado mudo e cama, colchões ainda de capim e mobília completa de sala com cabide e espelho. Em outro anúncio Salvador Artese informa a variedade de móveis de produção própria e importados em seu depósito, os quais ele destaca os vários tipos de cadeira austríaca da marca Thonet, camas de ferro e de madeira, e porta bibelô. Ressalta ainda que a mobília fina era a especialidade da casa, comercializando também acolchoados, colchões, almofadas, capachos, esteiras, tapetes entre outros. Muito provavelmente essa marcenaria tinha destaque na cidade em consequência dos seus produtos e também pela localização do seu depósito nas proximidades da Igreja Matriz, área mais valorizada do núcleo urbano. Outra loja era a Marcenaria $e$ Carpintaria Paulista de Miguel Ceravolo que, assim como Salvador Artese, produzia qualquer serviço de marcenaria, mas destacava principalmente o sortimento de quadros, vidros, espelhos e camas com estrados de arame e lavatórios, e apontava para o aperfeiçoamento, elegância e higiene como expressão de distinção e qualificação.

Certamente havia público diverso que consumia o que essas lojas comercializavam, como as cadeiras Thonet que se tornaram objeto de desejo e elegância, e aqueles mais requintados e sofisticados produzidos artesanalmente ou importados e que por isso eram mais caros, logo acessíveis a uma parcela restrita da população.

Figura 218: Anúncios de mobília, objetos e acessórios.

\footnotetext{
MA CHI É ?!
MARCINERIA ARTISTICA
SALVADOR ARTESE

Nesta officina apromtam se com a maxima perfeiçà, arte e gosto todos os trabelhos como sejam:

Mobilia completa-Trabalho de entalhe-Altares-Palpitos

Especialidade em trubalhos „Art-Noveau,

Exposição permanente com deposito de mobilias

Alguns pregos de mobilias que a MARCINERIA ARTISTICA dicidiu fazer até o fim do anno, para bem servir seus numerosns freguezes :

Lavatorio estylo . Ma chi 6 p, 258000

, Rinascensa $40 \$ 50 \$$ e $100 \$ 000$

Creado mudo estylo. Sla chi é... idiota 1. $20 \$ 000$ para cima.

Elegante mobtlia de sala, completa com cabido e espelho $50 \$ 000$

Cama estylo .Ma chi é. . Diplomadn. de $10 \$ 000$ para cima,

Colchôes de capim bem beca para solteiro 78000

Idem para ensal $14 \$ 000$.

Deducjio de preços etn todos os outros objectus.

Seceato de Carpintaria.-Executa ue qualquer trabalbo de enquadria, como eccarreganse de conatruccbes de casas etc. Tirn plastas pera construesdes, otc.

Grande Deposito de Moveis

0 proprietario dn MARCENARIA ARTISTICA tendo um grande o rariqdo sortimento de moveis de fabricaça propris e im grande varects acha-so em cundięaso de vender a precos muito re. portacilo
duzidos.

B eis o resumo de lista dos preços: Cadeiras Austriacas marea Tonét a

- " qualidade suCadeiras Austriacas marea Tonét de Jaearanda a

- - - de diverscs ty.

pos a $55 \$ 000$ a $50 \$ 000$ e
Meia mobilia completa Austriaca de $150 \$ 000$ e $175 \$ 000$ a duzia. Meia mobilia completa Austraca de 1508000 e $170 \$ 000$

Mobilis de vime : - Jocaratuda por $115 \$ 000$

Mobil a de vime a 1201500

Mobilia com encosto estofadas a 2504000

Camas de ferro baratissimas.

Caminbas de madeiras para creatças descle 128000
Porta bibelotes a 258000 .

Mobilia fla especialidade da cass a prepos razonveis

Aleochoadns, Colchoes, almotadas, Capachos, osteiras, tapetes, ete.

Palhisha para cadeiras de $10^{*}$ a $1 \$ 500$ e $1 \$ 600$

Parafusos de catmas a 700 e 800

Tela metaliea superior a 18500 o metro.

Lira de primeira a 500 a iluzia.

Deposito de Puanos Nacionnes da afamada fabriea NARDELLI,

Anteo de comprar visitem a Marcenaria Artiotica de

SALVADOR ARTESE

PRAGA DR CANDIDO RODKIGUES NS $2-4-6$. OFFILANA NA RUA AMERICO DE CAMPOS $\mathrm{N}$. $\mathrm{B}$

Sao José do Rio Pardo 


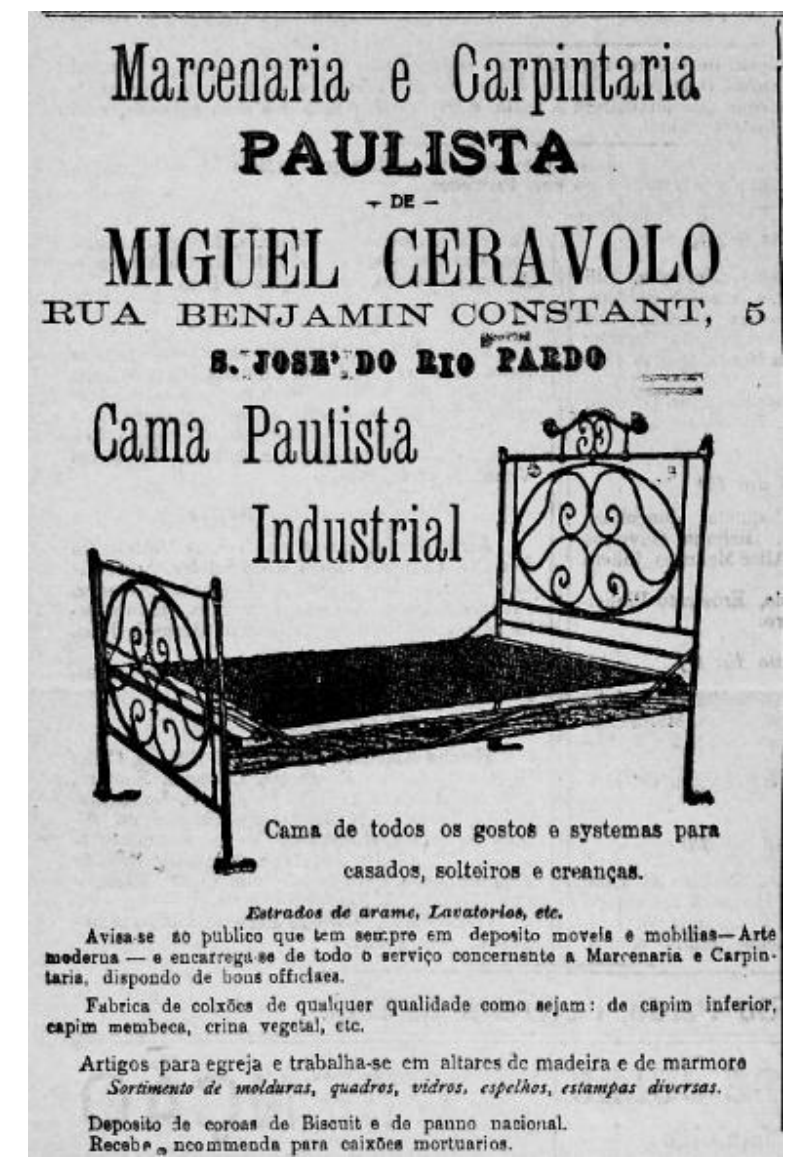

Anúncio da Marcenaria e Carpintaria Paulista em 13 de abriu de 1911.

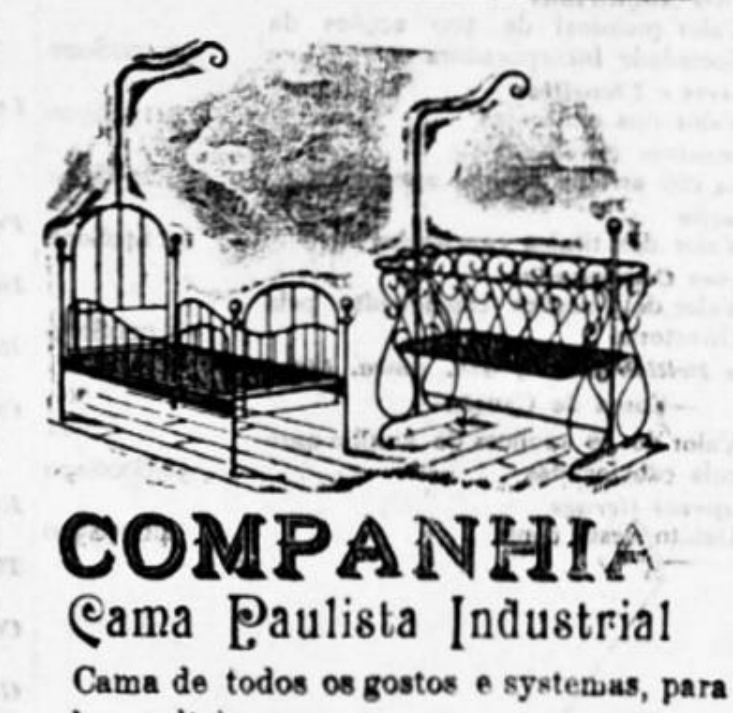

casados, solteiros e creanças

Estrados de arame, Lavatonos etc.

()s artigos de Fabricaçáo desta Companhia sâo todos aperfeiçoados, elegantes e bygienicos. Pinturas com vernises inglezes de 1" e telas que nunca affrouxam.

AGENTE NESTA CIDADE

ZTEUEL OARATOLO,

RUA BENYAMIM CONSTANT, S

Preços baratissimos

A DINHEIRO

Anúncio da Companhia Cama Paulista Industrial em 30 de janeiro de 1910

Fonte: Jornal O Rio Pardo, 1910-1912.

De fato, e como já descrito por autores como Reis Filho (2011) e Lemos, C. (1989a) sobre a sofisticação da residência eclética que assimilou as inovações segundo as condições técnicas, financeiras e climáticas da segunda metade do século XIX, em São José do Rio Pardo vimos que essa arquitetura foi predominantemente praticada entre os anos de 1903 e 1917, estando presente nas grandes e pequenas moradias. Condicionadas pelo contexto social e econômico associado às aspirações de prestígio e ascensão social, essa produção vai ao encontro do que Fabris (1993, p. 134) chamou de atitude poliestílistica do ecletismo que denota não apenas

\footnotetext{
um fato artístico, mas uma nova organização social e cultural, que põe fim a toda e qualquer ideia de unidade para apontar para o múltiplo, o diversificado, para privilegiar o instável e o relativo em detrimento do absoluto e do eterno. (FABRIS, 1993, p. 134).
}

Por certo a moradia se tornou representativa do momento pelo qual passou a cidade e a arquitetura no início do século, sofrendo com isso mudanças significativas introduzidas no âmbito formal e no agenciamento interno da edificação. Sem dúvida alguma o desejo do poder público, dos dirigentes e intelectuais em promover ações na direção de uma cidade moderna, higiênica e salubre resultou na ampliação dos instrumentos reguladores da atividade edificativa e também na implantação de 
infraestrutura de acordo com os seus interesses, como podemos acompanhar através do discurso de Paschoal Artese (ver item 2.2, página 195-197) e no trecho a seguir.

Sentimos-nos brasileiro, mais por merecimento do que por naturalização, quisemos, num gesto igualmente infeliz, testemunhar nosso amor a terra acolhedora, eregindo um monumento à sua Independência. Não estava ainda terminando quando entregamo-lo aos cuidados do Poder Municipal. Depois disso, durou pouco: demoliram-no barbaramente [...].

Outra questão relevante e determinante para a construção civil rio-pardense desse período foi a mão de obra do imigrante, sobretudo italiana - conforme analisado no item 2.2 desse capítulo -, que atuou como partícipe e protagonista das mudanças formais e técnico-construtivas empregadas, bem como das tipologias e arranjos compositivos.

Apesar da arquitetura desse período ressentir de documentação que nos forneça informações mais precisas como o ano de construção, responsável pela obra e quem foram os proprietários, nos deparamos com fragmentos de projetos que não eram uma exigência legal do momento. Mas que se tornará uma exigência após a administração pública colocar em discussão a proposição de um novo código de posturas atrelado ao que estava sendo feito na capital. Sobre isso, consta na ata da Câmara Municipal do dia 05 de março de 1917 o seguinte, "pede a palavra o capitão Mário Rodrigues para fundamentar alguns projectos, que vae offerecer à consideração da Câmara. [...] entra a analysar o Código de Posturas actual, que é defficiente e não satisfaz já as necessidades administrativas, de accordo com a evolução feita pela cidade". (ATA..., 05/03/1917, p. 42). Certamente havia um contato estreito, seja pessoal ou por meio de cartas, a ponto das novas posturas municipais, aprovadas na sessão da Câmara Municipal do dia 17 de dezembro de 1917 (ATA..., 17/12/1917, p. 58-59) e publicadas em janeiro de 1918, possuírem artigos análogos aos da Lei n. $1.596^{184}$ que também entrou em vigor em janeiro de 1918, e do novo Código Sanitário Estadual publicado em abril desse mesmo ano. Entre os mais recentes artigos estava a exigência de projeto aprovado de acordo com as leis e preceitos sanitários. A partir de então, todo o conteúdo dos critérios que utilizamos para analisar a moradia - implantação, cobertura, planta e aspecto formal - ainda iam ter singulares contribuições da legislação para promover transformações. Com isso, o Código de Posturas de 1918 se tornou o marco de uma nova etapa que vai ser trabalhada no próximo capítulo.

\footnotetext{
${ }^{184}$ A Lei n. ${ }^{\circ}$ 1.596, de 29 de dezembro de 1917, que dispõe sobre a reorganização do serviço sanitário do Estado de São Paulo fo publicada no diário oficial em 11 de janeiro de 1918.
} 


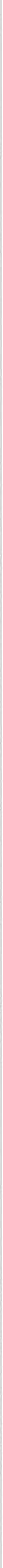




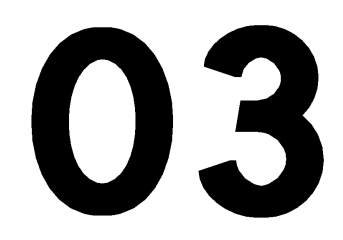

\section{São José do Rio Pardo e as moradias urbanas entre guerras: 1918-1940}

"[...] nada tem de fixo, imóvel. Cada vez que a sociedade passa por um processo de mudança, a economia, as relações sociais e políticas também mudam, em ritmos e intensidades variados, a mesma coisa acontece em relação ao espaço e à paisagem que se transforma para se adaptar às novas necessidades da sociedade" 


\subsection{A cidade e uma nova perspectiva}

Toda mudança precede e/ou ocasiona transformações, sejam elas sociais, econômicas, políticas, culturais, assim como a arquitetura, o espaço e a paisagem. E como nada tem de fixo, no final da década de 1910 foi promulgado o terceiro Código de Posturas de São José do Rio Pardo que contribuiu para assinalar o início de um período de significativas transformações - em paralelo aos acontecimentos externos de um período entre guerras e da debilidade e retraimento da economia baseada na cafeicultura, conforme veremos ao longo deste capítulo - que afetaram diretamente a produção da cidade e de sua arquitetura. Mais uma vez houve a conjugação de esforços de políticos e letrados em promover uma nova legislação, e como discutido no primeiro item do capítulo 02 , vinha para legitimar a anterior, mas segundo as mudanças que ocorriam na sociedade que exigiam respostas plausíveis às necessidades e ao novo modo de vida. Com isso, essas posturas municipais foram um marco na normatização dos mais variados aspectos da dinâmica urbana, sobretudo quanto ao seu funcionamento e desenvolvimento. Assim sendo, consideramos essas posturas um documento de importância basilar para nossa pesquisa, principalmente para a compreensão das mudanças que se processaram a partir de então. Interessa-nos ressaltar as novas normas criadas e demandas específicas, em particular quando revelava uma estreita ligação entre a dinâmica citadina, a construção de infraestrutura, a produção da arquitetura e os modos e costumes da população rio-pardense.

Nesse sentido, pela primeira vez as posturas municipais apresentaram atenção especial ao estabelecimento do perímetro da cidade e sua divisão em zonas. Logo no primeiro título do Código - "Do município e sua divisão" - os artigos permeiam essa questão através da descrição dos limites das respectivas zonas urbana, suburbana e rural (Figura 219). Consequentemente, a área delimitada como urbana correspondia à região central da cidade que, como vem sendo possível perceber desde o capítulo anterior, já se apresentava consolidada. Desse modo, o Código apontou que esta zona começava na

Ponte Metallica sobre o Rio Pardo, seguindo pelo córrego que desagua a sua direita até encontrar o fim da rua José Theodoro, dahi em rumo da pequena caixa de recepção da agua que vem de Espirito Santo do Rio do Peixe, junto a um vallo e por este abaixo até a avenida Bello Monte e por esta até a Praça Tiradentes, seguindo dahi pela avenida João de Souza até a Ponte Metallica. (CÓDIGO DE POSTURAS, 1918, p. 01).

Para além desse perímetro, em uma distância de um quilômetro, situava-se a zona suburbana, e as demais áreas do município eram caracterizadas como rural. O Código determinava ainda que a área ocupada pelas estações da estrada de ferro, independentemente de sua localização, constituía uma povoação, logo era considerada zona urbana em uma distância de até 500 metros. Mas, diferentemente das obrigatoriedades previstas, as edificações que estivessem dentro desse perímetro e que fossem de serventia exclusiva da propriedade agrícola ou pastoril eram isentas de imposto predial. Vale lembrar que o nosso recorte espacial, correspondente ao Centro Histórico, está contido nessa zona urbana. 
Figura 219: Divisão do município de São José do Rio Pardo em zonas conforme Código de Posturas de 1918.
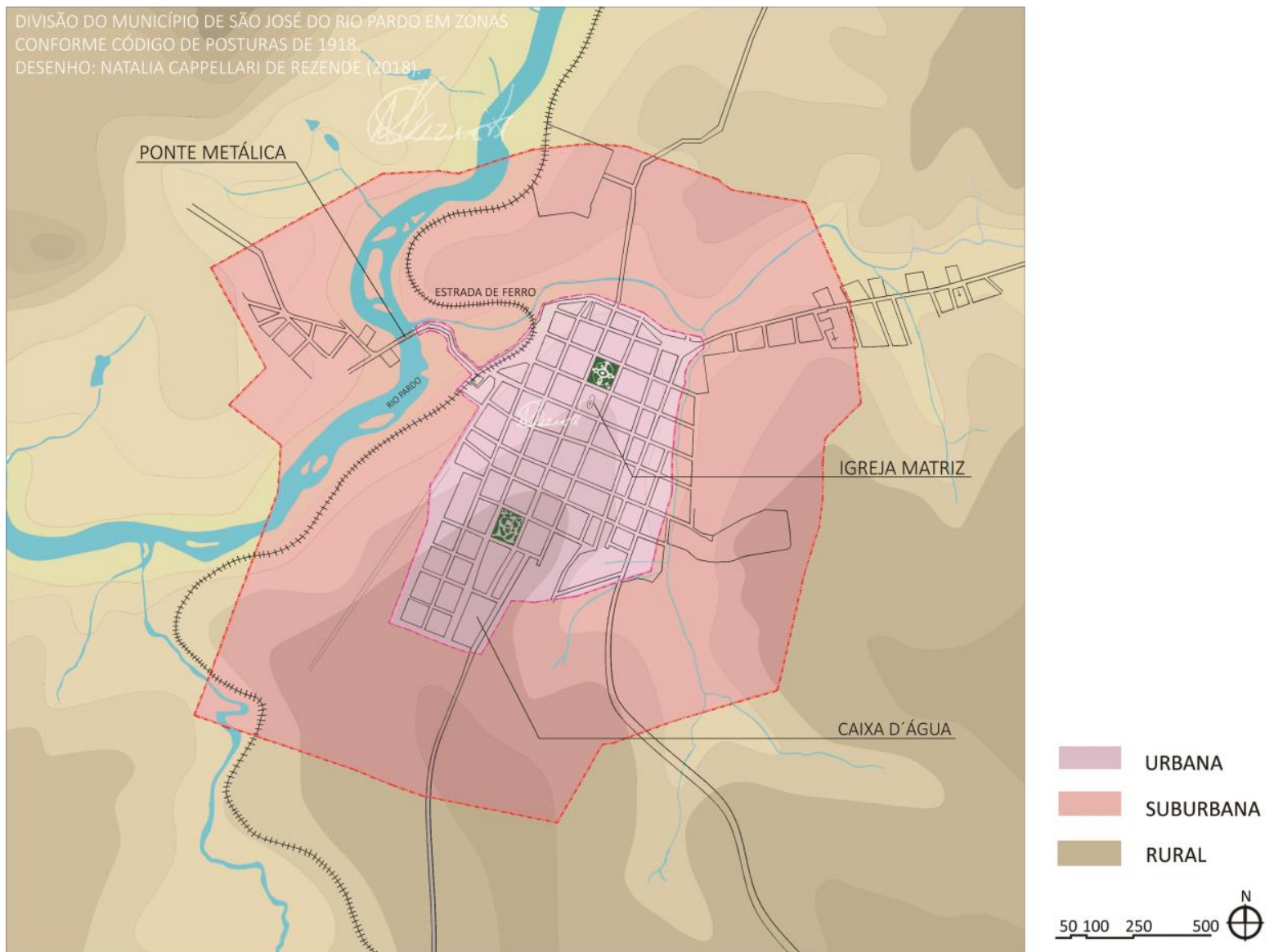

Desenho: Natalia Cappellari de Rezende (2018) com base em dados históricos e cartografia disponibilizada pela Secretaria de Obras de São José do Rio Pardo.

Foi nessa zona urbana, reconhecida pelo Código de 1918, que a municipalidade exigiu o cumprimento das novas disposições legais na tentativa de torná-la saneada e embelezada em todos os aspectos físicos, sociais e simbólicos, a esfera pública e também a privada, o que incluía a condição das vias. Apesar do Código de 1918 ter mantido a largura mínima de 16 metros para as novas ruas, o que já era uma imposição em 1903, para as avenidas - termo utilizado pela primeira vez em uma legislação rio-pardense - a dimensão mínima foi de 25 metros, seguindo as mesmas medidas adotadas em Campinas (LAPA, 1996). Esse novo Código inovou ainda ao exigir alvará de licença emitido pela Prefeitura para a abertura de ruas. Porém esse alvará era liberado mediante a apresentação de plantas que possuíssem

A) - Projecção horisontal das vias projetadas, em toda a sua extensão, com indicação das ruas que the ficam adjacentes, e tendo assignaladas as estacas indicadoras do alinhamento e nivelamento.

B) - Perfil longitudinal, cotado de vinte em vinte metros, no máximo, com indicação da linha e declive projectados.

C) - Perfis transversaes e de vinte em vinte metros, no máximo, de maneira a ser apreciado o movimento da terra.

Único - A projecção horisontal deverá ser em escala 1:200 e os perfis longitudinaes obedecerão às escalas 1:1000 para as alturas, e as secções transversaes na escala única de 1:100. (CÓDIGO DE POSTURAS, 1918, p. 02). 
Também fazia parte das posturas o alinhamento das vias que deveriam ser regulares, e as praças e largos retangulares, mas abria exceções para alterar a forma quando as condições do terreno não permitissem.

A preocupação mais presente nas posturas era com a higiene, tratamento anteriormente encontrado no Código de 1903, ainda que de modo incipiente se comparado a esse de 1918 que introduziu novidades que visavam a limpeza permanente das ruas e edificações. E para atuar de maneira incisiva, as determinações do Código de 1918 se estenderam à esfera privada. A partir de então, se tornou proibido atirar qualquer material sólido ou líquido nas ruas, praças, pátios e quintais que prejudicassem a salubridade pública ou que causassem algum incomodo às pessoas, assim como queimar qualquer material que tornasse o ar impuro. A lei incluía também os cuidados que os proprietários e inquilinos deveriam ter com os passeios e os muros, proibindo a forração de capim e mato. Ainda trazia a obrigatoriedade de depositar o lixo produzido em um reservatório provisório e hermeticamente fechado para ser recolhido pela Prefeitura que se encarregaria do descarte final. Outra disposição tratava da proibição do despejo de águas servidas em áreas públicas, terrenos ou quintais particulares, bem como a conservação de água estagnada. Para todas as questões abordadas pelas posturas de 1918 havia penalidades, caso não fossem observadas as obrigatoriedades previstas aos moradores ou inquilinos. O Código também estabelecia multa para quem possuísse chiqueiros ou criasse porcos soltos nos quintais ou pátios das casas, nas chácaras ou terrenos. Notadamente, a preocupação com essas questões recaía na região compreendida pelo perímetro urbano que correspondia à área mais valorizada da cidade.

Especificamente sobre as canalizações de água e esgoto, as posturas municipais apontaram a obrigatoriedade - em vigor desde 1903 quando foram implementadas ambas as redes - da respectiva ligação dos prédios, caso contrário seria interditado. Além disso, de acordo com o artigo 81, era imprescindível que todos os edifícios tivessem ao menos uma latrina, revelando a nítida preocupação com a condição sanitária desses lugares e consequentemente dos usuários. Muito mais detalhadas que as anteriores, essas posturas municipais de 1918 estabeleciam ainda a necessária inspeção das habitações e suas dependências por fiscais e médicos do município, devendo o trânsito desses profissionais ser devidamente liberado pelos moradores, sob pena de multa. Nos casos em que fosse constatada alguma irregularidade que comprometesse a saúde pública ou incomodasse a vizinhança, a edificação era interditada com prazo máximo para que todos os melhoramentos fossem realizados, e na impossibilidade do atendimento, deveria ser demolida e construída segundo as normas da nova lei, e respaldada pelo Código Sanitário do Estado de São Paulo, de 1918.

Lemos, C. (1999), ao analisar a legislação republicana brasileira e sua interferência na casa, apontou um novo Código Estadual resultante da reorganização do Serviço Sanitário, promulgado em janeiro de 1918. Segundo esse autor (LEMOS, C., 1999), o Código de 1917, como ficou conhecido por ter sido decretado em 29 de dezembro, inovou bastante, sobretudo no que dizia respeito a ventilação permanente e renovação do ar, exigindo para isso venezianas nos dormitórios. Mas foi em abril de 1918 que finalmente surgiu o "célebre" Código Sanitário que vasculhou "todos os programas de necessidades, passando pelos 
estabelecimentos comerciais, indústrias, hospitais, residências, cemitérios e tudo o mais que pudesse construir" (LEMOS, C., 1999, p. 78). Com escopo semelhante, o Código de Posturas (1918) rio-pardense, publicado três meses antes, especificou normas para diferentes programas de uso, e assim como o Código Sanitário, possuía efeito retroativo, logo as disposições passaram a valer para todos, inclusive para as edificações existentes e em funcionamento. Esse quadro levou Lemos, C. (1999) a afirmar que a partir de então as edificações passaram a ser "vigiadíssimas" na tentativa de fazer valer as novas normas. Além disso, nos casos de construção e reconstrução rio-pardenses era imprescindível a aprovação dos projetos pela Prefeitura, conforme artigo 38 das posturas municipais e artigo 342 do Código Sanitário Estadual, denotando a incisiva ação do poder público na atividade edificativa local.

Art. 38 - É absolutamente vedado o início de construç̧ão ou reconstrucção de edifício, bem como de obras de qualquer natureza, a face das ruas, avenidas ou praças, no perímetro urbano e suburbano da cidade e povoações do Município, sem o preenchimento das condiç̧ões impostas pelo Código Sanitário do Estado, e sem previa licença do Executivo.

* o interessado, no requerimento que dirigir ao Executivo, deverá declarar com precisão e clareza o logar, a natureza e destino da obra, juntando em duplicata:

A) Planta do terreno, sendo indicado a disposição e área da construcção projectada;

B) Planta dos vários pavimentos;

C) Elevações das fachadas;

D) Cortes longitudinaes e transversaes;

E) Disposição dos encanamentos para agua e exgotos, que dêm ideia do projecto.

* 2 - As plantas obdecerão a escala 1:100, e as elevações e seç̧ões serão em escala de 1:50.

*3 - Das plantas, uma vez aprovadas, um exemplar ficará archivado na repartição competente e o outro será restituído ao requerente, que não poderá fazer modificações por quaesquer forma. (CÓDIGO DE POSTURAS, 1918, p. 07).

Artigo 342. - Nenhuma construcção ou reconstrucção deverá ser iniciada sem planta organizada de accôrdo com as posturas municipaes e leis sanitarias do Estado. (Art. 148, lei 1.596).

§ 1. - Ao Serviço Sanitario será entregue um exemplar da planta do predio e dos exgottos projectados.

§ 2.ㅇ - Se o Serviço Sanitario verificar que a planta não está de accôrdo com a legislação sanitaria estadual ou municipal, representará nesse sentido a auctoridade municipal competente. (CÓDIGO SANITÁRIO, 1918, p. 44).

Condição semelhante foi aplicada à população, que teve seus hábitos e sociabilidades policiados. O Código municipal proibia a circulação pelas ruas, praças e edifícios públicos de pessoa que não estivesse "decentemente vestida", assim como nos banhos realizados nos rios e córregos da cidade, "de modo a não ofender o pudor". A preocupação com a "moral" impunha a repressão a qualquer palavra proferida, gesto, ou algazarra que ofendesse os "bons costumes" e perturbasse o sossego público. E, ainda, estabelecia que qualquer pessoa encontrada sem ocupação pré-determinada, podia ser processada na forma da lei pela autoridade policial, configurando seu estado um crime para a sociedade (CÓDIGO DE POSTURA, 1918 p. 39 40). Nesse sentido, Lira $\left(1999\right.$, p. 51) ${ }^{185}$ ao tratar da formação do espaço urbano no Brasil ressalta que alinhado à abordagem sanitária, urbanística e legislativa estava o "discurso da raça e da cultura no debate da cidade", que servia para "contrapor a um meio urbano visto como degenerador de uma cidade asséptica,

\footnotetext{
${ }^{185}$ Lira (1999) demonstra como que as ações de disciplinamento legal, policiamento e medicalização do espaço urbano e da habitação estavam suscetíveis ao discurso sanitarista atingindo diretamente a preocupações com a moral, a família, os costumes, a sensibilidade, a sexualidade e a reprodução.
} 
civilizada e domesticada para as funções do trabalho, mas também 'eugênica', quer dizer, racialmente higienizada". E, conforme constatado por Sevcenko (1998, p. 544) ao analisar o Rio de Janeiro, mas que muito serve para explicar o que acontecia em outras cidades do país, havia uma contradição intrínseca e excludente onde os grupos carentes eram compelidos a uma mudança de comportamento social pela política urbana "abrupta e ameaçadora da autoridade a qualquer hora e em qualquer lugar".

De fato, é explicito no texto do Código a persistência do embasamento higienista como determinante para o funcionamento e crescimento da cidade e na condição da vida urbana, sobretudo no desenvolvimento físico e moral da população, associado às necessidades de organização social com vistas ao trabalho e consequentemente ao desenvolvimento do capital (CORREIA, 2004; SEVCENKO, 1998). Fato notadamente evidenciado no relatório do prefeito capitão Mário Rodrigues ${ }^{186}$ que exaltou a publicação do novo Código juntamente com a execução de obras, a implementação de infraestruturas e outras medidas empregadas visando a "remodelação da cidade" (UM RELATÓRIO, 1918, p. 01). Mário se referia à construção de praças e ao ajardinamento de outras, exprimindo a estreita ligação existente entre as condições higiênicas e salubres, a moral e a estética.

A cidade, como um todo, mas de forma mais enfática a área central, estava inserida em um campo de forças físicas e simbólicas que tendiam a torná-la representativa material e socialmente do progresso e da modernidade. Peça fundamental na manutenção da teia que dominou o cenário político e econômico riopardense no início do século XX foi esse prefeito Mário Rodrigues, que não por acaso centrou esforços na materialização de benfeitorias, respaldadas pelas novas posturas municipais. Obras como a construção da Praça Prudente de Moraes que devido à topografia acidentada adotou um traçado mais orgânico, seguindo as brechas deixadas do novo Código, como é possível observar na Figura 220 e Figura 221; o ajardinamento e a construção da Herma Euclides da Cunha (Figura 222) em homenagem ao responsável pela reconstrução da ponte metálica e escritor de Os Sertões; apoio financeiro para a construção da Gruta de Nossa Senhora de Lourdes (Figura 223) localizada na entrada do Asilo Padre Euclides Carneiro; e o ajardinamento, arborização e fechamento com cercas e portões do Parque Independência (Figura 224), localizado ao sul da Rua Treze de Maio onde foram construídas caixas d'água com projeto e execução de Ernesto Rugani ${ }^{187}$ (Figura 225). O Jardim Artístico foi outro melhoramento que se assemelhou a estes, mas não foi uma medida desse governo, e nem de outros, e menos ainda teve apoio desse tipo, pelo contrário, foi construído e cuidado pelo italiano Paschoal Artese (ver o discurso nas páginas 196 e 197).

\footnotetext{
186 O republicano Mário Rodrigues, filho de Antônio Candido Rodrigues, permaneceu no cargo de prefeito entre os anos de 1915 e 1919. Durante o seu mandado, e sob a influência de seu pai que era o vice-presidente do estado junto com Altino Arantes (1916-1920), Mário empreendeu ações que combinava facilidades e compadrio em acordo com os ideais republicanos.

${ }^{187}$ Veremos mais sobre esse construtor no próximo item deste capítulo, na página 271. 
Figura 220: Vista aérea da Praça Prudente de Moraes.

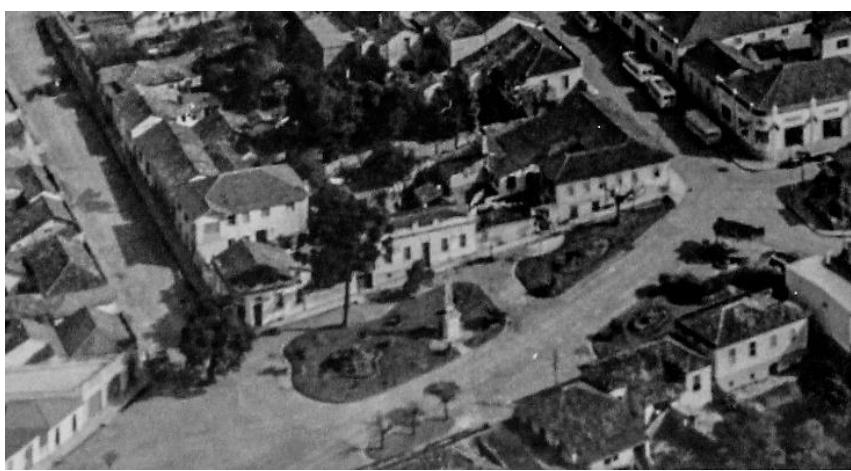

Fonte: Arquivo do Centro da Memória Rio-Pardense Rodolpho José Del Guerra.

Figura 222: Herma Euclides da Cunha, primeira metade do século XX.

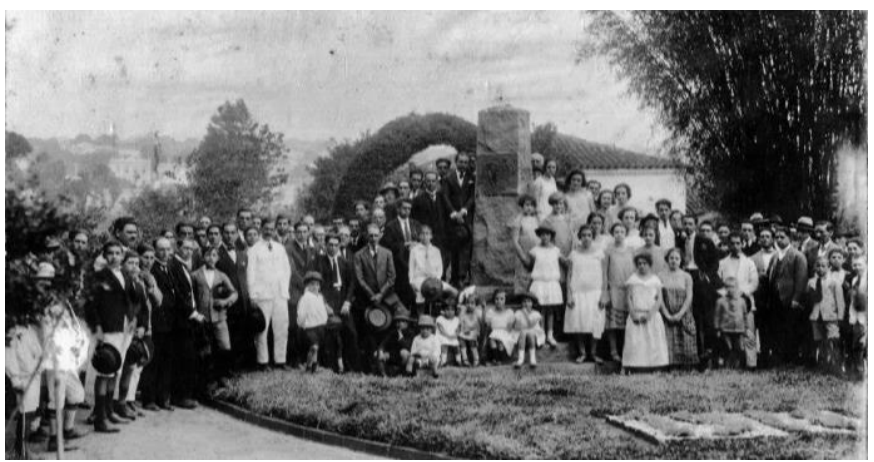

Fonte: Arquivo do Centro da Memória Rio-Pardense Rodolpho José De Guerra.
Figura 221: Vista frontal da Praça Prudente de Moraes, 1922.

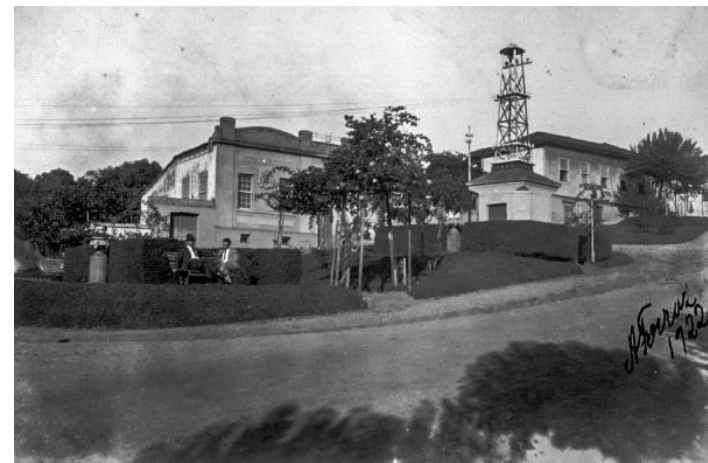

Fonte: Arquivo da Hemeroteca Jornalista Paschoal Artese.

Figura 223: Inauguração da Gruta Nossa Senhora de Lourdes em 18 de maio de 1918.

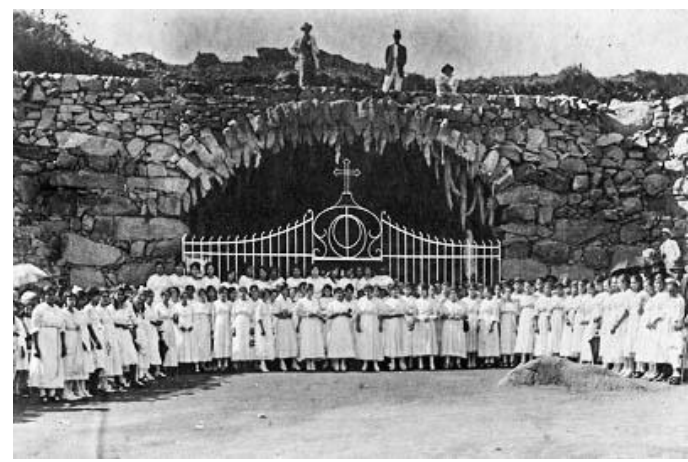

Fonte: Arquivo da Hemeroteca Jornalista Paschoa Artese. Fotografia de Celestin Detinne.
Figura 224: Vista parcial do Parque Independência em construção na década de 1910

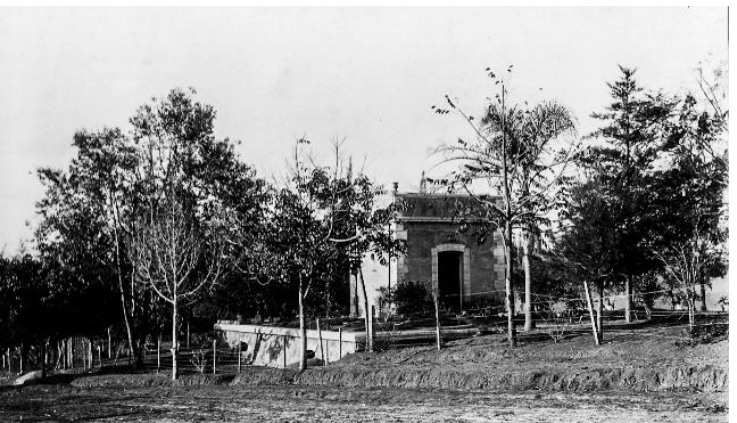

Fonte: Arquivo da Hemeroteca Jornalista Paschoal Artese. Fotografia de Innocencio Vilhegas.
Figura 225: Construção da caixa d'água no Parque Independência, década de 1920

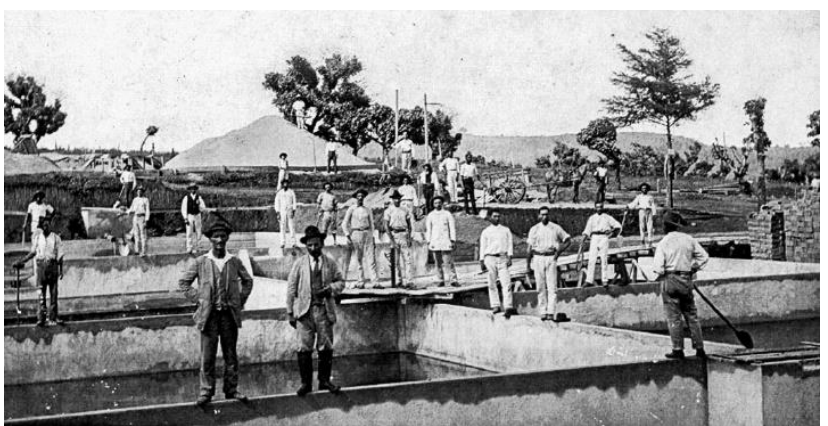

Fonte: Arquivo da Hemeroteca Jornalista Paschoal Artese. Fotografia de Celestin Detinne.

Como constatado nas figuras acima, todas as obras denotavam a busca por rigor, disciplina e organização ao criar lugares de contemplação, produzidos artificialmente e quase pitorescos, e onde as posturas municipais policiavam os usuários que poderiam frequentá-los a partir das suas vestimentas e do modo de se portar. 
Obras que exacerbavam um outro estilo de vida e uma nova forma de lazer. Destarte, conceberam lugares transformados em recintos da sociabilidade burguesa rio-pardense onde as regras de refinamento expunham as vaidades. Não obstante e com exceção da Gruta, todas as benfeitorias se localizavam no limite do perímetro urbano estabelecido pelo Código de 1918 e nas principais vias de acesso à área central da cidade, como podemos ver na Figura 226.

Figura 226: Localização das instalações construídas na gestão do prefeito Mário Rodrigues (1915-1919).

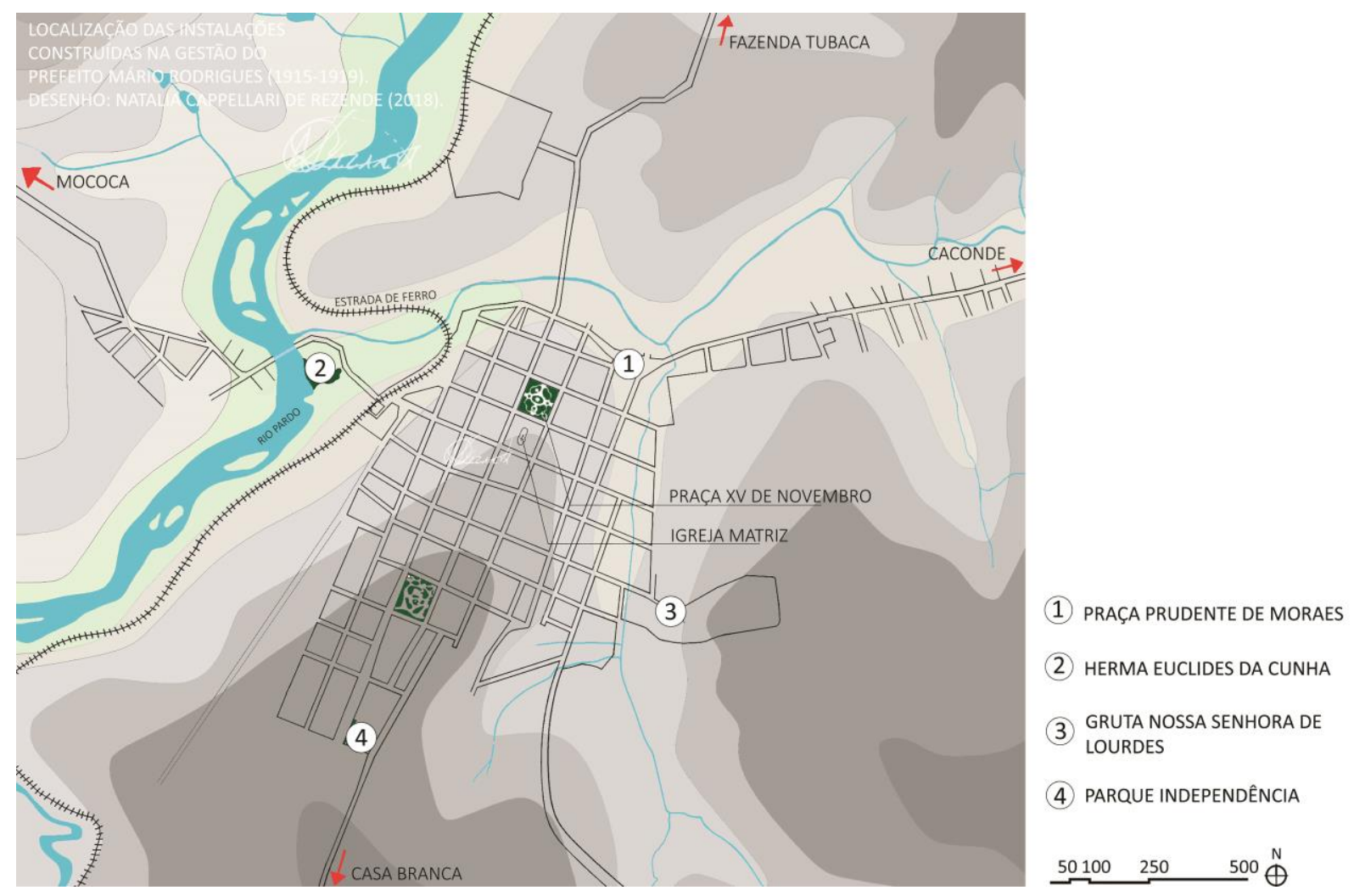

Desenho: Natalia Cappellari de Rezende (2018) com base em dados históricos e cartografia disponibilizada pela Secretaria de Obras de São José do Rio Pardo.

Logo eram locais propícios para apresentar aos visitantes a beleza e a organização local. Qualidades que cabiam aos moradores conservar e também contribuir através de suas edificações, conforme veremos no terceiro item.

Inflexíveis, as posturas municipais e o Código Sanitário Estadual se tornaram instrumentos de controle urbano e social, publicados exatamente no último ano da primeira Grande Guerra, e por isso foram drasticamente criticados, apesar de serem reconhecidos os benefícios das medidas em questão. Testemunho exemplar dessa situação é o relatório escrito em 1920 pelo delegado de saúde de São Carlos, Dr. Álvaro Sanches, que atestou as dificuldades encontradas e justificadas por consequência da crise econômica causada pela guerra, os prejuízos sofridos pelas geadas que afetaram a lavoura, a elevação do 
preço dos materiais de construção, a dificuldade de importação, a falta de mão de obra e o aumento dos impostos (BORTOLUCCI, 1991; LEMOS, C., 1999). Como nos disse Lemos, C. (1999, p. 82), o documento escrito por Sanches certamente "espelhava o pensamento não só dos habitantes daquela cidade, mas também a ideia de todos os paulistas". Sem nenhuma dúvida, essas observações se aplicam ao contexto riopardense, dadas as poucas edificações construídas nesse período conforme pudemos identificar em nosso levantamento de campo e documental ${ }^{188}$. Certamente todas as dificuldades que atingiram a população alcançaram também o desempenho da gestão municipal dessa época, razão pela qual não foi construído nenhum edifício público, a exceção das praças e manutenção das vias.

A insatisfação era geral com o estado de adversidades que o município estava atravessando. Situação que foi agravada com o aumento de impostos sobre o comércio, conforme reportado pelo jornal O Progresso do dia 09 de março de 1918:

Foi exagerada a taxa com que se quis tributar o nosso commercio, tocando essa elevação descommunal, às raias do absurdo. Tornando eco da enorme celeuma, provocada justamente pelo aviso da collecta feita para o presente exercício; vemos que casas commerciaes que pagaram, o anno passado $49 \$ 000$ de imposto hoje tiveram o imposto elevado para mais de 200\$000. (IMPOSTOS ESTADOAES, 1918, p. 02)

Cabe salientarmos que foi nesse contexto que se propôs a construção de um estabelecimento onde os comerciantes pudessem reunir diferentes mercadorias e vendê-las por um preço mais acessível. Todavia, a limitação financeira da municipalidade não permitia tal investimento. A alternativa encontrada foi o livre comércio de alimentos realizado a princípio na Praça Barão do Rio Branco, posteriormente alterado para a Praça Dr. Candido Rodrigues. O objetivo dessa ação era melhorar as vendas, conforme foi estabelecido pela Lei . $^{\circ} 27$ de 06 de setembro de 1918 que regulamentou as feiras livres:

Art. $2^{\circ}$ - Fica isento de imposto tudo o que se venda para o consumo público nesses mercados, dentro das referidas horas (período das 6:00 as 12:00 horas de todos os domingos do mês).

Art. $5^{\circ}$ - Os preços de venda deverão ser no minimo $10 \%$ mais baixos que os communs dos negócios a varejo, e constarão de uma tabella, que será affixada no local do mercado. (LEI N. 27/1918).

A falta de importantes obras era constantemente denunciada no jornal Resenha que ratificava a frustração de uma parcela da população com a movimentação e gritaria dos mascates e ambulantes nas proximidades da igreja Matriz, propondo à municipalidade a construção de um Mercado Municipal (DEL GUERRA, 2001). Somente em 1924 a discussão foi retomada, sem consenso sobre o local mais adequado. Isso porque foi decidido pela Praça Barão do Rio Branco que foi desapropriada e a igreja do Rosário demolida em 1908, após ser inaugurado o Grupo Escolar Candido Rodrigues, por considerar os cultos religiosos prejudiciais ao bom funcionamento do ensino ${ }^{189}$. Assim sendo, a construção do Mercado Municipal nesse local foi criticada

\footnotetext{
${ }^{188}$ Foi possível constatar a diminuição do ritmo da construção civil através dos relatórios de governo e reportagens publicadas nos jornais locais, e também através da data das construções quando escrita na platibanda e dos dados levantados no Cartório de Registro.

${ }^{189}$ A decisão da demolição da igreja do Rosário foi tomada pelo prefeito da época, João Baptista de Souza Moreira do partido republicano que permaneceu no cargo no período de 15/01/1908 a 14/01/1914. A justificativa de tal ação foi de que os barulhos produzidos nos cultos religiosos prejudicariam o desenvolvimento das aulas.
} 
pela população devido à perturbação e ao mau cheiro que causaria nas suas proximidades, além de alterar a estética da principal via de acesso ao sul da área central. Sobre isso o jornal Resenha comentou que

O malogrado Mercado! Sacrificaste a praça, sacrificio esse que não passa de um crime e um atentado à esthetica, não deixando de affectar também a saúde publica!.. (...) O Mercado com as suas exposições de rabanetes, couves, bananas, toucinho salgado, peixes fedorentos e titica de galinha, sim! Ó Santo critério de todos os hygienistas, maior cabeçada não podias dar!... (O MERCADO ..., 1925, p. 02).

No entanto, a localização e o projeto foram aprovados na sessão da Câmara Municipal e registrados na ata do dia 06 de abril de 1925 e 04 de maio do mesmo ano, e foram também deferidos pelo delegado de saúde pública de Ribeirão Preto ${ }^{190}$, sendo a obra concluída em 1926. O prédio de composição volumétrica diferenciada das comumente utilizadas no Brasil ${ }^{191}$ foi implantado no centro da Praça, e consiste em uma forma elíptica circundada por alpendre em toda a sua extensão. Ao redor de todo o edifício havia um $a^{a l p e n d r e ~}{ }^{192}$ que garantia a ventilação e iluminação. Vale destacar as semelhanças que este edifício guarda com o Matadouro construído em 1917 (ver Figura 112 na página 158), na medida em que ambos apresentam uma cobertura central e elevada, e aberturas que foram propiciadas pela diferença de altura dos telhados (principal e do alpendre) envidraçadas que garantem a troca do ar de acordo com as determinações do Código Sanitário Estadual (Figura 227). Além disso, em ambos os edifícios há uma estrutura metálica que sustenta o letreiro indicando sua função, como podemos ver na Figura 228.

Figura 227: Mercado municipal de São José do Rio Pardo, final da década de 1920.

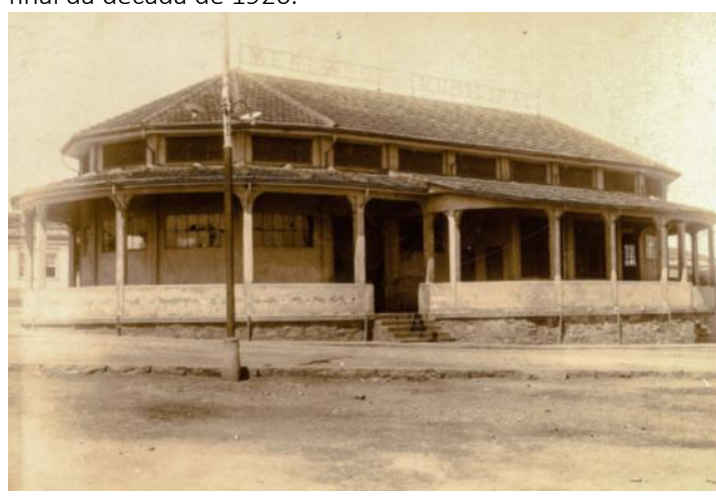

Fonte: Arquivo da Hemeroteca Jornalista Paschoal Artese.
Figura 228: Estrutura metálica que sustenta o letreiro indicando a função do edifício: Mercado Municipal, 1929.

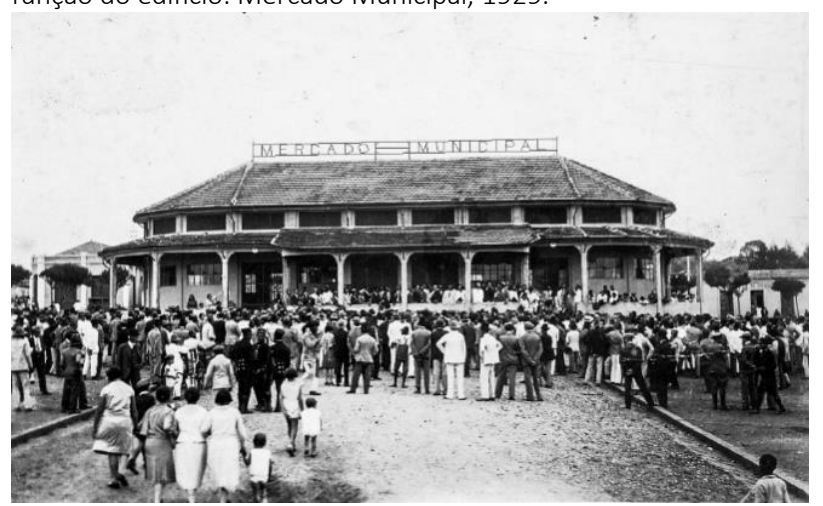

Fonte: Arquivo do Centro da Memória Rio-Pardense Rodolpho José Del Guerra.

\footnotetext{
${ }^{190}$ O delegado de saúde pública de Ribeirão Preto entre os anos de 1925 e 1928 foi o Dr. Eduardo da Silva. Segundo Fernando Cerqueira Lemos (1954, p. 45), ele se formou "em medicina no Rio de Janeiro no ano de 1891, colaborando desde então com o Dr. Emílio Ribas, no combate à febre amarela. Foi nomeado delegado de saúde de Ribeirão Preto, em 1918, ocupando este cargo até seu falecimento, e m 13 de setembro de 1931".

${ }^{191}$ As características tipológicas e construtivas de muitos mercados públicos construídos no Brasil durante meados do século XIX e início do XX seguiram exemplos de edifícios fechados com pátio interno aberto, e plantas simétricas de forma quadrada e retangular. Esta tipologia pode ser observada no Mercado da Candelária no Rio de Janeiro, Mercado Público de Florianópolis e de Rio Claro, e o Mercado da Rua 25 de Março em São Paulo. Outra tipologia adotada neste período foi o edifício coberto em estrutura de ferro dotado de lanternim, a exemplos do Mercado de São José no Recife, o Mercado Público de São Carlos e o de São João em São Paulo. Para saber mais sobre isso, ver Murilha (2011).

192 Segundo Del Guerra (2001), o alpendre foi bastante utilizado como palanque para comícios e festividades, e era local de encontro das procissões, mas pouco tempo depois se tornou motivo de reclamações por parte da população que o considerava perigoso em razão dos agrupamentos que ali ocorriam e por apresentar mau cheiro, tornando o local desagradável. Tais reclamações conduziram à primeira reforma realizada no prédio em 1951, que resultou na supressão do alpendre como justificativa de ampliação do espaço interno. Ainda hoje o prédio mantém suas características iniciais, mas não o uso, sendo tombado CONDEPHAC-SJRP em 2010.
} 
As preocupações com a infraestrutura, a estética e a saúde pública guiaram as gestões municipais na década de 1920 e de 1930, período em que o número de construções aumentou consideravelmente, como veremos na página 257. O poder público, engajado no estabelecimento de novas dinâmicas de uso da cidade, investiu em equipamentos e melhorias viárias na área central. Importantes obras foram empreendidas. Destacamos, nesse sentido, o início do calçamento em paralelepípedo da Rua Ananias Barbosa (1924), a canalização de cursos d'água nos trechos urbanos (1925), vários melhoramentos no sistema de abastecimento de água, como troca de filtros e construção de caixas d'água (1927), implantação de bueiros (1924-1927), melhorias no fornecimento de luz elétrica e no sistema de telefonia (1927), a construção de novo edifício para estação ferroviária (1927) e hospital (1930).

A nova estação ferroviária foi construída no mesmo local da anterior (RELATÓRIO..., 1927, p. 18) com estética e técnicas elaboradas que fatalmente influenciariam outras construções urbanas da época, as quais serão melhor analisadas nos próximos itens deste capítulo. Esse prédio da Estação Central (Figura 229), evidencia características das construções realizadas pela Mogyana e são fortes as semelhanças com estações de outras cidades servidas por esta companhia. Segundo Kühl (1998), a singularidade e opulência dos prédios eram restritas à importância da própria cidade, ainda que guardasse analogia com as demais. Ainda de acordo com essa autora (KÜHL, 1998), o processo de reforma e construção de estações no início do século XX foi resultado de aumento da crescente produção agrícola de exportações, a movimentação de mercadorias e também de pessoas. De planta retangular e um pavimento, a Estação Central de São José do Rio Pardo se destaca pela sua horizontalidade, acentuada pela cobertura de proteção da plataforma; composição de aberturas com arco tripartido; arco pleno e de verga reta que diferenciam as funções dos ambientes; pilastras lisas elevadas até a platibanda dotada de cimalha; e ático revestido de placas e losangos que se assemelham a placas metálicas - formas possivelmente derivadas da industrialização -, representando um vocabulário inovador, inventivo e moderno. Adjacente à Estação, o Armazém compõe o conjunto e garante o equilíbrio horizontal (Figura 230).

Figura 229: Vista parcial da Estação Central construída em 1927.

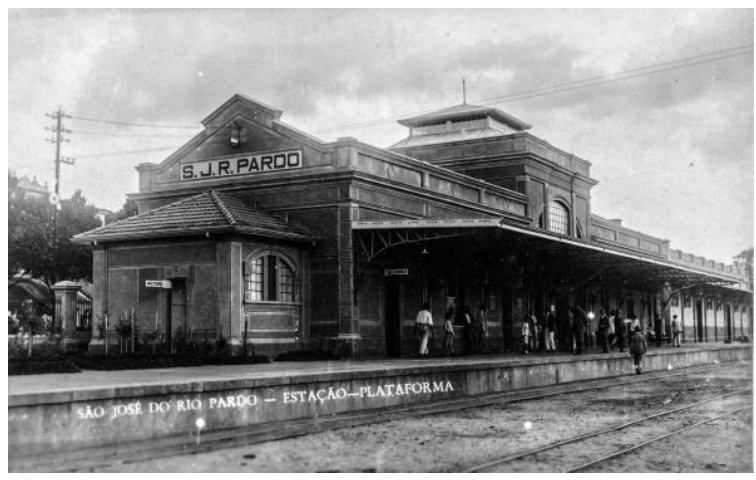

Fonte: Arquivo do Centro da Memória Rio-Pardense Rodolpho José Del Guerra.
Figura 230: Vista parcial da Estação Central e do armazém construídos em 1927.

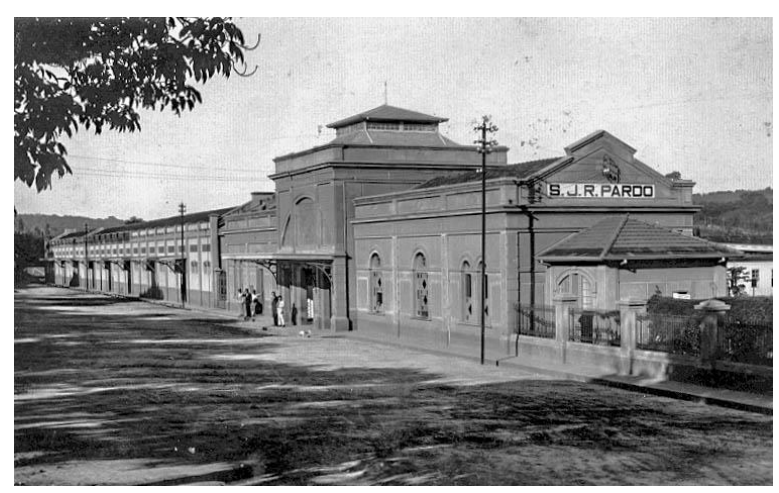

Fonte: Arquivo do Centro da Memória Rio-Pardense Rodolpho José Del Guerra. 
Foi nesse ímpeto que um novo hospital foi construído para substituir o antigo. Assim como aconteceu com o velho cemitério, o hospital Santa Casa de Misericórdia foi desativado por não comportar mais as funções, e também devido à aproximação da malha urbana que se desenvolvia em sua direção. Em 1929 o Almanaque já anunciava que seria o "prédio de mais majestosas proporções" de São José do Rio Pardo (ALMANACK, 1929, p.31). Em 1930, antes mesmo de serem finalizadas todas as etapas da obra, o Hospital São Vicente foi inaugurado em uma área alta e afastada dos terrenos insalubres, suficientemente distante da área central da cidade, interrompendo a continuação da Rua Treze de Maio ${ }^{193}$ (Figura 231). Construído isolado em um terreno amplo, o prédio era formado por um corpo principal com acesso frontal e pavilhões recuados e dispostos perpendicularmente. Todas as salas possuíam um generoso pé-direito permitindo iluminação e ventilação natural por amplas aberturas e "de accordo com os mais modernos preceitos de hygiene hospitalar" (ALMANACK, 1929, p.30). Havia porões que, além de distanciar o edifício do terreno, facultavam o nivelamento dos blocos em uma mesma cota. Destaque para a horizontalidade do bloco central e a estrita simetria realçada pela sequência ritmada de aberturas, como é possível observar na Figura 232 a seguir.

Figura 231: Localização do Hospital São Vicente.

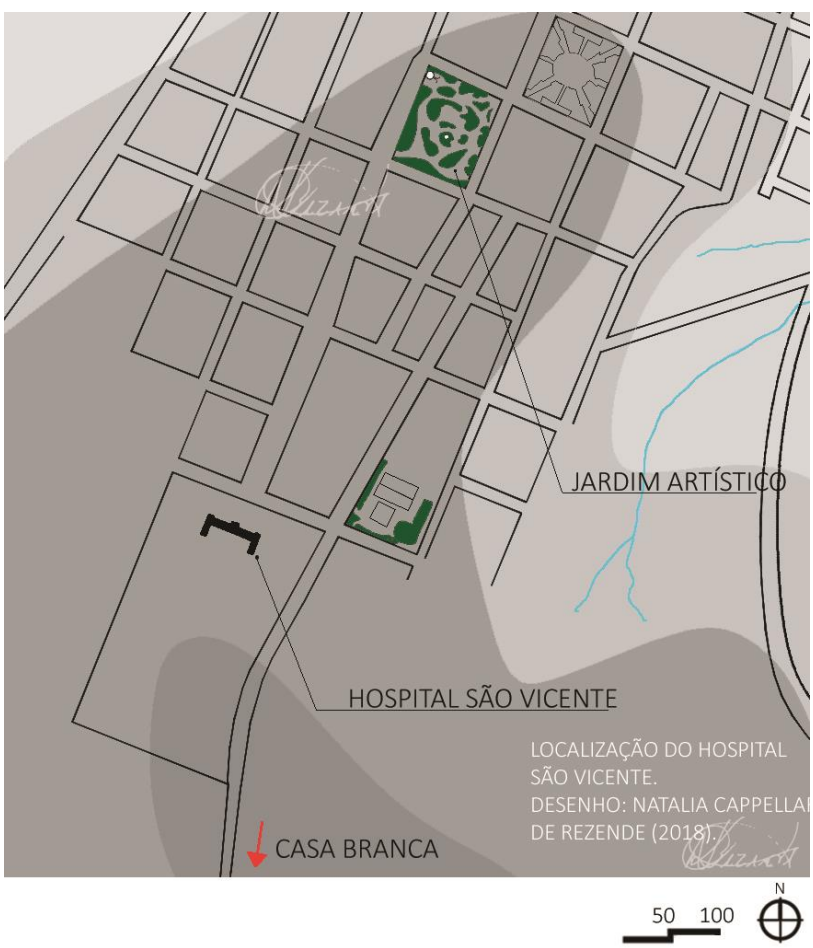

Desenho: Natalia Cappellari de Rezende (2018) com base em dados históricos e cartografia disponibilizada pela Secretaria de Obras de São José do Rio Pardo.

\footnotetext{
${ }^{193}$ A configuração urbana dessa área se mantêm nos dias de hoje, diferentemente das ruas adjacentes que se prolongaram com a expansão urbana.
} 


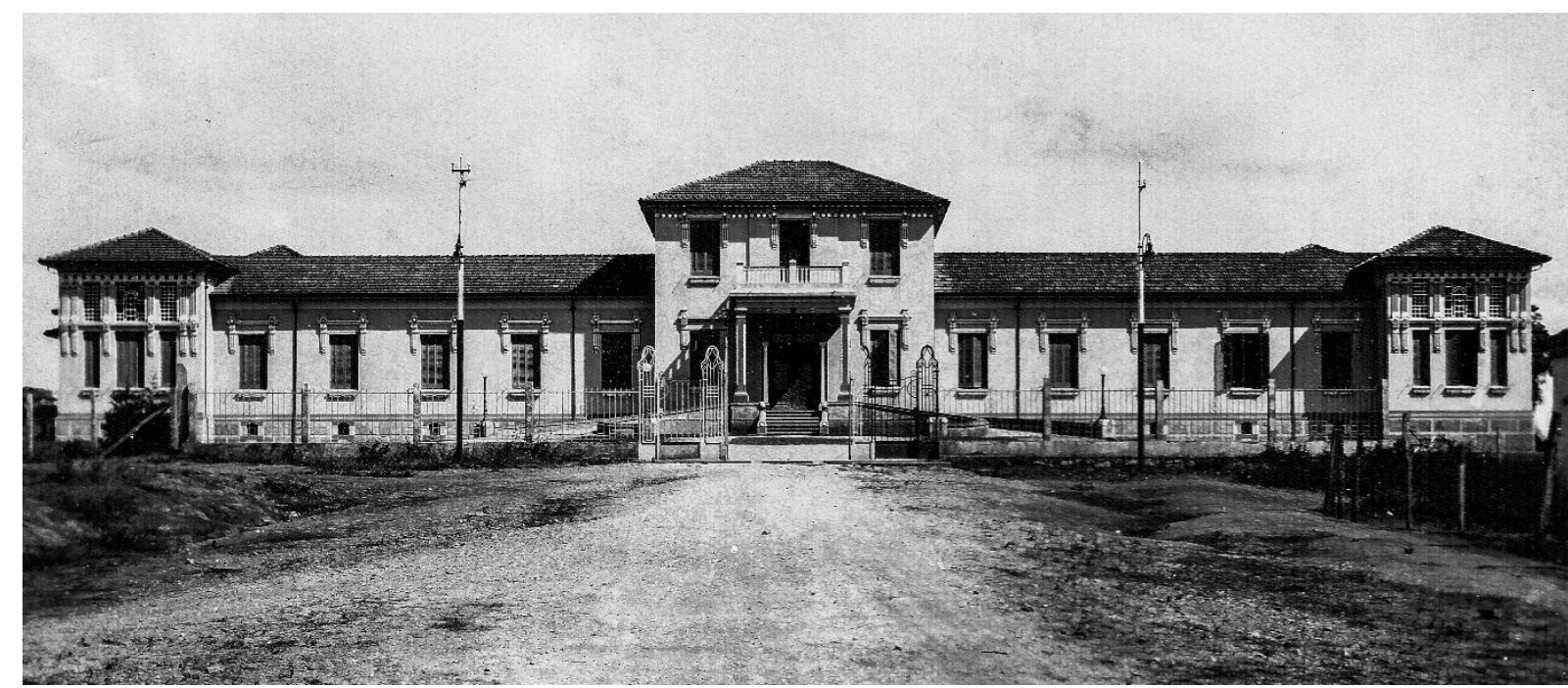

Fonte: Arquivo da Hemeroteca Jornalista Paschoal Artese.

$\mathrm{Na}$ esteira dos melhoramentos urbanos, a área central da cidade foi ocupada por estabelecimentos comerciais e atividades provenientes do fluxo econômico, gerado principalmente pelos negócios relativos ao café e também à industrialização e à pecuária. Entre os principais estabelecimentos estavam as casas bancárias, como o Banco do Brasil, que se instalou em 1923 na Rua Treze de Maio, e o Banco Francisco Muniz Barretto, fundado na vizinha cidade de Mococa, que abriu filial em São José do Rio Pardo em agosto de 1917, instalando-se provisoriamente em um casarão (25.0 ANIVERSARIO, 1942, p. 01), até ser construído o seu próprio edifício também na Rua Treze de Maio. O Escritório de Engenharia de Elias Machado ${ }^{194}$ foi o escolhido para elaborar o projeto do novo prédio, que foi finalizado em 1928 e inaugurado em 01 de janeiro de 1929 com a nova denominação de Banco F. Barretto S.A. (25.0 ANIVERSARIO, 1942, p. 01). Construído na esquina da Rua Treze de Maio com a Rua Marechal Deodoro, o novo edifício é eclético e ostenta estrita simetria nas duas fachadas laterais a partir do chanfro da esquina, como pode ser constatado no desenho rebatido (Figura 233). Sobressaem as entrâncias na argamassa, lembrando bossagens; as pseudo pilastras que remetem à ordem jônica com caneluras dispostas entre as janelas que apresentam verga em arco pleno encimadas por elementos que lembram aduelas ornamentadas com elemento floral; e a arquitrave e a platibanda que percorre o edifício (Figura 231). Características muito semelhantes ao edifício construído em Mococa para sede do mesmo banco, o que nos leva a acreditar que tenha sido obra do mesmo escritório, como é possível ver na Figura 235.

\footnotetext{
${ }^{194}$ Elias Machado Almeida graduou-se em engenharia no Mackenzie College em 1919. Para mais informações ver Prospecto do Mackenzie College ( $28^{\circ}$ anno) e da Escola Americana (48 anno), 1910-1919.
} 


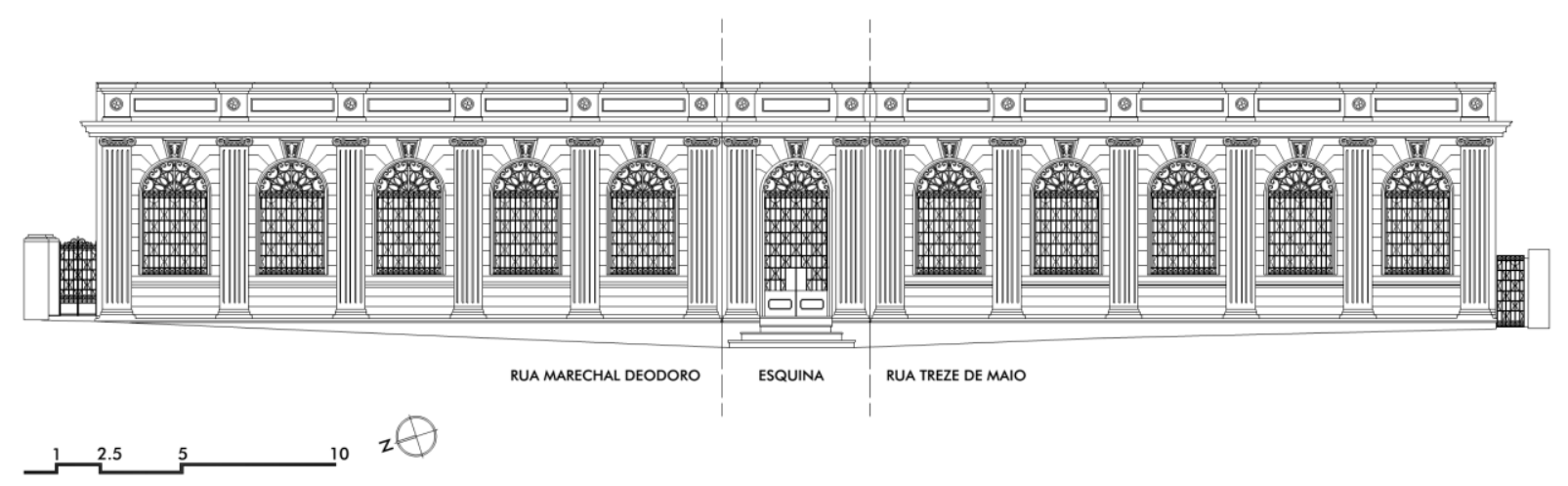

Desenho: Natalia Cappellari de Rezende (2018) a partir de levantamento in loco (2016).

Figura 234: Vista parcial do Banco F. Barreto (1928) em São José do Rio Pardo, em primeiro plano no canto esquerdo.

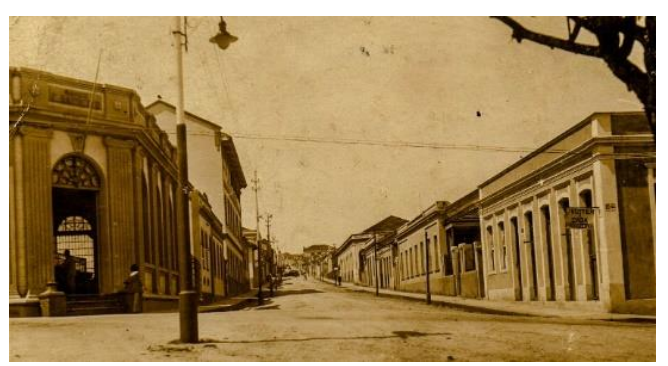

Fonte: Arquivo da Hemeroteca Jornalista Paschoal Artese.
Figura 235: Prédio do antigo Banco F. Barreto em Mococa.

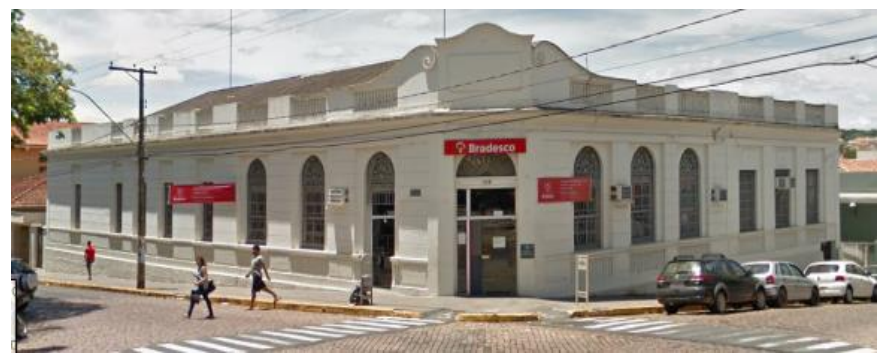

Fonte: Google Street View (2014)

Como reportou o jornal Resenha, o edifício do Banco F. Barreto foi um "grande melhoramento, uma construção moderna para embelezar nossa urbe e localizada num dos melhores pontos da cidade, em substituição a um casarão velho, feio e anti-higiênico" (PEQUENA HISTÓRIA..., 1942, p. 01). Os vários adjetivos utilizados nesse pequeno trecho, "moderna", "embelezar", "velho", "feio", "anti-higiênico", evidenciam a oposição entre o desejo pelo novo e a aspiração pelo apagamento do antigo. Única exceção desse desejo foi a construção, em 1928, de uma redoma para preservar o escritório de zinco de Euclides da Cunha (Figura 236), nas margens do rio Pardo, como parte das pioneiras ações para tornar São José do Rio Pardo a Meca do Euclidianismo ${ }^{195}$ (ABREU, 1994; MASCHIETTO, 2002).

\footnotetext{
195 Esse termo foi alcunhado em 1918 por Vicente de Carvalho no bojo das inúmeras ações realizadas em São José do Rio Pardo com o objetivo de cultuar a memória de Euclides da Cunha. Para saber mais sobre isso ver os trabalhos desenvolvidos por Cármen Trovatto Maschietto e Regina Abreu.
} 
Figura 236: Escritório de zinco protegido por uma redoma nas margens do rio Pardo.

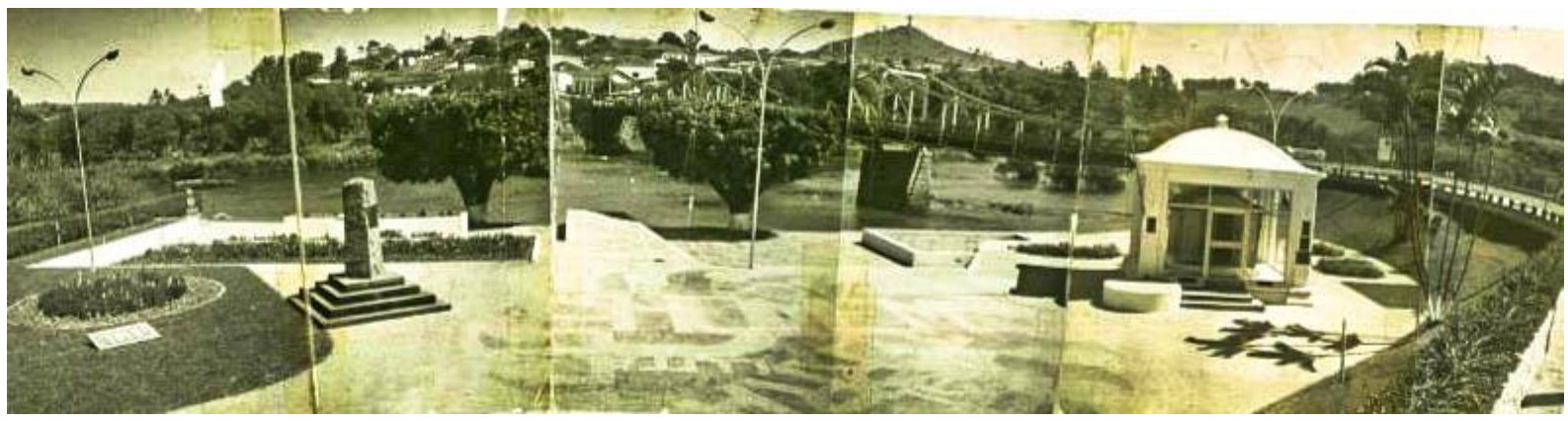

Fonte: Arquivo da Hemeroteca Jornalista Paschoal Artese.

Uma nova paisagem urbana se constituía com outros edifícios de representação que foram substituindo o que se considerava velho, como a sede da Società di Mutuo Soccorso 20 Settembre, demolida e no seu lugar inaugurado, em 1929, um novo edifício projetado pelo engenheiro Luigi Munaro. Tal edificação, construída em dois pavimentos, caracteriza-se pelo realce da verticalização, com alinhamento chanfrado e recuado na esquina, e pilastras que se estendem até a cobertura arrematadas por elementos inspirados nos coruchéus triangulares do neorromânico. Há ainda elementos do fascismo como os feixes de varas amarrados e ladeados por machado. Complementando as características do edifício, no primeiro pavimento há um balcão balaustrado em alvenaria decorado por consolos que são fundidos em colunas decoradas com elementos geométricos. Com exceção do módulo chanfrado, as fachadas laterais são organizadas seguindo o vitrinismo das salas comerciais do térreo. Todas as aberturas apresentam verga reta e são emolduradas, com exceção das aberturas das laterais do chanfro que se organizam de forma escalonada e são encimadas por um óculo arrematado por frisos e fechado com vidro colorido. Toda a platibanda é ornada por cornija, sendo que no frontispício a linearidade é interrompida formando um degrau que confere destaque ao letreiro: Fascio Italiano ${ }^{196}$ ano 1929 ano VII. No geral, o edifício se destaca pelo seu ritmo plástico singular entre cheios e vazios como é possível observar na Figura 237.

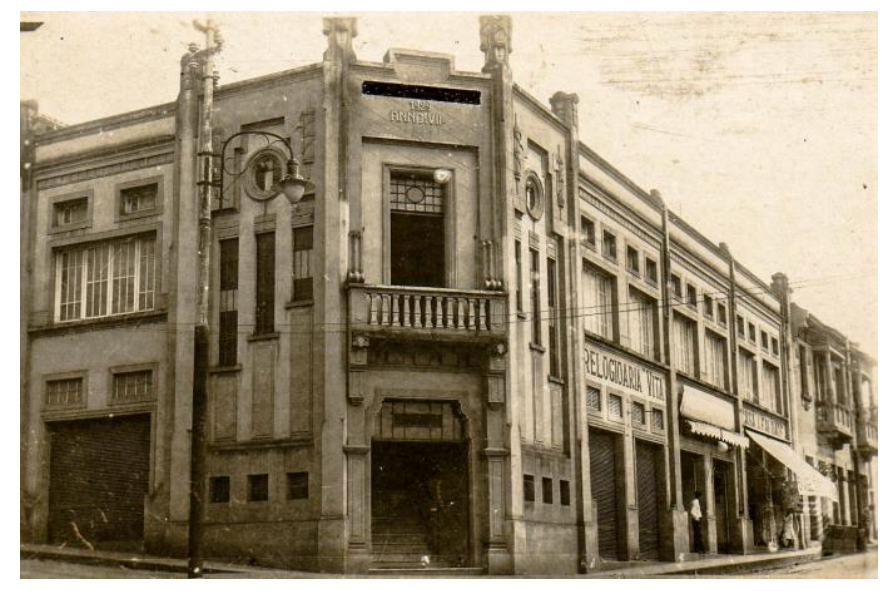

Figura 237: Sede da Società di Mutuo Soccorso 20 Settembre (1929), década de 1940.

Fonte: Arquivo do Centro da Memória Rio-Pardense Rodolpho José Del Guerra.

\footnotetext{
${ }^{196}$ Durante a Segunda Guerra Mundial a sede da Società di Mutuo Soccorso 20 Settembre foi confiscada e os elementos representativos do fascismo foram destruídos, a exemplo dos feixes de varas e do letreiro. As iconografias também foram danificadas, como podemos observar na fotografia onde se nota que o letreiro foi encoberto por uma tarja preta. Hoje o prédio é conhecido como Centro Cultural Ítalo-Brasileiro, denominação que adotou em 17 de dezembro de 1962. O frontispício não conta mais com o título original, apenas com a data de 1929.
} 
Nesse panorama de melhoramentos, a preocupação com a educação foi uma constante, criticada em vários artigos nos jornais locais.

\begin{abstract}
Um dos maiores interesses pelo qual devem pugnar os chefes de família, é, não há como negar, a instrucção. Até nas localidades de menos vida social e de menos movimento commercial não faltam estabelecimentos de ensino, onde econominamente as creanças possam receber instrucção de que tanto é mister hoje a todos no convívio da sociedade. Entretanto, esta cidade que se ufana de seu progresso, riqueza e civilização, carece de institutos de ensino primário e secundário, sem que provenha do lado dos maiores interessados uma iniciativa eficaz e profícua no sentido de fundar-se um estabelecimento, onde tantas intelligencias infantis possam receber a instrucção, que as prepare para um futuro mais elevado, aparelhando-se para triunfar na luta da concorrência, que, por toda a parte e cada vez mais, se torna realidade. (PELA INSTRUCÇÃO, 1927, p. 01).
\end{abstract}

A falta de instrução era considerada um problema para a moralidade e a civilidade pública levando as autoridades a arregimentar esforços na criação de novos colégios. Como resultante desse processo foi criado em 1928 o segundo grupo escolar, posteriormente denominado de "Tarqüínio Cobra Olyntho", funcionando em prédios alugados. Outras escolas particulares foram criadas nesse período com destaque para a Escola Theorico-pratica de Commercio que iniciou suas atividades ainda em 1925 e oferecia um curso que contava com disciplinas sobre direito comercial e economia política, contabilidade financeira e administrativa, estatística, tecnologia industrial e mercantil para maiores de 15 anos. Reflexo do desenvolvimento comercial e industrial rio-pardense, que se acentuará após a crise de $1929^{197}$, como veremos adiante.

Nessa época, a população do município era de 34.096 habitantes dos quais 8.436 (RECENSEAMENTO, 1950, p. 573) moravam na área urbana e suburbana, formada até 1929 por "30 ruas, 3 avenidas e 8 praças" e contava com 1360 casas (ALMANACK, 1929, p.31). A malha urbana seguiu o desenvolvimento nas direções que já vinha apresentando, ou seja, sul da área central nas proximidades do Parque Independência; leste ao longo da estrada de ligação com o município de Mococa; e oeste no caminho que seguia para Caconde, como é possível observar no mapa a seguir (Figura 238). A expansão urbana nessas direções pode ser constatada ainda através da Figura 239, uma fotografia de 1921, onde é possível ver a ocupação ao longo do caminho que seguia na direção de Caconde, já a fotografia da Figura 240, do mesmo ano, revela o desenvolvimento do Bairro Santo Antônio, na orientação da estrada que seguia para Mococa, após cruzar a ponte metálica. Nesta figura é interessante evidenciar a ocupação margeando a estrada de ferro que aparece parcialmente próxima do canto superior direito da fotografia.

\footnotetext{
197 Até o ano de 1928 havia dois grupos escolares estaduais, duas municipais, duas reunidas e 28 isoladas (ALMANACK, 1929). Posteriormente, foram criadas outras três escolas particulares com cursos voltados para a prática comercial, dois grupos de e ducação primária, um ginásio municipal e uma escola normal, como veremos adiante. 
Figura 238: Expansão urbana e localização das edificações na década de 1920.

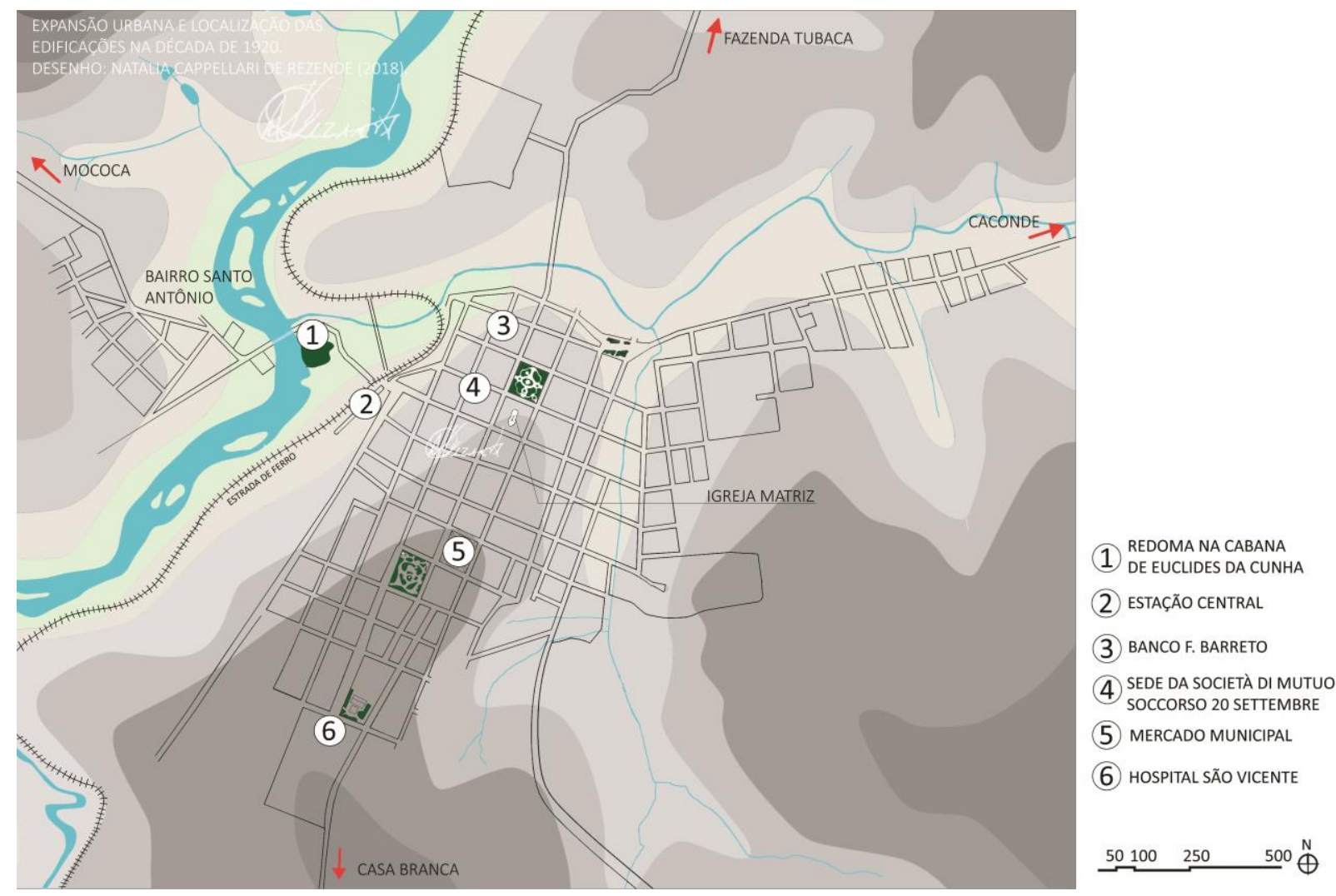

Desenho: Natalia Cappellari de Rezende (2018) com base em dados históricos e cartografia disponibilizada pela Secretaria de Obras de São José do Rio Pardo.

Figura 239: Vista parcial da cidade de São José do Rio Pardo em 1921.

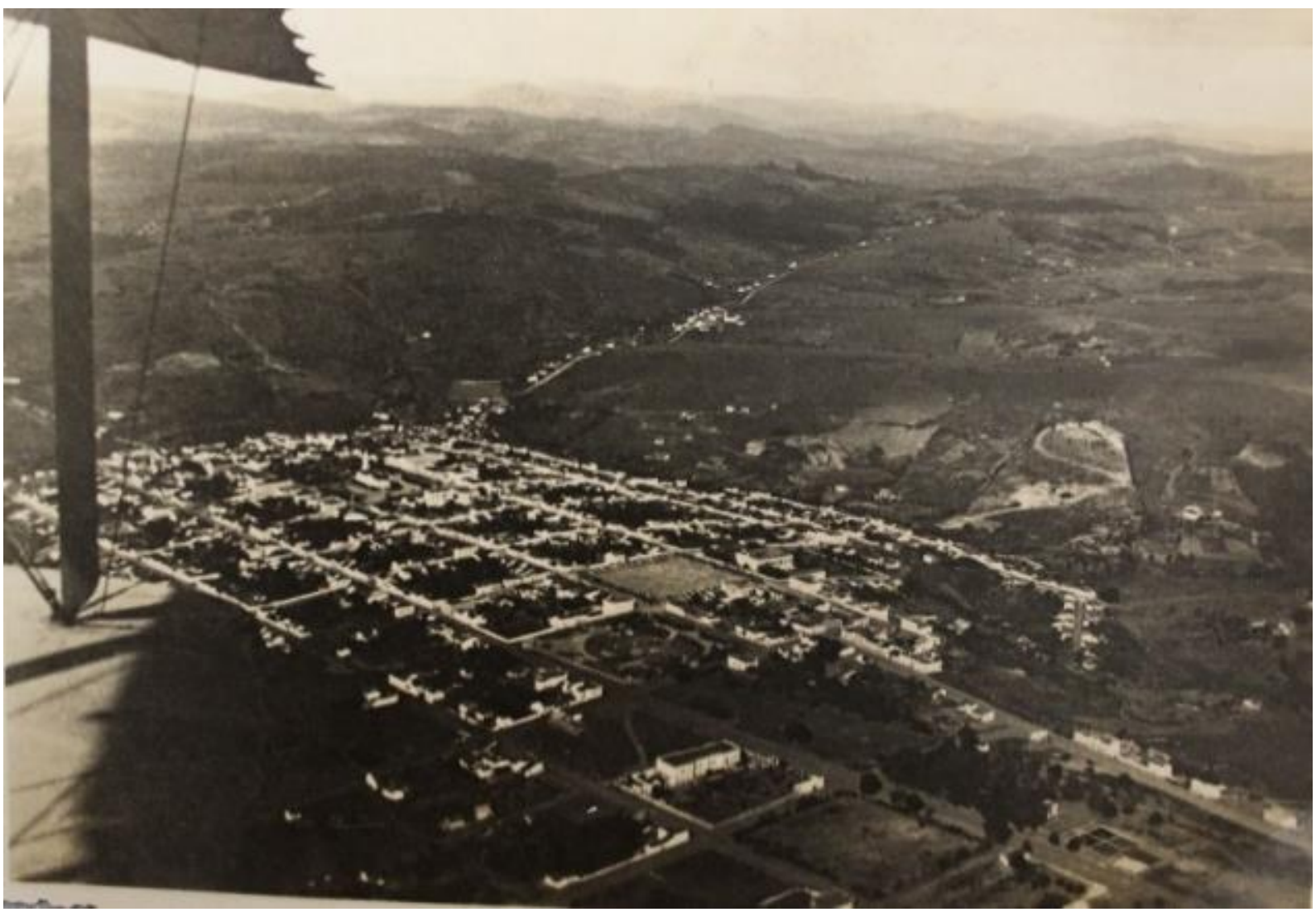

Fonte: Arquivo do Centro da Memória Rio-Pardense Rodolpho José Del Guerra. Fotografia de Innocencio Vilhegas. 
Figura 240: Vista parcial da ocupação urbana à oeste da área central da cidade de São José do Rio Pardo em 1921.

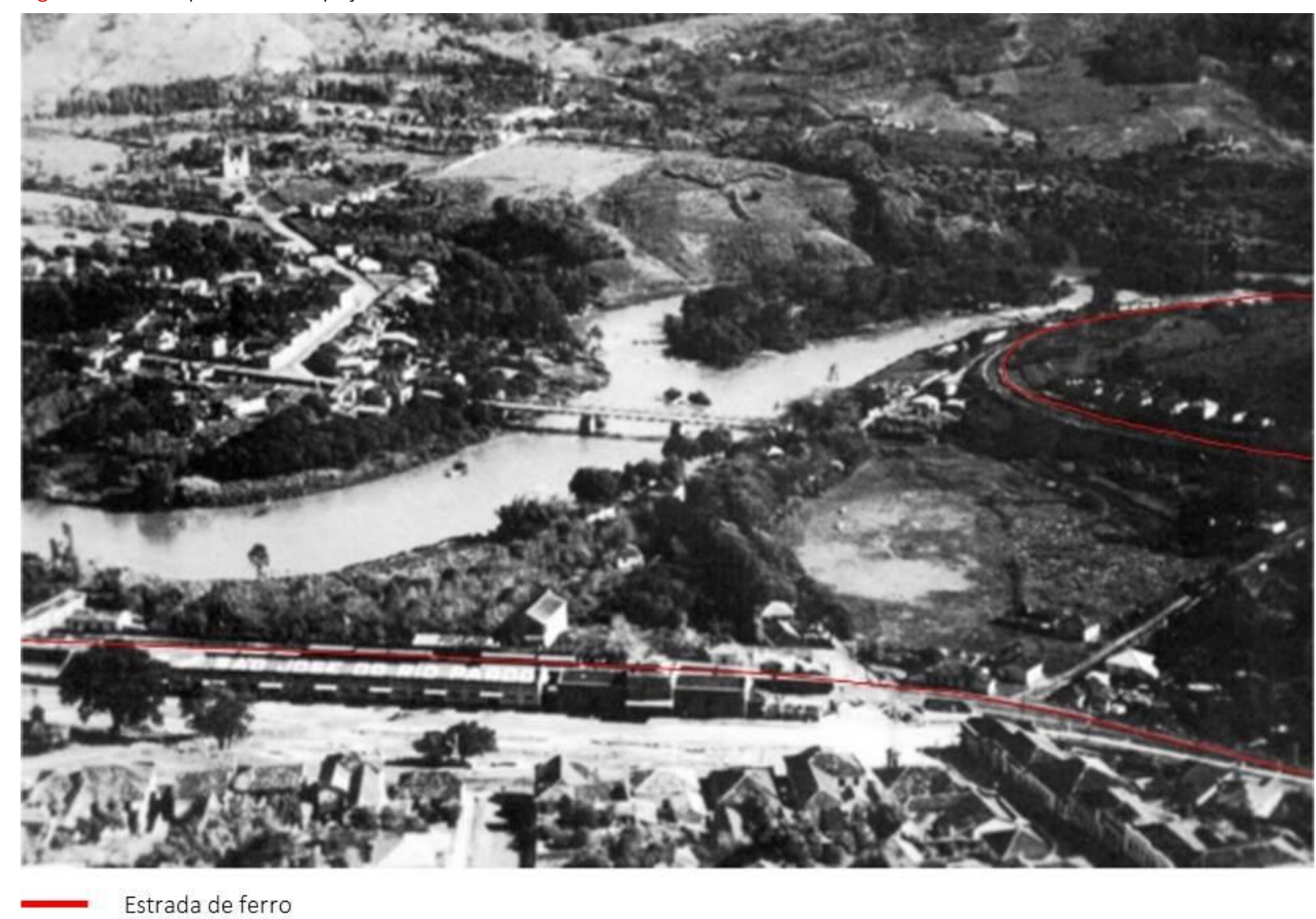

Fonte: Arquivo do Centro da Memória Rio-Pardense Rodolpho José Del Guerra. Fotografia de Innocencio Vilhegas.

Segundo o Almanaque de 1929, dentro do perímetro urbano havia um comércio diversificado de

25 lojas de fazendas e armarinho, 20 armazens de seccos e molhados, 3 hoteis, 4 padarias, 5 açougues, 12 sapatarias, 8 pharmacias, 12 salões de barbeiro, 4 bars e confeitarias, 8 casas de moveis, 2 fabricas de mosaicos, 2 fabricas de gelo, 1 fabrica de lacticínios, 2 fabricas de bebidas, 1 fabrica de meias e tecidos de malha, 2 cortumes, 2 officinas mecânicas, 4 ourivesarias, 2 marmoristas, 2 tinturarias, 3 livrarias, 4 typographias, 4 fabricas de macarrão, 4 bancos, 2 ateliers photographicos, 10 alfaiatarias, 2 fabricas de sabão, 4 casas de ferragens, 6 depositos de materiaes para construção, 3 garagens depósitos de automóveis, muitos armazéns de café e uma infinidade de pequenos estabelecimentos e pequenas industrias. (ALMANACK, 1929, p. 32).

Contudo, sabemos que de acordo com do Código de Posturas de 1918, alguns estabelecimentos comerciais e fabris eram proibidos em algumas ruas da área central. Sobre isso, o artigo 168 determinava que

na parte central da cidade, dentro do perímetro formado pelas ruas Marechal Deodoro, 13 de Maio, até a esquina da rua Coronel Marçal, e por esta até a rua Benjamim Constant, e por esta até a rua Marechal Deodoro, é prohibido o estabelecimento de fabricas de sabão, óleos, machinas de beneficio e rebeneficio de produtos agrícolas, deposito de sal em grande quantidade, e outros que, pelas matérias primas, seus produtos e combustível empregado, viciem a athmosphera com vapores nocivos à saúde publica ou incomodem a vizinhança. (CÓDIGO DE POSTURAS, 1918, p. 25).

Apesar das imposições do Código, confirmamos com alguns de nossos entrevistados a existência de duas fábricas de sabão e sabonete dentro do respectivo perímetro, uma localizada na esquina da Rua Francisquinho Dias com a Rua Coronel Marçal (MASCHIETTO, 2016; CURI, 2016; LAURIA, 2016), e a outra 
nas proximidades da Rua João Gabriel Ribeiro (TREVISAN, 2016). Sobre a existência de curtumes dentro do perímetro urbano como descrito pelo Almanaque (1929), eles também eram condenados pelas posturas municipais. Essas situações nos evidenciam que a legislação não era suficiente o bastante para determinar os usos e atividades que ocorriam na área urbana, e em relação à fiscalização, esta certamente ocorria de modo precário.

Não obstante, a existência de fábricas de sabão e sabonete acusam as novas sensibilidades acerca da higiene que permeavam o cotidiano, e que juntamente com as noções de conforto facultaram a abertura de estabelecimentos como os salões de barbeiro e cabeleireiro do Antonio Cerboni e do Carmo Lauria, e consequentemente oficinas de armeiro como a de Antonio Piovesan, especializada em máquinas de cortar cabelo (Figura 241). Os hotéis procurando se adequar às novas condições foram reformados e ampliados, oferecendo banho quente e alimentação cautelosamente preparada, como podemos ver nos anúncios do Hotel Globo, Rio Pardo Hotel e Hotel Brasil (Figura 242). Ambos os anúncios destacavam a condição higiênica como diferencial do estabelecimento. Esse era o teor também dos anúncios de venda de lotes de terra (Figura 243) que se localizavam entre o Jardim Artístico e o Parque Independência, mas nesse caso, foi ainda associado às qualidades do lugar, a existência de ar puro, belezas naturais e salubridade, como questões indispensáveis ao conforto e à felicidade.

Figura 241: Anúncios de barbeiro, salão de cabeleireiro e oficina de armeiro.
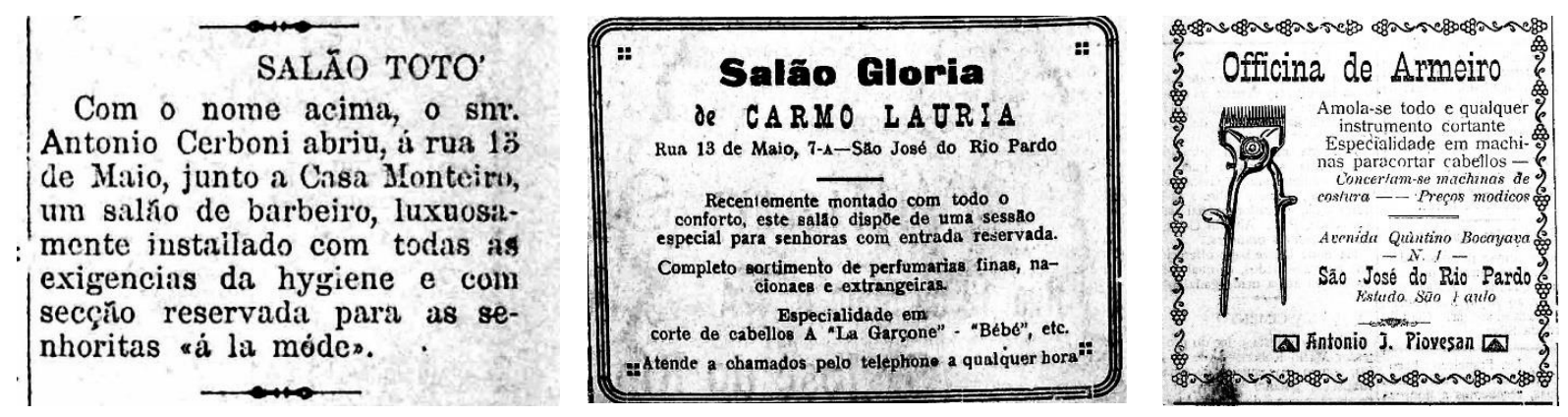

Fonte: Jornal Resenha, 02 de agosto de 1925, 20 de outubro de 1926 e 02 de agosto de 1925.

Figura 242: Anúncios de hotéis em São José do Rio Pardo.
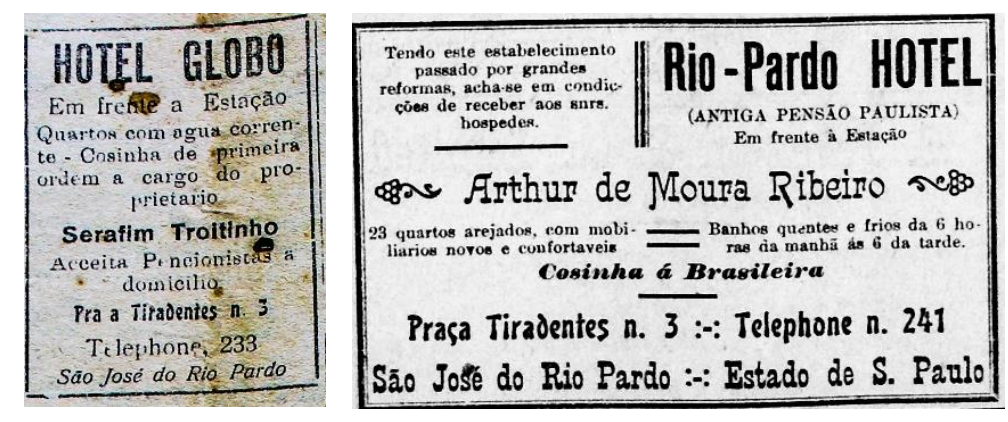

Fonte: Jornal Resenha, 09 de novembro de 1924, 13 de abril de 1930 e 03 novembro de 1930.

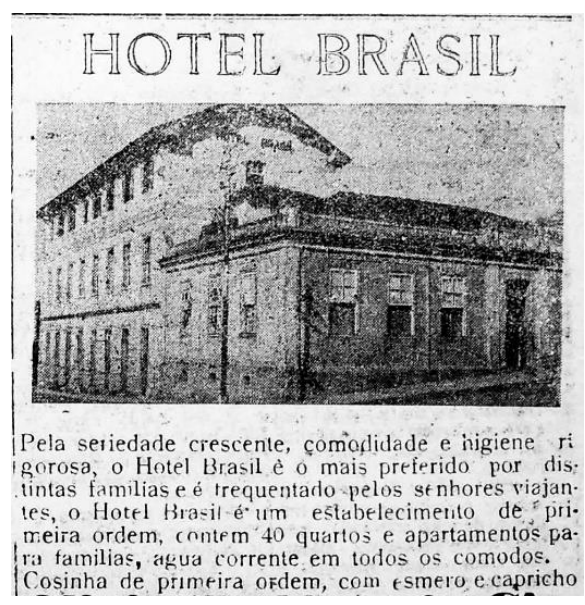


Figura 243: Anúncios de casas e lotes à venda.

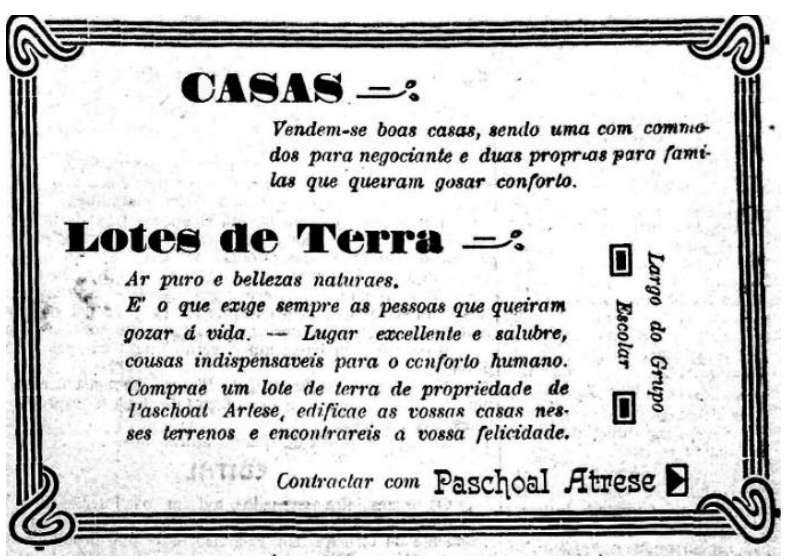

Fonte: Jornal Resenha, 02 de novembro de 1924.

Nas áreas suburbana e rural também existiam fábricas e estabelecimentos comerciais, como descrito no Almanaque de 1929. Eram cinco oficinas mecânicas, uma marmoraria, uma livraria, uma tipografia, uma fábrica de cerâmica, oito fábricas de aguardente, quatro fábricas de veículo, uma fábrica de ferradura, duas fábricas de barril, seis olarias e três bares (ALMANACK, 1929).

Sem dúvida, a atividade industrial e comercial se intensificou em comparação aos períodos anteriores, consequentemente contribuiu para influenciar a vida da cidade, que apesar de ainda não apresentar uma estrita divisão entre a área rural e urbana, já demonstrava o estabelecimento industrial, de comércio e de serviço na dinamização econômica.

Nos capítulos anteriores chamamos a atenção para o capital gerado com a produção cafeeira que por vezes foi aplicado em várias funções urbanas, como na estrada de ferro, na empresa de luz elétrica, de telefonia, em bancos, em atividades ligadas a construção civil e também indústrias e comércios, os quais contribuíram para mover o mercado interno. Assim também procedeu no campo, e como visto anteriormente, já em 1907 principiou uma redefinição das atividades rurais com a produção de diferentes culturas, com destaque para o arroz de Alípio Dias que naquele ano exportou entre 8 e 10 mil sacas (CASSASSOLA, 2009). Nos anos que se seguiram, a tendência foi o desenvolvimento da policultura, como atestado por Eugênio Egas (1925) e analisado por Cassassola (2009, p. 58), que em termos quantitativos estão discriminados na Tabela 6:

Tabela 6: Valores correspondentes à produção agrícola rio-pardense no início dos anos 1920.

PRODUÇÃO AGRÍCOLA DE SÃO JOSÉ DO RIO PARDO NO INÍCIO DA DÉCADA DE 1920

\begin{tabular}{l|l|l|l|l|l}
\hline Café & Arroz & Feijão & Milho & Fumo \\
\hline $\begin{array}{l}67,7 \text { arrobas } \\
\text { por mil pés }\end{array}$ & 28.800 hectolitros & 30.600 hectolitros & 207.000 hectolitros & 3.000 arrobas & 30.000 sacos \\
\hline
\end{tabular}

Fonte: Elaborado pela autora com base em Cassassola (2009, p. 58). 
Assim também ocorreu na pecuária que, devido à debilidade econômica enfrentada durante a Primeira Guerra Mundial, foi o caminho seguido para a recuperação, culminando na primeira Exposição de Animais de São José do Rio Pardo em 1918 (1 $1^{a}$ EXPOSIÇÃO..., 1918). De acordo com os dados apresentados por Cassassola (2009) e exibidos na Tabela 7, o crescimento desse ramo foi muito superior aos demais, se comparado com o quantitativo de $1901^{198}$.

Tabela 7: Valores correspondentes a pecuária rio-pardense no início dos anos 1920

\begin{tabular}{l|l}
\hline \multicolumn{2}{c}{ PECUÁRIA EM SÃO JOSÉ DO RIO PARDO NO INÍCIO DA DÉCADA DE 1920 } \\
\hline Rebanho & No de cabeças \\
\hline equinos & 5.544 \\
\hline asininos e muares & 2.933 \\
\hline bovinos & 19.276 \\
\hline suínos & 39.743 \\
\hline caprinos & 1.928 \\
\hline ovinos & 998 \\
\hline Total & 8.460 \\
\hline
\end{tabular}

Fonte: Elaborado pela autora com base em Cassassola (2009, p. 59) e Egas (1925, p. 1845).

A partir desses dados é certo afirmar que houve uma diversificação nas atividades rurais, ainda que a produção cafeeira predominasse mesmo com a acentuada queda a partir de 1918, como mostra a Tabela 8.

Tabela 8: Valores correspondentes ao café produzido em São José do Rio Pardo entre os anos 1911 e 1921.

PRODUÇÃO CAFEEIRA DE SÃO JOSÉ DO RIO PARDO (1911 - 1921)

\begin{tabular}{l|l|l|l}
\hline Anos & Cafeeiros produzindo & Produção total (@) & Por mil pés (@) \\
\hline $1911-1912$ & 10.586 .000 & 921.290 & 87,0 \\
\hline $1912-1913$ & 10.586 .000 & 876.421 & 80,7 \\
\hline $1913-1914$ & 10.586 .600 & 992.748 & 92,8 \\
\hline $1914-1915$ & 10.586 .600 & 883.580 & 83,4 \\
\hline $1915-1916$ & 10.586 .600 & 871.990 & 82,2 \\
\hline $1916-1917$ & 10.883 .270 & 703.530 & 59,2 \\
\hline $1917-1918$ & 12.278 .600 & 920.000 & 74,9 \\
\hline $1918-1919$ & 12.278 .600 & 402.000 & 32,7 \\
\hline $1919-1920$ & 12.278 .600 & 420.000 & 34,2 \\
\hline $1920-1921$ & 12.278 .600 & 682.000 & 55,5 \\
\hline
\end{tabular}

Fonte: Elaborado pela autora com base em Cassassola (2009, p. 58) e Egas (1925, p. 1845).

198 Dados apresentados na página 64. 
Contudo, a cidade que aparentemente progredia bem sentiu os efeitos do declínio do capital cafeeiro com a deflagração de uma gravíssima crise ${ }^{199}$ que, segundo Taunay (1945, p. 426), citando o discurso do Dr. Paulo de Moraes de Barros $^{200}$, era decorrente de um processo complexo que envolvia diversas causas, entre elas:

o desenvolvimento excessivo da produção, em desproporção com o consumo; ao excesso, daí decorrente, do produto em estoque no país; ao aumento da concorrência estrangeira; ao campo restrito da propaganda brasileira; às dificuldades de financiamento dos volumosos remanescentes. (TAUNAY, 1945, p. 426)

Considerando, ainda, segundo Furtado (1984) e Martins, A. (2012), a associação desses eventos com o craque mundial dos mercados financeiros decorrente da quebra da bolsa de Nova lorque. Tal situação arregimentou a queda do valor de "todas as mercadorias de largo consumo, colocadas em regime de superprodução", incluindo o café (TAUNAY, 1945, p. 428). Sobre isso, Furtado (1984) ressaltou que o ponto básico do problema que cabia equacionar para criar um mecanismo de defesa da crise, sobretudo do principal produto brasileiro, eram os seguintes:

a) Que mais convinha, colher o café ou deixa-lo apodrecer nos arbustos, abandonando parte das plantações como uma fábrica cujas portas se fecham durante a cise?

b) Caso se decidisse colher o café, que destino deveria dar-se ao mesmo? Forçar o mercado mundial, retê-lo em estoques ou destruí-lo?

c) Caso se decidisse estocar ou destruir o produto, como financiar essa operação? Isto é, sobre quem recairia a carga, caso fosse colhido o café? (FURTADO, 1984, p. 186).

Todavia, a questão principal recaía não em saber o que fazer com o café e sim quem pagaria pela perda. Por conseguinte, Furtado (1984) salientou que a organização da classe dirigente cafeeira logrou transferir parte dos prejuízos para a linha de menor resistência, ou seja, do trabalhador que teve seu poder de compra diminuído, afetando outras instâncias da economia, como o comércio.

Os jornais locais criticaram intensamente o cenário econômico, sobretudo rio-pardense, dada a ausência de investimentos mais consistentes em outras áreas como meio de recuperar a economia e o crescimento do município. Comparações não faltaram com o desenvolvimento apresentado pelas cidades vizinhas como São João da Boa Vista, Guaxupé e Mococa. Assim o jornal Resenha reportou a situação:

\begin{abstract}
Ultimamente, Guaranesia, Guaxupé, S. Sabastião do Paraizo, Mocóca, S. João da Boa Vista e muitas outras cidades, dotaram-se das mais importantes indústrias, como sejam: fabricas de tecidos, de chapéos, de pregos e de meias. São os fazendeiros desses lugares que applicam os grandes resultados que tiveram com a alta do café em proveito do progresso da terra de onde residem e não medem sacrifícios, com tanto que a cidade se impulsione e se encaminhe para o desenvolvimento moral e material. (NOSSA CIDADE ..., 1929, p. 02).
\end{abstract}

\footnotetext{
199 Somekh (1997) fez algumas ressalvas sobre a crise econômica de 1929 e destacou os benefícios que a mesma causou para a indúst ria brasileira. Segundo a autora (SOMEKH, 1997), a suspensão das importações de café por parte da Inglaterra provocou desestímulos de novos investimentos no setor cafeeiro, propiciando a disponibilização de capitais para outros setores. "A suspensão forçada das importações mobiliza a produção interna de bens industrializados. Além desses fatores, a existência de uma demanda interna e o aproveitamento da capacidade ociosa da indústria já disponível contribuem para o avanço do setor industrial" (SOMEKH, 1997, p. 68-70).

200 Paulo de Morais de Barros (1866 - 1940) era deputado federal, eleito pelo Partido Democrático para a mandato de 1927 e 1929 . Atuou contra a política de valorização do café, adotada pelo presidente Washington Luís. Para saber mais sobre Morais de Barros, ver o verbete produzido pelo Centro de Pesquisa e Documentação de História Contemporânea do Brasil (CPDOC) da Fundação Getúlio Vargas.
} 
A fragilidade econômica gerada pela crise provocou incertezas, inclusive sobre o custo dos alimentos de subsistência, como apontado no seguinte trecho que comenta a situação explorando adjetivos de modo a caracterizar as indefinições do momento:

Num barato de incertezas, entra-se no anno novo, chamado anno bom com o espirito pejado de anceios e aflicções, sem sabermos como abrir o livro de lucros e de perdas de subsistência. Café vendido na bacia das almas, e todos os generos necessários ao sustento da vida pela hora da morte [...] pão caro, carne cara, ovos caros, tudo custa um dinheirão ... (A CRISE, 1929, p. 01).

Como visto, a crise afetou diferentes instâncias e sobre isso o Sr. Nicola Saran, em entrevista realizada por Del Guerra (2001, p. 65) contou que na época (1929) o "governo exigia para si 40\% do café beneficiado, sem nada pagar... O preço caiu, passando de 300 para 60 mil-réis... Foi um desespero!" justamente porque os fazendeiros estavam acostumados a obter venda garantida e altos lucros. Conforme Furtado (1984), a "retirada" de parte da produção de café do mercado foi assumida pelos governos a custo de endividamento do próprio governo brasileiro sem que houvesse "nenhuma possibilidade de ser vendido dentro de um prazo que se pudesse considerar como razoável", uma vez que a produção excedia com sobras a capacidade de absorção dos mercados compradores. Contudo, o que se tinha em vista era o "equilíbrio entre a oferta e a procura a nível mais elevado de preços" (FURTADO, 1984, p. 189). Segundo Sr. Nicola, nessa conjuntura muitos fazendeiros rio-pardenses

perderam suas fazendas, principalmente os que não tinham gado, que era uma solução para o sustento da propriedade... Os que tinham duas ou três fazendas vendiam uma para sustentar e salvar a outra, ou as outras... Pedaços de fazendas eram vendidos a baixo preço... [...] O Dr. Pinheiro, que possuía as fazendas Rio Doce e Floresta, vendeu a segunda e ainda ficou com uma dívida de 500 contos! (SARAN apud DEL GUERRA, 2001, p. 65-66).

Diante das dificuldades econômicas, alguns fazendeiros locais passaram a explorar a floresta para vender a madeira; procederam à substituição do café por outras culturas; e reformularam os contratos com os trabalhadores rurais, como aconteceu em abrangência nacional ${ }^{201}$.

Os contratos com os colonos foram rompidos. Um caseiro que ganhava 150 mil-réis por mês passou a ganhar 90. Os colonos não tinham para onde ir e ficavam plantando mandioca nos cafezais... E muitos cafezais foram cortados, destruídos... A mandioca também ajudou fazendeiros a sobreviver, servindo de alimento para o gado e para a fabricação da farinha e do polvilho doce e azedo... (SARAN apud DEL GUERRA, 2001, p. 65-66).

A crise cafeeira citada pelo Sr. Nicola Saran pode ser constatada na Tabela 9, elaborada com bases nos dados apresentados por Milliet (1941), e que também expõe a diminuição populacional que ocorreu no mesmo período, certamente como consequência da crise econômica e produtiva estabelecida, quadro que não foi exclusivo de São José do Rio Pardo, e sim de toda a zona Mogiana.

${ }^{201}$ Para saber mais, ver Milliet (1941). 
Tabela 9: Produção cafeeira e quadro populacional de São José do Rio Pardo entre os anos de 1854 e 1935.

\begin{tabular}{l|l|l|l|l|l|l}
\hline \multicolumn{5}{c}{ PRODUÇÃO CAFEEIRA E NÚMERO POPULACIONAL DE SÃO JOSÉ DO RIO PARDO (1854 - 1935) } \\
\hline \multirow{3}{*}{ Ano } & \multicolumn{3}{c}{ Café } & \multicolumn{4}{c}{ População } \\
\cline { 2 - 7 } & 1886 & 1920 & 1935 & 1886 & 1920 & 1935 \\
\hline $\begin{array}{l}\text { Unidades } \\
\text { Estatísticas }\end{array}$ & 200.000 & 650.753 & 294.240 & 4.455 & 32507 & 30.953 \\
\hline
\end{tabular}

Fonte: Elaborado pela autora com base em Milliet (1941).

A economia local até então respaldada na produção cafeeira, como ressaltado pelo Sr. Nicola Saran, os baixos preços do café provocaram a venda de terras e contribuíram para a redefinição de atividades e a diversificação de produtos. De acordo com os dados da Secretaria da Agricultura, Indústria e Comércio de 1934 e ratificado pelo Relatório Estatístico de São José do Rio Pardo publicado no jornal Resenha do dia 18 de outubro de 1936, a atividade agrícola gradativamente variou para culturas de arroz, feijão, mandioca, milho, cana-de-açúcar, batata e algodão, junto com a pecuária e a avicultura (DADOS ESTATíSTICOS, 1936). Ainda sobre o reflexo da crise, muitas das indústrias e estabelecimentos ligados diretamente à atividade cafeeira não resistiram, em contraposição ao surgimento de outras que vieram para dar suporte à nova dinâmica econômica que começava a se definir. Como apontado no Relatório de 1936, o município contava com 29 fábricas, predominando aquelas ligadas à fabricação de bens de consumo, sobretudo alimentício e de veículos (DADOS ESTATÍSTICOS..., 1936, p. 10). As perspectivas de redirecionamento econômico e desenvolvimento local foram confirmados no Relatório elaborado em $1941^{202}$ que apontou a existência de 136 fábricas, sendo a área de dominância alimentar e transporte. O fortalecimento das atividades industriais e agropecuárias acertadamente foi acompanhado pelo setor comercial que apresentou um crescimento de $225 \%$ (REFORMA ..., 1943, p. 01).

Chama a atenção, desde logo, a difusão dos meios de transporte, e o aumento do número de veículos de tração animal e motorizados pela cidade. Seguramente, o impulso desse consumo em São José do Rio Pardo ocorreu juntamente com a abertura das rodovias e o aumento dos estabelecimentos de fabricação, comercialização e manutenção dos automóveis que investiram pesadamente em publicidade. Páginas inteiras dos jornais passaram a ser ocupadas com anúncios que destacavam as qualidades, a beleza e o preço dos veículos, como o da agência Lima, Andracolli \& Cia. Ltda. (Figura 244) que ressaltavam ainda a resistência, a velocidade e a qualidade das peças utilizadas na produção dos carros da Chevrolet, ou a exemplo da Lincoln Fordson que diferenciava o carro Ford pela segurança e economia de combustível (Figura 245). Segundo o Almanaque de 1929 e anúncios que encontramos nos jornais locais da década de 1930, as principais fábricas de veículos em São José do Rio Pardo eram a de Odolo del Sarto, Flamínio \& Filhos, Dal Moro \& Filhos e Luiz Martini; as agências eram de F. Barreto: Chevrolet; Lima Andracolli \&Cia. Ltda.: Chevrolet; V. Nasser \& Irmãos: Ford; Palmyro Petrocelli \& Irmãos: Ford; Lincoln Fordson: Ford; Alvares \& Taddei: Chrysler; Luiz Martini: Fiat; Pedro Luiz \& Cia: Studebaker; G. Della Torre \& Irmão: International;

\footnotetext{
202 Relatório elaborado e apresentado ao Secretário da Justiça e Negócios do Interior Dr. Abelardo Vergueiro Cesar em 1941.
} 
Antonio Pinesi: Rugby; Neves \& Cia: Nasch Packard e Rugby e Scarano Masini \& Cia: Citroen; e as oficinas mecânicas de Otto Ornchuch \& Filhos, Atilio Piovesan, Mario Bertocco \& Cia, Jorge Edilio \& Cia, e aquelas que já faziam parte das agências de venda citadas acima. A diversidade de marcas, e os diversos estabelecimentos indicam que o mercado automobilístico em São José do Rio Pardo era ativo economicamente. Outros estabelecimentos ligados diretamente a esse gênero da indústria também apareceram com maior frequência, sobretudo firmas comerciais de pneus e de combustíveis, oficinas de funilaria e pintura.

Figura 244: Anúncio da agência Chevrolet em São José do Rio Pardo.

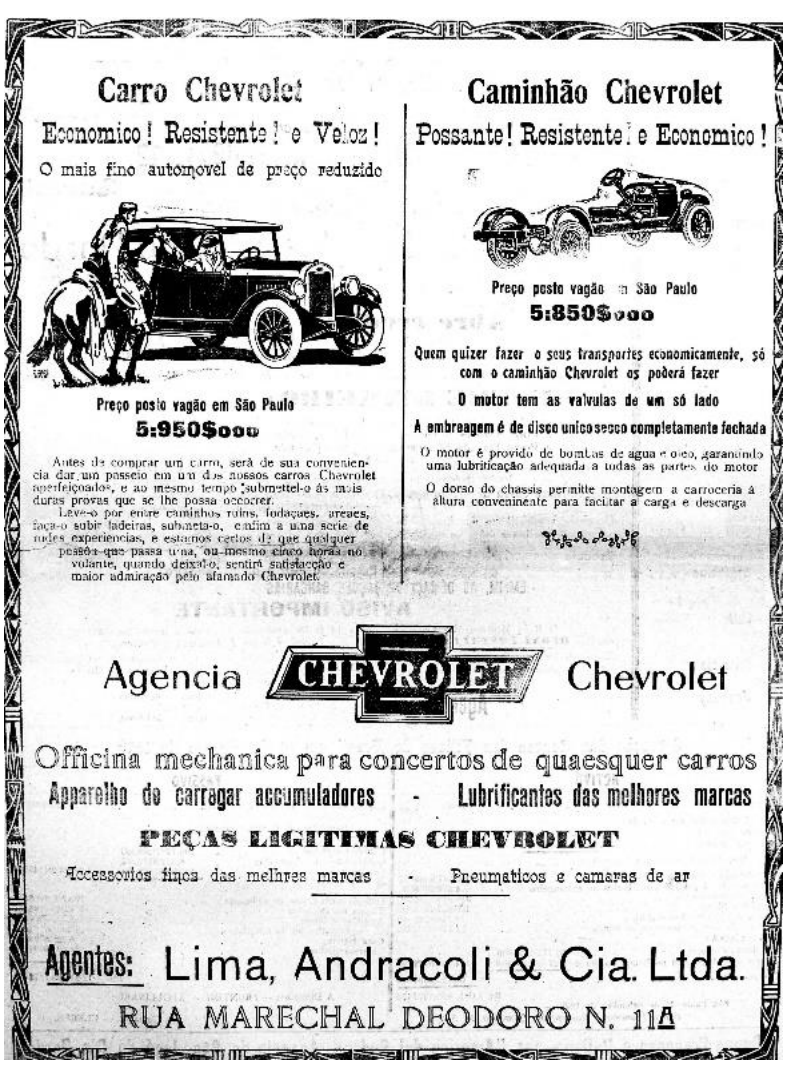

Fonte: Jornal Resenha, 12 de outubro de 1926.
Figura 245: Anúncio da agência Ford em São José do Rio Pardo.

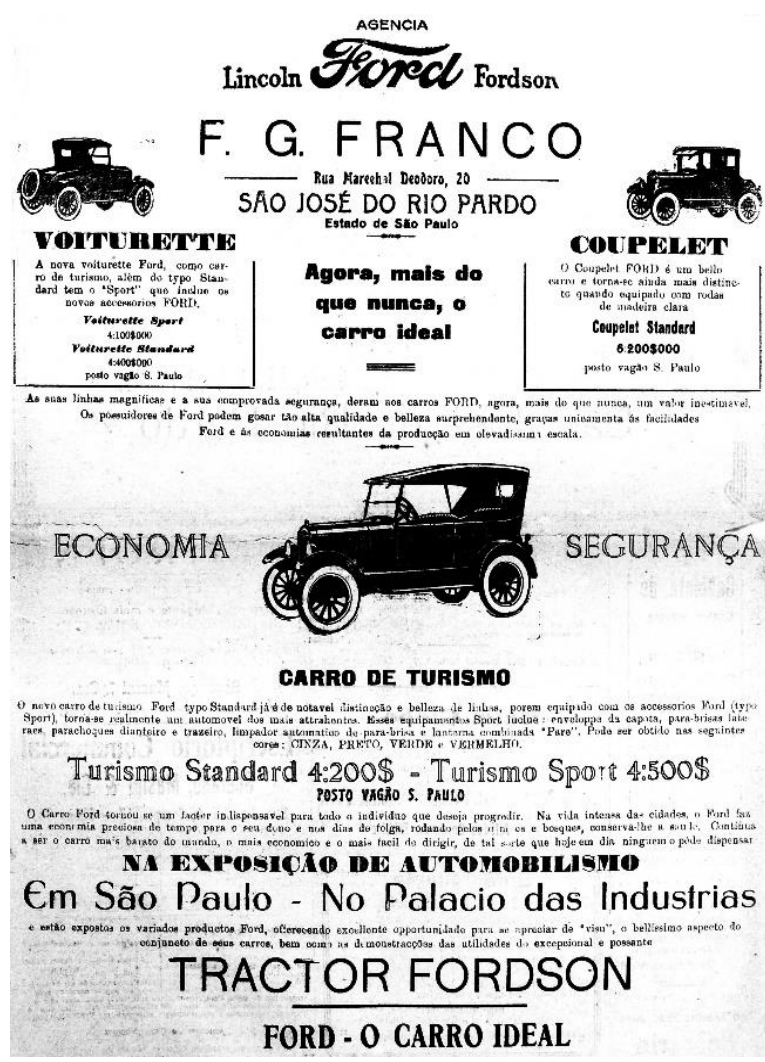

Fonte: Jornal Resenha, 12 de outubro de 1926.

O crescimento desse ramo do comércio não aconteceu somente em São José do Rio Pardo, como podemos verificar nas análises feitas por Atique (2007) sobre a maciça chegada de companhias estadunidenses a partir da década de 1920 no Brasil. Segundo esse autor (ATIQUE, 2007), as principais empresas instaladas no país foram as automobilísticas, as alimentícias e cinematográficas, ambas inscritas em uma estratégia de consolidação de mercado externo que alcançou o mundo todo. Ainda de acordo com Atique (2007),

o automóvel se transformou, para parte da elite econômica brasileira, na principal demonstração de que os limites das antigas cidades estavam sendo quebrados não apenas em relação às alturas das construções - com os skyscrapers -, mas, também, no que dizia respeito às distâncias a serem percorridas - com os carros. (ATIQUE, 2007, p. 115). 
Nesse momento, São José do Rio Pardo não apresentava construções com mais de três pavimentos, como atestado por Atique (2007) em São Paulo, mas é evidente que a construção civil local sofreu transformações com a entrada de empresas automobilísticas. Edifícios foram reformados e outros construídos para atender especificamente as suas atividades, como podemos observar na Figura 246 e Figura 247.

Figura 246: Agência Vicente Nasser \& Irmãos, década de 1920.

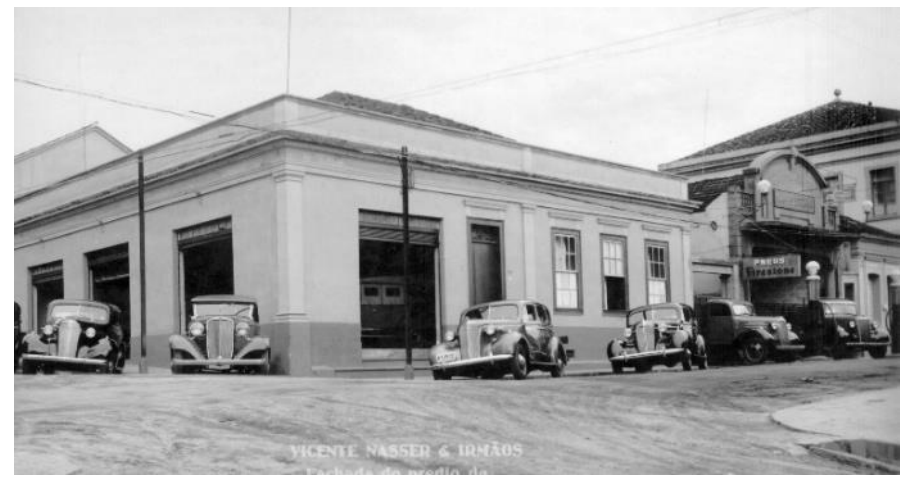

Fonte: Arquivo do Centro da Memória Rio-Pardense Rodolpho José Del Guerra.
Figura 247: Agência de Lincoln Fordson, década de 1920.

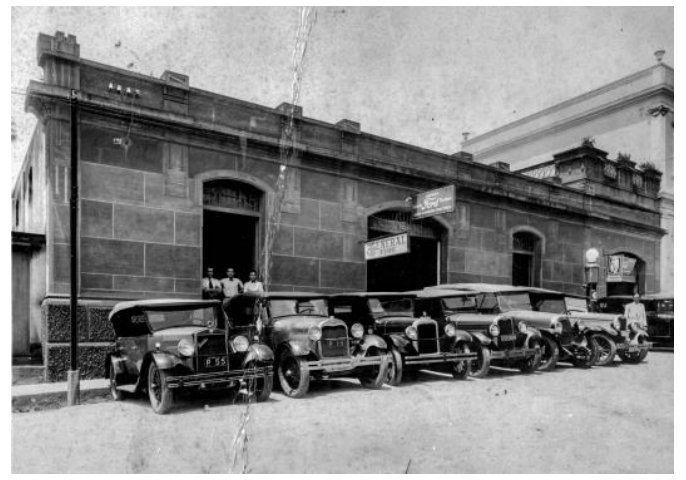

Fonte: Arquivo do Centro da Memória Rio-Pardense Rodolpho José Del Guerra.
Figura 248: Anúncio da agência Ford em São José do Rio Pardo.

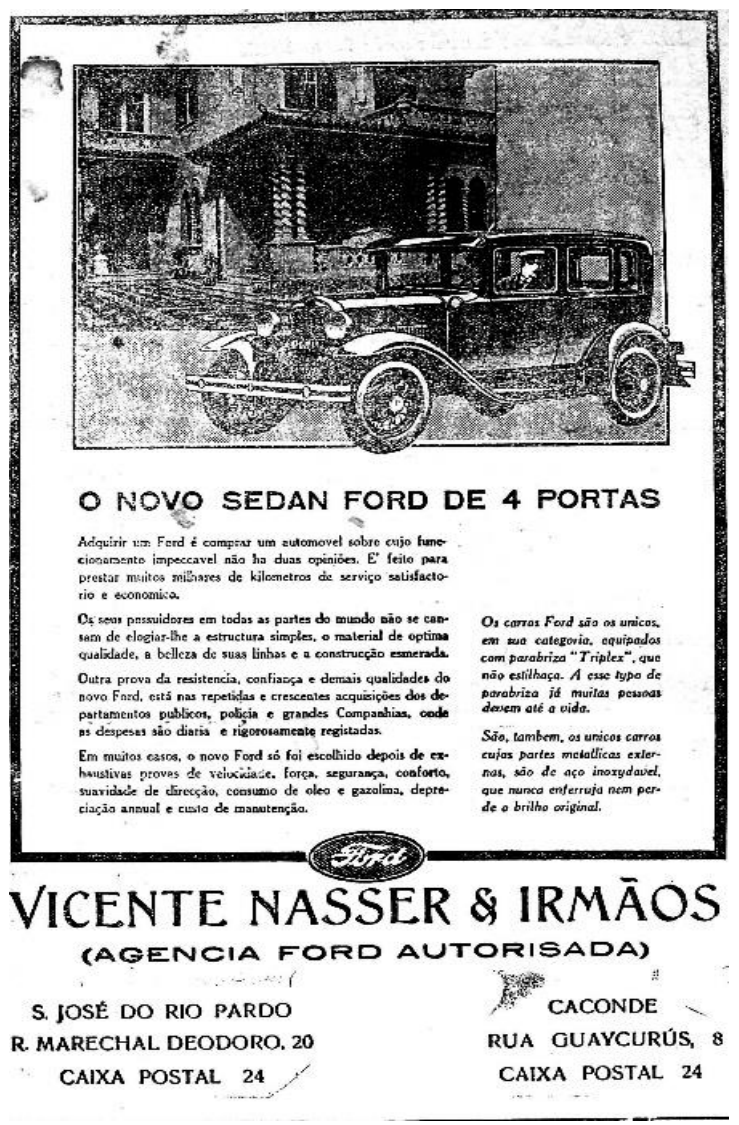

Fonte: Jornal Resenha, 04 de abril de 1931.
É interessante enfatizar que o esforço para compatibilizar a nova dinâmica urbana que incluiu o automóvel abarcou a atividade edilícia também com as novas imposições programáticas e estilísticas, que inclusive passaram a fazer parte dos anúncios da empresa de Vicente Nasser \& Irmãos (Figura 248). A associação de modernidade expressa nos estilos adotados teve como interferência direta a própria organização em planta das edificações com um espaço destinado ao abrigo do automóvel, e nas casas mais requintadas com o quarto do motorista, como veremos no terceiro item desse capítulo.

Investimentos na área cultural parecem ter sido outro campo seguido em São José do Rio Pardo durante a década de 1930, como aconteceu em outras cidades e destacado por Ghirardello. Segundo esse autor (GHIRARDELLO, 2010), o que mais recorrentemente aconteceu nas cidades 
paulistas foi a criação de casas de espetáculos pela iniciativa privada, pois tratava-se de um bom negócio em locais carentes de entretenimento, e era ainda uma novidade que se afirmava nesse período devido aos avanços tecnológicos e a maciça propaganda norte-americana (ATIQUE, 2007). Foram dois os cinemas abertos, o Cine Theatro Império (1930) de Paschoal Artese que alugou o edifício que foi sede do clube maçônico Loja "União Universal" na Rua Francisquinho Dias, e o Cine Theatro Colombo (1935), arrendado pela empresa F. Consolo e Landini, que foi construído no mesmo lugar onde funcionou o Theatro São José que foi demolido.

A riqueza de detalhes e de elementos decorativos é marcante no Cine Theatro Colombo, propriedade da Sociedade Italiana, que foi construído sob responsabilidade de Adolpho Bacci e de João Bergamasco ${ }^{203}$, em 1935. Edifício imponente que se caracteriza pela repetição de colunas duplas que remetem a ordem jônica, marquise balaustrada sustentada por consolos decorados e arquitrave ornada com frisos seccionados por elementos que se assemelham a mísulas. Apresenta ainda no ático a inscrição Cine Theatro Colombo ladeada por medalhões envoltos em pendentes e arrematados por cimalha. Coroando o edifício, o frontispício em forma triangular e decorado por fitas é completado por um vaso estilizado que lembra uma pinha aberta. Há ainda cartelas onde se lê 1935, ano de construção, e a inscrição XIII, em alusão aos anos de Benito Mussolini no poder. Percebe-se nas características plásticas uma tendência à geometrização, combinadas com elementos florais, o que configura e vincula o edifício ao ecletismo, como podemos ver em uma imagem atual (Figura 249), ainda que tenha sofrido reformas que modificaram suas aberturas para atender a outros usos mais Figura 249: Cine Theatro Colombo (1935) na Rua Marechal Floriano, 110

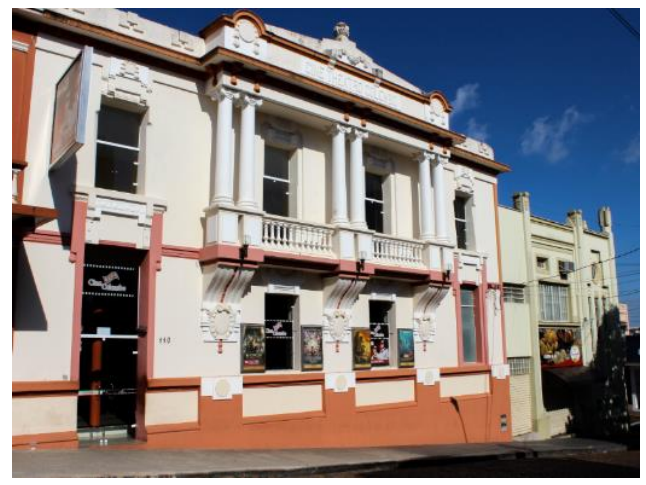

Fonte: Acervo pessoal da autora (2016). recentemente.

Um dos reflexos do processo de transformação econômica do município de São José do Rio Pardo na década de 1930 se torna visível no espaço central. Em 11 anos houve um aumento de 118,83\% no número de prédios construídos, segundo o Relatório elaborado em 1941, ratificando a publicação do jornal Resenha que expôs em um trecho publicado no dia 23 de maio de 1936: "Em todas as ruas desta cidade nota-se reformas de prédios, quando não são novas construções, desenvolvendo consideravelmente o urbanismo" (SÃO JOSÉ..., 1936, p. 03), condição bastante diversa se compararmos com a realidade do final da década de 1910 e início da seguinte (ver páginas 159, 233-239). “A cidade engalana-se de importantes edifícios" (SÃO JOSÉ..., 1936, p. 03). Dentre eles, destacamos a obra do Ginásio do Estado, marco para a educação

\footnotetext{
${ }^{203}$ Analisaremos a atuação e produção desse personagem no próximo item deste capítulo.
} 
secundária local, que foi criado pelo decreto n. 6.691 de 21 de setembro de 1934. Esse decreto instituiu ainda outras três escolas, localizadas nas cidades de Avaré, Itapeva da Faxina e Sorocaba, todas, incluindo a de São José do Rio Pardo, com características formais semelhantes. Com projeto elaborado pelo corpo técnico da Secretaria de Obras Públicas do Estado de São Paulo, sob responsabilidade do engenheiroarquiteto José Maria da Silva Neves ${ }^{204}$, o Ginásio Estadual de São José do Rio Pardo era parte do estudo de um novo tipo de prédio escolar desenvolvido por essa Secretaria que contava ainda com a participação de Francisco Prestes Maia ${ }^{205}$ e Carlos Alberto Gomes Cardim Filho ${ }^{206}$. Francamente favoráveis a estética moderna para prédios públicos, José Maria da Silva Neves defendeu a nova forma arquitetônica adotada ${ }^{207}$

Fazer arquitetura não é somente construir fachadas. A arquitetura é função dos processos de construção da época. [...] O colonial exige riqueza de ornamentação interna e externa, o que não é admissível num prédio escolar, que deve ser simples, harmonioso e de fácil asseio. [...] Sejamos artistas do nosso tempo e teremos realizado uma nobre missão. Não podemos admitir hoje uma arquitetura que não seja racional, pois, a escola deve aproveitar de todo o conforto das construções modernas, de todas as conquistas da ciência no sentido de realizar a perfeição sob o ponto de vista da higiene pedagógica. (SÃO PAULO, 1936, p. 63-64).

Em São José do Rio Pardo, o edifício do Ginásio foi construído em 1936 em um extenso terreno doado pela Prefeitura ao Estado ${ }^{208}$, nas proximidades do Parque da Independência, com dois pavimentos, isolado no lote e sobre porão alto. A implantação em área nobre, visibilidade valorizada pelo próprio Parque e acesso amplo assegurado pela Rua Treze de Maio (posteriormente denominada de Avenida Deputado Eduardo Vicente Nasser) que seguia até a entrada do Hospital São Vicente garantiram mais imponência ao sóbrio edifício de fachadas simétricas, com sequência rítmica marcada pelas pilastras e aberturas regulares, amplos beirais e geometrização de detalhes e elementos que o vinculam ao estilo art-déco ${ }^{209}$. Possui duas entradas protegidas por marquise de concreto e na platibanda a inscrição da função do prédio: Ginásio Estadual. No alinhamento do lote com o passeio há uma mureta baixa com pilaretes e fechamento em madeira que permite a livre visualização e equilibra a aparência pesada e sólida do edifício (Figura 250).

\footnotetext{
204 Segundo Ficher (2005), José Maria da Silva Neves (1896-1978) diplomou-se engenheiro-arquiteto em 1922 pela Escola Politécnica. Em 1931, Silva Neves “ingressou na Diretoria de Obras Públicas, da Secretaria da Viação e Obras Públicas. Comissionado na Secretaria da Educação e Saúde Pública, de 1935 a 1937 dirigiu a Secção de Arquitetura do Serviço de Prédios Escolares. Silva Neves foi ain da professor adjunto da Escola Politécnica e Professor da Escola de Belas Artes. Para saber mais sobre esse engenheiro-arquiteto, ver Ficher (2005, p. 210-214).

${ }^{205}$ Francisco Prestes Maia (1896-1965) diplomou-se engenheiro-arquiteto e civil em 1917 pela Escola Politécnica. Assim como Silva Neves, foi professor interino da Politécnica, mas sua atuação se destacou mais como urbanista, administrador e executor de obras públicas na Diretoria de Obras Públicas, da Secretaria de Viaão e Obras Públicas e como prefeito de São Paulo durante os anos de 1938 a 1941 e de 1961 a 1965. Para saber mais sobre Prestes Maia, ver Ficher (2005, p. 154-166).

${ }^{206}$ Carlos Alberto Gomes Cardim Filho (1899-1990) diplomou-se engenheiro civil pela Politécnica em 1923 e em engenheiro-arquiteto em 1925. Em 1924 foi contratado pela Prefeitura de São Paulo para trabalhar como engenheiro da Seção de Fiscalização de Obras Particulares. Entre os anos de 1935 a 1937 fez parte do Serviço de Prédios Escolares, órgão da Diretoria do Ensino da Secretaria da Educação e Saúde Pública, estudando e construindo novos tipos de prédios escolares. Para saber mais sobre Cardim Filho, ver Ficher (2005, p. 215-221).

207 Para maiores detalhes sobre o assunto, ver o trabalho de Fabiana Valeck de Oliveira (2007), intitulado Arquitetura escolar paulista nos anos 30 .

${ }^{208}$ A aprovação a título de doação do terreno para a edificação do Ginásio foi registrada na ata da $12^{\circ}$ sessão do Conselho Consultivo, do dia 31 de dezembro de 1934.

${ }^{209}$ De acordo com Czajkowski (2000, p. 09) essa linguagem foi "um conjunto de manifestações artísticas, estilisticamente co eso, originado na Europa e que se expandiu para as Américas do Norte e do Sul, inclusive o Brasil", difundida principalmente através do cinema, das revistas ilustradas e do rádio (CAMPOS, V., 2003). Segundo Campos, V. (2003) a estética do art-déco apresentava-se como uma manifestação moderna, sem uma homogeneidade definida, híbrida e influenciada por várias fontes decorativas, o que para Pinheiro (1997) não inviabilizou a sua fácil identificação. Correia (2010, p. 14), por sua vez, fornece um repertório acerca das possibilidades de caracterização do art-déco e o destaca por seu aspecto inovador na frequente "simplificação geometrizante de seus elementos decorativos e na diversificação e atualização de suas fontes de referência ornamental". Entre os recursos que integraram o seu repertório formal estão: marquises; platibandas e volutas de formas simplificadas; ornatos em alto ou baixo relevo representando formas geométricas, temas florais simplificados ou linhas retas ou em ziguezague; volumes, vãos e superfícies escalonadas. (CORREIA, 2010, p. 15). A manifestação dessa linguagem estilística será melhor discutida no terceiro item desse capítulo.
} 
Apesar de esse edifício possuir características diversas do prédio da escola normal inaugurada em Casa Branca em 1932, se assemelha ao de Mococa, construído em 1939, como é possível observar na Figura 251 e Figura 252. Nesse sentido, é válido ressaltar o esforço para compatibilizar a tipologia das escolas ao estilo em voga, resultando em uma limpeza muito maior de fachada, tendendo a geometrização, portanto distanciando-se do que era produzido no final do século XIX e início do século XX.

Figura 250: Ginásio do Estado (1936) fotografado em 1937.

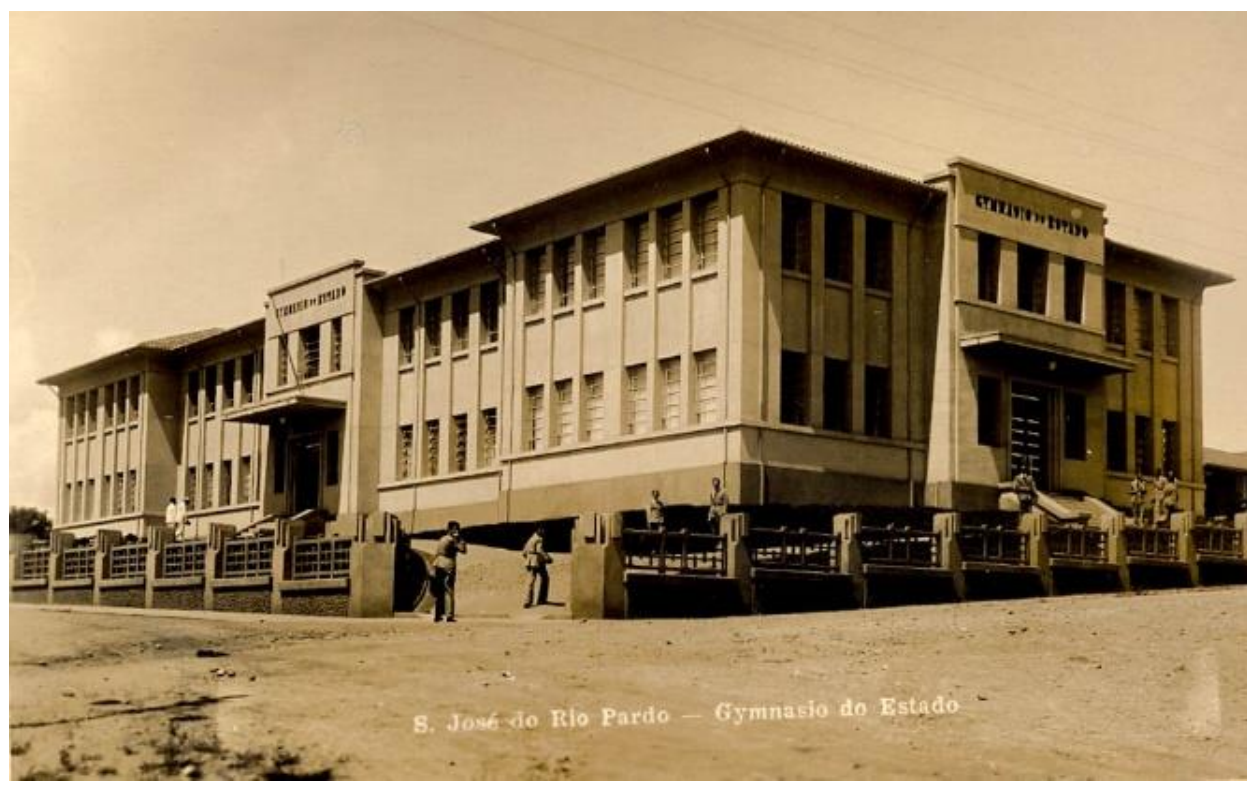

Fonte: Arquivo do Centro da Memória Rio-Pardense Rodolpho José Del Guerra.

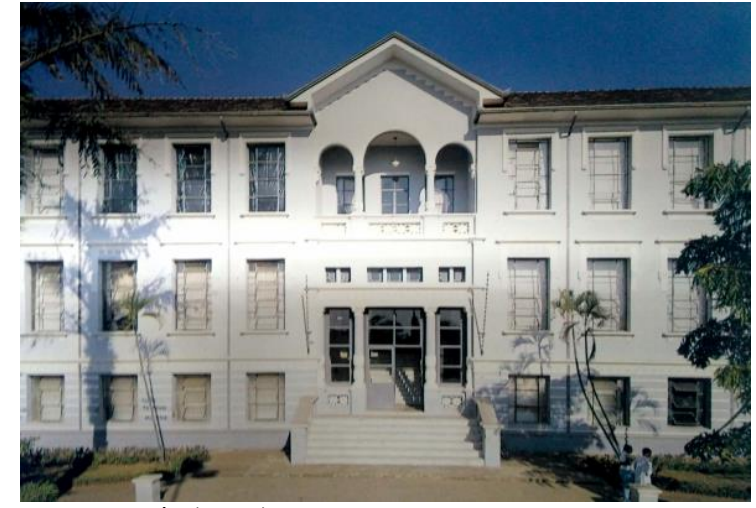

Fonte: Corrêa (1991).

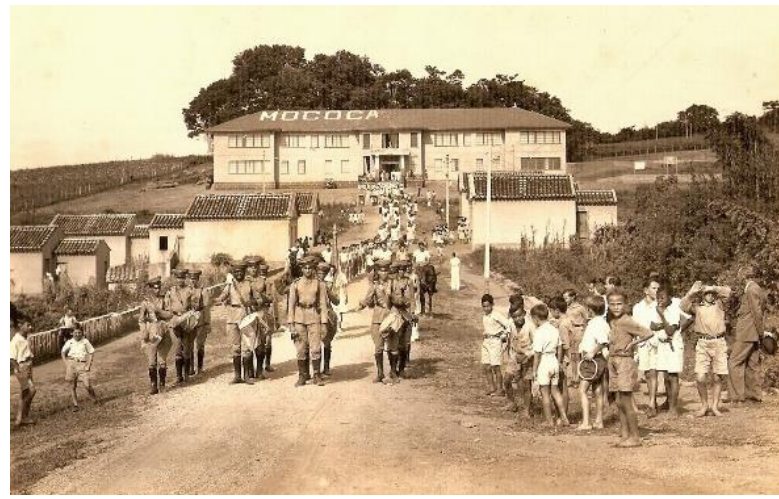

Fonte: Museu Histórico Pedagógico Marquês de Três Rios.

Nesse período foi construído outro prédio escolar, dessa vez para atender ao grupo Tarqüínio Cobra Olyntho que estava funcionando em edifícios alugados desde 1928. Conforme a ata da sessão ordinária do dia 04 de agosto de 1930, a Diretoria de Obras Públicas do Estado de São Paulo enviou um ofício requerendo a indicação de "uma área de terreno com espaço que comporte oito salas de aula para nelle ser 
edificado um edifício destinado ao $2^{\circ}$ Grupo Escolar desta cidade" (ATA..., 04/08/1930, p. 29). A obra foi iniciada em 1938 e concluída somente em 1941. Assim como o Ginásio do Estado, esse prédio foi construído com projeto elaborado pela Secretaria de Obras Públicas do Estado de São Paulo, e se caracteriza pelos amplos beirais e os perfis alongados das aberturas que contribuem para a linearidade do prédio (Figura 253).

Figura 253: Grupo escolar Tarqüínio Cobra Olyntho (1941).

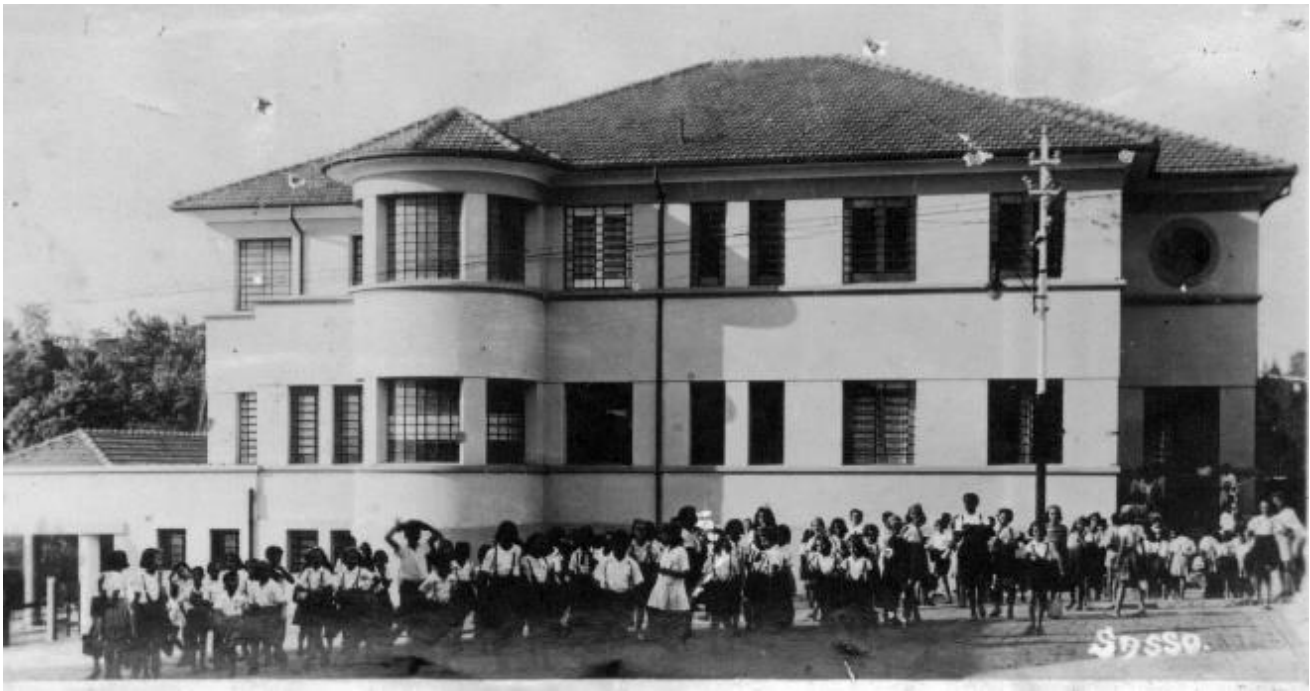

Fonte: Arquivo do Centro da Memória Rio-Pardense Rodolpho José Del Guerra.

É fato que apesar das mudanças na base econômica e política nacional com o governo de Getúlio Vargas, o poder local permaneceu sob o domínio dos grandes possuidores de capital, descendentes da velha oligarquia cafeeira, não se caracterizando como uma ruptura efetiva em relação ao que se praticava na primeira república. Exemplo disso foi a posse como prefeito de Luiz Gonçalves Júnior, em 1936, que era fazendeiro produtor de café, proprietário de armazéns de beneficiamento e comercialização, e provedor do hospital São Vicente. Sua gestão foi marcada por um estudo de melhoramento e remodelação da cidade que tinha como princípio abrir novas avenidas, reformar a canalização de água e esgoto, demarcar os níveis das ruas, construir galerias de águas pluviais e executar o calçamento das vias faltantes. A próxima pessoa a assumir a cadeira de prefeito em 1938 foi Dr. Antonio Ribeiro Nogueira Junior, formado em medicina pela Faculdade do Rio de Janeiro e filho do abastado lavrador Nhô Ribeiro, que acabou deixando o posto para assumir o cargo de chefe do Posto de Saúde dessa cidade. No lugar deste último foi nomeado Aurino Villela de Andrade, fazendeiro agricultor e pecuarista, que se encarregou da função em 11 de março de 1939 onde permaneceu até 27 de março de 1943. Logo no primeiro ano de sua gestão foram retomados os serviços de calçamento das vias e dos passeios, dando continuidade e concluindo parte dos estudos feitos por Luiz Gonçalves Júnior, como podemos ver nas figuras a seguir (Figura 254). 
Figura 254: Grupo de operários durante a execução do calçamento da Rua Francisco Glicério e da Rua Marechal Floriano.
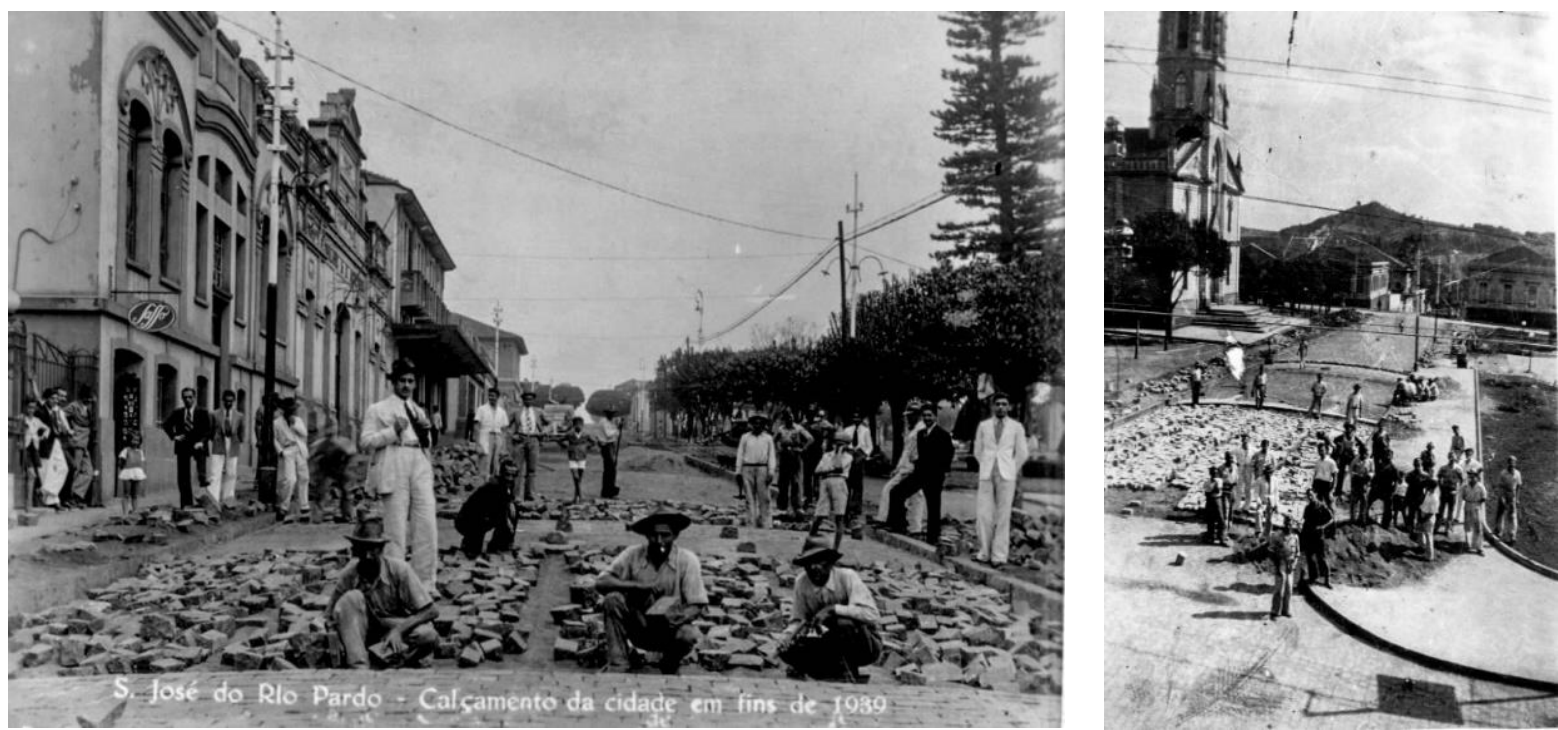

Fonte: Arquivo do Centro da Memória Rio-Pardense Rodolpho José Del Guerra.

Uma nova velocidade de circulação foi assegurada através do nivelamento, drenagem, colocação de meiofio, calçamento das vias e dos passeios, aliado ainda aos aspectos higiênicos, ao conforto e à estética das ruas. Melhoramentos que evitavam o acúmulo de poeira, buracos e água estagnada nas ruas, e ao mesmo tempo facultavam maior comodidade nos deslocamentos. Sobre isso, Lapa (1996, p. 203) ao analisar a cidade de Campinas ratifica tais benefícios que o calçamento trouxe e ainda nos diz que a impermeabilização do leito das ruas impedia "que matérias orgânicas penetrassem no solo e o infectassem e ao mesmo tempo preservava o interior das habitações da umidade proveniente das águas pluviais" e da poeira que levantava com o vento e o trânsito dos carros. Nesse sentido, a pavimentação dos passeios viabilizava as mesmas qualidades, garantindo ainda a segurança aos pedestres que foi posta em risco pelos veículos automotores, como mencionou o jornal Resenha do dia 12 de novembro de 1940 que

urgia providencias policiais a corrida dos autos em nossas terras [...] o que há aqui é um constante desafio às leis de transito e o maior menosprezo à vida do próximo, que corre o risco de uma hora para outra ser esmagado sob as rodas de um automóvel. (URGE PROVIDÊNCIAS, 1940, p. 01).

Além do mais, a separação dos fluxos foi uma medida de direcionamento e de ordem dos costumes que deveriam ser seguidos pela população, na aspiração de práticas consideradas civilizadas.

A perda da dianteira da cafeicultura na economia a partir da década de 1930, fez com que, ao longo dos anos que se seguiram, se definisse a expansão da cidade com a criação de novos bairros, abertos a partir da venda de glebas de antigas fazendas, sítios e chácaras que circundavam a ocupação urbana. Nesse momento, as quadras que constituem o Centro Histórico, reconhecido nos dias de hoje, estavam ocupadas e consolidadas; algumas avenidas foram prolongadas a exemplo da Municipal e outras foram abertas como a Independência; os novos bairros foram se afirmando, como a Vila Pereira ao leste da área central, nas proximidades do Asilo e do Bairro Bonsucesso; a Vila Maschietto ao sul, entre a linha do trem e o hospital 
São Vicente; a Vila Progresso no prolongamento do Bairro Santo Antônio; e o início da ocupação da zona norte da cidade, nas margens da linha férrea, conhecido como Bairro João de Souza e na vizinhança do Cemitério Municipal, dando origem à Vila Formosa, como podemos ver no mapa da Figura 255.

Figura 255: Mapa de São José do Rio Pardo em 1940.

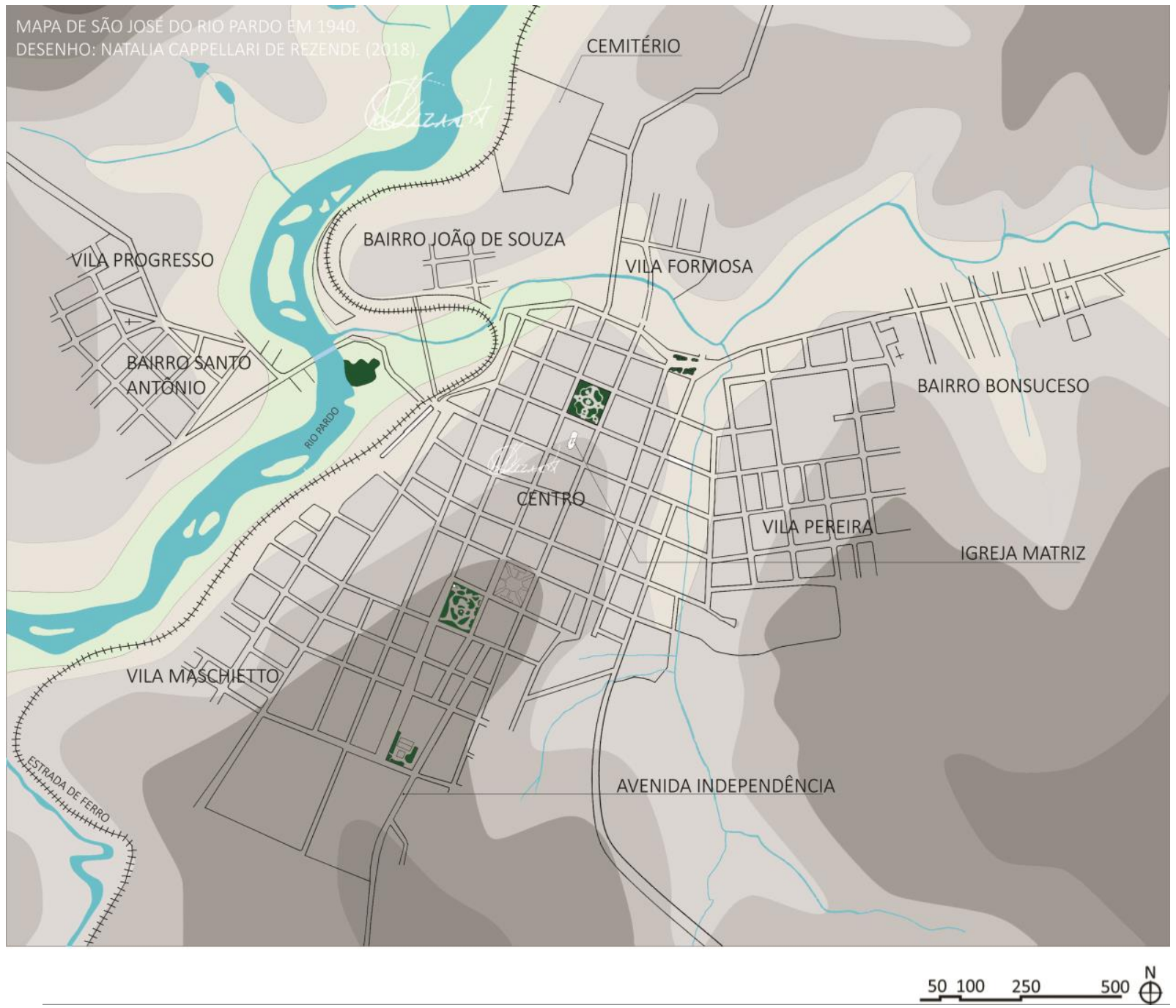

Desenho: Natalia Cappellari de Rezende (2018) com base em dados históricos e cartografia disponibilizada pela Secretaria de Obras de São José do Rio Pardo.

Apesar da expansão da malha urbana ter acontecido em todas as direções, constatamos uma ênfase maior na conclusão de várias obras de infraestrutura, na construção de equipamentos públicos e de estabelecimentos de consumo primários realizados especialmente dentro do perímetro urbano e nas proximidades da igreja Matriz. A não revisão do respectivo perímetro e a manutenção dos interesses que abarcavam os ideais de modernização da cidade excluía os bairros e vilas adjacentes, que gradativamente se espraiaram devido à consolidação da ocupação da área central e do preço da terra. Rede de água e esgoto, energia elétrica, calçamento e equipamentos públicos não alcançaram essas regiões até meados dos anos 
de 1930, com exceção da Vila Pereira - estabelecida com a ocupação de camadas sociais mais abastadas que possuiu todos os serviços logo no início dessa década ${ }^{210}$. À mercê de pressões populares e do capital político e econômico, a cidade iniciou o seu segundo cinquentenário, comemorado em 1941, com propostas de transformações, sobretudo urbanas e arquitetônicas, com planos de desapropriação de amplos terrenos nas margens da Avenida Municipal, à beira da linha da estrada de ferro até o Cemitério Municipal, com o intuito de criar lagos artificiais e acabar com a desagradável impressão que as casinhas "inestéticas e insalubres" causavam aos viajantes que chegavam à cidade pela estrada de ferro (SÃO JOSÉ ..., 1944, p. 03). O desejo de afastar os pobres para distâncias cada vez maiores de áreas enobrecidas confirma que a política higienista, moralista e elitista ainda persistia nas práticas adotadas pelo governo local. Para Chalhoub (1996), a intenção que se manteve na política brasileira, a exemplo da rio-pardense, foi a de afastamento e invisibilidade do pobre segregando-o da "cidade" que não foi feita para ele ocupar e circular. Com isso, um mercado de terrenos se expandiu, especialmente nos bairros Santo Antônio e Bonsucesso, para atender à população menos favorecida. Era nítida a distinção dos bairros ocupados pelos diferentes estratos sociais, revelando a relação entre a estrutura social concatenada com a sua capacidade financeira e a ocupação urbana, com reflexo direto na construção de moradia.

Ainda que o crescimento urbano de cidades pequenas como São José do Rio Pardo tenha acontecido de modo muito menos intenso do que em outras regiões do estado, ou mesmo do Brasil, como apontado por Marx (1991, p. 127), onde foram empreendidas "novas construções para atender a outras exigências além daquelas do negócio e do habitar tradicional, novas aspirações de vida e, enfim, outras soluções técnicas para a questão do acúmulo das gentes e seus afazeres", guardou semelhanças. Marx (1991) afirma ainda que em termos espaciais, tais mudanças foram perturbadoras porque subverteu a paisagem urbana que se tinha, a prova disso foi a substituição do destaque da igreja para a valorização do teatro, cinema, biblioteca, lojas, escritórios, ruas e passeios públicos cuidados. Nesse sentido, São José do Rio Pardo que não se constituía como uma grande cidade e não apresentava um processo de adensamento e verticalização como já ocorria em São Paulo (FELDMAN, 2005) ou em Ribeirão Preto (DEMINICE, 2015) - atingidas por um boom imobiliário que provocou fortes mudanças urbanas e arquitetônicas - também sofreu com o aumento de edifícios construídos. Foi nessa época que se criou uma companhia construtora, denominada de Companhia Melhoramentos Riopardense, que empreendeu forte domínio sobre o mercado da construção civil local, sobretudo com a produção de casas para venda nos bairros adjacentes à região central da cidade, contribuindo com a expansão e ocupação de novas áreas. Logo, um novo momento se iniciou com outro viés de desenvolvimento urbano e da própria história da cidade com implicações diretas na produção da moradia urbana - não mais como produto do ciclo econômico cafeeiro -, fugindo do escopo de análise proposto nesta dissertação.

\footnotetext{
${ }^{210}$ Segundo Somekh (1997, p. 113), o espaço enquanto produto social tem seu valor definido pela sociedade que atribui um preço para a terra urbana, mediante manipulações da classe capitalista. Com isso, cria-se "diferentes demandas por solo urbano, pelas condições específicas de valorização e pela lógica de cada fração do capital. Isto provoca a constituição de uma multiplicidade de mercados fundiários, hierarquicamente estabelecidos, que por sua vez definem uma hierarquia de uso do solo urbano".
} 
Portanto, o período que se iniciou com a publicação do Código de Posturas em 1918 e tem fim em 1940, provocou mudanças significativas em termos legais, infraestruturais, urbanas e arquitetônicas que contribuíram para alterar a fisionomia local. Sendo assim, discutiremos no próximo item a atuação de personagens, como o João Bergamasco e Américo Braghetta, que foram fundamentais na inevitável transformação da arquitetura produzida em São José do Rio Pardo nessa última etapa do nosso recorte temporal. 


\subsection{Diplomados e práticos licenciados (1918-1940)}

Enfatizamos no capítulo anterior a significativa contribuição dos estrangeiros - construtores, mestre de obras, pedreiros, entre outros - na construção civil rio-pardense do final do século XIX e início do século XX. E, ainda que as reticências persistissem na impossibilidade de identificar os autores dos projetos e a mão de obra empregada na construção das edificações, vasculhando os arquivos do Arquivo Público da Secretaria de Obras e da Hemeroteca Jornalista Paschoal Artese e cruzando os dados e fontes consultadas conseguimos identificar um número significativo de pessoas que atuaram no período de 1918 a 1940. Com isso, uma cidade que estava sendo construída por sujeitos de nacionalidades distintas nos foi revelada. Nomes como o de José Lourenço, Manoel Fernandes, Octaviano Villani e Ernesto Rugani figuraram no Almanaque de 1929 como empreiteiros construtores. Entre eles estava também Paschoal Artese, que teve uma atuação mais intensa em períodos anteriores - como pudemos constatar no item 2.2 - e prosseguia atuando nesse ramo. Através dos anúncios dos jornais encontramos profissionais que se identificaram como diplomados e davam destaque às atividades e serviços oferecidos, como o engenheiro civil Labienio Baptista Machado que se estabeleceu na Rua Francisco Glicério e oferecia serviços concernentes a sua profissão, sobretudo construções, plantas topográficas e projetos hidráulicos (Figura 256); Danielo Clementi, engenheiro civil e arquiteto, radicado em Ribeirão Preto ${ }^{211}$, e que por intermédio de Salvador Artese se disponibilizava para trabalho de divisões de terrenos, levantamento de plantas e realização de projetos industriais (Figura 257); e o engenheiro civil Ladeira Rosa e Affonso Sammartino, engenheiro civil e de minas, que se dispunham a executar divisões e demarcações de terras e construções em geral, destacando em seus anúncios a facilidade de pagamento e a procedência dos materiais utilizados (Figura 258).

Figura 256: Anúncio de Labienio Baptista Machado.

\section{Labienio Baptista Machado} Acceita trabalhos referentes a sua profissăo:- Hydraulicos, construcços, mediçoes e divisбes, plantas topographicas, ete. RUa Francisco Glycisio, 39 Fonte: Jornal Resenha, 23 de maio de 1926.
Figura 257: Anúncio de Danielo Clementi.

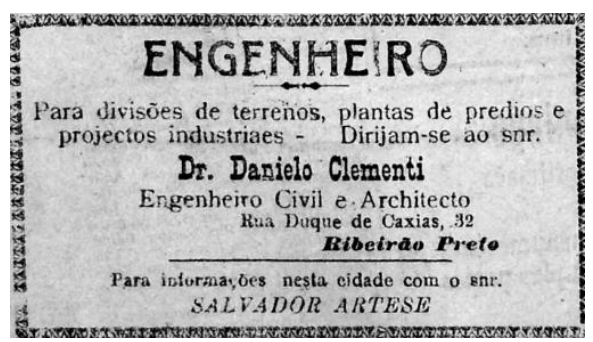

Fonte: Jornal Resenha, 15 de novembro de 1927
Figura 258: Anúncio de Ladeira Rosa e Affonso Sammartino.

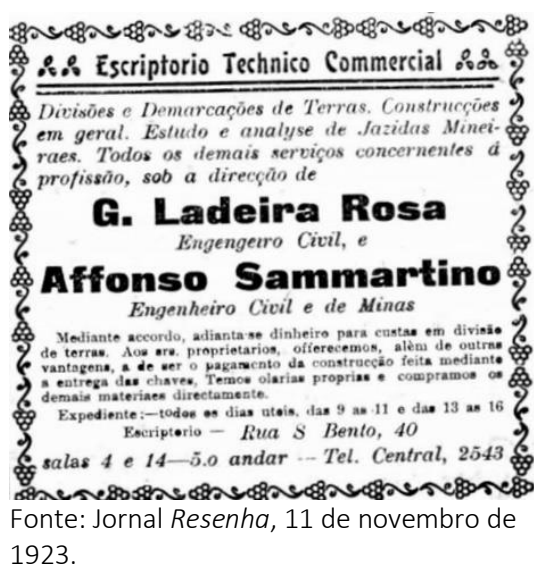

\footnotetext{
${ }^{211}$ Para saber mais sobre quem foram e como atuaram os profissionais e artífices em Ribeirão Preto, ver o trabalho que está sendo desenvolvido no Instituto de Arquitetura e Urbanismo da Universidade de São Paulo pela pesquisadora Ana Carolina Gléria Lima, "Arquitetura residencial urbana através do acervo de Obras Particulares do Arquivo Público e Histórico de Ribeirão Preto - SP".
} 
Nomes de diplomados como Elias Machado ${ }^{212}$ e Abdiel Cavalcanti Braga e não diplomados como João Bergamasco, Américo Braghetta, Antônio Molfi, Francisco E. Garcia, A. Figueiredo e Ettore Braga, apareceram entre os 339 projetos de construção, ampliação e reforma levantados no Arquivo Público da Secretaria de Obras. Cumpre aqui relembrar as particularidades dessa documentação, a sistematização e catalogação de todos os processos aprovados pela Prefeitura Municipal que deu ensejo para conhecermos as pessoas atuantes na construção civil rio-pardense assim como as características de suas obras, o ano, endereço e tipo de solicitação. Mas vale nesse sentido também salientarmos que o Arquivo Público da Secretaria de Obras possui projetos arquivados somente a partir de $1925^{213}$ apesar da obrigatoriedade de apresentação e aprovação valer desde 1918 quando o terceiro Código de Posturas foi publicado e o artigo 38 entrou em vigor. Consequentemente, após a sua validação, os requerimentos necessariamente deveriam apresentar uma série de desenhos que fosse capaz de representar o projeto, seu local e o funcionamento da edificação. Todavia, a esmagadora maioria dos processos que consultamos apresentam somente a fachada principal e a planta, sem cortes e disposições do encanamento, indicação incompleta de seu endereço e mesmo sem o profissional responsável pelo projeto e execução, como é possível observar na Figura 259. Em outros casos, não estão representados os limites do lote, o que inviabiliza conhecermos os recuos, assim como a inclusão das dimensões dos ambientes e sua denominação. Encontrar algum detalhamento foi algo singular nos 339 projetos consultados, que, aliás, eram cópias em ferro prussiato e raros foram os desenhos em papel vegetal (Figura 260). Apesar da falta de informações, os desenhos apresentam alta qualidade técnica, que nos permitiu verificar as condições impostas pela normativa municipal e pautadas no Código Sanitário Estadual, sobretudo quanto ao arejamento e a iluminação natural dos ambientes, o que evidencia a ressonância do controle da prática edificativa a que os responsáveis pela obra estavam sujeitos. Cabe ressaltar que a maneira de representação dos projetos apresentados para aprovação na Prefeitura de São José do Rio Pardo não diferia muito do que era submetido na capital paulista, como pudemos constatar em Lody $(2015)^{214}$.

\footnotetext{
212 Para saber mais sobre o engenheiro Elias Machado, ver nota 194 na página 243.

213 Ver Apêndice 03.

214 Jorge Lody (2015) analisou as transformações arquitetônicas e urbanísticas de São Paulo, entre os anos de 1906 e 1915 , com base no registro oficial das solicitações de permissão para construir encaminhadas por profissionais aos órgãos públicos municipais. 
Figura 259: Projeto submetido à aprovação na Prefeitura Municipal de São José do Rio Pardo, 1926.

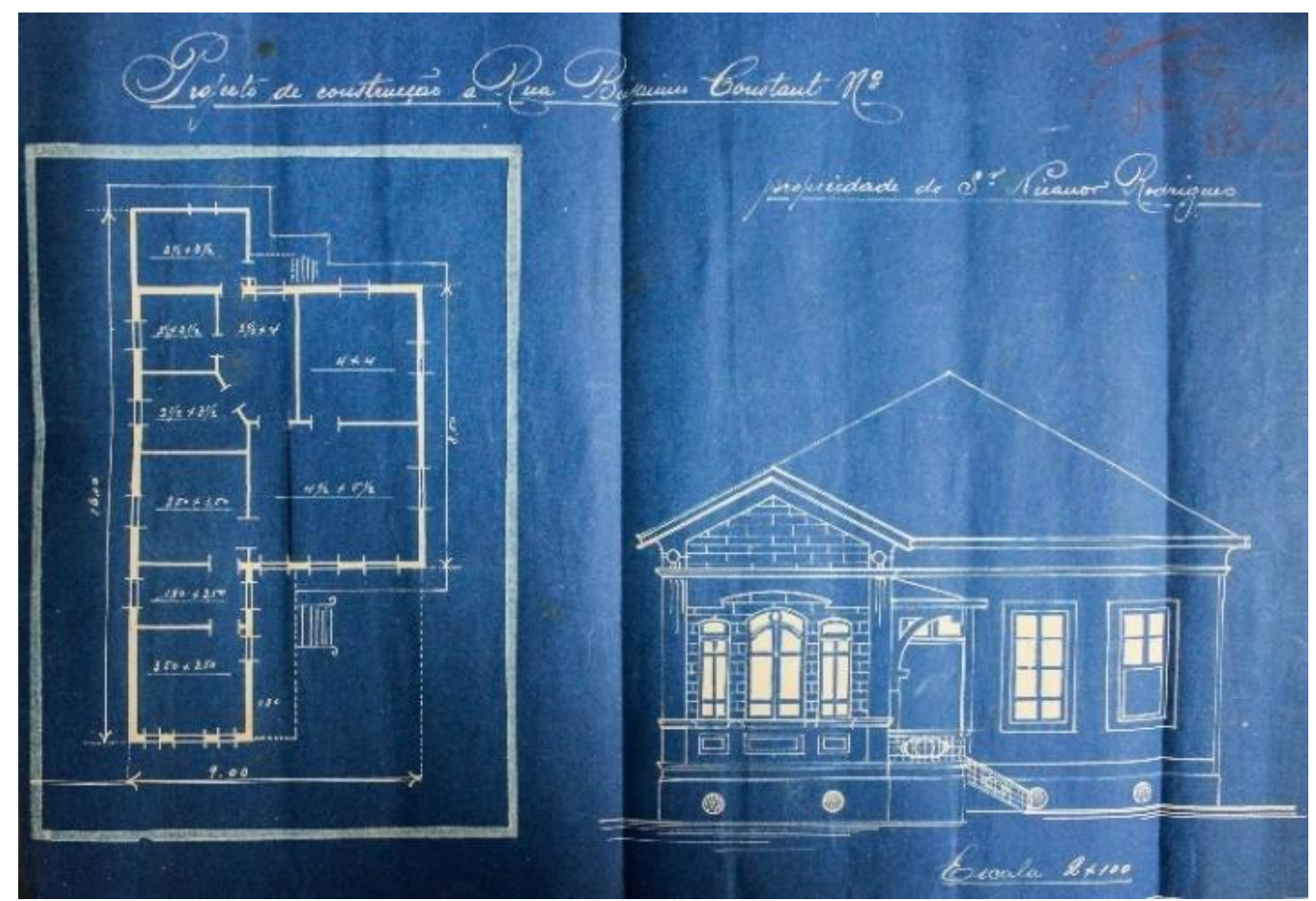

Fonte: Arquivo Público da Secretaria de Obras (1926, P01).

Figura 260: Projeto submetido à aprovação na Prefeitura Municipal de São José do Rio Pardo, 1930.

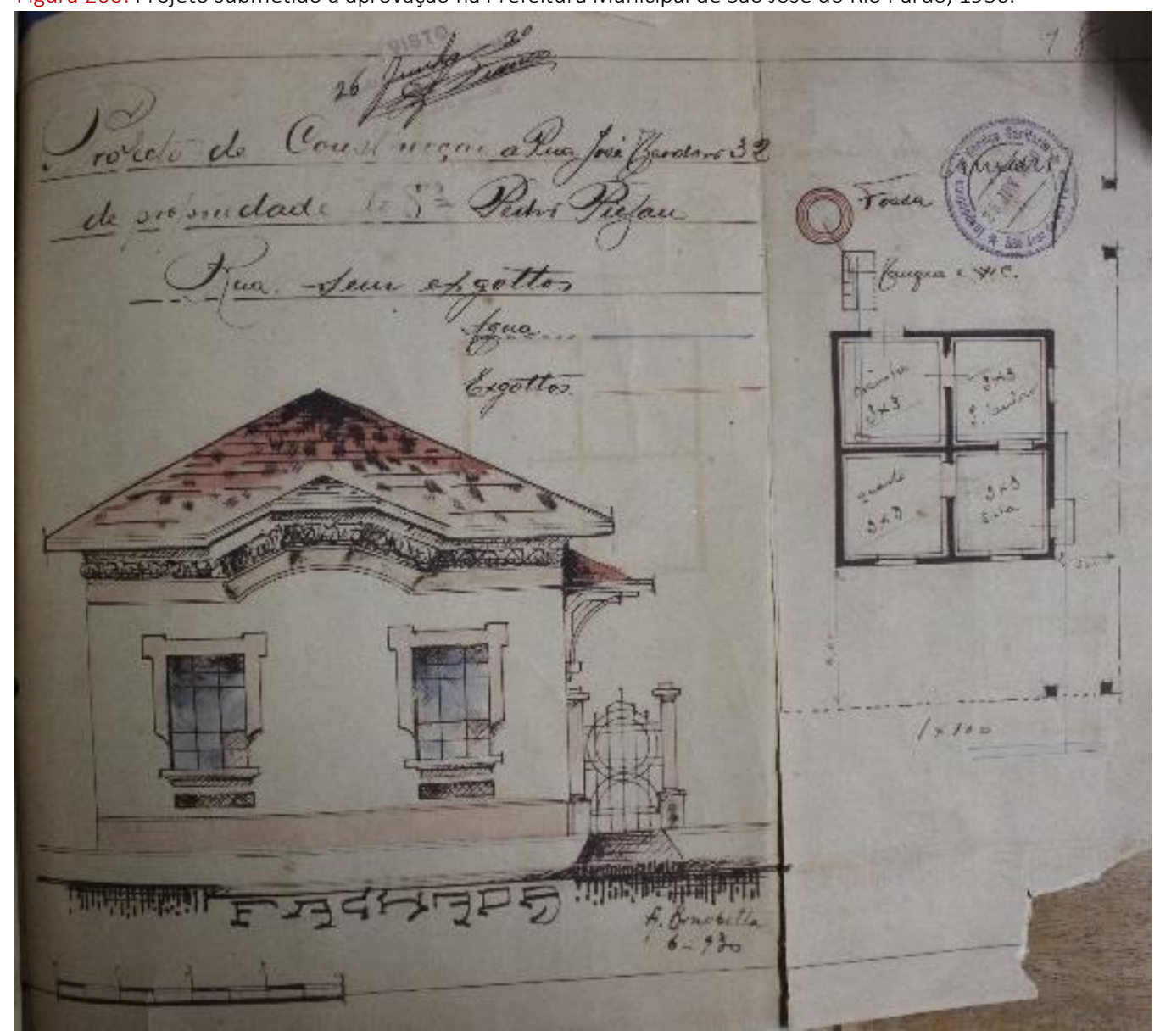

Fonte: Arquivo Público da Secretaria de Obras (1930, P15). 
Ainda que algumas informações se apresentem incompletas, podemos revelar através desse acervo que 155 projetos, ou seja 46\%, não possui indicação do projetista, construtor ou responsável pela obra; 2\% dos projetos, o que equivale a 7 , são firmados por engenheiros; e outros 177, correspondente a 52\%, é assinado por não diplomados (Gráfico 02).

Esse esforço de quantificação nos permitiu também constatar a distribuição espacial de tais obras - levando em consideração a verificação de que todos os projetos aprovados foram executados -, contribuindo ainda mais para a compreensão do processo de crescimento da mancha urbana, como podemos ver na Gráfico 03 e no mapa da Figura 261. Correspondentemente, nesse período, o Centro ainda figura como local onde houve maior quantidade de solicitações de aprovação de projetos, em relação aos demais bairros, totalizando 214, ou seja 63\%, o que se deve a quadras abertas mais ao sul e certamente ao desejo dos proprietários em construir novos imóveis que atendessem às necessidades e novidades da época, como aconteceu com o antigo Theatro São José (ver Figura 100 na página 149), demolido para dar lugar a um edifício maior onde mais pessoas pudessem desfrutar das seções cinematográficas. Entre os bairros localizados na periferia do Centro, a Vila Pereira foi o que possuiu o maior número de solicitações de aprovação de projeto com 55, representando 16\%, o que certamente se deve a existência de energia elétrica, rede de água e esgoto, calçamento e equipamentos públicos já no início da década de 1930, diferentemente dos demais.

Gráfico 03: Ocorrência de projetos aprovados por bairro entre os anos de 1925 a 1940.

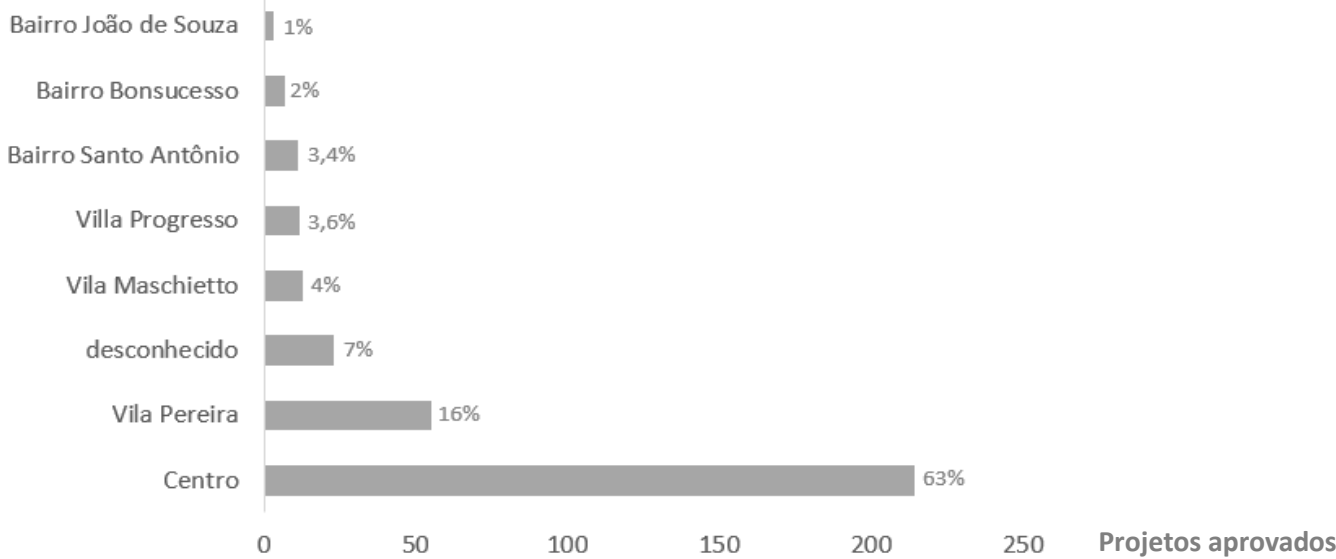

Fonte dos dados: Projetos pertencentes ao Arquivo Público da Secretaria de Obras. 
Figura 261: Mapa da malha urbana com a divisão de bairros de São José do Rio Pardo em 1940.

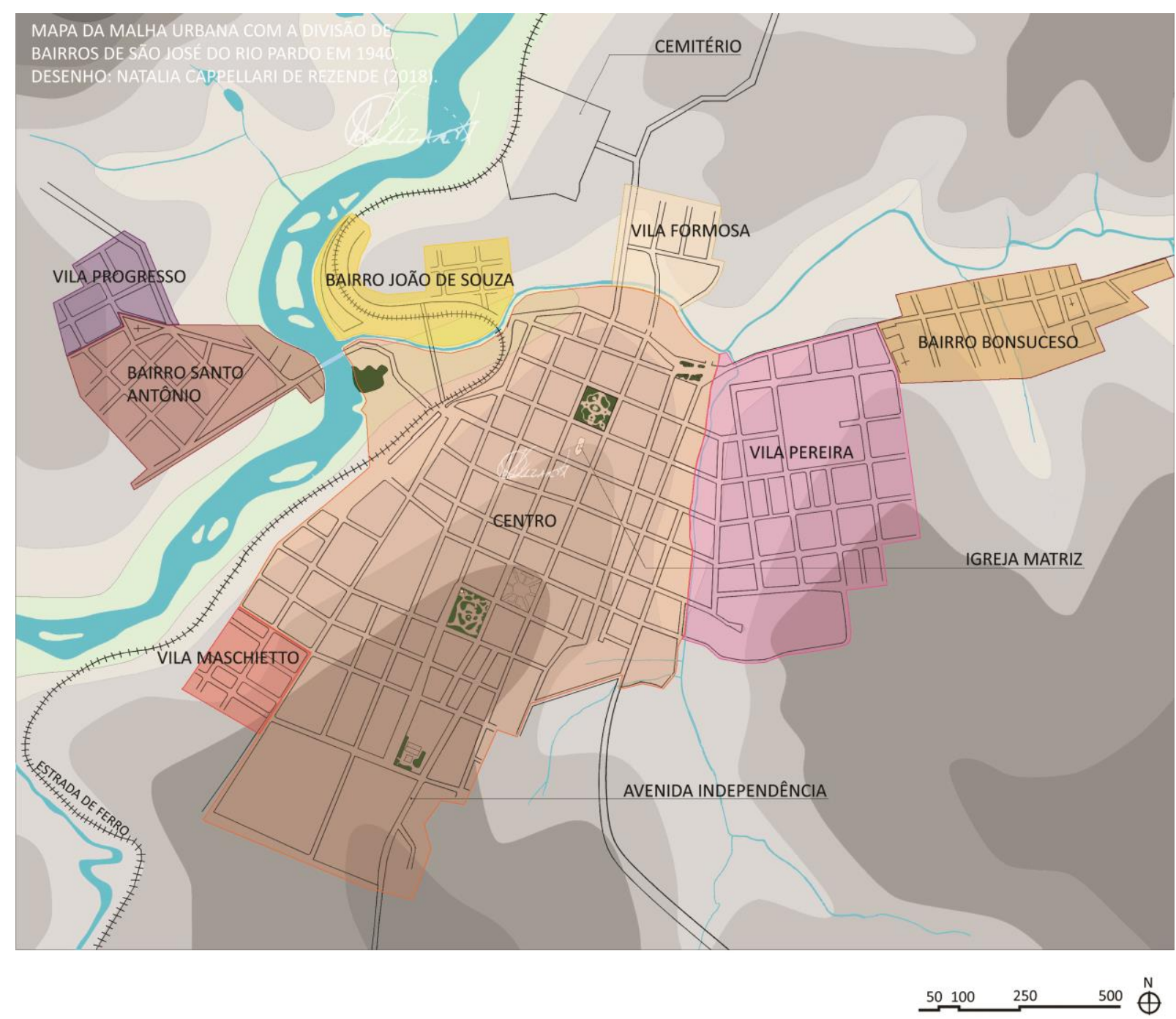

Desenho: Natalia Cappellari de Rezende (2018) com base em dados históricos e cartografia disponibilizada pela Secretaria de Obras de São José do Rio Pardo.

Como segue no Gráfico 04, do total de 339 solicitações de aprovação de projetos, 280, ou seja 82,3\%, representam novas edificações, 34 ampliações e 25 reformas, o que significa 10,3\% e 7,4\% respectivamente. Nossa suposição em relação à maior quantificação de projetos aprovados na área central da cidade (Figura 262) fica bem próxima de uma comprovação quando extraímos dessa sistematização de dados a informação que da totalidade de novas construções, 165, representando 48,7\% localizam-se nessa área.

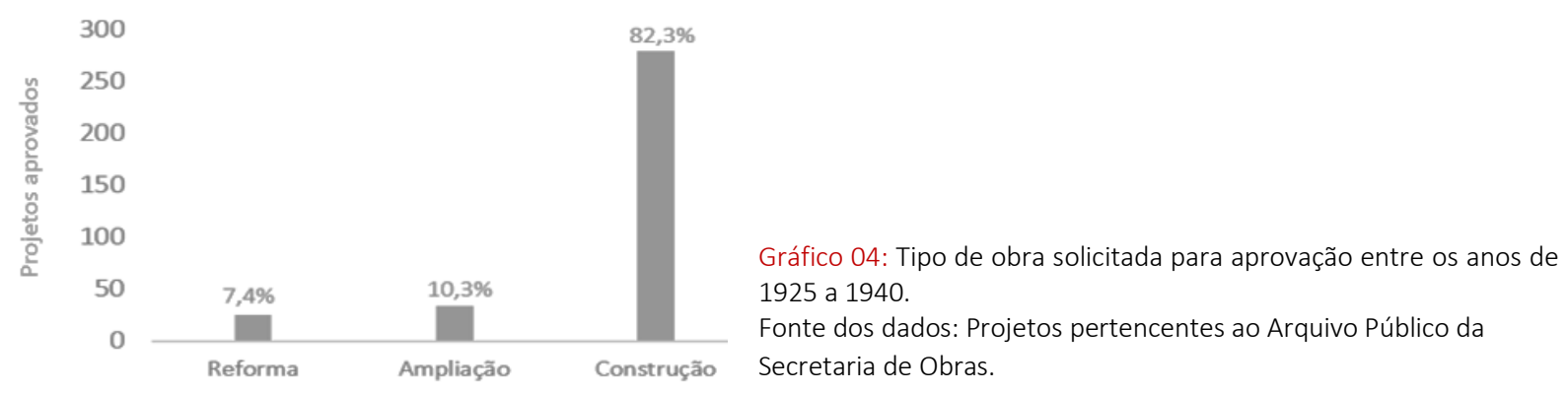




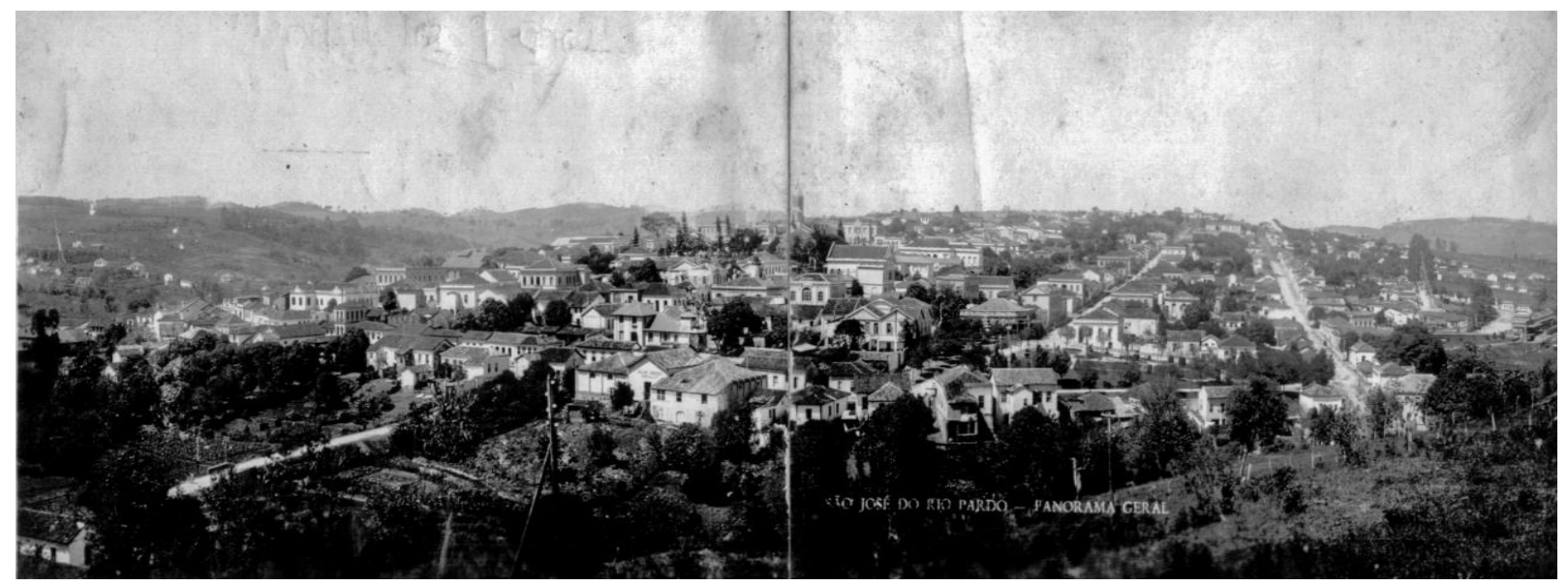

Fonte: Arquivo do Centro da Memória Rio-Pardense Rodolpho José Del Guerra.

Com a sistematização e catalogação de todos os processos referentes à solicitação de autorização para construir, ampliar ou reformar, se tornou possível ainda constatar a ampla diversidade de obras, públicas e privadas, desde singelas residências de três cômodos a programas complexos de edifícios com uso comercial e de serviços, assim como a incorporação de novos gostos e exigências legais municipais e estaduais. A organização desse material também possibilitou a averiguação dos sujeitos mais atuantes, os quais edificaram todo tipo de obra, em contraposição àqueles que apesar de terem sido citados em algum documento pesquisado ${ }^{215}$ como profissional da construção civil, não encontramos informações complementares, a exemplo de Manoel Fernandes, Octaviano Villani, A. Figueiredo, Ettore Braga, Francisco Eladio Garcia e Antonio Molfi. Já sobre Abdiel Cavalcanti Braga, sabemos através dos registros da Universidade Federal de Itajubá que ele nasceu em Conceição do Macabu, Rio de Janeiro, a 9 de novembro de 1889. Em 1920 se formou em Engenharia Eletrotécnica pelo Instituto Eletrotécnico e Mecânico de Itajubá (IEMI) - atual Universidade Federal de Itajubá - e em 1932 passou a residir em São José do Rio Pardo após uma passagem por Muzambinho onde exerceu o cargo de diretor de um liceu. A mudança de cidade ocorreu consoante seu desejo de instalar um ginásio em São José do Rio Pardo, o qual se efetivou em 1933 quando passou a funcionar com o nome de Ginásio Municipal Rio-pardense, na antiga residência de Honório Luiz Dias (ver Figura 73 na página 127). Anos depois esse Ginásio se tornou do Estado e Abdiel continuou a exercer a função de diretor e também professor de matemática até a sua aposentadoria. Fora da instituição, Abdiel trabalhou como engenheiro eletricista e projetista. Em 1963, o jornal Resenha noticiou o seu falecimento: "a 13 do corrente faleceu nesta cidade o sr. dr. Abdiel Cavalcante Braga a quem devemos devotados longos anos de eficientes serviços prestados ao Ensino Secundário local” (DR. ABDIEL ..., 1963, p. 01).

Entre os agentes que atuaram em São José do Rio Pardo no período de 1918 e 1940, Ernesto Rugani, José Lourenço, Américo Braghetta e João Bergamasco se apresentaram como os de maior produção na

\footnotetext{
${ }^{215}$ Os principais documentos consultados foram os projetos aprovados pela Prefeitura Municipal e que hoje fazem parte do Arquivo Público da Secretaria de Obras; o jornal Resenha e Rio Pardo e os almanaques que pertencem ao Arquivo da Hemeroteca Jornalista Paschoal Artese.
} 
construção civil local. Essa afirmação tem como base a quantificação de projetos, ou seja, da totalidade de solicitações de construção, ampliação e reforma que possuíam assinatura de responsabilidade técnica, 89\% pertenciam a eles. Essa quantificação aparentemente representa um claro domínio desses sujeitos na construção civil rio-pardense, e por este motivo vamos dedicar maior ênfase em nossa análise às trajetórias deles e às características de seus projetos.

\section{Ernesto Giovani Rugani}

Ernesto Rugani foi outro agente que obtivemos um pouco de sua trajetória através de seus netos Myrian Rugani Viana (2017) e Leo Lucas Rugani (2017). Eles nos informaram que Ernesto nasceu a 7 de dezembro de 1885 em San Macario In Piano, na comuna de Lucca, Itália. Segundo Marília Rugani (2017), também sua neta, seu avô veio para o Brasil juntamente com o pai Alibrando Rugani que havia sido convidado para construir os capitéis do Museu do Ipiranga em São Paulo. De acordo com Marília (2017), após o término da obra, os Ruganis se instalaram em Poços de Caldas-MG, onde participaram da construção das redes de esgoto e de captação das águas termais. Ernesto que não era diplomado, aprendeu o ofício com seu pai, e se mudou para São José do Rio Pardo na década de 1920 onde trabalhou como construtor realizando importantes obras, como o Hospital São Vicente e a rede de abastecimento de água da Vila Pereira. A atuação desse italiano não ficou restrita apenas ao canteiro, mas também elaborando projetos, como os das caixas d'água construídas nas proximidades do hospital e de alguns edifícios privados. Foi-nos possível constatar sua atividade como projetista ao encontrarmos diversos projetos com sua assinatura no arquivo do Arquivo Público da Secretaria de Obras. Dentre eles, o mais antigo é de abril de 1925, foi uma oficina (Figura 263), cuja estética remete ao geometrismo do $\operatorname{art-déco~}^{216}$, estilo que só iria aparecer com mais evidência em São José do Rio Pardo a partir dos anos 1930, notadamente nas moradias urbanas, e por esse motivo será melhor analisado no item 3.3. Entretanto, nos chama a atenção que nos cinco projetos (Figura 264, Figura 265, Figura 266, Figura 267 e Figura 268) de residência encontrados no acervo, ele tenha adotado uma postura mais conservadora onde constatamos a presença de características mais usuais à época, como alpendres, beirais largos, aberturas emolduradas, balaústres e faixas decorativas. Salvo a oficina e as duas edificações térreas, predominou em seus projetos a verticalização, ainda que o programa tenha sido variado. Com exceção do sobrado que foi sua própria residência (ver Figura 264) - informação confirmada por Marília (2017) -, os demais não apresentam indicação de endereço, nos impedindo de saber se de fato foram construídos e se ainda existiriam, mesmo que alterados ${ }^{217}$.

\footnotetext{
${ }^{216}$ A linguagem estética do art-déco foi lançado formalmente na Exposition Internacionalle des Arts Décoratives et Industrielles Modernes de Paris, em 1925, o que mostra a erudição de Ernesto Rugani e a simultaneidade dessa manifestação em uma cidade do interior paulista. Sobre isso ver Czajkowski (2000), Campos, V. (2003) e Pinheiro (1997, 2008).

${ }^{217}$ Percorremos toda a área central, Vila Pereira e Vila Maschietto a procura de evidências da existência desses edifícios, mas não tivemos sucesso. Desse modo, julgamos a possibilidade de eles não terem sido construídos, mas caso tenham sido, já foram completamente demolidos. A exceção é a moradia de Ernesto Rugani, localizada na Rua Francisco Glicério, 724, que apesar de ter sofrido reformas que a alterou parcialmente, mantem-se na paisagem do Centro Histórico rio-pardense.
} 


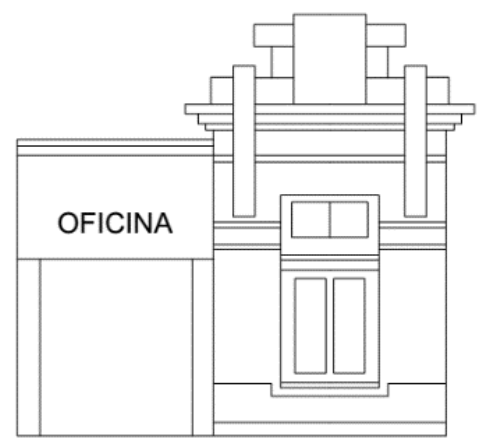

Figura 263: Desenho da fachada de uma oficina projetada por Ernesto Giovani Rugani.

Fonte: Arquivo Público da Secretaria de Obras (1925, P18) Desenho: Natalia Cappellari de Rezende (2018).

Figura 264: Desenho da fachada da moradia de Ernesto Giovani Rugani na Rua Francisco Glicério.
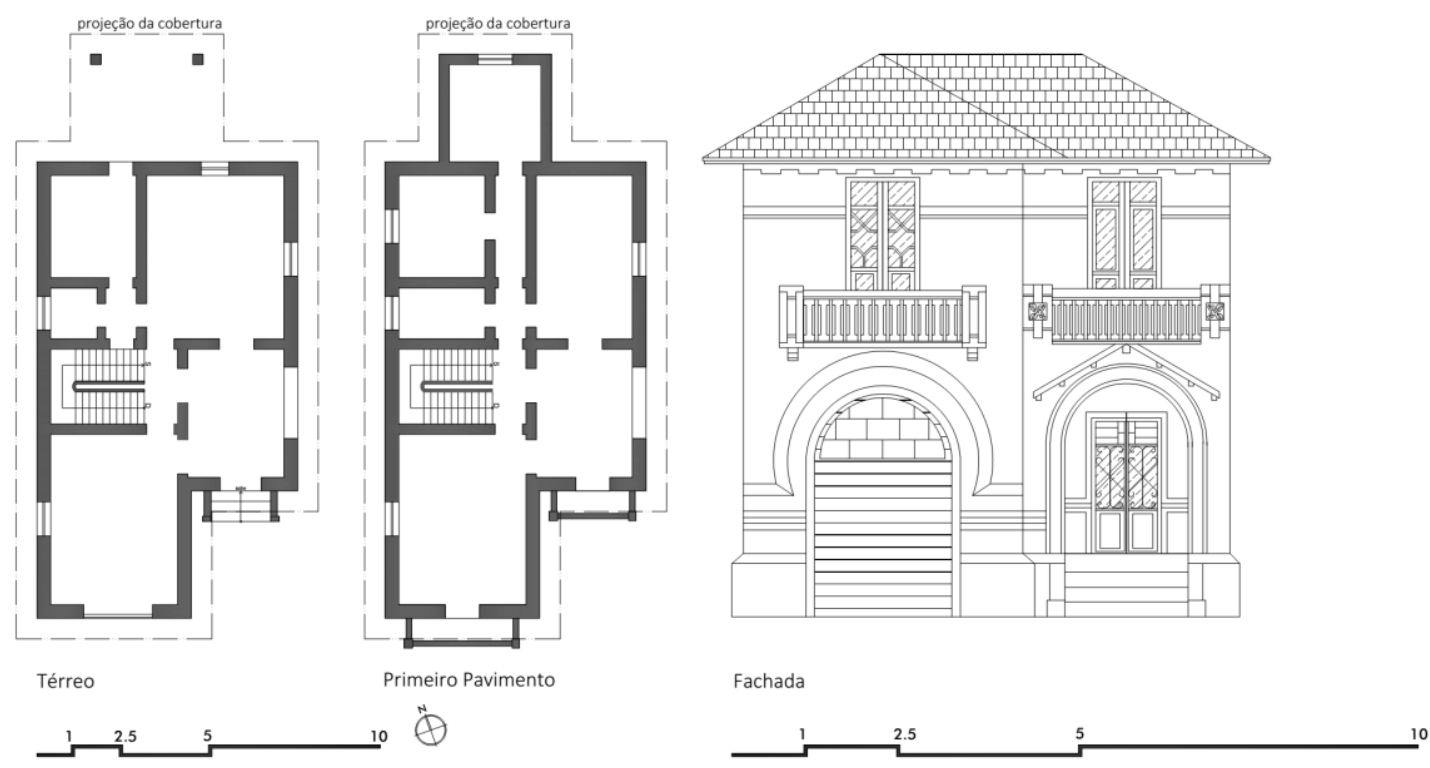

Fonte: Arquivo Público da Secretaria de Obras (1929, P24). Desenho: Natalia Cappellari de Rezende (2017).

Figura 265: Desenho da fachada de uma moradia projetada por Ernesto Giovani Rugani.

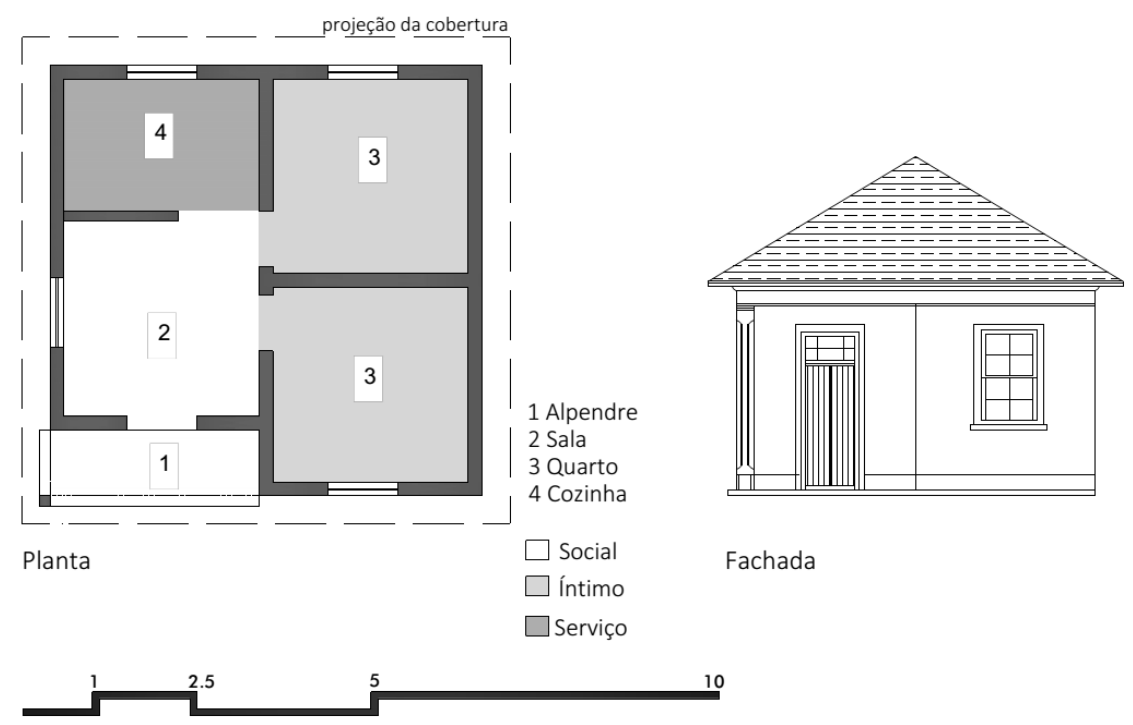

Fonte: Arquivo Público da Secretaria de Obras (1930, P26). Desenho: Natalia Cappellari de Rezende (2018). 
Figura 266: Desenho da fachada de uma moradia projetada por Ernesto Giovani Rugani.

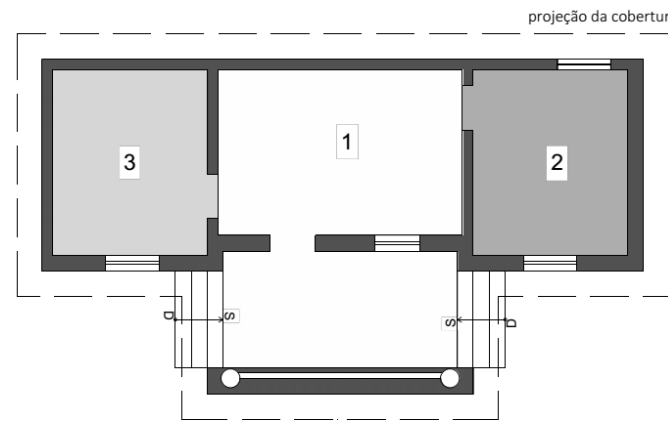

Planta

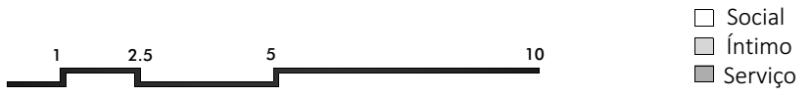

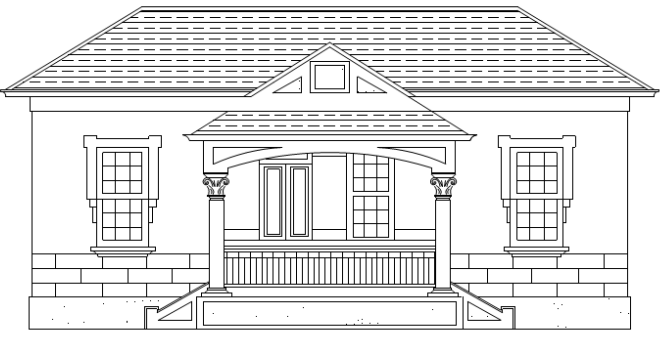

Fachada

$\square$ Íntimo

). Desenho: Natalia Cappellari de Rezende (2018).

Figura 267: Desenho da fachada de uma moradia projetada por Ernesto Giovani Rugani.

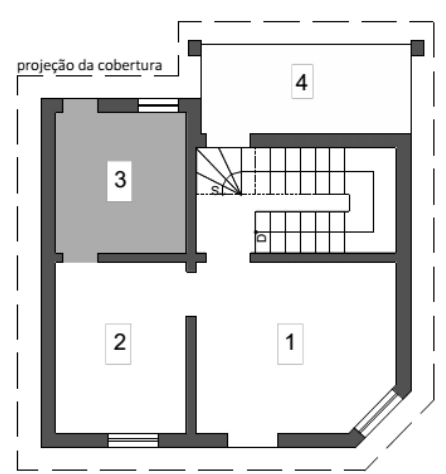

Térreo

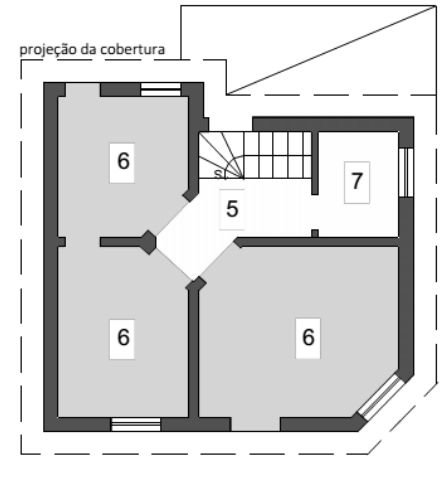

Primeiro Pavimento

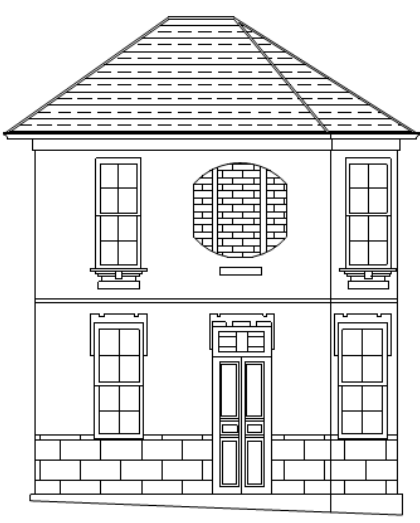

Fachada

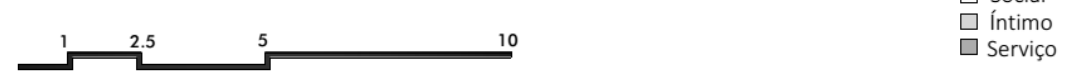

Fonte: Arquivo Público da Secretaria de Obras (1931, P15). Desenho: Natalia Cappellari de Rezende (2018).

Figura 268: Desenho da fachada de uma moradia projetada por Ernesto Giovani Rugani.

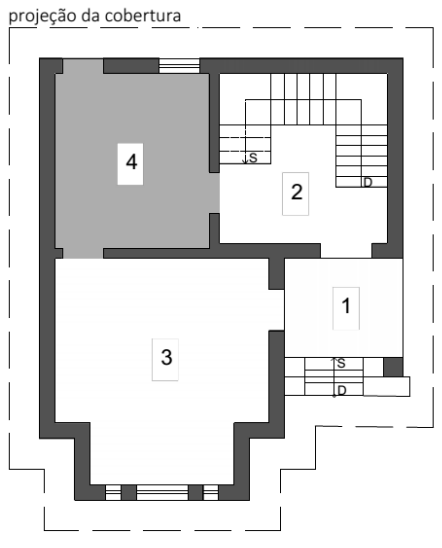

Térreo

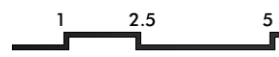

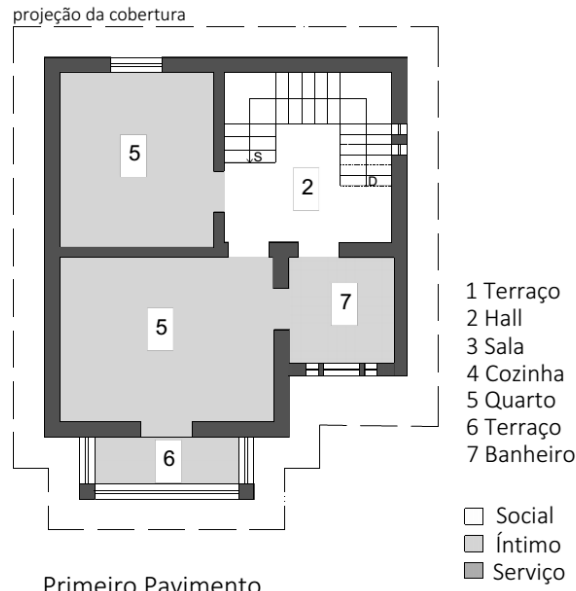

10

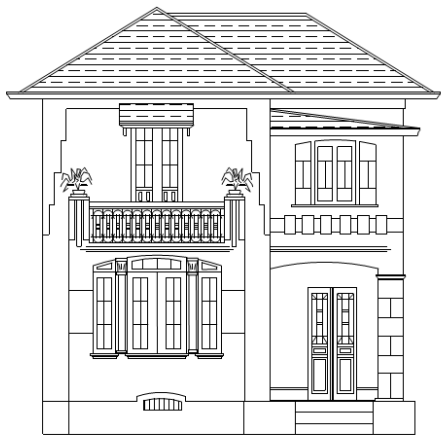

Fachada

Fonte: Arquivo Público da Secretaria de Obras (1931, P27). Desenho: Natalia Cappellari de Rezende (2018). 
Por outro lado, averiguamos que o projeto de janeiro de 1928 para a ampliação do Hotel Brasil, situado na Rua Treze de Maio, foi de sua autoria. Essa ampliação contrasta fortemente com a parte mais antiga do hotel (ver Figura 44 na página 87), caracterizada por um volume de aspecto eclético, de proporções acanhadas, de um só pavimento, com porão e platibanda, enquanto a parte da ampliação é formada por uma massa volumétrica de três pavimentos em que Rugani adota estilemas ${ }^{218}$ inspirados no neocolonial. Como veremos no terceiro item deste capítulo, este estilo passou a ser utilizado em São José do Rio Pardo majoritariamente a partir de meados da década de 1920, principalmente em edificações residenciais, não estando outros programas excluídos dessa tendência, caso do Hotel Brasil, como é possível observar na Figura 269.

Conforme nos informou Leo Lucas (2017), seu avô se mudou de São José do Rio Pardo quando tinha 47 anos, em 1932, após a Revolução, episódio em que ele foi obrigado pelas tropas getulistas a religar a água do Grupo Escolar Candido Rodrigues, ocupado por eles. Ao término da Revolução, a população local julgou Ernesto traidor, e revoltada depredou o sobrado em que ele morava, na Rua Francisco Glicério, até mesmo, segundo Del Guerra (2000, p. 56), "queimando coisas raras no meio da rua, Figura 269: Vista do Hotel Brasil, mostrando a parte antiga, voltada para a Rua Ananias Barbosa, e a ampliação projetada por Rugani com acesso pela Rua Treze de Maio.

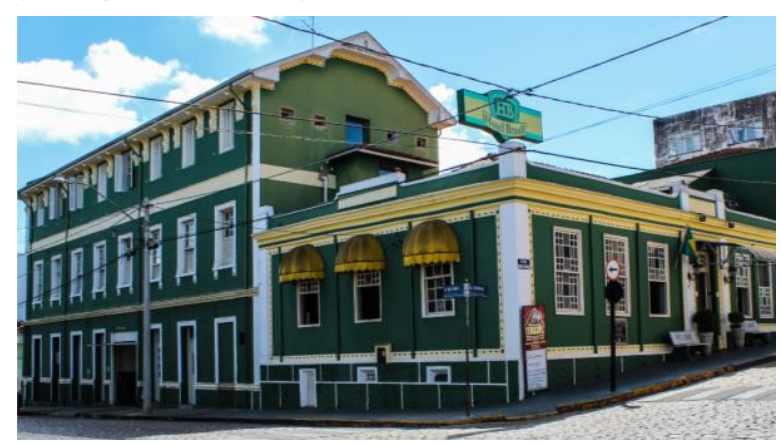

Fonte: Acervo pessoal da autora (2017). inclusive o piano alemão da família que, jogado do terraço, desceu sonante para o fogaréu". E conforme Leo Lucas (2018) nos informou, logo após esse incidente, Ernesto se mudou para Belo Horizonte onde trabalhou na construtora de sua família, a JRugani. Seu falecimento ocorreu no dia 09 de outubro de 1962 em consequência de um infarto.

\section{José Lourenço}

Encontramos informações sobre o construtor José Lourenço em algumas notícias de jornais locais. A primeira reportagem foi em 22 de agosto de 1926, quando a Resenha mencionou o incidente da queda de placas de estuque do teto da Igreja Matriz, sendo José Lourenço o construtor que assinou o laudo de reforma. Outras notícias também do jornal Resenha de 1939 o indicaram como guarda sanitário do Centro de Saúde dessa cidade, mas sua atuação ficou mesmo marcada como construtor, assinando inúmeros projetos durante todo o período de 1927 a 1940, o que mostra a sua consistência no ramo da atividade

\footnotetext{
218 "Estilema é uma palavra usada para designar as partes constitutivas de um estilo, as características imprescindíveis para sua exata classificação. Sem um mínimo de estilemas, a obra assume uma nova configuração, às vezes migrando para outro estilo que não a quele desejado". (ATIQUE, 2007, p. 298). 
edilícia local. Dentre suas obras construídas, selecionamos quatro edificações que são bastante elucidativas do seu trabalho: as residências já demolidas de Heroino Machado (Figura 270) e de Honório Dias Siqueira (Figura 271) na Rua Benjamin Constant, 15 e 189 respectivamente; a moradia de Francisco Barreto na esquina da Praça Tiradentes, 63 (Figura 272) 219 ; e um edifício de uso misto (comércio e moradia da família), propriedade de Gabriel Gervásio ${ }^{220}$, na esquina da Praça Barão do Rio Branco, 110 ( Figura 273).

Figura 270: Desenho do projeto de Heroino Machado, Rua Benjamin Constant, 15.
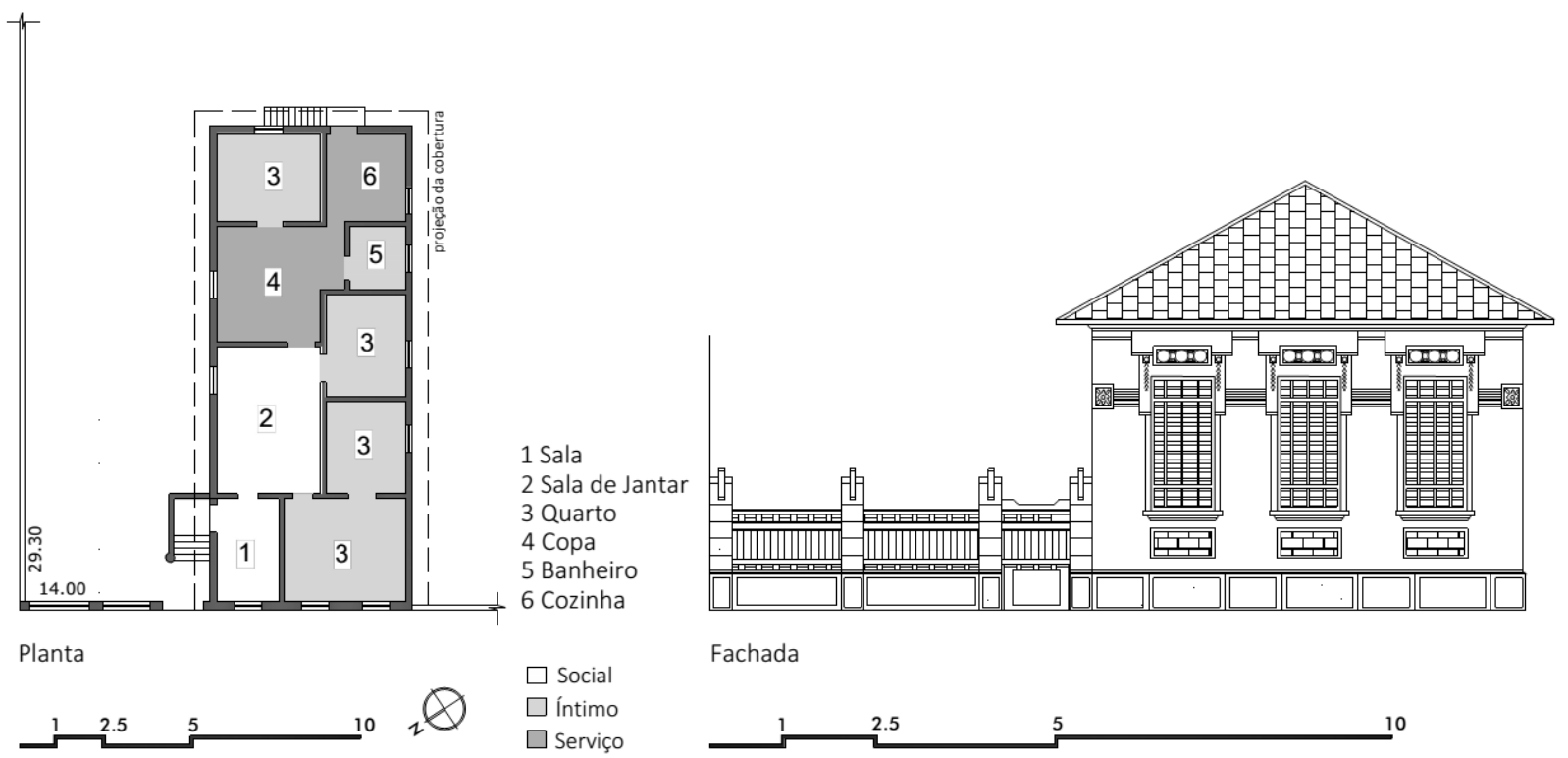

Fonte: Arquivo Público da Secretaria de Obras (1929, P06). Desenho: Natalia Cappellari de Rezende (2017).

Figura 271: Desenho do projeto da moradia de Honório Dias Siqueira, Rua Benjamin Constant, 189.
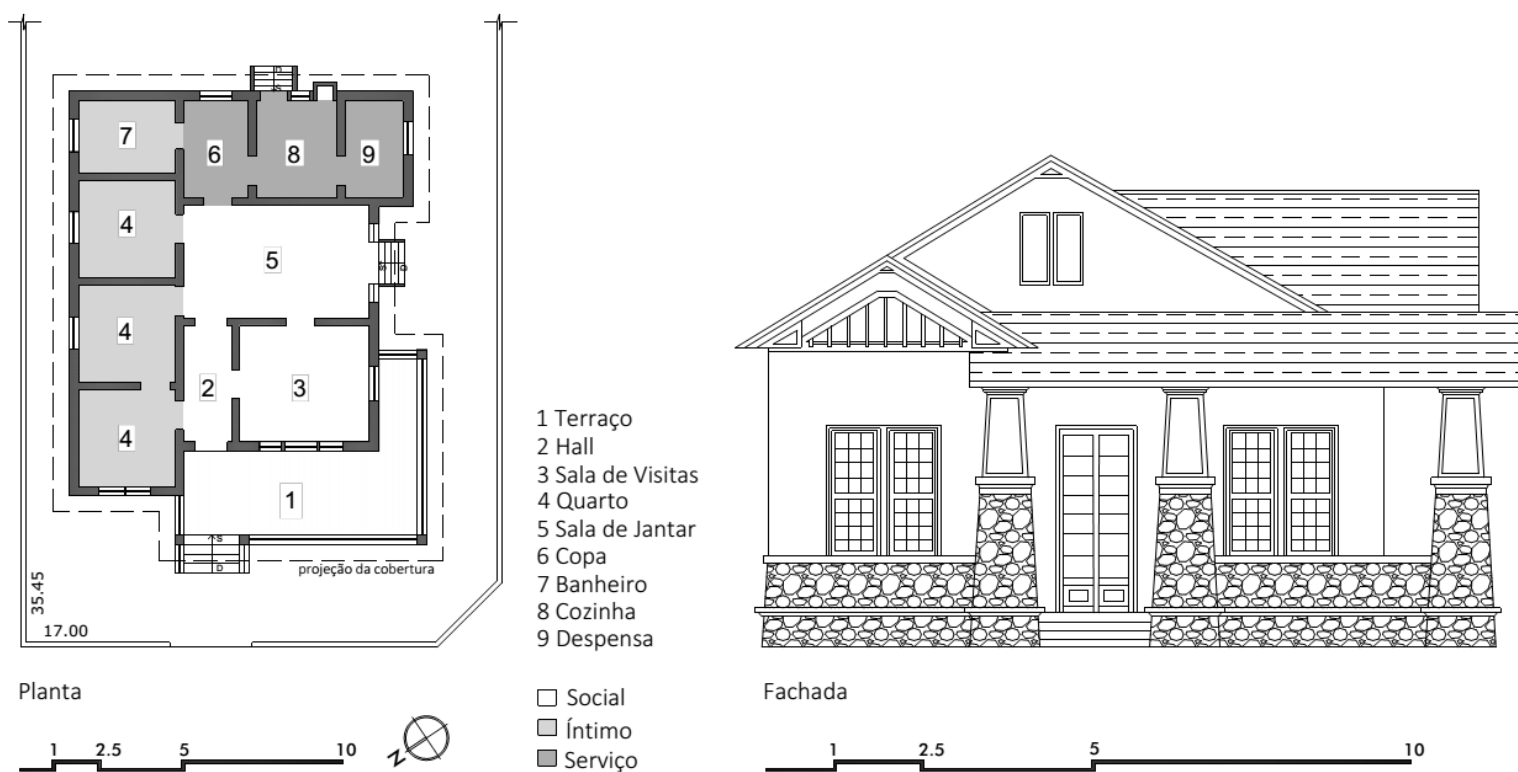

Fonte: Arquivo Público da Secretaria de Obras (1929, P20). Desenho: Natalia Cappellari de Rezende (2017).

\footnotetext{
${ }^{219}$ Constatamos através de fotografias antigas que esta moradia já existia na década de 1910, sendo José Lourenço contratado em 1929 para projetar uma nova fachada e os ambientes de serviço.

${ }^{220}$ Gervásio era proprietário de uma loja de secos e molhados, denominada "Feira do Mercado", que funcionava no térreo de seu edifício.
} 

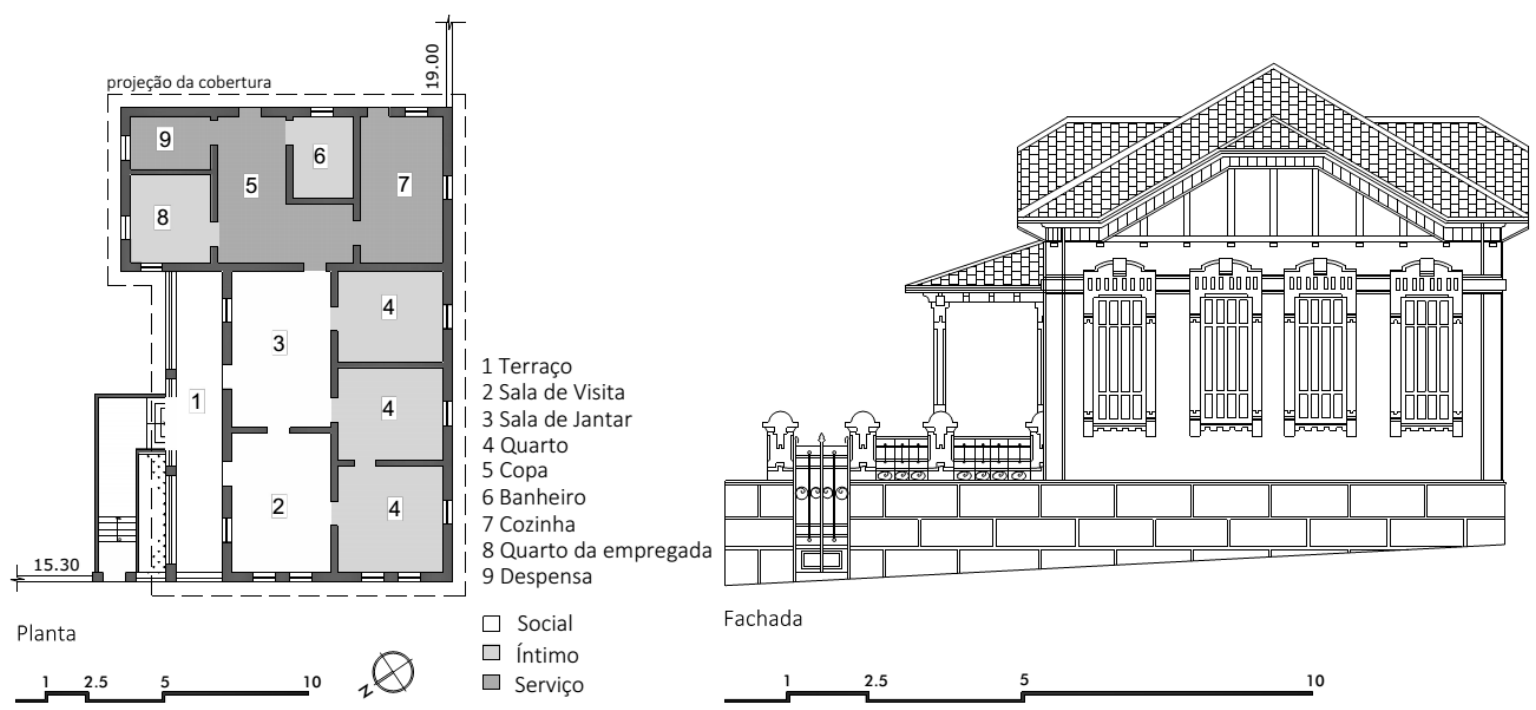

Fonte: Arquivo Público da Secretaria de Obras (1929, P38). Desenho: Natalia Cappellari de Rezende (2017)

Figura 273: Desenho do projeto de Gabriel Gervásio na Praça Barão do Rio Branco, 110.
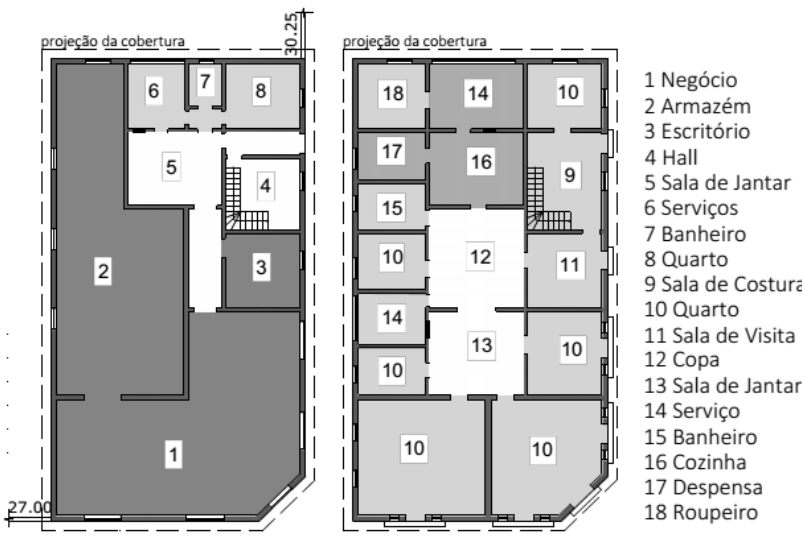

Térreo

Primeiro Pavimento

$\square$ Social

$\square$ Íntimo

$\square$ Serviço

$\square$ Negócio

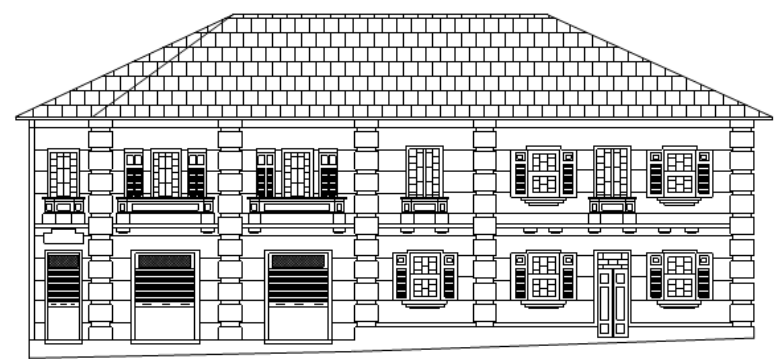

Fachada

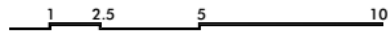

Fonte: Arquivo Público da Secretaria de Obras (1936, P20). Desenho: Natalia Cappellari de Rezende (2017).

É interessante notar nestes projetos algumas características, a começar pelo esquema de implantação da moradia de Honório Dias Siqueira completamente isolada no lote, afastada quatros metros da via pública em atendimento à normativa do Código de Posturas de 1918 que em seu artigo 20 permitia

independente de pedido de alinhamento, a construcção ou reconstrucção no interior dos terrenos, contanto que seja pelo menos afastada quatro metros da linha de arruamento, devendo os referidos terrenos ser fechados de accordo com as prescricções deste Código. (CÓDIGO DE POSTURAS, 1918, p. 04).

Mas também era permitida a manutenção da fachada frontal no limite com a via pública e o recuo das demais divisas, como na casa de Heroino Machado; e ainda a conservação da construção em ao menos dois 
lados do lote, como na moradia de Francisco Barreto e do edifício de Gabriel Gervásio (Figura 274), desde que o alinhamento fosse feito pelo Executivo, mediante solicitação, conforme o artigo 15 do Código:

Conjuntamente com a solicitação da licença para qualquer construcção ou reconstrucção de prédios, muros e outras obras, em face das ruas da cidade e povoações do Município, deverão ser requeridos ao Executivo os respectivos alinhamentos e nivelamentos, que serão dados pela repartição competente, na hypothese de ser approvado o projecto apresentado. (CÓDIGO DE POSTURAS, 1918, p. 03).

Esse mesmo Código em seu artigo 22 estabeleceu que as "construcções levantadas em esquinas de ruas, avenidas, praças ou largos, deverão ter o canto cortado em ângulo de 45, ou disposto em curvas regulares" (CÓDIGO DE POSTURAS, 1918, p. 04). Contudo, essa condição parece não ter sido respeitada por José Lourenço, a exemplo da moradia de Francisco Barreto, localizada na esquina da Praça Tiradentes com a Rua Ruy Barbosa, o que nos leva a acreditar que o projeto se trata de uma reforma, mas há também a possibilidade de desrespeito à normativa, tendo em vista o efeito retroativo desse Código. Todavia, no ano de 1929 outro projeto, anterior a este (nos referimos à moradia de Honório Dias Siqueira), foi elaborado de acordo com as exigências do Código. Além disso, constam nas anotações do responsável pela aprovação do projeto somente questões de encanamento e do tipo de ligação com as redes gerais de água e esgoto, o que reforça o pressuposto de reforma.

Apesar de José Lourenço ter experimentado variados esquemas de implantação da edificação no lote, a volumetria e a espacialidade das moradias guardam muitas similaridades, assim como a distribuição dos ambientes. Todas apresentam o corpo da edificação em forma volumetricamente retangular e com poucos recortes, apesar dos telhados apresentarem-se bastante complexos. Ambos modo de implantação e programa condicionaram os acessos e fluxos, principalmente o social através de escadas e terraço referindo-se ao espaço que é um alpendre -, e o de serviços pelos fundos da edificação, como podemos perceber através das plantas. No que se refere às intenções plásticas, é possível afirmar que a produção de José Lourenço ainda está vinculada ao ecletismo, mas se permitindo combinar de modo mais evidente com a tipologia do bangalô ${ }^{221}$ e a linguagem plástica do neocolonial que, conforme caracterizado por Lemos, C. (1989a) em Alvenaria Burguesa acabou por abandonar o beiral horizontal e se projetar em balanço com a cumeeira perpendicular à fachada, com estuque aplicado à tela de arame, de modo a esconder a sua estrutura, padrão muito difundido em São José do Rio Pardo.

\footnotetext{
${ }^{221}$ Segundo Weissman (1988, p. vi), "a palavra "bungalow", do híndi banglã, ou casa no estilo de Bengala originalmente se referia a um tipo de habitação colonial do leste da Índia. Era uma casa térrea cujos cômodos bem ventilados abriam-se para um hall central arejado, e que tinha um telhado pouco inclinado e varandas em todas as faces da edificação. Por algum tempo, certo tipo de bangalô torno u-se moda na Inglaterra. No início do século XX, o movimento americano Arts and Crafts, de maneira informal, o adotou como a casa Craftsman ideal". De acordo com King (1982) a casa bangalô caracteriza-se por ser uma construção simples, aconchegantes, rústica, com balcões e varandas, telhados pouco inclinados e com beirais, presença de madeira e pedras na fachada, salas de jantar e estar integradas, mobília embutida, jardins domésticos com floreiras e trepadeiras. Trata-se de uma maneira de morar que se difundiu em vários países, tornando-se um fenômeno de massa, produzido para a elite, classe média e baixa renda. Para saber mais, ver Downing (1969), King (1982), Lancaster (1985), Kramer (2006), Wolff (2001) e Atique (2007).
} 
Figura 274: Desenho da implantação das obras de José Lourenço.
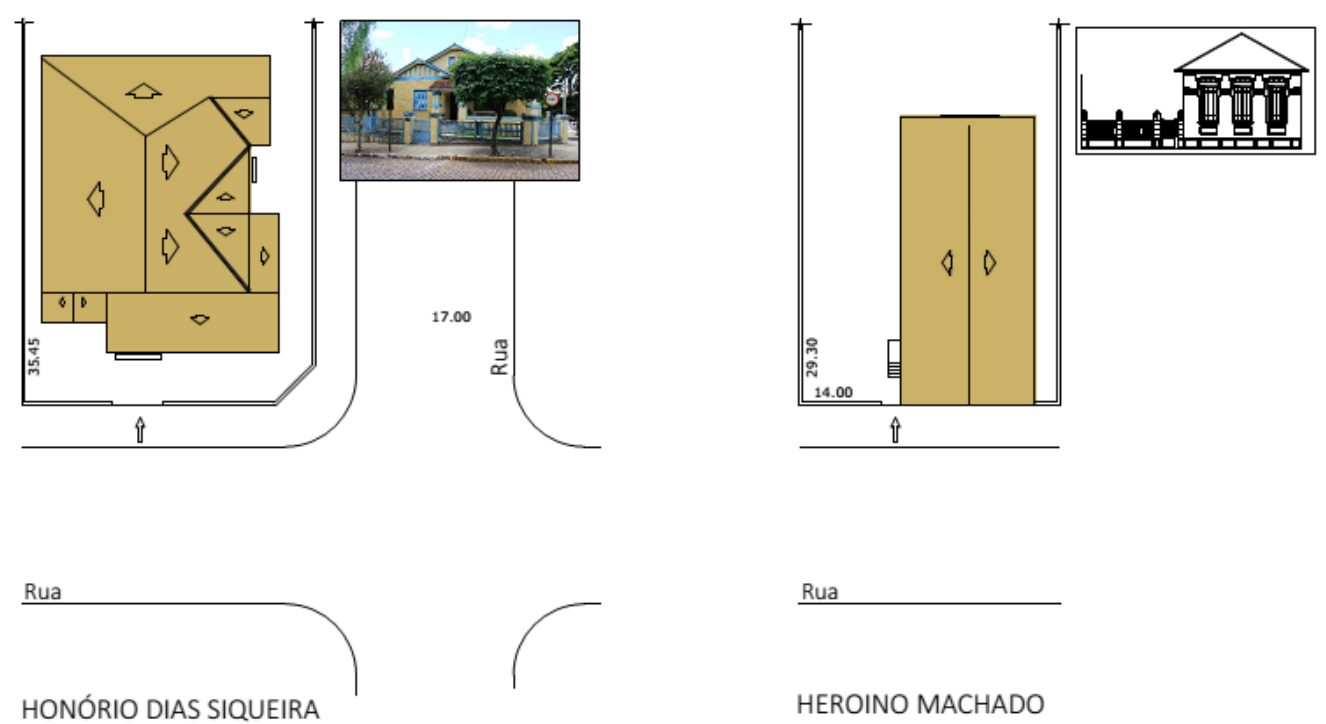

$\underline{\text { Rua }}$

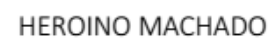

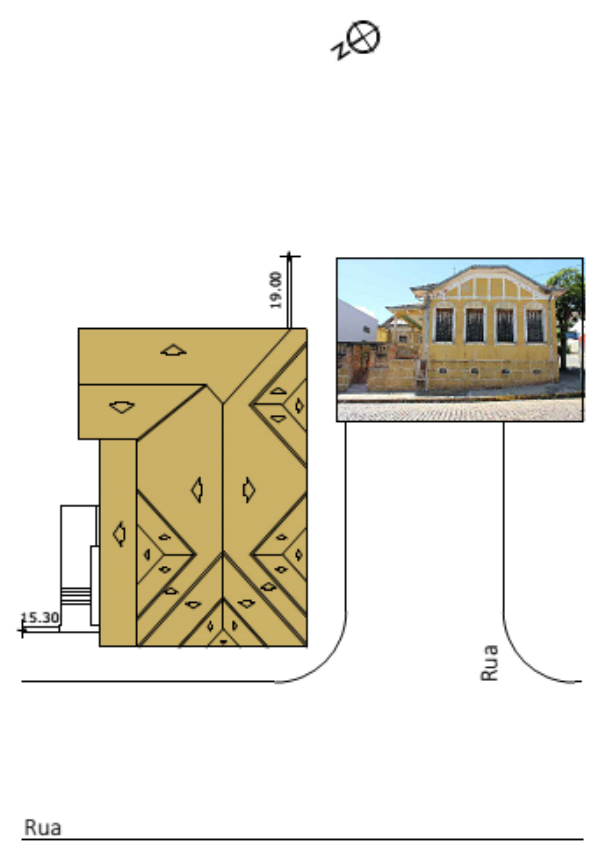

FRANCISCO BARRETO

$$
\text { Q }
$$

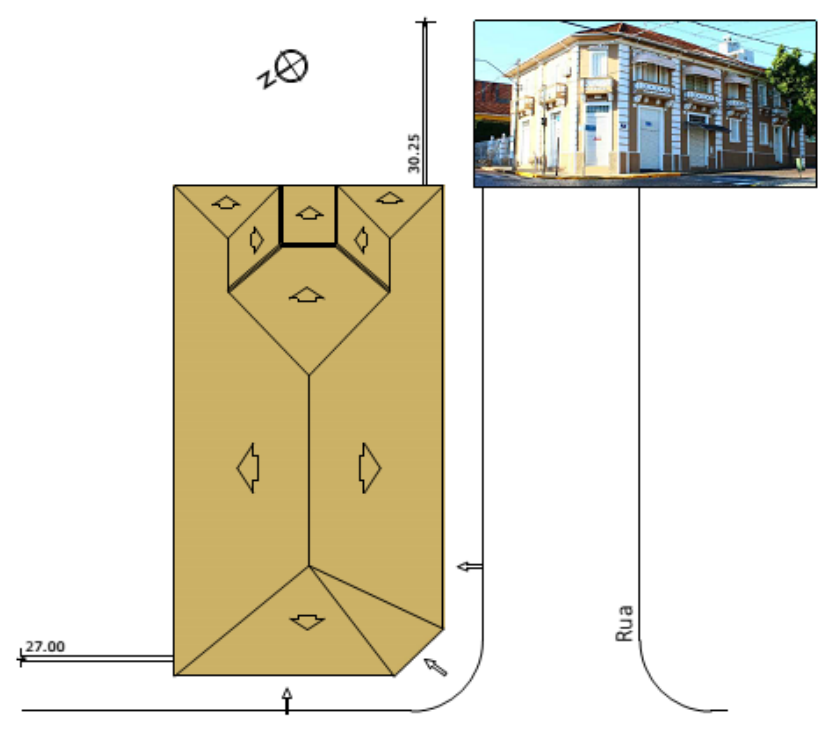

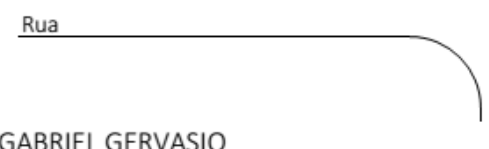

$\oplus_{h}$

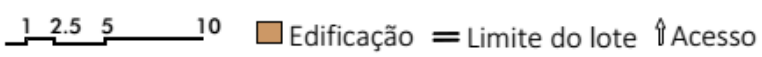

Fonte: Arquivo Público da Secretaria de Obras . Desenho: Natalia Cappellari de Rezende (2018). 


\section{Américo Braghetta}

Outro sujeito bastante atuante na construção civil rio-pardense desse período foi o Américo Braghetta, filho dos italianos Luiz Braghetta e Laura Braghetta que chegaram ao Brasil no início da década de 1880, indo residir em Campinas que naquele momento era uma cidade com crescimento expressivo no cenário paulista ${ }^{222}$, o que certamente tenha sido um atrativo para a chegada dos Braghettas. Segundo a base de dados FamilySearch, disponibilizada pelo Arquivo Público do Estado de São Paulo, Luiz Braghetta e Laura Braghetta tiveram três filhos, todos nascidos em Campinas. A primogênita foi Ermida que nasceu em 08 de janeiro de 1883, depois Américo no dia 03 de fevereiro de 1886, e por fim, Gabriel em 13 de fevereiro de 1888. Em 1889, a família Braghetta mudou-se de Campinas devido às epidemias de febre amarela que assolavam a cidade ${ }^{223}$, indo residir em São José do Rio Pardo. Acreditamos que um dos motivos que fizeram os Braghettas escolherem essa cidade seja a existência de algum vínculo de amizade que tenha fornecido informações sobre o comércio local. O que reforça nossas suposições é o fato da família adquirir um terreno muito bem localizado, nas proximidades da Igreja Matriz, especificamente na esquina da Rua Marechal Floriano com a Rua Francisco Glicério, onde fundaram a Casa Braghetta ${ }^{224}$ já em 1889.

Em 1924, quando Américo tinha cerca de 38 anos, uma reportagem de jornal Ihe atribuiu o título de arquiteto (Figura 275). Certamente, essa qualificação deve ter sido dada em consequência da qualidade dos trabalhos projetados e executados por ele, visto que não tenhamos encontrado outros indícios no sentido de reafirmar uma diplomação. O que de fato constatamos é que em todos os projetos assinados por Américo há a indicação de construtor.
Figura 275: Reportagem do jornal exaltando Américo Braghetta.

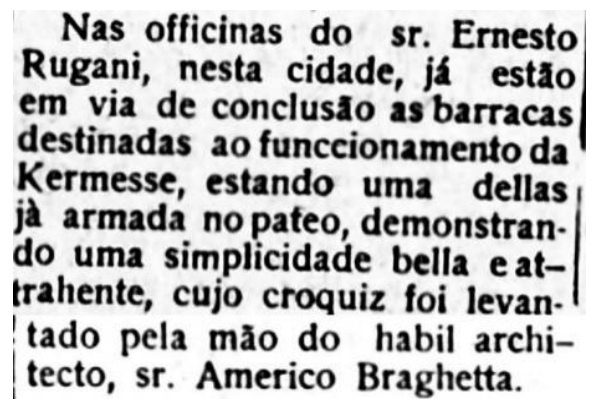

Fonte: Jornal Resenha, 23 de novembro de 1924.

Está explícita em seus desenhos da década de 1920 sua adesão ao ecletismo impregnado de elementos classicizantes, mas, assim como percebemos nas obras de José Lourenço, nos anos de 1930 ele se filiou à vertente do bangalô. Entretanto, independentemente das variações estilísticas, sua produção é marcada

\footnotetext{
222 Segundo Lapa (1996), em 1874 Campinas tornou-se a cidade mais populosa da província com 31.397 habitantes, ultrapassando a própria capital. O autor (LAPA, 1996, p. 110-111) ainda destaca que Campinas também mantinha o maior número de pessoas escravizadas com 13.685, e "nas duas últimas décadas do século (1882 a 1900), a cidade recebeu 10.631 imigrantes estrangeiros". Para mais informações sobre a cidade de Campinas no final do século XIX, ver Lapa (1996).

${ }^{223}$ Maria Alice Rosa Ribeiro (1993) abordou em História sem fim, Inventário da saúde pública o impacto da febre amarela em Campinas Segundo a autora (RIBEIRO, M., 1993), a maciça quantidade de imigrantes que chegavam ao Brasil pelos portos, locais onde a doença já havia se instalado, com destino a Campinas, favoreceu a propagação da febre que seguiu a rota da ferrovia.

224 Segundo a reportagem do jornal Resenha de 22 de setembro de 1961, a Casa Braghetta comercializava produtos diversos, bebidas, roupas, louças, máquinas de costura, objetos de decoração e etc., até que em 1938 a Casa especializou-se em máquinas agrícolas e materiais para a construção civil, e a partir de 1958 tornou-se concessionária de automóveis, representando a Willys Overland Brasil.
} 
pela peculiaridade de atender à moradia de até dois dormitórios, a qual, segundo as definições de Lemos, C. (1999, p. 34) pode ser classificada como moradia operária. Exemplos disso é o chalé de José Luzio, na Rua Marechal Floriano n. ${ }^{1}$ (Figura 276), a moradia de Francisco Consolo na Rua Benjamin Constant (Figura 277) e de Pedro Nogueira na Rua Marechal Floriano, na Vila Pereira (Figura 278).

Figura 276: Desenho do projeto de José Luzio na Rua Marechal Floriano, 1.

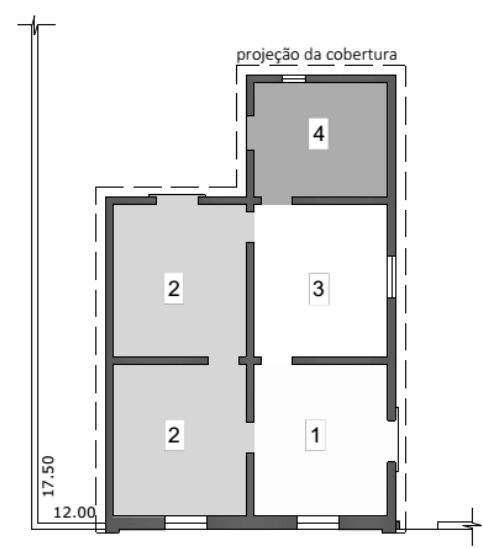

Planta

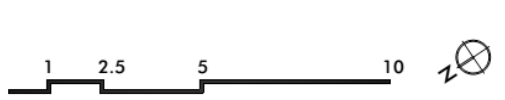

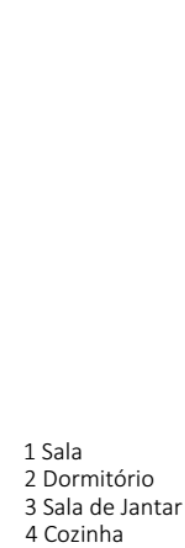

$\square$ Social

$\square$ Íntimo $\square$ Serviço

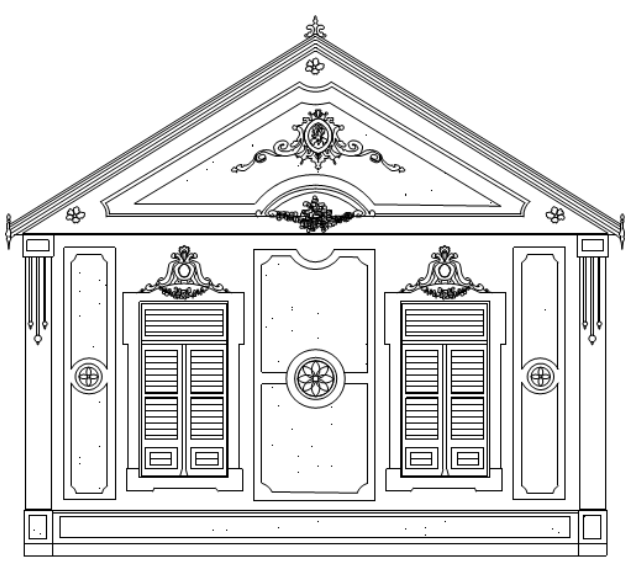

Fachada

Fonte: Arquivo Público da Secretaria de Obras (1927, P04). Desenho: Natalia Cappellari de Rezende (2016)

Figura 277: Desenho do projeto de Francisco Consolo na Rua Benjamin Constant.

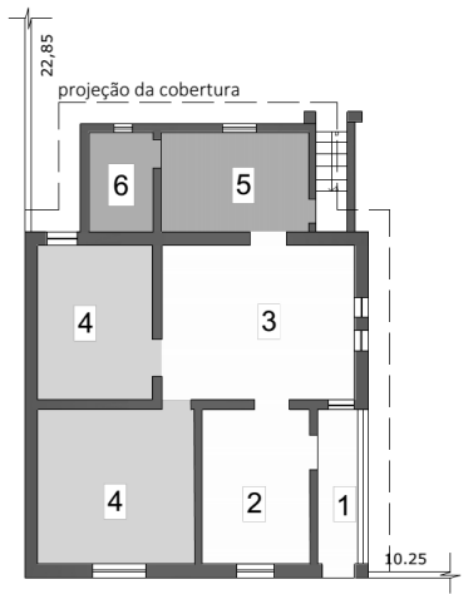

Planta
1 Terraço

2 Sala de Visita

3 Sala de Jantar

4 Dormitório

5 Cozinha

6 Banheiro

$\square$ Social

$\varnothing$ $\square$ Íntimo

$\square$ Serviço

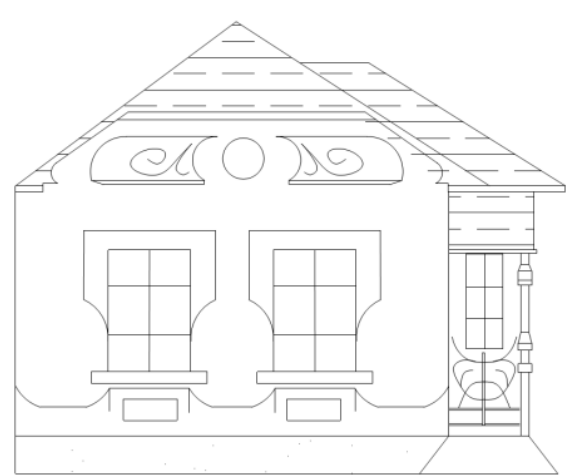

Fachada

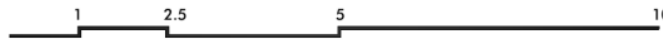

Fonte: Arquivo Público da Secretaria de Obras (1935, P08). Desenho: Natalia Cappellari de Rezende (2016). 


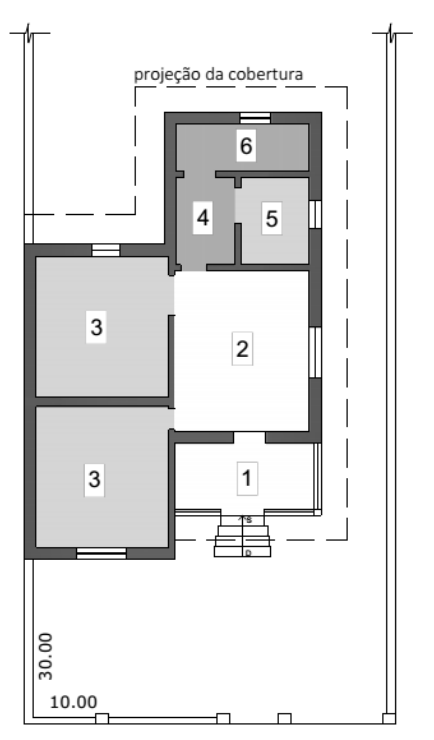

Planta

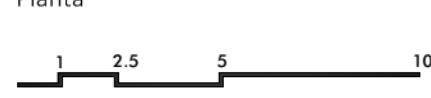

$10 \stackrel{N}{ }$

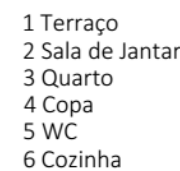

6 Cozinha

$\square$ Serviço

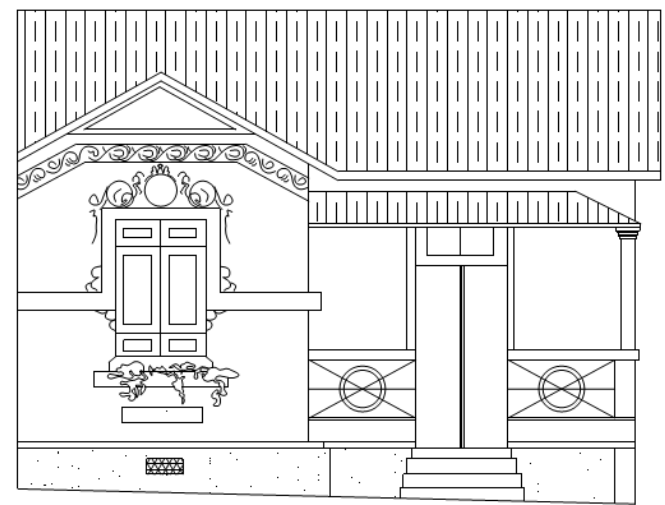

Fachada

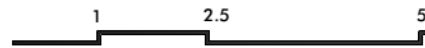

Fonte: Arquivo Público da Secretaria de Obras (1935, P16). Desenho: Natalia Cappellari de Rezende (2016).

Os programas se diferenciam um pouco, apesar da manutenção do número de dormitórios. Por exemplo, a casa de Pedro Nogueira possui uma copa, à medida que a residência de Francisco Consolo apresenta uma sala de visitas. Com exceção do chalé de José Luzio, nas outras duas o binômio banheiro-cozinha aparece na parte posterior do corpo da edificação, provocando um recorte no desenho da planta e consequentemente exigindo uma maior complexidade na definição do telhado. Com relação à implantação da edificação no lote, predominou o alinhamento frontal com recuos laterais, ou isolada totalmente no terreno (Figura 279). Nesse último caso, a moradia de Pedro Nogueira foi projetada e construída com um recuo de quatro metros da via pública, evidenciando que Braghetta não somente conhecia as normas como as aplicava em seus projetos.

Diferentemente de José Lourenço, Américo Braghetta realizou projetos de outras tipologias arquitetônicas, contribuindo para ampliar a nossa percepção da erudição manifestada por Braghetta, como a capela de Nossa Senhora das Angústias (Figura 280) quando ele estava com cerca de 44 anos. É uma igreja eclética com tendência gótica, como podemos perceber pela rosácea e a torre e sua propensão à verticalidade, embora o frontão ainda seja triangular e o tijolo e a pedra apareçam como revestimento de fachada. 

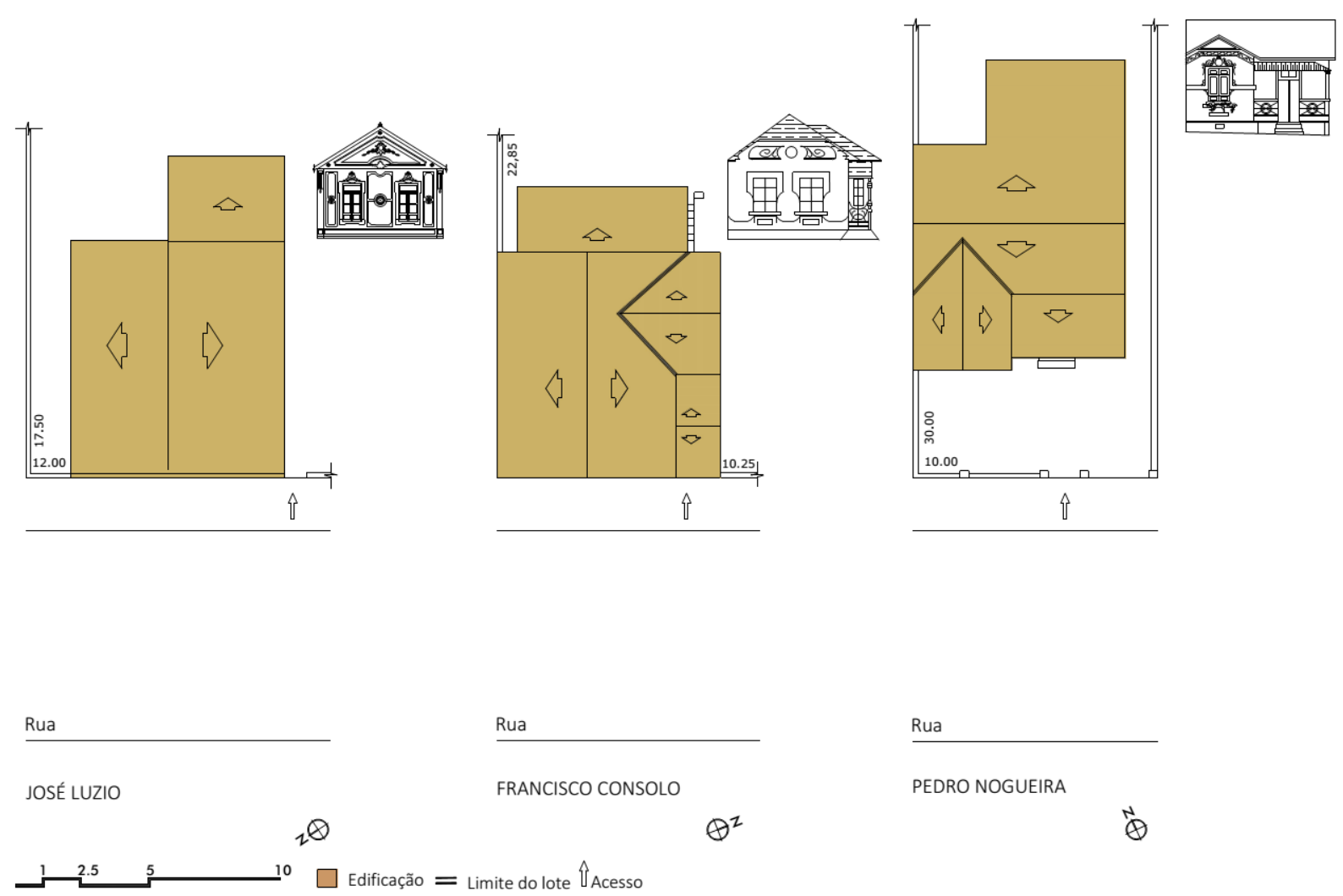

Rua

PEDRO NOGUEIRA

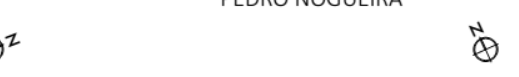

Fonte: Arquivo Público da Secretaria de Obras. Desenho: Natalia Cappellari de Rezende (2017).

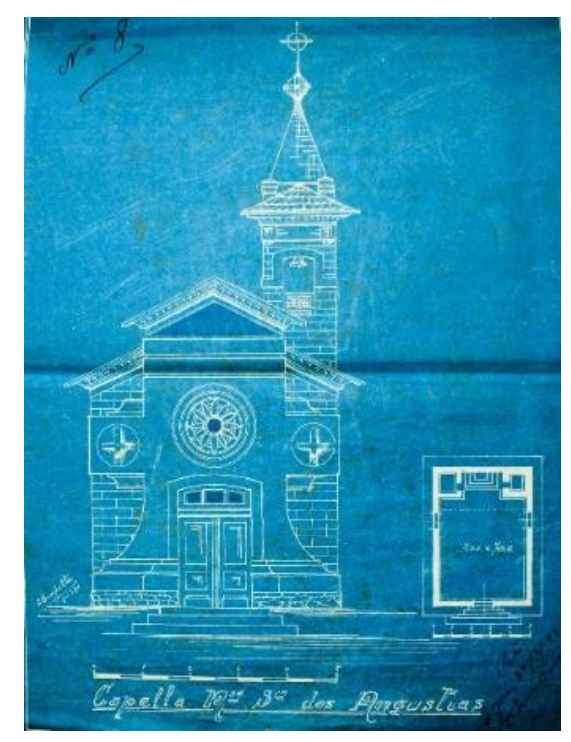

Figura 280: Projeto arquitetônico da capela de Nossa Senhora das Angústias. Fonte: Arquivo Público da Secretaria de Obras (1931, P21). Desenho: Natalia Cappellari de Rezende (2018).

\section{João Bergamasco}

Sem nenhuma dúvida a atuação que persistiu por mais tempo na construção civil rio-pardense nesse período de 1918 a 1940 foi a de João Bergamasco, exercendo as atividades de projetista e construtor. Encontramos 92 projetos assinados por ele, o que representa 52\% do total de requerimentos com 
assinatura, e é esse motivo que nos permitiu tratar com mais propriedade as principais características de sua produção.

Natural de Córdoba, na Argentina, João Bergamasco foi um construtor de intensa e prolongada atuação na cidade de São José do Rio Pardo, muito provavelmente desde o final da década de 1920 até o ano de $1951^{225}$. Segundo as pesquisas realizadas por Del Guerra (2000), Bergamasco nasceu em 21 de maio de 1894 e ainda jovem se mudou para o Brasil, iniciando suas atividades na construção civil como pedreiro. Algum tempo após se casar com Rosa Cerávolo, filha do marceneiro Paschoal Cerávolo, João Bergamasco com 25 anos volta para a Argentina acompanhado da sua esposa, permanecendo naquele país por dez anos, quando retorna à São José do Rio Pardo com as quatro filhas. Del Guerra (2000) afirma que o retorno de Bergamasco ocorreu em 1930, entretanto, encontramos nas fichas do "Serviço de Registro de Estrangeiros”226 de 1928 os nomes de Virgínia, Margarida, Clotilde e Alícia (filhas de João Bergamasco e Rosa Cerávolo) que vieram com os seus pais da cidade de Pellegrini, localizada na província de Buenos Aires. Além desse fato intrigante, outro documento localizado na Secretaria da Segurança Pública - Delegacia Especializada de Estrangeiros - reforça nossas suspeitas, trata-se do cartão de imigração de Virgínia Bergamasco onde consta o seu desembarque no Brasil em 20 de maio de 1928. Foi também a partir desse ano que encontramos alguns projetos arquitetônicos assinados por João Bergamasco em São José do Rio Pardo, confirmando assim a data do seu retorno a essa cidade.

Curiosamente, no regresso de João Bergamasco à São José do Rio Pardo, quando ele já estava com quase 40 anos, a profissão de pedreiro foi deixada em segundo plano para atuar como projetista e construtor, conforme podemos observar no seu cartão de imigração. Nesse documento consta, além da atividade exercida e a forma de emprego por conta própria, a nacionalidade argentina, os nomes dos seus pais Luiz e Clotilde, o endereço residencial na Rua Francisco Glicério, 727, em São José do Rio Pardo, e a sua admissão no Brasil em caráter permanente (Figura 281).

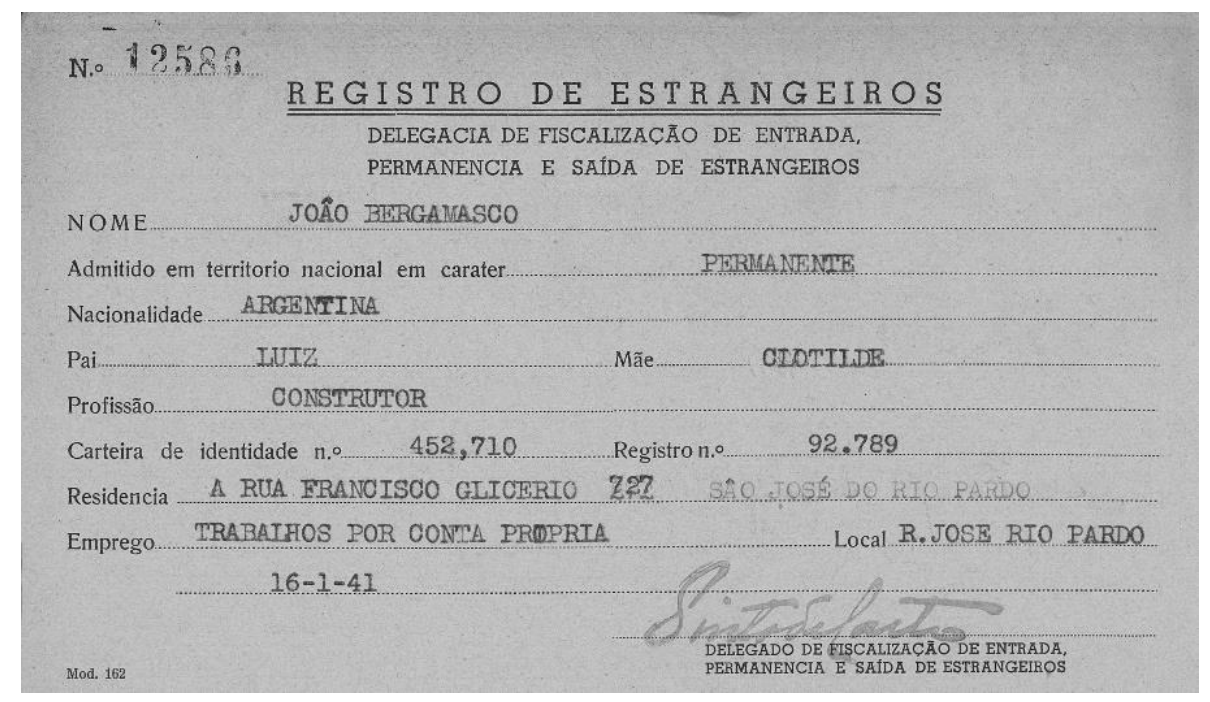

Figura 281: Frente do Cartão de Imigração de João Bergamasco. Fonte: "Brasil, São Paulo, Cartão de Imigração, 19021980", database with images Familysearch Arquivo Público do Estado de São Paulo.

\footnotetext{
225 O último projeto que encontramos aprovado e arquivado com assinatura de João Bergamasco data de abril de 1951 . Uma casa de morada para o Sr. Chrispin Basili na esquina da Rua Treze de Maio com a Rua Ruy Barbosa.

${ }^{226}$ As fichas do "Serviço de Registro de Estrangeiros" encontram-se arquivadas no Centro Cultural Ítalo Brasileiro.
} 
A autopromoção da atividade de pedreiro para projetista construtor parece ter sido algo corriqueiro, uma vez que também foi constatado por Debenedetti e Salmoni (1981) em São Paulo e Bortolucci (1991) em São Carlos. Mas, conforme os anúncios publicados no jornal Resenha, Bergamasco se identificava como perito construtor licenciado. Certamente esse argentino pertencia a categoria dos não diplomados, mas que possuía o registro de "licenciado", ou seja, era reconhecido pelo poder público para a prática edificativa.

Sobre esse termo, Pareto Júnior (2016) explica que

as expressões "prático" e "prático licenciado" são usadas a partir de década de 1920, justamente quando o debate em torno da regulamentação da profissão começava a ganhar contornos mais dramáticos diante do expressivo aumento da influência dos diplomados na produção da cidade. A paulatina utilização do termo nas décadas de 1920 e 1930 está estreitamente relacionada à campanha pela regulamentação da profissão, que atinge seu auge na década de 1930. (PARETO JÚNIOR, 2016, p. 23).

Desse modo, o termo "licenciado" está diretamente relacionado à criação de uma categoria no contexto da regulamentação da profissão de engenheiro e arquiteto com a Lei Estadual n. 2022 de 27 dezembro de 1924. Sobre isso, Francisco (2013, p. 06) ao analisar "o panorama da construção civil de Campinas" teceu considerações sobre o modo como era obtido esse título, destacando que a licença somente era expedida pela Secretaria de Agricultura do Estado mediante a comprovação da atuação por no mínimo cinco anos em execuções e direções de trabalhos, e a aprovação por congregação da Escola Politécnica em caso de ser diplomado em escola estrangeira (LEI N.2022/1924).

Assim como ocorreu nas grandes cidades como São Paulo (PARETO JÚNIOR, 2016) e Campinas (FRANCISCO, 2013), em São José do Rio Pardo o domínio da cidade construída era de não diplomados. Contudo, havia em Campinas, por exemplo, um cuidado a mais na regulamentação das atividades exercidas por essa pessoas $^{227}$, conforme averiguado por Francisco (2013),

Campinas, por exemplo, viu surgir, pouco mais de um ano depois da promulgação do regulamento estadual, a primeira normativa municipal que tratava do assunto: a Lei no. 400 de 26 de fevereiro de 1927. Essa lei, que na verdade tratava do Serviço de Águas e Esgotos, continha, entre os artigos 70 e 17, determinações sobre o exercício profissional dos construtores na cidade e vinculava sua admissão ao atendimento das normas estaduais. [...] Mais tarde, em 1928, quando um novo regulamento profissional foi implementado [...] a Lei no. 418/1928, corroborando o que acontecia no âmbito federal, deu início à limitação do escopo de ação dos licenciados, que passaram a ter permissão apenas para "executar e construir, sob sua exclusiva responsabilidade, prédios térreos e comuns, outras obras de arte, pequenas reformas, consertos, etc., tudo a juízo da Repartição de Obras. (FRANCISCO, 2013, p. 25-30).

Além disso, havia também um exame de proficiência para atestar os conhecimentos desses sujeitos sobre material, fundação, estrutura, composição espacial e questões de salubridade. De modo seguro, julgamos que a atuação dos práticos licenciados em São José do Rio Pardo projetando e construindo todo tipo de obra, desde prédios térreos e comuns a edifícios com mais de um pavimento (Figura 282 e Figura 283) estava pautada na experiência adquirida e conferida no canteiro de obras, e também no conhecimento das

\footnotetext{
${ }^{227}$ Segundo Francisco (2013) a normativa do município de Campinas que tratava do assunto era a Lei no. 400 de 26 de fevereiro de 1927. Para saber mais sobre isso, ver Francisco (2013).
} 
normativas urbanística e sanitária, como veremos ao longo da análise dos edifícios projetados por João Bergamasco

Figura 282: Projeto de José Lourenço aprovado pela Prefeitura Municipal de São José do Rio Pardo.

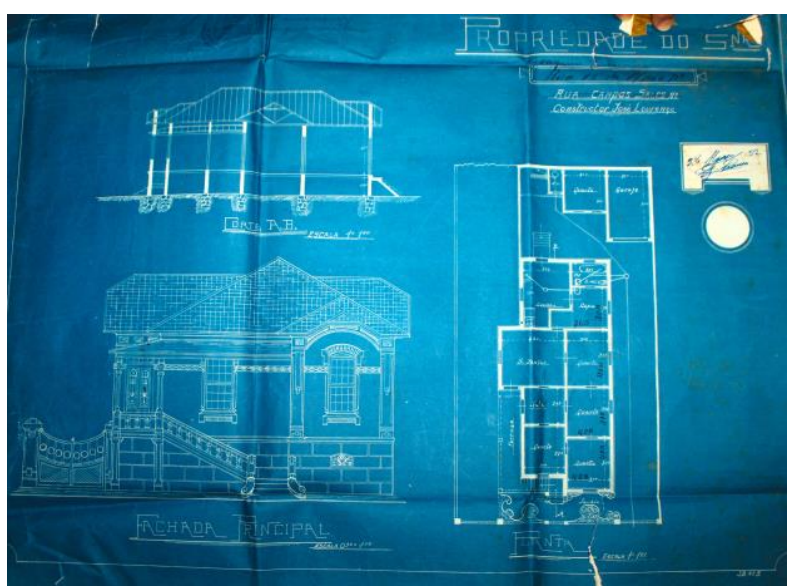

Fonte: Arquivo Público da Secretaria de Obras (1932, P21).
Figura 283: Projeto de João Bergamasco aprovado pela Prefeitura Municipal de São José do Rio Pardo.

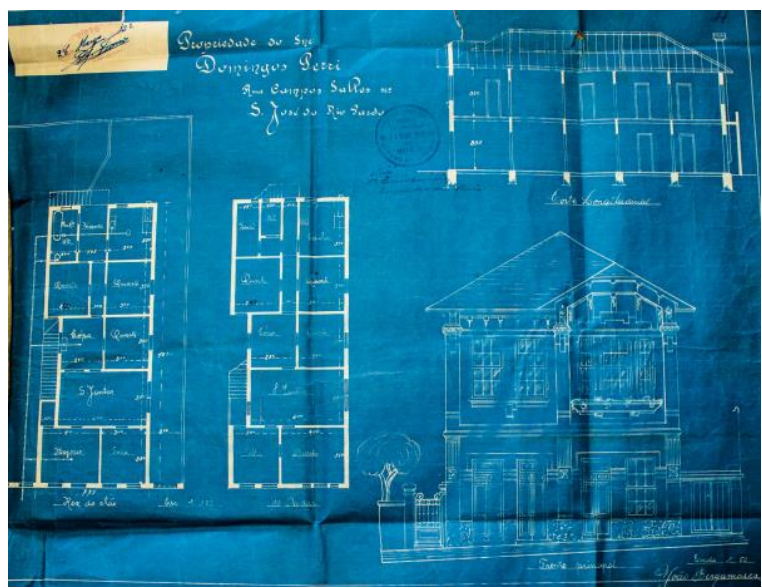

Fonte: Arquivo Público da Secretaria de Obras (1932, P22).

Como mostra o anúncio (Figura 284) e os registros que encontramos no Arquivo Público da Secretaria de Obras, a atuação de Bergamasco foi garantida mesmo após a regulamentação definitiva das profissões de engenheiro e arquiteto em nível federal, ocorrido através do Decreto n. ${ }^{\circ} 23.569$ de 11 de dezembro de 1933. De acordo com essa normativa, os não-diplomados que trabalhavam com atividade privada e possuíam licenças expedidas por órgãos estaduais e municipais até a data da publicação do decreto puderam continuar atuando, porém, a critério do recém-criado Conselho de Engenharia, Arquitetura e Agrimensura (FICHER, 2005), conforme segue o artigo a seguir:

Figura 284: Anúncio de João Bergamasco.

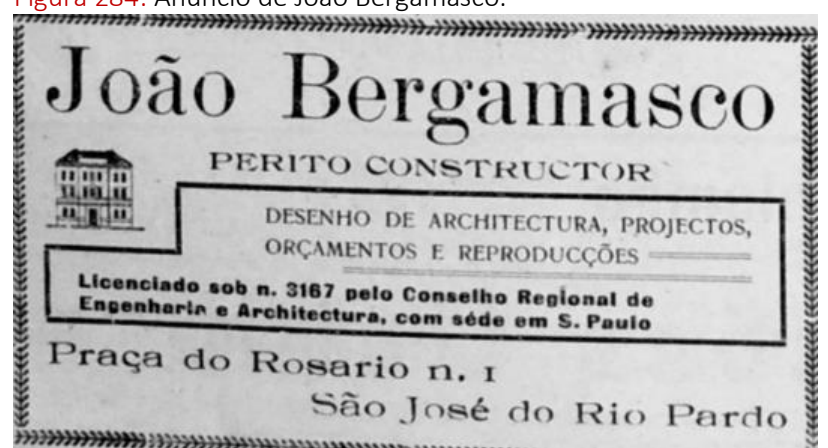

Fonte: Rio Pardo Jornal, 23 de agosto de 1936. $3^{\circ}$ É garantido o exercício de suas funções, dentro dos limites das respectivas licenças e circunscrições, aos arquitetos, arquitetos-construtores, construtores e agrimensores que, não diplomados, mas licenciados pelos Estados e Distrito Federal, provarem, com as competentes licenças, o exercício das mesmas funções à data da publicação dêste decreto, sem notas que os desabonem, a critério do Conselho de Engenharia e Arquitetura. (LEI N. 23569/1933).

Segundo Silvia Ficher (2005),

o decreto se caracterizou pela adoção intransigente de uma doutrina de proteção ao título acadêmico, restringindo o exercício da profissão aos portadores de diploma. Ainda que reconhecesse a figura dos não-diplomados e garantisse algo de seus direitos adquiridos, determinava medidas discriminatórias muito fortes. (FICHER, 2005, p. 188-189). 
Sobre isso, a autora (FICHER, 2005) cita ainda o parágrafo único:

Os profissionais de que trata este artigo perderão o direito às licenças se deixarem de pagar os respectivos impostos durante um ano, ou se cometerem erros técnicos ou atos desabonadores, devidamente apurados pelo Conselho de Engenharia e Arquitetura', penalidades a que não estava sujeito o profissional diplomado caso fosse inadimplente ou cometesse erros técnicos e atos desabonadores. (FICHER, 2005, p. 189).

Portanto, a regulamentação da profissão se caracterizou por uma medida restritiva e corporativista, tornando a atuação dos licenciados bastante dificultosa, ainda que eles fossem muito capacitados, competentes e instruídos a respeito de todos os aspectos relacionados à atividade construtiva, inclusive leis, estilos em voga e etc..

A trajetória de João Bergamasco na construção civil foi marcada por uma diversidade de atuação, o que certamente se deve, não somente pela destacada competência, mas também pelo círculo social que ele se inseriu em São José do Rio Pardo. Esse argentino se ocupou de obras no setor público e privado, com projeto e execução de prédios institucionais, comerciais, de serviços e residenciais, com construções novas, reformas e pequenas alterações em imóveis existentes que se distribuíam em diversas áreas da cidade. Como é possível perceber na Figura 285, sua apresentação gráfica primorosa expõe um cuidado em desenhar plantas arquitetônicas, com indicação das dimensões e da função de cada ambiente, fachadas e cortes, além da disposição dos encanamentos para água e esgoto, em conformidade com a legislação.

Figura 285: Projeto de João Bergamasco aprovado pela Prefeitura Municipal de São José do Rio Pardo.

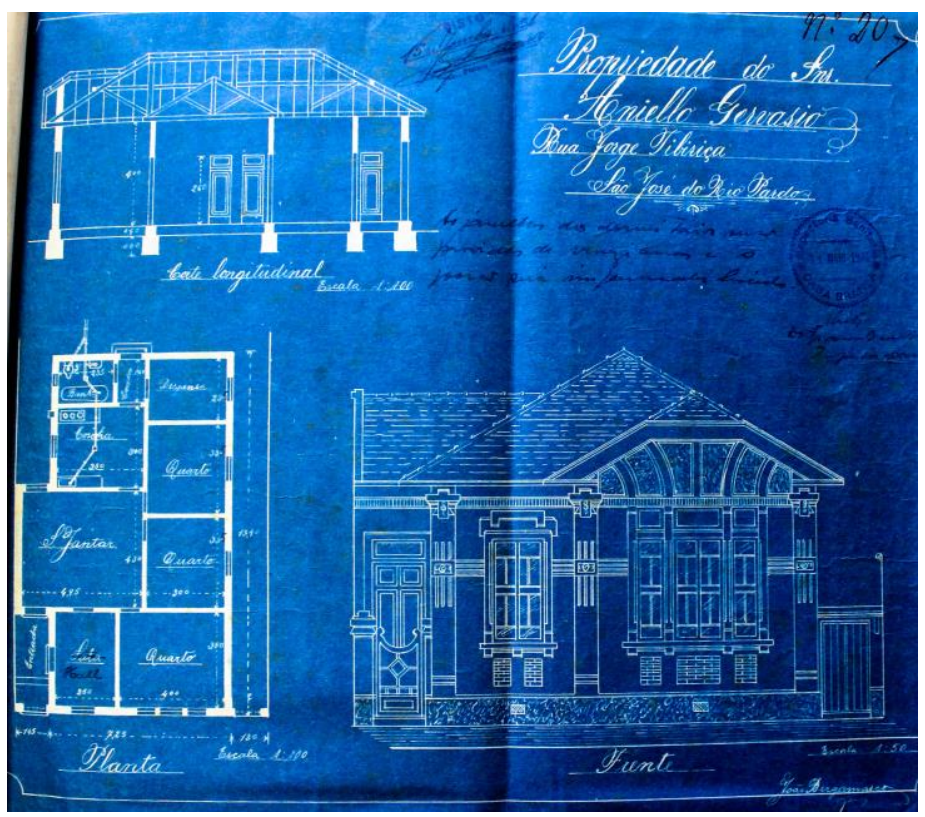

Fonte: Arquivo Público da Secretaria de Obras (1931, P23).
Suas qualidades não ficaram restritas ao conhecimento projetual e se estendem a uma ampla e diversificada atividade na prática edificativa, o que the rendeu o cargo de diretor de obras da Associação Atlética Riopardense - clube fundado em 1930 - quando foi responsável pela construção do campo e arquibancadas (1935) na Vila Pereira (Figura 286) e da sede social na Praça XV de Novembro (1946) (Figura 287). 
Figura 286: Arquibancadas da Associação Atlética Riopardense em construção (1933).

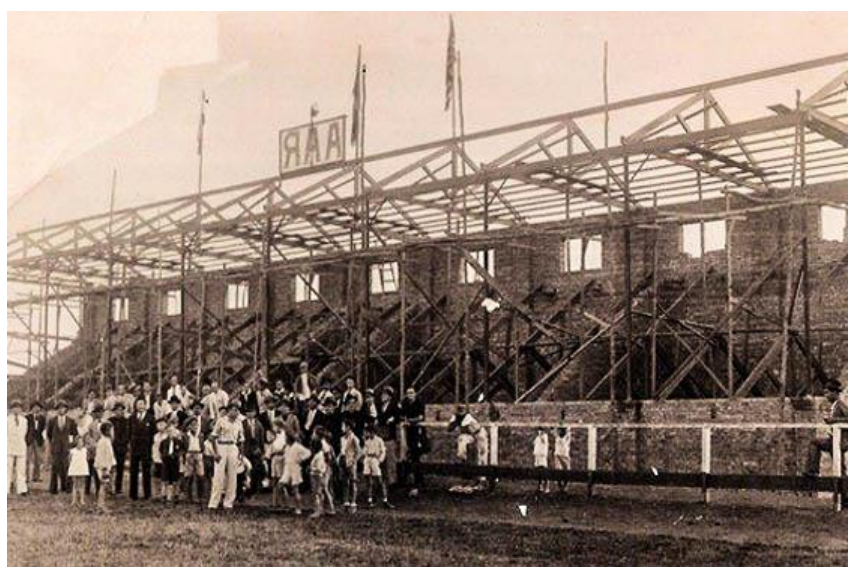

Fonte: Arquivo do Centro da Memória Rio-Pardense Rodolpho José Del Guerra.
Figura 287: Sede social da Associação Atlética Riopardense concluída em 1946.

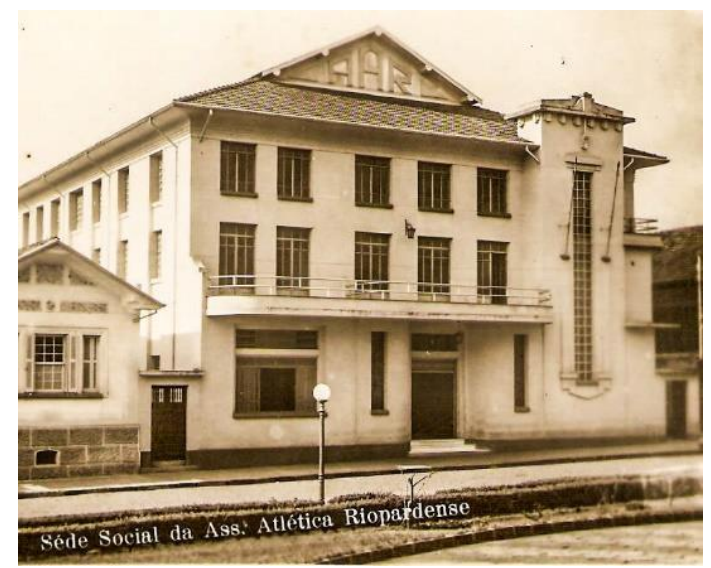

Fonte: Arquivo do Centro da Memória Rio-Pardense Rodolpho José Del Guerra.

Como veremos adiante, suas obras possuíam características estilísticas variadas, sempre envolvendo rigor estético, o que nos revela a erudição que esse licenciado tinha da prática edificativa. Sendo assim, destacamos aqui alguns dos exemplares extraídos da ampla diversidade de trabalhos desenvolvidos por ele, que encontramos no Arquivo Público da Secretaria de Obras, entre os anos de 1925 e 1940: Cine Theatro Colombo (1935) (Figura 288); Ginásio do Estado (1936) (Figura 289); igreja de São Roque (1930) (Figura 290); Fábrica de Massas Perocco (1930) (Figura 291); Padaria e Confeitaria Raddi (1935) (Figura 292) e uma ponte pênsil (1937) (Figura 293). Com exceção das duas primeiras obras - o Cine Theatro e o Ginásio, que foram apenas executadas -, todas as demais foram projetadas e construídas sob a sua responsabilidade, e por isso serão detalhadas a seguir.

Figura 288: Cine Theatro Colombo em construção em 1934.

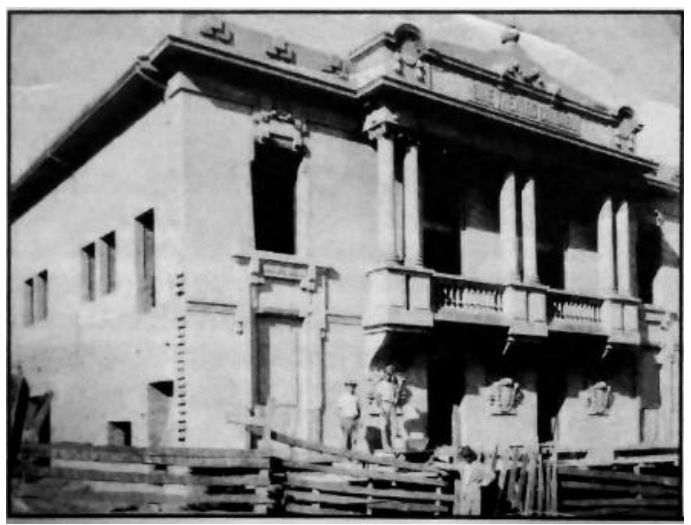

Fonte: Arquivo do Centro da Memória Rio-Pardense Rodolpho José Del Guerra.
Figura 289: Ginásio do Estado em construção em 1934.

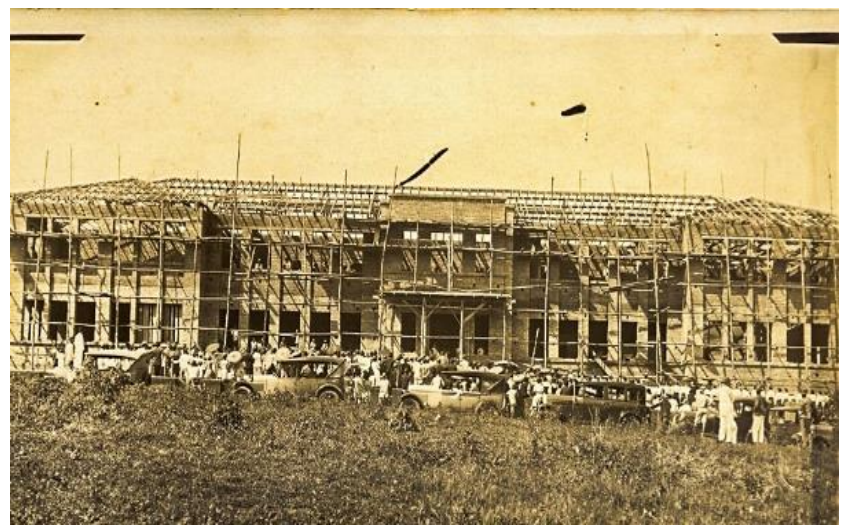

Fonte: Arquivo do Centro da Memória Rio-Pardense Rodolpho José Del Guerra. 
Figura 290: Igreja de São Roque em construção, década de 1930.

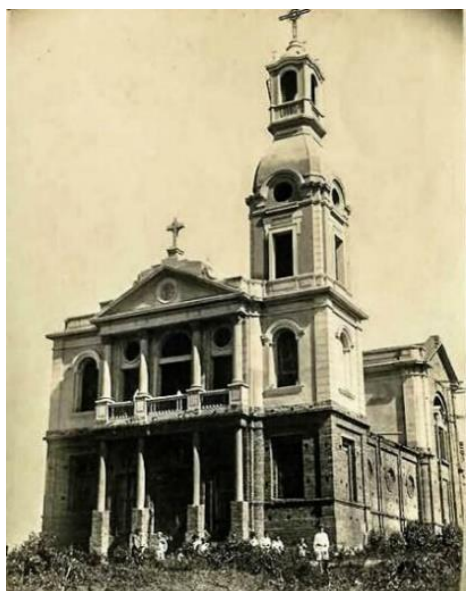

Fonte: Arquivo do Centro da Memória Rio-Pardense Rodolpho José Del Guerra.
Figura 291: Fábrica de massas Perocco em construção em 1929.

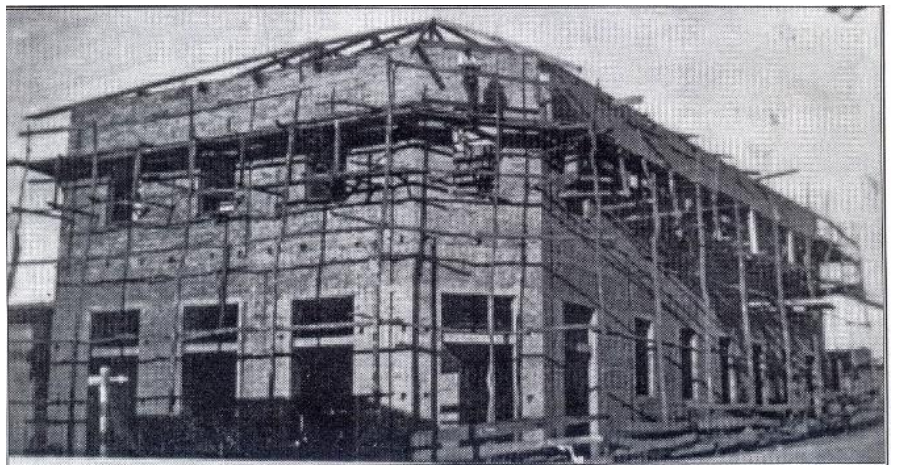

Fonte: Arquivo da Hemeroteca Jornalista Paschoal Artese.
Figura 292: Padaria e Confeitaria Raddi em construção, 1934.

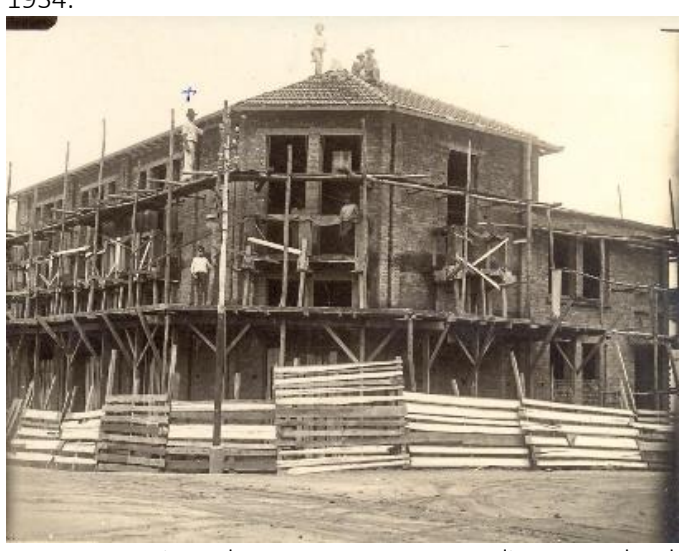

Fonte: Arquivo da Hemeroteca Jornalista Paschoal Artese.
Figura 293: Ponte pênsil em 1939.

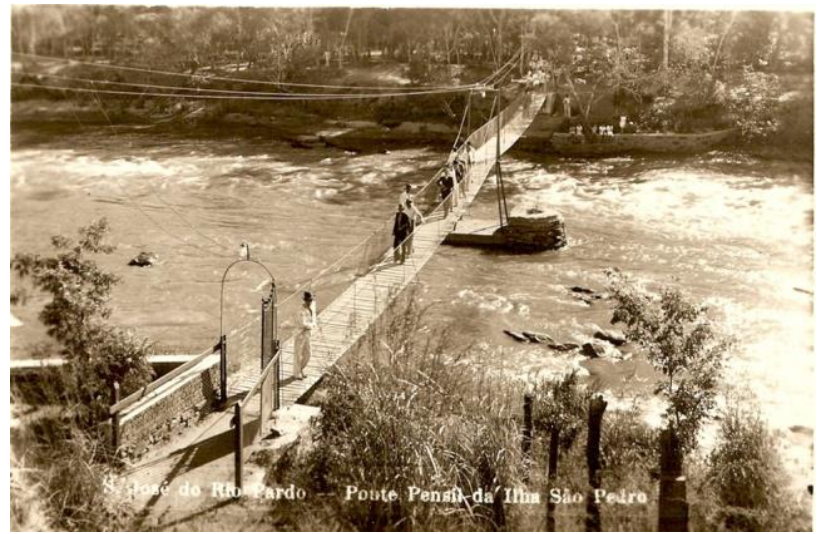

Fonte: Arquivo da Hemeroteca Jornalista Paschoal Artese.

Segundo Del Guerra (2002), a igreja de São Roque foi uma das obras de maior destaque da construção civil rio-pardense da década de 1930. Foi ainda no início dessa década que João Bergamasco foi contratado para projetar e edificar essa igreja no alto do Bonsucesso, no mesmo local onde havia sido construída a primeira capela destruída por um vendaval. À época, essa região que ainda era pouco habitada e distante do centro da cidade, já dava indícios da expansão da malha urbana e consequente ocupação, que ocorreria com edificações de grande significação social, a exemplo dessa igreja de majestosas proporções que naquele momento ainda se destacava na paisagem, conforme constatamos na fotografia da década de 1930 (Figura 294). 


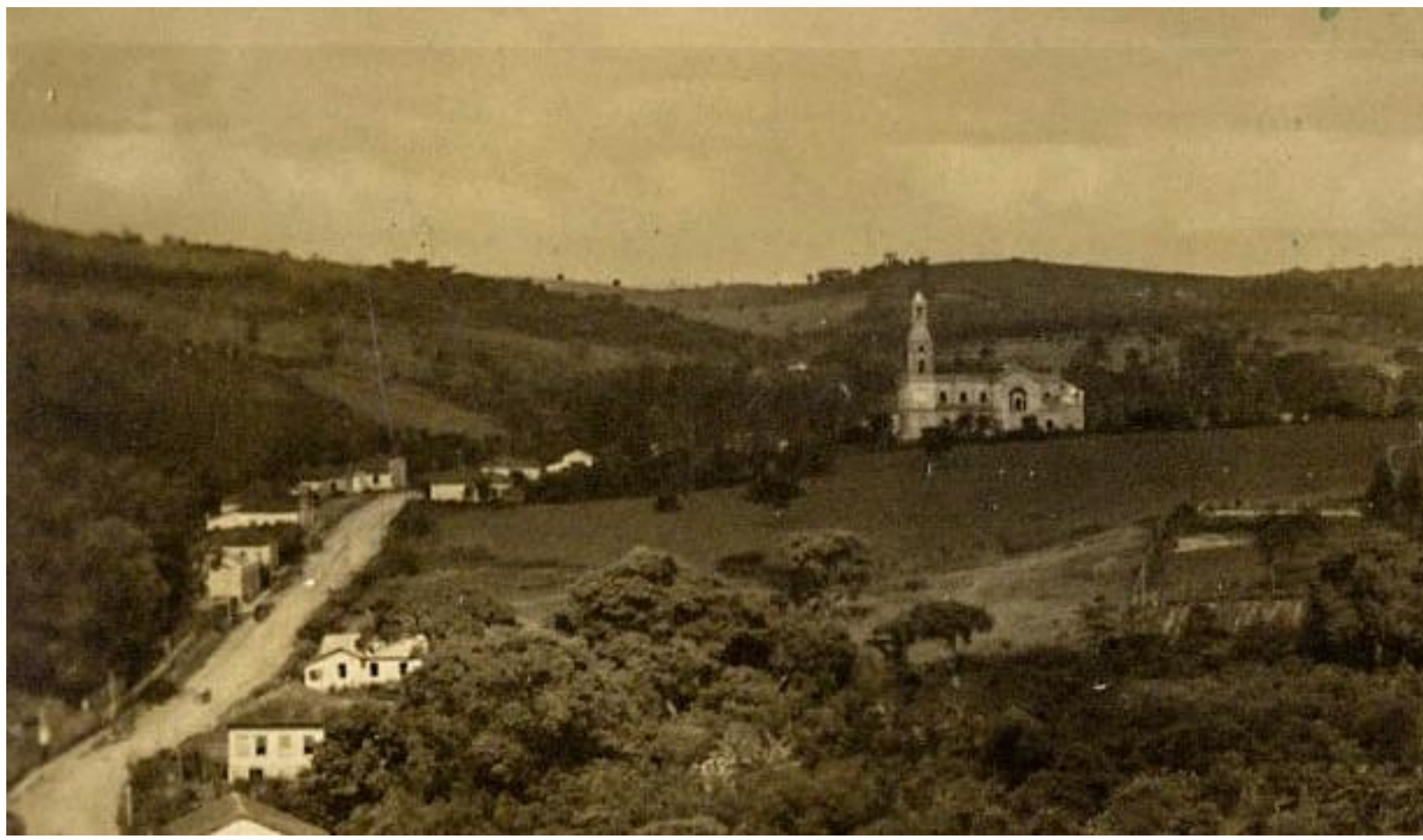

Fonte: Arquivo da Hemeroteca Jornalista Paschoal Artese.

Nesse projeto (Figura 295), Bergamasco adotou elementos da arquitetura clássica com frontão e pilares que remetem à ordem jônica. A fachada simétrica e marcada pela diversidade de aberturas de verga reta, arco pleno e circular é quebrada pela torre do sino. O acesso através de escadarias protegidas por balaústres de mesmo desenho do fechamento da sacada equilibra o conjunto (Figura 296). Interessante observar o detalhe do acabamento executado em argamassa na cobertura da abside (Figura 297) e da torre do sino (Figura 298), que lembram escamas de peixe. O uso desses recursos formais demonstra, mais uma vez, erudição e exeriência profissional desse prático licenciado no exercício de suas atividades de projeto e de construção.

Figura 295: Projeto da Igreja de São Roque elaborado por João Bergamasco.

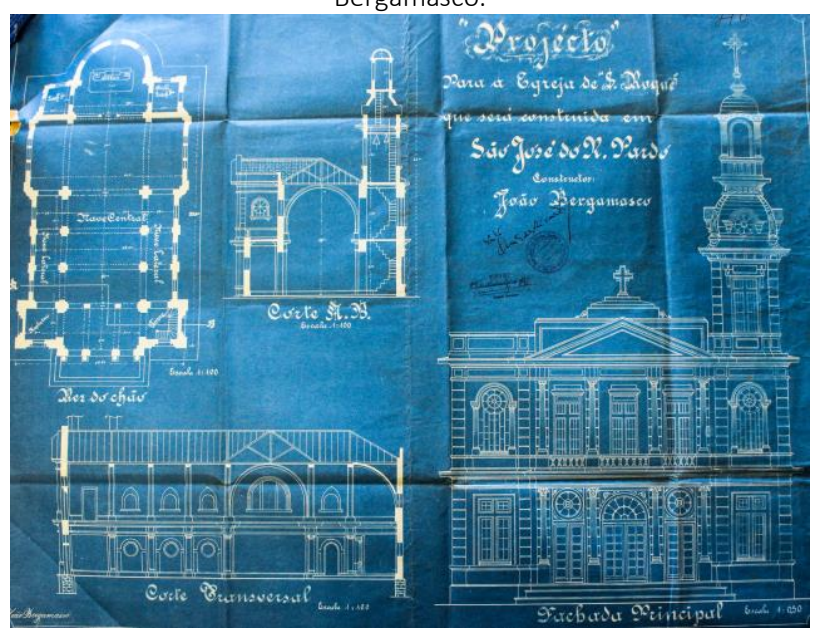

Fonte: Arquivo Público da Secretaria de Obras (1930, P01).
Figura 296: Igreja de São Roque, 2018.

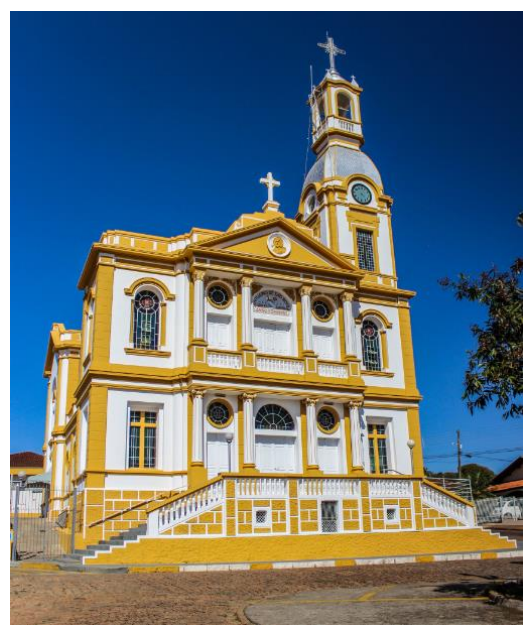

Fonte: Acervo pessoal da autora (2018) 
Figura 297: Detalhe do acabamento da cobertura do altar da Igreja de São Roque, 2018.

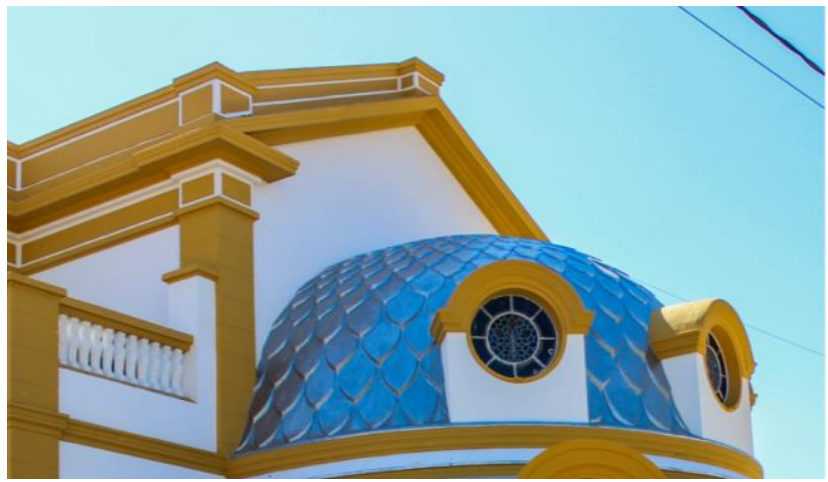

Fonte: Acervo pessoal da autora (2018).
Figura 298: Detalhe do acabamento da cobertura da torre do sino da Igreja de São Roque, 2018.

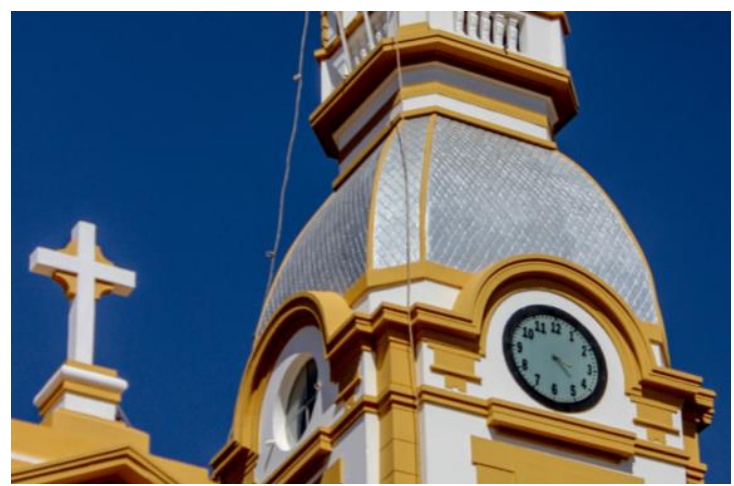

Fonte: Acervo pessoal da autora (2018).

É oportuno enfatizar que as mesmas características formais presentes nessa igreja de 1930 são encontradas na igreja Nossa Senhora Aparecida (Figura 299), com projeto aprovado apenas alguns meses antes, no ano de 1929, sem identificação, mas que nos leva a crer que seja João Bergamasco o autor deste projeto. Como é possível observar na Figura 300 e Figura 301, no projeto da igreja de N. S. Aparecida há uma série de elementos similares aos utilizados na igreja de São Roque, como o mesmo tipo de frontão triangular, as aberturas de verga reta e circular, o acesso frontal através de escadarias, a presença de balaústres, de argamassa imitando bossagens, de cartela circular com a imagem da padroeira e do acabamento na cobertura das alas laterais e da torre lembrando escamas de peixe.

Figura 299: Projeto da Igreja Nossa Senhora Aparecida.

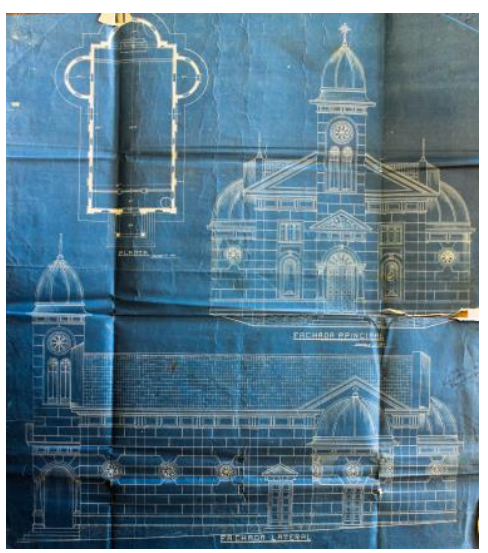

Fonte: Arquivo Público da Secretaria de Obras (1929, P19).
Figura 300: Igreja Nossa Senhora Aparecida, 2018

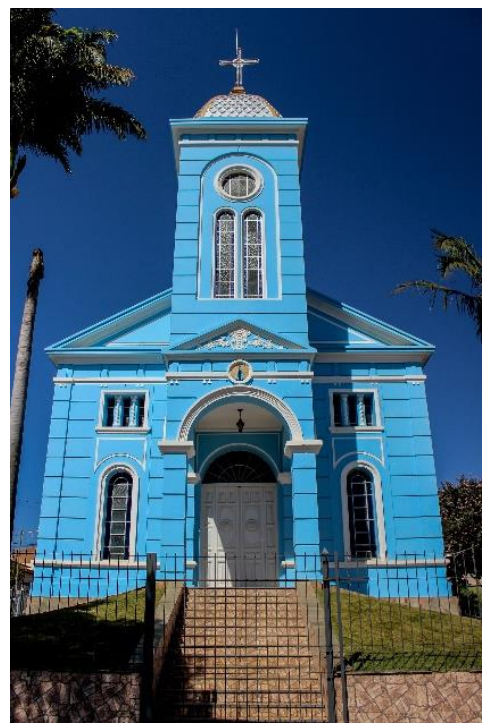

Fonte: Acervo pessoal da autora (2018).
Figura 301: Detalhe do acabamento da cobertura da ala lateral da Igreja Nossa Senhora Aparecida, 2018.

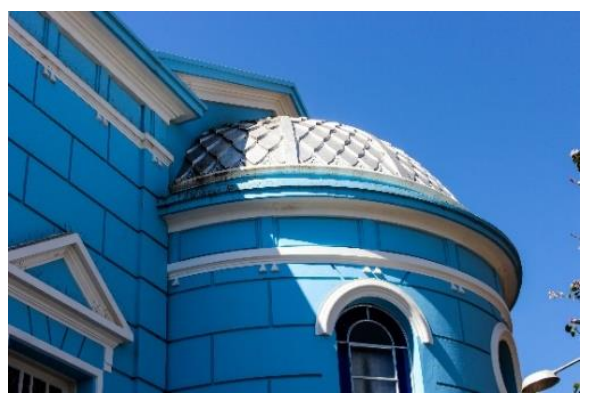

Fonte: Acervo pessoal da autora (2018). 
O projeto (Figura 302) elaborado por Bergamasco em 1930 para Domingos Perocco instalar uma fábrica de massas foi construído na esquina da Rua Francisquinho Dias com a Rua Coronel Marçal. Esse prédio é caracterizado por amplos beirais e fachada marcada por discreta decoração com molduras ao redor das aberturas e frisos assinalando a divisão dos pavimentos (Figura 303).

Figura 302: Desenho do projeto da fábrica de massas Perocco.

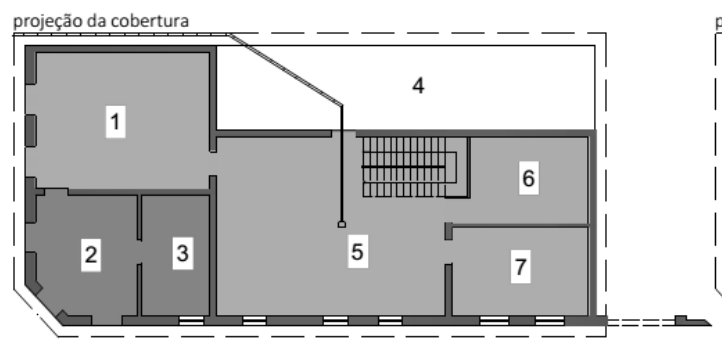

Térreo
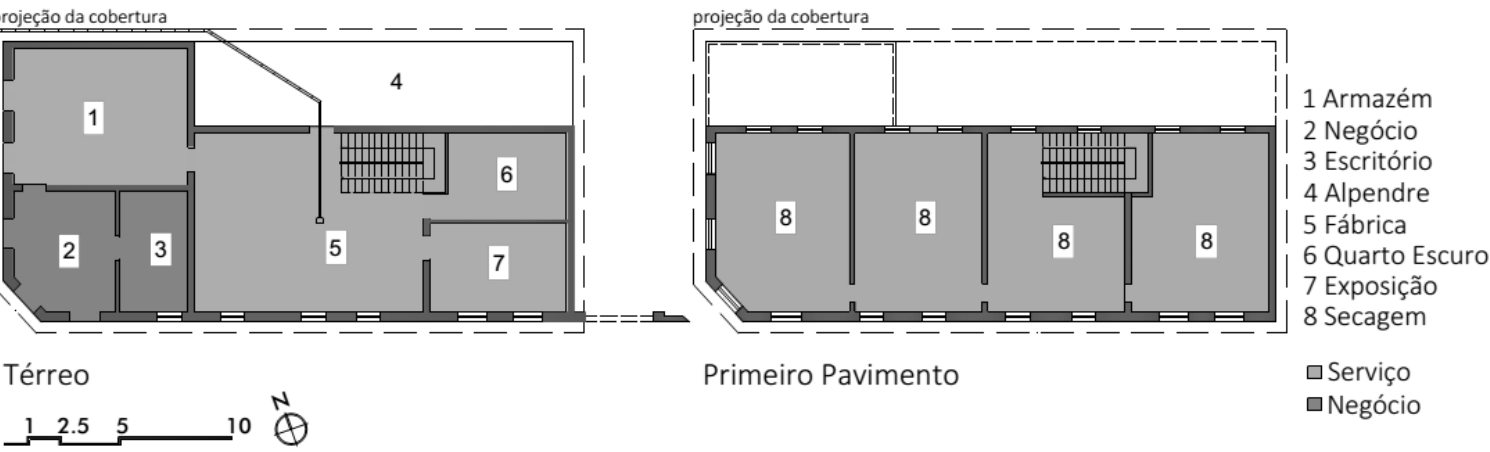

Primeiro Pavimento

口Serviço

口Negócio

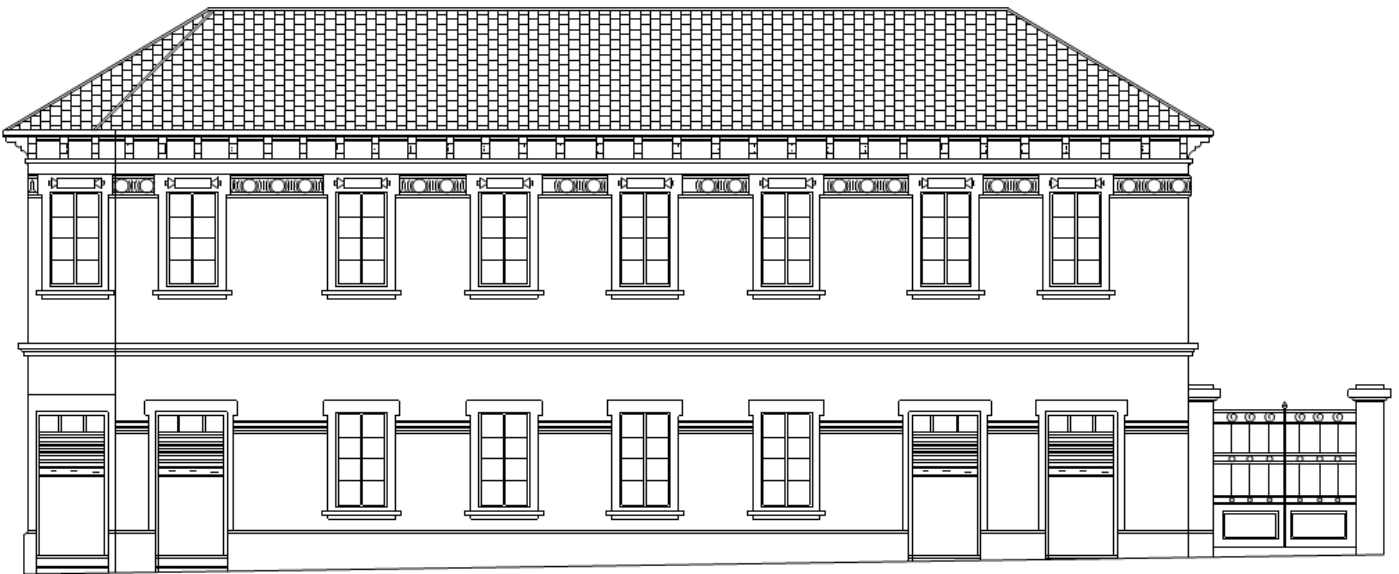

Fachada

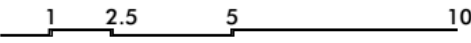

Fonte: Arquivo Público da Secretaria de Obras (1930, P33). Desenho: Natalia Cappellari de Rezende (2016).

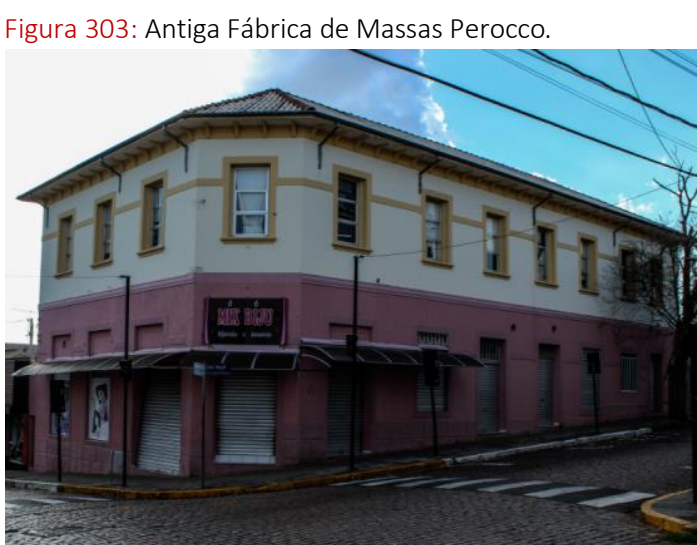

Fonte: Acervo pessoal da autora (2015).
Nessa época, Bergamasco - que estava com 36 anos de idade - trouxe uma inovação na técnica construtiva desse edifício utilizando uma estrutura em concreto armado ${ }^{228}$, o que evidentemente the possibilitou maior liberdade para articular e criar ambientes mais espaçosos, representando sua intenção de modernização no modo de construir. A documentação levantada no Arquivo Público da Secretaria de Obras indica que esse sobrado foi,

\footnotetext{
${ }^{228}$ Sobre o uso do concreto armado na construção civil brasileira ver Alambert (2002), "Um Novo Modo de Construção no Limiar do século XX. Concreto Armado: Experiências Técnicas / Especulações Estéticas".
} 
se não o primeiro, um dos que iniciou o emprego dessa técnica em São José do Rio Pardo, constatando mais uma vez o domínio e erudição que João Bergamasco possuía das práticas projetiva e construtiva.

Contemporânea à fábrica Perocco foi a construção do prédio de dois pavimentos e de uso misto de Antonio Raddi, popularmente conhecido como Padaria Raddi, em substituição à edificação térrea onde funcionava o Hotel Lutti (Figura 304).
Figura 304: Hotel Lutti no início do século XX.

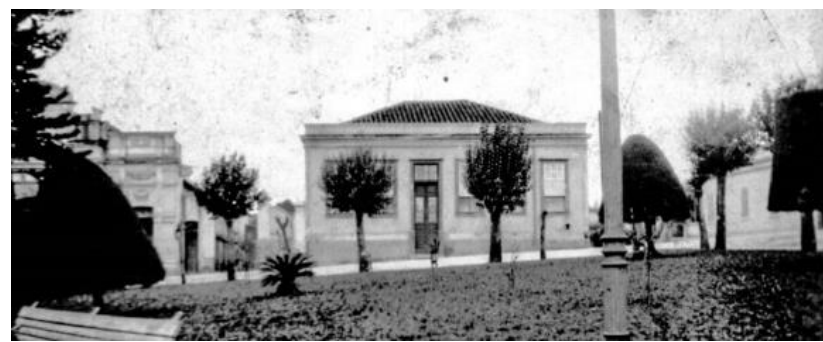

Fonte: Arquivo da Hemeroteca Jornalista Paschoal Artese.

Como é possível observar na Figura 305, o térreo foi projetado sem divisões de ambientes com dimensões de 17,25 m x 6,00 m de vão livre, solução possível pelo uso do concreto armado. Já o primeiro pavimento, destinado à moradia da família Raddi, apresenta a planta com as divisões e funções de ambientes.

Figura 305: Desenho do projeto de um edifício de uso misto de Antonio Raddi.

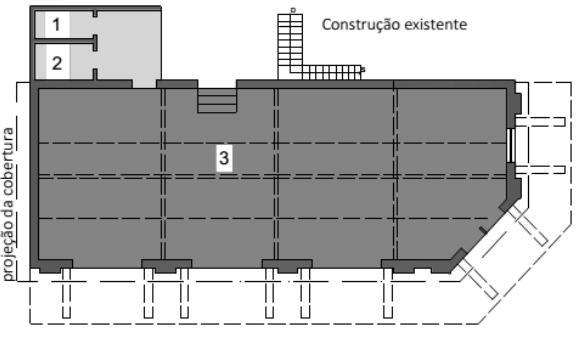

Térreo

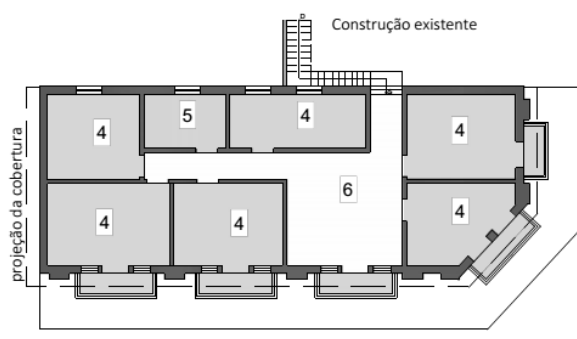

Primeiro Pavimento
1 W.C

3 Sala de Negócios

4 Quarto

5 Banheir

6 Sala

$\square$ Social

$\square$ Serviço

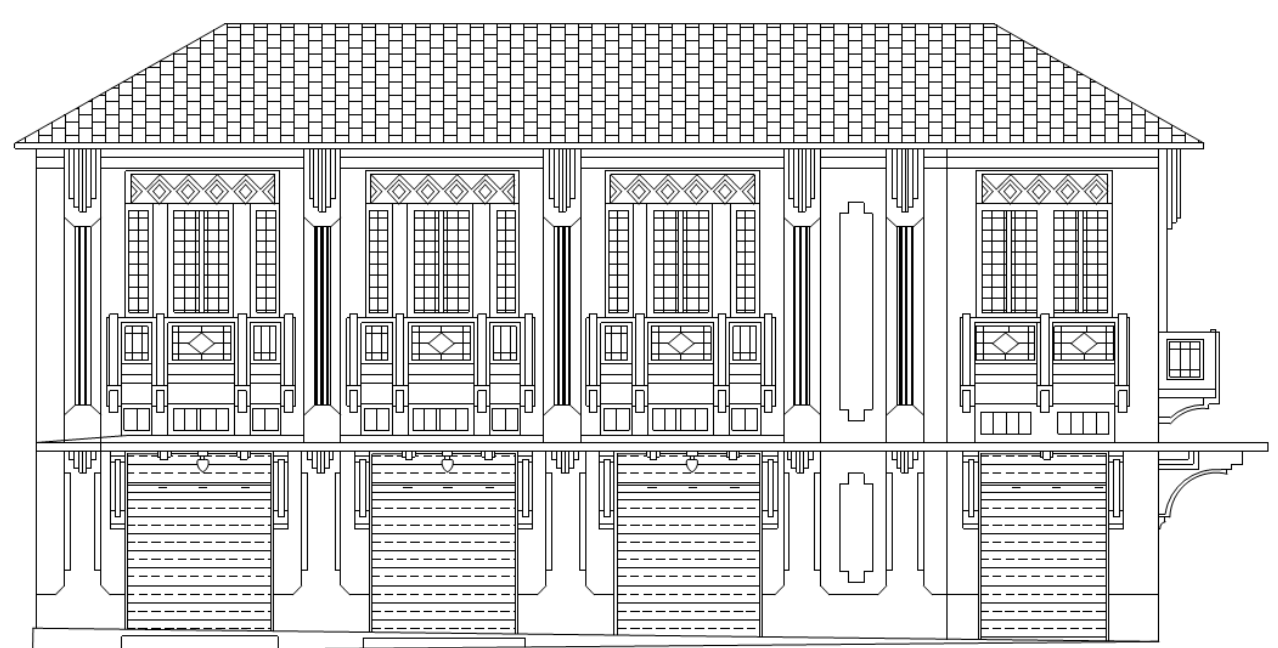

Fachada

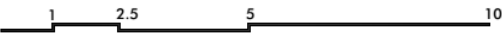

Fonte: Arquivo Público da Secretaria de Obras (1935, P17). Desenho: Natalia Cappellari de Rezende (2016). 
Apesar dos amplos beirais e do modo de implantação (Figura 306) ser muito semelhante ao edifício de Domingos Perocco - ambos em acordo com o artigo 22 do Código de Posturas de 1918 - o prédio da Padaria Raddi possui maior profusão decorativa nas fachadas, com elementos geométricos que remetem ao art-déco. Além disso, uma ampla marquise sustentada por mísulas e executada em concreto armado se estende por toda a fachada até o limite do passeio (Figura 307).

Figura 306: Desenho da implantação do edifício de Antonio Raddi e Domingos Perocco.

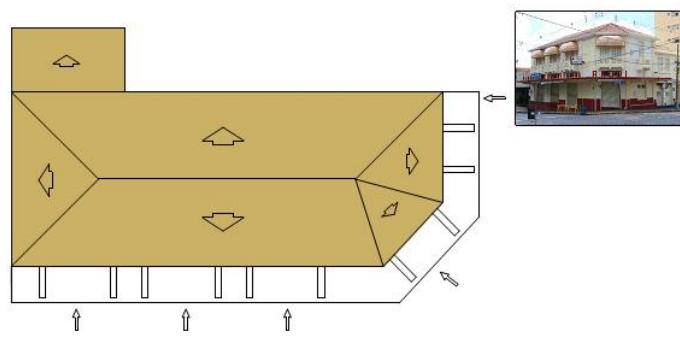

ANTONIO RADDI

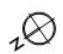

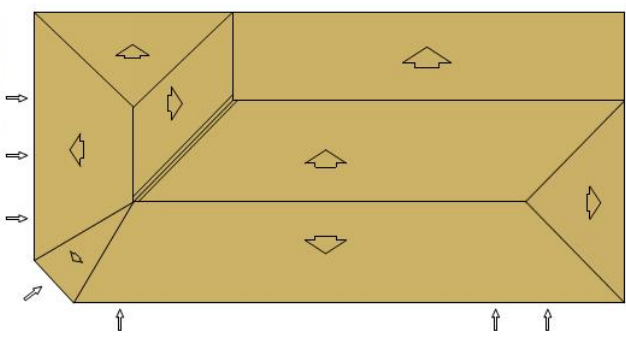

DOMINGOS PEROCCO

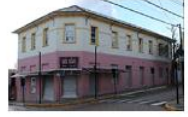

$\stackrel{N}{N}$

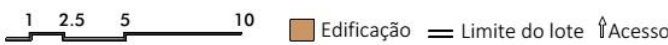

Fonte: Arquivo Público da Secretaria de Obras. Desenho: Natalia Cappellari de Rezende (2018).

Figura 307: Edifício de Antonio Raddi (1935), década de 1940.

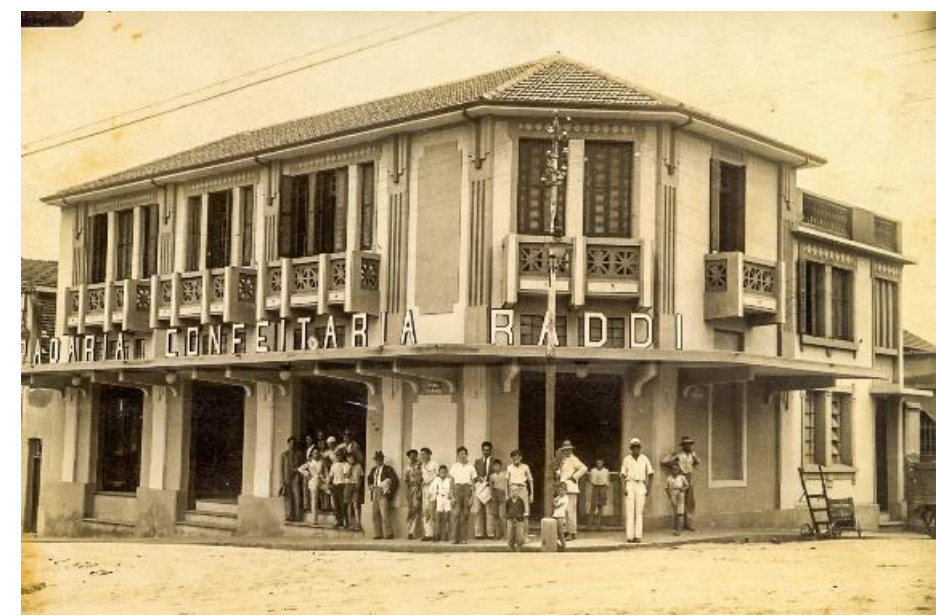

Fonte: Arquivo do Centro da Memória Rio-Pardense Rodolpho José Del Guerra.

Nessa diversidade de tipologias arquitetônicas havia ainda um projeto bastante emblemático da carreira de Bergamasco, a ponte pênsil (ver Figura 293 na página 288 e Figura 308) para passagem de pedestres, que foi construída entre o Bairro João de Souza e a llha de São Pedro, dez anos após a ponte anterior ser levada pela enchente de 1929. Sobre o projeto, o jornal Resenha reportou que ao

examinar o "croqui" da planta da ponte a ser aprovada pelos poderes Públicos, projetado pelo insigne técnico e artista João Bergamasco, verificamos que se trata realmente de um trabalho 


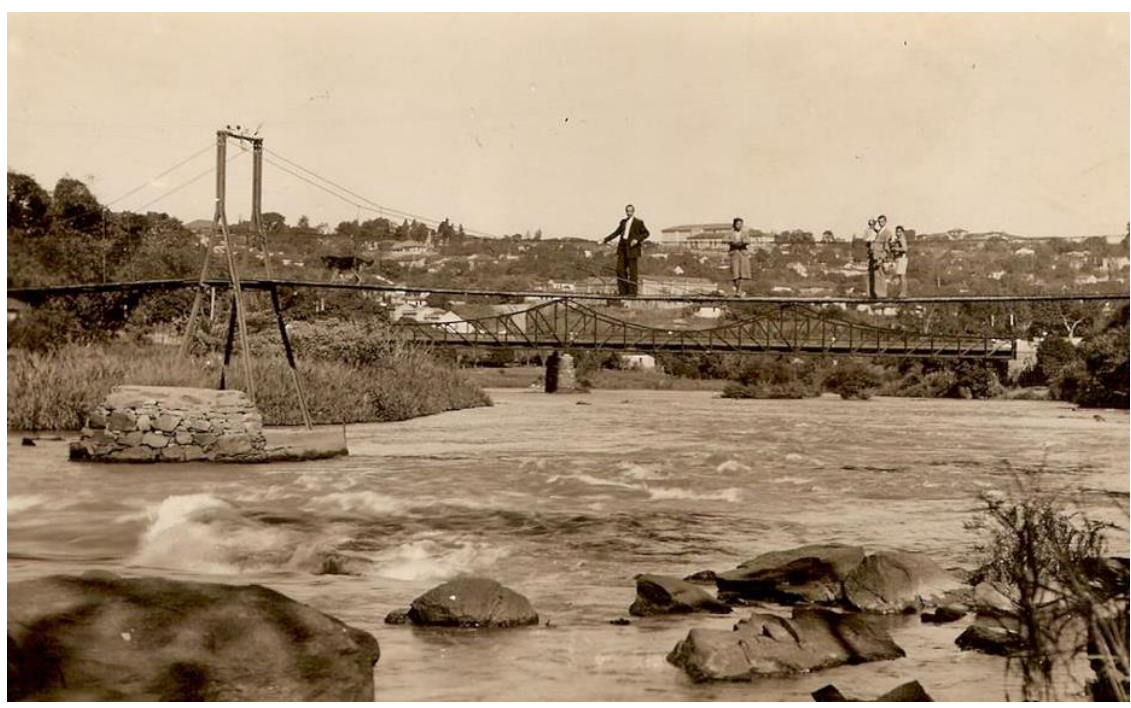

Fonte: Arquivo do Centro da Memória Rio-Pardense Rodolpho José Del Guerra.

Certamente, ao destacar a "elegância das linhas" associadas à "solidez da construção", o jornal reflete o entusiasmo local com o feliz resultado alcançado por Bergamasco para solucionar o problema de ligação entre a ilha e a cidade, permitindo ainda a passagem de energia elétrica para a ilha também. A silhueta delgada desta passarela, sustentada por cabos de aço e auxiliada por um apoio metálico no meio do vão, causava pouca interferência na paisagem formada pela ponte metálica Euclides da Cunha e pela cidade ao fundo. O jornal ainda exalta outras importantes qualidades proporcionadas por Bergamasco em sua solução: o local escolhido para ser implantada a ponte, permitiu uma obra de menores dimensões que proporcionou mais segurança à travessia de pedestres e ofereceu lindas paisagens, maior proximidade entre a cidade e a ilha, e ainda a criação de uma avenida de acesso margeando o rio Pardo, que garantiria espaços de lazer à população local e a visitantes:

não podia ser melhor, preenche todas as boas qualidades: vista encantadora, pitorescas paisagens, comodidade econômica, não sendo necessária a mesma extensão da antiga ponte a qual era de 145 metros, quando agora permite um comprimento pouco mais de 60 metros, e, além de todas as vantagens desse lugar, teremos igualmente mais uma extensa avenida que conduzirá ao local descrito, em cujas margens o povo e todas as pessoas que nos visitarem poderão gozar as delicias de uma admirável praia (ILHA DE SÃO PEDRO, 1937, p. 01).

A produção de Bergamasco ainda contempla edifícios de menor destaque, mas representa a sua atuação em diversas tipologias arquitetônicas, adotando uma pluralidade de elementos na composição formal, entre os quais destacamos a presença de balaústres na platibanda, aberturas em arco pleno e em verga reta, tímpano triangular, colunas que remetem à ordem jônica e dórica, mísulas, revestimentos com tijolo 
cerâmico e ornatos geométricos. O ecletismo foi o estilo empregado, exibindo linhas classicizantes, mas com tendências à simplificação do art-déco. Na sequência apresentamos alguns desses edifícios de uso misto com função residencial e comercial, todos projetados no ano de 1933 (Figura 309, Figura 310, Figura 311 e Figura 312).

Figura 309: Desenho da fachada do edifício de Antonio Flora, Rua Marechal Deodoro.

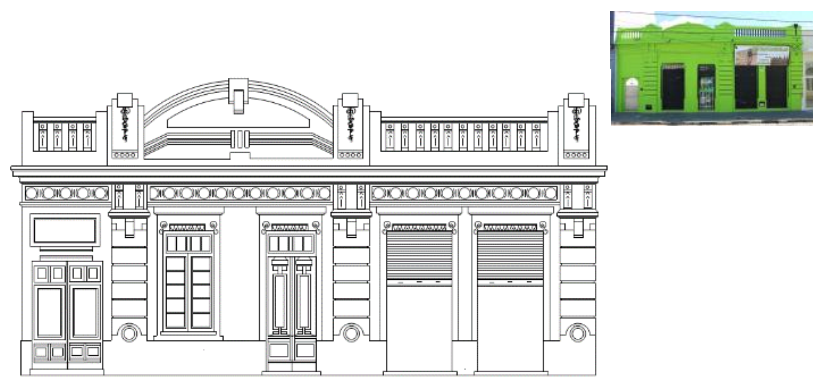

Fonte: Arquivo Público da Secretaria de Obras (1933, P02). Desenho: Natalia Cappellari de Rezende (2016).
Figura 310: Desenho da fachada do edifício de Manoe Ferreira Pinto Júnior, Rua Marechal Floriano.

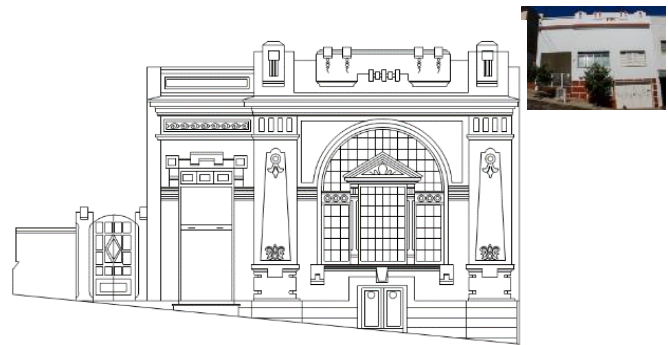

Fonte: Arquivo Público da Secretaria de Obras (1933, P08). Desenho: Natalia Cappellari de Rezende (2016).

Figura 312: Desenho da fachada do edifício de Vicenza Cogato, Rua Treze de Maio.

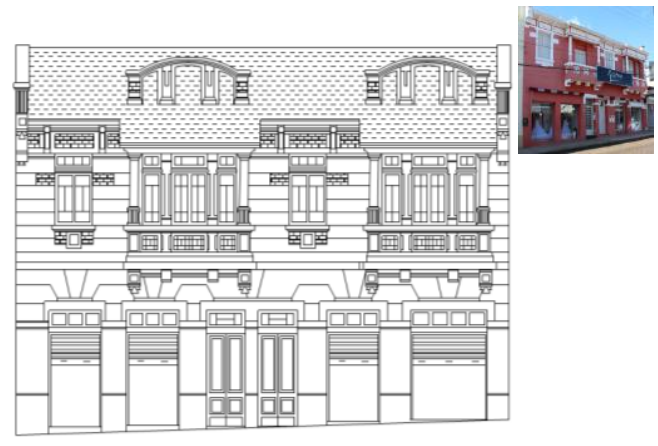

Fonte: Arquivo Público da Secretaria de Obras (1933, P18). Desenho: Natalia Cappellari de Rezende (2016).

Fonte: Arquivo Público da Secretaria de Obras (1933, P14) Desenho: Natalia Cappellari de Rezende (2016). 
Figura 313: Desenho da fachada do edifício de Pedro Darcie, Rua Ruy Barbosa.

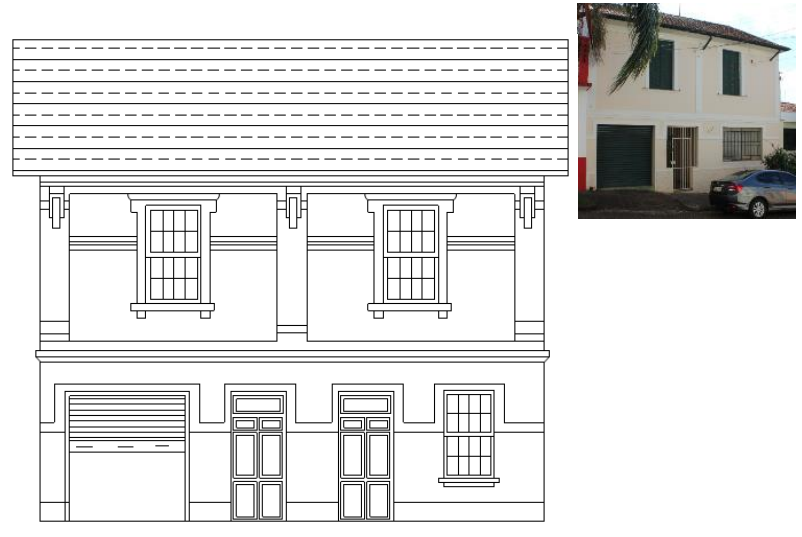

Fonte: Arquivo Público da Secretaria de Obras (1931, P24). Desenho: Natalia Cappellari de Rezende (2016).
Figura 314: Desenho da fachada do edifício de Francisco Martinez, posteriormente reformado, na Rua Nove de Julho.

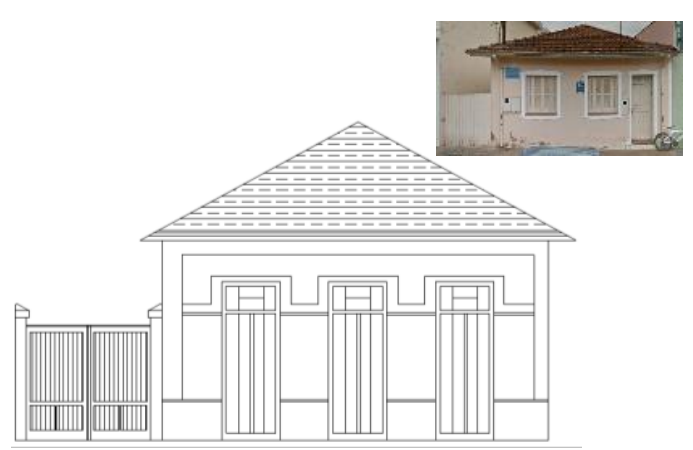

Fonte: Arquivo Público da Secretaria de Obras (1932, P20). Desenho: Natalia Cappellari de Rezende (2016).
Mas apesar da importância de todas essas obras, o predomínio de sua atuação está na elaboração de projetos de moradias urbanas que representa $58,5 \%$, ou seja 54 do total de 92 projetos aprovados, como é possível observar na Gráfico 05. Na sequência, aparece as edificações de uso misto com $18,5 \%$ e por último o projeto de uma única fábrica, a de Massas Perocco.
Gráfico 05: Ocorrência de projetos aprovados de acordo com o uso por João Bergamasco entre 1925 e 1940.

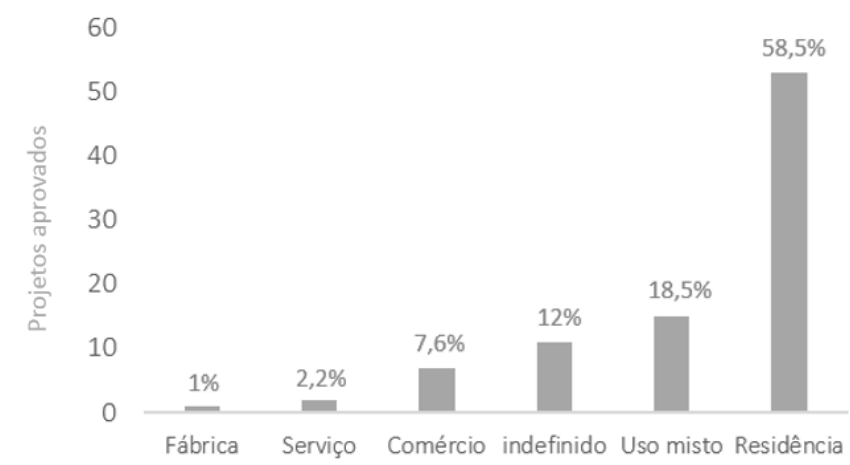

Fonte dos dados: Projetos arquivados na Secretaria de Obras.

A vasta quantidade de projetos residenciais desse prático licenciado demonstra a importância de sua atuação na construção da paisagem urbana de São José do Rio Pardo, sobretudo na década de 1930, período em que ele aprovou maior número de projetos. São moradias construídas para os diferentes estratos econômicos, conforme as figuras (315, 316, 317, 318, 319 e 320), compreendendo as vertentes estilísticas da época e com variados graus de sofisticação no que diz respeito a agenciamento dos ambientes e composição das fachadas. 
Figura 315: Desenho do projeto da moradia de Maria Eugênia.

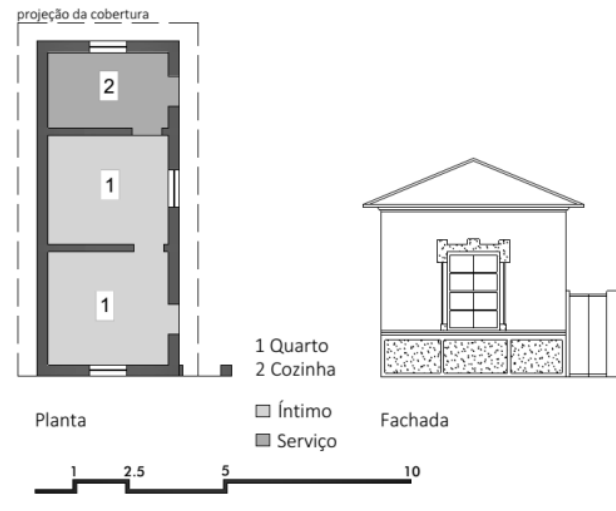

Fonte: Arquivo Público da Secretaria de Obras (1928, P26). Desenho: Natalia Cappellari de Rezende (2018). Diminuir números
Figura 316: Desenho do projeto da moradia de Victorio Lavratte, Avenida Independência, 129.
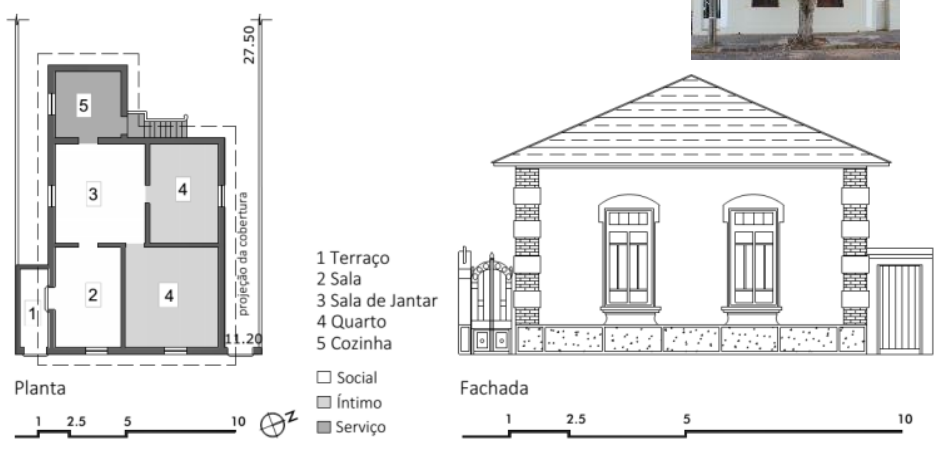

Fonte: Arquivo Público da Secretaria de Obras (1928, P25). Desenho: Natalia Cappellari de Rezende (2016).

Figura 317: Desenho do projeto da moradia de Francisco Sberce, Rua Ruy Barbosa, 577.
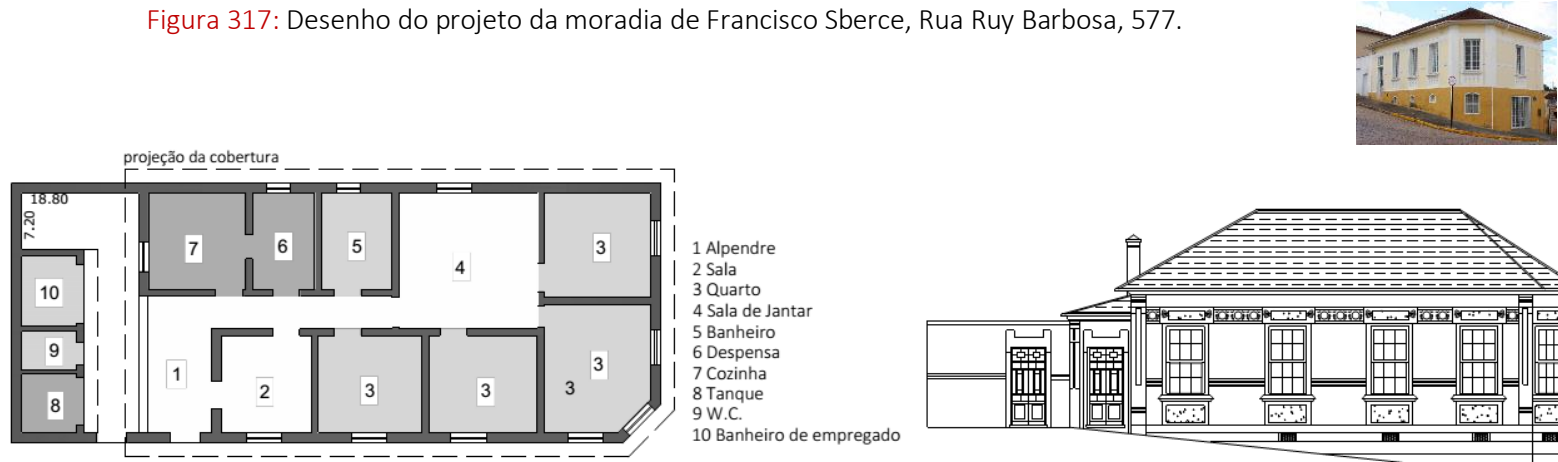

Planta

$\theta^{2}$

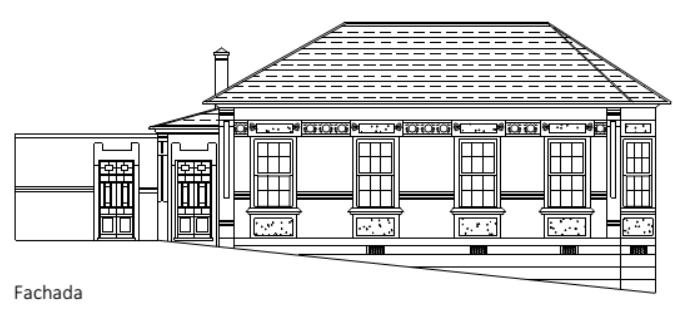

$\square$ Social

$\square$ Íntimo
$\square$ Serviço

Fonte: Arquivo Público da Secretaria de Obras (1930, P38). Desenho: Natalia Cappellari de Rezende (2016).

Figura 318: Desenho do projeto da moradia de Paschoal Cerávolo, Rua Francisquinho Dias, 783.
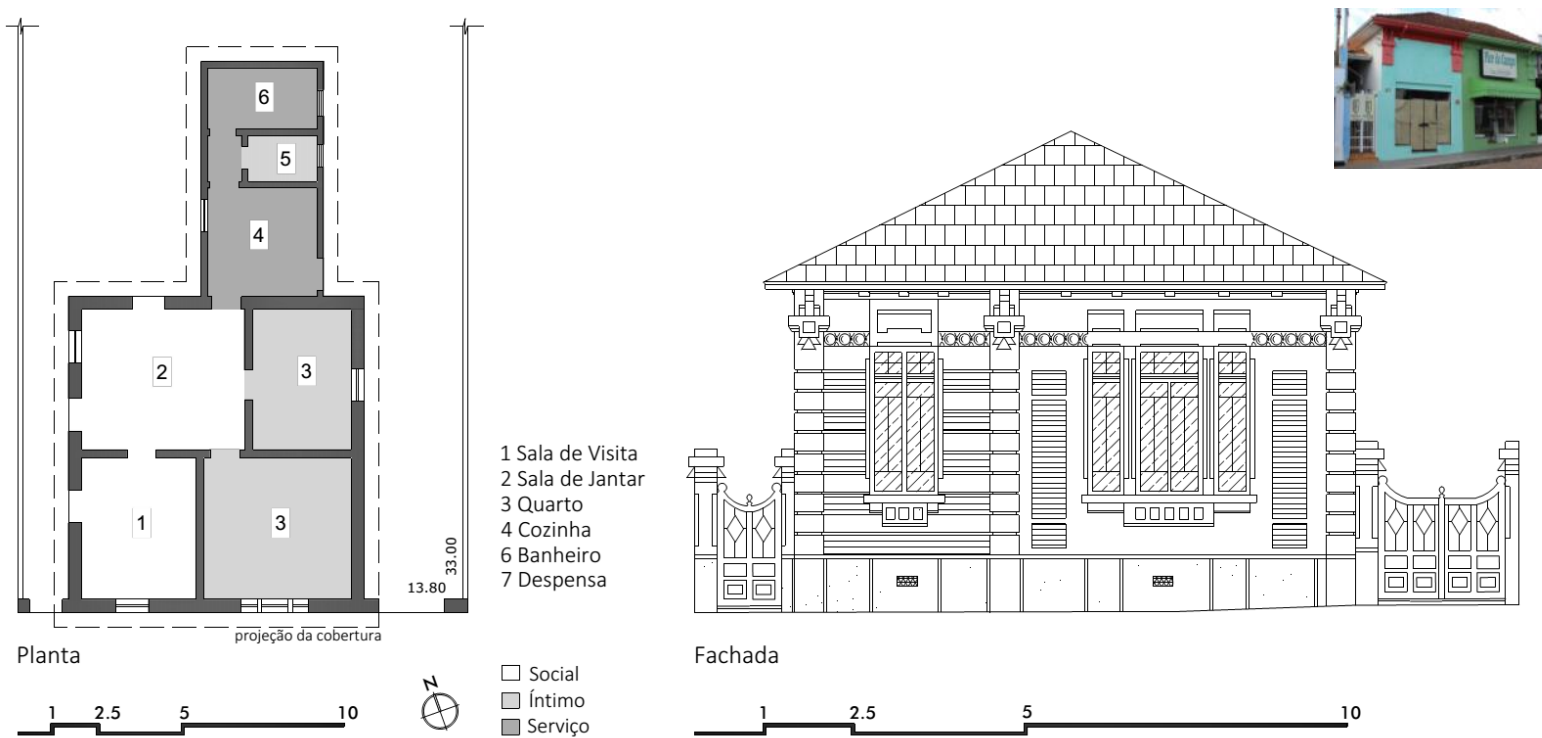

Fachada

Fonte: Arquivo Público da Secretaria de Obras (1931, P29). Desenho: Natalia Cappellari de Rezende (2016). 
Figura 319: Desenho do projeto da moradia de Paulo Ferreira da Silva, Rua Benjamin Constant (demolido).

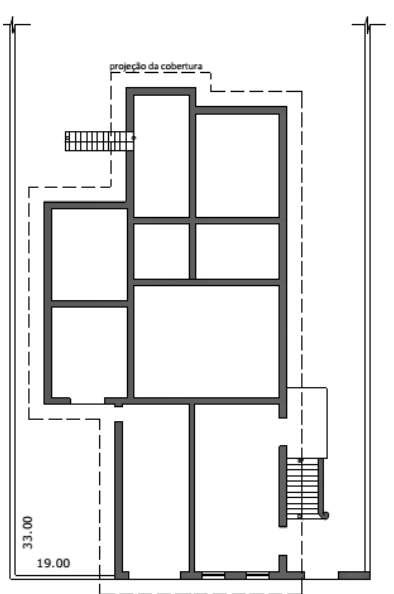

Térreo

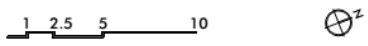

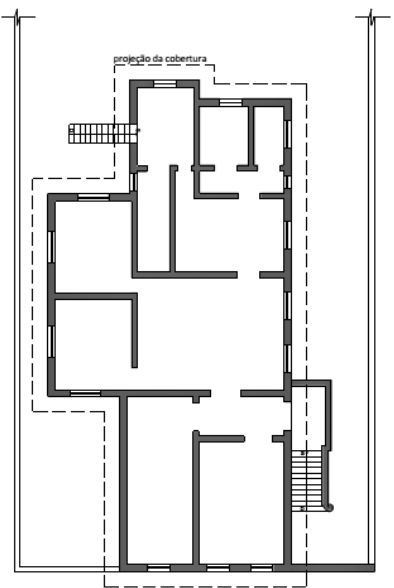

Primeiro Pavimento

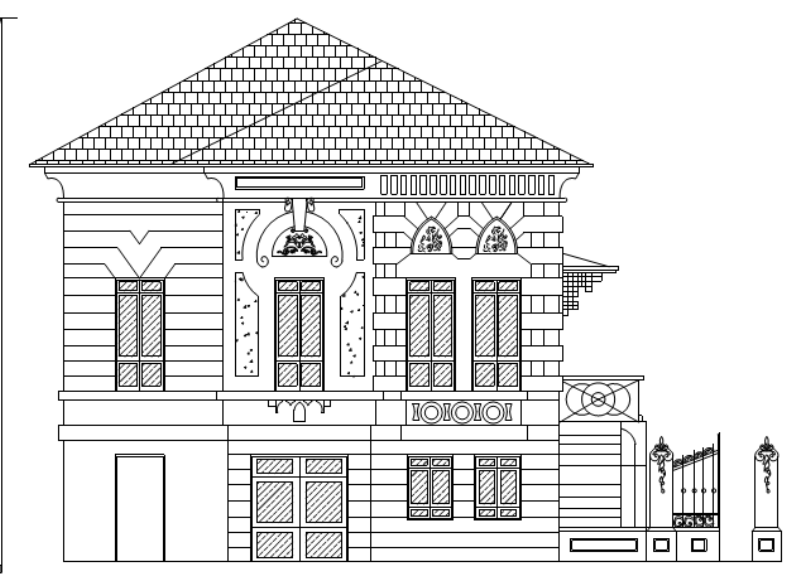

Fachada

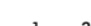

$1 \quad 2.5$

Fonte: Arquivo Público da Secretaria de Obras (1927, P33). Desenho: Natalia Cappellari de Rezende (2016).

Figura 320: Desenho do projeto da moradia de João Bergamasco, Rua Ruy Barbosa (demolido).

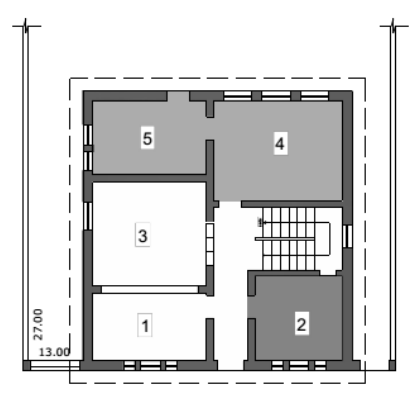

Térreo

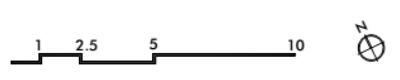

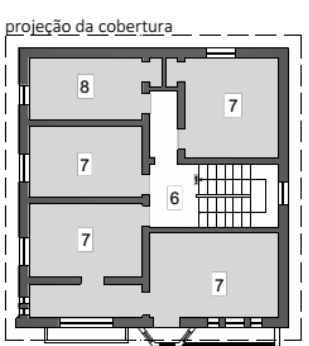

Primeiro Pavimento

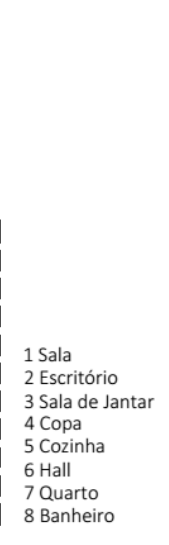

$\square$ Social

$\square$ Íntimo

$\square$ Serviço

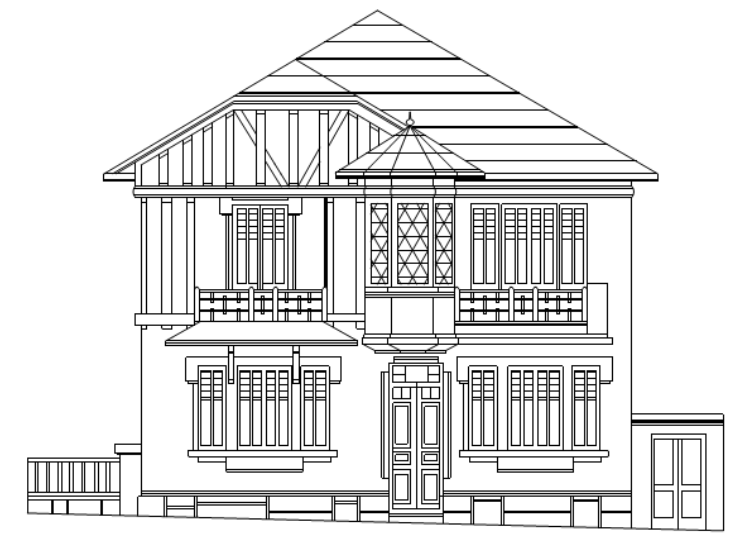

Fachada

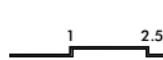

Fonte: Arquivo Público da Secretaria de Obras (1936, P17). Desenho: Natalia Cappellari de Rezende (2016).

São edificações bastante singulares, mas possuidoras de características semelhantes, por exemplo, a elevação do piso em relação ao solo que ocorreu independente da sofisticação da moradia, sendo que na residência de Paulo Ferreira da Silva a inclinação do terreno permitiu que os ambientes dianteiros fossem utilizados. Apresentam implantações variadas (Figura 321) e afastamentos de pelo menos uma das laterais do lote, criando um espaço de circulação, ao mesmo tempo propiciando a abertura de janelas. Nesse sentido, persiste o alinhamento na testada do lote - por exemplo na moradia de João Bergamasco que ostenta distanciamento das duas laterais -, mas mantêm o acesso principal praticamente no eixo da sua fachada. A organização interna dos ambientes se diferencia do modo tradicional de morar que se praticava em períodos anteriores, sobretudo com a definição do vestíbulo distribuidor - também denominado de hall 
a partir da década de 1920 - e de espaços com novas funções como a copa, os quais serão melhor analisados no próximo item desse capítulo.

Figura 321: Desenho da implantação de moradias urbanas projetadas por João Bergamasco.
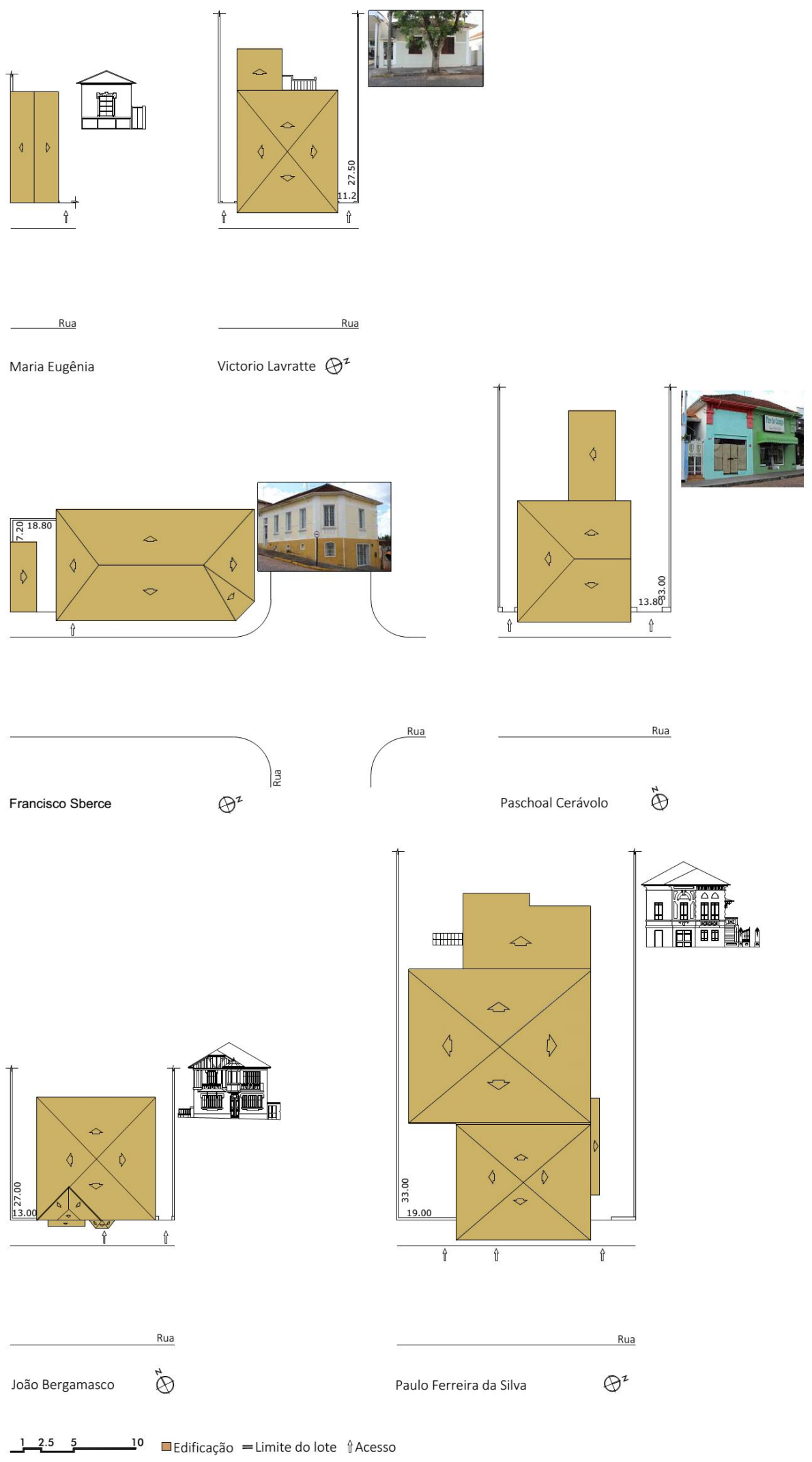

Fonte: Arquivo Público da Secretaria de Obras . Desenho: Natalia Cappellari de Rezende (2018). 
Outra questão a ser ressaltada é a liberdade de combinações e também a erudição de Bergamasco, que fizeram com que uma multiplicidade de motivos fosse utilizada dentro da linguagem eclética. Mas, diferentemente de Paschoal Artese - que criou variações nos padrões existentes apresentados em manuais e catálogos -, Bergamasco se apropriou deles e os combinou à mercê do refinamento desejado nas edificações que projetou e construiu, como é possível observar na Figura 322.
Figura 322: Elementos decorativos utilizados por Bergamasco na sua produção edificativa.
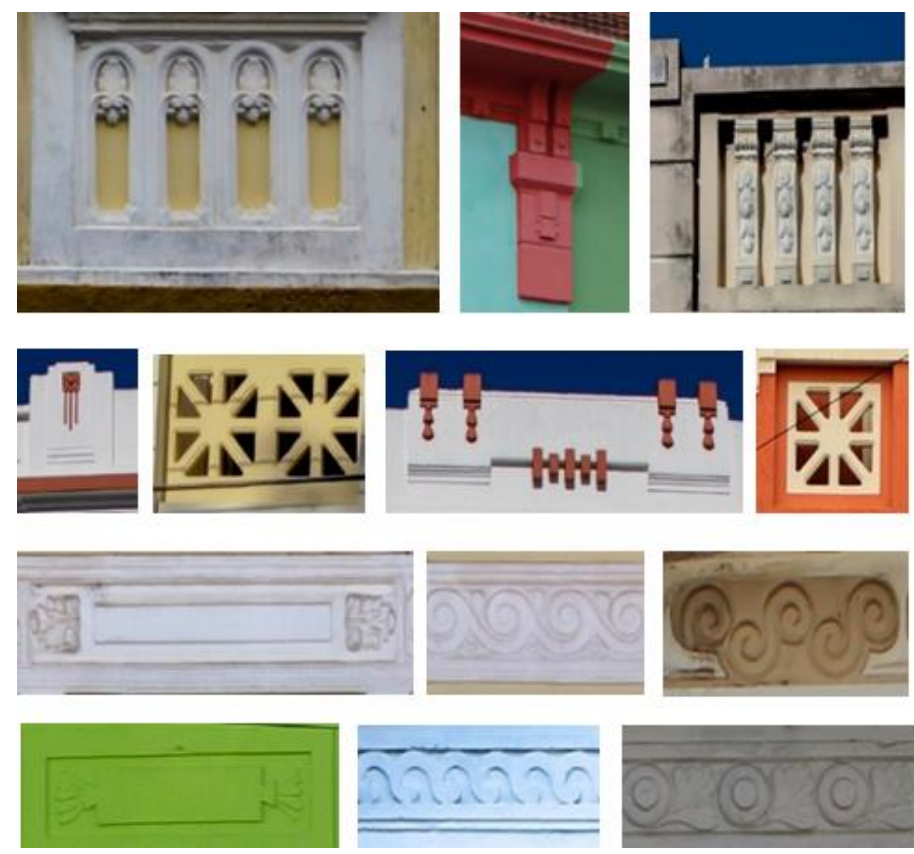

Fonte: Acervo pessoal da autora (2018).

A produção desse prático licenciado e a dos demais sujeitos que atuaram em São José do Rio Pardo entre os anos de 1918 e 1940 - analisada através dos projetos arquivados na Secretaria de Obras e da pesquisa de campo - demonstrou a proficiência que eles possuíam na atividade projetiva e edificativa e como foi variado o desempenho de cada um. Além disso, o cenário que se revelou nos permitiu reconhecer como essas edificações contribuíram na espacialização da cidade (Figura 323) ${ }^{229}$, sobretudo quando tratado da moradia urbana, que se apresentou em um número bastante expressivo, totalizando 55,75\% do total, ou seja das 339 solicitações de aprovação de projeto, 189 foram de residência, universo que será melhor analisado no terceiro item deste capítulo

\footnotetext{
229 No intuito de vislumbrar espacialmente a produção dos sujeitos apresentados neste item, optamos por desenvolver um mapa tematizado, representando a relação entre a obra e o projetista/construtor. Todavia, algumas limitações impediram que todas as obras fossem relacionadas, isso porque após cada projeto ser catalogado na base de dados que desenvolvemos, muitas não apresentaram o endereço físico, inviabilizando a sua espacialização no território. Além disso, foi comum encontrarmos e ndereços com grafias antigas e que sofreram diversas mudanças de nome até os dias de hoje, o que exigiu um tratamento das fontes e a compreensão dessas transformações ao longo do tempo. Outra questão é a ausência da numeração do imóvel e, assim como no nome da rua, muitos foram alterados diante dos novos emplacamentos. A vista disso, priorizamos o cotejamento das informações, por exemplo, comparando os projetos com fotografias antigas, com edifícios existentes, ou através do nome do proprietário, mas nos casos que se mostraram inviáveis, optamos por localizar os imóveis sem numeração no ponto médio da rua. Como resultado final, procuramos demonstrar através do mapa a concentração de obras a partir da atuação dessas pessoas nas diferentes regiões e bairros da cidade. Apesar do método adotado não garantir a exata localização dos imóveis, o entendemos como uma possibilidade de vislumbrar espacialmente essa produção que certamente representa a identidade arquitetônica da cidade de São José do Rio Pardo nas primeiras décadas do século XX.
} 
Figura 323: Espacialização dos projetos/obras de acordo como o responsável pelo projeto e construção.

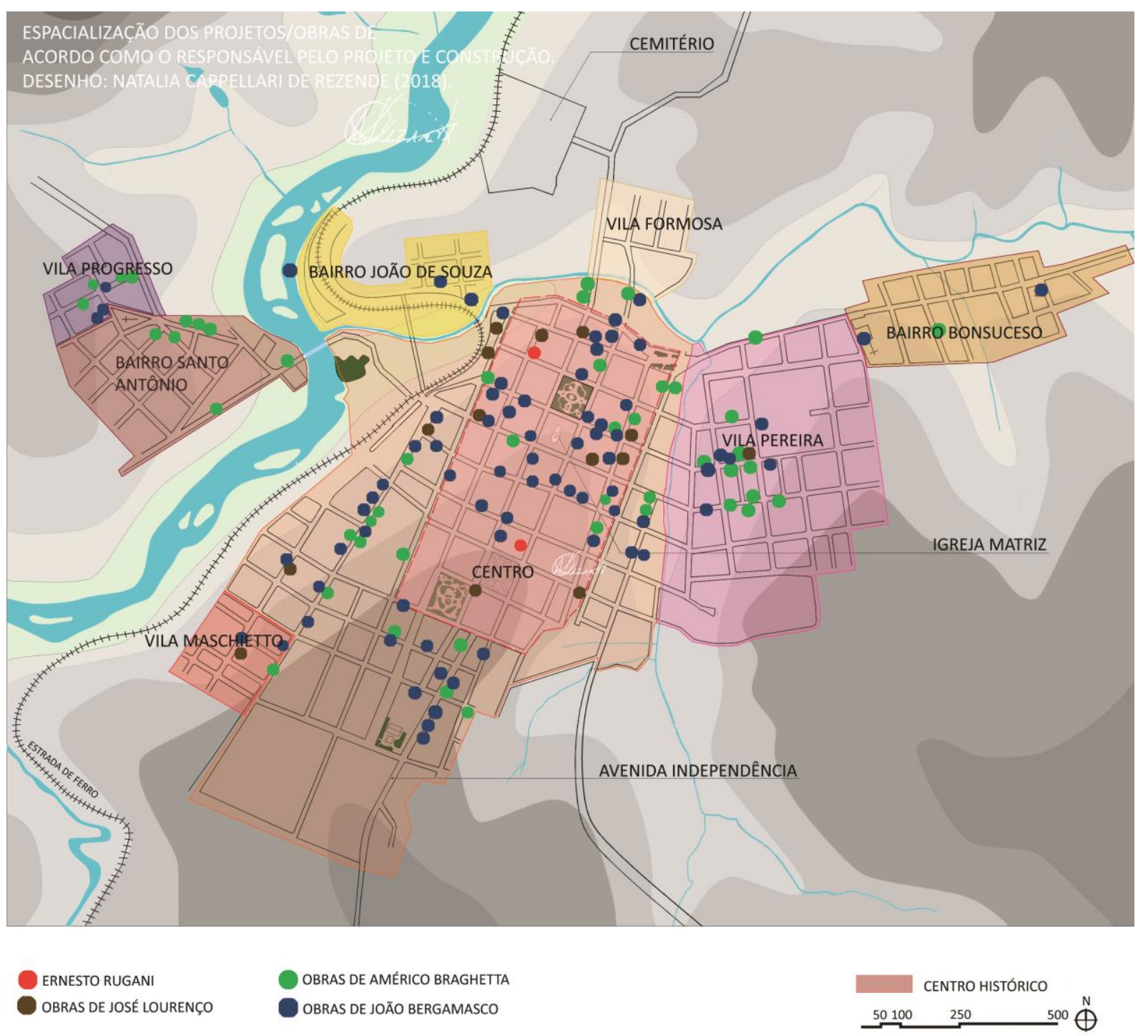

Desenho: Natalia Cappellari de Rezende (2018) com base em dados históricos e cartografia disponibilizada pela Secretaria de Obras de São José do Rio Pardo.

\section{Movimento de migrações}

Ao longo da análise da produção e trajetória dos diversos agentes da construção civil que atuaram em São José do Rio Pardo entre 1918 e 1940, uma questão muito pertinente foi constatada, a forma como ocorreu o processo de migração desses sujeitos. Em se tratando desse movimento, podemos afirmar que o processo de João Bergamasco e Erneto Rugani ocorreu de modo diverso ao de Américo Braghetta, por exemplo. Enquanto este último se estabeleceu em São José do Rio Pardo acompanhado de seus pais, Bergamasco e Rugani vieram para ficar como patriarcas de suas famílias. Mas, apesar dessa diferença e utilizando o conceito de redes em processos migratórios, explorado por Oswaldo Truzzi (2011) com base nas definições 
de Tilly (1978), podemos conjecturar que os deslocamentos das famílias Braghetta, Bergamasco e Rugani podem ser explicados pela categoria de cadeia que é aquela "que envolve o deslocamento de indivíduos motivados por uma série de arranjos e informações fornecidas por parentes e conterrâneos já instalados no local de destino" (TRUZZI, 2011, p. 20). E pode ser ainda explicado pela carreira, ou seja, é a categoria em que "o indivíduo se desloca respondendo a oportunidades de ocupação de postos oferecidos por uma organização a que pertence ou associados a uma profissão que já exerce" (TRUZZI, 2011, p. 20). Em qualquer uma das situações, é possível ter havido interferência de conterrâneos, parentes, amigos e agentes de propaganda na transmissão de informações que alimentaram os deslocamentos. Além disso, na possibilidade de os indivíduos estabelecidos terem se tornado bem-sucedidos acabaram agindo como elemento de atração e facilitador da fixação dos novos ingressantes. De qualquer modo, e conforme advertiu Leite (2000) ao analisar a imigração portuguesa para a América Latina, havia também um fator individual na tomada de decisão. Certamente esse foi o caso de Rugani e Bergamasco para se estabeleceram em São José do Rio Pardo atraídos pela oferta de trabalho na construção civil local. Nesse sentido, sabemos que o fator decisivo para a chegada de Rugani nessa cidade, após passar por Poços de Caldas - MG, foi a construção da infraestrutura de água e também de esgoto que só contemplavam naquele momento uma área restrita e precisava ser expandida. Nesse período, década de 1910, Francisco Escobar era o prefeito de Poços de Caldas e muito possivelmente foi o agente decisivo entre o Ernesto Rugani e a prefeitura de São José do Rio Pardo, uma vez que aqui manteve os laços políticos e de amizade construídos durante a década de 1890 quando esteve à frente da gestão pública municipal como intendente, vicepresidente da Câmera e vereador. Já o caso de João Bergamasco, após casar-se em São José do Rio Pardo com Rosa Cerávolo, filha do marceneiro e carpinteiro Paschoal Cerávolo, volta para a Argentina onde aperfeiçoa seus conhecimentos relacionados à atividade construtiva e retorna às terras rio-pardenses para atuar como empreiteiro e construtor, não mais como pedreiro como foi na sua primeira passagem por essa cidade. Nesse caso, a relação familiar foi determinante para o retorno, uma vez que o relacionamento estava comprometido devido à distância, e ao mesmo tempo, o sogro de Bergamasco era um artífice que exercia atividades concernentes à construção civil, portando conhecedor da exiguidade de agentes atuantes no mercado rio-pardense, o qual seu genro poderia se ocupar com êxito.

Logo, podemos inferir através dos casos de Ernesto Rugani e João Bergamasco que a adoção de uma perspectiva de rede de migração, seja através da categoria de cadeia ou de carreira, foi determinante no enfrentamento dos desafios na nova terra na medida em que se valeram de laços prévios. Contudo, o aspecto mais importante no estabelecimento de ambos como agentes da construção civil rio-pardense foram as relações sociais estabelecidas, e não os atributos profissionais propriamente ditos. A par dessa discussão, a produção arquitetônica rio-pardense entre os anos de 1918 e 1940 foi, sem nenhuma dúvida, resultado da atuação dessas pessoas, responsáveis pela visualidade encontrada hoje - ainda que parcialmente alterada - no Centro Histórico, onde o produto principal foi a moradia urbana, analisada a seguir. 


\subsection{As moradias urbanas construídas entre 1918 e 1940}

A cidade de São José do Rio Pardo no final da década de 1910 e início da década seguinte sofreu uma desaceleração no ritmo de crescimento urbano, reflexo dos impactos negativos causados na economia pela Primeira Guerra Mundial, sobretudo com a retração da exportação cafeeira. Além disso, a interrupção das importações europeias acabou por provocar aumento nos preços dos materiais de construção, impactando a construção civil rio-pardense e causando forte queda no número de prédios construídos no período de 1917 a 1923, conforme atestado nos relatórios do prefeito capitão Mário Rodrigues ${ }^{230}$. Além das limitações de ordem econômica, havia novas imposições da legislação municipal, com a publicação do terceiro Código de Posturas, e também da estadual com o Código Sanitário, ambos sancionados no último ano da Grande Guerra em 1918. Como enfatizado nos itens anteriores, essas novas posturas se tornaram o marco de uma nova etapa, exercendo decisiva influência na produção e adequação das edificações em relação às noções de higiene, já pressupostas nos códigos anteriores, mas acrescidas de referências aos benefícios propiciados pela ação bactericida do sol, o que culminou em efetivas recomendações relativas a implantação, tamanho e orientação das janelas, e também atendimento às novas expectativas de volumetria, programa, técnica construtiva e manifestação estilística. Apesar de serem claras as determinações e o empenho do poder público na melhoria das condições de habitabilidade das construções, as dificuldades econômicas, a escassez e a elevação do custo dos materiais de construção dificultaram o atendimento por parte da população, sobretudo nas reformas e adequações que deveriam ser realizadas nas casas para atender às condições higiênicas, segundo o artigo 399.

Todas as casas que vagarem serão visitadas pela autoridade sanitária, que verificará se offerecem ou não as condições de hygiene para serem habitadas. (Art. 171, lei 1.596).

$\S$ unico. Para o disposto neste artigo, os proprietários ou seus procuradores são obrigados a enviar às Delegacias de Saúde as respectivas chaves, que deverão ser desembaraçadas dentro de três dias úteis. (CÓDIGO SANITÁRIO ESTADUAL, 1918, p. 50).

Desse modo, todas as casas que fossem desocupadas deveriam ser desinfetadas e visitadas pela Delegacia que procederia à averiguação da sua condição de salubridade, e conforme a situação o proprietário seria intimado a realizar as reformas necessárias. Tal atitude levou os jornais locais a publicarem artigos criticando as medidas exigidas que tornaram as reformas verdadeiras reconstruções, como segue o trecho

[...] devem obedecer aos requisitos de concertos, reparos propriamente ditos, pinturas, modificações num ou noutro departamento do prédio, etc. Com relação às reconstruções assim não pensam, por isso que entendem que para reconstruir-se um prédio é preciso deitálo abaixo e fazê-lo todo de novo! Se o Código Sanitario, assim obrigasse os proprietários a fazer, teríamos, por certo, de que a demolição é uma verdade, - que no geral é constituída de prédios que não obedeceram às prescrições Sanitarias. Assim as leis não devem, pincipalmente essas que dizem respeito à hygiene pública ser executadas com tanto rigor, a bem da economia pública e particular, porque nem todos estão em condições de arcar com elas! [...] Fazemos apenas um leve comentário sobre esse assunto em foco - que vae preocupando seriamente a população desta cidade pelas medidas enérgicas empregadas pelo Sr. Inspector Sanitario - que antes de tudo, precisa levar em consideração a classe pobre, os trabalhadores que mal ganham para a sua manutenção e não podem arcar com as medidas

\footnotetext{
${ }^{230}$ Para saber mais detalhes desse relatório, ver página 162
} 
enérgicas e dispendiosas que tem sido empregadas por si. [...] Fazemos esse comentário levados pelo espírito de humanitarismo. É de defesa em prol da causa de todos - em benefício geral. (A HYGIENE, 1923, p. 01).

As diversas dificuldades enfrentadas pela população rio-pardense para atender ao novo Código não eram exclusividade local. Outros municípios paulistas também manifestaram problemática semelhante, como em São Carlos onde o delegado de saúde descreveu a situação em um relatório publicado em 1920 (BORTOLUCCI, 1991). Apesar das adversidades alegadas pelos munícipes são-carlenses, "das 798 intimações feitas até 30 de setembro de 1919, apenas 51 prédios continuavam interditos" (BORTOLUCCI, 1991, p. 218), demonstrando obediência às determinações do Código e reconhecimento das melhorias nas condições de higiene e habitabilidade. Não encontramos nenhum documento semelhante em São José do Rio Pardo que atestasse o número de intimações e prédios interditados, mas sabemos através dos jornais o empenho do delegado local em fazer valer as normas, exigindo alterações em cozinha e banheiro; criação de aberturas para receber ar e luz direta; ventilação do porão; modificações no telhado e instalação de sistema de calhas; impermeabilização dos pisos; pintura e elevação da altura das paredes, o que certamente resultou em muitas moradias impedidas de serem novamente alocadas.

Continua chover intimações e multas, os absurdos se multiplicam, dia para dia! ... Onde vamos desse modo? [...] Chegou em nossas mãos uma das tantas intimações effectuadas nesses últimos 5 dias, cuja intimação é do theor seguinte:

29 de Junho de 1923. Snr. proprietário do Botequim n. 4 da rua Marechal Floriano Peixoto. Não tendo sido cumprida a intimação relativa ao prédio acima, e como essa falta importa numa infracção regulamentar susceptivel de multa, communico-vos, de acordo com o Regulamento Sanitário, que deveis dar cumprimento exacto à mesma dentro de 3 dias afim de evitares que se torne effective a multa. (INSPECTORIA SANITARIA, 1923, p. 02).

Essa situação, somada à problemática da falta de novas construções, persistiu de 1917 até pelo menos 1923 quando o jornal $O$ Rio Pardo publicou um artigo que manifestava a diminuição do número de construções e a carência de moradias.

[...] aqui em S. José, as construcções se tornaram raras, e passam-se mezes, ao que estamos informados, em que a directoria de obras não tem o prazer de approvar uma planta para nova construcção; o mesmo não acontece quanto ao material, porque os oleiros, em número reduzido, somente com reparos de fachadas e modificações internas, dia a dia, quem sabe se movidos pelos seus optimos conhecimentos financeiros, aumentam o preço do material. As casas em S. José estão todas occupadas, e muitas pessoas tem-se visto obrigadas a mudar de cidade, por não encontrar habitações, e essas hoje, são aqui encarecidamente disputadas. [...] se assim continuar, nós teremos que alojar na gruta N. S. de Lourdes, se os que possuem alguns "cobres" adquirem as poucas casas que ainda existem de aluguel! (AS CONSTRUCÇÕES, 1923, p. 01).

Essa reportagem relatava a condição da construção civil de São José do Rio Pardo tendo como referência a capital paulista, que segundo essa mesma publicação,

as construç̧ões em S. Paulo, ao que nos dizem os diários, dia a dia aumentam, tendo a directoria de obras Municipal, mensalmente, uma média de 2000 pedidos de approvação de plantas para novas edificações. Em virtude disso, o tijolo que antes era vendido a razão de $70 \$$ O milheiro, alcançou ultimamente, o preço de 120\$. (AS CONSTRUCÇÕES, 1923, p. 01).

De fato, nesse período, São Paulo já havia recuperado o ritmo de crescimento econômico, apresentando em 1923 mais de 4200 novas licenças de construção, conforme constatado no "diagrama das construções em S. 
Paulo, de 1901 a 1928" elaborado por Arthur Saboya e publicado por Lemos, C. (1989a). Sobre esse fato, Alambert (2003, p. 22) ressalta que no inicio da década de 1920 a capital foi "retomando o seu nível de urbanização acelerada e iniciando o processo de metropolização". Contexto bastante diverso de São José do Rio Pardo e de São Carlos (BORTOLUCCI, 1991) onde a escassez de moradia se tornou um problema sério. É intrigante notar que, apesar dessa falta, não houve uma proliferação de habitações coletivas como os cortiços. Certamente isso se deve ao Código de Posturas (1918, p. 14), que exigia licença e ainda proibia a existência dentro do perímetro urbano, conforme os artigos a seguir:

Art. 88 - Não serão admittidas installações de hotéis, collegios, hospitaes, ou outras casas collectivas, sem previa licença da Prefeitura.

Art 89 - Requerida a licença, o Prefeito mandará que a repartição competente proceda um rigoroso exame e verifique as condicções hygienicas do local e do prédio projectado ou adaptado, se estão ou não de accordo com as disposições do Codigo Sanitário do Estado, concedendo ou denegando a licença.

Art. 90 - É absolutamente prohibido no perímetro central da cidade, ainda mesmo no interior dos terrenos particulares, a construção de cortiços ou cabiculos. (CÓDIGO DE POSTURAS, 1918, p. 13-14).

Apesar dessa normativa e de não termos encontrado nenhuma informação textual que mencionasse a existência de cortiço no perímetro urbano, Maschietto (2016) nos afirmou a existência de duas habitações coletivas na Rua Ruy Barbosa. Possivelmente, a fiscalização não era tão eficiente, ou simplesmente dissimulava a realidade dada à escassez de moradia, todavia, ainda assim a propagação desse tipo de habitação não fez parte da realidade local.

A tentativa de assegurar higiene, solidez e aspecto das casas e consequentemente da paisagem urbana foi uma constante na cidade, mesmo em momentos de crise como a do início dos anos 1920. O novo Código de 1918 ratificou as posturas anteriores que determinavam caiação e pintura dos prédios, acrescentando a necessidade de os mesmos serem rebocados exteriormente, para posterior recebimento da pintural à cal ou à óleo.

Art. 58 - Todos os prédios da cidade, arrabaldes ou povoações do Município serão exteriormente pintados e caiados, de dois em dois annos, durante o mez de março. Este prazo será contado a partir do mez de março do anno de 1917.

Art. 59 - Os prédios pintados a óleo terão a pintura renovada quando esteja descorada ou estragada.

Art. 60 - Na cidade, arrabaldes e povoações do Município, todos os prédios serão rebocados, exteriormente, além de pintados ou caiados.

Art. 61 - O proprietário que não cumprir as determinações dos artigos antecedentes, será multado em $40 \$ 000$.

Art. 62 - Uma vez imposta a multa será novamente o proprietário intimado por edital, para no prazo de 30 dias cumprir a obrigação, e não a cumprindo, o Executivo mandará executar o serviço, cobrando as despesas que se fizer com o accrescimo de $20 \%$ a título de administração. Esta cobrança será feita pelos meios ordinários. (CÓDIGO DE POSTURAS, 1918, p. 10-11).

Tal fato foi veementemente criticado pelo jornal Resenha que julgou a determinação ser uma vaidade estética dada a necessidade de caiação somente da fachada e também em contraposição à condição sanitária precária que a cidade apresentava. 
Preste bem atenção leitor, só a fachada. Cousa tradicional do systema de fachada. Não se trata de medida hygienica, porem de boniteza de fachada! O Governo Municipal obriga sob pena de multa quem não obedecer caiar a frente de sua casa. [...] O mais interessante é que os homens do poder Municipal, querem aparecer com cousas bonitas a custa alheia [...] Que se quer é exterioridade e não se faz conta que a hygiene soffra consideravelmente; que as ruas estejam em estado lastimável e todas esburacadas; que o lixo da limpeza pública apodreça no ponto mais pintoresco da cidade e bem em frente à estação da Mogyana; que o mesmo lixo é conduzido com um systema o mais nojento e indecente, ao ponto de o público tapar o nariz, tal é a fedentina que exala. Que o povo é obrigado a urinar nas paredes e portas das casas por falta de um mictório; que a água do Sapecado continue a fazer as suas victimas! Tudo é exagero, não passam de coisinhas de nenhuma importância perante a exterioridade e boniteza das fachadas das casas bem caiadinhas! (COUSAS ABSURDAS, 1924, p. 02).

No final do ano de 1924, esse mesmo jornal publicou uma reportagem sobre as novas construções no prolongamento das principais ruas da cidade, denotando uma retomada do crescimento da atividade civil com a produção de moradia. Eram casas modestas e luxuosas, construídas conforme exigido no artigo 20 do Código de 1918, ou seja, a uma distância de quatro metros do alinhamento do lote com a via pública, criando com isso uma paisagem distinta se comparada com o que era produzido anteriormente. Além disso, as novas construções sofreram mudanças significativas, algumas ainda inspiradas na heterogeneidade do ecletismo, conforme apresentaremos ao longo da análise das moradias desse período, e outras nas características da arquitetura neocolonial ${ }^{231}$ ou ainda tendendo ao bangalô e ao art-déco que se afirmaram em São José do Rio Pardo a partir da década de 1930, alinhada com o contexto de transformações que estavam ocorrendo desde o final dos anos 1910 em São Paulo (LEMOS, C., 1989a) e mais tarde no Rio de Janeiro (PINHEIRO, 2011; KESSEL, 2008; AMARAL, 1994). Na Figura 324 é possível observar moradias com estilemas da arquitetura neocolonial ${ }^{232}$, construídas entre o final da década de 1920 e 1930, e uma casa eclética do início dos anos 1910.

Figura 324: Vista parcial da Rua Costa Machado com a Rua Treze de Maio (posteriormente denominada de Avenida Deputado Eduardo Vicente Nasser), década de 1940.

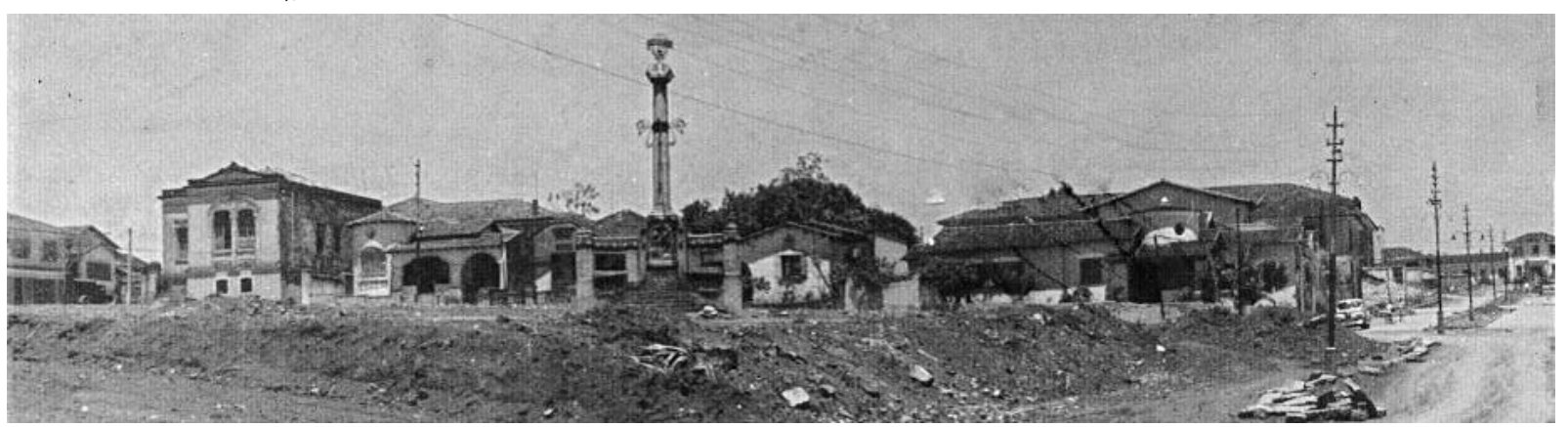

Fonte: Arquivo do Centro da Memória Rio-Pardense Rodolpho José Del Guerra.

\footnotetext{
${ }^{231}$ Segundo Atique (2007, p. 272), "o termo 'neocolonial' foi criado para se referir ao movimento de produção arquitetônica cujas matrizes estavam, supostamente, na antiga condição colonial das diversas repúblicas americanas, consideradas, via de regra, como detentoras da 'essência primária' dos países do continente americano". Já Pinheiro (2011, p. 288) esclarece que o neocolonial "configurase como uma corrente tradicionalista por excelência, o que, longe de significar uma postura passadista ou imobilizante, não só admite como preconiza a constante transformação - porém, de forma modulada e gradual”. Para saber mais sobre isso ver Kessel (2008), Pinheiro (2011) e Segawa (2014)

${ }^{232}$ Foi na década de 1910 e 1920 que discursos por uma arquitetura nacionalista ganharam força em São Paulo e no Rio de Janeiro após ser lançada, por Ricardo Severo em 1914, as bases do movimento que ficou conhecido como neocolonial. Mas, destacamos que não faz parte desse trabalho analisar as motivações teóricas e conceituais desse movimento, e sim evidenciar os desdobramentos práticos presentes na arquitetura residencial de São José do Rio Pardo. Para saber mais sobre o movimento, os debates acirrados e o estilo neocolonial, ver autores que discutiram o assunto, como Lemos, C. (1989a), Amaral (1994), Atique (2007), Kessel (2008), Mascaro (2008) e Pinheiro (2011).
} 
A partir da regulamentação do Código de Posturas de 1918, artigo 38, toda construção e reconstrução deveria necessariamente ser aprovada pela municipalidade mediante solicitação prévia através de um requerimento feito pelo interessado. Esse documento (Figura 325) careceria do acompanhamento das plantas do terreno e pavimentos da edificação, das elevações, dos cortes longitudinais e transversais, e também da disposição dos encanamentos de água e esgoto ${ }^{233}$, exigência inédita que passou a ser válida para as atividades que ocorressem exclusivamente dentro do perímetro urbano e suburbano (Figura 326). Nos chama a atenção no requerimento que ilustramos a seguir a agilidade de tramitação, apenas três dias, o que certamente se deve a uma preocupação de incentivar a atividade civil em um ano (1930) de abalo econômico. Outra questão que observamos no despacho se refere à descrição de obra "em bairro fora da cidade", em endereço correspondente à Vila Pereira, localizada na área suburbana, conforme a delimitação estabelecida pelas posturas, como é possível observar no mapa da Figura 327. Essa obrigatoriedade de apresentação e consequente aprovação de projetos evidencia o controle que o setor público passou a desempenhar sobre a atividade de construção civil.

Figura 325: Requerimento de licença para construir.

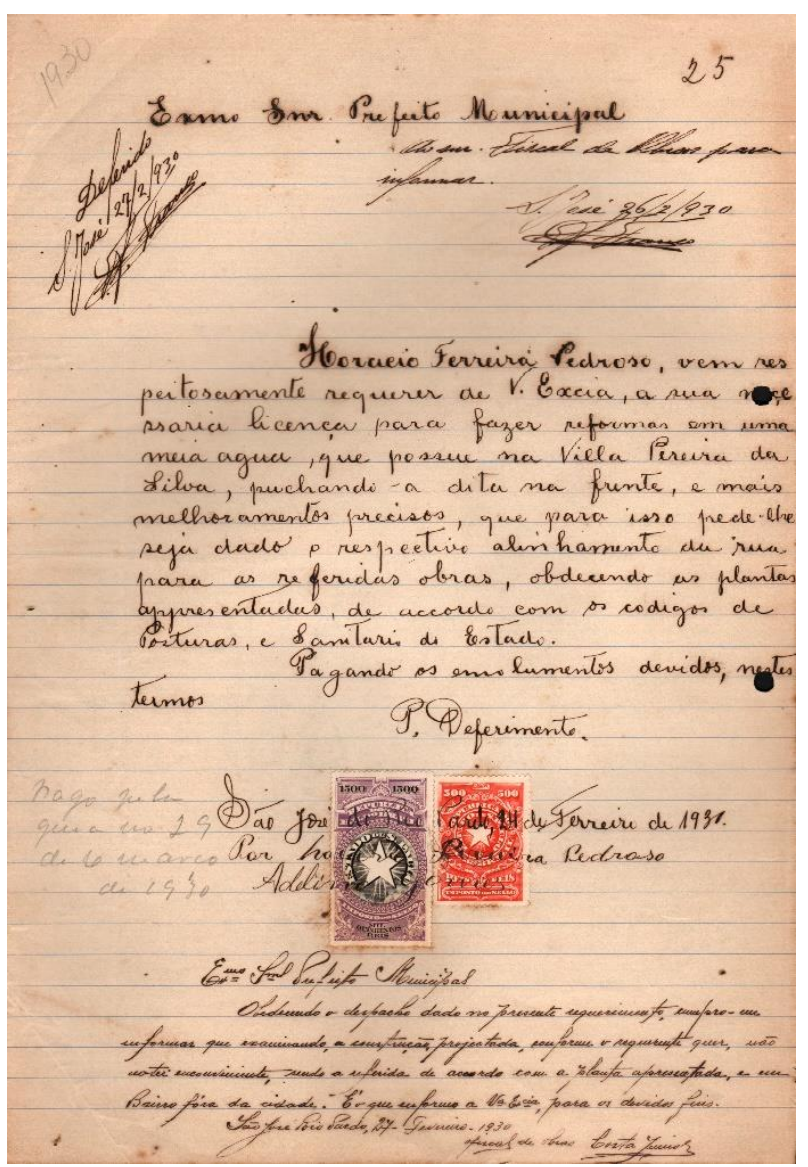

Fonte: Hemeroteca Paschoal Artese.
Figura 326: Projeto da moradia de Horacio Ferreira Pedroso na Vila Pereira, São José do Rio Pardo.

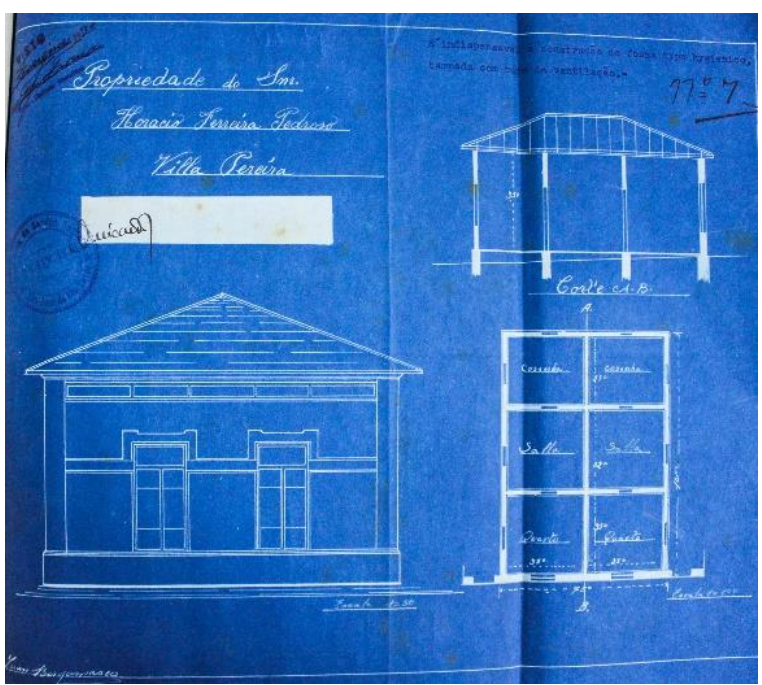

Fonte: Arquivo Público da Secretaria de Obras de São José do Rio Pardo (1930, P10).

\footnotetext{
${ }^{233}$ Os requerimentos foram encontrados sem nenhum tipo de catalogação no Arquivo da Hemeroteca Jornalista Paschoal Artese, portanto desvinculados dos projetos originais que pertencem ao Arquivo Público da Secretaria de Obras de São José do Rio Pardo.
} 
Figura 327: Perímetro urbano e suburbano de São José do Rio Pardo conforme Código de Posturas de 1918.

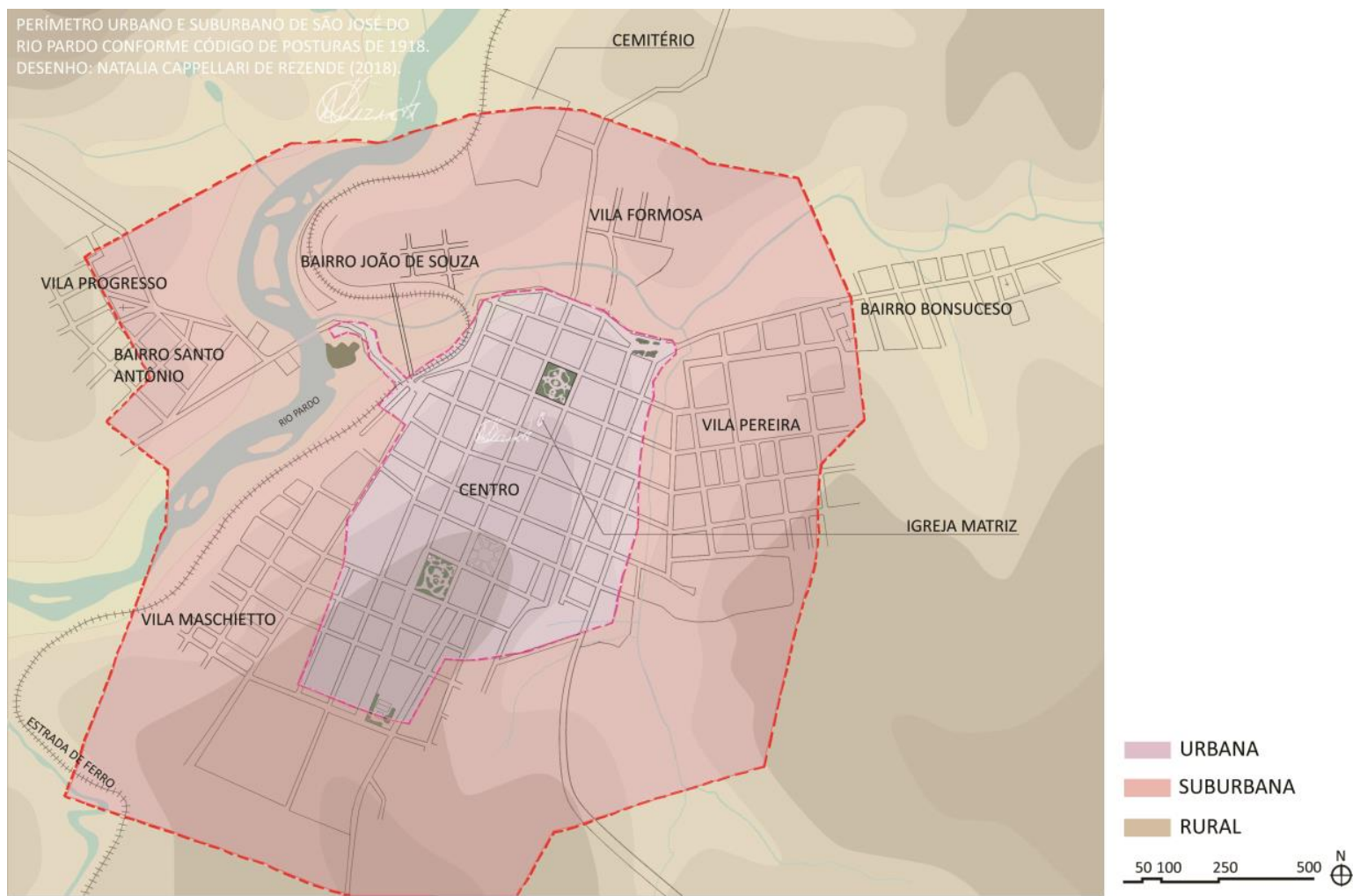

Desenho: Natalia Cappellari de Rezende (2018) com base em dados históricos e cartografia disponibilizada pela Secretaria de Obras de São José do Rio Pardo.

Como o objetivo é compreender o quadro arquitetônico residencial, suas mudanças e permanências na cidade de São José do Rio Pardo entre 1918 e 1940, utilizaremos vários exemplares, com especial atenção para a moradia de João Gabriel Ribeiro ${ }^{234}$ na Rua João Gabriel Ribeiro, 196 (Figura 328); das casas de Willian Simonsen ${ }^{235}$ na Rua Benjamin Constant, 344-354 (Figura 329) e de Ciro Ferraz na mesma Rua, 18A (Figura 330); Messias Candido Ribeiro ${ }^{236}$ na Praça XV de Novembro, 152 (Figura 331); de Maria da Conceição Damasio $^{237}$ na Rua Benjamin Constant, 228 (Figura 332) e o sobrado de Benedicto Amaral ${ }^{238}$ na Rua Ruy Barbosa, 381 (Figura 333). Todas essas habitações pertenceram a famílias abastadas que usufruíram dos privilégios de morar nas proximidades da igreja Matriz e nas principais ruas do Centro, como é possível observar as localizações no mapa (Figura 334).

\footnotetext{
${ }^{234}$ João Gabriel Ribeiro atuou ativamente na política rio-pardense, sendo prefeito entre os anos de 1926 e 1929 e entre 1960 e 1963 . Sua moradia, construída em 1924, foi adquirida de um português que possuía terras em São José do Rio Pardo.

${ }^{235}$ Willian Simonsen pertencia a uma família de ingleses que imigraram para o Brasil e se instalaram em São José do Rio Pardo no início do século XX. Sua família era proprietária de um grande armazém de café localizado na esquina da Rua Francisco Glicério com a Rua José Andreóli. Simonsen atuava como comprador de café conforme registrado no Almanack de 1929.

236 Messias Candido Ribeiro Nogueira era filha de Venerando Ribeiro da Silva Filho e Luzia Delphina Dias, uma família tradicional riopardense que tinha como principal atividade econômica a exportação de café. Messias casou-se com João Ribeiro Nogueira Sobrinho em 1877 (Del Guerra, 2005b). Para saber mais sobre essa família, ver nota 179, página 210

${ }^{237}$ De acordo com a lista de impostos sobre o café de 1898(IMPOSTO..., 1899, p. 03), a família Damasio era proprietária de terras de produção de café. Segundo Del Guerra (2003), Maria da Conceição Damasio exerceu a profissão de professora do Grupo Escolar Cândido Rodrigues.

${ }^{238}$ Benedicto Amaral era formado em odontologia e atuava em São José do Rio Pardo, conforme registrado no Almanack de 1929
} 
Figura 328: Desenho da fachada da moradia de João Gabriel Ribeiro, Rua João Gabriel Ribeiro, 196 (1924).

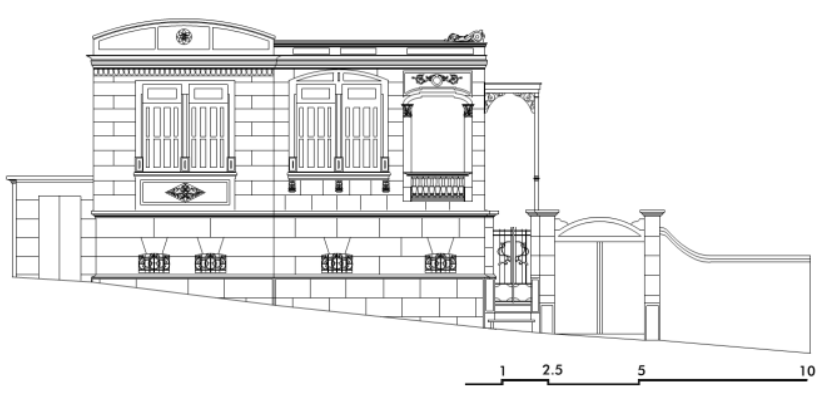

Desenho: Natalia Cappellari de Rezende (2017), conferido in loco.

Figura 330: Desenho da fachada da moradia de Ciro Ferraz, Rua Benjamin Constant, 18A (1926).

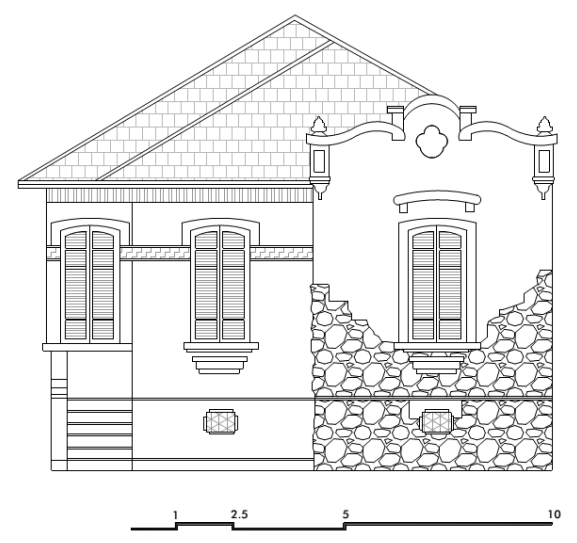

Fonte: Arquivo Público da Secretaria de Obras de São José do Rio Pardo (1926, P11). Desenho: Natalia Cappellari de Rezende (2016).

Figura 332: Desenho da fachada da moradia de Maria da Conceição Damasio, Rua Benjamin Constant, 228 (1934).
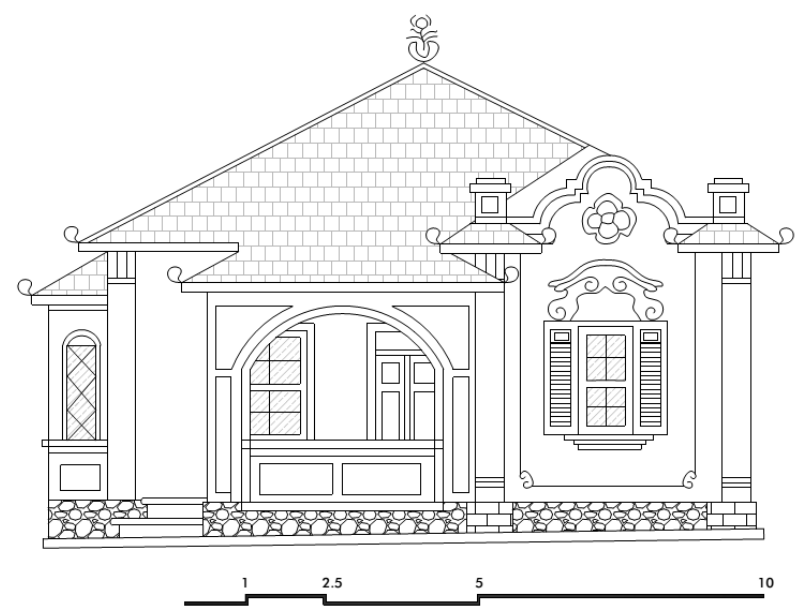

Fonte: Arquivo Público da Secretaria de Obras de São José do Rio Pardo (1934, P10). Desenho: Natalia Cappellari de Rezende (2016).
Figura 329: Desenho da fachada das casa de Willian Simonsen, Rua Benjamin Constant, 354 (1925).

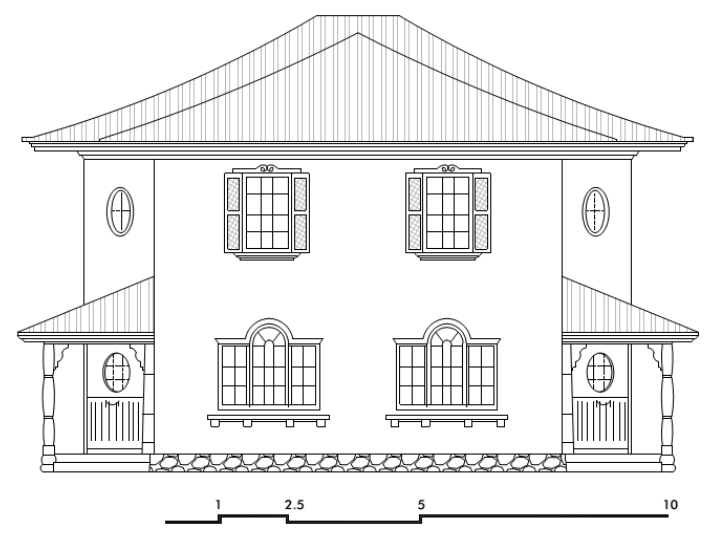

Fonte: Arquivo Público da Secretaria de Obras de São José do Rio Pardo (1925, P06). Desenho: Natalia Cappellari de Rezende (2016).

Figura 331: Desenho da fachada da moradia de Messias Candido Ribeiro, Praça XV de Novembro, 152 (1929).

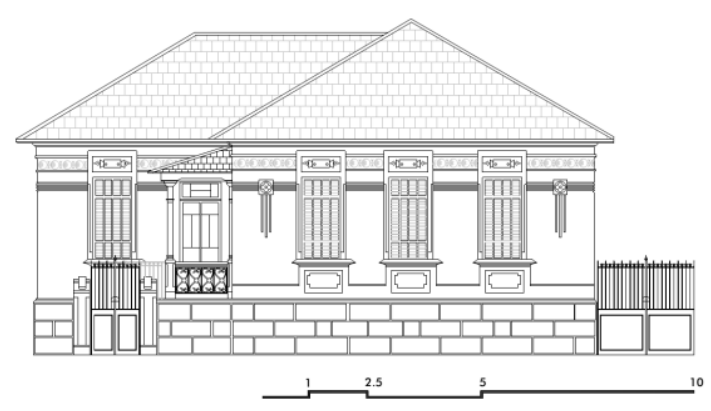

Fonte: Arquivo Público da Secretaria de Obras de São José do Rio Pardo (1929, P16). Desenho: Natalia Cappellari de Rezende (2016).

Figura 333: Desenho da fachada da moradia de Benedicto Amaral, Rua Ruy Barbosa, 381 (1936).

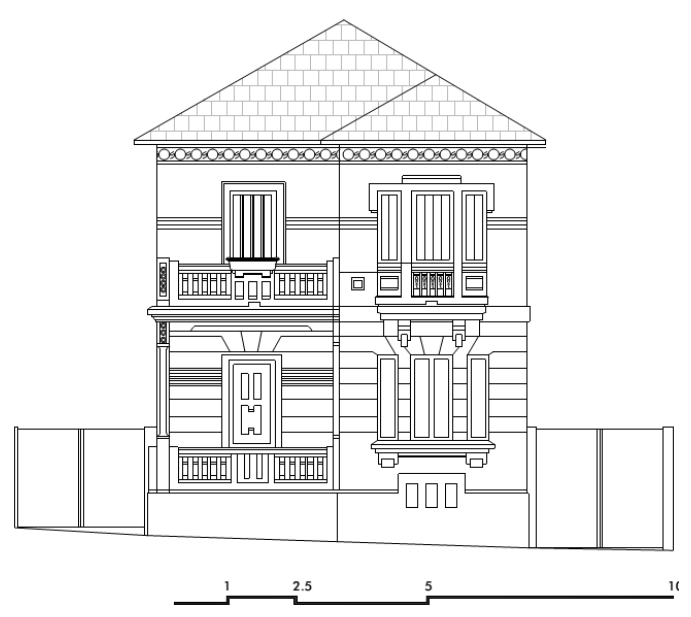

Fonte: Arquivo Público da Secretaria de Obras de São José do Rio Pardo (1936, P25). Desenho: Natalia Cappellari de Rezende (2016). 
Figura 334: Localização dos exemplares de moradias construídas em São José do Rio Pardo entre 1918 e 1940.

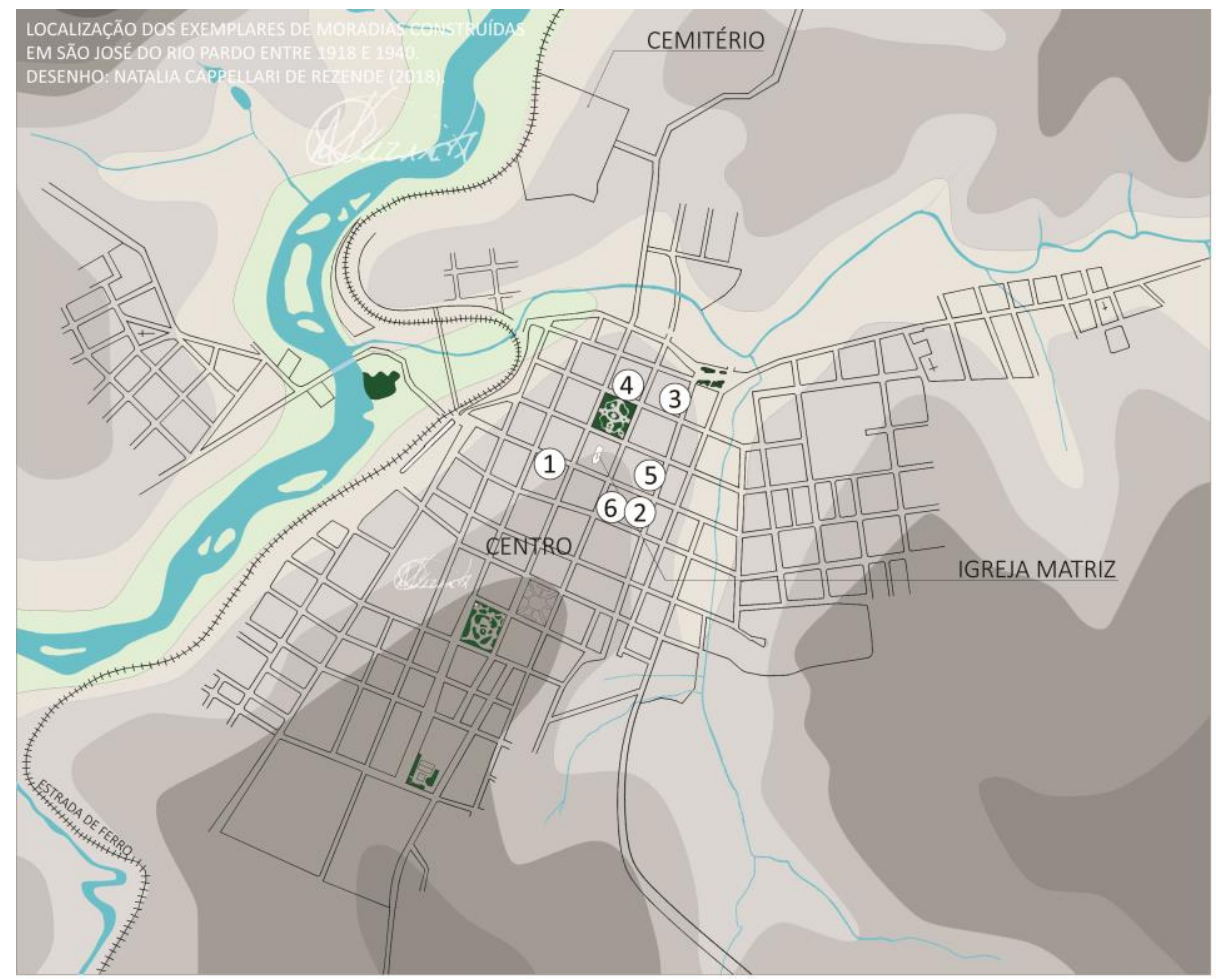

(1) JOÃO GABRIEL RIBEIRO
(2) WILLIAN SIMONSEN
(3) CIRO FERRAZ
(4) MESSIAS CANDIDO RIBEIRO
(5) MARIA DA CONCEIÇÃOO DAMASIO
(6) BENEDICTO AMARAL
50 $100 \quad 250 \quad 500$

Desenho: Natalia Cappellari de Rezende (2018) com base em dados históricos e cartografia disponibilizada pela Secretaria de Obras de São José do Rio Pardo.

Nas residências construídas a partir de 1918, a implantação é uma das características analisadas que foi sendo alterada e marcou a transformação da arquitetura desse período em relação aos anteriores. Apesar do Código de Posturas de 1918 não exigir afastamentos da edificação em relação aos limites do lote e determinar que toda obra fosse alinhada e nivelada de acordo com as definições dadas pela prefeitura, facultava às construções que fossem executadas no interior do terreno a ausência de pedidos de alinhamentos, mas desde que respeitassem a distância mínima de quatro metros da linha de arruamento. Já o Código Sanitário Estadual (1918) foi mais incisivo na definição da implantação, volumetria e orientação das aberturas das edificações ao reconhecer os benefícios da ação bactericida do sol (LEMOS, C. 1999), as quais foram incorporadas no Código Arthur Saboya em 1934. Este último Código foi responsável por estabelecer novas condições de afastamento ao definir recuos mínimos - frontais, laterais e de fundo - que deveriam ser atendidos pelas construções particulares. Desse modo, a legislação foi determinante na configuração de um padrão de implantação que se tornou mais usual em São José do Rio Pardo nesse período (Figura 335). Há ainda outra questão levantada por Homem (1996) ao se referir a implantação da casa isolada no lote que era a noção de intimidade e o desejo de conforto dos seus moradores. Estava ainda relacionado ao modo de se viver difundido pelo movimento Arts and Crafts e adotado, por consequência nos bangalôs, que representava um retorno à natureza a partir de uma adequação do edifício ao seu entorno, possibilitado pelas dimensões generosas do lote (PINHEIRO, 2011; JANJULIO, 2009). 
Figura 335: Exemplos de edificações implantadas afastadas dos limites do lote.

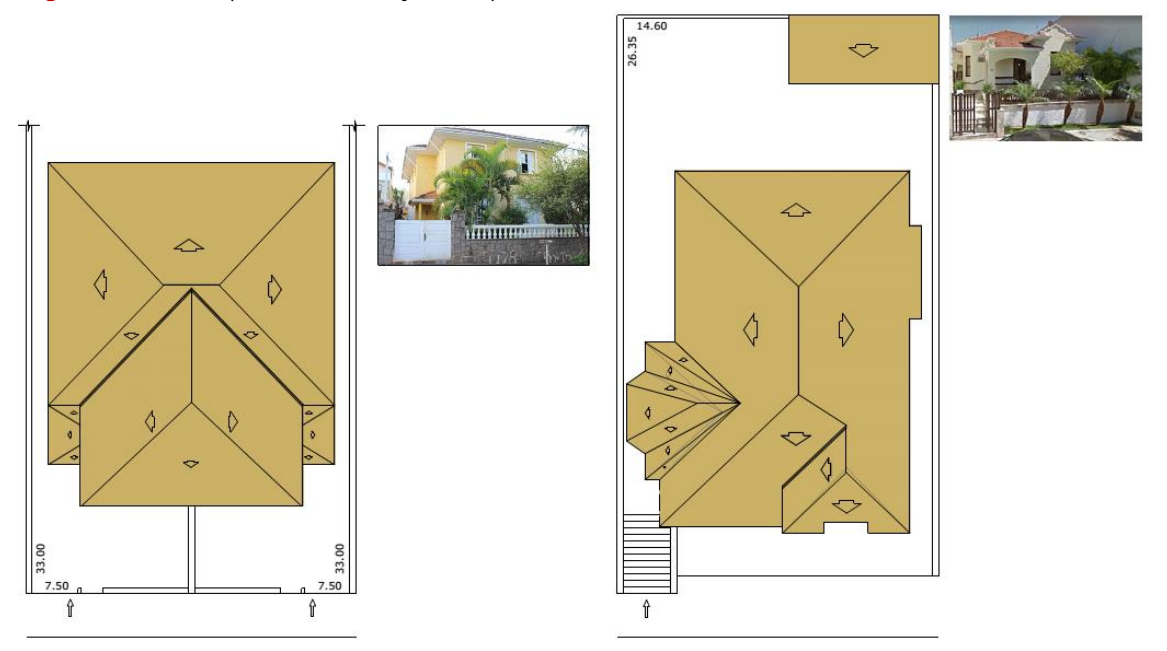

Rua

Rua

WILLIAN SIMONSEN

$\theta^{2}$

MARIA DA CONCEIÇÃO DAMASIO

$\imath^{\ominus}$

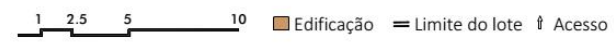

Fonte: Arquivo Público da Secretaria de Obras de São José do Rio Pardo. Desenho: Natalia Cappellari de Rezende (2018).

Mas apesar da clara tendência de construir a edificação isolada no lote, verificamos a existência de permanências, como as moradias de Benedicto Amaral, Messias Candido Ribeiro e de João Gabriel Ribeiro, que foram construídas no alinhamento do terreno com a via pública (Figura 336).

Figura 336: Exemplos de edificações implantadas no limite do lote.

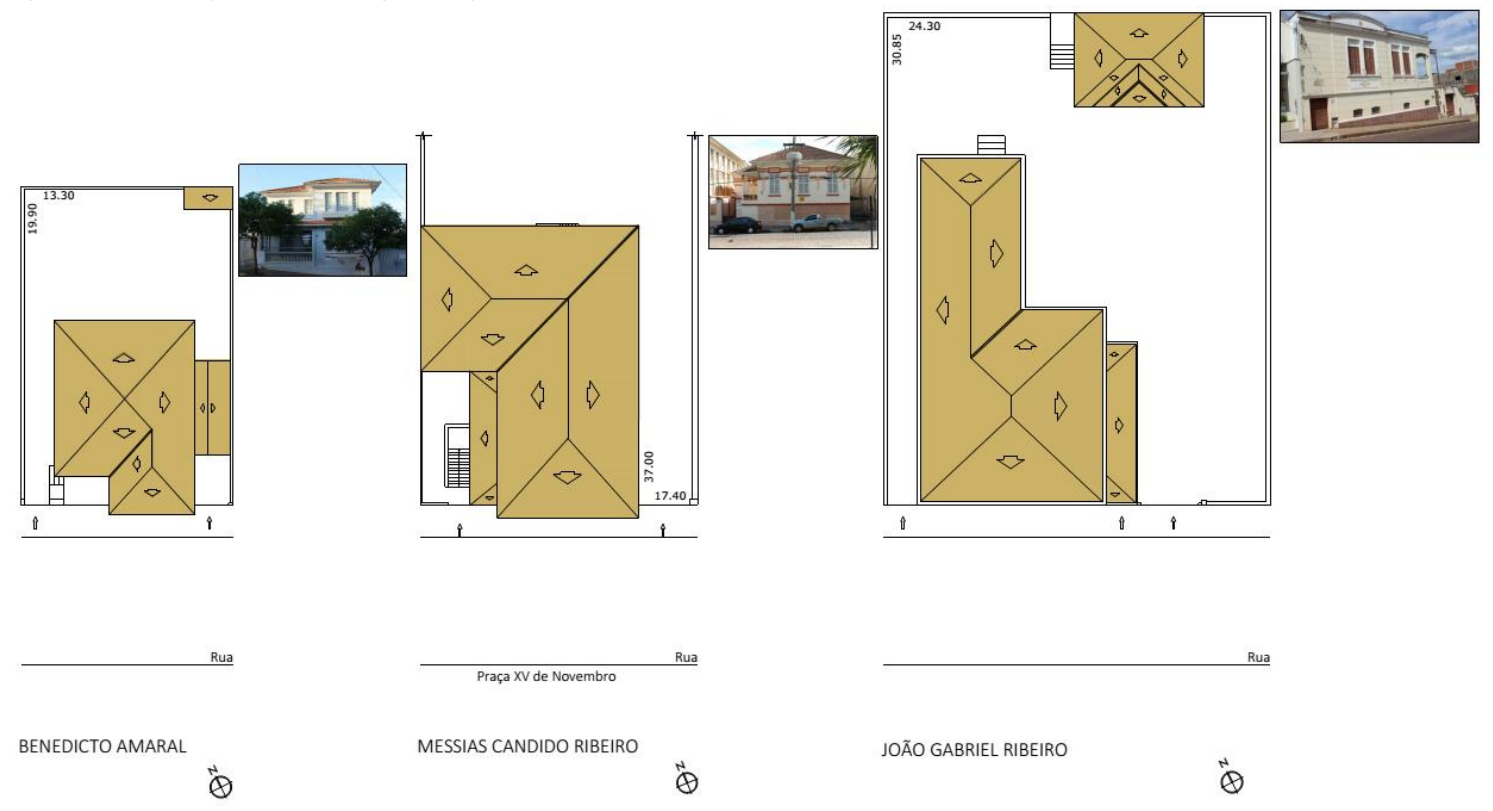

12.5510 Edificação $=$ Limite do lote $\uparrow$ Acesso

Fonte: Arquivo Público da Secretaria de Obras de São José do Rio Pardo. Desenho: Natalia Cappellari de Rezende (2018). 
Afora a heterogeneidade no modo de implantação da construção no lote urbano, ressaltamos o paralelismo apresentado pelas residências menores e mais simples e também pelas mais sofisticadas em relação às configurações do lote, aspecto evidenciado por Reis Filho (2011, p. 71) ao afirmar a manutenção desse predomínio na cidade de São Paulo, entre as décadas de 1920 a 1940, "ainda que os lotes apresentassem, em média, maiores dimensões".

Outra questão importante e que determinou o modo de implantação das edificações localizadas nas esquinas das quadras foi o artigo 22 do Código de Posturas que estabeleceu a aresta em ângulo de $45^{\circ}$, ou a sua disposição em curva regular, considerada uma solução na melhoria da visibilidade das vias, o que supostamente conferiria ao tráfego maior segurança após a difusão do automóvel ${ }^{239}$, como apontado no item anterior desse capítulo e exemplificado pela moradia da Rua Benjamin Constant com a Rua Júlio Mesquita, 576 (Figura 337), e da Rua Silva Jardim com a também Rua Júlio Mesquita, 506 (Figura 338). Apesar da norma valer apenas para aquelas construções que fossem levantadas no limite do lote com a via pública, tornou-se corrente, mesmo que fosse apenas nos muros da divisa, a aresta chanfrada, que foi aproveitada para posicionar o portão de acesso social, conforme as edificações das ruas Costa Machado com a Francisco Glicério, 592 (Figura 339), e da Rua Benjamin Constant com a Marechal Floriano, 189 (Figura 340). Ocorrência semelhante foi encontrada em Caconde (Figura 341 e Figura 342) e em Guaxupé (Figura 343 e Figura 344), ainda que nessas cidades não foi possível relacionar a configuração apresentada com a legislação em vigor na ocasião.

Figura 337: Moradia da Rua Benjamin Constant com a Rua Júlio Mesquita, 576 (1918)

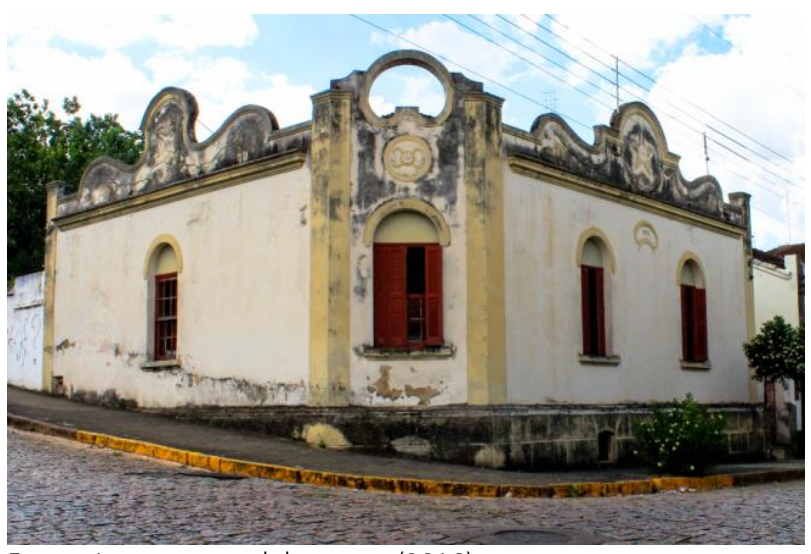

Fonte: Acervo pessoal da autora (2016).
Figura 338: Moradia da Rua Silva Jardim com a também Rua Júlio Mesquita, 506 (1923).

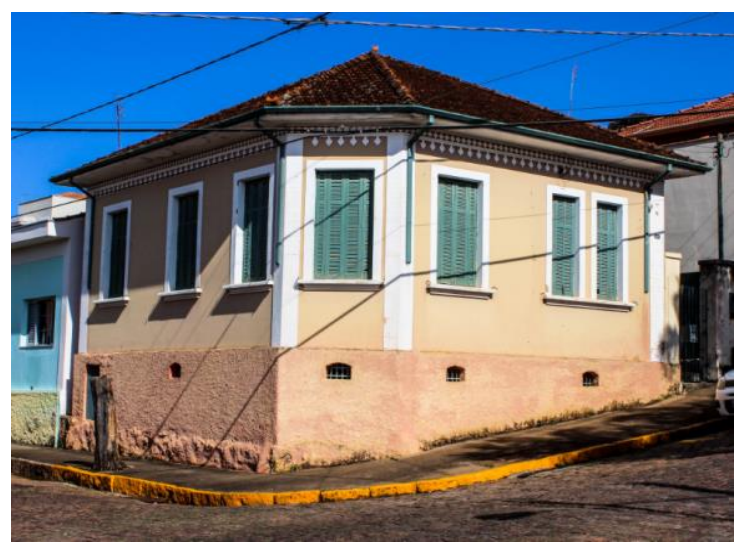

Fonte: Acervo pessoal da autora (2016).

\footnotetext{
239 Segundo Atique (2007, p. 118) citando Szmereczániy (2003), “o carro, o caminhão, os ônibus produzidos em massa, e vendidos a crédito, foram postos ao alcance de médias poupanças ou ganhos medíocres, funcionando como um pequeno capital ao serem explor ados comercialmente, assim satisfazendo a ânsia de elevação social dos imigrantes e migrantes internos. De outro ângulo, a circulação automotiva, com todas suas exigências infra-estruturais faz parte de um projeto econômico e político que, como foi indicado, já está em pleno andamento nos anos de governança de Washington Luís (1916-1930) cujo lema mais conhecido foi 'governar é abrir estradas' (de rodagem)".
} 
Figura 339: Moradia da Rua Costa Machado com a Rua Francisco Glicério, 592 (década de 1910).

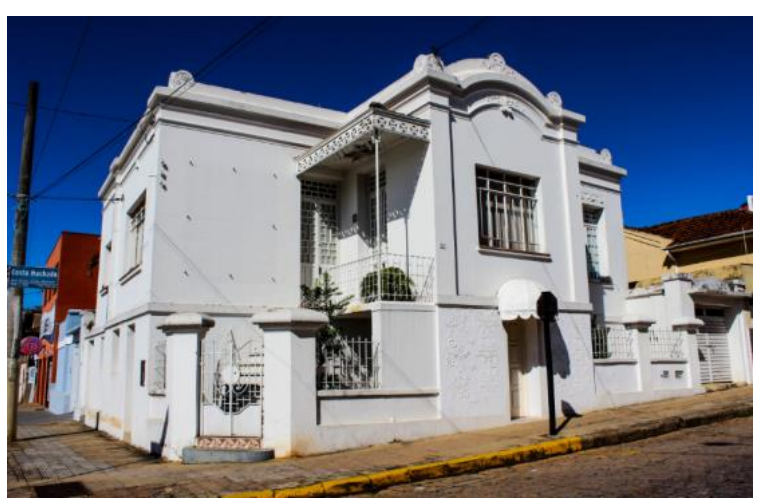

Fonte: Acervo pessoal da autora (2016).

Figura 341: Moradia da Rua Dr. Pedro de Toledo com a Rua Floriano Peixoto, 343, Caconde.

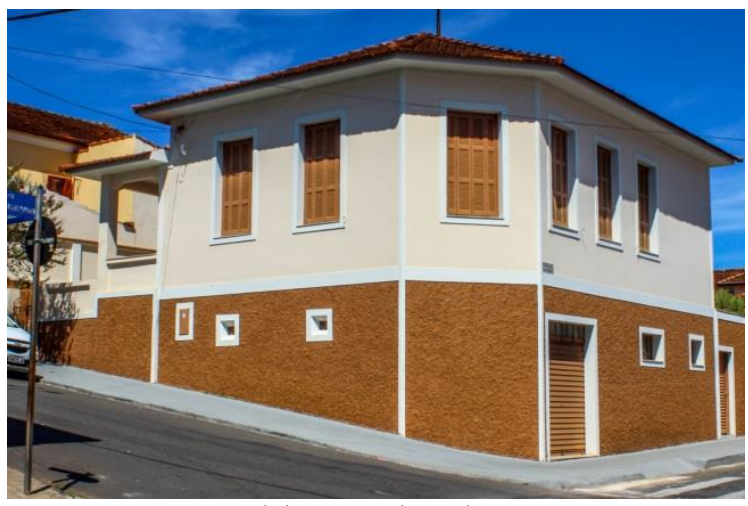

Fonte: Acervo pessoal da autora (2018).

Figura 343: Moradia da Rua Coronel Antônio Costa com a Rua Francisco Ribeiro do Valle, 05, Guaxupé.

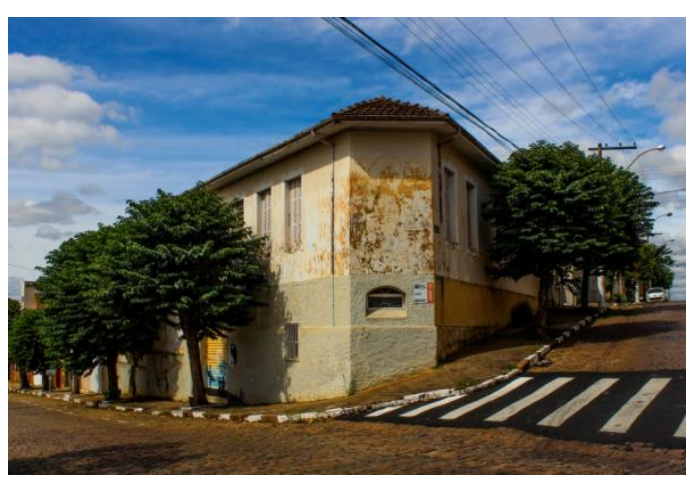

Fonte: Acervo pessoal da autora (2018).
Figura 340: Moradia da Rua Benjamin Constant com a Marechal Floriano, 189 (1929)

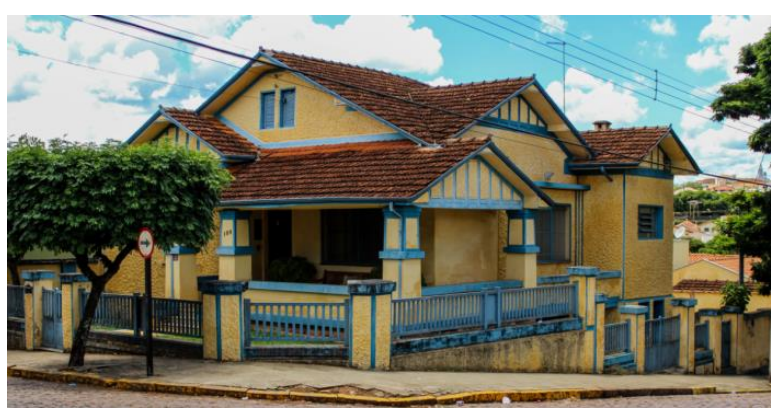

Fonte: Acervo pessoal da autora (2016).

Figura 342: Moradia da Rua Benjamin Constant com a Rua Vinte e Quatro de Dezembro, 98, Caconde.

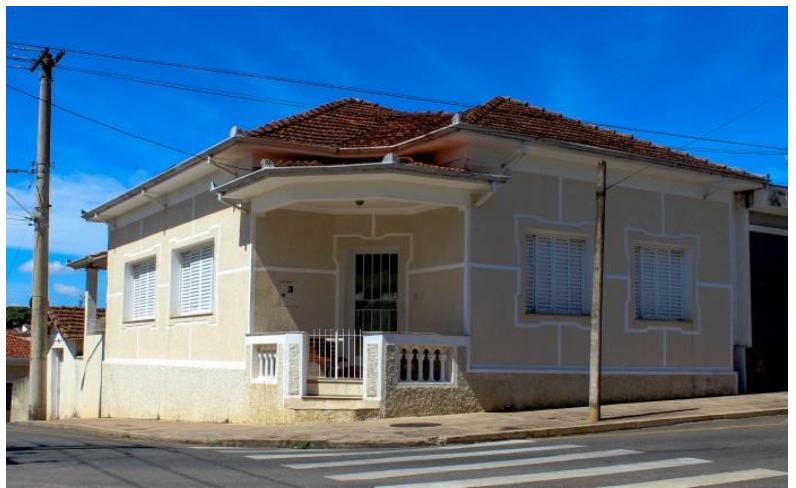

Fonte: Acervo pessoal da autora (2018)
Figura 344: Moradia da Rua Capitão Eugênio com a Rua Norberto Ribeiro do Valle, 130, Guaxupé.

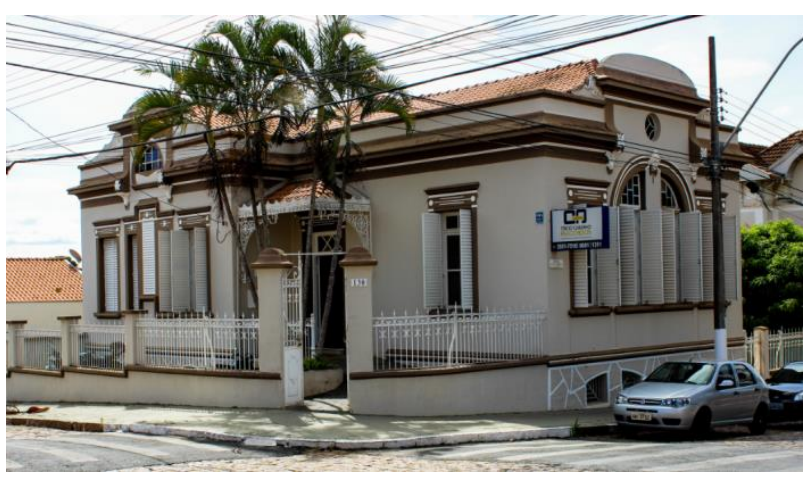

Fonte: Acervo pessoal da autora (2018).

Com os afastamentos da edificação dos limites do lote, popularizou-se a mureta baixa com fechamento em madeira ou ferro rebitado como elemento de separação entre o espaço público e o esaço privado, permitindo, ao mesmo tempo, a visualização da construção sem grandes interferências e equilibrando a aparência compacta das vias até então delimitadas pelas edificações nas testadas dos lotes. Com isso, 
verificamos uma variedade de desenhos compondo uma paisagem de maior dinamicidade, observada até os dias de hoje, como podemos observar nas Figura 345 a Figura 348.

Figura 345: Moradia da Rua Coronel Marçal, 260 (1945).

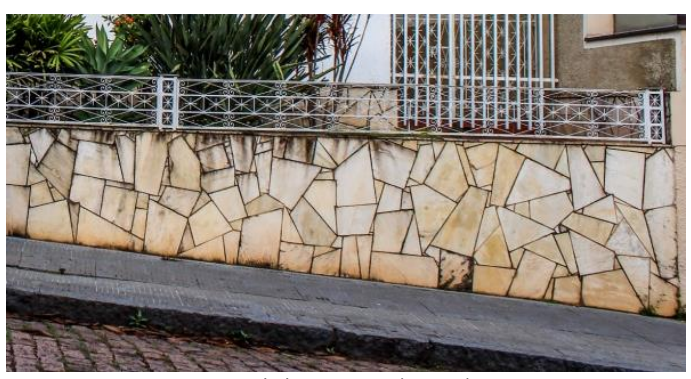

Fonte: Acervo pessoal da autora (2016).

Figura 347: Moradia da Rua Benjamin Constant, 344 (1925).

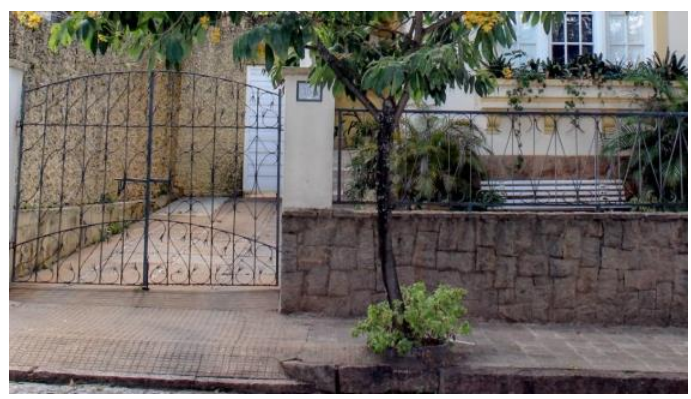

Fonte: Acervo pessoal da autora (2016).
Figura 346: Moradia da Rua Treze de Maio com a Rua João Gabriel Ribeiro, 285 (década de 1930).

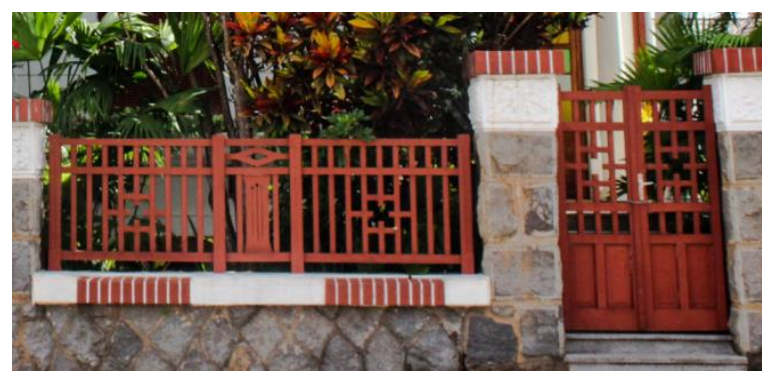

Fonte: Acervo pessoal da autora (2016). 1940).

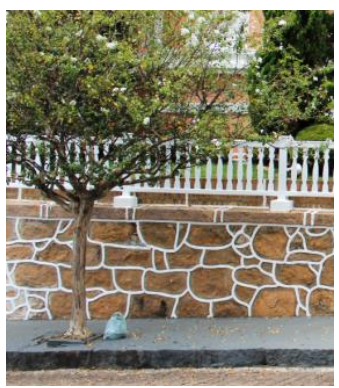

Fonte: Acervo pessoal da autora (2016)

Além das exigências legais que contribuíram na transformação da implantação das edificações, a difusão do automóvel tornou a garagem um espaço

Figura 349: Construção de garagem aproveitando o desnível do terreno na moradia da Rua Silva Jardim, 337.

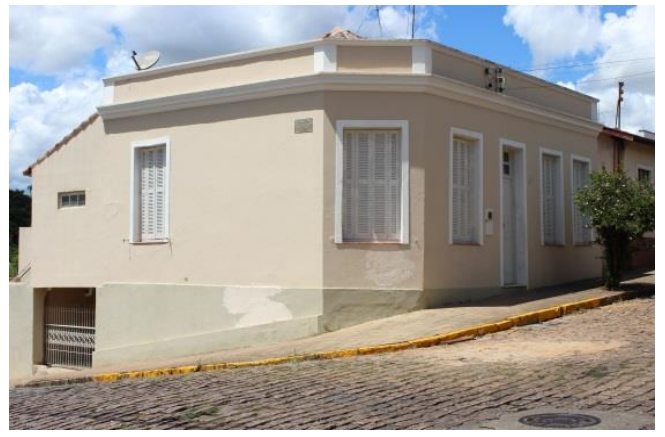

Fonte: Acervo pessoal da autora (2016). residência, assim como a inserção de garagem aproveitando o desnível do terreno como é possível observar na Figura 349.

Sobre a inclusão da garagem, Reis Filho (2011, p. 74) descreve que entre os anos de 1920 e 1940, tanto nas casas populares como nas da classe média e dos mais abastados, verificou-se a ocorrência do afastamento 
lateral "com três a cinco metros de largura, correspondendo à passagem de automóvel, evidenciada pela respectiva cobertura, saliente no corpo da casa". Segundo Alambert (2003, p. 99), nas moradias paulistanas os espaços destinados

\begin{abstract}
à guarda e proteção dos automóveis ficavam localizadas geralmente no fundo dos lotes. O acesso até as garagens era feito através de uma estreita passagem lateral; nas casas geminadas duas a duas, tipologia residencial muito comum naquele período, este corredor situava-se ora à esquerda, ora à direita, conforme a posição da habitação. Em geral as garagens possuíam dimensões suficientes apenas para o abrigo do carro da família; porém, em alguns casos de casas de classe média alta e de palacetes ocorriam edículas de dois pavimentos, com garagem, oficinas e instalações de lavagem de roupa no térreo e apartamentos para o motorista (ou "chauffeur", como se dizia antigamente) e/ou criadagem no pavimento superior. (ALAMBERT, 2003, p. 99).
\end{abstract}

A descrição de Reis Filho (2011) e a complementação de Alambert (2003) retratam de maneira bastante semelhante o que estava acontecendo em São José do Rio Pardo, onde identificamos a presença de passagem lateral destinada ao veículo, sem cobertura, e nesse caso evidenciada pelo portão externo e a guia rebaixada (Figura 350); extensão da cobertura do telhado da edificação principal para a respectiva proteção do automóvel (Figura 351); uma edificação destinada especificamente para abrigar o automóvel (Figura 352); e uma edícula de dois pavimentos com garagem, oficina e apartamento para o motorista e criadagem nos fundos do lote (Figura 353).

Figura 350: Passagem lateral destinada a veículo na moradia da Rua Benjamin Constant, 344-354 (1925).

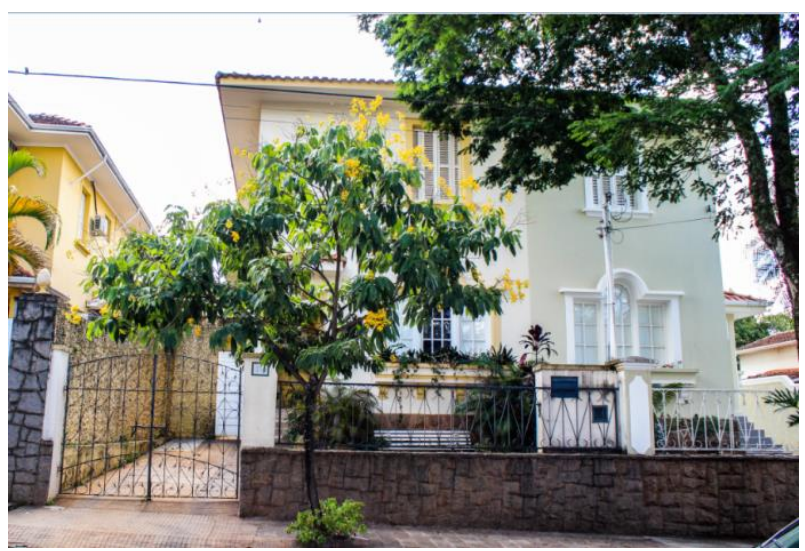

Fonte: Acervo pessoal da autora (2016).
Figura 351: Garagem coberta pela extensão do telhado da edificação principal na moradia da Praça dos Três Poderes, 24.

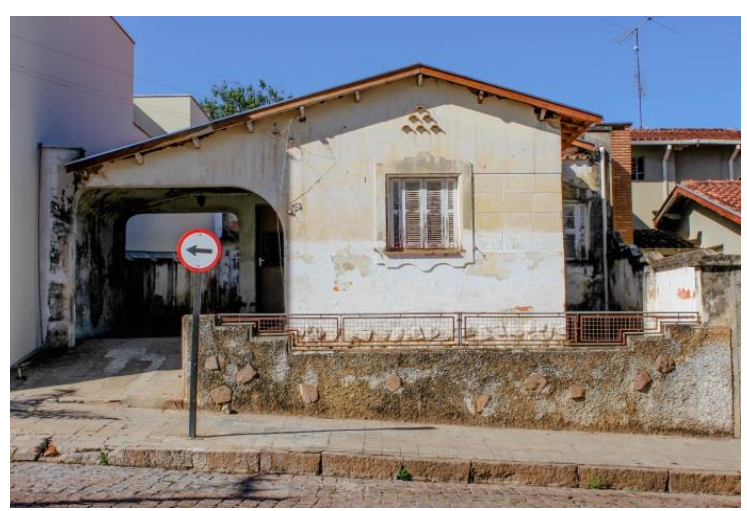

Fonte: Acervo pessoal da autora (2016) 
Figura 352: Abrigo (indicado pela seta preta) destinado especialmente para automóvel na moradia da Rua Ruy Barbosa, 381 (1936).

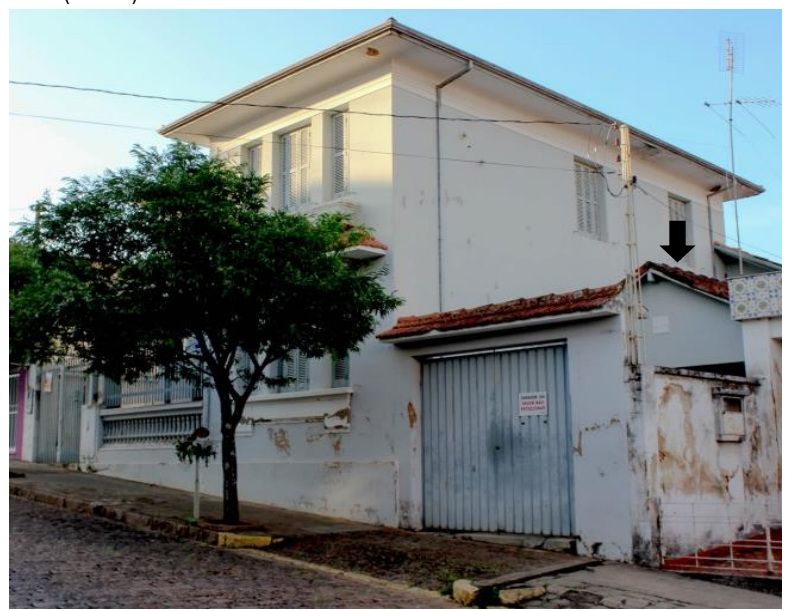

Fonte: Acervo pessoal de Rodolpho José Del Guerra.
Figura 353: Edícula (indicado pela seta preta) destinada a garagem, oficina e apartamento para $\mathrm{o}$ motorista e criadagem na moradia da Rua João Gabriel Ribeiro, 196 (1924).

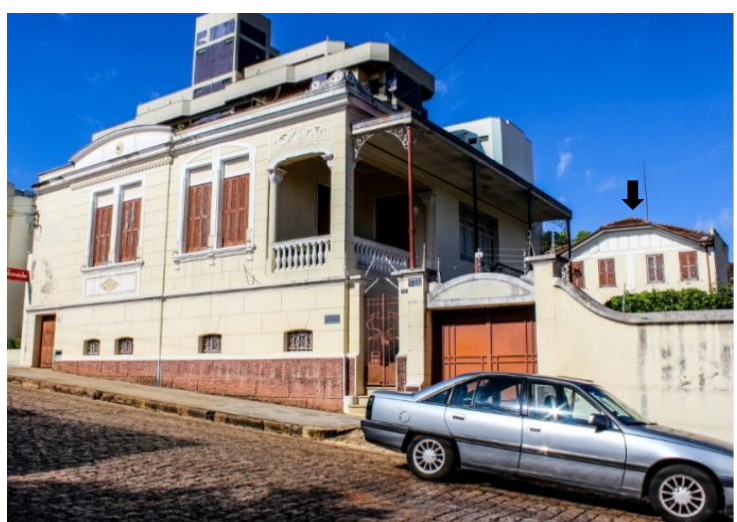

Fonte: Acervo pessoal da autora (2016).

Figura 354: Desenho da planta da moradia de Ciro Ferraz na Rua Benjamin Constant, 18A (1926).

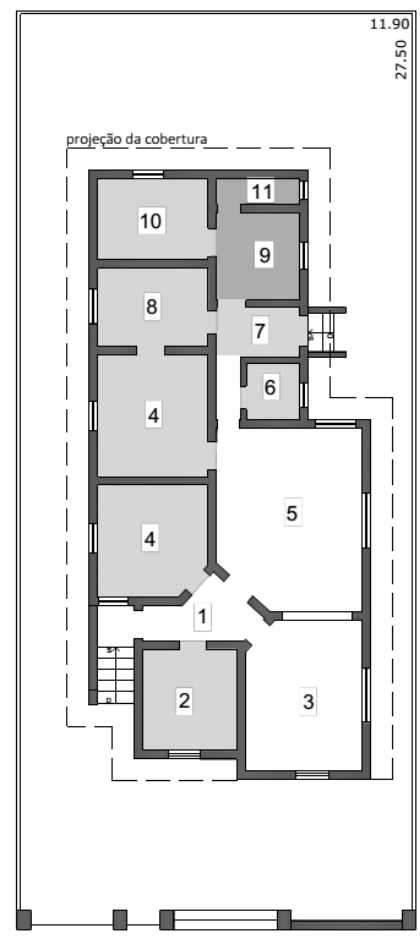

1 Vestíbulo

2 Quarto de visita

3 Sala de Visita

4 Quarto

5 Sala de Jantar

$6 \mathrm{WC}$

7 Copa

8 Banheiro

9 Cozinha

10 Quarto da empregada

11 Despensa

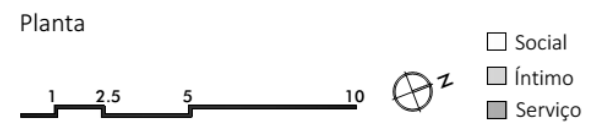

Fonte: Arquivo Público da Secretaria de Obras de São José do Rio Pardo (1926, P11). Desenho: Natalia Cappellari de Rezende (2016). 
característico do movimento Arts and Crafts e adotado, por consequência nos bangalôs. (PINHEIRO, 2011; JANJULIO, 2009).

Apesar de concordarmos com as análises desenvolvidas por Alambert (2013, p. 97) ao destacar que o "vestíbulo provocou o desaparecimento progressivo do esquema tradicional adotado nas residências populares desde os tempos de colônia ${ }^{241 ",}$, fazemos algumas ressalvas, sobretudo quando tratado da sala de jantar que integrada à sala de visita se manteve como o centro de interesse e passagem interna obrigatória em direção aos ambientes localizados na parte posterior da edificação. É nessa região da casa que se situa a área de serviço, reduzida ao mínimo, assim como o banheiro e o dormitório (denominado de quarto) da empregada, mas apresentando dimensões próximas às dos demais.

A disposição das aberturas em várias paredes de um mesmo cômodo e em direções variadas garantiu a ventilação e iluminação natural além de proporcionar o desfrute da área externa.

Outra novidade que se firmou na moradia da classe média rio-pardense no período entre 1918 e 1940 foi a copa. A exemplo da moradia de Ciro Ferraz, esse ambiente, situado próximo à cozinha, se configurou como um espaço de transição entre a zona de estar, o banheiro completo e as dependências de serviço posicionados no fundo da habitação. Diferentemente do que aconteceu na moradia de Maria da Conceição Damasio (Figura 355), localizada também na Rua Benjamin Constant, 228, onde a copa se estabeleceu como centro de interesse da casa no lugar da sala de jantar, indo ao encontro do exposto por Lemos, C. (1978),

tem origem erudita e foi copiada dos projetos maiores surgidos a partir da presença de arquitetos inovadores a serviço da elite. Era uma dependência que nossa arquitetura colonial, ou do Império não conhecera direito.

Figura 355: Desenho da planta da moradia de Maria da Conceição Damasio na Rua Benjamin Constant, 228 (1934).
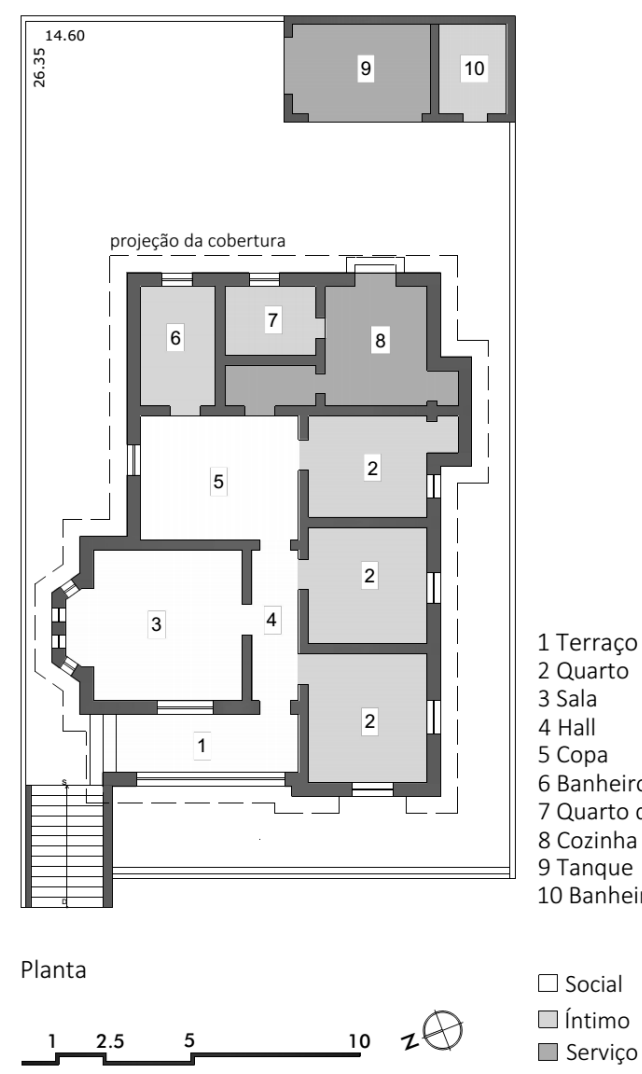

Fonte: Arquivo Público da Secretaria de Obras de São José do Rio Pardo (1934, P10). Desenho: Natalia Cappellari de Rezende (2016).

\footnotetext{
241 Segundo Alambert (2013, p. 97) a casa popular do tempo da colônia era "caracterizada pela sala de jantar ou "varanda", que representava o centro de interesse da moradia e era passagem obrigatória em direção à cozinha e aos dormitórios (ou alcovas)"
} 
Portanto, a copa da casa vulgar foi inspirada na do palacete importante constituindo exemplo de influência de cima para baixo, do particular para o geral, do rico para o pobre [...] assim, surgiu mais uma zona de estar na casa paulista, enquanto a velha varanda foi desaparecendo, inclusive o uso da palavra, firmando-se a expressão "sala de jantar". A copa tornou-se o local de estar preferido da família de classe média. (LEMOS, C., 1978, p. 149).

Em uma mesma realidade temporal da descrita por Lemos, C. (1978), essa moradia rio-pardense representa as mudanças que estavam ocorrendo no período, ou seja, a tendência de alterar o esquema tradicional de organização dos ambientes a fim de garantir mais privacidade, especialmente àqueles destinados ao repouso, e maior integração entre as áreas de estar, e entre o interior e exterior da edificação através de aberturas e janelas envidraçadas. Outro elemento que contribui nesse quesito é o alpendre ${ }^{242}$. 0 aproveitamento dos espaços dessa moradia é evidente no interior dos ambientes, como podemos perceber, por exemplo, através dos recuos nas paredes para serem ocupados com armários e móveis, ilustrando as transformações que estavam ocorrendo também no modo de morar.

Apesar da tendência de isolamento da edificação no lote e do desuso do porão, verificamos a existência de permanências, como na residência de Messias Candido Ribeiro na Praça XV de Novembro, 152 (Figura 356), e de João Gabriel Ribeiro na Rua de mesmo nome, 196 (Figura 357), ambas implantadas no limite do terreno com a via pública.

Todavia, na moradia de Messias Candido Ribeiro há um esforço de integração entre o alpendre, a sala de visita e a sala de jantar, e destas com a copa, quase que constituindo uma área contínuo. Não há perda de espaço com corredores internos e todos os dormitórios da família são acessados através das salas. Já na casa de João Gabriel Ribeiro não há a mesma integração, apesar de a sala de visita estar em comunicação direta com o alpendre, que conforme nos informou leda Ribeiro ${ }^{243}$, era utilizado para apreciar a paisagem, de onde conseguiam avistar as áreas localizadas na porção oeste do núcleo central. A perda de espaço com corredores é mínima e o banheiro junto à cozinha demonstra a otimização no uso das instalações hidráulicas.

É oportuno destacar a quebra da monotonia com a criação de espaços pitorescos como o jardim - que era caprichosamente cuidado pela esposa de João Gabriel - a pérgula coberta com vegetação e árvores frutíferas e os canteiros de flores, outra questão ligada ao Arts and Crafts e ao bangalô, como podemos observar na Figura 358.

\footnotetext{
${ }^{242}$ Observamos nos projetos arquivados na Secretaria de Obras de São José do Rio Pardo que o espaço que antecede a entrada principal da moradia foi denominado ora de alpendre ora de terraço.

${ }^{243}$ Ieda Ribeiro, nora de João Gabriel Ribeiro, é a atual proprietária da casa localizada na Rua João Gabriel Ribeiro, 196. 
Figura 356: Desenho da planta da moradia de Messias Candido Ribeiro na Praça XV de Novembro, 152 (1929).

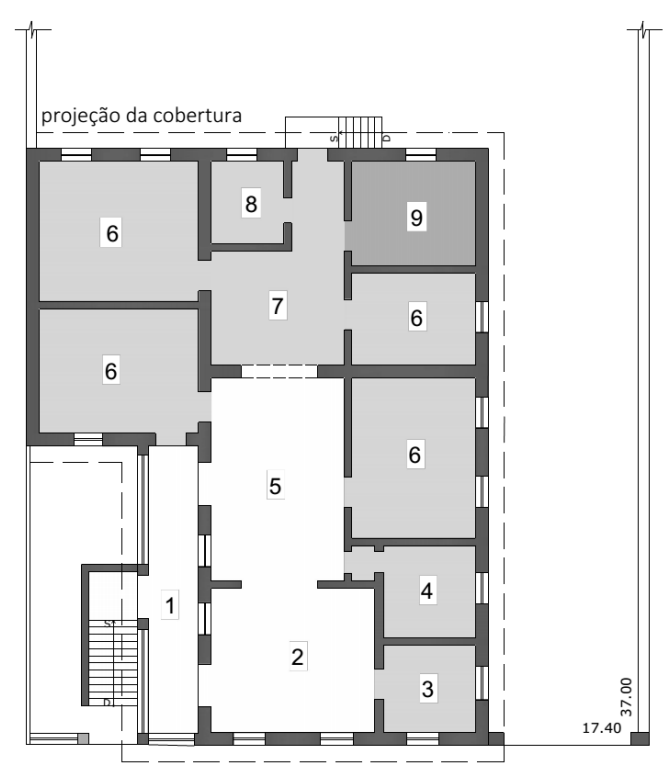

Térreo

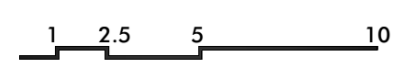

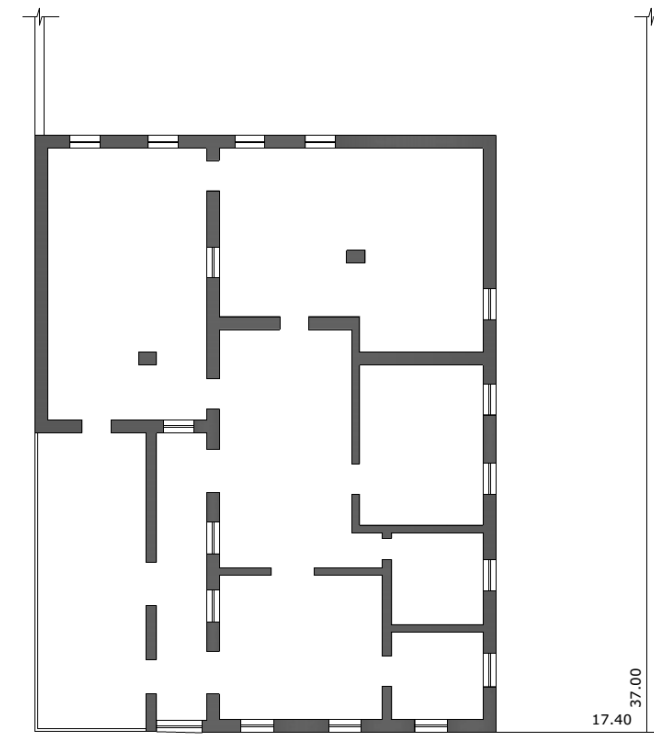

Porão

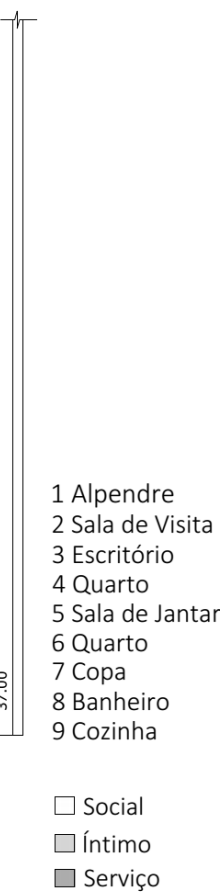

Fonte: Arquivo Público da Secretaria de Obras de São José do Rio Pardo (1929, P16). Desenho: Natalia Cappellari de Rezende (2016).

Figura 357: Desenho da planta da moradia de João Gabriel Ribeiro na Rua de mesmo nome, 196 (1924).

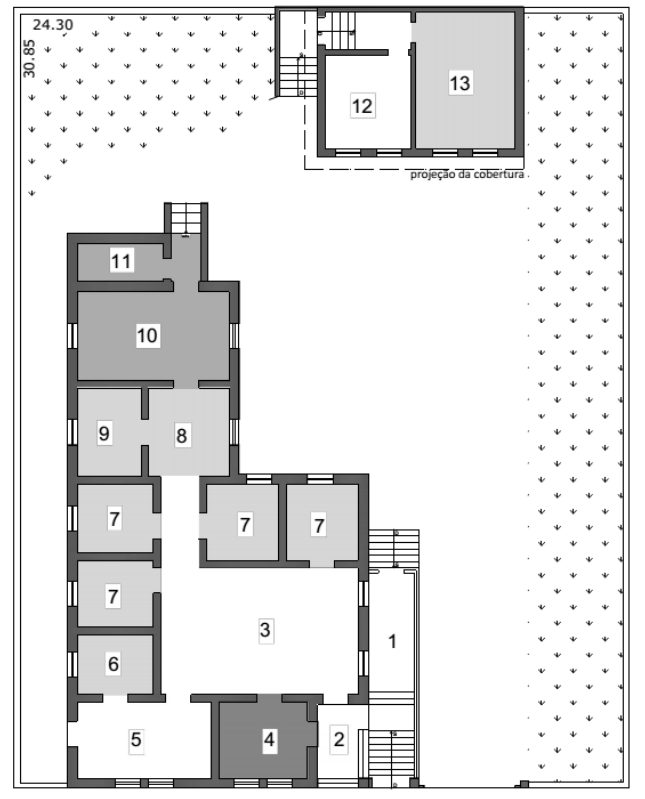

Térreo

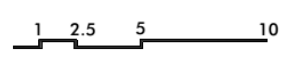

$\ddot{\oplus}$

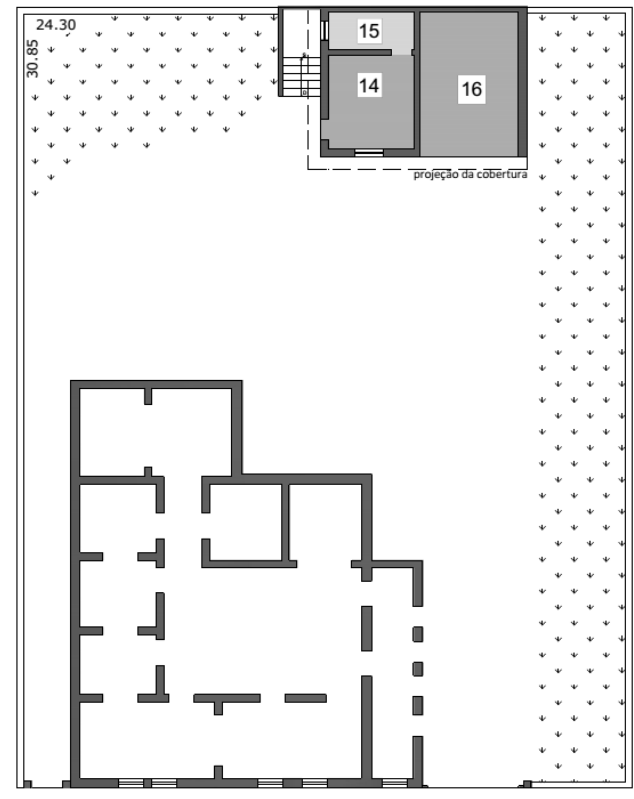

Porão

2 Terraço

3 Sala de Jantar

4 Escritório

6 Quarto de vestir

7 Quarto

8 Copa

9 Banheiro

10 Cozinha

11 Despensa

12 Sala

13 Quarto dos empregados

14 Serviço

15 Banheiro dos empregados

16 Garagem

$\square$ Social

$\square$ Íntimo

$\square$ Serviço

Fonte: Desenho de Natalia Cappellari de Rezende (2016), conferido in loco. 
Figura 358: Jardim, pérgula coberta com vegetação e frutíferas e os canteiros de flores da moradia de João Gabriel Ribeiro (1924), 2017.
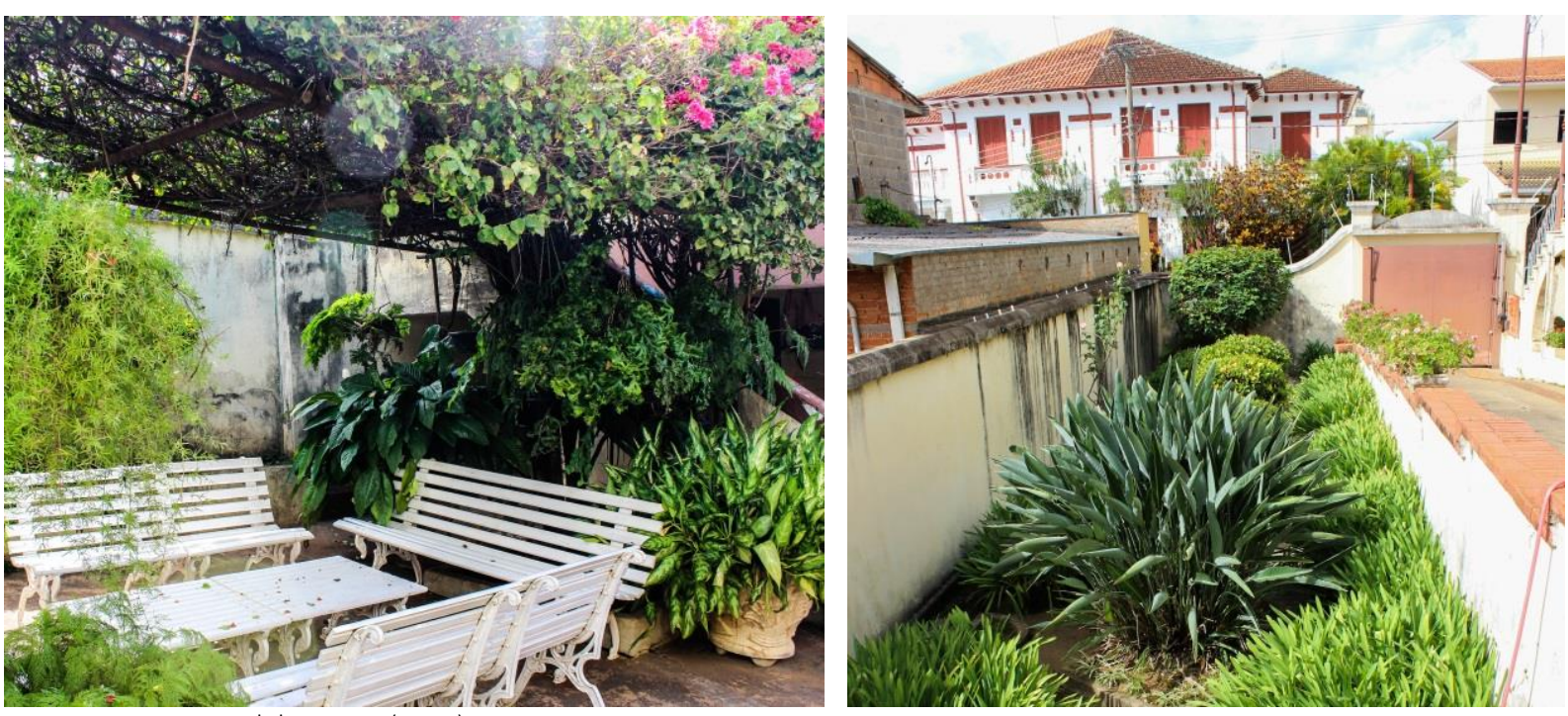

Fonte: Acervo pessoal da autora (2017).

Outra edificação desse período é a de Benedicto Amaral que foi projetada por João Bergamasco em 1932 e construída em 1933 para servir de consultório odontológico. Possuía apenas três ambientes: a sala de espera, o gabinete onde Amaral atendia seus pacientes e uma sala reserva. Em 1936, Bergamasco foi novamente contratado para ampliar a edificação a partir de um novo programa e um novo zoneamento interno. Para atender às expectativas programáticas foi construída uma sala de jantar no térreo integrada à sala de visita e esta ao alpendre, e no local da sala reserva foi construído um vestíbulo com escada interna interligando o térreo ao pavimento superior, onde foram distribuídas as áreas de repouso, como podemos observar na Figura 359. A maior diversidade funcional dos ambientes, assim como da circulação,fez com que essa moradia fosse adaptada para se adequar à vulgarização do "morar à francesa", manifestação que se difundiu nos anos 20 e 30 na casa da classe média paulistana (LEMOS, C., 1999; ALAMBERT, 2003) e que também se firmava em São José do Rio Pardo. 


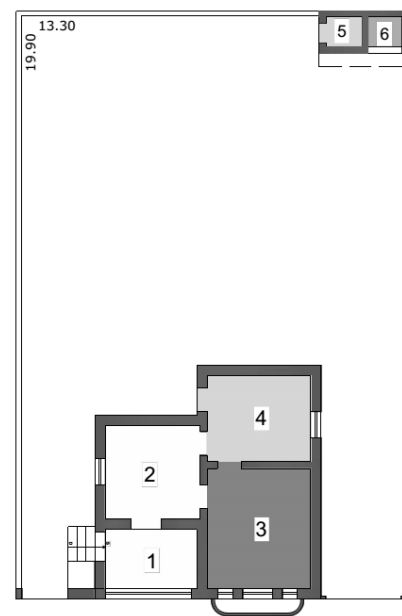

Planta

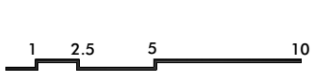

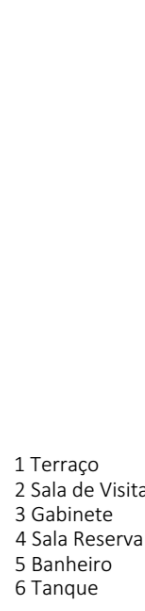

$\square$ Social

ה $\square$ Íntimo

$\bigotimes \quad \square$ Serviço

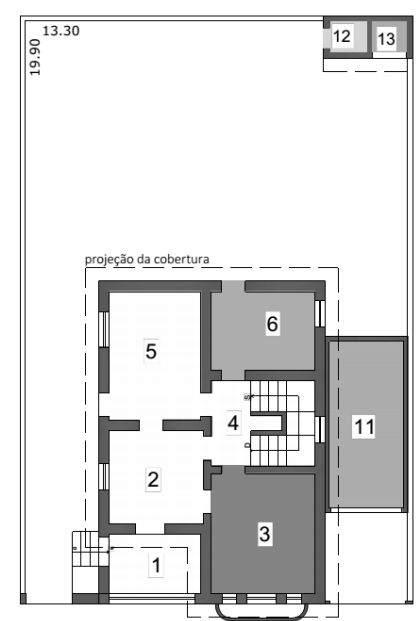

Térreo

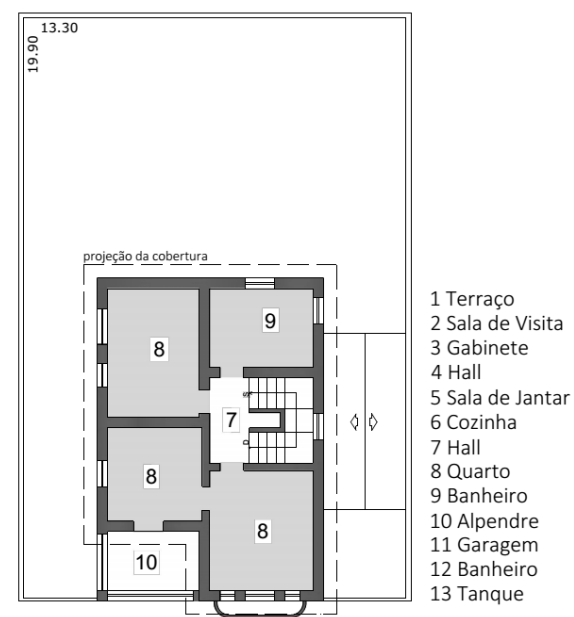

Primeiro Pavimento

$\square$ Social

$\square$ Íntimo

$\square$ Serviço

$\square$ Negócio

Fonte: Arquivo Público da Secretaria de Obras de São José do Rio Pardo (1932, P13) e (1936, P25). Desenho: Natalia Cappellari de Rezende (2016).

E conforme comentado anteriormente, foi frequente nesse período construções e reformas que possibilitaram a inserção definitiva do banheiro no interior da habitação de forma a proporcionar maior conforto e melhores condições higiênicas. O modelo de instalação sanitária doméstica que predominou nas moradias rio-pardenses foi o norte-americano, como descrito por Lemos, C. (1999) ao tratar da moradia da república.

Casas com água encanada, a maioria, já com instalações sanitárias internas, sempre contíguas às cozinhas por causa da economia da tubulação importada, mesmo nas casas de sobrado, que eram raras na classe média desse tempo. Instalações que, em virtude da moderna moda americana, acomodavam num mesmo espaço a latrina e os equipamentos destinados à higiene das pessoas: chuveiro, banheira com pés de garra de leão, semicúpio e bidê. o costume francês que separava a latrina em compartimento especial, sempre minúsculo, apartado da "casa de banhos", foi totalmente ignorado. Aparelhos ingleses ou americanos. (LEMOS, C., 1999, p. 67).

A existência de ao menos uma latrina na casa foi uma condição prescrita no Código de Posturas de 1918 que em seu artigo 81 normatizou que a mesma deveria ser "assentada e instalada de acordo com as prescripções do Código Sanitário do Estado" (CÓDIGO DE POSTURAS, 1918, p. 13), assim como os banheiros completos, tanques, pias e lavabos. Como medida higiênica, a normativa do Código Sanitário Estadual determinou que esse ambiente da casa necessariamente deveria ser instalado de modo a obter ventilação e iluminação naturais através de aberturas para o exterior, respeitar as dimensões mínimas estabelecidas e ter seu piso e paredes impermeáveis, de acordo com os artigos a seguir:

Artigo 436. As latrinas deverão ter pelo menos uma face exterior; serão bem illuminadas e ventiladas por meio de janellas de dimensões proporcionaes à sua área. (Art. 322, dec. 2.141). 
Artigo 437. As latrinas das habitações em geral, quando internas, terão uma área mínima do dois metros quadrados e o pé direito não inferior a três metros; quando nos porões, deverão ter o pé direito não inferior a dois metros e cincoenta centímetros e estarão sujeitas a todas as demais exigências para as latrinas internas; quando exteriores, poderão ter a área mínima de um metro e vinte centímetros, por um metro e altura mínima de dois metros e cincoenta centímetros. (Art. 192, lei 1.596).

Artigo 438. O piso das latrinas e as paredes, na sua face interna, até a altura de um metro e cincoenta centímetros, deverão ser revestidos de camada resistente, lisa, impermeável e não absorvente. Na impermeabilização do piso das latrinas e mictórios não será permittido o emprego do cimento. (Art. 324, dec. 2.141). (CÓDIGO SANITÁRIO, 1918, p. 54).

Conforme analisado nas moradias de Ciro Ferraz, de Maria da Conceição Damasio e de Messias Candido Ribeiro, o banheiro foi projetado e construído no interior da habitação, de modo a atender às normativas, e, além disso, esse espaço apareceu separado da cozinha. Certamente, fatores como o aperfeiçoamento técnico, o desenvolvimento dos materiais e a condição econômica dos proprietários foram determinantes para a não adoção do binômio banheiro-cozinha e também para a construção de um espaço sanitário de grande dimensão. É necessário ainda ressaltar a adoção da expressão WC (water closet) na moradia de Ciro Ferraz. Segundo Lemos, C. (1978, p. 134), essa denominação certamente foi introduzida pelos técnicos ingleses que instalaram a primeira rede de água potável na cidade de São Paulo e também pelos importadores de peças sanitárias da Inglaterra. Mas foi na década de 1920 que essa expressão, assim como hall e living-room, em substituição ao vestíbulo e sala de estar, surgiu com mais frequência em razão da influência que a cultura norte-americana estava exercendo através dos meios de comunicação (publicações diversas, imprensa e cinema) $)^{244}$ (LEMOS, C., 2015).

O alpendre foi outro espaço que surgiu com mais frequência na moradia rio-pardense desse período, disposto na lateral, a exemplo da casa de João Gabriel Ribeiro, ou na parte frontal, de modo a anteceder o vestíbulo, como na propriedade de Maria da Conceição Damasio. Independente de sua localização, o alpendre propiciou a integração entre o exterior e interior da moradia, aspecto característico do Arts and Crafts, que tinha o bangalô como seu símbolo.

Já a edícula ${ }^{245}$, comumente localizada no fundo do lote, apareceu nos programas residenciais como uma construção auxiliar com possibilidade de abrigar quarto da empregada, instalação sanitária, lavanderia, depósito e a garagem, como nas residências de Benedicto Amaral e João Gabriel Ribeiro (Figura 360).

\footnotetext{
${ }^{244}$ Sobre isso, ver Atique (2007).

${ }^{245}$ Ao tratar da edícula, Lemos, C. (1978, p. 142-145) destacou que "com o tempo, as cavalariças das casas ricas foram dando, aos poucos, lugar às garagens. E estas, por sua vez, em telhados puxados, sugeriram a proximidade dos apartamentos de empregadas e depósitos formando um todo separado da construção principal. Foi a época em que entrou para o linguajar cotidiano o termo edícula. [...] A e dícula - quarto de empregada, instalação sanitária, lavanderia, depósitos e garagem - parece constituir outra solução arquitetônica eminentemente nacional. Por mais que se procure, em quantos livros existam sobre a arquitetura residencial em outras terras, não são encontrados exemplos de casas possuindo, à parte, construções para abrigo de empregados".
} 
Figura 360: Edícula da moradia de João Gabriel Ribeiro (1933), 2017.

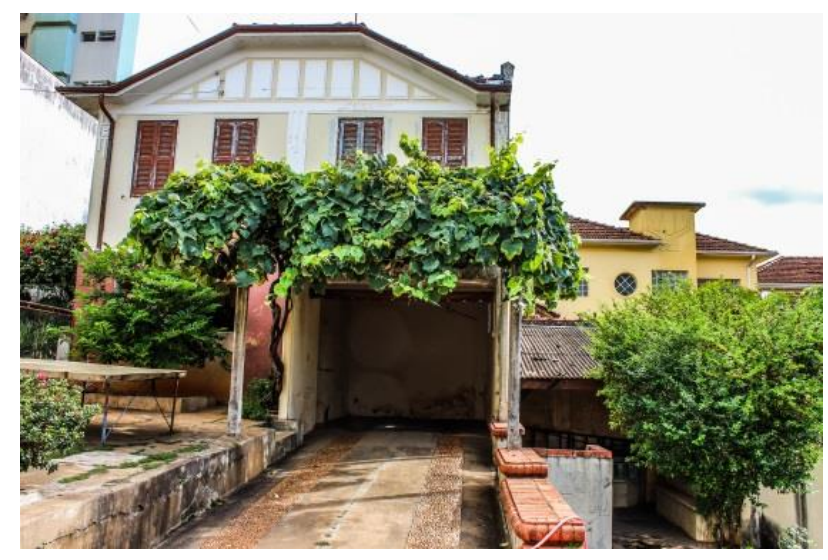

Fonte: Acervo pessoal da autora (2017).
Para Reis Filho (2011), a existência da edícula com acomodações estava associada ao desaparecimento dos porões habitáveis, os quais, segundo as afirmações de Alambert (2003), deixaram de existir na arquitetura residencial paulistana de classe média no período entre as Guerras. Com isso, as casas de porão alto, situadas no alinhamento, foram substituídas por sobrados isolados no terreno. Nesse sentido, Lemos, C. (1989a) chama a atenção para o "surgimento dos sobradinhos para aluguel formando conjuntos com mais de três unidades (tipo "Ford" ${ }^{246}$ ), ou geminados dois a dois de frente para a rua, ou formando vilas (com entrada comum para todas as unidades)". Um caso exemplar desse tipo de moradia em São José do Rio Pardo são as duas unidades de sobrados geminados (Figura 361), construídos a pedido de Willian Simonsen na Rua Benjamin Constant em 1925. Evidentemente que Simonsen construiu essas edificações para atender à carência de habitação destinada à classe média rio-pardense, conforme discutido anteriormente. E, ao tratar da capital paulista, Lemos, C. (1989a) destaca que esse tipo de moradia se propagou após o fim da Primeira Guerra Mundial, o que evidencia a concomitância dos acontecimentos na capital e no interior do Estado.

Nesse sentido, é importante salientarmos a ordenação do programa da edificação de Willian Simonsen, com destaque para o WC e o tanque que, dispostos no térreo, não possuem acesso pelo interior da casa. É interessante o fato do WC ser externo, porque certamente era de uso dos funcionários ou devido a inexistência de sifão hidráulico, e o tanque, porque estava ligado às atividades diretamente realizadas no quintal, como quarar a roupa ao sol, evidenciando a rotina daquela época. O modo de convivência também pode ser percebido através da organização das áreas de repouso (dormitórios e banheiro completo) que, destinadas à família, localizam-se no andar superior e são acessadas privativamente por meio da escada. Destacamos outras questões como a implantação da casa no centro do lote e em meio ao jardim, a integração entre as áreas de estar e as amplas aberturas envidraçadas, que demonstram a identificação com a manifestação formal do Arts and Crafts.

\footnotetext{
${ }^{246}$ Segundo Lemos, C. (1989a, p. 77) o apelido "sobradinho ford" foi "inspirado na fabricação em série do carro Ford, tanto foram os conjuntos que surgiram da noite para o dia e isso até meados da década dos anos quarenta no império do art-déco".
} 
Figura 361: Desenho da planta da edificação de Willian Simonsen na Rua Benjamin Constant, 344-354 (1925).

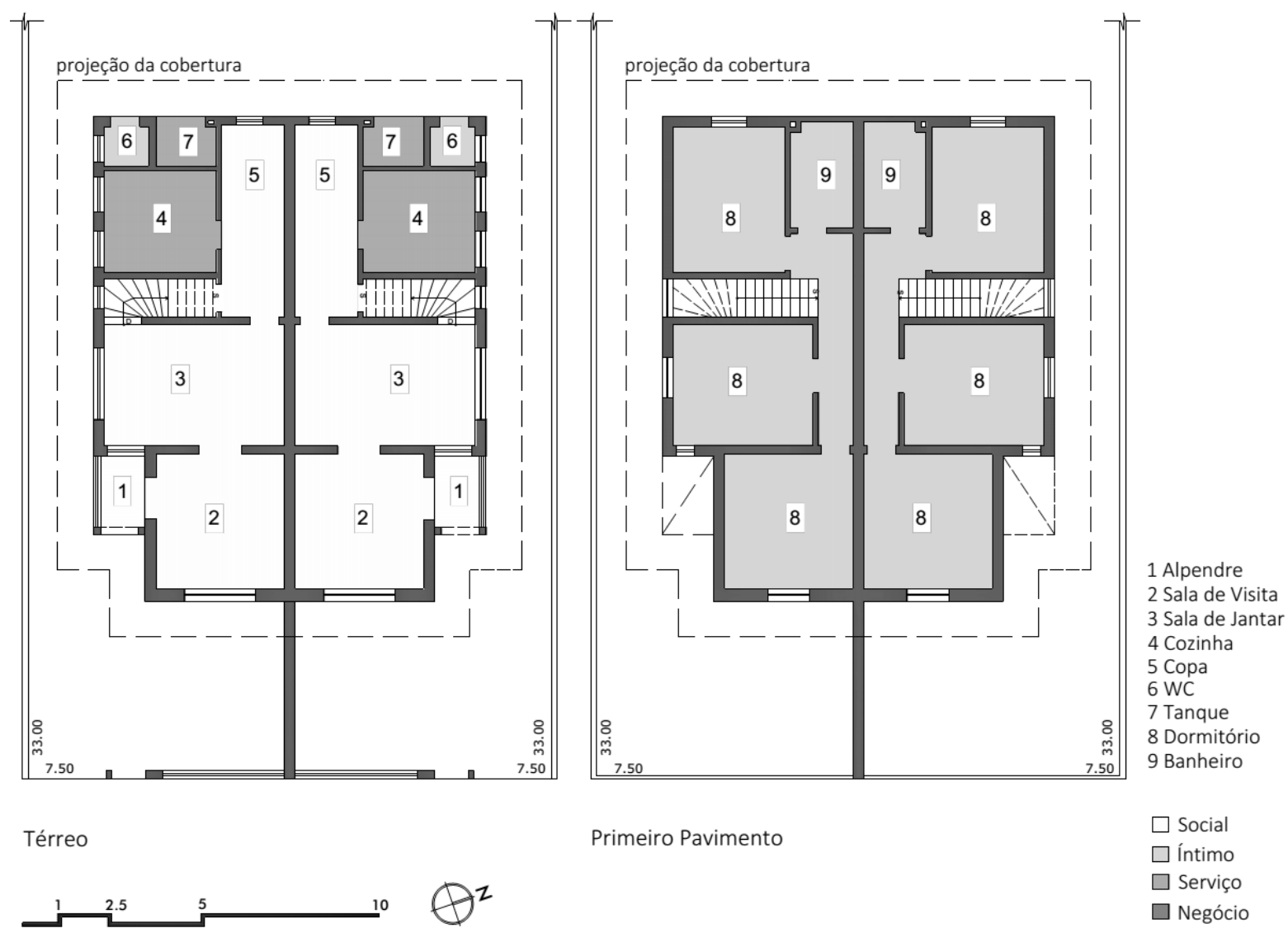

Fonte: Arquivo Público da Secretaria de Obras de São José do Rio Pardo (1925, P06). Desenho: Natalia Cappellari de Rezende (2016).

Diretamente relacionado ao progressivo desuso dos porões habitáveis estava o desenvolvimento técnico e material aplicado no embasamento das edificações. Conforme salientado por Reis Filho (2011), o uso de impermeabilizantes na infraestrutura da casa contribuiu no desaparecimento dos grandes afastamentos da edificação do solo, e consequentemente a abolição do assoalho. Além do emprego do impermeabilizante, a utilização das lajes de concreto e de cimento armado se apresentou de maneira gradual, tornando-se recorrente na década de 1930 em São José do Rio Pardo, praticamente coincidindo com o que Lemos, C. (1989a), Reis Filho (2011) e Alambert (2003) mostraram acontecer no cenário nacional, mais especificamente na capital paulista. Nesse sentido, Lemos (1989a, p. 49) destaca que o tijolo de "pedra artificial" por ser muito mais caro que o tijolo de barro queimado demorou para se popularizar, sendo mais utilizado em "moldagens decorativas destinadas à ornamentação externa".

Até a década de 20 o emprego de estruturas de concreto armado em residências paulistanas era pouco habitual, limitado em geral a terraços e a lajes de piso de banheiros localizados no pavimento superior. $\mathrm{O}$ alto custo do cimento e das barras de ferro/aço (que até meados dos anos 20 eram importados) dificultava a vulgarização do uso residencial do concreto armado. [...] Na década de 30 o concreto armado passou a ser utilizado mais comumente na arquitetura residencial paulistana para resolver problemas estruturais e construtivos (maiores vãos, execução de banheiros nos andares superiores, uso de lajes planas impermeabilizadas) e para obter maior liberdade de projetação (distribuição de cômodos no pavimento superior independente da planta inferior). (ALAMBERT, 2003, p. 90). 
No projeto original da residência de Ciro Ferraz (1926), através do corte, é possível observar a inexistência de porão habitável, mas ainda assim está presente o afastamento entre o piso e o terreno, sendo o cimento e o concreto utilizados na infraestrutura da edificação (Figura 362). É provável que nesse caso a falta de conhecimento sobre as propriedades dos materiais, ou a confiabilidade nas características dos mesmos, fez com se mantivesse o afastamento. Já na casa da Rua Silva Jardim, 29 (1934), o desnível do terreno permitiu a existência do WC e da lavanderia no porão, sendo o cimento armado utilizado na laje de piso da edificação (Figura 363). Na edícula da casa de João Gabriel Ribeiro (1933) a mesma solução também foi empregada, mas dessa vez na laje do piso do primeiro pavimento, conforme é possível observar na Figura 364.

Figura 363: Corte apresentado no projeto da residência da Rua Silva Jardim, 29 (1934).

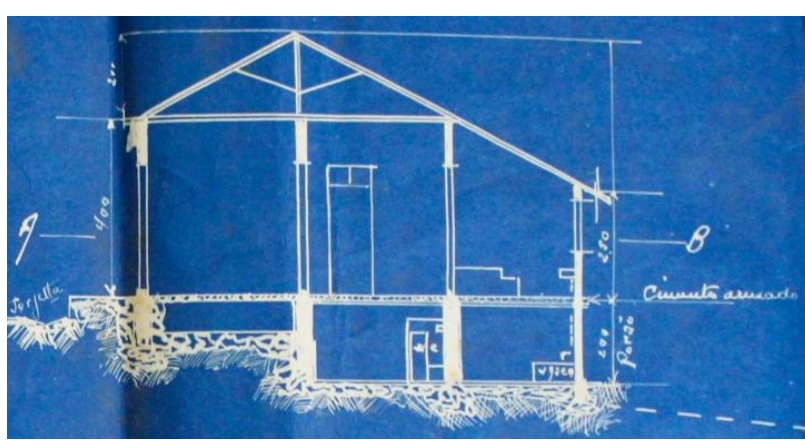

Fonte: Arquivo Público da Secretaria de Obras de São José do Rio Pardo (1934, P15).
Figura 362: Corte apresentado no projeto da residência de Ciro Ferraz, na Rua Benjamin Constant, 18A.

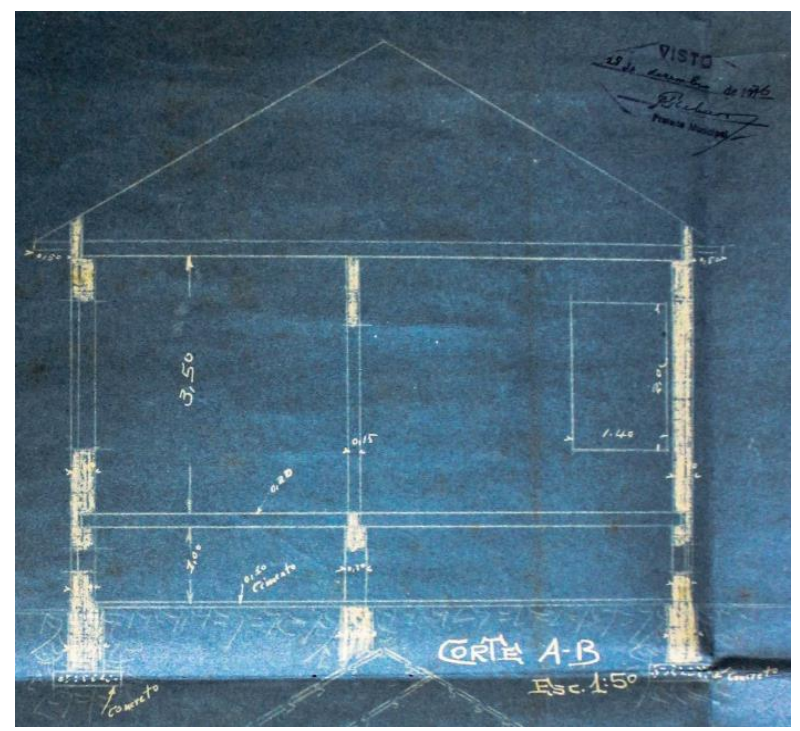

Fonte: Arquivo Público da Secretaria de Obras de São José do Rio Pardo (1926, P11).

\footnotetext{
doprimeiro pavimento, conforme é possivel observar na Figura 364.
}
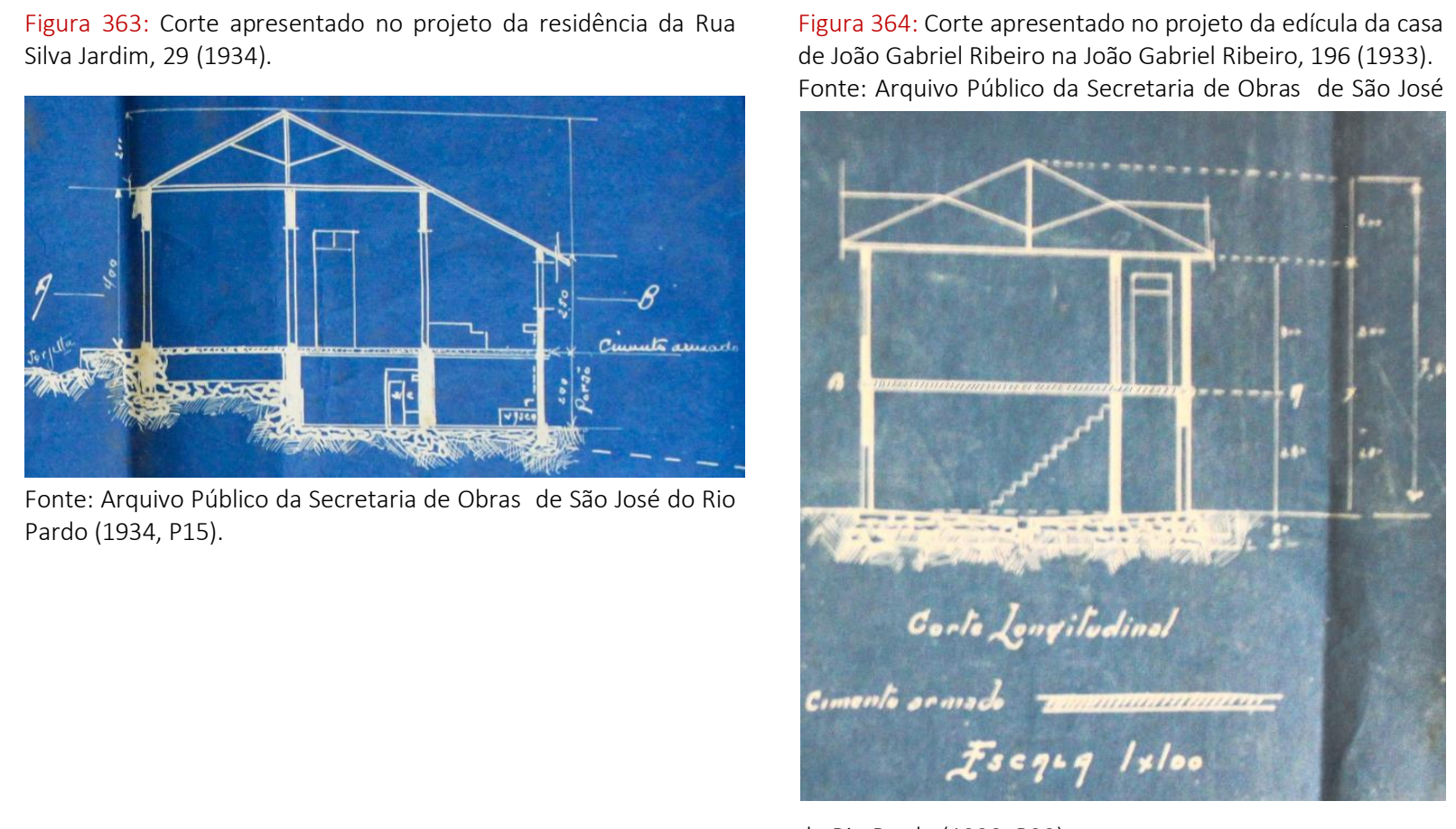

do Rio Pardo (1933, P20). 
Apesar do emprego de estruturas de cimento armado na arquitetura residencial rio-pardense ter se tornado habitual a partir dos anos 1930, concordamos com a análise de Reis Filho (2011) sobre a carência de alterações tecnológicas fundamentais nas moradias construídas entre 1920 e 1940:

No conjunto, porém, pode-se dizer que as residências individuais dessa época não apresentavam alterações tecnológicas fundamentais. Apenas, pouco a pouco, substituíam-se, por produtos nacionais, equipamentos e materiais inicialmente importados. As soluções técnicas eram sempre mais ou menos semelhantes. As paredes de tijolos forçavam a repetição das plantas nos dois pavimentos. Os pisos de madeira exigiam a existência de porões no pavimento térreo e de forros de gesso ou madeira nos dois andares. Os telhados amplos, quase sempre com beirais, lançavam as águas sobre os jardins, ou, quando possível, ostentavam um sistema completo de condutores e calhas em balanço. (REIS FILHO, 2011, p. 78)

De fato, podemos constatar através dos levantamentos in loco a similaridade entre a descrição de Reis Filho (2011) e o que encontramos nas moradias rio-pardenses. Como é possível observar através das figuras a seguir, o assoalho de madeira (Figura 365), o ladrilho hidráulico (Figura 366 e Figura 367) e o granilite (Figura 368) foram os principais materiais empregados no piso, sendo os dois últimos utilizados principalmente nas áreas com lavagens freuentes, nos alpendres e nas áreas descobertas.

Figura 365: Piso em madeira da casa de João Gabriel Ribeiro.

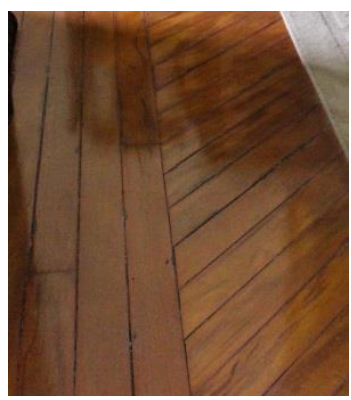

Fonte: Acervo pessoal da autora (2017).
Figura 366: Piso em ladrilho hidráulico da casa da Rua Treze de Maio, 338.

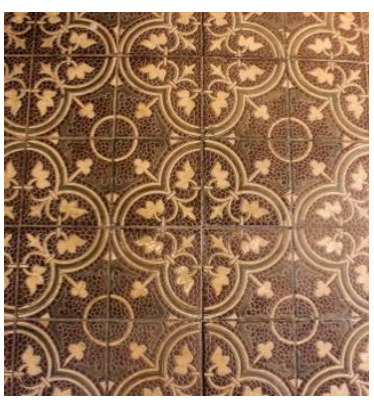

Fonte: Acervo pessoal da autora (2016).
Figura 367: Piso em ladrilho hidráulico da casa de Messias Candido Ribeiro.

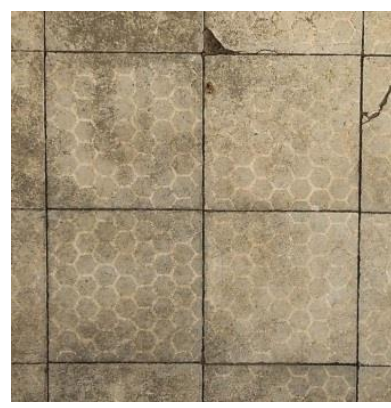

Fonte: Acervo pessoal da autora (2018)
Figura 368: Piso granilite da casa de João Gabriel Ribeiro.

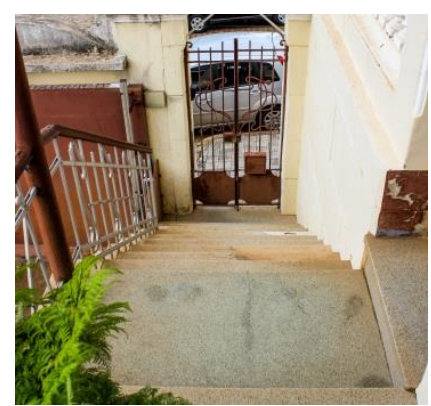

Fonte: Acervo pessoal da autora (2017).

Apesar de ser quase uma exceção frente aos forros de madeira, o emprego de estuque (Figura 369) foi observado na sala de visitas e na cozinha da moradia de João Gabriel Ribeiro, o que prejudicou o conforto térmico então favorecido pelos discretos orifícios que propiciavam ventilação, a exemplo da moradia da Rua Treze de Maio, 338 (Figura 370). 
Figura 369: Forro de estuque da sala de visita da moradia de João Gabriel Ribeiro.

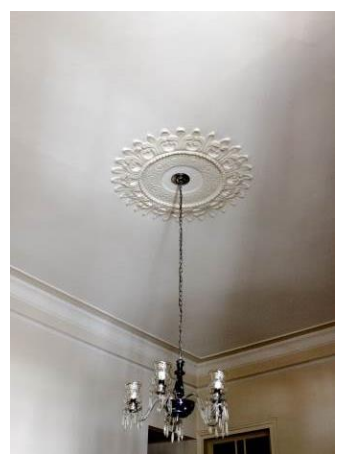

Fonte: Acervo pessoal da autora (2017).
Figura 370: Forro em madeira trabalhado da sala de visita da casa da Rua Treze de Maio, 338.

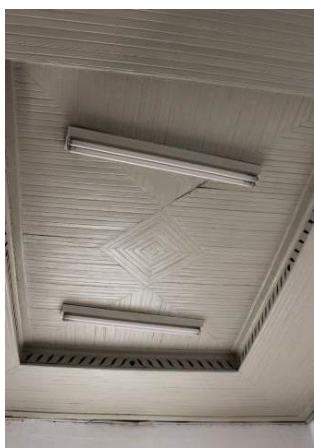

Fonte: Acervo pessoal da autora (2016).

Em relação aos telhados, o artigo 50 do Código de Posturas de 1918 exigia que

dentro do perímetro urbano da cidade, toda construcção ou reconstrucção de prédio deverá ter platibanda, cornijas ou outro qualquer systema de ornamento, ficando prohibidos os telhados com abas para a rua. (CÓDIGO DE POSTURAS, 1918, p. 09).

Telhados "com abas" que jorrassem a água pluvial nos passeios já constituía uma proibição desde 1903 quando foi publicado o segundo Código municipal que obrigou o uso de platibanda e permitiu os beirais desde que apresentasse sistema de calhas e condutores de águas pluviais. Mas as novas posturas inovaram ao compelir as edificações erguidas na testada do lote a esconder seus telhados com platibanda, cornija ou qualquer sistema ornamental, como alternativas que contribuiriam na construção de uma boa imagem da cidade. Todavia, a própria legislação abria precedentes para a existência de beirais, conforme segue o artigo 51

Nas casas existentes actualmente, e que não guardarem as prescripções impostas no artigo anterior, os seus proprietários são obrigados a collocar nos telhados calhas de cobre ou de ferro zincado que recebam as águas pluviais e as conduzam para as guias por meio de cannos embutidos nas paredes e por baixo dos passeios.

Único - Os proprietários que não cumprirem as disposições supra incidirão no pagamento de uma taxa especial que será consignada na lei do orçamento. (CÓDIGO DE POSTURAS, 1918, p. 09).

E de fato, conforme constatamos em nosso levantamento de campo e da análise dos projetos arquivados na Secretaria de Obras de São José do Rio Pardo, os telhados com beirais predominaram nas edificações residenciais rio-pardenses desse período (ver Figura 329, Figura 330, Figura 331 e Figura 333 na página 309), certamente em virtude da brecha na legislação ${ }^{247}$, da construção de edificações afastadas dos limites do lote, da dificuldade de importação de material para produzir calha no período entre Guerras e em função da tendência à adesão ao neocolonial e ao bangalô. Portanto são fatores que competiram e ao mesmo tempo favoreceram a retomada do beiral.

\footnotetext{
247 Possivelmente essa brecha já fosse um resultado e não a causa do predomínio de telhados com beirais, muito em função das discussões que estavam ocorrendo na época acerca do neocolonial, da situação econômica, das condições de importação e estágio da industrialização brasileira.
} 
Seguramente, as maiores transformações observadas na arquitetura das moradias de São José do Rio Pardo dos anos 20 e 30 foi a experimentação das características e estilemas do neocolonial, do Arts and Crafts e do art-déco. Constatação semelhante à observada por Mascaro (2008), ao analisar as manifestações do estilo neocolonial em várias cidades do interior paulista, acrescentando ainda as vários rebuscamentos, até mesmo inventados, que caracterizaram essa produção no período de 1920 a 1950, o que evidencia a aceitação e popularização desse estilo.

Assim sendo, verificamos a difusão das intenções plásticas do neocolonial ${ }^{248}$ em São José do Rio Pardo desde $1925^{249}$, o que nos mostra que essa tendência estava ocorrendo de modo praticamente simultâneo nas capitais e no interior. Um exemplo do emprego dos estilemas do neocolonial é a moradia de Ciro Ferraz e de Maria da Conceição Damasio que apresenta um frontão curvilíneo com volutas, janela emoldurada de guilhotina, óculo quadrilobado, jardineira, embasamento em pedra e telhado com largos beirais, tendo nos vértices uma telha em forma de pluma virada para cima. Apesar da fachada da casa de Damasio ter sofrido reformas após ser adquirida e transformada em um consultório médico, ainda é possível percebermos as linhas originais desta edificação (Figura 271). Há a possibilidade de permeabilidade visual proporcionada pelo jardim circundante, ainda que seja uma natureza domesticada, e o fechamento em madeira no limite entre os espaços público e o privado. Essas características formais, associadas ao arranjo da planta, mostram a nova forma de morar ${ }^{250}$ adotada pela classe média rio-pardense.

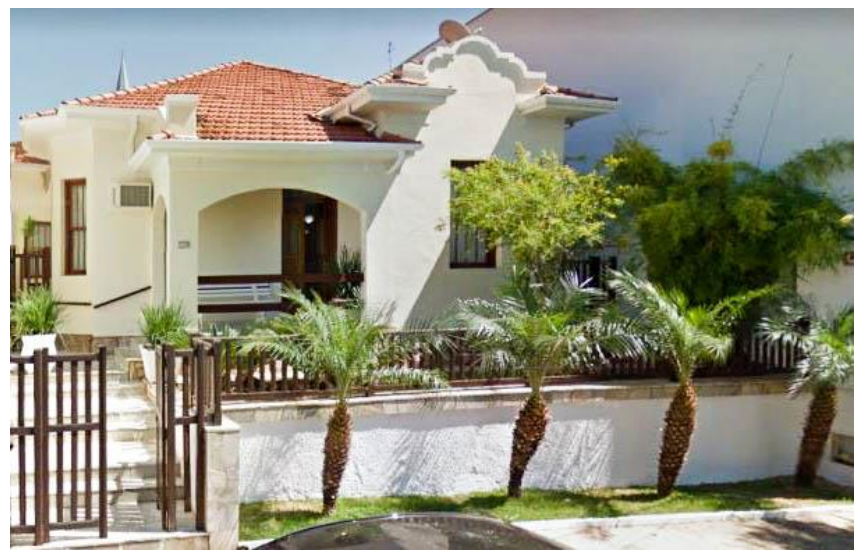

Figura 371: Fachada reformada da moradia de Maria da Conceição Damasio (1934), 2014. Fonte: Google Street View (2014).

\footnotetext{
248 De acordo com Lemos, C. (1989a) o neocolonial assumiu algumas vertentes: uma erudita e outra popular. A vertente erudita foi marcada por obras emblemáticas de autoria de arquitetos e engenheiros renomados, as quais se destacavam, segundo Bruand (1981) pelo "emprego sistemático de elementos tomados de empréstimo à arquitetura civil portuguesa dos séculos XVII e XVIII: varandas sustentadas por simples colunas toscanas, telhados planos com largos beirais, feitos de telhas - canal e tendo, nos vértices, uma telha em forma de pluma virada para cima (lembrando a moda do exotismo chinês no Século das Luzes), rótulas e muxarabis de longínqua origem muçulmana, azulejos fabricados diretamente no Porto recobrindo as paredes das varandas" (BRUAND, 1981, p. 53). Já a vertente popular se diferenciou pela simplificação e livre reinterpretação do estilo nas edificações residenciais de classe média entre os anos $20,30,40$ e 50, e foi denominado de Neocolonial Simplificado por Carlos Lemos (1989a, p. 20). Conforme destacado por Kessel (2008, p. 140), outra vertente que se difundiu influenciado diretamente pelo cinema norte-americano e pela veiculação de revistas foi o Neocolonial hispanoamericano, também conhecida como Mission Style, que se configurou de maneira muito variável, sendo, portanto caracterizado por alguns elementos que se tornaram signos dessa arquitetura, conforme destacado por Amaral (1994), como torreão de planta circular, coberto por telhado cônico; fachada principal arrematada, total ou parcialmente, por telhado de duas águas; alpendres com arcos plenos, abatidos ou goticizantes; revestimento rústico com reboco grosso em relevo; pátios internos, geralmente conformados por arcadas; edificações térreas; uso de telhas cerâmicas do tipo capa e canal; colunas salomônicas ou torneadas; e pedras dispostas aleatoriamente. Ver a esse respeito Amaral (1994), Wolff (2001), Pinheiro (2005), Alambert (2003), Kessel (2008) e Mascaro (2008)

${ }^{249}$ Não podemos descartar a possibilidade de ter ocorrido adesão à arquitetura neocolonial anterior a 1925 . Essa data é assertiva em razão dos projetos arquivados na Secretaria de Obras de São José do Rio Pardo, os quais analisamos e constatamos a presença da manifestação neocolonial na arquitetura.

${ }^{250}$ Essa forma de morar estava associada às cidades-jardins inglesas e aos subúrbios anglo-americanos que encontraram sua máxima expressão no Jardim América em São Paulo. Sobre isso ver Andrade (1998), Wolff (2001) e Janjulio (2009).
} 
Outras características formais também se manifestaram em São José do Rio Pardo, como nas casas de Willian Simonsen (Figura 372) onde a delicadeza, a simplicidade, a ordem e a racionalidade predominam. As linhas retas, o telhado pouco inclinado com amplos beirais, a presença da pedra no embasamento, na mureta e no calçamento, o azulejo circundando as aberturas, balaústre e o gradil de fechamento, a integração do interior da residência com o exterior através do alpendre, dos balcões e das aberturas, o jardim frontal e a natureza presente nas jardineiras, todas remetendo ao estilo Arts and Crafts.

Figura 372: Moradias de Willian Simonsen (1925), 2016.
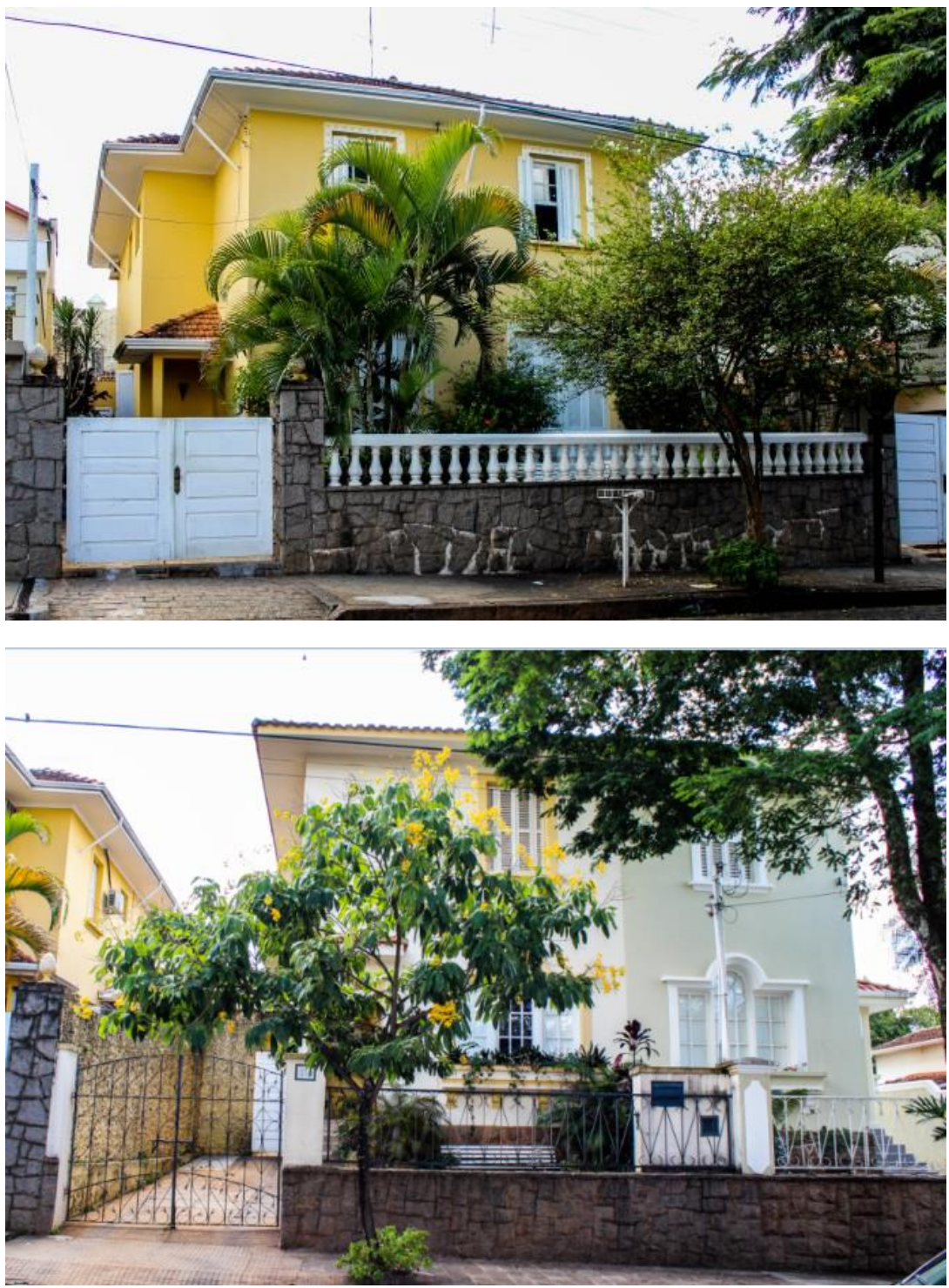

Fonte: Acervo pessoal da autora (2016).

As principais características do neocolonial hispano-americano ou Mission Style também foram empregadas na arquitetura rio-pardense, sendo mais notória a presença de torreão de planta circular coberto por telhado cônico com telhas "capa-e-canal", de reboco áspero, alpendre com arco goticizante, de pedras dispostas aleatoriamente e do telhado pouco inclinado acentuando a horizontalidade da edificação, a exemplo da moradia na Avenida Deputado Eduardo Vicente Nasser, 813 (Figura 373). Além dos aspectos 
formais, observamos nesta moradia uma maior integração entre a sala de jantar, de estar e o alpendre que se configura como um espaço aberto, mas ao mesmo tempo fechado por elementos vazados, sendo o hall um espaço intermediário entre ambos. A disposição racional e o aproveitamento total do espaço exclui a presença de corredores e, desse modo, a cozinha, a copa e as salas formam praticamente uma área única, integrada pelas amplas aberturas. O banheiro, por sua vez, localiza-se próximo à cozinha, de modo a reduzir custos com as instalações hidráulicas (Figura 374).

Figura 373: Moradia na Avenida Deputado Eduardo Vicente Nasser, 813, 2016.

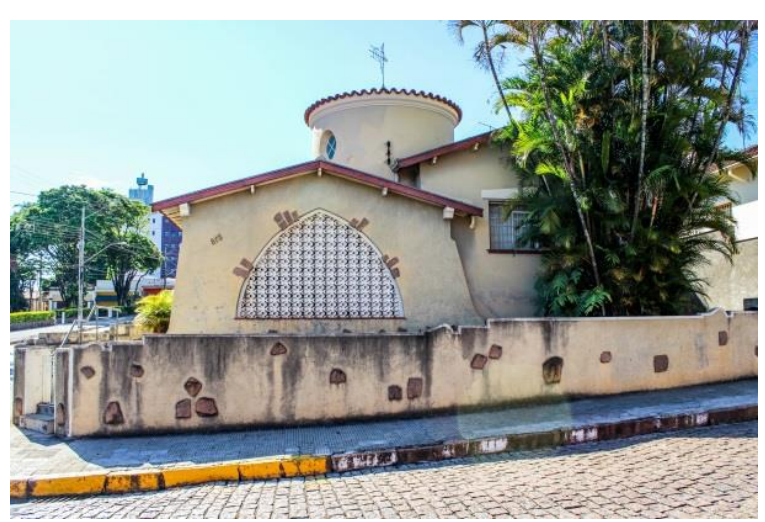

Fonte: Acervo pessoal da autora (2016).
Figura 374: Desenho da planta da edificação na Avenida Deputado Eduardo Vicente Nasser, 813.

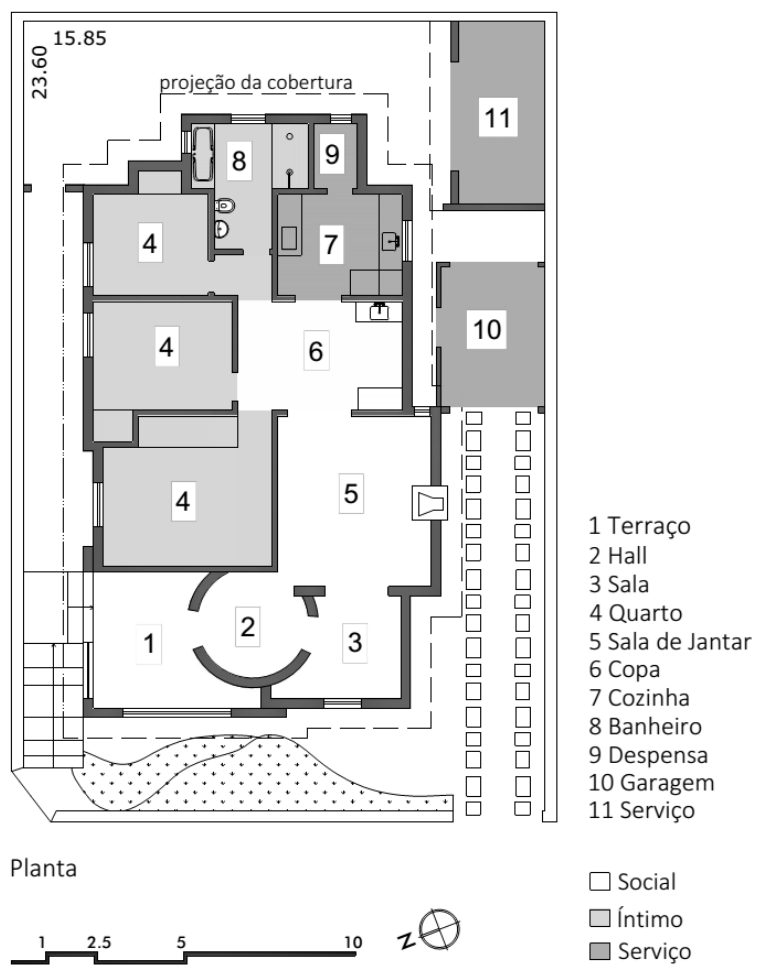

Fonte: Arquivo Público da Secretaria de Obras de São José do Rio Pardo (1941, P26). Desenho: Natalia Cappellari de Rezende (2018).

É importante enfatizarmos que as inovações em planta estavam ocorrendo independente das opções estilísticas que foram experimentadas de modo concomitante com o ecletismo que continuou sendo adotado, ainda que com menos expressividade se comparado com os períodos anteriores, como nas moradias de João Gabriel Ribeiro (Figura 375) e de Benedicto Amaral. Esta última é interessante de ser ressaltada devido à transformação que sofreu em um espaço temporal de apenas três anos. Projetada em 1932 e construída em 1933, sua fachada possuía uma linguagem eclética, mas a mesma foi alterada em 1936, quando passou a se enquadrar na temática do Arts and Crafts, conforme podemos observar na Figura 376. 
Figura 375: Fachada de moradia de João Gabriel Ribeiro (1924), 2016.

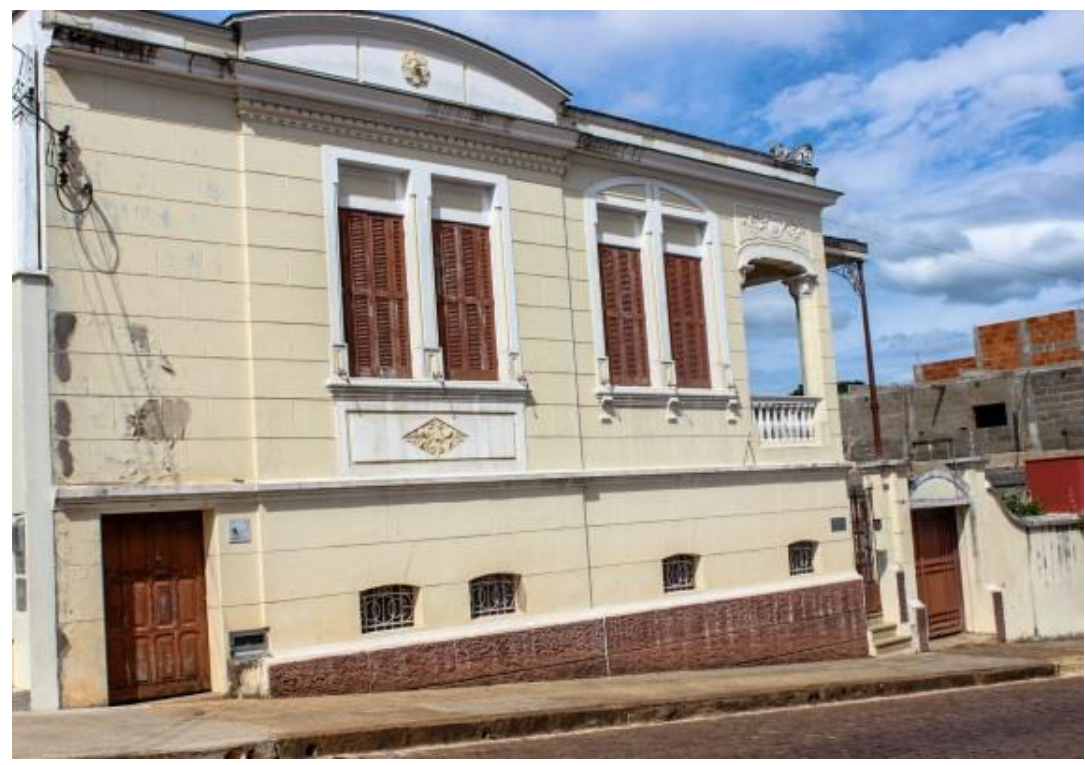

Fonte: Acervo pessoal da autora (2016).

Figura 376: Desenho da fachada da moradia de Benedicto Amaral de 1932 e fotografia atual.
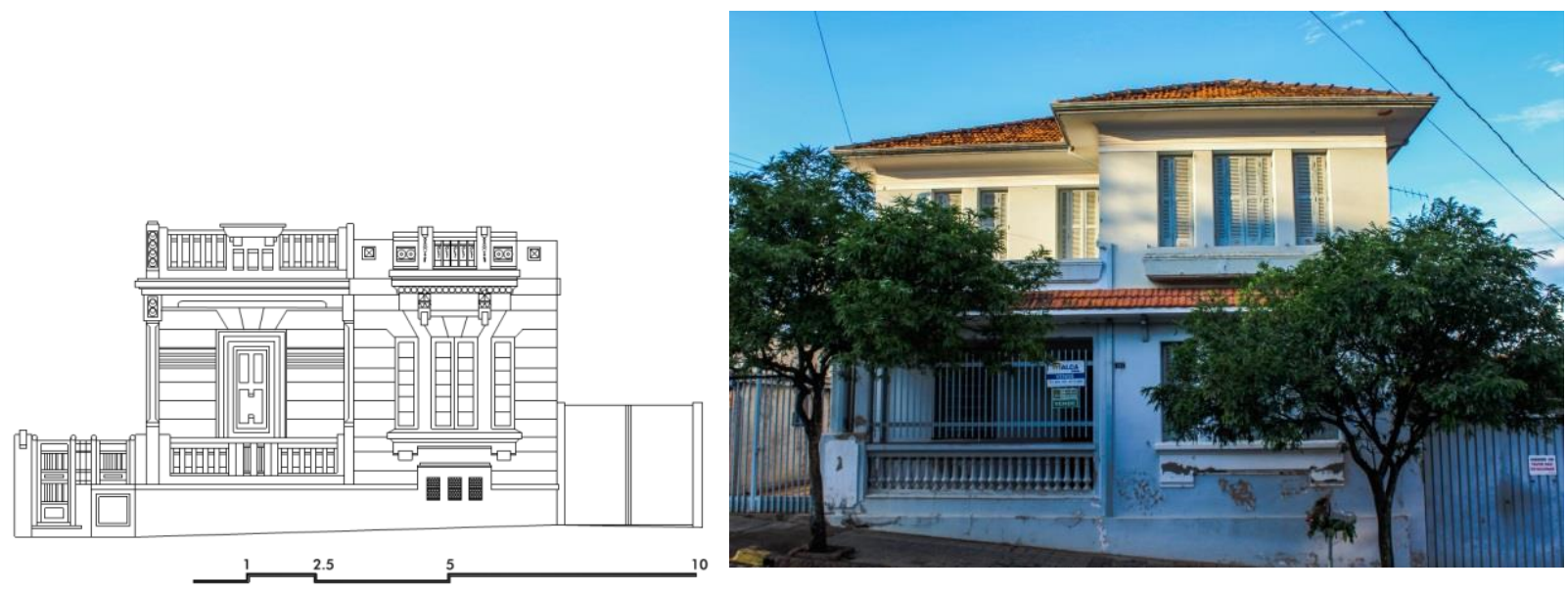

Fonte: Desenho e foto da autora (2016).

Outra manifestação estilística presente nas casas rio-pardenses da década de 1930 foi o art-déco. A simplificação formal e a tendência à geometrização induziram a ideia de modernidade ${ }^{251}$, aplicada aos mais diversos programas e escalas. Apesar de não ter constituído uma regra em termos de técnica construtiva, a arquitetura déco - assim como a neocolonial -, esteve associada a novos modos de construção com o emprego de estruturas de cimento armado ${ }^{252}$, ferro e caixilhos de metal, e plantas onde os espaços eram

\footnotetext{
${ }^{251}$ Pinheiro (2008, p. 120) afirma que o art-déco "representou, de fato, apenas uma atualização dos valores arquitetônicos pré-existentes sem questioná-los em profundidade" e implicou "realmente numa diminuição dos custos da construção, pela diminuição dos ornamentos ou por sua estilização, vale dizer, simplificação"

${ }^{252}$ Campos, V. (1996) destacou no cenário paulistano a construção de edifícios em altura destinados a moradia. Para Pinheiro (2008, p. 117), o aspecto que mais contribuiu para a popularização do art-déco principalmente na construção de edifícios verticalizados "fo certamente o estabelecimento de uma relação direta entre o despojamento de suas linhas e ornamentos, o apelo de modernidade e o barateamento da construção".
} 
organizados de forma integrado, conforme podemos observar na planta da moradia localizada na Rua Coronel Marçal, 260 (Figura 377).

Figura 377: Desenho da planta da moradia localizada na Rua Coronel Marçal, 260 (1945).

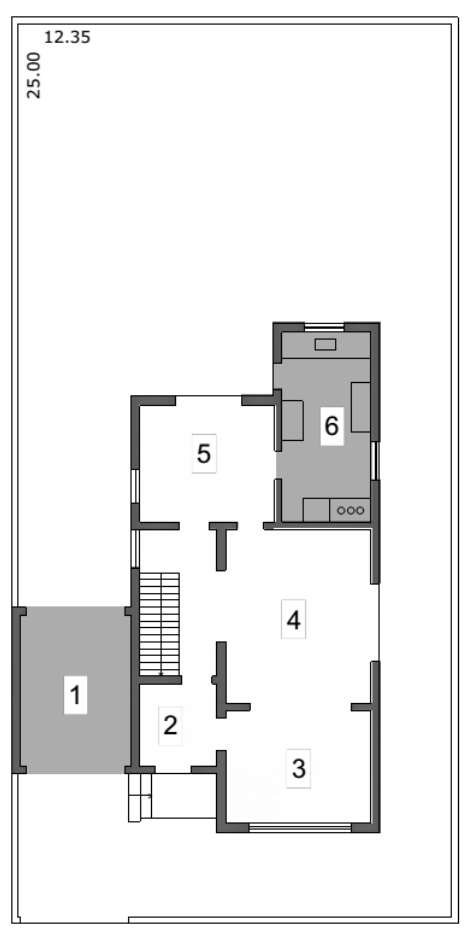

Térreo

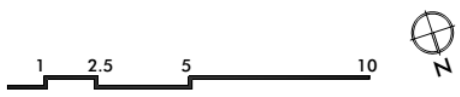

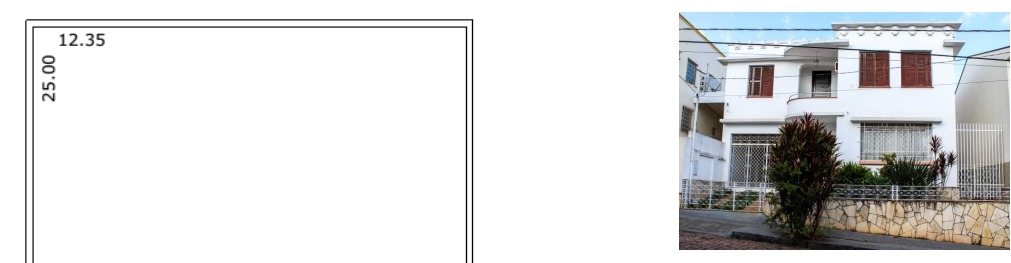

1 Garagem

2 Hall

3 Sala

4 Sala de Jantar

5 Copa

6 Cozinha

7 Quarto

8 Terraço

9 Banheiro

Primeiro Pavimento

$\square$ Social

$\square$ Íntimo

$\square$ Serviço

Fonte: Arquivo Público da Secretaria de Obras de São José do Rio Pardo (1945, P02). Desenho: Natalia Cappellari de Rezende (2018).

Com isso, e como destacado por Campos (2003), na arquitetura essa manifestação rapidamente se difundiu e se tornou acessível às diferentes classes sociais ${ }^{253}$, conquistando o gosto popular devido à "diminuição dos custos da construção, pela diminuição dos ornamentos ou por sua estilização, vale dizer, simplificação" (PINHEIRO, 2008, p. 120). Desse modo, constatamos em São José do Rio Pardo inúmeros edifícios com programas distintos na linguagem art-déco que se difundiram a partir do final da década de 20, como o Ginásio Estadual (ver Figura 250 na página 259), a Sede da Societàdi Mutuo Soccorso 20 Settembre (ver Figura 237 na página 245), posto de combustível (Figura 378), edifício de uso misto (Figura 379) e residências (Figura 380).

\footnotetext{
253 "Diferentemente de outros momentos da História da Arquitetura na América Latina, onde o 'novo' sempre chegava com uma defasagem de alguns anos, o Art Déco disseminou-se com muita rapidez contando com a vantagem de não ter ficado restrito aos círculos internos das elites econômica e cultural. Pelo contrário, foi absorvido por amplos setores da sociedade, contemplando praticamente todas as categorias de edificações - do grande edifício comercial à casa operária”. (CAMPOS, V., 2003, p. 13). 
Figura 378: Postos de combustível com características da arquitetura art-déco.

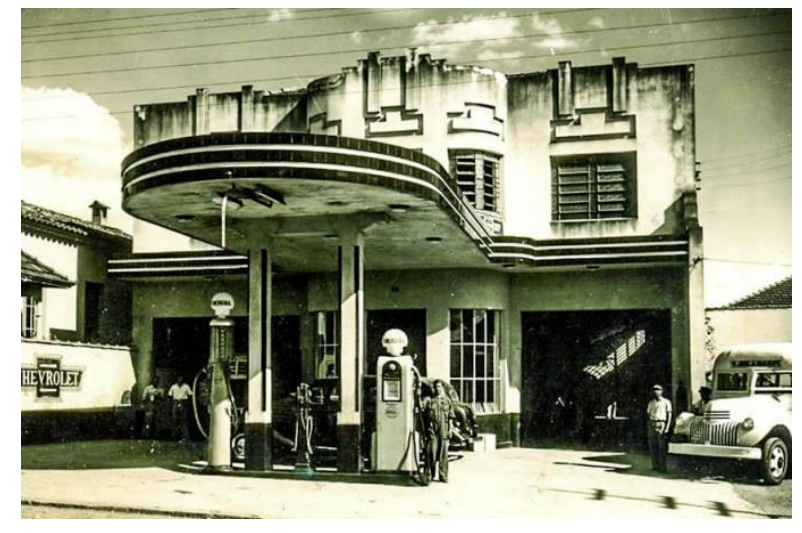

Fonte: Arquivo do Centro da Memória Rio-Pardense Rodolpho José Del Guerra.

Figura 380: Residências no estilo art-déco.

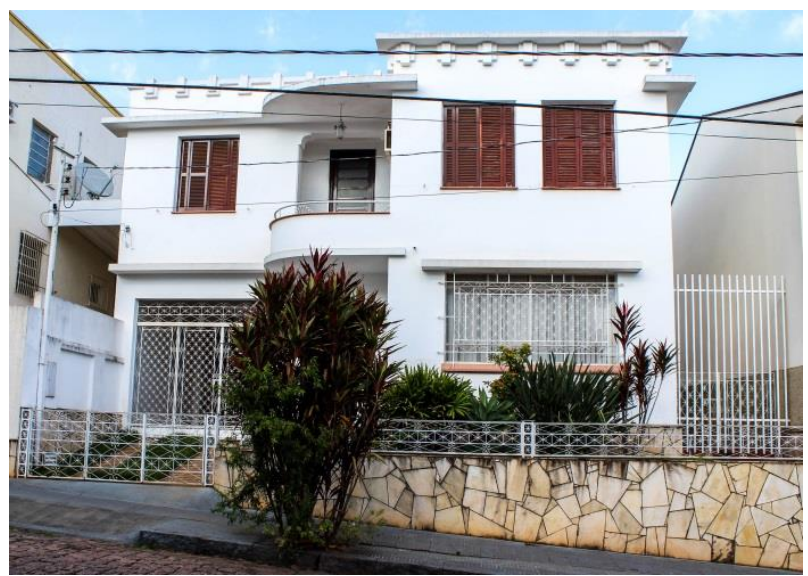

Figura 379: Edificações de uso misto com características da arquitetura art-déco (1941).

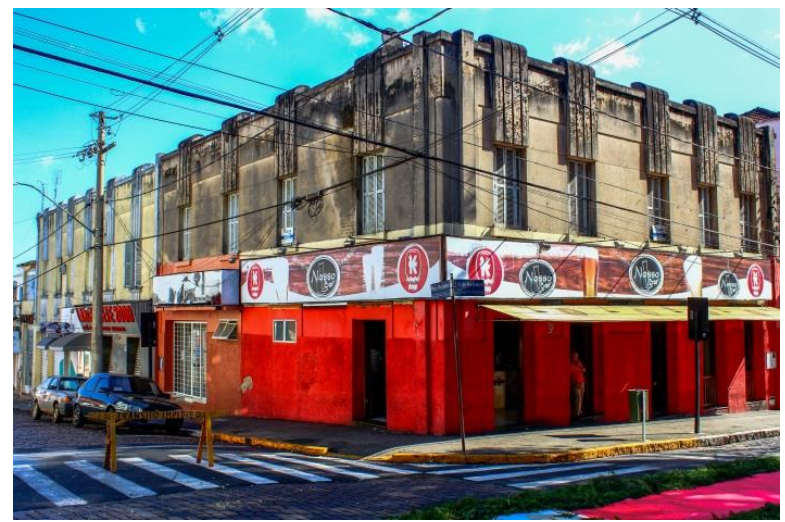

Fonte: Acervo pessoal da autora (2016)

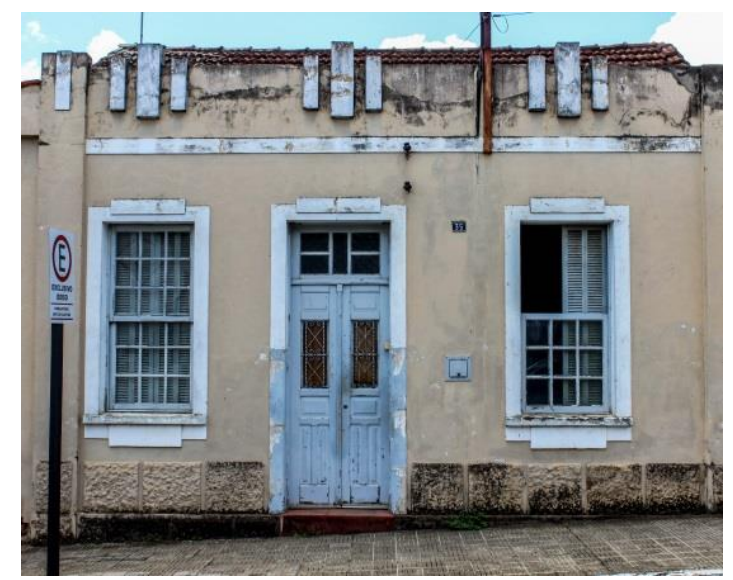

Fonte: Acervo pessoal da autora (2016).

Desse modo, ainda que muitas das edificações construídas em São José do Rio Pardo no período de 1918 a 1940 tenham sido descaracterizadas, podemos analisar uma parcela de moradias que nos possibilitou perceber a adesão à normativa do Código de Posturas e do Código Sanitário Estadual, ambos publicados em 1918, além de certas recorrências que influíram diretamente na composição formal e programática, como o estabelecimento de edificações implantadas afastadas dos limites do lote, do espaço destinado à guarda de veículos, da copa e do alpendre. Além disso, a adesão às características estilíisticas do neocolonial, do Arts and Crafts, do bangalô e do art-déco, ainda coexistindo com o ecletismo, representaram o ímpeto de novidade, contribuindo grandemente na transformação do modo de morar e da paisagem urbana. Outro aspecto que precisa ser ressaltado, apesar de não ter se constituído como uma característica dominante, foi o desenvolvimento e aplicação do cimento armado que, juntamente com as novas expectativas programáticas e o novo gosto estético, demonstraram outros caminhos que o campo da arquitetura riopardense estava seguindo. 
Esta assertiva também foi possível de ser constatada através da análise dos projetos aprovados pela Diretoria de Obras, que nos mostrou que a partir dos anos 1940 um mercado especializado em auferir lucros mediante a multiplicação do solo urbano - principalmente nos bairros periféricos com a construção de habitações modestas para a venda ${ }^{254}$ - tornou-se o promotor da arquitetura urbana com características formais variadas, mas predominando a tipologia do bangalô, como é possível perceber através de um dos projetos aprovados em 1945 (Figura 381).

Figura 381: Habitações destinadas a venda em São José do Rio Pardo.

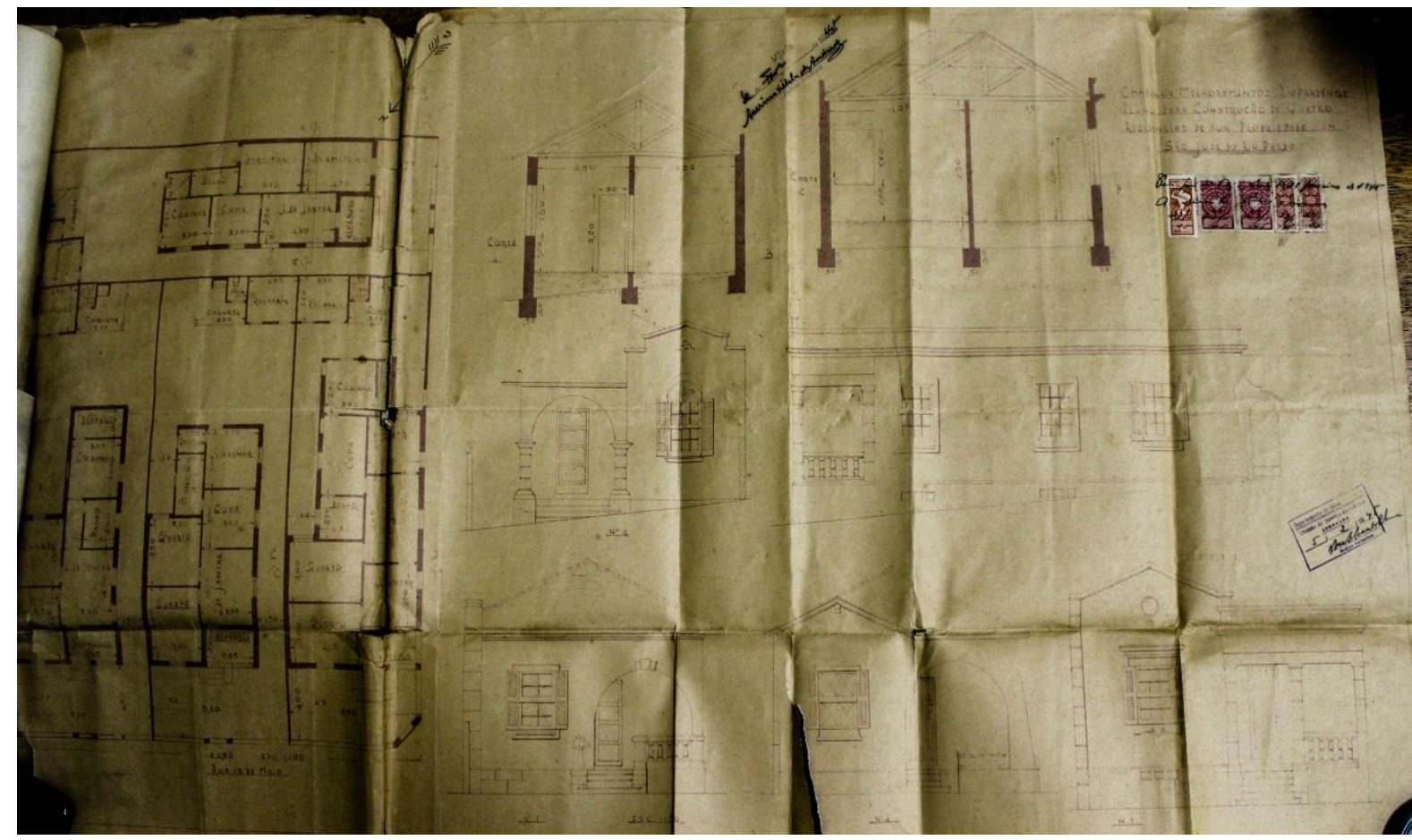

Fonte: Arquivo Público da Secretaria de Obras de São José do Rio Pardo $(1945$, P38).

\footnotetext{
${ }^{254}$ Segundo Bonduki (2011), a partir de 1942, ano em que os aluguéis foram congelados pela Lei do Inquilinato, houve a desestimulação da produção rentista e o incentivo da construção da casa própria. Bonduki (2011) ainda acrescenta que essa política resultou em uma busca de loteamentos na periferia, o que contribuiu para o espraiamento das cidades. Aproveitando dessa política, foi criada em São José do Rio Pardo uma empresa denominada de Companhia Melhoramentos Riopardense que investiu na produção de uma série de casas modestas para venda nos bairros periféricos ao núcleo urbano central.
} 
"[...]nada tem de fixo, imóvel. Cada vez que a sociedade passa por um processo de mudança, a economia, as relações sociais e políticas também mudam, em ritmos e intensidades variados, a mesma coisa acontece em relação ao espaço e à paisagem que se transforma para se adaptar às novas necessidades da sociedade"

(MILTON SANTOS, 2012, p. 54). 


\title{
Considerações Finais
}

\author{
"Dialética entre utopia e realidade construída [...] a \\ linguagem da arquitetura é uma linguagem social; \\ suas mudanças não são discretas, mas um \\ constante ir e vir entre o estabelecido \\ e o porvir"
}

(SOLA-MORALES, 1980, p. 13)

\author{
"As cidades, como os sonhos, \\ são construídas por desenhos e medos, \\ ainda que o fio condutor \\ de seu discurso seja secreto, \\ que as suas regras sejam absurdas, \\ as suas perspectivas enganosas, \\ e que todas as coisas \\ escondam uma outra coisa"
}

(ITALO CALVINO, 1998, p. 44)

Desde as primeiras linhas desta dissertação e ainda sem ter uma ideia muito clara dos resultados que alcançaríamos, seguimos o objetivo de compreender, caracterizar e analisar a moradia do Centro Histórico de São José do Rio Pardo a partir de sua relação com a cidade e o contexto social, político e econômico local entre fins do século XIX e as três primeiras décadas do século XX. Depois de tantas palavras lidas e escritas, de ideias, confrontações, cruzamentos de fontes e dados diversos, superamos nossas expectativas naquilo que nos propusemos realizar. Entre as principais constatações estão a atuação e a circulação dos artífices, mestre de obras, carpinteiros, serralheiros, pedreiros, pintores, construtores e práticos licenciados que efetivamente construíram a cidade produzindo uma arquitetura com a liberdade de criação, de seus próprios desenhos, da invenção, do gosto, das referências dos manuais e catálogos, ainda que atendendo às exigências impostas pelos Códigos de Posturas. Outra revelação é a constatação de que a arquitetura, ainda que seja tida como resultado, foi também vetor de transformações, por exemplo, ao apresentar afastamentos da edificação em relação aos limites laterais do lote antes mesmo que houvesse exigência da legislação. E nesse sentido, os Códigos de Posturas se tornaram importantes documentos ao delimitar e ao mesmo tempo indicar transição no modo de construir e de se relacionar com a arquitetura e o espaço urbano, como ocorreu com a determinação da abertura de todos os ambientes da casa para o exterior. Há 
ainda comprovação do processo de consolidação do núcleo urbano durante o século XIX, a partir da produção cafeeira e das novas possibilidades de escoamento com a chegada dos trilhos da ferrovia. Outro importante conhecimento foi sobre a existência de redes e as relações estabelecidas entre os envolvidos, o que propiciou a circulação de saber, ideias, pessoas e materiais, as quais refletiram na produção do espaço e da moradia verificada através de semelhanças, a exemplo do jardim da Praça XV de Novembro e a Praça Marechal Deodoro em Mococa, e entre a residência de Saint' Clair Andrade Junqueira e a casa de Conde Ribeiro do Valle em Guaxupé. Além disso, há o conhecimento da imbricada relação existente entre o processo de transformação da moradia e as novidades que chegavam em São José do Rio Pardo, como ocorreu com os materiais e técnicas construtivas, a exemplo das calhas e rufos e do cimento, e a inserção do automóvel no programa da casa.

Todo esse amplo universo de compreensão que tem a moradia como objeto central se efetivou porque, como já dissemos na introdução deste trabalho, desde o início propusemos a análise a partir de três eixos que são o café e ferrovia como estimuladores da ocupação e desenvolvimento urbano do interior paulista; contexto sociocultural que influenciou a produção da moradia urbana rio-pardense; e os principais agentes difusores dessa arquitetura no cenário local. Esses eixos foram fundamentais para entendermos as bases que influenciaram e determinaram a produção da cidade e da moradia. Por exemplo, no primeiro eixo constatamos que foi com o avanço da produção cafeeira, intensificada com a chegada da ferrovia que o núcleo urbano se consolidou e surgiu como instrumento de aplicação do capital através de obras de infraestrutura, construção de edificações e local de ação política. No segundo eixo, averiguamos que a entrada de imigrantes e outros personagens com seus modos de vida, o governo republicano, as epidemias, a promulgação de legislação, por exemplo, através dos Códigos de Posturas, condicionaram a vida da cidade e consequentemente foram determinantes nas características das moradias construídas. E no terceiro eixo, ao identificarmos quem foi e como atuaram os agentes, fossem eles diplomados ou não, revelamos como suas ações repercutiram na produção e nos aspectos da arquitetura residencial do Centro Histórico riopardense. Com isso, buscamos demonstrar ao longo dos capítulos que abarcam um período temporal de 75 anos como a moradia, enquanto objeto heterogêneo e complexo, se modificou a partir das características arquitetônicas, formais e compositivas, dos usos e arranjos internos, dos partidos adotados e das técnicas construtivas empregadas. Para isso, e sem a pretensão de uma divisão temporal rígida, identificamos três momentos em que determinados fatos incidiram e ocasionaram alterações na produção residencial e no modo de morar.

O primeiro momento compreendeu desde a fundação de São José do Rio Pardo em 1865 até o ano de 1902. Nesse período, o núcleo urbano inicial foi traçado, consolidando um padrão de quadra e subdivisões dos lotes concedidos através do sistema de aforamento. Em 1887 foi publicado o primeiro Código de Posturas que estabeleceu normas referentes ao aspecto urbano e à construção de casas, de modo a assegurar padrões mínimos e contribuir no arranjo e nas características arquitetônicas das moradias. Foi ainda nesse ano que a ferrovia foi implantada, estabelecendo com o café estreita relação de dependência mútua no 
processo de expansão da lavoura e no estímulo ao desenvolvimento de inúmeras atividades urbanas. Uma série de melhoramentos ocorreu nesse período, ora financiados pelo poder público ora pela elite local, que tinha o suporte econômico aliado ao interesse de expansão dos negócios através dos serviços urbanos, a exemplo da instalação de luz elétrica em 1897, contribuindo de maneira irreversível na alteração da feição da cidade e corroborando com a dinamização da própria vida urbana. Na arquitetura, prevaleceram às características atreladas à arquitetura tradicional e das casas de fazenda, mas apresentando inovações técnicas e estéticas como a utilização do tijolo e o desenvolvimento da fundição e da ferraria. Predominaram as moradias térreas, implantadas nos limites dos lotes, e sem grandes preocupações com a composição das fachadas e dos elementos decorativos, salvo aquelas que pertenciam a proprietários que almejavam a representação de seu status, como foi o caso de Honório Luiz Dias. Ou ainda como as moradias de Saint' Clair Andrade Junqueira e José Dias Machado, construídas afastadas de um dos lados do lote, refletindo desejos de conforto e seguindo os preceitos das correntes higienistas que dominaram os debates sobre saúde e higiene no final do século XIX e acabaram por afetar o modo de vida doméstico e urbano.

O aumento populacional, o desenvolvimento urbano e a implantação de infraestrutura com as redes de água e esgoto em 1903 marcaram o início do segundo momento, juntamente com a publicação de um novo Código de Posturas que dedicou uma atenção especial à estética e à higiene da cidade, da casa e das pessoas. Decisivamente, a construção das redes contribuiu na alteração das condições sanitárias da cidade e de seus edifícios, e no modo de morar e usar o espaço público na medida em que canalizou os fluídos e propiciou a aproximação do banheiro e da cozinha. Já a legislação orientou a prática construtiva, reordenando a distribuição do interior da moradia rio-pardense - por exemplo, com a proibição de alcovas -, exigindo aberturas em todos os cômodos para o exterior e afastamento da edificação do solo, visando atender, sobretudo normas sanitárias. Cerceou ainda a atuação dos agentes da construção civil, e exigiu dos proprietários a permissão de licença para construir ou reformar mediante requerimento que informasse o local, a natureza e o destino da obra, desenho das elevações, a disposição dos encanamentos e o plano de execução. Evidenciamos ainda nesse segundo momento a identificação de um amplo quadro de artífices e profissionais mantidos até hoje no anonimato, entre pedreiros, serventes, marceneiros, carpinteiros, pintores, construtores, empreiteiros, mestre de obras e engenheiros que exerceram seus ofícios na construção civil rio-pardense. Dentre eles, o destaque foi a atuação do italiano, empreiteiro, construtor, desenhista e professor Paschoal Artese, que promoveu um saber fazer técnico e formal com soluções estéticas apropriadas e reinterpretadas de acordo com a sua erudição, do que tinha a sua disposição e do gosto do cliente. Guardando as devidas escalas, Artese dominou a construção civil local tanto quanto Ramos de Azevedo em São Paulo. Foi um profissional completo, visionário, que promoveu a formação de operários através de aulas de desenho gratuitas, projetou e construiu inúmeras casas, além de influenciar o modo de vida urbano ao promover a abertura e o prolongamento de ruas e a obra do Jardim Artístico, em oposição ao poder político, social e econômico local. Em relação à moradia desse período, se caracterizou pela busca de maior privacidade e conforto através da segmentação e especialização dos espaços internos, a exemplo da residência de Dante Artese. O porão foi adotado como elemento que atendia duplamente essas 
questões afastando os olhares indiscretos da rua e a umidade do solo, como vimos na casa da esquina da Rua Francisco Glicério com a Praça Barão do Rio Branco. Os forros treliçados e as esquadrias foram adotados como soluções que facilitavam a ventilação, facultando o conforto térmico. O banheiro foi incorporado ao interior das residências e a copa surgiu como local de refeições rápidas, como na moradia da família Penna. Em termos estéticos, houve o predomínio de edificações caracterizadas pela incorporação de elementos mais fortemente ligados à linguagem eclética com uma ampla diversidade de expressões, resultando em características muito singulares.

A publicação de um novo Código de Posturas em 1918 marcou o início do terceiro momento, assinalando o princípio de um período de significativas transformações que afetaram diretamente a produção da cidade e de sua arquitetura. Pela primeira vez a cidade de São José do Rio Pardo foi dividida legalmente em zonas urbana, suburbana e rural com disposições normativas específicas para cada uma. O declínio do capital cafeeiro e o investimento em atividades industriais e agropecuárias foram acompanhados pelo setor comercial, marcando uma nova dinâmica econômica. Novos bairros surgiram nas adjacências da área urbana central, intensificando o mercado de terrenos e causando um crescimento na construção civil com novas edificações para atender outras exigências, além dos negócios e do habitar tradicional. Ao analisar os projetos e construções desse período, conhecemos os nomes dos sujeitos que atuaram na construção civil rio-pardense. Prevaleceram os empreiteiros e construtores - os chamados práticos licenciados - que projetaram e construíram obras que se distribuíram nos diferentes bairros da cidade, atingindo várias classes sociais. Três nomes se destacaram pelo volume produzido José Lourenço, Américo Braghetta e João Bergamasco. Reiteramos a proficiência que eles possuíam da atividade projetiva, edificativa e normativa, e como foi variado o desempenho de cada um. Além disso, destacamos como ocorreu a migração dessas pessoas, chamando a atenção para o trânsito de João Bergamasco entre Córdoba, na Argentina, e São José do Rio Pardo, contribuindo, assim, na ampliação do conhecimento sobre a circulação de mão de obra e de saber na América Latina. Ressaltamos ainda as dificuldades enfrentadas pela população rio-pardense no atendimento à legislação municipal e estadual que exigiam melhorias nas condições de higiene e habitabilidade, por exemplo, através da impermeabilização de pisos, pintura e elevação da altura das paredes; criação de aberturas para receber ar e luz direta; ventilação do porão; modificações no telhado e instalação de sistema de calhas. Além disso, foi a partir de 1918 que a municipalidade passou a atuar mais incisivamente ao requerer a aprovação de toda construção e reconstrução através de documentação acompanhada de plantas do terreno e pavimentos da edificação, das elevações, dos cortes longitudinais e transversais, e também da disposição dos encanamentos de água e esgoto. Ao analisar o modo como as moradias foram implantadas, constatamos o predomínio dos afastamentos laterais, e também da construção isolada no lote, fato diretamente relacionado à noção de intimidade e conforto dos seus moradores, como foi o caso da residência de Maria da Conceição Damasio e de Ciro Ferraz. Juntamente com os afastamentos da edificação dos limites do lote se popularizou a mureta baixa e as esquinas chanfradas em ângulo de $45^{\circ}$. Averiguamos ainda no programa das moradias uma nova imposição para incluir o automóvel, e a afirmação do critério burguês de bem morar baseado no zoneamento funcional 
com a distinção das áreas de estar, repouso e serviço que foram organizados a partir do vestíbulo. A copa se estabeleceu como centro de convivência da família, forçando a aproximação entre as salas de jantar e de visita. $\mathrm{O}$ alpendre lateral e frontal, antecedendo o vestíbulo, apareceu com mais frequência nesse período, assim como a edícula localizada no fundo do lote, que comumente abrigava o quarto da empregada, instalação sanitária, lavanderia, depósito e a garagem, como na moradia de João Gabriel Ribeiro. Outra novidade que surgiu e se afirmou no período entre Guerras foi o sobrado destinado ao aluguel, formando conjuntos geminados de duas ou mais unidades de moradia, a exemplo da propriedade de Willian Simonsen. Constatamos ainda a contribuição do desenvolvimento da técnica e dos materiais utilizados na construção das moradias desse período, a exemplo dos impermeabilizantes que permitiram o desaparecimento da elevação da edificação do solo, e consequentemente a abolição do assoalho e o surgimento das lajes de concreto armado. Destacamos também as permanências e mudanças na arquitetura das moradias construídas nesse período que se sobressaíram pela incorporação e combinação de elementos da linguagem do neocolonial, do art-déco e do bangalô, acompanhando uma tendência nacional.

Pudemos perceber ao longo das análises empreendidas e organizadas em três capítulos o quanto a moradia do Centro Histórico rio-pardense se alterou entre os anos de 1865 e 1940, coadunada com as transformações que estavam ocorrendo no espaço urbano com a implantação de infraestrutura, com a capacidade de atuação da política de compadrio e seus interesses, com a base econômica cafeeira associada à ferrovia, e a disponibilidade de material e mão de obra. Ao suplantar os aspectos formais mais elementares dessa produção através da análise abrangente de documentação primária, como cartas de aforamento, atas da câmara, relatórios de governo, projetos aprovados para novas construções e fotografias antigas de vários profissionais, e secundária, como reportagens de jornal e almanaques, produzimos 26 mapas que contemplam o contexto de ocupação e desenvolvimento urbano. Além desses documentos, descobrimos nos livros de impostos e na produção historiográfica de autores locais 90 pessoas que atuaram na construção civil rio-pardense entre o final do século XIX e primeira década do século XX. E ao analisarmos os processos de construção aprovados pela Prefeitura Municipal entre os anos de 1925 e 1940, descobrimos outros 16 agentes envolvidos, assim como as características de suas obras, o ano, endereço e tipo de solicitação, o que nos permitiu constatar diferenças entre as diversas gerações de profissionais que atuaram em São José do Rio Pardo. Esclarecemos ainda informações ao verificar nas moradias existentes como se alterou o programa, como as novidades foram absorvidas, e como as normativas edilícias foram aperfeiçoadas. Com isso, descobrimos a multiplicidade da moradia com diferentes graus de sofisticação no que diz respeito à composição das fachadas, ao modo de implantação, ao agenciamento dos ambientes e às relações estabelecidas entre o público e o privado. Foram 112 moradias identificadas no recorte espacial e temporal e 38 selecionadas e analisadas a partir de um intensivo e inédito levantamento fotográfico que privilegiou o exterior e o interior, de modo a captar desde o ornamento da fachada até os detalhes construtivos, os materiais e o mobiliário, além de desenhos de implantação, plantas e elevações. Intencionamos, assim, com esta dissertação colaborar com o 
reconhecimento, registro e análise da moradia urbana de modo a contribuir com a historiografia da arquitetura paulista e também brasileira. Vale, nesse sentido, enfatizar ainda que este trabalho contribui para abrir novas possibilidades de pesquisas que tenham como objetivo ampliar a abordagem e o conhecimento sobre essa produção, tendo em vista o reconhecimento da moradia como fruto de um contexto cultural e de uma história social em que prevalecem os costumes tradicionais da sociedade e da própria comunidade e, portanto a oportunidade de ser analisada enquanto produção regional. Nessa perspectiva, a compreensão de um universo bem mais amplo através da leitura de produções semelhantes podem trazer novas luzes para questões em torno dos fluxos de mercadoria, as resistências e contaminações em relação às novidades materiais e tecnológicas, à promulgação e determinações legais, à circulação de agentes da construção civil, sejam eles artífices, práticos licenciados ou diplomados, assim como de manuais e catálogos, e ainda da própria produção da arquitetura e do urbano, dos gostos e dos estilos adotados, pouco explorados pela historiografia brasileira. 


\title{
Referências
}

\author{
Livros e capítulos de livro
}

ALAMBERT, Clara Correia. Tijolo nas construções paulistanas do século XIX. São Paulo, 1993.

AMARAL, Aracy (coord.). Arquitectura neocolonial: América Latina, Caribe, Estados Unidos. São Paulo: Memorial: Fundo de Cultura Econômica, 1994.

ANDRADE, Francisco P. D. Subsídios para o estudo da influência da legislação na ordenação e na arquitetura das cidades brasileiras. São Paulo, 1966.

ANGOTTI-SALGUEIRO, H. . La casaque d'Arlequin: Belo Horizonte, une capitale écletique au XIX e siècle. Paris: Editions de l'École des Hautes Etudes en Sciences Sociales (EHESS), 1997.

BACELLAR, Carlos de Almeida Prado; BRIOSCHI, Lucila Reis (Orgs.). Na estrada do Anhanguera: uma visão regional da história paulista. São Paulo: Humanitas FFLCH/USP, 1999.

BARATA, Mário. Séc. XIX. Transição e início do século XX. In ZANINI, Walter (Org.), História Geral da Arte no Brasil. São Paulo, Instituto Wather Moreira Salles, vol. 1, p. 377-451, 1983

BASSANEZI, Maria S. C. B. (Org.). São Paulo do passado: dados demográficos, 1886, IV. Núcleo de Estudos de População - NEPO, Universidade Estadual de Campinas - Unicamp, 1999.

São Paulo do passado: dados demográficos, 1890, V. Núcleo de Estudos de População - NEPO, Universidade Estadual de Campinas - Unicamp, 1998.

BONDUKI, Nabil Georges. Origens da habitação social no Brasil: arquitetura moderna, lei do inquilinato e difusão da casa própria. São Paulo: Estação Liberdade: FAPESP, 2011.

BRESCIANI, Maria S. M. Melhoramentos entre intervenções e projetos estéticos: São Paulo 1850-1950. In: BRESCIANI, M. S. M. Palavras da cidade. Porto Alegre: Universidade/UFRGS, 2001.

BRIOSCHI, Lucila R. Caminhos do ouro. In: BACELLAR, Carlos de A. P. (Org.) e BRIOSCHI, Lucila Reis (Org.). Na estrada do Anhangüera: uma visão regional da história paulista. São Paulo: Humanitas FFLCH/USP, 1999.

BRUAND, Yves. Arquitetura contemporânea no Brasil. São Paulo: Perspectiva, 1981.

CALVINO, Italo. As cidades invisíveis. Trad. Diogo Mainardi. São Paulo: Companhia das Letras, 1998.

CAMPANHOLE, Adriano. Memória da cidade de Caconde: freguesia antiga de N. S. Da Conseyção do Bom Sucesso do Rio Pardo. São Paulo: Latina, 1979.

CANTI, Tilde. O móvel do século XIX no Brasil. Rio de Janeiro: Candido Guinle de Paula Machado, 1989. CESARINO, Aprígio. Artigo no Diário Popular. São Paulo - SP, out. 1887.

CHALHOUB, Sidney. Cidade febril: cortiços e epidemias na Corte imperial. São Paulo: Companhia de Letras, 1996.

CHIACHIRI FILHO, Jose. Do sertão do rio pardo a vila franca do imperador. Ribeirão Preto: Ribeira, 1986.

CORBIN. Alain. Saberes e odores: o olfato e o imaginário social nos séculos XVIII e XIX. São Paulo: Companhia das Letras, 1987. 
CORREIA, Telma de Barros. A construção do habitat moderno no Brasil - 1870-1950. São Carlos: RiMa, 2004.

CORRÊA, Maria Elizabeth Peirão. Arquitetura escolar paulista, 1890-1920. São Paulo-SP: Fundação para o Desenvolvimento da Educação, 1991.

COSTA, Cacilda Teixeira da. O sonho e a técnica: a arquitetura de ferro no Brasil. São Paulo: EDUSP, 2001.

CRUZ, Cícero Ferraz. Fazendas do Sul de Minas: Arquitetura rural nos séculos XVIII e XIX. Brasília, DF: Iphan / Programa Monumenta, 2010.

CZAJKOWSKI, Jorge (org.). Guia da Arquitetura Eclética no Rio de Janeiro. Rio de Janeiro, Prefeitura da Cidade do Rio de Janeiro - SMU / Centro de Arquitetura e Urbanismo do Rio de Janeiro, 2000.

DEBENEDETTI, Emma; SALMONI, Anita. Arquitetura italiana em São Paulo. Ed. Perspectiva: São Paulo, 1981.

DEL GUERRA, Rodolpho J. A beleza do amor. São José do Rio Pardo - SP: Graf-Center, $2004 a$.

A São José: uma nuova storia. S. S. da Grama - SP: Grass, 1999.

1998.

Conhecendo Euclides da Cunha: Ano 100 (1898-1998). São José do Rio Pardo - SP: Graf-Center,

. E as Sementes Florescem... . São José do Rio Pardo - SP: Graf-Center, 2002.

Enquanto a noite não vem. São José do Rio Pardo - SP: Graf-Center, 2005a.

Esvasiando o Baú. São José do Rio Pardo - SP: Graf-Center, 2005b.

Fênix: o renascer de velhos textos. São José do Rio Pardo - SP: Graf-Center, 2004b.

Meu gambá: outras crônicas e histórias. São José do Rio Pardo - SP: Graf-Center, 2003.

. No Ventre da Terra Mãe. São José do Rio Pardo - SP: Graf-Center, 2001.

. O Décimo Terceiro. São José do Rio Pardo - SP: Graf-Center, 2007.

. Perseverando. São José do Rio Pardo - SP: Graf-Center, 2008.

Riquezas do Baú Provinciano. S. S. da Grama - SP: Grass, 2000.

São José do Rio Pardo, história que muitos fizeram. S. J. do Rio Pardo, SP: Gazeta do Rio Pardo, 1983.

Unindo meus dois livretos São José do Rio Pardo: história que muitos fizeram, Conhecendo Euclides da Cunha. S. J. do Rio Pardo, SP: Graf-Center, 2010.

DELSON, Roberta Marx. Novas Vilas para o Brasil-Colônia: Planejamento Especial e Social no Século XVIII. Brasília: Editora Alva-Ciord, 1997.

DOWNING, Andrew J.. The architecture of country houses. New York: Dover publications, 1969.

EGAS, Eugenio (Org.). Os municípios paulistas. São Paulo: Seção de Obras do Estado de S. Paulo, v. 2, p. 1841-1848, 1925.

FABRIS, Annateresa (Org.). Ecletismo na Arquitetura Brasileira. São Paulo: Nobel/USP, Editora da Universidade de São Paulo, 1987. 
FAORO, Raymundo. Os donos do poder: formação do patronato político brasileiro. 5ed. São Paulo: Globo, 2012.

FARIA, Rodrigo dos Santos. Ribeirão Preto, uma cidade em construção: o discurso da higiene, beleza e disciplina na modernização Entre Rios (1895-1930). São Paulo: Annablume, 2010.

FELDMAN, Sarah. Planejamento e Zoneamento: São Paulo (1947- 1972). São Paulo: Edusp/Fapesp, 2005.

FICHER, Sylvia. Os Arquitetos da Poli: Ensino e Profissão em São Paulo. Edusp: São Paulo, 2005.

FREIRE, Maria C. M. Além dos mapas: os monumentos no imaginário urbano contemporâneo. São Paulo: SESC: Annablume, 1997.

FONSECA, Cláudia Damasceno. Arraiais e vilas d'el rei: espaço e poder nas Minas setecentistas. Belo Horizonte: Editora UFMG, 2011.

FOUCAULT, M. Microfísica do poder. Tradução de Roberto Machado. 4ạ edição. Rio de Janeiro: Edições Graal, 1984.

. Vigiar e punir: nascimento da prisão: história da violência nas prisões. Petrópolis: Vozes, 2009.

FURLANI, Geraldo Majella. O Município de Casa Branca. Casa Branca: Impressos São Sebastião Editora e Gráfica Ltda., 2003.

FURTADO, Celso. Formação econômica do Brasil. São Paulo: Ed. Nacional, 1984

GHIRARDELLO, Nilson. A formação dos patrimônios religiosos no processo de expansão urbana paulista (1850/1900). São Paulo: Editora UNESP, 2010.

GORDINHO, Margarida Cintra (text); CANNABRAVA, latã (fotog); TEODORO, Malu (fotog); ASSENCIO, Vinicius (fotog). Patrimônio escolar: uma saga republicana. São Paulo: Governo do Estado de São Paulo, Secretaria da Cultura, 2013.

GUERRAND, Roger H. Espaços privados. In: PERROT, Michelle (Org.), História da Vida Privada. Da Revolução Francesa à Primeira Guerra. São Paulo: Companhia das Letras, 1991.

HALL, Catherine. Sweet Home. In: PERROT, Michelle (Org.), História da Vida Privada. Da Revolução Francesa à Primeira Guerra. São Paulo: Companhia das Letras, 1991.

HOMEM, Maria C. N. O palacete paulistano e outras formas de morar da elite cafeeira: 1867-1918. São Paulo, Martins Fontes, 1996. Paulo, 2015.

Cozinha e indústria em São Paulo: do rural ao urbano. São Paulo: Editora da Universidade de São

IL BRASILE E GLI ITALIANI. São Paulo: Publicazione del "Fanfulla", 1187, p. 1906.

JOSÉ, Ganymedes. Era uma vez Casa Branca. Casa Branca: Biblioteca Municipal, 1972.

KESSEL, Carlos. Arquitetura neocolonial no Brasil: entre o pastiche e a modernidade. Rio de Janeiro, Jauá Editora, 2008.

KOSSOY, Boris. Fotografia \& História. São Paulo: Ateliê Editorial, 2001. 
KRAMER, K.. Applying the Lessons of Indian Vernacular Architecture: The Bungalow as Example of Adaptive Climatic Response. PLEA 2006-The 23rd Conference on Passive and Low Energy Architecture, Geneva, Switzerland, 2006.

$\mathrm{KÜHL}$, Beatriz M. Arquitetura do ferro e arquitetura ferroviária em São Paulo reflexões sobre a sua preservação. São Paulo, FAPESP, 1998.

LANCASTER, Clay. The American Bungalow: 1880-1930. Nova York: Abbeville Press, 1985.

LAPA, José R. A. A cidade: os cantos e os antros: Campinas, 1850-1900. São Paulo, SP: Editora da USP; Campinas, SP: Editora da Unicamp, 1996.

LEAL, Vitor Nunes. Coronelismo, enxada e voto. São Paulo, Editora Alfa-Omega, 1976.

LEITE, Joaquim da Costa. O Brasil e a emigração portuguesa (1855-1914). In: B. Fausto (Ed.). Fazer a América. A imigração de Massa para a América Latina. São Paulo: EDUSP, p.177-200, 2000.

LE GOFF, Jacques. História e Memória. Campinas: SP, Editora da Unicamp, 1990.

LEMOS, Carlos A. C. Alvenaria Burguesa. São Paulo: Nobel, 1989a.

A república ensina a morar (melhor). São Paulo, SP: Editora Hucitec, 1999.

Casa Paulista: história das moradias anteriores ao ecletismo trazido pelo café. São Paulo: Editora da Universidade de São Paulo, 2015.

Cozinhas, etc.. São Paulo: Perspectivas, 1978.

Ecletismo em São Paulo. In FABRIS, Annateresa (Org.), Ecletismo na Arquitetura Brasileira. São Paulo: Nobel/USP, Editora da Universidade de São Paulo, 1987 (p. 68-103).

História da casa brasileira. São Paulo: Perspectivas, 1989b.

LEPETIT, Bernard. Por uma nova história urbana. São Paulo: Edusp, 2001.

LEVI, Darrell E. A família Prado. Tradução de José E. Mendonça. São Paulo: Cultura 70, 1977.

LIMA, Solange Ferraz de. Profissão: pintor-decorador. Oreste Sercelli na cultura da ornamentação arquitetônica de São Paulo. In: LANNA, Ana Lúcia Duarte [et al] (orgs.). São Paulo, os estrangeiros e a construção das cidades. São Paulo: Alameda, 2011.

LÜDKE, Menga; ANDRÉ, Marli E. D. A. Pesquisa em Educação: abordagens qualitativas. São Paulo: E.P.U., 2012.

LUZ, Madel Therezinha. Medicina e ordem política brasileira: políticas e instituições de saúde (1850-1930). Rio de Janeiro: Edições Graal, 1982.

MACAMBIRA, Yvoty. Os mestres da fachada. São Paulo: Centro Cultural, 1985.

MARINS, Paulo César Garcez. Vida cotidiana entre os paulistas: moradias, alimentação, indumentária. In: SETUBAL, Maria Alice. (Org.). Terra paulista: histórias, arte, costumes. São Paulo: CENPEC; IMESP, v. 02, p. 89-190, 2004.

MARTINS, Ana Luiza. A invenção e/ou eleição dos símbolos urbanos: história e memória da cidade paulista. In: BRESCIANI, Stella (Org.), Imagens da cidade: séculos XIX e XX. São Paulo: Marco Zero/Fapesp, p. 177-190, 1994. 
História do café. São Paulo: Contexto, 2012.

MARX, Murilo. Cidade no Brasil: terra de quem? São Paulo: Nobel/EDUSP, 1991.

Cidade Brasileira. São Paulo: Ed. Melhoramentos, EDUSP, 1980.

Nosso chão do sagrado ao profano. São Paulo: EDUSP, 2003.

MASCHIETTO, Carmen C. T. A tradição euclidiana: uma ponte entre a história e memória. São Paulo: Arte \& Ciência; São Paulo: UNIRIU, 2002.

MATOS, Odilon N. de. Café e ferrovias: a evolução ferroviária de São Paulo e o desenvolvimento da cultura cafeeira. Campinas, SP: Pontes, 1990.

MEIRA MOLINARI, Ezio José. 200 Anos Casa Branca. Casa Branca: Jornal Casa Branca, 2014.

MILLIET, Sérgio. Roteiro do café e outros ensaios. São Paulo: Coleção Departamento de Cultura, volume XXV, 1941.

MORALES, Ignasi de Sola. Eclecticismo Y Vanguardia El Caso de La Arquitectura. Gustavo Gili, 1980.

MONAT, Henrique. Caxambú. Rio de Janeiro, 1894.

MONBEIG, Pierre. Pioneiros e Fazendeiros de São Paulo. 2a ed. São Paulo: Hucitec-Polis, 1998.

MONTEIRO, Ana Maria Reis de Góes. Ramos de Azevedo: presença e atuação profissional em Campinas. Campinas: UNICAMP/CMU Publicações: Arte Escrita, 2009.

NAYLOR, Gillian. The Arts and Crafts Moviment: a study of its sources, ideals and influence on design theory. Londres: Studio Vista, 1971.

OLIVEIRA, Joana D’Arc de. Da senzala para onde? negros e negras no pós-abolição em São Carlos-SP (18801910). São Carlos: FPMSC, 2018.

PALADINI, Carlos Alberto. Os Italianos em Mococa. Ribeirão Preto: Editora São Francisco. 2009.

PATETTA, Luciano. Considerações sobre o ecletismo na Europa. In: FABRIS, Annatereza (Org.) Ecletismo na Arquitetura Brasileira. São Paulo: Nobel/USP, Editora da Universidade de São Paulo, 1987.

PERROT, Michelle. Maneiras de morar. In: PERROT, Michelle (Org.), História da Vida Privada. Da Revolução Francesa à Primeira Guerra. São Paulo: Companhia das Letras, 1991.

A família triunfante. In: PERROT, Michelle (Org.), História da Vida Privada. Da Revolução Francesa à Primeira Guerra. São Paulo: Companhia das Letras, 1991.

Funções da família. In: PERROT, Michelle (Org.), História da Vida Privada. Da Revolução Francesa à Primeira Guerra. São Paulo: Companhia das Letras, 1991.

PESAVENTO, Sandra J. Com os olhos no passado: a cidade como palimpsesto. Esboços, Florianópolis, v. 11, n. ${ }^{\circ} 11$, p. 25-30, 2004.

PINHEIRO, Maria Lucia Bressan. Neocolonial, Modernismo e Preservação do Patrimônio no Debate Cultural dos Anos 1920 no Brasil. São Paulo: EDUSP - Editora da Universidade de São Paulo, 2011. 
PINTO, Adolfo Augusto. História da viação pública de São Paulo. São Paulo, Typographia e Papelaria de Vanorden \& Cia, 1903.

PROSPECTO DO MACKENZIE COLLEGE E ESCOLA AMERICANA. São Paulo, 1910-1919.

PUPPI, Marcelo. Por uma história não moderna da arquitetura brasileira: questões de historiografia. Campinas, SP: Pontes: Associação dos Amigos da História da Arte: CPHA: IFCH: Unicamp, 1998.

PURDOM, Charles Benjamin. The Garden City: a study in the development of a modern town. Londres: J.M.Dent \& Sons, 1913.

RAGO, Margareth. Do Cabaré ao Lar: a utopia da cidade disciplinar - Brasil 1890-1930. Rio de Janeiro: Paz e Terra, 1985.

REIS FILHO, Nestor Goulart. Arquitetura residencial brasileira no século XIX. São Paulo: Museu Paulista, 1965. Quadro da arquitetura no Brasil. São Paulo, Editora Perspectiva, 2011. Racionalismo e proto-modernismo na obra de Victor Dubugras. São Paulo: FBSP, 1997.

REIS, Nestor Goulart. Contribuição ao estudo da evolução urbana do Brasil: 1500/1720. São Paulo: Liv. Pioneira e Ed. da Universidade, 2000.

RIOS, Ana Lugão e MATTOS, Hebe. Memórias do cativeiro: família, trabalho e cidadania no pós-abolição. Rio de Janeiro: Civilização Brasileira, 2005.

RIBEIRO, Maria Alice Rosa. História sem Fim... Inventário da saúde pública. São Paulo: Editora da Universidade Estadual Paulista, 1993.

RIBEIRO, Suzana Barretto. Inventário Arquitetônico de Mococa. Campinas: Direção Cultura, 2011.

ROCHA FILHO, Gustavo Neves da. Casa Branca: levantamento sistemático destinado a inventariar bens culturais do Estado de São Paulo. São Paulo: Condephaat, 2005

Caconde: levantamento sistemático destinado a inventariar bens culturais do Estado de São Paulo. São Paulo: Condephaat, 2005.

ROLNIK, Raquel. A Cidade e a lei: legislação, política urbana e territórios na cidade de São Paulo. São Paulo: Studio Nobel; FAPESP, 2007.

ROSA, Timotheo Pereira Projectos de abastecimento d'água e rêde de exgottos da cidade de S. José do Rio Pardo. São José do Rio Pardo, 1900.

ROSEN, George. Uma história da saúde pública. São Paulo: Hucitec, 1994.

ROSSINI, Rosa Ester; OLIVEIRA, Raimunda Maria. Sociedade e Natureza. In: BACELLAR, Carlos de Almeida Prado; BRIOSCHI, Lucila Reis. Na Estrada do Anhanguera: uma visão regional da história paulista. São Paulo: Humanitas, 1999.

RYBCZYNSKI, Witold. Casa: pequena história de uma idéia. Rio de Janeiro: Record, 2002.

SAES, Flavio A. M. As ferrovias de São Paulo, 1870-1940. São Paulo, SP: Hucitec, 1981. 
A grande empresa de serviços públicos na economia cafeeira (1850-1930). São Paulo: Hucitec, 1986.

SALGADO, Ivone. Pierre Patte e a cultura urbanística do iluminismo francês. Caderno de pesquisa do LAP no 38, Série Urbanização e Urbanismo, USP/FAU, 2003.

Urbanismo sanitarista em Campinas no final do século XIX. In: PADILHA, Nino. (Org.). Cidade e Urbanismo - História, Teorias e Práticas. Salvador - BA: FAUFBA, p. 218-241, 1998.

SALLES, Iraci Galvão. Trabalho, progresso e a sociedade civilizada: o partido republicano e a política de mão de obras 1870-1889. São Paulo: Hucitec, 1986.

SALVADORE, Waldir. Italiano e nosso: Felisberto Ranzini e o "estilo florentino". São Paulo: Cultura Acadêmica, 2015.

SANTOS, Carlos J. F. Nem tudo era italiano: São Paulo e pobreza: 1890-1915. São Paulo: Annablume / Fapesp, 2008.

SANTOS, Milton. Pensando o Espaço do Homem. São Paulo: Editora da Universidade de São Paulo, 2012.

SÃO PAULO [Município]. Secretaria da Educação e Saúde Pública. Novos prédios para grupo escolar. São Paulo: Diretoria do Ensino. Departamento de Obras Públicas, 1936.

SEGAWA, Hugo M. Modernidade pragmática: arquitetura no Brasil dos anos 1920 a 1940. Rio de Janeiro: Solar Grandjean de Montigny/PUC, 1997.

Arquiteturas no Brasil 1900-1990. São Paulo: Editora da Universidade de São Paulo, 2014.

SEVCENKO, Nicolau (Org.). O prelúdio republicano, astúcias da ordem e das ilusões do progresso. In: História da Vida Privada no Brasil. Vol 3. São Paulo: Companhia das Letras, 1998.

Tensões sociais e criação cultural na primeira República. São Paulo: Brasiliense, 1985.

SOMEKH, Nadia. A Cidade Vertical e o Urbanismo Modernizador. São Paulo, EDUSP / Studio Nobel / FAPESP, 1997.

SOUZA, Alberto. Arquitetura neoclássica brasileira: um reexame. São Paulo: Pini, 1994.

SYNOPSE DO RECENSEAMENTO DE 1890. Directoria Geral de Estatística. Rio de Janeiro, Officina da Estatística, 1898.

SZMRECZÁNYI, Maria Irene de Queiroz Ferreira. A americanização da cidade brasileira: a substituição de modelos urbanísticos em São Paulo, no século XX. Buenos Aires: Procedings of the XIII International Economic History Congress, 2003.

TAUNAY, Affonso de E. História do café no Brasil. Rio de Janeiro: Departamento Nacional do Café, v. 6-9, 1939.

História do café no Brasil. Rio de Janeiro: Departamento Nacional do Café, v. 10-12, 1941.

Pequena história do café no Brasil (1727-1937). Rio de Janeiro: Departamento Nacional do Café, 1945. 
TELAROLLI JUNIOR. Rodolpho. Poder e saúde. As epidemias e a formação dos serviços de saúde em São Paulo. São Paulo: Editora da Universidade Estadual Paulista, 1996.

TILLY, Charles. Migration in Modern European History. In: MCNEILL, William H. \& ADAMS, Ruth S. (orgs.). Human migration, patterns and policies. Indiana University Press, pp. 48-72, 1978.

TRENTO, Angelo. Do outro lado do Atlântico. São Paulo: Nobel: Instituto Italiano di Cultura di San Paolo: Instituto Cultural Ítalo-Brasileiro, 1988.

TREVISAN, Amélia F. A Ponte e a Cidade - Igreja Matriz - O Cristo Redentor Desceu na Colina - Santa Casa de Misericórdia - A Câmara Municipal de São José do Rio Pardo - Companhia Ramal Férreo do Rio. São José do Rio Pardo, Editora: do Autor, 1980.

Capela de São José do Rio Pardo: livro de atas das reuniões dos fundadores 1865/1874. Vargem Grande do Sul, Tatoni \& Cia. Ltda, 1986.

Casa Branca, a povoação dos Ilhéus. São Paulo: Arquivo do Estado, 1982.

TRUZZI, Oswaldo. Redes em processos migratórios. In: LANNA, Ana Lúcia Duarte [et al] (orgs.). São Paulo, os estrangeiros e a construção das cidades. São Paulo: Alameda, 2011.

VASCONCELLOS, Syvio de. Arquitetura dois estudos. Goiania, MEC, SESU, PIMEG, UCG, 1983.

VERÍSSIMO, Francisco S.; BITTAR, William S. M. 500 anos da casa no Brasil. Rio de Janeiro: Ediouro, 1999.

VIANNA, Oliveira. Evolução do povo brasileiro. São Paulo: Cia. Editora Nacional, 1933.

ZVEIBIL, Vera H. B. Machado: retrato de família. São Paulo: V. H. B. Zveibil, 2000.

WAISMAN, Marina. O interior da história: historiografia arquitetônica para uso de latino-americanos. São Paulo, Perspectiva, 2013.

WEISSMAN, Alan. Introduction to the Dover Edition. In: Craftsman Bungalows: 59 homes from "The Craftsman". Nova York: Dover Publications, 1998.

WOLFF, Silvia Ferreira Santos. Escolas para a república: os primeiros passos da arquitetura das escolas públicas paulistas. São Paulo, Edusp, 2010.

. Jardim América: O Primeiro Bairro-jardim de São Paulo e Sua Arquitetura. São Paulo: EDUSP, 2001.

\section{Teses, dissertações e monografias}

ALAMBERT, Clara Correia. Manifestações da arquitetura residencial paulistana entre as Grandes Guerras. Tese (Doutorado) - Faculdade de Arquitetura e Urbanismo, Universidade de São Paulo, São Paulo, 2003.

Um Novo Modo de Construção no Limiar do século XX. Concreto Armado: Experiências Técnicas / Especulações Estéticas. Trabalho programado (Arquitetura e Urbanismo) - Faculdade de Arquitetura e Urbanismo, Universidade de São Paulo, São Paulo, 2002.

ANDRADE, Carlos Roberto Monteiro de. A peste e o plano: o urbanismo sanitarista do engenheiro Saturnino de Brito. Dissertação (Mestrado) - Faculdade de Arquitetura e Urbanismo, Universidade de São Paulo, São Paulo, 1992. 
Barry Parker: um arquiteto inglês na cidade de São Paulo. Tese (Doutorado) - Faculdade de Arquitetura e Urbanismo, Universidade de São Paulo, São Paulo, 1998.

ATIQUE, Fernando. Arquitetando a "Boa Vizinhança": a sociedade urbana do Brasil e a recepção do mundo norte-americano (1876-1945). Tese (Doutorado). ) - Faculdade de Arquitetura e Urbanismo, Universidade de São Paulo, São Paulo, 2007.

BELLUZZO, Ana Maria de Moraes. Artesanato, Arte e Indústria. Tese (Doutorado) - Faculdade de Arquitetura e Urbanismo, Universidade de São Paulo, São Paulo, 1988.

BENINCASA, Vladimir. Fazendas Paulistas: Arquitetura Rural no Ciclo Cafeeiro. Tese (Doutorado) Departamento de Arquitetura e Urbanismo da Escola de Engenharia, Universidade de São Paulo, São Carlos, 2007.

BERNARDINI, Sidney Piochi. Construindo Infra-Estruturas, Planejando Territórios: A Secretaria de Agricultura, Comércio e Obras Públicas do Governo Estadual Paulista (1892-1926). Tese (Doutorado) - Faculdade de Arquitetura e Urbanismo, Universidade de São Paulo, São Paulo, 2007.

BORTOLUCCI, Maria Â. P. C. S. Moradias urbanas construídas em São Carlos no período cafeeiro. Tese (Doutorado) - Faculdade de Arquitetura e Urbanismo, Universidade de São Paulo, São Paulo, 1991.

CACHIONI, Marcelo. Arquitetura eclética na cidade de Piracicaba. Dissertação (Mestrado) - Faculdade de Arquitetura e Urbanismo, Pontifícia Universidade Católica, Campinas, 2002.

CAMPOS, Vitor J. B. O art-decó e a construção do imaginário moderno: um estudo de linguagem arquitetônica. Tese (Doutorado) - Faculdade de Arquitetura e Urbanismo, Universidade de São Paulo, São Paulo, 2003.

. "O art déco na arquitetura paulistana: uma outra face do moderno". Dissertação (Mestrado) Faculdade de Arquitetura e Urbanismo, Universidade de São Paulo, São Paulo, 1996.

CASSASSOLA, Luiz A. Família, Capitalismo e Modernização: um estudo de caso da família Dias de São José do Rio Pardo-SP (1870-1930). Dissertação (Mestrado) - Faculdade de História, Direito e Serviço Social, Universidade Estadual Paulista, Franca, 2009.

CELESTE, Marcos. Cabeceiras do Rio Pardo: ocupação e formação da região de Caconde - SP (1765 - 1820). Dissertação (Mestrado) - Faculdade de Ciências Humanas e Sociais, Universidade Estadual Paulista, Franca, 2010.

COSTA, Natália. Espaços negros na cidade do pós-abolição. Dissertação (Mestrado) - Instituto de Arquitetura e Urbanismo, Universidade de São Paulo, São Carlos, 2015.

CYRINO FILHO, Moacyr Albino de Almeida. Edifícios tombados na cidade de Guaxupé - MG. Dissertação (Mestrado) - Faculdade de Arquitetura e Urbanismo, Universidade de São Paulo, São Paulo, 2008.

DEMINICE, Daniel. A arte de se construir cidades em meio à política local: Ribeirão Preto, 1890-1960. Dissertação (Mestrado) - Instituto de Arquitetura e Urbanismo, Universidade de São Paulo, São Carlos, 2015.

DERNTL, Maria F. Método e Arte: criação urbana e organização territorial na capitania de São Paulo, 17651811. Tese (Doutorado) - Faculdade de Arquitetura e Urbanismo, Universidade de São Paulo, São Paulo, 2010.

FERREIRA, Monica C. B. F. Higiene e Habitação: o Controle da Atividade Edificativa em Campinas: 1880-1934. Tese (Doutorado) - Instituto de Arquitetura e Urbanismo, Universidade de São Paulo, São Carlos, 2017. 
FRANCISCO, Rita de Cássia. Construtores anônimos em Campinas (1892-1933): fortuna crítica de suas obras na historiografia e nas políticas de preservação da cidade. Tese (Doutorado) - Faculdade de Arquitetura e Urbanismo, Universidade de São Paulo, São Paulo, 2013.

GARCIA, Valéria E. As tramas e o poder. Jaboticabal 1895-1936, praça, igreja e uma outra história. Dissertação (Mestrado) - Departamento de Arquitetura e Urbanismo da Escola de Engenharia, Universidade de São Paulo, São Carlos, 2008.

Do Santo? Ou de quem... Ribeirão Preto: gênese da cidade mercadoria. Tese (doutorado) - Instituto de Arquitetura e Urbanismo, Universidade de São Paulo, São Carlos, 2013.

JANJULIO, Maristela da Silva. Arquitetura residencial paulistana dos anos 1920: ressonâncias do Arts and Crafts? Dissertação (Mestrado) - Instituto de Arquitetura e Urbanismo, Universidade de São Paulo, São Carlos, 2009.

KING, Antony Douglas. The Bungalow 1600 - 1980: A study of the cultural, social, political and economic factors in the production of a global house-type. Tese (doutorado) - Escola de Ciências Sociais, Universidade de Brunel, Londres, 1982.

KROHG, Daniela da Silva Santos. A reconfiguração urbana de Campinas no contexto das epidemias de febre amarela no final do século XIX (1880-1900). Dissertação (Mestrado) - Centro de Ciências Exatas, Ambientais e de Tecnologia, Pontifícia Universidade Católica, Campinas, 2012

LANNA, Ana L. D. Ferrovias, cidades, trabalhadores 1870-1920. Tese (Livre-docência) - Faculdade de Arquitetura e Urbanismo, Universidade de São Paulo, São Paulo, 2002.

LIMA, Roberto P. T. Modelos portugueses e arquitetura brasileira. Tese (Doutorado) - Instituto de Filosofia e Ciências Humanas, Departamento de História, Universidade de Campinas, Campinas, 2001.

Transformação urbana: inventário, análise e interpretação de um corpus específico da arquitetura paulista, o município de Amparo até a crise de 1929. Dissertação (Mestrado) - Instituto de Filosofia e Ciências Humanas, Departamento de História, Universidade de Campinas, Campinas, 1992.

LIMA, Ana Carolina G.. Arquitetura residencial urbana através do acervo de Obras Particulares do Arquivo Público e Histórico de Ribeirão Preto - SP. Tese em desenvolvimento (Doutorado) - Instituto de Arquitetura e Urbanismo, Universidade de São Paulo, São Carlos.

LODY, Jorge. Arquitetura e Cidade. Obras particulares em São Paulo 1906-1915. Tese (Doutorado) Faculdade de Arquitetura e Urbanismo, Universidade de São Paulo, São Paulo, 2015.

MALUF, Marina Kosovski. Leveza, design e mobiliário no Brasil: aspectos visuais de uma ideia. Dissertação (Mestrado) - Departamento de Artes \& Design, Pontifícia Universidade Católica, Rio de Janeiro, 2013.

MASCARO, Luciana Pelaes. Difusão da arquitetura neocolonial no interior paulista, 1920-1950. Tese (Doutorado) - Departamento de Arquitetura e Urbanismo da Escola de Engenharia, Universidade de São Paulo, São Carlos, 2008.

MENECHINO, Luís A. P. Restauração da antiga Casa de Câmara e Cadeia de São José do Rio Pardo. Dissertação (Mestrado) - Departamento de Arquitetura e Urbanismo da Escola de Engenharia, Universidade de São Paulo, São Carlos, 1986.

MERCADANTE JÚNIO, Carlos M. D. Características do desenvolvimento arquitetônico de Ribeirão Preto 1856 - 1960. Dissertação (Mestrado) - Departamento de Arquitetura e Urbanismo da Escola de Engenharia, Universidade de São Paulo, São Carlos, 1988. 
MISSURA, Fábio A. Costa Machado: ação política e empresarial na sociedade do café em Rio Pardo (18871917). Dissertação (Mestrado) - Faculdade de História, Direito e Serviço Social, Universidade Estadual Paulista, Franca, 2003.

MOREIRA, Amanda Cavalcante. Teresina e as moradias da região central da cidade (1852-1952). Dissertação (Mestrado) - Instituto de Arquitetura e Urbanismo, Universidade de São Paulo, São Carlos, 2016.

MURILHA, Douglas. O Higienismo e a construção dos matadouros e mercados públicos. Dissertação (Mestrado) - Centro de Ciências Exatas, Ambientais e de Tecnologia, Pontifícia Universidade Católica, Campinas., 2011.

OLIVEIRA, Fabiana Valeck de. Arquitetura escolar paulista nos anos 30. Dissertação (Mestrado) - Faculdade de Arquitetura e Urbanismo, Universidade de São Paulo, São Paulo, 2007.

PARETO JÚNIOR, Lindener. O cotidiano em construção: os "práticos licenciados" em São Paulo (1893-1933). Dissertação (Mestrado) - Faculdade de Arquitetura e Urbanismo, Universidade de São Paulo, São Paulo, 2011.

Pândegos, rábulas, gamelas: Os construtores não-diplomados entre a engenharia e a arquitetura (1890 - 1960). Tese (Doutorado) - Faculdade de Arquitetura e Urbanismo, Universidade de São Paulo, São Paulo, 2016

PAULINO, Ruth Cristina M. Clima, moradia, hábitos alimentares na micro-região de São José do Rio Pardo, SP. Dissertação (Mestrado) - Departamento de Arquitetura e Urbanismo da Escola de Engenharia, Universidade de São Paulo, São Carlos, 1993.

PICCINATO JUNIOR, Dirceu. Em chão urbano, o senhorio é santo: urbanização e aforamento de terras no Bispado do Ribeirão Preto entre o Brasil Império e a Primeira República. Tese (Doutorado) - Faculdade de Arquitetura e Urbanismo, Pontifícia Universidade Católica, Campinas, 2016.

Terra urbana, patrimônio fundiário: uma análise histórica da apropriação do solo na configuração do urbano no nordeste paulista (1800-1930). Dissertação (Mestrado) - Faculdade de Arquitetura e Urbanismo, Pontifícia Universidade Católica, Campinas, 2012.

PINTO, Liliane Faria Corrêa. São José do Rio Pardo e sua revolta republicana. Tese (Doutorado) - Centro de Pesquisa e Documentação de História Contemporânea do Brasil, Fundação Getulio Vargas, Rio de Janeiro, 2014.

RAMALHO, Maria Lucia Bressan. Da Beaux-Arts ao Bungalow: Uma Amostragem da Arquitetura Eclética no Rio de Janeiro e em São Paulo. Dissertação (Mestrado) - Faculdade de Arquitetura e Urbanismo, Universidade de São Paulo, São Paulo, 1989.

REZENDE, Natalia Cappellari. A construção urbana através da memória social coletiva: entre o rio Pardo e São José. Iniciação científica (Monografia) - Faculdade de Arquitetura e Urbanismo, Pontifícia Universidade Católica, Poços de Caldas, 2015.

Construindo a história através da memória: reabilitação do patrimônio urbano e arquitetônico de São José do Rio Pardo. Trabalho Final de Graduação (Monografia) - Faculdade de Arquitetura e Urbanismo, Pontifícia Universidade Católica, Poços de Caldas, 2014.

RODRIGUES, Mariana P. H. Patrimônio rural do município de Casa Branca: 1830-1900. Dissertação (Mestrado). São Paulo: Faculdade de Arquitetura e Urbanismo da Universidade de São Paulo, 2010. 
Evolução Urbana de uma Cidade no Interior Paulista Casa Branca no Caminho de Goiás. Trabalho Final de Graduação (Monografia) - Faculdade de Arquitetura e Urbanismo, Universidade de São Paulo, São Paulo, 2006.

ROSADA, Mateus. Igrejas paulistas da Colônia e do Império: arquitetura e ornamentação. Tese (Doutorado) Instituto de Arquitetura e Urbanismo, Universidade de São Paulo, São Carlos, 2016.

SILVA, Rachel A. B. O Projeto de construção da nação republicana na visão de Euclides da Cunha. Dissertação (Mestrado) - Faculdade de Educação, Universidade Estadual de Campinas, Campinas, 2004.

\section{Periódicos}

ABREU, Regina. Emblemas da nacionalidade: o culto feito a Euclides da Cunha. In: Revista Brasileira de Ciências Sociais, São Paulo, n. ${ }^{\circ}$ 24, p. 66-84, 1994.

BEGUIN, François. As máquinas inglesas do conforto. In: Espaço e debates, São Paulo, n.34, p. 39-54, 1991.

BONI, Valdete; QUARESMA, Sílvia Jurema. Aprendendo a entrevistar: como fazer entrevistas em Ciências Sociais. In: Em Tese: Revista Eletrônica dos Pós-Graduandos em Sociologia Política da UFSC, vol. 2, n. ${ }^{\circ} 1$ (3) , p. 68-80, janeiro-julho/2005.

BORIN, Monique Félix. A contribuição de Theodoro Sampaio ao relatório dos cortiços de Santa Ifigênia: saneamento e urbanismo na trajetória de um engenheiro. In: Risco: revista de pesquisa em arquitetura e urbanismo, Instituto de Arquitetura e Urbanismo, Universidade de São Paulo, v. 14, n. ํ 1, p. 49-57, 2016.

COSTA, Lúcio. Notas sobre a evolução do mobiliário Luso-Brasileiro. In: Revista do Serviço do Patrimônio Histórico e Artístico Nacional, Rio de Janeiro, n. ${ }^{\circ}$ 3, 1939.

ENOKIBARA, Marta. Organizações Dierberger (1893-1940). In: Paisagem e Ambiente: Ensaios, São Paulo, n. ${ }^{\circ}$ 38, p. $35-54,2016$.

FRANK, Zephyr Lake. Elite families and oligarchic politics on the brazilian frontier: Mato Grosso, 1889-1937. Latin American Research Review, Albuquerque, v. 36, n. 1, p. 49-74, 2001.

ISOLDI, Maria Celina. A família Mello de São José do Rio Pardo e região. In: Revista da ASBRAP, n. ${ }^{2}$ 2, p. 267 331, 1995.

LEMOS, Carlos A. C. Uma nova proposta de abordagem da história da arquitetura brasileira. In: Arquitextos, Vitruvius, 141.00, ano 12, 2012.

LEMOS, Fernando Cerqueira. Contribuição a historia do Instituto Bacteriológico 1892 - 1940. In: Revista do Instituto Adolfo Lutz, v. 14, cap. V, 1954.

LIRA, José T. C. O urbanismo e o seu outro: raça, cultura e cidade no Brasil (1920-1945). In: Revista Brasileira de Estudos Urbanos e Regionais, no 1, maio de 1999.

MACAMBIRA, Yvoty. Os italianos e a arquitetura paulistana. In: R. Italinística, ano III, n. 3, p. 57-72, 1995.

MAGNANI, José G. C. A etnografia e um método, não uma mera ferramenta de pesquisa...que se pode usar de qualquer maneira. Revista de Ciências Sociais, fortaleza, v. 43, n. ${ }^{\circ}$ 2, jul/dez, p. 169 -178, 2012.

MARTINS, José de Souza. A ferrovia e a modernidade em São Paulo: a gestação do ser dividido. Revista USP, n. ${ }^{\circ} 63$, p. 6-16, setembro/novembro, 2004 
MISSURA, Fábio A. Ramal Férreo do Rio Pardo. Revista Eletrônica da UNESP-FRANCA, 05 jun. 2002.

PANTOJA, Maria Aparecida. Estudo funcional de um centro urbano: a cidade de Casa Branca. Revista do Arquivo Municipal, Publicação do Departamento de Cultura, Órgão da Sociedade de Etnografia e Folclore e da Sociedade de Sociologia, São Paulo, ano VII, vol. LXXXIV, julho - agosto 1942.

RAMOS, Fernando Guillermo Vázquez. Redesenho: Conceitos gerais para compreender uma prática de pesquisa histórica em arquitetura. In: Arquitextos, Vitruvius, 195.09, ano 17, ago. 2016.

\section{Anais}

CAMPOS, Eudes. Nos caminhos da Luz, antigos palacetes da elite paulistana. In: Anais do Museu Paulista. São Paulo. v. 13. n.1., p. 11-57, jan - jun de 2005.

FABRIS, Annateresa. Arquitetura eclética no Brasil: o cenário da modernização. In: Anais do Museu Paulista Nova Série n. ${ }^{\circ}$, p. 131-146, 1993.

FOLHARINI, Saulo O.; OLIVEIRA, Regina Célia. Características físicas do município de São José do Rio Pardo-SP. In: XIV Simpósio Brasileiro de Geografia Física Aplicada. Dourados: UFGD, v. 1. p. 1-16, 2011.

LEMOS, Carlos A. C. Transformações do espaço habitacional ocorridas na arquitetura brasileira do século XIX. In: Anais do Museu Paulista Nova Série n. ${ }^{\circ}$ 1, p. 95-106, 1993.

LIMA, Solange Ferraz de. O trânsito dos ornatos: modelos ornamentais da Europa para o Brasil, seus usos (e abusos?). In: Anais do Museu Paulista (Impresso), v. 16, p. 151-199, 2008.

OLIVEIRA, Regina Célia. Características físicas do município de São José do Rio Pardo-SP. In: XIV Simpósio Brasileiro de Geografia Física Aplicada. Dourados: UFGD, v. 1. p. 1-16, 2011.

PINHEIRO, Maria Lucia Bressan. Moderno ou Moderne? Questões sobre a arquitetura francesa no entreguerras. In: Seminário Internacional Art-déco na América Latina. Rio de Janeiro. Anais...Rio de Janeiro: Prefeitura da Cidade do Rio de Janeiro; PUC-RJ, p. 205-210, 1997.

Arquitetura residencial verticalizada em São Paulo nas décadas de 1930 e 1940. In: Anais do Museu Paulista, São Paulo, v. 16, n. 1, p. 109-149, jan./jun. 2008.

SALGADO, Ivone. A modernização da cidade setecentista: o contributo das culturas urbanísticas francesa e inglesa. In: 60 Seminário da História da Cidade e do Urbanismo, 2000, Natal. Caderno de Resumos do VI Seminário de História da Cidade e do Urbanismo. Natal: Cooperativa Cultural/ UFRN, 2000.

\section{Jornais}

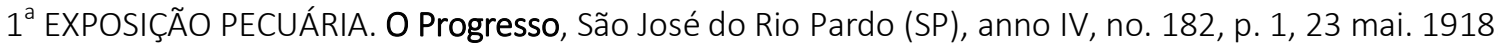

A CRISE. Resenha, São José do Rio Pardo (SP), anno VIII, no. 290, p. 2, 22 dez. 1929.

ÁGUA. O Rio Pardo, São José do Rio Pardo (SP), anno 1, no. 18, p. 1, 16 abr. 1899.

ARAÚJO GUERRA. A Platea, São Paulo (SP), anno 2, n. ${ }^{\circ}$ 61, p. 01, 1889.

AS CONSTRUCÇÕES. Resenha, São José do Rio Pardo (SP), anno I, no. 36, p. 01, 09 set. 1923. 
AS GRÉVES. O Rio Pardo, São José do Rio Pardo (SP), anno XV, no. 846, p. 2, 6 abr. 1913.

A HYGIENE. Resenha, São José do Rio Pardo (SP), anno I, no. 28, p. 01, 20 mai. 1923.

AULA NOCTURNA PARA O ENSINO DO DESENHO. O Rio Pardo, São José do Rio Pardo (SP), anno II, no. 140, p. 2, 26 jul. 1900.

CADEIA PUBLICA. O Rio Pardo, São José do Rio Pardo (SP), anno IV, no. 247, p. 1, 04 abr. 1902.

CAMARA MUNICIPAL. O Rio Pardo, São José do Rio Pardo (SP), anno XIV, no. 839, p. 2, 26 jan. 1913.

COUSAS ABSURDAS. Resenha, São José do Rio Pardo (SP), anno 2, no. 63, p. 10, 30 mar. 1924.

DADOS ESTATí́STICOS. Resenha, São José do Rio Pardo (SP), anno XV, no. 384, p. 10, 18 out. 1936.

DR. Abdiel Cavalcanti Braga. Resenha, São José do Rio Pardo (SP), anno XLI, no. 740, p. 01, 27 jan. 1963.

EDITAIS - CÂMARA MUNICIPAL. O Rio Pardo, São José do Rio Pardo (SP), anno VI, n. 380, p. 2, 22 jan. 1905.

EMPRESTIMO MUNICIPAL. O Rio Pardo, São José do Rio Pardo (SP), anno 2, n. 114, p. 2, 22 abr. 1900.

ESTRADA DE S. JOSÉ A CACONDE. O Rio Pardo, São José do Rio Pardo (SP), anno 01, n. 50, p. 1, 24 ago. 1899.

EXPOSIÇÃO DE S. LUIZ. O Rio Pardo, São José do Rio Pardo (SP), ano VI, n. ํ 368, p. 1, 30 out. 1904.

FESTA. O Rio Pardo, São José do Rio Pardo (SP), ano VII, n. ํำ, p. 2, 20 ago. 1905.

FESTA DO DIVINO. O Rio Pardo, São José do Rio Pardo (SP), ano II, n. ำ169, p. 2, 8 nov. 1900.

GRUPO ESCOLAR. O Rio Pardo, São José do Rio Pardo (SP), anno VI, no. 362, p. 1, 18 set. 1904.

O Rio Pardo, São José do Rio Pardo (SP), anno VII, no. 387, p. 1, 12 mar. 1905.

GRUPO ESCOLAR "DR. CÂNDIDO RODRIGUES". Jornal Gazeta do Rio Pardo, São José do Rio Pardo (SP): Edição de Natal, 25 dez. 1965.

GRUPO ESCHOLAR. O Rio Pardo, São José do Rio Pardo (SP), anno IV, no. 275, p. 2, 26 out. 1902.

GRUPOS ESCOLARES II. O Rio Pardo, São José do Rio Pardo (SP), anno X, no. 621, p. 1, 19 jul. 1908.

HYGIENe ESCOLAR. O Rio Pardo, São José do Rio Pardo (SP), anno VIII, no. 499, p. 1, 25 fev. 1906.

HYGIENE PUBLICA. O Rio Pardo, São José do Rio Pardo (SP), anno IX, no. 551, p. 1, 17 mar. 1907.

HYGIENE SOCIAL. O Rio Pardo, São José do Rio Pardo (SP), anno IX, no. 561, p. 1, 26 mai. 1907.

HOTEL PAULISTA. O Rio Pardo, São José do Rio Pardo (SP), anno V, no. 307, p. 2, 16 ago. 1903.

ILHA DE SÃO PEDRO. Resenha, São José do Rio Pardo (SP), anno XV, no. 387, p. 1, 23 fev. 1937.

IMIGRANTES. O Mosquito, São José do Rio Pardo (SP), p. 3, 28 nov. 1887.

IMPOSTOS ESTADOAES. O Progresso, São José do Rio Pardo (SP), anno IV, no. 173, p. 2, 09 mar. 1918. 
IMPOSTO. O Rio Pardo, São José do Rio Pardo (SP), anno 1, no. 18, p. 3, 16 abr. 1899.

INSPECTORIA SANITARIA. Resenha, São José do Rio Pardo (SP), anno I, no. 32, p. 02, 01 jul. 1923.

INSTRUIR PARA EDUCAR. O Rio Pardo, São José do Rio Pardo (SP), anno VII, no. 496, p. 1, 04 fev. 1906.

JARDIM PUBLICO. O Rio Pardo, São José do Rio Pardo (SP), anno V, no. 299, p. 2, 20 jun. 1903.

JORNAL O RIO PARDO. São José do Rio Pardo (SP), editais 21/05/1899; 15/02/1900; 27/02/1900; 02/09/1900; 09/03/1902; 16/02/1902; 20/07/1903; 13/12/1903; 24/07/1904; 19/02/1905; 16/07/1905; 03/12/1905; 23/12/1906; 26/01/1908; 01/11/1908; 05/07/1908; 20/08/1908; 30/01/1910; 18/08/1910; 09/10/1910; 22/01/1911; 13/04/1911; 08/02/1912; 05/04/1912; 25/04/1912; 08/11/1913; 24/04/1913.

JORNAL RESENHA. São José do Rio Pardo (SP), editais 16/09/1923; 11/11/1923; 02/11/1924; 09/11/1924; 23/11/1924; 02/08/1925; 23/05/1926; 22/08/1926; 12/10/1926; 20/10/1926; 15/11/1927; 13/04/1930; 03/11/1930; 04/04/1931; 23/05/1936; 22/09/1961.

RIO PARDO JORNAL. São José do Rio Pardo (SP), editais 23/08/1936.

LOCAES. O Rio Pardo, São José do Rio Pardo (SP), anno XIV, no. 809, p. 1, 29 jun. 1912.

LUZ ELECTRICA. O Rio Pardo, São José do Rio Pardo (SP), anno 1, no. 48, p. 1, 17 ago. 1899.

MASCHIETTO, Carmen C. T. História da iluminação de São José do Rio Pardo. Gazeta do Rio Pardo, São José do Rio Pardo, p. 26-32, 25 dez. 1979.

MEDIDA SANITARIA. O Rio Pardo, São José do Rio Pardo (SP), anno IV, no. 289, p. 1, 01 fev. 1903.

MELHORAMENTOS LOCAES. O Rio Pardo, São José do Rio Pardo (SP), anno 1, no. 36, p. 1, 28 jun. 1899.

MELHORAMENTOS MUNICIPAES II. O Rio Pardo, São José do Rio Pardo (SP), anno 1, no. 26, p. 1, 18 mai. 1899.

MELHORAMENTOS MUNICIPAES III. O Rio Pardo, São José do Rio Pardo (SP), anno 1, no. 27, p. 1, 21 mai. 1899.

MERCADO. O Rio Pardo, São José do Rio Pardo (SP), anno 1, no. 17, p. 1, 13 abr. 1899.

NOSSA CIDADE VAE A DECADÊNCIA. Resenha, São José do Rio Pardo (SP), anno VII, no. 271, p. 2, 18 mai. 1929.

NOSSA POPULAÇÃO. O Rio Pardo, São José do Rio Pardo (SP), anno XIV, no. 800, p. 2, 11 abr. 1912.

NOTAS E NOTÍCIAS. O Progresso, São José do Rio Pardo (SP), anno II, no. 95, p. 2, 22 ago. 1916.

NOTICIÁRIO. O Rio Pardo, São José do Rio Pardo (SP), anno X, no. 619, p. 2, 05 jul. 1908.

O MERCADO EM CONSTRUÇÃO. Resenha, São José do Rio Pardo (SP), anno 4, no. 145, p. 2, 22 nov. 1925.

O NOSSO MUNICÍPIO. O Rio Pardo, São José do Rio Pardo (SP), anno X, no. 614, p. 2, 31 mai. 1908.

O VELHO CEMITÉRIO. O Rio Pardo, São José do Rio Pardo (SP), anno XIV, no. 840, p. 2, 01 fev. 1913.

O MERCADO DO CAFÉ E A VALORIZAÇÃO. O Rio Pardo, São José do Rio Pardo (SP), anno XI, no. 670, p. 1, 30 jan. 1910. 
PEQUENA HISTÓRIA DO BANCO F. BARRETTO. Resenha, São José do Rio Pardo (SP), anno XX, no. 463, p. 1, 27 ago. 1942.

PELA INSTRUCÇÃO. Resenha, São José do Rio Pardo (SP), anno V, no. 220, p. 1, 25 set. 1927.

PROGRESSO. O Rio Pardo, São José do Rio Pardo (SP), anno IX, no. 572, p. 1, 11 ago. 1907.

PROGRESSO LOCAL. O Rio Pardo, São José do Rio Pardo (SP), anno XIV, no. 800, p. 1, 11 abr. 1912.

REFORMA JUDICIAL. Resenha, São José do Rio Pardo (SP), anno XXI, no. 493, p. 1-2, 18 jul. 1943.

REGRESSO. O Rio Pardo, São José do Rio Pardo (SP), anno VII, no. 390, p. 2, 2 abr. 1905a.

O Rio Pardo, São José do Rio Pardo (SP), ano 6, n. ${ }^{3}$ 379, p. 2, 15 jan. 1905b.

SANTA CASA. O Rio Pardo, São José do Rio Pardo (SP), anno XV, no. 848, p. 1, 24 abr. 1913.

SANTOS, Paulo. 400 Anos Memoráveis. In: Jornal do Brasil, p. 295, 09 de dezembro de 1965.

SÃO JOSÉ DO RIO PARDO NECESSITA PROGREDIR. Resenha, São José do Rio Pardo (SP), anno XXI, no. 511, p. 3, 09 jan. 1944.

SÃO JOSÉ DO RIO PARDO PROGRIDE. Resenha, São José do Rio Pardo (SP), anno XIV, no. 378, p. 3, 23 mai. 1936.

SÃO JOSÉ DO RIO PARDO EM UMA REPORTAGEM MUITO ANTIGA. Jornal O Democrata, São José do Rio Pardo (SP), ano 27, no. 1338, p. 2, 17 jan. 2015.

SARAU. O Rio Pardo, São José do Rio Pardo (SP), ano 2, no. 169, p. 2, 08 nov. 1900.

SENHORES E ESCRAVOS. Gazeta do Rio Pardo, São José do Rio Pardo (SP), ano LXXX, n. ${ }^{1361, ~ p . ~ 07, ~} 18$ jun. 1988.

Gazeta do Rio Pardo, São José do Rio Pardo (SP), ano LXXX, n. ำ1362, p. 07, 25 jun. 1988.

S. JOSÉ DO RIO PARDO. O Rio Pardo, São José do Rio Pardo (SP), ano 2, n. 108, p. 01, 29 mar. 1900.

TREVISAN, Amélia F. Paschoal Artese, o urbanista e jornalista. In: Jornal Gazeta do Rio Pardo, São José do Rio Pardo, página 3a, 10 abr. 1977.

UMA IDÉA. O Rio Pardo, São José do Rio Pardo (SP), anno VI, no. 348, p. 1, 12 jun. 1904.

UM FACTO A REPRIMIR. O Rio Pardo, São José do Rio Pardo (SP), anno II, no. 132, p. 1, 28 jun. 1900.

UM RELATÓRIO. O Progresso, São José do Rio Pardo (SP), anno IV, no. 176, p. 1, 02 abr. 1918.

URGE PROVIDÊNCIAS. Resenha, São José do Rio Pardo (SP), anno XVIII, no. 428, p. 1, 12 nov. 1940.

VISITAS DOMICILIARIAS. O Rio Pardo, São José do Rio Pardo (SP), anno V, no. 302, p. 1, 12 jul. 1903.

25.0 ANIVERSARIO DA FUNDAÇÃO DA FILIAL DO BANCO F. BARRETLO S. A. NESTA CIDADE. Resenha, São José do Rio Pardo (SP), anno XX, no. 463, p. 1, 27 ago. 1942. 


\section{Legislações}

BRASIL [Federação]. Lei n. ${ }^{\circ}$ 601, de 18 de setembro de 1850, disponível em http://www.planalto.gov.br/ccivil_03/Leis/L0601-1850.htm, acesso em abr. 2016.

Recenseamento do Brasil de 1920. Rio de Janeiro: Typ. Da Estatística, volume IV , 4º parte, 1929.

Recenseamento do Brasil de 1940. Censo Demográfico. Rio de Janeiro: Serviço Geográfico do Instituto Brasileiro de Geografia e Estatística, volume IV, parte XVII, tomo 2, população, 1950.

Brasil [Império]. Lei de $1^{\circ}$ de outubro de 1828, disponível em http://www.planalto.gov.br/ccivil_03/leis/lim/LIM-1-10-1828.htm, acesso em nov. 2017.

. Lei n. ${ }^{\circ} 1.237$, de 24 de setembro de 1864, disponível em http://www.planalto.gov.br/ccivil_03/leis/lim/LIM1237.htm, acesso em nov. 2017.

CACONDE [Município]. Ata da sessão ordinária da Câmara Municipal, 07/11/1868.

CACONDE [Província]. Código de Posturas de 1866, disponível em: http://www.al.sp.gov.br/repositorio/legislacao/lei/1866/lei-74-28.05.1866.html, acesso em abr. 2016.

CASA BRANCA [Província]. Código de Posturas de 1882, disponível em: https://www.al.sp.gov.br/repositorio/legislacao/resolucao/1882/resolucao-4-15.03.1882.html, acesso em jan. 2017.

SÃO JOSÉ DO RIO PARDO [Município]. Código de Posturas de 1903. São José do Rio Pardo, 1903.

Código de Posturas de 1918. São José do Rio Pardo, 1918.

. Lei n. 2920, 15 de janeiro de 2007, disponível em: http://www.camarasjriopardo.sp.gov.br/leis/lei.php\#lei, acesso em fev. 2016.

Lei n. ${ }^{\circ} 13,05$ de junho de 1899.

Livro de lançamentos dos impostos de indústrias e profissões: 1887 a 1903.

SÃO JOSÉ DO RIO PARDO [Província]. Lei n. ${ }^{\circ}$ 70, 14 de abril de 1880, disponível em: http://www.al.sp.gov.br/repositorio/legislacao/lei/1880/lei-70-14.04.1880.html, acesso em abr. 2016.

Lei . $^{\circ} \quad 49,20$ de março de 1885, disponível em http://www.al.sp.gov.br/repositorio/legislacao/lei/1885/lei-49-20.03.1885.html, acesso em abr. 2016.

Lei n. ${ }^{\circ}$ 27, 06 de setembro de 1918, publicada no jornal Resenha, São José do Rio Pardo (SP), ano 2 , n. 65, p. 01,13 abr. 1924.

Código de Posturas, Resolução n. ${ }^{\circ} 122,03$ de maio de 1887, disponível em http://www.al.sp.gov.br/repositorio/legislacao/resolucao/1887/resolucao-122-03.05.1887.html, acesso em mar. 2016.

SÃO PAULO [Estado]. Decreto n. ${ }^{\circ} 179,29$ de maio de 1891, disponível em: http://www.al.sp.gov.br/repositorio/legislacao/decreto/1891/decreto-179-29.05.1891.html, acesso em fev. 2016. 
Lei n. ${ }^{\circ}$ 1.596, de 29 de dezembro de 1917, disponível em: https://www.al.sp.gov.br/repositorio/legislacao/lei/1917/lei-1596-29.12.1917.html, acesso em nov. 2017.

SÃO PAULO [Província]. Lei no 87, 21 de abril de 1880, disponível em: http://www.al.sp.gov.br/repositorio/legislacao/lei/1880/lei-87-21.04.1880.html, acesso em set. 2015; Lei n. ${ }^{\circ}$ 24, 27 de março de 1884, disponível em: http://www.al.sp.gov.br/repositorio/legislacao/lei/1884/lei-2427.03.1884.html, acesso em set. 2015.

SÃO PAULO [Município]. Código de Posturas, Resolução n. ${ }^{\circ}$ 62, 31 de maio de 1875, disponível em: https://www.al.sp.gov.br/repositorio/legislacao/resolucao/1875/resolucao-62-31.05.1875.html, acesso em jun. 2017.

Decreto n. ${ }^{\circ}$ 233, de 2 de março de 1894. Estabelece o Código Sanitário do Estado de São Paulo, disponível em: https://www.al.sp.gov.br/repositorio/legislacao/decreto/1894/decreto-23302.03.1894.html, acesso em mai. 2016.

Decreto n. ${ }^{\circ}$ 2.918, de 9 de abril de 1918. Dá execução ao Código Sanitário do Estado de São Paulo, disponível em: http://www.al.sp.gov.br/repositorio/legislacao/decreto/1918/decreto-291809.04.1918.html, acesso em mar. 2018.

Lei n. ${ }^{\circ} 2.022$ de 27 de dezembro de 1924. Regula o exercício da profissão de engenheiro, architecto e agrimensor, disponível em http://dobuscadireta.imprensaoficial.com.br/default.aspx?DataPublicacao=19250103\&Caderno=Diario\%20 Oficial\&NumeroPagina=42, acesso em mar. 2018.

\section{Atas}

SÃO JOSÉ DO RIO PARDO [Município]. Ata da sessão ordinária da Câmara Municipal, 04/04/1865; 22/12/1888; 29/09/1891; 09/03/1895; 03/02/1896; 06/07/1896; 11/07/1896; 03/07/1899; 22/05/1914; 05/04/1915; 05/03/1917; 17/12/1917; 06/04/1925; 04/05/1925; 01/07/1929; 04/08/1930; 31/12/1934.

\section{Relatórios e Solicitações}

CARTA DE AFORAMENTO. Registro de pedidos e concessões de aforamento. São José do Rio Pardo / Casa Branca: 1886 a 1889.

São José do Rio Pardo [Município]. Solicitações para construção de obras particulares de edificações. Requerimentos e projetos: 1925 (P0 ao P21); 1926 (P01 ao P12); 1927 (P01 ao P34); 1928 (P01 ao P45); 1929 (P01 ao P43); 1930 (P01 ao P38); 1931 (P01 ao P32); 1932 (P01 ao P25); 1933 (P01 ao P23); 1934-35 (P01 ao P17); 1936 (P12 ao P47); 1937 (P01 ao P14); 1940 (P31 ao P41); 1941 (P01 ao P41); 1942 (P01 ao P45); 1943 (P01 ao P17); 1944 (P01 ao P24); 1945 (P01 ao P40); 1946 (P01 ao P59); 1947 (P01 ao P49); 1948 (P01 ao P72); 1949 (P01 ao P65); 1950 (P01 ao P91); 1950-59 (P01-P86); 1960 (P01-P119).

RELATORIO. Relatorio da Directoria da Companhia Mogyana de Estradas de Ferro e Navegação para a Assembleia Geral de 1900. S. Paulo: Typographia da Industrial de S. Paulo, 1900, 1901, 1927.

RELATORIO DO EXERCÍCIO DE 1915. Câmara Municipal de São José do Rio Pardo, 1915. 
RELATORIO DA REPARTIÇÃO DE OBRAS, EXERCíCIO DE 1916. Câmara Municipal de São José do Rio Pardo, 1916.

RODRIGUES, Antonio C. Estudos e planos orçamentários para o abastecimento de água da Villa de São José do Rio Pardo. São José do Rio Pardo, 24 dez. 1887.

Relatório descritivo dos trabalhos projetados para o abastecimento de água da Villa de São José do Rio Pardo. São José do Rio Pardo, 31 mai. 1888.

TERMO DE LINHAMENTO. Pedidos de alinhamento. São José do Rio Pardo - Hemeroteca Jornalista Paschoal Artese, 03 jul. 1887.

TOLEDO, Benedito Lima de. Vila Penteado: Carlos Ekman: um arquiteto sueco no Brasil. In: Boletim Técnico de São Paulo, São Paulo, n. ${ }^{\circ}$ 9, p. 9-22, 1993.

\section{Almanaques}

SECKLER, Jorge. Almanach da Província de São Paulo para 1888. São Paulo: Jorge Seckler \& Comp., 1888.

T., A. Almanack de São José do Rio Pardo e Grama. São Paulo, Edanee, 1929.

TREVISAN, Amélia F. Almanaque de São José do Rio Pardo de 1887. In: Jornal Gazeta do Rio Pardo, São José do Rio Pardo, 25 dez. 1987.

\section{Entrevistados (História Oral)}

ALCIDES, Doraci Aparecida C.. Entrevista concedida a autora da dissertação. São José do Rio Pardo, 2016.

CALLEGARI, Rômulo. Entrevista concedida a autora da dissertação. São José do Rio Pardo, 2017.

CAPELLARI, Dorival. Entrevista concedida a autora da dissertação. São José do Rio Pardo, 2016.

CAPPELLARI, Phelomena Stivalle. Entrevista concedida a autora da dissertação. São José do Rio Pardo, 2016.

CURI, José Hibrain. Entrevista concedida a autora da dissertação. São José do Rio Pardo, 2016.

DE VITTA, Guilherminda Cappellari. Entrevista concedida a autora da dissertação. São José do Rio Pardo, 2016.

FERNANDES, Luis. Entrevista concedida a autora da dissertação. São José do Rio Pardo, 2014.

GARCIA, Clara A. G.. Entrevista concedida a autora da dissertação. São José do Rio Pardo, 2016.

LAURIA, Marcio José. Entrevista concedida a autora da dissertação. São José do Rio Pardo, 2016.

LUZ, Maria Helena. Entrevista concedida a autora da dissertação. São José do Rio Pardo, 2017.

MASCHIETTO, Carmém C. T.. Entrevista concedida a autora da dissertação. São José do Rio Pardo, 2016. 
NOGUEIRA, Maria Paula Ribeiro. Entrevista concedida a autora da dissertação. São José do Rio Pardo, 2015.

PAIVA, Leonardo. Entrevista concedida a autora da dissertação. São José do Rio Pardo, 2017.

RIBEIRO, leda. Entrevista concedida a autora da dissertação. São José do Rio Pardo, 2017.

RUGANI, Leo Lucas. Entrevista concedida a autora da dissertação. São José do Rio Pardo, 2017.

RUGANI, Marilia. Entrevista concedida a autora da dissertação. São José do Rio Pardo, 2017.

RUGANI, Myrian. Entrevista concedida a autora da dissertação. São José do Rio Pardo, 2017.

TIEZZI, Alcides. Entrevista concedida a autora da dissertação. São José do Rio Pardo, 2016.

TRAVASSOS, Doroti. Entrevista concedida a autora da dissertação. São José do Rio Pardo, 2016.

TRAVASSOS, Hélio. Entrevista concedida a autora da dissertação. São José do Rio Pardo, 2016.

TREVISAN, Francisco. Entrevista concedida a autora da dissertação. São José do Rio Pardo, 2014.

\section{Arquivos Pesquisados}

\section{São José do Rio Pardo}

Arquivo Público da Secretaria de Obras

Endereço: Av. Belmonte, 300 - Vila Brasil

Telefone: (19) 3682-7844

Email: engenharia@saojosedoriopardo.sp.gov.br

Biblioteca da Faculdade Euclides da Cunha

Endereço: Rua Jorge Tibiriçá, 451 - Centro

Telefone: (19) 3608-4704 - (19) 3681-3088

Site: www.feucriopard.edu.br

Biblioteca Municipal Monteiro Lobato

Endereço: Praça Capitão Vicente Dias, 9 - Centro.

Telefone: (19) 3608-8888

\section{Câmara Municipal}

Endereço: Praça dos Três Poderes, 2 - Centro

Telefone: (19) 3608-5102 - (19) 3681-2241

Site: http://www.camarasjriopardo.sp.gov.br

Cartório de Registro de Imóveis

Endereço: Rua São Vicente, 41 - C

Telefone: (19) 3682-7844

Email: engenharia@saojosedoriopardo.sp.gov.br

Centro da Memória Rio-Pardense Rodolpho José Del Guerra

Endereço: situada no Cine Colombo, Rua Marechal Floriano, 110 - Centro

Telefone: (19) 3608-4358

Email: contato@italobrasileiro.com / rcagaroque@bol.com.br 
Hemeroteca Jornalística Paschoal Artese

Endereço: situada na Biblioteca Monteiro Lobato, Praça Capitão Vicente Dias, 9 - Centro.

Telefone: (19) 3608-8888

Email: hemerotecasjrp@gmail.com

Museu Rio-Pardense Arsênio Frigo

Endereço: Praça Capitão Vicente Dias, 9 - Centro.

Telefone: (19) 3682-7856

Email:museu@saojosedoriopardo.sp.gov.br

\section{Casa Branca}

Arquivo Público de Casa Branca

Endereço: Rua Mariquinha Lameiro, 28R - Centro

Telefone: (19) 3671-1773

Email: arquivo@casabranca.sp.gov.br.

Biblioteca Municipal Padre Santana

Endereço: Rua Barão Casa Branca, Centro

Telefone: (19) 3671-0341

Museu Histórico Pedagógico Alfredo e Afonso de Taunay de Casa Branca

Endereço: Praça Rui Barbosa, 56, Centro

\section{Caconde}

Biblioteca Pública Municipal

Endereço: Praça Cel. Joaquim José, Centro

Câmara Municipal de Caconde

Endereço: Rua Duque de Caxias, 123

Telefone: (19) 3662-1589

Site: http://www.camaracaconde.sp.gov.br/novo_site/

Casa de Cultura

Endereço: Praça Cel. Joaquim José, Centro

\section{São Carlos}

Biblioteca da Escola de Engenharia de São Carlos - EESC

Endereço: Avenida Trabalhador são-carlense, 400, Pq Arnold Schimidt

Telefone: (16) 3373-9247 / 3373-9207

Email: biblioteca@eesc.usp.br

Biblioteca do Instituto de Arquitetura e Urbanismo da Universidade de São Paulo, São Carlos - IAU-USP

Endereço: Avenida Trabalhador são-carlense, 400, Pq Arnold Schimidt

Telefone: (16) 3373-9282

E-mail: bibiau@sc.usp.br

\section{Campinas}

Biblioteca Octávio lanni do Instituto de Filosofia e Ciências Humanas da Universidade Estadual de Campinas - Ifch - Unicamp

Endereço: Rua Cora Coralina, 100 - Cidade Universitária, Campinas.

Telefone: (19) 3521-1618

Biblioteca Central Cesar Lattes da Universidade Estadual de Campinas, Campinas - Unicamp

Endereço: R. Sérgio Buarque de Holanda, 421 - Cidade Universitária, Campinas

Telefone: (19) 3521-6486 


\section{São Paulo}

Arquivo Público do Estado de São Paulo

Endereço: Rua Voluntários da Pátria, 596, Santana

Telefone: (11) 2089-8100

Email: faleconosco@arquivoestado.sp.gov.br 


\section{Anexo 01}

A figura abaixo corresponde a primeira folha da Ata de Fundação de São José do Rio Pardo, em 04 de abril de 1865, quando alguns fazendeiros se reuniram com o propósito de edificar uma capela, dando início a etapa de criação da futura Freguesia.

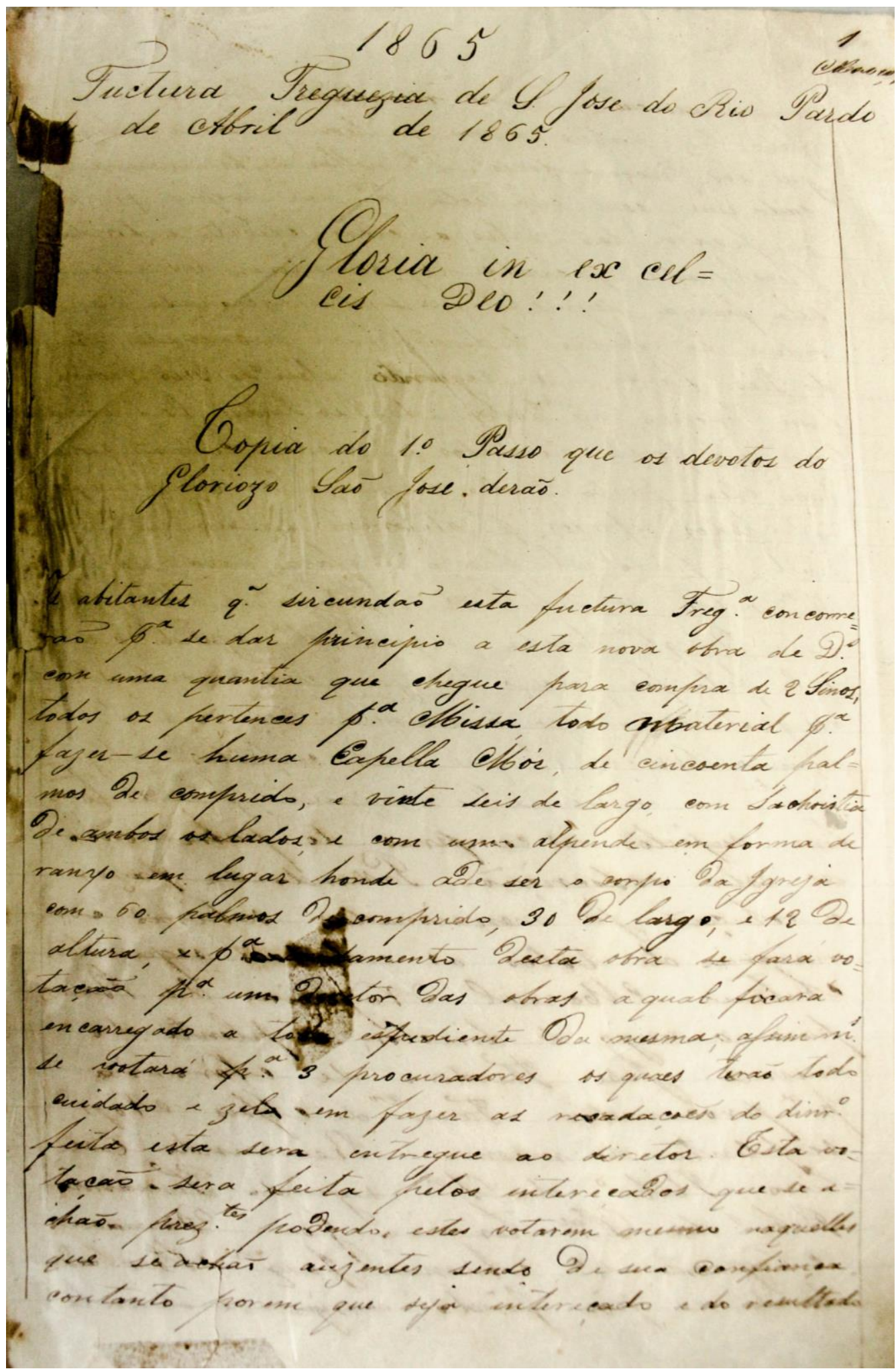

Fonte: Acerco da Hemeroteca Jornalista Paschoal Artese, 2016. 


\section{Anexo 02}

A Companhia Ramal Férreo do Rio Pardo foi fundada em 1884 por um grupo de acionistas liderados por José da Costa Machado e Souza. Inicialmente, 144 pessoas de diferentes localidades investiram em ações da Cia, conforme discriminado abaixo.

\begin{tabular}{|c|c|c|}
\hline \multicolumn{3}{|c|}{ ACIONISTAS DO RAMAL FÉRREO DO RIO PARDO } \\
\hline Accionistas & Cidade & Ações \\
\hline 01 - Affonso de Vergueiro & Santos & 20 \\
\hline 02 - Antonio da Silva Prado (Dr.) & São Paulo & 30 \\
\hline 03 - André Hary Montenegro & Casa Branca & 5 \\
\hline 04 - Antonio Corrêa de Souza (Capitão) & São José do Rio Pardo & 100 \\
\hline 05 - Antonio Marçal N. de Barros (T. Coronel) & São José do Rio Pardo & 50 \\
\hline 06 - Alfredo Theodoro Nogueira & São José do Rio Pardo & 5 \\
\hline 07 - Antonio Xavier de Souza & Mococa & 5 \\
\hline 08 - Antonio José Dias Lima & Mococa & 100 \\
\hline 09 - Antonio da Cossta Monteiro & Guaxupé & 30 \\
\hline 10 - Antonio C. Ezaú dos Santos (Vigário) & Mozambinho & 5 \\
\hline 11 - Antonio C. de Azevedo Coimbra (Capitão) & Mozambinho & 5 \\
\hline 12 - Antonio Gomes de Oliveira & Mozambinho & 5 \\
\hline 13 - Braga Junior \& C. & Santos & 30 \\
\hline 14 - Bernardo de Oliveira Brandão & Casa Branca & 10 \\
\hline 15 - Bernardino José de Freitas & Monte Santo & 1 \\
\hline 16 - Bernardo Jacintho Ferreira Lopes & Guaxupé & 5 \\
\hline 17 - Cezario Coimbra & Santos & 5 \\
\hline 18 - Custodio Ribeiro Leite (Major) & Guaxupé & 30 \\
\hline 19 - Custodio Leite Ribeiro Sobrinho & Guaxupé & 30 \\
\hline 20 - Candida Carolina de Araujo (D.) & Guaxupé & 5 \\
\hline 21 - Daniel José Rodrigues & Santos & 10 \\
\hline 22 - Damaso Ribeiro Nogueira & Casa Branca & 50 \\
\hline 23 - Domiciano de Alvarenga e Silva & Casa Branca & 2 \\
\hline 24 - E. Adamczyk \& C. & Santos & 10 \\
\hline 25 - Estevão Victorino Teixeira & São José do Rio Pardo & 5 \\
\hline 26 - Estebio Ribeiro da Silva & Mococa & 10 \\
\hline 27 - Estevão Ribeiro do Valle & Guaxupé & 20 \\
\hline 28 - Eugenio Ribeiro do Valle & Guaxupé & 50 \\
\hline 29 - Floriano Ferreirade Camargo Andrade & Santos & 20 \\
\hline 30 - Francisco Eugenio de Lima & Casa Branca & 5 \\
\hline 31 - Firminio de Araujo Aguiar & Casa Branca & 25 \\
\hline 32 - Francisco Nogueira de Carvalho & Casa Branca & 5 \\
\hline 33 - Francisco Garcia de Figueiredo & Mococa & 100 \\
\hline 34 - Francisco Custodio Pinheiro & Mococa & 5 \\
\hline 35 - Francisco Pereira do Nascimento & Guaxupé & 10 \\
\hline 36 - Francisco de Paula Ribeiro & Guaxupé & 20 \\
\hline 37 - Francisco Vieira do Valle & Guaxupé & 10 \\
\hline 38 - Francisco José do Souza & Guaxupé & 5 \\
\hline 39 - Gabriel Fernandes Pinheiro & Mococa & 25 \\
\hline 40 - Gabriel Lacruz Pinheiro & Mococa & 5 \\
\hline 41 - Geraldo Ribeiro do Valle & Guaxupé & 40 \\
\hline 42 - Indalecio de Souza Dias & Caconde & 10 \\
\hline 43 - J. F. Lacerda \& C. & Santos & 20 \\
\hline 44 - João Evangelista de Araujo Branco & Casa Branca & 5 \\
\hline 45 - Julio Brandão Sobrinho & Casa Branca & 3 \\
\hline 46 - Julieta Brandão & Casa Branca & 3 \\
\hline 47 - José de Freitas Garcez & Casa Branca & 5 \\
\hline 48 - José Alves P. da Silva Musa (Capitão) & Casa Branca & 10 \\
\hline 49 - José de V. Bittencourt Junior (Capitão) & Casa Branca & 5 \\
\hline 50 - João Carlos Arantes & Casa Branca & 25 \\
\hline 51 - José Divino Nogueira de Sá & São José do Rio Pardo & 20 \\
\hline
\end{tabular}


ACIONISTAS DO RAMAL FÉRREO DO RIO PARDO

\section{Accionistas}

Cidade

52 - Julio Scheibell \& Pfuhl

53 - José Antonio de Lima (Major)

54 - João Batista Junqueira

55 - José Dias Machado

56 - Joaquim Custodio Dias

57 - Joaquim Pinto da Silveira (Major)

58 - José Jorge Nogueira

59 - José Carlos Nogueira

60 - José da Costa Machado e Souza (Dr.)

61 - José Julio de Araujo Macedo

62 - José Gabriel Pinheiro

63 - José Pires Eustaquio

64 - José de Souza Dias

65 - José Custodio da Cunha Canto (Dr.)

66 - José Cassiano Gomes

67 - Jeremias Gomes de Fontes

68 - João Baptista Pereira de Magalhães

69 - José Theodoro Pereira da Cruz

70 - José Jacintho Pereira de Magalhães

71 - Joaquim Leite Ribeiro

72 - Joaquim da Costa Monteiro

73 - Joaquim Pedro Leite Ribeiro

74 - Joaquim Augusto Ribeiro do Valle

75 - João Januario de Magalhães

76 - Joaquim Verissimo da Silva

77 - Joaquim Antonio Bueno

78 - João Chrysotomo Ferreira Brandão

79 - Lucas Alves Fortunato

80 - Luis Carlos Mello (Tem.)

81 - Luiz José de Souza Pena

82 - Martinho da Silva Prado Junio (Dr.)

83 - Martiniano Brandão (Engenheiro)

84 - Mathilde Josephina Brandão (D.)

85 - Martiniano Brandão Neto

86 - Maria Candida Ribeiro (D.)

87 - Manoel Francisco Ribeiro Junior

88 - Manoel Theodoro de Avelino

89 - Manoel Joaquim de Andrade

90 - Miguel Ferreira da Silva

91 - Mizael J. Barboza Sandoval

92 - Maria Guilhermina P. do Nascimento (D.)

93 - Manoel Antonio de Araujo

94 - Manoel J. Ribeiro do Valle (T. Coronel)

95 - Mizael Marques de Araujo

96 - Nicoláo Victorino Teixeira

97 - Pedro Arbues da Silva (Dr.)

98 - Prospero Paoiello

99 - Querino Ribeiro \& C.

100 - Quintino Ribeiro de Souza

101 - Rodrigo Ribeiro de Souza

102 - Ricardo Soares Baptista (Dr.)

103 - Salustiano Fernandes Pinheiro

104 - Urias Fernandes Pinheiro

105 - Vicente Teixeira Marques

106 - Vicente Alves de Araujo Dias (Capitão)

107 - Antonio Gonçalves dos Santos

108 - Antonia Ignacia de Medeiros (D.)

109 - Alexandrina Rozalina de Medeiros (D.)

110 - Antonio José de Lima

111 - Antonia Leopoldina de Sillos (D.)

São José do Rio Pardo

São José do Rio Pardo

São José do Rio Pardo

São José do Rio Pardo

São José do Rio Pardo

São José do Rio Pardo

São José do Rio Pardo

São José do Rio Pardo

São José do Rio Pardo

Mococa

Mococa

Mococa

Mococa

Mococa

Monte Santo

Santa Barbara

Guaxupé

Guaxupé

Guaxupé

Guaxupé

Guaxupé

Guaxupé

Guaxupé

Guaxupé

Guaxupé

Guaxupé

Campanha

Santos

São José do Rio Pardo

Mococa

São José do Rio Pardo

Casa Branca

Casa Branca

Casa Branca

São José do Rio Pardo

São José do Rio Pardo

Mococa

Mococa

Mococa

Santa Barbara

Guaxupé

Guaxupé

Guaxupé

Mozambinho

São José do Rio Pardo

Casa Branca

Mozambinho

Santos

Mozambinho

Santos

Casa Branca

Mococa

Mococa

Mococa

São José do Rio Pardo

Casa Branca

Casa Branca

Casa Branca

Casa Branca

Casa Branca

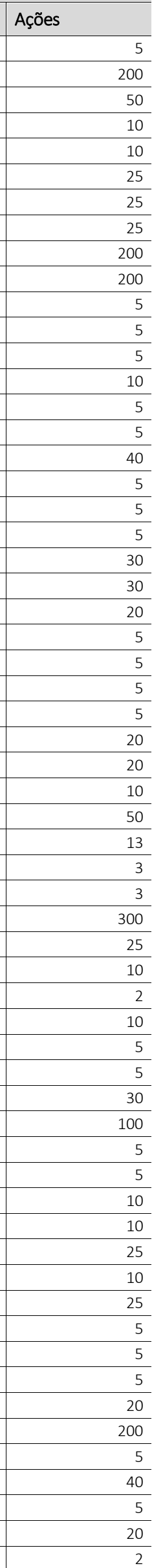




\begin{tabular}{|c|c|c|}
\hline \multicolumn{3}{|c|}{ ACIONISTAS DO RAMAL FÉRREO DO RIO PARDO } \\
\hline Accionistas & Cidade & Ações \\
\hline 112 - Adelina Adelia de Sillos (D.) & Casa Branca & 2 \\
\hline 113 - Antonio Dias dos Reys & Mococa & 5 \\
\hline 114 - Brazilio de Sillos & Casa Branca & 2 \\
\hline 115 - Celiza de Sillos (D.) & Casa Branca & 2 \\
\hline 116 - Carolia Emilia de Figueiredo (D.) & Mococa & 50 \\
\hline 117 - Diogo Garcia de Fiqueiredo & Mococa & 50 \\
\hline 118 - Francisco Augusto Pereira de Lima (Dr.) & Campinas & 5 \\
\hline 119 - Gabriel Garcia de Figueiredo (Coronel) & Mococa & 250 \\
\hline 120 - Honorio de Sillos & Casa Branca & 20 \\
\hline 121 - Hermantina de Sillos (D.) & Casa Branca & 2 \\
\hline 122 - Iria Malvina de Sillos (D.) & Casa Branca & 2 \\
\hline 123 - José de Magalhães Passos & Casa Branca & 5 \\
\hline 124 - João Domingues da Costa & Casa Branca & 15 \\
\hline 125 - José Leão de Sillos & Casa Branca & 2 \\
\hline 126 - Jovino de Sillos & Casa Branca & 2 \\
\hline 127 - João Carlos Leite Penteado (Coronel) & Casa Branca & 10 \\
\hline 128 - Jeremias Barboza Sandoval & Casa Branca & 50 \\
\hline 129 - José Caetano de Lima (Capitão) & Casa Branca & 15 \\
\hline 130 - Joaquim Gonçalves dos Santos & São José do Rio Pardo & 15 \\
\hline 131 - Joaquim Silverio de Figueiredo & Mococa & 10 \\
\hline 132 - José Gabriel de Figueiredo & Mococa & 10 \\
\hline 133 - José Pereira dos Santos & Mococa & 100 \\
\hline 134 - João Thomaz de Carvalho & Mococa & 25 \\
\hline 135 - José Joaquim de Figueiredo & Mococa & 50 \\
\hline 136 - Luiz Vicente de Sillos & Casa Branca & 2 \\
\hline 137 - Manoel Martins Teixeira Carvalho & Casa Branca & 5 \\
\hline 138 - Marianna Umelina de Padua Sillos (D.) & Casa Branca & 20 \\
\hline 139 - Maria Christina de Sillos (D.) & Casa Branca & 2 \\
\hline 140 - Manoel Thomaz de Carvalho & Mococa & 25 \\
\hline 141 - Urias Gonçalves dos Santos (Major) & Casa Branca & 20 \\
\hline 142 - Victor Cruz & Casa Branca & 10 \\
\hline 143 - Vicente Ferreira de Sillos Pereira (T. Cel.) & Casa Branca & 10 \\
\hline 144 - Vicente Ozias de Sillos & Casa Branca & 5 \\
\hline Total de ações & & 751 \\
\hline
\end{tabular}

Fonte dos dados: Missura (2003, p. 122-125). 


\section{Anexo 03}

Um grupo formado por cafeicultores, fazendeiros, médicos, políticos, comerciantes, e três imigrantes italianos investiram cerca de 50:000\$000 contos no "Syndicato da Luz Electrica de São José do Rio Pardo", responsável pela inauguração da iluminação pública em 1897.

\begin{tabular}{l|l|l}
\hline \multicolumn{2}{c}{ PRIMEIROS SÓCIOS DO SYNDICATO DA LUZ ELECTRICA DE SÃO JOSÉ DO RIO PARDO } \\
\hline Associado & Ocupação & Participação \\
\hline Dr. Arthur P. D. de Montmorency & Engenheiro & $5: 000 \$ 000$ \\
\hline Dr. Álvaro de Oliveira Ribeiro & Médico & $3: 000 \$ 000$ \\
\hline Dr. Guilherme Tell Guillon & Médico & $3: 000 \$ 000$ \\
\hline Coronel Vicente Dias Jr. & Fazendeiro & $3: 000 \$ 000$ \\
\hline Antonio Monteiro de Oliveira Jr. & Fazendeiro & $3: 000 \$ 000$ \\
\hline Coronel Honório Luiz Dias & Fazendeiro & $3: 000 \$ 000$ \\
\hline Coronel Alípio Luiz Dias & Fazendeiro & $3: 000 \$ 000$ \\
\hline Coronel Antonio Silvério da S. Musa & Fazendeiro & $3: 000 \$ 000$ \\
\hline Coronel Francisco S. de Camargo & Fazendeiro & $3: 000 \$ 000$ \\
\hline Manoel Ribeiro Machado & Fazendeiro & $3: 000 \$ 000$ \\
\hline Major José Dias Machado & Fazendeiro & $1: 500 \$ 000$ \\
\hline José Monteiro de Noronha & Fazendeiro & $1: 500 \$ 000$ \\
\hline José Carlos G. de Nogueira & Fazendeiro & $1: 500 \$ 000$ \\
\hline Coronel Francisco do Nascimento & Comerciante e faz. & $1: 500 \$ 000$ \\
\hline Tarquínio Cobra Olyntho & Farmacêutico & $1: 500 \$ 000$ \\
\hline Coronel João B. de Souza Moreira & Fazendeiro & $1: 500 \$ 000$ \\
\hline Coronel José Ezequiel de Souza & Fazendeiro & $1: 500 \$ 000$ \\
\hline Evaristo Araújo de Aguiar & Fazendeiro & $1: 500 \$ 000$ \\
\hline Major José Octaviano Machado & Fazendeiro & $1: 500 \$ 000$ \\
\hline Felício Maria Calvite & Construtor civil & $1: 500 \$ 000$ \\
\hline Luigi Botelli & Sitiante e oleiro & $1: 500 \$ 000$ \\
\hline Antonio Migliaccio Total & Barbeiro & $1: 500 \$ 000$ \\
\hline Total & & $50: 000 \$ 000$ \\
\hline
\end{tabular}

Fonte: Elaborado pela autora com base em MASCHIETTO (1979, p. 27). 


\section{Anexo 04}

Carta de aforamento a título de ilustração da especificidade desse documento encontrado na Hemeroteca Jornalista Paschoal Artese.

\section{GARTA DE AFORAMHTTO}

A. Camara Municipal da villa de S. José do Rio Pardo, a todos quantos apresentem carta de aforamento virem, faz saber que sendo no anno do nascimento de

Nosso Senhor Jesus Christo de 1888 aos 2 - dias do mez de Nlanea do dito anno, em sessào ondmaniffoi resolvido unanimemente que, se rafasis

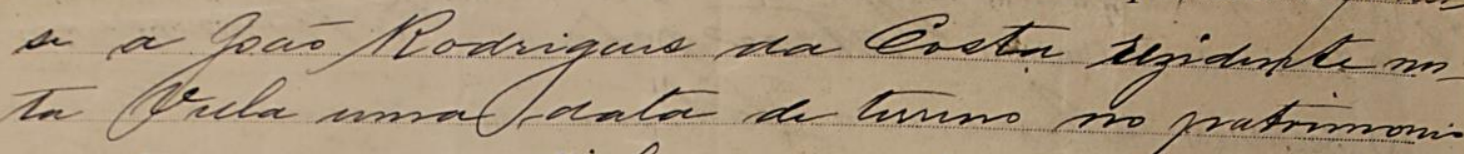

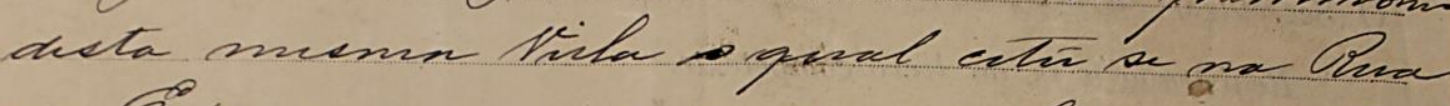

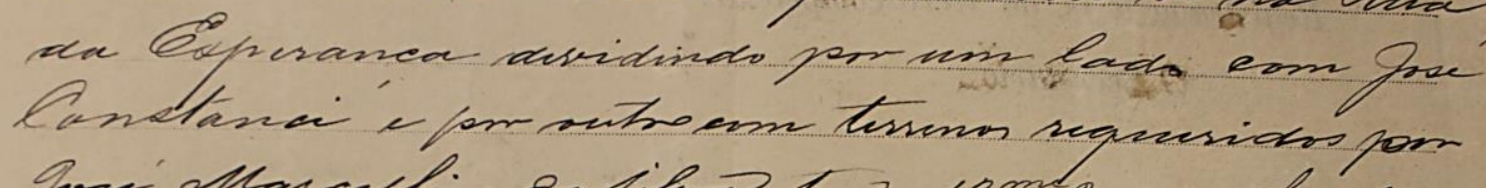

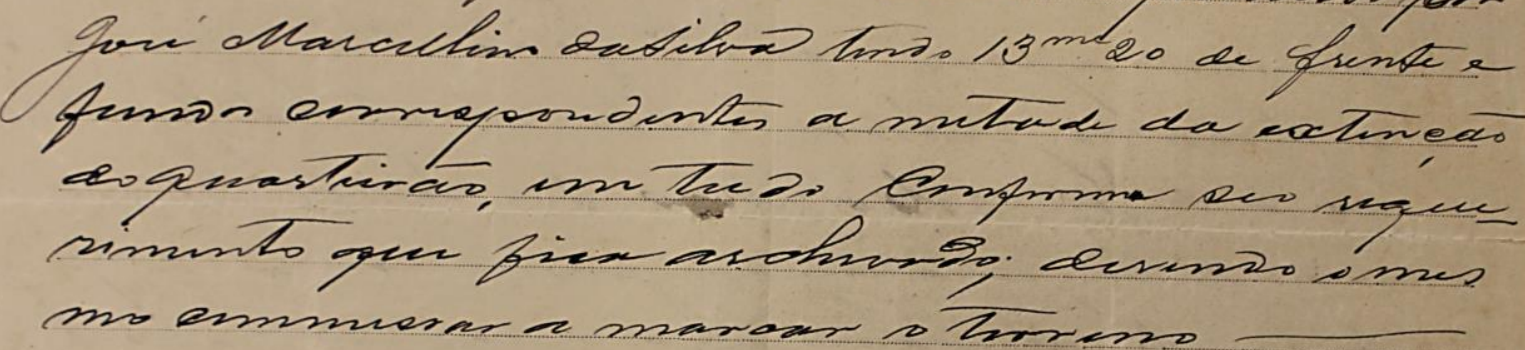

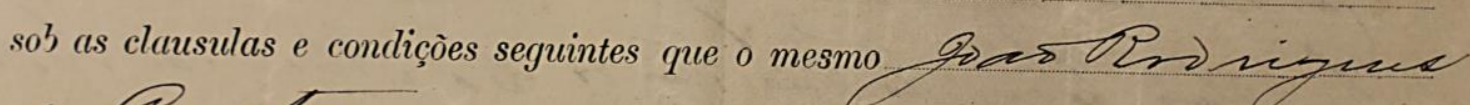
dxerecto se obrigne a cumprir: 1 Fica elle por si e por seos herdeiros obrigado ao pagamento ammual (que será contado da data deste em diante) de $/ 6$ acis de cala metro de terreno que a fóra a esta Camara; 2. Sugeitar-se elle foreiro, por si e scus herdeiros a responder em juizo executivamente pelo pagamento do estipulado fôro, nào podendo nunca invoear em seu favor qualquer prescripçào, ainda que a divida seja atrazada de mais de 10 annos; ¿ Incorrem elle e seus herdeiros na pena de commisso, perdendo nào só o dominio util do terreno aforado, como quaesquter bemifeitortus que neste tenhn, se deixar de pagar ò fôro for espaço de 10 annos, consecuit vos; e bem assim deverá todo proprietario que possiir terreno, a titulo de aforamento começar a marcal-o fincando dois esteios na frente dentro do prazo te tres mezes, começar a edificiar dentro do prazo de se's mezes e concluir o edificio ao menos exteriormente na frente, dentro do prazo de um anno. Nào podendo vender, trocal-o ou de qualquer modo alienal-o, sem consentimento da Camara, a qual cosnentindo haverá de laudemio dois e meio por cento sobre o producto do fôro de um anno, multiplicado vinte vezes. 


\section{Anexo 05}

Relação dos devedores do imposto predial da cidade de São José do Rio Pardo. Na lista consta o nome do devedor com o respectivo endereço (rua e número), valor locativo mensal, imposto anual, e se a edificação era própria ou alugada.

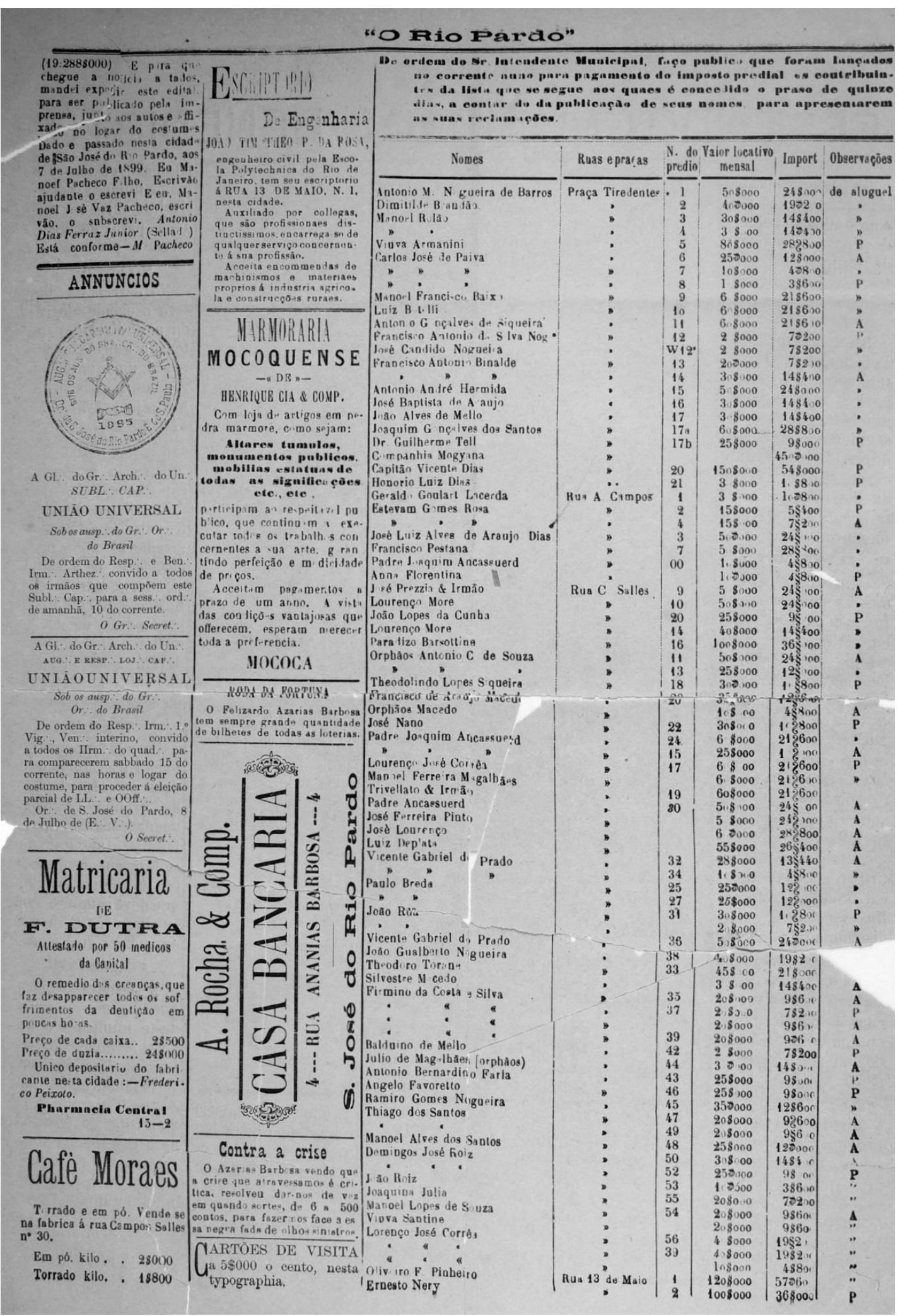

Fonte: Jornal O Rio Pardo, 09 de julho de 1899, p.04 


\section{"O Rio Parto"}

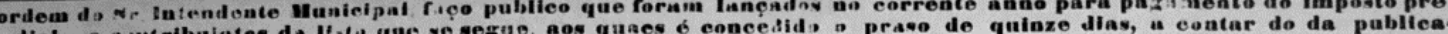
cáo de neur names, para uprevencarem as suas rechmacōes

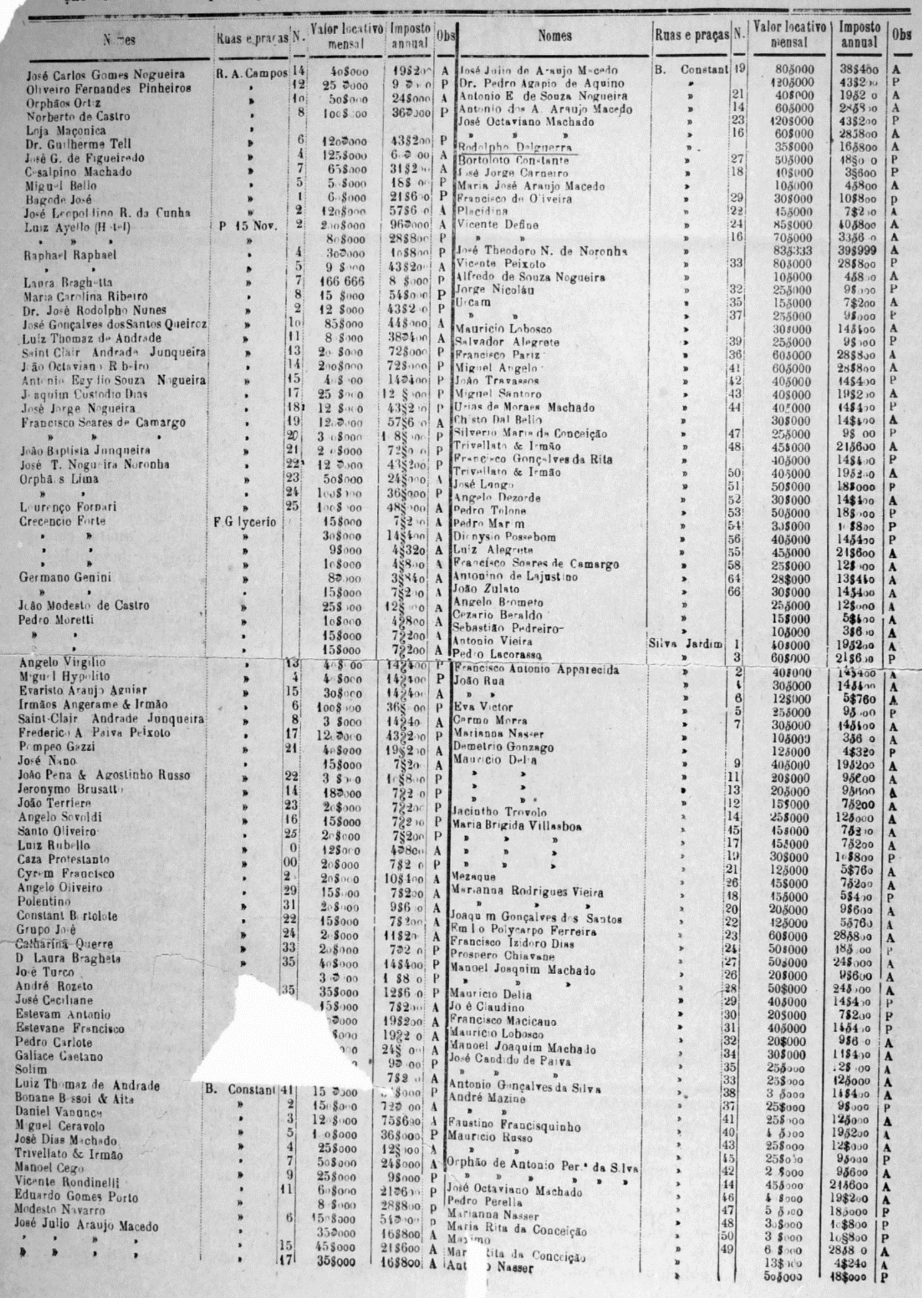

Fonte: Jornal O Rio Pardo, 20 de julho de 1899, p.03. 
"O Rio Paxdo"

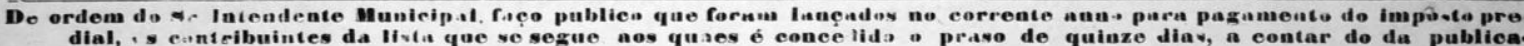
câo do seus nomor para npreveurarem as suas rechitaceóes

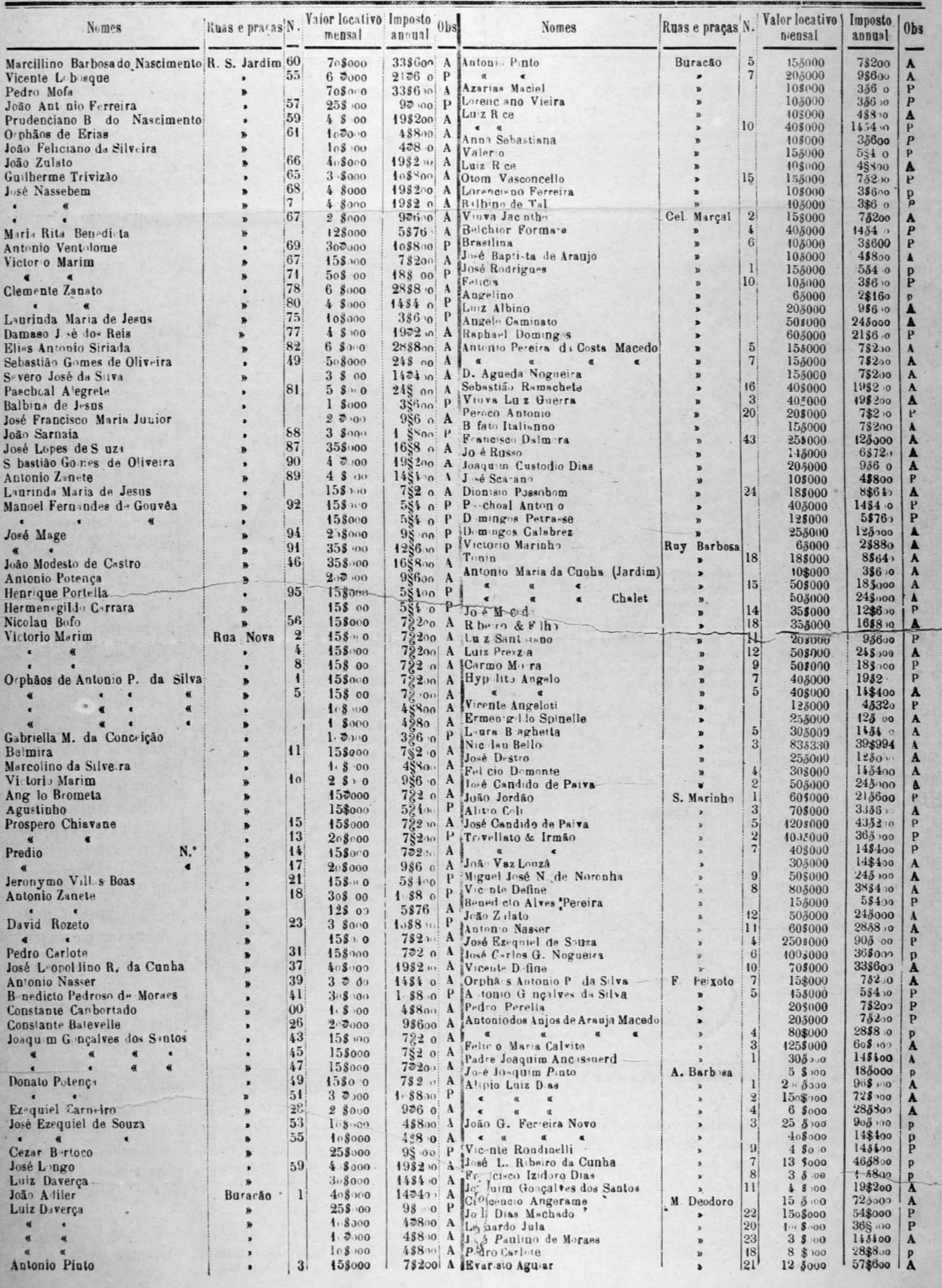

Fonte: Jornal O Rio Pardo, 23 de julho de 1899, p.03. 
Do ordeon de Nr. Intendente Munielpal, faço publien que forum lanģados no correate anno para pagameate do Impante pres. pào de seus nomes p.ura aprenencarem as suas reclamnęes.

\begin{tabular}{|c|c|c|c|c|c|c|c|c|c|c|c|}
\hline Nomes & as : & & & $\begin{array}{l}\text { nposto } \\
\text { nnual }\end{array}$ & & Nomes & uas e & & niensal & & \\
\hline 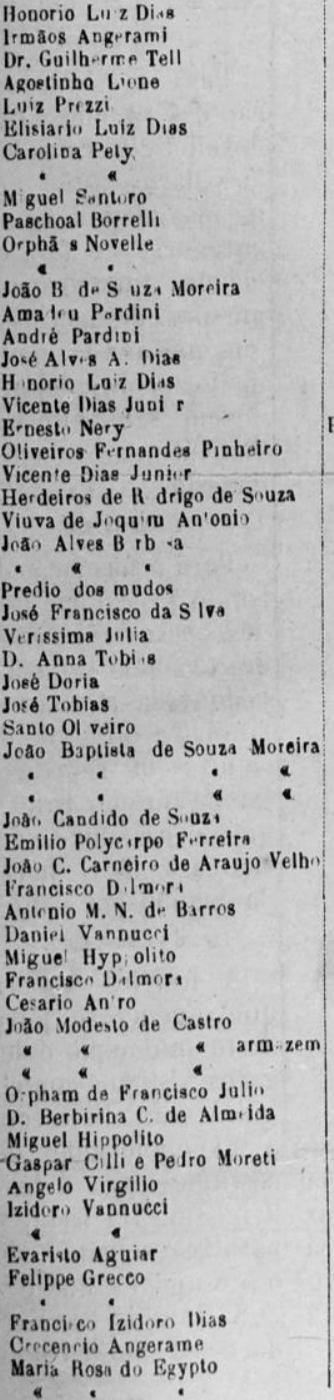 & $\begin{array}{c}\vdots \\
\vdots \\
\vdots \\
\text { PQ Boc.yuva } \\
\vdots \\
\vdots \\
\vdots \\
\vdots \\
\vdots \\
\vdots \\
\vdots \\
\vdots \\
\vdots \\
\vdots \\
\vdots \\
\vdots \\
\vdots \\
\vdots \\
\vdots \\
\vdots \\
\vdots \\
\vdots \\
\vdots\end{array}$ & $\begin{array}{l}19 \\
18 \\
21 \\
22 \\
21 \\
24 \\
23 \\
25 \\
26 \\
27 \\
29 \\
28 \\
20 \\
19 \\
18\end{array}$ & 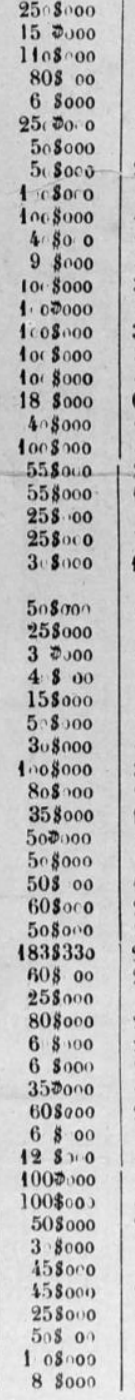 & 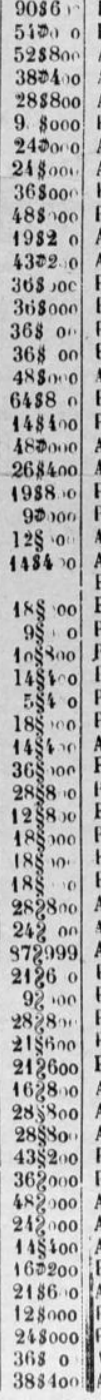 & 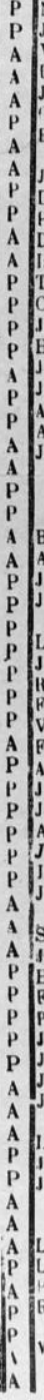 & 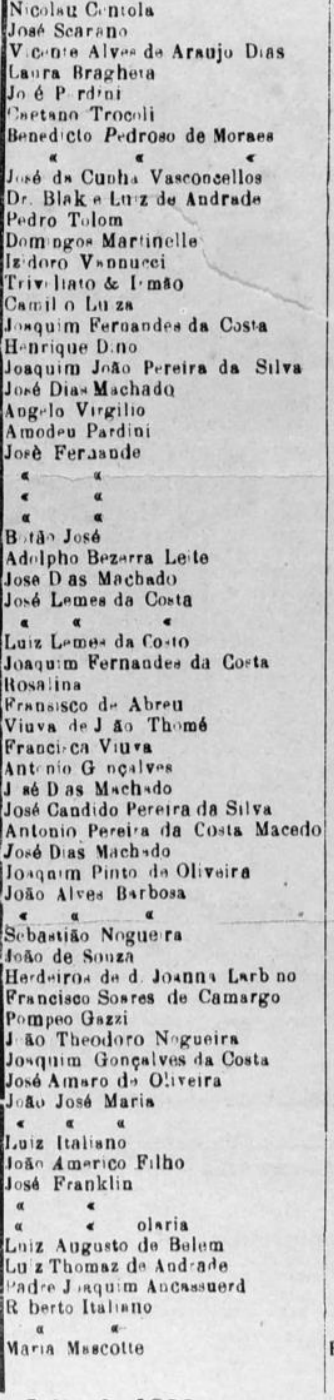 & $\begin{array}{c}\text { P. P. Morae } \\
\vdots \\
\vdots \\
\vdots \\
\vdots \\
\text { Acrebaldu } \\
\vdots \\
\vdots \\
\text { B.Sucersso } \\
\vdots \\
\vdots \\
\vdots \\
\text { Suburbio } \\
\text { Cbacara } \\
\text { Suburbio } \\
\text { Chacara } \\
\text { Suburbao } \\
\vdots \\
\vdots \\
\text { Chacara } \\
\vdots \\
\vdots \\
\vdots \\
\vdots\end{array}$ & $\mid \begin{array}{r}17 \\
16 \\
14 \\
12 \\
10 \\
8 \\
15 \\
13 \\
11 \\
0\end{array}$ & 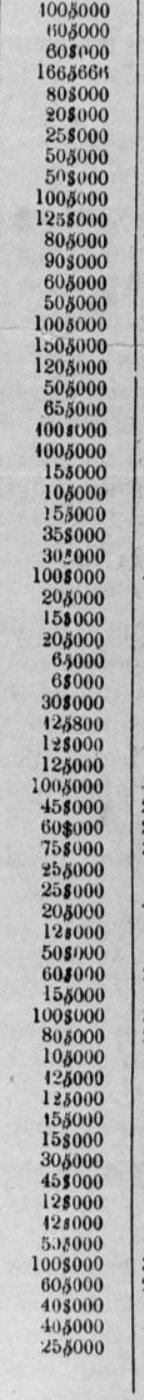 & 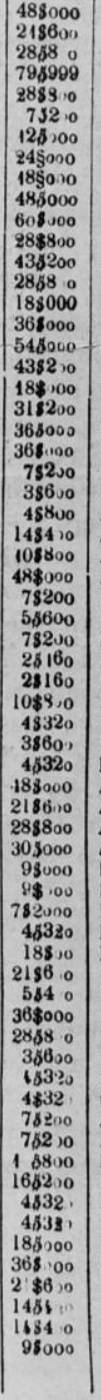 & 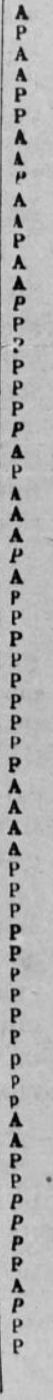 \\
\hline
\end{tabular}

Intendeneria Munieipal de San José de Rlo Pardo, 18 de Julto de 1898.

- Langador o Cobrador, - Fancisco avrevio da silva vogueats.

Fonte: Jornal O Rio Pardo, 27 de julho de 1899, p.03 


\section{Apêndice 01}

Tendo em vista a necessidade de apreender as transformações urbanas e identificar as edificações que possuíam uso residencial localizadas no Centro Histórico rio-pardense e nas vertentes de acesso a essa região, e que também compreendessem o recorte temporal estabelecido (1865-1940), foram percorridas todas as ruas com a posse de um mapa cartográfico impresso, câmera fotográfica digital e caderno de anotações. A identificação da data de construção das edificações foi feita, quando possível, através da inscrição na platibanda e de projetos arquivados na Secretaria de Obras de São José do Rio Pardo; informações passadas por antigos proprietários ou moradores; registro no Cartório Civil; e através da comparação entre duas fotografias antigas datadas com pequeno intervalo de tempo. Assim sendo, apresentamos no quadro a seguir as edificações identificadas.

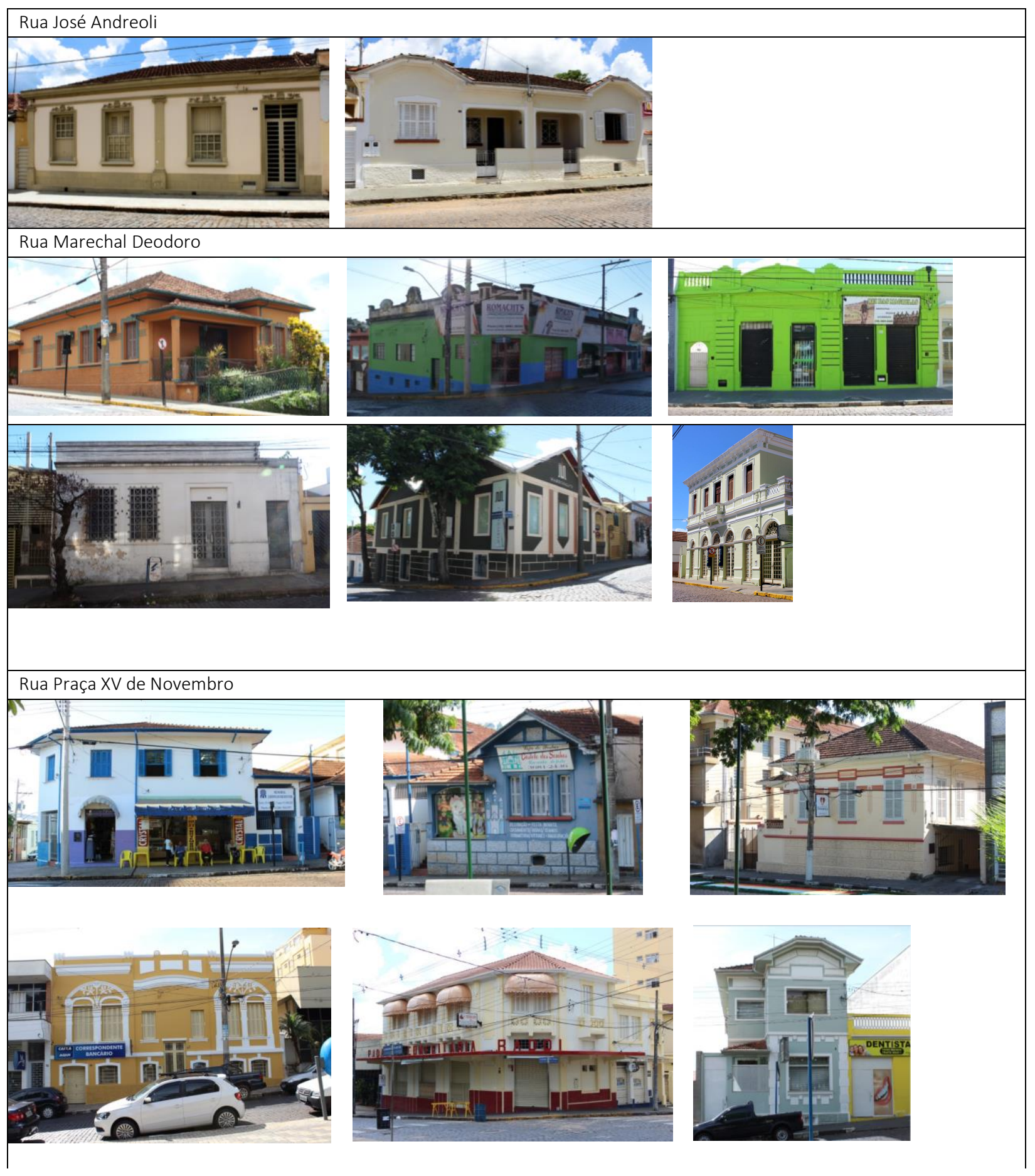



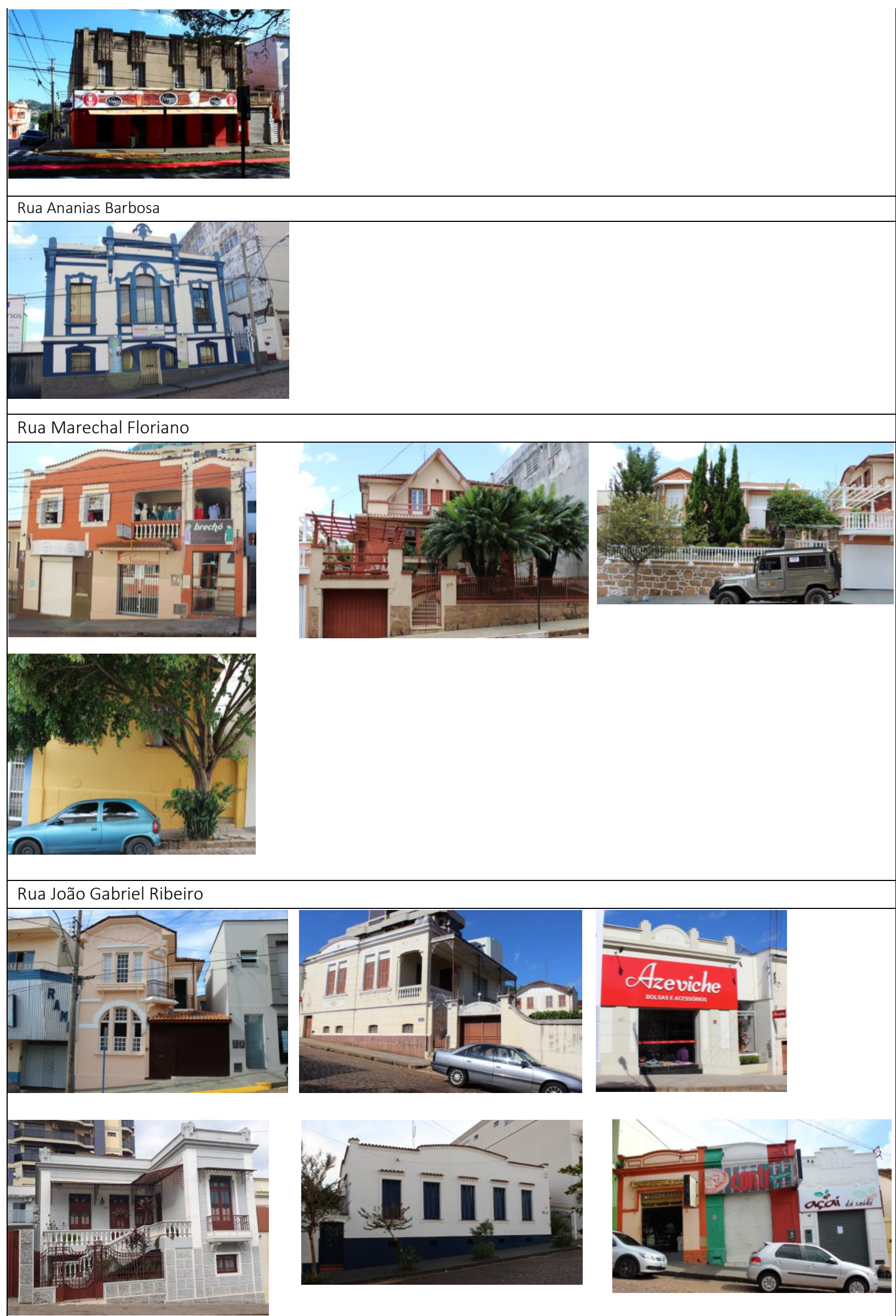

Rua Ruy Barbosa 

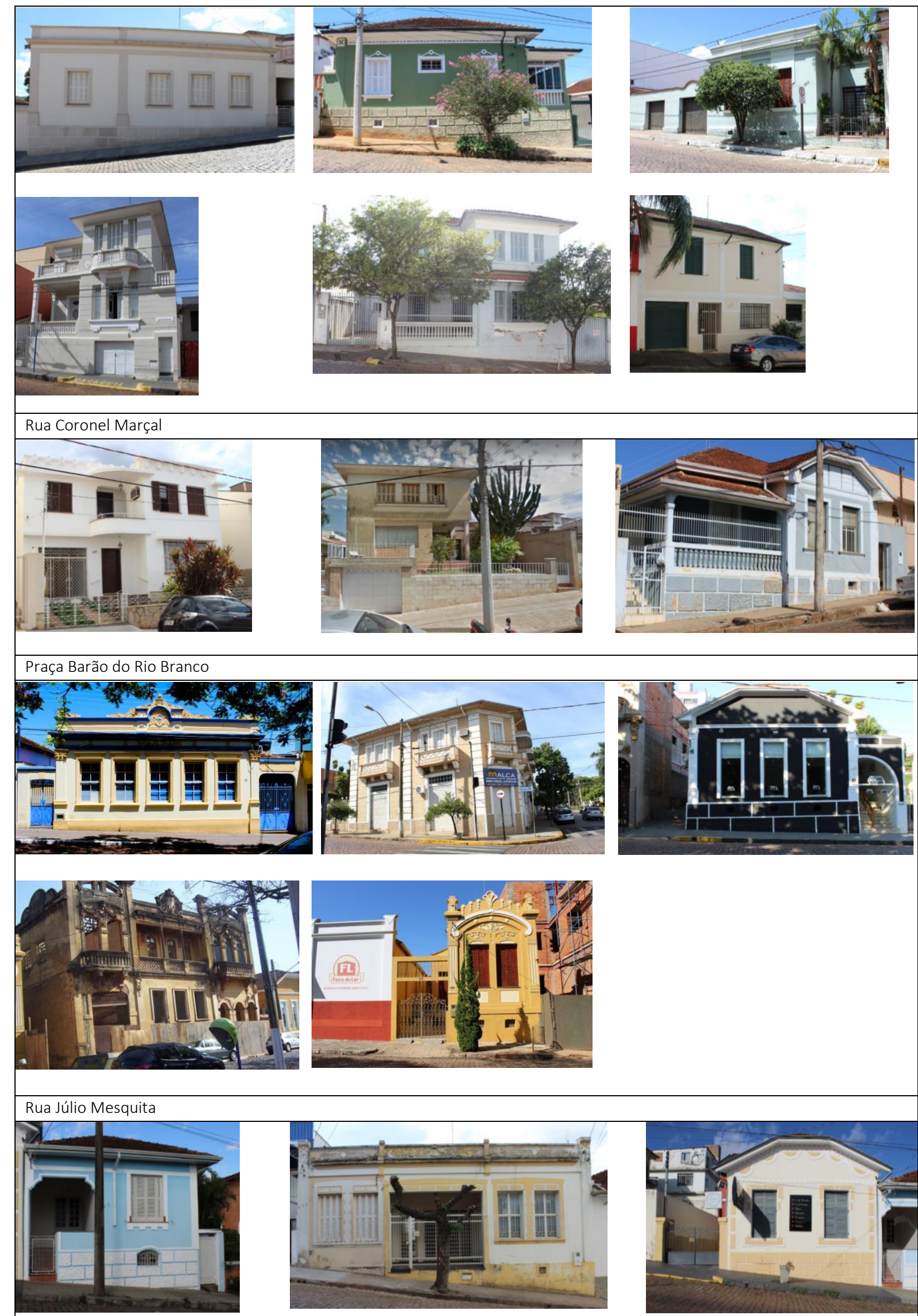

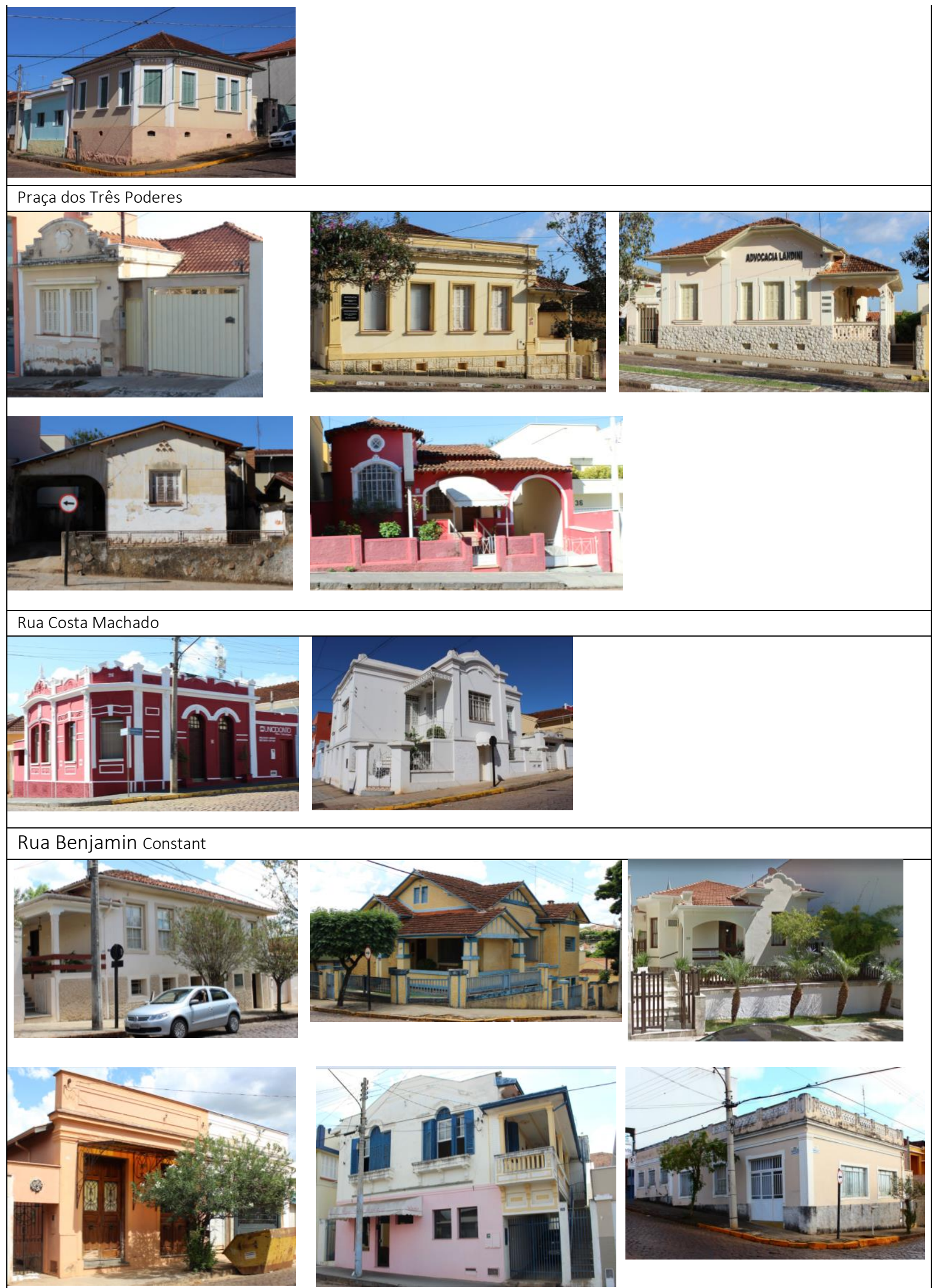

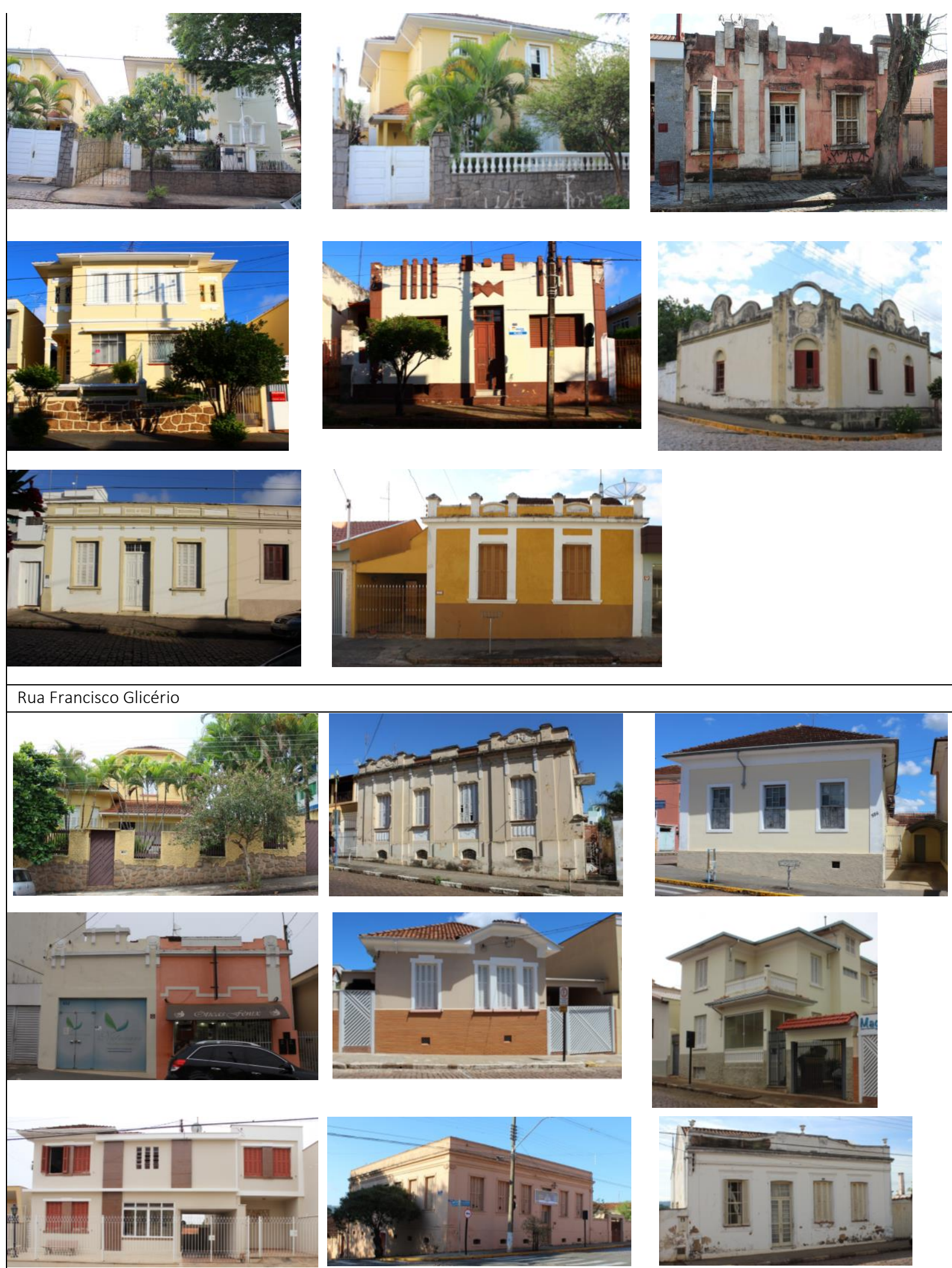

Rua Francisquinho Dias 

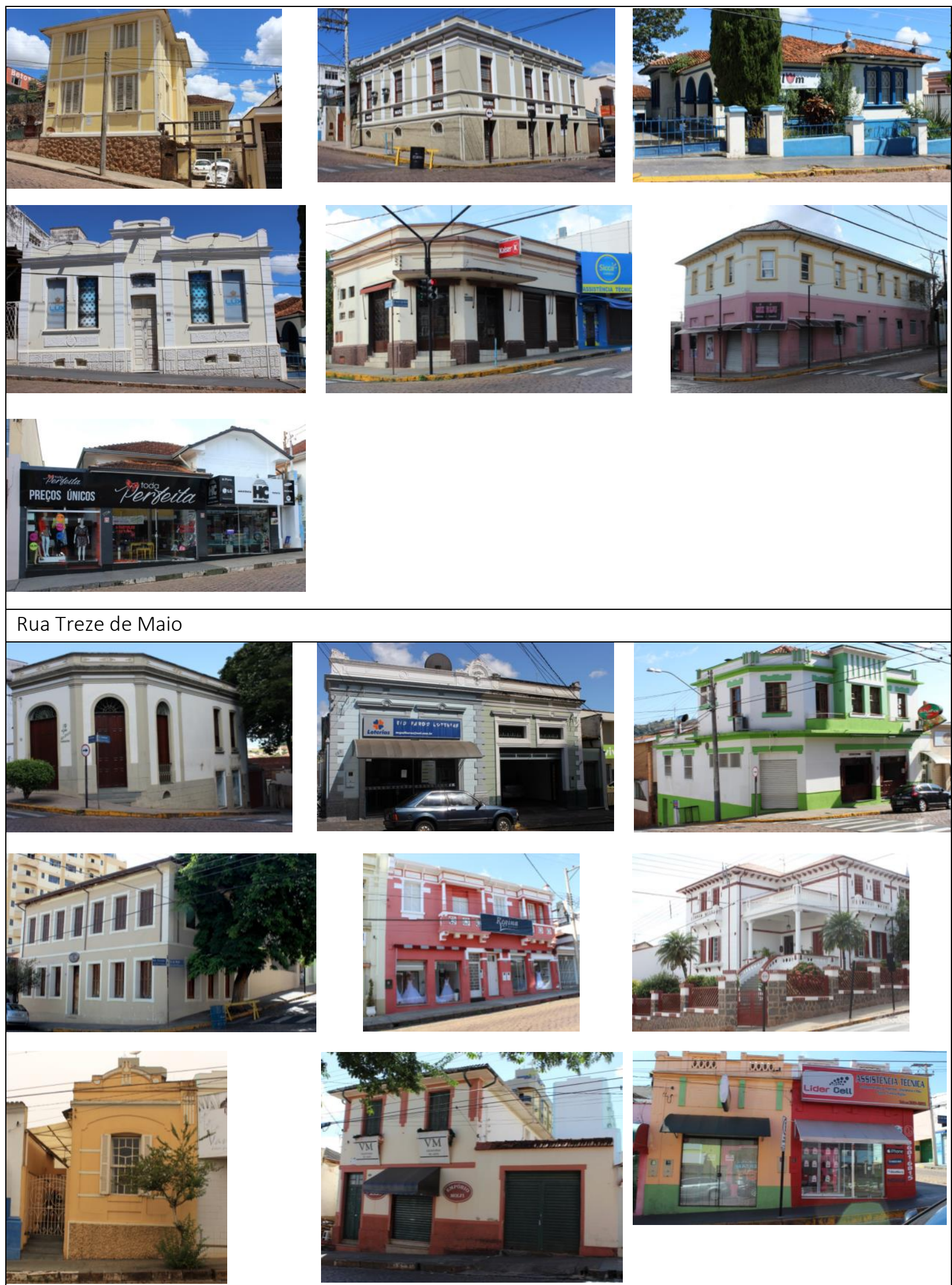

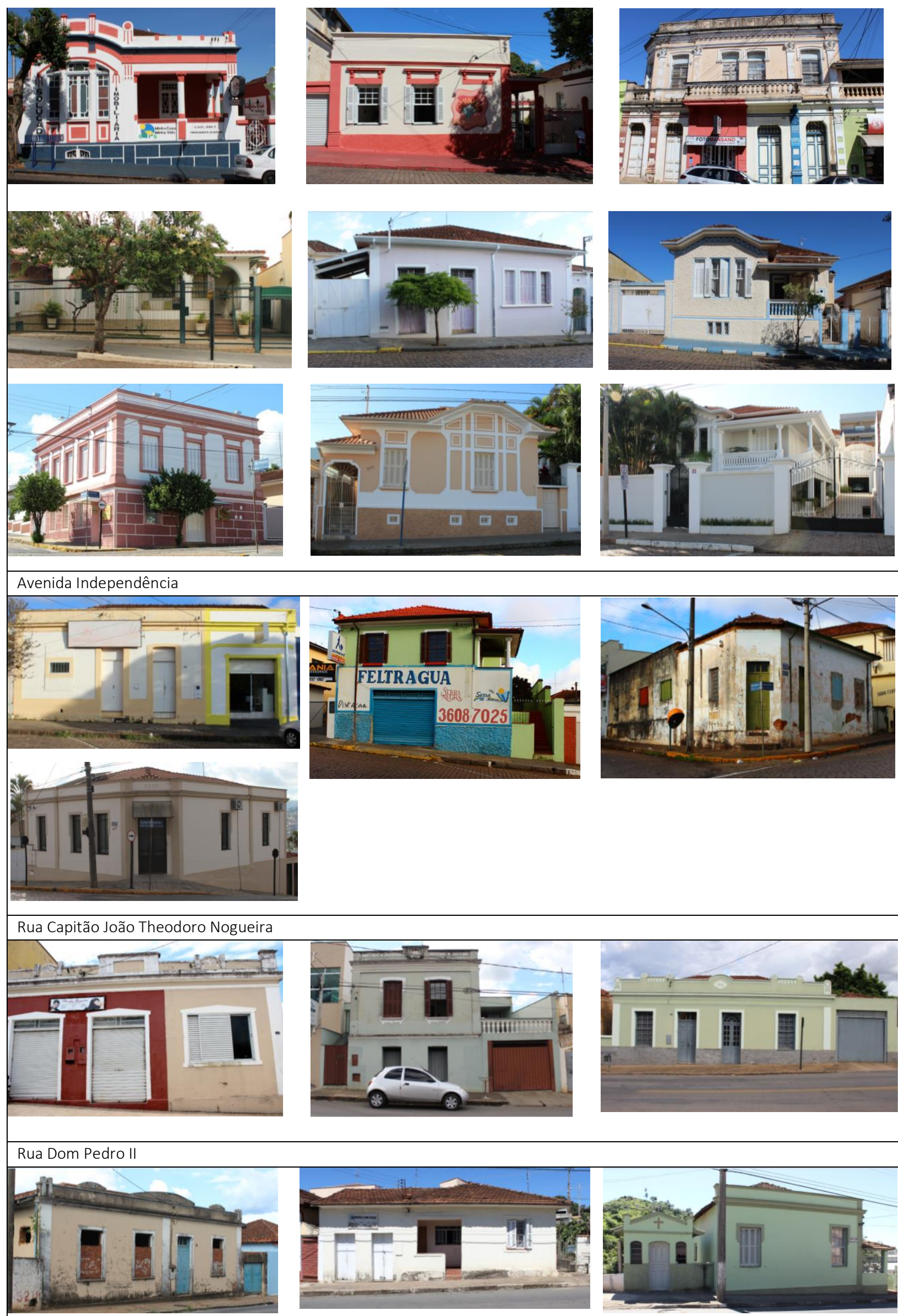

Rua Siqueira Campos 


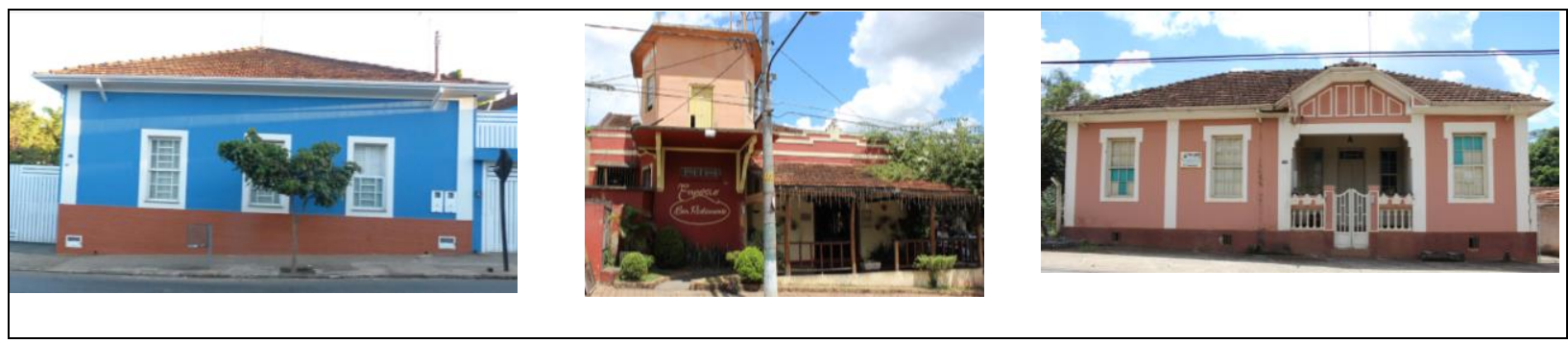

Fonte: Acervo pessoal da autora (2015). 


\section{Apêndice 02}

Trata das entrevistas semiestruturadas que foram realizadas com a população local. A escolha dos entrevistados se pautou no engajamento com a história e os movimentos culturais da cidade; pessoas idosas que moraram ou ainda moram no Centro Histórico rio-pardense; e pessoas que possuíam comércio nesta região da cidade. Todas as entrevistas foram gravadas em áudio e vídeo com o auxilio de um gravador e uma câmera digital, e posteriormente foram transcritas na íntegra no software Microsoft Word. O objetivo foi colher informações sobre a formação e transformações urbanas e arquitetônicas do Centro Histórico. Abaixo segue a estrutura da entrevista:

ENTREVISTADA:

ENTREVISTADORA:

DATA:

LOCAL:

- Bloco 1: Identificação Pessoal

1- Qual o seu nome completo?

2- Qual seu endereço e telefone para contato?

3- Data e local de nascimento?

4- Qual o nome de seus pais?

5- Qual seu estado civil?

6- Você tem filhos? Quantos?

7- Onde eles nasceram?

8- Você frequentou a escola? Onde? Quando?

9- Quais são as atividades profissionais que você desempenhou ao longa da vida?

10- Qual é a sua religião?

11- Tem título de eleitor?

- Bloco 2: a inserção no tema (como era usado o espaço interno da residência e o urbano)

12- Quais foram as suas experiências antes de você vir pra SJRP? Onde morava? Como chegou a SJRP (trabalho, família, escola)?

13- Há quanto tempo você mora em SJRP?

14- Quais os locais em que você morou em São José do Rio Pardo?

15- A sua casa era própria ou alugada?

16- Quantas pessoas moravam na casa?

17- Como era o interior da sua casa (disposição dos cômodos)?

18- Como era a vida dentro da casa (atividades)?

19- Quais eram os móveis (mobília) e utensílios da casa?

20- Havia abastecimento de água? Se não, onde e como faziam para pegar água?

21- E a rede de esgoto? Se não, como era realizada o despejo dos dejetos?

22- Havia energia elétrica dentro de casa?

23- Você se recorda da chagada do telefone à cidade? Como funcionava? Quem tinha?

24- Tinha rádio na sua casa? Onde ficava? Quem usava? O que e quando ouviam?

25- E a televisão (mesmas perguntas)? Mudou alguma coisa na rotina da família?

26- Lembra-se de outras novidades importantes que chegaram a sua casa?

27- Conte para mim como era o centro quando você era jovem.

28- Como se chegava ao centro? Por quais ruas?

29- Tinha muitas residências no centro?

30- Quem morava no centro?

31- Em que parte do centro moravam os ricos e os pobres?

32- De que forma eram as moradias e o jeito de viver?

33- Tinha muitos comércios no centro? Você se lembra de algum, me conte.

34- Quais são os prédios do centro que você mais se recorda?

35- Como eram os prédios? Baixos ou altos?

36- Os telhados dos prédios jogavam a água na rua?

37- Havia uma distância em relação ao prédio e a calçada?

38- Tinha jardim na frente dos prédios?

39- Como eram as ruas, de terra ou pedra?

40- As ruas e praças eram iluminadas? Se não, como faziam quando escurecia?

41- Onde que acontecia o comércio de alimentos? Como funcionava este comércio?

42- Me conte como fazia para adquirir os alimentos básicos como arroz, feijão, verdura, legumes, frutas, carne e leite? 
43- Por exemplo: o pão, você fazia em casa ou comprava em alguma padaria? Qual padaria?

44- Havia gente trabalhando nas ruas? O que faziam (engraxates, carregadores etc.)?

45- Existia comércio ambulante (vendedores de quitutes por exemplo)?

46- Que tipo de pessoas circulava nas ruas (homens, mulheres, crianças, ricos ou pobres, etc.)? O que faziam?

47- Como era a segurança? Havia muitos roubos e assaltos?

48- Que tipo de veículos circulava nas ruas (carroças, carros, particulares etc.)?

49- Quando teve transporte público? Como era? De onde para onde?

50- Onde e como funcionavam as indústrias?

51- E a Ferrovia?

52- Havia muitas igrejas na cidade? e no centro?

53- Em sua opinião, qual era a religião que as pessoas mais seguiam?

54- As crianças e jovens frequentavam as escolas, ou a maioria começam a trabalhar cedo abandonando os estudos?

55- Em relação a saúde, havia muitos médicos, enfermeiros, parteiras? A consulta era de graça?

56- Em relação a política, havia grupos dominantes (família por exemplo)?

57- Como era a economia da cidade?

58- Qual a loja mais chique para fazer compra na época?

59- Tinha farmácia? Qual era a sua localização?

60- Como eram as praças da Várzea, Matriz, e Mercado (perguntar uma de cada vez)? Como você utilizava esse espaço? Quem e como frequentava?

61- Você se recorda do Jardim Artístico do Artese? Como era? Como você utilizava esse espaço? Quem e como frequentava?

62- $O$ que aconteceu depois do fechamento do Jardim?

63- Você se recorda dos prédios do cinema? Como era? Você frequentava esse espaço?

64- Você se recorda do prédio da antiga prefeitura? Como era?

65- Você se recorda do prédio do antigo fórum? Como era?

66- Havia lugares de lazer no centro? Se não, onde frequentavam? Quem frequentava?

67- Existiam outros lugares para passeios, jogos, dança e outros tipos de diversão (meretrício)? 


\section{Apêndice 03}

Elencamos na tabela a seguir informações de todos os projetos arquivados na Secretaria de Obras de São José do Rio Pardo entre os anos de 1925 a 1940. A sistematização foi realizada a partir das seguintes informações: ano, número do processo, assinatura, proprietário, endereço, bairro, natureza da solicitação e uso.

Tabela 10: Lista parcial dos processos de aprovação de construção pertencentes ao Arquivo Público da Secretaria de Obra de São José do Rio Pardo com as seguintes informações: ano, número do processo, assinatura, proprietário, endereço, natureza da solicitação (construção (C), reforma (R) ou ampliação (A)), uso (residencial (R), comercial (C), serviço (S), industrial (I), indefinido (II) e misto (M)), e característica da implantação (geminada $(\mathrm{G})$, solta no lote $(S)$, sem recuo $(S R)$, um recuo (1R), dois recuos (2R), três recuos (3R), esquina sem recuo (E) e esquina com recuo (ER)).

\begin{tabular}{|c|c|c|c|c|c|c|c|}
\hline Ano & Processo & Assinatura & Proprietário & Endereço & Bairro & Solicitação & Uso \\
\hline 1925 & P1 & Desconhecido & $\begin{array}{l}\text { João Carneiro de Araujo } \\
\text { Velho }\end{array}$ & Rua Treze de Maio & Centro & Reforma & II \\
\hline 1925 & $\mathrm{P} 2$ & A. Braghetta & Alberto da Silva & Avenida Nove de Julho & Centro & Construção & $\mathrm{R}$ \\
\hline 1925 & P4 & Desconhecido & Augusto Tiesi & Rua Euclides da Cunha & Centro & Ampliação & 1 \\
\hline 1925 & P5 & Antônio Molfi & Ezidro Vieira Guimarães & Rua Campos Salles & Centro & Reforma & $\mathrm{R}$ \\
\hline 1925 & P6 & Desconhecido & Willian Simonsen & Rua Benjamin Constant & Centro & Construção & $\mathrm{R}$ \\
\hline 1925 & P7 & Desconhecido & Francisco Parisi & Rua Ruy Barbosa & Centro & Ampliação & ॥ \\
\hline 1925 & P8 & A. Braghetta & Donato Caruso & Rua Campos Salles & Centro & Construção & $\mathrm{R}$ \\
\hline 1925 & P9 & Desconhecido & João Barroso & Rua Treze de Maio & Centro & Construção & II \\
\hline 1925 & P10 & Desconhecido & Manuel C. Janero & Rua Benjamin Constant & Centro & Construção & $\mathrm{R}$ \\
\hline 1925 & P11 & Desconhecido & Joaquim Pinheiro da Silva & Rua Treze de Maio & Centro & Construção & $\mathrm{R}$ \\
\hline 1925 & P12 & Desconhecido & Manuel de Paiva & Bairro Euclides da Cunha & $\begin{array}{l}\text { Bairro Santo } \\
\text { Antônio }\end{array}$ & Construção & ॥ \\
\hline 1925 & P13 & Desconhecido & Vicença Cogato & Rua Treze de Maio & Centro & Construção & $\mathrm{R}$ \\
\hline 1925 & P14 & Desconhecido & Vicente Darveça & Avenida Central & Centro & Construção & ॥ \\
\hline 1925 & P15 & Desconhecido & Antônio Molfi & Rua José Theodoro & Centro & Construção & $\mathrm{R}$ \\
\hline 1925 & P16 & A. Braghetta & Domingos Precioso & Avenida Nova & Centro & Construção & $\mathrm{R}$ \\
\hline 1925 & P17 & Desconhecido & Domingos Perri & Rua Campos Salles & Centro & Ampliação & ॥ \\
\hline 1925 & P18 & Ernesto Rugani & Ernesto Rugani & desconhecido & desconhecido & Construção & $\mathrm{C}$ \\
\hline 1925 & P19 & Desconhecido & Antonio Luciano & Avenida Nova & Centro & Construção & $\mathrm{R}$ \\
\hline 1925 & P20 & Desconhecido & $\begin{array}{l}\text { Joaquim Pinto Figueira } \\
\text { Filho }\end{array}$ & Avenida Belmonte & Centro & Construção & ॥ \\
\hline 1925 & $\mathrm{P} 21$ & A. Braghetta & Antonio Luciano & Avenida Nova & Centro & Construção & ॥ \\
\hline 1926 & S.N. & Desconhecido & $\begin{array}{l}\text { Anna Candida da } \\
\text { Conceição }\end{array}$ & Rua Silva Jardim & Centro & Ampliação & ॥ \\
\hline 1926 & P1 & Desconhecido & Nicanor Rodrigues & Rua Benjamin Constant & Centro & Construção & ॥ \\
\hline 1926 & $\mathrm{P} 2$ & Desconhecido & Carlos Frigo & Rua Silva Jardim & Centro & Construção & $\mathrm{R}$ \\
\hline 1926 & P3 & A. Braghetta & Alice Moreira & Avenida Belmonte & Centro & Construção & ॥ \\
\hline 1926 & P5 & Desconhecido & Silvio Carvalhães & Rua Benjamin Constant & Centro & Construção & ॥ \\
\hline 1926 & P6 & João Molfi & Achiles Fagioli & Avenida Belmonte & Centro & Construção & $\mathrm{R}$ \\
\hline 1926 & P7 & $\begin{array}{l}\text { José Lourenço } \\
\text { Filho }\end{array}$ & Guilherme Garcia & Rua Campos Salles & Centro & Reforma & ॥ \\
\hline 1926 & P8 & Desconhecido & Francisco Pozo & Rua Ruy Barbosa & Centro & Reforma & $\|$ \\
\hline 1926 & P9 & Desconhecido & Joaquim Pinheiro & Rua Campos Salles & Centro & Construção & $\mathrm{R}$ \\
\hline 1926 & P10 & Desconhecido & Aníbal de Sá Pinto & Rua Benjamin Constant & Centro & Construção & M \\
\hline 1926 & P11 & Desconhecido & Ciro Ferraz & Rua Benjamin Constant & Centro & Construção & $\mathrm{R}$ \\
\hline
\end{tabular}


PROCESSOS DE APROVAÇÃO DE CONSTRUÇÃO PERTENCENTES AO ARQUIVO PÚBLICO DA SECRETARIA DE OBRA DE SÃO JOSÉ DO RIO PARDO

\begin{tabular}{|c|c|c|c|c|c|c|c|}
\hline Ano & Processo & Assinatura & Proprietário & Endereço & Bairro & Solicitação & Uso \\
\hline 1926 & P12 & Desconhecido & Joaquin Amancio & Avenida Central & Centro & Construção & $\mathrm{C}$ \\
\hline 1927 & P1 & Desconhecido & Benedito da Silva Amaral & Avenida Independência & Centro & Construção & $\mathrm{C}$ \\
\hline 1927 & $\mathrm{P} 2$ & Desconhecido & Mathias Sawssvich & Avenida Belmonte & Centro & Construção & $\mathrm{C}$ \\
\hline 1927 & P3 & Desconhecido & Thomás Ferraiolo & Villa Pereira & Vila Pereira & Construção & $\mathrm{C}$ \\
\hline 1927 & P4 & A. Braghetta & José Luzio & Rua Marechal Floriano & Centro & Construção & $\mathrm{C}$ \\
\hline 1927 & P5 & Desconhecido & Francisco Bortot & Rua Euclides da Cunha & Centro & Construção & ॥ \\
\hline 1927 & P6 & A. Braghetta & Armando Ferrari & Rua Benjamin Constant & Centro & Construção & II \\
\hline 1927 & P7 & $\begin{array}{l}\text { Engenheiro Elias } \\
\text { Machado }\end{array}$ & Francisco Barreto & Rua Treze de Maio & Centro & Construção & $S$ \\
\hline 1927 & P8 & Desconhecido & Caetano Lopes & Rua Rio Pardo & Centro & Construção & II \\
\hline 1927 & P9 & Desconhecido & João Cezario & Rua Campos Salles & Centro & Construção & II \\
\hline 1927 & $\mathrm{P} 10$ & Desconhecido & Pedro Folchetti (Fargetti) & Avenida Independência & Centro & Construção & M \\
\hline 1927 & P11 & Desconhecido & Nicolau Vista & $\begin{array}{l}\text { Praça Prudente de } \\
\text { Moraes }\end{array}$ & Centro & Construção & C \\
\hline 1927 & P12 & Antônio Molfi & João Gonçalves & Rua João Travesso & $\begin{array}{l}\text { Bairro Santo } \\
\text { Antônio }\end{array}$ & Construção & $\mathrm{R}$ \\
\hline 1927 & P13 & Desconhecido & Lourenço Tempesta & Rua Benjamin Constant & Centro & Construção & $\mathrm{R}$ \\
\hline 1927 & P14 & Antônio Molfi & João Gonçalves & Rua João Travesso & $\begin{array}{l}\text { Bairro Santo } \\
\text { Antônio }\end{array}$ & Construção & $R$ \\
\hline 1927 & P15 & José Lourenço & Pompilio Lutti & Rua Treze de Maio & Centro & Reforma & II \\
\hline 1927 & P16 & Desconhecido & José Bráz & Avenida Independência & Centro & Construção & $\mathrm{R}$ \\
\hline 1927 & P17 & Desconhecido & Sipião Tibério & Avenida Belmonte & Centro & Construção & II \\
\hline 1927 & P18 & Desconhecido & José Favero & Rua Jorge Tibiriça & Centro & Construção & $R$ \\
\hline 1927 & P19 & Desconhecido & Pedro Vieira & Rua Benjamin Constant & Centro & Construção & $\mathrm{R}$ \\
\hline 1927 & P20 & A. Braghetta & José Martino & Rua Marechal Floriano & Centro & Construção & $\mathrm{R}$ \\
\hline 1927 & P21 & Desconhecido & Agostino Manaca & Rua Ruy Barbosa & Centro & Construção & ॥ \\
\hline 1927 & P22 & Desconhecido & Casa Braguetta & fundos da casa Braguetta & Centro & Construção & C \\
\hline 1927 & P23 & Desconhecido & Jonnas Ribeiro de Oliveira & Rua João Barbosa & $\begin{array}{l}\text { Bairro } \\
\text { Bonsucesso }\end{array}$ & Construção & $\mathrm{R}$ \\
\hline 1927 & P24 & Desconhecido & José Argenti & Rua Benjamin Constant & Centro & Ampliação & II \\
\hline 1927 & $\mathrm{P} 25$ & Desconhecido & Felippe Antonio & Rua Saldanha Marinho & Centro & Ampliação & II \\
\hline 1927 & P26 & Desconhecido & José Egidio Chagas & Villa Progresso & Villa Progresso & Construção & ॥ \\
\hline 1927 & $\mathrm{P} 27$ & Desconhecido & A. João Pinesi & Bairro Santo Antônio & $\begin{array}{l}\text { Bairro Santo } \\
\text { Antônio }\end{array}$ & Construção & ॥ \\
\hline 1927 & P28 & Desconhecido & Militão Siqueira & Rua Campos Salles & Centro & Construção & ॥ \\
\hline 1927 & P29 & Ernesto Rugani & Francisco Rugani & $\begin{array}{l}\text { Rua Belmonte com Rua } \\
\text { Jorge Tibiriça }\end{array}$ & Centro & Construção & $\mathrm{R}$ \\
\hline 1927 & P30 & Desconhecido & Antonio Lauria & Rua João Barbosa & $\begin{array}{l}\text { Bairro } \\
\text { Bonsucesso }\end{array}$ & Construção & C \\
\hline 1927 & P31 & A. Braghetta & Joaquim Armando Dias & Bairro Santo Antônio & $\begin{array}{l}\text { Bairro Santo } \\
\text { Antônio }\end{array}$ & Construção & ॥ \\
\hline 1927 & P32 & Desconhecido & Antonio Nobrega & Avenida Belmonte & Centro & Construção & $\mathrm{M}$ \\
\hline 1927 & P33 & Desconhecido & Paulo Ferreira da Silva & Rua Benjamin Constant & Centro & Construção & ॥ \\
\hline 1927 & P34 & A. Braghetta & Sipião Tibério & Avenida Belmonte & Centro & Construção & $\mathrm{R}$ \\
\hline 1928 & P1 & A. Braghetta & Marcos do Nascimento & Avenida Belmonte & Centro & Construção & ॥ \\
\hline 1928 & P2 & Desconhecido & João di Napoli & Rua Jorge Tibiriça & Centro & Construção & II \\
\hline 1928 & P3 & Desconhecido & Igreja Santo Antonio & Bairro Santo Antônio & $\begin{array}{l}\text { Bairro Santo } \\
\text { Antônio }\end{array}$ & Ampliação & S \\
\hline 1928 & P4 & Desconhecido & João Membrines & Rua Juca Soares & $\begin{array}{l}\text { Bairro Santo } \\
\text { Antônio }\end{array}$ & Construção & $\mathrm{R}$ \\
\hline 1928 & P5 & José Lourenço & João Américo Ribeiro & Rua Saldanha Marinho & Centro & Construção & II \\
\hline 1928 & P6 & Desconhecido & João Juliani & desconhecido & desconhecido & Construção & $\mathrm{R}$ \\
\hline 1928 & P7 & Desconhecido & Florinda Virgili & Rua Francisco Glicério & Centro & Construção & $\mathrm{R}$ \\
\hline 1928 & P8 & João Bergamasco & Pedro Carneiro & Rua Costa Machado & Centro & Construção & $\mathrm{R}$ \\
\hline
\end{tabular}


PROCESSOS DE APROVAÇÃO DE CONSTRUÇÃO PERTENCENTES AO ARQUIVO PÚBLICO DA SECRETARIA DE OBRA DE SÃO JOSÉ DO RIO PARDO

\begin{tabular}{|c|c|c|c|c|c|c|c|}
\hline Ano & Processo & Assinatura & Proprietário & Endereço & Bairro & Solicitação & Uso \\
\hline 1928 & P9 & João Bergamasco & Achiles Fagioli & Rua Belmonte & Centro & Construção & M \\
\hline 1928 & P10 & João Bergamasco & Adelino Gomes & desconhecido & desconhecido & Construção & $\mathrm{R}$ \\
\hline 1928 & P11 & Desconhecido & Francisco Gimenes & $\begin{array}{l}\text { Avenida Belmonte e a } \\
\text { linha ferrea }\end{array}$ & Centro & Construção & $\mathrm{R}$ \\
\hline 1928 & P12 & Desconhecido & José Ovidio Figueiredo & Rua Coronel Marçal & Centro & Construção & $\mathrm{R}$ \\
\hline 1928 & P13 & Desconhecido & Joaquim Pinto Figueira & Praça Tiradentes & Centro & Construção & ॥ \\
\hline 1928 & P14 & Desconhecido & João Juliani & desconhecido & desconhecido & Construção & $\mathrm{R}$ \\
\hline 1928 & P15 & A. Figueiredo & Pedro Maringolo & Rua Saldanha Marinho & Centro & Construção & II \\
\hline 1928 & P16 & A. Braghetta & Arlindo Victorio Teixeira & Rua Marechal Floriano & Vila Pereira & Construção & ॥ \\
\hline 1928 & P17 & Desconhecido & Domingos Sileri & Bairro Pereira da Silva & Vila Pereira & Construção & ॥ \\
\hline 1928 & P18 & Desconhecido & Hotel Brasil & Rua Treze de Maio & Centro & Ampliação & $\mathrm{S}$ \\
\hline 1928 & P19 & Desconhecido & Zeferino Vicente & $\begin{array}{l}\text { Avenida Euclides da } \\
\text { Cunha }\end{array}$ & Centro & Construção & ॥ \\
\hline 1928 & $\mathrm{P} 20$ & Eng. Desconhecido & Silvio Simomi & desconhecido & desconhecido & Construção & $\mathrm{R}$ \\
\hline 1928 & P21 & Desconhecido & Cirilo Rotundo & Villa Pereira & Vila Pereira & Construção & $\mathrm{R}$ \\
\hline 1928 & P22 & Antônio Molfi & Carlos Frigoli & Rua Silva Jardim & Centro & Construção & $\mathrm{R}$ \\
\hline 1928 & $\mathrm{P} 23$ & José Lourenço & $\begin{array}{l}\text { João Ribeiro Nogueira } \\
\text { Sobrinho }\end{array}$ & Rua Silva Jardim & Centro & Construção & ॥ \\
\hline 1928 & P24 & Desconhecido & Acacio Marques & Rua Campos Salles & Centro & Construção & $\mathrm{R}$ \\
\hline 1928 & P25 & João Bergamasco & Victorino Lafratte & Avenida Independência & Centro & Construção & $\mathrm{R}$ \\
\hline 1928 & P26 & João Bergamasco & Maria Eugenia & desconhecido & desconhecido & Construção & $\mathrm{R}$ \\
\hline 1928 & $\mathrm{P} 27$ & $\begin{array}{l}\text { Manoel } \\
\text { Fernandes Filho }\end{array}$ & Farmácia & desconhecido & desconhecido & Construção & C \\
\hline 1928 & P28 & Desconhecido & Caetano Lopes & $\begin{array}{l}\text { Rua Cel. Antonio Candido } \\
\text { Machado }\end{array}$ & Centro & Construção & $\|$ \\
\hline 1928 & P29 & Desconhecido & Luiz Martini & Rua Rangel Pestana & Centro & Reforma & $\|$ \\
\hline 1928 & P30 & $\begin{array}{l}\text { Manoel } \\
\text { Fernandes Filho }\end{array}$ & Manoel de Souza & Praça Tiradentes & Centro & Construção & ॥ \\
\hline 1928 & P31 & Desconhecido & José Gallego Ramos & $\begin{array}{l}\text { Largo de Nossa Senhora } \\
\text { Aparecida }\end{array}$ & $\begin{array}{l}\text { Bairro } \\
\text { Bonsucesso }\end{array}$ & Ampliação & ॥ \\
\hline 1928 & P32 & A. Braghetta & Joaquim Vicente Santos & Rua Francisco Glicério & Centro & Construção & II \\
\hline 1928 & P33 & A. Braghetta & João Garcia Gimenes & Bairro Santo Antônio & Villa Progresso & Construção & $\|$ \\
\hline 1928 & P34 & Desconhecido & Antonio Luciano & Rua Nova & Centro & Construção & $\|$ \\
\hline 1928 & P35 & Desconhecido & J. G. Paschoal & Rua Américo de Campos & Centro & Construção & ॥ \\
\hline 1928 & P36 & Arthur Machado & Vicente Carrizo & Rua Rio Pardo & Centro & Construção & $\mathrm{R}$ \\
\hline 1928 & P37 & Desconhecido & João Pinto Figueira & Avenida Belmonte & Centro & Construção & $M$ \\
\hline 1928 & P38 & A. Braghetta & Arthur Grassi & Rua Américo de Campos & Centro & Construção & $\mathrm{C}$ \\
\hline 1928 & P39 & Desconhecido & J. G. Paschoal & Rua Américo de Campos & Centro & Construção & II \\
\hline 1928 & $\mathrm{P} 40$ & Desconhecido & Octaviano Villani & Rua Francisco Glicério & Centro & Construção & $\mathrm{R}$ \\
\hline 1928 & P41 & Antônio Molfi & $\begin{array}{l}\text { Hotel Paulista - Pedro } \\
\text { Perella }\end{array}$ & Rua Saldanha Marinho & Centro & Ampliação & S \\
\hline 1928 & P42 & $\begin{array}{l}\text { Benedieto } \\
\text { Eleodoro }\end{array}$ & Affonso Arnalto & desconhecido & desconhecido & Construção & $M$ \\
\hline 1929 & P1 & João Bergamasco & José Bagodi & Rua Benjamin Constant & Centro & Construção & $\mathrm{R}$ \\
\hline 1929 & P2 & Desconhecido & Valentin Viezzi & Rua Treze de Maio & Centro & Construção & M \\
\hline 1929 & P3 & Desconhecido & Democreto de Barros & Rua Américo de Campos & Centro & Construção & $\mathrm{R}$ \\
\hline 1929 & P4 & Desconhecido & Armando Pinheiro & Rua Dr. Costa Machado & Centro & Construção & $\mathrm{R}$ \\
\hline 1929 & P5 & Desconhecido & Antonio Luciano & Avenida Independência & Centro & Ampliação & ॥ \\
\hline 1929 & P6 & José Lourenço & Heroino Machado & Rua Benjamin Constant & Centro & Construção & $\mathrm{R}$ \\
\hline 1929 & P7 & Desconhecido & Antonio de Paula Pires & Rua Cândido Faria & Centro & Construção & $\mathrm{R}$ \\
\hline 1929 & P8 & Desconhecido & João Quessada & Villa Progresso & Villa Progresso & Construção & $M$ \\
\hline 1929 & P9 & João Bergamasco & Paulo Caruzo & Rua Jorge Tibiriça & Centro & Construção & $\mathrm{R}$ \\
\hline
\end{tabular}


PROCESSOS DE APROVAÇÃO DE CONSTRUÇÃO PERTENCENTES AO ARQUIVO PÚBLICO DA SECRETARIA DE OBRA DE SÃO JOSÉ DO RIO PARDO

\begin{tabular}{|c|c|c|c|c|c|c|c|}
\hline Ano & Processo & Assinatura & Proprietário & Endereço & Bairro & Solicitação & Uso \\
\hline 1929 & P10 & Desconhecido & Simões dos Santos & estrada para Mococa & $\begin{array}{l}\text { Bairro Santo } \\
\text { Antônio }\end{array}$ & Ampliação & $\|$ \\
\hline 1929 & P11 & João Bergamasco & Francisco Villa Verde & Bairro João de Souza & $\begin{array}{l}\text { Bairro João de } \\
\text { Souza }\end{array}$ & Construção & $\mathrm{R}$ \\
\hline 1929 & P12 & João Bergamasco & Rafael Cautella & Rua Américo de Campos & Centro & Reforma & $\|$ \\
\hline 1929 & P13 & $\begin{array}{l}\text { Joaquin } \\
\text { Magdalena }\end{array}$ & Aurélio C. Monteiro & Rua Saldanha Marinho & Centro & Ampliação & $\mathrm{M}$ \\
\hline 1929 & P14 & A. Braghetta & José Lopes Sanches & Villa Progresso & Villa Progresso & Construção & $\|$ \\
\hline 1929 & P15 & A. Braghetta & José Paulo Rodrigues & Rua Francisco Glicério & Centro & Construção & $\mathrm{R}$ \\
\hline 1929 & P16 & Desconhecido & Messias Candido Ribeiro & Rua XV de Novembro & Centro & Construção & $\mathrm{R}$ \\
\hline 1929 & P17 & A. Machado & Pedro Maringolo & linha férrea & $\begin{array}{l}\text { Bairro João de } \\
\text { Souza }\end{array}$ & Construção & $\mathrm{R}$ \\
\hline 1929 & P18 & Desconhecido & Pedro Rua & Rua Júlio Mesquita & Centro & Construção & $\|$ \\
\hline 1929 & P19 & Desconhecido & Igreja N. S. Aparecida & Bom Sucesso & $\begin{array}{l}\text { Bairro } \\
\text { Bonsucesso }\end{array}$ & Construção & S \\
\hline 1929 & P20 & José Lourenço & Honório Dias Siqueira & Rua Benjamin Constant & Centro & Construção & $\mathrm{R}$ \\
\hline 1929 & P21 & Desconhecido & Dolores Gottardini & Rua Dr. Costa Machado & Centro & Construção & $\mathrm{R}$ \\
\hline 1929 & P22 & Desconhecido & Paschoal Dessimoni & Avenida Belmonte & Centro & Construção & M \\
\hline 1929 & $\mathrm{P} 23$ & Desconhecido & Pedro Paulo Fernandes & Rua Treze de Maio & Centro & Reforma & ॥ \\
\hline 1929 & P24 & Ernesto Rugani & Ernesto Rugani & Rua Francisco Glicério & Centro & Construção & $\|$ \\
\hline 1929 & P25 & A. Braghetta & Custodio Pereira da Silvaz & Rua Silva Jardim & Centro & Construção & $\|$ \\
\hline 1929 & P26 & Desconhecido & Aparecido A. & Rua Ruy Barbosa & Centro & Construção & $\mathrm{R}$ \\
\hline 1929 & $\mathrm{P} 27$ & $\begin{array}{l}\text { João Bergamasco/ } \\
\text { Joaquin } \\
\text { Magdalena }\end{array}$ & Tulio Blandino & Avenida Municipal & $\begin{array}{l}\text { Bairro } \\
\text { Bonsucesso } \\
\end{array}$ & Construção & $\mathrm{R}$ \\
\hline 1929 & P28 & José Lourenço & Cezar Luzzio & Rua Saldanha Marinho & Centro & Construção & $\mathrm{M}$ \\
\hline 1929 & P29 & João Bergamasco & Sebastião Leite & Praça Tiradentes & Centro & Construção & M \\
\hline 1929 & P30 & A. Braghetta & Cezar Pichau & Rua José Theodoro & Centro & Construção & $\mathrm{R}$ \\
\hline 1929 & P31 & Desconhecido & Sebastião de Lima & Rua Jorge Tibiriça & Centro & Reforma & $\mathrm{R}$ \\
\hline 1929 & P32 & Desconhecido & Aurélio C. Monteiro & Rua Saldanha Marinho & Centro & Construção & $\mathrm{R}$ \\
\hline 1929 & P33 & Desconhecido & Pedro Fornari & Rua Silva Jardim & Centro & Reforma & $\|$ \\
\hline 1929 & P34 & Desconhecido & Evaristo Rodrigues & Villa Progresso & Villa Progresso & Construção & $\|$ \\
\hline 1929 & P35 & Desconhecido & José Seara Gil & Rua Ruy Barbosa & Centro & Construção & $\mathrm{R}$ \\
\hline 1929 & P36 & Desconhecido & Luiz Botelli & Praça Tiradentes & Centro & Reforma & $\|$ \\
\hline 1929 & P37 & $\begin{array}{l}\text { João Bergamasco } \\
\text { / A. Gervasio }\end{array}$ & Sebastião Leite & Praça Tiradentes & Centro & Construção & M \\
\hline 1929 & P38 & José Lourenço & Francisco Barreto & Praça Tiradentes & Centro & Construção & $\mathrm{R}$ \\
\hline 1929 & P39 & João Bergamasco & Adelino Gomes & desconhecido & desconhecido & Construção & $\mathrm{R}$ \\
\hline 1929 & P40 & Desconhecido & Cervino Rotundo & Villa Pereira & Vila Pereira & Construção & C \\
\hline 1929 & P41 & Desconhecido & Miguel Constaneio & Rua Buracão & Centro & Construção & $\mathrm{R}$ \\
\hline 1929 & P42 & $\begin{array}{l}\text { João Bergamasco } \\
\text { / A. Gervasio }\end{array}$ & Sebastião Leite & Praça Tiradentes & Centro & Construção & M \\
\hline 1929 & P43 & A. Braghetta & Sebastião Leite & Praça Tiradentes & Centro & Ampliação & $\|$ \\
\hline 1930 & P1 & João Bergamasco & Igreja de São Roque & São Roque & Vila Pereira & Construção & $\mathrm{s}$ \\
\hline 1930 & $\mathrm{P} 2$ & Desconhecido & Luis Penna & Villa Pereira & Vila Pereira & Construção & $\mathrm{R}$ \\
\hline 1930 & P3 & João Bergamasco & Nicola Aracre & Rua José Theodoro & Centro & Ampliação & $\mathrm{R}$ \\
\hline 1930 & P4 & A. Braghetta & Henrique José de Almeida & Villa Progresso & Villa Progresso & Construção & $\|$ \\
\hline 1930 & P5 & Desconhecido & Américo Braghetta & Villa Pereira da Silva & Vila Pereira & Construção & $\mathrm{R}$ \\
\hline 1930 & P6 & Desconhecido & João Pedro da Silva & Villa Progresso & Villa Progresso & Construção & $\mathrm{R}$ \\
\hline 1930 & P7 & Desconhecido & Reinaldo Ferreira & Villa Pereira & Vila Pereira & Construção & $\mathrm{R}$ \\
\hline 1930 & P8 & Desconhecido & Luis Fiori & Villa Pereira & Vila Pereira & Construção & $R$ \\
\hline
\end{tabular}


PROCESSOS DE APROVAÇÃO DE CONSTRUÇÃO PERTENCENTES AO ARQUIVO PÚBLICO DA SECRETARIA DE OBRA DE SÃO JOSÉ DO RIO PARDO

\begin{tabular}{|c|c|c|c|c|c|c|c|}
\hline Ano & Processo & Assinatura & Proprietário & Endereço & Bairro & Solicitação & Uso \\
\hline 1930 & P9 & A. Braghetta & João Baptista Carvalho & Rua João Barbosa & $\begin{array}{l}\text { Bairro } \\
\text { Bonsucesso }\end{array}$ & Construção & M \\
\hline 1930 & P10 & João Bergamasco & Horacio Ferreira Pedroso & Villa Pereira & Vila Pereira & Construção & $\mathrm{R}$ \\
\hline 1930 & P11 & João Bergamasco & Abel Pinto & Avenida Belmonte & Centro & Construção & $\mathrm{R}$ \\
\hline 1930 & P12 & João Bergamasco & Francisco Garcia & Avenida Independência & Centro & Construção & $\mathrm{R}$ \\
\hline 1930 & P13 & João Bergamasco & Enrique Losetti & Avenida Independência & Centro & Construção & $\mathrm{R}$ \\
\hline 1930 & P14 & João Bergamasco & Antonio Rancan & Villa Pereira & Vila Pereira & Construção & $\mathrm{R}$ \\
\hline 1930 & P15 & Desconhecido & Pedro Pichau & Rua Jose Barbosa & $\begin{array}{l}\text { Bairro Santo } \\
\text { Antônio }\end{array}$ & Construção & $\mathrm{R}$ \\
\hline 1930 & P16 & Desconhecido & Joaquim Inacio Junior & Villa Pereira & Vila Pereira & Construção & $\mathrm{R}$ \\
\hline 1930 & P17 & $\begin{array}{l}\text { Baptistella } \\
\text { Machado? }\end{array}$ & José Carvalhaes & Rua Honório Dias & Centro & Construção & ॥ \\
\hline 1930 & P18 & João Bergamasco & Bráz Bello & Rua Américo de Campos & Centro & Ampliação & M \\
\hline 1930 & P19 & Desconhecido & Domingos Gervásio & Villa Pereira da Silva & Vila Pereira & Construção & $\mathrm{R}$ \\
\hline 1930 & P20 & João Bergamasco & Marciano A. Pedra & Villa Pereira & Vila Pereira & Construção & $\mathrm{R}$ \\
\hline 1930 & P21 & Desconhecido & Gabriel Braghetta & Villa Pereira da Silva & Vila Pereira & Construção & $\mathrm{R}$ \\
\hline 1930 & P22 & Desconhecido & Pedro Palha & Rua Floriano Peixoto & Vila Pereira & Construção & $\mathrm{R}$ \\
\hline 1930 & $\mathrm{P} 23$ & João Bergamasco & Roque Daversa & Avenida Independência & Centro & Construção & $\mathrm{R}$ \\
\hline 1930 & P24 & João Bergamasco & Luiz Leone & Villa Progresso & Villa Progresso & Construção & $\mathrm{R}$ \\
\hline 1930 & P25 & Desconhecido & Francisco Ventura & Villa Pereira & Vila Pereira & Construção & $\mathrm{R}$ \\
\hline 1930 & P26 & Ernesto Rugani & Ernesto Rugani & Villa Pereira & Vila Pereira & Construção & $\mathrm{R}$ \\
\hline 1930 & P27 & Desconhecido & Gregorio Catalano & Villa Pereira da Silva & Vila Pereira & Construção & $\mathrm{R}$ \\
\hline 1930 & P28 & João Bergamasco & João Baptista & Avenida Independência & Centro & Construção & $\mathrm{R}$ \\
\hline 1930 & P29 & A. Braghetta & João Pinto Figueira & Avenida Belmonte & Vila Maschietto & Construção & $\mathrm{R}$ \\
\hline 1930 & P30 & João Bergamasco & Vicente Ferreira Dias & desconhecido & desconhecido & Construção & $\mathrm{R}$ \\
\hline 1930 & P31 & Desconhecido & Carmo Carvalhaes & Villa Pereira da Silva & Vila Pereira & Construção & $\mathrm{R}$ \\
\hline 1930 & P32 & João Bergamasco & Cezar Luzzio & Avenida Belmonte & Vila Maschietto & Construção & $\mathrm{R}$ \\
\hline 1930 & P33 & João Bergamasco & Domingos Perocco & Rua João Pessoa & Centro & Construção & I \\
\hline 1930 & P34 & João Bergamasco & Angelo Sernaglia & Villa Pereira & Vila Pereira & Construção & $\mathrm{R}$ \\
\hline 1930 & P35 & A. Braghetta & Joaquin Urias de Leme & Rua Francisco Glicério & Centro & Construção & $\mathrm{R}$ \\
\hline 1930 & P36 & Antônio Molfi & José Barsottini & Rua Coronel Marçal & Centro & Ampliação & $M$ \\
\hline 1930 & P37 & Desconhecido & $\begin{array}{l}\text { Gabriel Matheus de } \\
\text { Azevedo }\end{array}$ & Rua Ruy Barbosa & Centro & Construção & $\mathrm{R}$ \\
\hline 1930 & P38 & João Bergamasco & Francisco Sbersi & Rua Ruy Barbosa & Centro & Construção & $\mathrm{R}$ \\
\hline 1931 & P1 & Desconhecido & Fellippe Quessada & $\begin{array}{l}\text { Estrada que vai para o } \\
\text { Venerando }\end{array}$ & Villa Progresso & Construção & $\mathrm{C}$ \\
\hline 1931 & P2 & A. Braghetta & João Pedro da Silva & Villa Progresso & Villa Progresso & Construção & $\mathrm{R}$ \\
\hline 1931 & P3 & Desconhecido & Roque Ventura Filho & Villa Pereira da Silva & Vila Pereira & Construção & $\mathrm{R}$ \\
\hline 1931 & P4 & João Bergamasco & Sebastião Rissaro & desconhecido & desconhecido & Construção & $\mathrm{R}$ \\
\hline 1931 & P5 & A. Braghetta & Francisco Cappellari & Villa Pereira da Silva & Vila Pereira & Construção & $\mathrm{R}$ \\
\hline 1931 & P6 & A. Braghetta & Vicente Vicente & Bairro Euclides da Cunha & $\begin{array}{l}\text { Bairro Santo } \\
\text { Antônio }\end{array}$ & Construção & $\mathrm{R}$ \\
\hline 1931 & P7 & A. Braghetta & Epipobano Assumpção & Avenida Independência & Centro & Construção & $\mathrm{R}$ \\
\hline 1931 & P8 & João Bergamasco & Alfredo Del Buono & Rua Francisco Glicério & Centro & Construção & $\mathrm{R}$ \\
\hline 1931 & P9 & A. Braghetta & Fiori Fiorindo & Villa Pereira da Silva & Vila Pereira & Construção & $\mathrm{R}$ \\
\hline 1931 & P10 & Ernesto Rugani & Ernesto Rugani & desconhecido & desconhecido & Construção & $\mathrm{R}$ \\
\hline 1931 & P11 & João Bergamasco & Negra Pinto & Rua Ruy Barbosa & Centro & Reforma & $\|$ \\
\hline 1931 & P12 & Desconhecido & Antonio Luciano & Avenida Independência & Centro & Ampliação & $\mathrm{R}$ \\
\hline 1931 & P13 & A. Braghetta & Guerino Della Torre & Rua Siqueira Campos & Vila Pereira & Ampliação & desconhecido \\
\hline 1931 & P14 & João Bergamasco & Justina dos Santos Pires & Villa Progresso & Villa Progresso & Construção & $\mathrm{R}$ \\
\hline
\end{tabular}


PROCESSOS DE APROVAÇÃO DE CONSTRUÇÃO PERTENCENTES AO ARQUIVO PÚBLICO DA SECRETARIA DE OBRA DE SÃO JOSÉ DO RIO PARDO

\begin{tabular}{|c|c|c|c|c|c|c|c|}
\hline Ano & Processo & Assinatura & Proprietário & Endereço & Bairro & Solicitação & Uso \\
\hline 1931 & P15 & Ernesto Rugani & Angela Brunetta & desconhecido & desconhecido & Construção & $\mathrm{R}$ \\
\hline 1931 & P16 & João Bergamasco & Consolação Barbero & Avenida Independência & Centro & Construção & $\mathrm{R}$ \\
\hline 1931 & P17 & João Bergamasco & Donato Padula & Rua Francisco Glicério & Centro & Construção & $\mathrm{R}$ \\
\hline 1931 & P18 & João Bergamasco & João de Castro & Rua Ruy Barbosa & Centro & Reforma & II \\
\hline 1931 & P19 & A. Braghetta & Carlos Peres & Rua Marechal Floriano & Vila Pereira & Construção & $\mathrm{R}$ \\
\hline 1931 & P20 & João Bergamasco & Francisco Sbersi & Avenida Independência & Centro & Construção & $\mathrm{R}$ \\
\hline 1931 & P21 & A. Braghetta & $\begin{array}{l}\text { Igreja Nossa Senhora das } \\
\text { Angustias }\end{array}$ & desconhecido & desconhecido & Construção & S \\
\hline 1931 & P22 & A. Braghetta & Efreu Carlesso & Villa Pereira da Silva & Vila Pereira & Construção & desconhecido \\
\hline 1931 & P23 & João Bergamasco & Anielo Gervásio & Rua Jorge Tibiriça & Centro & Construção & $\mathrm{R}$ \\
\hline 1931 & P24 & João Bergamasco & Pedro Darcie & Rua Ruy Barbosa & Centro & Construção & M \\
\hline 1931 & P25 & Desconhecido & Vicente Vicente & Bairro Euclides da Cunha & $\begin{array}{l}\text { Bairro Santo } \\
\text { Antônio }\end{array}$ & Construção & $\mathrm{M}$ \\
\hline 1931 & $\mathrm{P} 26$ & João Bergamasco & Francisco Martines Torres & Avenida Belmonte & Vila Maschietto & Construção & C \\
\hline 1931 & $\mathrm{P} 27$ & Ernesto Rugani & Ernesto Rugani & desconhecido & desconhecido & Construção & $\mathrm{R}$ \\
\hline 1931 & P28 & João Bergamasco & Érico Alves Dias & Rua Coronel Marçal & Centro & Construção & $\mathrm{C}$ \\
\hline 1931 & P29 & João Bergamasco & Paschoal Cerávolo & Rua João Pessoa & Centro & Ampliação & $\mathrm{R}$ \\
\hline 1931 & P30 & João Bergamasco & Maria Carvalho Macedo & Rua Francisco Glicério & Centro & Construção & $\mathrm{R}$ \\
\hline 1931 & P31 & Desconhecido & Maria Stori & Rua Coronel Marçal & Centro & Ampliação & $\mathrm{R}$ \\
\hline 1931 & P32 & José Lourenço & Francisco Vieira Barretto & Rua Campos Salles & Centro & Ampliação & $\mathrm{C}$ \\
\hline 1932 & P1 & Desconhecido & Adolfo Macedo & Bairro João de Souza & $\begin{array}{l}\text { Bairro João de } \\
\text { Souza }\end{array}$ & Construção & $\mathrm{R}$ \\
\hline 1932 & $\mathrm{P} 2$ & Desconhecido & Clotilde da Silva & Estrada do Paula Lima & Vila Maschietto & Construção & $\mathrm{R}$ \\
\hline 1932 & P3 & João Bergamasco & Antônio Tinti & Rua Marechal Floriano & Vila Pereira & Construção & $\mathrm{M}$ \\
\hline 1932 & P4 & João Bergamasco & Tulio Blandino & Praça Antônio Prado & Vila Maschietto & Construção & 1 \\
\hline 1932 & P5 & João Bergamasco & Joaquim Ferreira Pinto & Praça Tiradentes & Centro & Ampliação & ॥ \\
\hline 1932 & P6 & Desconhecido & Pedro Pichau & Rua José Theodoro & Centro & Ampliação & $\mathrm{R}$ \\
\hline 1932 & P7 & Desconhecido & Viriato Cunha & Rua Costa Machado & Centro & Construção & $\mathrm{R}$ \\
\hline 1932 & P8 & João Bergamasco & João Abel Pinto & Avenida Nove de Julho & Vila Maschietto & Construção & $\mathrm{R}$ \\
\hline 1932 & P9 & Desconhecido & Amélia Guimarães & Villa Pereira da Silva & Vila Pereira & Construção & $\mathrm{R}$ \\
\hline 1932 & P10 & Desconhecido & Domingos Amato & desconhecido & desconhecido & Ampliação & $\mathrm{R}$ \\
\hline 1932 & P11 & Desconhecido & Antonio Rodrigues & Villa Progresso & Villa Progresso & Construção & $\mathrm{R}$ \\
\hline 1932 & P12 & desconhecido & José Carneiro Lima & Rua Siqueira Campos & Vila Pereira & Construção & $\mathrm{R}$ \\
\hline 1932 & P13 & João Bergamasco & Benedito Amaral & Rua Ruy Barbosa & Centro & Construção & $\mathrm{S}$ \\
\hline 1932 & P14 & Desconhecido & Carlos Peres & Villa Pereira da Silva & Vila Pereira & Construção & $\mathrm{R}$ \\
\hline 1932 & P15 & Desconhecido & Fiorindo Constancio & desconhecido & desconhecido & Construção & $\mathrm{R}$ \\
\hline 1932 & P16 & João Bergamasco & Paulo Modesto & Avenida Belmonte & Vila Maschietto & Construção & $\mathrm{R}$ \\
\hline 1932 & P17 & Desconhecido & Roque Martinucci & Villa Pereira da Silva & Vila Pereira & Construção & $\mathrm{R}$ \\
\hline 1932 & P18 & Desconhecido & José Otaviano Machado & Praça XV de Novembro & Centro & Construção & $\mathrm{R}$ \\
\hline 1932 & P19 & João Bergamasco & Luiz Pedro & Rua Francisco Glicério & Centro & Construção & $\mathrm{C}$ \\
\hline 1932 & P20 & João Bergamasco & Francisco Martinez & Avenida Belmonte & Vila Maschietto & Construção & M \\
\hline 1932 & P21 & Desconhecido & Joaquim Francisco & Rua Campos Salles & Centro & Construção & $\mathrm{R}$ \\
\hline 1932 & P22 & João Bergamasco & Domingos Perri & Rua Campos Salles & Centro & Construção & M \\
\hline 1932 & P23 & João Bergamasco & Tulio Blandino & Praça Antônio Prado & Vila Maschietto & Ampliação & II \\
\hline 1932 & P24 & João Bergamasco & Irmãos Raddi & Rua Campos Salles & Centro & Construção & $\mathrm{C}$ \\
\hline 1933 & P1 & Desconhecido & Pedro Gualberto Nogueira & Rua Marechal Floriano & Vila Pereira & Construção & $\mathrm{R}$ \\
\hline
\end{tabular}




\begin{tabular}{|c|c|c|c|c|c|c|c|}
\hline \multicolumn{8}{|c|}{ PROCESSOS DE APROVAÇÃO DE CONSTRUÇÃO PERTENCENTES AO ARQUIVO PÚBLICO DA SECRETARIA DE OBRA DE SÃO JOSÉ DO RIO PARDO } \\
\hline Ano & Processo & Assinatura & Proprietário & Endereço & Bairro & solicitação & Uso \\
\hline 1933 & $\mathrm{P} 2$ & João Bergamasco & Antonio Flora & Rua Marechal Deodoro & Centro & Reforma & II \\
\hline 1933 & P3 & João Bergamasco & Alberta Pasterini & Rua Ruy Barbosa & Centro & Construção & $\mathrm{R}$ \\
\hline 1933 & P5 & Desconhecido & Adelina P. Destefani & Rua Francisco Glicério & Centro & Construção & $\mathrm{R}$ \\
\hline 1933 & P6 & Desconhecido & Horacio Pedrosa & Estrada de Casa Branca & Centro & Construção & $\mathrm{R}$ \\
\hline 1933 & P7 & João Bergamasco & Sebastião Rosa & Rua Floriano Peixoto & Vila Pereira & Construção & $\mathrm{R}$ \\
\hline 1933 & P8 & João Bergamasco & $\begin{array}{l}\text { Manoel Ferreira Pinto } \\
\text { Junior }\end{array}$ & Rua Marechal Floriano & Vila Pereira & Construção & M \\
\hline 1933 & P9 & A. Braghetta & Agostinho Monarco & Villa Pereira & Vila Pereira & Construção & $\mathrm{R}$ \\
\hline 1933 & P10 & João Bergamasco & José Azze & Avenida Independência & Centro & Construção & $\mathrm{M}$ \\
\hline 1933 & P11 & A. Braghetta & Martins Ernani & Villa Pereira & Vila Pereira & Construção & $\mathrm{R}$ \\
\hline 1933 & $\mathrm{P} 12$ & Desconhecido & Florindo Constancio & Rua Saldanha Marinho & Centro & Construção & $\mathrm{R}$ \\
\hline 1933 & P13 & A. Braghetta & Joaquin A. Vicente & Rua Francisco Glicério & Centro & Reforma & $\mathrm{R}$ \\
\hline 1933 & P14 & João Bergamasco & Vicente Nasser e Irmãos & Rua Marechal Deodoro & Centro & Construção & $\mathrm{C}$ \\
\hline 1933 & P15 & João Bergamasco & José Azze & Avenida Independência & Centro & Ampliação & $\mathrm{M}$ \\
\hline 1933 & P16 & A. Braghetta & José Fonseca & Villa Pereira da Silva & Vila Pereira & Construção & $\mathrm{R}$ \\
\hline 1933 & P17 & A. Braghetta & Maria Butierrez & Villa Pereira da Silva & Vila Pereira & Construção & $\mathrm{R}$ \\
\hline 1933 & P18 & João Bergamasco & Vicenza B. Cogato & Rua Treze de Maio & Centro & Construção & $\mathrm{M}$ \\
\hline 1933 & P19 & Desconhecido & Salão Fascio Italiano & Desconhecido & desconhecido & Construção & $S$ \\
\hline 1933 & $\mathrm{P} 20$ & A. Braghetta & João Gabriel Ribeiro & Rua Saldanha Marinho & Centro & Ampliação & $\mathrm{R}$ \\
\hline 1933 & $\mathrm{P} 21$ & João Bergamasco & Dr. Heitor Correa & $\begin{array}{l}\text { Praça Doutor Candido } \\
\text { Rodrigues }\end{array}$ & Centro & Construção & $\mathrm{R}$ \\
\hline 1933 & $\mathrm{P} 22$ & João Bergamasco & Dr. Heitor Correa & $\begin{array}{l}\text { Praça Doutor Candido } \\
\text { Rodrigues }\end{array}$ & Centro & Construção & $\mathrm{R}$ \\
\hline 1934 & P1 & A. Braghetta & Donato Padula & Avenida Independência & Centro & Construção & $\mathrm{R}$ \\
\hline 1934 & $\mathrm{P} 2$ & A. Braghetta & Agenor Vasconcelos & Villa Pereira da Silva & Vila Pereira & Construção & $\mathrm{R}$ \\
\hline 1934 & P3 & A. Braghetta & José Martin & Rua João Barbosa & $\begin{array}{l}\text { Bairro } \\
\text { Bonsucesso }\end{array}$ & Reforma & C \\
\hline 1934 & P4 & Desconhecido & Rubens Machado & Rua Coronel Marçal & Centro & Construção & $\mathrm{R}$ \\
\hline 1934 & P5 & A. Braghetta & Octavio Leite & Rua Benjamin Constant & Centro & Reforma & ॥ \\
\hline 1934 & P6 & A. Braghetta & João Baptista Azevedo & Avenida Independência & Centro & Construção & $\mathrm{M}$ \\
\hline 1934 & P7 & Desconhecido & Paschoal Dessimoni & Avenida Belmonte & Vila Maschietto & Construção & C \\
\hline 1934 & P8 & A. Braghetta & Francisco Consolo & Rua Benjamin Constant & Centro & Construção & $\mathrm{R}$ \\
\hline 1934 & P9 & Desconhecido & José de Ávila Ribeiro & desconhecido & desconhecido & Construção & $\mathrm{R}$ \\
\hline 1934 & P10 & Ettore Braga & $\begin{array}{l}\text { Maria da Conceição } \\
\text { Damasio }\end{array}$ & Rua Benjamin Constant & Centro & Construção & $\mathrm{R}$ \\
\hline 1934 & P11 & João Bergamasco & José Braghetta & desconhecido & desconhecido & Construção & $\mathrm{R}$ \\
\hline 1935 & P12 & João Bergamasco & Irmãos Pretocelli & Rua Marechal Floriano & Vila Pereira & Construção & C \\
\hline 1935 & P13 & João Bergamasco & Carmelo Consolo & Rua Costa Machado & Centro & Construção & $\mathrm{R}$ \\
\hline 1935 & P14 & A. Braghetta & José Bráz & Rua Jorge Tibiriça & Centro & Construção & $\mathrm{R}$ \\
\hline 1935 & P15 & A. Braghetta & Antônio Tinti & Rua Silva Jardim & Centro & Construção & $\mathrm{M}$ \\
\hline 1935 & $\mathrm{P} 16$ & A. Braghetta & Pedro Gualberto Nogueira & Rua Marechal Floriano & Vila Pereira & Construção & $\mathrm{R}$ \\
\hline 1935 & P17 & João Bergamasco & Antonio Raddi & Praça XV de Novembro & Centro & Ampliação & $\mathrm{M}$ \\
\hline 1936 & P17 & João Bergamasco & João Bergamasco & Rua Ruy Barbosa & Centro & Construção & $\mathrm{R}$ \\
\hline 1936 & P18 & João Bergamasco & Domingos Bello & Rua Treze de Maio & Centro & Construção & $\mathrm{M}$ \\
\hline 1936 & P19 & João Bergamasco & Domingos Bello & Rua Treze de Maio & Centro & Construção & $\mathrm{M}$ \\
\hline 1936 & $\mathrm{P} 20$ & José Lourenço & Gabriel Gervásio & $\begin{array}{l}\text { Praça Doutor Candido } \\
\text { Rodrigues }\end{array}$ & Centro & Construção & M \\
\hline 1936 & $\mathrm{P} 21$ & Desconhecido & Roque Potenza & desconhecido & desconhecido & Construção & $\mathrm{R}$ \\
\hline 1936 & P23 & $\begin{array}{l}\text { Francisco E. } \\
\text { Garcia }\end{array}$ & Cezar Luzzio & Rua Honório Dias & Centro & Construção & $\mathrm{R}$ \\
\hline
\end{tabular}


PROCESSOS DE APROVAÇÃO DE CONSTRUÇÃO PERTENCENTES AO ARQUIVO PÚBLICO DA SECRETARIA DE OBRA DE SÃO JOSÉ DO RIO PARDO

\begin{tabular}{|c|c|c|c|c|c|c|c|}
\hline Ano & Processo & Assinatura & Proprietário & Endereço & Bairro & Solicitação & Uso \\
\hline 1936 & P24 & Desconhecido & Euclides Trovatto & Rua Siqueira Campos & Vila Pereira & Construção & $\mathrm{R}$ \\
\hline 1936 & P25 & João Bergamasco & Benedito Amaral & Rua Ruy Barbosa & Centro & Ampliação & $\mathrm{R}$ \\
\hline 1936 & P26 & João Bergamasco & José Molfi & Rua Benjamin Constant & Centro & Ampliação & II \\
\hline 1936 & P27 & $\begin{array}{l}\text { Francisco E. } \\
\text { Garcia }\end{array}$ & Cezar Luzzio & Rua Honório Dias & Centro & Construção & $\mathrm{R}$ \\
\hline 1936 & P28 & $\begin{array}{l}\text { Francisco E. } \\
\text { Garcia }\end{array}$ & Antônio Tinti & Rua Benjamin Constant & Centro & Construção & M \\
\hline 1936 & P29 & João Bergamasco & Henrique Camilo & Rua José Theodoro & Centro & Construção & $\mathrm{R}$ \\
\hline 1936 & P30 & João Bergamasco & Henrique Camilo & Rua José Theodoro & Centro & Construção & $\mathrm{R}$ \\
\hline 1936 & P31 & João Bergamasco & José Barsottini & Rua Benjamin Constant & Centro & Construção & $\mathrm{R}$ \\
\hline 1936 & P32 & Desconhecido & Antônio Tinti & Rua Benjamin Constant & Centro & Construção & ॥ \\
\hline 1936 & P33 & Desconhecido & Octaviano Villani & Rua Francisco Glicério & Centro & Reforma & $\|$ \\
\hline 1936 & P34 & João Bergamasco & Gabriel Gervásio & $\begin{array}{l}\text { Praça Doutor Candido } \\
\text { Rodrigues }\end{array}$ & Centro & Construção & $\mathrm{M}$ \\
\hline 1936 & P35 & João Bergamasco & Thomaz Potenza & Villa Pereira & Vila Pereira & Construção & $\mathrm{R}$ \\
\hline 1936 & P36 & João Bergamasco & Thomaz Potenza & Villa Pereira & Vila Pereira & Construção & $\mathrm{R}$ \\
\hline 1936 & P37 & João Bergamasco & $\begin{array}{l}\text { Noraldino Alvez do } \\
\text { Nascimento }\end{array}$ & Villa Pereira & Vila Pereira & Construção & $\mathrm{R}$ \\
\hline 1936 & P38 & João Bergamasco & $\begin{array}{l}\text { Noraldino Alvez do } \\
\text { Nascimento }\end{array}$ & Villa Pereira & Vila Pereira & Construção & $\mathrm{R}$ \\
\hline 1936 & P39 & Desconhecido & $\begin{array}{l}\text { João Batista Pereira da } \\
\text { Silva }\end{array}$ & Rua Ananias Barbosa & Centro & Construção & $\mathrm{R}$ \\
\hline 1936 & P40 & Desconhecido & Hospital São Vicente & mesmo local de hoje & Centro & Construção & $\mathrm{S}$ \\
\hline 1936 & P41 & Desconhecido & Hospital São Vicente & mesmo local de hoje & Centro & Construção & $\mathrm{S}$ \\
\hline 1936 & P42 & Desconhecido & Hospital São Vicente & mesmo local de hoje & Centro & Construção & $\mathrm{S}$ \\
\hline 1936 & P43 & Desconhecido & Hospital São Vicente & mesmo local de hoje & Centro & Construção & $\mathrm{S}$ \\
\hline 1936 & P44 & Desconhecido & João Bergamasco & Rua Benjamin Constant & Centro & Construção & $\mathrm{R}$ \\
\hline 1936 & P46 & João Bergamasco & Alcides Foiadelli & Rua Francisco Glicério & Centro & Construção & $\mathrm{R}$ \\
\hline 1936 & P47 & João Bergamasco & Alcides Foiadelli & Rua Francisco Glicério & Centro & Construção & $\mathrm{R}$ \\
\hline 1936 & P48 & Desconhecido & Francisco Corrêa & Rua Costa Machado & Centro & Construção & ॥ \\
\hline 1937 & P1 N12 & João Bergamasco & Joaquim Ferreira Pinto & Avenida Nove de Julho & Vila Maschietto & Ampliação & II \\
\hline 1937 & P3 N9 & Desconhecido & Antonio Luciano & $\begin{array}{l}\text { Rua João Batista } \\
\text { Junqueira }\end{array}$ & Vila Maschietto & Construção & $\mathrm{R}$ \\
\hline 1937 & P4 N10 & Desconhecido & Francisco Consolo & Rua Benjamin Constant & Centro & Construção & $\mathrm{R}$ \\
\hline 1937 & P5 N9 & Desconhecido & Antonio Luciano & $\begin{array}{l}\text { Rua João Batista } \\
\text { Junqueira }\end{array}$ & Vila Maschietto & Construção & $\mathrm{R}$ \\
\hline 1937 & P6 N8 & João Bergamasco & Domingos Bello & Rua Ruy Barbosa & Centro & Construção & $\mathrm{C}$ \\
\hline 1937 & P7 N7 & Desconhecido & João Landini & Rua Treze de Maio & Centro & Reforma & $\mathrm{R}$ \\
\hline 1937 & P8 N6 & Desconhecido & Lourenço Scalli & Rua João Pessoa & Centro & Construção & $\mathrm{s}$ \\
\hline 1937 & P9 N5 & Desconhecido & Pedro Fargetti & Avenida Independência & Centro & Reforma & $\mathrm{R}$ \\
\hline 1937 & P10 N5 & Desconhecido & Pedro Fargetti & Avenida Independência & Centro & Reforma & $\mathrm{R}$ \\
\hline 1937 & P11 N4 & José Lourenço & Rachel Meringolo & Rua Marechal Floriano & Vila Pereira & Construção & $\mathrm{R}$ \\
\hline 1937 & P12 N4 & José Lourenço & Rachel Meringolo & Rua Marechal Floriano & Vila Pereira & Construção & $\mathrm{R}$ \\
\hline 1937 & P13 N4 & José Lourenço & Rachel Meringolo & Rua Marechal Floriano & Vila Pereira & Construção & $\mathrm{R}$ \\
\hline 1937 & P15 N2 & Desconhecido & Anibal de Oliveira & Rua José Theodoro & Centro & Reforma & $\mathrm{R}$ \\
\hline 1937 & P16 N1 & Francisco E. Garcia & Antonio Bizzarri & Rua João Pessoa & Centro & Construção & $\mathrm{R}$ \\
\hline 1940 & P31 & José Lourenço & Benedito Rodrigues Correa & $\begin{array}{l}\text { Rua Tarquinio Cobra } \\
\text { Olintho }\end{array}$ & Vila Pereira & Construção & $\mathrm{R}$ \\
\hline 1940 & P32 & José Lourenço & Henrique Camilo & Rua Curupaiti & Centro & Construção & $\mathrm{R}$ \\
\hline 1940 & P33 & João Bergamasco & Roque Martinucci & Villa Pereira & Vila Pereira & Construção & $\mathrm{R}$ \\
\hline 1940 & P34 & Desconhecido & Vicente Nasser e Irmãos & desconhecido & desconhecido & Reforma & । \\
\hline
\end{tabular}




\begin{tabular}{|c|c|c|c|c|c|c|c|}
\hline Ano & Processo & Assinatura & Proprietário & Endereço & Bairro & Solicitação & Uso \\
\hline 1940 & P35 & João Bergamasco & Maria Guerra & desconhecido & desconhecido & Ampliação & II \\
\hline 1940 & P36 & João Bergamasco & Joaquin Costa & Rua Marechal Floriano & Vila Pereira & Construção & $\mathrm{R}$ \\
\hline 1940 & P37 & Desconhecido & Igreja Matriz & Praça XV de Novembro & Centro & Construção & $S$ \\
\hline 1940 & P38 & João Bergamasco & Horacio F. Pedrosa & $\begin{array}{l}\text { Rua Tarquinio Cobra } \\
\text { Olintho }\end{array}$ & Vila Pereira & Construção & $\mathrm{R}$ \\
\hline 1940 & P39 & João Bergamasco & Pedro Paia & Rua Benjamin Constant & Centro & Reforma & ॥ \\
\hline 1940 & P40 & José Lourenço & Banco do Brasil & Rua Marechal Deodoro & Centro & Reforma & C \\
\hline 1940 & P41 & Desconhecido & Casa (Marechal Deodoro) & Rua Marechal Deodoro & Centro & Ampliação & ॥ \\
\hline
\end{tabular}

Fonte: Processos de aprovação de construção pertencentes ao Arquivo Público da Secretaria de Obra de São José do Rio Pardo. 


\section{Apêndice 04}

Abaixo foi elencado informações encontradas nos registros e nas cartas de aforamento arquivadas na Hemeroteca Jornalista Paschoal Artese e no Arquivo Público de Casa Branca. Essa rica documentação traz informações dos aforeiros, a localização e a dimensão da testada do lote, quem ou quais eram as confrontações e a existência de prédio edificado. Cabe ressaltar que as informações foram transcritas na íntegra.

\begin{tabular}{|c|c|c|c|c|c|}
\hline \multicolumn{6}{|c|}{ CARTAS DE AFORAMENTO DE SÃO JOSÉ DO RIO PARDO 1885-1889 } \\
\hline N. ${ }^{\circ}$ & Nome do aforeiro & Localização & Confrontação & Melhorias & Testada \\
\hline 1 & Antonio Pereira da Silva & Largo do Mercado & Donato Potensa e esquina Rua do Comércio & Prédio edificado & $15,20 \mathrm{~m}$ \\
\hline 2 & Donato Potenza & Largo do Mercado & Antonio Pereira da Silva e José Paulino de Moraes & Prédio em construção & $13,20 \mathrm{~m}$ \\
\hline 3 & José Paulino de Moraes & Largo do Mercado & Donato Potenza e José Paulino de Moraes & Prédio em construção & $14,40 \mathrm{~m}$ \\
\hline 4 & Vicente Lauria & Largo do Mercado & Com o beco e José Paulino de Moraes & Prédio edificado & $28,00 \mathrm{~m}$ \\
\hline 5 & Baptista Tardelli & Largo do Mercado & Com o beco e Henrique Dini & 2 prédios edificados & $38,90 \mathrm{~m}$ \\
\hline 6 & Henrique Dini & Largo do Mercado & Baptista Tardelli e Antonio T. & Prédio edificado & $13,40 \mathrm{~m}$ \\
\hline 7 & Antonio T. & Largo do Mercado & Henrique Dini e Silveira Maria de B. & $\begin{array}{l}\text { casa para dentro do } \\
\text { alinhamento }\end{array}$ & $13,20 \mathrm{~m}$ \\
\hline 8 & Silveira Maria de B. & Largo do Mercado & Antonio T. e o córrego & $\begin{array}{l}\text { Com casa para dentro do } \\
\text { alinhamento }\end{array}$ & $13,20 \mathrm{~m}$ \\
\hline 9 & Antonio Antunes & Largo do Mercado & J. Russo e J. Luis Nery & casa baixa & $14,40 \mathrm{~m}$ \\
\hline 10 & José Nery da Silva & Largo do Mercado & Antonio Antunes e João Candido C. de A. & Prédio edificado & $13,20 \mathrm{~m}$ \\
\hline 11 & João Candido C. de A. & Largo do Mercado & J. Nery e Antonio Poly & Prédio edificado & $17,20 \mathrm{~m}$ \\
\hline 12 & Antonio Poly & Largo do Mercado & João Candido C. de A. e João Olímpio dos Santos & Prédio edificado & $14,00 \mathrm{~m}$ \\
\hline 13 & João Olímpio dos Santos & Largo do Mercado & Antonio Poly e João Olímpio dos Santos & Com casa baixa & $13,20 \mathrm{~m}$ \\
\hline 14 & Porfírio Alves dos Santos & Largo do Mercado & João Olímpio dos Santos e o córrego & $\begin{array}{l}\text { meia água para dentro do } \\
\text { alinhamento }\end{array}$ & $20,20 \mathrm{~m}$ \\
\hline 15 & G. Maria Roza & Largo do Mercado & Bento Ribeiro Nogueira e uma propriedade & Com casa precária & $16,70 \mathrm{~m}$ \\
\hline 16 & Ritha Barbosa de Lene & Largo do Mercado & $\begin{array}{l}\text { Esquina Rua Direita, Manoel de Almeida e Pedro } \\
\text { Antônio Perella }\end{array}$ & & \\
\hline 17 & G. Maria Rosa & Rua das Flores & Francisca Antonia da Aparecida e Largo do Mercado & uma casa edificada na esquina & $16,00 \mathrm{~m}$ \\
\hline 18 & Pedro Lacoraca & Rua das Flores & José Russo e Maria? & Prédio edificado & $19,00 \mathrm{~m}$ \\
\hline 19 & José Russo & Largo do Mercado & Pedro Lacoraca e Antonio Antunes & $\begin{array}{l}\text { uma casa baixa para dentro do } \\
\text { alinhamento }\end{array}$ & $13,20 \mathrm{~m}$ \\
\hline 20 & $\begin{array}{l}\text { Francisca Antonia da } \\
\text { Aparecida }\end{array}$ & Rua das Flores & Maria Rosa e Alexandre João Damasceno & uma casa precária & $16,00 \mathrm{~m}$ \\
\hline 21 & Maria Joaquina de Jesus & Rua das Flores & Pedro Lacoraca e Magdalena Maria de Jesus & Casa em construção & $11,40 \mathrm{~m}$ \\
\hline 22 & Magdalena Maria de Jesus & Rua das Flores & Maria Joaquina de Jesus e Alexandre João Damasceno & Tem uma casa precária & $12,30 \mathrm{~m}$ \\
\hline 23 & $\begin{array}{l}\text { Alexandre João } \\
\text { Damasceno }\end{array}$ & Rua das Flores & $\begin{array}{l}\text { Francisca Antonia da Aparecida e João Antonio } \\
\text { Cardozo }\end{array}$ & $\begin{array}{l}\text { ? diversos quartos para dentro } \\
\text { do alinhamento }\end{array}$ & $30,00 \mathrm{~m}$ \\
\hline 24 & $\begin{array}{l}\text { Alexandre João } \\
\text { Damasceno }\end{array}$ & Rua das Flores & Magdalena Maria de Jesus e João Antonio Cardozo & Duas casas edificadas & $25,00 \mathrm{~m}$ \\
\hline 25 & João Antonio Cardozo & Rua das Flores & Alexandre João Damasceno e Maria ? & uma casa & $14,40 \mathrm{~m}$ \\
\hline 26 & Antonio Vieira & Rua das Flores & Alexandre João Damasceno e Carlos José de Paiva & Meia água no alinhamento & $11,30 \mathrm{~m}$ \\
\hline 27 & Carlo José de Paiva & Rua das Flores & Antonio ? e Maria Brigida & Meia água no alinhamento & $9,30 \mathrm{~m}$ \\
\hline 28 & Maria Brigida & Rua das Flores & Carlos de Paiva e Mariana Roiz Vieira & Casa baixa no alinhamento & $7,80 \mathrm{~m}$ \\
\hline 29 & Mariana Roiz Vieira & Rua das Flores & João Antonio Cardozo e Elias de Andr. & $\begin{array}{l}\text { Meia água para dentro do } \\
\text { alinhamento }\end{array}$ & $14,00 \mathrm{~m}$ \\
\hline 30 & $\begin{array}{l}\text { Herculano Alves de } \\
\text { Moraes }\end{array}$ & Rua das Flores & Maria Brigida e travessa do Ipiranga & Casa & $9,20 \mathrm{~m}$ \\
\hline 31 & Elias de Andr. & Rua das Flores & ?Maurício Deba e travessa do Ipiranga & Casa assobradada & $13,20 \mathrm{~m}$ \\
\hline 32 & J. Hipólito G. & Rua das Flores & Travessa do Ipiranga e Maurício Deba & Meia-água para dentro do lote & $17,40 \mathrm{~m}$ \\
\hline 33 & Maurício Deba & Rua das Flores & J. Hipólito e Domingos Deba & Casa edificada & $14,30 \mathrm{~m}$ \\
\hline 34 & Domingos Deba & Rua das Flores & Maurício Deba e Antonio de Souza & Casa edificada & $12,50 \mathrm{~m}$ \\
\hline 35 & Antonio de Souza & Rua das Flores & Domingos Deba e Andrea Marcim & Casa edificada & $13,40 \mathrm{~m}$ \\
\hline 36 & Andrea Marcim & Rua das Flores & $\begin{array}{l}\text { Negociante Antonio Luis Souza e Manoel Pedro de } \\
\text { Nogueira }\end{array}$ & Casa edificada & $13,20 \mathrm{~m}$ \\
\hline 37 & $\begin{array}{l}\text { Manoel Pedro de } \\
\text { Nogueira }\end{array}$ & Rua das Flores & Antonio Luis Souza e travessa da Imperatriz & Casa edificada & $13,20 \mathrm{~m}$ \\
\hline 38 & $\begin{array}{l}\text { Alfredo de Souza } \\
\text { Nogueira }\end{array}$ & Rua das Flores & Rua do Ipiranga e Isabel França Carolina & Casa edificada & $13,00 \mathrm{~m}$ \\
\hline 39 & Isabel França Carolina & Rua das Flores & Alfredo de Souza Nogueira e José Pereira da Silva & Casa edificada & $13,80 \mathrm{~m}$ \\
\hline 40 & José Pereira da Silva & Rua das Flores & Isabel Carolina e Magdalena & Casa edificada & $13,20 \mathrm{~m}$ \\
\hline 41 & Magdalena & Rua das Flores & José Pereira da Silva e & Casa baixa no alinhamento & $4,30 \mathrm{~m}$ \\
\hline 42 & G.A.B. & Rua das Flores & Magdalena de Tal e & Casa baixa no alinhamento & $3,9 m$ \\
\hline 43 & $\begin{array}{l}\text { Manoel José C. } \\
\text { (português) }\end{array}$ & Rua das Flores & G. A. B. e Rita Maria Conceição & Casa baixa no alinhamento & $9,10 \mathrm{~m}$ \\
\hline 44 & Rosa Maria Cardozo & Rua das Flores & Antonio Pereira da Silva e outros & $\begin{array}{l}\text { Meia-água dentro do } \\
\text { alinhamento }\end{array}$ & $13,20 \mathrm{~m}$ \\
\hline 45 & Antonio Pereira da Silva & Rua das Flores & Rosa Maria Cardozo e travessa do Ipiranga & Casa edificada & $13,20 \mathrm{~m}$ \\
\hline 46 & Devoluta & Rua das Flores & Rosa Maria Cardozo & Não tem edificação (sobra) & $3,10 \mathrm{~m}$ \\
\hline 47 & Manoel Serafim dos Anjos & Rua das Flores & Travessa da Imperatriz e Rita Catharina & Meia-água & $26,40 \mathrm{~m}$ \\
\hline 48 & Rita Catharina & Rua das Flores & Maria Catharina Serafim e J. Justino & Casa edificada & $13,20 \mathrm{~m}$ \\
\hline 49 & J. Justino & Rua das Flores & Rita Catharina e Vicente L. & Casa edificada & $18,50 \mathrm{~m}$ \\
\hline 50 & Vicente L. & Rua das Flores & J. Justino e João Antonio Ferreira & Casa edificada & $13,20 \mathrm{~m}$ \\
\hline 51 & João Antonio Ferreira & Rua das Flores & Vicente L. e travessa da Cadeia & $\begin{array}{l}\text { Meia-água dentro do } \\
\text { alinhamento }\end{array}$ & $13,20 \mathrm{~m}$ \\
\hline
\end{tabular}


CARTAS DE AFORAMENTO DE SÃO JOSÉ DO RIO PARDO 1885-1889

\begin{tabular}{|c|c|c|c|c|c|}
\hline N. ${ }^{\circ}$ & Nome do aforeiro & Localização & Confrontação & Melhorias & Testada \\
\hline 52 & João Feliciano da Silveira & Rua das Flores & $\begin{array}{l}\text { (era devoluta) Travessa da Imperatriz e Maria da } \\
\text { Conceição Divina }\end{array}$ & ? & $13,20 \mathrm{~m}$ \\
\hline 53 & $\begin{array}{l}\text { Maria da Conceição } \\
\text { Divina }\end{array}$ & Rua das Flores & $\begin{array}{l}\text { Entre data da esquina e Martimano Saturnino de } \\
\text { Andrade }\end{array}$ & Casa edificada & $13,20 \mathrm{~m}$ \\
\hline 54 & $\begin{array}{l}\text { Martimano Saturnino de } \\
\text { Andrade }\end{array}$ & Rua das Flores & Maria da Conceição Divina e L. & Casa edificada & $15,50 \mathrm{~m}$ \\
\hline 55 & Antonio Luiz de Souza & Rua das Flores & M. B. S. e Marcelino Barbosa Nascimento & Casa edificada & $5,50 \mathrm{~m}$ \\
\hline 56 & $\begin{array}{l}\text { Marcelino Barbosa } \\
\text { Nascimento }\end{array}$ & Rua das Flores & Martimano Saturnino de Andrade e Maria Euprasca & Casa baixa & $14,30 \mathrm{~m}$ \\
\hline 57 & $\begin{array}{l}\text { Maria Euprasca - } 1888 \text { - } \\
\text { Gabriel Arcanjo da } \\
\text { Sunpção - } 1889\end{array}$ & Rua das Flores & Marcelino e Pedro Molfi & $\begin{array}{l}\text { Meia-água para dentro do } \\
\text { alinhamento }\end{array}$ & $13,20 \mathrm{~m}$ \\
\hline 58 & Pedro Molfi & Rua das Flores & Maria Euprasca e travessa da Cadeia & Meia-água & $13,20 \mathrm{~m}$ \\
\hline 59 & João Andrade Ferreira & Rua das Flores & Becco e Mathias Barbosa & Meia-água & $13,20 \mathrm{~m}$ \\
\hline 60 & devoluta & Rua das Flores & João Andrade Ferreira e Mathias & Sem edificação & $4,30 \mathrm{~m}$ \\
\hline 61 & Mathias Barbosa & Rua das Flores & Entre o buracão e Lourenciano Vieira de Andrade & Casa em construção & $13,20 \mathrm{~m}$ \\
\hline 62 & $\begin{array}{l}\text { Lourenciano Vieira de } \\
\text { Andrade }\end{array}$ & Rua das Flores & Mathias e Anna Joaquina de Oliveira & $\begin{array}{l}\text { Construção baixa para dentro } \\
\text { do alinhamento }\end{array}$ & $13,20 \mathrm{~m}$ \\
\hline 63 & Anna Joaquina de Oliveira & Rua das Flores & Lourenciano e Maria do Carmo & Construção baixa & $13,20 \mathrm{~m}$ \\
\hline 64 & $\begin{array}{l}\text { Maria do Carmo da } \\
\text { Conceição }\end{array}$ & Rua das Flores & Maria Joaquina de Oliveira e José Português & Esteios afincados & $9,40 m$ \\
\hline 65 & José Português & Rua das Flores & Maria do Carmo e Maria Cecília do Rosário & 1 quarto & $3,00 \mathrm{~m}$ \\
\hline 66 & Maria Cecília do Rosário & Rua das Flores & José Português e Serafim & 1 quarto & $2,20 \mathrm{~m}$ \\
\hline 67 & Serafim & Rua das Flores & Maria Cecília do Rosário e Becco & Casa individual & $13,20 \mathrm{~m}$ \\
\hline 68 & Maurício Travasco & Rua das Flores & Joaquim Ferreira de Paula e Belisario de T. & Início de edificação & $13,20 \mathrm{~m}$ \\
\hline 69 & devoluta & Rua das Flores & Joaquim José de Souza e devoluta & devoluta & $13,20 \mathrm{~m}$ \\
\hline 70 & Joaquim José de Souza & Rua das Flores & Entre datas devolutas & Casa dentro do alinhamento & $13,20 \mathrm{~m}$ \\
\hline 71 & Devoluta & Rua das Flores & Joaquim José de Souza e travessa da Estação & devoluta & $13,20 \mathrm{~m}$ \\
\hline 72 & João A. Moreira & Rua das Flores & Rua da Estação e Manoel Couto & Casa edificada & $13,20 \mathrm{~m}$ \\
\hline 73 & Manoel Couto & Rua das Flores & J. Alves e Honório da Silva & Casa edificada & $13,20 \mathrm{~m}$ \\
\hline 74 & devoluta & Rua das Flores & Manoel Couto e Honório da Silva & Devoluta & $5,30 \mathrm{~m}$ \\
\hline 75 & Honório da Silva & Rua das Flores & Manoel Couto e José Lopes Souza & Casa em construção & $13,00 \mathrm{~m}$ \\
\hline 76 & José Lopes Souza & Rua das Flores & Honório da Silva e Maria da Conceição & Casa dentro do alinhamento & $13,20 \mathrm{~m}$ \\
\hline 77 & Maria da Conceição & Rua das Flores & José Lopes Souza e Joaquim Ferreira de Paula & 1 quarto & $6,80 \mathrm{~m}$ \\
\hline 78 & Joaquim Ferreira de Paula & Rua das Flores & Maria da Conceição e uma data devoluta & Casa edificada & $10,10 \mathrm{~m}$ \\
\hline 79 & devoluta & Rua das Flores & Rua da Estação e Miguel Cruz & Devoluta & $13,20 \mathrm{~m}$ \\
\hline 80 & Miguel Cruz & Rua das Flores & Entre datas devolutas & Casa dentro do alinhamento & $13,90 \mathrm{~m}$ \\
\hline 81 & Devoluta & Rua das Flores & Rua do Cemitério e Miguel Cruz & Datas devolutas & $52,80 \mathrm{~m}$ \\
\hline 82 & $\begin{array}{l}\text { Domingos Francisco de } \\
\text { Souza (proprietário de } \\
\text { uma armazém } \\
\text { secos/molhados/aguarde } \\
\text { ntes/louças/gêneros) }\end{array}$ & Rua das Flores & Rua do Cemitério e terreno devoluto & 1 casa no centro da $R$. & $13,20 \mathrm{~m}$ \\
\hline 83 & Francisco José de Almeida & Rua das Flores & Laurindo Xavier de Tolledo e devoluto & & \\
\hline 84 & Bento Ribeiro Nogueira & Rua do Comércio & Largo do Mercado e terreno devoluto & Casa edificada & $22,00 \mathrm{~m}$ \\
\hline 85 & $\begin{array}{l}\text { Major José Antônio de } \\
\text { Lima }\end{array}$ & Rua do Comércio & $\begin{array}{l}\text { Esquina da Rua Boa Vista e Major José Antônio de } \\
\text { Lima }\end{array}$ & Casa edificada & $28,30 \mathrm{~m}$ \\
\hline 86 & $\begin{array}{l}\text { Major José Antônio de } \\
\text { Lima }\end{array}$ & Rua do Comércio & $\begin{array}{l}\text { Major José Antônio de Lima e Gabriel de Assis } \\
\text { Nogueira }\end{array}$ & Casa edificada & $25,30 \mathrm{~m}$ \\
\hline 87 & devoluta & Rua do Comércio & Bento Ribeiro Nogueira e Joaquim ? & devoluta & $8,80 \mathrm{~m}$ \\
\hline 88 & Joaquim? & Rua do Comércio & Data devoluta e Domeniano Antunes & Casa edificada & $13,85 \mathrm{~m}$ \\
\hline 89 & Domeniano Antunes & Rua do Comércio & Joaquim ? e L. Angelo & $\begin{array}{l}\text { Meia-água fora do } \\
\text { alinhamento }\end{array}$ & $15,20 \mathrm{~m}$ \\
\hline 90 & L. Angelo & Rua do Comércio & Domeniano Antunes e Candido Vital & Casa edificada & $13,20 \mathrm{~m}$ \\
\hline 91 & Candido Vital & Rua do Comércio & L. Angelo e Bento Ribeiro Nogueira & $\begin{array}{l}\text { Meia-água fora do } \\
\text { alinhamento }\end{array}$ & $13,20 \mathrm{~m}$ \\
\hline 92 & Bento Ribeiro Nogueira & Rua do Comércio & Candido Vital e R. de Ipiranga & Casa edificada & $13,20 \mathrm{~m}$ \\
\hline 93 & Gabriel de Assis Nogueira & Rua do Comércio & Major José Antônio de Lima e Vicente Define & casa edificada & $13,30 \mathrm{~m}$ \\
\hline 94 & Vicente Define & Rua do Comércio & Gabriel de Assis Nogueira e Rua do Ipiranga & casa edificada & $24,50 \mathrm{~m}$ \\
\hline 95 & Vicente Define & Rua do Comércio & Rua do Ipiranga e Antonio Pereira da Silva & Casa edificada & $13,20 \mathrm{~m}$ \\
\hline 96 & Antonio Candido Rois & Rua do Comércio & Rua do Ipiranga e José Julio de Araujo Macedo & Casa edificada & $13,20 \mathrm{~m}$ \\
\hline 97 & Antonio Pereira da Silva & Rua do Comércio & Vicente Define e José Julio de Araujo Macedo & Casa edificada & $16,50 \mathrm{~m}$ \\
\hline 98 & $\begin{array}{l}\text { José Julio de Araujo } \\
\text { Macedo }\end{array}$ & Rua do Comércio & Antonio Pereira da Silva e José Antonio Ferreira & Casa edificada & $22,80 \mathrm{~m}$ \\
\hline 99 & José Antonio Ferreira & Rua do Comércio & José Julio de Araujo M. e Pedro C. Nogueira da Silva & Casa edificada & $17,00 \mathrm{~m}$ \\
\hline 100 & $\begin{array}{l}\text { Pedro C. Nogueira da } \\
\text { Silva }\end{array}$ & Rua do Comércio & Rua da Imperatriz e José Antônio Ferreira & Terreno sem edificação & $13,20 \mathrm{~m}$ \\
\hline 101 & $\begin{array}{l}\text { José Julio de Araujo } \\
\text { Macedo }\end{array}$ & Rua do Comércio & Dr. Antonio Candido e José Julio de Araujo Macedo & Terreno sem edificação & $18,50 \mathrm{~m}$ \\
\hline 102 & $\begin{array}{l}\text { José Julio de Araujo } \\
\text { Macedo }\end{array}$ & Rua do Comércio & José Julio de Araujo Macedo e Joaquim Costa & casa e meia-água & $38,10 \mathrm{~m}$ \\
\hline 103 & Joaquim Costa & Rua do Comércio & José Julio de Araujo Macedo e Rua da Imperatriz & Casa edificada & $14,20 \mathrm{~m}$ \\
\hline 104 & devoluto & Rua do Comércio & José Julio de Araujo Macedo e Rua da Imperatriz & Devoluto & $13,20 \mathrm{~m}$ \\
\hline 105 & $\begin{array}{l}\text { José Julio de Araujo } \\
\text { Macedo }\end{array}$ & Rua do Comércio & Terreno devoluto & $\begin{array}{l}2 \text { casas para dentro do } \\
\text { alinhamento }\end{array}$ & $39,60 \mathrm{~m}$ \\
\hline 106 & Delmira de T. & Rua do Comércio & Terreno devoluto & $\begin{array}{l}\text { Meia-água fora do } \\
\text { alinhamento }\end{array}$ & $13,20 \mathrm{~m}$ \\
\hline 107 & Devoluto & Rua do Comércio & Rua da Imperatriz e Delmira de T. & Devoluta & $13,20 \mathrm{~m}$ \\
\hline 108 & José Thomaz de Oliveira & Rua do Comércio & $\begin{array}{l}\text { Lado esquerdo João Antônio Cardoso e lado direito } \\
\text { devoluto }\end{array}$ & & \\
\hline 109 & Devoluta & Rua Direita & Rua do Comércio e data devoluta & Devoluta & $10,95 \mathrm{~m}$ \\
\hline 110 & Devoluta & Rua Direita & Devoluta e Joaquim Antonio Ferreira & Devoluta & $13,20 \mathrm{~m}$ \\
\hline
\end{tabular}


CARTAS DE AFORAMENTO DE SÃO JOSÉ DO RIO PARDO 1885-1889

\begin{tabular}{|c|c|c|c|c|c|}
\hline N. ${ }^{\circ}$ & Nome do aforeiro & Localização & Confrontação & Melhorias & Testada \\
\hline 111 & Joaquim Antonio Ferreira & Rua Direita & Devoluta e José Pinto de Aguiar & Casa edificada & $13,20 \mathrm{~m}$ \\
\hline 112 & José Pinto de Aguiar & Rua Direita & Antonio Ferreira e Pedro José Dias & Casa edificada & $13,20 \mathrm{~m}$ \\
\hline 113 & Pedro José Dias & Rua Direita & José Pinto de Aguiar e Vicente Gabriel do Prado & Casa edificada & $13,20 \mathrm{~m}$ \\
\hline 114 & Vicente Gabriel do Prado & Rua Direita & Pedro José Dias e Bárbara Maria de Jesus & $\begin{array}{l}\text { Meia-água fora do } \\
\text { alinhamento }\end{array}$ & $4,20 \mathrm{~m}$ \\
\hline 115 & Bárbara Maria de Jesus & Rua Direita & Vicente Gabriel do Prado e Rua da Conceição & $\begin{array}{l}\text { Casa edificada fora do } \\
\text { alinhamento }\end{array}$ & $13,20 \mathrm{~m}$ \\
\hline 116 & Francisco Isidoro Dias & Rua Direita & Leonardo Define e Honório Luiz Dias & Casa edificada & $13,20 \mathrm{~m}$ \\
\hline 117 & Honório Luiz Dias & Rua Direita & Francisco Isidoro Dias e Francisco Messias & Casa edificada & $13,20 \mathrm{~m}$ \\
\hline 118 & Francisco Messias & Rua Direita & Honório Luiz Dias e Baptista Conte & Casa edificada & $13,20 \mathrm{~m}$ \\
\hline 119 & Baptista Conte & Rua Direita & Francisco Messias e Rua da Conceição & Casa edificada & $20,80 \mathrm{~m}$ \\
\hline 120 & Pedro Gomes da Fonseca & Rua Direita & Rua da Conceição e Francisco Júlio A. M. & Casa edificada & $13,10 \mathrm{~m}$ \\
\hline 121 & Francisco Júlio A. M. & Rua Direita & Pedro Gomes da Fonseca e Joaquim Reis Carneiro & Casa edificada & $23,50 \mathrm{~m}$ \\
\hline 122 & Joaquim Reis Carneiro & Rua Direita & Francisco Júlio A. M. e Ramim Alonso & Meia-água edificada & $14,55 \mathrm{~m}$ \\
\hline 123 & Ramim Alonso & Rua Direita & $\begin{array}{l}\text { Joaquim Reis Carneiro e João Carneiro de Araújo } \\
\text { Velho }\end{array}$ & Casa edificada & $22,00 \mathrm{~m}$ \\
\hline 124 & $\begin{array}{l}\text { João Carneiro de Araújo } \\
\text { Velho }\end{array}$ & Rua Direita & Ramim Alonso e esquina Rua do Carmo & Casa edificada & $17,60 \mathrm{~m}$ \\
\hline 125 & $\begin{array}{l}\text { Luis Precia Rodolpho Del } \\
\text { Guerra }\end{array}$ & Rua Direita & Rua da Conceição e Pereira da Silva e irmãos & Casa edificada & $19,50 \mathrm{~m}$ \\
\hline 126 & Pereira da Silva e irmãos & Rua Direita & $\begin{array}{l}\text { Luis Precia Rodolpho Del Guerra e Capitão } \\
\text { Saturnino Barbosa }\end{array}$ & Casa edificada & $23,40 \mathrm{~m}$ \\
\hline 127 & Alberto $\mathrm{H}$. & Rua Direita & Luis Precia Rodolpho Del Guerra e o Ribeirão & Casa edificada & $39,00 \mathrm{~m}$ \\
\hline 128 & $\begin{array}{l}\text { Capitão Saturnino } \\
\text { Barbosa }\end{array}$ & Rua Direita & $\begin{array}{l}\text { Pereira da Silva e irmãos e Capitão Saturnino } \\
\text { Barbosa }\end{array}$ & Sem edificação & $11,90 \mathrm{~m}$ \\
\hline 129 & $\begin{array}{l}\text { Capitão Saturnino } \\
\text { Barbosa }\end{array}$ & Rua Direita & Terreno sem edificação e Mamede $\mathrm{H}$. & Casa edificada & $23,30 \mathrm{~m}$ \\
\hline 130 & $\begin{array}{l}\text { Antonio Roiz Lopes } \\
\text { representado por } \\
\text { Mamede } \mathrm{H} \text {. }\end{array}$ & Rua Direita & Rua do Carmo e Saturnino Barbosa & Casa edificada & $22,00 \mathrm{~m}$ \\
\hline 131 & Francisco Eduardo Bessa & Rua Direita & Rua do Carmo e Carlos de Souza Luiz & Casa edificada & $15,10 \mathrm{~m}$ \\
\hline 132 & Carlos de Souza Luiz & Rua Direita & Francisco Eduardo Bessa e João Candido de Souza & Casa edificada & $15,30 \mathrm{~m}$ \\
\hline 133 & João Candido de Souza & Rua Direita & Carlos de Souza Luiz e terreno devoluto & Casa edificada & $8,40 \mathrm{~m}$ \\
\hline 134 & Devoluto & Rua Direita & João Candido de Souza e Largo do Rosário & 2 terrenos devolutos & $26,40 \mathrm{~m}$ \\
\hline 135 & Devoluto & Rua Direita & Rua do Carmo e João Velho & ? & $6,20 \mathrm{~m}$ \\
\hline 136 & $\begin{array}{l}\text { João Candido A. Velho - } \\
1888 \text { pode ser João } \\
\text { Pereira de Mattos }\end{array}$ & Rua Direita & $\begin{array}{l}\text { Terreno devoluto e terreno comprado Delphina } \\
\text { (órfã) de Antônio Teodoro Nogueira }\end{array}$ & Casa edificada & $22,00 \mathrm{~m}$ \\
\hline 137 & $\begin{array}{l}\text { Delphina (órfã) de } \\
\text { Antonio Teodoro } \\
\text { Nogueira }\end{array}$ & Rua Direita & João Candido A. Velho e a mesma & Terreno sem edificação & $12,60 \mathrm{~m}$ \\
\hline 138 & $\begin{array}{l}\text { Delphina por Pedro Claro } \\
\text { Nogueira de Sá }\end{array}$ & Rua Direita & mesma e D. Anna Balbina & Casa edificada & $13,20 \mathrm{~m}$ \\
\hline 139 & D. Anna Balbina & Rua Direita & $\begin{array}{l}\text { Delphina (órfã) de Antônio Teodoro Nogueira e } \\
\text { Joaquim Antônio }\end{array}$ & Casa edificada & $22,00 \mathrm{~m}$ \\
\hline 140 & Joaquim Antônio & Rua Direita & D. Anna Balbina e Rua da Esperança & Casa edificada & $22,00 \mathrm{~m}$ \\
\hline 141 & João Alves Barbosa & Rua Direita & Rua da Esperança e o mesmo & Casa edificada & $17,50 \mathrm{~m}$ \\
\hline 142 & João Alves Barbosa & Rua Direita & Do mesmo e D. Felicidade com fundo até o córrego & & \\
\hline 143 & João Alves Barbosa & Rua Direita & o mesmo e terreno devoluto & Casa edificada & $13,20 \mathrm{~m}$ \\
\hline 144 & $\begin{array}{l}\text { Francisco Julio de Araujo } \\
\text { Macedo }\end{array}$ & Rua Direita & João Alves Barbosa e Manoel Marques Damasceno & Casa edificada & $21,00 \mathrm{~m}$ \\
\hline 145 & $\begin{array}{l}\text { Manoel Marques } \\
\text { Damasceno }\end{array}$ & Rua Direita & Terreno devoluto e Rua da Floresta & Casa edificada & $21,50 \mathrm{~m}$ \\
\hline 146 & $\begin{array}{l}\text { Francisco Antônio da Silva } \\
\text { Nogueira }\end{array}$ & Rua Direita & $\begin{array}{l}\text { José do Carmo e Castro e casa de Antônio de Tal, } \\
\text { fazendo fundo com Antônio Joaquim Teixeira }\end{array}$ & $\begin{array}{l}\text { Pode ser que não tenha } \\
\text { conseguido? }\end{array}$ & $\begin{array}{l}+- \\
25 \\
\text { palmos }\end{array}$ \\
\hline 147 & José do Carmo e Castro & Rua Direita (na esquina) & Antonio Leopoldino e Antonio Joaquim L. & & \\
\hline 148 & $\begin{array}{l}\text { Manoel Joaquim } \\
\text { Montenegro }\end{array}$ & Rua Direita & $\begin{array}{l}\text { Rita Barbara e esquina de um trecho que vai ser } \\
\text { aberto }\end{array}$ & & \\
\hline 149 & Leonardo Define & Rua Boa Vista & Largo do Mercado e Francisco Isidoro Dias & Casa edificada & $29,20 \mathrm{~m}$ \\
\hline 150 & Francisco Isidoro Dias & Rua Boa Vista & Leonardo Define e Luis de Souza Neves & Casa edificada & $13,00 \mathrm{~m}$ \\
\hline 151 & Luis de Souza Neves & Rua Boa Vista & Francisco Isidoro Dias e Rua da Conceição & Casa edificada & $33,60 \mathrm{~m}$ \\
\hline 152 & Felix Ribeiro & Rua Boa Vista & Major Jose Antonio de Lima e Pedro Cepoline & Casa edificada & $16,10 \mathrm{~m}$ \\
\hline 153 & $\begin{array}{l}\text { Francisco Lanulotti } \\
\text { representando Pedro } \\
\text { Cepoline }\end{array}$ & Rua Boa Vista & Felix Ribeiro e Honório Luiz Dias & Casa edificada & $21,10 \mathrm{~m}$ \\
\hline 154 & Honório Luiz Dias & Rua Boa Vista & Pedro Cepoline e Rua da Conceição & Casa edificada & $14,50 \mathrm{~m}$ \\
\hline 155 & Felicia Define & Rua Boa Vista & Rua da Conceição e Caetano Trocosle & Casa edificada & $23,30 \mathrm{~m}$ \\
\hline 156 & Caetano Trocosle & Rua Boa Vista & Felicia Define e Ritta Vieira & Casa edificada & $41,10 \mathrm{~m}$ \\
\hline 157 & Ritta Vieira & Rua Boa Vista & Caetano Trocosle e devoluto & Casa edificada & $9,65 \mathrm{~m}$ \\
\hline 158 & -1888 & Rua Boa Vista & Ritta Vieira e Rua do Carmo & Devoluto & $13,20 \mathrm{~m}$ \\
\hline 159 & $\begin{array}{l}\text { Manoel Francisco Ribeiro } \\
\text { J. }\end{array}$ & Rua Boa Vista & Rua da Conceição e terreno sem propriedade & Casa edificada & $27,90 \mathrm{~m}$ \\
\hline 160 & Devoluto & Rua Boa Vista & Manoel Francisco Ribeiro J. Niculão Betti & Devoluto & $13,70 \mathrm{~m}$ \\
\hline 161 & Niculão Betti & Rua Boa Vista & Terreno devoluto e do mesmo & Casa edificada & $13,20 \mathrm{~m}$ \\
\hline 162 & Niculão Betti & Rua Boa Vista & do mesmo e terreno devoluto & $\begin{array}{l}\text { Cercado e plantado sem } \\
\text { edificação }\end{array}$ & \\
\hline 163 & Devoluto & Rua Boa Vista & Niculão Betti e Rua do Carmo & 2 datas devolutas & $\begin{array}{l}13,20 \mathrm{~m} \\
10,00 \mathrm{~m}\end{array}$ \\
\hline 164 & -1888 & Rua Boa Vista & Rua do Carmo e devoluto & devoluta & $13,20 \mathrm{~m}$ \\
\hline 165 & Honório Luiz Dias & Rua Boa Vista & Do mesmo e Luiz Bartalot & & \\
\hline 166 & Domingos Prezia & Rua Boa Vista & $\begin{array}{l}\text { (era devoluta) Luiz Bartalot e esquina com a Rua do } \\
\text { Carmo }\end{array}$ & & \\
\hline
\end{tabular}


CARTAS DE AFORAMENTO DE SÃO JOSÉ DO RIO PARDO 1885-1889

\begin{tabular}{|c|c|c|c|c|c|}
\hline N. ${ }^{\circ}$ & Nome do aforeiro & Localização & Confrontação & Melhorias & Testada \\
\hline 167 & Luis Prezia & Rua Boa Vista & $\begin{array}{l}\text { Data requerida por Domingos Prezia e esquina Rua } \\
\text { do Carmo }\end{array}$ & & \\
\hline 168 & -1888 & Rua Boa Vista & João D. e Largo do Rosário & 4 devolutos & $13,20 \mathrm{~m}$ \\
\hline 169 & Carlos de Souza Luiz & Rua Boa Vista & Devoluta e Francisco Eduardo Bessa & Sem edificação & $13,20 \mathrm{~m}$ \\
\hline 170 & Francisco Eduardo Bessa & Rua Boa Vista & Esquina com a Rua do Carmo & Sem edificação & $13,20 \mathrm{~m}$ \\
\hline 171 & Francisco Eduardo Bessa & Rua Boa Vista & $\begin{array}{l}\text { Terreno devoluto contíguo a sua residência na } \\
\text { esquina com a Rua do Carmo }\end{array}$ & & \\
\hline 172 & Saturnino F. Barbosa & Rua Boa Vista & $\begin{array}{l}\text { Esquina do Carmo. Confrontando na Rua do Carmo } \\
\text { com Francisco E. Bessa e na Boa Vista devoluta }\end{array}$ & & \\
\hline 173 & $\begin{array}{l}\text { João Carneiro de Araújo } \\
\text { Velho }\end{array}$ & Rua Boa Vista & Eliziario Luis Dias e com outro supp? & & \\
\hline 174 & João Campus & Rua da Conceição & Felicia Define e Saint Clair Junqueira & Casa edificada & $16,40 \mathrm{~m}$ \\
\hline 175 & José Octaviano Machado & Rua da Conceição & Honório Luiz Dias e D. Maria Rosa & Casa edificada & $26,80 \mathrm{~m}$ \\
\hline 176 & Honório Luiz Dias & Rua da Conceição & Rua Boa Vista e José Octaviano Machado & $\begin{array}{l}1 \text { terreno fechado com grade } \\
\text { para jardim }\end{array}$ & $13,20 \mathrm{~m}$ \\
\hline 177 & D. Maria Rosa Hygidie & Rua da Conceição & José Octaviano Machado e Rua do Ipiranga & Casa edificada & $18,40 \mathrm{~m}$ \\
\hline 178 & Devoluta & Largo de São José & Rua do Ipiranga e Misael Costa & Devoluta & $13,20 \mathrm{~m}$ \\
\hline 179 & João Agostinho de Souza & Largo de São José & Custódio de Andrade e João Gonçalves & & \\
\hline 180 & -1888 & Largo de São José & Francisco Paolielo e Custódio de Andrade & Devoluta & $13,20 \mathrm{~m}$ \\
\hline 181 & Custódio de Andrade & Largo de São José & Devoluta e Luis Carlos de Mello & Casa edificada & $13,20 \mathrm{~m}$ \\
\hline 182 & Luis Carlos de Mello & Largo de São José & Custódio de Andrade J. e Ezequiel de Souza & $\begin{array}{l}1 \text { porta e } 3 \text { janelas de frente, } \\
\text { terreno cercado de tijolos }\end{array}$ & $13,20 \mathrm{~m}$ \\
\hline 183 & $\begin{array}{l}\text { Tenente coronel José } \\
\text { Ezequiel de Souza (esposa } \\
\text { D. Francisca Ribeiro de } \\
\text { Souza) }\end{array}$ & Largo de São José & Luis de Mello e D. Maria Carolina Ribeiro & Sem edificação & $13,20 \mathrm{~m}$ \\
\hline 184 & D. Maria Carolina Ribeiro & Largo de São José & Ezequiel de Souza e Rua da Imperatriz & Casa edificada & $22,00 \mathrm{~m}$ \\
\hline 185 & Corrêa e Irmãos & Largo de São José & Rua da Imperatriz e Maria Pinto de Souza & Casa edificada & $10,90 \mathrm{~m}$ \\
\hline 186 & Maria Pinto de Souza & Largo de São José & Corrêa e Irmãos e Raphael Raphael & Casa em ruina & $26,50 \mathrm{~m}$ \\
\hline 187 & Raphael Raphael & Largo de São José & Maria Pinto de Souza e Paschoal Tessari & Casa edificada & $26,50 \mathrm{~m}$ \\
\hline 188 & Paschoal Tessari & Largo de São José & Raphael Raphael e Lourenço Espanhol & Casa edificada & $12,80 \mathrm{~m}$ \\
\hline 189 & Lourenço Espanhol & Largo de São José & Paschoal Tessari e Rua da Cadeia & Casa em princípio & $14,40 \mathrm{~m}$ \\
\hline 190 & Câmara & Largo de São José & Rua da Conceição e terreno da Igreja & Edifício da Câmara & $15,50 \mathrm{~m}$ \\
\hline 191 & -1888 & Largo de São José & $\begin{array}{l}\text { Edifício da Câmara e outro terreno para edifício } \\
\text { público }\end{array}$ & Terreno destinado à Igreja & $56,50 \mathrm{~m}$ \\
\hline 192 & -1888 & Largo de São José & $\begin{array}{l}\text { Edifício da Câmara e outro terreno para edifício } \\
\text { público e Rua do Carmo }\end{array}$ & $\begin{array}{l}\text { Terreno destinado Edifício } \\
\text { Público }\end{array}$ & $15,50 \mathrm{~m}$ \\
\hline 193 & $\begin{array}{l}\text { Horácio M. Nogueira de } \\
\text { Castro }\end{array}$ & Largo de São José & Rua da Cadeia e Joaquim G. & Casa edificada & $22,00 \mathrm{~m}$ \\
\hline 194 & $\begin{array}{l}\text { Joaquim Custódio Dias } \\
\text { (fazendeiro) }\end{array}$ & $\begin{array}{l}\text { Largo de São José } \\
\text { (esquina, de frente p a } \\
\text { casa do Antônio Marçal } \\
\text { Nogueira) }\end{array}$ & $\begin{array}{l}\text { Horácio M. Nogueira de Castro e Antônio Correa da } \\
\text { Silva }\end{array}$ & Casa edificada & $22,00 \mathrm{~m}$ \\
\hline 195 & Joaquim Custódio Dias & Rua do Carmo & Esquina com Ipiranga & & \\
\hline 196 & $\begin{array}{l}\text { Ananias José Ferreira } \\
\text { Barbosa - }\end{array}$ & $\begin{array}{l}\text { Largo de São José } \\
\text { Rua do Carmo }\end{array}$ & $\begin{array}{l}\text { Terreno requerido por Joaquim Custódio Dias, Rua } \\
\text { do Carmo esquina com o Pateo da Matriz, divisando } \\
\text { Domingos Júlio }\end{array}$ & & \\
\hline 197 & Antônio Correa da Silva & Largo de São José & Joaquim Custódio Dias e João Batista Junqueira & Casa edificada & $22,00 \mathrm{~m}$ \\
\hline 198 & João Batista Junqueira & Largo de São José & Antônio Correa da Silva e Rua da Imperatriz & Casa edificada & $22,00 \mathrm{~m}$ \\
\hline 199 & $\begin{array}{l}\text { Miguel Nogueira de } \\
\text { Noronha }\end{array}$ & Largo de São José & Rua da Imperatriz e Capitão Vicente Dias & Casa edificada & $22,00 \mathrm{~m}$ \\
\hline 200 & Capitão Vicente Dias & Largo de São José & $\begin{array}{l}\text { Miguel Nogueira de Noronha e João Theodoro } \\
\text { Nogueira }\end{array}$ & Casa edificada & $24,10 \mathrm{~m}$ \\
\hline 201 & João Theodoro Nogueira & Largo de São José & Capitão Vicente Dias e José Maria Paolielo & Casa edificada & $20,50 \mathrm{~m}$ \\
\hline 202 & José Maria Paolielo & Largo de São José & João Theodoro Nogueira e Rua do Ipiranga & Casa edificada & $21,60 \mathrm{~m}$ \\
\hline 203 & $\begin{array}{l}\text { Antônio Marçal Nogueira } \\
\text { de Barros }\end{array}$ & Largo de São José & Rua do Carmo e D. G. Nogueira & Casa edificada & $22,00 \mathrm{~m}$ \\
\hline 204 & $\begin{array}{l}\text { D. G. Nogueira }-1888 \\
\text { (pode ser q era de } \\
\text { Joaquim Feliciano } \\
\text { Lasbino) }\end{array}$ & Largo de São José & $\begin{array}{l}\text { Antônio Marçal Nogueira de Barros e Luis Carlos de } \\
\text { Mello }\end{array}$ & Casa edificada & $22,00 \mathrm{~m}$ \\
\hline 205 & -1888 & Largo de São José & Antônio Marçal Nogueira de Barros e D. G. Nogueira & Devoluta & $10,00 \mathrm{~m}$ \\
\hline 206 & Luis Carlos de Mello & Largo de São José & $\begin{array}{l}\text { D. G. Nogueira (pode ser q era de Joaquim Feliciano } \\
\text { Lasbino) e Saint Clair de Andrade Junqueira }\end{array}$ & Sem edificação & $13,20 \mathrm{~m}$ \\
\hline 207 & $\begin{array}{l}\text { Ananias José Ferreira } \\
\text { Barbosa }\end{array}$ & Largo de São José & $\begin{array}{l}\text { (era devoluto) Manoel Correia de Souza Lima e Saint } \\
\text { Clair de Andrade Junqueira }\end{array}$ & & \\
\hline 208 & $\begin{array}{l}\text { Saint Clair de Andrade } \\
\text { Junqueira }\end{array}$ & Largo de São José & Rua da Conceição e Luis Carlos de Mello & Sem edificação & $22,00 \mathrm{~m}$ \\
\hline 209 & José Firmino de Lima & Largo de São José & Esquina Rua do Carmo até a Rua da Estação & ? pode não ter conseguido & 120 palmo \\
\hline 210 & José Luis de Souza Nery & Largo de São José & $\begin{array}{l}\text { Esquina Rua do Carmo, dividindo com Domingos } \\
\text { Francisco de A. e no fundo com Eliziario Luis Dias }\end{array}$ & & \\
\hline 211 & José Destro Italiano & Rua do Carmo & $\begin{array}{l}\text { (era devoluto) Acima do largo de SJ, ao lado de } \\
\text { Angelo Landini }\end{array}$ & & \\
\hline 212 & $\begin{array}{l}\text { Francisco Mariano } \\
\text { Parreira }\end{array}$ & Rua do Carmo & Rua do Ipiranga e Domingos Francisco de Souza & Sem edificação & $13,20 \mathrm{~m}$ \\
\hline 213 & $\begin{array}{l}\text { Domingos Francisco de } \\
\text { Souza }\end{array}$ & Rua do Carmo & Francisco Mariano Parreira e Francisco Maggri & Sem edificação & $13,20 \mathrm{~m}$ \\
\hline 214 & Francisco Maggri & Rua do Carmo & Domingos Francisco da Silva e terreno devoluto & Casa edificada & $13,20 \mathrm{~m}$ \\
\hline 215 & Antônio Angerame & $\begin{array}{l}\text { Rua do Carmo esquina } \\
\text { com a Rua Boa Vista (ou } \\
\text { o contrário) }\end{array}$ & Francisco Maggri e João Velho & 2 datas devolutas & $24,40 \mathrm{~m}$ \\
\hline 216 & $\begin{array}{l}\text { João Carneiro de Araújo } \\
\text { Velho }\end{array}$ & Rua do Carmo & Antônio Angerame e Rua Boa Vista & Casa edificada & $15,30 \mathrm{~m}$ \\
\hline
\end{tabular}


CARTAS DE AFORAMENTO DE SÃO JOSÉ DO RIO PARDO 1885-1889

\begin{tabular}{|c|c|c|c|c|c|}
\hline N. ${ }^{\circ}$ & Nome do aforeiro & Localização & Confrontação & Melhorias & Testada \\
\hline 217 & Vicente Torres & Rua do Carmo & $\begin{array}{l}\text { (era devoluto) esquina com a Rua da Estação. - José } \\
\text { Divino Nogueira de Sá e casa em construção de José } \\
\text { Destro }\end{array}$ & & \\
\hline 218 & Vicente Torres & Rua do Carmo & Vicente Torres e Nicolau Ispinella e devoluto & & \\
\hline 219 & Nicolau Ispinella & Rua do Carmo & Terreno requerido por Angelo Ipolieto & & \\
\hline 220 & Angelo Ipolieto & $\begin{array}{l}\text { Rua do Carmo (largo da } \\
\text { matriz) }\end{array}$ & Casa em construção de José Destro e devoluto & & \\
\hline 221 & $\begin{array}{l}\text { Americo Salomé M. } \\
\text { Vianna }\end{array}$ & Rua da Esperança & Rua Boa vista e devoluta & Princípios de edificação & $13,20 \mathrm{~m}$ \\
\hline 222 & Devoluta & Rua da Esperança & Americo Salomé M. Vianna e devoluto & Devoluto & $4,00 \mathrm{~m}$ \\
\hline 223 & Devoluto & Rua da Esperança & Devoluto e Estavão Victorino F. & Devoluto & $13,20 \mathrm{~m}$ \\
\hline 224 & requerida & Rua da Esperança & Devoluto e Antônio José S. G. & Requerido & $13,20 \mathrm{~m}$ \\
\hline 225 & requerida & Rua da Esperança & Estavão Victorino F. e Antônio José S. G. & Requerido & $13,20 \mathrm{~m}$ \\
\hline 226 & Basílio Berlini & Rua da Esperança & Requerida Antônio e Rua do Ipiranga & Casa edificada & $13,41 \mathrm{~m}$ \\
\hline 227 & & & Largo do Rosário e Rua do Ipiranga & 5 datas devolutas & $13,20 \mathrm{~m}$ \\
\hline 228 & José Maria Paolielo & Rua da Esperança & $\begin{array}{l}\text { Rua do Ipiranga e outra do mesmo } \\
\text { Esquina na Rua da Esperança com a travessa do } \\
\text { Ipiranga - fundo com o Largo SJ - Largo do Rosário e } \\
\text { Rua do Ipiranga }\end{array}$ & Casa edificada & $13,20 \mathrm{~m}$ \\
\hline 229 & -1888 & Rua da Esperança & José Maria Paolielo e devoluto & Fechada de tábua & $8,20 \mathrm{~m}$ \\
\hline 230 & José Constanci & Rua da Esperança & $\begin{array}{l}\text { (armazém) José Maria Paolielo e João Rodrigues da } \\
\text { Costa }\end{array}$ & & $13,20 \mathrm{~m}$ \\
\hline 231 & João Rodrigues da Costa & Rua da Esperança & José Constanci e José Marcelino da Silva & & $13,20 \mathrm{~m}$ \\
\hline 232 & & Rua da Esperança & José Maria Paolielo e Rua da Imperatriz & 3 datas devolutas & $13,20 \mathrm{~m}$ \\
\hline 233 & & Rua da Esperança & Rua do Ipiranga e Braulino da Costa e Silva & 3 datas devolutas & $13,20 \mathrm{~m}$ \\
\hline 234 & Braulino da Costa e Silva & Rua da Esperança & Devoluta e requerida & Casa edificada & $13,20 \mathrm{~m}$ \\
\hline 235 & -1888 & Rua da Esperança & Braulino da Costa e Silva e D. Anna F. & Sem edificação & $13,20 \mathrm{~m}$ \\
\hline 236 & $\begin{array}{l}\text { D. Francisco Ribeiro de } \\
\text { Souza }\end{array}$ & Rua da Esperança & Antonio Francisco A. e devoluto & Casa edificada & $13,30 \mathrm{~m}$ \\
\hline 237 & -1888 & Rua da Esperança & D. Francisco Ribeiro de Souza e Rua da Imperatriz & Devoluto & $8,30 \mathrm{~m}$ \\
\hline 238 & -1888 & Rua da Esperança & Rua da Imperatriz e José Carlos Nogueira & 6 datas devolutas & $13,20 \mathrm{~m}$ \\
\hline 239 & Orias de Paula Cardozo. & Rua da Esperança & $\begin{array}{l}\text { (era devoluta) a esquerda José Carlos Nogueira e a } \\
\text { direita Pasqual Sauto Mauro }\end{array}$ & & \\
\hline 240 & José Carlos Nogueira & Rua da Esperança & Devoluta e Rua da Cadeia & Casa edificada & $22,00 \mathrm{~m}$ \\
\hline 241 & Devoluto & Rua da Esperança & Rua da Imperatriz e Antonio Alvez & Devoluto & $13,20 \mathrm{~m}$ \\
\hline 242 & Antonio Alves & Rua da Esperança & Devoluto e devoluto & Casa edificada & $13,20 \mathrm{~m}$ \\
\hline 243 & -1888 & Rua da Esperança & Antonio Alves e Fortunato Damasceno & 3 datas cada uma menos uma & $\begin{array}{l}13,20 \mathrm{~m} \\
4,40 \mathrm{~m}\end{array}$ \\
\hline 244 & Fortunato Damasceno & Rua da Esperança & José Marques e Rua da Cadeia & Casa edificada & $13,20 \mathrm{~m}$ \\
\hline 245 & José Marques & Rua da Esperança & Fortunato Damasceno e Rua da Cadeia & Meia-água edificada & $13,20 \mathrm{~m}$ \\
\hline 246 & Benedito Alves Pererira & Rua da Esperança & Domingos Elias e Fortunato Damasceno & & \\
\hline 247 & Jubias Martins Parreira & Rua da Esperança & $\begin{array}{l}\text { José Maria e Rua da Cadeia -fundo com o italiano } \\
\text { Luis de Mengo sendo o terreno de esquina }\end{array}$ & Devoluto & $13,20 \mathrm{~m}$ \\
\hline 248 & $\begin{array}{l}\text { José Maria Feliciano } \\
\text { Lasbino ou J. M. de } \\
\text { Almeida }\end{array}$ & Rua da Esperança & Devoluta e data requerida & Casa edificada & $13,20 \mathrm{~m}$ \\
\hline 249 & -1888 & Rua da Esperança & José Maria Feliciano Lasbino e devoluto & Data sem edificação & $13,20 \mathrm{~m}$ \\
\hline 250 & $\begin{array}{l}\text { Major José Antônio de } \\
\text { Lima }\end{array}$ & $\begin{array}{l}\text { Rua da Esperança (esta } \\
\text { rua continua em fim } \\
\text { complementa devoluta) }\end{array}$ & $\begin{array}{l}\text { Esquina rua que desce da Cadeia no Largo da } \\
\text { Estação, José Divino Nogueira de Sá e devoluto }\end{array}$ & Princípios de construção & $13,20 \mathrm{~m}$ \\
\hline 251 & $\begin{array}{l}\text { Mizael José Barbosa } \\
\text { Sandoval }\end{array}$ & Rua da Esperança & 2 datas seguidas de Major José Antônio de Lima & & \\
\hline 252 & Paschoal Santo Manso & Rua da Esperança & José Funcia e data requerida por Pedro Dotto & & \\
\hline 253 & $\begin{array}{l}\text { Sociedade Italiana } \\
\text { Socorro Mútuo }\end{array}$ & Rua da Esperança & $\begin{array}{l}\text { Esquina com a Rua Imperatriz, por um lado Capitão } \\
\text { Antônio Correa de Souza e nos fundo com João } \\
\text { Baptista Junqueira }\end{array}$ & & \\
\hline 254 & Augusto Correa & Rua da Esperança & $\begin{array}{l}\text { Entre a Sociedade Italiana Socorro Mútuo e Antônio } \\
\text { Correa da Silva na extensão de } 69 \text { palmos de frente } \\
\text { e } 200 \text { de fundo, pede } 49 \text { de concessão }\end{array}$ & & 49 palmos \\
\hline 255 & Damazo Ribeiro Machado & Rua da Esperança & $\begin{array}{l}\text { entre Sociedade Italiana Socorro Mútuo e Antônio } \\
\text { Correa da Silva, contendo de } 65 \text { a } 69 \text { palmos }\end{array}$ & & \\
\hline 256 & Antônio Correa de Souza & Rua da Esperança & $\begin{array}{l}\text { Entre Miguel José Nogueira de Noronha e a } \\
\text { Beneficência Italiana. Terreno fica no fundo do } \\
\text { terreno do mesmo }\end{array}$ & & \\
\hline 257 & José Maria de Almeida & Rua da Esperança & $\begin{array}{l}\text { (era devoluto) Manoel Gonçalves Magalhães e data } \\
\text { do mesmo }\end{array}$ & & \\
\hline 258 & Damazo Ribeiro Machado & & $\begin{array}{l}\text { Direita Luís Gomes de Faria e esquerda com Manoel } \\
\text { Gonçalves Magalhães, e ambos entre si }\end{array}$ & & \\
\hline 259 & $\begin{array}{l}\text { Antonio Zeferino } \\
\text { Gonçalves }\end{array}$ & Rua da Esperança & $\begin{array}{l}\text { (era devoluto) na esquina da rua que desce do largo } \\
\text { da Igreja, dividindo com o mesmo e no fundo com o } \\
\text { Padre Joaquim }\end{array}$ & & \\
\hline 260 & José Pardim & Rua da Esperança & José Alves A. Dias e Antônio José dos Santos & & \\
\hline 261 & $\begin{array}{l}\text { Antônio Honório de } \\
\text { Araújo }\end{array}$ & Rua da Esperança & $\begin{array}{l}\text { João Manoel Espanhol e do outro lado com o } \\
\text { mesmo patrimônio: confrontando o quintal com a } \\
\text { Rua da Floresta. Terreno este devoluto. }\end{array}$ & & \\
\hline 262 & Theodoro de Campos L. & Rua da Esperança & João Manoel Espanhol e devoluto & & \\
\hline 263 & José Manoel Espanhol & Rua da Esperança & $\begin{array}{l}\text { Subindo a Rua da Estação do lado direito além da } \\
\text { esquina, todos os lados devoluto }\end{array}$ & & \\
\hline 264 & Lazaro Isidorio de Araújo & Rua da Esperança & José Manoel Espanhol e devoluto & & \\
\hline 265 & José Candido de Paiva & Rua da Esperança & Esquina da Boa Vista com a Esperança & & \\
\hline 266 & $\begin{array}{l}\text { Antônio Mercado } \\
\text { (advogado) }\end{array}$ & Rua da Esperança & 2 datas esquina com a Rua da Estação & & \\
\hline 267 & Geraldo G. Lacerda & Rua da Floresta & Esquina de frente a casa de Estevão Gomes Rosa & & \\
\hline
\end{tabular}


CARTAS DE AFORAMENTO DE SÃO JOSÉ DO RIO PARDO 1885-1889

\begin{tabular}{|c|c|c|c|c|c|}
\hline N. ${ }^{\circ}$ & Nome do aforeiro & Localização & Confrontação & Melhorias & Testada \\
\hline 268 & João Alvez Barboza & Rua da Floresta & Ribeirão e Curral do Conselho & Uma faixa com casa dentro & $40,00 \mathrm{~m}$ \\
\hline 269 & -1888 & Rua da Floresta & João Alvez Barboza e Estevão Gomes Rosa & Sem edificação & $26,35 \mathrm{~m}$ \\
\hline 270 & $\begin{array}{l}\text { Estevão Gomes Rosa } \\
\text { (ferreiro) }\end{array}$ & Rua da Floresta & Curral do Conselho e Anna Florentina & Casa edificada & $30,40 m$ \\
\hline 271 & Anna Florentina & Rua da Floresta & $\begin{array}{l}\text { Estevão Gomes Rosa e Antonio Francisco Augusto } \\
\text { da Silva }\end{array}$ & Casa edificada & $13,20 \mathrm{~m}$ \\
\hline 272 & $\begin{array}{l}\text { Antonio Francisco } \\
\text { Augusto da Silva }\end{array}$ & Rua da Floresta & Anna Florentina e Sebastião José Ribeiro & Sem construção & $13,20 \mathrm{~m}$ \\
\hline 273 & Sebastião José Ribeiro & Rua da Floresta & Antonio Francisco Augusto da Silva e devolutas & Casa edificada & $13,20 \mathrm{~m}$ \\
\hline 274 & -1888 & Rua da Floresta & Sebastião José Ribeiro e José Ferreira Pinto & 2 datas devolutas & $13,20 \mathrm{~m}$ \\
\hline 275 & José Ferreira Pinto & Rua da Floresta & Devoluto e Antonio Julio de Araujo Macedo & Casa edificada & $22,00 \mathrm{~m}$ \\
\hline 276 & $\begin{array}{l}\text { Antonio Julio de Araujo } \\
\text { Macedo }\end{array}$ & Rua da Floresta & Devoluto edificada e devoluta & 2 casas edificadas & $24,10 \mathrm{~m}$ \\
\hline 277 & Orias de Paula Cardozo & $\begin{array}{l}\text { Rua da Floresta } \\
\text { (todo lado esquerdo } \\
\text { desta rua esta devoluta } \\
\text { até o buracão) }\end{array}$ & $\begin{array}{l}\text { Antonio Julio de Araujo Macedo e buracão da mina } \\
\text { de água (sendo o terreno do fundo propriedade do } \\
\text { suppl. na Rua da Floresta) }\end{array}$ & 2 datas devolutas & $13,20 \mathrm{~m}$ \\
\hline 278 & $\begin{array}{l}\text { Domingos Francisco de } \\
\text { Souza }\end{array}$ & $\begin{array}{l}\text { Rua da Floresta e } \\
\text { Esperança }\end{array}$ & $\begin{array}{l}\text { Rua da Floresta e Rua da Esperança e terrenos entre } \\
\text { as duas ruas devolutas }\end{array}$ & 1 casa edificada & $\begin{array}{l}31,10 \mathrm{~m} \\
\text { cada rua }\end{array}$ \\
\hline 279 & Padre Joaquim Thomaz & Rua da Floresta & Buracão da mina e João Manoel da Silveira & 3 casas edificadas & $53,20 \mathrm{~m}$ \\
\hline 280 & João Manoel da Silveira & Rua da Floresta & Padre Joaquim Thomaz e Rua da Cadeia & Casa edificada & $13,20 \mathrm{~m}$ \\
\hline 281 & Erasmos S. de Barros & Rua da Floresta & Largo da mina de água e D. Anna Honório & Casa edificada & $13,20 \mathrm{~m}$ \\
\hline 282 & D. Anna Honório & Rua da Floresta & Erasmos S. de Barros e Rua da Cadeia & Casa edificada & $13,20 \mathrm{~m}$ \\
\hline 283 & Joaquim A. de Mello & Rua da Floresta & Rua da Cadeia e terreno sem edificação do mesmo & Meia água edificada & $15,55 \mathrm{~m}$ \\
\hline 284 & -1888 & Rua da Floresta & Joaquim A. de Mello e João Antonio de Souza & Sem edificação & $13,20 \mathrm{~m}$ \\
\hline 285 & João Antonio de Souza & Rua da Floresta & $\begin{array}{l}\text { Terreno pertencente Joaquim A. de Mello e Damazo } \\
\text { Ferreira de Aguiar }\end{array}$ & Casa fora do alinhamento & $17,35 \mathrm{~m}$ \\
\hline 286 & $\begin{array}{l}\text { Damazo Ferreira de } \\
\text { Aguiar }\end{array}$ & Rua da Floresta & João Antonio de Souza e Rua da Estação & Casa edificada & $41,50 \mathrm{~m}$ \\
\hline 287 & Guilherme Escarpelim & Rua da Floresta & Rua da Cadeia e Manoel Eusébio & Casa edificada & $13,20 \mathrm{~m}$ \\
\hline 288 & Manoel Eusébio & Rua da Floresta & Guilherme Escarpelim e João Antonio de S. & Casa edificada & $13,20 \mathrm{~m}$ \\
\hline 289 & João Antonio de S. & Rua da Floresta & Manoel Eusébio e Zeferino Gomes Avelino & Casa edificada & $14,24 m$ \\
\hline 290 & Zeferino Gomes Avelino & Rua da Floresta & $\begin{array}{l}\text { João Antonio de S. e data requerida por Antonio } \\
\text { Pereira da Silva }\end{array}$ & Casa em construção & $14,24 m$ \\
\hline 291 & -1888 & Rua da Floresta & Zeferino Gomes Avelino e devoluto & Sem edificação & $13,20 \mathrm{~m}$ \\
\hline 292 & -1888 & Rua da Floresta & Antonio da Costa e Zeferino Gomes Avelino & Devoluto & $7,66 \mathrm{~m}$ \\
\hline 293 & -1888 & Rua da Floresta & Devoluto e requerido por Zeferino Gomes Avelino & Princípios de edificação & $13,20 \mathrm{~m}$ \\
\hline 294 & -1888 & Rua da Floresta & Rua da Estação e Militão & Sem edificação & $13,20 \mathrm{~m}$ \\
\hline 295 & José Antonio Julio & Rua da Floresta & $\begin{array}{l}\text { Antonio Pereira da Silva e Saturnino Aguiar, e aos } \\
\text { fundos com Francisco Antonio da Silva Nogueira }\end{array}$ & & $13,20 \mathrm{~m}$ \\
\hline 296 & Saturnino Aguiar Musa & Rua da Floresta & Esquina que segue para o largo da estação & & \\
\hline 297 & Antonio Pereira da Silva & Rua da Floresta & Data de Saturnino Aguiar e Manoel Gomes Leal & Casa edificada & $13,20 \mathrm{~m}$ \\
\hline 298 & Manoel Gomes Leal & Rua da Floresta & Antonio Pereira da Silva e devoluta & Casa edificada & $13,20 \mathrm{~m}$ \\
\hline 299 & Catarina Niqeus & Rua da Floresta & $\begin{array}{l}\text { Lourenço José Correia e Manoel Lopes, aos fundos } \\
\text { com José Amaro }\end{array}$ & & \\
\hline 300 & João José Maria & Rua da Floresta & $\begin{array}{l}\text { Esquina da rua que vai para a estação. Divide com a } \\
\text { casa de Manoel Lopes e por outro lado fica em } \\
\text { frente a casa de Rita Vieira de Manoel Joaquim, } \\
\text { fundos com Joaquim José Pereira e José Amaro }\end{array}$ & & \\
\hline 301 & José Pinto de Aguiar & Rua da Floresta & $\begin{array}{l}\text { Francisco Julio de Araujo Macedo e a mina de água } \\
\text { fazendo fundo com a linha férrea }\end{array}$ & & \\
\hline 302 & Thomaz Ancassuerd & $\begin{array}{l}\text { Várzea (fora do } \\
\text { arruamento) }\end{array}$ & João de Souza e Linha férrea. & & \\
\hline 303 & $\begin{array}{l}\text { Francisco Theodoro } \\
\text { Nogueira }\end{array}$ & $\begin{array}{l}\text { Várzea (fora do } \\
\text { arruamento) }\end{array}$ & João de Souza e Linha férrea. (terreno pequeno) & & \\
\hline 304 & $\begin{array}{l}\text { Antônio Pereira de } \\
\text { Mattos }\end{array}$ & Largo da Estação férrea & $\begin{array}{l}\text { Entre prédio do Bento de Oliveira Brandão e } \\
\text { terreno da Companhia do Ramal Férreo }\end{array}$ & & \\
\hline 305 & $\begin{array}{l}\text { Bento de Oliveira } \\
\text { Brandão }\end{array}$ & Largo da Estação férrea & Linha de ferro e data requerida & Casa edificada & $15,33 m$ \\
\hline 306 & -1888 & Largo da Estação férrea & Bento Brandão e data requerida & Sem edificação & $15,33 \mathrm{~m}$ \\
\hline 307 & Angelo Tardelli & Largo da Estação férrea & $\begin{array}{l}\text { Rua da Cadeia (esquina Largo da Estação) e Carlos } \\
\text { José de Paiva }\end{array}$ & Casa edificada & $14,60 \mathrm{~m}$ \\
\hline 308 & Carlos José de Paiva & Largo da Estação férrea & Angelo Tardelli e Capitão Saturnino Barbosa & Sem edificação & $13,90 \mathrm{~m}$ \\
\hline 309 & Saturnino Barbosa & Largo da Estação férrea & Carlos José de Paiva e João Antonio de Noronha & Sem edificação & $13,90 \mathrm{~m}$ \\
\hline 310 & João Antonio de Noronha & Largo da Estação férrea & Saturnino Barbosa e João Damasceno Negrão & Casa edificada & $13,93 m$ \\
\hline 311 & Devoluta & Largo da Estação férrea & João Antonio de Noronha e Rua da Estação & 2 estacas afincadas & $13,43 m$ \\
\hline 312 & $\begin{array}{l}\text { Francisco Antonio } \\
\text { Nogueira }\end{array}$ & Largo da Estação férrea & Rua da Estação e Domingos Vicente da Silva & Casa edificada & $13,20 \mathrm{~m}$ \\
\hline 313 & $\begin{array}{l}\text { Domingos Vicente da } \\
\text { Silva }\end{array}$ & Largo da Estação férrea & Francisco Antonio Nogueira e devoluta & Sem edificação & $13,20 \mathrm{~m}$ \\
\hline 314 & -1888 & Largo da Estação férrea & Domingos Vicente da Silva e Manoel Carpinteiro & 2 datas devolutas casa & $13,20 \mathrm{~m}$ \\
\hline 315 & José Antônio & Largo da Estação férrea & Joaquim do Prado e Manoel Catla Carpinteiro & & \\
\hline 316 & Manoel Catla Carpinteiro & Largo da Estação férrea & Devoluto e José Batista A. & $\begin{array}{l}\text { Meia água fora do } \\
\text { alinhamento }\end{array}$ & $13,20 \mathrm{~m}$ \\
\hline 317 & José Batista A. & Largo da Estação férrea & Manoel Carpinteiro e devoluto & Casa edificada & $13,20 \mathrm{~m}$ \\
\hline 318 & -1888 & Largo da Estação férrea & José Batista A. e Rua do Cemitério & Sem edificação & $10,34 \mathrm{~m}$ \\
\hline 319 & $\begin{array}{l}\text { Francisco Antonio } \\
\text { Nogueira }\end{array}$ & Rua da Estação & Terreno do mesmo e Saturnino de Aguiar & Casa edificada & $13,20 \mathrm{~m}$ \\
\hline 320 & Candido lourenço & Rua da Cadeia & $\begin{array}{l}\text { Angelo Foiadeli e João Norberto Raymundo. } \\
\text { Requerida por Candido lourenço. }\end{array}$ & Sem edificação & $15,33 m$ \\
\hline 321 & João Norberto Raymundo & Rua da Cadeia & $\begin{array}{l}\text { Candido Lourenço e João Manoel da Silva. } \\
\text { Requerida por João Norberto Raymundo. }\end{array}$ & Sem edificação & $15,33 m$ \\
\hline
\end{tabular}


CARTAS DE AFORAMENTO DE SÃO JOSÉ DO RIO PARDO 1885-1889

\begin{tabular}{|c|c|c|c|c|c|}
\hline N. ${ }^{\circ}$ & Nome do aforeiro & Localização & Confrontação & Melhorias & Testada \\
\hline 322 & Atílio Carli & Rua da Cadeia & $\begin{array}{l}\text { (era devoluto) sai no Largo da Estação, por um lado } \\
\text { ? e outro prédio de Manoel Rolan }\end{array}$ & & $\begin{array}{l}66 \text { palmos } \\
\text { frente e } 57 \\
\text { fundo }\end{array}$ \\
\hline 323 & José V. M. & Rua da Cadeia & $\begin{array}{l}\text { (era devoluto) Angelo Santel e a direita fazendo } \\
\text { esquina na mesma rua }\end{array}$ & & \\
\hline 324 & Devoluto & Rua Nova & Buracão e Antonio G. da Silva & Devoluto & $13,20 \mathrm{~m}$ \\
\hline 325 & Antonio G. da Silva & Rua Nova & Devoluto e Maria do Carmo & Casa edificada & $13,20 \mathrm{~m}$ \\
\hline 326 & Maria do Carmo - 1888 & Rua Nova & Antonio G. da Silva e devoluto & Casa edificada & $13,20 \mathrm{~m}$ \\
\hline 327 & Maria do Carmo & Rua Nova & (era devoluto) Maria do Carmo e Rua da Estação & Devoluto & $13,20 \mathrm{~m}$ \\
\hline 328 & Laurinda M. J. & Rua Nova & Rua da Estação e M. de Moraes Machado & Meia-água edificada & $13,20 \mathrm{~m}$ \\
\hline 329 & M. de Moraes Machado & Rua Nova & Laurinda M. J. e Laurindo Xavier de Tolledo & Casa em construção & $13,20 \mathrm{~m}$ \\
\hline 330 & -1888 & Rua Nova & $\begin{array}{l}\text { M. de Moraes Machado e Laurinda Xavier de } \\
\text { Tolledo }\end{array}$ & 2 devolutas & $13,20 \mathrm{~m}$ \\
\hline 331 & $\begin{array}{l}\text { Laurindo Xavier de } \\
\text { Tolledo }\end{array}$ & Rua Nova & Devoluto e devoluto & 1 data & $13,20 \mathrm{~m}$ \\
\hline 332 & -1888 & Rua Nova & Laurindo Xavier de Tolledo e Maria do Carmo & Devoluto & $8,43 \mathrm{~m}$ \\
\hline 333 & -1888 & Rua Nova & Rua do Cemitério e Antônio Luiz Marques & Sem edificação & $13,20 \mathrm{~m}$ \\
\hline 334 & Antônio Luiz Marques & Rua Nova & Devoluto e Manoel Ferreira & Casa edificada & $13,20 \mathrm{~m}$ \\
\hline 335 & Manoel Ferreira & Rua Nova & Antônio Luiz Marques e devoluto & Casa edificada & $13,20 \mathrm{~m}$ \\
\hline 336 & -1888 & Rua Nova & Marculino Candido e Manoel Ferreira & Devoluto & $8,75 \mathrm{~m}$ \\
\hline 337 & Marculino Candido & Rua Nova & Devoluto & Casa edificada & $13,20 \mathrm{~m}$ \\
\hline 338 & -1888 & Rua Nova & Marculino Candido e rua sem nome destinado & Devoluto & $13,20 \mathrm{~m}$ \\
\hline 339 & -1888 & Rua Nova & Rua Direita e Cosme José Damião & Sem edificação & $13,20 \mathrm{~m}$ \\
\hline 340 & Cosme José Damião & Rua Nova & Data requerida e idem & Casa edificada & $13,20 \mathrm{~m}$ \\
\hline 341 & Honorato José Ribeiro & Rua Nova & José Adriano e Cosme José Damião & & $13,20 \mathrm{~m}$ \\
\hline 342 & Luis Nery de Souza & Rua Nova & $\begin{array}{l}3 \text { datas contíguas divisando Gosme José Damião e } \\
\text { Manoel Gonçalves Coimbra, no fundo com o } \\
\text { córrego }\end{array}$ & & \\
\hline 343 & $\begin{array}{l}\text { Antônio Flamínio de } \\
\text { Oliveira }\end{array}$ & Rua Nova & & $\begin{array}{l}\text { Casa edificada fora do } \\
\text { alinhamento }\end{array}$ & $13,20 \mathrm{~m}$ \\
\hline 344 & $\begin{array}{l}\text { Domingos Pires de } \\
\text { Tolledo }\end{array}$ & Rua Nova & Luis Gomes de Farias e Generoso de tal & Sem edificação & $13,20 \mathrm{~m}$ \\
\hline 345 & Luis Gomes de Farias & Rua Nova & & & $13,20 \mathrm{~m}$ \\
\hline 346 & Manoel Ignacio de Mello & Rua Nova & Luis Gomes de Farias e Francisco Ribeiro & & $13,20 \mathrm{~m}$ \\
\hline 347 & João Baptista Correa & Rua Nova & & Sem edificação & $13,20 \mathrm{~m}$ \\
\hline 348 & Laurindo de Tal (Tolledo) & & & & \\
\hline 349 & $\begin{array}{l}\text { Francisco Theodoro } \\
\text { Nogueira- } 1886 \text { - passada } \\
\text { para Antonio Candido de } \\
\text { Araujo }\end{array}$ & Rua Nova & Mel. De Souza e Laurindo de Tal (Tolledo) & Sem edificação & $13,20 \mathrm{~m}$ \\
\hline 350 & José Lopes de Souza & Rua Nova & Joaquim Ferreira de Paula e terreno não requerido & & \\
\hline 351 & Joaquim Ferreira de Paula & Rua Nova & $\begin{array}{l}\text { (fundo com a data do mesmo na Rua das flores) } \\
\text { Requerido pelo mesmo e devoluto }\end{array}$ & Sem edificação & $13,20 \mathrm{~m}$ \\
\hline 352 & Joaquim Ferreira de Paula & Rua Nova & $\begin{array}{l}\text { (fundo com a data do mesmo na Rua das flores) } \\
\text { Obras que vai para a estação e requerido pelo } \\
\text { mesmo }\end{array}$ & Sem edificação & $13,20 \mathrm{~m}$ \\
\hline 353 & João Manoel Espanhol & Rua Nova do Buracão & Rafael Ferrari e Joaquina P. Rodrigues & & $13,20 \mathrm{~m}$ \\
\hline 354 & José Alves & Rua Nova do Buracão & Luis Carreiro e Generoso de tal & & \\
\hline 355 & Rafael Ferrari & Rua Nova do Buracão & José Alves e João Manoel Espanhol & & $13,20 \mathrm{~m}$ \\
\hline 356 & Joaquina P. Rodrigues & Rua Nova do Buracão & $\begin{array}{l}\text { Cosme José Damião e terreno requerido por João } \\
\text { Manoel Espanhol }\end{array}$ & & $13,20 \mathrm{~m}$ \\
\hline 357 & João de Moraes Anta & Rua Nova do Buracão & José Alves de Pinho e João Manoel Espanhol & & \\
\hline 358 & $\begin{array}{l}\text { Urias de Moraes } \\
\text { Machado }\end{array}$ & Rua Nova do Buracão & $\begin{array}{l}\text { Com a Rua das Flores, Joaquim Gomes Nogueira de } \\
\text { Sá e Generoso Ribeiro }\end{array}$ & ? pode não ter conseguido & \\
\hline 359 & José Firmino de Lima - & Rua Nova do Buracão & $\begin{array}{l}2 \text { datas - aos fundo José Alves e por um lado com G. } \\
\text { Vieira Sá Ribeiro }\end{array}$ & ? pode não ter conseguido & \\
\hline 360 & $\begin{array}{l}\text { Américo Salomé Marques } \\
\text { Vianna }\end{array}$ & Rua Boa Vista & $\begin{array}{l}\text { Esquina da Rua Boa Vista com a Rua da Esperança - } \\
\text { próximo de Basílio Berlini Italiano, dando aos fundos } \\
\text { com Estevão (Rua da Floresta) }\end{array}$ & & \\
\hline 361 & $\begin{array}{l}\text { Manoel Antônio de } \\
\text { Castro }\end{array}$ & Rua do Ipiranga & Devoluto e devoluto & & \\
\hline
\end{tabular}

Fonte: Cartas de Aforamento de São José do Rio Pardo, 1885-1889. 


\section{Apêndice 05}

Na tabela abaixo é possível verificar as alterações nas denominações das vias urbanas de São José do Rio Pardo. A identificação destas alterações foi feita a partir da indicação nas Atas da Câmara e através de Decretos publicados nos jornais de circulação local.

\begin{tabular}{|c|c|c|}
\hline \multicolumn{3}{|c|}{ DENOMINAÇÕES DAS RUAS DE SÃO JOSÉ DO RIO PARDO } \\
\hline Primeira denominação & Após a proclamação da República & Atual \\
\hline Rua das Flores & Avenida Silva Jardim & Rua Silva Jardim \\
\hline Rua do Comércio & Avenida Benjamin Constant & Rua Benjamin Constant \\
\hline Rua dos Calabreses - Rua do Carmo & Avenida Américo de Campos - Rua João Pessoa & Rua Francisquinho Dias \\
\hline Rua Boa Vista & Avenida Marechal Deodoro & Rua Marechal Deodoro \\
\hline Rua da Floresta & Avenida Campos Salles & Rua Campos Salles \\
\hline Rua da Esperança & Rua Beneficência Italiana & Rua Treze de Maio \\
\hline Rua Ipiranga & Rua Ananias Barbosa & Rua Ananias Barbosa \\
\hline Rua da Direita & Avenida Rangel Pestana & Rua José Andreoli \\
\hline Rua Nova & Rua José Theodoro & Rua José Theodoro \\
\hline Rua Conceição & Avenida Francisco Glicério & Rua Francisco Glicério \\
\hline Rua Rio Pardo & Rua Costa Machado & Rua Costa Machado \\
\hline Avenida Nova & Avenida Central & Rua Cândido Faria \\
\hline Travessa Rio Branco & Rua Coronel Honório Dias & Rua Coronel Honório Dias \\
\hline Largo da Igreja - Largo da Matriz & Praça XV de Novembro & Praça XV de Novembro \\
\hline Rua da Cadeia & Avenida Saldanha Marinho & Rua João Gabriel Ribeiro \\
\hline Rua da Estação & Avenida Ruy Barbosa & Rua Ruy Barbosa \\
\hline Rua da Imperatriz & Rua Marechal Floriano & Rua Marechal Floriano \\
\hline $\begin{array}{l}\text { Largo do Mercado (popularmente } \\
\text { conhecido como Várzea) }\end{array}$ & Praça Prudente de Morais & Praça Prudente de Morais \\
\hline Largo do Rosário & $\begin{array}{l}\text { Praça Barão do Rio Branco (popularmente conhecido por } \\
\text { Largo do Grupo, depois Largo do Mercado) }\end{array}$ & Praça Barão do Rio Branco \\
\hline Largo do Igreja & Praça Quintino Bocaiúva & Praça Capital Vicente Dias \\
\hline Largo da Estação & Praça Tiradentes & Praça Tiradentes \\
\hline Avenida Belmonte & Avenida Belmonte & Rua Nove de Julho \\
\hline Rua Rangel Pestana & Rua José Andreoli & Rua José Andreoli \\
\hline Avenida Euclides da Cunha & Avenida Euclides da Cunha & $\begin{array}{l}\text { Avenida João de Souza - Av. Euclides da } \\
\text { Cunha }\end{array}$ \\
\hline
\end{tabular}

Fonte: Atas da Câmara (1866-194) e Cartório de Registro. 
" 0 território é essencialmente uma memória, e seu conteúdo é todo constituído de formas passadas - isto é, de algumas dentre elas, das quais só subsiste o que pode ser compreendido pela sociedade que, em cada época, trabalha em seus quadros"

(LEPETIT, 2001, p. 149) 